\title{
GEOLOGICAL CHARACTERIZATION REPORT WASTE ISOLATION PILOT PLANT (WIPP) SITE, SOUTHEASTERN NEW MEXICO
}

SAND78-1596

VOLUME II

Dennis W. Powers, Steven J. Lambert, Sue-Ellen Shaffer, Leslie R. Hill, Wendell D. Weart, Editors

Department 4510

Waste Management Technology

Sandia Laboratories

Albuquerque, New Mexico 87185

AUGUST, 1978

This report was prepared as an account of work

Sponsored by the United States Government. Neither the

Enited States nor the United States Department of

Energy, nor any of their employees, nor any of their

any warranty, subcontractors, or their employees, makes

liability or responsibs or implied, or assumes any legai

or usefulness of any information, appary, completeness

process disclosed, or represents that its useduct or

infringe privately owned rights.

PRINTED DECEMBER, 1978 


\section{DISCLAIMER}

This report was prepared as an account of work sponsored by an agency of the United States Government. Neither the United States Government nor any agency Thereof, nor any of their employees, makes any warranty, express or implied, or assumes any legal liability or responsibility for the accuracy, completeness, or usefulness of any information, apparatus, product, or process disclosed, or represents that its use would not infringe privately owned rights. Reference herein to any specific commercial product, process, or service by trade name, trademark, manufacturer, or otherwise does not necessarily constitute or imply its endorsement, recommendation, or favoring by the United States Government or any agency thereof. The views and opinions of authors expressed herein do not necessarily state or reflect those of the United States Government or any agency thereof. 


\section{DISCLAIMER}

Portions of this document may be illegible in electronic image products. Images are produced from the best available original document. 
GEOLOGICAL CHARACTERIZATION REPORT

TABLE OF CONTENTS

VOLUME I I

$\underline{\text { PAGE }}$

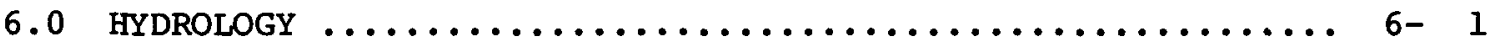

6.1 INTRODUCTION $\ldots \ldots \ldots \ldots \ldots \ldots \ldots \ldots \ldots \ldots \ldots \ldots \ldots \ldots \ldots \ldots \ldots \ldots \ldots \ldots . \ldots \ldots$

6.2 SURFACE HYDROLOGY $\ldots \ldots \ldots \ldots \ldots \ldots \ldots \ldots \ldots \ldots \ldots \ldots \ldots \ldots \ldots \ldots \ldots$

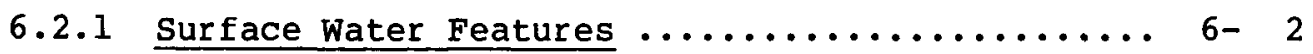

6.2 .2 Precipitation Patterns $\ldots \ldots \ldots \ldots \ldots \ldots \ldots \ldots \ldots$

6.2 .3 Drainage $\ldots \ldots \ldots \ldots \ldots \ldots \ldots \ldots \ldots \ldots \ldots \ldots \ldots \ldots \ldots \ldots \ldots \ldots$

6.2 .4 Floods $\ldots \ldots \ldots \ldots \ldots \ldots \ldots \ldots \ldots \ldots \ldots \ldots \ldots \ldots \ldots \ldots$

6.2 .5 Evaporation and Transpiration ............. 6- 6

6.2 .6 Infiltration $\ldots \ldots \ldots \ldots \ldots \ldots \ldots \ldots \ldots \ldots \ldots \ldots$

6.2 .7 Surface water Quality ................... 6- 7

6.3 GROUND WATER HYDROLOGY ......................... $6-\ldots$

6.3 .1 Regional Ground Water Conditions ............ 6- 8

6.3.2 Hydrology of Rocks Underlying the Salado

Formation ........................... 6- 10

Deep Hydrologic Units .................6 6- 11

Ellenburger Group ................. 6- 11

Devonian zone .................... 6- 12

Mississippian-Pennsylvanian Zone ...... 6- 12

Bone Springs Formation ............. 6- 13

Guadalupian Age Rocks Hydrologic System. 6- 13

Castile Formation ................. 6- 19

Salado Formation ................. 6- 20

6.3.3 Hydrology of Rocks Overlying the Salado

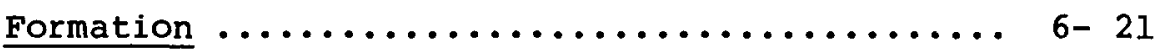

Rustler Formation .................... 6- 22

The Dewey Lake Red Beds ................ 6- 23

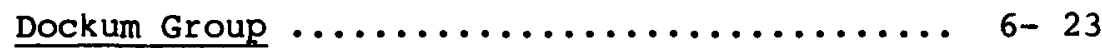

Ogallala Formation ................... 6- 24

Quaternary Deposits .................. 6- 25 
6.3 .4 Regional Ground water Use $\ldots \ldots \ldots \ldots \ldots \ldots \ldots 66.26$

Oil Field Secondary Recovery ........... 6- 27

Ground Water Utilization East of the

Pecos River, Southeast New Mexico ........ 6- 28

6.3.5 Ground Water Occurrence at the Proposed Site ... 6- 28

Fluid-Bearing zones $\ldots \ldots \ldots \ldots \ldots \ldots \ldots \ldots$ 6. 29

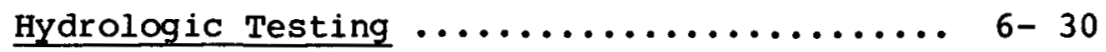

Bell Canyon Formation $\ldots \ldots \ldots \ldots \ldots \ldots \ldots 6,6 \ldots \ldots$

Rustler-Salado Contact $\ldots \ldots \ldots \ldots \ldots \ldots \ldots$ 6. $6-35$

Culebra Dolomite..$\ldots \ldots \ldots \ldots \ldots \ldots \ldots .6 .6 .6 \ldots$

Magenta Dolomite $\ldots \ldots \ldots \ldots \ldots \ldots \ldots \ldots .6 . \ldots \ldots$

Salt-Residue Zone $\ldots \ldots \ldots \ldots \ldots \ldots \ldots \ldots \ldots$ 6. 6 . 36

6.3.6 Dissolution of Salt in the Permian Evaporites .. 6- 37

Shallow Dissolution $\ldots \ldots \ldots \ldots \ldots \ldots \ldots \ldots, 6-38$

Deep Dissolution $\ldots \ldots \ldots \ldots \ldots \ldots \ldots \ldots \ldots, 6-40$

Rates of Dissolution $\ldots \ldots \ldots \ldots \ldots \ldots \ldots \ldots, 6-42$

6.4 HYDROLOGY DRILLING AND TESTING SUMMARY $\ldots \ldots \ldots \ldots \ldots \ldots$ 6- 46

6.4 .1 Hole No. H-1 ..................... 6- 46

6.4 .2 Hole No. H-2a $\ldots \ldots \ldots \ldots \ldots \ldots \ldots \ldots \ldots \ldots \ldots .6 .48$

6.4 .3 Hole No. H-2b .................... 6- 49

6.4 .4 Hole No. H-2c $\ldots \ldots \ldots \ldots \ldots \ldots \ldots \ldots \ldots \ldots \ldots .6 .6$. 50

6.4 .5 Hole No. H-3 $\ldots \ldots \ldots \ldots \ldots \ldots \ldots \ldots \ldots \ldots \ldots .6 .61$

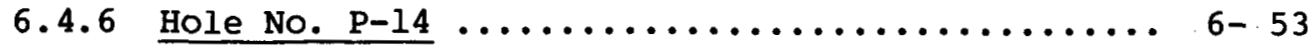

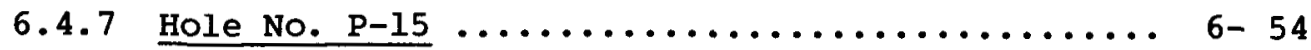

6.4 .8 Hole No. P-17 ..................... 6- 56

6.4 .9 Hole No. P-18 $\ldots \ldots \ldots \ldots \ldots \ldots \ldots \ldots \ldots \ldots \ldots .6 . \ldots \ldots$

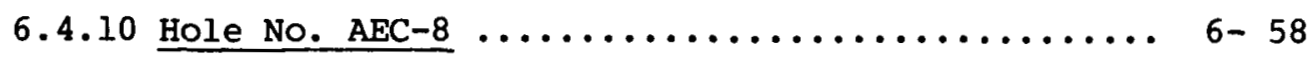

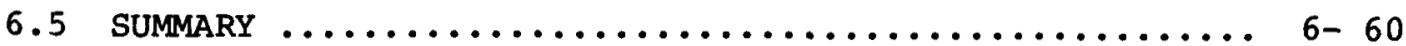

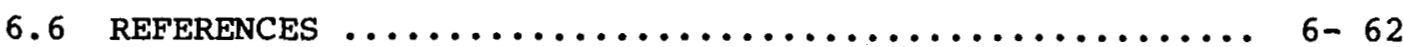




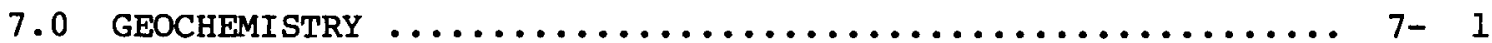

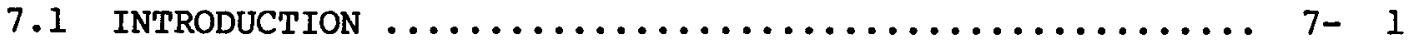

7.2 THE MINERALOGY OF DELAWARE BASIN EVAPORITES AND RELATED ROCKS OF THE LOS MEDANOS AREA ............ $7-2$

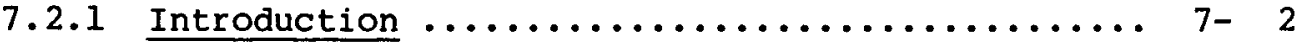

7.2 .2 Previous Work $\ldots \ldots \ldots \ldots \ldots \ldots \ldots \ldots \ldots \ldots \ldots \ldots \ldots \ldots$

7.2.3 Overview of Evaporite Mineralogy $\ldots \ldots \ldots \ldots \ldots .7-3$

7.2.4 Mineralogy of Fluid-Bearing zones in the

Rustler Formation and Delaware Mountain Group .. 7- 4 Magenta Member, Rustler Formation (AEC No. 8) 7- 4 Culebra Member, Rustler Formation (AEC No. 8) 7- 4 Bell Canyon Sandstone (AEC No. 8) ......... 7- 4 Cherry Canyon Sandstone (Pine Springs Outcrop) 7- 4

7.3 DETAILED CHEMISTRY AND MINERALOGY OF SOLUBLE AND INSOLUBLE COMPONENTS OF THE SALADO FORMATION $\ldots \ldots \ldots \ldots 7-5$

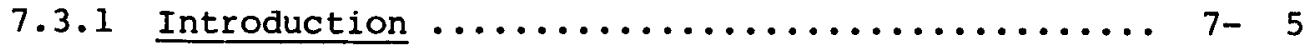

7.3.2 Material and Methods $\ldots \ldots \ldots \ldots \ldots \ldots \ldots \ldots \ldots$ 7- 6

Sample Preparation and Handling $\ldots \ldots \ldots \ldots$ 7- 6

Analysis of Soluble Portion $\ldots \ldots \ldots \ldots \ldots .7-6$

Analysis of Insoluble Portion $\ldots \ldots \ldots \ldots \ldots$ 7- 6

Thermal Analysis ................. $7-7$

Results of Analyses $\ldots \ldots \ldots \ldots \ldots \ldots \ldots \ldots \ldots$ 7 7

7.3.3 Results and Discussion $\ldots \ldots \ldots \ldots \ldots \ldots \ldots \ldots . \ldots .7-8$

Distribution of Mineral Phases $\ldots \ldots \ldots \ldots \ldots$ 7- 8

Effects of Heating Samples $\ldots \ldots \ldots \ldots \ldots \ldots$ 7- 12

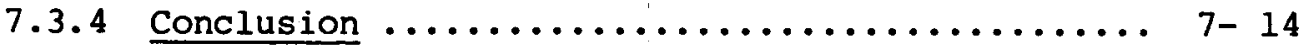

7.4 DETAILED PETROLOGY AND SILICATE MINERALOGY OF SOME

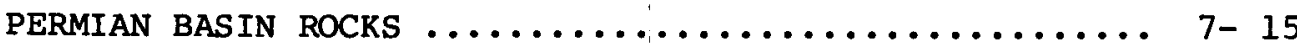

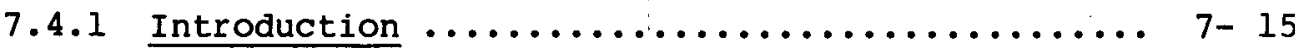

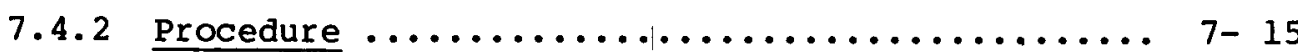

7.4.3 Silicate Mineralogy and Geochemistry ........ 7- 16

Sample Preparation and Analysis ......... 7- 17

Silicate Mineralogy $\ldots \ldots \ldots \ldots \ldots \ldots \ldots . \ldots \ldots$

Distribution of Clay Materials .......... 7- 21 
7.4.4 Mineralogy of Duval Mine Samples $\ldots \ldots \ldots \ldots \ldots .7-21$

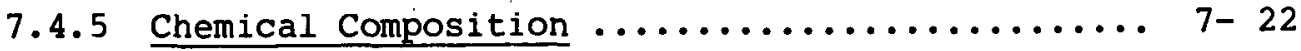

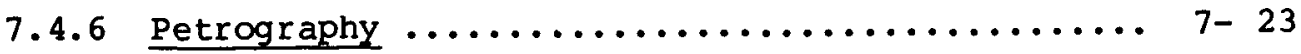

Macroscopic Petrography .............. 7- 23

Microscopic Petrography $\ldots \ldots \ldots \ldots \ldots \ldots \ldots$ 7- 25

7.4.7 Interpretations and Tentative Conclusions ..... 7- 27

7.5 VOLATILES AND FLUID INCLUSIONS IN MINERALS OF THE

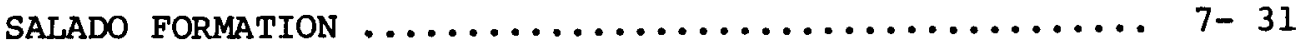

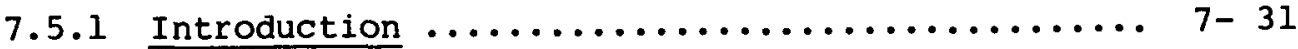

7.5.2 Overview of Volatile Contents of Evaporites .... 7- 32

7.5.3 Mineral Sources of Water in the Salado

Evaporite Sequence $\ldots \ldots \ldots \ldots \ldots \ldots \ldots \ldots \ldots \ldots$ 7 35

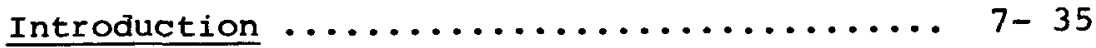

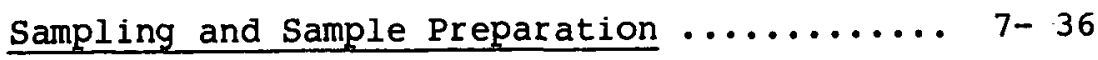

Analytical Methods Used in This Study ...... 7- 37

Weight Losses for Cores, AEC No. 7 and $8 \ldots 7$ 7- 38

Mineralogy and Petrology of Cores No. 7 and 8 7- 40

Summary and Conclusions .............. $7-45$

7.6 FLUID INCLUSIONS IN CORE SAMPLES FROM ERDA NO. $9 \ldots \ldots$ 7- 47

7.6 .1 Introduction $\ldots \ldots \ldots \ldots \ldots \ldots \ldots \ldots \ldots \ldots \ldots .47$

7.6 .2 Samples Studied $\ldots \ldots \ldots \ldots \ldots \ldots \ldots \ldots \ldots \ldots \ldots .478$

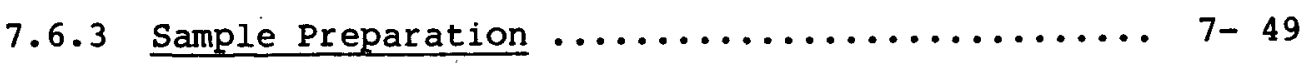

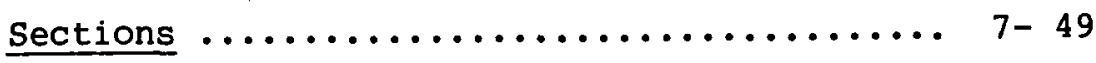

Coarse water-soluble residues $\ldots \ldots \ldots \ldots \ldots$ 7- 50

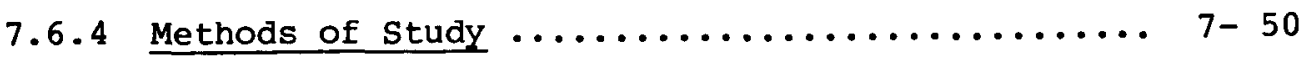

Petrographic Examination $\ldots \ldots \ldots \ldots \ldots \ldots \ldots$ 7 50

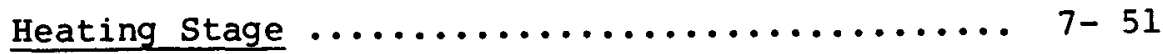

Freezing stage $\ldots \ldots \ldots \ldots \ldots \ldots \ldots \ldots \ldots \ldots$ 7- 51

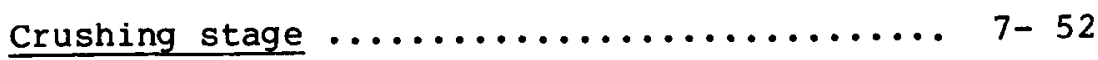

Coarse water-soluble residues $\ldots \ldots \ldots \ldots \ldots 7-52$

Decrepitation ................... $7-52$

7.6.5 Results of Petrographic Examination $\ldots \ldots \ldots \ldots 7-53$

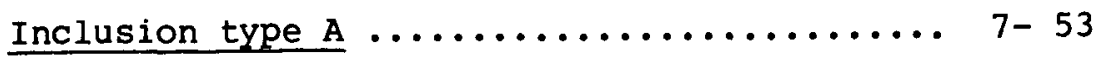

Inclusion type $B \ldots \ldots \ldots \ldots \ldots \ldots \ldots \ldots \ldots, 7-54$

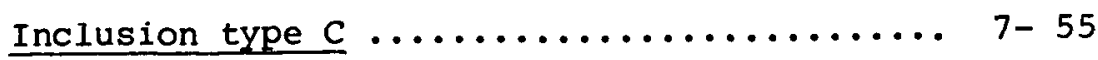

Inclusion type D ................ $7-55$ 
7.6.6 Weight Percent of Fluid $\ldots \ldots \ldots \ldots \ldots \ldots \ldots \ldots 7-55$

7.6 .7 Results of Heating Stage Studies $\ldots \ldots \ldots \ldots \ldots 7-56$

7.6.8 Results of Freezing Stage Studies $\ldots \ldots \ldots \ldots \ldots 7-57$

7.6 .9 Results of Crushing Stage Studies $\ldots \ldots \ldots \ldots \ldots 7-57$

7.6.10 Results of Study of coarse Water-Insoluble

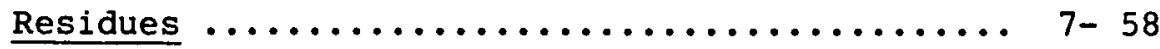

7.6.11 Decrepitation Tests $\ldots \ldots \ldots \ldots \ldots \ldots \ldots \ldots \ldots$ 7- 58

7.6.12 Study of Suite of Samples from Kerr-McGee ..... 7- 59

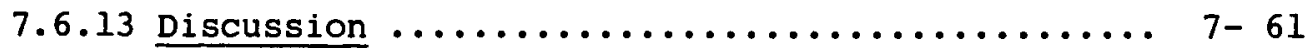

Geological significance $\ldots \ldots \ldots \ldots \ldots \ldots \ldots .7-61$

Nuclear Waste Disposal Significance $\ldots \ldots \ldots$ 7- 63

7.7 THE GEOCHEMISTRY OF DELAWARE BASIN GROUNDWATERS IN RELATION TO THEIR HOST ROCKS $\ldots \ldots \ldots \ldots \ldots \ldots \ldots \ldots \ldots$ 7- 70

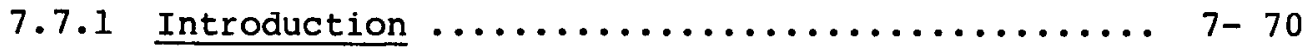

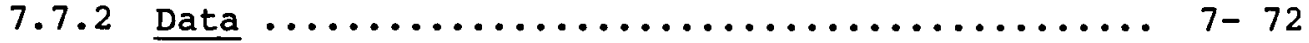

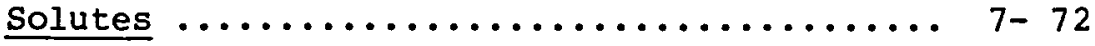

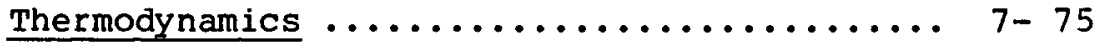

Stable Isotopes $\ldots \ldots \ldots \ldots \ldots \ldots \ldots \ldots \ldots$ 7-76

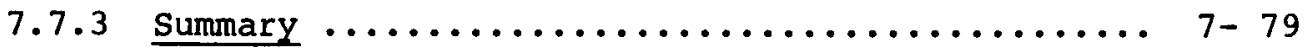

7.8 RUBIDIUM- STRONTIUM SYSTEMATICS OF THE SALADO FORMATION, SOUTHEASTERN NEW MEXICO .................... 7-79

7.8 .1 Introduction $\ldots \ldots \ldots \ldots \ldots \ldots \ldots \ldots \ldots \ldots \ldots . \ldots . \ldots . \ldots . \ldots$

7.8 .2 Previous work $\ldots \ldots \ldots \ldots \ldots \ldots \ldots \ldots \ldots \ldots \ldots . \ldots \ldots$

7.8.3 Analytical Procedure $\ldots \ldots \ldots \ldots \ldots \ldots \ldots \ldots \ldots$ 7- 82

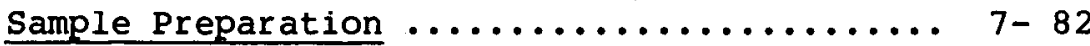

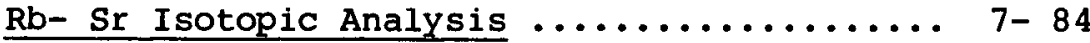

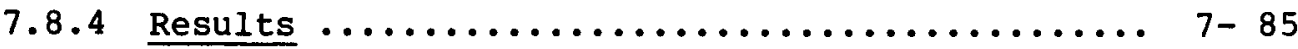

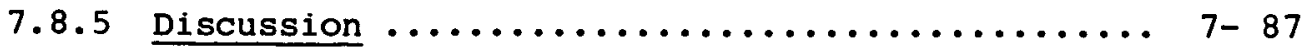

7.8.6 Concluding statements $\ldots \ldots \ldots \ldots \ldots \ldots \ldots \ldots$ 7- 88

7.9 URANIUM ISOTOPE DISEQUILIBRIUM IN GROUNDWATERS OF SOUTHEASTERN NEW MEXICO AND IMPLICATIONS REGARDING AGE-DATING OF WATERS $\ldots \ldots \ldots \ldots \ldots \ldots \ldots \ldots \ldots \ldots \ldots \ldots$ 7- 89

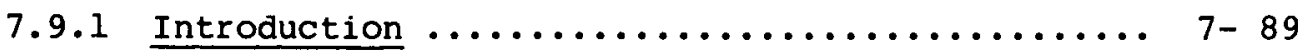

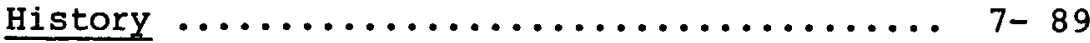

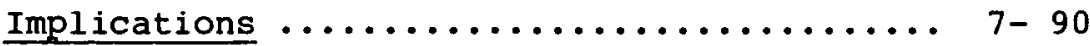


7.9.2 Analytical Approach $\ldots \ldots \ldots \ldots \ldots \ldots \ldots \ldots \ldots$ 7-9. 91

General Geochemistry of Groundwaters ...... 7- 91

Experimental Procedures $\ldots \ldots \ldots \ldots \ldots \ldots \ldots$ 7 91

7.9 .3 Results and Discussion $\ldots \ldots \ldots \ldots \ldots \ldots \ldots \ldots . \ldots \ldots$

7.9.4 Application of the Uranium Isotope Disequilibrium Model .................. 7- 93

7.9.5 Model Ages Based on No Leaching $\ldots \ldots \ldots \ldots \ldots$ 7- 97

7.9.6 Implications and Conclusions ............. 7-99

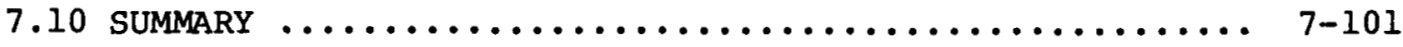

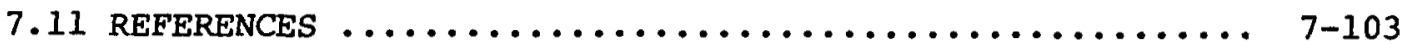

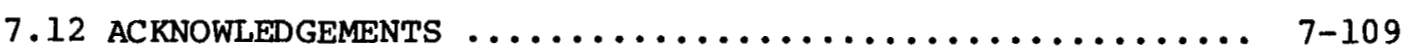

8.0 RESOURCES $\ldots \ldots \ldots \ldots \ldots \ldots \ldots \ldots \ldots \ldots \ldots \ldots \ldots \ldots \ldots \ldots \ldots \ldots \ldots$

8.1 INTRODUCTION $\ldots \ldots \ldots \ldots \ldots \ldots \ldots \ldots \ldots \ldots \ldots \ldots \ldots \ldots \ldots$. 8 . 1

8.2 ORGANIZATIONS INVOLVED IN RESOURCE EVALUATION AND THEIR REPORTS $\ldots \ldots \ldots \ldots \ldots \ldots \ldots \ldots \ldots \ldots \ldots \ldots \ldots$. 8 . 1

8.3 POTENTIAL RESOURCES IN RELATIONSHIP TO STRATIGRAPHY AT THE WIPP SITE $\ldots \ldots \ldots \ldots \ldots \ldots \ldots \ldots \ldots \ldots \ldots \ldots, 8,2$

8.4 RESOURCE DESCRIPTION BY SPECIFIC COMMODITIES ......... 8- 2

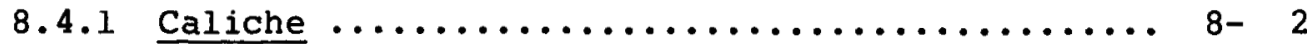

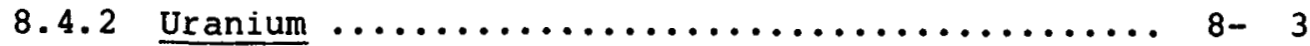

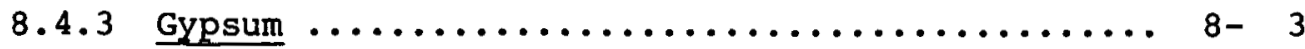

8.4 .4 Halite (Salt) $\ldots \ldots \ldots \ldots \ldots \ldots \ldots \ldots \ldots . .4$

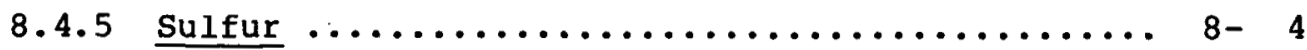

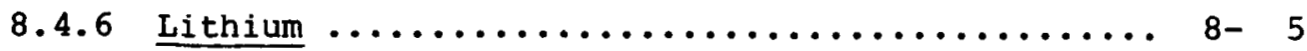

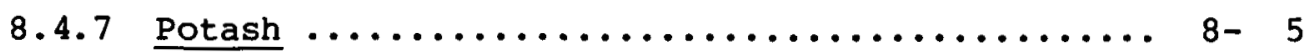

Method of Evaluation .................. 8- 5

Description of the Potash Exploration

Drilling Phase $\ldots \ldots \ldots \ldots \ldots \ldots \ldots \ldots \ldots \ldots$. $8-6$

Calculation of Potash Resource Distribution

Volume and Grade $. . \ldots \ldots \ldots \ldots \ldots \ldots \ldots . \ldots . \ldots 8$

Results of the USGS Resource Estimate ...... 8- 9

Results of the USBM Valuation of Potash

Resources ........................ 8- 10

Summary of Conclusions Concerning Potash

Resources in the WIPP site ............ 8- 11 


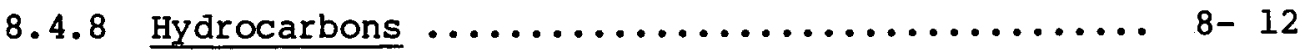

Method of Evaluation $\ldots \ldots \ldots \ldots \ldots \ldots \ldots \ldots$ 8. 12

Total Hydrocarbon Resources at the WIPP Site 8- 14

Estimate of the Economically Recoverable

Hydrocarbon Resources $\ldots \ldots \ldots \ldots \ldots \ldots \ldots$. 8- 16

Summary of Conclusions Concerning Hydrocarbon

Resources ....................... 8 8 . 19

8.4.9 Metalliferous Deposits in the Precambrian .... 8- 19

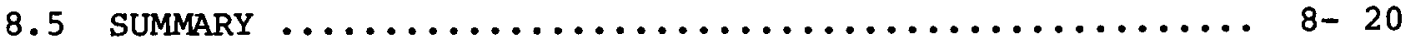

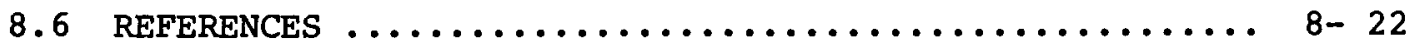

9.0 SPECIAL STUDIES OF WIPP REPOSITORY ROCKS

9.1 INTRODUCTION $\ldots \ldots \ldots \ldots \ldots \ldots \ldots \ldots \ldots \ldots \ldots \ldots \ldots . \ldots . \ldots . \ldots . \ldots . \ldots$

9.2 THERMOPHYSICAL PROPERTIES ..................... 9- 2

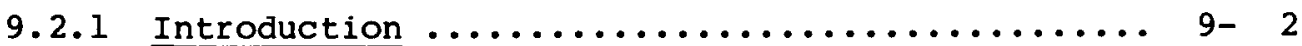

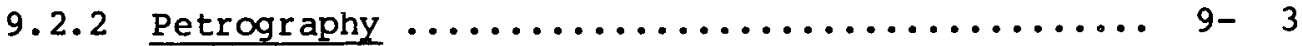

Fabric $\ldots \ldots \ldots \ldots \ldots \ldots \ldots \ldots \ldots \ldots \ldots \ldots \ldots \ldots \ldots \ldots \ldots, 4$

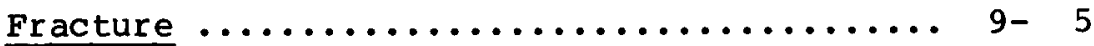

9.2.3 Physical Properties .................. 9- 6

Density and Resistivity $\ldots \ldots \ldots \ldots \ldots \ldots \ldots$. $9-6$

Volatile Mass Loss $\ldots \ldots \ldots \ldots \ldots \ldots \ldots \ldots . .69$

Permeability ..................... $9-7$

Thermal Conductivity ............... 9- 7

Sonic Pulse Velocity ................. $9-8$

Summary of Data .................. 9- 8

9.2.4 Thermomechanical Properties .............. 9- 8

Introduction $\ldots \ldots \ldots \ldots \ldots \ldots \ldots \ldots \ldots . \ldots \ldots$ 9. 8

Apparatus, Experiments, Capabilities and

Data Handling Material and Test Specimens ... 9- 10

Quasistatic Rock Salt Properties ......... 9- 11

Quasistatic Unconfined Properties ..... 9- 12

Quasistatic Triaxial Properties ....... 9- 12

Quasistatic Stress-Strain Relationships. 9- 14

Deviatoric Loading at Constant Confining

Pressure ...................... 9- 14 
Nonelastic Behavior and Pressure Effects

at Ambient Temperature .............. 9- 15

Elevated Temperature Data ........... 9- 15

Influence of Load Path ............. 9- 15

Interpretation of Quasistatic Data .... 9- 18

Creep of Rock salt .................. 9- 18

Creep strain Limits of Rock salt at

Failure ........................ 9. 19

Applicability of Laboratory Measurements ... 9- 20

9.2.5 summary and Conclusions .................. 9- 20

9.3 RADIONUCLIDE SORPTION ON WIPP ROCKS ............... $9-21$

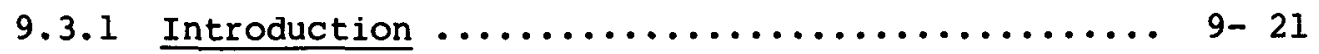

9.3 .2 Geological Media ...................... 9- 23

Sample selection ..................... 9- 23

Sample preparation .................. 9- 24

9.3.3 Brine and Groundwater simulants ............. 9- 24

9.3 .4 Solution Chemistry ...................... 9- 24

Solutes ........................... $9-24$

Oxidation Potential .................. 9- 25

Hydrogen Ion Activity ................... 9- 25

Radionuclide Concentration ............. 9- 26

9.3.5 Experimental procedures .................. 9- 26

Apparatus, Sample Size and Sampling ....... 9- 26

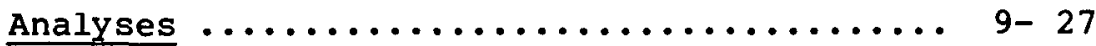

Equilibration Time $\ldots \ldots \ldots \ldots \ldots . \ldots \ldots . \ldots . \ldots 9-27$

$9.3 .6 \mathrm{Kd} \mathrm{Data} \ldots \ldots \ldots \ldots \ldots \ldots \ldots \ldots \ldots \ldots \ldots \ldots \ldots . \ldots \ldots . \ldots \ldots$

9.3 .7 Discussion of $\mathrm{Kd}$ Data $\ldots \ldots \ldots \ldots \ldots \ldots \ldots \ldots \ldots \ldots . \ldots . \ldots . \ldots$

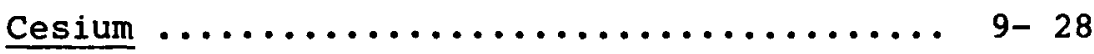

strontium ........................... $9-29$

Europium, Gadalinium and Cerium ......... 9- 29

Technetium and Iodine ................ 9- 30

Ruthenium and Antimony ................ 9- 30

Actinides ......................... $9-31$

9.3.8 Parametric Effects .................... 9- 31 
$\mathrm{pH}$ and Nuclide Concentration Effects on Kd .. 9- 31 The Effect of Trace Organic Contaminants on Kd's of ${ }^{152} \mathrm{Eu},{ }^{153} \mathrm{Gd}$, and ${ }^{144} \mathrm{Ce} \ldots \ldots \ldots \ldots 99-32$ The Effect of Oxidation State on Radionuclide

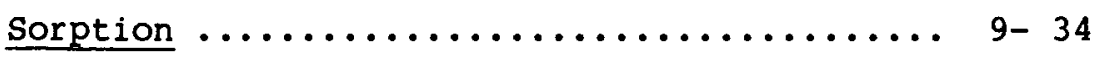

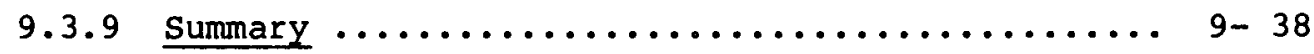

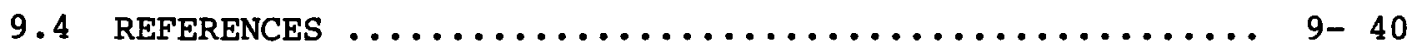

10.0 CONTINUING STUDIES $\ldots \ldots \ldots \ldots \ldots \ldots \ldots \ldots \ldots \ldots \ldots \ldots \ldots$ 10 1

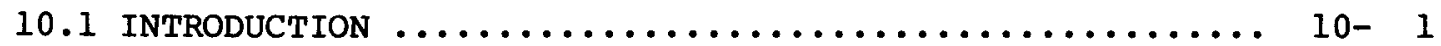

10.2 SITE SELECTION $\ldots \ldots \ldots \ldots \ldots \ldots \ldots \ldots \ldots \ldots \ldots \ldots \ldots \ldots$ 10- 1

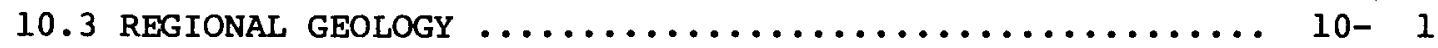

10.3 .1 Paleoclimatology $. . . \ldots \ldots \ldots \ldots \ldots \ldots \ldots \ldots \ldots . \ldots 10,1$

10.3.2 Regional Tectonic Studies ................ 10- 2

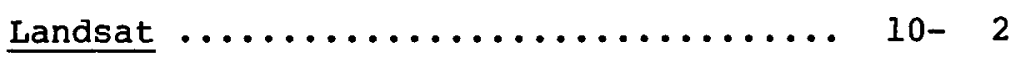

Leveling surveys $\ldots \ldots \ldots \ldots \ldots \ldots \ldots, 10-2$

West Texas Salt Flats Graben .......... 10- 3

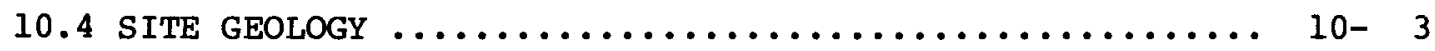

10.4 .1 Geologic Mapping $\ldots \ldots \ldots \ldots \ldots \ldots \ldots \ldots \ldots \ldots . \ldots \ldots$ 10 3

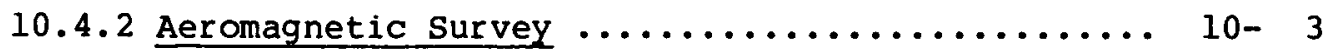

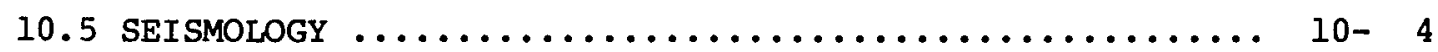

10.5 .1 Near-Site Activity $\ldots \ldots \ldots \ldots \ldots \ldots \ldots \ldots \ldots . \ldots 10-4$

10.5.2 Central Basin Platform ................. 10- 4

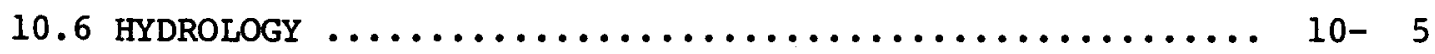

10.6 .1 Introduction $\ldots \ldots \ldots \ldots \ldots \ldots \ldots \ldots \ldots \ldots \ldots \ldots \ldots \ldots . \ldots \ldots \ldots$

10.6.2 Purpose of Hydrologic Testing .............. 10- 5

10.6.3 Direction and Rate of Fluid Migration ........ 10- 6

10.6.4 Dewey Lake Redbeds $\ldots \ldots \ldots \ldots \ldots \ldots \ldots \ldots \ldots \ldots . \ldots 10-7$

10.6.5 Long-Term Monitoring $\ldots \ldots \ldots \ldots \ldots \ldots \ldots \ldots \ldots . \ldots \ldots$ 10 7

10.6 .6 Surface Hydrology $. . . \ldots \ldots \ldots \ldots \ldots \ldots \ldots \ldots . \ldots 10-8$

10.6.7 Overview of Deep Hydrologic Testing ......... 10- 9

10.6.8 Long-Term Monitoring of Deep Wells .......... 10- 9

10.6.9 Continuing Studies in Salt Dissolution and 
Overburden Subsidence Program Objectives ...... 10- 10 Nash Draw Investigations ........... 10- 10 Cemented Rubble Chimney Investigations.. 10- 12 Mine Subsidence Investigations ....... 10- 13

10.6.10 Modeling of Regional Hydrology .......... 10- 13

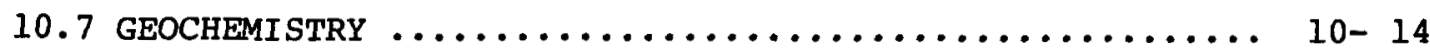

10.7 .1 Introduction $\ldots \ldots \ldots \ldots \ldots \ldots \ldots \ldots \ldots \ldots \ldots \ldots \ldots .10 \ldots \ldots$

10.7.2 Mineralogy and Petrology ............... 10- 15

10.7.3 Volatiles Characterization .............. 10- 15

10.7.4 Origins of Evaporite Assemblages $\ldots \ldots \ldots \ldots \ldots 10-16$

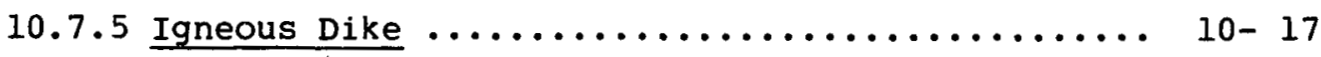

10.7.6 Trace Elements and Age-Dating ........... 10- 17

10.7.7 Reef and Back-Reef waters ............... 10- 19

10.7.8 Future Work on Fluid Inclusions $\ldots \ldots \ldots \ldots \ldots$ 10 19

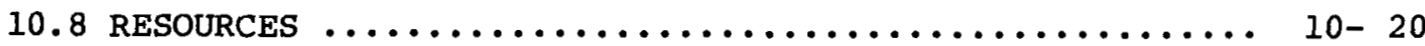

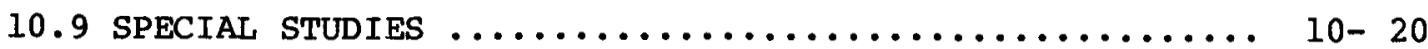

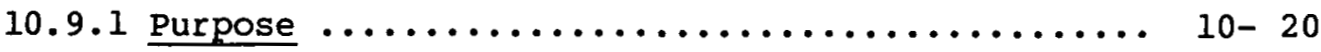

10.9.2 Thermophysical Properties ............... 10- 20

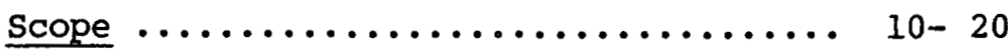

Continuing Studies............... 10- 21

10.9.3 Radionuclide Sorption Properties ........... 10- 22

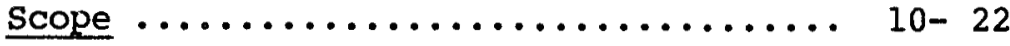

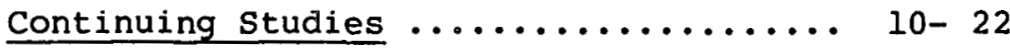

APPENDICES 
GCR CHAPTER 6

HYDROLOGY

\subsection{INTRODUCTION}

The location of the proposed WIPP site is within the surface water boundaries of the Rio Grande Water Resources Region and the groundwater boundaries of the Unglaciated Central region of the Permian Basin. In addition, the site lies within the boundaries of the Delaware Basin, a portion of the Unglaciated Central region that includes some of the least productive aquifers in the United States. The Delaware Basin is characterized by a semiarid climate with low rainfall and runoff, high evaporation, and frequent strong winds. The proposed site contains neither perennial streams nor surface water impoundment, and the water bearing strata beneath the site do not yield large quantities of water to wells. Shallow wells in the local area are generally used only for watering livestock and typically produce non-potable groundwater with total dissolved solids (TDS) concentrations in excess of 3,000 parts per million (ppm).

Hydrologic studies of the water resources surrounding the site have been supported by universities and state and federal agencies since the late 1930 's (Robinson and Lang, 1938; Theis and Sayre, 1942; Hendrickson and Jones, 1952; Bjorklund and Motts, 1959; Nicholson and Clebsch, 1961; Brokaw et al., 1972; Hiss, 1975a). The early studies were primarily concerned with the control of water quality in the Pecos River for agricultural usage downstream from the brine discharge at Malaga Bend (Robinson and Lang, 1938; Hale et al., 1954). The first investigations of hydrogeologic parameters describing the occurrence and flow of groundwater in close proximity to the proposed WIPP location began in the late 1950's with Project Gnome (Cooper, 1962; Gard, 1968; Cooper, 1971).

Hydrologic studies at the site and adjacent site areas have concentrated on defining the hydrogeology and associated salt dissolution phenomena (Griswold, 1977; Lambert and Mercer, 1977; Mercer and orr, 1977; Mercer and Orr, 1978; Anderson, 1978). These investigations are directed toward a more quantitative evaluation of the salt dissolution process, the 
hydrogeologic parameters affecting groundwater movement, and the major elements of surface and groundwater quality affecting water resource use and local ecology. The collection of hydrologic data is projected to continue for several years to provide site-specific information for a detailed safety analysis of the WIPP.

Hydrologic test results to date have been used to make bounding calculations of hypothetical occurrences based upon simplifying assumptions of the physical system. Future measurements obtained from the experimental programs and analysis of the test data will be used to refine the initial bounding calculations and to provide a more detailed description of the physical system and system dynamics. The use of computer models as predictive tools is expected to be closely coordinated with current test results from an established monitoring network. Compatible chemical tracers will be injected directly into the groundwater system as a test of the predictive computer results. Also, the use of chemical tracers during construction phases of the WIPP may provide an early indication of leaky borehole plugs or faulty repository seals, if any, far in advance of radionuclide concentrations in the groundwater system.

\subsection{SURFACE WATER HYDROLOGY}

The area proposed for the Waste Isolation Pilot Plant (WIPP), located in southeastern Eddy County, New Mexico, lies at an average elevation of 3410 feet above mean sea level (MSL) in the Northern Chihuahuan Desert. Although the area belongs to the drainage basin of the Pecos River, surface drainage patterns at the site are not well defined. Preliminary studies indicated that areal requirements for the surface facilities, underground storage, and safety considerations during the operation of the repository would be as shown in Table 6.2-1 (see also Table 2.1).

\subsubsection{Surface Water Features}

The Rio Grande Water Resources Region, which includes the Pecos River basin, is an area of 88,968 square miles. The Pecos River basin has a 
total drainage area of about 44,535 square miles (approximately 20,500 square miles of which do not contribute to river flow), a maximum basin width of about 130 miles, and an overall length of about 500 miles before combining with the Rio Grande River. The Pecos is generally perennial, except in the reach below Anton Chico and in the reach between Fort Sumner and Roswell, where the low flows percolate into the stream bed. About 60 percent of the annual flow occurs between April and September.

The Pecos River is located west of the site and flows southeast through Carlsbad. At the closest point (river mile 430), the Pecos River is approximately 14 miles west of the WIPP site center. The total drainage area of the river at this location is 19,000 sq. miles. A few small unnamed creeks and draws constitute all tributaries flowing westward of the Pecos River within 20 miles north or south of the site. From the west, the Black River (drainage area of 400 square miles) joins the Pecos at a point approximately 16 miles southwest of the site near river mile 436. The Delaware River (drainage area of 700 square miles) joins the Pecos near river mile 446, and a number of small unnamed creeks and draws join at various points along this reach. Pecos River flow in this reach is regulated by storage in Lake sumner (river mile 401.9), Lake McMillan (river mile 404.2), Lake Avalon (river mile 407.2) and several other smaller upstream dams that divert water for irrigation. The salient features of the five existing dams on the Pecos River in a reach extending 25 miles upstream and 25 miles downstream of the WIPP site are listed in Table 6.2-2. The approximate slope of the Pecos riverbed in the vicinity of the WIPP site is $4.5 \mathrm{ft} / \mathrm{mile}$ (U.S.G.S. Topographic Maps NI 13-11\& NI 13-12).

There are no major lakes or ponds within 10 miles of the WIPP site center. Laguna Gatuna, Laguna Tonto, Laguna Plata and Laguna Toston are lakes located to the north more than 10 miles from the site. All these lakes are at or above elevation 3,450 feet. Therefore, surface runoff from the site would not flow toward any of the lakes to the north. To the west and northwest, Red Lake, Lindsey Lake, Salt Lake, and a few unnamed ponds are located more than 10 miles from the site, between elevations 3,000 and 3,300 feet (U.S.G.S. Topo. Maps, 1:250,000). 
Surface water and groundwater withdrawals in the Pecos River basin are listed in Table 6.2-3.

\subsubsection{Precipitation Patterns}

The nearest station to the WIPP site for which climatological records are available is located at Carlsbad, about 26 miles west of the site, at an elevation of 3,120 feet MSI (U.S. Weather Bureau, 1961). Over a period of more than 71 years (NOAA, 1977), the annual precipitation at Carlsbad ranged from 2.95 inches to 33.94 inches. The average annual precipitation over a period of 30 years (1931-1960) was 12.43 inches (U.S. Weather Bureau, 1961). The average annual precipitation from 1951 to 1974 was 9.78 inches at Artesia (elevation 3320 feet), which is about 48 miles northwest of the WIPP site. At Hobbs (elevation 3615 feet), which is about 44 miles northeast of the site, the average annual precipitation for the period 1951-1974 was 14.29 inches. Interpolation of precipitation data for Carlsbad, Artesia and Hobbs indicates that the average annual precipitation at the site should be approximately 12 inches, which is nearly equal to the average annual precipitation at Carlsbad. Therefore, the precipitation patterns at Carlsbad are assumed to be representative of the conditions at the WIPP site.

Maximum, average, and minimum monthly precipitation at Carlsbad over a period of 30 years (1931-1960) are given in Table 6.2-4. The maximum monthly precipitation, 12.28 inches, occurred in May. With the exception of May and August, when the record minimum monthly precipitation were 0.18 and 0.01 inch, respectively, the record minimum precipitation for all other months has been 0.00 inch. The maximum daily precipitation since 1905 occurred in August, 1916, and was 5.12 inches.

The maximum daily and monthly snowfalls at Carlsbad since 1905 have been 10 inches (December, 1923) and 17.8 inches (February, 1905), respectively (U:S. Weather Bureau, 1961). 
In general, summer rain is more abundant than that of other seasons and is caused by thunderstorms generated by the southeasterly circulation of moist air from the Gulf of Mexico. Approximately 75 percent of the total annual precipitation occurs from April through September. Winter rainfall is least abundant and is caused mainly by frontal activity associated with the movement of the Pacific storms across the country from west to east (NOAA, 1977).

\subsubsection{Drainage}

The site is located between elevations 3,250 and 3,570 feet MSL (Griswold, 1977). General ground slope in the vicinity is approximately $39 \mathrm{feet} / \mathrm{mile}$ from the northeast to southwest. Average ground slope from north to south is approximately 13 feet/mile. A topographic and surface water divide (Antelope Ridge) exists approximately 8 miles east of the site center and 4 miles from the exterior boundary of zone IV (Refer to Table 6.2-1).

In general, the surface in the site vicinity is hummocky and covered by sand dunes. The local slope is poorly defined, and rain collects in pools between sand dunes and evaporates, is transpired, or sinks into the sand. Surface runoff from an area of about $10 \mathrm{sq}$. miles to the northeast, along with that from the site area, drains through a number of small draws which terminate in unnamed ponds to the southwest. Runoff is typically 0.1 to 0.2 inches annually.

\subsubsection{Floods}

Historically, floods for the Pecos River are reported to have occurred in 1904, 1905, 1915, 1916, 1919, 1937, 1941, 1942, and 1966 (NOAA, 1977). The earliest flood for which discharge information is available occurred on October 2, 1904, following the failure of Avalon Dam. During this flood, the flow at Avalon gaging station (river mile 406.3) exceeded 90,000 cfs. The corresponding river stage is not available. The river stage at Red Bluff ( $r$ iver mile 459.8) is reported to have reached 28 feet 
(gage datum of 2850.05 feet) during this flood. Another major flood occurred on August 7, 1916, when the discharge at Carlsbad Station (river mile 419.1 ) reached 70,000 cfs.

A third major flood occurred in September, 1919, when the river stage at Malaga gaging station (river mile 432.2) was recorded as 29.4 feet (gage datum of 2895.64 feet). The corresponding discharge was $40,400 \mathrm{cfs}$. The highest flood of record (through 1976) for the Pecos River occurred on August 23, 1966, when the discharge and stage at Malaga were 120,000 cfs and 42.1 feet, respectively (U.S. Geological Survey, 1976). The minimum surface elevation of the site is more than 310 feet above this maximum historic flood level.

\subsubsection{Evaporation and Transpiration}

In New Mexico, potential evaporation is much greater than the average annual precipitation. In the southeastern valleys, evaporation from a class A pan is on the order of 110 inches per year. During the warm months, May through October, evaporation in the southeast portion of the state is approximately 73 inches.

The record high temperature at Carlsbad is $112^{\circ} \mathrm{F}$ (June, 1902). The record low temperature at this station is $7^{\circ} \mathrm{F}$ (January, 1911). The maximum, average and minimum monthly temperatures at this station over a period of 30 years (1931-1960) are given in Table 6.2-5 (U.S. Weather Bureau, 1961). June, July and August are the warmest (average temperature of $80.7^{\circ} \mathrm{F}$ ) while December and January are the coldest months of the year (average temperature of $44.3^{\circ} \mathrm{F}$ ).

In this type of desert climate, more than 90 percent of all infiltrated water evaporates or transpires. The high rate of evapotranspiration is aided by the frequent winds, the low relative humidity (typically 36 percent during daylight hours), and the high mean annual temperature $\left(61^{\circ} \mathrm{F}\right)$. 


\subsubsection{Infiltration}

Soils at the site are generally comprised of sands extending to a depth of as much as 25 feet. Actual sand dunes cover a good portion of the site area. With pervious sand on the surface, infiltration rates are high and probably similar to the 1.6 inch-per-hour intake rate of Harkey Sand Loam (75 percent sand) near Carlsbad (Blaney and Hanson, 1965). Groundwater in the area of the site is more than 50 feet below surface elevations. Because the surface sands are underlain by a caliche layer about 2 to 8 feet thick, percolation of rainfall through the sands to the nearest groundwater would be only a portion of the total infiltration. Most infiltration will return to the atmosphere by evapotranspiration.

\subsubsection{Surface Water Quality}

Water quality in the Pecos River basin is affected by mineral pollution from natural sources and from irrigation return flows. Springs near the headwaters of the basin below Colonias, New Mexico, are estimated to discharge approximately 707 tons per day of dissolved solids into the Pecos River. Below Lake McMillan, springs flowing into the river are usually submerged and difficult to sample; however, dissolved solids concentrations between 3350 and 4000 ppm have been measured in springs that could be sampled. The chemical quality of these mineral discharges indicates the nonpotable character of the ground water in contributing source beds. Inflow of concentrated brine solutions at Malaga Bend increases the chloride content of the Pecos River by an estimated 370 tons per day (see account by Swenson in Bachman and Johnson, 1973). Time-weighted averages of water quality parameters for three sampling stations on the Pecos River between Carlsbad and Malaga Bend are shown in Table 6.2-6. In general, natural spring flows and irrigation return flows progressively concentrate salts downstream. Further downstream at Red Bluff Reservoir, the water is useable occasionally during high flow periods. 


\subsection{GROUND WATER HYDROLOGY}

Detailed investigations of ground water conditions at the proposed site are being conducted to identify the presence of ground water, to measure ground water quality, and to determine hydraulic conductivity and other characteristics of the stratified rocks. The data will provide a basis for assessment of the continued isolation of the proposed repository from ground water circulation. The thick halite beds of the salado Formation at the WIPP site are isolated from circulating ground water by beds of low hydraulic conductivity, both above and below the formation. In the vicinity of the proposed site, fresh or potable ground water is not present except in small, isolated, near-surface perched bodies.

Investigations to evaluate the transport of radionuclides by ground water flow in the southeastern New Mexico portion of the Delaware Basin were made by the Water Resources Division of the U.S. Geological Survey for Project Gnome in the late 1950's. Since that time, several studies have been carried out by individual consultants, the U.S. Geological Survey, Oak Ridge National Laboratories, and Sandia Laboratories. These studies have been directed to the specific task of providing a better understanding of the relationship between the proposed waste repository and ground water movement. The following is a description of ground water occurrence and flow as understood from the studies completed to date. Ground water is first described on a regional basis, then the results of site specific studies are reviewed, and, finally, dissolution of salt evaporites is discussed.

\subsubsection{Regional Ground Water Conditions}

Ground water within the Delaware Basin is predominantly of poor quality, with total dissolved solids concentrations in excess of $3,000 \mathrm{ppm}$. The only large quantities of potable ground water are found in aquifers west of and along the Pecos River. To the west in the Guadalupe Mountains, many rock units of the basin crop out, and the soluble salts have been leached from the Ochoan evaporites. 
Important aquifers of the region are the San Andres Limestone and the Capitan Limestone and related reef limestones. The San Andres is a major source for irrigation waters in the Roswell basin, and other areas to the north and northwest of the site. The Capitan aquifer southwest of the community of Carlsbad is the primary source of municipal water. An important aquifer in the region east of the proposed site is the ogallala Formation. Unconsolidated alluvium along the Pecos River yields large amounts of relatively fresh ground water in some areas, although it is commonly of marginal quality for drinking purposes.

From the outcrop areas west of the Pecos River, ground water moves eastward. The shallow aquifers, those cut by the Pecos River, discharge to the river, either directly or to alluvium of the river channel. The Capitan aquifer is the oldest permeable formation that may have contact with the river. Ground water in permeable formations older than the Capitan is not directly affected by the river, is present under confined conditions, and migrates eastward into the Delaware Basin.

East of the Pecos River, thick beds of evaporites are present at depth, and brines are common in the underlying permeable formations. Ground water in any of the rock units east of the river in Eddy County is of brackish quality, at best. Fresh meteorically-derived ground water does not flush out the poor quality waters in these aquifers. Consequently, the major utilization of ground water in the central and eastern Delaware Basin is for oil-field flooding. The predominant source of the ground water is the Capitan aquifer.

The shallow aquifers east of the Pecos River are limited in extent, are low yielding, and usually contain water of poor quality. Recharge to these shallow aquifers is presumed to be from precipitation on outcrop areas or from overlying formations, and migration of the water generally follows surface drainage patterns, eventually reaching the Pecos River. 
In discussing ground water occurrences in relation to the proposed repository, it is convenient to relate them to the salado Formation because the salado and its associated evaporite formations have very low hydraulic conductivities and form a barrier to vertical flow (see Table 9.2.3-1). Aquifers stratigraphically below the salado are widespread and contain large quantities of brine under confined conditions. Aquifers present above the Salado in the proposed site area are either limited in extent or very low-yielding. This upper ground water is of poor quality (TDS concentrations greater than 3,000 ppm) and occurs under unconfined, as well as confined, conditions.

\subsubsection{Hydrology of Rocks Underlying the Salado Formation}

The halite beds of the Salado Formation that are proposed for the repository are underlain by thick anhydrite and salt beds of the castile Formation. They act as an aquiclude, separating the Salado from the underlying sandstones of the Delaware Mountain Group. The sandstones are present at a depth of about 4,200 feet in the site area. The hydraulic conductivity of the sandstones of the Delaware Mountain Group, associated with the relatively high hydraulic conductivity of the shelf-margin facies (the Capitan Limestone) and the shelf facies (which includes the San Andres Limestone) make this group the most important hydrologic system underlying the salado. The hydrology of these Guadalupian-age rocks has been investigated in detail by Hiss (1975a).

Considerable information derived from hydrocarbon exploration in the basin is available on the hydrologic properties of the formations underlying the Permian evaporites. As reported by Lambert and Mercer (1977), the Delaware Mountain Group is the uppermost of the oil- and gas-producing horizons, which extend to the Ellenburger Group at a depth of about 18,000 feet. Several zones are encountered that contain water, oil, and/or gas that are under sufficient pressure to maintain a potentiometric surface at an elevation above that of the salado Formation. Some of the zones have sufficient hydraulic conductivity to allow flow rates of several hundred barrels per day. In addition to the 
Delaware Mountain Group, the Atoka zone at a depth of about 13,150 feet, and the Strawn (Desmoinesian) zone at about 12,900 feet are other oil and gas production zones that are considered deep aquifers by Lambert and Mercer (1977).

Deep Hydrologic Units. The hydrologic parameters of pre-Guadalupian zones are not as well defined, nor are they as hydrologically significant to the proposed repository as the Guadalupian-age rocks. Nevertheless, a review of them is presented, based primarily on McNeal's (1965) analysis of hydrodynamics of the Permian Basin. He described the potentiometric surfaces of seven zones, using elevations of outcrops where cut by a stream or body of water, static water levels in cable tool holes or water wells, and formation pressures converted to potentiometric surface elevations. McNeal prepared maps showing the regional potentiometric surfaces in terms of fresh water, using density differences of the various brine concentrations and depths of the nearby wells. The three deep hydrologic units reviewed are the Ellenburger Group, the Devonian zone, and the Mississippian- Pennsylvanian zone.

1) Ellenburger Group. The Ellenburger Group consists mainly of chert-bearing limestones and dolomites. It is a widespread unit, covering some 100,000 square miles in southeastern New Mexico and northwestern Texas (McNeal, 1965, Figure 1). The unit is estimated to be 350 feet thick at the proposed site (Lambert and Mercer, 1977) and as much as 1000 feet thick elsewhere in the region. The potentiometric surface compiled by McNeal for the Ellenburger indicates an altitude range from 4,200 feet MSL southwest of the site to less than 1,400 feet MSL in central Texas. In the vicinity of the WIPP site, the ground surface elevation is about 3200 feet MSL. The average gradient of the potentiometric surface is about 8 feet per mile in an easterly direction. Water in the Ellenburger is a brine solution, with a dissolved solids range of $50,000 \mathrm{ppm}$ to more than 200,000 ppm. No water production data are available for this group. 
2) Devonian zone. McNeal's potentiometric surface for the Devonian hydrodynamic zone ranges in altitude from 4,000 feet MSL in the vicinity of the Glass Mountains to 3,200 MSL feet along the Lea County - Texas line. In the Midland Basin, there are nearly hydrostatic conditions at an elevation range of 2,800 to 3,200 feet MSL. A high potentiometric nose extending across southeast Eddy County indicates a potentiometric surface at the proposed site of about 3,700 feet MSL. Salinity of the formation water is less than 50,000 ppm in most of southeast New Mexico. In west Texas, salinity reaches $200,000 \mathrm{ppm}$ in one area.

The Devonian, as inferred from McNeal's potentiometric map, extends throughout southeast New Mexico and northwest Texas. He has included Silurian data in the eastern (Texas) subcrop area. The potentiometric surface generally slopes to the east, and the average gradient appears to be about 7 feet per mile.

3) Mississippian-Pennsylvanian Zone. Mississippian rocks are thin and few data are available on the occurrence of fluids under the Delaware Basin. McNeal (1965) delineated a potentiometric surface for the Mississippian zone of West Texas, but has not extended it into New Mexico.

There are three water-bearing zones in Pennsylvanian age rocks. In ascending order they are the Morrow, the Atoka, and the Strawn (Desmoinesian). Lambert and Mercer (1977, p. III-2) report that the Morrow may be a high pressure, low capacity reservoir with water-production rates ranging from 10 to 20 barrels per day. The Atoka also may be an overpressured reservoir with enough head to yield fluid columns of 3375 to 6552 feet MSL at gradients of 0.47 psi per foot. The water is produced from gas wells at rates ranging from 21.6 barrels per day to as much as 214.4 barrels per day (Texas American's Todd Federal Well No. 1).

Lambert and Mercer (1977) report that several wells have been drill stem tested in the Desmoinesian age Strawn zone and several others have been completed as oil wells. On five drill stem tests, the calculated heads 
ranged from 3350 to 6203 feet MSL. Water production was reported to be as much as 416 barrels per day in one drill-stem test, and one well (Phillip's James "E" NO. 1) produced an average of 106 barrels per day. A potentiometric surface of the Strawn zone is presented by McNeal. (1964, Figure 4), but the only area in the Delaware Basin for which data were available was in the southwestern part of Eddy County. Elevation of levels in that area range from 3,200 feet to 3,800 feet MSL. The gradient is easterly at about 20 feet per mile.

Bone Spring Formation. According to Lambert and Mercer (1977), the Bone Spring Formation (Leonardian Series) can be considered an aquiclude. They report that bottom-hole pressure data from the majority of seven wells tested had insufficient heads to prevent downward movement of shallower water. They suggest the pressure data indicate the formation has a low capacity and contains reservoirs of limited volume.

Guadalupian Age Rocks. The most important aquifers of the Delaware Basin are part of a hydrologic system that incorporates rocks of Guadalupian age. The system comprises three interconnected aquifer groups; the shelf aquifers (including the San Andres Limestone and the Artesia Group), the Capitan aquifer (including primarily the reef deposits - Capitan and Goat Seep Limestones), and the basin aquifers (sands of the Delaware Mountain Group). These aquifers are depositionally juxtaposed, but are distinguished in most areas by contrasting hydraulic conductivities, water salinities, and potentiometric levels. Along the north and northwest interface, hydraulic conductivity of the shelf aquifer, although lower, is near the hydraulic conductivity of the capitan aquifer. The basin aquifers have the lowest values of hydraulic conductivity, and the Capitan is a discharge point for ground water flows in them. Recharge to these basin aquifers probably occurs in outcrop areas along the west flank of the Delaware Basin. Ground water then moves generally eastward, downdip in the tilted beds. Data on aquifer characteristics, compiled by Hiss (1975a), are summarized in Table 6.3-1. Hydrologic, lithologic, and physical properties of the formations in which these aquifers occur are discussed below. 
1) Delaware Mountain Group Aguifer. The Delaware Mountain Group includes, in ascending order, the Brushy Canyon, Cherry Canyon, and Bell Canyon Formations and comprises the basin facies of the system. The combined thickness of these formations ranges from less than 2,000 feet in the southern part of the Delaware Basin to more than 4,000 feet in southwestern Lea and eastern Eddy Counties, New Mexico (Hiss, 1975a).

The Brushy Canyon Formation is as much as 1,000 feet thick and consists chiefly of sandstone with limestone lenses and occasional conglomerate at the base. No wells are known to be extracting water from this formation in Eddy County (Hendrickson and Jones, 1952).

The Cherry Canyon Formation is also as much as 1,000 feet thick and consists of thin-bedded, fine-grained sandstone and some persistent Iimestone beds. The lower one-fourth of the formation persists as a sandstone tongue striking northwestward into the Guadalupe Mountains which may yield water to some wells and springs in that area (Hendrickson and Jones, 1952).

The Bell Canyon Formation ranges in thickness from 670 to 1,040 feet and consists mainly of sandstone and thin beds of limestone (King, 1948). The formation interfingers to the northwest with the reef limestone of the Capitan Formation, providing the potential hydrologic interconnection of the Guadalupian Age rocks. Large springs near the base of the reef escarpment west of the Pecos River are probably supplied by ground water moving through the upper beds of the Bell Canyon Formation (Hendrickson and Jones, 1952).

An average hydraulic conductivity of $0.016 \mathrm{ft} / \mathrm{a}$ (feet per day) and a porosity of 15.65 percent were determined by Hiss (1975a) from analyses of approximately 4,500 samples of rock core cut from the Delaware Mountain Group in Eddy and Lea Counties, New Mexico, and Ward and Winkler Counties, Texas. Hiss also computed a similar hydraulic conductivity from productivity indexes (approximately equivalent to specific 
capacities) obtained from an oil company for two wells in the El Mar field located on the boundary between Lea County, New Mexico, and Loving County, Texas.

Hiss (1975a) indicated that similar values of hydraulic conductivity were reported by earlier writers for much of the same part of the Delaware Basin.

Hiss compiled a potentiometric surface map of the Delaware Mountain Group, of which the northern Delaware Basin portion is shown in Figure 6.3-1. The data used by Hiss in compiling the map were taken at different times over a period of about 25 years between the late 1940's and early 1970's. However, he believes the contours are representative of conditions during the period 1960 and 1970. Although some local changes to the potentiometric surface are due to oil and water withdrawals during that period, no data suggest that the regional directional trend has changed. The potentiometric surface data for the brines have been corrected to "fresh-water" density, indicating a potentiometric elevation of 3350 feet MSL in the vicinity of the proposed WIPP site. The hydraulic gradient in the northern portion of the basin dips northeasterly at approximately 15 feet per mile.

Quality of the water in the Delaware Mountain Group is generally poor. An isochlor map compiled by Hiss (1975a, Figure 26) shows a chloride-ion concentration range from 50,000 to 150,000 ppm in the east half of the Delaware Basin. Concentration diminishes to approximately 1,000 ppm southward in the vicinity of the Glass Mountains and northwestward in the vicinity of the Guadalupe Mountains. These are outcrop areas where the Guadalupian Age rocks probably have been recharged by precipitation. However, analyses of water samples taken from the hydrologic system in the vicinity of the repository site indicate that the brine solutions do not contain oxygen and hydrogen isotopes in ratios characteristic of meteoric waters. The relative proportions of $018 / 016$, and deuterium/ hydrogen ratios have probably been altered through interaction with the rock of the formation (Lambert, 1978; see also Chapter 7 of this report). 
According to Hiss, recharge to the basin aquifers is through precipitation on the outcrops in the Guadalupe, Delaware, Apache, and Glass Mountains, and from downward leakage through the younger rocks in areas where the overlying soluble ochoan evaporites have been removed. The potentiometric surface (Figure 6.3-1) indicates water moves north and northeastward, and discharge is to the overlying Capitan and shelf aquifers.

2) Capitan Aguifer. The Capitan Limestone and the underlying Goat seep Limestone constitute the main body of the Capitan aquifer, which is the reef facies of the Guadalupian rocks. Hiss (1975a) describes the aquifer as a long continuous unit that extends in an arcuate strip along the north and east margins of the basin, with exposures in the Guadalupe and Glass Mountains, as well as the Delaware and Apache Mountains. The thickness of the aquifer ranges from a few hundred to more than 2,000 feet, and the average width is approximately 10 miles (Hiss, 1975a, Figure 11). It is one of the most important aquifers of the region and is a major control in the hydrologic system (Mercer and orr, 1977).

Relatively few aquifer tests have been performed to measure the hydraulic conductivity of the Capitan aquifer. The data compiled by Hiss (1975a) are summarized in Table 6.3-1. Hiss calculated that the hydraulic conductivity of the Capitan aquifer along the western margin of the Central Basin Platform in Texas and New Mexico ranges from 1 to $25 \mathrm{ft} / \mathrm{d}$ and estimated that for most of southern Lea county and for about 15 miles east of the Pecos River valley from Carlsbad it is about $5.0 \mathrm{ft} / \mathrm{d}$. Although Hiss was unable to conduct any aquifer tests in the area west of the Pecos River, he concluded that high production wells, the presence of caverns, and high porosity suggest that the hydraulic conductivity of the Capitan is higher west of the river than east of the river. The hydraulic conductivity is probably very high, as well, in the Glass Mountains, because of numerous small caverns (Hiss, 1975a). The coefficient of transmissivity of the Capitan aquifer along the northern and eastern margins of the Delaware Basin is estimated by Hiss to range from $10,000 \mathrm{ft}^{2} / \mathrm{d}$ (square feet per day) in thick sections to less than $500 \mathrm{ft}^{2} / \mathrm{d}$ in the vicinity of eroded, thin sections of the reef. 
The Capitan aquifer receives some recharge by direct infiltration on outcrops in the Guadalupe and Glass Mountains, and probably more by percolation of discharge from the basin and shelf aquifers along the north and east margins of the basin. Water-table conditions exist in the aquifer west of the Pecos River and in the Glass Mountains, but to the north of the Glass Mountains and east of Carlsbad water in the aquifer is confined. Hiss believes that water entering the Capitan aquifer in the Guadalupe Mountains moves northeastward toward Carlsbad where most of the water discharges into the Pecos and Carlsbad Springs. The Pecos River controls the movement of ground water in the Capitan aquifer in the vicinity of Carlsbad, and east to the ground-water divide near the Eddy-Lea County line (figure 6.3-1).

Hiss (1975a) believes that a deep submarine canyon cut into the Capitan Limestone is present near the Eddy-Lea county line, and a hydraulic restriction is formed to constrain the eastward movement of water in the aquifer from the vicinity of the Pecos River. Apparently there is little movement of water between the Pecos River and the Eddy - Lea County line. East of the hydraulic restriction, the potentiometric surface declines with an eastward gradient. Hydrographs of observation wells, established by the U. S. Geological survey in the Capitan aquifer from Carlsbad east and south to the Texas - New Mexico state line have recorded these water level differences. Water levels during the years 1967 through 1972 indicate that from Carlsbad eastward to near the Eddy Lea county line, the potentiometric surface has remained nearly constant, responding to minor fluctuations of the Pecos Rivex. East of the county line, water levels declined more than 100 feet, at a constant rate, during those 6 years (Hiss, 1975a, Figure 24). The eastward gradient and decline in potentiometric surface are caused primarily by the large withdrawals of water for oil-field water flooding in eastern New Mexico and western Texas (Mercer and Orr, 1977). These withdrawals are apparently the primary discharge from the aquifer at the present time. The similar potentiometric heads and directions of movement of the Capitan and shelf aquifers along the northeast and east sides of the basin (Figure 6.3-1) suggest some discharge from the shelf aquifer also 
occurs. In analyzing potentiometric data prior to 1950, when large extractions of water from the Capitan had not developed, Hiss (1975a), concluded that discharge at the time was east, into the shelf aquifers.

Water of good quality, although hard, is available in the Capitan aquifer in the area west of Carlsbad (Hendrickson and Jones, 1952), and apparently in the Glass Mountains. However, in the major portion of the aquifer, east of the Pecos River, quality is poor. Chloride-ion concentration increases from 200 ppn just west of Carlsbad to as much as 23,000 ppm east of the community. Along the east flank of the basin, salinity of Capitan water is significantly lower than that in the adjacent shelf and basin aquifers, ranging from about 1,100 to 5,000 ppm in most wells (Hiss, 1975a, Figure 26).

\section{3) Shelf Aquifers.}

The shelf aquifers do not have a direct impact on hydrologic conditions underlying the proposed site because the Capitan aquifer is a hydrologic boundary. Nevertheless, they are in close hydraulic connection with that aquifer, and would apparently accept some discharge from the Capitan, should the extensive pumping from the capitan be discontinued.

The lowermost unit of the Guadalupian age shelf or "back-reef" facies, known as the San Andres Limestone, extends over much of southeast New Mexico and into northwest Texas. The average thickness of the unit is about 1500 feet. Overlying the San Andres are formations of the Artesia Group. Strata in these formations that yield significant quantities of water are the shelf aquifers. The contact between the Capitan and shelf aquifers is gradational and difficult to differentiate in some areas. In the Pecos River Valley between Carlsbad and Roswell, and to the west of that area, the shelf aquifers are quite porous and yield large quantities of potable water to wells (Hendrickson and Jones 1952). The hydraulic conductivity of the aquifers east of the river and in the Central Basin Platform are significantly less than those to the west, and water quality is poor (Hiss, 1975a). 
Measurements of nydraulic conductivity and porosity of core samples of the shelf aquifers were collected by Hiss (1975a) and the data are summarized in Table 6.3-1. It can be seen that the hydraulic conductivities in this area are at least one order of magnitude less than hydraulic conductivities of the Capitan aquifer. Potentiometric levels of the shelf aquifer, shown on Figure 6.3-1, are similar to those of the Capitan aquifer along the east side of the Delaware Basin. In the vicinity of Carlsbad, however, the levels are as much as 200 feet higher than those of the Capitan, suggesting poor interconnection between aquifers in that area.

The major areas of recharge to the shelf aquifers are probably north and west of Carlsbad in the Guadalupe mountains and areas west of the Roswell basin. Water in the shelf aquifers to the north moves either southwestward to the Pecos River, or southeastward onto the Central Basin platform. Water quality in the shelf aquifers varies considerably from one area to another, but is generally poor east of the Pecos River. Chloride-ion concentrations in excess of 150,000 ppm are indicated by Hiss (1975a, Figure 26) north of the Capitan aquifer and along the east flank of the Delaware Basin. However, a narrow band of better quality water (salinity less than 10,000 ppm) in the San Andres Limestone is indicated to the northeast, between the shelf and the Central Basin Platform.

Castile Formation. The Castile Formation overlies the Delaware Mountain Group and consists predominantly of anhydrite with halite interbeds, and subordinate limestone. Its thickness ranges from 1,300 to 2,000 feet over most of the Delaware Basin. In most of the basin hydraulic conductivity of the Castile is very low so that this formation acts as a confining layer for the underlying Delaware Mountain Group (Mercer and orr, 1977). However, west of the Pecos River, the salt beds have been removed, hydraulic conductivity of the residuum is higher and water is available to wells (Bjorklund and Motts, 1959).

In the central Delaware Basin, isolated pockets of brine and associated hydrogen-sulfide gas have been encountered by various oil companies in 
the Castile, and also in the Sandia Laboratories exploratory hole, ERDA-6 (Mercer and orr, 1977). High-pressured brines encountered in three oil wells east of the proposed site reportedly have had flow rates as high as 20,000 barrels per day. These brines are present near the top of the formation, suggesting a brine zone, but since no other wells have encountered brines, the zone is apparently not continuous (Rose, 1977). Brine from ERDA-6 further suggests a long isolation time on the order of one million years for that pocket (Barr, Lambert and Carter, 1978).

Salado Formation. Massive beds of halite of the Salado Formation are the intended host rock for the WIPP repository. The formation extends more than 100 miles both north and east of the Delaware Basin and underlies an area of approximately 25,000 square miles (Pierce and Rich, 1962). Formation thickness in the Los Medanos area is 1,976 feet, as measured at ERDA-9, and the depth to the top is 848 feet.

Porosity of the halite is very low and interconnected pores are virtually non-existent. Lack of open fractures is assured because of the high plasticity of the material. As a result, hydraulic conductivity of the beds is effectively zero. As reported by C. L. Jones (1973), microscopic to very small angular cavities in grains of halite contain very minor amounts of brine and gas. Less common are much larger cavities or pockets in the halite beds that contain halite-saturated brine and nitrogenous gas confined under pressure sufficient to produce a "blow-out" when encountered during drilling. Nevertheless, the brine pockets do not appear to be interconnected, but seem to be isolated fluid bodies within the rock.

Because halite is quite soluble, it would readily dissolve if the beds came in contact with circulating, unsaturated solutions. West of the proposed site, where the salado rises to the surface, progressively less halite is present as a result of leaching by percolating ground water. Where exposures existed, all of the salt has been removed (see section 4.3.2:). 
As discussed in Section 4.3.2., removal of salt from the Salado Formation in the western portion of the basin where it is exposed, or near the surface, has formed a residuum of clay, gypsum and sand. In the carlsbad area along the Pecos River and to the west, Bjorklund and Motts (1959) report that these clays are dense, and are referred to as "red beds". They suggested that the residue has slowed ground-water infiltration and subsequent salt removal.

Underlying Nash Draw, a salt dissolution zone is present in the residuum at the contact between the salado and the overlying Rustler Formation. As reported by Mercer and Orr (1977), the dissolution zone extends from the recharge area north of Nash Draw to its termination in the vicinity of Malaga Bend. Water penetrates the overlying units through fractures and solution zones in the recharge area and moves southward along the top salt, and discharges into the Pecos River at Malaga Bend (Figure 6.3-2). The dissolved solids content of the brine at the river has been reported to be in excess of $300,000 \mathrm{ppm}$. Theis and Sayre (1942) calculated the discharge from the brine aquifer into the Pecos River at Malaga Bend to be about $200 \mathrm{gpm}$. Hale (in Hale, Hughes, and Cox, 1954) calculated a value of transmissivity of $8,000 \mathrm{ft}^{2} / \mathrm{d}$ from aquifer tests in the area between Malaga Bend and Laguna Grande de la Sal. Apparently, as salt has been progressively leached from the overlying beds, the residuum has developed a base of low hydraulic conductivity, preventing further downward leaching, and the dissolution zone has developed along the same structural control as Nash Draw (Robinson and Lang, 1938).

\subsubsection{Hydrology of Rocks Overlying the Salado Formation}

Nearly all of the water bearing formations overlying the salado in the Delaware Basin are of materials with low hydraulic conductivity and which contain limited amounts of poor-quality water. The major hydrologic unit in the area that yields moderate quantities of marginal-quality water to wells is the alluvium of the Pecos River valley. Information on the hydraulic characteristics of these water bearing formations is limited, and only regional descriptions of potentiometric levels and hydraulic conductivity can be established. 
Rustler Formation The Rustler Formation extends laterally beyond the limits of the Salado Formation and consists of interbedded anhydrite, dolomite, siltstones, clays, and halite. Two dolomite beds in the formation are water-bearing units, other than the Rustler-Salado contact, discussed above. The thickness of the dolomite beds ranges from 20 to 30 feet; these beds are areally extensive. The Magenta Dolomite is a finely crystalline, dense dolomite, and the Culebra Dolomite is vuggy and commonly associated with some anhydrite. The Magenta transmits only minor amounts of water and is not considered an important aquifer (Lambert and Mercer, 1977).

Although the Culebra Dolomite is areally persistent, yields of water vary considerably from place to place. Cooper and Glanzman (1971) suggested that the variability of yields is related to the size and number of fractures and openings in the dolomite, which in turn, could be related to its depth. In the northern part of Nash Draw, the dolomite is near the surface and is reported to yield as much as $700 \mathrm{gpm}$. East of Nash Draw, where the dolomite is covered with Triassic and younger rocks, yields are typically at least two orders of magnitude less.

Measurements of the hydraulic properties of the Culebra in the region are scarce, primarily originating from studies related to Project Gnome investigations (Cooper and Glanzman, 1971). Aquifer-performance tests in holes drilled for Project Gnome studies indicate a transmissivity of 460 $\mathrm{ft}^{2} / \mathrm{d}$, an average hydraulic conductivity of $16 \mathrm{ft} / \mathrm{d}$, a storage coefficient of about $10^{-4}$, and an average effective porosity of 10 percent.

Mercer and orr (1977) prepared a map of the potentiometric surface from water levels measured in wells open to the Rustler Formation in the north portion of the Delaware Basin (Figure 6.3-2). The data were taken from several sources and represent a composite of the Culebra and Magenta dolomites, or other zones. However, it is believed that most wells are open to the Culebra dolomite bed because it is the most consistently producing rock in the vicinity. 
These data indicate that water in the Rustler Formation moves west and southwestward across the Lea - Eddy County line, and southeastward from the community of Carlsbad toward Nash Draw, and the Pecos River to the south. Only the Magenta is exposed locally on the flanks of Nash Draw, and both the Culebra and the Magenta form the floor of wide sections of Nash Draw in the vicinity of Laguna Grande de la Sal.

A single water well in Lea County is reportedly deep enough to have reached Permian beds (Nicholson and Clebsch, 1961); otherwise no additional information is available on occurrence of water in the Rustler Formation in the area.

The Dewey Lake Redbeds. The youngest formation in the Ochoan Series, the Dewey Lake Redbeds, consists of orange-red siltstone with some mudstone and sandstone. This formation has been removed from the western and southern parts of the Delaware Basin by post-Permian erosion but is present in the subsurface throughout most of the site area. The thickness of the formation varies from about 200 feet to as much as 600 feet (Hiss, 1975a).

The Dewey Lake Redbeds are not an aquifer, although some permeable sand lenses are present and yield small quantities of water to a few wells. Regionally, the beds act as an aquiclude, restricting water at the surface from percolating downward to more permeable units in the underlying Rustler Formation.

Dockum Group. The Dockum Group consists of three formations. In ascending order, they are, 1) the Tecovas Formation; which consists of up to 300 feet of red shale, siltstone, and fine-grained sandstone, 2) the Santa Rosa Sandstone, which is composed of 100 to 650 feet of red, brown, and gray sandstone, and 3 ) the Chinle Formation equivalent, which consists of up to 1,300 feet of red, maroon, and purple shales and siltstones with lenses of fine-grained red-to-gray sandstone (Hiss, 1975a). The group is present only as a thin wedge in Eddy County, thickening to the east in Lea county and in Texas. 
Both the Chinle Formation equilvalent and the Tecovas Formation are present only as thin, isolated remnants in southeastern New Mexico, primarily in Lea County. The few wells drilled into these formations yield small quantities of poor-quality water (Hiss, 1975a). In contrast, the Tecovas and Chinle are not considered aquifers in the Delaware Basin. The Santa Rosa Sandstone is a principal aquifer in several areas, particularly in winkler and ward Counties, Texas (Hiss, 1975a). It produces both fresh and saline water, depending on location. The westernmost extent of the Santa Rosa Sandstone is just into Eddy County, as shown in Figure 6.3-3. Water levels in wells open to the santa Rosa Sandstone, reported by several sources, are the basis of the potentiometric surface by Mercer and Orr (1977) shown in Figure 6.3-3. Wells completed in the Santa Rosa Sandstone have low yields with specific capacities of 0.14-0.2 gpm per foot of drawdown (Nicholson and Clebsch, 1961); the formation porosity is about 13 percent.

Ground water recharge to the Santa Rosa Formation is Erom precipitation on the outcrop and percolation through sand dunes and the overlying Ogallala Formation to the east (Nicholson and Clebsch, 1961). Movement is generally southwest, but additional recharge apparently occurs along the potentiometric high that trends southwest along the eastern side of Eddy County. Discharge is to underlying formations at the edge of outcrops and reportedly downward through collapse zones such as San simon Swale.

Ogallala Formation. The High Plains (Llano Estacado) region south of the Canadian River is mantled by the Ogallala Formation, which consists of Pleistocene sediments from 0 to 500 feet thick. South of Mescalero Ridge in Lea County the formation becomes discontinuous, and there are no definite remnants of the Ogallala west of easternmost Eddy County. Recharge to the ogallala is by direct precipitation on the outcrop and by percolation through overlying sand dunes and alluvium. Nicholson and Clebsch (1961) reported that the saturated thickness of the Ogallala ranges from 25 to 175 feet. This variability can be attributed to the very irregular Triassic surface that underlies it. Movement of water in 
the Ogallala is controlled to a great extent by the generally southeastward slope of the underlying Triassic red beds (Mercer and orr, 1977).

Quaternary Deposits The Gatuna Formation is the oldest known Quaternary formation in the area and fills channels and steep-walled valleys cut primarily into the Dewey Lake red beds and Rustler Formation. In the type section and in the vicinity of Nash Draw where the Gatuna is readily recognizable, it is overlain by an extensive caliche zone that marks the Mescalero surface (Bachman, 1974). East of Nash Draw, there are few outcrops of the formation.

The Gatuna Formation yields limited amounts of water to wells where the water is in isolated gravel and sand lenses. Yields of one to five gpm are small but are usually sufficient for stock and domestic use. Ground water from the Gatuna probably percolates downward into Triassic sandstone or the Rustler Formation (Mercer and Orr, 1977).

Younger quaternary deposits are represented by alluvium. The most extensive alluvial deposits are along the west side of the Pecos River north of Malaga. Isolated patches of alluvium, however, occur along the Pecos to the south. In some areas the thickness is nearly 300 feet, and yields are reported to be as much as 3,000 gpm (Hendrickson and Jones, 1952). The source of water is primarily underflow from west of the pecos River augmented by leakage from canals and from irrigation return flow.

Alluvium east of the Pecos River is restricted to relatively small closed depressions. Nash Draw and Clayton Basin contain Quaternary alluvium, and, in places such as Laguna Grande de la Sal, contain lake or playa deposits. The thickest alluvial deposits occur within San Simon Swale where they are in excess of 500 feet. Ground water present in the San Simon alluvium may be derived from discharge from the Santa Rosa Sandstone (Mercer and orr, 1977). The lake and playa deposits often yield some water, although it is generally highly mineralized. 


\subsubsection{Regional Ground Water Use}

Ground water is used in the region for irrigation, municipal supplies, rural domestic supplies, stock watering, a few industrial purposes, and for secondary oil recovery (usually referred to as "oil field flooding"). In southeastern New Mexico and western Texas almost all the ground water produced is used for this latter category. The Capitan aquifer is the largest source, but supplies are also taken from the santa Rosa Sandstone and the Rustler Formation (Hiss, 1975a).

Demand for water throughout the region has increased steadily over the past three decades and is expected to continue into the 1980's. Production from the Capitan aquifer alone increased from approximately 80,000 acre-feet in 1950 to about 700,000 acre-feet in 1970 (Hiss, 1975a, Figure 38). The increase has been fairly linear over the 20 year period. Most of the increased demand has been for oil-field flooding which began in the early 1950's. The largest amount of pumping for this purpose is in ward and winkler Counties, Texas, and is primarily extracted from the Capitan aquifer. The other major source is the san Andres Limestone. According to Hiss (1975a), the cumulative total of water produced from these aquifers for the period 1920-1969, in thousands of acre-feet, is as follows:

\begin{tabular}{lcccr} 
& Eddy County & Lea County & West Texas & Total \\
Industrial & 65.4 & - & - & 65.4 \\
Irrigation & 151.0 & - & 223.7 & 374.7 \\
Municipal & 162.0 & - & - & 162.0 \\
Secondary Recovery & 0.6 & 2.8 & 293.0 & 296.4 \\
\multicolumn{1}{c}{ TOTAL } & 379.0 & 2.8 & 516.7 & 898.5
\end{tabular}

Listed below (in acre-feet) is a summary of usage in Eddy county for the year 1949 (Hendrikson and Jones, 1952) and in Lea County for the year 1954 (Nicholson and Clebsch, 1961). It is reasonable to assume that the quantities reported for industrial, irrigation, municipal, and rural use 
have increased a moderate amount. The quantity listed for secondary recovery has increased moderately in southeastern New Mexico and dramatically in west Texas, as noted above.

Industrial

Irrigation

Secondary Recovery

Rural Domestic/Stock

TOTAL
Eddy County (1949)

$$
4,000
$$$$
130,000
$$

0

2,000

141,000
Lea County (1954)

2,710

2,600

40

450

6,350

Occurrence of large quantities of potable ground water is restricted to west of the Pecos River, and most of this water is extracted from the Capitan aquifer. Hiss (1975a) reported that the municipal water supplies for the communities of Carlsbad and White's City are obtained from wells completed in the Capitan aquifer. Hiss also reported that water pumped from the Capitan aquifer is used to irrigate about 2,300 acres of farmland in the Pecos River valley, the immediate vicinity of Carlsbad.

In addition, water pumped from the Capitan aquifer at Carlsbad is transported by pipeline to a potash refining plant located about 18 miles east of Carlsbad. Approximately 3,740 acre-feet of water per year was used to refine potash ore during the period 1965-1969.

Oil Field Secondary Recovery. In the early 1950 's, the petroleum companies operating in the region initiated a process to recover crude oil that could no longer move to wells under existing reservoir pressure. This secondary recovery technique is one in which water is injected under pressure into the oil-bearing formation to drive the residual oil to the pumping wells. Injection may be into existing depleted wells or into wells constructed specifically for this purpose.

According to Hiss (1975a, Table 15), a cumulative total of nearly 300,000 acre-feet of water has been produced from the Capitan aquifer for 
secondary recovery versus a total of about 725,000 acre-feet actually used in the flooding process. The difference of 425,000 acre-feet has been supplied from other sources including the San Andres Limestone and the Ogallala and Rustler Formations. The major areas of extraction for this use are in ward and winkler Counties, Texas.

Ground Water Utilization East of the Pecos River, Southeast New Mexico. In this area, small amounts of ground water are used for rural domestic supplies, stock watering, gasoline plants, and gas stripping. The Rustler Formation, the Santa Rosa Sandstone, and the Artesia Group are the principal hydrologic units pumped for those purposes. In the Nash Draw area, relatively large quantities of ground water have been taken from the Rustler Formation for use in potash refining. In the past, considerable amounts were pumped for irrigation in Lea County, but this has apparently been discontinued (Nicholson and Clebsch, 1961).

Gasoline plants use a considerable amount of water for their cooling and boiler systems. Nicholson and Clebsch (1961) report that in Lea County a total of 2400 acre-feet of ground water was used for this purpose in 1959. Gas stripping plants in the area also use water for extracting hydrogen sulfide and carbon dioxide from residual gas. Nicholson and Clebsch (1961) estimated that 150 acre-feet per year is used for this purpose.

In 1972, Cooley (1973, Table 4) inventoried the existing and abandoned wells in a nine-township block in east-central Eddy and west-central Lea Counties, New Mexico. Most of these wells are of low yields and are used mainly for domestic supplies and stock watering. Table 6.3-2 is extracted from the Cooley survey; well locations are shown on Figure 6.3-4.

\subsubsection{Ground-Water Occurrence at the Proposed Site}

The wells in the vicinity of the site (Figure 6.3-4) indicate that ground water above the Salado Formation is found only in limited quantities, and 
is commonly of such poor quality, that it is not usable. Where the quality is marginal, it is utilized for watering stock, and is considered a valuable resource (Nicholson and Clebsch, 1961). Below the Castile Formation, at considerable depth, the Bell Canyon Formation might yield large quantities of water, but it would be brine. Although these units are technically regarded as aquifers, in the following discussion, only the hydrologic characteristics of fluid-bearing zones underlying the proposed site will be described. These zones are not identified as aquifers because an aquifer readily yields good quality water to wells.

Fluid-bearing zones. The hydrologic exploration at the proposed site performed by the U. S. Geological survey to date has been directed primarily to the fluid-bearing rocks of the Rustler Formation, and to the Rustler-Salado contact zone. They directly overlie the salado salt and furnish a potential, although remote avenue for salt dissolution and radionuclide transport (Mercer and orr, 1978). Additionally, brines in the sands of the underlying Bell Canyon Formation have been tested. These fluids are under sufficient head to allow them to reach the Salado salt. Because the brines are undersaturated, they could dissolve the salt. However, to reach the Salado, these fluids would have to first penetrate the Castile Formation. Permeabilities (or lack of permeability) of the Castile and Salado Formations at the site have been determined by drill-stem tests in two exploratory holes: ERDA No. 9 and AEC No. 8. The tests, summarized by Lambert and Mercer, 1977, Tables 1 and 2 , indicate that the two formations are extremely tight. The tests gave no indication of fluid content in either formation.

Other zones that were briefly tested include zones in the Dewey Lake red beds where circulation was lost during drilling, or where hydraulic conductivity was believed to be measurable. However, no appreciable amounts of fluid were encountered (Mercer and Orr, 1978).

When the exploration and testing were completed, Mercer and orr (1978) made several conclusions concerning the occurrence of fluids in the rocks. These include the following: 
Monitoring of fluid-bearing zones in the Rustler Formation indicate that stabilized heads decrease with depth; consequently, potential fluid movement would be downward in rocks above the salt. However, the large head differences between fluid-bearing units within the Rustler indicate little or no vertical connection.

Head distribution determined for the Culebra dolomite indicates fluid movement to the southeast across the site. Gradients range from 7 to $120 \mathrm{ft} / \mathrm{mi}$ and vary as a function of hydraulic conductivity.

Head distribution within the Magenta dolomite has been determined only in three holes and indicates fluid movement to the southwest. The hydraulic gradient is $50 \mathrm{ft} / \mathrm{mi}$.

Fluids in the Culebra and Magenta are expected to move primarily along fracture systems, and measurements of the effective porosities and hydraulic conductivities in low-yielding fractured rocks are very difficult to obtain.

Brines were found at some locations along the Rustler-Salado contact, but extremely low yields were measured.

Although evaluation of the testing of Bell Canyon sands is not complete, preliminary results at AEC-8 indicate the potentiometric surface, corrected to fresh-water density, is higher than similarily corrected levels of fluid zones in the Rustler Formation.

Hydrologic Testing. The geologic and geophysical exploration performed at the site provides a detailed understanding of the stratigraphy and structure of the underlying formations. This work was described in previous sections. In coordination with the exploratory drilling, a program of hydrologic testing and monitoring was established. As a result, considerable data on the occurrence of ground water have been collected. The ground-water studies are continuing and the data collected will further our understanding of the site conditions. 
In addition to continued monitoring of the existing observation wells, long-term pumping tests to measure vertical connection between zones, and other tests have been planned. Also, some hydrologic information is available from the recently completed ERDA 10 test hole, located approximately 8.5 miles southwest of the proposed site.

One of the major problems faced in this program is the difficulty of measuring hydrologic parameters in materials of extremely low hydraulic conductivity in the field. Thorough testing of even the more permeable zones, such as the Culebra Dolomite, requires long periods of time, as well as close control of the interval being tested. To collect a sufficient quantity of water from these materials for proper water quality sampling requires long periods of time. Recovery of water levels in observation wells to static conditions is very slow; levels in some of the wells on site had not stabilized after more than 12 months of monitoring. Nevertheless, the data collected are sufficient to provide a good measure of the hydraulic characteristics and an understanding of ground-water occurrence at the proposed site. Hydrologic test data as of August, 1978, are available from 9 exploratory holes within the proposed land withdrawal boundary, and from the hole designated AEC 8, which is just outside the boundary, as shown on Figure 6.3-5. The U. S. Geological Survey water Resources Division has been directing the testing program. A summary of drilling and testing operations is given for each hole in section 6.4. A full description of the testing program and the data collected is presented in Mercer and orr, 1978. The following discussion is extracted from that report.

The objectives of the program have been to determine the static head or reservoir pressure, the water-yielding potential (i.e., hydraulic conductivity and transmissivity) of the rock strata, and the chemistry of formation waters. These hydrologic tests are made in the exploratory test holes both during drilling and after the hole has been drilled to total depth. 
Five of the test holes were specifically designed for hydrologic testing ( $\mathrm{H}-1, \mathrm{H}-2$ complex, and $\mathrm{H}-3)$; the others were drilled for other purposes as well (potash mineral evaluation and/or geologic exploration) but were adapted for hydrologic testing. After drilling and testing wells $\mathrm{H}-1$ and $\mathrm{H}-3$, triangular arrays $\mathrm{H}-4, \mathrm{H}-5$, and $\mathrm{H}-6$ complexes were designed similar to the $\mathrm{H}-2$ complex but with a 100-foot well spacing. The additional sets of triangular arrays ( $\mathrm{H}-4, \mathrm{H}-5$, and $\mathrm{H}-6)$ have been completed recently and testing has started.

The H-series test holes were drilled with air and detergent to avoid the undesirable mudcake that occurs when drilling with gel. This method also allows detection of fluid-producing zones that are encountered during drilling. When detected, some of these zones were tested before completion of drilling for a preliminary estimate of yield. On completion of drilling, geophysical logging was performed in all holes. These logs provided detailed information on lithologic changes, formational characterstics, potential zones of water yield, and borehole diameter changes. These data are used to select intervals to be tested, as well as provide information on hole conditions in the selection of packer seats.

Following logging, each potential zone of water $y^{i e l d}$ was isolated with packers, and a drill-stem test (DST) was conducted. The DST is a temporary well completion designed to furnish hydrologic data, such as representative samples of formation fluid, undisturbed formation pressures, and indications of the formation permeablity, and/or transmissivity. The standard DST, as used in oil-field exploration, was run in test holes AEC 8 and ERDA 9, but in the other tests the procedures were modified. The modification most commonly made was in the method of recording formation pressures. In the standard DST, pressures are recorded throughout the test by a Bourdon-tube pressure recording gage (pressure bomb) -located near the bottom of the drill string. Data from this pressure bomb cannot be retrieved until after completion of the test. In the modification DST used in these investigations, the fluid was initially removed from the tubing, and the stabilizing fluid levels 
were measured in the drill string. This modification allowed for continuous monitoring throughout the test. Additionally, pressure-monitoring devices were placed above and below packers to determine the degree of isolation of the zone from the rest of the borehole.

The test zones were bailed or swabbed until temperature, conductivity, and density of fluid in the casing stabilized to assure that the fluid was representative of formation fluid. Samples were then collected, treated according to standard U. S. Geological Survey techniques, and chemically analyzed for the major and trace elements and for radiochemistry. Results of these analyses are listed in Table 6.3-3. The geochemistry of these fluids is discussed in Chapter 7 .

During the bailing, the volume and rate of fluid withdrawal were monitored. The rate of recovery following withdrawal was measured, and yields from test zones were then calculated. The results of these tests are summarized in Table 6.3-4.

After all potential water zones were tested in the open hole, casing was installed and grouted in all holes except ERDA 9. Selected intervals were perforated for monitoring potentiometric levels, and provision was made for long-term hydrologic testing. Radioactive tracer tests were conducted in some of the holes after they had been cased and perforated to examine the cement-bond for leaks between casing and the borehole wall. These tests also yielded some information on vertical distribution of permeability across the test interval. The perforated zones were then tested for yield by bailing or swabbing, as was done in the open hole, and results are summarized in Table 6.3-4.

When the testing of the cased holes was completed, the holes were prepared as multiple observation wells. The holes are used to monitor potentiometric levels of two separate zones with the use of packers and inner tubing. In some wells, a-third zone was perforated, but a bridge plug was set above it, and the zone is not available for periodic 
monitoring. Figure 6.3-6 illustrates the method of completing the wells, and Table 6.3-5 indicates the zones monitored at each observation well.

Periodic monitoring of the fluid levels in the wells began after completion of testing. Because of the low yield of the zones tested, considerable time is required after bailing for the recovery of fluid to reach a stabilized level. Most levels had stabilized by October 1977, as indicated in Table 6.3-6. These levels provide a measure of the potentiometric surfaces of the monitored zones, and an indication of hydraulic gradients.

Bell Canyon Formation. During the WIPP hydrologic testing program, cores were taken in the Bell Canyon Formation in exploratory hole AEC 8. Analyses of these cores indicated the presence of two sandstone units whose permeabilities were higher than those of the surrounding rocks. These units are referred to as the lower sand and upper sand; their depths are, respectively, 4,844 to 4,860 feet, and 4,821 to 4,827 feet.

Hydrologic testing of the two sand units was made only in cased, perforated zones. There was no open-hole testing. These tests included formation pressure testing, fluid level monitoring, aquifer yields, recovery rates, water sampling, and geophysical logs. Radioactive tracer logs were also run on this hole. Analysis of the data had not been completed at the time of the report by Mercer and orr (1978).

After the fluid in the casing had been removed by swabbing to a depth of approximately 4,200 feet, the lower sand yielded 31 gallons of fluid in 166 minutes (average $0.2 \mathrm{gpm}$ ), recovering to a depth of 4,095 feet. The zone was then shut-in, and a static formation pressure of $2,037 \mathrm{lbs} / \mathrm{in}^{2}$ was reached in 44-1/2 hrs. The upper sand was not tested for yield. Static formation pressure was $2,0441 \mathrm{bs} / \mathrm{in}^{2}$ after 57 hours.

Samples collected from the two sand units indicate that these units contain dense brines. For example, the upper sand contains 189,000 ppm of total dissolved solids, 175,000 ppm of which is sodium chloride 
(Mercer and Orr, 1978, p. 80). The major constituents from the analyses are listed in Table 6.3-3. Density of the brines of each zone was determined to be $1.11 \mathrm{gm} / \mathrm{cm}^{3}$ for the upper sand, and $1.12 \mathrm{gm} / \mathrm{cm}^{3}$ for the lower sand. These values were used to correct static heads to fresh-water equivalents (Table 6.3-6).

Rustler-Salado Contact. The contact zone between the Rustler and Salado Formations was tested in holes $\mathrm{H}-1, \mathrm{H}-2 \mathrm{C}, \mathrm{H}-3, \mathrm{P}-14, \mathrm{P}-15, \mathrm{P}-17$, and $\mathrm{P}-18$.

Both open-hole and cased-hole tests were $r$ un on the Rustler-Salado contact in $\mathrm{H}-1$ and $\mathrm{H}-3$, and cased hole tests were $r$ un in $\mathrm{H}-2 \mathrm{C}, \mathrm{P}-14$, P-15, P-17, and P-18. Without exception, all tests showed very low yields, typically producing a few gallons per day in the cased holes and only slightly more in the open holes (Table 6.3-4). A yield of 9.1 gallons in a 20-hour period (in $\mathrm{H}-1$ ) was the highest yield recorded. Based on the collected data, Mercer and orr (1978, p. 83) calculated transmissivities from the yield data, ranging from $10^{-1} \mathrm{ft}^{2} /$ day (in $\mathrm{P}-14$ ) to $10^{-4} \mathrm{ft}^{2} /$ day (in $\mathrm{P}-18$ ). Recovery rates in the monitoring wells are so slow that the level had not stabilized in P-18, after 4 months (Table 6.3-6).

Samples were taken from all of the test wells except P-18. Analyses of these samples show that the fluid in the Rustler-Salado contact zone is a saturated brine containing more than 300,000 ppm total dissolved solids (Table 6.3-3).

Culebra Dolomite. The Culebra dolomite was tested in holes $\mathrm{H}-1, \mathrm{H}-2 \mathrm{~b}$, $\mathrm{H}-2 \mathrm{C}, \mathrm{H}-3, \mathrm{P}-14, \mathrm{P}-15, \mathrm{P}-17$, and P-18. Logs of these holes indicate that the thickness of this unit is about 28 feet and that its depth ranges from 410 to 940 feet below ground level.

Both open-hole and cased-hole tests were $r$ un in the Culebra in $\mathrm{H}-1$ and $\mathrm{H}-3$, and cased hole tests were run in $\mathrm{H}-2 \mathrm{C}, \mathrm{P}-14, \mathrm{P}-15, \mathrm{P}-17$, and $\mathrm{P}-18$. Yields varied considerably. At P-14, 720 gallons of fluid were bailed with no noticable drawdown, while P-18 produced only 16 gallons of fluid 
in 33 days of monitoring. Preliminary transmissivity values calculated by Mercer and Orr (1978) also reflect the variability with values of 140 $\mathrm{ft} 2 /$ day at $\mathrm{P}-14,10^{-1} \mathrm{ft}^{2} /$ day at $\mathrm{H}-1$, and $10^{-4} \mathrm{ft}^{2} /$ day at $\mathrm{P}-18$.

Mercer and orr (1978) reported that fluids in.the Culebra have a total dissolved solid range of 23,700 to $118,300 \mathrm{ppm}$, and a sodium chloride range of 17,900 to $89,200 \mathrm{ppm}$. The major constituents of samples taken from the Culebra are listed in Table 6.3-3.

Magenta Dolomite. The Magenta Dolomite was tested only in $\mathrm{H}-1, \mathrm{H}-2 \mathrm{a}$, and H-3. In these holes the Magenta is 25 feet thick and the top of the unit is 502 feet below ground level.

Both open-hole and cased-hole modified drill stem tests were run on the Magenta in $\mathrm{H}-\mathrm{l}$ and $\mathrm{H}-3$; well number $\mathrm{H}-2 \mathrm{a}$ was constructed as an observation well for the Magenta. The open-hole drill-stem test on the Magenta in $\mathrm{H}-1$ produced only 13 gallons of fluid in 13 hours. A subsequent swabbing of the permeable zone produced 107 gallons of fluid, which indicated higher productivity than the DST displayed. In the cased-hole test, the Magenta zone was bailed constantly until a pumping level of 424 feet (depth) was attained. After bailing was stopped, the fluid level recovered to a depth of 340 feet in 33 days. In $\mathrm{H}-3$, an open hole drill-stem test produced 23 gallons of fluid in 38 hours, but 442 gallons were swabbed from the hole after the DST was discontinued. In the cased hole test, 1 hour of bailing produced 6 feet of drawdown, and recovery was from 405 to 401 feet in 33 days of monitoring. Preliminary transmissivity values computed by Mercer and orr (1978) range from 40 $\mathrm{ft} 2 / \mathrm{d}$ to less than $1 \mathrm{ft} 2 / \mathrm{d}$.

The quality of the Magenta fluids is poor (Table 6.3-3), with a total dissolved solids range of 10,300 to $29,700 \mathrm{ppm}$. The sodium chloride range is from 6800 to $24,300 \mathrm{ppm}$.

Salt-Residue zone. Rocks of the Rustler Formation in which halite beds have been removed by leaching--salt-residue zones--were considered to be 
areas for possible fiuid retention. A potential zone was identified from geophysical logging and drill stem tests performed in $\mathrm{H}-1$ and $\mathrm{H}-3$. Results show that very little fluid now exists in those zones. In $\mathrm{H}-1$, the suspected zone yielded 11.2 gallons of fluid in 12 hours of monitoring .

\subsubsection{Dissolution of Salt in the Permian Evaporites}

Features apparently caused by solution and/or subsidence are common in southeastern New Mexico. The extensive karst plain of the Llano Estacado (the High Plains or Caprock region) indicate the prominence or rock solution as a geologic process. Depressions near the WIPP site range from small features no more than a few meters in diameter to large features such as Laguna Grande de la Sal (Salt Lake), 11 miles to the west-southwest of the WIPP site, and Laguna Plata and Laguna Gatuna, 14 miles to the north. Not all depressions in the region, however, have been formed by solution and collapse. Some have been formed by wind action, and others are the result of solution or etching of the caliche. Salt Lake does appear to occupy an area of coalesced collapse dissolution sinks, but Laguna Plata and Laguna Gatuna appear to have formed as solution blowouts in windborne sand deposits.

A report to Sandia Laboratories by R. Y. Anderson was prepared in early 1978. This report served to assemble and summarize available data regarding the dissolution of evaporites in the Delaware Basin. The Anderson (1978) report also proposed a set of working hypotheses for the origin of various dissolution features, in order to guide future sandia investigations of evaporite dissolution relevant to the potential integrity of the WIPP horizons and adjacent evaporites. In the text that follows, an attempt is made to distinguish available data from working hypothesis, whenever Anderson (1978) is cited.

It has been estimated that as much as 50 percent of the original salt of the Delaware Basin evaporites has been removed (Anderson, 1978) either by surface erosion or by subsurface dissolution and transport by ground 
water. These processes have been in progress intermittently through more than 100 million years (Bachman, 1974). At least four erosional periods, in which the removal of salt could have been accomplished, can be recognized. These include: 1) Early Triassic time, 2) Jurassic through Early Cretaceous time, 3) a Late Cretaceous through mid-Tertiary period, and 4) post-ogallala uplift and erosion.

Of the processes which accomplished the removal, two types of salt dissolution have been recognized in the Delaware Basin. The more familiar dissolution is the removal of salt by waters percolating downward from above (primarily from precipitation falling directly on the ground surface above the salt). The percolating water removes soluble salts, leaving behind a residuum of insoluble material that is referred to as a leached zone (Vine, 1963). The shallow dissolution beneath Nash Draw is such a zone and is apparently the route of lateral migration of the leached salts that discharge into the Pecos River.

A second type of salt dissolution has been recognized as having dissolved salt from somewhere within the body of evaporites, generally resulting in the collapse and lowering of the overlying stratigraphic units. Anderson (1978) recognized the resulting insoluble residue as a blanket

dissolution breccia which occurs to the west of the present salt edge in the basin. In addition, deep dissolution phenomena within the evaporites may have developed more localized collapse features that have been recognized around the margin of the basin and within the basin (Maley and Huffington, 1953). The origin of these deep dissolution features and breccias is more problematical than the origin of surface dissolution and the rates of dissolution more difficult to assess. Source of the water to dissolve the salt is hypothetically assumed to be aquifers underlying the salt beds, communicating through fracture systems in the intervening anhydrite beds.

Shallow Dissolution. The depth of shallow dissolution in the evaporites (base of leached zone) is highly irregular, but is usually less than 300 feet in the vicinity of the proposed site (see section 4.3.2). It is 
developed in the western part of the Delaware Basin where the evaporites are exposed, or near the surface. For example, in Nash Draw, where the Rustler Formation is exposed, leaching extends into the Salado, and the permeable residuum contains brine (Vine, 1963). It appears that percolating ground waters move laterally toward Nash Draw, eventually discharging to the Pecos River after becoming saturated with salt.

East of Nash Draw, down dip into the basin, the evaporite formations become progressively deeper, and the present-day top of salt becomes progressively higher in the stratigraphic section. The top of salt is at the top of the Salado Formation about 2 miles west of the center of the proposed site, and becomes progressively higher in the Rustler Formation across the site (Figure 6.3-7, also see Figure 2-6).

Jones (1972) reported the solution front in the Salado Formation to be between 2 and 3 miles west of the center of the site. Bachman (1974) described a thinning of the upper member of the Salado Formation to the west and north that he attributed to a combination of thinning inherent in the original deposition processes and thinning due to subrosion "during the middle and late Cenozoic. West of the line marked "edge of Salado salt" in Figure 6.3-8, there is almost a fourfold reduction in thickness of the upper member of the Salado Formation to as little as 150-170 feet in some places. This is the residue of a 500-foot thick section from which the soluble portions have been leached by circulating ground water. Wherever the upper member of the salado has been thinned by dissolution, the section of rock between the upper surface of the remaining salt and the top of the formation consists of clay with crudely interlayered seams of broken gypsum (from rehydration of anhydrite) and fine-grained sandstone.

As dissolution progresses and the salts are carried away, voids develop and the residual layer is weakened until it is no longer able to support the overlying material. Slumping of the residue and the associated collapse of the roof can extend to surface elevations, resulting in a 
topographic sink. The distinctive pitted topography that results is termed karst. Such topography, in which surface drainage is poorly defined, is extensive in southeastern New Mexico. .

Bachman (1974) reported that dolines (that are believed to develop into shallow sinks on the rock surface beneath the soil mantle) are very common, and suggested that the course of the Pecos River southward from Carlsbad to the proximity of the New Mexico-Texas state line lies in a major belt of collapsed sinks. For example, along the east side of the Pecos River, southeast of Carlsbad at Malaga Bend, a linear scarp is believed to have formed along a collapse structure that is now occupied by the river. Other major collapse features mentioned by Bachman include Clayton Basin and Nash Draw. Bachman believes that these features formed as coalescing sinks, probably during Pleistocene time.

Another large depression cited by Bachman is San Simon Sink, located 22 miles east of the proposed site. Shallow dissolution is a factor in the development of this sink, which is apparently still in process. The last recorded collapse in San Simon sink occurred approximately 40 years ago (Nicholson and Clebsch, 1961). Many sinks along the Pecos River Valley have collapsed in historic time (Bachman, 1974). As recently as 1973 a small collapse sink formed at Lake Arthur, N.M., about 50 miles $(80 \mathrm{~km})$ north of Carlsbad.

Deep Dissolution. Large, deep dissolution features filled with Cenozoic sediments overlying the inner margin of the Capitan reef (Figure 6.3-8) were recognized by some of the first geologists working in the Delaware Basin (Maley and Huffington, 1953). The source of water to dissolve the salt was assumed to be the Capitan aquifer.

The extent of large-scale dissolution structures is shown on Figure 6.3-8. The dissolution wedges were identified through varve correlation across the basin in the Castile Formation and recognition of dissolution breccia beds in the western part of the basin (Anderson et al., 1972). These studies suggest that deep dissolution wedges in the Castile 
Formation occurred in the lower Salado and upper Castile salt beds (Anderson, 1978). The position of the eastern margin of the western wedge coincides with the location of dissolution features containing deep Cenozoic fill (Figure 6.3-8). The development of these features and the wedge was apparently a complex process. It probably included initial wedge development adjacent to the reef, similar to that seen in the eastern wedge (Anderson 1978), and later combined with shallow dissolution.

The most prominent small-scale, (less than 1 mile across) dissolution features in the vicinity of the Delaware Basin have been described by Vine (1960) as "domal karst features". The subsurface projection of one of these (dome "C") was encountered at the level of the McNutt potash zone by Mississippi Chemical Corporation. It was found to be a chimney in the Salado Formation filled with clay-cemented brecciated rock belonging to strata above the 7 th ore zone. There are other erosion-breached domes similar to Vine's dome " $C$ " in the vicinity of Nash Draw. The subsurface expression of the domes, if any, is virtually unknown. A chimney containing cemented rubble (incorrectly termed a "breccia pipe") was encountered in commercial exploratory drilling within the proximity of a low circular hill near the wills-Weaver Mine, but this chimney was not associated with a breached-dome at the surface. Recent geophysical surveys of the region have revealed that some of these hills, including the "Weaver Pipe" and dome "C", are associated with resistivity lows. Both Vine (1960) and Anderson (1978) have proposed mechanisms for origin of these features, all of which remain to be tested by field investigations of their subsurface structure and composition (see chapter 10). These mechanisms involve various combinations of differential solution, hydration of anhydrite to gypsum, and salt intrusion. An attempt to reconcile these mechanisms and apply them to the origin of domes near Queen Lake southwest of Nash Draw was made by Reddy (1961).

Anderson believes that the dissolution giving $r$ ise to these features is an ongoing process. The proposed site is in an area of the Delaware Basin that is free of regional deep dissolution, but localized features 
are present in the vicinity. Nevertheless, the extensive investigation carried out at and near the proposed site, including exploratory holes, ERDA-10, ERDA-11, ERDA-9, and AEC-8, indicate that deep dissolution is not taking place there. ERDA 10 was located and drilled specifically to evaluate the suggestion of Anderson that the absence of Halite III in the Castile south of the WIPP site was due to deep dissolution. Examination of the core revealed no apparent solution residue or collapse breccia; the recently collected data indicate nondeposition rather than dissolution since this was the nearest probable location of regional deep dissolution, its absence implies a lack of threat to the WIPP site from this phenomenon.

Rates of Dissolution. It is evident that dissolution is an active process, and can be expected to continue in the future. The potential hazard to the proposed site by continued dissolution in nearby places such as Nash Draw, 7 to 8 miles west of the site, can be evaluated if the rates of dissolution are known. In relation to human activity, the rate of dissolution is almost immeasureably slow. However, in terms of geologic processes, an attempt to estimate the rate is not altogether impractical. As stated by Bachman (1974): "Active geologic processes have not changed since the close of Tertiary Ogallala time, about 3-4 $m \cdot y$. (million years) ago. However, the rates of these processes have varied considerably. It is assumed that the rates of these processes will continue to vary and that prediction of future events can be made by assuming that the extremes of past conditions will not be exceeded in the future."

With this in mind, Bachman analyzed the rate of dissolution in Nash Draw since the development of the Mescalero caliche, estimated to be 600,000 years ago. The following summarizes his analysis (Bachman, 1974):

Collapse of the Mescalero caliche along the margins of Nash Draw indicates that this depression has formed, at least in part, since the deposition of the caliche. 
Along Livingstone Ridge on the east side of Nash Draw, the Mescalero caliche is undeformed at elevations above 3,300 feet. It dips steeply into the depression along the ridge and occurs at elevations of 3,200 feet, and less, within the depression. Along Quahada Ridge on the west side of Nash Draw the Mescalero is likewise undeformed at elevations about 3,300 feet, but it dips steeply into Nash Draw and occurs as collapsed fractured masses within the depression (NE 1/4 sec. 1, T. 22 S., R. 29 E.).

A cross section through potash exploratory holes in Nash Draw indicates the approximate extent of salt dissolution in the Salado Formation since Mescalero time (Figure 6.3-9).

Nash Draw appears to have subsided between Livingstone and Quahada Ridges as much as 180 feet since Mescalero time. At one locality the surface of Nash Draw is 180 feet below the projected altitude of the Mescalero caliche (See figure 6.3-9). However, the interval between the top of the Salado Formation and the top of marker bed 124 at the same location is 420 feet, or 330 feet less than at Livingston Ridge where relatively little salado salt has been removed. It is therefore interpreted that about 150 feet of Salado salt was removed before Mescalero time and about 180 feet has been removed since Mescalero time. At another locality, Nash Draw subsided approximatley 160 feet below the projected elevation of the Mescalero caliche while about 120 feet of Salado salt was being removed. There is a discrepancy here of about 40 feet that could be explained by surficial erosion.

Thus, in the area of Nash Draw that subsided 180 feet, the average rate of vertical dissolution over the 600,000 years was about 0.33 feet per 1000 years (Bachman, 1974).

These conclusions are based on the available geologic evidence, but the assumption should not be made that this rate of dissolution is a constant for the region. At least two other factors must be considered in this interpretation, but geologic information is not currently available to permit evaluation of them. The factors are: 
Dissolution and subsidence rates probably have not been constant in Nash Draw during the past 600,000 years. A major part of this subsidence may have occurred during periods of high humidity in late Pleistocene (Wisconsin time).

The subsidence in Nash Draw, whenever it occurred in the Pleistocene, is not an average rate for the region. In the area of "the Divide," between Antelope and Livingstone Ridges, the Mescalero caliche is relatively undisturbed and probably no dissolution has occurred there since Mescalero time.

Calculations have also been made of the removal of salt from the Rustler and Salado Formations in Nash Draw based on the rates of discharge of dissolved sodium chloride and calcium sulfate into the Pecos River by brine seeps at Malaga Bend. Active dissolution of halite from the upper part of the Salado Formation occurs in the solution breccia zone at the base of the Rustler Formation in Nash Draw (Brokaw et al. 1972). The brine solution is believed to be recharged by aquifers in the Rustler and above, and its discharge is thought to be primarily at the Malaga Bend brine seeps and the salt lakes in Nash Draw. Piper (1973) calculated that the salts discharged into the Pecos River between Malaga Bend and a point 6 miles $(10 \mathrm{~km})$ downstream amount to 310,000 tons $\left(2.8 \times 10^{8} \mathrm{~kg}\right)$ of $\mathrm{NaCl}$ and 170 tons $\left(1.5 \times 10^{8} \mathrm{~kg}\right)$ of $\mathrm{CaSO}_{4}$ each year. This is equivalent to a loss of 0.16 vertical feet of salt section per thousand years, a rate of the same order of magnitude as that calculated from the subsidence of Nash Draw.

An alternative approach of estimating vertical dissolution was used by F.A. Swenson (Bachman and Johnson 1973). He investigated the tonnage of salt dissolved and discharged by springs and streams along the east flank of the basin and found the maximum tonnage for the many subbasins to be 955 tons per square mile of drainage area each year. If the discharge continued at that rate it would mean a vertical dissolution of about 0.5 foot of salt in 1,000 years, provided the dissolution was distributed evenly over the area drained. 
A rate of lateral shallow dissolution of salt in the western part of the Delaware Basin has been estimated to be about 6 to 8 miles per million years horizontally (Bachman and Johnson 1973). These estimates were based on the assumption that the salt-bearing Salado Formation extended to the Capitan reef escarpment on the western edge of the basin at the end of Ogallala time. It is now recognized that dissolution of this salt could have occurred at previous times in the past, and the average rate of salt removal by shallow dissolution is believed to be much slower than those estimates which establish an upper bound.

As stated previously, it is estimated that about 50 percent of the original volume of salt has been removed from the Basin. In considering the rate at which the salt was removed, it is generally recognized that much of the erosion and dissolution probably occurred since the beginning of Cenozoic time. This is a period of major uplift and erosion. Anderson pointed out (1978) that the dissolution features are closely associated with Cenozoic and postuplift hydrologic and structural controls. Nevertheless, as early as Jurassic time the basin was tilted and the western portion shown on Figure 6.3-8 was exposed and subject to erosion (Bachman, 1976). The hydrologic and structural conditions were apparently similar at that time to those of the cenozoic, and the Jurassic climate is recognized to have been wet. Thus, it seems quite likely that the deep dissolution and erosional processes of salt removal could have been significantly accelerated during the Jurassic period.

The rate of deep dissolution is difficult to assess, and Anderson (1978) does not believe that estimates can be made with any degree of confidence, considering the available data. He suggests that if it is assumed that 1). deep dissolution progresses at a constant rate, and 2) that significant dissolution did not begin until after stripping of the Ogallala Formation from the basin (3-4 million years ago), projection of that rate would imply all of the lower salado salt would be removed in about another million years. However, he does not believe the assumptions are valid. 
Deep dissolution, as hypothesized by Anderson, would seem to have been a significant geologic process in Jurassic time, as well as in the Cenozoic. It is apparent that further study of these factors is needed to fully assess the impact on the proposed site. Sandia Laboratories and the U.S. Geological survey are currently performing studies to provide data which should aid in this evaluation (see Chapter 10).

\subsection{HYDROLOGY DRILLING AND TESTING SUMMARY}

6.4 .1 HOLE NO. H-1

LOCATION :

T. 22 S., R. 31 E., Sec. 29

ELEVAT ION :

$3,403.2$ feet (ground level)

DEPTH DRILLED: 848 feet

DATE COMPLETED: June 9, 1976

DRILLING CONTRACTOR: Sonora Drilling Co., Carlsbad, N. Mexico

DRILLING METHOD: Auger 18 inch hole (0-40 feet)

Rotary 7.88 inch hole with air-air/mist (40-731 feet)

Core 4.75 inch hole with air mist (731-842 feet)

Ream 9.88 inch hole (40-848 feet)

CASING RECORD: 10.75 inch O.D. steel surface pipe, (0-40 feet) cemented to surface

7 inch 0. D. steel casing (0-848 feet), cemented to surface (cement plug to 797 feet, drilled to 831 feet)

GEOPHYSICAL LOGS: Differential Temperatures

BHC Acoustic

Compensated Densilog

Dual-Laterolog 
Micro-Laterolog

Compensated Neutron-Gamma

Sperry-Sun Magnetic Survey

HYDROLOGIC TESTING (OPEN HOLE) :

A. 699-842 feet: DST, of Rustler-Salado Contact, 9.1 gallons of water in 20 hours

B. 667-699 feet: DST of Culebra Dolomite, 10.6 gallons of water in 11.5 hours

C. 626-667 feet: DST, of suspected salt residue, 11.2 gallons of water in 12 hours.

D. 562-592: DST of Magenta Dolomite, 13 gallons of water in 13.5 hours; after hole was drilled to 592 feet inflow of $490 \mathrm{gpd}$ was observed.

HYDROLOGIC TESTING (CASED HOLE) :

E. 803-837 feet: Perforated zone, Rustler-Salado contact, water level rose from 826.5 to 811 ( 25 gallons) in 33 days.

F. 675-703 feet: Perforated zone, Culebra Dolomite, fluid level rose from 665 to 406 (4l6 gallons) in nine days.

G. Tracer, ${ }^{131} I$, no annulus leaks, no flow in 694-703 interval, major loss in 675-694 interval, tracer injection rate of $8 \mathrm{gpm}$, total $1634 \mathrm{gal}$. injected.

H. 562-590 feet: Perforated zone, Magenta Dolomite, after bailing, water rose from 424.5 to 340.7 feet in 33 days (53 gallons), could not bail below 424 feet. 
I. Culebra water level stable at 390 feet depth. (October 1977)

J. Magenta water level stable at 249 feet depth. (October 1977)

DRILLING \& TESTING SUMMARY

\subsubsection{HOLE NO. H-2a}

LOCATION :

T. 22 S., R. 31, E. , Sec. 29

ELEVATION:

$3,377.1$ feet (ground leve1)

DEPTH DRILLED: 563 feet

DATE COMPLETED: Febr uary 19, 1977

DRILLING CONTRACTOR: Pennsylvania drilling Co., Carlsbad, N. Mexico

DRILLING METHOD: Auger 18 inch hole (0-33 feet)

Rotary 8.75 inch hole with air-air/mist (33-513 feet)

Core 4.75 inch hole with air/mist (513-563 feet)

(cut 2.25 inch diameter core)

CASING RECORD: $\quad 10.75$ inch O.D. steel casing (C-33 feet) cemented to surface

6.63 inch O.D. steel casing, (0-511 feet), cemented to surface

Geophysical Logs: None. Available from H2C, 90 feet away.

HYDROLOGIC TESTING:

A. 0-188 feet: Stopped drilling after encountering wet zone at 185 feet; interval produced no appreciable fluid in 5 hours 
B. 513-563 feet: Open hole, Magenta Dolomite, water rose from 556.8 to 538.7 in one day (22 gallons).

C. Magenta static level at 249 feet, October, 1977

DRILLING \& TESTING SUMMARY

6.4 .3 HOLE NO. H-2b

LOCATION: $\quad$ T. 22 S., R. 31 E., Sec 29

ELEVATION: $\quad 3,377.1$ feet (ground level)

DEPTH DRILLED: 661 feet

DATE COMPLETED: February 12, 1977

DRILLING CONTRACTOR: Pennsylvania Drilling Co., Carlsbad, N. Mexico

DRILLING METHOD: Auger 18 inch hole (0-33 feet)

Rotary 8.75 feet hole with air-air/mist (33-611 feet)

Core 4.75 inch hole with air/mist (611-661 feet) (cut 2.25 inch diameter core)

CASING RECORD: 10.75 inch O.D. steel casing (0-33 feet) cemented to surface

6.63 inch O.D. steel casing, (0-609 feet)., cemented to surface

Geophysical Logs: None. Available from H2C, 75 feet away.

HYDROLOGIC TESTING:

A. 611-661 feet: Open hole, Culebra cored interval, water rose from 636.9 to 458.0 feet in one day (260 gallons). Level stable at 352 feet (February 1977) 
B. Hole \# $\mathrm{H}-2 \mathrm{C}$ was bailed from the Culebra while monitoring $\mathrm{H}-2 \mathrm{~b}$ in the Culebra. First response in $\mathrm{H} 2 \mathrm{~b}$ was detected 50 minutes after bailing of H2C started.

c. 510-538 feet: Perforated zone, Magenta Dolomite, water rose from 560 to 420 feet in one day ( 210 gallons).

D. Well constructed for monitoring at Culebra Dolomite via tubing and Magenta via annulus. Culebra static level at 351 feet, Magenta static level at 292 feet (perforations may be blocked).

DRILLING \& TESTING SUMMARY

\subsubsection{HOLE NO. H-2C}

LOCATION:

T. 22 S., R. 31 E., Sec 29

ELEVATION :

$3,377.1$ feet (ground level)

DEPTH DRILLED: 795 feet

DATE COMPLETED: February 5, 1977

DRILLING METHOD: Auger 18 inch hole (0-33 feet)

Rotary 8.75 inch hole with air/mist (33-743 feet)

Core 4.75 inch hole with air/mist (743-795 feet)

(cut 2.25 inch diameter core)

CASING RECORD: $\quad 10.75$ inch steel casing (0-33 feet) cemented to surface 6.63 inch O.D. steel casing, (0-742 feet), cemented to surface.

Geophysical Logs: Compensated Densilog

Dual-Laterolog

BHC Acoustilog

Micro-Laterolog 
Compensated Neutron-Gamma

4-Arm Caliper

USGS Lithologic-log

HYDROLOGIC TESTING:

A. 743-795 feet: Open hole, Rustler-Salado cored interval produced 14 gallons in 18 days.

B. 624-652 feet: Culebra perforated zone, water rose from 656.4 to 446.6 in one day ( 310 gallons). Static level at 352 feet. (March 1977)

c. Tracer $13 l_{I}$, no flow below 642 in casing, fluid loss zone was between 631 and 644, especially 640-644 where core indicates pitted and fractured dolomite, tracer injection rate was $8 \mathrm{gpm}$, total $697 \mathrm{gal}$. injected.

D. Dual completion monitoring (Rustler-Salado via tubing and Culebra via annulus) shows Culebra stable at 355 feet (October 1977) and Rustler-Salado still recovering at 34 feet per month. (June 1978)

DRILLING AND TESTING SUMMARY

6.4.5 HOLE NO. H-3

LOCATION: T.22 S., R.31 E., Sec. 29

ELEVATION: $\quad 3,388.7$ feet (ground level)

DEPTH DRILLED: 894 feet

DATE COMPLETED: August 12, 1976

DRILLING CONTRACTOR: Pennsylvania Drilling Co., Carlsbad, New Mexico 
DRILLING METHOD: Auger 18 inch hole (0-38 feet)

Rotary 7.88 inch hole with air-air/mist (38-894 feet)

Ream 8.75 inch hole (38-894 feet)

CASING RECORD: $\quad 10.75$ inch O.D. steel surface pipe (0-38 feet) cemented to surface.

6.63 inch O.D. steel casing, (0-891 feet), cemented to surface (cement plug to 804 feet drilled to 864 feet)

Geophysical Logs: Compensated Densilog

Micro-Laterolog

Dual-Laterolog

BHC Acoustilog

Compensated Neutron-Gamma

Differential Temperature

HYDROLOGIC TESTING (OPEN HOLE)

A. 800-868 feet: DST, Rustler-Salado contact, produced 1.8 gallons of water in 16.5 hours;

B. 672-703 feet: DST, Culebra, produced 2.1 gallons of water in 21.5 hours.

C. 703-780 feet: DST, salt residue, 2 gallons of water in 26 hours.

D. 558-608 feet: DST, Magenta, 23 gallons after 37.5 hours. after developing operation via swabbing.

HYDROLOGIC TESTING (CASED HOLE)

E. 813-837 feet: Perforated Rustler-Salado contact; produced 37 gallons in 32 days. 
F. 675-703 feet: Perforated Culebra, bailed hole and monitored, recovery was up to 410 from an initial level of 550 feet $(200$ gallons in 8 days).

G. Tracer ${ }^{131} \mathrm{I}$, showed no flow below 696 feet; major fluid losses in intervals 684-692 and 692-695; tracer injection rate was $8 \mathrm{gpm}$, total injected $450 \mathrm{gal}$.

H. 562-590 feet: Perforated Magenta, bailed 360 gallons in one hour with 6 feet of drawdown.

I. Dual-completion monitoring (Culebra via tubing and Magenta via annulus) indicate Culebra static level at 404.5 and Magenta static level at 245.1 as of October 1977.

DRILLING \& TESTING SUMMARY

6.4.6 HOLE NO. P-14

LOCATION: T.22 S., R. 30 E., Sec. 24

ELEVATION: $\quad 3,358.1$ feet (ground level)

DEPTH DRILLED: $\quad 1,545$ feet.

DATE COMPLETED: October 3, 1976

DRILLING CONTRACTOR: BOyles Brothers Drilling Co., Las Cruces, New Mexico

DRILLING METHOD: Rotary 8.75 inch hole with air (0-20 feet)

Rotary 7.88 inch hole with air-air/mist (20-784 feet)

Rotary with air/mist (784-1,168 feet)

Core with brine mud $(1,168-1,545$ feet) 
CASING RECORD: 8.63 inch O.D. steel casing (0-20 feet)

4.50 inch O.D. steel casing, (0-775 feet) cemented to surface, hole plugged back from 1,345 feet to 759 feet with cement.

Geophysical Logs: Gamma

Gamma-Gamma

Neutron

Caliper

HYDROLOGIC TESTING (CASED HOLE)

A. 676-700 feet: Perforated Rustler-Salado, fluid level rose from 730 to 620 feet in one day (75 gallons).

B. 573-601 feet: Perforated Culebra, bailed 720 gallons of water in three hours with no drawdown.

C. Tracer ${ }^{131}$, showed 63 percent fluid loss in interval 583-590, remaining loss in interval 573-583; no loss below 590 feet. Injection rate $7 \mathrm{gpm}$. Total injected $1634 \mathrm{gal}$.

D. Dual-completion monitoring (Rustler-Salado via tubing and Culebra via annulus); Rustler-Salado stabilized at 386 feet, Culebra stabilized at 324 feet (October 1977)

DRILLING \& TESTING SUMMARY

6.4.7 HOLE NO. P-15

LOCATION: $\quad$ T.22 S., R.31 E., Sec. 31

ELEVATION: $\quad 3,309.7$ feet (ground level)

DEPTH DRILLED: $\quad 1,465$ feet 
DATE COMPLETED: October 14,1976

DRILLING CONTRACTOR: Boyles Brothers Drilling Co., Las Cruces, New Mexico.

DRILLING METHOD: Rotary 8.75 inch hole with air (0-20 feet)

Rotary 7.88 inch hole with air-air/mist (20-515 feet)

Core 4.75 inch hole with air/mist (515-600 feet) (cut 2.25 inch diameter core)

Ream 7.88 inch hole with air/mist (515-637 feet)

Rotary 5 inch hole with air/mist (637-1,038 feet)

Core with brine mud $(1,038-1,465$ feet $)$

CASING RECORD: $\quad 8.63$ inch O.D. steel casing (0-20 feet)

4.50 inch O.D. steel casing, (0-635 feet), cemented to surface, hole plugged back from 1,465 to 600 feet with cement, cement drilled out to 620 feet.

Geophysical Logs: Gamma

Gamma-Gamma

Neutron

Caliper

Spectralog

HYDROLOGIC TESTING:

A. 532-556 feet: Perforated Rustler-Salado contact, fluid rise from 618 to 497 in 42 days ( 81 gallons).

B. 410-438 feet: perforated Culebra, fluid rose from 496 to 420 feet in one day ( 50 gallons); 125 gallons in 33 days

C. Dual Completion monitoring (Rustler-Salado via tubing and Culebra via annulus) shows Rustler-Salado static level at 324 feet and Culebra at 308 feet as of October, 1977. 
DRILLING AND TESTING SUMMARY

6.4.8 HOLE NO. P-17

LOCATION: T.23 S., R.31 E., Sec. 4

ELEVATION: $3,339.5$ feet (ground level)

DEPTH DRILLED: $\quad 1,660$ feet

DATE COMPLETED: October 26, 1976

DRILLING CONTRACTOR: BOyles Brothers Drilling Co., Las Cruces, New Mexico.

DRILLING METHOD: Rotary 8.75 inch hole with air (0-20 feet)

Rotary 7.88 inch hole with air-air/mist (20-755 feet)

Rotary with air/mist (755-1,220 feet)

Core with brine mud $(1,220-1,660$ feet)

CASING: 8.63 inch O.D. steel casing $(0-20 \mathrm{feet})$

4.50 inch O.D. steel casing, (0-751 feet), cemented to surface, hole plugged back from 1,660 feet to 720 feet with cement, cement drilled out to 731 feet.

Geophysical Logs: Gamma

Gamma-Gamma

Neutron

Caliper

HYDROLOGIC TESTING (CASED HOLE)

A. 702-726 feet: Perforated Rustler-Salado contact; fluid rose from 726 to 622 feet (71 gallons in 73 days). 


\section{6-57}

B. 558-586 feet: Perforated Culebra, single packer set at 683 feet, bailed and monitored for 29 days with fluid rise from 622 to 372 feet.

C. Dual Completion monitoring (Rustler-Salado via tubing and Culebra via annulus) indicates fluctuating levels; problem could be leaking bridge packer or communication in cemented annulus.

DRILLING \& TESTING SUMMARY

6.4.9 HOLE NO. P-18

LOCATION: T.22 S., R. 31 E., Sec. 26

ELEVATON: $\quad 3,478.7$ feet (ground level)

DEPTH DRILLED: 1,998 feet

DATE COMPLETED: November 5, 1976

DRILLING CONTRACTOR: Pennylsvania Drilling Co., Carlsbad, New Mexico.

DRILLING METHOD: Rotary 8.75 inch hole with brine mud (0-18 feet)

Rotary 7.88 inch hole with brine mud (18-1139 feet) to casing depth.

Rotary with brine mud $(1,139-1,630$ feet)

Core with brine mud $(1,630-1,998$ feet $)$

CASING RECORD: 8.63 inch O.D. steel casing (0-18 feet)

4.50 inch 0.D. steel casing, (0-1, 138 feet), cemented to surface, hole plugged back from 1,998 feet to 1,125 feet with cement.

Geophysical Logs: Gamma

Gamma-Gamma

Neutron

Caliper 
HYDROLOGIC TESTING (CASED HOLE)

A. 1076-1100 feet: Perforated Rustler-Salado contact, fluid rise from 1123 to 1073 feet in 73 days ( 34 gallons)

B. 912-940 feet: Perforated Culebra, bailed and monitored recovery for 33 days with fluid rise from 1045 to 1022 feet (16 gallons).

C. Dual completion (Rustler-Salado via tubing, Culebra via annulus) indicated Rustler-Salado at 755 feet and still recovering as of October, 1977.

DRILLING \& TESTING SUMMARY

6.4.10 HOLE NO. AEC-8

LOCATION: T.22 S., R.31 E., Sec. 11

ELEVATION: $3,531.9$ feet (ground level)

DEPTH DRILLED: 3,019 feet (1974), deepened to 4,910 feet (1976)

DATE COMPLETED: August 5, 1976

DRILLING CONTRACTOR: Sonora Drilling Co., Carlsbad, New Mexico

DRILLING METHOD: Core, ream, rotary 7.88 inch hole with brine mud (31-3,019 feet)

Core, ream, rotary 7.88 inch hole with brine mud $(3,018,5-4,910.5$ feet)

CASING RECORD: $\quad 8.63$ feet O.D. steel casing (0-874 feet), cemented to surface.

5.50 inch O.D. steel casing, (0-4,907 feet), cemented to 880 feet. 
Geophysical Logs; Compensated Neutron

Micro-Later $10 g$

Dual-Laterolog

Gamma

HYDROLOGIC TESTING (CASED HOLE)

A. 4,844-4,860 feet: Perforated lower sand lense of Bell Canyon Formation; fluid level rose from 4126 feet to 4095 feet in 166 minutes (31 gallons).

B. 4,832 - 4,910 feet: Production packer with sentry monitoring device showed formational pressure of $2037 \mathrm{lbs} /$ in $^{2}$ reached in 44.5 hours; fluid density was $1.11 \mathrm{~g} / \mathrm{cm}^{3}$.

C. Tracer $131_{I}$, along with temperature logs, indicated major fluid loss in interval 4839 to 4860 feet; minor communication down casing to 4870 feet; tracer injection rate was $14 \mathrm{gpm}$. Total injected $2289 \mathrm{gal}$.

D. 4,821-4,827 feet: Perforated upper sand lense of Bell Canyon Formation; single packer set at 4835 feet; swabbed fluid to 2600 feet; pressure monitor installed at 4805 feet; shut-in pressure recovered to $2037 \mathrm{lbs} / \mathrm{in}^{2}$ in 57 hours, fluid density was $1.12 \mathrm{gm} / \mathrm{cm}^{3}$,

E. Tracer ${ }^{131} \mathrm{I}$, showed no upward or downward communication; injection rate at tracer was $11 \mathrm{gpm}$. Total injected $300 \mathrm{gal}$. Injection was occurring uniformly in the lower 4 feet of perforations.

F. Dual completion monitoring (lowering sand via tubing and upper sand via annulus) indicate lower sand stablized at 615 feet and upper sand at 560 feet as of November, 1977. 


\subsection{SUMMARY}

The proposed site contains neither perennial streams nor surface water impoundment, and the water bearing strata above and below the evaporite section do not yield large quantities of water to wells. At its closest point, the Pecos River is approximately 14 miles southwest of the WIPP site. Water bearing strata in the local site area at stratigraphic horizons above the proposed repository include the Santa Rosa Sandstone and the Culebra and Magenta members of the Rustler Formation. Hydrologic units below the repository horizons include the Bell Canyon Formation of the Delaware Mountain Group. Ground water velocities vary with porosity, hydraulic conductivity, and head gradient but are typically $0.3 \mathrm{ft} / \mathrm{d}$ in the Santa Rosa Sandstone, $0.5 \mathrm{ft} / \mathrm{d}$ in the Rustler Formation, and 0.0006 $\mathrm{ft} / \mathrm{d}$ in the Bell Canyon Formation. Shallow wells in the local area are generally used only for watering livestock and typically produce nonpotable ground water with total solute concentrations in excess of $3,000 \mathrm{ppm}$.

Natural potentiometric levels of fluids from rocks above and below the evaporites at the WIPP site (from the Rustler and Bell Canyon Formations, respectively) are comparable (about 2950 to 3050 above mean sea level). The head differential between upper and lower units varies within about 200 feet on the periphery of the site, the sign and magnitude of the differential depending upon precise geographic location.

Gentle eastward tilting of the Delaware Basin resulting in the exposure of the Salado Formation to near-surface waters has given rise to the removal of a wedge-shaped mass of soluble salts between the Guadalupe escarpment ( $30 \mathrm{miles}$ due west of the site), where there remains no rock salt, and a point about 3 miles due west of the site center, where the Salado Formation is intact.

The proposed site is in an area of the Delaware Basin that is free of regional deep dissolution, but localized shallow features are present in the vicinity. A shallow salt dissolution zone (called the "brine aquifer") occurs in Nash Draw at the contact between the Salado and 
Rustler Formations. This local shallow dissolution area ranges in width from 2 to 10 miles and has a length of approximately 30 miles. The brine solution flows southwesterly at a rate of about $0.2 \mathrm{ft} / \mathrm{d}$ and discharges into the Pecos River at Malaga Bend. The average rate of vertical dissolution has been estimated to be between 0.33 and 0.5 feet per 1,000 years, and the average rate for lateral dissolution has been estimated to be between 6 and 8 miles per million years.

Climatological records show that mean annual precipitation of the site is approximately 12 inches per year. Aided by the low relative humidity (typically 368 during daylight hours) and high mean annual temperature $\left(61{ }^{\circ} \mathrm{F}\right)$, most of the annual precipitation returns to the atmosphere through evaporation and transpiration. Runoff is typically 0.1 to 0.2 inches annually. 


\subsection{REFERENCES}

Anderson, R.Y., Dean, W.E., Kirkland, D.N., and Snider, H.I., 1972, Permian Castile varved evaporite sequence West Texas and New Mexico: Geol. Sọc. Amer. Bull. v. 83, p. 59-86.

Anderson, R. Y., 1978, Report to Sandia Laboratories on deep dissolution of salt, northern Delaware Basin, New Mexico, January 1978, 98pp.

Anderson, R.Y., and Powers, D. W. (in press). Salt anticlines in the Castile-Salado evaporite sequence, Northern Delaware Basin, New Mexico, Symposium on the Ochoan rocks of southeastern New Mexico and West Texas, Cir. 159, New Mexico Bureau of Mines and Mineral Resources.

Bachman, G.O., and Johnson, R., 1973, Stability of salt in the Permian Salt Basin of Kansa, Oklahoma, Texas and New Mexico: U.S. Geol. Survey Open-file report $4339-4$.

Bachman, G.0., 1974, Geologic processes and Cenozoic history related to salt dissolution in southeastern New Mexico: U.S. Geol. Survey Open-file report 74-194.

Bachman, G. O., 1976, Cenozoic deposits of southeastern New Mexico and an outline of the history of evaporite dissolution: U.S. Geol. Survey, Jour. Research v. 4, No. 2, p. 135-149.

Barr, G.E., Lambert, S.J., and Carter, J.A., 1978, Uranium isotope disequilibrium in groundwaters of southeastern New Mexico and implications regarding age-dating of waters. SAND77-1779. IAEA-SM-228/32, Sandia Laboratories, Albuquerque, New Mexico.

Bjorklund, L. J. and Motts, W. S., 1959, Geology and water resources of Carlsbad area, New Mexico: U.S. Geol. Survey Open-file report 59-9.

Blaney, H.F., and Hanson, E.G., 1965, Consumptive use and water requirements in New Mexico: New Mexico state engineer, technical report 32 .

Brokaw, Arnold L., Jones, C.L., Cooley, M.E., and Hays, W.H., 1972, Geology and hydrology of the Carlsbad potash area, Eddy and Lea Counties, New Mexico: U.S. Geol. Survey Open-file report 4339-1.

Cooper, J.B., 1962, Ground-water investigations of the Project Gnome area, Eddy and Lea Counties, New Mexico: U.S. Geol. Survey Report REI-802.

Cooper, J. B., and Glanzman, V. M., 1971, Geohydrology of project Gnome site, Eddy County, New Mexico: U.S. Geol. Survey, Prof. Paper 712-A, 24 p.

Gard, L.M., Jr., 1968, Geologic studies, Project Gnome, Eddy County, New Mexico: U.S. Geol. Survey Prof. Paper 589. 
Griswold, G. B., 1977, Site selection and valuation studies of the Waste Isolation Pilot Plant (WIPP), Los Medanos, Eddy County, New Mexico: SAND77-0946 Sandia Laboratories, Albuquerque, New Mexico.

Hale, W. E., Hughes, L.S., and Cox, E.R., 1954, Possible improvement of quality of water of the Pecos River by diversion of brine of Malaga Bend, Eddy County, New Mexico: Report of the Pecos River Commission, New Mexico and Texas with U.S. Geol. Survey Water Resources Division.

Hendrickson, G. E., and Jones, R. J., 1952, Geology and ground water resources of Eddy County, New Mexico: New Mexico Bureau of Mines and Mineral Resources, Ground-Water Report 3.

Hiss, W.L., 1975a, Stratigraphy and ground-water hydrology of the Capitan Aquifer, southeastern New Mexico and western Texas, unpublished Ph.D. thesis, University of Colorado, Boulder, Colorado.

Hiss, W.L., 1975b, Thickness of the Permian Guadalupian Capitan aquifer, southeast New Mexico and west Texas: New Mexico Bureau of Mines and Mineral Resources, Resource Map 5.

Hiss, W.L., 1975c, Chloride-ion concentration in ground water in Permian Guadalupian rocks, southeast New Mexico and west Texas: New Mexico Bureau of Mines and Mineral Resources, Resource Map 5.

Hiss, W. L., 1976a, Structure of the Permian Ochoan Rustler Formation, southeast New Mexico and West Texas: New Mexico Bureau of Mines and Mineral Resources, Resource Map 7, 1976.

Hiss, W.L., 1976b, Structure of the Permian Guadalupian Capitan Aquifer southeast New Mexico and west Texas: New Mexico Bureau of Mines and Mineral Resources, Resource Map 6.

Jones, C. L., Cooley, M.E., and Bachman, G.O., 1973, Salt deposits of Los Medanos area, Eddy and Lea Counties, New Mexico, U.S. Geol. Survey Open-file report $4339-7$.

Kelley, V.C., 1971, Geology of the Pecos country, southeastern New Mexico New Mexico Bureau of Mines and Mineral Resources, Memoir 24.

King, P. B., 1948, Geology of the southern Guadalupe Mountains, Texas: U.S. Geol. Survey Prof. Paper 215.

Lambert, S.J., 1977, The geochemistry of Delaware Basin groundwaters, Sandia Laboratories Report, Albuquerque, New Mexico, SAND77-0420. Report also in New Mexico Bureau of Mines and Mineral. Resources, Circ. 159 (1978 - in press).

Lambert, S. J. and Mercer, J. W., 1977, Hydrologic investigations of the Los Medanos area, southeastern New Mexico, 1977: SAND77-1401, Sandia Laboratories, Albuquerque, New Mexico. 
Lohman, S.W., 1972, Definitions of selected ground-water terms-revisions and conceptual refinements: U.S. Geol. Survey Water Supply Paper 1988 .

Maley, V. C., and Huffington, R. M., 1953, Cenozic fill and evaporite solution in the Delaware Basin, Texas and New Mexico: Geol. Soc. Amer. Bull. v. 64, pp 539-546..

McNeal, R. P., 1965, Hydrodynamics of the Permian Basin Fluids, in subsurface environments symposium: Amer. Assoc. of Petrol. Geologists Memoir No. 4, p. 308-326.

Mercer, J.W., (to be published), Hydrologic tests and observations in the potash-hydro holes P-14, P-15, P-17, and P-18, U.S. Geol. Survey.

Mercer, J.W., and Orr, B. R., 1977, Review and analysis of hydrogeologic conditions near the site of a potential nuclear waste laboratory, Eddy and Lee Counties, New Mexico, U.S. Geol. Survey Open-file report 77-123.

Mercer, J. W., and Orr. B. R., 1978, Geohydrology of the proposed Waste Isolation Pilot Plant, southeastern New Mexico: U.S. Geol. Survey report submitted to DOE (preliminary).

Motts, W.S., 1957, Geology and ground water resources of the Carlsbad area, New Mexico, unpublished Ph.D. Thesis, University of Illinois (Urbana).

Nicholson, Alexander, Jr., and Clebsch, A., Jr., 1961, Geology and ground-water conditions in southern Lea County, New Mexico: Ground-water Report 6, New Mexico Bureau of Mines and Mineral Resources.

NOAA Environmental Data Service, 1977, Climatography of the United States, No. 60, Climate of New Mexico: U.S. Dept. of Commerce, March 1977.

Pettigrew, Richard R. and Assoc., 1977, WIPP conceptual design report (soils and foundation investigation): Prepared for Sandia Laboratories Albuquerque, New Mexico.

Pierce, W. G. and Rich, E. I., 1962, Summary of rock salt deposits in the United States as possible storage sites for radioactive waste materials: U.S. Geol. Survey Bull. 1148, 33-35P.

Piper, A.M., 1973. Subrosion in and about the four-township study area near Carlsbad, New Mexico, ORNL subcontract 3745, Oak Ridge National Laboratory, Oak Ridge, TN.

Reddy, G. R., 1961, Geology of the Queen Lake domes near Malaga, Eddy County, New Mexico: unpublished M.S. Thesis, Univ. of New Mexico. 
Robinson, T. W., and Lang, W. G., 1938, Geology and ground water conditions of the Pecos River Valley in the vicinity of Laguna Grande de la Sal, New Mexico, with special reference to the salt content of the river water. N. Mex. State Engineer 12 th and 13th Bienn. Repts., p. 77-100.

Rose, Walter, 1977, Development of a conceptual model to explain brine flowage into wells drilled thru the Salado-Castile Formation. Contact in locations such as the ERDA \#6 site near Carlsbad in southeastern New Mexico: Report to Sandia Laboratories.

Theis, C.V., and Sayre, A.N., 1942, Geology and ground water, in (U.S.) National Resources Planning Board, 1942, Pecos River Joint Investigation-Reports of the participating agencies: Washington, U.S. Govt. Printing office, P. 27-38.

U.S. Department of Agriculture, Soil Conservation Service, 1971, Soil survey of Eddy area, New Mexico, U.S. Government Printing office, Washington, D.C.

U.S. Department of Agriculture, Soil Conservation Service, 1974, Soil survey of Lea area, New Mexico, U.S. Government Printing Office, Washington, D.C.

U.S. Department of Commerce, Weather Bureau, 1952, Mean number of thunderstorm days in the United States, Technical paper No. 19.

U.S. Department of Commerce, Weather Bureau, 1955, Rainfall intensity-duration-frequency curves. Technical paper No. 25 .

U. S. Department of Commerce, Weather Bureau, 1969, Severe local storm occurrences, 1955-1967. Technical Memorandum WBTM FCST 12.

U.S. Department of Commerce, Weather Bureau, 1961, Climatological Survey Station, Carlsbad, New Mexico.

U.S. Department of Commerce and U.S. Department of Army, Weather Bureau and corps of Engineers, 1976, Hydrometeorological report No. 33, seasonal variation of the probable maximum precipitation east of the 105th meridian.

U.S. Department of the Interior, 1975, Preliminary regional environmental analysis record potash leasing in southeastern New Mexico: Bureau of Land Management, New Mexico state Office.

U.S. Geological Survey, 1976, Water resources data for New Mexico, water year 1976: U.S. Geol. Survey Water-Data Report NM-76-1.

U.S. Geological Survey Topographic maps, 15 minute series $(1: 62,500)$ for Nash Draw and Hat Mesa, New Mexico.

U. S. Geological Survey Topographic Maps, $(1: 250,000)$, NI 13-11 (Carlsbad) and NI 13-12 (Hobbs), New Mexico. 
Vine, J. D., 1960, Recent domal structures in southeastern New Mexico: Amer. Assoc. Petrol. Geol. Bull., v. 44, no. 12, p. 1903-1911.

Vine, J. D., 1963, Surface geology of the Nash Draw quadrangle, Eddy County, New Mexico: U.S. Geol. Survey Bull. 1l4l-B.

Wolfe, H.G., editor, 1977a. An environmental baseline study of the Los Medanos Waste Isolation Pilot Plant (WIPP) project area of New Mexico: a progress report: SAND77-7017, Sandia Laboratories, Albuquerque, New Mexico.

Wolfe, H.G., editor, 1977b. An environmental baseline study of the Los Medanos Waste Isolation Pilot Plant (WIPP) project area of New Mexico: a progress report. An addendum: SAND77-7018, Sandia Laboratories, Al buquerque, New Mexico. 


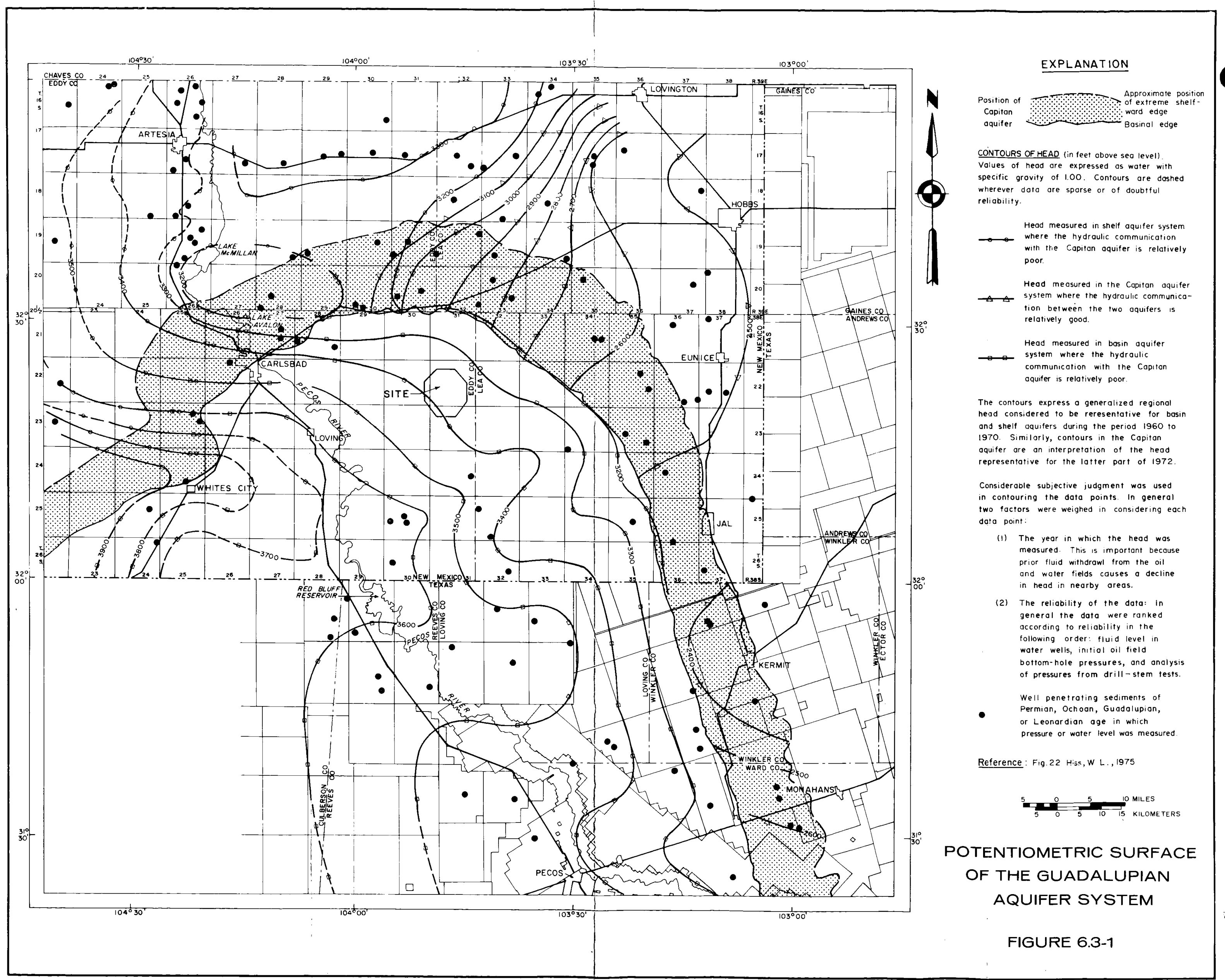




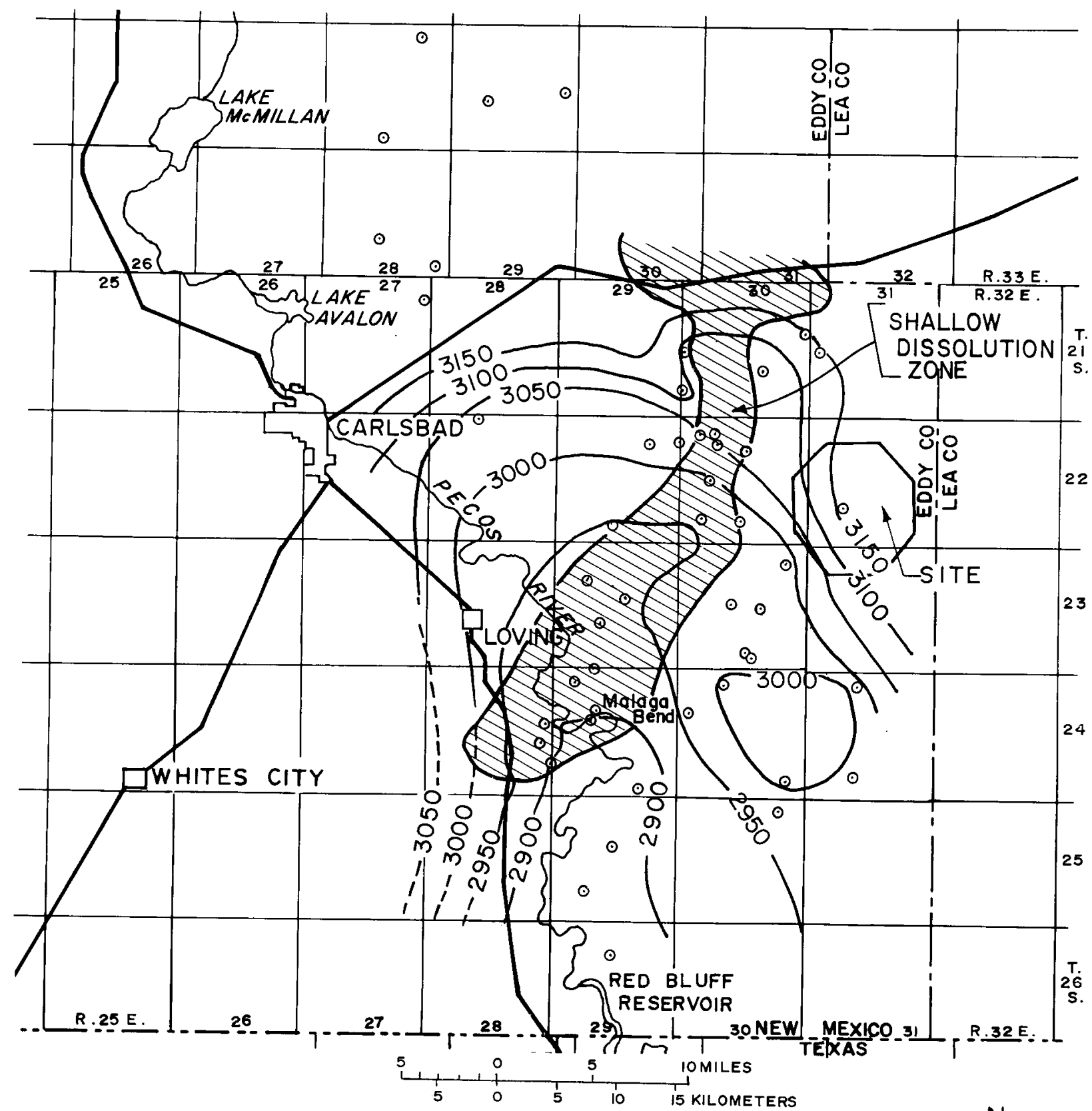

EXPLANATION

- Well or exploratory hole open to the Rustler Formation.

${ }_{0} \mathrm{O}^{--}$Potentiometric elevation contour based on water levels measured in wells, 1952-1973. Dashed where approximately located.

Datum is mean sea level.

Reference: Figures 5 \&6, U.S.G.S. Open File Rpt.77-123, 1977

POTENTIOMETRIC SURFACE

RUSTLER FORMATION AND AREAL

EXTENT OF SHALLOW DISSOLUTION ZONE

FIGURE 6.3-2 


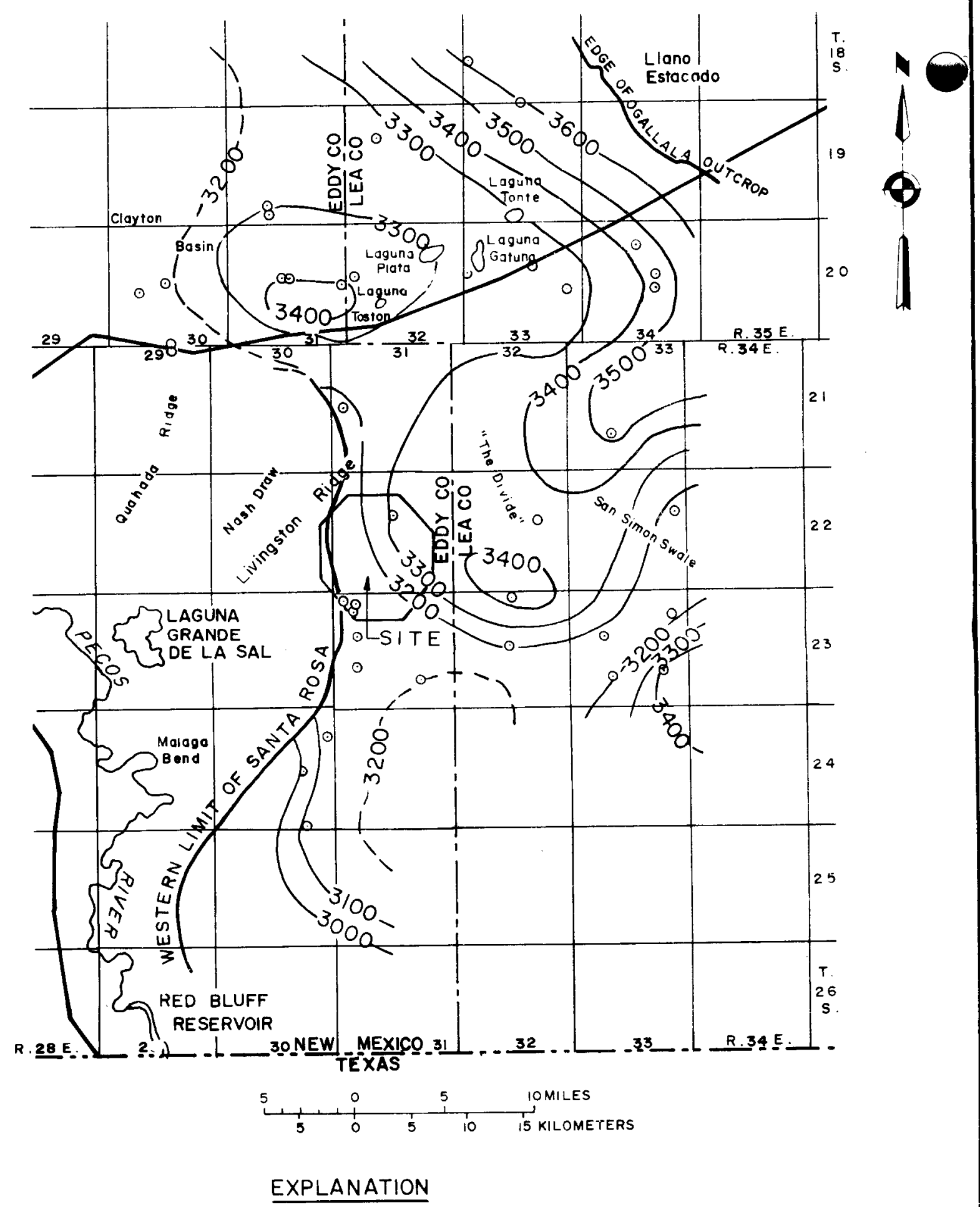

$\odot$

Well open to Triassic rocks

Potentiometric elevation contour, based on water levels

measuerd in wells, 1952 - 1973. Dashed where approximately

located. Dotum is mean sea level.

Reference:

POTENTIOMETRIC SURFACE

SANTA ROSA SANDSTONE

Mercer and Orr, 1977, figure 7.

FIGURE 6.3.3 


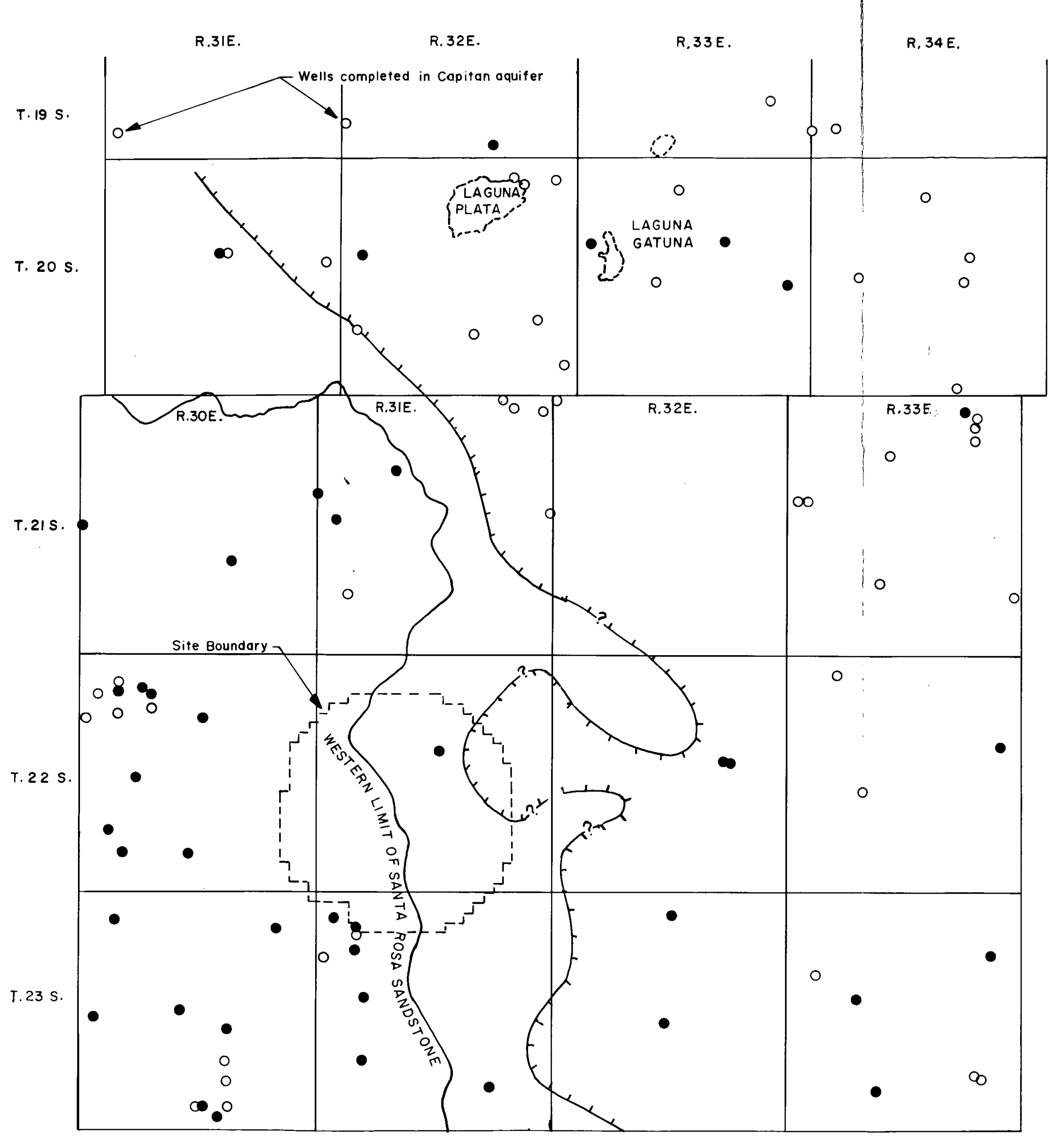

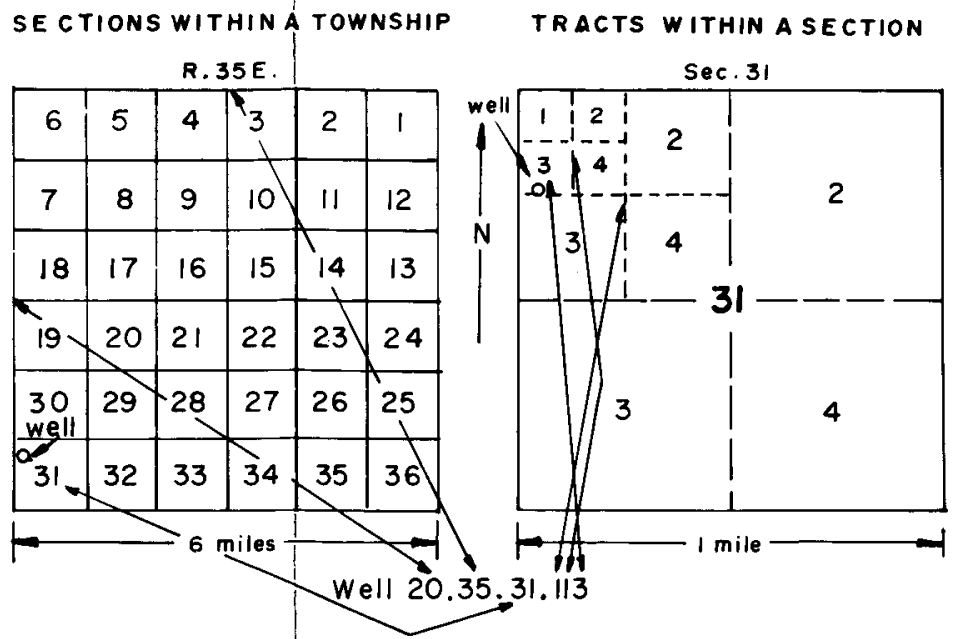

WELL-NUMBERING SYSTEM

The well number consists of four parts separated by periods. The first part is the township number, the second part is the range number, and the
third part is the section number. The fourth part of the number consists
of three digits which denote the particular 10 -acre tract within the section of three digits which denote the particular lo-acre tract within the section in which the well is locoted.

\section{EXPLANATION}

L. Approximate western limit of occurrence of ground water in the Santa Rosa Sandstone.

- Water well completed in surfical deposits or upper sandstone beds of the Chinle Formation.

- Water well completed in lower sandstone beds of the Chinle Formation, Santa Rosa Sandstone, Dewey Lake Redbeds, or Rustler Formation.

NOTE:

See Table $6.3-2$ for descriptions of wells.

Reference: USGS Open File, Report 4339-7, Jones, C.L., et al, 1973

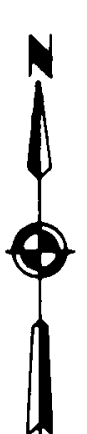




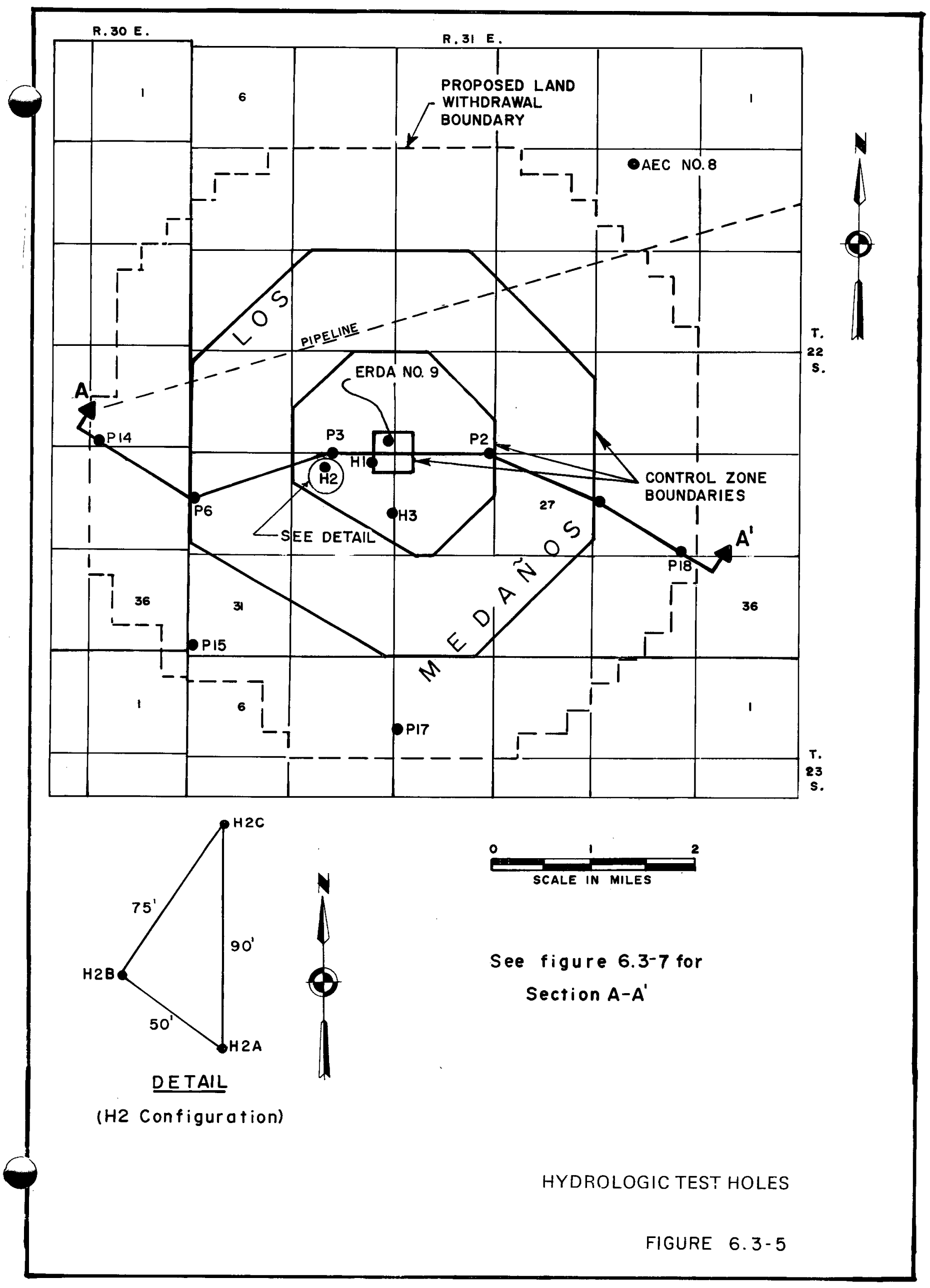




\section{DEPTHS IN}

FEET

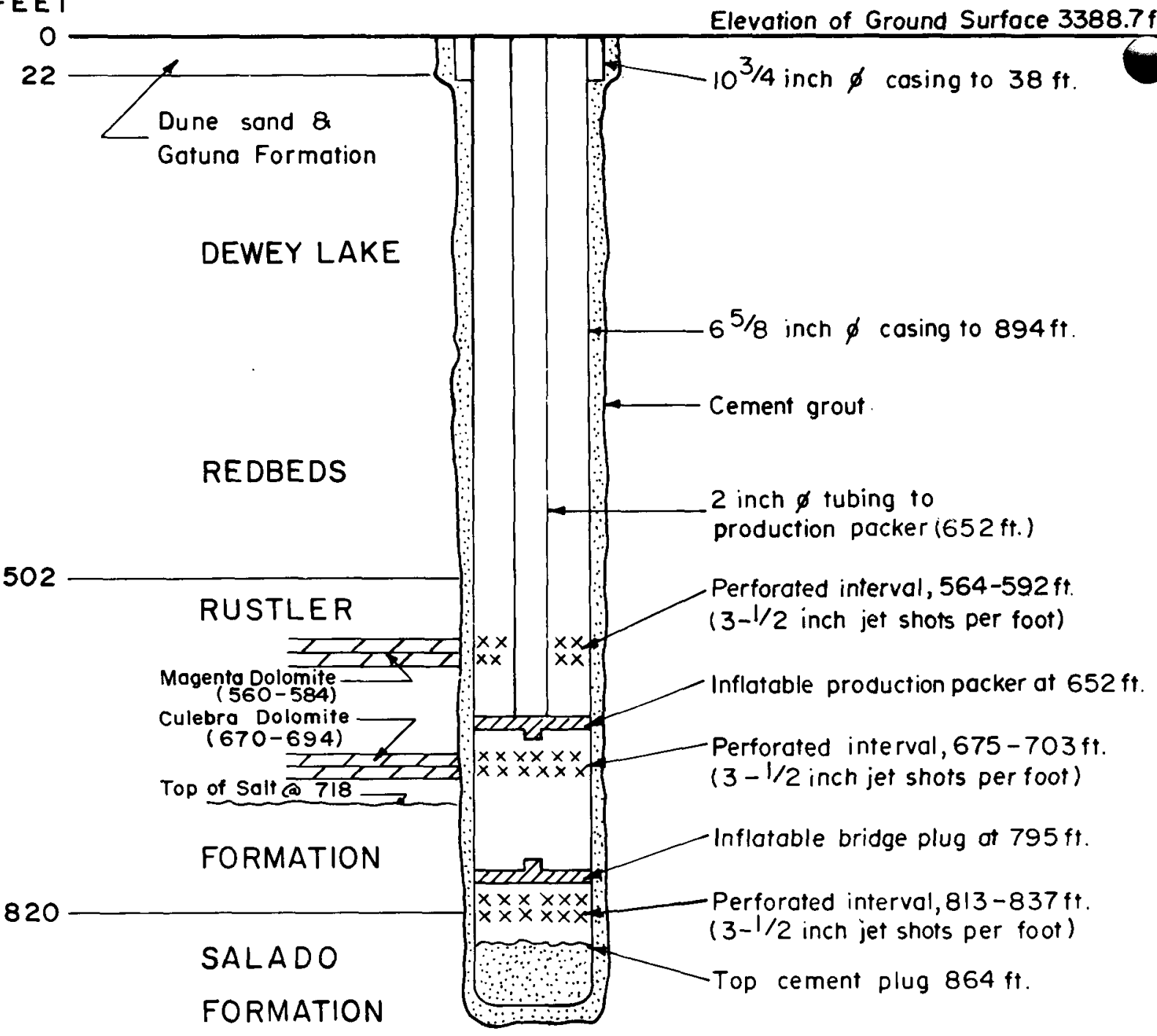

\section{Status October $1977^{\circ}$.}

Total depth drilled: $894 \mathrm{ft}$

Diameter of drilled hole: $9 \geqslant 8$ inch

Monitoring Culebra through tubing

Monitoring Magenta in annulus

Contact zone not accessible (bridge plug) 


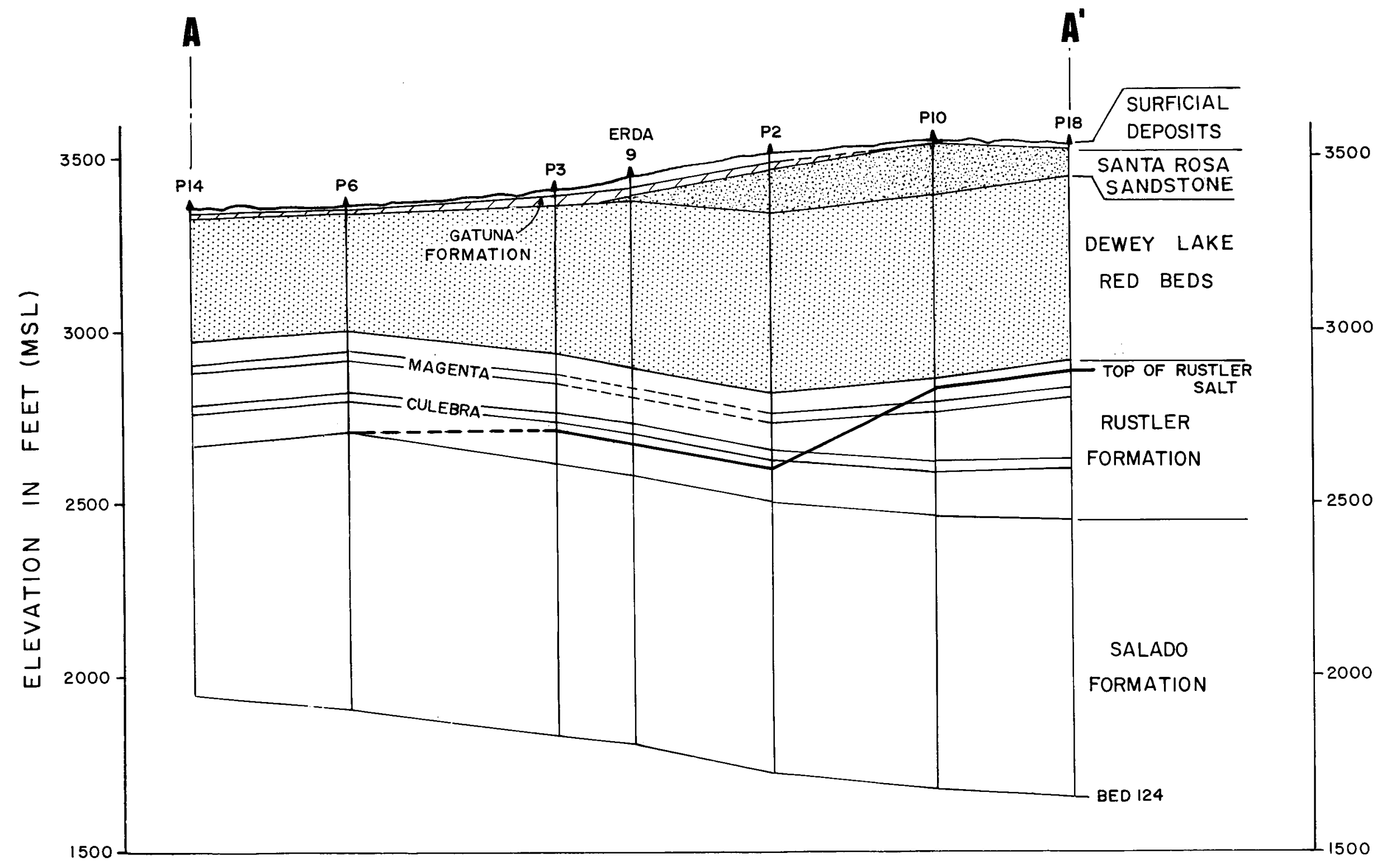

\section{REFERENCES}

Lambert and Mercer, 1978, fig.4, P.I-15

\section{NOTE:}

For location of Section see

Figure 6.3-5.

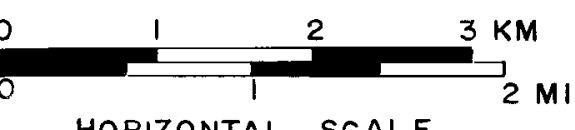

GEOLOGIC SECTION

THROUGH THE LOS MEDANOS AREA

FIGURE $6.3-7$ 


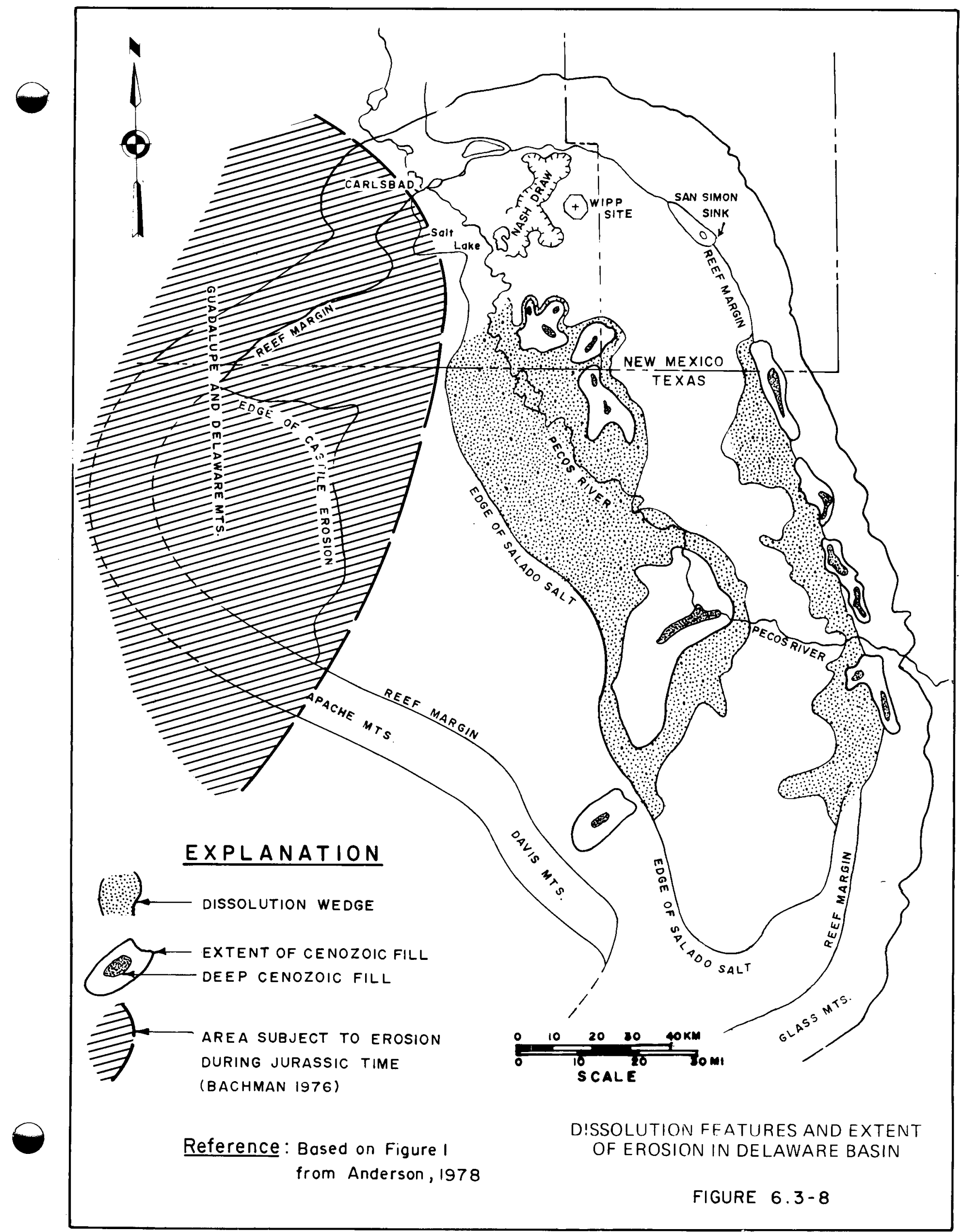




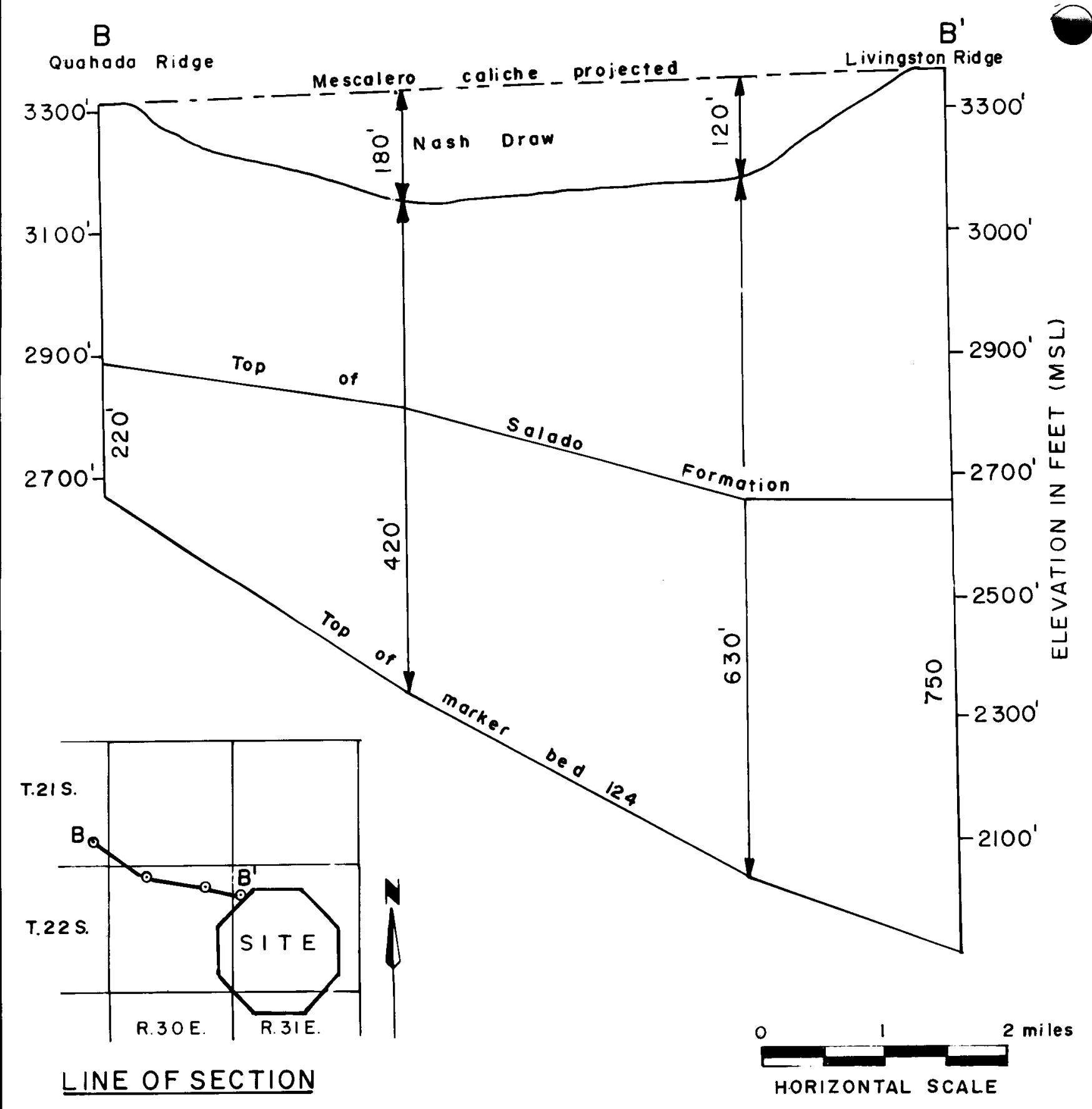

Reference: Fig.II, USGS Open File Report 74-194, 1974

RE LATIONSHIP OF NASH DRAW TO DISSOLUTION IN SALADO FORMATIUN

FIGURE 6.3-9 
Table 6.2-1. AREAL REQUIREMENTS OF THE WIPP SITE

Zone Zone Use

Approximate Acreage

I Surface Facilities

$60-(100)$

I Underground Storage

1,860

III $\quad 1$-mile wide zone surrounding zone II

No mining or drilling.

6,230

IV $\quad 1-m i l e$ wide zone surrounding zone III. Mining and drilling in conformance with ERDA specifications are allowed.

10,810

TOTAL

$\underline{18,960}$

29.6 square miles 
TABLE $6.2-2$

SALIENT FEATURES OF MAJOR DAMS UPSTREAM AND

DOWNSTREAM FROM WIPP SITE

\begin{tabular}{|c|c|c|c|c|c|c|c|}
\hline $\begin{array}{l}\text { Name of } \\
\text { Reservoir }\end{array}$ & River & $\begin{array}{c}\text { Drainage Area } \\
\text { (sq.-mi.) } \\
\end{array}$ & $\begin{array}{c}\text { Type of } \\
\text { Dam }\end{array}$ & $\begin{array}{c}\text { Year } \\
\text { Completed } \\
\end{array}$ & $\begin{array}{l}\text { Height } \\
\text { (ft.) } \\
\end{array}$ & $\begin{array}{l}\text { Max. Storage } \\
\text { Capacity (AF) }\end{array}$ & Purpose \\
\hline Sumner & Pecos & 4,390 & earth & 1937 & 143 & 258,500 & Irrigation \\
\hline McMillan & Pecos & 16,990 & earth & 1908 & 40 & 66,600 & Irrigation \\
\hline Avalon & Pecos & 18,070 & earth & 1907 & 40 & 36,600 & Irrigation \\
\hline Red Bluff & Pecos & 20,720 & earth & 1937 & 98 & 405,000 & $\begin{array}{l}\text { Irrigation \& } \\
\text { Hydro-power }\end{array}$ \\
\hline Two Rivers & $\begin{array}{l}\text { Rio Hond } \\
\text { Rocky Ar }\end{array}$ & $\begin{array}{r}963 \\
64\end{array}$ & $\begin{array}{l}\text { earth } \\
\text { earth }\end{array}$ & $\begin{array}{l}1963 \\
1963\end{array}$ & $\begin{array}{r}93 \\
116\end{array}$ & 262,221 & $\begin{array}{l}\text { Flood } \\
\text { Control }\end{array}$ \\
\hline
\end{tabular}


TABLE $6.2-3$

WATER USE DATA FOR THE PECOS BASIN

\begin{tabular}{lr} 
& \multicolumn{2}{c}{$\begin{array}{c}\text { Surface-water and } \\
\text { Uroundwater withdrawals (mgd) }\end{array}$} \\
\cline { 2 - 2 } & $1975^{\mathrm{a}}$ \\
\hline Agriculture & 1546 \\
Steam-electricity & 12 \\
Manufacturing & 0 \\
Domestic & 47 \\
Commercial & 8 \\
Mining & 151 \\
Public lands & 4 \\
Fish hatcheries & 3 \\
Total & 1771
\end{tabular}

SOURCE: U.S. Water Resources Council, Second National Assessment of Water and Related Land Resources, in press.

aThe total groundwater withdrawal for 1975 was 1079 mgd. 
TABLE NO. $6.2-4$

PRECIPITATION AT CARLSBAD, N.M. (in inches)

Period of Record 1931-1960

\begin{tabular}{llllllllllllll} 
MONTH & JAN. & FEB. & MARCH & APRIL & MAY & JUNE & JULY & AUG. & SEPT. & OCT. & NOV. & DEC. & ANNUAL \\
\hline Max. Precip & 2.31 & 1.93 & 4.27 & 3.99 & 12.28 & 6.24 & 5.48 & 4.41 & 7.36 & 6.13 & 1.55 & 2.12 & 33.94 \\
Av. Precip. & 0.44 & 0.37 & 0.46 & 0.54 & 1.76 & 1.33 & 1.56 & 1.60 & 1.94 & 1.61 & 0.35 & 0.47 & 12.43 \\
Min. Precip. & 0 & 0 & 0 & 0 & 0.18 & 0 & 0 & 0.01 & 0 & 0 & 0 & 0 & 4.40 \\
\end{tabular}

SOURCE: U. S. Weather Bureau, 1961. 
TABLE NO. $6.2-5$

TEMPERATURES AT CARLSBAD, N.M. (in ${ }^{\circ}$ )

Period of Record 1931-1960

\begin{tabular}{|c|c|c|c|c|c|c|c|c|c|c|c|c|c|}
\hline MONTH & JAN. & FEB. & MARCH & APRIL & MAY & JUNE & JULY & AUG. & SEPT. & OCT. & Nov. & DEC. & ANNUAL \\
\hline Max. Temp & 50.4 & 54.8 & 61.2 & 69.1 & 74.6 & 83.6 & 84.2 & 84.6 & 80.6 & 70.8 & 57.4 & 52.6 & 66.3 \\
\hline Av. Temp. & 43.8 & 48.4 & 54.8 & 63.3 & 71.4 & 79.8 & 81.4 & 80.8 & 74.2 & 64.1 & 51.5 & 44.7 & 63.2 \\
\hline Min. Temp. & 35.2 & 43.6 & 47.8 & 60.1 & 68.4 & 73.4 & 77.4 & 76.7 & 70.2 & 58.2 & 45.8 & 37.5 & 60.3 \\
\hline
\end{tabular}

SOURCE: U. S. Weather Bureau, 1961. 
TABLE NO. $6.2-6$

WATER QUALITY PARAMETERS (TIME-WEIGHTED AVERAGE)

FOR SAMPLING STATIONS ON THE PECOS RIVER, OCTOBER, 1975, TO SEPTEMBER, 1976

Dissolved-solids concentration (mg/1)

\begin{tabular}{|c|c|c|c|c|c|c|c|}
\hline $\begin{array}{c}\text { Station } \\
\text { No. } \\
\end{array}$ & $\begin{array}{c}\text { Discharge } \\
\text { (cfs) }\end{array}$ & $\mathrm{pH}$ & Total & Chloride & Sulfate & Sodium & Calcium \\
\hline $\begin{array}{l}08405000 \\
\text { (Carlsbad) }\end{array}$ & 12 & 7.7 & 2,500 & 531 & 1100 & 322 & 334 \\
\hline $\begin{array}{l}08406500 \\
\text { (Near Malaga) }\end{array}$ & 26 & 7.7 & 5,390 & 1690 & 1820 & 1030 & 524 \\
\hline $\begin{array}{l}08407000 \\
\text { (Pierce } \\
\text { Canyon } \\
\text { Crossing) }\end{array}$ & 28 & 7.5 & 13,900 & 6500 & 2280 & 4020 & 551 \\
\hline
\end{tabular}

SOURCE: U. W. Geological Survey, Water-Data Report NM-76-1. 
TABLE NO. 6.3-1 AQUIFER CHARACTERISTICS OF THE GUADALUPIAN AGE ROCKS (ADAPTED FROM HISS, 1976,

TABLES 6 AND 7)

\begin{tabular}{lr} 
Geologic Unit & $\begin{array}{r}\text { Avg. Hydr } \\
\text { Conductivity }\end{array}$ \\
\cline { 2 - 2 } Rock Core Analysis & \\
Tansill Fm. & 0.006 \\
Yates Fm. & 0.026 \\
Seven River Fm. & 0.140 \\
Queen Fm. & 0.029 \\
Grayburg Fm. & 0.032 \\
Grayburg-San Andres (Und.) & 0.033 \\
Glorieta Sandstone & 0.027 \\
Delaware Mt. Gp. & 0.016
\end{tabular}

\title{
Average Porosity.(\%) Conductivity Porosity
}

Pumping Tests (San Andres)

$\begin{array}{ll}\text { T.20S, R.38E, Sec. } 7 & 0.20 \\ \text { Same well as above } & 0.20 \\ \text { T.22S, R.37E, Sec. 29 } & 0.30\end{array}$

\begin{abstract}
(Drawdown Test)
(Recovery Test)
\end{abstract}

(Drawdown Test)

\section{Pumping Tests (Capitan)}

T.21S, R27E, Sec. 5

T.21S, R.28E, Sec. 30

T.21S, R.34E, Sec. 24

T.21S, R34E, Sec. 14

Same Well

Same Well

T.24S, R36E, Sec 4

T.24S, R36E, Sec. 16

$$
\begin{array}{r}
2.4 \\
16.0 \\
3.0 \\
1.7 \\
1.9 \\
1.4 \\
24.0 \\
7.4
\end{array}
$$

$\begin{array}{rr}399 & 381 \\ 11,287 & 11,387 \\ 4,367 & 4,485 \\ 7,324 & 7,648 \\ 1,971 & 1,973 \\ 7,062 & 7,313 \\ 3,128 & 3,115 \\ 4,549 & 4,493\end{array}$

381

11,387

7,648

1,973

3,115
4,493

\author{
(Recovery Test) \\ (Recovery Test) \\ (Specific Capacity) \\ (Specific Capacity) \\ (Drawdown Test) \\ (Recovery Test) \\ (Drawdown Test) \\ (Specific Capacity)
}


TABLE 6.3-2 -- Records of Wells in the Los Medanos Area, New Mexico

(Adapted from Cooley, 1972, Table 4)

\begin{tabular}{|c|c|c|c|c|c|c|}
\hline $\begin{array}{l}\text { Location } \\
\text { Number }\end{array}$ & $\begin{array}{l}\text { Altitude } \\
\text { Above Mean } \\
\text { Sea Level } \\
\text { (feet) }\end{array}$ & $\begin{array}{l}\text { Depth } \\
\text { of WeIl } \\
\text { (feet) }\end{array}$ & $\begin{array}{l}\text { Diameter } \\
\text { of Well } \\
\text { Casing } \\
\text { (inches) }\end{array}$ & $\begin{array}{l}\text { Depth } \\
\text { Below Land } \\
\text { Surface } \\
\text { (feet) }\end{array}$ & $\begin{array}{l}\text { Date of } \\
\text { Measure- } \\
\text { ment }\end{array}$ & $\begin{array}{l}\text { Geologic } \\
\text { Source }\end{array}$ \\
\hline $19 \cdot 32 \cdot 34 \cdot 434$ & 3560 & 260 & -- & Dry & $9-22-72$ & $\begin{array}{l}\text { QTs, Tre, } \\
\operatorname{Trsr}(?)\end{array}$ \\
\hline $\begin{array}{r}19 \cdot 33 \cdot 26.244 \\
26.244 a\end{array}$ & $\begin{array}{l}3609 \\
3609\end{array}$ & $\overline{101}$ & $\begin{array}{r}6 \\
--\end{array}$ & $\begin{array}{l}90.58 \\
90.93\end{array}$ & $\begin{array}{l}9-25-72 \\
9-25-72\end{array}$ & $\begin{array}{l}\text { QTs, } \operatorname{Trc}(?) \\
\text { QTs, } \operatorname{Trc}(?)\end{array}$ \\
\hline 19.34 .31 .131 & 3620 & 53 & 6 & Dry & $9-25-72$ & QTs \\
\hline 31.232 & 3632 & $120 \mathrm{R}$ & 6 & -- & $9-25-72$ & QTs, $\operatorname{Trc}(?)$ \\
\hline $\begin{array}{r}20.31 .13 .412 \\
15.130 \\
15.130 \mathrm{a}\end{array}$ & $\begin{array}{l}3440 \\
3460 \\
3460\end{array}$ & $\begin{array}{r}30 \\
105 \\
79\end{array}$ & $\begin{array}{l}6 \\
6 \\
6\end{array}$ & $\begin{array}{r}1.12 \\
62.10 \\
63.39\end{array}$ & $\begin{array}{l}9-18-72 \\
9-18-72 \\
9-18-72\end{array}$ & $\begin{array}{l}\text { QTs } \\
\text { QTs(?), Trsr } \\
\text { QTs(?), Trsr }\end{array}$ \\
\hline $15.130 \mathrm{~b}$ & - & -- & -- & -- & - & QTs(?), Trsr \\
\hline $20.32 \cdot 1.312$ & 3510 & 20 & 6 & Dry & $9-22-72$ & QTS \\
\hline $\begin{array}{l}24.333 \\
24.333 \mathrm{a} \\
27.144 \\
36.214\end{array}$ & $\begin{array}{l}3555 \\
3555 \\
3545 \\
3585\end{array}$ & $\begin{array}{l}67 \\
-- \\
30 \\
--\end{array}$ & $\begin{array}{l}5 \\
-- \\
--\end{array}$ & $\begin{array}{r}37.67 \\
-- \\
23.67 \\
P 43.88\end{array}$ & $\begin{array}{r}9-11-72 \\
-- \\
9-18-72 \\
9-18-72\end{array}$ & $\begin{array}{l}\text { QTs } \\
\text { QTs(?) } \\
\text { QTs } \\
\text { QTs }\end{array}$ \\
\hline
\end{tabular}

Use and Remarks

Unused; 3 wells at this locality; no access for entering casing in the other 2 wells.

Electric Submersible; stock.

Unused; $2 \mathrm{ft}$. of water in bottom of hole--probably does not represent true water level.

Windmill; stock; "Hardin Well," no access to enter casing.

Unused.

Unused.

Unused; 5 wells at this location of which only 1 is an operating well.

Windmill; stock.

Unused; deepest of 4 wells at this location, all wells are dry.

Unused

Windmill; stock.

Unused; no casing present.

Windmill; stock; 3 wells at this location at

Bingham ranch, well pumping estimated at

2. gallons per minute. 
TABLE 6.3-2 (continued)-- Records of Wells in the Los Medanos Area, New Mexico

\begin{tabular}{|c|c|c|c|c|c|c|c|}
\hline $\begin{array}{l}\text { Location } \\
\text { Number }\end{array}$ & $\begin{array}{l}\text { Altitude } \\
\text { Above Mean } \\
\text { Sea Level } \\
\text { (feet) }\end{array}$ & $\begin{array}{l}\text { Depth } \\
\text { of Well } \\
\text { (feet) }\end{array}$ & $\begin{array}{l}\text { Diameter } \\
\text { of Well } \\
\text { Casing } \\
\text { (inches) }\end{array}$ & $\begin{array}{l}\text { Depth } \\
\text { Below Land } \\
\text { Surface } \\
\text { (feet) }\end{array}$ & $\begin{array}{l}\text { Date of } \\
\text { Measure- } \\
\text { ment }\end{array}$ & $\begin{array}{c}\text { Geologic } \\
\text { Source }\end{array}$ & Use and Remarks \\
\hline $\begin{array}{r}40.33 .432 \\
18.123 \\
21.111 \\
24.124\end{array}$ & $\begin{array}{l}3555 \\
3521 \\
3536 \\
3630\end{array}$ & $\begin{array}{r}4 \\
249 \\
49 \\
680\end{array}$ & $\begin{array}{l}6.5 \\
6 \\
12\end{array}$ & $\begin{array}{r}\text { Dry } \\
245.58 \\
36.90 \\
405.15\end{array}$ & $\begin{array}{l}9-22-72 \\
9-25-72 \\
9-25-72 \\
9-22-72\end{array}$ & $\begin{array}{l}\text { QTs } \\
\text { Trc } \\
\text { QTs } \\
\text { Trc, Trsr(?) }\end{array}$ & $\begin{array}{l}\text { Unused. } \\
\text { Unused. } \\
\text { Unused. } \\
\text { Windmill; stock; "West Windmill," watersand } \\
\quad \text { at about } 300 \text { feet as reported by driller. }\end{array}$ \\
\hline 20.34 .4 .444 & 3633 & 200 & 8 & P174.08 & $10-2-72$ & Tre & $\begin{array}{l}\text { Windmill; stock; "Robert's Well," old oil } \\
\text { test drilled before } 1930 \text {. }\end{array}$ \\
\hline $\begin{array}{l}14.133 \\
17.334\end{array}$ & $\begin{array}{l}3648 \\
3640\end{array}$ & $\begin{array}{c}230 \\
220(?)\end{array}$ & 8 & $\begin{array}{r}190.25 \\
P 129.68\end{array}$ & $\begin{array}{l}10-2-72 \\
10-2-72\end{array}$ & $\begin{array}{l}\text { Tre } \\
\operatorname{Trc}\end{array}$ & $\begin{array}{l}\text { Windmill; stock. } \\
\text { Windmill; stock; "City Service Well," } \\
\text { possibly oil test. }\end{array}$ \\
\hline $\begin{array}{l}22.224 \\
34.432\end{array}$ & $\begin{array}{l}3655 \\
3770\end{array}$ & $\begin{array}{r}220 \\
96\end{array}$ & $\begin{array}{r}12 \\
6\end{array}$ & $\begin{array}{r}196.49 \\
89.50\end{array}$ & $\begin{array}{l}10-2-72 \\
10-2-72\end{array}$ & $\begin{array}{l}\text { Tro } \\
\text { QTs }\end{array}$ & $\begin{array}{l}\text { Windmill; stock; "North Well," old oil test } \\
\text { Windmill; stock. }\end{array}$ \\
\hline $\begin{array}{r}21.30 .18 .333 \\
22.423\end{array}$ & $\begin{array}{l}3220 \\
3180\end{array}$ & $\begin{array}{l}156 \\
130\end{array}$ & $\begin{array}{l}6 \\
6\end{array}$ & $\begin{array}{l}129.54 \\
111.50\end{array}$ & $\begin{array}{l}9-25-72 \\
9-25-72\end{array}$ & $\begin{array}{l}\text { Pru } \\
\text { Pru }\end{array}$ & $\begin{array}{l}\text { Unused. } \\
\text { Unused. }\end{array}$ \\
\hline $\begin{array}{r}1.131 \\
1.241 \\
2.221 \\
7.331 \\
13.244 \\
18.411 \\
30.421\end{array}$ & $\begin{array}{l}3580 \\
3600 \\
3570 \\
3350 \\
3600 \\
3310 \\
3300\end{array}$ & $\begin{array}{r}30 \mathrm{R} \\
\overline{35} \\
367 \\
68 \\
-\overline{176}\end{array}$ & $\begin{array}{c}6 \\
-- \\
-- \\
14 \\
6 \\
6 \\
6\end{array}$ & $\begin{array}{l}20.80 \\
-- \\
29.80 \\
192.10 \\
\text { Dry } \\
158.32 \\
\text { Dry }\end{array}$ & $\begin{array}{r}9-18-72 \\
--2 \\
9-18-72 \\
9-14-72 \\
9-13-72 \\
9-14-72 \\
9-25-72\end{array}$ & $\begin{array}{l}\text { QTs } \\
\text { QTs } \\
\text { Pru, Prc (?) } \\
\text { QTs, Trc } \\
\text { Pru } \\
\text { Pru }\end{array}$ & $\begin{array}{l}\text { Windmill; domestic \& in stock; at Campbell Ranch. } \\
\text { "Grave Well." } \\
\text { Windmill; stock. } \\
\text { Unused. } \\
\text { Unused. } \\
\text { Windmill; stock; "New Well." } \\
\text { Unused. }\end{array}$ \\
\hline
\end{tabular}


TABLE 6.3-2 (continued)-- Records of Wells in the Los Medanos Area, New Mexico

\begin{tabular}{|c|c|c|c|c|c|c|c|c|}
\hline $\begin{array}{l}\text { Locatic } \\
\text { Number }\end{array}$ & & $\begin{array}{c}\text { Altitude } \\
\text { Above Mean } \\
\text { Sea Level } \\
\text { (feet) }\end{array}$ & $\begin{array}{l}\text { Depth } \\
\text { of Well } \\
\text { (feet) }\end{array}$ & $\begin{array}{l}\text { Diameier } \\
\text { of Well } \\
\text { Casing } \\
\text { (inches) }\end{array}$ & $\begin{array}{l}\text { Depth } \\
\text { Below Land } \\
\text { Surface } \\
\text { (feet) }\end{array}$ & $\begin{array}{l}\text { Date of } \\
\text { Measure- } \\
\text { ment }\end{array}$ & $\begin{array}{l}\text { Geologic } \\
\text { Source }\end{array}$ & Use and Remarks \\
\hline 21.32 & 6.111 & 3598 & $54 R$ & -- & $44.00 R$ & $9-18-72$ & QTs & $\begin{array}{l}\text { Windmill; domestic \& stock; at Allred Ranch; } \\
2 \text { wells at this location. }\end{array}$ \\
\hline 21.33 & $\begin{array}{l}2.231 \\
\\
2.420 \\
4.434 \\
4.434 \mathrm{a} \\
18.114 \\
18.114 \mathrm{a} \\
18.123 \\
18.123 \mathrm{a} \\
18.131 \\
25.421 \\
28.124\end{array}$ & $\begin{array}{l}3810 \\
3770 \\
3805 \\
3805 \\
3890 \\
3890 \\
3855 \\
3855 \\
3895 \\
3670 \\
3688\end{array}$ & $\begin{array}{r}1150 R \\
94 \\
147 \\
127 \\
150 \\
175 \\
-- \\
145 \\
11 \\
67 \\
210\end{array}$ & $\begin{array}{c}-- \\
6 \\
-- \\
-- \\
-- \\
-- \\
-- \\
-- \\
-- \\
-\end{array}$ & $\begin{array}{l}-- \\
79.58 \\
129.66 \\
\text { Dry } \\
140.75 \\
142.88 \\
-\overline{17} \\
117.30 \\
\text { Dry } \\
56.58 \\
179.00\end{array}$ & $\begin{array}{l}9-22-72 \\
9-22-72 \\
10-2-72 \\
10-2-72 \\
9-12-72 \\
9-12-72 \\
9-12-72 \\
9-12-72 \\
9-12-72 \\
9-22-72 \\
9-22-72\end{array}$ & $\begin{array}{l}\text { Trsr } \\
\text { QTs } \\
\text { QTs(?), Trc } \\
\text { QTs(?), Trc } \\
\text { QTs } \\
\text { QTs } \\
\text { QTs(?) } \\
\text { QTs } \\
\text { QTs } \\
\text { QTs } \\
\text { Trc }\end{array}$ & $\begin{array}{l}\text { Unused; could not pass tape below } 550 \text { feet } \\
\text { in } 1972 \text {. } \\
\text { Windmill; stock. } \\
\text { Unised. } \\
\text { Unused. } \\
\text { Windmill; stock. } \\
\text { Unused. } \\
\text { Windmill; stock. } \\
\text { Unused. } \\
\text { Unused. } \\
\text { Windmill; stock; "West Well." } \\
\text { Windmill; stock; "Standard Wells," } 3 \text { wells at } \\
\text { this location. }\end{array}$ \\
\hline 22.30 & $\begin{array}{r}5.431 \\
6.444 \\
7.244 \\
10.311 \\
20.120 \\
32.111\end{array}$ & $\begin{array}{l}3120 \\
3140 \\
3110 \\
3135 \\
3076 \\
3010\end{array}$ & $\begin{array}{r}225 \\
176 \\
58 \\
68 \\
10 \\
35\end{array}$ & $\begin{array}{r}14 \\
22 \\
12 \\
6 \\
5 \\
6\end{array}$ & $\begin{array}{l}53.25 \\
92.40 \\
\text { Dry } \\
63.70 \\
\text { Dry } \\
32.70\end{array}$ & $\begin{array}{l}9-19-72 \\
9-19-72 \\
9-19-72 \\
9-12-72 \\
9-19-72 \\
9-19-72\end{array}$ & $\begin{array}{l}\text { Pru, Prc(?) } \\
\text { Pru } \\
\text { Pru } \\
\text { Pru } \\
\text { QTs, Pru } \\
\text { Pru }\end{array}$ & $\begin{array}{l}\text { Unused. } \\
\text { Unused. } \\
\text { Unused. } \\
\text { Unused; at Crawford Ranch. } \\
\text { Unused. } \\
\text { Unused. }\end{array}$ \\
\hline 22.31 .1 & $\begin{array}{l}15 \cdot 130 \\
15 \cdot 130 a\end{array}$ & $\begin{array}{l}3460 \\
3460\end{array}$ & - & -- & $\begin{array}{l}144.07 \\
145.50\end{array}$ & $\begin{array}{l}9-12-72 \\
9-12-72\end{array}$ & $\begin{array}{l}\text { Trsr(?) Pdl } \\
\text { Trsr(?) Pdl }\end{array}$ & $\begin{array}{l}\text { Windmill; stock. } \\
\text { Unused. }\end{array}$ \\
\hline
\end{tabular}


TABLE 6.3-2 (continued)-- Records of Wells in the Los Medanos Area, New Mexico

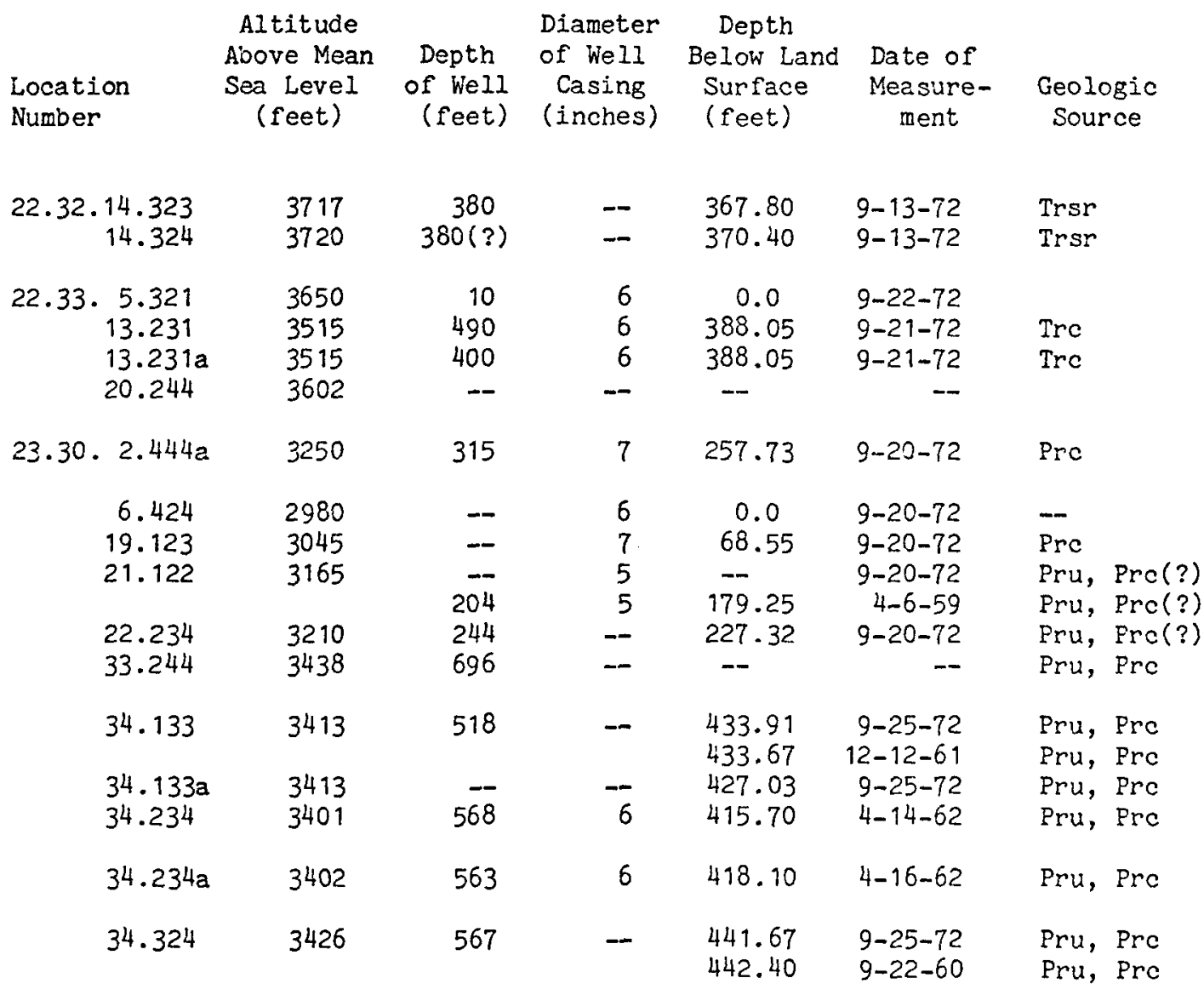

Use and Remarks

Jenson Jack; stock; "Comanche Wells."

Windmill; stock; "Comanche Wells."

Windmill; stock; well on edge of Dagger Lake.

Windmill; stock; "Roger's Well."

Windmill; stock.

Unable to locate well in 1972.

Winghili stock; "Little windnill," weil 444 destroyed.

Unused; "Nash WeII," area flooded by lake.

Windmill; stock.

Windmill; stock; "Indian Well," no access for water level measurement.

Unused.

Abandoned; at Gnome Site, plugged 6-25-69, USGS No. 5 .

Observation; at Gnome Site, USGS No. 4.

Unused; at Gncme Site, USGS No. 8.

Observation; at Gnome Site, USGS No. 6 , drld to $1499^{\prime}$ \& plugged back to $568^{\prime}$. Observation; at Gnome Site, USGS No. 7 , drld to $1507^{\prime}$ \& plugged back to 563'.

Observation; at Gnome Site, USGS No. 1. 
TABLE 6.3-2 (continued)-- Records of Wells in the Los Medanos Area, New Mexico

\begin{tabular}{|c|c|c|c|c|c|c|c|}
\hline $\begin{array}{l}\text { Location } \\
\text { Number }\end{array}$ & $\begin{array}{c}\text { Altitude } \\
\text { Above Mean } \\
\text { Sea Level } \\
\text { (feet) }\end{array}$ & $\begin{array}{l}\text { Depth } \\
\text { of Well } \\
\text { (feet) }\end{array}$ & $\begin{array}{l}\text { Diameter } \\
\text { of Well } \\
\text { Casing } \\
\text { (inches) }\end{array}$ & $\begin{array}{l}\text { Depth } \\
\text { Below Land } \\
\text { Surface } \\
\text { (feet) }\end{array}$ & $\begin{array}{l}\text { Date of } \\
\text { Mea sure- } \\
\text { ment }\end{array}$ & $\begin{array}{c}\text { Geologic } \\
\text { Source }\end{array}$ & Use and Remarks \\
\hline $\begin{array}{r}23.31 .6 .320 \\
6.320 \mathrm{a} \\
6.444 \\
7.240 \mathrm{a} \\
17.310 \\
26.340 \\
29.113\end{array}$ & $\begin{array}{l}3310 \\
3315 \\
3305 \\
3451 \\
3335\end{array}$ & $\begin{array}{l}-- \\
-- \\
-- \\
--\end{array}$ & $\begin{array}{r}6 \\
6 \\
-- \\
6 \\
4\end{array}$ & $\begin{array}{l}144.72 \\
-- \\
106.35 \\
62.27 \\
-- \\
250.47 \\
139.90\end{array}$ & $\begin{array}{r}2-4-59 \\
-- \\
9-20-72 \\
9-20-72 \\
9-20-72 \\
9-20-72 \\
9-20-72\end{array}$ & $\begin{array}{l}\text { Pdl } \\
\text { Pdl, Pru } \\
\text { Pdl } \\
\text { Pdl } \\
\text { Pdl, Pru } \\
\text { PdI } \\
\text { Pdl }\end{array}$ & $\begin{array}{l}\text { Windmill; domestic. } \\
\text { Windmill; domestic; tape will not pass } \\
\quad 222 \text { in } 1972 . \\
\text { Windmill; domestic. } \\
\text { Windmill; stock. } \\
\text { Windmill; stock. } \\
\text { Windmill; stock. } \\
\text { Windmill; stock. }\end{array}$ \\
\hline 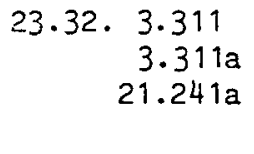 & $\begin{array}{l}3660 \\
3660 \\
3680\end{array}$ & $\begin{array}{r}550 \mathrm{R} \\
\overline{515} \\
550\end{array}$ & $\begin{array}{r}8 \\
10 \\
-- \\
6\end{array}$ & $\begin{array}{l}-\overline{204.18} \\
480.75 \\
510.00 \mathrm{R}\end{array}$ & $\begin{array}{l}9-13-72 \\
9-13-72 \\
9-21-72 \\
4-13-59\end{array}$ & $\begin{array}{l}\text { Trsr } \\
\text { Trsr } \\
\text { Trsr } \\
\text { Trsr }\end{array}$ & $\begin{array}{l}\text { Windmill; stock. } \\
\text { Unused. } \\
\text { Windmill; stock. }\end{array}$ \\
\hline $\begin{array}{r}23.33 .12 .312 \\
17.423 \\
26.421 \\
26.421 a \\
28.334\end{array}$ & $\begin{array}{l}3530 \\
3702 \\
3645 \\
3645 \\
3675\end{array}$ & $\begin{array}{c}388 \\
650(?) \\
173 \\
189 \\
544(?)\end{array}$ & $\begin{array}{r}12 \\
8 \\
6 \\
6 \\
--\end{array}$ & $\begin{array}{c}351.45 \\
504.40 \\
165.15 \\
\text { P184.00 } \\
500.00 \mathrm{R}\end{array}$ & $\begin{array}{r}9-21-72 \\
9-21-72 \\
9-21-72 \\
9-21-72 \\
11-27-53\end{array}$ & $\begin{array}{l}\text { Trsr } \\
\operatorname{Trc}(?), \operatorname{Trsr} \\
\operatorname{Trc} \\
\operatorname{Trc} \\
\operatorname{Trc}(?), \operatorname{Trsr}\end{array}$ & $\begin{array}{l}\text { Windmill; stock; "Allred Well." } \\
\text { Submersible; stock "Graham Welis." } \\
\text { Windmill; stock; "Tip Top Wells." } \\
\text { Windmill; stock; "Tip Top Wells." } \\
\text { Windmill; stock \& domestic; at Brinninstool Ranch, } \\
\quad 2 \text { wells at this location, tape will not pass } \\
220 \text { ' in either well. }\end{array}$ \\
\hline
\end{tabular}

\section{Explanations}

(1) Geologic source: QTs, surficial deposits; Trc, sandstone beds in the Chinle Formation; Trsr, Santa Rosa Sandstone; Pdl, Dewey Lake Redbeds; Pru, Rustler Formation above Culebra Dolomite Member, including Magenta Dolomite Members; Prc, Culebra Dolomite Member of Rustler Formation.

(2) Altitute: From topograhical maps.

(3) Depth of well: All depths of wells were obtained in 1972; all depths to water in the wells measured in 1972 or before are listed; $R$, reported depth; $P$, pumping level; $<$, less than. 
TABLE 6.3-3: Water Quality Data (from Table 2, Mercer and Orr, 1978) reported in parts per million

Monitor Well Date
of Sample
Magenta.Dolomite

$\begin{array}{ll}\mathrm{H}-1 & 5 / 10 / 77 \\ \mathrm{H}-2 \mathrm{a} & 2 / 22 / 77 \\ \mathrm{H}-3 & 5 / 10 / 77 \\ & \\ \text { Culebra. Dolonite }\end{array}$

H-1 3/17/77

$\mathrm{H}-2 \mathrm{~b} \quad 2 / 22 / 77$

H-2c $3 / 16 / 77$

H-3 3/17/77

$P-14 \quad 3 / 14 / 77$

$P-15 \quad 5 / 10 / 77$

P-17 $5 / 10 / 77$

Tempera-
pH ture

Units (Celsius)

Calcium

Magnesium
Sodium
(Na)

Potassium
(K)

Bicar-

$\left(\mathrm{HCO}_{3}\right)$

Carbonate

$\left(\mathrm{CO}_{3}\right)$

Sulfate

P-18 5/10/77

$\begin{array}{ll}7.2 & 22.0 \\ 8.6 & 22.0\end{array}$

22.0
22.0

1,000
820

820
1,200

460
170

6,200

2,700

9,300

840
81
250

93
74

51

$\begin{array}{ll}0 & 3,600 \\ 0 & 2,400 \\ 0 & 3,400\end{array}$

8.022 .5

$\begin{array}{rr}7.3 & 22.5 \\ 8.4 & 21.5 \\ 8.1 & 20.5 \\ 7.4 & 21.5 \\ 6.0 & 21.5 \\ 10.2 & 21.5 \\ 7.4 & 22.5 \\ 7.2 & 24.5\end{array}$

\section{0}

690

680

1,500

3,100

770

1,700

5,600

$\begin{array}{rr}1,800 & 29,000 \\ 160 & 2,100 \\ 120 & 3,600 \\ 670 & 19,000 \\ 760 & 7,600 \\ 63 & 6,900 \\ 1,600 & 30,000 \\ 16,000 & 9,200\end{array}$

5,600
91
120
630
600
1,700
120
6,200

100
59
62
115
357
63
77
310

$\begin{array}{rr}0 & 11,000 \\ 5 & 3,000 \\ 0 & 3,200 \\ 0 & 5,700 \\ 0 & 1,400 \\ 24 & 3,200 \\ 0 & 5,000 \\ 0 & 980\end{array}$

\section{Rustler-Salado Contact}

\section{$\mathrm{H}-1 \quad 2 / 22 / 77$ \\ $\mathrm{H}-2 \mathrm{C} \quad 2 / 23 / 77$ \\ $\mathrm{H}-3 \quad 2 / 24 / 77$ \\ P-14 2/24/77 \\ Delaware. Sand}

$\begin{array}{ll}7.9 & 21.0 \\ 5.9 & 20.5\end{array}$

13,000
9,200

30,000

7.6

21.5

18,000

570

25,000

25,000

56,000

66,000

59,000

17,000
9,100
14,000
1,300

675

120,000

199
467

222

AEC-8 $9 / 22 / 77$

$6.0 \quad 30.0 \quad 10,000$

2,500

55,000

860

420 
Table 6.3-3 Continued

\begin{tabular}{|c|c|c|c|c|c|c|c|c|}
\hline Monitor Well & $\begin{array}{l}\text { ChIoride } \\
\text { (CI) }\end{array}$ & $\begin{array}{l}\text { Fluoride } \\
\text { (F) }\end{array}$ & $\begin{array}{l}\text { Silica } \\
\left(\mathrm{SiO}_{2}\right)\end{array}$ & $\begin{array}{l}\text { Dissoived Solids } \\
\text { (Sum of } \\
\text { constitents) }\end{array}$ & $\begin{array}{l}\text { Nitrate* } \\
+ \text { Nitrate } \\
\quad \text { (N) }\end{array}$ & $\begin{array}{l}\text { Ortho* } \\
\text { Phosphorus } \\
\text { (P) }\end{array}$ & $\begin{array}{l}\text { Boron* Iron* } \\
(B)(\mathrm{Fe})\end{array}$ & $\begin{array}{l}\text { Manganese* } \\
\left(M_{n}\right)\end{array}$ \\
\hline
\end{tabular}

Magenta Dolomite

$\begin{array}{lrlllllrrrr}H-1 & 10,000 & 2.0 & 1.7 & 22,200 & 0.04 & 0.03 & 3.3 & 0.22 & 0.95 \\ H-2 a & 4,100 & - & 6.0 & 10,300 & 0.04 & 0.01 & 0.22 & 0.06 & <0.05 \\ H-3 & 15,000 & 1.8 & 6.4 & 29,700 & 0.08 & 0.04 & 13.0 & 0.04 & 0.22\end{array}$

\section{Culebra Dolomite}

$\begin{array}{lrrrrrrrrr}\mathrm{H}-1 & 49,000 & 0.8 & 0.6 & 97,300 & 0.03 & 0.00 & 18.0 & 0.79 & 2.8 \\ \mathrm{H}-2 \mathrm{~b} & 2,800 & 2.0 & 1.7 & 8,890 & 0.01 & 0.03 & 9.5 & 0.02 & 0.2 \\ \mathrm{H}-2 \mathrm{c} & 4,700 & 1.6 & 3.5 & 12,500 & 0.16 & 0.00 & 10.0 & 0.11 & 0.14 \\ \mathrm{H}-3 & 29,600 & 0.5 & 1.2 & 57,200 & 0.07 & 0.00 & 20.0 & 0.05 & 0.72 \\ \mathrm{P}-14 & 20,000 & 0.9 & 33 & 33,700 & 0.01 & 0.02 & 0.7 & 17 & 0.5 \\ \mathrm{P}-15 & 11,000 & 1.2 & 1.6 & 23,700 & 0.04 & 0.03 & 4.7 & 0.1 & 0.02 \\ \mathrm{P}-17 & 54,000 & 1.5 & 1.0 & 92,500 & 0.06 & 0.11 & 1.7 & 1.2 & 3.0 \\ \mathrm{P}-18 & 80,000 & 1.2 & 1.0 & 118,000 & 0.81 & 0.40 & 100.0 & 0.54 & 4.5\end{array}$

Rustler-Salado. Contact

$\begin{array}{lllllllrrr}H-1 & 210,000 & - & 0.0 & 327,000 & 0.29 & 0.00 & 110 & 1.5 & 52 \\ H-2 c & 200,000 & - & 2.0 & 311,000 & 1.1 & 0.00 & 150 & 2.5 & 78 \\ H-3 & 210,000 & - & 1.0 & 327,000 & 0.77 & 0.00 & 1.9 & 1.5 & 3.8 \\ \text { P-14 } & 180,000 & - & 2.0 & 313,000 & 0.34 & 0.08 & 1.7 & 2.1 & 3.4\end{array}$

\section{Delaware Sand}

$\begin{array}{lllllllllll}\text { AEC-8 } & 120,000 & 1.2 & 3.6 & 189,000 & 0.11 & 0.05 & 53 & 23 & 14.0\end{array}$

* Due to sampling conditions, analyses of $\mathrm{NO}_{3}^{-1}, \mathrm{PO}_{4}^{-3}, \mathrm{BO}_{3}^{-3}, \mathrm{Fe}^{+2}$, and lin ${ }^{+2}$ are probably no more piecise than \pm i5: The others have a precision of about $\pm 5 \%$. 
TABLE 6.3-4 Fluid Yield From Test Zones

(gallons per day)

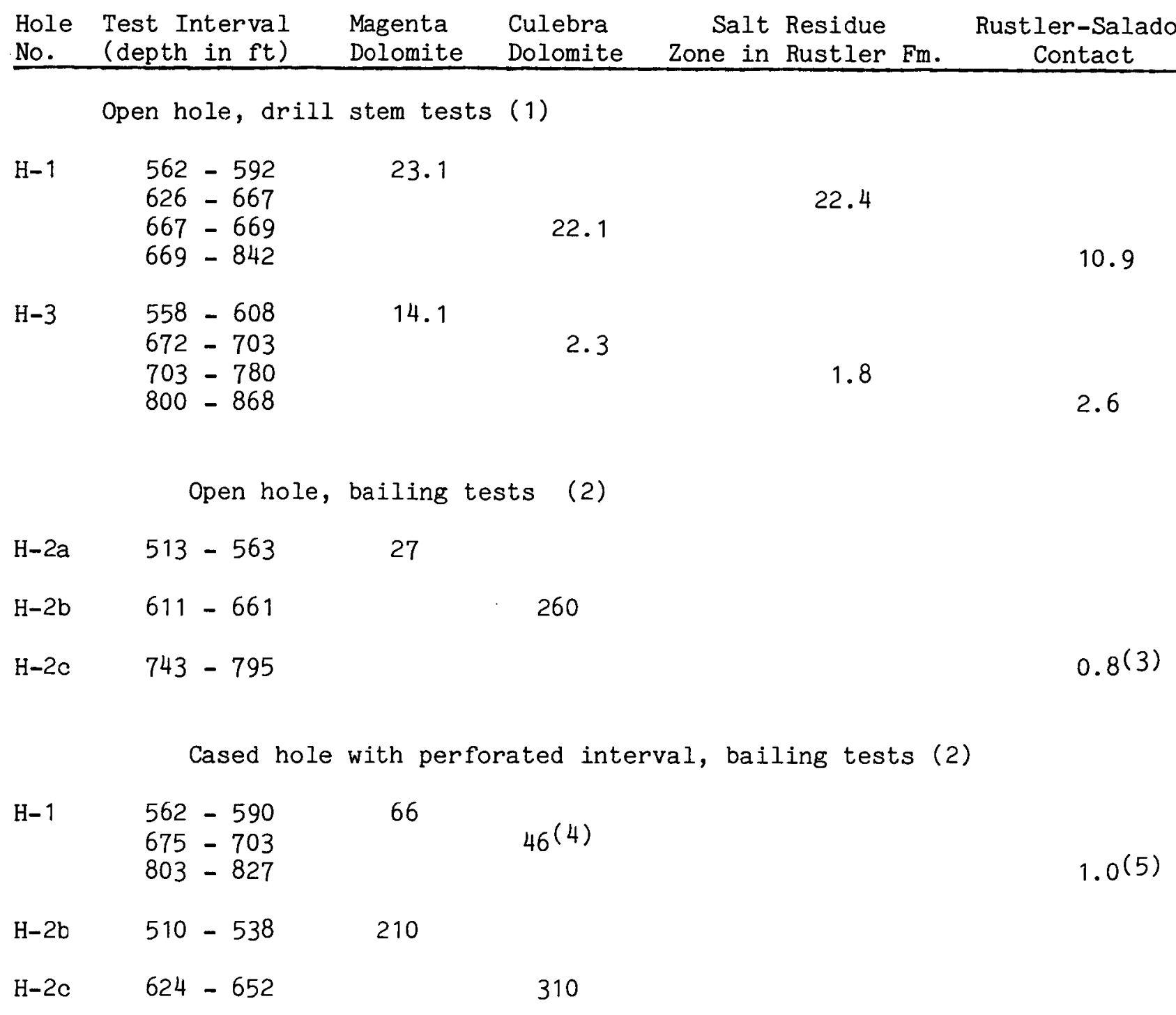


TABLE 6.3-4 (continued) Fluid Yield From Test Zones

(gallons per day)

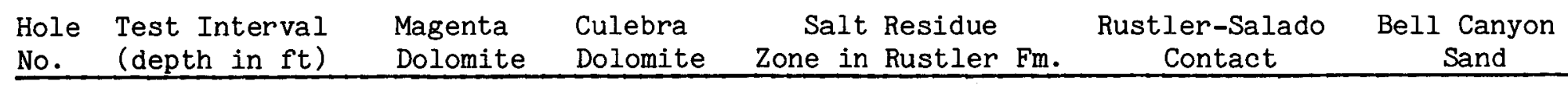

Cased hole with perforated interval, bailing tests (2)

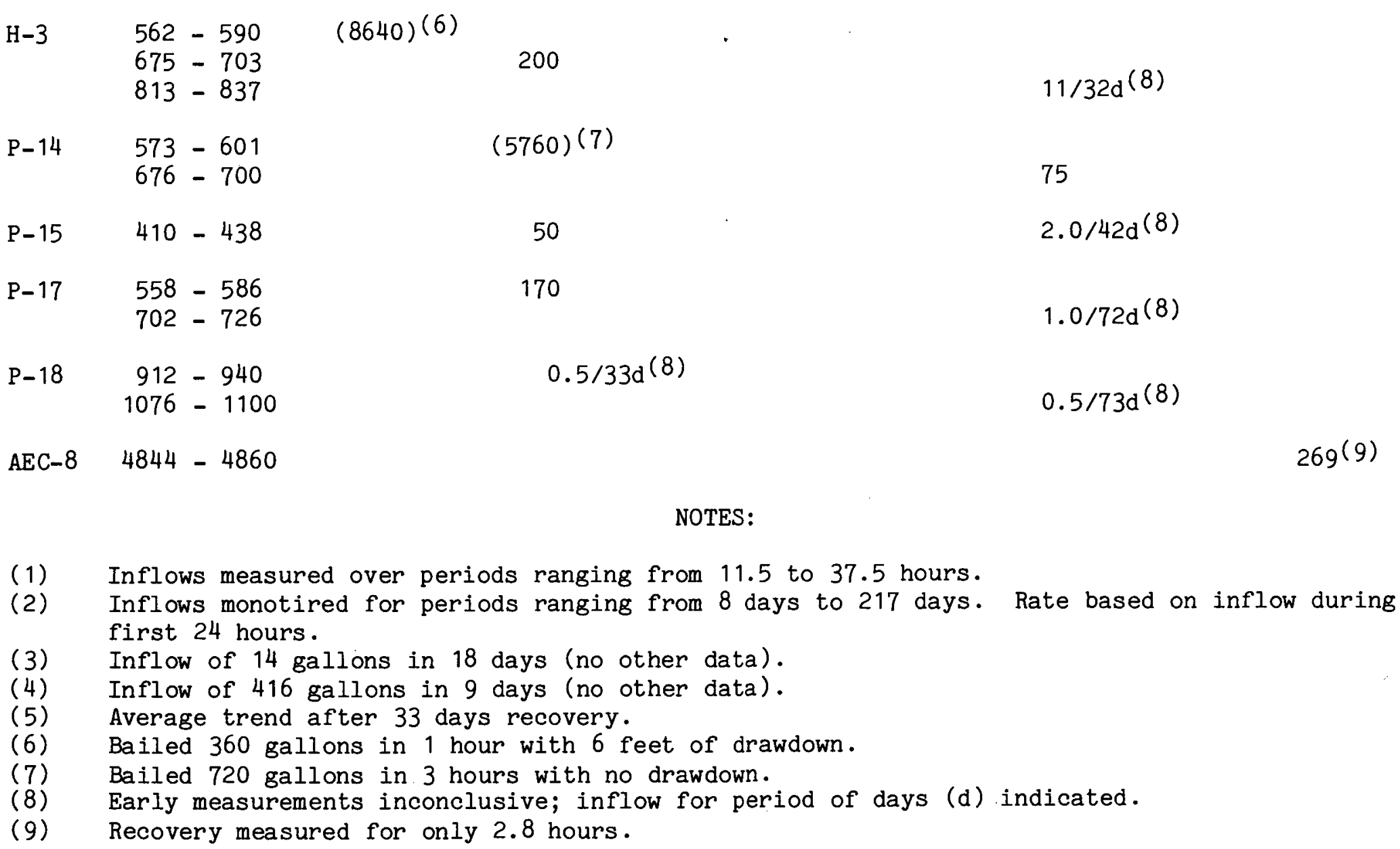


TABLE NO. $6 \cdot 3-5$

OBSERVATION WELLS - MONITORING ZONES

WELL NO.

(GROUND

ELEV.)

ZONE TESTED

$\begin{array}{cl}\text { ACCESSIBLE } & \text { INTERVALS } \\ \text { DEPTH } & \text { ELEV. }\end{array}$

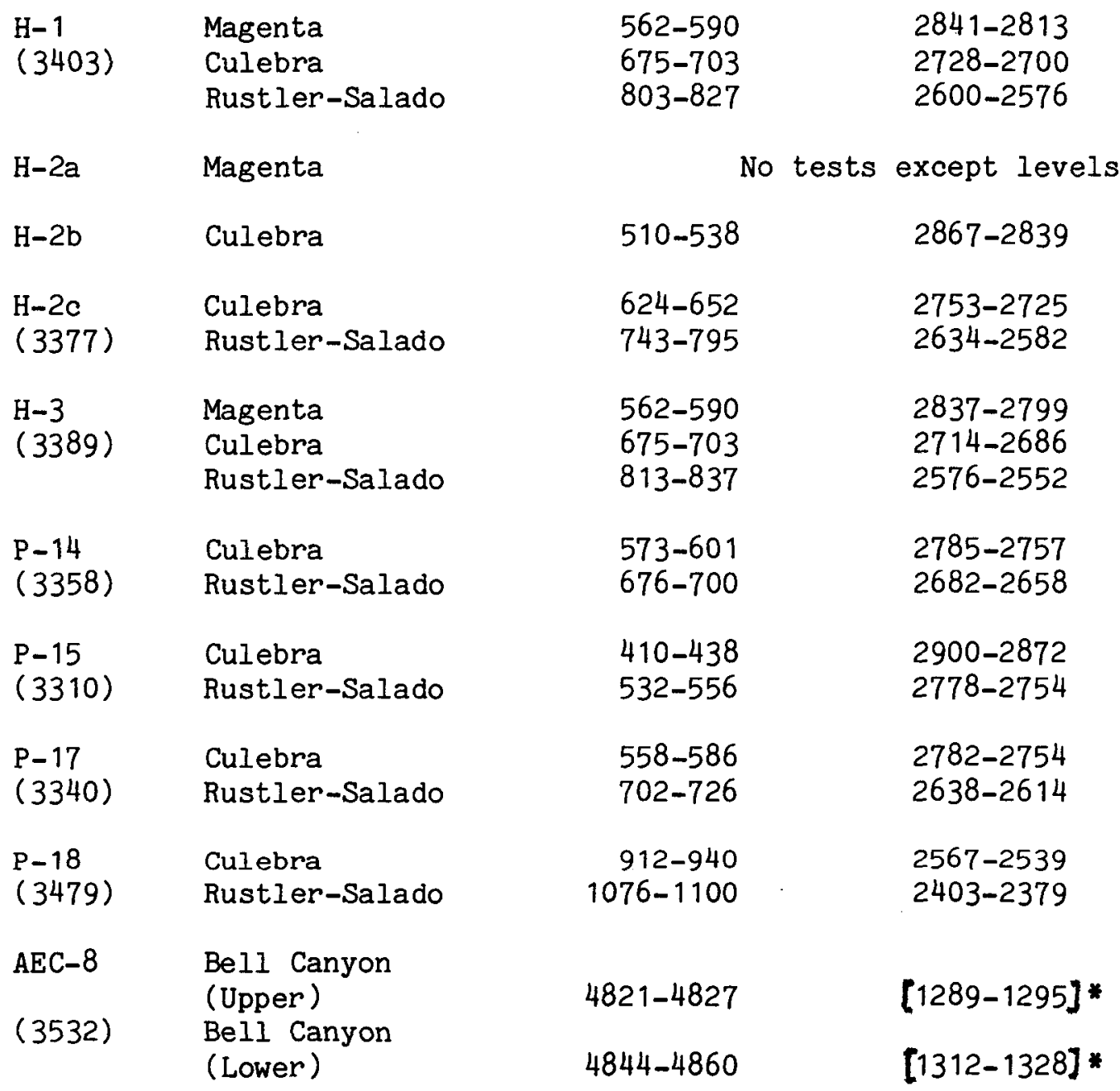

*Elevations in brackets are below mean sea level; all other elevations are above msl. All depths and elevations are given in feet. 
TABLE NO. 6.3-6

\section{POTENTIOMETRIC LEVELS \\ OCTOBER 1977 \\ (Elevation in Feet)}

\begin{tabular}{|c|c|c|c|c|c|}
\hline $\begin{array}{c}\text { Observation } \\
\text { Well }\end{array}$ & $\begin{array}{l}\text { Ground } \\
\text { Surface } \\
\text { Elevation }\end{array}$ & $\begin{array}{l}\text { Magenta } \\
\text { Dolomite }\end{array}$ & $\begin{array}{l}\text { Culebra } \\
\text { Dolomite }\end{array}$ & $\begin{array}{l}\text { Rustler- } \\
\text { Salado } \\
\text { Contact }\end{array}$ & $\begin{array}{l}\text { Delaware Sands } \\
\text { "Upper" "Lower" }\end{array}$ \\
\hline $\mathrm{H}-1$ & 3,403 & 3,154 & 3,013 & $\begin{array}{l}\text { Not } \\
\text { Monitored } 1\end{array}$ & \\
\hline $\mathrm{H}-2 \mathrm{a}$ & 3,377 & 3,128 & $\begin{array}{l}\text { Not } \\
\text { Penetrated }\end{array}$ & $\begin{array}{l}\text { Not } \\
\text { Penetrated }\end{array}$ & \\
\hline $\mathrm{H}-2 \mathrm{~b}$ & 3,377 & 3,081 & 3,026 & $\begin{array}{l}\text { Not } \\
\text { Penetrated }\end{array}$ & \\
\hline $\mathrm{H}-2 \mathrm{c}$ & 3,377 & $\begin{array}{l}\text { Not } \\
\text { Screened }\end{array}$ & 3,021 & $34 \cdot /$ Month $^{2}$ & \\
\hline $\mathrm{H}-3$ & 3,389 & 3,141 & 2,984 & $\begin{array}{l}\text { Not } \\
\text { Monitored }\end{array}$ & \\
\hline$P-14$ & 3,358 & $\begin{array}{l}\text { Not } \\
\text { Screened }\end{array}$ & 3,034 & 2,970 & \\
\hline P-15 & 3,310 & $\begin{array}{l}\text { Not } \\
\text { Screened }\end{array}$ & 3,002 & 2,975 & \\
\hline$P-17$ & 3,340 & $\begin{array}{l}\text { Not } \\
\text { Screened }\end{array}$ & 2,968 & 2,970 & \\
\hline$P-18$ & 3,479 & $\begin{array}{l}\text { Not } \\
\text { Screened }\end{array}$ & $8^{\prime} /$ month $^{2}$ & $401 /$ month ${ }^{2}$ & \\
\hline AEC-8 & 3,532 & $\begin{array}{l}\text { Not } \\
\text { Screened }\end{array}$ & $\begin{array}{l}\text { Not } \\
\text { Screened }\end{array}$ & $\begin{array}{l}\text { Not } \\
\text { Screened }\end{array}$ & 2,933 \\
\hline
\end{tabular}

NOTES:

${ }^{1}$ The Rustler-Salado contact is accessible, but is temporarily off.

${ }^{2}$ Recovery Rate: Level in tubing had not reached static level in October, 1977 


\section{GCR CHAPTER 7}

GEOCHEMISTRY

\subsection{INTRODUCTION}

In the context of this Geological Characterization Report, "geochemistry" is taken here to include a description of chemical properties of geologic media presently found in the surface and subsurface environments of southeastern New Mexico in general, and of the proposed WIPP withdrawal area in particular. "Chemical properties of geologic media" might be extended to include a description of present understanding of chemical processes which have taken or are taking place in southeastern New Mexico rocks. This geochemistry chapter of the WIPP Geological Characterization Report does not consider any aspect of artificially-introduced material, temperature, pressure, or any other physico-chemical condition not native to the rocks of southeastern New Mexico. These as-yet hypothetical considerations belong in the realm of interactions between radioactive waste and rock, a subject of the experimental programs initiated as part of the WIPP studies that are not yet completed. Early experimental results of radionuclide interactions with southeast New Mexico rocks and fluids are reported in Chapter 9.

A substantial fraction of this chapter consists of original source material, never before published in any format aside from reports of investigations resulting from research contracts. Much of this material is, however, in the process of being recast so as to be suitable for presentation in various professional forums. Some material has already been so presented.

Information contained herein was offered if the work involved was at a suitable stage of completion so as to allow conclusions to be drawn. Some subjects of investigation related to geochemistry require several years more investigation, even for final site characterization, and are discussed in Chapter 10, "Continuing Studies." Subjects of the present chapter are those which provide background data of relevance to (1) 
experimental programs involving radioactive waste and its interaction with geomedia, (2) borehole plugging, (3) the intrinsic physico-chemical stability of southeastern New Mexico rocks in the geologic past, and (4) safety assessment, which is described in other major documents relating to the proposed WIPP. These data include mineralogy, volatile constituents of rocks, the constitution, origin and history of liquids and gases found in rocks, and the lengths of time which have passed since the latest episodes of thermodynamic instability resulting in rock/fluid interactions.

In the absence of a satisfactory theoretically-formulated mathematical model which can accurately predict phase equilibria among complex evaporite minerals, an empirical approach, based on observed assemblages, is adopted here. Such modelling is beyond the scope of this document.

It will be noted that volatile contents of evaporites were determined by three different methods: static heating (Section 7.5.3), thermogravimetric analysis (Section 7.5.2) and counting of fluid inclusions (Section 7.6). Each set of data was collected for a different geochemical purpose, but results from all techniques show comparable amounts of volatile constituents in the evaporites. The most accurate results, however, are probably those derived from static heating.

7.2 THE MINERALOGY OF DELAWARE BASIN EVAPORITES AND RELATED ROCKS OF THE LOS MEDANOS AREA

\subsubsection{Introduction}

The foregoing sections on geology and stratigraphy have briefly mentioned generalized mineralogies of Delaware Basin rocks of the Los Medanos area. Here it becomes of interest to present a more thorough exposition of mineralogies. This is done for a variety of reasons: mineralogies affect properties of rocks important to physical aspects of mining, (2) soluble minerals in rocks potentially give rise to solutions which can interact with waste and its containers, and (3) minerals in 
rocks have various degrees of sorptive affinities for radionuclides and can serve to decrease their mobility. While this section is devoted mainly to an account of the minerals found in the main Ochoan evaporite section (Castile and Salado Formations), mineralogies of some Guadalupian rocks and some rocks above the main evaporite section are included. This information is particularly useful to the consideration of radionuclide mobility in rocks containing substantially more fluid than the evaporites, and is of fundamental importance to in situ experiments involving waste-rock interactions. Also, investigations of fluid inclusions, sources of volatiles, groundwater geochemistry and age-dating of rocks and waters are closely related to mineralogy.

\subsubsection{Previous Work}

Southeastern New Mexico evaporites have been economically important for many years because they contain the well-known McNutt Potash Zone in the middle part of the Salado Formation. Descriptions of mineralogies of the McNutt and adjacent portions of the Salado have been given in several previous reports covering much of the Permian Basin, and environs of southeastern New Mexico (Brokaw et al., 1972; Jones, 1973; Jones, 1974a; Jones, 1974b; Jones, 1975). A detailed review of the economic mineralogy of the McNutt Potash Zone underlying Los Medanos appears in Chapter 8 of this report. This section on mineralogy has been developed as background critical to mine design, waste-rock-fluid interactions, and other aspects of geochemistry, such as age-dating and radionuclide migration.

\subsubsection{Overview of Evaporite Mineralogy}

$x$-ray powder diffraction examination of 50 core samples from ERDA \# 9 in the center of the study area (Figure 4.1-2) has been completed. Only qualitative information was obtained from these preliminary cores in order to assess mineralogical variations among selected horizons.

As-received cores were crushed and ground to bulk powder to provide a representative sample of that zone, $x$-ray specimen mounts weres scanned 
at $1^{\circ} /$ min on a diffractometer equipped with copper $x$-ray source, graphite monochrometer and scintillation detector.

Eight minerals were identified in the 50 samples:

$\begin{array}{llll}\text { 1. anhydrite } & \mathrm{CaSO}_{4} & \\ \text { 2. clay } & \mathrm{Al}_{2} \mathrm{Si}_{4} \mathrm{O}_{10}(\mathrm{OH})_{2} & \mathrm{xH}_{2} \mathrm{O} \\ \text { 3. halite } & \mathrm{NaCl} & & \\ \text { 4. loeweite } & \mathrm{Na}_{12} \mathrm{Mg}_{7}\left(\mathrm{SO}_{4}\right)_{13} & 15 \mathrm{H}_{2} \mathrm{O} \\ \text { 5. magnesite } & \mathrm{MgCO}_{3} & \\ \text { 6. polyhalite } & \mathrm{K}_{2} \mathrm{Ca}_{2} \mathrm{Mg}\left(\mathrm{SO}_{4}\right)_{4} & 2 \mathrm{H}_{2} \mathrm{O} \\ \text { 7. quartz } & \mathrm{SiO}_{2} & \\ \text { 8. sylvite } & \mathrm{KCl} & \end{array}$

Their occurrence is given qualitatively in Table 7.1 with a corresponding graphical distribution shown in Figure 7.1. Trace amounts of the potassium minerals sylvite and polyhalite were found in the proposed TRU horizon (2034-2110'), and the high-level horizon (2594-2692') was void of potash.

\subsubsection{Mineralogy of Fluid-Bearing Zones in the Rustler Formation and Delaware Mountain Group}

Mineralogies of certain fluid-bearing rocks above and below the main evaporite sequence have been determined as background information for radionuclide sorption studies.

Magenta Member, Rustler Formation (AEC No. 8). The Magenta member of the Rustler Formation is largely ferroan dolomite, probably containing minor ankerite which gives rise to the reddish color in weathered outcrops. This rock also contains detrital quartz, and gypsum forms as crystals, filling the vugs in the dolomite, which can be up to several cm across.

Culebra Member, Rustler Formation (AEC No. 8). Like the Magenta, the Culebra member is largely dolomite, with traces of detrital quartz. In addition, small amounts of calcite are found. 
Bell Canyon Sandstone (AEC No. 8). The Bell Canyon Formation is the uppermost unit in the Delaware Mountain Group immediately underneath the main evaporite sequence. It is mostly detrital quartz and major feldspar with a matrix of kaolinite and chlorite cemented with calcite and minor amounts of dolomite.

Cherry Canyon Sandstone (Pine Springs Outcrop). Although the Cherry Canyon Formation was not sampled in any WIPP exploratory borehole, its stratigraphic position directly underneath the Bell Canyon made it of interest in preliminary radionuclide sorption measurements. The detrital component is largely quartz, and the cement is mostly dolomite. Minor amounts of albite and microcline contribute to the detrital component, and minor amounts of gypsum and calcite are found in the cement.

7.3 DETAILED CHEMISTRY AND MINERALOGY OF SOLUBLE AND INSOLUBLE COMPONENTS OF THE SALADO FORMATION

\subsubsection{Introduction}

While this section deals primarily with results obtained from cores from $A E C$ No. 7 and $A E C$ No. 8, exploratory holes three miles northeast of the present study area (Figure 4.1-2), these holes provided material of sufficient lithologic similarity to ERDA No. 9 so as to be of value. The analytical strategy employs a normative-type calculation, in which mineralogical compositions are derived mathematically from bulk chemical compositions. The results of those calculations then can be compared to mineralogies determined petrographically or by $x$-ray diffraction. This section serves as fundamental background information for the chapters on silicate mineralogy and sources of volatile components within the evaporites. 


\subsubsection{Materials and Methods}

Sample Preparation and Handling. The core samples as received were halved and one-half was retained while the remaining half was crushed and ground. The ground sample was size-distributed as shown in Table 7.2.

The samples were all double-wrapped for storage in plastic bags due to their hygroscopic nature. A portion of the crushed sample weighing approximately 20 grams was accurately weighed and dried in an oven at $70^{\circ} \mathrm{C}$ for two hours to determine weight loss. The dried sample was then added to $200 \mathrm{ml}$ of distilled water, stirred for 1 hour, and filtered. The filtered material was dried and weighed to determine the insoluble portion of the sample while the filtrate contained the soluble portion of the sample.

Analysis of Soluble Portion. The elements potassium, calcium, magnesium, silicon, iron, aluminum, and strontium were analyzed by standard atomic absorption methods using a Perkin-Elmer 403 Atomic Absorption Spectrophotometer. Sodium, typically difficult to analyze precisely, was analyzed using an Orion Specific Ion Sodium electrode and an Orion Research Model 801 pH meter. Sulfate was determined gravimetrically as barium sulfate; chloride was determined volumetrically by titrating with mercuric nitrate (Vogel, 1961)

Analysis of Insoluble Portion. The insoluble portion was separately analyzed only if the insoluble percentage was greater than 0.58 of the total sample weight. Samples containing less than 0.58 insolubles did not provide sufficient material for analysis, and it was deemed that even a major constituent in such a small percentage of the total would not contribute significantly to the sample behavior. A portion of the water-insoluble material weighing about $100 \mathrm{mg}$ was dissolved in $\mathrm{HF}$, using the following procedure in a teflon-lined high pressure bomb (Bernas, 1968; 1973) obtained from Parr Instruments. Nitric acid (1 ml) was added 
to wet the sample and $3 \mathrm{ml}$ of $508 \mathrm{HF}$ were added. The bomb was assembled and placed in a $70^{\circ} \mathrm{C}$ oven for 2 hours. The contents of the bomb were quantitatively transferred to a polypropylene beaker containing $2.8 \mathrm{~g}$ of boric acid and about $30-40 \mathrm{ml}$ deionized water. The boric acid was allowed to dissolve with stirring and the solution diluted to $100 \mathrm{ml}$ in a volumetric flask and stored in a polyethylene bottle. A solution containing all of the matrix material was prepared for use in making standards for the atomic absorption spectrophotometer. All analyses were performed as described in the preceding section. Samples were tested for the presence of carbonates using concentrated HCl but only occasionally was a trace amount detected.

Thermal Analysis. Samples analyzed for weight loss upon heating were ground so that greater than 908 of the sample was smaller than 100 mesh. Each sample was dried for at least 3 days at $65^{\circ} \mathrm{C}$ in a thermostatically regulated oven. This temperature was chosen to avoid the long-term dehydration of gypsum described elsewhere in this report. Low temperature weight loss $\left(70^{\circ} \mathrm{C}\right.$ for 2 hours) was used to measure absorbed water. This weight loss is probably higher than for rock distant from the sample collection point owing to absorption of drilling water. Samples of $100 \mathrm{mg}$ weight were heated for differential thermal analysis (DTA) using a Fisher 200A DTA apparatus at a rate of $10^{\circ} \mathrm{C} / \mathrm{min}$ from $25^{\circ} \mathrm{C}$ to $500^{\circ} \mathrm{C}$.

Thermogravimetric analysis was carried out with a Fisher 100A TGA apparatus and a Cahn Model $R 6$ electrobalance at a rate of $5^{\circ} \mathrm{C} / \mathrm{min}$ from $60^{\circ} \mathrm{C}$ to $5000^{\mathrm{C}}$ using $100 \mathrm{mg}$ of sample material. A few samples were heated to $800^{\circ} \mathrm{C}$ and are described elsewhere in this subsection.

Results of Analyses. Whole-rock chemical analyses, soluble-insoluble fractions, and weight losses upon heating are presented in Appendix 7.A. These analyses are converted to relative numbers of moles of components by multiplying weight percents by appropriate values of $1000 /$ molecular weight. The results are listed in Appendix 7.B. If the insoluble fraction of a sample exceeds 0.5 weight percent, separate calculations are provided for both the soluble and insoluble fractions of the sample. 


\subsubsection{Results and Discussion}

Distribution of Mineral phases. Chemical analyses may be used to estimate, semiquantitatively, the amounts of constituent minerals present in a rock. This is accomplished by distributing the quantitatively determined chemical components among mineral phases known qualitatively to be present in the rock. The method was as follows:

The distribution of the total number of moles (Nt) of a given chemical component (c) among the various mineral phases (p) present in a rock is described by the equation

$$
N t, c=\sum(\mathrm{Np})(\mathrm{NC}, \mathrm{p})
$$

where:

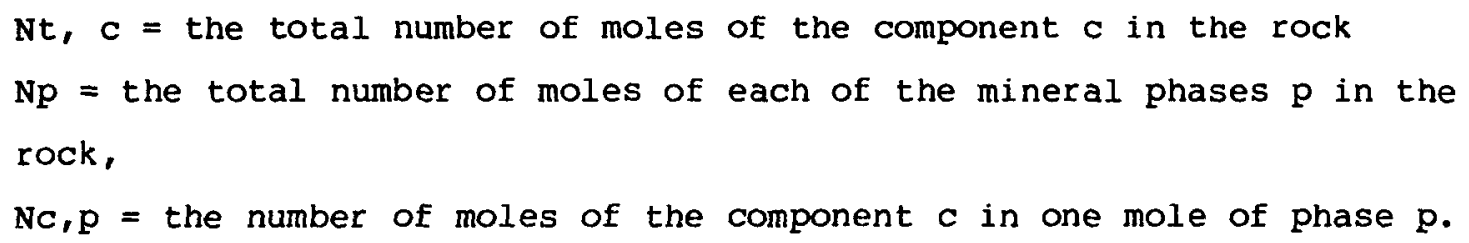

This equation is simply a statement of conservation of mass, indicating that the total amount of a given chemical component must be distributed among the minerals containing that component; this distribution is controlled by the specific chemical compositions of the minerals. An expression of the form of the above equation may be written for each of the components present in a rock sample. For a given rock, one of three conditions are possible for the set of simultaneous equations describing the distribution of all components in that rock:

1) if the number of equations ( 1 for each component) is equal to the number of unknowns (the moles of each of the phases), an exact solution to the equations may be determined.

2 if the number of components exceeds the number of phases (more equations than unknowns) the system is overdetermined and a solution to the equations may be evaluated by a method such as least squares regression.

$3)$ if the number of components is less than the number of phases (more unknowns than equations), the system is indeterminate. 
If either of the first two criteria are met, the chemical composition of the rock can be employed to calculate the quantitative amounts of minerals known, qualitatively, to be present.

An important assumption for the treatment described above is that the chemical composition of all mineral phases is known. This is necessary in order to define NC,p for all phases in the mass balance equations. If a mineral of variable composition is present in a rock sample (i.e., a solid solution), an additional variable is introduced to the set of equations; that is, the composition of the solid solution. This additional variable may change a set of $\mathrm{N}$ equations and $\mathrm{N}$ unknowns (condition 1 above) to an indeterminate set containing $\mathrm{N}+1$ unknowns. If such is the case, it is necessary to employ some additional analytical technique to determine the actual composition of the unknown. On the other hand, if the solid solution is present in a rock meeting condition 2 above, it will suffice to simply introduce two values of $\mathrm{Np}$ for the phase; in other words, an unknown for the number of moles of each of the pure end-members of the solid solution present. The composition of the mineral is then defined by the relative number of moles of each of the end-members present.

Qualitative mineralogy may be carried out by a variety of methods such as $x$-ray diffraction and thin-section analysis in addition to straight-forward examination. The chemical data obtained during this study have been used to attempt to estimate relative amounts of minerals present in the various samples. With only a few exceptions, the rocks are made up essentially of halite, and other mineral phases are present in comparatively minor or trace amounts.

Samples from the Carlsbad boreholes consist of two chemically distinct fractions: (1) water-soluble chlorides and sulfates of sodium, potassium, calcium, and magnesium, and (2) water-insoluble silicates of potassium, magnesium, and aluminum with quartz and iron oxide. Minerals of the first group generally contain stoichiometric compositions, whereas those of the second group exhibit extensive compositional variation. In 
the case of the soluble portion, sodium occurs mainly with chloride as halite, while the other cations combine in various proportions with sulfate (and only occasionally chloride) forming minerals such as polyhalite, anhydrite, and kainite. These sulfates are of importance because they contain hydrate water which may be released upon heating. Silicates also undergo dehydration at elevated temperatures, but generally much higher temperatures are required than for the soluble salts because the water must be derived through destruction of hydroxyl groups. Compositions of minerals from these two classes are listed in Table 7.3 .

Recognizing that soluble potassium, calcium, and magnesium are combined with sulfate, a semiquantitative estimate of various sulfate phases may be made by plotting the relative numbers of moles of the cations on triangular composition diagrams. The compositions of various stoichiometric mineral phases in the sulfate group are shown on such a diagram in Figure 7.2. No sulfate of potassium alone is common in nature, so sylvite is placed at the potassium apex of the triangle. Also shown on this diagram are the chloride and chloride-sulfate of potassium and magnesium. Not shown on Figure 7.2 are the soluble sulfates containing sodium. After plotting a given sample composition in terms of relative numbers of moles of soluble $\mathrm{K}_{2} \mathrm{O}, \mathrm{CaO}$, and $\mathrm{MgO}$, the total number of moles of these cations is compared to the number of moles of sulfate determined analytically; if the two are equal, then the minerals in the rock are estimated using the location of the sample on the diagram. If the cation sum is greater than available sulfate, an appropriate amount of chloride is added to make up the charge balance. Relative amounts of chloride and sulfate are then used in conjunction with the cations to determine appropriate amounts of carnallite, kainite and/or sylvite. If on the other hand, cations are deficient relative to sulfate, then sodium is added to the sulfate group to form bloedite, glaserite and/or glauberite.

The addition of sodium or chloride must be compatible with the relative amounts of these two components in the analysis. Generally, these are 
present in such large amounts that a small error in their contents provides sufficient amounts for addition to the potassium-calciummagnesium-sulfate fraction. In many instances, it is found that when it is necessary to do such addition, the appropriate component (sodium or chloride) is present in excess of the other necessary to form halite. Where such addition is not compatible with the chemical analysis, examination must be made of the insoluble portion of the sample. Where anhydrite-gypsum is present in significant amounts in a sample, the relatively low solubility of $\mathrm{CaSO}_{4}$ (and possibly polyhalite) causes this phase to appear in both the soluble and insoluble fractions.

Minerals of the insoluble fraction consist of quartz, iron oxide, and a variety of clay minerals which are difficult to identify due to fine-grain-size and compositional variability. Iron probably occurs chiefly as either hematite (much of the halite is tinted orange) or an equivalent hydrated form although it may substitute for aluminum to a minor extent in clay minerals.

According to our chemical analyses, the remainder of the insoluble fraction is made up of the components $\mathrm{K}_{2} \mathrm{O}, \mathrm{Al}_{2} \mathrm{O}_{3}, \mathrm{MgO}$, and $\mathrm{SiO}_{2}$. Because the first three of these generally occur combined with the fourth, potential mineralogy of the samples may be evaluated by comparing insoluble analyses to mineral compositions plotted on the compositonal triangle $\mathrm{K}_{2} \mathrm{O}-\mathrm{Al}_{2} \mathrm{O}_{3}$-MgO shown in Figure 7.3. On this diagram, mixed-layer solid solution among potassium and magnesium montmorillonites and seawater-illite is indicated by the shaded area between these three endmember components. It should be noted that the chlorite composition plotted on Figure 7.3 is that which has been observed in present day seawater sediments and evaporites. Relative proportions and amounts of minerals occurring in a given sample are evaluated by distributing potassium, aluminum, and magnesium along appropriate limiting phase compositions. Silica is then distributed among these phases according to stoichiometry, and any excess occurring in the sample analysis is considered to be free quartz. 
Halite is by far the most abundant mineral in the soluble fractions of the samples. In only a few cases is halite a minor or trace constituent. Polyhalite and anhydrite/gypsum are accessory minerals in most samples, and in two of these, $\mathrm{CasO}_{4}$, is a major component. In normative calculations for sulfate deficient samples, kainite and carnallite are included, whereas thenardite, glaserite, bloedite, and kieserite appear in sulfate-excess and balanced samples. These phases are rarely present in more than trace amounts and are calculated to occur in such small quantities as to be insignificant in terms of contributions to hydrate water. Sample 8-1652 (i.e., 1652 feet depth in AEC No. 8) is significantly different from other soluble material in that it is calculated to contain relatively large amounts of the soluble salts sylvite, polyhalite, leonite, and glaserite. The drilling log reports loss of mud at this point, so it is uncertain as to whether a rock is of exotic mineralogy, or one from which certain cations have been leached by moving drilling mud, or one which has exhibited the incongruent solubility of polyhalite, leaving a sample of abnormal chemistry.

Most of the insoluble analyses plot within the triangle bounded by the phases Mg chlorite-K Eeldspar-talc on Figure 7.3. These minerals are recognized to occur in evaporite sequences which have undergone mild diagenesis $\left(P<100 \mathrm{~atm}, \mathrm{~T}<100^{\circ} \mathrm{C}\right)$, forming as a result of interaction of brine with amorphous aluminosilicate detrital material (Braitsch, 1971). The only other phases calculated to occur in the insoluble fraction are mixed-layer illite-montmorillonite, quartz, and iron oxide. It should be noted that the presence of the mixed layer silicate as well as chlorite and talc may be difficult to establish if they occur in very fine grain size. None of the observed silicate phases undergo dehydration below $500^{\circ} \mathrm{C}$, according to the DTA.

Effects of Heating Samples. A number of different responses to heating were exhibited by the samples. Heating to $70^{\circ} \mathrm{C}$ was designed to measure absorbed water recognizing that gypsum dehydrates, according to thermochemical data, at about $70^{\circ} \mathrm{C}$. In normal differential thermal analysis, gypsum undergoes stepwise dehydration to hemihydrite and 
anhydrite at about $150^{\circ}$ and $185^{\circ} \mathrm{C}$, respectively. Kopp, (University of Tennessee, pers. comm.) has observed that gypsum dehydrates upon fine grinding and prolonged heating at $70^{\circ} \mathrm{C}$, hence the observed DTA breakdown is probably a result of kinetic factors. Consequently, samples analyzed using thermogravimetric analysis were powdered and placed in an oven at $70^{\circ} \mathrm{C}$ for several days prior to analysis of weight loss at elevated temperatures. Samples 7-1171 and 8-2563 both contain major $\mathrm{CaSO}_{4}$, but only the latter showed gypsum-type dehydration. This appears to indicate that sample 7-1171 actually contained anhydrite whereas sample 8-2563 contained gypsum since only 8-2563 showed significant weight loss at $70^{\circ} \mathrm{C}$ but both analyses summed to near 1008 .

Essentially isothermal dehydration was observed over a continuum of temperatures from $100^{\circ}$ to $500^{\circ} \mathrm{C}$ for a large number of samples. In addition, weight loss over a $50^{\circ}$ to $100^{\circ} \mathrm{C}$ span in temperature was observed for most samples, but generally at temperatures above $300^{\circ} \mathrm{C}$. These two types of weight loss probably indicate single-mineral dehydration for isothermal loss, and dehydration as a result of mineral-mineral chemical interaction for the weight loss occurring over a large temperature span. Such solid interaction is demonstrated by sample 8-1953 which contains both anhydrite and polyhalite but minimal bloedite. Figure 7.4 shows the DTA curves for pure polyhalite and gypsum. Comparison of these two curves to that of sample 8-1953 shows the $325^{\circ} \mathrm{C}$ exotherm of polyhalite to be lacking while the lower temperature endotherms of gypsum are present. We suggest the missing polyhalite endotherm is a result of chemical interaction between polyhalite and anhydrite somewhere between $200^{\circ}$ and $325^{\circ} \mathrm{C}$. Such interaction among evaporite minerals should probably be investigated in some detail in terms of retention of hydrate $\mathrm{H}_{2} \mathrm{O}$.

A few samples were heated to $800^{\circ} \mathrm{C}$ to get an indication of how much weight might be lost from samples at high temperatures $\left(>500^{\circ} \mathrm{C}\right)$. Of the nine samples examined under these "extreme" conditions, four began gaining weight at about $700^{\circ} \mathrm{C}$. One sample increased in weight by about 158 between $725^{\circ}$ and $800^{\circ} \mathrm{C}$. This gain in weight is not a result of 
oxidation of iron (eg. $\mathrm{Fe}^{+2}$ in chlorite) since sample 8-2050 did not contain any iron. That the gain in weight may be caused by formation of an extremely hygroscopic phase at high temperatures as a result of solid-solid chemical interaction upon heating. Whether or not such a phase forms would undoubtedly depend upon the initial mineralogy of the rock to provide the correct reactant phases since not all sample exhibited this weight gain. The water necessary for this rehydration is probably a result of the fact that the testing laboratory is cooled during the summer months (the analyses were run in early June) by evaporation which results in high relative humidity.

A composite histogram of weight loss of all samples at elevated temperatures is shown in Figure 7.5. The distribution appears to be log-normal with the maximum density near $0.25 \%$ weight loss upon heating $500^{\circ} \mathrm{C}$. Over half of the samples $(568)$ show weight loss of 0.58 or less, and only 15 samples exceed 18 . Figures $7.6 \mathrm{~A}$ and $7.6 \mathrm{~B}$ are plots of sample weight loss vs depth for the two drill holes. Samples showing more than 18 weight loss upon heating are scattered throughout the depth range but are generally separated by more than one hundred feet of low-water-loss material. There is a broad correlation between higher weight loss and increasing insoluble content of sample, but no clearcut relationship is seen between weight loss and silica content. It is concluded that high temperature weight loss is contributed by both silicate and sulfate minerals. It can be stated in general, however, that samples showing less than 18 weight loss contain less than 10 wt 8 insoluble material.

\subsubsection{Conclusion}

Most of the samples showed very little water loss between $200^{\circ}$ and $300^{\circ} \mathrm{C}$ and there were only small water losses at temperatures $200^{\circ} \mathrm{C}$ and $300^{\circ} \mathrm{C}$. As can be seen by examining the data, there are several zones where there is essentially no change in sample behavior with heating to moderate temperatures. These areas show good potential as burial sites for nuclear waste. 


\subsection{DETAILED PETROLOGY AND SILICATE MINERALOGY OF SOME PERMIAN BASIN ROCKS}

\subsubsection{Introduction}

The purpose of this section is to describe and evaluate the petrologic, mineralogic and geochemical properties of designated core samples, primarily from the ERDA - 9 drill hole and various grab samples exposed in mines and at the surface, in connection with the WIPP (Waste Isolation Pilot Plant) site evaluation.

ERDA - 9 penetrates the Mescalero Caliche, Gatuna Formation Santa Rosa Sandstone, Dewey Lake Red Beds, Rustler Formation, Salado Formation and the uppermost 50 feet of the Castile Formation (Figure 4.3-3). Primary interest is focused on selected intervals within the salado and uppermost Castile Formations.

The general problems under study are: 1) the genesis of the dominantly evaporite succession with associated silicates and 2) the extent of post-depositional alteration of these sediments. The basic approach (and analytical method) is broadly threefold. First, detailed study of the occurrence and mineralogy of silicates, particularly clay minerals, in the evaporite succession (disaggregation, size fractionation, $x$-ray diffractometry). Second, bulk chemical analysis of whole rock, water soluble, acid insoluble, and clay size fraction ( $x$-ray fluorescence, atomic absorbtion spectroscopy, other rapid procedures). Third, macroscopic and microscopic petrography (handspecimen and microscope mineral identification, description of form, texture and lithology of mineral associations, and $x$-ray diffractometry of bulk samples).

\subsubsection{Procedure}

After core intervals were selected for study, cores were cut lengthwise, mostly in the form of $1 / 2$, less commonly $1 / 4$, of the core. Criteria for selection and additional procedures for analysis of these samples are 
described in the following sections on the silicate mineralogy, geochemistry and petrography.

\subsubsection{Silicate Mineralogy and Geochemistry}

Systematic logging of ERDA - 9 core and accompanying gross mineralogy have been described in Chapter 4. This section is focused on selected segments of the core and examination of the paragenesis of minor constituents, namely the silicate minerals, their composition, and their interpretation in terms of depositional and postdepositional phenomena.

Silicate mineralogy and geochemistry have not been comprehensively studied within the Ochoan rocks and the Permian Basin. Adams (1969) has reported briefly on the occurrences of talc in argillaceous rocks as a part of this extensive study of bromine distribution throughout the section; specialized clay mineral determinations by Grim et al. (1961) and Fournier (1961) have been undertaken on a limited number of samples and with minimal regard to their detailed stratigraphic setting and geneses.

In an effort to provide substantially more complete understanding of the silicates associated with the Permian evaporites, some 70 samples of the ERDA - 9 core ranging from 300 feet below the Salado-Rustler contact (1163.3 foot depth) down to a few tens of feet below the salado-Castile contact (2867.6 foot depth) were selected. The following criteria were used in the selection: (1) representation of major lithologies; detailed.representation of an apparent "cycle" of evaporite deposition which occurs repeatedly through the Salado Formation section; (3) representation of intervals under consideration for waste storage sites; (4) detailed representation of selected polyhalite-anhydrite occurrences toward interpreting the genesis of the unusually abundant polyhalite; and (5) representation of the sequences which may provide data for interpreting postdepositional solution and recrystallization phenomena. In Table 7.4, we list the samples by depth, gross lithology, and stratigraphic position, as well as by character of data obtained; Table 7.5 provides a cross-listing for relating sample number to depth. 
Sample Preparation and Analysis. The core was split and one split rebagged for future reference. One to $10 \mathrm{~cm}$ segments of the remaining half were selected for analysis (petrographic, mineralogic, and/or chemical) and sectioned off. A $1 \mathrm{~cm}$ slab of this was retained for petrographic examination; the remainder was coarsely crushed and a split retained for whole rock analysis. The larger fraction of the sample was leached with excess demineralized water to dissolve the halite host. This was repeatedly centrifuged, decanted, and rewashed to remove all traces of dissolved halite from the residue. The residue was dried, reweighed, and a split suspended in boiling EDTA solution in order to separate the "acid-soluble" salts (sulfate and carbonate minerals) following the procedure of Bodine and Fernalld (1973). Again, after repeated centrifuging, decanting and washing to remove EDTA and to dissolve solid components from the insoluble residue, the suspension was dried and reweighed. Table 7.6 depicts the quantities of sample residues insoluble in water and EDTA. A split of this fraction was resuspended in water, thoroughly disaggregated with an ultrasonic probe, and separated into the $>2 \mu \mathrm{m}$ and $<2 \mu \mathrm{m}$ (effective spherical diameter) fractions by timed gravity settling. Oriented diffractometer mounts of the fine fraction were prepared by pipetting several drops of each suspension onto glass slides and air-drying. Smear (paste) mounts and mounts using the conventional commercial powder mounts were used for the $<2 \mu \mathrm{m}$ insoluble fraction as well as for the other fractions. In addition, pellet or uniformly compressed mounts or "briquettes" of these fractions prepared for $x$-ray fluoresence were also used for diffraction.

Where sufficient sample was available, normal procedure for the silicate fraction included: (1) diffraction data for the whole EDTA-insoluble fraction using the briquettes or paste mounts; (2) oriented (sedimented) clay-size mounts on glass which were air-dried, glycol saturated, heated to $300^{\circ} \mathrm{C}$, and heated to $500^{\circ} \mathrm{C}$. Conventional $\mathrm{x}$-ray diffractometer traces were obtained at a scanning speed of $2^{\circ} 2 \theta /$ min with cu-radiation and a curved crystal monochromator. 
$x$-ray fluorescence work involved briquette mounts using the vacuum-path Norelco fluorescence goniometer with quartz and gypsum analyzing crystals. In this study, standard regression procedures are used along with matrix evaluation for calculating abundances from the raw data. However, at this time the data can only be reported in terms of a unit-slope regression from one standard. Because of the severe errors such a procedure may induce, only "semi-quantitative" chemical results are claimed for this report.

\section{Silicate Mineralogy. The following silicate minerals have been} identified in the course of this study; their distribution is given in Table 7.7 .

Quartz - Quartz occurs throughout the entire interval of the stratigraphic section analyzed; however, it does not occur in every sample. Quartz is generally fine-grained $(<10 \mu \mathrm{m})$, subhedral to anhedral, and readily identified in diffraction traces by its very strong peak at $3.34 \AA$ and moderate peak at $4.26 \AA$; interference by the micas and mica-clays with the former and by potash feldspar for the latter only rarely preclude its ready identification.

Illite (mica-clay) - Illite also occurs throughout much of the stratigraphic interval. It is readily observable in diffraction traces with its strong $10 \AA$ and $3.34 \AA$ peaks and its moderate $5.0 \AA$ peak $(001,003$, and 003 respectively). All illites observed in the core are dioctahedral as based upon $(060)<1.52 \AA$ and $(001,002$, and 003)<1.0, 5.1, and $3.44 \AA$ respectively. Many of the illites contain recognizable but small quantities of interlayered smectite, presumably saponite or other trioctahedral varieties, based on the slight asymmetry of the (001) reflection.

Feldspar - Feldspar occurs frequently, but generally in small quantities, throughout the section and its identification is based principally on one or more diffraction maxima in the $3.17-3.30 \AA$ range. Unfortunately, its abundance is usually low and when coupled with the presence of other 
minerals its diffraction maxima for resolving its composition and its thermal character are not interpretable; both plagioclase and $\mathrm{K}$-feldspar have, on occasion, been recognized.

Chlorite - Chlorite is commonly a minor constituent and its presence is of ten difficult to establish. With a $14 \AA$ periodicity its maxima can be masked by smectities, various interlayered species, and by the $7 \AA$ minerals, kaolinite and serpentine. In glycol saturated specimens, the $14 \AA$ peak from expandable clays can be removed and at $500^{\circ} \mathrm{C}$ the $7 \AA$ peak from kaolinite is lost. Even so with only a small amount present in such an assemblage it can remain undetected.

Talc - Talc is rare throughout the core. It is common in the ore zones (Adams, 1969) but appears to be nearly absent from the other lithologies. Talc is identified by very sharp, strong reflections at 9.5 and $3.15 \AA(001$ and 003$)$; the former is quite distinct from the broad reflection at $9.0-9.7$ from a regular interlayered chlorite-saponite (corrensite).

Serpentine - Serpentine, like talc, is relatively rare in the section and is confined to the lowermost interval (below 2820.3 and at or below the Salado-Castile contact) in rock salt and anhydrite. Serpentine is identified by strong peaks at $\sim 7.3 \AA$ and $\sim 3.6 \AA(001$ and 002 respectively for a single-layered variety). These maxima are noticeably greater than the $7.0-7.2 \AA$ and $3.5-3.65 \AA$ reflections attributable to chlorite. In our samples, these larger spacings are characteristically sharp and are not accompanied by the odd $(00)$ reflections of the $14 \AA$ minerals.

Expandable Clays - Expandable clays, the smectities, vermiculites, and mixed-layer clays containing either of these constituents, are the dominant clays of the section and are ubiquitous (Table 7.8). We have recognized at least four such clays; however, their definitive identity has not yet been resolved. 
a. Saponite (e.g. JS-CS-9 at 1466.9') expands to $>16 \AA$ with glycol saturation and collapses to $<J 4 \AA$ upon heating, (further heating would yield an $\sim 9.5 \AA$ peak).

b. (?) Illite-saponite (e.g. JL-CS-2 at 1440.5' JL-CS-10 at 1325.3') with an air-dried maximum at 10.2 - $10.3 \AA$ glycol saturation at $10.0 \AA$ and with or without a less intense shoulder or separate peak at $11.3-12.1 \AA$, and collapsing to $9.8 \AA$ at $300^{\circ} \mathrm{C}$. We have not ruled out a mixed-layer talc saponite identification for this phase.

c. Chlorite-saponite (e.g. MB-CS-21 at 1404.6' and MB-CS-32 at $\left.2541.5^{\prime}\right)$ exhibits a $14 \AA$ peak expanding to $15.5 \AA$ with glycol saturation and collapse to $<14 \AA$ upon heating. The chlorite-vermiculite phase described by Fournier (1961) and Grim et al. (1961) is probably this chlorite-saponite; the expansion with glycol is too great for this to be a chlorite-vermiculite. In some cases the interlaying is random; in others it is regular and produces a distinct superlattice peak ( $29 \AA)$; in most there is some regularity with a slight shoulder present in the $25-30^{\circ} 2 \theta$ present (these shoulder "maxima" are exceedingly difficult to plot precisely and all contain $\pm 0.3-0.5^{\circ} 2 \theta$ definition).

Nearly all of the diffraction data in Table 7.8 can be assigned to one of these three clay phases, yet data from several samples are not yet resolved, e.g. MG-CS-13 at 2518.3. It should be noted that smectities are smectite-bearing mixed-layer clays which commonly appear to be "stripped" by the EDTA-dissolution of nonsilicates; they commonly show 12-13.8A air-dried spacings. However, suspending these clays in $\mathrm{MgCl}_{2}$ or $\mathrm{NaCl}$ solutions and then rewashing and redrying restores the appropriate $14-15 \AA$ spacing.

In Appendix 7.C, we present a number of the diffraction diagrams illustrating these silicate assemblages. 
Distribution of Clay Materials. Some general but tentative observations regarding these minerals throughout the section are:

(1) Serpentine appears to be restricted to the lower

40 feet of the analyzed section; it most commonly occurs in anhydrite and associated rock salt.

(2) Talc is not restricted to assemblages from bitterns as suggested by Adams (1969).

(3) Interlayered illite-saponite (or talc-saponite) appears to be resricted to polyhalite lithologies or adjacent anhydrite. It appears to be absent from clay beds and associated rock salts and from the polyhalite-free remainder of the section.

(4) Expandable clays appear to show somewhat less relative abundance in clay beds $(1244.8,1247.2,1328.6,1441.7$, and 1468.1 ft.) than in the silicate assemblages from the evaporite rocks.

(5) Furthermore, the mixed-layered clay species in each of these clay seams consists solely of the well developed regularly interstratified chlorite-saponite (corrensite).

\subsubsection{Mineralogy of Duval Mine Samples}

Several samples of wall-rock were taken from the 4 th ore zone (langbeinite level) of the Duval Nash Draw potash mine, about 5 miles west-by-southwest from the study area. These samples include a dark brown clay parting (the DV-4 series) taken from the upper boundary of the 4 th ore zone.

Untreated oriented powders were scanned from 2 to 60 degrees two theta. The untreated slide was glycolated by vapor-soaking on a rack in a container filled partially with ethylene glycol. An additional oriented powder was heated at $450^{\circ} \mathrm{C}$. Both the glycolated and the heated specimens were scanned from 2 to 3 degrees two theta. 
Whole rock samples were analyzed by loading a small amount of randomly oriented rock powder in a Norelco powder holder. This powder was scanned from 5 to 80 degrees two theta and the resulting diffractogram compared to values compiled in the Joint Committee on Powder Diffraction Standards file to determine bulk mineralogic composition. Mineralogic abundances noted were estimates based on comparative peak intensities.

All samples $x$-rayed (both clays and whole rocks) were scanned with Ni-filtered cuk $\alpha$ radiation. A time constant of two seconds was used with a scintillation counter detector and pulse height analyzer. The goniometer slit system consisted of a divergent and anti-scatter slit of 1 degree and a 0.003 inch receiving slit.

The results for Duval Mine samples appear in Table 7.9. For comparison, "dirty salt" from about 2100 feet depth in ERDA No. 9 has about 88 by weight insolubles.

\subsubsection{Chemical Composition}

Since appropriate regressions for each component based on several standards have not yet been calculated and matrix effect corrections have not yet been made, the analyses in Table 7.10 must be considered as only semiquantitative. In most cases, most totals are between 85 and 988 ; perfectly reasonable totals with the remainder being chiefly water. A few totals exceed $100 \%$ and a few others are less than 85\%; these are unquestionably in error. These data, however, do illustrate a number of important relations and are compatible with the mineralogic data.

Thus for example, those analyses with high alkali content (JS-CS-2 at 1440.5', JC-CS-6 at 1441.5, MB-CS-27 at 2067.0, MB-CS-31 at 2512.5, MB-CS-13 at 2518.3, MB-CS-10 at 2705.8, and MB-CS-36 at 2758.4) show substantial feldspar with or without abundant mica-clay.

In general, the chemical data support the mineralogic determinations. The silicate fractions are extraordinarily high in Mgo ( 20-30 wt 8 MgO) 
and correspondingly low in $\mathrm{CaO}(\sim 1$ wt $8 \mathrm{CaO}) ; \mathrm{Al}_{2} \mathrm{O}_{3}$ is low $(\sim 8-12$ wt $8 \mathrm{Al}_{2} \mathrm{O}_{3}$ ) for clay mineral assemblages. Thus, except for illite, our clays are trioctahedral with only chlorite containing appreciable $\mathrm{Al}_{2} \mathrm{O}_{3}$

\subsubsection{Petrography}

Petrographic analysis, both macroscopic and microscopic, is used in three ways: first, determination of the mineralogy of samples; second, given the mineralogy of a sample, description of lithology; third, the primary utility of petrographic analysis in this study, description of the texture of the sample. Texture refers to grain or crystal size, shape (habit or form), orientation, relationships (such as nature of contacts between crystals or grains) among different minerals and lithologies.

\section{Macroscopic Petrography.}

Sample Preparation and Procedures - Slabs, approximately $1 \mathrm{~cm}$ thick, were cut lengthwise using a band saw, from the $1 / 2$ or $1 / 4$ core samples. One face of a remaining core sample was then polished using a sander with various grit sandpapers. The sample was not to be used for silicate mineralogy-geochemistry analysis in order to avoid contamination. The polishing enhanced textural detail. Faces were also polished on some slabs.

Samples were selected from the core in which mineralogy based on macroscopic identification was obscure or uncertain for $x$-ray diffractometry of the bulk sample. Conventional diffractometry methods, as described previously, were used.

Macroscopic Petrographic Description - The mineralogy, lithology and texture in the polished sections of all the core intervals selected were described. Appendix 7.D is a brief extract from 54 pages of sketches accompanied by textural descriptions of these core intervals. Table 7.11 is a summary of the gross lithology reported largely as macroscopic 
mineral identification and core footage. Table 7.11 indicates that macroscopic mineral identifications are generally reliable, especially for coarse-grained minerals, but visual estimation of the relative minerals abundances are less reliable. Estimates of relative abundances based on $\mathrm{x}$-ray diffraction analysis are regarded as "semi-quantitative" and maybe in error, but it is still more reliable because of its greater precision, if not accuracy, compared to visual estimation.

Plates 7.1 through 7.6 are photographs of polished faces of cores or slabs illustrating typical textures. Plate 7.1 shows a variety of shapes of halite in anhydrite. The occurrence as beds or laminae or irregular lenses is inferred to be primary because halite and anhydrite can precipitate jointly or alternately from evaporating seawater. The apparent swallow-tail form of halite in laminated anhydrite is a problem because no primary occurrence of this form of halite is known. The swallow-tail form can occur as a twinned crystal of gypsum, but coprecipitation of gypsum and anhydrite is thermodynamically impossible. One interpretation is primary precipitation of calcium sulfate only as gypsum in the form of rapidly growing swallow-tail twins and finely crystalline aggregates. Then post-depositional alteration of the finely crystalline aggregates to anhydrite takes place, and the twinned crystals alter either directly to halite or first to anhydrite which then alters to halite, with preservation of the primary swallow-tail forms. This interpretation is favored by the almost exclusive dominance of gypsum rather than anhydrite as the primary precipitate in modern environments and lab experiments. Controversial thermodynamic analyses also favor gypsum as the primary precipitate, even metastably.

Plate 7.2 also illustrates occurrence of halite in well laminated anhydrite. This is interpreted as primary coprecipitation of halite and gypsum with these textures followed by post-depositional alteration of gypsum to anhydrite with preservation of primary texture.

Plate 7.3 illustrates an occurrence of halite and polyhalite. The triclinic crystal system of polyhalite is unlikely to produce a rectangular outline in cross section whereas the cubic habit of halite or 
the orthogonal morphology of anhydrite would. Thus, the rectangular outline of the polyhalite body suggests post-depositional alteration of anhydrite, (to a lesser extent of halite) to polyhalite as does the occurrence of most polyhalite in irregular masses among halite masses. Thermodynamic and experimental considerations as well as observation of modern evaporites indicate that polyhalite does not precipitate from evaporating seawater.

Plate 7.4 illustrates coarse, relatively pure halite with anhedral, granular texture. The halite contains small crystals of anhydrite, probably a post-depositional alteration product of a primary coprecipitate of halite and gypsum.

Plate 7.5 illustrates another texture of halite in anhydrite with traces of magnesite. As previously indicated, it is believed to result from primary co-precipitation of halite and gypsum with post-depositional alteration of gypsum to anhydrite with preservation of primary texture. Magnesite is not known to precipitate from evaporating seawater but calcite does, suggesting post-depositional alteration of a primary (probably calcium) carbonate to magnesium carbonate.

Plate 7.6 illustrates textures in a dominantly anhydrite rock. The occurrence of the swallow-tail form near the stratigraphic top of the specimen as well as previously related discussions suggest primary precipitation of gypsum followed by post-depositional alteration of anhydrite, which could occur shortly after deposition, with preservation of primary textures.

\section{Microscopic Petrography.}

Sample Preparation and Procedure - The $1 \mathrm{~cm}$ thick slabs were converted to standard and oversize thin sections following conventional procedures (with the following exceptions) to minimize chemical alteration of the sample. Fluid in contact with the sample was a pure vegetable cooking 
oil. Temperatures during the thin sectioning process did not exceed $30^{\circ} \mathrm{C}$. Samples were put in dessication jars during impregnation to minimize contact of fluid acetone with the sample.

Microscopic Petrographic Description - Plates 7.7 through 7.12B are photomicrographs of thin sections of rock samples from the Permian Basin of southeast New Mexico. The samples are not from ERDA-9 core but are representative of mineralogies, lithologies and textures commonly encountered in the core.

Plate 7.7 is a photomicrograph of relatively finely crystalline euhedral to subhedral halite. The crystal form, relative clarity (although containing very fine crystals of anhydrite) and occurrence of fluid inclusions as both negative crystals and subspherical forms all suggest little post-depositional alteration with the exception of alteration of primary gypsum to anhydrite.

In Plate 7.8 also dominantly of halite (typical of the rock in Plate 7.4), there is a startling contrast to the texture in Plate 7.7. Crystals in Plate 7.8 are anhedral to subhedral, cloudy, coarser and devoid of fluid inclusions (the apparent void in the lower left was produced by plucking of a cleavage fragment from the specimen during sectioning). Because the texture shown in Plate 7.7 is regarded as indicative of little post-depositional alteration, the texture in Plate 7.8 is considered as indicative of extensive alteration, greater than that required for the postulated gypsum to anhydrite alteration which is also postulated for very fine crystals of anhydrite within the halite in plate 7.8. These contrasting textures are also apparent in thin sections of carbonate rocks. Bathurst, (1975, especially Chapter 12), deals with recognition of chemically precipitated calcite (analogous to plate 7.7) versus calcite post-depositionally altered from argonite or some other form of pre-existing calcite (analogous to Plate 7.8). Bathurst uses and builds upon terminology and concepts of the causes and processes of these alterations developed by Folk (1965). 
Plate 7.9 shows an occurrence of halite with sylvite. The irreguiar bodies and irregular contacts of the sylvite (as well as the anhedral nature of the halite and bodies of intimately mixed halite and sylvite) are interpreted to be the product of post-depositional alteration. This interpretation is also favored by the fact that sylvite does not occur as a primary precipitate in the marine evaporite succession.

Plates 7.10A and 7.10B show the irregular and gradational nature of the contact between polyhalite and halite and the concentration of opaques, probably hematite, along the contact. These observations and those discussed under Plate 7.3 are interpreted to be products of post-depositional alteration of either anhydrite or halite to polyhalite.

Plate 7.11 shows the microscopic texture typical of many laminated or banded anhydrites of the Castile and Salado Formations. Neither x-ray diffractometry nor staining techniques have been used to determine the mineralogy of the carbonate. This texture is interpreted as annual varves by Anderson et al. (1972).

Plate $7.12 \mathrm{~A}$ and $7.12 \mathrm{~B}$ show dominately massive anhydrite, typical of much of the unlaminated anhydrite in the salado Formation but atypically cut by a veinlet of gypsum. The rock sample was taken from outcrop and the gypsum veinlet is interpreted to have been produced by alteration of anhydrite to gypsum during uplift and exposure.

The petrographic descriptions and interpretations generally agree with those in the classic and relevant report of Schaller and Henderson (1932).

\subsubsection{Interpretations and Tentative Conclusions}

1. All of the samples discussed under macroscopic and microscopic petrography exhibit mineralogy, lithology and textures which are indicative of post-depositional alteration of the sediments (dated at 204 million years in section 7.8 ). It is believed that fluids 
migrating through the sediments are responsible for most of these alterations. Interestingly, the alteration of primary gypsum to anhydrite would liberate abundant volumes of fluid.

2. The abundance of polyhalite and the atypical mineral assemblages (sylvite-langbeinite vs kainite/carnallite-kieserite) of the ore zones suggest either drastic recrystallization or a former primary evaporite depositional environment. The areal extent of the Ochoan rocks and their great thickness coupled with paleogeographic evidence and the marine character of the underlying Permian strata appear to preclude the second alternative. Further evidence of the post-depositional origin of the present assemblage includes the low and highly variable bromine values in the Salado Formation rock salts (Holser, 1966; Adams, 1969). Age dates on K-bearing salts, discussed later in this chapter, further suggest recrystallization shortly after deposition.

3. The general mineralogy and chemistry of the EDTA-insoluble (silicate) fractions of the evaporite beds throughout the Salado and uppermost Castile Formations preclude their detrital origin.

4. The silicate assemblages and their chemistry further supports the hypothesis of post-depositional alteration of these rocks -- at least throughout much of the Salado Formation.

a. The predominance of smectities (saponite) and trioctahedral smectite-bearing clays suggest relatively immature assemblages. The silicate assemblages of the Zechstein (Permian) of Germany are almost entirely nonsmectitic except for the well-crystallized, well-ordered regular interstratified chlorite-(smectite/vermiculite) mineral corrensite (Fuchtbauer and Goldschmidt, 1969). The Haselgebrige (Permo-triassic) of the Austrian alps similarly contains no smectites nor even smectite-bearing mixed-layered clays (Bodine, 1971), and the same is true for the Silurian salts of New York (Bodine and Standaert, 1977). The development of the unusual illite-saponite/talc/ saponite phase with polyhalite suggests immaturity of the silicate 
phase with respect to the evaporite phase. Any further phase changes that would take place in the silicate appear to be kinetically inhibited.

b. The variability of the clay assemblages and their lack of correlation with major evaporite lithologies bespeaks strongly of recrystallization accompanying migrating post-depositional pore fluids. Except for the unusual $10.3 \AA$ phase with polyhalite, the only other lithic correlations are: (1) reasonably well crystallized corrensite as the only expandable clay in the discreet clay seams and (2) the occurrence of serpentine in the uppermost Castile Formation. The former is tentatively attributed to the "closed system" nature of the impermeable salzton beds; they were not subject to the attacks by a variety of migrating pore fluids of different composition. The latter relates to the vertical distance between $\mathrm{K}$-Mg-bearing salt beds and the Castile Formation, which essentially comes in contact only with less mobile fluids in equilibrium with halite-anhydrite.

c. It is very tentatively suggested that many of the salzton seams formed through accumulation of silicate debris included in salts which have been dissolved; their association with the soluble $\mathrm{K}-\mathrm{Mg}$ salt ore zones and with the extensive polyhalite replacement of anhydrite beds appears remarkable and may provide the geometry for the "plumbing system" in which migrating pore fluids circulated. It is also recognized that some of the salzton beds may well represent recrystallized detrital accumulations during periods of no evaporite deposition as suggested by Adams (1969). If migrating groundwaters do flow in some such controlled pattern, ore mineral distribution in each ore zone should reflect this, i.e. remnants of the primary carnallite-kieserite farthest from the source of the brines, enveloped by langbeinite and langbeinite-sylvite assemblages, in turn enveloped by langbeinite and langbeinite-sylvite assemblages, in turn enveloped by sylvite, and finally by barren halite. Similarly polyhalite 
crystallization should be at a maximum under the langbeinite-sylvite assemblage within a given "cell" and would likely decrease both away from and toward the lateral pore fluid source.

In summary, substantial evidence has been accumulated that there has been extensive salt recrystallization, most noticeably within the McNutt ore zone. This is considerably less noticeable in the lower Salado and Castile Formations, but may simply reflect the far simpler evaporite mineralogy and persistence of substantially more homogeneous compositions within the pore fluids.

Preliminary computer modeling does, for example, substantiate that a typical primary marine evaporite salt assemblage of carnallite-kieserite-halite can, when under continued attack by migrating halite-gypsum saturated pore fluids flowing down dip in a hypothetical cell, generate a progression of salt facies with remnants of the primary assemblages farthest from the source. Toward the source, the following succession of assemblages would be found: langbeinite-carnallite-halite (or langbeinite-kieserite-halite) then langbeinite-halite, then langbeinite-sylvite-halite facies, then sylvite-halite, culminating toward the source in a barren halite facies. At the same time, the $\mathrm{K}-\mathrm{Mg}$ rich pore fluids which were generated through ore mineral dissolution and alteration would no longer be in equilibrium with anhydrite; anhydrite would alter to polyhalite until the solution chemistry reached the polyhalite-anhydrite equilibrium composition. The precise thermodynamic conditions and mineralogic reactions which governed these alterations are not known; however, the age of this recrystallization of evaporites has been determined to be in excess of 204 million years. For more details regarding this recrystallization which closely followed deposition, the reader is referred to section 7.8 . 
$7-31$

7.5 VOLATILES AND FLUID INCLUSIONS IN MINERALS OF THE SALADO FORMATION

\section{5 .1 Introduction}

Sources of liquids and gases native to the evaporites must be considered. One source is the intergranular fluid to be found in the pore spaces between mineral crystals and lithic fragments. These fluids are discussed in detail in a subsequent section (7.7). Another fluid source is the water of crystallization chemically bound in hydrous minerals. Yet a third source is fluid inclusions inside the mineral crystals themselves, which can behave as separate micro-geochemical systems.

Data presented in the overview Section 7.5 .2 , and Section 7.5 .3 result from heating bulk rock samples to recover all types of fluid. In the major portion of the Salado, the total recovered amounted to less than 0.5 weight percent of the rock. As discussed in the overview section, it was possible to separately identify: (1) loosely-bound volatiles, (2) chemically-bound volatiles, and (3) fluid inclusions.

The sections on mineral sources of water and on fluid inclusions endeavor to place the data in the context of the mineralogy of the rocks serving as hosts for the volatiles. It will be noted that geochemistry in the context of the mineralogy is a pervasive theme in all parts of the geochemistry section of this report. This is true for the sections which follow on groundwater geochemistry and radiometric age-dating also. It will also be noted that the characterization of geochemical properties of solutions in the Salado confirm the qualitative measurements of fluid inclusion solute contents.

This chapter contains considerable data which will assist in the anticipation of short and long term physico-chemical conditions likely to arise during the experiments involving heat-producing radioactive wastes. 


\subsubsection{Overview of Volatile Contents of Evaporites}

Themogravimetric analyses of 35 selected core samples from ERDA No. 9 were made. These were many of the same samples which were qualitatively examined for mineralogy by $x$-ray diffraction (refer to section 7.2.3).

These analyses were made by suspending powdered samples from a microbalance while dry nitrogen flowed above the sample. The samples were heated by $5^{\circ} \mathrm{C} /$ minute until the temperature reached $500^{\circ} \mathrm{C}$ and were held there until gas evolution had ceased. A hygrometer was inserted downstream to register qualitatively whenever moisture was evolved.

The as-received salt core specimens were massive pieces approximately 4 inches in diameter and 1-2 inches thick. No attempt was made to obtain homogenized samples by powdering the entire piece. Instead nuggets were chiseled from the center of the specimen. The nuggets were crushed and ground to a powder just prior to the weighing and transferring to the microbalance system. A maximum of ten minutes elapsed between the start of crushing and the start of analysis. Thus, the possible loss or gain of moisture prior to testing was minimized. Powdered samples were necessary to minimize decrepitation.

The complete test results are presented in Table 7.12. Figure 7.7 illustrates the typical kinds of weight-loss curves observed. About half the specimens showed 0.58 weight-loss (curve $A$ ). Curve $B$ is common with the rapid weight-loss occurring sometimes at $300^{\circ}$ and sometimes above $400^{\circ} \mathrm{C}$. Some samples show two stages. Only two samples followed curve $C$, where weight-loss was observed from the beginning of the run. The weight-loss curves for all samples are filed and are available for inspections.

Replicate runs were made in several cases, predominantly those which showed the larger weight-losses, and good agreement, i.e. within 58, was observed. 
All mass-loss is not due solely to water. Only the weight-loss below $300^{\circ} \mathrm{C}$ can be attributed largely to water; the weight-loss at higher temperatures is in part due to decomposition of carbonates or other volatile-bearing minerals.

Results were correlated with the x-ray diffraction results previously reported in an effort to identify which minerals may be decomposing. No definite conclusions could be reached so selected samples were analyzed for the evolved gases by gas chromatography/mass spectrometry. In particular, this was done for the samples 2302.6, 2516.3, 2658.5, 2786.5 and 2821.0 .

The highest weight-loss was experienced by sample 2302.6. Its total ion chromatogram (Appendix 7.E) shows data channel numbers calibrated approximately in terms of temperature. Conspicious peaks occur at $100^{\circ} \mathrm{C}, 250^{\circ} \mathrm{C}$ and $300^{\circ} \mathrm{C}$. Detailed mass spectra are given for $50^{\circ} \mathrm{C}, 100^{\circ} \mathrm{C}, 150^{\circ} \mathrm{C}, 200^{\circ} \mathrm{C}$ and $250^{\circ} \mathrm{C}$; the most prominent mass peak is 18, corresponding to water. At higher temperatures, mass 14 (monoatomic nitrogen) becomes abundant. Even at lower temperatures, mass 28 (diatomic nitrogen) is present.

Sets of peaks separated by 12 mass units, corresponding to carbon, (95, $83,71 ; 81,69,57,45)$ probably represent fragments of hydrocarbons present in the diesel oil which was the lubricant used to core the hole. The contribution of mass $44\left(\mathrm{CO}_{2}\right)$ to the spectrum is a minimum at $200^{\circ} \mathrm{C}$ and rises again at higher temperatures. The low-temperature contribution is again probably due to the contaminant diesel oil.

At the highest temperatures, the mass peaks 15,16 , and $17\left(\mathrm{CH}_{3}, \mathrm{CH}_{4}\right.$, $\mathrm{O}, \mathrm{OH})$ are accentuated along with 14,18 , and $28\left(\mathrm{~N}, \mathrm{H}_{2} \mathrm{O}\right.$ and $\left.\mathrm{N}_{2}\right)$.

All the individual ion chromatrograms for mass numbers 14, 18, 19, 20 and 44 have coincidental peaks at about $25^{\circ} \mathrm{C}$ and $300^{\circ} \mathrm{C}$. Water and carbon dioxide are almost continuously evolved over the entire temperature range, but the coincidence of all the peaks for $\mathrm{N}, \mathrm{H}_{2} \mathrm{O}, \mathrm{F}\left(\right.$ ?) and $\mathrm{CO}_{2}$ (mass peaks 14, 18, 19, and 44, respectively) implies that evolution of 
these components at $250^{\circ} \mathrm{C}$ and $300^{\circ} \mathrm{C}$ is related to a common source. since halite decrepitates, releasing its fluid inclusions at about $250^{\circ} \mathrm{C}$, those inclusions appear to be the most probable source of volatiles evolved at $250^{\circ} \mathrm{C}$. Similarly since polyhalite dehydrates at a temperature slightly above $300^{\circ} \mathrm{C}$, fluid inclusions in that mineral might be also released at that temperature (see section 7.3). A detailed treatment of fluid inclusions appears in a subsequent discussion.

Mass numbers $32,48,64$ and 80 have sharp coincidental chromatogram peaks at channel 517. These mass numbers most probably represent $\mathrm{O}_{2}, \mathrm{so}^{+2}$, (possibly $\mathrm{O}_{3}$ made inside the mass spectrometer) $\mathrm{SO}_{2}$ and $\mathrm{SO}_{3}$ released from the sudden decomposition of a sulfate. Similarly mass 36 (HCl) is released in major quantity at this point. All these phenomena occur at a slightly lower temperature than the main $200^{\circ} \mathrm{C}$ event, and their relationship with that event possibly indicates the presence of a very volatile sulfate phase rapidly decomposing when the halite fluid inclusions begin to rupture. Daughter crystals of gypsum in halite fluid inclusions would indicate a high concentration of sulfate in the inclusions (see subsequent discussion) and such a solution might give rise to the observed sulfur species in the mass spectrum.

The sample with the next greatest total mass loss $(2786.5,3.648)$ is considered next. Many of the same features of the chromatograms in Appendix 7.E are observed here as in the previous sample. The main difference is the appearance of a large hump of many volatiles $\left(\mathrm{H}_{2} \mathrm{O}, \mathrm{F}\right.$, $\mathrm{N}_{2}, \mathrm{O}_{2}$ ) released at less than $100^{\circ} \mathrm{C}$. This is consistent with the occurrence of clay minerals which can absorb various volatiles at surface and interlayer sites. Volatiles would be expected to be weakly bound at these sites. The same hump as before appears at $250^{\circ} \mathrm{C}$, incorporating $\mathrm{N}, \mathrm{H}_{2} \mathrm{O}, \mathrm{HF}(?), \mathrm{N}_{2}, \mathrm{O}_{2}, \mathrm{HCl}, \mathrm{CO}_{2}$ and $\mathrm{so}^{+2}$, but only the postulated $\mathrm{SO}_{2}$ species appears to be catastrophically released and is probably a product of ionization in the mass spectrometer. 
A hump incorporating $\mathrm{N}, \mathrm{H}_{2} \mathrm{O}, \mathrm{HF}, \mathrm{N}_{2}, \mathrm{O}_{2}, \mathrm{HCl}, \mathrm{CO}_{2}$ and $\mathrm{so}^{+2}$ occurs substantially below $300^{\circ} \mathrm{C}$. This peak probably corresponds to release of water and other volatiles born of $\mathrm{OH}$ and fluid inclusions in the clay minerals, when the clays decompose upon dehydration.

Sample 2516.3 (2.158 mass 10ss) was unusual in that it contained magnesite. As is seen in the chromatograms in Appendix 7.E, the loss of $\mathrm{H}_{2} \mathrm{O}$ and $\mathrm{N}_{2}$ from various sources provides most of the pattern, which was not sampled at a temperature greater than about $240^{\circ} \mathrm{C}$. There is almost a continuum of absorbed $\mathrm{O}_{2}$ released. The most significant feature of this sample is the high-temperature loss of $\mathrm{CO}_{2}$, presumably from the decomposition of magnesite.

Finally, the most abundant-type sample is considered: those which have mass losses less than 0.58 . These are characteristic of most of the main evaporite section and contain very little other than halite and anhydrite. Typical examples of these rocks are samples 2658.5 and 2821.0 (Appendix 7.E). The main difference between these two is the apparent larger number of types of volatile sites in the shallower sample. Absorbed $\mathrm{N}, \mathrm{H}_{2} \mathrm{O}, \mathrm{N}_{2}$, and $\mathrm{O}_{2}$ form a large, broad hump at low temperature, with catastrophic release (of fluid inclusions?) of $\mathrm{H}_{2} \mathrm{O}$, $\mathrm{N}_{2}, \mathrm{HCl}$, and $\mathrm{CO}_{2}$ at higher temperature in 2821.0 . In 2658.5 , the catastrophic release of $\mathrm{H}_{2} \mathrm{O}, \mathrm{N}_{2}, \mathrm{HCl}$, and $\mathrm{CO}_{2}$ (with possibly some $\mathrm{so}^{+2}$ ) appears to occur in smaller episodes as various sets of fluid inclusions are ruptured at higher temperature.

\subsubsection{Mineral Sources of Water in the Salado Evaporite Sequence}

Introduction. The purpose of this section is to describe the mineralogy and petrologic characteristics of samples taken from two coreholes of the Salado salt from the boreholes AEC Nos. 7 and 8 in Lea and Eddy Counties, near Carlsbad, New Mexico, and the degree to which the evaporite rocks present would dehydrate if subjected to the heat generated by containers of radioactive wastes (radwaste). In a previous study, (Fallis, 1973) the general characteristics of evaporite deposits and their minerals were 
described and a detailed mineralogic and petrologic study of two cores from the Hutchinson Salt near Lyons, Kansas, was made. The results at that time indicated that water losses ranging from 0.4 to 19.0 weight 8 might be anticipated if the surrounding rocks were heated to $100^{\circ} \mathrm{C}$.

Sample splits corresponding to ones in this section were also discussed in section 7.3. A comparison of those results and these is presented in the following section.

Sampling and Sample Preparation. Segments of the original 4 inch (10.2 $\mathrm{cm})$ cores were split in half, lengthwise, for chemical analysis and weight loss determination by thermogravimetric analysis (previous section). Eighty-three samples (coded by core number and depth) arrived wrapped in plastic to reduce the possibility of absorption of moisture during shipping and handling. Core AEC-7 was drilled in Lea County, New Mexico, and core AEC-8 in Eddy County, New Mexico.

Throughout the sample preparation, care was taken to not expose any of the samples to water; however, since it was necessary to cut, grind and sieve various portions of the samples, it was not possible to completely protect them from exposure to moisture in the air. During those periods when samples were not actively being worked upon, they were kept in plastic bags, tightly-stoppered bottles, etc.

Since several different analyses were to be made, it was necessary to obtain representative sample splits which would correspond to each other as closely as possible. A more complete discussion of sample preparation is given in the thesis by combs. However, for convenience, a brief summary of the methods used in sample preparation is given below:

1. A representative segment of each core sample was chosen and removed by sawing the original core (normal to the axis of the core) with a dry blade, masonry-type saw. This new segment was typically about three inches $(8 \mathrm{~cm})$ long. 
2. Next, a slice was cut from each core segment (parallel to the axis of the core) with the approximate dimensions $3 \times 2 \times 1 / 2$ inches ( 8 $\times 5 \times 1 \mathrm{~cm}$ ) for use in preparing the thin sections. The sections were prepared by Fred Roberts Petrographic Section Service, Monterey Park, California. They were cut using oil rather than water and mounted with an epoxy cement which was not heated.

3. About one-half of the remainder of each core segment was crushed and sieved, and representative portions selected to be analyzed by $x$-ray diffraction, $x$-ray spectroscopy and by static heating methods for water loss determination. (Later, some additional separations were made and portions of the samples selected for bromine analysis using $x$-ray spectrocopy. These procedures will be described briefly in the following sections.)

Analytical Methods Used in This Study. Several different kinds of analyses were performed on the samples received. The methods used include static weight loss determinations (water loss), mineralogical and petrological analysis, and some chemical analyses using $\mathrm{x}$-ray spectrocopy.

The weight loss determinations were made in essentially the same manner as for samples studied from Lyons, Kansas, and which was reported previously (Fallis, 1973). Splits of the several samples (sample size generally ranged from 1.5 to $2.0 \mathrm{gms}$ and in the 60 to $120 \mathrm{mesh} \mathrm{size}$ fraction) were heated to $102 \pm 5^{\circ} \mathrm{C}$ for periods ranging from 2 to 42 days. The results of repeated analyses indicated that the precision of weight loss determinations was generally \pm 0.1 to 0.28 . When new sample splits were used, the "precision" dropped to approximately \pm 0.2 to 0.38. Some data concerning precision are presented in Appendix 7.F.

In addition to the weight loss determinations performed near $100^{\circ} \mathrm{C}$, weight loss determinations were also made for several samples which had been heated to $170 \pm 5^{\circ}$ (for 2 days) and $300 \pm 10^{\circ} \mathrm{C}$ for (2 to 3 days). The results of the weight loss analyses are reported in Appendix $7 . G$ and discussed in the following section. 
Mineralogical and petrological analyses were made using $x$-ray diffraction and standard petrological techniques. A summary of important mineralogical and petrological data is given in Appendix 7.H and discussed following the next section. The chemical analyses were made using two variants of the $x$-ray spectrographic method, $x$-ray fluorescence analysis (wave length dispersive) and $x$-ray emission spectroscopy (non-dispersive). The chemical analyses were made primarily for bromine, which can be used to aid in the interpretation of the origin of evaporite deposits, and semi-quantitative analyses were made for chlorine, sulfur and iron.

Weight Losses for Cores, AEC NO. 7 and 8 . Weight loss data for the samples studied are tabulated in Appendix 7.G and illustrated in Figure 7.8. In general, the weight losses are much less than those found for samples from the site at Lyons, Kansas. The range of weight loss values at $102 \pm 5^{\circ} \mathrm{C}$ for the Carlsbad samples (Salado salt), Cores Nos. 7 and 8 was from 0.0 to 3.58 with the majority of samples showing losses less than 0.58 , while the Hutchinson salt, Cores Nos. 1 and 2 was from 0.5 to 19.08, and most of the samples showed weight losses from I to 58. A plot of approximate range of water loss at $102 \pm 5^{\circ} \mathrm{C}$ to be expected at various depths is shown in Figure 7.9. This is based on data from both Lyons, Kansas and Carlsbad, New Mexico sites.

Based on the results of the various heat treatments, the following conclusions can be drawn concerning the behaviour of the samples from Carlsbad:

1. Samples consisting almost entirely of halite and/or anhydrite show weight losses (up to $300^{\circ} \mathrm{C}$ ) which are typically less than 0.58 and probably less than 0.38 . The final total loss will depend on the amounts of clay minerals and minor hydrated evaporite minerals, such as polyhalite, which are present.

2. Larger water losses ( $>18$ at $102 \pm 5^{\circ} \mathrm{C}$ ) are generally associated with the presence of clay minerals (and/or gypsum) in more than trace amounts. The exact losses will depend on 
the kinds and amounts of clays present, the temperatures to which they are heated and the length of time for which they are heated.

3. At some temperatures between $170^{\circ}$ and $300^{\circ} \mathrm{C}$, polyhalite, which is a common accessory mineral constituent in some parts of the Salado salt, will start to break down. It can contribute water to the extent of about 68 of its weight in the rock being heated.

4. Although present in only minor amounts (or absent) in the samples that were analyzed, there are other evaporite minerals such as carnallite, kainite, leonite, etc., near the potash ore zones (the McNutt potash zone at approximately 1600' to $\left.1800^{\prime}\right)$.

The weight losses determined in Section 7.3 are compared with these in Appendix 7.G. It should be noted that the earlier data were determined by thermogravimetric analysis; hence, weight losses were not determined at any fixed temperatures but at the actual temperatures at which the decompositions were detected. In order to make the data more comparable, the previous data were rearranged and weight losses taking place within certain temperature ranges were combined. The reader is referred to Section 7.3 for the specific temperatures at which weight losses occurred. It should also be noted that the two sets of data are not directly comparable, since the weight losses of this section were accomplished by heating under static heating conditions for periods of 2 or more days, while the previous data were obtained under dynamic conditions (much more rapid heating). As a general rule, the decomposition temperature of any given mineral will be higher under conditions of dynamic heating rather than static heating.

Even so, there is generally good agreement between the two sets of data which were obtained by different investigators using different techniques. Most minor discrepancies can be explained on the basis of 
differences in the methods of analysis. Only a few real discrepancies seem to exist (such as for sample at 1697 in Core \#7). This is to be expected since each group rceived different halves of the core and since Section 7.3 involved sample splits of the entire core segment while this work involved only a sample split corresponding to the portion of the core used in preparing the thin section. Since there are both vertical and lateral variations in mineral content within the cores, samples might occasionally have been analyzed which were mineralogically different.

The rocks being considered at the proposed WIPP site, New Mexico, appear to be much more favorable than those from Lyons, Kansas. Even so, some mineral water is still present and is apt to be released during the period when the rocks are heated by the waste containers. It will be important to determine the maximum temperatures to be reached, the volume of rock which will be heated, and the probable maximum volume of water which will be released.

Mineralogy and Petrology of Cores No. 7 and 8 . In some respects the mineralogy and petrology of the core samples from Carlsbad are similar to those of the core samples from Lyons. Both cores were taken through evaporite sequences and hence encountered sedimentary sequences containing typical saline minerals such as halite, anhydrite and polyhalite. In addition, clay minerals, magnesite, gypsum, quartz, feldspar, carnallite, celestite (?), glauconite and kainite (?), were detected in smaller amounts. The presence of any of the other less common evaporite minerals in the samples studied is uncertain. In general, they only occur in such small amounts and/or such fine grain sizes that positive identification was not possible using the diffractometer and petrographic miscroscope. In Section 7.3 it was noted that several of these less common minerals are apparently present in many of the samples analyzed. Readers of this section should be aware that the analyses are based on the actual minerals observed (modal analysis) in thin section as supplemented by $\mathrm{X}$-ray diffraction while the analyses presented in Section 7.3 were done by computer manipulation of the chemical analyses determined for each sample (normative analysis). Such 
normative analyses can be quite useful, especialy when working with very fine grained or glassy materials. However, it should be noted that normative analyses may generate mineral assemblages which do not agree with the actual minerals present, as was pointed out in section 7.3.

Summaries of the mineralogic and petrologic features of the individual samples studies are presented in Appendix 7.H. For the reader's convenience, some general comments about the mineralogy and petrology of these samples are presented below. An excellent study of the mineralogy and petrology of the rocks in this region is given by Schaller and Henderson, 1932. Brief description of the major minerals noted in the Carlsbad samples follow.

Halite. Most of the halite is colorless and shows excellent cubic cleavage. These features, coupled with less low relief and isotropic optical character, make its identification easy. Sometimes the halite is colored red or orange by minute inclusions of hematite (or other iron oxides) or other minerals such as polyhalite. The grain size showed a wide range, from less than $1 \mathrm{~mm}$ (fine grained), to greater than $1 \mathrm{~cm}$ (coarse grained). Grains between $1 \mathrm{~mm}$ and $\mathrm{l} \mathrm{cm}$ are considered to be medium grained.

Because halite fractures and cleaves so readily, it is difficult to determine whether the numerous breaks observed in thin sections were already present at depth or whether they developed during the coring operation, shipping, handling, thin section preparation, etc. More fractures are noted at the outer margins of each of the thin sections. However, some of them must have occurred prior to the taking of the core because they are filled (at least in part) with other minerals, petroliferous material, etc. In several cases fracture zones could be traced across the entire width of a thin section.

Inclusions (liquid, solid and gas) are common in the halite. During the preparation of some samples hydrogen sulfide (gas) was released. In many cases the inclusions are oriented with respect to the cubic crystal 
planes. These oriented inclusions appear to represent hopper crystals which grew at the water surface in times of quiet water and are inferred to represent deposition from shallow water.

Intergrowths of relatively well-formed, cubic crystals of halite with clay and silt-size minerals are likewise inferred to represent very shallow conditions, perhaps even subaerial exposure for brief period.

"Patches" (regular to irregular, more or less equidimensional areas) and "stringers" (regular to irregular areas which are generally elongated in one direction) of anhydrite, polyhalite, clay and silt-sized minerals are common in halite. Sometimes these patches and stringers follow grain boundaries, but of ten they cut across grains. Where they follow grain boundaries, they may represent (nearly) simultaneous growth of the halite crystals and smaller amounts of the other mineral phase(s). Where they cut across grains, they presumably represent deposition of the minerals along zones of weakness or along which solutions passed. Enough of this latter material is present to demonstrate that there were opportunities for solutions to migrate through these relatively impermeable rocks, even though it is not possible to determine just how far the solutions actually traveled.

Anhydrite. Anhydrite was recognized on the basis of its relatively high birefringence, differences in relief upon rotation and cleavages at right angles. Normally, anhydrite shows parallel extinction, too, but because of twinning, replacement phenomena, etc., this characteristic was not always useful.

Anhydrite occurs in three major types. "Primary" anhydrite, which is commonly bedded, is very fine grained (much less than $1 \mathrm{~mm}$ ) and somewhat fibrous in character. It also occurs in coarser-grained crystals and twinned crystals (sometimes over $1 \mathrm{~cm}$ long). At least some of these larger crystals appear to be pseudomorphs (replacement) after previously-existing gypsum crystals. Sometimes, very small amounts of questionable gypsum are noted nearby, perhaps as a result of partial 
rehydration of the anhydrite. Finally, there are more or less isolated crystals and crystal clusters of anhydrite which occur in patches and stringers within the halite or are intergranular with halite. These may be associated with polyhalite and/or clay and silt-sized minerals. This type of anhydrite is thought to be authigenic (formed in place from fluids contained in the pores of the rock or passing through the rock).

Anhydrite can be replaced by polyhalite if fluids containing potassium, magnesium and additional sulfate ions are present. Many examples of this replacement were observed.

A few examples of bedded, nodular anhydrite were observed. The nodules may have originally been composed of gypsum which was later replaced by anhydrite. The origin of such bedded nodules is thought by some workers to represent depositions in very shallow water which was periodically exposed (Sabkha facies).

Polyhalite. Polyhalite was recognized on the basis of its relatively low birefringence, inclined extinction and complex twinning. (Unfortunately in some fine-grained material and/or mixtures, polyhalite and anhydrite can be confused because their optical properties of relief and birefringence are almost the same in certain orientations).

Much of the polyhalite observed is rather fine grained (much less than 1 $\mathrm{mm}$ in size for the individual cyrstallites) and often fibrous. However, some larger crystals are numerous, isolated crystals and crystal clusters were observed. Polyhalite is often reddish due to iron oxide inclusions, but this is not universally true.

Some of the polyhalite appeared to be a bedded form associated primarily with halite and lesser anhydrite. Polyhalite also is found replacing anhydrite and associated with nearby patches and stringers of clay and silt-sized minerals. Whether the clay, etc., provided some of the ions necessary for formation of polyhalite or just acted as a pathway for solutions passing through the rock cannot be determined. 
Minor Minerals. Minor minerals were identified on the basis of their optical properties and X-ray diffraction analyses, which were occasionally aided by information contained in the well logs for the cores. Just a few brief comments for each mineral are given here.

Clay minerals. Overall, much less clay is present in the samples from Carlsbad than was present in the Lyons samples. X-ray diffraction peaks attributed to clay minerals were noted in nine samples from Core \#7 and in fourteen samples from Core \#8. Based on the $X$-ray patterns and peaks noted at approximately $7,10,11.5,14$ and 15 angstroms, major clay minerals present include illite, chlorite, mixed-layer clays and possibly some kaolinite.

Magnesite. Although well-crystallized magnesite was not detected in thin sections, some very fine-grained, relatively high birefringent phase was noted in some thin sections and magnesite peaks were detected in some thin sections and magnesite peaks were detected in a number of $x$-ray patterns. Schaller and Henderson (1932) stated that many of the clays in the samples they studied were magnesitic. The common association of polyhalite with clay and silt-sized minerals may be due in part to the magnesium ions in the magnesitic shales and clays.

Gypsum. Gypsum is monoclinic and in thin section has low birefringence and low, negative relief. Twins ("swallowtail") are fairly common. Well-crystallized gypsum was detected in only one thin section among the samples studied. In addition, several of the sections contained small amounts of questionable gypsum in association with anhydrite and/or polyhalite. However, the amounts present were much less than 18 and could not be confirmed by $x$-ray diffraction.

Quartz and feldspar. These minerals are present in two forms, as detrital (silt and very fine sand-sized) material deposited along with the clays, and also as authigenic minerals which formed in or near patches and stringers of clay and silt-sized minerals. 
Sylvite. A few thin sections contain small amounts of sylvite which was recognized on the basis of its distinctive reddish purple color (due to iron oxide inclusions) and lower relief than halite. Most of the sylvite observed was associated with polyhalite as well as with halite. There were no samples from the sylvinite (mixed halite and sylvite) zones. Adams (1967) reported that not all sylvite is colored; however, in the thin sections studied, the distinctive color was useful in locating the small amounts present.

Carnallite. Only one section contains detectable carnallite. This mineral was suspected on the basis of nearby carnallite as noted in the well log. Its high negative relief and "metallic" luster due to inclusions were used to confirm its presence.

Celestite (?). In two or three thin sections some isolated spear-shaped crystals and clusters of crystals with relatively high relief were noted. Although no positive identification could be made, it is suspected that these are celestite, which is the most common strontium mineral present in evaporite deposits.

Glauconite. A few greenish, rounded grains of glauconite were noted, generally associated with the clay and silt-sized minerals. Not enough of this material was present to attempt to determine its origin or source.

Kainite(?). Kainite (?) was observed in only one thin section. It is a monoclinic mineral with moderate birefringence and negative relief.

Summary and conclusions. The results of this study indicate that the Salado Salt in the samples received is composed primarily of fine to coarse-grained halite with polyhalite, anhydrite, and clay minerals. other minerals detected in small amounts include gypsum, magnesite, quartz, feldspar, sylvite, carnallite, celestite (?), glauconite, and kainite(?). It should be noted that the samples received for analysis were selected from halite-rich zones in most cases; hence, some of the rarer evaporite minerals such as kieserite, langbeinite, leonite, 
bischofite, etc., noted by Schaller and Henderson (1932) were not detected either because they were absent from the specimens analyzed or present in amounts too small (or too fine grained) to identify.

There is much petrographic evidence that the Salado salt was deposited in rather shallow water and may have been exposed subaerially at times. This evidence includes the presence of numerous hopper crystals (which can develop at the air-water interface of quiet, shallow seas) and the intergrowth of euhedral grains of halite with clay and silt-sized minerals, anhydrite, and polyhalite. The latter texture can develop in an exposed, mud-flat type environment. Previous workers, such as Anderson, et al. (1972), have concluded that the underlying, Castile Formation was deposited in deep water, perhaps as much as $2100^{\prime}(650 \mathrm{~m})$ deep. Hence, there must have been a major change in environmental conditions between the deposition of Castile and that of the salado.

Petrographic evidence also suggests that local fluids native to the Salado have been able to move through the salado salt (during recrystallization) along beds and seams of clay and silt, and to a lesser degree along fractures (see Section 7.8). These paths are now marked by entrapped fluid inclusions, zones of altered minerals and zones along which new minerals have been deposited.

Water loss determinations for over eighty samples from cores \#7 and \#8, indicate a range of water loss (upon heating to $102 \pm 5^{\circ} \mathrm{C}$ ) from 0.0 to 3.58, which is considerably below the water losses for samples from Lyons, Kansas. It whould be noted that the samples from the Lyons site came from much shallower depths than those from the Carlsbad area. In the section on weight losses, the ranges of dehydration to be anticipated with respect to depth are shown graphically. It appears that the ranges determined for the relatively shallow Lyons site merge with the ranges determined for the deeper Carlsbad site.

Most of the dehydration water at relatively low temperatures (near $100^{\circ} \mathrm{C}$ ) appears to come from clay minerals, although gypsum may make a 
contribution for samples taken at shallow depths. At higher temperatures, polyhalite will start to contribute to the dehydration of water. This dehydration takes place somewhere between $170^{\circ}$ and $300^{\circ} \mathrm{C}$. Pure polyhalite rock can lose up to 68 water. In general, the purer halite beds have weight losses below 0.3 to 0.58 .

As far as can be determined from the samples available for study, the rock units present in the Salado salt seem to release much less water when dehydrated than do the rocks of the Hutchinson salt from Lyons. Hence, the site near Carlsbad would seem to be more favorable (in so far as dehydration water goes) than Lyons. However, these rocks are not totally without water, and most units will lose from 0.0 to 0.38 water when heated and some units may lose up to 3.58 water.

Finally, it was noted during the preparaton of some of the samples that $\mathrm{H}_{2} \mathrm{~S}$ (and possibly some natural gas) was released when the samples were crushed. No $\mathrm{H}_{2} \mathrm{~S}$ was detected mass spectrometrically (previous section), which probably attests to a sensitivity of the human nose for $\mathrm{H}_{2} \mathrm{~S}$ that is unapproachable even with the most sophisticated available instrumentation.

7.6 FLUID INCLUSIONS IN CORE SAMPLES FROM ERDA NO. 9

\subsubsection{Introduction}

Fluid inclusions in the host rock are of interest to several aspects of nuclear waste disposal. First, determination of their origin and nature may provide insight into the complex sequence of processes and events from original deposition of the salt through to the present; such insight may well be of value in site evaluation. Second, fluid inclusions provide one source of water (and other volatiles) that would certainly aid in the corrosion and eventual breach of the waste containers, and subsequent leaching of the waste itself. Third, fluid inclusions, and their reaction under the thermal pulse from hot wastes, could have an effect on important physical properties of the hot host rock, such as deformation rates and particularly melting. 


\subsubsection{Samples Studied}

Most samples studied were taken from ERDA core No. 9, and came from the following footage intervals:

$\begin{array}{cc}\text { From } & \text { To } \\ 1799.0 & 1799.5 \\ 1902.0 & 1902.3 \\ 2065.0 & 2065.4 \\ 2095.1 & 2095.5 \\ 2272.4 & 2272.7 \\ 2391.0 & 2391.3 \\ 2611.5 & 2611.8 \\ 2658.7 & 2659.0 \\ 2760.0 & 2760.2 \\ 2820.8 & 2821.2 \\ 2058.8 & 2059.0 \\ 2070.4 & 2070.6 \\ 2606.5 & 2606.9 \\ 2617.2 & 2617.7 \\ 2626.7 & 2627.0 \\ 2659.0 & 2659.2 \\ 2665.0 & 2665.1 \\ 2692.4 & 2692.6 \\ 2699.8 & 2700.0\end{array}$

In addition to the above "representative" samples, four nonrepresentative samples from ERDA No.9 were selected because they contained plainly visible large inclusions, suitable for special tests:

$$
\begin{aligned}
& 2061.2-2061.6 \\
& 2064.5-2065.0 \\
& 2614.7-2615.0 \\
& 2518.5-2619.0
\end{aligned}
$$


In order to test certain sample preparation and inclusion extraction procedures with no loss of important core, two pieces of core from AEC 8 were also picked:

$$
\begin{aligned}
& 2059.5-2059.8 \\
& 2462.0-2462.9
\end{aligned}
$$

In the Kerr-McGee potash mine, Lea County, New Mexico, northwest of the WIPP site a $4-m$ igneous dike has cut potash ore beds. As this represents a natural simulation of some of the heat effects of canister storage, it is instructive to examine the fluid inclusions in samples taken at measured distances from this dike:

$$
\begin{aligned}
& \text { MB-77-8 White halite 1-2 cm from dike } \\
& \text { MB-76-3 Barren salt } 0.2 \mathrm{~m} \text { from dike } \\
& \text { MB-76-4 "Ore" horizon } 2.5 \mathrm{~m} \text { from dike } \\
& \text { MB-76-5 "Ore" }-21 \mathrm{~m} \text { from dike }
\end{aligned}
$$

of these samples, the field evidence indicates that only MB-77-8 has been molten. The others show some mineralogical effects of the heating, but as sedimentary structures are preserved, they have presumably not melted (M. Bodine, personal communication).

\subsubsection{Sample Preparation}

Sections. A thick slice was cut from each sample using a diamond saw and ethyl alcohol lubricant. One side was fine ground with an alcohol slurry of abrasive (1200 grit), ultrasonically cleaned in alcohol, mounted on glass with cold-setting epoxy resin, and cured in 16 hrs. at room temperature. The section was then ground down on a lap, using an alcohol slurry, to 3-8 mm thickness (depending on opacity) and then polished by finer abrasives, ending with either $1200 \mathrm{grit}$ or $0.3 \mu \mathrm{m} \mathrm{Al}_{2} \mathrm{O}_{3}$. Plates with fine-ground surfaces were examined using a matching silicone oil or saturated brine and coverglass. Coarse cleavages could be examined directly, without polishing.

A small section $(\sim 2 \times 4 \mathrm{~cm})$ was cut first, perpendicular to the core axis (when nature of sample permitted orienting), then one or more larger plates $(5 \times 8 \mathrm{~cm})$ were cut parallel with the core axis. 
Coarse water-soluble residues. 100 - to 150-gram samples were dissolved in tap water at room temperature with frequent stirring. The solution was decanted frequently to remove dissolved salts and finely divided solids such as clays.

\subsubsection{Methods of study}

Petrographic Examination. All slides and preparations were examained with the petrographic microscope, but phases present other than halite were not determined due to the short time available and the redundancy with extensive mineralogical work by others. Most examination time was spent on finding and characterizing the nature, size, frequency and distribution of the fluid inclusions.

Considerable time was spent determining the volume of fluid inclusions in the plates, through counts of representative portions. This determination was based on measurements with a graduated ocular (calibrated with a stage micrometer) and several assumptions. First, the inclusions were considered to be cubes (based on observation); one edge was measured and then the volume calculated. Larger inclusions $(\sim 1 \mathrm{~mm}$ edge length) that were obviously not cubes were estimated from the summation of a series of smaller cubes. Second, since bubbles were very rare (only about 0.18 of the inclusions), and small ( $\sim 18$ of inclusion volume), they were ignored. Third, most inclusions in these samples were of one or the other of two types (essentially the same as the types "A" and " $B$ " discussed in a later section on Results), and any given small portion of salt contained only one type. As the bulk of the sample in any plate could be characterized easily into these two types the approximate volume percent of the samples for each type could be estimated. A $\sim 500 \mathrm{~mm}^{3}$ volume of the plate was then selected from each type, visually estimated to be representative of that type in that plate, and the volume percent of inclusions determined in it by measurement and counting, using a transparent grid template at 500x. The total volume percent of inclusions was then calculated from the weighted average. The weight percent of inclusion fluid was calculated, assuming the salt to have a density of 2.2 and the brine to be $1.3 \mathrm{~g} / \mathrm{cm}^{3}$. Large numbers of very tiny inclusions were estimated from counts and estimates of small 
but visually representative volumes. Although the relative errors involved in this step are large, the total contribution by these small inclusions, even though they are extremely abundant, was very small. Most of the fluid found was present as a small number of large inclusions that could be measured more accurately. All inclusions over $200 \mu \mathrm{m}$ (edge length) in the count volume were measured. The overall measurement error in volume percent of inclusions present is believed to be on the order of \pm 58 of the value stated for a given plate. Other variables, particularly rare, still larger, centimeter-sized inclusions that were opened during coring or sample preparation (and hence not counted), and the large difference between different plates from the same sample, introduced much larger errors.

Heating stage. The liquid in inclusions trapped as homogenous fluid at above surface temperature shrinks on cooling, forming a bubble that provides a measure of the amount of differential shrinkage of liquid and host crystal. As the bubbles in the inclusions were small, relatively little heating was needed to cause homogenization. Hence a new heating stage was set up, consisting of a bath of silicone oil with an electric immersion heater and thermometer. Temperature equilibration was achieved through convection and frequent stirring. The individual runs were approximately 2-3 hrs. in length. Many inclusions that had no bubble as received developed one on cooling the silicone to $\sim-6^{\circ} \mathrm{C}$ with solid $\mathrm{CO}_{2}$. On subsequent heating this bubble would decrease in volume but persist as a very small bubble at room temperature. Heating was done on the stage of a low power binocular microscope, since the inclusions were large and scattered.

Freezing stage. The depression of the freezing point of the fluid in an inclusion (i.e., the "freezing temperature") is a function of the composition of the fluid. Using this techique under the microscope can permit a quick measure of the salinity of $10^{-10} \mathrm{~g}$ of fluid, a far smaller sample than can be measured by any other method. Metastable supercooling is common, so most inclusions had to be cooled to very low temperatures (three hours in $\mathrm{CO}_{2}$-acetone at $-78^{\circ}$ or even $\mathrm{LN}_{2}$ at $-196^{\circ} \mathrm{C}$ ) to cause freezing. Subsequent slow warming of the sample while 
surrounded by rapidly circulating refrigerated acetone of known temperature under the microscope permits recording the temperature of disappearance of the various solid phases formed on freezing (salts, hydrates, and ice), under equilibrium conditions.

If an inclusion is frozen completely to a mixture of solids, with no liquid, it becomes rather opaque. On warming, the first melting wets the crystal interfaces, suddenly making the mass more translucent, and permitting recrystallization to coarser crystals with time. This is called the "first melting temperature." It ranges from $-21^{\circ} \mathrm{C}$ for pure $\mathrm{NaCl}$ solutions to $-51^{\circ} \mathrm{C}$ for $\mathrm{CaCl}_{2}$ solutions.

Crushing stage. If a host crystal containing an inclusion with a bubble is surrounded by a fluid and gradually crushed while under the microscope so that the behavior of the bubble can be observed, the presence of noncondensable gas in the bubble, and its pressure, can be determined. The test is only crudely quantitative in terms of pressure (based on the volume precent expansion), but it is extremely sensitive as a detector of small amounts of gas. Less than one billion molecules of gas can be detected readily. Numerous cleavage fragments of salt containing various types of inclusions were crushed on several models of crushing stages to determine the amount and pressure of any noncondensable gases present.

Coarse water-soluble residues. These were studied in oil immersion mounts in hopes that some of these phases were sufficiently coarse to contain fluid inclusions that would provide data on their conditions of formation.

Decrepitation. A portion of the core weighing approximately $100 \mathrm{~g}$ was split out with a rock splitter; where possible the outside core surface was avoided, due to the probability of physical deformation and resultant leakage of incluions. This piece was wrapped loosely in aluminum foil, weighed, and heated to the run temperature $\left(150-250^{\circ} \mathrm{C}\right)$ over a period of 8 hours to avoid thermal shock, held at run temperature for 3-4 days, cooled and reweighed to determine weight loss. Following this the homogenization temperature range was redetermined for a series of 
inclusions that appeared, on petrographic examination, to be representative. Crushing tests were also repeated on the heated samples to detect the presence of noncondensable gases under pressure.

\subsubsection{Results of Petrographic Examination}

Inclusions type $A$. This is the most abundant type by far. It consists of slightly rounded cubic cavities (Plates 7.13 and 7.14 ) filled with liquid and generally no other phase, except for rare tiny vacuum (shrinkage) bubbles that comprise $\sim 18$ by volume of those inclusions having bubbles. Only about 0.18 of the inclusions have bubbles, usually the larger inclusions only, but there are exceptions (see below). Type A inclusions occur as dense irregularly shaped clouds of randomly distributed but crystallographically oriented inclusions (e.g., Plate 7.16). In such dense arrays, individual inclusions are rarely over $20 \mu$ $\mathrm{m}$ on an edge (Plate 7.18), few are $>5 \mu \mathrm{m}$, and most are in the range 0.5-2.0 $\mu \mathrm{m}$, with the highest concentrations in the smallest sizes (Plate 7.19). Estimates of the maximum number of such inclusions, based on counts of representative volumes, show about one inclusion per $100 \mu$ $\mathrm{m}^{3}$, or $10^{10}$ per $\mathrm{cm}^{3}$. If these are assumed to average one $\mu \mathrm{m}^{3}$ in volume, such cloudy halite would contain about one volume percent of fluid.

In addition to these irregular clouds, abundant type $A$ inclusions occur in crystallographically arranged (cubic) planes and zones in the host halite, frequently with parallel inclusion-free zones (Plates 7.13 and $7.14)$.

In some zones type A inclusions grade into more sparsely distributed but larger inclusions $(\leq 100 \mu \mathrm{m})$, as seen in Plates 7.14 and 23-24. These coarser inclusions may represent incipient recrystallization of the host. The distinction between these larger type A inclusions and type $B$ (next section) may seem inexact, but actually there is little overlap. 
Inclusion type B. Type B inclusions, although far less abundant than type A, carry most of the inclusion fluid in these samples, since they are much larger ( $\geq 100 \mu \mathrm{m}$ to several millimeters). Although large, many have no bubble as found (Plate 7.20), but may develop one if cooled slightly $\left(\sim-7^{\circ} \mathrm{C}\right)$ and warmed back to room temperature. They are generally irregular if large $(>500 \mu \mathrm{m})$ and are more nearly euhedral negative cubes if smaller (Plates 7.15 and 7.17). They occur as single isolated inclusions in otherwise almost optically clear halite, and as dense groups of many inclusions, in part interconnected with tubular extensions (Plate 7.15).

The host halite for type $B$ inclusions may occasionally have cloudy wisps of type $A$ inclusions, but they are never immediately adjacent to a large inclusion (Plates 7.15 and 7.17). These features suggest that salt originally containing only clouds of "primary" type $A$ inclusions has been partly or completely recrystallized to form coarser crystals of clear salt with type $B$ inclusions. This interpretation is supported by the grain size of the host salt, which is almost always coarser in those parts of a sample containing type $B$ inclusions (see Table 7.13 in next section on weight percent of fluid). The boundary between cloudy primary and clear recrystallized salt is sometimes curved (Plate 7.16). If it were straight, it might not be possible to distinguish it from a primary growth zone boundary between fast cloudy and slow clear growth. Most areas of type $A$ occur as irregular masses within single crystals of mainly recrystallized halite (Plates 7.15 and 7.17 ).

Relatively few samples, particularly sample 1902.2, show birefringent crystals of an unidentified phase inside what appear otherwise to be type $B$ inclusions. These are equant to bladed crystals of moderately high birefringence $(\sim 0.06)$ and moderate index of refraction (but well above that of the surrounding brine). Many are twinned (Plates 7.25 and 7.26), and when prismatic or bladed, the extinction positions are strongly inclined to the crystal elongation. As the distribution of these crystals is irregular, and as a similar birefringent phase occurs in some of the same samples (Plate 7.27) the occurrence in the inclusions might be interpreted as accidental trapping of solids present at the time of 
trapping of the inclusions. All 10 inclusions in one group in sample 1902.2 (Plate 7.27) contain these crystals, in roughly the same amount (estimated at $\sim 5 \%$ by volume), thus suggesting that they are true daughter crystals, formed by precipitation from the trapped fluid. Another plane of inclusions in this same sample, only $400 \mu \mathrm{m}$ away, contains only liquid (Plate 7.28 ) so it is concluded that the fluids present during recrystallization changed in composition with time.

Inclusions Type C. This type is similar to type B in size, shape, and occurrence, but rarer, and differs only in containing a relatively larger gas bubble, of variable volume, but $>18$ by vol. (Plate 7.29). A larger gas bubble can originiate by several processes -- leakage, necking down, higher temperature of trapping, or primary gas. The gas bubbles in these inclusions are found to be under pressure (see "Results of crushing stage studies"), so it is believed that such inclusions have trapped a mixture of gas and liquid (i.e., primary gas). In some (e.g., plate 7.30), such inclusions have apparently formed by a refilling of an earlier type $B$ inclusion with a gas-liquid mixture along a crack.

Inclusion Type D. This type occurs in curving planes outlining some of the individual crystal boundaries (Plates 7.31 and 7.32). It was probably full of fluid under natural conditions, but as the grain boundary permitted leakage and desiccation, these are now full of gas (presumably air).

\subsubsection{Weight Percent of Fluid}

A summary of the results of measurements of the volume percent of fluid in the inclusions is given in Table 7.13. In calculating these volumes some simplifying assumptions had to be made, in addition to those mentioned in Section 7.6.5. For simplicity the host salt volume counted was categorized as type $A$ or $B$ on the basis of the maxiumum size of inclusions it contained. If these were $\leq 1 \mathrm{~mm}$, it was called type $A$. This division is not the same as given in the descriptions of type $A$ and B inclusions, where $\sim 100 \mu \mathrm{m}$ inclusions are considered as probably indicative of recrystallization, but this has little effect on the results, since on the average, over $90 \%$ of the fluid is present as type $B$ 
inclusions $>1 \mathrm{~mm}$ in about 308 of the volume of the salt. Table 7.13 shows that these samples now contain a total of from 0.17 to 2.868 fluid by volume, and average 0.61 . These values correspond to 0.1 to 1.7 weight percent fluid as extremes, and average 0.36 weight percent. These results are compatible with those reported in Sections 7.5 .2 and 7.5.3.

These values have a measurement error of about $\pm 5 \%$ of the amount found. Much larger, however, is the variability introduced by the samples themselves. Thus three parallel plates were cut at $\sim 3-\mathrm{cm}$ intervals through samples 2272 , and yielded $1.23,0.36$, and 0.20 volume percent fluid.

Even more important to consider is the bias inherent in these measurements due to substantial and unpreventable loss of inclusions. Examination of the cores showed some centimeter-sized cavities, the sites of former fluid inclusions. No inclusion this size could possibly be included in our count since the plates counted had to be $<1 \mathrm{~cm}$ in thickness to be translucent. In addition, in situ all natural intergranular porosity in these salt beds was possibly full of fluids. The type $D$ inclusions found represent probably only a trivial part of the total in situ water content present as such "imperfectly sealed fluid inclusion." Large scale in situ porosity tests would be needed to evaluate this variable.

\subsubsection{Results of Heating Stage Studies}

Only 35 inclusions were run, as listed in Table 7.14. These are mostly from type $B$ inclusions. Some of these inclusions had to be cooled to below room temperature to nucleate a bubble before the run (Plates 7.20, 33 and 34 ). Why some very tiny inclusions have vapor bubbles (Plate 7.36), yet many large ones have persisted metastably as stretched liquid (i.e., one phase) is puzzling. The data are too sparsely distributed to determine whether the range of values $\left(20.4\right.$ to $\left.45.5^{\circ} \mathrm{C}\right)$ represents a real difference between samples. One group of inclusions in sample 2821 with birefringent daughter crystals showed no change in the crystals on heating to $24.5^{\circ} \mathrm{C}$. 


\subsubsection{Results of Freezing Stage Studies}

Inclusions in $\mathrm{NaCl}$ have a special type of behavior on freezing, as a result of reaction of the water of the inclusions with the walls to form the new incongruently-melting phase hydrohalite $\left(\mathrm{NaCl} \cdot 2 \mathrm{H}_{2} 0\right)$, at temperatures below $+0.15^{\circ} \mathrm{C}$. As a result, the inclusion enlarges and becomes full of birefingent crystals upon being held at low temperatures. Evidence of this expansion remains on warming to room temperature. Furthermore, the volume resulting from expansion to form ice is frequently larger than the original volume of the inclusion, and the inclusion's walls crack to relieve the pressure (Plate 7.35 ).

The freezing data are summarized in Table 7.15. If the solution present is simply $\mathrm{NaCl}$ and $\mathrm{H}_{2} 0$, the last crystal of hydrohalite will melt at $+0.15^{\circ} \mathrm{C}$, assuming equilibrium has been obtained (which is an extremely slow process for this phase). Although only relatively few large type $B$ inclusions were run, many smaller type A inclusions were also watched at the same time. None were found to have either first melting at $-21^{\circ}$ or freezing at $+0.15^{\circ} \mathrm{C}$, so none consist of essentially pure $\mathrm{NaCl}$ solutions. Much hydrohalite formed in these inclusions, but as there were birefringent crystals (generally with birefringence less than that of hydrohalite) that persisted well above $+0.15^{\circ} \mathrm{C}$, the last solid is a phase other than hydrohalite, and the solutions must contain significant quantities of materials other than NaCl (Plate 7.37). This is also very evident from the first melting temperatures.

\subsubsection{Results of Crushing Stage Studies}

Bubbles in types $B$ and $D$ inclusions from several samples were examined on the crushing stage. All disappeared immediately on opening, indicating that they consist of water vapor (at $\sim 20 \mathrm{~mm}$ pressure), and hence collapse at one atmosphere. The bubbles in several type $\mathrm{C}$ inclusions showed considerable expansion, however, indicating gas under pressure. Thus the bubble in the inclusions shown in Plate 7.38 expanded 2708 by volume on opening (Plate 7.39), indicating that nearly three atmospheres of noncondensable gas is present. The composition of this gas is unknown at present. 
A previously unrecorded inclusion deformation phenomenon was also observed in some inclusions that were in a sample that was under uniaxial stress on the crushing stage at room temperature but had not been broken to release the inclusions. These inclusions developed a scalloped pattern along the corners (Plate 7.40), presumably due to solution at points of stress concentration and redeposition elsewhere. This pattern developed over a relatively few minutes at effectively constant stress. At least some volume change occurred in this process, since the bubble in the inclusion disappeared at constant temperature.

\subsubsection{Results of Study of Coarse Water-Insoluble Residues}

The weight percent of such residues ranged from 0.0058 (sample 2391 to 0.38 (sample 2821). Unfortunately, however, although there were a variety of phases present in the residues, none of the crystals contained visible fluid inclusions. Some samples emitted a petroliferous odor and showed oily films on the water surface during leaching; it is not known whether these represent contamination from the oil-based drilling mud used in part of the coring, or natural oil in the samples (as is present in other salt deposits, as integranular films and inclusions). No oil inclusions were seen in this work.

\subsubsection{Decrepitation Tests}

These tests were run only on the last nine samples of the first 19. A summary of the test data and results is given in Table 7.16. On examination of the material after the decrepitation tests, several general features were evident. The nature of the test is such that systematic inclusion counts before and after the test on the same sample are impossible. It was obvious that although most of the larger inclusions had decrepitated, and were empty, many small inclusions ( $\leq \sim 100 \mu \mathrm{m}$ ) had not. These small inclusions appear perfectly normal in distribution, but almost all had developed appreciable vapor bubbles (Plate 7.41), with a vapor/liquid ratio that is obviously higher after heating than that present in two-phase inclusions before heating. Only the $150^{\circ} \mathrm{C}$ sample still had inclusions without bubbles; a few 10-20 $\mu \mathrm{m}$ one-phase liquid inclusions were found there. All three samples showed some "steam" inclusions - cubic negative crystals with fillets of liquid 
in the corners. No gas under pressure was found in any of the heated inclusions. In most cases, the weight losses increase with increasing run temperature; the several exceptions are probably a result of nonhomogeneous distribution of inclusion in the sample aliquots taken.

Homogenization temperatures were determined on two-phase inclusions remaining in the samples after the decrepitation tests. The results are given in Table 7.17, along with the volume percent of vapor phase, estimated from measurements of bubble diameters.

\subsubsection{Study of Suite of Samples from Kerr-McGee}

The three samples closest to the lamprophyre dike (See Chapter 3) yielded usable inclusions. (Sample MB-76-5 was too fine grained and opaque to be usable by the sample preparation techniques used here, and will not be considered futher in this report.) In all three samples about 158 of the small inclusions $(<\sim 20 \mu \mathrm{m})$ were without bubbles as received. Most inclusions in all three samples were normal, two-phase inclusions with a small bubble. Homogenization temperatures were determined on a representative group of these two-phase inclusions in each, with results as shown in Table 7.18 .

Freezing runs were made on inclusions in two of these samples. In both cases the first melting temperatures were well below that of a pure $\mathrm{NaCl}-\mathrm{H}_{2} \mathrm{O}$ system $\left(<-28^{\circ} \mathrm{C}\right.$ for $\mathrm{MB}-77-8$ and $<-31.0^{\circ} \mathrm{C}$ for $\left.\mathrm{MB}-76-4\right)$. On warming, the last solid phase to dissolve in both samples was an unidentified phase, presumably a hydrate other than $\mathrm{NaCl} \cdot 2 \mathrm{H}_{2} 0$. This dissolved at +11 to $+18^{\circ} \mathrm{C}(\mathrm{MB}-77-8)$ and at +4 to $+7.2^{\circ} \mathrm{C}(\mathrm{MB}-76-4)$.

One 75- $\mu \mathrm{m}$ inclusion was found in MB-77-8 that yielded an entirely different freezing behavior. This inclusion contains a single homogenous fluid at room temperature, presumed to be gas (Plate 7.43a). On cooling to the range -70 to $-75^{\circ} \mathrm{C}$ this inclusion develops a number of grains of an unidentified solid (Plate $7.43 f$ ). On warming to about $-68^{\circ} \mathrm{C}$, a liquid/vapor meniscus becomes visible (Plate $7.43 e$ ), with solid grains 
still present. The last of these grains disappears at $\sim-56^{\circ} \mathrm{C}$ (Plate 7.43d); on further warming the liquid/gas meniscus becomes faint (Plate $7.43 \mathrm{C}$ ) and the two homogenize, by expansion of the liquid, at $-20.9^{\circ} \mathrm{C}$ (Plate 7.43b). This behavior is difficult to interpret in terms of composition. $\mathrm{CO}_{2}$ has its triple point at $-56^{\circ} \mathrm{C}$, in exact agreement with the disappearance of the solid phase at $-56^{\circ} \mathrm{C}$ observed here, but obviously the inclusions cannot contain just $\mathrm{CO}_{2}$, as there is liquid present at a lower temperature. The nature of the mixture of gases can only be guessed at this time.

The crushing tests in the Kerr-McGee mine samples were most revealing. The normal, small-bubble inclusions contain a vacuum bubble (i.e., water vapor at $\sim 20 \mathrm{~mm}$ presure). Many inclusions that either had a very large bubble or appeared to contain gas only, from all three samples, were found to contain either vacuum (Plates 7.44 and 7.45 ), or a partial vacuum (Plates 7.46 and 7.47). These are probably from the trapping of bubbles of steam, with or without some noncondensable gas and brine. All three samples also contained a few inclusions with gas under greater than atmospheric pressure. These inclusions were one-phase as first observed, and except under special circumstances, it is not possible to distinguish between a vacuum, dense gas, or even liquid, in such single inclusions. It is only on crushing, when these inclusions formed bubbles of noncondensable gas in the surrounding fluid, that the internal pressure became evident. By measuring the size of the inclusions before crushing, and the diameter of the bubbles evolved, we obtain a crude measure of the internal pressure, assuming each unit volume expansion corresponds to one bar pressure. In a few inclusions, the contents changed to a two-phase, liquid + vapor system during the expansion (Plate 7.48), but usually the pressure release was too sudden to reveal if there was a transient two-phase condition. The volume expansion varies for different inclusions, from 30- to 40-fold (Plates 7.49 and 7.50 ) to a maxiumum of perhaps 100-fold (Plate 7.51). As the immersion medium used is an oil in which methane is probably readily soluble, this gas is more likely $\mathrm{CO}_{2}$ ' since the bubbles dissolve in the oil very slowly. 
Interpretation of the data from the Kerr-McGee mine samples is difficult at this time. The presence of an inclusion filled with a dense $\mathrm{CO}_{2}-\mathrm{rich}$ (?) gas in sample $\mathrm{MB}-77-8$, (in halite that was probably molten at the time of intrusion of the dike) is not unexpected, since there is a small amount $(0.2-28$ ) of magnesite in the adjoining rock (M. Bodine, personal communication). The dike shows no evidence of carbonate alteration, however, and there is a problem in explaining the presence of inclusions of low-temperature, gas-free brine, apparently pure steam, and dense $\mathrm{CO}_{2}$ in the same sample. Formation of these types at different times is obviously required, but there is no other indication of differences in conditions or time of origin.

The temperature at which the dense gas inclusion was trapped is of interest. Although the melting point of pure $\mathrm{NaCl}$ is $800^{\circ} \mathrm{C}$, other materials present here in the potash ore zone (such as KCl) will lower this temperature. If we assume that the gas inclusion contains pure $\mathrm{CO}_{2}$, the $-21^{\circ} \mathrm{C}$ homogenization indicates a filling density of about $1.03 \mathrm{~g} / \mathrm{cm}^{3}$ (Roedder, 1965). Combining this with the estimate of confining pressure of $\sim 38 \mathrm{MPa}$ (380 bars) yields an obviously erroneous "trapping temperature" of $0^{\circ} \mathrm{C}$. The several inconsistencies and difficulties in interpretation of the data from the Kerr-McGee samples cannot be resolved until additional studies are made.

\subsubsection{Discussion}

Geological Significance. Several aspects are evident from these various results. First, the fluids in all the inclusions, both type $A$ in primary salt crystals and type $B$ in recrystallized salt, are strongly saline brines, with significant amounts of other salts present in addition to $\mathrm{NaCl}$. These brines differ from one inclusion to another, indicating that a range of fluids has been present at various times in these beds, but no inclusions with simple $\mathrm{NaCl}$ solutions were found, as are found in other salt beds and as might be expected if pure salt beds have been fractured in the presence of meteroically-derived (fresh) ground water. The original deposition of salt occurred from highly-concentrated brines, and 
presumably all waters that have passed through these samples since have had dissolved in them amounts of other minerals in addition to NaCl. Such fluids have caused extensive recrystallization of the salt, and presumably other mineralogical changes, so that little of the original salt texture remains. Second, at some stage in this recrystallization, gas-liquid mixtures were present in the pores of these beds. Third, this recrystallization occurred at near-surface temperatures $\left(20-45^{\circ} \mathrm{C}\right)$. Fourth, the movement of these fluids must have been slow, as the evidence of extensive inclusion metastability indicates very clean solutions, free from the solid nuclei present in most fast-moving near-surface waters.

The fluids from which the salt crystals making up these beds originally crystallized were exceedingly saline brines with much material other than $\mathrm{NaCl}$ in solution, as shown by the freezing data on primary inclusions in hopper salt. These hopper crystals appear to have grown on the surface and then to have sunk, as described by Dellwig (1955). All but about 18 of this original hopper salt texture has been eliminated by recrystallization at some unknown later time, yielding coarser, clearer crystals of salt, and presumably gross changes in the mineral assemblage other than halite. Some of the clear salt surrounding the chevron structures may represent crystallization of these hopper nuclei on the bottom of the basin, but most is believed to be from recrystallization. This recrystallization occurred in the presence of exceedingly saline brines and with much material other than $\mathrm{NaCl}$ in solution. The brine may have been composed essentially of fluids from the primary fluid inclusions, released during the recrystallization. It was trapped as large inclusions in the recrystallized salt and comprised the bulk of the liquid now present in the samples as studied in the laboratory. Although the salt beds now appear dry to the eye, the samples contain 0.1 to 1.7 weight 8 fluid as examined, and may contain more in situ. At some stage or stages early in the history of these beds, the fluids present in these rocks varied in composition. (See section 7.7) A very few were saturated with organic gases such as methane and actually contained bubbles of a separate gas phase. Others contained additional salts in solution, resulting in the precipitation of various crystalline solids 
from the liquid within inclusions in halite. The relative time sequence of these various fluids is not known, and most inclusions have neither methane nor crystalline solids. The latest episode of any recrystallization has been dated at 204 million years, slightly younger than Permian.

Homogenization temperatures of inclusions in recrystallized salt range from 20.4 to $45.5^{\circ} \mathrm{C}$. During burial, creep from recrystallization in a salt bed with intergranular films of solution should result in the hydrostatic pressure on fluids (during trapping in a crystal) being essentially equal to the lithostatic pressure. If an overburden of 5000 ft. $(1524 \mathrm{~m})$ is assumed to have been present during the recrystallization, the maxiumum pressure (1ithostatic) would have been $\sim 38 \mathrm{MPa}$ (380 bars). There are no PVT data on the specific fluids present in the inclusions, but if the data on a 25-percent $\mathrm{NaCl}$ solution are used, this pressure would suggest a maximum pressure correction of $36^{\circ} \mathrm{C}$ (Potter, 1977), and hence trapping (i.e., recrystallization) temperatures of 56-82 ${ }^{\circ} \mathrm{C}$. However, the true pressure correction may be lower, particularly since the fluids are more saline than 25-percent NaCl. Thus there is a drop of $12^{\circ} \mathrm{C}$ in the pressure correction on changing from 20-percent $\mathrm{NaCl}$ to 25-percent $\mathrm{NaCl}$.

The presence of smooth planes of primary hopper salt inclusions of various sizes, separated by planes of inclusion-free salt, with the plane orientation horizontal, proves that these minute inclusions have not moved measurably since deposition, although they have been in a geothermal gradient presumably similar to that of the present for about $225 \mathrm{~m} \cdot \mathrm{y} \cdot$

The widespread occurrence of metastable phenomena in these inclusions, even in some large ones, suggests that fluid flow in the past through these beds has been very slow. Also, the fact that all inclusions that have been frozen prove to contain bitterns, and none was found with just $\mathrm{NaCl}-\mathrm{H}_{2} \mathrm{O}$ solution, proves that at no time during the history of these samples did ground water, saturated only with respect to $\mathrm{NaCl}$, ever penetrate into these particular samples. 
Nuclear waste Disposal Significance. The most signficant aspects at this stage in the study are as follows: First, the amount of fluid water solution now present in the samples as fluid inclusions averages 0.36 weight percent. Second, although noncondensable gases are present under pressure in some inclusions, the total amount is very small. Third, the inclusions change dimensions signficantly within minutes at room temperatures when the host crystal is subjected to uniaxial stress; this might suggest more rapid movement of inclusions in a thermal gradient if simultaneously under stress, as in mine pillars. Fourth, and possibly most significantly, the distribution of primary inclusions indicates that they have not moved visibly (i.e., less than a few micrometers at most), in the 225 million years since they formed, yet they have been in the small but finite geothermal gradient all this time. All fluid inclusions can be expected to move when placed in a thermal gradient. Since there is usually a thermal coefficient of solubility, material will dissolve on one wall and precipitate on the other. The rate of movement is a complex function of numerous variables (including inclusion size), but the temperature coefficient of solubility is probably the most limiting parameter in the case of $\mathrm{NaCl}$. In the pure system $\mathrm{NaCl}-\mathrm{H}_{2} 0$, the solubility change per $100 \mathrm{~g} \mathrm{H}_{2} \mathrm{O}$ is low, only $0.03 \mathrm{gm} /{ }^{\circ} \mathrm{C}$ in the range of $0-100^{\circ} \mathrm{C}$. This increases by approximately a factor of two at the elevated temperatures expected near the wastes. This coefficient is comparable in the $\mathrm{NaCl}-\mathrm{MgCl}_{2}-\mathrm{H}_{2} \mathrm{O}$ system.

All these aspects will now be treated in expanded detail.

Amount of Water in the Beds. Although this is the most important single datum that might be obtained from inclusion studies, fluid inclusion counting can provide only approximate values. The nature of the samples and the necessary sample preparation are such that there is a bias toward low values built into these data. Superimposed on this uncertainty in accuracy is poor precision in the measurement, due to variability of the sample material. For example, adjacent slabs of the same sample showed a five-fold $r$ ange. It is probable that precisely calibrated neutron logs, reflecting the amount of hydrogen in the beds, give a more accurate 
evaluation of the total water present, since they would effectively integrate over a much larger sample and would include the effects of the liquid-filled intergranular cavities which these tests miss.

One important aspect of the inclusions on the properties of the salt is the effect of the constitutents present on the lowering of the temperature of melting, and on the amount of liquid present at any given temperature. In this connection it is important to note that the inclusions' fluid is not water, but a strong bittern with probably significant quantities of magnesium ions. This will certainly affect the temperature coefficient of solubility of $\mathrm{NaCl}$ in these liquids, and will have important effects on the vapor pressure of these liquids (see below).

Corrosive Gases in the Inclusions. Although gas analyses by mass spectrometry are still to be made on the inclusion fluids, it is evident from the crushing studies that the inclusions in these samples, at least, contain very little noncondensable gases. Although hydrogen sulfide was found as an important constituent of gases in a gas pocket in another drill hole, (ERDA-No. 6, Section 7.7), there can be very little, if any, in these inclusions. The human nose is a rather sensitive detector of $\mathrm{H}_{2} \mathrm{~S}$, ordinarily responding to a minimum of $\sim 10^{-10} \mathrm{~g}$. No odor of $\mathrm{H}_{2} \mathrm{~S}$ was detected during preparation of these samples, when relatively large volumes of inclusion liquid were exposed to the air. Gases such as $\mathrm{HCl}$ formed within the inclusions or by reactions of inclusion fluids with other minerals during heating, and under intense gamma radiation, may be a much more important cause for corrosion than those now present in the inclusions.

Effects of Water on Physical Properties of the Salt. The intergranular porosity in these salt beds, in situ, possibly contains some aqueous solution. Such fluids will tend to be squeezed out of the salt beds over geological time as recrystallization along grain boundaries and other processes permit compaction, just as the residual water in a sandstone is eliminated during the formation of a quartzite. Such flow will occur, however, only if there is an escape route for the fluid to take. As 
pointed out very aptly by Baar (1977), there is much evidence from high pressure fluid pockets that salt rocks in situ are generally impermeable at depths exceeding about $300 \mathrm{~m}$. It may well be that under such conditions, which preclude further "dewatering", the fluid in these intergranular films is still able to migrate short distances, enough to permit it to coalesce into "pockets", perhaps at points of slightly reduced pressure, just as a plastic shale will flow to the crest of folds in firmer rocks. These "pockets" might be represented in part as the short-lived seeps observed in potash mines.

Even if the intergranular liquid were to be removed completely, yielding a polycrystalline texture with salt crystals in true contact with each other, there is no driving force to remove the fluid inclusions from within the individual halite crystals. If such a salt bed is deformed to the point of rupture of salt crystals, any inclusions along the rupture will provide water to "lubricate" the fracture and hence lower the apparent strength of the rock. Although one might expect that a new fracture would preferentially follow planes of inclusions, as from the healing of former fractures, Gerlach and Heller (1966) have shown that the salt recrystallized in the vicinity of such a healed fracture is actually stronger than the adjacent unrecrystallized salt, and new fractures could not be made through the inclusions. Actually, most of the fluid in inclusions in the Carlsbad salt is in large, apparently randomly arrayed inclusions in recrystallized salt, and examination of fractures through such samples suggests that cracks induced in the laboratory experiments reported here have preferentially taken routes through such inclusions.

One example of the surprising effects of inclusion fluids on the properties of salt crystals is found in the behavior of fluid inclusions in single crystals of salt under uniaxial stress (Plate 7.40). Under these conditions, fluid inclusions visibly change shape, and volume, within a few minutes, at room temperature. This is a new inclusion phenomenon, never reported before. 
Evidence of Previous Solution Movement in These Beds. The fluid inclusion evidence obtained so far on solution movements is encouraging in that it indicates at most only very slow movement, and suggests that part of the fluids now present in these beds may even be nearly Permian in age. The lack of any pure $\mathrm{NaCl}-\mathrm{H}_{2} \mathrm{O}$ inclusions also argues against any previous sudden inrush of groundwater that could be trapped as inclusions in halite before it had time to acquire a full complement of other salts.

Movement of Inclusions in a Thermal Gradient. All fluid inclusions should move when the host crystal is placed in a thermal gradient. The nature and rate of such movement has been the subject of numerous studies, since it is of consequence in the chemical industry. Wilcox (1968) summarizes this extensive work (citing 111 references). Similar migration of inclusions is also an important cause for degradation of laser crystals grown at high temperatures by the Czochralski technique (Hopkins et al., 1976). Most liquid inclusions move up the thermal gradient, but if the vapor bubble is large relative to the liquid, and particularly if boiling occurs, the movement may be in the reverse direction (Wilcox, 1969; Anthony and Cline, 1972; Chen and Wilcox, 1972). The rate of movement is independent of inclusion size in many systems, but strongly (and directly) dependent on inclusion size in others (Wilcox, 1969); there may be a threshold size below which no movement occurs $(\sim 10 \mu \mathrm{m}$ in $\mathrm{KCl}$; Anthony and Cline, 197la). Large inclusions may break up during movement (Wilcox, 1968; Anthony and Cline, 1973). Many factors may affect the rate of migration, even in a given host, including gravity, composition, surface tension, inclusion shape, crystal anisotropy and imperfections, presence of a foreign gas, etc. In salt, since the thermal coefficient of solubility is small at surface temperatures, but increases greatly with increase in temperature, the rate of movement in a given gradient can be expected to increase with increase in ambient temperature. Higher ambient temperature also increases the travel rate by increasing the solubility, the diffusion coefficient, and the interface kinetics, and the increase in rate was found to be particularly striking in NaCl (Wilcox, 1968, p. 20). The 
fact that the inclusions in Carlsbad salt have not moved measurably during geological time in the geothermal gradient is perhaps an indication of exceedingly slow rate, or perhaps a result of a very weak driving force.

Accurate prediction of behavior of in situ inclusions in the thermal gradient around a canister in salt cannot be obtained at this time, as there are too many uncontrolled variables. Since most inclusions at Carlsbad contain no bubble or only a very small bubble, they will move toward the canister, as was shown to occur at Project salt Vault (Holdoway, 1974). The rate of this movement will depend most particularly on the inclusion size, the ambient temperature of the grain, the temperature gradient, and the temperature coefficient of solubility of $\mathrm{NaCl}$ in the particular inclusion fluid involved. The average distance that an inclusion must travel before it intersects a grain boundary will vary with the grain size of the salt, but seldom would be over $1 \mathrm{~cm}$.

What can be expected when the inclusion reaches a grain boundary? Anthony and Cline (197ib) showed that grain boundaries in crystal aggregates tend to trap migrating droplets, but Anthony and Sigsbee (1971) showed that gas bubbles (10-50 $\mu \mathrm{m})$ migrating in polycrystalline camphor could cross grain boundaries. However, migrating bubbles were observed to drag grain boundaries when the bubble concentration on the grain boundary was large. In Project Salt Vault, Holdoway (1974) says only that "little migration across grain boundaries appears to have occurred." Obviously, if a grain boundary is very tight, a large inclusion could cross it without effect. But if the grain boundary is composed of different material, the fluid could spread out along it as a film. Any such film should act as an inclusion, with material diffusing across it away from the heat source.

The behavior of an inclusion migrating to the wall of an open cavity (e.g., that holding the canister) will be different. On contacting the cavity, Anthony and Cline (1974) and wilcox (1968, 1969) have shown that 
some evaporation occurs, a vapor bubble forms, the inclusion seals itself, and now that it has a large bubble, it reverses direction and moves back the way it came, this time going down the gradient.

Decrepitation Release of Liquid Inclusions. In view of the expected slow migration rates of liquid inclusions in the thermal gradients established by the canisters, it seems probable that release of inclusion fluid by decrepitation will be an important process. An individual inclusion, if it is assumed to have rigid walls, to contain 25-percent $\mathrm{NaCl}$ solution, and to homogenize at $40^{\circ} \mathrm{C}$, will develop $70.0 \mathrm{MPa}$ (700 bars) internal pressure when heated to $100^{\circ} \mathrm{C}$, and $200 \mathrm{MPa}\left(2000\right.$ bars) at $200^{\circ} \mathrm{C}$ (Potter, 1977). However, salt cannot stand such internal pressures without yielding. Even a strong, hard mineral such as quartz starts to decrepitate when the internal pressure in its fluid inclusion reaches 80 \pm 3 MPs ( $800 \pm 3$ bars) (Khetchikov and Samoilovich, 1970), and halite can be expected to decrepitate when the internal (inclusion) pressure reaches four times the yield stress for monolithic halite, under no confining stress (Cline and Anthony, 1971).

When Carlsbad halites were heated, some of the inclusions decrepitated in part causing the samples to fragment, and yielding an average weight loss of $0.138\left(150^{\circ} \mathrm{C}\right), 0.228\left(200^{\circ} \mathrm{C}\right)$, and $0.738\left(250^{\circ} \mathrm{C}\right)$. This means that this much volatiles left the system. More inclusion fluid may well have been exposed, and merely lost water until its concentration of salts was such that the vapor pressure of $\mathrm{H}_{2} 0$ at that temperature was less than one atmosphere. Salts in solutions in these brines (including materials other than $\mathrm{NaCl}$ as well) have effects on the vapor presure and hence on any vapor transport.

In addition to those inclusions that decrepitated, however, many inclusions remain sealed as liquid inclusions in the sample after heating, albeit in a changed form. These have permanently deformed their walls to form a larger chamber, and now have a much larger shrinkage bubble, proportional to the amount of expansion. (Why some decrepitate and others expand is at present unanswered; residual stresses in the host 
crystal may be involved.) This expansion phenomenon is not new - it has been reported at various times in the past. It is the net result of several volume changes during heating of the inclusion. On heating, the host salt expands, enlarging the cavity as well. This effect is small, yielding a cavity volume increase of only 1.28 from 40 to $140^{\circ} \mathrm{C}$. The fluid in the inclusion dissolves more salt from the walls on heating; the net volume effect of this (generally a decrease; i.e., an increase in cavity volume) will vary widely with the composition of the solution. Thermal expansion of the brine would develop high pressures if the walls were rigid, but instead, in the presence of liquid, the inclusion walls frequently just expand. The amount of expansion is roughly proportional to the temperature of heating, i.e., the inclusion fluid streches the walls until its internal pressure drops just below that needed to cause further stretching at that temperature. Nucleation of a vapor phase may even occur (Geguzin and Dzyba, 1973), in which case loss of water to the expanding vapor phase also helps to limit the expansion. Some of the thermodynamic variables of the process have been modeled by cline and Anthony (1971) for the pure halite system.

7.7

THE GEOCHEMISTRY OF DELAWARE BASIN GROUNDWATERS IN RELATION TO THEIR HOST ROCKS

\section{7 .1 Introduction}

Geochemical studies of waters found in Permian and younger rocks of the Delaware Basin (Southeast New Mexico, West Texas) have assumed a new importance in recent years. This began in 1975 when Sandia Laboratories, in cooperation with the United States Energy Research and Development Administration undertook studies of the suitability of Delaware Basin evaporite deposits for the long-term storage of radioactive wastes generated by the national nuclear defense program.

In particular, three aspects of fluid geochemistry have bearing on an understanding of the geology of the area: 
1. Rock history - the relationships between dissolution features and nearby fluids which may have dissolved evaporites.

2. Fluid history - evidence of rock/fluid interactions preserved in fluid chemistry, indicating the complexities of fluid movement.

3. Fluid origins - the ultimate sources of fluids which have participated or have potential for participating in dissolution of evaporites.

Many of the waters considered here were bailed from preexisting wells with the assistance of the United States Geological Survey, between December, 1975, and June, 1976. In addition, boreholes for subsurface exploration of Los Medanos (the ERDA study area) tapped some fluid producing zones. These holes include ERDA No. 6,. which at a depth of 2711 feet produced saturated brine associated with $\mathrm{H}_{2} \mathrm{~S}-\mathrm{rich}$ gas from the Castile Formation. In this hole, stratigraphic marker beds were found several hundred feet above their expected positions (Anderson and Powers, 1978). Nine holes penetrating the Rustler Formation have facilited hydrological testing and sampling of Rustler waters. Finally, samples of waters were collected from pools in Carlsbad Caverns. Table 7.19 is an inventory of water samples, together with their collection locations. New Mexico locations are given in Figure 7.10, showing their distribution with respect to the Capitan Limestone.

Three geochemical approaches will be followed in this subchapter. Each approach will consider a few examples of various "types" of water:

1. Solute chemistry - dissolved solids content.

2. Thermodynamics - equilibia and non-equilibria of a fluid-gas system.

3. Stable isotope ratios - variations in deuterium and oxygen 18 content. 


\section{7 .2 Data}

Analytical results for the 29 waters are given in Table 7.20. Solute analyses are expressed in mg/l, performed according to APHA (1971) methods, with modifications by Collins (1975). Analyses by Martin Water Laboratories have a precision of about \pm 5 to 108 ; others \pm 38 (Table 7.19).

Stable isotope analyses were made according to Epstein and Mayeda (1953) and Bigeleisen et al (1952), and are reported in " $\delta$ " notation as deviation of the $\mathrm{D} / \mathrm{H}$ or ${ }^{18} \mathrm{O} /{ }^{16} \mathrm{O}$ ratio from the corresponding ratio of Standard Mean Ocean Water (SMOW) (Craig, 196lb, Epstein and Mayeda, 1953), in parts per thousand (\%o, "per mille") for example:

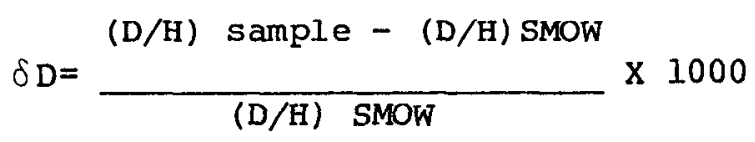

The precision of $\delta{ }^{18} 0$ values is better than $\pm 0.1_{\% 0}^{\prime}$ and that of $\delta \mathrm{D}$ is better than $\pm 1 \%$.

Solutes. In this discussion "fresh water" is taken to contain less than $3000 \mathrm{mg} / \mathrm{l}$ total dissolved solids (TDS), and is potable at least to local cattle. "Brackish water" refers to TDS contents between 3000 and 30000 $\mathrm{mg} / 1$. Brines are waters containing more than $30000 \mathrm{mg} / \mathrm{l}$ TDS. According to these definitions, number 1 , probably 18 and 26 through 29 (Table 7.19) are fresh waters, found in the Capitan and Santa Rosa Formations. Numbers 2, 6, 11, 17, 22, 24 and probably 19 through 21 are brackish, and include most Rustler waters, one Capitan and one Castile. The fresh and brackish waters contain the solutes expected to be found in carbonate and anhydritic or gypsiferous aquifers. All the other waters are brines, and include the Salado, Morrow, Delaware (Bell Canyon) waters, two Castile, one Capitan, and even two Rustler waters; these Rustler samples came from the Culebra dolomite member, adjacent to halite-bearing parts of the Rustler Formation. 
Brines are treated in the most detail here, since their presence has implications regarding either their representation of original evaporite mother-liquors, or their solutes having been derived through rock-water interaction. Their geochemical complexity cannot be understood from solute chemistry alone, and a brine occurrence in a particular rock unit does not necessarily imply that the brine has interacted with its host rock.

The chloride/bromide ratios, where obtainable, of all the brines were between 430 and 900 , compared to 292 for modern sea water (Collins, 1975). If the Permian Basin water had a $\mathrm{Cl} / \mathrm{Br}$ ratio similar to that of sea water, as suggested by Holser (1963) for fluid inclusions in Kansas salt, then these Delaware Basin brines do not contain "original" Permian water as a major component. Since halite crystallizing from sea water selectively excludes bromide from the $\mathrm{NaCl}$ lattice, halite has a $\mathrm{Cl} / \mathrm{Br}$ greater than 300 (Adams, 1969), as would brine resulting from the dissolution of halite. Hence, the sodium chloride in these brines has been dissolved from rocks, but not necessarily the rocks in which the brines were found.

Rather than discuss abundances of individual ions in brine solutions, it is more instructive to consider solute ions combined as solids which might be expected to precipitate from solution upon complete evaporation. Following the crystallization sequences compiled by Braitsch (1971), not only some similarities will be noted between the resulting normative mineral assemblages, but also some significant differences. Waters 16, 9, and 14 (Salado, Bell Canyon, Castile) will be presented as examples.

Water from the Duval Mine Vent Hole is similar to the other potash mine seeps (Numbers 3, 4 and 5) all of which are saturated solutions. Table 7.21 shows the relative proportions of minerals expected to precipitate from this solution. This assemblage is similar to that expected to precipitate from sea water, even though the relative proportions are different (note the overwhelming preponderance of carnallite). In view 
of the incongruent dissolution of polyhalite resulting in a calcium-poor solution, this brine is what one would expect for water which has dissolved a potash deposit. Note the presence of normative borax, an evaporite mineral not commonly reported in the Carlsbad potash district (cf. Jones, 1975).

Waters from the more saline portions of the Capitan aquifer (numbers 11, 12 and 13) contain the normative assemblage dolomite-anhydrite-kainite(or carnallite)-halitetsylvite, in various proportions, and are also indicative of solutes obtained by dissolution of adjacent evaporites.

Water number 9, from the Bell Canyon Formation, is examined in Table 7.22. The solution is calcium-rich, as indicated by the less common minerals tachyhydrite and antarcticite. These two minerals are not known to precipitate from sea water, and together with a magnesium deficit distinguish this water from a simple solution of primary evaporites. Graf et al. (1966), have given attention to the origin of calcium chloride waters, and emphasized shale ultrafiltration as an explanation. other possibilities include diagenetic reactions in which magnesium in solution displaces calcium in carbonates to form dolomite, or in which Mg-rich sheet silicates are formed, having given up more easily replaceable cations such as $\mathrm{Na}$ and $\mathrm{Ca}$ (Grim, 1968), which were present in the original minerals (kandites and smectities). Mg-rich sheet silicates are present in the Ochoan evaporites overlying the Bell Canyon (see subsection 7.4). Since brine number 9 is a saturated solution, and since calcite, not dolomite is the prevalent carbonate mineral of the Bell Canyon, neither dolomitization nor shale ultrafiltration (which tends also to produce a low-Ca water, which has not yet been found) appears to be a satisfactory model for the in situ evolution of Bell Canyon brine. The sulfate deficiency could have arisen from biogenic degradation of sulfate. The most likely explanation for the in situ Ca-enrichment is ion exchange. This brine probably did not originate in the Bell Canyon, but its solutes probably came from nearby evaporites. 
Waters 8 and 10 have a much lower TDS content than does 9, but otherwise yield most of the same minerals. The high strontium content of all three could be taken to indicate that these waters have indeed participated in the recrystallization of carbonates, but probably not within the Delaware Mountain Group of sandstones, which includes the Bell Canyon Formation. According to the Sr/Ca studies of oxburgh et al. (1959), this solution would have been in equilibrium with a calcite containing about $4000 \mathrm{ppm}$ Sr, a value too high for most natural calcites and dolomites. The Sr in solution could easily have come from the diagenetic alteration of aragonite outside the Bell Canyon.

On July 30, 1975, borehole ERDA No. 6 produced saturated brine (number 14, Table 7.19) and $\mathrm{H}_{2} \mathrm{~S}-\mathrm{rich}$ gas ( 0.16 cubic feet STP per gallon) from a fractured, gray, laminated Castile anhydrite unit 2711 feet below the surface. Similar phenomena in the Castile have been reported by oil companies, but with an order of magnitude more gas. The analysis of one other such brine (Shell Bootleg, number 15 in Table 7.19) is given in Table 7.20, and is quite similar to the ERDA No. 6 brine. The solutes are resolved in Table 7.23 , and aside from thenardite and LiCl (resulting from an almost economic concentration of lithium) are similar to the case of the dissolved potash deposit. $\mathrm{Na}_{2} \mathrm{SO}_{4}$ has been previously reported in subsurface brines (Reeves, 1963), and thenardite is known to precipitate from local surface lakes. Lithium is a common component of evaporites formed near igneous rocks, but the nearest igneous rock is several kilometers away (Calzia and Hiss, 1978). The brine is sodium-rich and magnesium poor. Once again in terms of ion exchange, a loss of evaporite-derived magnesium into silicates, which give up sodium, appears to be the mechanism here, although this need not have taken place in the Castile. Such like processes may account both for magnesium depletion in the solution and the formation of magnesium silicates in the evaporite sequence.

Thermodynamics. The ERDA No. 6 gas and brine are the only fluids which lend themselves to multiphase thermodynamic considerations. The gas amounted to 1.22 liters (STP) per liter of liquid, and consisted of 
$558 \mathrm{CO}_{2}, 28 \% \mathrm{H}_{2} \mathrm{~S}, 158 \mathrm{CH}_{4}, 1.5 \mathrm{~N}_{2}$ and $0.58 \mathrm{C}_{2} \mathrm{H}_{6}$, determined mass spectrometrically. The $\mathrm{H}_{2} \mathrm{~S}$ is not saturated in the solution, even in the light of the salting-out effect of high TDS content (Randall and Failey, 1927), and amounts only to 0.02 molal. In order to examine the role of sulfur in this system (the only multivalent element common to both liquid and gas phases) a predominance area diagram (cf. Garrels and Christ, 1965), was constructed for the system S-O-H with the variables pH and oxygen partial pressure, and with total sulfur equal to 0.36 molal (approximating the sulfate and $\mathrm{H}_{2} \mathrm{~S}$ in solution). The resulting diagram is Figure 7.11, for the field-temperature of $25^{\circ} \mathrm{C}$. The field-measured $\mathrm{pH}$ is 6.3 , and samples of the brine containing dissolved $\mathrm{H}_{2} \mathrm{~S}$ were observed to precipitate elemental sulfur upon standing at atmospheric conditions. The diagram shows that at pH 6.3, the sulfur field occurs between the sulfate and $\mathrm{H}_{2} \mathrm{~S}$ fields. Thus, the diagram correctly predicts the oxidation of $\mathrm{H}_{2} \mathrm{~S}$ to sulfur, and the sulfate and $\mathrm{H}_{2} \mathrm{~S}$ cannot be in thermodynamic equilibrium with one another at $\mathrm{pH}<7$. Unfortunately, the oxidation potential was not measured, and the precise position of the ERDA No. 6 system on the diagram is not known. The most probable origin of the $\mathrm{H}_{2} \mathrm{~S}$ is biogenic reduction of sulfate, an ion abundant in the surrounding rocks as anhydrite as well as in solution. Kuznetsov et al (1963), have indicated that bacteria such as Desulfovibrio aestuarii can exist in saturated NaCl solutions, although their activity is inhibited by bivalent cations, which are not prevalent in the ERDA No. 6 brine.

Stable Isotopes. Analysis of water samples for their ${ }^{18} \mathrm{O} /{ }^{16} \mathrm{O}$ and $\mathrm{D} / \mathrm{H}$ ratios has been found to be a useful method of identifying the source of water molecules, and to some degree identifying the types of interactions the water has undergone in the presence of other phases.

Figure 7.12 is a $\delta \mathrm{D}$ versus $\delta{ }^{18} \mathrm{O}$ plot for Delaware Basin groundwaters. Most of the earth's meteoric waters have isotopic compositions which fall between the lines described by the equations: 
$\delta D=8 \quad \delta^{18} 0+5$ (Epstein et al. , 1965; 1970)

and

$$
\delta D=8 \delta^{18} 0+10 \text { (Craig, 1961a) }
$$

These lines are included in Figure 7.12 , and the area between them is labelled "Meteoric Field."

Most of the points in Figure 7.12 lie in or near the meteoric field. Except for Carlsbad Caverns, a $\delta{ }^{18} \mathrm{O}$ value of $-7 \%$ and $\mathrm{a} \delta \mathrm{D}$ value of -50 , so appears to be a good approximation to local meteoric water in the Delaware Basin. The Caverns are part of the hydrologic system independent of the rest of the Capitan. Their enrichment in $D$ and ${ }^{18} \mathrm{O}$ reflects the water's origin from air mass conditions different from those which produce other Basin rains.

Bracketing the cluster of meteoric points are two dashed lines whose intervening field is labelled "evaporation." This field is the trajectory of isotopic compositions that the meteoric waters would follow during evaporation. The trajectory slope is 5, according to craig et al. (1963). The few points that lie in or near the evaporation field (4 Rustler and I Castile) may indeed have suffered partial evaporation prior to infiltration, but definitely originated as metoric water.

The dashed line through the origin, also of slope 5, is the trajectory of isotopic compositions of evaporating sea water. This line is also valid for the evaporation of warm-climate coastal meteoric waters $1 \delta{ }^{18} \mathrm{O} \approx-2 \%, \delta \mathrm{D} \approx-10 \% \mathrm{o}$, as indicated by the intersection of this line with the meteoric field. Such waters were postulated by Holser $(1963 ; 1966)$ to have been potential contributors to the Delaware Basin. The figure shows that the waters of positive $\delta^{18} \mathrm{o}$ values are not the products of partial evaporation either of Delaware Basin water or of modern meteoric water. This conclusion is the same as that drawn from the $\mathrm{Cl} / \mathrm{Br}$ ratios. 
The environments in which the Salado, Morrow and Delaware (Bell Canyon) waters were found involved a rock/water ratio that was very large, as deduced from the low productivity of these reservoirs. Consequently, any interaction involving isotopic exchange between these waters and host rocks would tend to alter the isotopic composition of the water toward $\delta \mathrm{D}$ and $\delta^{18} \mathrm{O}$ values consistent with equilibrium isotopic fractionation between water and minerals in the rock. Calcite in the Bell Canyon Sandstone had a $\delta{ }^{18} 0$ value of $+25.1^{\prime \prime}$ a a value only slightly less than typical marine carbonate. This implies only minor isotopic alteration of easily exchanged carbonate oxygen in the rock through the action of water, and indicates lack of calcite-water isotopic equilibrium in the Bell Canyon. The oxygen and hydrogen in clay minerals are known to be readily exchangeable with water 10 'Neil and Kharaka, 1976). The Delaware, Morrow and Salado waters have isotopic compositions that are suggestive of at least partial isotopic exchange between local meteoric waters and clay minerals in the sediments, in which the mineral/water ratio was very large (cf. Savin and Epstein, 1970) for at least several thousand years. Other mineral sources of exchangeable oxygen and hydrogen are fluid inclusions, whose stable isotopes have yet to be studied, and the water of crystallization of many evaporite minerals. The potash seep waters may have interacted with hydrous minerals. However, gypsum-water is the only such mineral-water system for which the ${ }^{18} \mathrm{O} /{ }^{16} \mathrm{O}$ and $\mathrm{D} / \mathrm{H}$ fractionation factors are known.

None of the waters have resulted directly from the dehydration of gypsum to form anhydrite. If ERDA No. 6 were such a water, the point marked "G" in Figure 7.12 would be the isotopic composition of the water from which that gypsum precipitated (using the gypsum-water fractionation factors of Fontes and Gonfiantini, 1967). "G" is not consistent with evaporating Delaware Basin water, whose anticipated $\delta \mathrm{D}-\delta^{18} \mathrm{O}$ trajectory was discussed above. The isotopic composition of ERDA No. 6 brine is consistent with an approach to isotopic equilibrium between water and clay minerals, not necessarily in the castile. Its isotopic exchange, together with its history of cation exchange, has resulted in a brine whose history appears to be similar to that of oil field brines of Alberta and the Gulf Coast (cf. Clayton et al., 1966). 


\subsubsection{Summary}

Many types of rock/fluid interactions are evident in the geochemistry of groundwaters found in the Delaware Basin. It is not possible to completely characterize these interactions from solutes or stable isotopes alone, nor through a study of water alone without a similar study of rock. In addition to fresh and brackish waters, which have acquired solutes from their host rocks, the brines have here illustrated three examples of various types of rock/fluid interactions:

1. dissolution of evaporites (saline Capitan waters).

2. dissolution of evaporites with isotopic exchange between fluid and rock (Salado potash seeps).

3. dissolution of evaporites, isotopic exchange, and cationic exchange (Delaware, Morrow and ERDA No. 6 waters).

The latter two types indicate more profound interaction than the first, since these involve changes in the water molecules themselves.

No original Permian waters could be identified. If much of the evaporite section has been recrystallized, as Holser (1963) suggests, not even the fluid inclusions are expected to preserve such waters.

\subsection{RUBIDIUM-STRONTIUM SYSTEMATICS OF THE SALADO FORMATION, SOUTHEASTERN NEW MEXICO}

\subsubsection{Introduction}

One of the important reasons for studying bedded salt deposits for a radioactive waste repository is to determine their intrinsic geological stability and to understand the behavior of alkali and alkaline earths in such a system assuming leakage of isotopes such as ${ }^{90} \mathrm{Sr}$ and ${ }^{137} \mathrm{Cs}$. 
If it can be demonstrated that such isotopes are likely to be retained at or very near the possible leakage area, then the potential danger of such leakage is minimized. Alternately, if it is found that there has been widespread migration of alkali and alkaline earth elements in the prospective storage sites, then these sites may be unfavorable for retention of ${ }^{90} \mathrm{Sr},{ }^{137} \mathrm{Cs}$, etc. assuming leakage occurs. Furthermore, if the latest episode of diagenetic evaporite recrystallization can be dated, arguments can be made for the geochemical requilibration of the evaporite assemblage into a thermodynamically stable configuration, reducing the liklihood of such events in the future.

To address this problem the WIPP study area and nearby sites were chosen for investigation, utilizing the well-established Rb-Sr geochronologic method of age determinations. This method is especially well suited for addressing alkali and alkaline earth retention and/or migration because of the species involved and its simplicity. Because of geochemical similarities (ionic radii, ionization potential, charge) $\mathrm{Rb}$ can be used as an analogue for $\mathrm{Cs}$, and ${ }^{90} \mathrm{Sr}$ will behave as any other $\mathrm{Sr}$ isotope. Hence the Rb-Sr ages will allow, in theory, meaningful interpretation of the stability of the Salado Formation in terms of $\mathrm{Rb}$ and $\mathrm{Sr}$ retention and/or migration.

The basic age equation is:

$$
T=\frac{\left({ }^{87} \mathrm{Sr} /{ }^{86} \mathrm{Sr}\right)_{\mathrm{m}}-\left({ }^{87} \mathrm{Sr} /{ }^{86} \mathrm{Sr}\right)_{\mathrm{o}}}{\left({ }^{87} \mathrm{Rb} /{ }^{86} \mathrm{Sr}\right)_{\mathrm{m}}(\lambda)}
$$

where:

$$
\begin{aligned}
& \mathrm{T}=\text { age in years } \\
& \left({ }^{87} \mathrm{Sr} /{ }^{86} \mathrm{Sr}\right)_{\mathrm{m}}=\text { measured isotopic ratio normalized to } \\
& \left({ }^{86} \mathrm{Sr} /{ }^{88} \mathrm{Sr}\right)=0.1194 \text { (the average } \\
& \text { abundance ratio in the earth) } \\
& \left({ }^{87} \mathrm{Sr} /{ }^{86} \mathrm{Sr}\right)_{\circ}=\begin{array}{c}
\text { initial isotopic ratio before } \\
87 \mathrm{Rb}(\beta-)^{87} \mathrm{Sr} \text { radiogenic decay } \\
\left(\mathrm{R}_{\mathrm{O}}\right) \text { occurs. }
\end{array}
\end{aligned}
$$




$$
\begin{aligned}
& \left({ }^{87} \mathrm{Rb} /{ }^{86} \mathrm{Sr}\right)_{\mathrm{m}}=\text { measured isotopic ratio } \\
& \\
& \quad \begin{aligned}
(\mathrm{calculated} \text { from } \mathrm{Rb} / \mathrm{Sr} \text { ratio) } \\
\quad=\text { decay constant for }{ }^{87} \mathrm{Rb} \\
=1.42 \times 10^{-11} / \mathrm{y} .
\end{aligned}
\end{aligned}
$$

The $\left({ }^{87} \mathrm{Sr} /{ }^{86} \mathrm{Sr}\right)_{\mathrm{m}}$ term is the sum of

$$
\left.\left({ }^{\star 87}+87 \mathrm{~N}\right)_{\mathrm{Sr}}\right)^{86} \mathrm{Sr}
$$

where $\star 87$ and ${ }^{87} \mathrm{~N}$ refer to radiogenic and normal mass 87 respectively.

The initial ratio $\left({ }^{87} \mathrm{Sr} /{ }^{86} \mathrm{Sr}\right)$ can either be assumed, determined by measurements on $\mathrm{Rb}-\mathrm{free}$ phases formed at $\mathrm{T}=0$, or determined by extrapolation from an isochron (i.e. line of slope $e^{T} \lambda-1$ along which all samples of the same age and initial ratio but with different $\mathrm{Rb} / \mathrm{Sr}$ ratios will fall; see Faure and Powell, 1972). The last of these choices is considered the most reliable due to natural variations of the initial ratios in nature, even from supposedly uniform, Rb-free, reservoirs.

\subsubsection{Previous Work}

$\mathrm{K}$-Ar dating of evaporites has been shown by numerous investigators to be extremely risky (see discussion in Faure, 1977) due to loss of radiogenic ${ }^{40} \mathrm{Ar}$ by diffusion and other processes. Some $\mathrm{K}-\mathrm{Ar}$ ages have been attempted for salts from the WIPP study area at Los Medanos (Shell Dev. Co.; 1973). For sylvites, minimum dates from $18 \pm 8$ to $74 \pm 8 \mathrm{~m} \cdot \mathrm{y}$. were obtained while two langbeinite-sylvite mixtures yielded nearly identical dates of $137 \pm 8$ and $147 \pm 8 \mathrm{~m} \cdot \mathrm{y}$. Only one very pure langbeinite (188K) yielded a date of $245 \pm 10 \mathrm{~m} \cdot \mathrm{y} \cdot ;$ this date is in excellent agreement with the 225-240 m.y. age range assigned to the Late Permian evaporites of the Castile and Salado formations.

The only other officially reported work is that by E. L. Tremba (1973; unpub. Ph.D. dissertation) in which he reports widely scattered data for evaporites from the Los Medanos area. Tremba's (1973) work was not directed toward problems of local alkali or alkaline earth migration, however, and composite samples were commonly taken which would, in 
effect, mask any such local effects. He reports two model $\mathrm{Rb}-\mathrm{Sr}$ dates of $241 \pm 23 \mathrm{~m} \cdot \mathrm{y} \cdot$ and $208 \pm 8 \mathrm{~m} \cdot \mathrm{y}$. respectively for (1) a $\mathrm{K}$-ore zone from the Saunders Mine and (2) two separate aliquots of a water-soluble k-ore. An initial ratio of 0.7077 was used in both cases. For water soluble samples from mine faces within the Saunders Mine, Tremba reports a $129 \pm 5 \mathrm{~m} \cdot \mathrm{y}$. isochron but, without adequate justification, one point (\#3SS) is omitted from the isochron calculation. As a model age for this one point yields an apparent model date of $330 \mathrm{~m} \cdot \mathrm{y} \cdot\left(\mathrm{R}_{\mathrm{o}}=0.708\right)$, then the significance of the $129 \pm 8 \mathrm{~m} \cdot \mathrm{y}$. date, based on only 4 of 5 samples, is difficult to interpret.

Similarly, five samples from Tremba's core 184, first ore zone, yield an apparent isochron date of $120 \pm 28 \mathrm{~m} \cdot \mathrm{y}$. but with an extremely high initial ratio of $0.7226 \pm 0.0092$. The argument is made that the two 120 to $129 \mathrm{~m} \cdot \mathrm{y}$. isochrons can be explained by some type of cretaceous "rehomogenization event". This interpretation can be criticized because 27 low-K samples from core 184 yield a mean $\left({ }^{87} \mathrm{Sr} /{ }^{86} \mathrm{Sr}\right)_{\mathrm{m}}=0.7077 \pm$ 0.0001 ; and any hypothesized rehomogenization event must explain how selective parts of the core can be affected whereas others are not. For example, Tremba argues that recrystallization involving polyhalite may have taken place at approximately $120 \mathrm{~m} . \mathrm{y}$. ago at which time the initial ratio was increased by rehomogenization to above 0.72 ; yet the data in Table 7.24 yield at least one sample (ERDA-9, 1759.1-1759.8) with ${ }^{87} \mathrm{Sr} /{ }^{86} \mathrm{Sr}_{\mathrm{m}}=0.7064$. Furthermore, if one uses the individual points for Tremba's $129 \mathrm{~m} \cdot \mathrm{y}$. isochron and assumes an initial ratio of 0.7077 (based on his data), a range in model dates results from about 185 $\mathrm{m} \cdot \mathrm{y}$. to $100 \mathrm{~m} \cdot \mathrm{y}$. (not counting sample EV-13 with a very low ${ }^{87} \mathrm{Rb} /{ }^{86} \mathrm{Sr}$ ratio). The reason for this apparent scatter is unanswered by Tremba's work.

\subsubsection{Analytical Procedure}

Sample preparation. Samples studied thus far have been core segments from WIPP exploratory holes. The core segments were about four inches in diameter and ranged in length from 4 to 12 inches. These samples first 
were trimmed by air saw to remove all outer surfaces that may have contacted drilling brines or been otherwise contaminated. Only the remaining prism of rock was retained for analysis; the outer portions were stored for possible use in the future.

Enough of the remaining inner portions were ground to -100 mesh to produce approximately $200 \mathrm{~g}$ of rock powder. About $30 \mathrm{~g}$ of this powder was quartered out and saved for whole rock analysis.

Separation of Water-Insoluble From Water-Soluble Material. The concentration of water-insoluble residue in a sample was determined during the separation of the soluble from the insoluble material. Approximately $60 \mathrm{~g}$ of powdered sample, weighed to the nearest $0.01 \mathrm{~g}$, was placed in a $250 \mathrm{ml}$ glass centrifuge tube together with about $175 \mathrm{ml}$ of distilled and deionized $\mathrm{H}_{2} \mathrm{O}$. The bottle was then capped and the mixture shaken vigorously for about 3 minutes, centrifuged for 15 minutes and decanted into $S$ and $S 576$ filter paper. This procedure was repeated with $175 \mathrm{ml}$ of $\mathrm{H}_{2} \mathrm{O}$ followed by a third leaching of $150 \mathrm{ml}$ of $\mathrm{H}_{2} \mathrm{O}$.

The resulting solution was transferred into a Pyrex $600 \mathrm{ml}$ beaker, which was placed on a $150^{\circ} \mathrm{C}$ hotplate until no more liquid remained. The salt residue was then quantitatively removed from the beaker, weighed, and stored for analysis.

Separation of the $<2$ Micron Fraction. The $<2$ micron fraction was separated from the insoluble residue remaining from the above procedure. The insoluble residue was repeatedly washed and centrifuged until a disperson of the clay-sized material was obtained. The washed slurry was then put into $1000 \mathrm{ml}$ cylinders for gravity settling. The length of time necessary for settling was calculated from the equation noted by Folk (1968). Fractions finer than 2 microns were siphoned off after the proper length of time had passed. A portion of the $<2$ micron fraction was used for oriented slides (for x-ray diffraction analysis); the remainder was dried, ground to -100 mesh and used for $\mathrm{Rb}-\mathrm{Sr}$ isotopic and other geochemical analyses. 
X-ray Diffraction Analysis of Clay and Evaporite Minerals. Thus far, identification of clay minerals has been based solely on $x$-ray diffractograms, obtained from a Norelco wide range diffractometer. Untreated oriented powders were scanned from 2 to 60 degrees two theta. The untreated slide was glycolated by vapor-soaking on a rack in a container filled partially with ethylene glycol. An additional oriented powder was heated to $450^{\circ} \mathrm{C}$. Both the glycolated and the heated specimens were scanned from 2 to 30 degrees two theta.

Whole rock samples were analyzed by loading a small amount of randomly oriented rock powder in a Norelco powder holder. This powder was scanned from 5 to 80 degrees two theta and the resulting diffractogram compared to values compiled in the Joint Committee on Powder Diffraction Standards file to determine bulk mineralogic composition. Mineralogic abundances noted were estimates based on comparative peak intensities. All samples $x$-rayed (both clays and whole rocks) were scanned with Ni-filtered CuK radiation. A time constant of two seconds was used with a scintillation counter detector and pulse height analyzer. The goniometer slit system consisted of a divergent and anti-scatter slit of 1 degree and a 0.003 inch receiving slit.

Rb-Sr Isotopic Analysis. Procedures for the dissolution of samples for $\mathrm{Rb}-\mathrm{Sr}$ isotopic analyses varied dependent on the samples mineralogic composition. All samples were first weighed accurately and placed into a $100 \mathrm{ml}$ teflon evaporating dish; the amount of sample to be dissolved was determined to ensure at least $10 \mathrm{mg} \mathrm{Sr}$ and $\mathrm{Rb}$ would be in solution. The sample was then spiked with ${ }^{84} \mathrm{Sr}$ and ${ }^{87} \mathrm{Rb}$ solutions. Samples which contained silicate minerals were dissolved with $30 \mathrm{ml}$ reagent grade HF and $3 \mathrm{ml}$ vycor distilled $\mathrm{HClO}_{4}$ on a hot plate. Samples containing only water soluble material were dissolved with $50 \mathrm{ml}$ of distilled and deionized $\mathrm{H}_{2} \mathrm{O}$ and $10 \mathrm{ml}$ of vycor distilled $6 \mathrm{~N} \mathrm{HCl}$. Samples containing large amounts of sulfate minerals were first dissolved in aqua regia and then treated with $\mathrm{HF}$ and $\mathrm{HClO}_{4}$.

After complete dissolution of the powder and evaporation of all HF and $\mathrm{HClO}_{4}$, the samples were digested with $25 \mathrm{ml}$ of $\mathrm{H}_{2} \mathrm{O}$ and $25 \mathrm{ml}$ of $\mathrm{HCl}$. 
The mixture was then reduced to about $5 \mathrm{ml}$ by slow evaporation and allowed to cool overnight. After cooling the solution was filtered through $S$ and $S \# 576$ filter paper and loaded onto the top of a chromatography column charged with sulfonated polystyrene, a chromatographic grade cation exchange resin.

The column was washed with $2 \mathrm{~N} \mathrm{HCl}$ repeatedly while the effluent was flame tested for cationic composition. $\mathrm{Rb}$ and $\mathrm{Sr}$ fractions were collected at the appropriate intervals indicated by the flame test. The collected fractions were subsequently dried, redissolved and transferred to precleaned quartz microvials. The microvials, containing the samples, were fused, cooled and stored for mass spectrometric analysis.

$\mathrm{All} \mathrm{Rb}$ and $\mathrm{Sr}$ concentrations were determined by standard isotope dilution techniques. All $\mathrm{Rb}$ and $\mathrm{Sr}$ isotopic ratios were measured using a 23 inch, 90 degree sector, solid source, single filament Nuclide mass spectrometer equipped with an electrometer and strip-chart recorder.

\section{8 .4 Results}

Samples for the present study were provided from Sandia Laboratories drill cores AEC-8, ERDA--6, and ERDA 9 drill cores. Samples were studied for their Rb-Sr systematics by mass spectrometer and (Table 7.24, 7.25), mineralogy by $x$-ray diffraction (Table 7.26). Additional geochemical studies are planned (i.e., rare earth elements, by instrumental neutron activation analysis).

Samples have been divided into whole rocks, water soluble portions, and the minus-two micron fractions. This approach varies significantly from Tremba's (1973) approach in that he worked with water soluble and total water insoluble fractions; the latter were not treated for separation of authigenic from allogenic fraction. This will be discussed later.

Whole rocks may yield uncertain results due to the unknown nature of water insoluble fractions within them. Similarly, the water soluble fractions are meaningful only if the nature of the water insoluble 
fraction is studied. This last point can best be addressed by detailed study of the clay-size (minus-two micron), authigenic minerals common to evaporites.

(1) Whole rocks: the water insoluble content of whole rocks varies from less than $I$ percent to 32 percent, with a mean of 6.5 percent if sample Dv-4D (clay rich) is omitted. The basic mineralogy of these samples is a halite rich assemblage with some samples $r i c h$ in sylvite and/or polyhalite as well. Langbeinite-rich samples are rare. The Rb-Sr isochron for eleven samples is shown in Figure 7.13. The date of $132 \mathrm{~m} . \mathrm{y}$. must be considered very approximate as nine of the eleven samples plot essentially on the ordinate. Of these last eleven, nine are used to yield a reasonable estimate of initial ratio $=0.7081 \pm 0.0005$ (in agreement with Tremba's 1973 value of 0.7077 ).

(2) Water soluble samples: in working with water soluble samples the assumption is made that ions released into solution will not be absorbed onto the surface of the insoluble material. This is probably true only if the insoluble material consists of allogenic quartz, feldspars, etc. but not clay minerals. An isochron for five water soluble samples yields an apparent date of $206 \mathrm{~m} . \mathrm{y}$. with $\mathrm{R}_{0}=0.7084$ (Figure 7.14). While this date is not unreasonable for the Permian-Triassic boundary, it is slightly low.

(3)

Minus-two micron fraction: the authigenic clay minerals which one might predict for an evaporite sequence are present in this fraction (Table 7.26). Of interest is that this material is (a) authigenic as demonstrated by the $x$-ray diffraction work and (b) is also the dominant part of the water insoluble fraction. Thus the apparent 


\begin{abstract}
isochron date (Figure 7.15) of $325 \mathrm{~m} . \mathrm{y}$. needs
explanation. If one remembers that many of the clay partings in the potash mines are interpreted as being of aeolian origin, then it is very likely that such aeolian clay minerals will, in part, reflect their provenance. This has been noted before by Hurley et al. (1962) for minus-two micron clay minerals from the Bermuda Rise. Of interest here is that our $325 \mathrm{~m} . \mathrm{y} \cdot$ - date (Figure 7.15) is virtually identical with Tremba's (1973) 331 m.y. date for total water-soluble material.
\end{abstract}

\title{
7.8.5 Discussion
}

There are several ways to treat the data gathered so far. First a composite of whole rocks, water soluble and minus-two micron size clay minerals yields an isochron date (Figure 7.16) of $165 \pm 20 \mathrm{~m} . \mathrm{y}$. with $\mathrm{R}_{\mathrm{O}}$ $=0.7115$. This date must be interpreted as a minimum due to the fact that the best estimate of $R_{o}$ is $0.7081 \pm 0.0004$ according to the data presented in Table 7.24 .

It is also apparent that the whole rocks by themselves are, in general, too halite-rich and possess $\mathrm{Rb} / \mathrm{Sr}$ ratios which are too low for isochron work. When to this is added the uncertainty introduced by the insoluble material mixed with possible pre-T ${ }_{S}$ (i.e. time of sedimentation) material smaller than two microns, plus some detrital feldspar, quartz, etc., then the whole rocks can be assumed to be unsuitable for the isochron work.

If the clay minerals in the minus-two micron fraction are aeolian, pre-T $\mathbf{T}_{\mathbf{S}}$ material may account for the pre-permian date of $325 \mathrm{~m} \cdot \mathrm{y}$. (Figure 7.15). Similarly, since the clay mineralogy (Table 7.26) is very typical of evaporite clay minerals, then an alternate explanation is that these clay minerals have acted as local sinks for some ${ }^{* 87} \mathrm{Sr}$ presumably remobilized during and after lithification and diagenesis. A lower age limit for this event is set by the $206 \mathrm{~m} . \mathrm{y}$. date from the water soluble fraction. 
When only the water soluble and minus-two micron clay mineral fractions are considered together, a $204 \mathrm{~m} \cdot \mathrm{y}$ isochron (Figure 7.17) results with $R_{0}=0.7137$. This date is only somewhat lower than the Permian-Triassic boundary and can safely be interpreted as a minimum due to the high initial ratio (0.7137). This interpretation assumes, however, that the clay minerals equilibrated with the evaporite medium (i.e. salts plus brine plus remnant sea water) at the time of sedimentation and this point remains to be unequivocally demonstrated.

Many of the above mentioned uncertainties will almost certainly be resolved by additional samples now in various stages of analysis for Rb-Sr systematics plus additional samples not yet treated. Furthermore, scanning electron microscope studies are planned to help resolve the problems of aeolian versus non-aeolian authigenesis hypotheses regarding clay mineral occurrences. Finally, rare earth element (REE) data, when complete, will greatly enhance understanding of the evaporite-insoluble material systematics of the Los Medanos area.

\subsubsection{Concluding Statements}

These data are of importance to he WIPP in the Los Medanos area because: (1) Widespread recent rehomogenization of radiogenic ${ }^{87} \mathrm{Sr}$ would be obvious if consistently high ${ }^{87} \mathrm{Sr} /{ }^{86} \mathrm{Sr}$ ratios were determined either from Rb-poor phases or by extrapolation from all samples with high Rb/Sr to the ordinate (Figures 7.13-7.17). This is not the case, and in fact values for whole rocks yield a mean of 0.7081 , and several isochrons yield extrapolated values from approximately 0.709 to 0.713 . The entire set of data argues against large amounts of radiogenic ${ }^{87} \mathrm{Sr}$-enriched brine, having been formed post $-200 \mathrm{~m} . \mathrm{y}$. ago, subsequently leaving its imprint in the recrystallized minerals. (2) the Rb-Sr isochron based on water soluble fractions and clay minerals, Figure 7.17 yields a date of $204 \mathrm{~m} . \mathrm{y}$. This date, in view of $R_{0}=0.7137$ (i.e. higher than 0.7084), must be interpreted as a minimum date pending further analyses. (3) The clay minerals (Table 7.26) are of special interest in that they are typical of evaporite clay minerals formed during evaporite diagenesis, 
yet they have been interpreted as aeolian. If they are aeolian, then some mixture of kaolinite-montmorillonite-illite would be expected rather than the saponite-chlor ite-montmorillonite-serpentine-talc-illite assemblage noted. Since the clay minerals yield (Figure 7.15) a pre-sedimentation apparent date of $325 \mathrm{~m} . \mathrm{y}$. with high $\mathrm{R}_{\mathrm{o}}(0.7123)$, then it is possible that these clays acted as local sinks for radiogenic ${ }^{87} \mathrm{Sr}$ (and Rb?) released during early diagenesis from roughly $235 \mathrm{~m} \cdot \mathrm{y}$ to $204 \mathrm{~m} . \mathrm{y} \cdot$; such an interpretation is consistent with the data obtained to date. Tremba (1973) has argued for some mid-Cretaceous "rehomogenization event" at about $120 \mathrm{~m} \cdot \mathrm{y}$. ago but inspection of his data coupled with these data do not support such an hypothesis. (4) REE are especially sensitive as geochemical tracers and forthcoming data, coupled with continued $\mathrm{Rb}-\mathrm{Sr}$ and other work, should permit resolution of some of the problems concerning alkali and alkaline earth retention/migration in the geologic past at the Los Medanos site.

\subsection{URANIUM ISOTOPE DISEQUILIBRIUM IN GROUNDWATERS OF SOUTHEASTERN NEW MEXICO AND IMPLICATIONS REGARDING AGE-DATING OF WATERS}

\subsubsection{Introduction}

History. Regional exploration of bedded salt deposits for a radioactive waste repository in the Delaware Basin (Permian, New Mexico) included boreholes into the evaporites and associated rocks. These rocks contained various amounts of fluids, already described (Lambert, 1978). Although the halite deposits of the Ochoan Epoch are the prime target of consideration for waste storage, the older rocks of the Guadalupian Epoch are included in the present study, because of the Capitan reef, a body of cavernous limestone which encircles the Basin. The Capitan not only is the dominant rock in the Carlsbad Caverns, but also supplies potable water to the city of Carlsbad. Therefore, it is appropriate to consider possible connections between the Capitan and accumulations of water found in pockets in the evaporites. Brine and gas pockets are known to occur in the Carlsbad district potash mines and in the Castile Formation (anhydrite and halite) underlying the Salado Formation. 
One exploration hole, ERDA No. 6, drew national attention (Boffey, 1975), when it encountered an accumulation of saturated $\mathrm{NaCl}$ brine laced with $\mathrm{Na}_{2} \mathrm{SO}_{4}$, accompanied by $\mathrm{H}_{2} \mathrm{~S}-\mathrm{rich}$ gas at $826 \mathrm{~m}$ below the surface. Discovery of this artesian fluid, together with bedding-plane dips in the host Castile Formation exceeding $70^{\circ}$, led to abandonment of that particular site. Geophysical investigations showed that this and other occurrences of brine and gas were associated with closed structure contours drawn for the Castile formation. These structures, restricted to a narrow strip of evaporites near the reef have been termed "salt anticlines" (Anderson and Powers, 1978). Core from the fluid-producing zone of ERDA No. 6 consisted of gray laminated anhydrite whose fractures were filled with massive crystalline white anhydrite (Plate 7.52). While isolated fluid accumulations are not rare in evaporites, the possible use of the region for radioactive waste disposal requires attention to the origin of this particular type of accumulation. In the extreme cases, the fluid originates directly from water from the capitan Reef, or the water was entrapped in the Castile Formation at the time for evaporite deposition in the Permian. In the first case, the water would have an age little older than Capitan waters. In the second case, the water would be in excess of 230 million years old.

Implications. Indeed, the very presence of the ERDA No. 6 accumulation of fluid poses several questions:

1. How long has the water been confined in the pocket?

2. Does the time of the water's intrusion correspond to any significant known geologic events?

3. What is the source of the water?

4. How long has this pocket been disconnected from nearby aquifers such as the Capitan Reef, if it ever was connected?

5. What are the limits to rates of influx (if any) or recharge and discharge (if any) of this fluid pocket?

6. To what degree does the ERDA No. 6 occurrence (or any other in the area) represent a flowing system?

6. Which radiometric clock should be used to age-date the water and what should be taken as initial conditions for age-dating? 


\subsubsection{Analytical Approach}

General Geochemistry of Groundwaters. A number of groundwaters from the Delaware Basin have been characterized in terms of their general geochemistry with respect to their host rocks (Lambert, 1978). In terms of solutes, all waters from below the fresh-saline interface in the Capitan were similar to each other. In addition all shallow $(\leq 300 \mathrm{~m}$ depth) waters were similar to one another and all deep ( $\geq 1000 \mathrm{~m}$ depth) waters were similar to one another. The ERDA No. 6 water was unique in its solute content, indicative of profound disequilibrium between solution and host rock and also between solution and associated gas phase.

In terms of $\mathrm{D} / \mathrm{H}$ and ${ }^{18} \mathrm{O} /{ }^{16} \mathrm{O}$ ratios, Capitan and shallow waters all are similar and are of meteoric origin. (Carlsbad Caverns waters are also of meteoric origin, but are not related to other waters in the Capitan.) Deep water stable isotope ratios are similar to one another, and are not characteristically meteoric. ERDA No. 6 has uniquely non-meteoric isotopic ratios among those of Delaware Basin waters. No waters were found which represent original evaporite mother-liquor.

Experimental procedures. In spite of the evidence that this fluid has experienced profound interactions with rock (Lambert, 1978), radioisotopes were examined to establish that the ERDA No. 6 fluid was not of relatively recent origin. Plutonium concentration was determined by isotope dilution employing a spike of ${ }^{244} \mathrm{Pu}$. The actual measurement was made on a three-stage thermal emission solid source mass spectrometer equipped with pulse counting for ion detection. The instrument has a very high abundance sensitivity $\left(10^{7}\right)$ and low background, allowing for the determination of precise isotopic ratios on small samples amounting to 0.1 to 1 nanograms of plutonium. The plutonium concentration of the ERDA No. 6 brine was found to be less than $10^{-15}$ grams per gram, corresponding to the lower limit of analytical detectability. The absence of plutonium suggests the brine has been isolated at least since 1945, a date corresponding to the first atmospheric detonation of nuclear weapons. 
Carbon 14 was measured in the $\mathrm{CO}_{2}$, which amounted to $55 \%$ of the total gas collected from ERDA No. 6. Carbon 14 content was counted in a gas proportional detector whose efficiency was calibrated with the NBS oxalate standard. The result was the same as the background, which was about 2 counts per minute in a 1.5 liter detector at 2 atmospheres pressure. From this it was concluded either that the brine is older than about 30,000 years or possibly that carbonates in the host rock have diluted the carbon in the system with non-radioactive carbon.

The disequilibrium of the activity of ${ }^{234} \mathrm{U}$ relative to ${ }^{238} \mathrm{U}$ in natural waters has been attractive as an indicator of the age of groundwaters (Osmond and Cowart, 1976). ${ }^{234} \mathrm{U}$ and ${ }^{238} \mathrm{U}$ are related by the decay scheme:

$$
238 \mathrm{Q} \frac{\alpha}{4.5 \times 10^{9} \mathrm{a}}{ }_{90}^{234} \operatorname{Th} \frac{\beta^{-}{ }_{91}^{34}}{24 \mathrm{~d}} \mathrm{~Pa} \frac{\beta}{1 \min }{ }_{92}^{234} \mathrm{U}
$$

It has been proposed that excess ${ }^{234} \mathrm{U}$ builds up in confined waters as an aging effect as a result of the alpha-recoil of ${ }^{234} \mathrm{Th}$, which ejects ${ }^{234} \mathrm{Th}$ out of the host rock crystal lattice into the water (Kigoshi, 1971; Kronfeld et al., 1975). From a knowledge of decay constants and initial activity ratio $\alpha_{0} \quad\left(\alpha=\lambda_{234} \mathrm{~N}_{234} / \lambda_{238} \mathrm{~N}_{238}\right)$, the time of confinement is calculated. It cannot be assumed, however, that the earth's natural abundance ratio, $\alpha=1.00$, is a priori valid for a confined rock-water system. The water carried in with it an initial uranium concentration and original activity ratio, $\alpha_{0}$. The water ultimately comes to thermodynamic equilibrium with its host rock and may leach or even deposit ${ }^{234} \mathrm{U}$ and ${ }^{234} \mathrm{Th}$. Uranium concentrations and $\alpha$ -ratios of rocks and waters in this study were determined by isotope dilution mass spectrometry, described above. Figure 7.18 shows the locations of principal water samples of this study. Table 7.27 shows uranium conentrations and values of $\alpha$ for various waters. 


\subsubsection{Results and Discussion}

The overleaf of plate 7.52 shows the variations of $U$ content and $\alpha$ in anhydrite of rock core taken from the zone which produced fluid in ERDA No. 6 (826 m, $2709 \mathrm{ft}$ depth). Table 7.27 shows that in ERDA No. 6, both $U$ concentration and $\alpha$ vary with time, until $U$ concentration falls asymptotically to about 2 parts in $10^{\circ}$, and $\alpha$ rises asymptotically to about 1.35. In the early part of a several-hour flow test, water samples were found to be contaminated with drill mud and spallations from metal pipe. By 1400 hours not only had the uranium reached steady state values, but the iron concentration had fallen from 260 parts in $10^{6}$ ( 1130 hours) to a steady value of 5 parts in $10^{6}$ (1400 hours), indicating the flushing out of drilling-introduced contaminants. Thus, the later samples are probably representative of the fluid accumulation.

The total variation in $\alpha$ among all water samples is relatively small (1.2 to 5.2). In contrast, absolute uranium content in the waters of Table 7.27 varies by more than two orders of magnitude. Similarly, rock material illustrated in Plate 7.52 shows a wide variation in $U$ content: 1 to 2 parts in $10^{6}$ for "original" laminated gray anhydrite down to 20 to 30 parts in $10^{9}$ in the secondary white anhydrite fracture filling only a few centimeters away.

\subsubsection{Applicaton of the Uranium Isotope Disequilibrium Model}

If $\mathrm{N}_{2}$ is the amount of ${ }^{234} \mathrm{U}$ present in a phase, and $\mathrm{N}_{I}$ is the amount of ${ }^{238} \mathrm{U}$, the change in ${ }^{234} \mathrm{U}$ content with time in the brine is

$$
\left(\frac{d N_{2}}{d t}\right) \text { brine }=\lambda_{1} N_{1}-\lambda_{2} N_{2}+Q_{1}+Q_{2},
$$

in which $Q_{1}$ is the rate of release of ${ }^{234} \mathrm{Th}$ (the parent of ${ }^{234} \mathrm{U}$ ) from the rock, $Q_{2}$ is the rate of release of ${ }^{234} \mathrm{U}$ from the rock and $\lambda_{1}$ and $\lambda_{2}$ are decay constants for ${ }^{238} \mathrm{U}$ and ${ }^{234} \mathrm{U}$, respectively. 
Release rates $Q_{1}$ and $Q_{2}$ can be modeled in the fashion of Kigoshi (1971), who studied the release of ${ }^{234}$ Th from zircon powder. He gave the accumulated activity of ${ }^{234} \mathrm{Th}$ in solution after time $t$ as

$$
\left(\lambda_{\mathrm{Th}} \mathrm{N}_{\mathrm{Th}}\right)_{\text {brine }}=1 / 4 \mathrm{~L} \operatorname{Sp}\left(\mathrm{N}_{238} \lambda_{1}\right)_{\text {rock }}\left(1-\mathrm{e}^{\left.-\lambda_{\mathrm{Th}}{ }^{t}\right)}\right. \text {, }
$$

in which $\lambda_{\mathrm{Th}}$ is for ${ }^{234} \mathrm{Th}, \mathrm{L}$ is the recoil distance of ${ }^{234} \mathrm{Th}$ in decay scheme (I) above, $S$ is the surface area of parent rock, $\rho$ is its density, and $\mathrm{N}_{238}$ is expressed as the number of ${ }^{238} \mathrm{U}$ atoms per gram of rock. Thus, the activity of ${ }^{234} \mathrm{Th}$ in the brine is related to the activity of ${ }^{238} \mathrm{U}$ in the rock by a proportionality constant, and, of course, the time-dependent term. When $t>24$ days, (3) can be approximated as

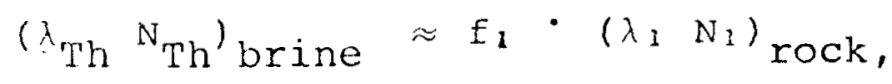

in which $f_{1}$ is now the leach fraction of ${ }^{234} \mathrm{Th}$, incorporating $1 / 4 \mathrm{~L} \mathrm{~S} \rho$ in (3). In general, ${ }^{238} \mathrm{U}$ activities in rock and coexisting brine will not be equal, but will be related by a distribution coefficient $r$, which is theoretically an equilibrium constant, neglecting the kinetics of dissolution and precipitation:

$\left(\begin{array}{ll}\lambda_{1} & N_{1}\end{array}\right)_{\text {rock }}=r\left(\lambda_{1} N_{1}\right)_{\text {brine }}$

In actual fact, the time required to achieve chemical equilibrium between rock and brine might be very long relative to the half-life of ${ }^{234} \mathrm{Th}$.

$Q_{1}$ now becomes

$Q_{1}=r \cdot f_{1} \cdot\left(\lambda_{1} N_{1}\right)_{\text {brine }}$

Similarly, the amount of ${ }^{234} \mathrm{U}$ released is dependent on the decay of its precursor ${ }^{238} \mathrm{U}$, and on the equilibrium ratio $r$, and on the leach fraction for ${ }^{234} \mathrm{U}, \mathrm{f}_{2}$ :

$\mathrm{Q}_{2}=r \cdot \mathrm{E}_{2} \cdot\left(\lambda_{1} \mathrm{~N}_{1}\right)_{\text {brine }}$ 
In addition, some fraction, $\mathrm{f}_{3}$, of the ${ }^{238} \mathrm{U}$ will be leached from the rock,

$\lambda_{1} \mathrm{~N}_{1}=\mathrm{r} \cdot \mathrm{f}_{3} \cdot\left(\lambda_{1} \mathrm{~N}_{1}\right)_{\text {brine }}+\left(\lambda_{1} \mathrm{~N}_{1}\right)_{\text {brine }}$

Now, equation (2) becomes:

$\left(\frac{d N_{2}}{d t}\right)_{\text {brine }}=\left(\lambda_{1} N_{1}\right)_{\text {brine }}\left[1+r\left(f_{1}+f_{2}+f_{3}\right)\right]-\lambda_{2} N_{2}$

If $f$ is defined as a composite leach fraction $\left(f_{1}+f_{2}+f_{3}\right)$, the solution to (9) is:

$N_{2}(t)=\frac{\lambda_{1}}{\lambda_{2}-\lambda_{1}}(I+f r) N_{1}(t)+N_{1}(t=0) \quad \frac{\lambda_{2} N_{2}(t=0)}{\lambda_{1} N_{1}(t=0)} \quad \frac{\lambda_{1}}{\lambda_{2}}(1+f r) \quad e^{-\lambda_{2} t}$

which allows us to express the solution in terms of $\alpha=\frac{\lambda_{2} N_{2}}{\lambda_{1} N_{1}}$ :

$\alpha_{\text {brine }}=\frac{\lambda_{2}}{\lambda_{2}-\lambda_{1}}(1+f r)+\left[\alpha_{0}-\frac{\lambda_{2}}{\lambda_{2}-\lambda_{1}}(1+f r)\right] e^{-\left(\lambda_{2}-\lambda_{1}\right) t}$

and since $\lambda_{2}>\lambda_{1}$

$\alpha_{\text {brine }} \approx 1+f r+\left[\alpha_{0}-1+f r\right] e^{-\lambda_{2} t} \approx \alpha_{b}$

The corresponding equation for the rock is:

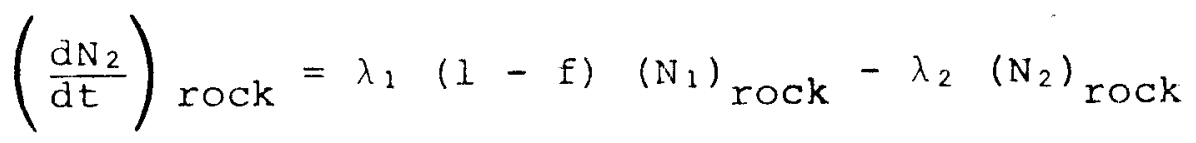

Since for a closed system, the ${ }^{234} \mathrm{U} /{ }^{238} \mathrm{U}$ equilibrium activity ratio is 1.000 , the solution to (13) is:

$$
\begin{aligned}
N_{2}(t)_{\text {rock }}=\frac{\lambda_{1}}{\lambda_{2}-\lambda_{1}} & (1-f) N_{1}(t) \text { rock }+\frac{\lambda_{1}}{\lambda_{2}} N_{1}(0)_{\text {rock }} e^{-\lambda_{2} t} \\
& -\frac{\lambda_{1}}{\lambda_{2}-\lambda_{1}} N_{1}(0)_{\text {rock }}(1-f) e^{-\lambda_{2} t}
\end{aligned}
$$


which in terms of $\alpha$ is

$$
\alpha_{\text {rock }}=\frac{\lambda_{2}}{\lambda_{2}-\lambda_{1}}(1-f)+e^{-\left(\lambda_{2}-\lambda_{1}\right) t}-\frac{\lambda_{2}}{\lambda_{2}-\lambda_{1}}(1-f) e^{-\left(\lambda_{2}-\lambda_{1}\right) t}
$$

The approximation $\lambda_{2}>>\lambda_{1}$ reduces the equation (15) to

$$
\alpha_{\text {rock }} \approx 1-f+f e^{-\lambda_{2} t} \approx \alpha_{r}
$$

Let us now assume that the geochemical conditions (i.e. U content and $\alpha$ ) observed in the ERDA No. 6 rock-fluid assemblage represent equilibrium conditions. This requires the mutual consistency of equations (12) and (16), and that

$$
f=\frac{\left(\alpha_{0}-1\right)\left(\alpha_{r}-1\right)}{\alpha_{b}-\alpha_{0}+r\left(\alpha_{r}-1\right)} .
$$

Anhydrite found in the veins is the most recently formed phase in the core, and using the $U$ values from 1709.4 white anhydrite $(U=33$ parts in $\left.10^{9}, \alpha=1.04\right)$; Plate 7.52 overleaf), and the averages of the last two ERDA No. 6 brines in Table 7.27, $\left(U=2.01\right.$ parts in $10^{9}, \alpha=$ 1.35) equation (17) gives rise to the plot in Figure 7.19. Note the prominent singularity at $\alpha_{0}=2.01$, and that $\alpha_{0} \leq 1.971$ at $\mathrm{E}=1$ (corresponding to $100 \%$ leaching, and $\alpha_{0} \geq 2.052$ at $f=-1$ (corresponding to all the uranium in the rock having precipitated from the brine).

Solving equation (12) for $t$, we obtain an expression for the age of the brine:

$$
t=\frac{\ln \left(\frac{\alpha_{b}-1-f r}{\alpha_{0}-1-f r}\right)}{-\lambda_{2}}
$$

For values of $\alpha_{0} \leq 1.971$, negative ages result. Only for values of $\alpha_{0} \geq 2.052$ are realistic ages obtained. This result implies that there has been minimal leaching from the rock. Furthermore, it suggests rather that precipitation of uranium has occured from brine to rock which is consistent with reducing conditions implied by the presence of $\mathrm{H}_{2} \mathrm{~S}$. 
Clearly, the amount of precipitation which has occurred (negative leaching) is related to the original $\alpha_{0}$ at the time of closure of the rock fluid system.

Values of $\alpha$ for nearby waters in the Capitan limestone (Table 7.27) which by proximity afford a possible source of water for the ERDA No. 6 brine pocket, are mostly in excess of 1.35. In addition, the ERDA No. 6 brine is not saturated in $\mathrm{CaSO}_{4}$ (Lambert, 1978), and is not likely to have been responsible for the precipitation of substantial amounts of vein anhydrite. Furthermore, the limited volume of the brine pocket (Griswold, 1977) could not realistically be expected to dissolve and reprecipitate anhydrite in veins to the extent observed in the core. Therefore, the $\alpha_{0}$ of the ERDA No. 6 brine must have been larger than 2.052, with very little interaction with the reservoir rock.

\subsubsection{Model Ages Based on No Leaching}

Values of $\alpha$ and $\alpha_{0}$ will in this model allow an age determination of a water to be made. The highest $\alpha$ value thus far determined is 14.2, the result of isotope dilution mass spectrometry performed on a sample from Israel supplied by $J$. Kronfeld, which gave an $\alpha$ value of $10.1 \pm 1.6$ by alpha-spectroscopy (Kronfeld et al., 1975). In addition, the occurrence of waters elsewhere in the Delaware Basin (Table 7.27 suggests that a reasonable $\alpha_{0}$ value might be 5.14 (in the Capitan limestone), the highest thus $f$ ar found in the Basin. If the ERDA No. 6 brine represents water escaped from the Capitan, and its $\alpha_{0}$ was on the order of 5 , Figure 7.19 shows that its interaction with the ERDA No.6 reservoir rock (fractured Castile anhydrite) precipitated less than 68 of the rock's uranium from the brine.

Neither total concentration nor isotopic composition of uranium in the ERDA No. 6 brine was inherited through interaction with the Capitan limestone, for the ERDA No. 6 brine contains substantially more uranium that the Capitan waters (Table 7.27) presently do. Likewise, uniformity in the stable isotope composition of Capitan waters (Lambert, 1978) shows 
that the peculiar stable isotope composition of ERDA No. 6 water cannot have arisen by interaction with the Capitan limestone. Composition of stable and unstable isotopes in ERDA No. 6 brine might have arisen from interaction between water and rocks encountered by the water if it moved from the Capitan to its ERDA No. 6 environment.

In its simplest form, equation (18), under conditions of no interaction between ERDA No. 6 brine and its reservoir rock, reduces to:

$$
t=\frac{\ln \left(\frac{\alpha_{b}-1}{\alpha_{0}-1}\right)}{-\lambda_{2}}
$$

which very nearly corresponds to the combination of the solutions to the equations $\frac{d N_{1}}{d t}=-\lambda_{1} N_{1}$

$$
\frac{d N_{2}}{d t}=-\lambda_{2} N_{2}+\lambda_{1} N_{1}
$$

for which

$$
t \approx \frac{\ln \left(\frac{\alpha_{b}-1}{\alpha_{0}-1}\right)}{-\lambda_{2}+\lambda_{1}}
$$

The above conclusions allow limits to be assigned to the age of confinement of the ERDA No. 6 brine, and also to ages of waters in the Capitan. Equation (20) differs from equation (19) only by the approximation that

$$
\frac{\lambda_{2}}{\lambda_{2}-\lambda_{1}} \approx 1,
$$

since $\lambda_{2}=2.806 \times 10^{-6} \mathrm{a}^{-1}$ for ${ }^{234} \mathrm{U}$ and $\lambda_{1}=1.537 \times 10^{-10} \mathrm{a}^{-1}$ for ${ }^{238} \mathrm{U}$.

Figure 7.20 shows the family of curves obtained from equation (20), using observed values of $\alpha$ from Table 7.29, and various values for $\alpha_{0}$. The model ages indicated on Figure 7.19 for the ERDA No. 6 brine are less 
than those in Figure 7.20 because 4 to 5 percent interaction between brine and rock (uranium precipitation) involves loss of uranium from solution by means other than radioactive decay. There is no evidence for any degree of chemical equilibrium between ERDA No. 6 rock and fluid. If we realistically limit $f$ (Figure 7.19) to have a value between -0.02 and -0.50 , the minimum age of the ERDA No. 6 occurrence is 570,000 years $\left(\alpha_{0}=6\right)$. In actual fact, as the data of Kronfeld et al. (1975) suggest, maximum $\alpha_{0}$ values are universally in the range 10 to 15 , and the age is between 800,000 and 1,000,000 years. According to the no-interaction model, (Figure 7.20), if water escaped from the Capitan $\left(\alpha_{0}=5.14\right)$ into the brine pocket, this must have occurred at least 880,000 years ago. The highest $\alpha_{0}$ value (14.2) confirmed by isotope dilution mass spectrometry gives an age of 1,300,000 years.

If the Carlsbad area (near the Pecos River) is a major recharge area for much of the Capitan reef, and if Carlsbad water $\left(\alpha_{0}=5.14\right)$ is the basis for age-dating other waters in the Capitan, ages between 300,000 and 1,100,000 years are obtained. The maximum $\alpha_{0}$ (14.2) would imply that Capitan waters are at least 400,000 years old.

\subsubsection{Implications and Conclusions}

A mathematical model based upon analytical data has showed that the ERDA No. 6 occurrence of brine can be age-dated by the uranium-disequilibrium method. Combinations of leach fractions and ages were derived, and the interaction between rock and fluid was indicated to be minimal. If the brine pocket was once connected to the Capitan Reef, the most productive aquifer in the region, such connection was severed at least 500,000 years ago, and probably more than 900,000 years ago. The brine pocket has been stagnant ever since, and there is little evidence to indicate that chemical equilibrium has been established among the solid, liquid and gaseous phases involved in the brine pocket. 
Even though the $\alpha$ value of the ERDA No. 6 brine was close to those of nearby metoric waters taken from the northern apex of the Capitan Reef, these $\alpha$ values are far removed from those of more remote meteoricallyderived saline Capitan waters from the east and west arms of the reef (Carlsbad No. 7 and Shell No. 28). In fact, the remote waters appear to be younger than apex waters (Hackberry and Middleton), implying the groundwater flow in the reef is indeed toward the apex and recharge is in the east and west part of the reef.

Fresh and saline Capitan Reef waters have retained their meteoric $D / H$ and ${ }^{18} \mathrm{O} /{ }^{16} \mathrm{O}$ ratios, even though the ages of some of them are comparable to that of ERDA No. 6. Although reef apex waters and ERDA No. 6 brine are radiometrically similar, the solutes and stable isotopes of ERDA No. 6 reflect a more profound rock/fluid interaction than Capitan waters have experienced. This interaction, however, is more likely to have taken place in rocks between the capitan and the brine pocket than in the brine pocket itself.

The ERDA No. 6 reservoir rock has not replenished ${ }^{234} \mathrm{U}$ to the brine in spite of long contact. Furthermore, uranium mobility into the white recrystallized anhydrite from the gray laminated anhydrite from the gray laminated anhydrite was shown to be very low in this anoxic environment.

Dating by the uranium-disequilibrium method is not necessarily dependent on a closed system, and bounds on ages can be assigned. Requirements for ${ }^{234} \mathrm{U} /{ }^{238} \mathrm{U}$ dating include: $\alpha$ values of fluid and rock, leach rate, and knowledge of a value for original activity ratio, $\alpha_{0}$. The $\alpha$ value for the rock is necessary to evaluate the degree of rock-fluid disequilibrium. The leach rate might be negligible even in a closed system. A unique solution to an age-dating problem, however, requires knowledge of initial conditions, just as in case of the well-established uranium-lead and carbon 14 age-dating techniques. 


\subsection{SUMMARY}

Geochemical investigations of the WIPP site have been undertaken to characterize and quantify the mineralogy and petrology of the Delaware Basin evaporites and associated non-evaporites, volatile constituents and fluid inclusions native to the evaporites, the geochemistry of groundwaters native to the rocks, and the lengths of time that the evaporites and groundwaters have existed in their present environments. While these investigations have utilized a number of techniques of analytical chemistry, the choice and analysis of samples, together with interpretations of results, are carried out in the context of the WIPP geology •

The most common mineral in the Permian (Ochoan) Salado Formation, which is proposed for radioactive waste emplacement, is halite. Some of the halite contains minor amounts of anhydrite, and traces of trioctahedral clays and detrital minerals. Locally throughout the Salado Formation marker beds of anhydrite and polyhalite occur at intervals of a few tens of meters. Local accumulations of potassium and magnesium sulfates occur in the McNutt potash zone in the upper part of the Salado.

The petrographic textures, geochronology, and the presence of minerals which are not primary precipitates of sea water, such as sylvite and polyhalite, indicate that much of the evaporite section last underwent recrystallization more than 200 million years ago, shortly after permian deposition. The trace clay mineral fraction of the rock salt has efficiently entrapped and held radiogenic strontium for at least the last 200 million years. The aqueous solutions involved in this recrystallization were not in communication with fluids outside the evaporite section.

Volatiles presently occur in the evaporite section as the chemically-combined water of crystallization, hydroxyl-groups bound in sheet silicates, short-lived seeps exposed in mines, and as physically-entrapped inter- and intracrystalline fluid inclusions. The 
total volatiles recovered from rock salt heated to $600^{\circ} \mathrm{C}$ typically amount to less than 0.5 weight percent (about 1.58 by volume). In addition to water, traces of nitrogen, $\mathrm{CO}_{2}$ and contaminants from the coring operation are recovered from subsurface evaporite cores taken from boreholes. The fluid inclusions appear to have been entrapped at 20 to $45^{\circ} \mathrm{C}$, and contain $\mathrm{NaCl}, \mathrm{MgCl}_{2}$ and minor amounts of other solutes. Fluid inclusions not affected by recrystallization have not moved in the ambient geothermal gradient since the Permian deposition.

Isolated pockets of aqueous solutions now found in the evaporites have no geochemical relationship to surface-derived meteoric waters or to groundwaters above and below the evaporites; neither do they represent original evaporite mother liquors. Such pockets probably are relics of the post-depositional recrystallization which took place more than 200 million years ago, at which time they might have inherited their geochemically distinct solute assemblages and stable isotope compositons.

Stable isotope and solute content studies of meteorically-derived groundwaters west of the WIPP site and peripheral to the Delaware Basin indicate that simple uptake of solutes from rocks with which they have. come in contact did not alter their meteoric isotope ratios. Thus, waters participating in active dissolution of salt, which has not occurred in the salado Formation at the WIPP site, could be readily identified by their geochemistry.

The origin and age of an artesian brine pocket in the Castile Formation, northeast of the WIPP site was evaluated by a uranium isotope disequilibrium model. It was concluded that this accumulation (encountered in borehole ERDA No. 6) has no connection with any other known groundwaters, and has been in its present environment for at least 880,000 years. 


\subsection{REFERENCES}

Adams, S. S., 1967, Bromine in the Salado Formation, Carlsbad potash district, New Mexico: Unpublished Ph.D. Dissertation, Harvard University, $202 \mathrm{pp}$.

Adams, S. S., 1969, Bromine in the Salado Formation, Carlsbad potash district, New Mexico: New Mexico Bur. Mines Min. Res. Bull. 93, 112 p.

American Public Health Association, 1971, Standard methods for the examination of water and wastewater (13th ed.): APHA, Am. Water Works Assn., Water Pollution Control Fed: Washington, D. C.

Anderson, R. Y., Dean, W. E., Kirkland, D. W., and Snider, H. I., 1972, Permian Castile varved evaporite sequence, West Texas and New Mexico: Bull. Geol. Soc. Amer., v. 83, p. 59-86.

Anderson, R. Y., and Powers, D. W., 1978, Salt anticlines in the Castile-Salado evaporite sequence, northern Delaware Basin, New Mexico: N. Mex. Bur. Mines Min. Res. Circ. 159, in press.

Anthony, T. R. and Cline, H. E., 1971a, Thermal migration of liquid droplets through solids: Jour. Applied Physics, v. 42, no. 9, p. 3380-3387.

Anthony, T. R. and Cline, H. E., 1971b, The interaction of liquid droplets with a grain boundary in large accelerational fields: Philosop. Mag., v. 24 , no. 189 , p. 695-703.

Anthony, T. R. and Cline, H. E., 1972, The thermomigration of biphase vapor-liquid droplets in solids: Acta Metallur., v. 20, p. 247-255.

Anthony, T. R. and Cline, H. E., 1973, The stability of migrating droplets in solids: Acta Metallur., v. 21, p. 117-122.

Anthony, T. R., and Cline, H. E., 1974, Thermomigration of liquid droplets in salt, in Fourth Symp. on Salt, v. l, A. H. Cougan, ed.: Cleveland, Ohio, Northern Ohio Geol. Soc., p. 313-321.

Anthony, T. R. and Sigsbee, R. A., 1971, The thermomigration of spherical bubbles through a transparent polycrystalline solid: Acta Metallur., v. 19, p. 1029-1035.

Baar, C. A., 1977, Applied salt-rock mechanics 1; the in-situ behavior of salt rocks: Elsevier Sci. Pub. Co., Amsterdam, 283 pp.

Bathurst, R. G. C. 1975, Carbonate Sediments and their Diagenesis, 2nd ed. Elsevier Scientific Publishing Company, New York, N.Y., 658 pp.

Bernas, B., 1968, New method for decomposition and comprehensive analysis of silicates by atomic absorption spectrophotometry: Anal. Chem. v. 40, p. 1682-1686. 
Bernas, B., 1973, Acid pressure decomposition device for interference-free AA analysis: Amer. Lab., v. 5, no. 8, p. 41.

Bigeleisen, J., Perlman, M.L., and Prosser, H.C., 1952, Conversion of hydrogenic materials to hydrogen for isotopic analysis: Anal. Chem., v. 24 , p. $1356-1357$.

Bodine, M. W., Jr. 1971, Alteration of basic volcanic rocks by marine hypersaline brines, Hallstatt, Upper Austria: (Abstract), Geol. Soc. Am. Abstr., v. 3, p. 509 .

Bodine, M. W., Jr. and Fernalld, T. H. 1973, EDTA dissolution of gypsum, anhydrite, and Ca-Mg carbonates: J. Sediment. Petrol. v. 43, p. 1152-1156.

Bodine, M. W., Jr. and Standaert, R. R., 1977, Chlorite and illite compositions from Upper Silurian rock salts, Retsof, New York: Clays and Clay Minerals, v. 25, p. 57-71.

Boffey, Philip M., 1975, Radioactive waste site search gets into deep water: Science, v. 190, p. 361.

Braitsch, 0., 1971, Salt deposits -- their origin and composition, trans. P. J. Bureck and A. E. M. Nairn: Springer-Verlag, Heidelberg, p. 1-297.

Brokaw, A. L., Jones, C. L., Cooley, M. E., and Hays, W. H., 1972, Geology and Hydrology of the Carlsbad Potash Area, Eddy and Lea Counties, New Mexico: U.S. Geologic Survey open-file report 4339-1, 86 pages.

Calzia, J. P., and Hiss, W. L., 1978, Petrographic character and extent of an oligocene basaltic dike system, northern Delaware Basin, New Mexico: N. Mex. Bur. Mines Min. Res. Circ. 159, in press.

Chen, K. H., and Wilcox, W. R., 1972, Boiling and convection during movement of solvent inclusions in crystals: Indust. Eng. Chem. Fundamentals, v. 11, no. 4, p. 563-565.

Clayton, R. N., Friedman, I., Graf, D. L., Mayeda, T. K., Meents, W. F., and Shimp, N. F., 1966, The origin of saline formation waters, I. Isotopic Composition: Jour. Geophys. Res., v. 71, p. 3869-3882.

Cline, H. E., and Anthony, T. R., 1971, Vaporization of liquid inclusion (sic) in solids: Philosoph. Mag., v. 24, p. 1483-1494.

Collins, A. G., 1975, Geochemistry of oilfield waters: Elsevier Scientific Publishing Company, Amsterdam, p. 1-496.

Craig, Gordon, L. I., and Horibe, Y., 1963, Isotopic exchange effects in the evaporation of water, I. Low-temperature experimental results:

Jour. Geophys. Res., v. 68, p. 5079-5087. 
Craig, H., 196la, Isotopic variations in meteoric waters: Science, v. 133 , p. 1702-1703.

Craig, H., 1961b, Standard for reporting concentrations of deuterium and oxygen - 18 in natural waters: Science, v. 133, p. 1833-1834.

Dellwig, L. F., 1955, Origin of the Salina salt of Michigan: Jour. Sed. Petrology, v. 25, p. 83-110.

Epstein, S., and Mayeda, T., 1953, Variaton of $18_{0}$ content of waters from natural sources: Geochim. Cosmochim. Acta, v. 4., p. 213-244.

Epstein, Sharp, R. P., and Gow, A. J., 1965, Six-year record of oxygen and hydrogen isotope variations in South Pole firn: Jour. Geophys. Res., v. 70 , p. $1809-1814$.

Epstein, 1970, Antarctic ice sheet: Stable isotope analyses of Byrd station cores and interhemispheric climatic implications: Science, $v$. 168 , p. $1570-1572$.

Fallis, S. M., 1973, Mineral sources of water and their influence on the safe disposal of radioactive wastes in bedded salt deposits: Unpublished Master's Thesis, University of Tennessee, Knoxville, $61 \mathrm{pp}$.

Faure, G., and Powell, J. L., 1972, Strontium isotope geology: Springer-Verlag, New York, $188 \mathrm{p}$.

Faure, G., 1977, Principles of Isotope Geology: J. Wiley \& Sons, Inc., New York, 464 p.

Folk, R. L., 1965, Some Aspects of Recrystallization in Ancient Limestones, in L. C. Pray and R. C. Murray (eds.): Soc. Econ. Paleontologists and Mineralogists, Spec. Pub. 13, p 14-48.

Folk, R. L., 1968, Petrology of sedimentary rocks: Hemphill's, Austin, Texas, $170 \mathrm{p}$.

Fontes, J., and Gonfiantini, R., 1967, Fractionment isotopique de 1 'hydrogene dans l'eau de cristallisation du gypse: C. R. Acad. So. Paris, Ser. D., v. 265, p. 4-6.

Fournier, R. O., 1961, Regular interlayered chlorite-vermiculite in evaporite of the Salado Formation, New Mexico: U.S.G.S., Prof. Paper 424-D, p. 323-327.

Fuchtbauer, H. and Goldschmidt, H., 1969, Die Tonminerale der Zechsteinformation: Beitr. Mineral. Petrogr. v. 6, p. 320-345.

Garrels, R. M., and Christ, C. L., 1965, Solutions, minerals, and equilibria: Harper and Row, New York, p. 1-450. 
Geguzin, Ya. E., and Dzyuba, A. S., 1973, Study of liquid inclusions in rock salt crystals in the entire range of their existence: Kristallografiya, v. 18, no. 7, p. 800-807 (in Russian; English abstract in Fluid Inclusion Research -- Proceedings of COFFI, v. 7, p. 62).

Gerlach, Hansludwig, and Heller, Siegfried, 1966, Uber Kunstliche Flussigkeitseinschusse in Steinsalzkristallen: Deutsche Gesell. Geol. Wiss., Reihe B., Mineralogie und Lagerstattenforschungen, Bd. 11, Heft 2, p. 195-214.

Graf, D. L., Meents, W. F., Friedman, I., and Shimp, N. F., 1966, The origin of saline formation waters, III. Calcium chloride waters: Illinois State Geol. Surv. Circ. 397, p. 1-60.

Grim, R. E., 1968, Clay Mineralogy (Second Edition), McGraw-Hill Book Company, New York, p. 1-596.

Grim, R. E., Droste, J. B., and Bradley, W. F., 1961, Diffraction data of a regular mixed layered clay mineral in an evaporite, in Eighth Natl. Conference on Clay and Clay Minerals: Pergamon Press, Inc., New York, p. $228-236$.

Griswold, G. B., 1977, Site selection and evaluation studies of the waste Isolation Pilot Plant (WIPP), Los Mendanos, Eddy County, New Mexico: Sandia Laboratories, SAND77-0946.

Hiss, W.L., 1975, Stratigraphy and ground-water hydrology of the capitan aquifer, southeastern New Mexico and west Texas: unpublished ph.D. thesis, University of Colorado, Boulder, $396 \mathrm{p}$.

Holdoway, K. A., 1974, Behavior of fluid inclusions in salt during heating and irradiation, in Fourth Symp. on salt, v. 1, A. H. Coogan, ed.: Northern Ohio Geol. Soc., Cleveland, Ohio, p. 303-312.

Hopkins, R. H., Seidensticker, R. G., and Stewart, A. M., 1976, Degradation of Czochralski silicate oxyapatite crystals by the thermomigration of liquid drops: Jour. Crystal Growth, v. 33, p. 223-231.

Holser, W. T., 1963, Chemistry of brine inclusions in Permian salt from Hutchison, Kansas in J. L. Rau (ed.), Symposium on salt: Northern Ohio Geological Society, Cleveland, Ohio, p. 86-103.

Holser, 1966, Bromide geochemistry of salt rocks in J. L. Rau (ed.), Second Symposium on Salt: Northern Ohio Geological Society, Cleveland, Ohio, p. 248-275.

Hurley, P. M., Heezen, B. C., Pinson, w. H., and Fairbairn, H. W., 1963, $K-A r$ age values in pelagic sediments of North Atlantic: Geochim. Cosmochim. Acta, v. 27, p. 393-399. 
Jones, C. L., 1973, Salt Deposits of Los Medanos Area, Eddy and Lea Counties, New Mexico, with sections on Ground-water Hydrology, by M. E. Cooley, and Surficial Geology, by G. O. Bachman: U.S. Geological Survey open-file report $4339-7,67$ pages.

Jones, C. L., 1974a, Salt Deposits of the Clovis-Portales Area, East-Central New Mexico: U.S. Geological Survey open-file report 74-60, 22 pages.

Jones, C. L., 1974b, Salt Deposits of the Mescalero Plains Area, Chavez County, New Mexico: U.S. Geological Survey open-file report 74-190, 21 pages.

Jones, C. L., 1975, Potash Deposits in Part of Los Medanos Area of Eddy and Lea Counties, New Mexico: U.S. Geological Survey open-file report $75-407,37$ pages.

Khetchikov, L. N., and Samoilovich, L. A., 1970, The possibilities of the decrepitation method in mineral thermometry: Akad. Nauk S.S.S.R., Izvest., Ser. Geol., 1970, no. 7, p. 92-98 (in Russian; translated in Fluid Inclusion Research -- Proceedings of COFFI, v. 3, 1970, p. 94-100).

Kigoshi, Kunihiko, 1971, Alpha-recoil thorium-234: dissolution into water and the uranium-234/uranium-238 disequilibrium in nature: Science, v. 173, p. 47.

Kronfeld, J., Gradsztajn, E., Muller, H.W., Raddin, J., Yaniv, A., Zach, R., 1975, Excess $234 \mathrm{U}$ : an aging effect in confined waters: Earth Planetary Sci. Letters, v. 27, p. 342.

Kuznetsov, S. I., Ivanov, M. V., and Lyalikova, N. N., 1963, Introduction to geological microbiology (transl. P. T. Broneer): McGraw-Hill Book Company, New York, p. 1-245.

Lambert, S. J., 1978, The geochemistry of Delaware Basin groundwaters: New Mexico Bur. Mines and Min. Res. Circ. 159, in press.

O'Neil, J. R., and Kharaka, Y. K., 1976, Hydrogen and oxygen isotope exchange reactions between clay minerals and water: Geochim. Cosmochim. Acta, v. 40 , p. 24l-246.

Osmond, J.K., and Cowart, J.B., 1976, The theory and uses of natural uranium isotopic variations in hydrology: Atomic Energy Review, v. 14, p. 621.

Oxburgh, V. M., Segnit, R. E., and Holland, H. D., 1959, Coprecipitation of strontium with calcium carbonate from aqueous solutions (abstr.):

Bull. Geol. Soc. Amer., v. 70, p. 1653. 
Potter, R. W., II, 1977, Pressure corrections for fluid-inclusion homogenization temperatures based on the volumetric properties of the system $\mathrm{NaCl}-\mathrm{H}_{20}$ : J. Research U.S. Geol. Survey, v. 5, no. 5, p. 603-607.

Randall, M., and Failey, C. F., 1927, The activity coefficient of gases in aqueous salt solutions: Chem. Rev., v. 4, p. 271-284.

Reeves, C. C., Jr., 1963, Subterranean natural brines produce sodium sulphate in West Texas: Ground Water, v. 1, p. 35-36.

Roedder, E., 1965, Liquid $\mathrm{CO}_{2}$ inclusions in olivine bearing nodules and phenocrysts from basalts: Amer. Min., v. 50, p. 1746-1782.

Savin, S. M., and Epstein, S., 1970, The oxygen and hydrogen isotope geochemistry of clay minerals: Geochim. Cosmochim. Acta, v. 34, p. 25-42.

Schaller, W. T. and E. P. Henderson, 1932, Mineralogy of drill cores from the potash field of New Mexico and Texas: U. S. Geol. Surv. Bull. No. $833,124 \mathrm{pp}$.

Shell Exploration and Production Research Center, 1973, Potassium-Argon dates on Permian potash minerals from southeastern New Mexico: Isochron/West, No. 6, p. 37.

Tremba, E. L., 1973, Isotope geochemistry of strontium in carbonate and evaporite rocks of marine origin: unpub. Ph.D. dissertaton, Ohio state Univ., $185 \mathrm{p}$.

Vogel, A. I., 1961, A Textbook of Quantitative Inorganic Analysis: 3rd Ed., John Wiley and Sons, Inc., N.Y., p. 462.

Wilcox, W. R., 1968, Removing inclusions from crystals by gradient techniques: Indust. Eng. Chem., v. 60, no. 3, p. 13-23.

Wilcox, W. R., 1969, Anomalous gas-liquid inclusion movement: Indust. Eng. Chem., v. 61, no. 3, p. 76-77. 


\subsection{ACKNOWLEDGEMENTS}

In addition to the editors of this entire document, recognition is given to the following contributors to Chapter 7 (Geochemistry):

Section 7.2: Gerald T. Gay and Edward J. Graeber (Sandia Laboratories).

Section 7.3: Richard E. Beane and Carl J. Popp, (New Mexico Institute of Mining and Technology).

Section 7.4: Marc W. Bodine, John R. MacMillan, David Petty, Susan Kent, John Laskin, Joseph Taggart, Patricia Valentine, Robert Smith, and Robert Jackson (New Mexico Institute of Mining and Technology).

Section 7.5: K. D. Boultinghouse, Robert A. Sallach and Frank Conrad (Sandia Laboratories), Otto C. Kopp and Douglas W. Combs (University of Tennessee, Knoxville).

Section 7.6: Edwin Roedder and H. E. Belkin (United States Geological Survey) and Glen Jenks (Oak Ridge National Laboratory).

Section 7.7: James O'Neil, Charles Jones, Jerry Mercer and Brennon Orr (United States Geological Survey), Gary Ahlstrand and Patricia Fry (National Park Service), Steven J. Lambert, Robert Dosch, William Vollendorf, Robert statler, George Barr and James Krumhansl (Sandia Laboratories).

Section 7.8: Douglas G. Brookins, Joseph K. Register and Marcia E. Register (University of New Mexico) and Steven J. Lambert Sandia Laboratories.

Section 7.9: George E. Barr and Steven J. Lambert (Sandia Laboratories), Joel A. Carter (Oak Ridge National Laboratorie) and $\mathrm{J}$. Kronfeld (Tel-Aviv University, Israel). 


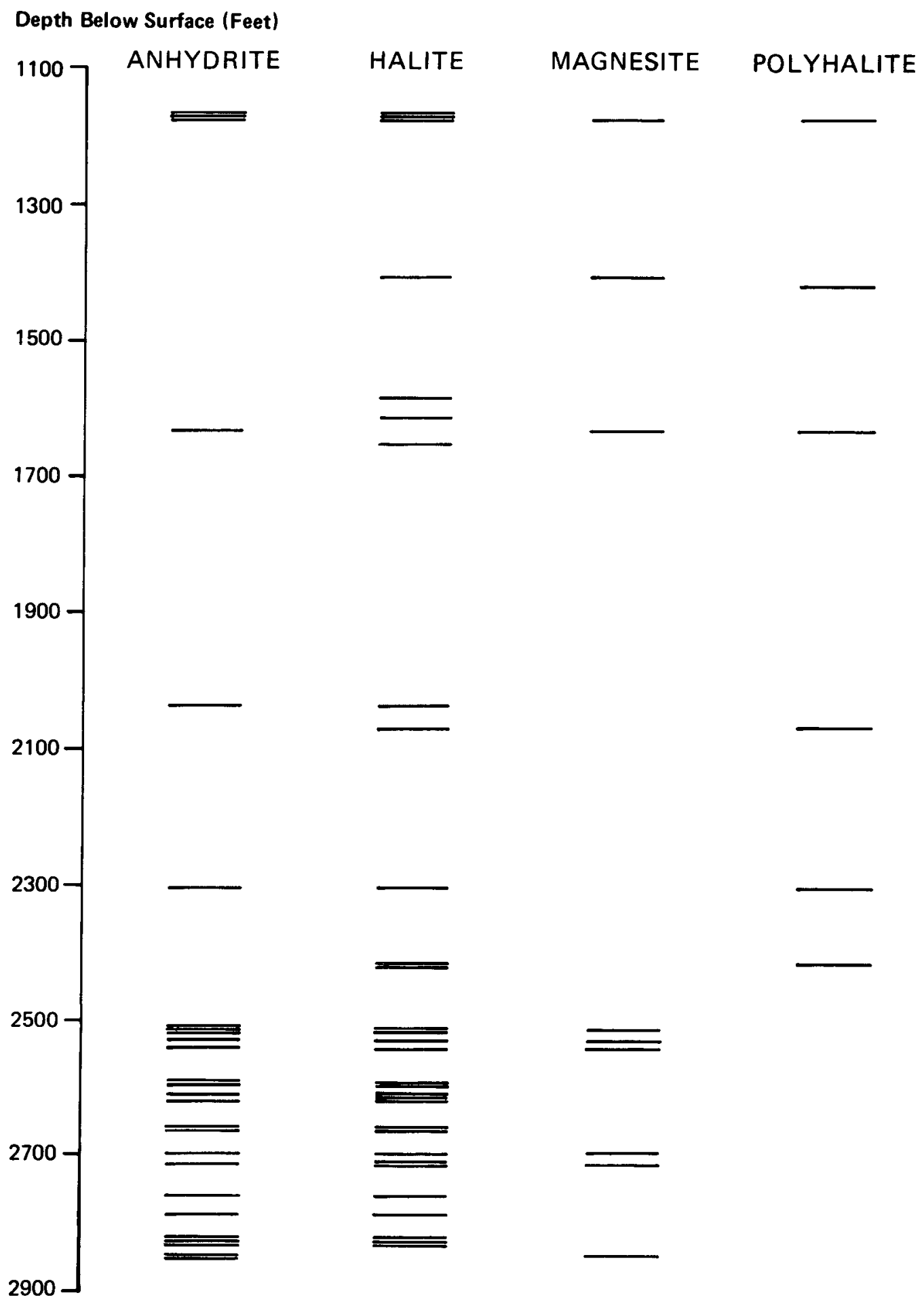

FIGURE 7.1

DISTRIBUTION OF MINERALS IN ERDA \#9 CORE SAMPLES 


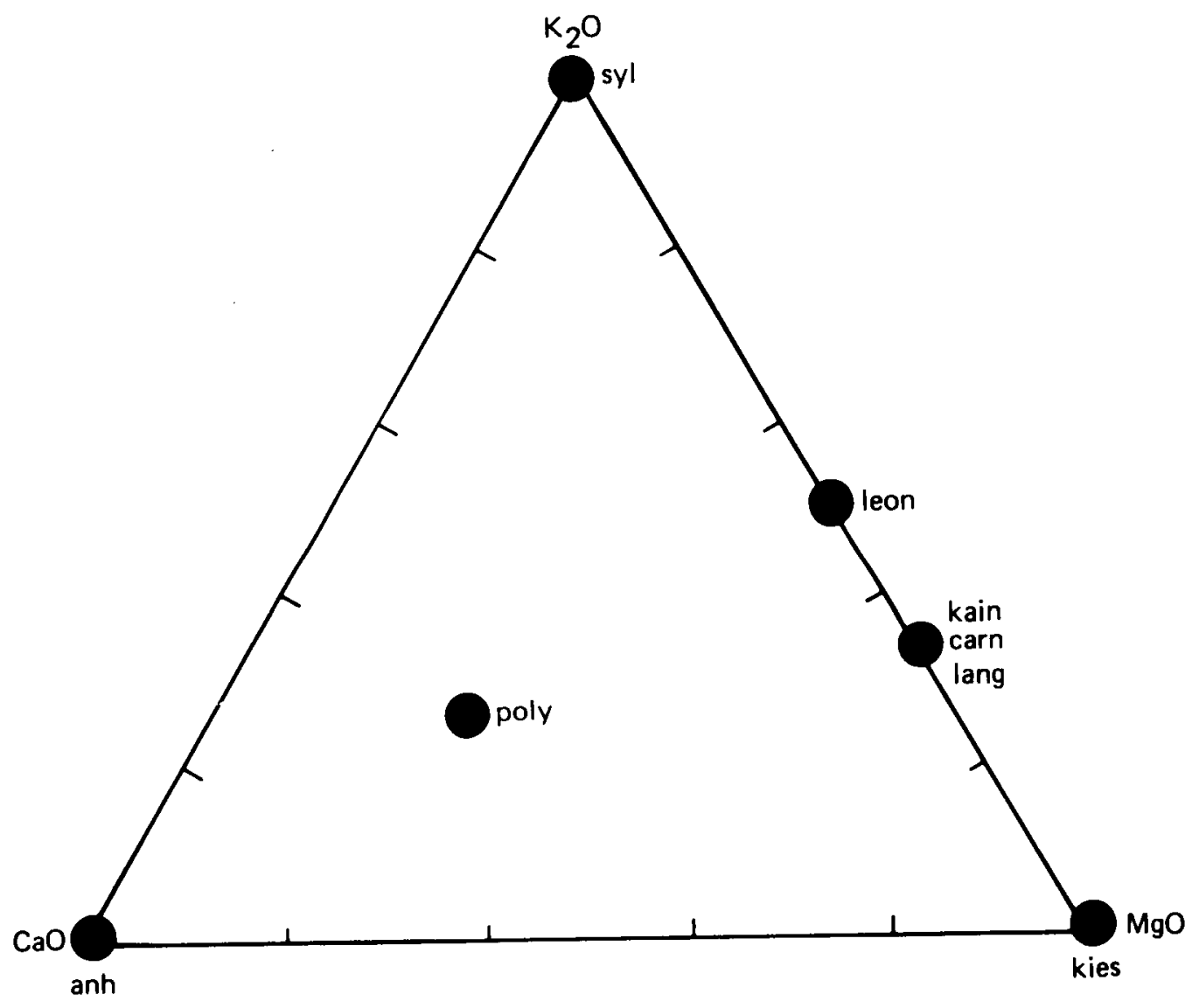

FIGURE 7.2

TRIANGULAR COMPOSITION DIAGRAM OF

SOLUBLE SULFATE-GROUP MINERALS 


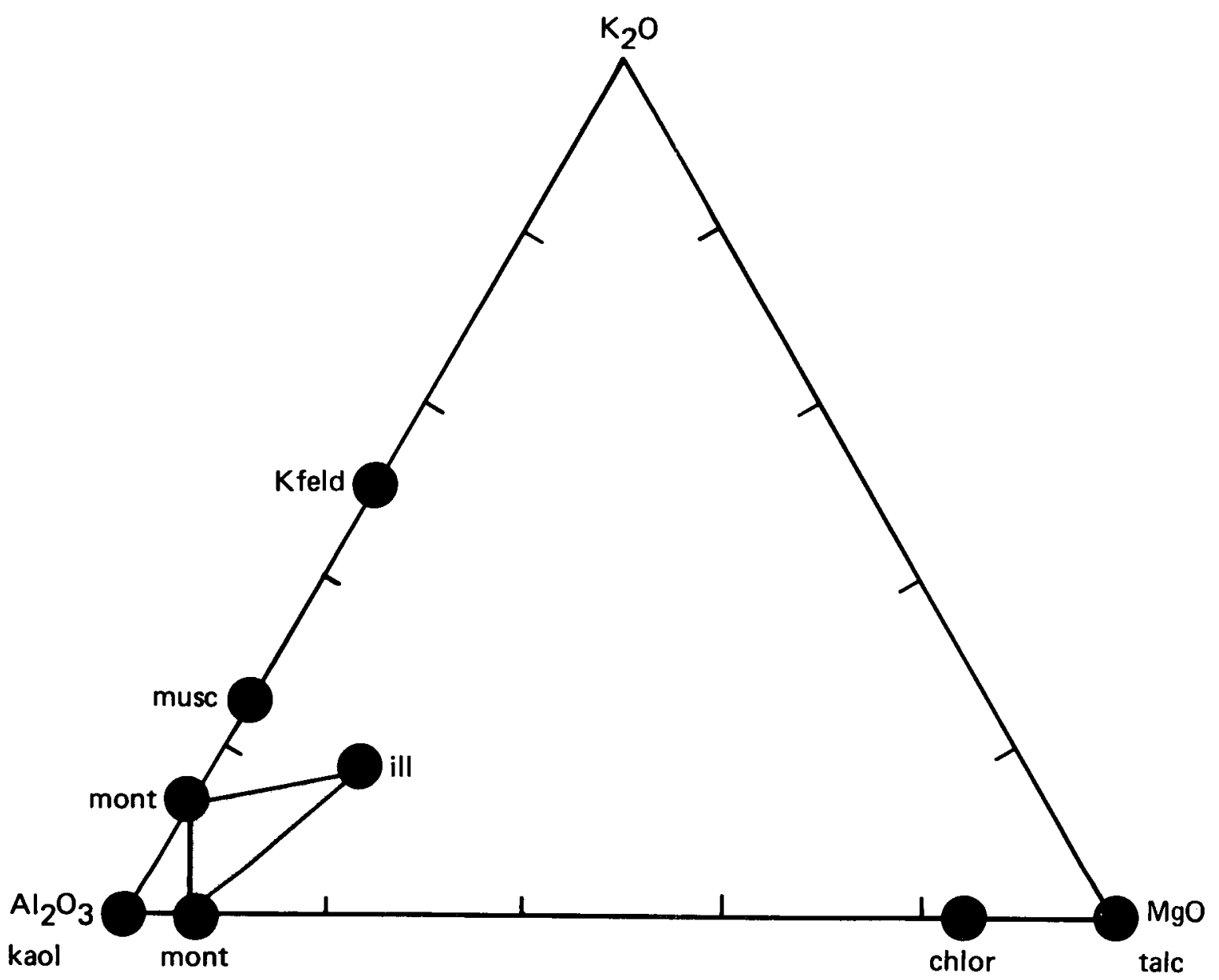

FIGURE 7.3

TRIANGULAR DIAGRAM OF

INSOLUBLE SILICATE-GROUP MINERALS 


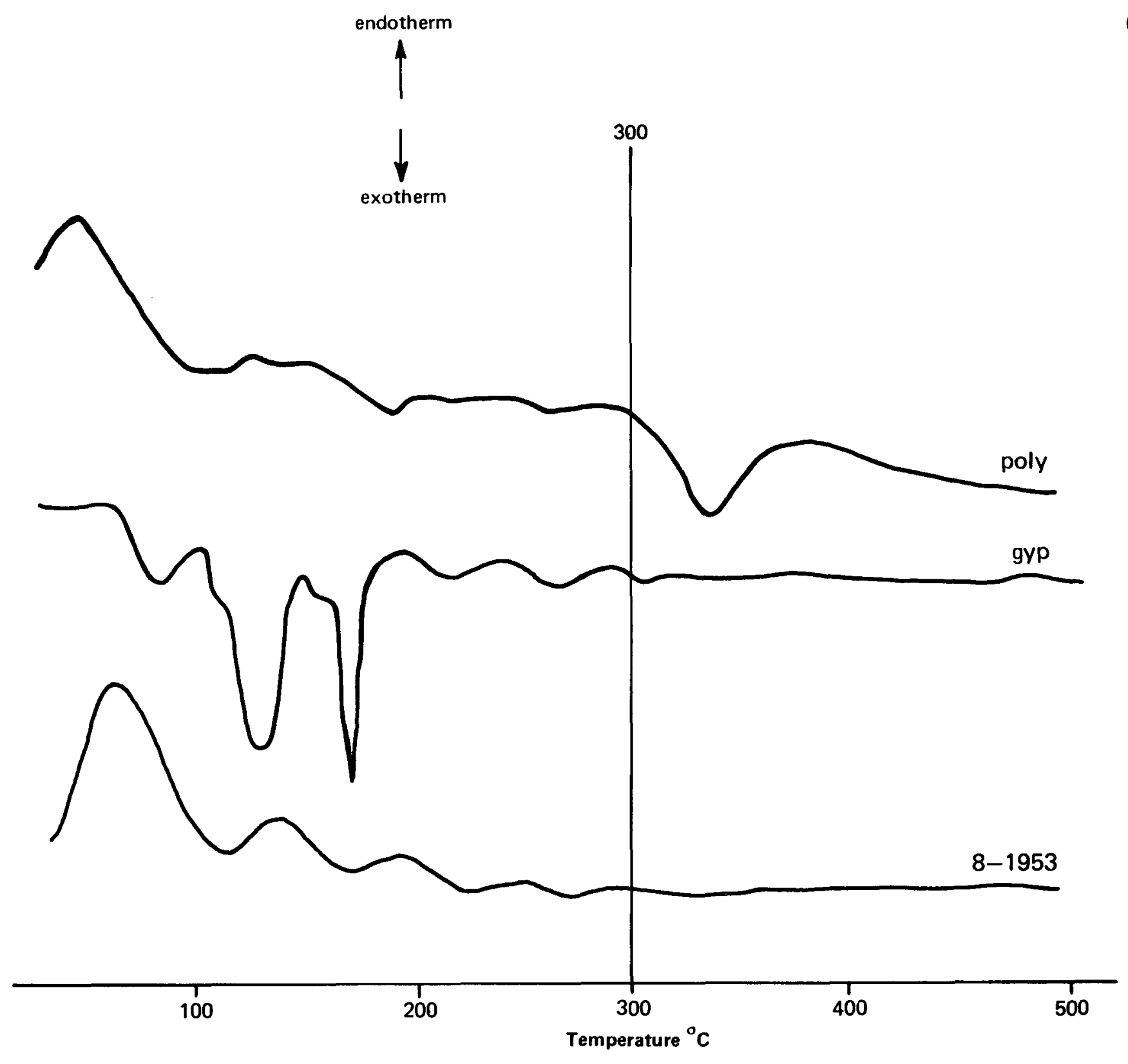

FIGURE 7.4

DIFFERENTIAL THERMAL ANALYSIS CURVES

FOR GYPSUM AND POLYHALITE 

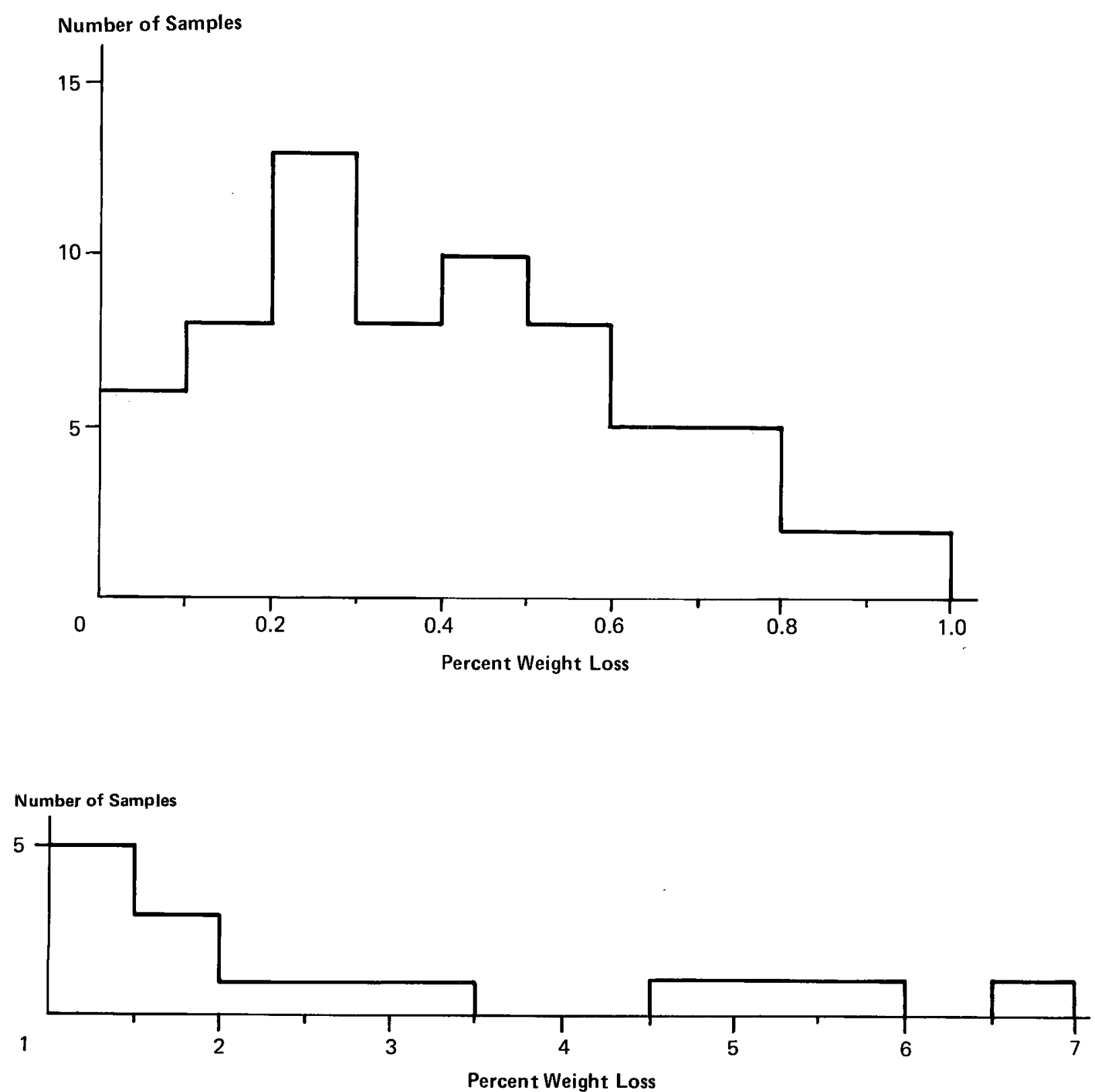

FIGURE 7.5

TOTAL WEIGHT LOSSES AT ELEVATED TEMPERATURES

$\left(500^{\circ} \mathrm{C}\right)$ FOR CORES FROM AEC NOS. 7 AND 8 


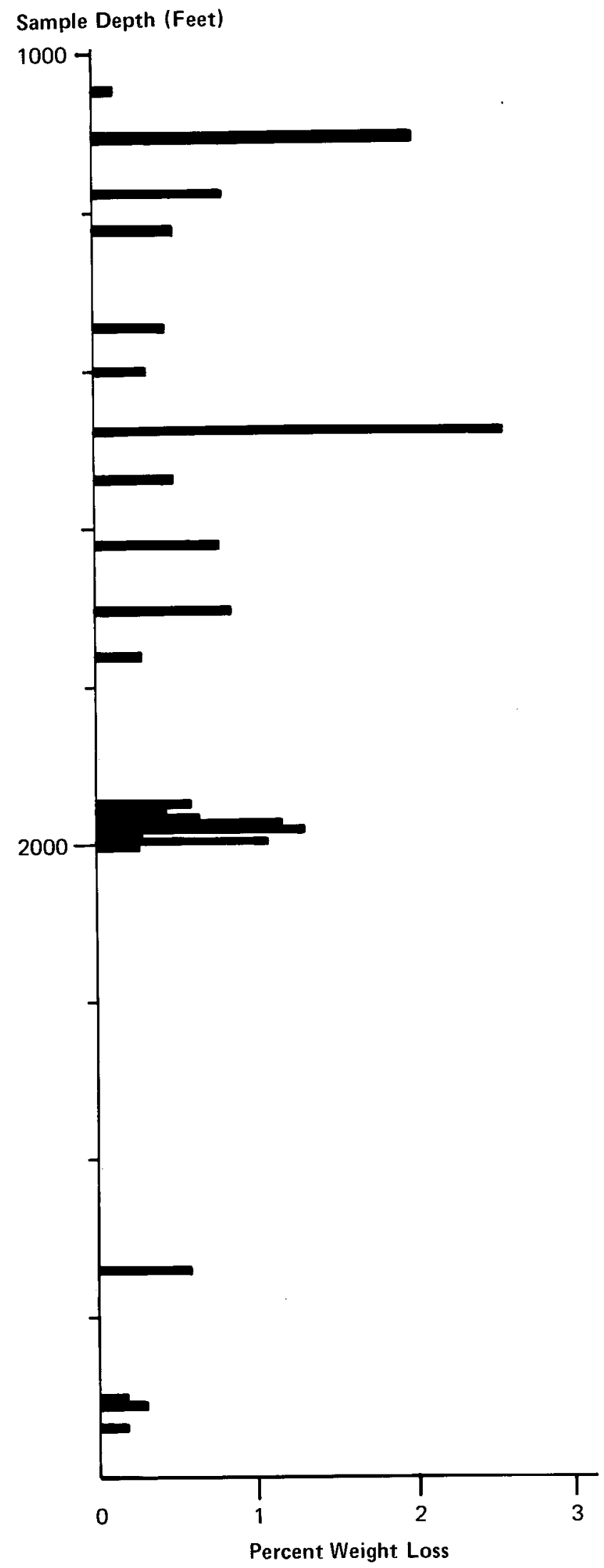

FIGURE 7.6A

AEC NO. 7 SAMPLE WEIGHT LOSSES VS. DEPTH

AT ELEVATED TEMPERATURES $\left(500^{\circ} \mathrm{C}\right)$ 


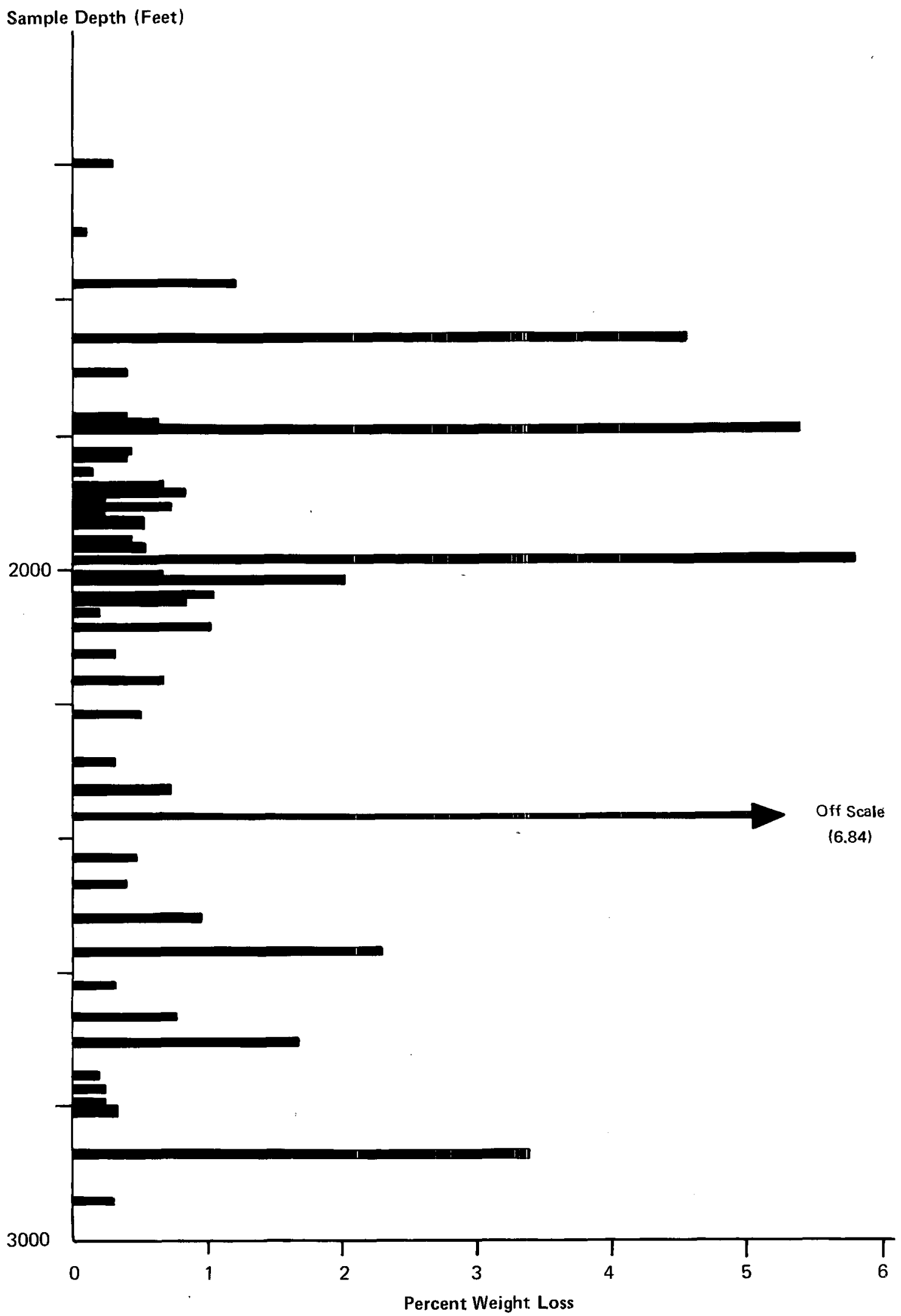

FIGURE 7.6B

AEC NO. 8 SAMPLE WEIGHT LOSSES VS. DEPTH

AT ELEVATED TEMPERATURES $\left(500^{\circ} \mathrm{C}\right)$ 


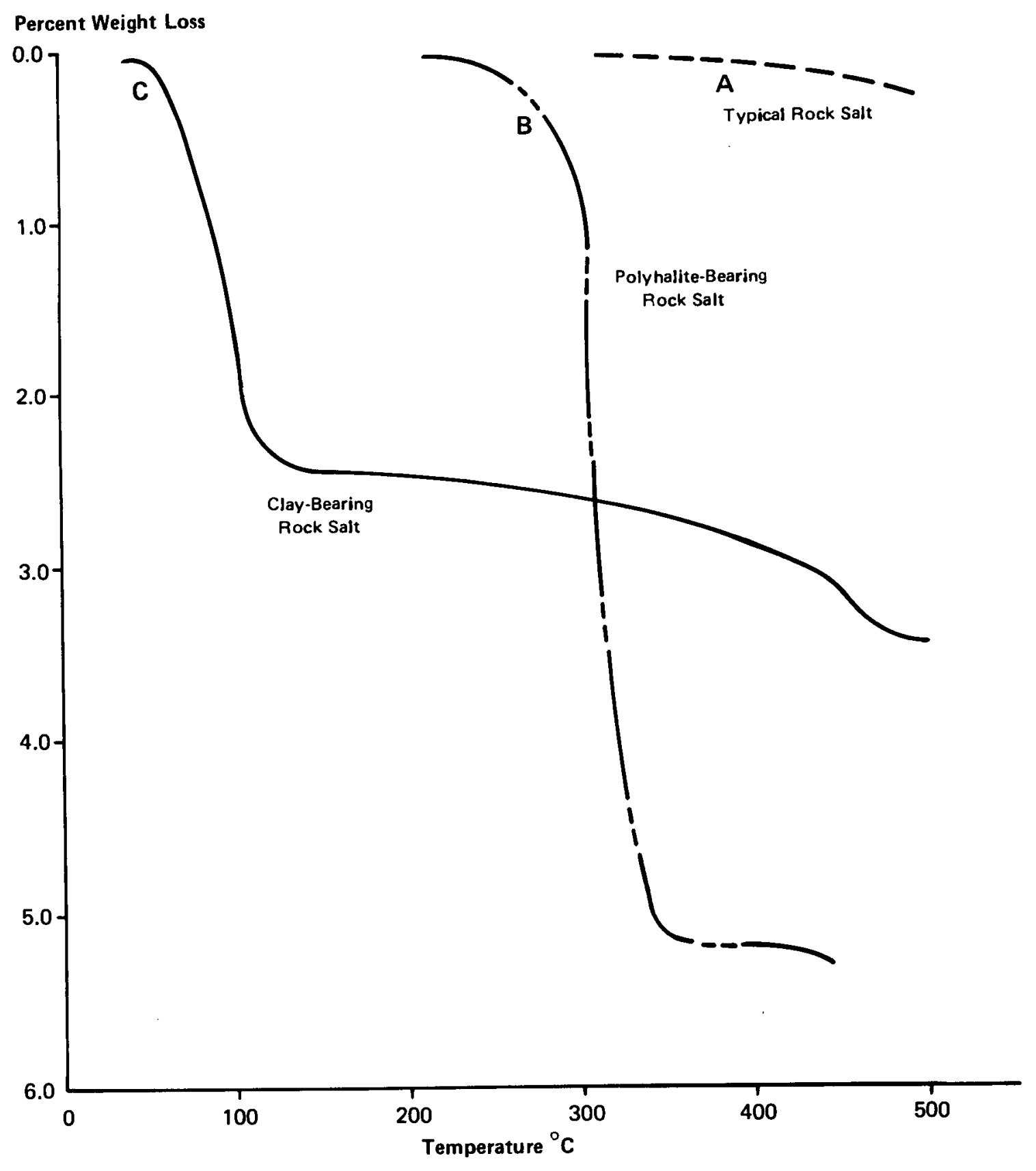

FIGURE 7.7

TYPICAL WEIGHT-LOSS CURVES FOR ERDA \#9 EVAPORITE CORE 


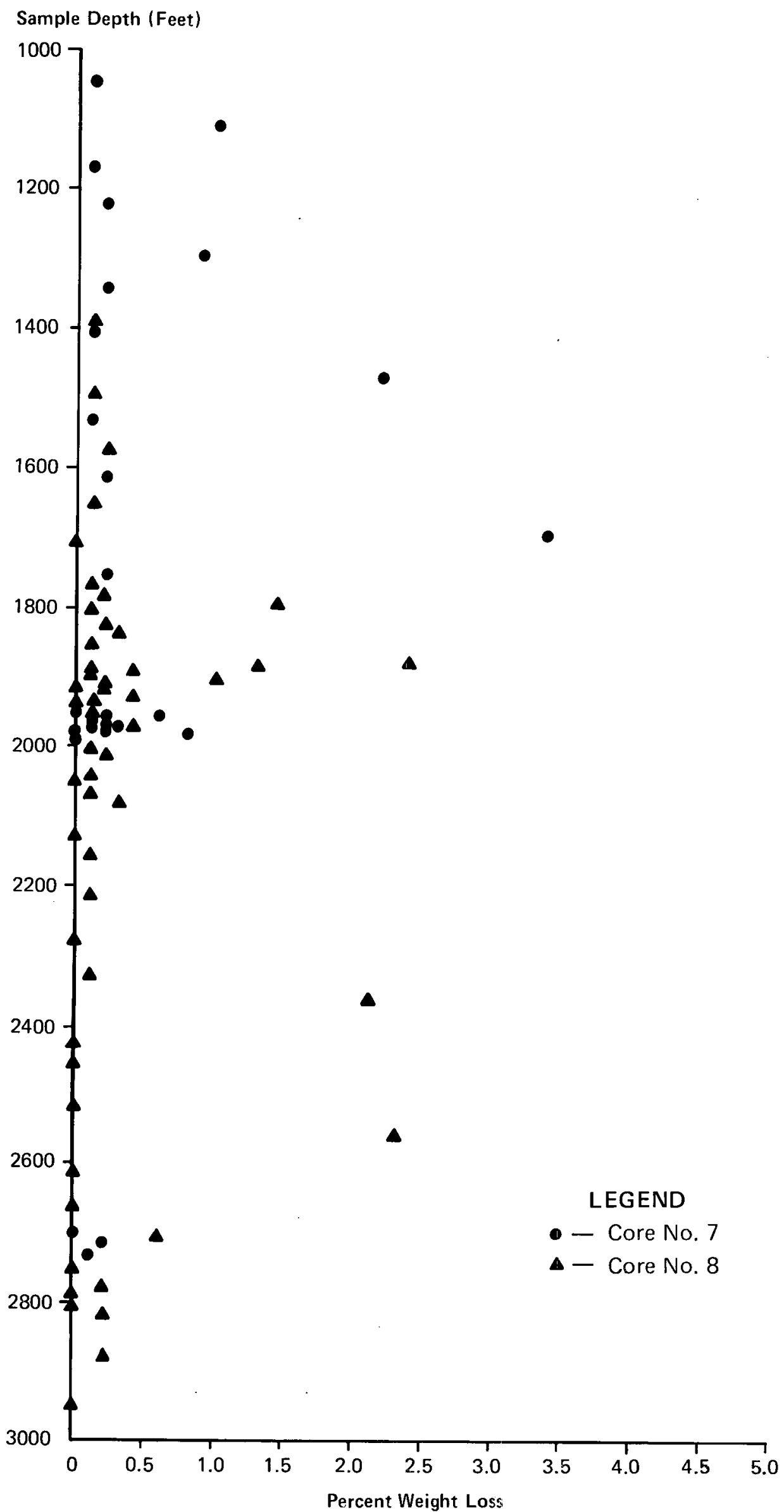

FIGURE 7.8 WEIGHT LOSS DATA FOR SAMPLES $\left(102 \pm 5^{\circ} \mathrm{C}\right)$

FROM CORES NO. 7 AND NO. 8 NEAR CARLSBAD, NEW MEXICO 


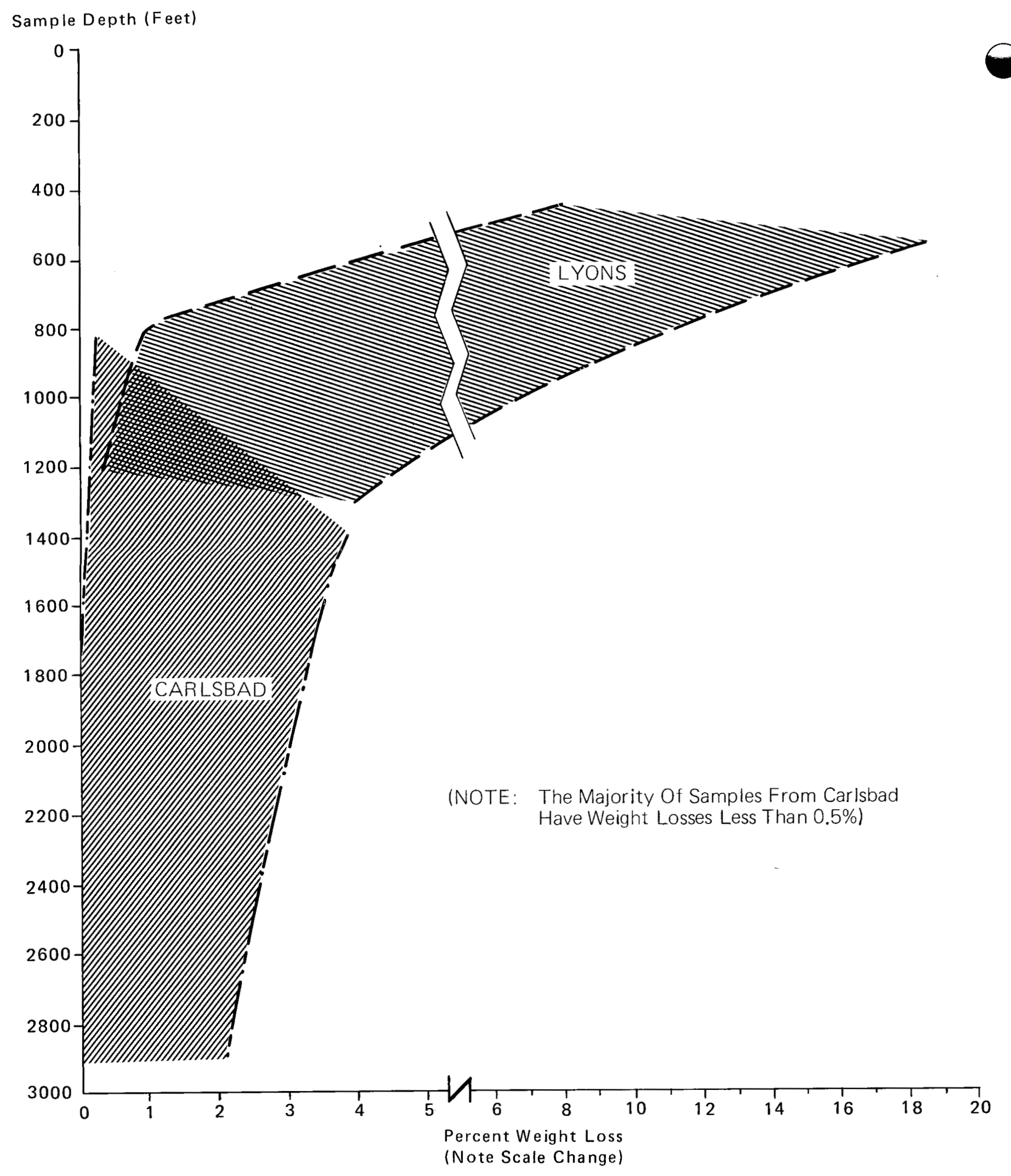

FIGURE 7.9 APPROXIMATE RANGE OF WEIGHT LOSS TO BE EXPECTED At $102+5^{\circ} \mathrm{C} V S$. DEPTH FOR SAMPLES FROM LYONS, KANSAS AND CARLSBAD, NEW MEXICO 


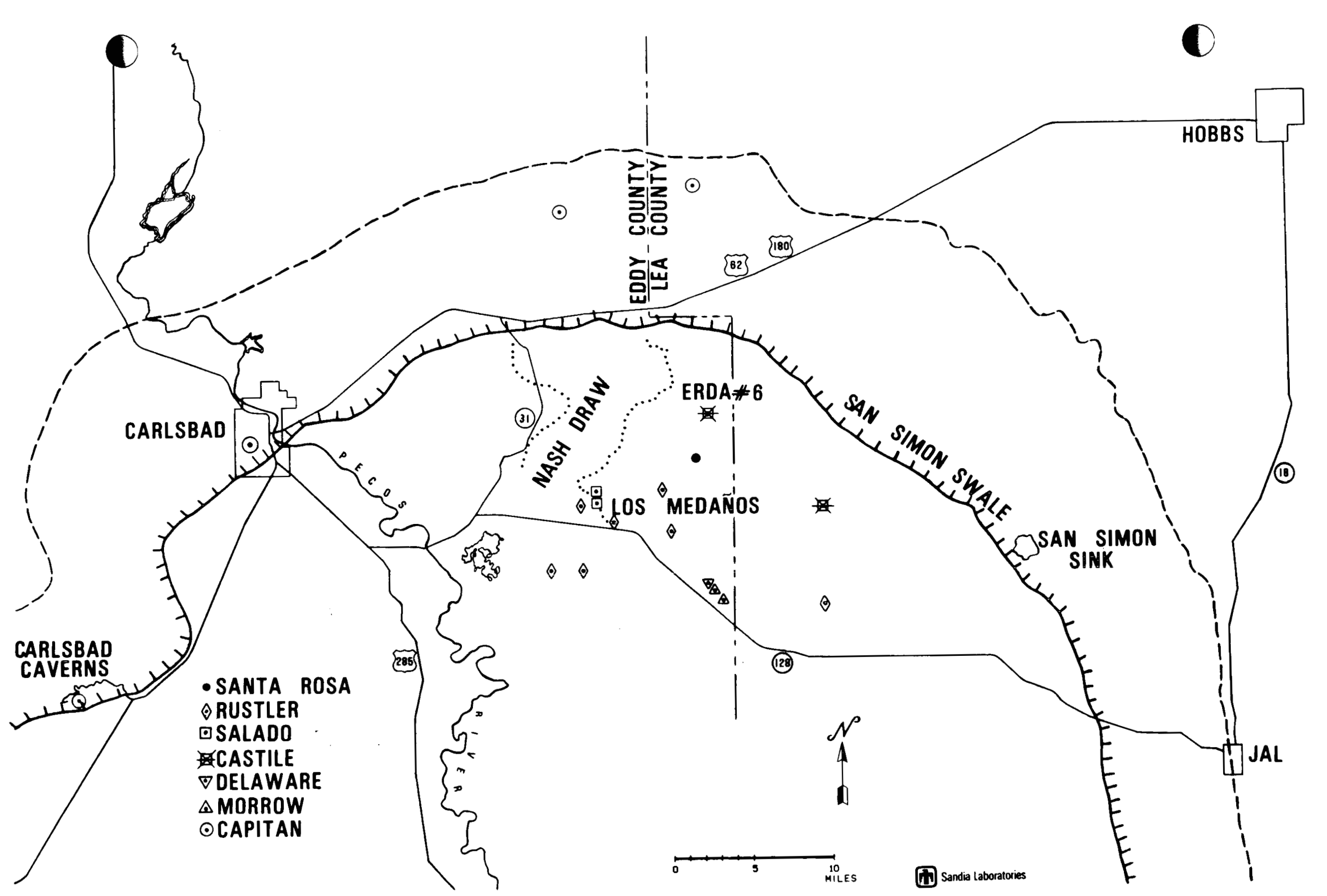

FIGURE 7.10 Map of the New Mexico portion of the Delaware Basin, showing locations of water sampling points in this study. The solid hachured line is the basinward margin of the Capitan Reef; the dashed line is the shelfward edge. 


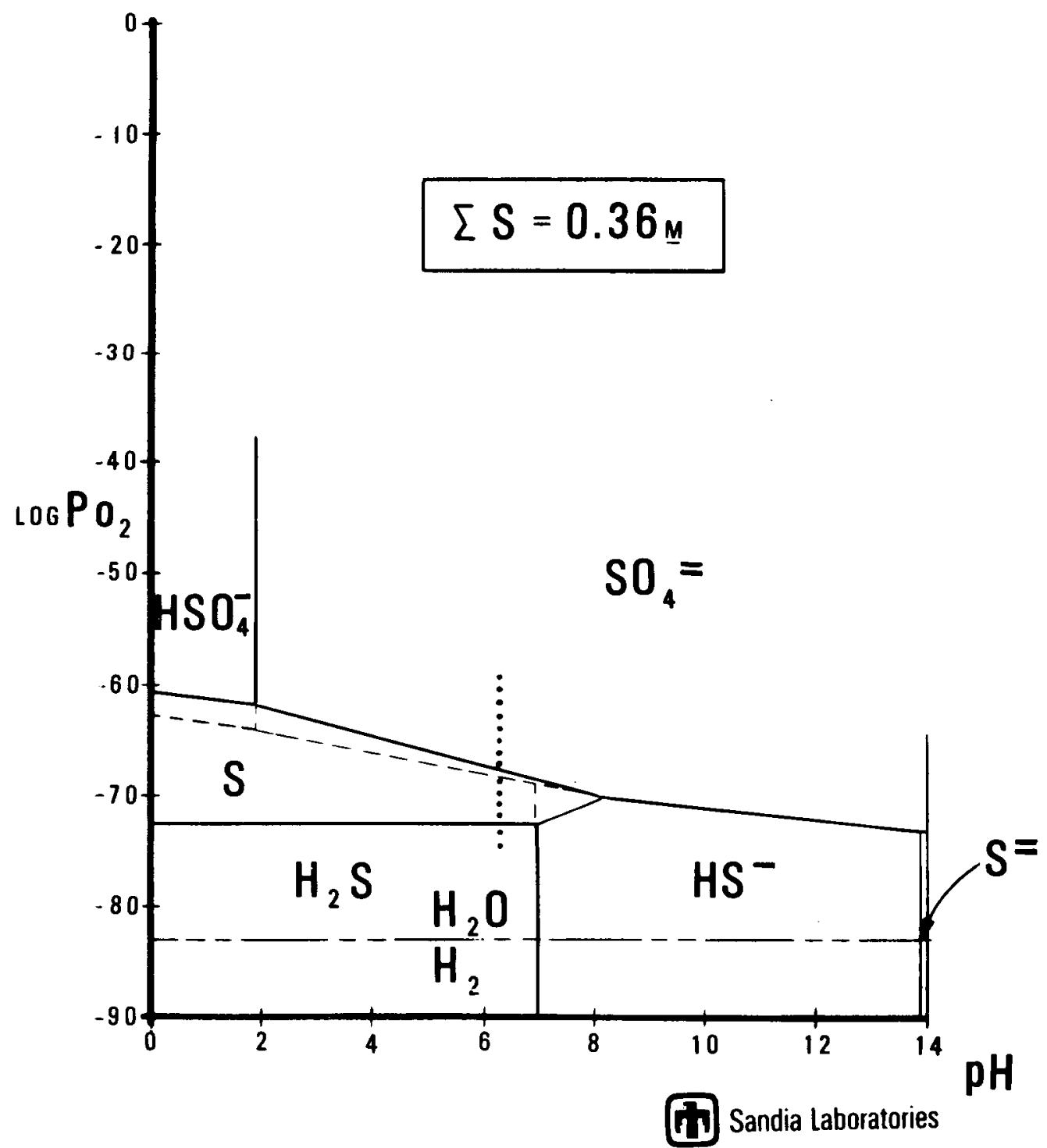

FIGURE 7.11 Predominance area diagram, oxygen partial pressure versus $\mathrm{pH}$, for the System $\mathrm{S}-\mathrm{O}-\mathrm{H}$ at $25^{\circ} \mathrm{C}, 1$ atmosphere and total sulfur concentration of $0.36 \mathrm{~m}$. Dashed lines are metastable extensions of boundaries.

Dotted line represents the field-measured DII of ERDA No. $6,6.3$. 


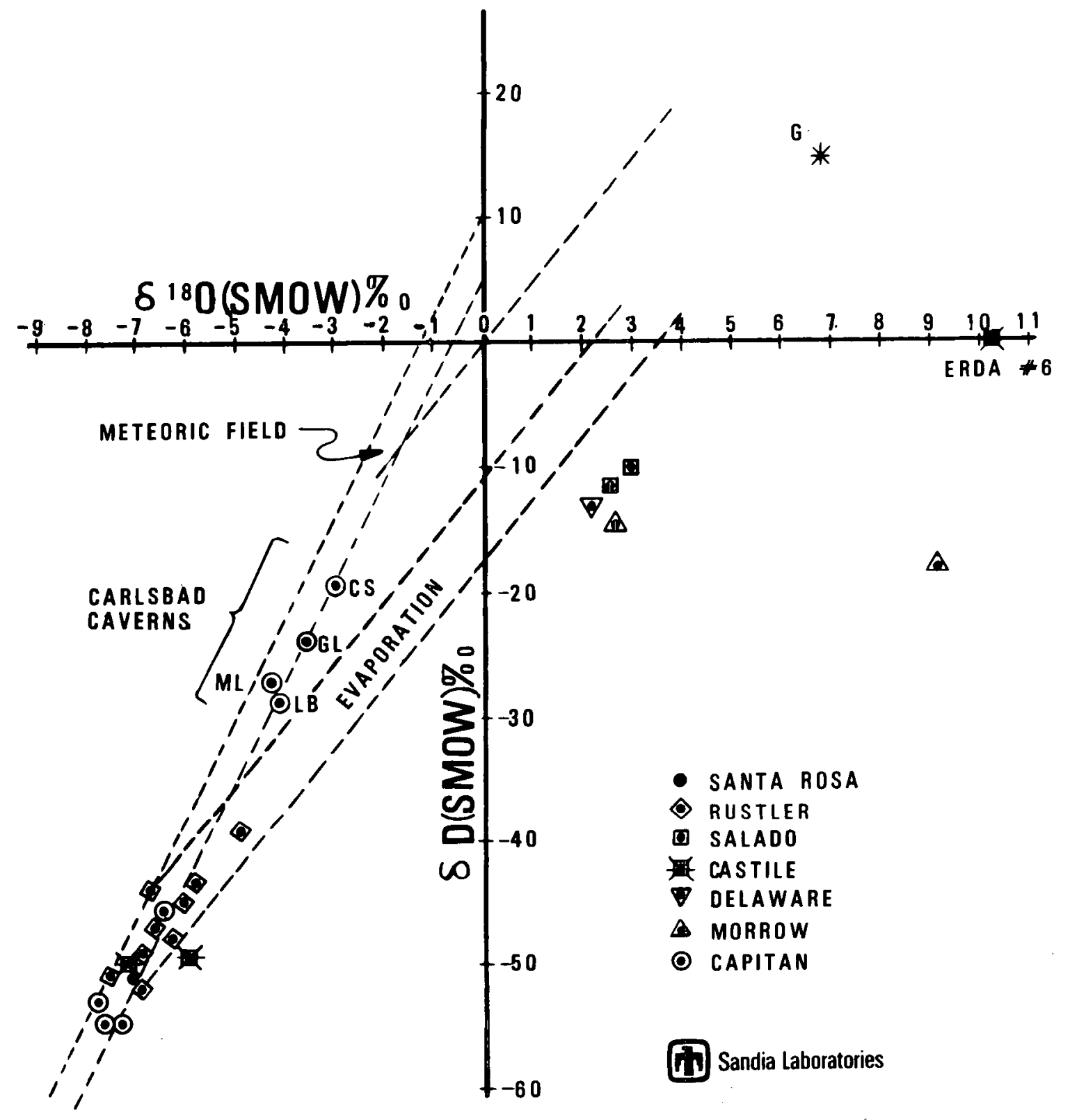

FIGURE 7.12 Stable isotope compositions, $\delta D$ versus $\delta^{18} 0$, for Delaware Basin groundwaters. Relationships are shown for meteoric waters, evaporating meteoric and sea waters. Iypothetical evaporite motherliquor for gypsum $(G)$ is shown for the case in which ERDA No. 6 is taken to be the water of crystallization for that gypsum. 


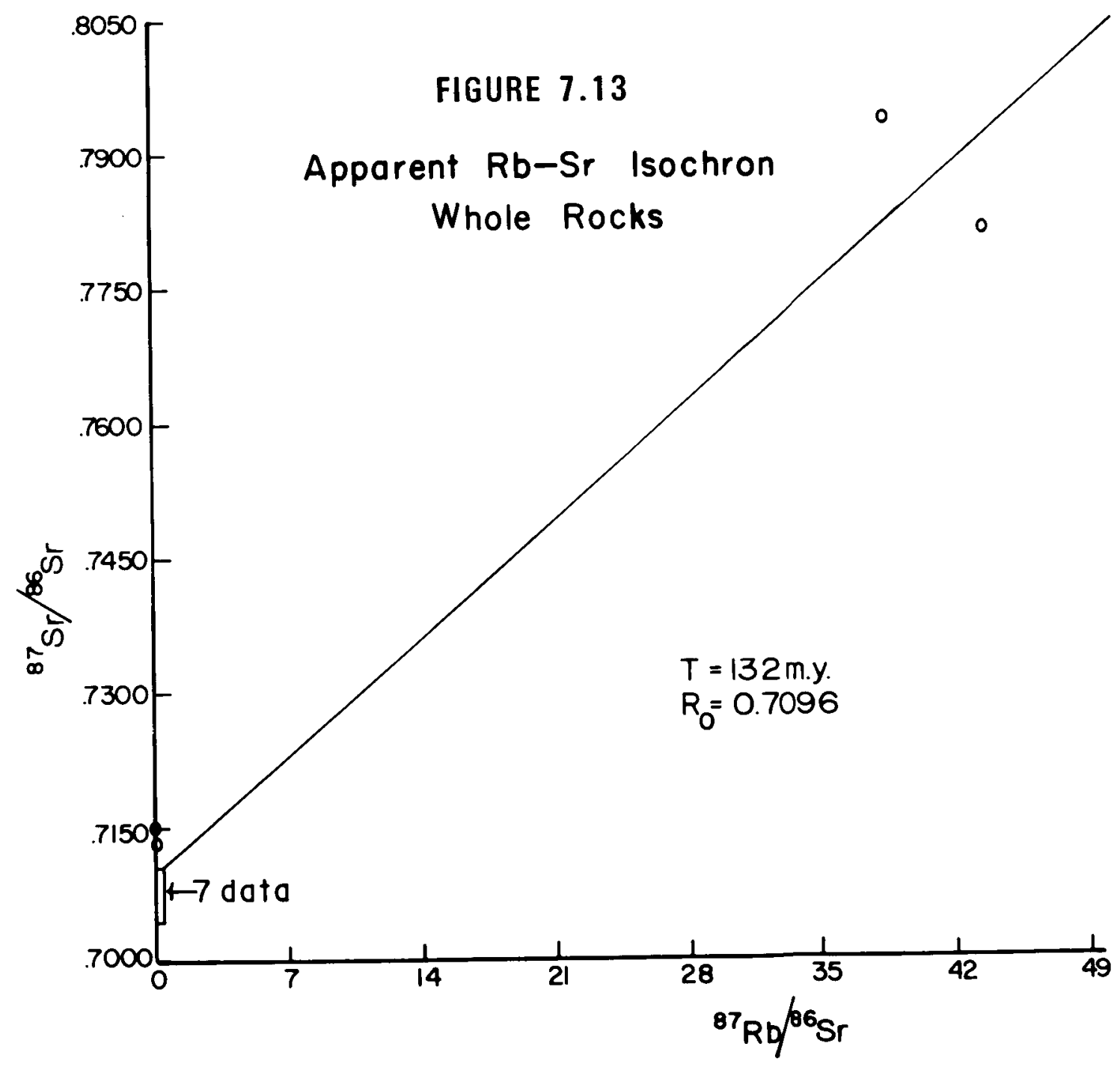




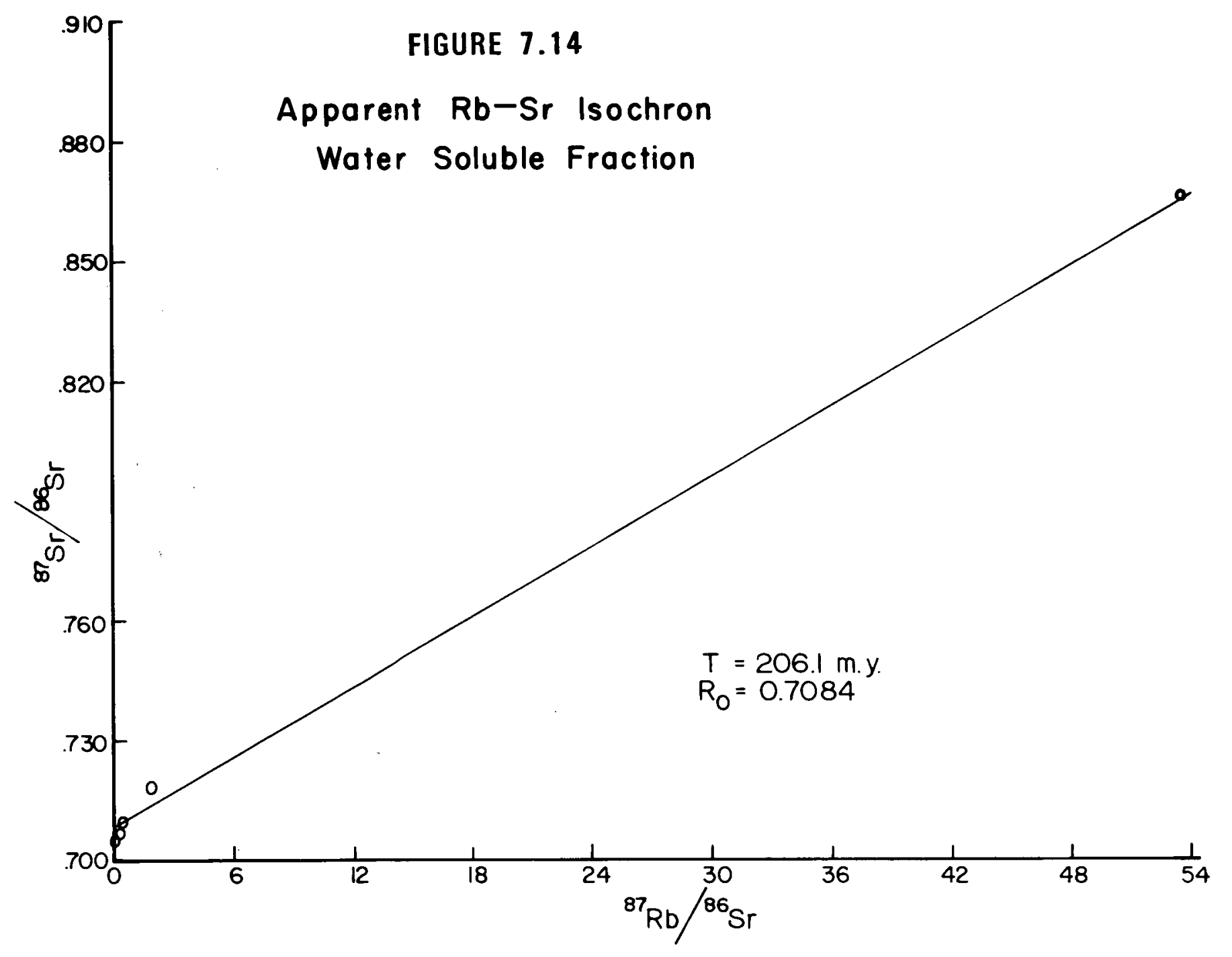




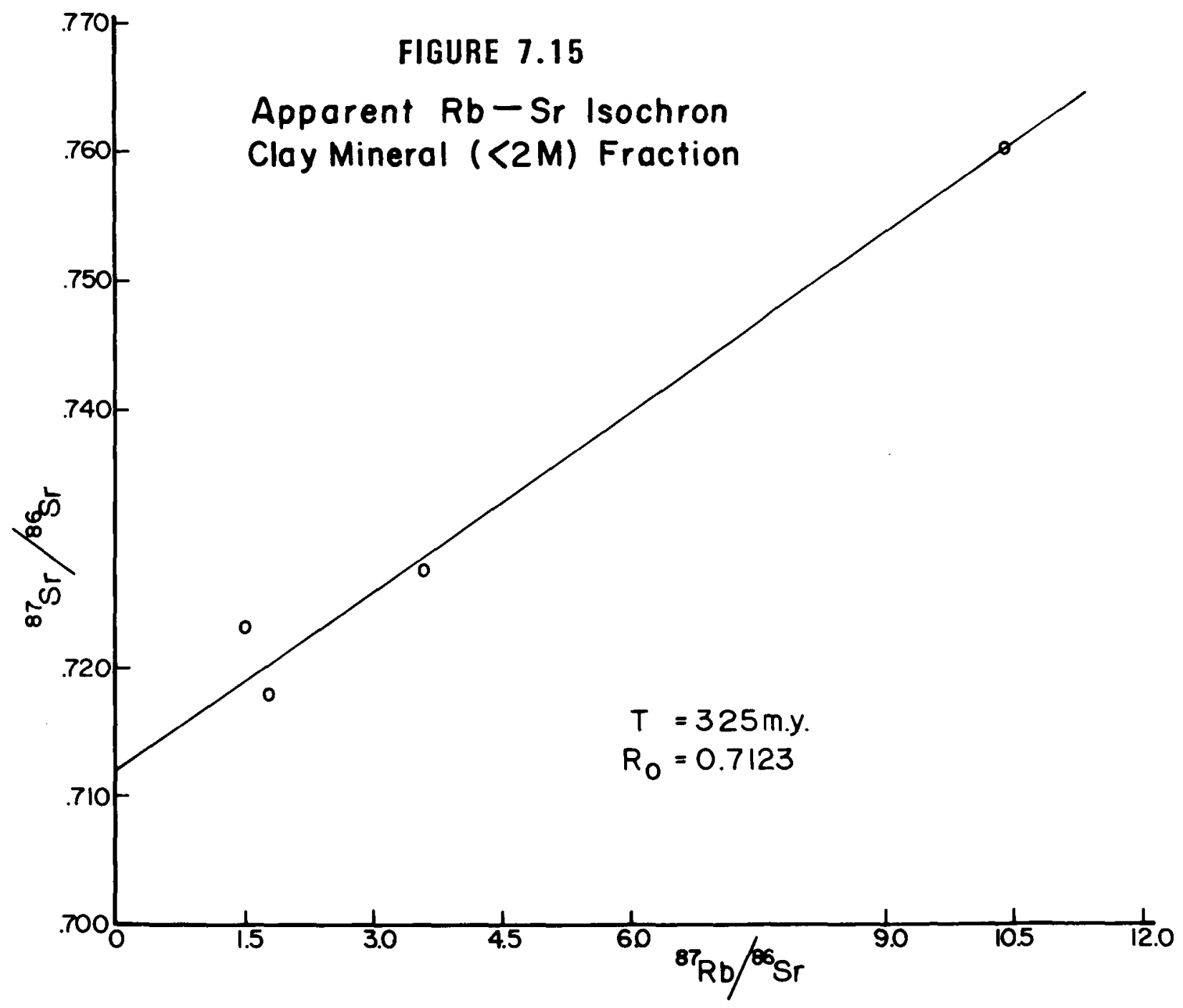




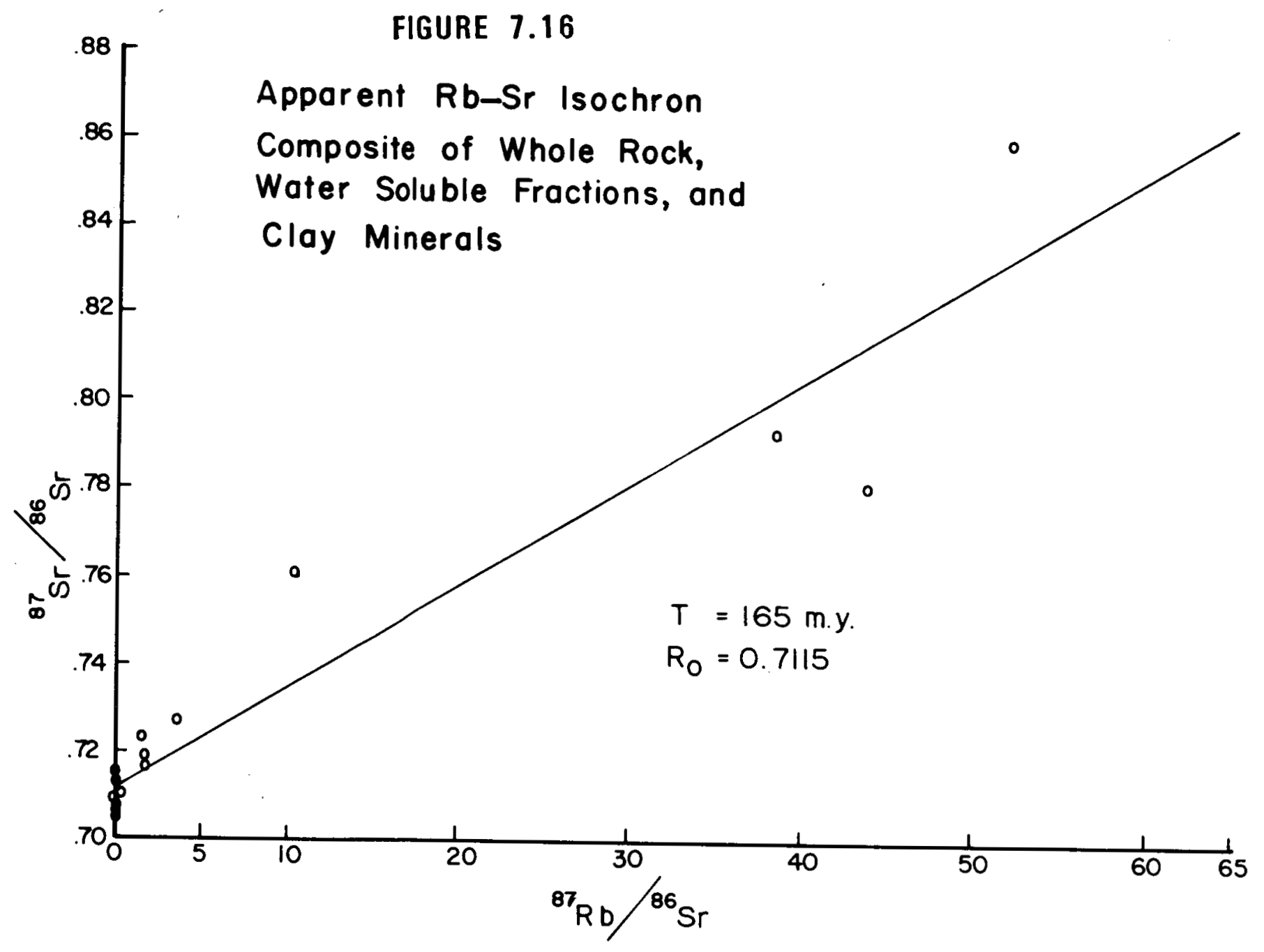




\section{FIGURE 7.17}

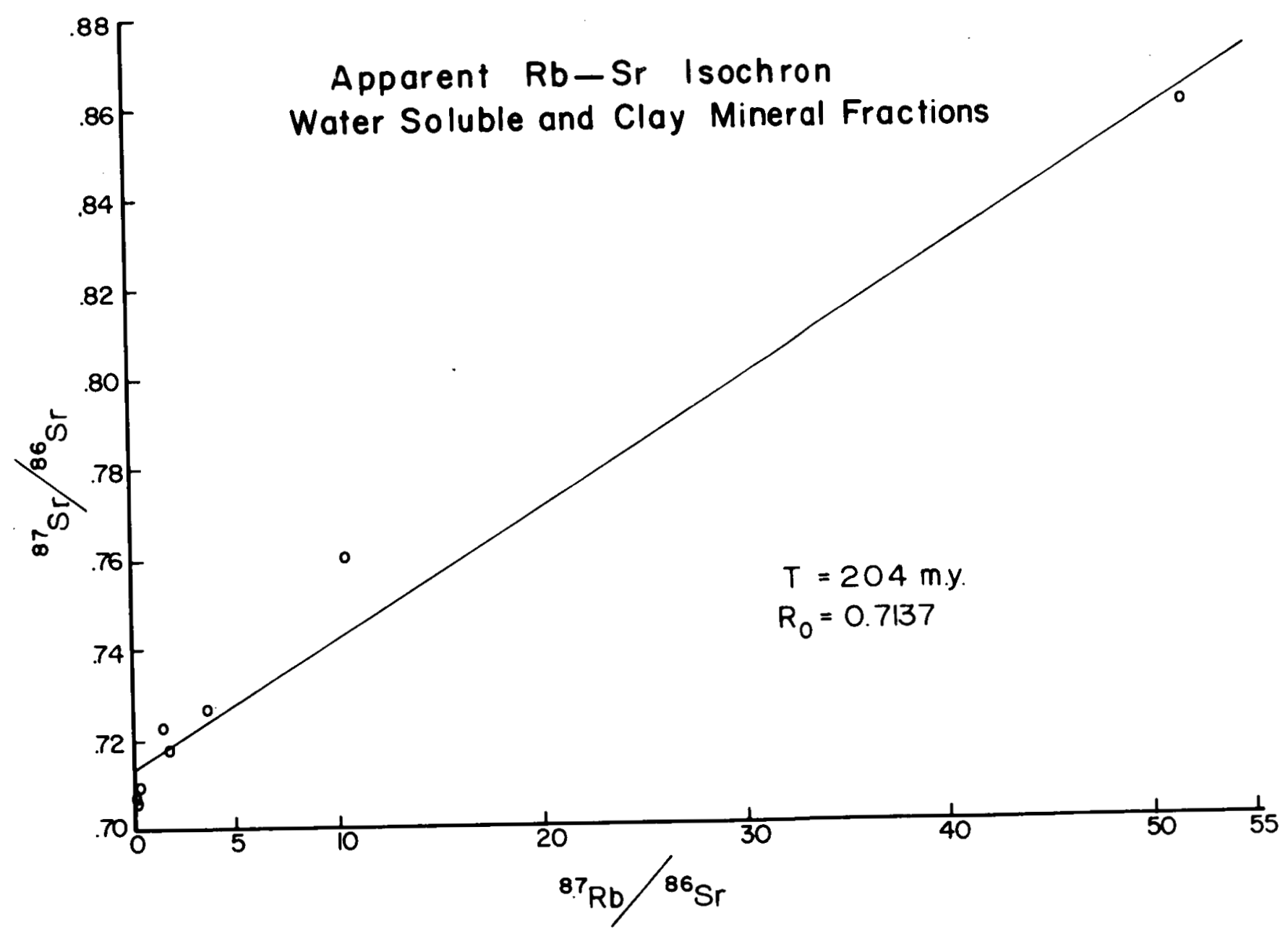




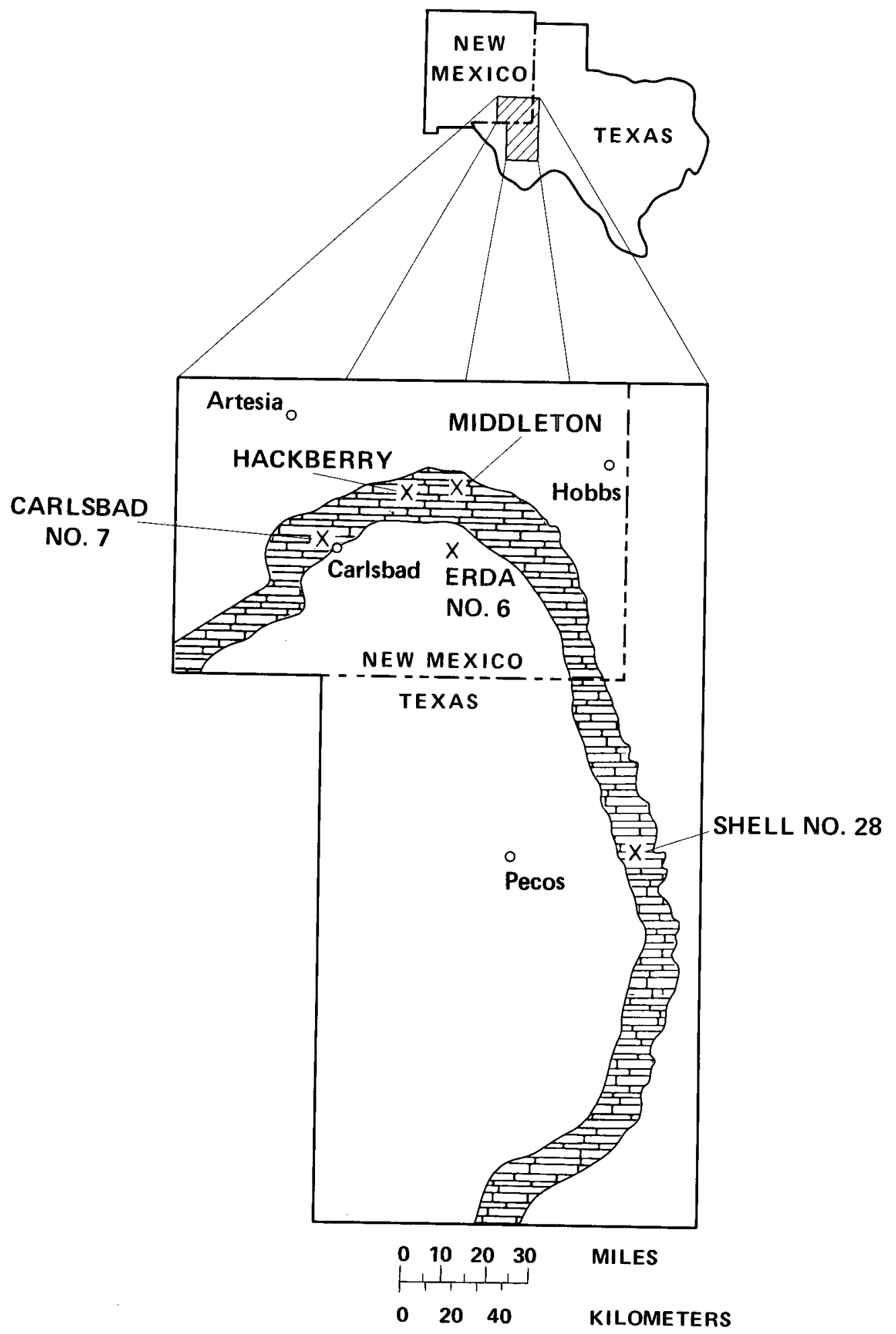

FIGURE 7.18 Map of a portion of the Delaware Basin (southeast New Mexico, west Texas) showing locations of holes whose fluids are sampled for $23.4 \mathrm{U} / 238 \mathrm{U}$-disequilibrium age-dating. The brick-pattern shows the surface projection and outcrop of the capitan reef limestone. (from Hiss, 1975) 


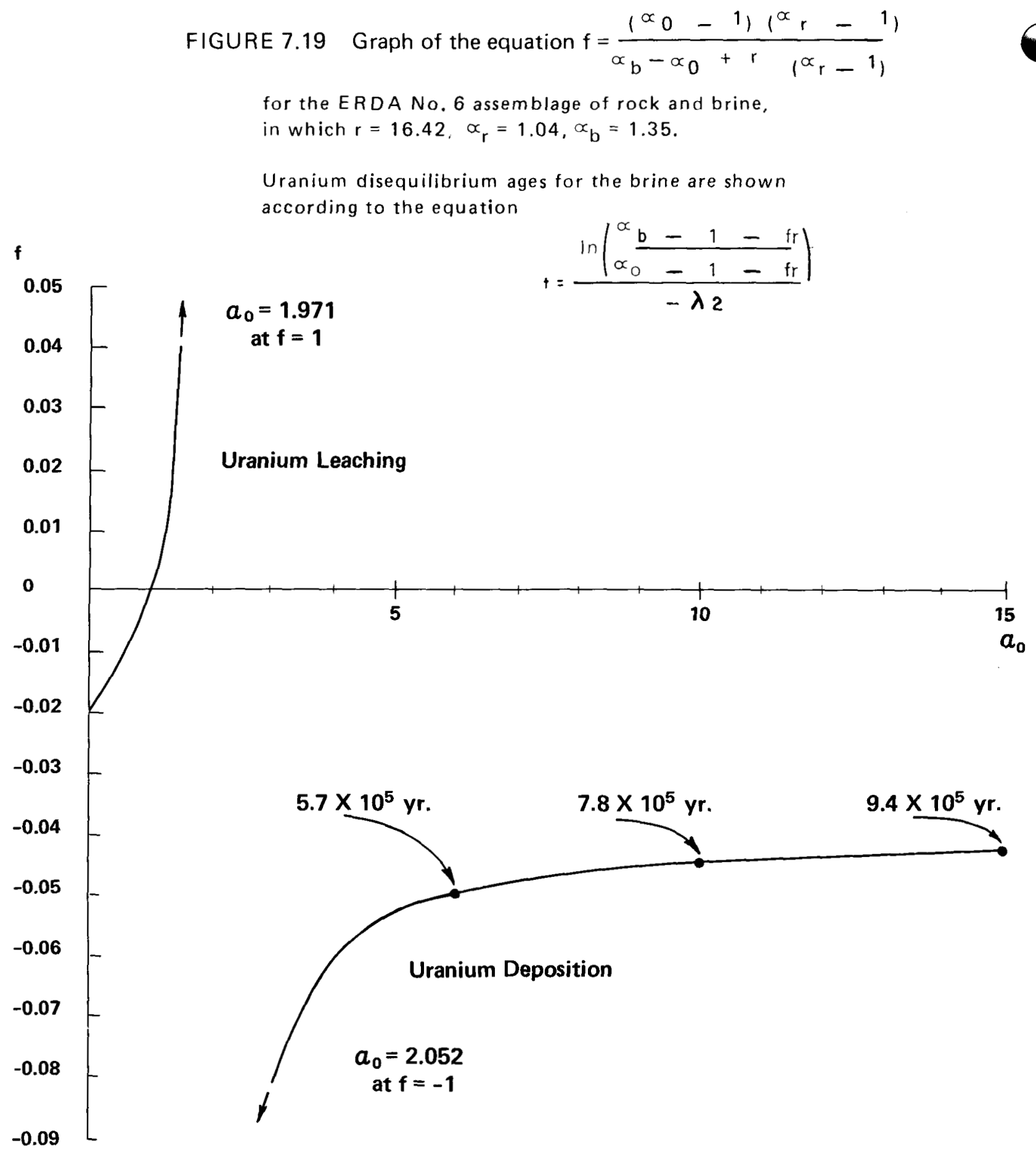

Note that the ERDA No. 6 assemblage is indicative of uranium deposition ( $f<0$ ) rather than uranium leaching. 


\section{$t$ (age)}

Million Years

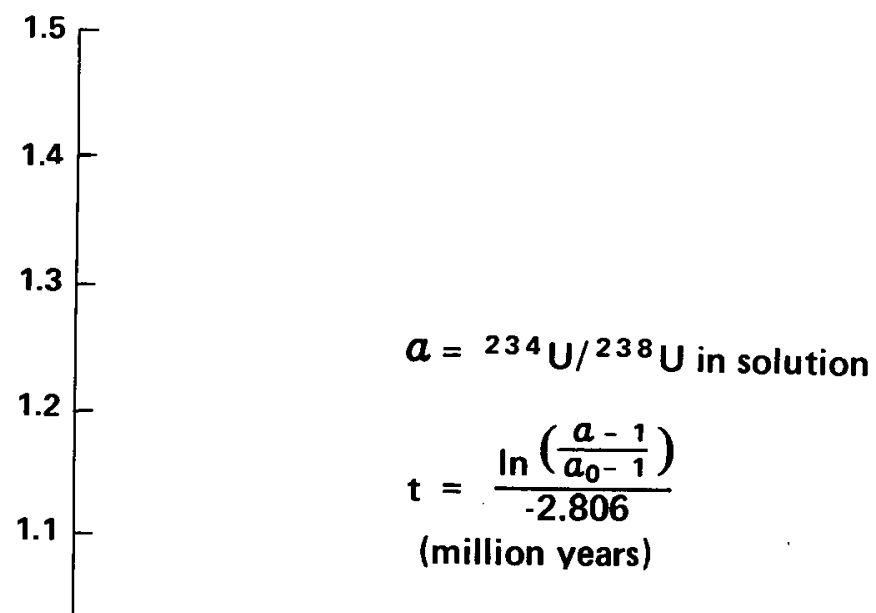

HACKBERRY
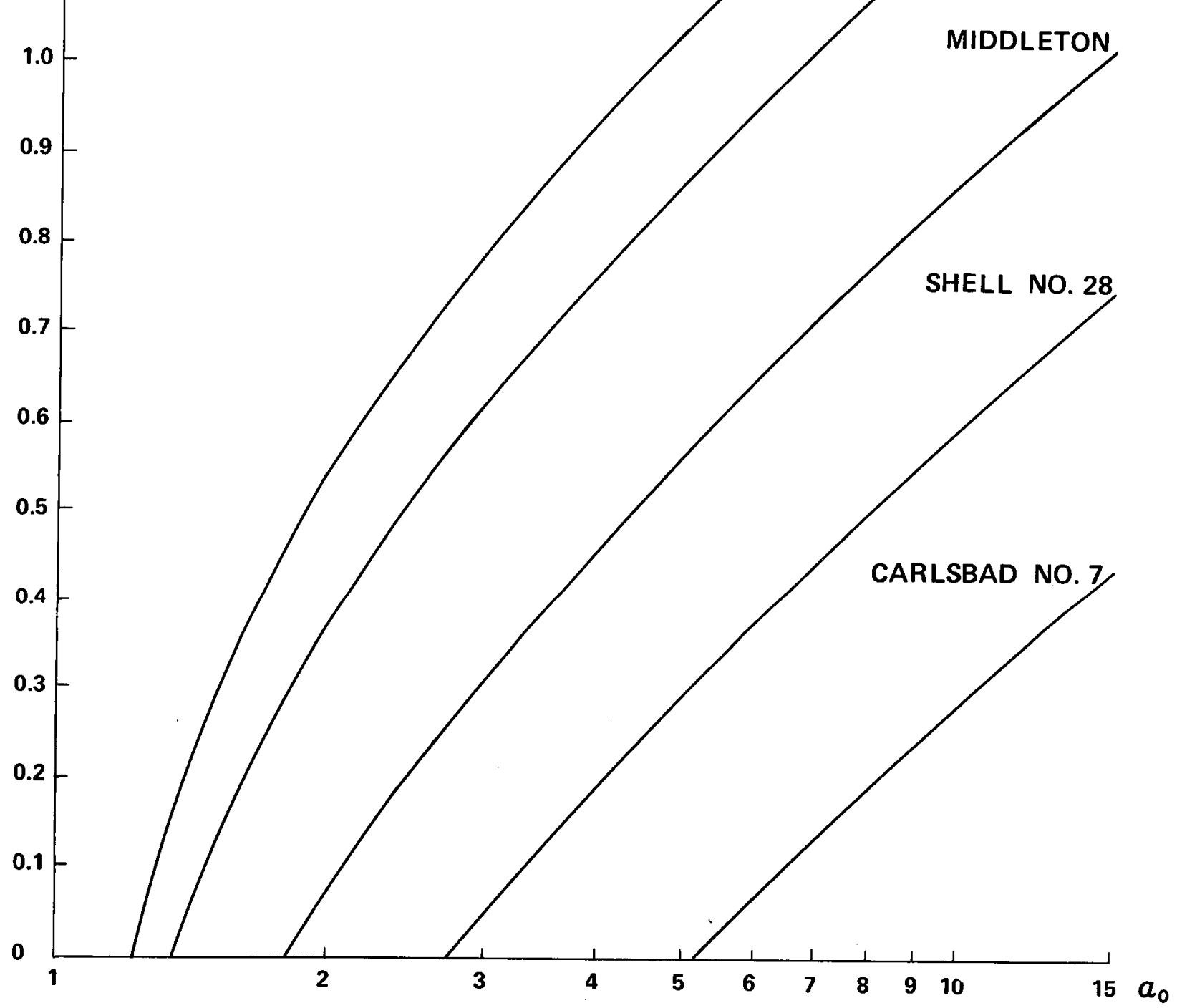

FIGURE 7.20 Uranium disequilibrium ages as a function of original $234 \mathrm{U} / 238 \mathrm{U}$ ratio, for Delaware Basin groundwaters. These curves are derived from a model involving no exchange or uranium between rock and water. 
TABLE 7.1. MINERAL CONTENT OF ERDA \# 9 CORE SAMPLES (M=MAJOR, T=TRACE).

ERDA 9

CORE \#

(DEPTH IN FEET) ANHYDRITE CLAY HALITE LOEWEITE MAGNESITE POLYHALITE QUARTZ SYLVITE

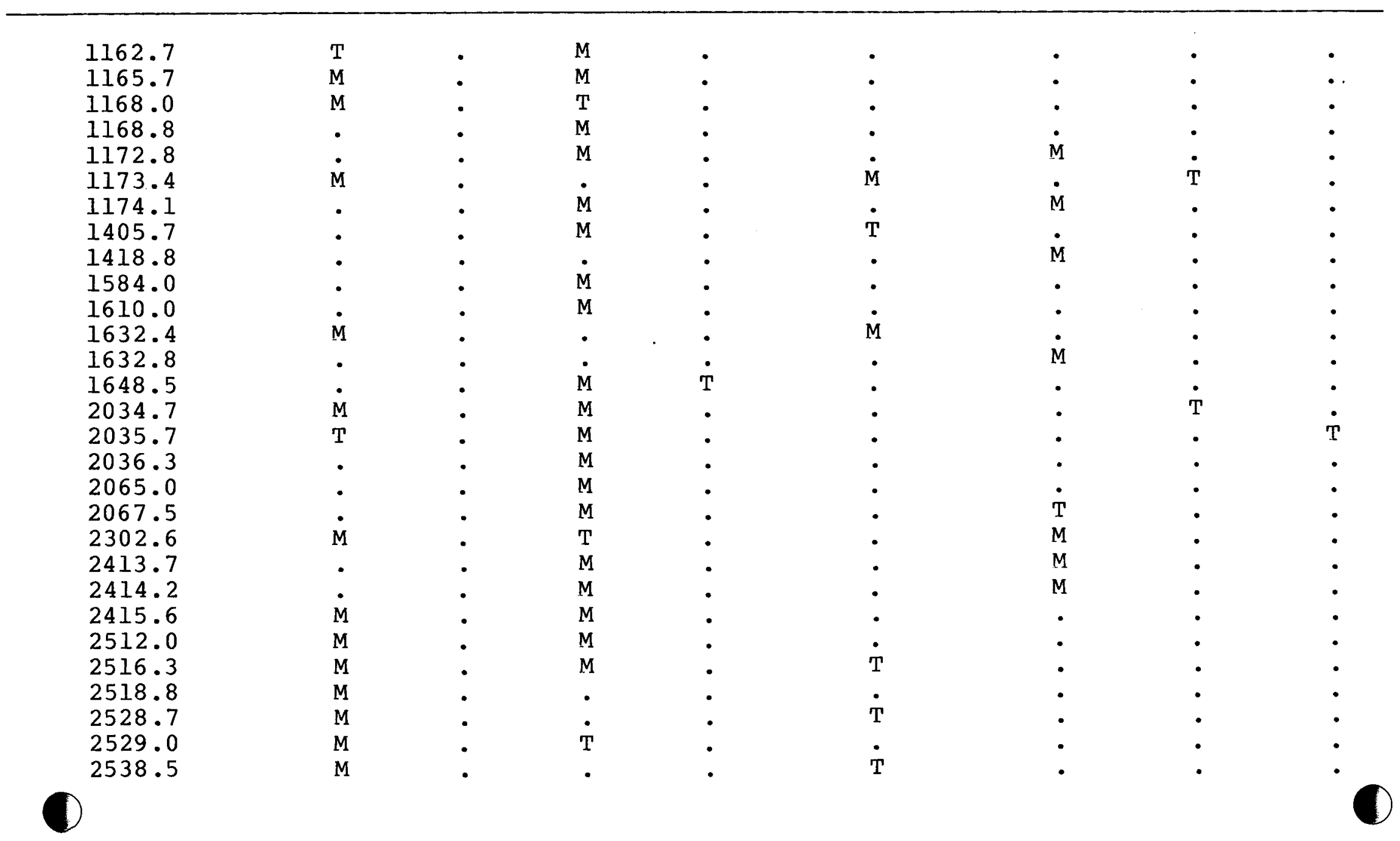


TABLE 7.1. MINERAL CONTENT OF ERDA \#9 CORE SAMPLES (M=MAJOR, T=TRACE), continued

ERDA 9

CORE \#

(DEPTH IN FEET) ANHYDRITE CLAY HALITE LOEWEITE MAGNESITE POLYHALITE QUARTZ SYLVITE

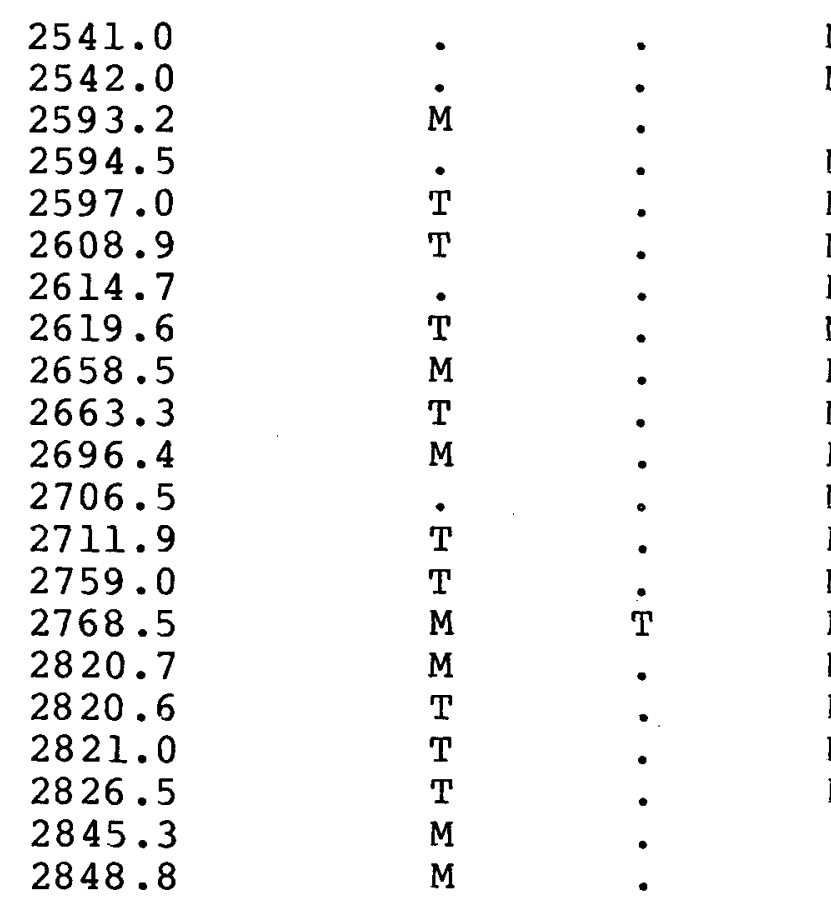

\begin{tabular}{|c|c|c|c|c|}
\hline M & - & - & • & $\bullet$ \\
\hline M & • & • & • & . \\
\hline$M$ & • & $\cdot$ & • & - \\
\hline$M$ & - & $\cdot$ & • & - \\
\hline M & • & • & • & • \\
\hline M & - & • & • & • \\
\hline M & - & • & • & - \\
\hline M & • & • & $\cdot$ & • \\
\hline M & • & • & • & • \\
\hline M & • & 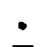 & • & . \\
\hline M & • & $\mathrm{T}$ & • & • \\
\hline M & • & $\dot{0}$ & • & - \\
\hline M & • & $\mathrm{T}$ & $\cdot$ & - \\
\hline M & • & • & • & • \\
\hline M & • & • & $\cdot$ & • \\
\hline M & • & • & $\cdot$ & - \\
\hline M & $\bullet$ & $\cdot$ & $\bullet$ & $\cdot$ \\
\hline $\begin{array}{l}M \\
M\end{array}$ & $\bullet$ & ${ }^{\circ}$ & : & $\therefore$ \\
\hline & & $\mathrm{T}$ & • & • \\
\hline & & • & & . \\
\hline
\end{tabular}


TABLE 7.2

Size Distribution of Ground Samples

$\begin{array}{lc}\frac{\text { Mesh }}{>20} & \text { of Sample* } \\ & 5.2 \\ 28035 & 8.8 \\ 35-65 & 19.9 \\ 65-100 & 57.0 \\ 100-200 & 6.1 \\ <200 & 2.9 \\ \end{array}$

*Total $\neq$ loo due to rounding 
TABLE 7.3

Iisting of Minerals Named in Subsection 7.3

\begin{tabular}{|c|c|}
\hline Mineral Name & Chemical Composition \\
\hline Anhydrite & $\mathrm{CaSO}_{4}$ \\
\hline Bloedite & $\mathrm{Na}_{2} \mathrm{Mg}\left(\mathrm{SO}_{4}\right)_{2} \cdot 4 \mathrm{H}_{2} \mathrm{O}$ \\
\hline Carnallite & $\mathrm{K} \mathrm{Mg} \mathrm{Cl}{ }_{3} \cdot 6 \mathrm{H}_{2} 0$ \\
\hline Chlorite & $\mathrm{Mg}_{5} \mathrm{Al}_{2} \mathrm{Si}_{3} \mathrm{O}_{10}(\mathrm{OH})_{8}$ \\
\hline Glaserite & $\mathrm{K}_{3} \mathrm{Na}\left(\mathrm{SO}_{4}\right)_{2}$ \\
\hline Glauberite & $\mathrm{Na}_{2} \mathrm{Ca}\left(\mathrm{SO}_{4}\right)_{2}$ \\
\hline Gypsum & $\mathrm{CaSO}_{4} \cdot 2 \mathrm{H}_{2} \mathrm{O}$ \\
\hline Halite & $\mathrm{NaCl}$ \\
\hline Illite & 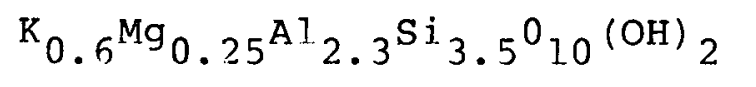 \\
\hline Iron Oxides (FEOX) & $\mathrm{Fe}_{2} \mathrm{O}_{3} \cdot \mathrm{XH}_{2} \mathrm{O}$ \\
\hline Kainite & $\mathrm{KMgCl} \mathrm{SO}_{4} \cdot 11 / 4 \mathrm{H}_{2} \mathrm{O}$ \\
\hline K-Feldspar & $\mathrm{KAI} \mathrm{Si}_{3}{ }^{0} 8$ \\
\hline Kieserite & $\mathrm{MgSO}_{4} \cdot \mathrm{H}_{2} \mathrm{O}$ \\
\hline Langbeinite & $\mathrm{K}_{2} \mathrm{Mg}_{2} \quad\left(\mathrm{SO}_{4}\right)_{3}$ \\
\hline Leonite & $\mathrm{K}_{2} \mathrm{Mg}\left(\mathrm{SO}_{4)} \cdot 4 \mathrm{H}_{2} \mathrm{O}\right.$ \\
\hline Montmorillonite & $\mathrm{Mg}_{0.16} \mathrm{Al}_{2.33} \mathrm{Si}_{3.67} 0_{10}^{(\mathrm{OH})_{2}}$ \\
\hline Polyhalite & $\mathrm{K}_{2} \mathrm{Mg} \mathrm{Ca}\left(\mathrm{SO}_{4}\right)_{4} \cdot 2 \mathrm{H}_{2} \mathrm{O}$ \\
\hline Quartz & $\mathrm{SiO}_{2}$ \\
\hline sylvite & $\mathrm{KCl}$ \\
\hline Talc & $\begin{array}{lllll}\mathrm{Mg}_{3} & \mathrm{Si}_{4} & 0_{10} & (\mathrm{OH})_{2}\end{array}$ \\
\hline Thenardite & $\mathrm{Na}_{2} \mathrm{SO}_{4}$ \\
\hline
\end{tabular}


TABLE 7.4

ERDA No. 9 Samples Chosen for Silicate Mineralogy

\section{Depth (ft)}

\section{$1163.3-1163.6$}

1165.1

1166.17

1167.5

1168.31

$1169.4-1169.5$

1172.9

$1173.7-1173.8$

\section{5 \\ $1242.9-1243.1$ \\ $1243.6-1243.7$ \\ $1244.2-1244.5$ \\ $1244.5-1244.8$ \\ 1244.8}

$1245.0-1245.3$

$1246.7-1247.1$

$1247.1-1247.2$

$1325.2-1325.4$

$1327.0-1327.2$

$1327.7-1327.8$

$1328.2-1328.4$

1328.6

$132.8 \cdot 7-1329.8$

\section{Sample}

MB-CS- 18

MB-CS-16

$M B-C S-17$

$\mathrm{MB}-\mathrm{CS}-1$

MB-C.S-6

MB-CS-19

MB-CS- 5

MB-CS-20

\section{Gross Lithology}

Rock salt

Anhydrite

- Anhydrite

Anhyarite

Anhydrite w/ halite

Rock salt

Polyhalite

Rock salt
Stratigraphic Position

SALADO Fm.

\section{$\mathrm{JL}-\mathrm{CS}-24$ \\ $\mathrm{JI}, \mathrm{CS}-18$ \\ $\mathrm{JL}-\mathrm{CS}-27$ \\ $\mathrm{J} \mathrm{I}-\mathrm{CS}-1.25$ \\ JL-CS-16 \\ $\mathrm{JL}-\mathrm{CS}-12$ \\ $\mathrm{JL}-\mathrm{CS}-20$ \\ $\mathrm{JL}-\mathrm{CS}-21$ \\ $\mathrm{JL}-\mathrm{CS}-5$}

Rock salt

Polyhalite w/ halite

Polyhalite $w /$ halite

Rock salt w/ polyhalite

Polyhalite w/ halite and clay

- Clay

Rock Salt

Rock Salt

o Clay
$\mathrm{JL}-\mathrm{CS}-10$

JL-CS -23

$J L-C S-26$

$\mathrm{JL}-\mathrm{CS}-25$

$\mathrm{JL}-\mathrm{CS}-3$

JL-CS -17
- Polyhalite $w /$ anhydrite veins Polyhalite Polyhalite $w /$ halite Polyhalite $w /$ halite and clay

- Clay Rock salt 


\section{Depth (ft)}

$1404.6-1404.7$

1418.2

1418.6

$1440.4-1440.6$

$1441.0-1.441 .3$ 1441.7

$1466.4-1466.6$

$1466.8-1467.1$

$1467.7-1468.1$ 1468.1
TABLE 7.4, continued

\section{Sample}

$M B-C S-21$

$\mathrm{MB}-\mathrm{CS}-7$

$\mathrm{JL}-\mathrm{CS}-2$

$\mathrm{JL}-\mathrm{CS}-6$

$\mathrm{JL}-\mathrm{CS}-4$

$\mathrm{JL}-\mathrm{CS}-11$

$\mathrm{JL}-\mathrm{CS}-9$

$\mathrm{JL}-\mathrm{CS}-22$

$\mathrm{JL}-\mathrm{CS}-14$
$\mathrm{MB}-\mathrm{CS}-8$

\section{Stratigraphic position}

Rock Salt

Anhydrite with clay seam

Polyhalite

11th ore zone

marker bed 117
- Polyhalite w/ hal ite

- Polyhalite

o Clay

- Polyhalite w/ clay

o Polyhalite w/ clay

Rock salt w/ clay

o Clay

$\begin{array}{cll}1535.6-1535.8 & \text { JL-CS }-8 & \text { Polyhalite w/ anhydrite } \\ 1536.5 & \text { JL-CS-7 } & \text { Anhydrite } \\ 1535.5-1536.6 & \text { JL-CS-19 } & \text { Polyhalite w/ clay } \\ 1537.8-1537.9 & \text { JL-CS-18 } & \text { o Polyhalite w/ anhydrite }\end{array}$

$1584.4-1584.5$

$1609.5-1609.8$

$1649.4-1649.6$

MB-CS- 22

MB-CS- 23

$M B-C S-24$

Rock sal.t

Rock salt

Rock salt

near 5 th ore zone

near 4 th ore zone

$\begin{array}{cll}2034.5 & \text { MB-CS-14 } & \text { Anhydrite } \\ 2035.6-2035.9 & \text { MB-CS-25 } & \text { Rock salt } \\ 2036.5-2036.7 & \text { MB-CS-26 } & \text { Rock salt } \\ 2037.3 & \text { MB-CS-4 } & \text { O Anhydrite }\end{array}$




\section{Depth (ft) \\ $2065.3-2065.4$ \\ 2066.1}

2067.0

Sample

MB-CS -29

MB-CS- 28

MB-CS- 27
TABLE 7.4 , continued

\section{Gross Lithology}

\section{Stratigraphic Position}

Rock salt

Rock salt

o Rock salt

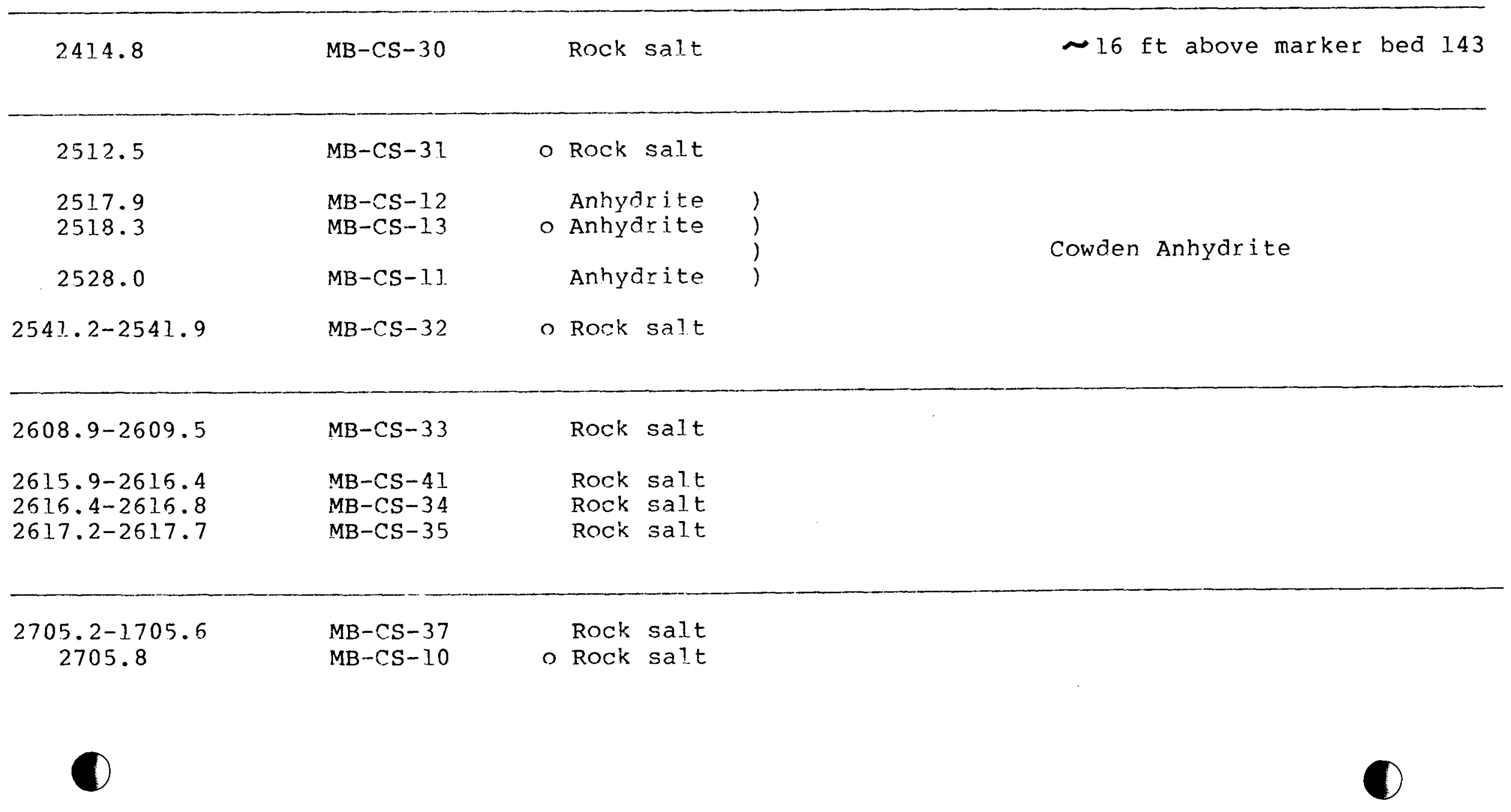


Depth (ft)

$2758.2-2758.6$

$2819.1-2819.6$

2820.2

2820.3

$2821.1-2821.7$

$2827.3-2827.5$

2846.0

2848.4

$2867.4-2867.6$

\section{Sample}

$M B-C S-36$

o Rock salt

\section{$\underline{\text { Stratigraphic Position }}$}

Gross Lithology

$\begin{array}{lc}\text { MB-CS-39 } & \text { O Rock salt } \\ \text { MB-CS-15 } & \text { o Anhydrite } \\ \text { MB-CS-2 } & \text { Anhydrite } \\ \text { MB-CS-38 } & \text { Rock salt } \\ \text { MB-CS-40 } & \text { o Rock salt } \\ \text { MB-CS-9 } & \text { o Anhydrite } \\ \text { MB-CS-3 } & \text { O Anhydrite } \\ \text { MB-CS-42 } & \text { Anhydrite }\end{array}$

Anhydrite Rock salt

Anhydrite
CASTILE Fm.

- Samples subjected to semi quantitative analysis (see Table 7.10). 
TABLE 7.5

Core depths of samples selected for mineralogic-geochemical analysis.

\begin{tabular}{|c|c|c|c|}
\hline Sample & Depth (ft) & Sample & Depth ( $f t)$ \\
\hline $\begin{array}{r}M B-C S-1 \\
-2 \\
-3 \\
-4 \\
-5\end{array}$ & $\begin{array}{l}1167.5 \\
2820.3 \\
2848.4 \\
2037.3 \\
1172.9\end{array}$ & $\begin{array}{r}M C-C S-36 \\
-37 \\
-38 \\
-39 \\
-40\end{array}$ & $\begin{array}{l}2758 \cdot 2-2758 \cdot 6 \\
2705.2-2705.6 \\
2821.1-2821.7 \\
2819.1-2818.6 \\
2827.3-2827.5\end{array}$ \\
\hline $\begin{array}{r}M B-C S-6 \\
-7 \\
-8 \\
-9 \\
-10\end{array}$ & $\begin{array}{l}1168.3 \\
1418.2 \\
1418.6 \\
2846.0 \\
2705.8\end{array}$ & $\begin{array}{r}M C-C S-41 \\
-42\end{array}$ & $\begin{array}{l}2615.9-2615.4 \\
2867.4-2867.6\end{array}$ \\
\hline $\begin{array}{r}M B-C S-11 \\
-12 \\
-13 \\
-14 \\
-15\end{array}$ & $\begin{array}{l}2528.0 \\
2517.9 \\
2518.3 \\
2034.5 \\
2820.2\end{array}$ & $\begin{array}{r}\mathrm{JL}-\mathrm{CS}-1 \\
-2 \\
-3 \\
-4 \\
-5\end{array}$ & $\begin{aligned} & 1441.5 \\
& 1440 . 4-1440.6 \\
& 1328.6 \\
& 1441.7 \\
& 1247 . 1-1247.3\end{aligned}$ \\
\hline $\begin{array}{r}M B-C S-16 \\
-17 \\
-18 \\
-19 \\
-20\end{array}$ & $\begin{array}{c}1165.1 \\
1166.2 \\
1163.3-1163.6 \\
1169.4-1169.5 \\
1173.7-1173.8\end{array}$ & $\begin{array}{r}\text { JL-CS }-6 \\
-7 \\
-8 \\
-9 \\
-10\end{array}$ & $\begin{array}{r}1441.0-1441.3 \\
1536.5 \\
1535.6-1535.8 \\
1466.8-1467.1 \\
1325.2-1325.4\end{array}$ \\
\hline $\begin{array}{r}M B-C S-21 \\
-22 \\
-23 \\
-24 \\
-25\end{array}$ & $\begin{array}{l}1404.6-1404.7 \\
1484.4-1584.5 \\
1609.5-1609.8 \\
1649.4-1649.6 \\
2035.5-2035.9\end{array}$ & $\begin{array}{r}J L-C S-11 \\
-12 \\
-13 \\
-14 \\
-15\end{array}$ & $\begin{array}{c}1466.4-1466.6 \\
1244.8 \\
1467.5 \\
1468.1 \\
1244.2-1244.5\end{array}$ \\
\hline $\begin{array}{r}M B-C S-26 \\
-27 \\
-28 \\
-29 \\
-30\end{array}$ & $\begin{array}{c}2036.5-2036.7 \\
2067.0 \\
2066.1 \\
2065.3 \\
2414.8\end{array}$ & $\begin{aligned} & J L-C S-16 \\
&-17 \\
&-18 \\
&-19 \\
&-20\end{aligned}$ & $\begin{array}{l}1244.5-1244.8 \\
1328.7-1329.8 \\
1537.8-1537.9 \\
1536.5-1536.6 \\
1245.0-1245.3\end{array}$ \\
\hline
\end{tabular}


TABLE 7.5, continued

Core depths of samples selected for mineralogic-geochemical analysis.

$\begin{array}{rc}\text { Sample } & \text { Depth (ft) } \\ \text { MB-CS-31 } & 2512.5 \\ -32 & 2541.2-2541.9 \\ -33 & 2608.9-2509.5 \\ -34 & 2616.4-2616.8 \\ -35 & 2617.2-2617.7\end{array}$

Sample Depth (ft)

JL-CS-21 $1246.7-1247.1$

$-22 \quad 1467.7-1468.1$

$-23 \quad 1327.0-1327.2$

$\begin{array}{ll}-24 & 1242.5-1242.8\end{array}$

$-25 \quad 1328.2-1328.4$

JL-CS-26 $1327.7-1327.8$

$-27 \quad 1343.6-1343.7$

$-28 \quad 1242.9-1243.1$ 
TABLE 7.6

Quantities of water-leach and EDTA-leach residues in samples from the ERDA-9 core. Sulfate lithologies (anhydrites and polyhalites) and salztons were not subjected to water leach.

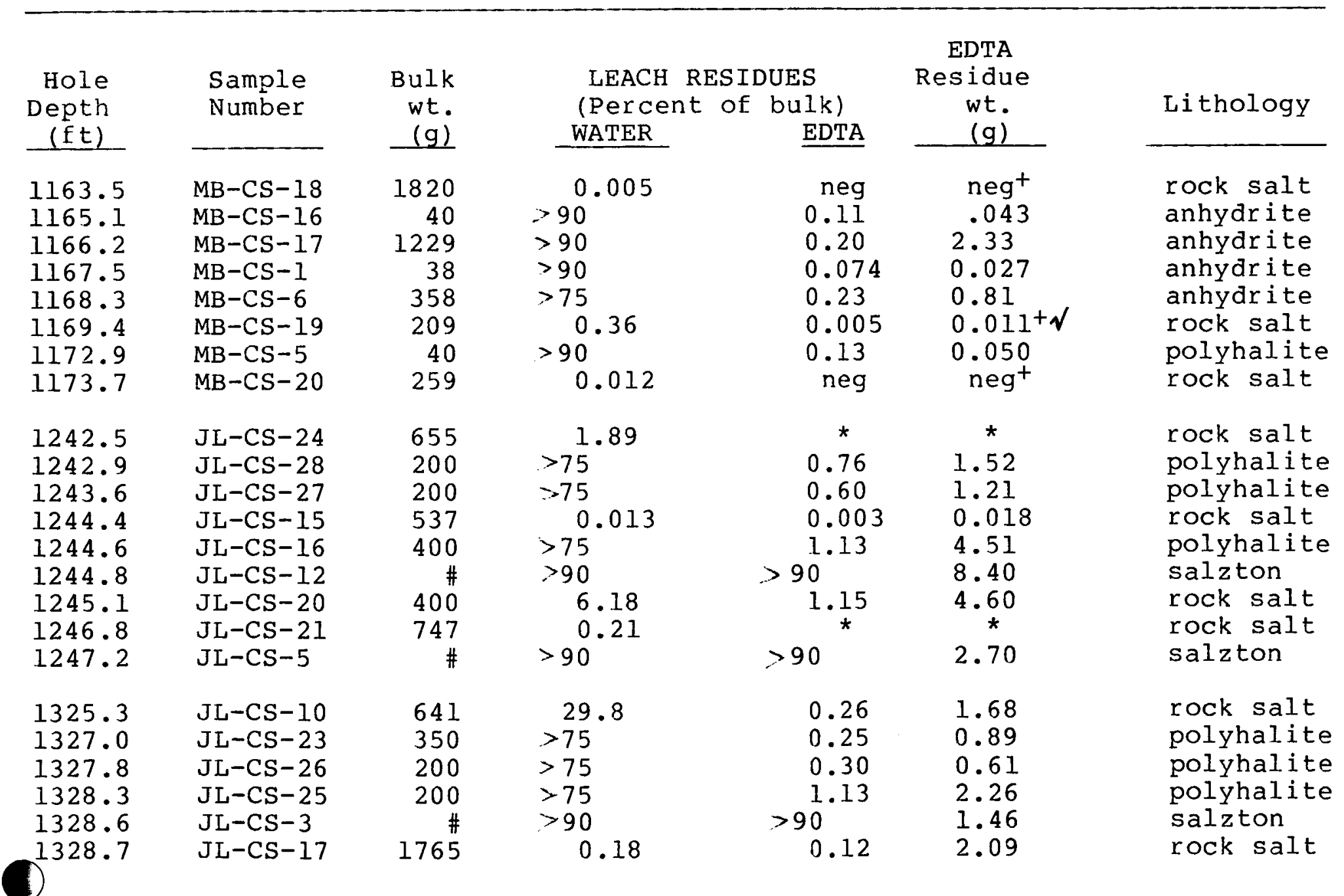




\begin{tabular}{|c|c|c|c|c|c|c|}
\hline $\begin{array}{r}\text { Hole } \\
\text { Depth } \\
(\mathrm{ft}) \\
\end{array}$ & $\begin{array}{l}\text { Sample } \\
\text { Number }\end{array}$ & $\begin{array}{r}\text { Bujk } \\
\text { wt. } \\
\text { (g) } \\
\end{array}$ & \multicolumn{2}{|c|}{$\begin{array}{l}\text { LEACH RESIDUES } \\
\text { (Percent of bu } 1 \mathrm{k} \text { ) }\end{array}$} & $\begin{array}{c}\text { EDTA } \\
\text { Residue } \\
\text { wt. } \\
(g) \\
\end{array}$ & Lithology \\
\hline $\begin{array}{l}1404.6 \\
1418.2 \\
1418.6\end{array}$ & $\begin{array}{l}\mathrm{MB}-\mathrm{CS}-21 \\
\mathrm{MB}-\mathrm{CS}-7 \\
\mathrm{MB}-\mathrm{CS}-8\end{array}$ & $\begin{array}{r}244 \\
40 \\
1120\end{array}$ & $\begin{aligned} & 2.5 \\
> & 90 \\
> & 90\end{aligned}$ & $\begin{array}{c}1.0 \\
20.80 \\
0.62\end{array}$ & $\begin{array}{l}2.43 \\
8.32 \\
6.94\end{array}$ & $\begin{array}{l}\text { rock salt } \\
\text { anhydrite } \\
\text { polyhalite }\end{array}$ \\
\hline $\begin{array}{l}1440.5 \\
1441.2 \\
1441.7\end{array}$ & $\begin{array}{l}J L-C S-2 \\
J L-C S-6 \\
J L-C S-4\end{array}$ & $\begin{array}{r}200 \\
600 \\
\#\end{array}$ & $\begin{array}{l}>75 \\
>75 \\
>90\end{array}$ & $\begin{array}{r}0.83 \\
0.13 \\
>90\end{array}$ & $\begin{array}{l}1.66 \\
0.80 \\
2.92\end{array}$ & $\begin{array}{l}\text { polyhalite } \\
\text { polyhalite } \\
\text { salzton }\end{array}$ \\
\hline $\begin{array}{l}1466.5 \\
1466.9 \\
1467.9 \\
1468.1\end{array}$ & $\begin{array}{l}J L-C S-11 \\
J L-C S-9 \\
J L-C S-22 \\
J L-C S 014\end{array}$ & $\begin{array}{r}400 \\
200 \\
860 \\
\#\end{array}$ & $\begin{array}{l}>75 \\
>75 \\
4.17 \\
>90\end{array}$ & $\begin{array}{r}0.42 \\
3.99 \\
1.22 \\
>90\end{array}$ & $\begin{array}{c}1.67 \\
7.97 \\
10.5 \\
3.30\end{array}$ & $\begin{array}{l}\text { polyhalite } \\
\text { polyhalite } \\
\text { rock salt. } \\
\text { saltzon }\end{array}$ \\
\hline $\begin{array}{l}1535.7 \\
1536.5 \\
1536.6 \\
1537.8\end{array}$ & $\begin{array}{l}J L-C S-8 \\
J L-C S-7 \\
J L-C S-19 \\
J L-C S-18\end{array}$ & $\begin{array}{l}400 \\
320 \\
360 \\
400\end{array}$ & $\begin{array}{l}>75 \\
>75 \\
>75 \\
>75\end{array}$ & $\begin{array}{l}0.44 \\
2.63 \\
0.37 \\
0.55\end{array}$ & $\begin{array}{l}1.76 \\
8.41 \\
1.33 \\
2.19\end{array}$ & $\begin{array}{l}\text { polyhalite } \\
\text { anhydrite } \\
\text { polyhalite } \\
\text { polyhalite }\end{array}$ \\
\hline $\begin{array}{l}1584.4 \\
1609.6 \\
1649.5 \\
2034.5 \\
2035.7 \\
2036.6 \\
2073.3\end{array}$ & $\begin{array}{l}M B-C S-22 \\
M B-C S-23 \\
M B-C S-24 \\
M B-C S-14 \\
M B-C S-25 \\
M B-C S-26 \\
M B-C S-4\end{array}$ & $\begin{array}{l}248 \\
473 \\
176 \\
104 \\
891 \\
810 \\
145\end{array}$ & $\begin{array}{rl} & 0.53 \\
0.037 & 1.6 \\
& 1.6 \\
> & 0 \\
& 0.23 \\
& 0.23 \\
>90\end{array}$ & $\begin{array}{l}0.42 \\
0.017 \\
1.1 \\
3.9 \\
0.009 \\
0.025 \\
5.0\end{array}$ & $\begin{array}{l}1.20+\sqrt{ } \\
0.081 \\
1.90+\sqrt{ } \\
4.07 \\
0.078+\sqrt{ } \\
0.20+\sqrt{ } \\
7.28\end{array}$ & $\begin{array}{l}\text { rock salt } \\
\text { rock salt } \\
\text { rock salt } \\
\text { anhydrite } \\
\text { rock salt } \\
\text { rock salt } \\
\text { anhydrite }\end{array}$ \\
\hline $\begin{array}{l}2065.3 \\
2065.1 \\
2067.0\end{array}$ & $\begin{array}{l}M B-C S-29 \\
M B-C S-28 \\
M B-C S-27\end{array}$ & $\begin{array}{r}1085 \\
220 \\
229\end{array}$ & $\begin{array}{l}0.18 \\
3.3 \\
2.8\end{array}$ & $\begin{array}{l}0.11 \\
1.5 \\
0.83\end{array}$ & $\begin{array}{l}1.17^{+\sqrt{ }} \\
3.38 \\
1.90\end{array}$ & $\begin{array}{ll}\text { rock salt } \\
\text { rock salt } \\
\text { rock salt }\end{array}$ \\
\hline 2414.8 & $M B-C S-30$ & 421 & 36.3 & 0.049 & 0.21 & rock salt \\
\hline
\end{tabular}


TABLE 7.5 , continued

\begin{tabular}{|c|c|c|c|c|c|c|}
\hline $\begin{array}{r}\text { Hole } \\
\text { Depth } \\
\text { (ft) } \\
\end{array}$ & $\begin{array}{l}\text { Sample } \\
\text { Number }\end{array}$ & $\begin{array}{l}\text { Bulk } \\
\text { wt. } \\
(g) \\
\end{array}$ & $\begin{array}{l}\text { LEACH } \\
\text { (Percen } \\
\text { WATER } \\
\end{array}$ & $\begin{array}{l}\text { RESIDUES } \\
\text { t of bu } 1 \mathrm{k}) \\
\text { EDTA }\end{array}$ & $\begin{array}{c}\text { EDTA } \\
\text { Residue } \\
\text { wt. } \\
(\mathrm{g}) \\
\end{array}$ & Lithology \\
\hline $\begin{array}{l}2512.5 \\
2517.9 \\
2518.3 \\
2528.0 \\
2541.5\end{array}$ & $\begin{array}{l}\mathrm{MB}-\mathrm{CS}-31 \\
\mathrm{MB}-\mathrm{CS}-12 \\
\mathrm{MB}-\mathrm{CS}-13 \\
\mathrm{MB}-\mathrm{CS}-11 \\
\mathrm{MB}-\mathrm{CS}-32\end{array}$ & $\begin{array}{r}1073 \\
40 \\
586 \\
40 \\
891\end{array}$ & $\begin{array}{l}1.79 \\
>90 \\
>90 \\
>90 \\
\quad 0.70\end{array}$ & $\begin{array}{l}0.074 \\
0.024 \\
0.55 \\
0.23 \\
0.21\end{array}$ & $\begin{array}{l}0.074 \\
0.010^{+} \\
3.20 \\
0.094 \\
1.83\end{array}$ & $\begin{array}{l}\text { rock salt } \\
\text { anhydrite } \\
\text { anhydrite } \\
\text { anhydrite } \\
\text { rock salt }\end{array}$ \\
\hline $\begin{array}{l}2609.2 \\
2616.2 \\
2616.5 \\
2617.5\end{array}$ & $\begin{array}{l}M B-C S-33 \\
M B-C S-41 \\
M B-C S-34 \\
M B-C S-35\end{array}$ & $\begin{array}{r}901 \\
811 \\
660 \\
1015\end{array}$ & $\begin{array}{l}0.043 \\
0.165 \\
0.071 \\
1.17\end{array}$ & $\begin{array}{l}0.015 \\
0.076 \\
0.004 \\
0.18\end{array}$ & $\begin{array}{l}0.14+\sqrt{ } \\
0.62+\sqrt{ } \\
0.027+\sqrt{ } \\
1.83\end{array}$ & $\begin{array}{ll}\text { rock sal.t } \\
\text { rock salt } \\
\text { rock salt } \\
\text { rock salt }\end{array}$ \\
\hline $\begin{array}{l}2705.4 \\
2705.8\end{array}$ & $\begin{array}{l}M B-C S-37 \\
M B-C S-10\end{array}$ & $\begin{array}{l}638 \\
450\end{array}$ & $\begin{aligned} & 13.3 \\
> & 90\end{aligned}$ & $\begin{array}{l}0.65 \\
2.2\end{array}$ & $\begin{array}{l}4.14 \\
9.87\end{array}$ & $\begin{array}{l}\text { rock salt } \\
\text { anhydrite }\end{array}$ \\
\hline 2758.4 & $M B-C S-36$ & 421 & 6.5 & 0.77 & 3.25 & rock salt \\
\hline $\begin{array}{l}2819.3 \\
2820.2 \\
2820.3 \\
2821.4 \\
2828.7\end{array}$ & $\begin{array}{l}M B-C S-39 \\
M B-C S-15 \\
M B-C S-2 \\
M B-C S-38 \\
M B-C S-40\end{array}$ & $\begin{array}{l}982 \\
520 \\
640 \\
916 \\
920\end{array}$ & $\begin{aligned} & 2.2 \\
&> 90 \\
&> 90 \\
& 1.25 \\
& 1.22\end{aligned}$ & $\begin{array}{l}0.27 \\
0.82 \\
0.59 \\
0.039 \\
0.13\end{array}$ & $\begin{array}{l}2.65 \\
4.25 \\
3.79 \\
0.36 \\
1.17\end{array}$ & $\begin{array}{l}\text { rock salt } \\
\text { anhydrite } \\
\text { anhydrite } \\
\text { rock salt } \\
\text { rock salt }\end{array}$ \\
\hline $\begin{array}{l}2846.0 \\
2848.4 \\
2867.5\end{array}$ & $\begin{array}{l}M B-C S-9 \\
M B-C S-3 \\
M B-C S-42\end{array}$ & $\begin{array}{l}200 \\
656 \\
240\end{array}$ & $\begin{array}{l}>90 \\
>90 \\
>90\end{array}$ & $\begin{array}{l}1.2 \\
0.90 \\
0.85\end{array}$ & $\begin{array}{l}2.45 \\
5.93 \\
2.04\end{array}$ & $\begin{array}{l}\text { anhydrite } \\
\text { anhydrite } \\
\text { anhydrite }\end{array}$ \\
\hline
\end{tabular}

* Water-leach and EDTA-leach dissolutions of this sample not complete.

Tample is hand-picked fragment of saltzton.

leported as containing "negligible insoluble residue" Table 7.7 .

n cirhonriunt comnnd ricanlution of a substantially qreater quantitiy of 
TABLE 7.7

Relative Abundances of minerals in EDTA-insoluble residues.

\begin{tabular}{|c|c|c|c|c|c|c|c|c|c|c|}
\hline \multirow{3}{*}{$\begin{array}{l}\text { Sample } \\
\text { MB-CS-18 }\end{array}$} & \multirow{3}{*}{$\begin{array}{c}\begin{array}{c}\text { Depth } \\
\text { (ft) }\end{array} \\
1163.5\end{array}$} & \multicolumn{4}{|c|}{ EDTA-insoluble residue } & \multicolumn{3}{|c|}{$<2 \mu \mathrm{m}$ fraction } & \multicolumn{2}{|c|}{ of residue } \\
\hline & & qtz & feld & hem & clay & i1 & $\mathrm{ch}$ & serp & talc & $\exp$ \\
\hline & & \multicolumn{4}{|c|}{ Negligible } & insoluble & \multicolumn{2}{|c|}{ residue } & & \\
\hline $\mathrm{MB}-\mathrm{CS}-15$ & 1165.1 & $\mathrm{XX}$ & -- & -- & $\mathrm{x}$ & $\mathrm{x}$ & a & -- & -- & $\mathrm{XX}$ \\
\hline $\mathrm{MB}-\mathrm{CS}-17$ & 1166.2 & $x x$ & $\mathrm{x}$ & -- & $\mathrm{xX}$ & $\mathrm{x}$ & a & -- & -- & $\mathrm{xx}$ \\
\hline $\mathrm{MB}-\mathrm{CS}-1$ & 1167.5 & -- & -- & -- & $\mathrm{XX}$ & $\mathrm{x}$ & -- & -- & -- & $\mathrm{XX}$ \\
\hline$M B-C S-6$ & 1168.3 & $x x$ & $\mathrm{x}$ & -- & $x X$ & $\mathrm{x}$ & a & -- & -- & $x x$ \\
\hline$M B-C S-19$ & 1169.4 & & & \multicolumn{2}{|c|}{ Negligible } & insoluble & \multicolumn{2}{|c|}{ residue } & & \\
\hline$M B-C S-5$ & 1172.9 & $\mathrm{XX}$ & -- & -- & $\mathrm{x}$ & $\mathrm{x}$ & -- & $\cdots$ & -- & $X X$ \\
\hline$M B-C S-20$ & 1173.7 & & & \multicolumn{2}{|c|}{ Negligible } & insoluble & \multicolumn{2}{|c|}{ residue } & & \\
\hline $\mathrm{JL}-\mathrm{CS}-12$ & 1244.8 & $\mathrm{XX}$ & $\mathrm{x}$ & -- & $x X$ & $\mathrm{x}$ & $\mathrm{x}$ & -- & -- & $\mathrm{X}$ \\
\hline$J L-C S-5$ & 1247.2 & $X X$ & $\mathrm{x}$ & -- & $\mathrm{XX}$ & $\mathrm{XX}$ & $\mathrm{x}$ & -- & -- & $\mathrm{X}$ \\
\hline$J I-C S-10$ & 1325.3 & $\mathrm{a}$ & -- & -- & $\mathrm{XX}$ & $\cdots$ & -- & -- & -- & $\mathrm{XX}$ \\
\hline$J L-C S-3$ & 1328.5 & $x X$ & $\mathrm{x}$ & -- & $\mathrm{XX}$ & $\mathrm{x}$ & $\mathrm{x}$ & -- & -- & $\mathrm{X}$ \\
\hline
\end{tabular}


TABLE 7.7 , continued

Relative Abundances of minerals in EDTA-insoluble residues (cont'd).

\begin{tabular}{|c|c|c|c|c|c|c|c|c|c|c|}
\hline \multirow[b]{2}{*}{ Sample } & \multirow{2}{*}{$\begin{array}{c}\text { Depth } \\
(\mathrm{ft}) \\
\end{array}$} & \multicolumn{4}{|c|}{ EDTA-insoluble residue } & \multicolumn{5}{|c|}{$<2 \mu \mathrm{m}$ fraction of residue } \\
\hline & & $q t z$ & feld & hem & clay & il & $\mathrm{ch}$ & serp & talc & exp \\
\hline$M B-C S-21$ & 1404.6 & $\mathrm{XX}$ & a & -- & $\mathrm{XX}$ & $\mathrm{x}$ & $x$ & -- & $\mathrm{x}$ & $x \mathrm{x}$ \\
\hline $\mathrm{MB}-\mathrm{CS}-7$ & 1418.2 & - & $\mathrm{x}$ & -- & $\mathrm{XX}$ & $\mathrm{xx}$ & $\mathrm{x}$ & -- & -- & $\mathrm{x}$ \\
\hline $\mathrm{MB}-\mathrm{CS}-8$ & 1418.6 & -- & a & $\mathrm{x}$ & $\mathrm{xX}$ & $\mathbf{x}$ & $\mathrm{x}$ & -- & -- & $x x$ \\
\hline$J L-C S-2$ & .1440 .5 & $\mathrm{X}$ & $\mathrm{XX}$ & a & $\mathrm{XX}$ & $\mathrm{a}$ & a & -- & -- & $x x$ \\
\hline $\mathrm{JL}-\mathrm{CS}-6$ & 1441.2 & $\mathrm{X}$ & $x X$ & $\mathrm{x}$ & $\mathrm{XX}$ & $x x$ & $\mathrm{x}$ & -- & -- & $\mathrm{x}$ \\
\hline$J L-C S-4$ & 144.1 .7 & -- & $\mathrm{x}$ & -- & $X X$ & $\mathrm{xx}$ & $\mathrm{x}$ & -- & -- & $\mathrm{x}$ \\
\hline$J L-C S-11$ & 1466.5 & - & $\mathrm{x}$ & $\mathrm{x}$ & $\mathrm{XX}$ & $\mathrm{XX}$ & $\mathrm{x}$ & -- & -- & $\mathrm{x}$ \\
\hline$J L-C S-9$ & 1466.9 & $X X$ & $x$ & $\mathrm{x}$ & $\mathrm{x}$ & $x x$ & $\mathrm{x}$ & -- & -- & $X X$ \\
\hline $\mathrm{JL}-\mathrm{CS}-14$ & 1468.1 & $\mathrm{X}$ & $\mathrm{x}$ & $-\sim$ & $\mathrm{XX}$ & $\mathrm{XX}$ & $\mathrm{X}$ & -- & -- & $\mathrm{XX}$ \\
\hline
\end{tabular}


TABLE 7.7 , continued

Relative Abundances of minerals in EDTA-insoluble residues (cont'd).

\begin{tabular}{|c|c|c|c|c|c|c|c|c|c|c|}
\hline \multirow[b]{2}{*}{ Sample } & \multirow{2}{*}{$\begin{array}{l}\text { Depth } \\
(\mathrm{ft}) \\
\end{array}$} & \multicolumn{4}{|c|}{ EDTA-insoluble residue } & \multicolumn{2}{|c|}{$<2 \mu \mathrm{m}$} & m fraction & \multicolumn{2}{|c|}{ of residue } \\
\hline & & qtz & feld & hem & clay & iI & $\mathrm{ch}$ & serp & talc & exp \\
\hline $\mathrm{JL}-\mathrm{CS}-8$ & 1535.7 & -- & $\mathrm{x}$ & $x$ & $\mathrm{xX}$ & $\mathrm{XX}$ & $\mathrm{x}$ & -- & -- & $x x$ \\
\hline $\mathrm{JL}-\mathrm{CS}-7$ & 1536.5 & a & -- & -- & $\mathrm{xX}$ & -- & - & -- & -- & $x x$ \\
\hline $\mathrm{JL}-\mathrm{CS}-18$ & 1537.8 & $\mathrm{x}$ & -- & $x$ & $\mathrm{XX}$ & $x x$ & $\mathrm{x}$ & -- & -- & $\mathrm{x}$ \\
\hline$M B-C S-22$ & 1584.4 & & & Negl & ible & insoluble & res & lue & & \\
\hline$M B-C S-23$ & 1609.6 & $x x$ & $\mathrm{x}$ & $x$ & $\mathrm{XX}$ & $\mathrm{xx}$ & $\mathrm{x}$ & -- & -- & $\mathrm{xX}$ \\
\hline$M B-C S-24$ & 1649.5 & & & Negl & gible & insoluble & res & lue & & \\
\hline$M B-C S-14$ & 2034.5 & $\mathrm{XX}$ & -- & -- & $x$ & $x$ & $\mathrm{x}$ & -- & -- & $\mathrm{XX}$ \\
\hline MB-CS- 25 & 2035.7 & & & Negl & gible & insoluble & res & lue & & \\
\hline$M B-C S-26$ & 2036.6 & & & Neg] & ible & insoluble & res & lue & & \\
\hline MB-CS- 4 & 2037.3 & $\mathrm{XX}$ & $\ldots$ & -- & $\mathrm{X}$ & $x$ & $\mathrm{x}$ & -- & - & $x X$ \\
\hline
\end{tabular}


TABLE 7.7 , continued

Relative Abundances of minerals in EDTA-insoluble residues (cont'd).

\begin{tabular}{|c|c|c|c|c|c|c|c|c|c|c|}
\hline \multirow[b]{2}{*}{ Sample } & \multirow{2}{*}{$\begin{array}{l}\text { Depth } \\
(\mathrm{ft}) \\
\end{array}$} & \multicolumn{3}{|c|}{ EDTA-insoluble } & residue & \multirow{2}{*}{$\begin{array}{l}<2 \mu \\
\text { i. } 1 \\
\end{array}$} & \multirow{2}{*}{$\begin{array}{l}\mathrm{mf} \\
\mathrm{ch}\end{array}$} & \multirow{2}{*}{$\begin{array}{l}\text { action } \\
\text { serp }\end{array}$} & \multicolumn{2}{|c|}{ of residue } \\
\hline & & $g t z$ & feld & hem & clay & & & & talc & exp \\
\hline$M B-C S-29$ & 2065.3 & & & Negl & gible & insoluble & res & due & & \\
\hline$M B-C S-28$ & 2066.1 & $\mathrm{XX}$ & $\mathrm{a}$ & -- & $\mathrm{XX}$ & a & $a$ & -- & - & $\mathrm{xX}$ \\
\hline$M B-C S-27$ & 2067.0 & $\mathrm{xx}$ & $\mathrm{x}$ & $\mathrm{x}$ & $\mathrm{xx}$ & $\mathrm{x}$ & $\mathrm{x}$ & -- & -- & $x x$ \\
\hline $\mathrm{MB}-\mathrm{CS}-30$ & 2414.8 & $\mathrm{xx}$ & $\mathrm{x}$ & -- & $\mathrm{x}$ & $a$ & $\mathrm{x}$ & -- & -- & $\mathrm{xx}$ \\
\hline $\mathrm{MB}-\mathrm{CS}-31$ & 2512.5 & $\mathrm{x}$ & -- & $a$ & $\mathrm{XX}$ & $\mathrm{x}$ & $\mathrm{x}$ & $\cdots$ & -- & $\mathrm{xx}$ \\
\hline$M B-C S-13$ & 2518.3 & $\mathrm{X}$ & $\mathrm{x}$ & -- & $\mathrm{XX}$ & $\mathrm{a}$ & $a$ & -- & - & $\mathrm{xx}$ \\
\hline MB-CS- 11 & 2528.0 & -- & -- & -- & $x \mathrm{x}$ & -- & $\cdots$ & -- & -- & $\mathrm{xx}$ \\
\hline$M B-C S-32$ & 2541.5 & $\mathrm{x}$ & $\mathrm{a}$ & -- & $\mathrm{XX}$ & $\mathrm{x}$ & $\mathrm{X}$ & -- & -- & $\mathrm{XX}$ \\
\hline
\end{tabular}


TABLE 7.7 , continued

Relative Abundances of minerals in EDTA-insoluble residues (cont'd).

\begin{tabular}{|c|c|c|c|c|c|c|c|c|c|c|}
\hline \multirow[b]{2}{*}{ Sample } & \multirow{2}{*}{$\begin{array}{l}\text { Depth } \\
(\mathrm{ft}) \\
\end{array}$} & \multicolumn{3}{|c|}{ EDTA-insoluble } & residue & \multirow{2}{*}{$\begin{array}{c}<2 \mu \\
i 1 \\
\end{array}$} & \multirow{2}{*}{$\begin{array}{l}\mathrm{m} \\
\mathrm{ch}\end{array}$} & \multirow{2}{*}{$\begin{array}{r}\text { raction } \\
\text { serp }\end{array}$} & \multicolumn{2}{|c|}{ of residue } \\
\hline & & gtz & feld & hem & clay & & & & talc & exp \\
\hline$M B-C S-33$ & 2609.2 & & & $\mathrm{Neg}]$ & gible & insoluble & res & due & & \\
\hline$M B-C S-41$ & 2616.2 & & & Neg 1 & gible & insoluble & res & due & & \\
\hline MB-CS-34 & 2616.6 & & & Neg? & gible & insoluble & res & due & & \\
\hline$M B-C S-35$ & 2617.5 & $x x$ & $\mathrm{x}$ & $\mathrm{a}$ & $\mathrm{xX}$ & $\mathrm{xx}$ & $x$ & -- & -- & $x x$ \\
\hline MB-CS-37 & 2705.4 & $x x$ & $\mathrm{x}$ & $a$ & $\mathrm{x}$ & $\mathrm{XX}$ & $\mathrm{X}$ & -- & -- & $\mathrm{XX}$ \\
\hline $\mathrm{MB}-\mathrm{CS}-10$ & 2705.8 & $\mathrm{XX}$ & $x$ & $\mathrm{a}$ & $\mathrm{x}$ & $\mathrm{x}$ & $\mathrm{x}$ & -- & -- & $\mathrm{xx}$ \\
\hline$M B-C S-36$ & 2758.4 & $\mathrm{xx}$ & $x$ & $a$ & $\mathrm{x}$ & $\mathrm{XX}$ & $\mathrm{x}$ & -- & $\ldots$ & $\mathrm{XX}$ \\
\hline
\end{tabular}


TABLE 7.7 , continued

Relative Abundances of minerals in EDTA-insoluble residues (cont'd).

\begin{tabular}{|c|c|c|c|c|c|c|c|c|c|c|}
\hline \multirow[b]{2}{*}{ Sample } & \multirow{2}{*}{$\begin{array}{l}\text { Depth } \\
(\mathrm{ft}) \\
\end{array}$} & \multicolumn{4}{|c|}{ EDTA-insoluble residue } & \multirow{2}{*}{$\begin{array}{l}<2 \\
i 1\end{array}$} & \multicolumn{2}{|c|}{ m Eraction } & \multicolumn{2}{|c|}{ of residue } \\
\hline & & gtz & feld & hem & clay & & $\mathrm{ch}$ & serp & talc & exp \\
\hline $\mathrm{MB}-\mathrm{CS}-39$ & 2819.3 & $\mathrm{XX}$ & $\mathrm{x}$ & -- & $\mathrm{x}$ & $\mathrm{xX}$ & $\mathrm{x}$ & -- & -- & $\mathrm{xX}$ \\
\hline$M B-C S-15$ & 2820.2 & $\mathrm{XX}$ & $\cdots$ & -- & $x x$ & -- & a & -- & $x X$ & $\mathrm{X}$ \\
\hline $\mathrm{MB}-\mathrm{CS}-2$ & 2820.3 & $\mathrm{a}$ & $\mathrm{x}$ & -- & $\mathrm{XX}$ & $\mathrm{XX}$ & -- & $\cdots$ & -- & $x x$ \\
\hline$M B-C S-38$ & 2821.4 & - & -- & -- & $\mathrm{XX}$ & -- & - & $\mathrm{XX}$ & -- & $\mathrm{XX}$ \\
\hline $\mathrm{MB}-\mathrm{CS}-40$ & 2827.4 & -- & -- & $\cdots$ & $\mathrm{XX}$ & -- & -- & $x x$ & -- & $\mathrm{XX}$ \\
\hline$M B-C S-9$ & 2846.0 & $a$ & -- & $a$ & $\mathrm{XX}$ & -- & -- & $X X$ & -- & $\mathrm{xx}$ \\
\hline$M B-C S-3$ & 2848.4 & -- & -- & -- & $\mathrm{XX}$ & -- & -- & $\mathrm{x}$ & -- & $\mathrm{XX}$ \\
\hline
\end{tabular}


TABLE 7.7, continued

Relative Abundances of minerals in EDTA-insoluble residues (cont'd).

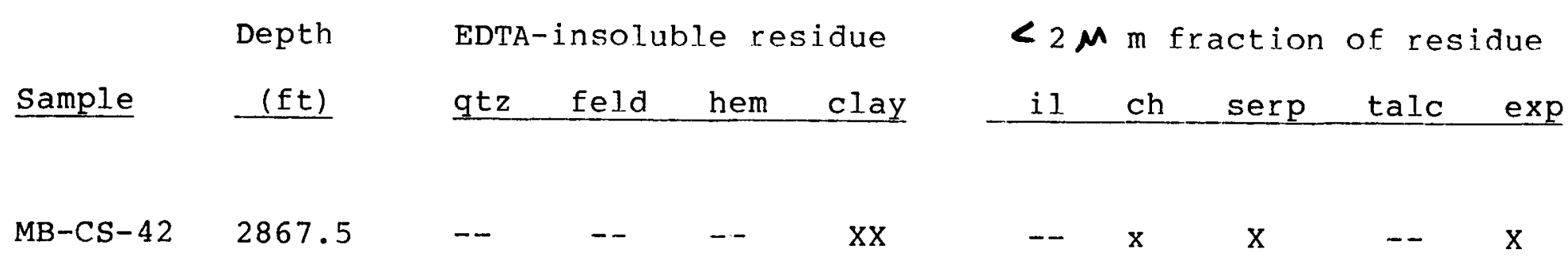

Minerals: $\quad$ qtz $=$ quartz; feld = feldspar; hem = hematite; il = illite;

$c h=$ chlorite; serp = serpentine; exp = expandable

(smectite-bearing).

Relative abundances: $\quad x x=$ dominant constituent; $x=$ major constituent; $\mathrm{x}=$ minor constituent; $\mathrm{a}=$ accessory constituent. All abundances based on relative intensities of major diffraction maxima. 
TABLE 7.8

Low-angle diffraction maxima $(\AA)$ of expandable clays in the $<2 \mu \mathrm{m}$ fraction of the EDTA-insoluble residues.

\begin{tabular}{|c|c|c|c|c|c|}
\hline Sample & $\begin{array}{l}\text { Depth } \\
\text { (ft) } \\
\end{array}$ & Air-dried & Glycol-saturated & $375^{\circ} \mathrm{C}(>1 \mathrm{hr})$ & $500^{\circ} \mathrm{C}(>\mathrm{Ihr})$ \\
\hline$M B-C S-16$ & 1165.1 & 14.5 & n.d. & $\mathrm{n}, \mathrm{d}$. & n.d. \\
\hline$M B-C S-17$ & 1166.2 & $13.8,30.5$ & $15.5,32.7$ & $13.8,(29.4)$ & $13.6,(25.2)$ \\
\hline$M B-C S-1$ & 1167.5 & 14.5 & n.d. & $\mathrm{n} . \mathrm{d}$ & $\mathrm{n} \cdot \mathrm{d}$ \\
\hline$M B-C S-6$ & 1168.3 & $14.5,(25.2)$ & $15.5,(35.3)$ & $13.6,31.6$ & $13.2,11.8,(27.6)$ \\
\hline$M B-C S-5$ & 1172.9 & 14.3 & $n \cdot d$. & n.d. & n. $a$. \\
\hline$J L-C S-16$ & 1244.6 & $13.8,29.4$ & $15.5,11.2,31.6$ & n.d. & n.d. \\
\hline $\mathrm{JL}-\mathrm{CS}-12$ & 1244.8 & $13.6,29.4$ & $15.5,31.5$ & 13.6 & 13.2 \\
\hline $\mathrm{JL}-\mathrm{CS}-20$ & 1245.1 & $13.8,(30.5)$ & $15.5,34.0$ & n.d. & n.d. \\
\hline$J L-C S-5$ & 1247.2 & $14.5,30.5$ & $15.5,11.2,31.6$ & 14.3 & 13.6 \\
\hline$J L-C S-10$ & 1325.3 & 10.2 & $10.4,(12.1)$ & 9.8 & $9.8,11.0-11.9$ \\
\hline $\mathrm{JL}-\mathrm{CS}-3$ & 1328.6 & $14.0,30.5$ & $15.5,11.2,31.6$ & $14.5,(31.6)$ & $12.6-14.7,(22.21)$ \\
\hline$M B-C S-21$ & 1404.6 & $13.8,31.6$ & $15.8,34.0$ & $13.8,(32.7)$ & $13.4,(29.4)$ \\
\hline $\mathrm{MB}-\mathrm{CS}-7$ & 1418.2 & $13.8,(30.5)$ & n.d. & $\mathrm{n} \cdot \mathrm{d}$. & $n \cdot d$ \\
\hline$M B-C S-8$ & 1418.6 & 13.4 & $15.5,(34.0)$ & $13.6,(27.6)$ & $11.6,(27.6)$ \\
\hline
\end{tabular}


TABLE 7.8 , continued

Low-angle diffraction maxima ( $\AA$ ) of expandable clays in the $<2 \mu$ fraction of the EDTA-insoluble residues (cont'd).

\begin{tabular}{|c|c|c|c|c|c|}
\hline Sample & $\begin{array}{l}\text { Depth } \\
(\mathrm{ft}) \\
\end{array}$ & Air-dried & Glycol-saturated & $375^{\circ} \mathrm{C}(>1 \mathrm{hr})$ & $5^{500^{\circ}} \mathrm{C}(>\operatorname{lh} \mathrm{r})$ \\
\hline JL-CS-2 & 1440.5 & 10.3 & $10.2,11.8$ & 9.8 & n.d. \\
\hline $\mathrm{JL}-\mathrm{CS}-6$ & 1441.2 & $10.7,13.6,(29.4)$ & $11.3,15.5,(31.6)$ & $10.2,13.0-14.3$ & 10.0 \\
\hline $\mathrm{JL}-\mathrm{CS}-4$ & 1441.7 & $13.8,31.6$ & $15.5,31.6$ & $13.8,(29.4)$ & 13.2 \\
\hline $\mathrm{JL}-\mathrm{CS}-11$ & 1466.5 & $13.8,11.2,(30.5)$ & $15.2,(32.7)$ & $13.6,(26.0)$ & n.d. \\
\hline JL-CS-9 & 1466.9 & 14.7 & 16.1 & 13.8 & 13.8 \\
\hline $\mathrm{JL}-\mathrm{CS}-22$ & 1467.9 & $14.1,31.6$ & $15.5,34.0$ & $\mathrm{n} \cdot \mathrm{d}$. & n.d. \\
\hline$J L-C S-14$ & 1468.1 & $13.6,30.5$ & $15.5,32.7$ & 13.6 & 13.2 \\
\hline $\mathrm{JL}-\mathrm{CS}-8$ & 1535.7 & $10.3,13.6$ & $9.4,11.5,16.1$ & $9.8,13.6$ & 9.7 \\
\hline $\mathrm{JL}-\mathrm{CS}-7$ & 1536.5 & 10.3 & $9.3,11.3$ & 9.9 & 9.8 \\
\hline$J \amalg-C S-18$ & 1537.8 & $14.3,32.7$ & $15.8,34.0$ & n.d. & $\mathrm{n} \cdot \mathrm{d}$. \\
\hline$M B-C S-23$ & 1609.6 & 12.3 & n.d. & n.d. & $\mathrm{n} \cdot \mathrm{d}$. \\
\hline YB-CS-14 & 2034.5 & $13.8,30.5$ & $15.2,31.6$ & $14.0,11.9,(31.6)$ & $11.9,13.2,29.4$ \\
\hline$M 3-C S-4$ & 2037.3 & 13.5 & $15.5,31.6$ & $13.2,(28.5)$ & 13.0 \\
\hline
\end{tabular}


TABLE 7.8 , continued

Low-angle diffraction maxima $(\AA)$ of expandable clays in the $<2 \mu$ m fraction of the EDTA-insoluble residues (cont'd).

\begin{tabular}{|c|c|c|c|c|c|}
\hline Sample & $\begin{array}{l}\text { Depth } \\
(\mathrm{ft}) \\
\end{array}$ & Air-dried & Glycol-saturated & $375^{\circ} \mathrm{C}(\geq \operatorname{lh} r)$ & $\underline{500}^{\circ} \mathrm{C}(>\operatorname{lh} r)$ \\
\hline$M B-C S-28$ & 2066.1 & $14.5,30.5$ & $15.5,31.6$ & $14.0,(29.4)$ & $13.6,(30.5,22.1)$ \\
\hline$M B-C S-27$ & 2067.0 & $14.7,29.4$ & $16.7,32.7$ & $14.0,(29.4)$ & $12.6,(26.0)$ \\
\hline $\mathrm{MB}-\mathrm{CS}-30$ & 2414.8 & $13.8,11.8,(29.4)$ & $15.8,12.8,(31.6)$ & $13.8,11.6,(24.5)$ & $11.6,(26.0)$ \\
\hline MB-CS- 31 & 2512.5 & 12.6 & n.d. & n.d. & $n \cdot d$ \\
\hline MB-CS- 12 & 2517.9 & $12.8,31.6$ & $15.5,31.6$ & n.d. & n.d. \\
\hline MB-CS- 13 & 2518.3 & $12.6,26.0$ & $17.0,25.2$ & $13.2,(26.8)$ & $12.3,10.3,26.0$ \\
\hline $\mathrm{MB}-\mathrm{CS}-11$ & 2528.0 & 13.2 & n.d. & $n \cdot d$. & n.d. \\
\hline MB-CS- 32 & 2541.5 & $13.8,29.4$ & $15.5,31.5$ & $13.4,(26.8)$ & $14.2,(31.6)$ \\
\hline MB-CS- 35 & 2617.5 & $13.8,(29.4)$ & $16.7,32.7$ & $13.8,(26.8)$ & $12.6,27.6$ \\
\hline$M B-C S-37$ & 2705.4 & $14.5,30.5$ & $16.4,34.0$ & $13.8,(29.4)$ & 12.5 \\
\hline$M B-C S-10$ & 2705.8 & 13.4 & $16.7,(35.3)$ & $14.3,(30.5)$ & $14.3,11.8,(27.6)$ \\
\hline $\mathrm{MB}-\mathrm{CS}-36$ & 2758.4 & $14.0,29.4$ & $16.4,32.7$ & $13.8,(29.4)$ & $12.5,(29.4)$ \\
\hline
\end{tabular}


TABLE 7.8 , continued

Low-angle diffraction maxima $(\AA)$ of expandable clays in the $<2 \mu m$ fraction of the EDTA-insoluble residues (cont'd).

\begin{tabular}{|c|c|c|c|c|c|}
\hline Sample & $\begin{array}{l}\text { Depth } \\
\text { (ft) } \\
\end{array}$ & Air-dried & Glycol-saturated & $375^{\circ} \mathrm{C}(>\operatorname{lhr})$ & $500^{\circ} \mathrm{C}(>1 \mathrm{hr})$ \\
\hline$M B-C S-39$ & 2819.3 & $14.5,29.4$ & $16.1,31.6$ & 14.5 & $13.6,(22.0)$ \\
\hline MB-CS-15. & 2820.2 & $11.6,(26.8)$ & $14.7,(27.6)$ & $11.6,(24.5)$ & $11.6,(26.8)$ \\
\hline $\mathrm{MB}-\mathrm{CS}-2$ & 2820.3 & 14.5 & ---- & 10.4 & $9.8-17.7$ \\
\hline$M B-C S-38$ & 2821.4 & 14.7 & --- & 13.8 & 13.8 \\
\hline$M B-C S-40$ & 2827.4 & $14.7,11.3$ & 17.0 & 14.7 & n.d. \\
\hline$M B-C S-9$ & 2846.0 & $12.3,(24.5)$ & $17.0,(28.5)$ & $10.0-13.6,(29.4)$ & 13.4 \\
\hline $\mathrm{MB}-\mathrm{CS}-3$ & 2848.4 & $12.3,(24.5)$ & $17.3,(27.6)$ & $12.63,(27.6)$ & $11.6,(24.5)$ \\
\hline$M B-C S-42$ & 2867.5 & 11.8 & 17.7 & 14.7 & ---- \\
\hline
\end{tabular}

n.d. - data not yet determined

Values in parentheses, e.g. (30.5) represent diffraction maximum present only as shoulder. 
TABLE 7.9

Mineralogy of Duval Mine Samples
4 th ore Zone

A. Evaporites

$$
\begin{gathered}
\text { Mine Wal } 1 \\
\text { Samples }
\end{gathered}
$$

DV-1A

DV-IB

DV $-1 C$

DV-ID

DV $-2 A$

DV-2B

$D V-4 A$

DV-4B

DV $-4 C$

DV $-4 \mathrm{D}$

$D V-4 E$

DV $-5 A$

$D V-5 B$
Hal ite

$t$
$V A$
$V A$
$V A$
$A$
$V A$
$A$
$V A$
$V A$
$V A$
$t$
$V A$
$V A$

$$
\text { Sylvite }
$$

VA

VA

VA

$-$

$-$

-

$-$

$\bar{t}$

$\bar{A}$
Polyhalite

VA
-
VA
$t$
-
$A$
VA
-
-
-
-
-
$t$
Langheinite

\begin{tabular}{|c|c|c|c|c|c|c|c|}
\hline $\begin{array}{c}\text { Mine Wall } \\
\text { Samples }\end{array}$ & ChIorite & Saponite & $\begin{array}{l}\text { Chlorite- } \\
\text { Saponite }\end{array}$ & Il1 ite & Talc & Serpentine & $\begin{array}{c}\text { Insoluble } \\
\text { Residue } \\
\text { (Wt. g) }\end{array}$ \\
\hline$D V-4 B$ & $t$ & - & VA & $\mathrm{VA}$ & $t$ & A & 15.7 \\
\hline$D V-4 C$ & - & - & VA & VA & $t$ & A & 12.3 \\
\hline$D V-4 D$ & $t$ & $t$ & VA & $A$ & - & $t$ & 32.3 \\
\hline$D V-5 A$ & $t$ & $t$ & $\mathrm{VA}$ & A & $t$ & A & 10.3 \\
\hline & & & & $\begin{array}{l}: \\
: \\
: \\
:\end{array}$ & \multicolumn{2}{|c|}{$\begin{array}{l}\text { very abundant } \\
\text { abundant } \\
\text { tract } \\
\text { not detected }\end{array}$} & \\
\hline
\end{tabular}

-
-
$t$
-
$t$
-
$t$
-
$t$
$t$
VA
-
-

B. 2 Micron Fractions (Silicates) 
Semiquantitive* chemical analysis of EDTA-insoluble fractions from ERDA-9 Core.

\begin{tabular}{cccccccc}
\hline & MB-CS-17 & JL-CS-12 & JL-CS-5 & JL-CS-10 & JL-CS-3 & $\frac{J L-C S-2}{J L-C S-6}$ & JL-CS-4 \\
Depth (ft) & 1166.2 & 1244.8 & 1247.1 & 1325.3 & 1328.5 & 1440.5 & 1441.2 \\
Lithology & Anhydr. & Clay & Clay & Polyhal. & Clay & Polyhal. Polyhal. Clay
\end{tabular}

\section{Weight Percent}

\begin{tabular}{|c|c|c|c|c|c|c|c|c|}
\hline $\mathrm{SiO}_{2}$ & 59. & 50. & 50. & 59. & 52 & 56. & 45 . & 38 \\
\hline $\mathrm{TiO}_{2}$ & .8 & .9 & 1.2 & .2 & 1.4 & .4 & .7 & 1.4 \\
\hline A] ${ }_{2}{ }^{0} 3$ & 12. & 13. & 15. & 12. & 15. & 5.2 & 2.5 & 18. \\
\hline Fe0 ${ }^{\circledR}$ & 1.2 & 2.4 & 3.8 & 1.3 & 3.2 & 5.3 & 14. & 4.5 \\
\hline $\mathrm{MgO}$ & 20. & 25. & 20. & 32. & 18. & 20 & 15. & 19. \\
\hline $\mathrm{CaO}$ & .0 .1 & .01 & .04 & .002 & .008 & .02 & .03 & .06 \\
\hline $\mathrm{Na}_{2} \mathrm{O}$ & 1.2 & 1.2 & 1.0 & 1.0 & .5 & 2.4 & 1.4 & 1.6 \\
\hline $\mathrm{K}_{2} \mathrm{O}$ & 1.8 & 2.3 & 3.0 & .3 & 3.3 & 2.9 & 2.0 & 4.6 \\
\hline
\end{tabular}


TABLE 7.10, continued

Semiquantitive* chemical analysis of EDTA-insoluble Eractions Erom ERDA-9 core.

\begin{tabular}{|c|c|c|c|c|c|c|c|c|}
\hline & $M B-C S-17$ & $J L-C S-12$ & $\mathrm{JL}-\mathrm{CS}-5$ & $\underline{J L}-\mathrm{CS}-10$ & $\mathrm{JL}-\mathrm{CS}-3$ & $\mathrm{JI}-\mathrm{CS}-2$ & $\underline{\mathrm{JL}}-\mathrm{CS}-6$ & $\underline{\mathrm{JL}-\mathrm{CS}-}$ \\
\hline Depth $(f t)$ & 21.66 .2 & 1244.8 & 2247.1 & 1325.3 & 1328.5 & 1440.5 & 1441.2 & 1441. \\
\hline Lithology ${ }^{+}$ & Anhydr. & clay & clay & Polyhal. & clay & Polyhal. & Polyhal. & clay \\
\hline \multicolumn{9}{|c|}{ Atom Proportions $(a)=1.0)$} \\
\hline si & 4.2 & 3.2 & 2.9 & 4.3 & 3.0 & 7.6 & 15 . & 1.8 \\
\hline $\mathrm{Ti}$ & .04 & .04 & .05 & .01 & .06 & .04 & .2 & .05 \\
\hline A]. & 1.0 & $? .0$ & 1.0 & 1.0 & 1.0 & 1.0 & 1.0 & 1.0 \\
\hline Fe & .07 & .13 & .18 & .08 & .15 & .61 & 4.0 & .17 \\
\hline Mg & 2.1 & 2.3 & 1.7 & 3.5 & 1.6 & 4.0 & 7.4 & 1.3 \\
\hline $\mathrm{Na}$ & .15 & .15 & .11 & .14 & .06 & .64 & 92 & .14 \\
\hline K & .16 & .19 & .22 & .03 & .24 & .51 & .87 & .27 \\
\hline
\end{tabular}


TABLE 7.10, continued

Semiquantitive* chemical analysis of EDTA-insoluble fractions from ERDA-9 Core.

\begin{tabular}{|c|c|c|c|c|c|c|c|c|}
\hline & $\underline{J L}-C S-11$ & $\mathrm{JL}-\mathrm{CS}-9$ & $\mathrm{JL}-\mathrm{CS}-14$ & $\mathrm{JL}-\mathrm{CS}-18$ & $\mathrm{MB}-\mathrm{CS}-4$ & $\underline{M B}-\mathrm{CS}-27$ & $\underline{M B}-\mathrm{CS}-31$ & $\underline{M B-C S}$ \\
\hline Depth (ft) & 1466.5 & 1467.0 & 1468.1 & 1537.8 & 2037.3 & 2067.0 & 2512.5 & 2518 \\
\hline Li thology $^{+}$ & Polyhal. & Polyhal. & Clay & Polyhal. & Anhydr. & Haljte & Hallite & Anhy \\
\hline \multicolumn{9}{|c|}{ Weight Percent } \\
\hline $\mathrm{SiO}_{2}$ & 34. & 42 . & 41. & 43. & 54. & 65. & 41. & 54. \\
\hline $\mathrm{TiO}_{2}$ & .6 & .6 & 1.2 & .6 & .8 & 1.0 & .9 & .4 \\
\hline $\mathrm{Al}_{2} \mathrm{O}_{3}$ & 10 & 9.0 & 14. & 8.8 & 12. & 14. & 24. & 7.0 \\
\hline $\mathrm{Fe} 0^{\circledR}$ & 23. & 3.7 & 3.3 & 8.2 & 3.7 & 4.7 & N.D. & 2.1 \\
\hline MgO & 19. & 29. & 22 . & $2 \mathrm{l}$. & 21. & 9.3 & 18. & 22. \\
\hline $\mathrm{CaO}$ & .005 & .005 & .001 & .03 & .002 & .02 & .02 & .04 \\
\hline $\mathrm{Na}_{2} \mathrm{O}$ & 1.3 & .4 & 1.6 & 1.2 & 1.0 & 3.9 & 2.2 & 2.7 \\
\hline $\mathrm{K}_{2} \mathrm{O}$ & 2.9 & 2.6 & 4.1 & 2.0 & 1.5 & 4.1 & 2.6 & 2.5 \\
\hline
\end{tabular}


TABLE 7.10, continued

Semiquantitive* chemical analysis of EDTA-insoluble fractions from ERDA-9 Core.

\begin{tabular}{|c|c|c|c|c|c|c|c|c|}
\hline & $\underline{J L}-\mathrm{CS}-11$ & $\mathrm{JL}-\mathrm{CS}-9$ & $\mathrm{JL}-\mathrm{CS}-14$ & $\mathrm{JL}-\mathrm{CS}-1.8$ & $\mathrm{MB}-\mathrm{CS}-4$ & $\underline{M B-C S-27}$ & $M B-C S-31$ & $M B-C S-1$ \\
\hline Depth (ft) & 1466.5 & 1467.0 & 1.468 .1 & 1537.8 & 2037.3 & 2067.0 & 2512.5 & 2518.3 \\
\hline Lithology ${ }^{+}$ & Polyhal. & Polyhal. & Clay & Polyhar. & Anhydr. & Halite & Halite & Anhydr \\
\hline \multicolumn{9}{|c|}{ Atom proportions $(A 1=1.0)$} \\
\hline $\mathrm{Si}$ & 2.9 & 3.9 & 2.5 & 4.2 & 4.0 & 3.9 & 2.5 & 6.2 \\
\hline $\mathrm{Ti}$ & .04 & .04 & .05 & .04 & .04 & .04 & .04 & .03 \\
\hline Al & 3.0 & 1.0 & 1.0 & 1.0 & 1.0 & 1.0 & 1.0 & 1.0 \\
\hline $\mathrm{Fe}$ & 1.7 & .29 & .17 & .65 & .23 & .23 & -- & .20 \\
\hline Mg & 2.4 & 4.0 & 2.0 & 3.1 & 2.3 & .83 & 1.7 & 3.8 \\
\hline $\mathrm{Na}$ & .21 & .07 & .19 & .22 & .14 & .45 & .26 & .60 \\
\hline $\mathrm{K}$ & .31 & .31 & .32 & .25 & .14 & .31 & .23 & .37 \\
\hline
\end{tabular}


TABLE 7.10, continued

Semiquantitive* chemical analysis of EDTA-insoluble fractions from ERDA-9 Core.

\begin{tabular}{|c|c|c|c|c|c|c|c|c|}
\hline & $\underline{M B}-\mathrm{CS}-32$ & MB-CS-10 & $\mathrm{MB}-\mathrm{CS}-36$ & $M B-C S-39$ & $\underline{M B}-\mathrm{CS}-15$ & $\mathrm{MB}-\mathrm{CS}-40$ & $\mathrm{MB}-\mathrm{CS}-9$ & $M B-C S-3$ \\
\hline Depth (ft) & 2541.5 & 2705.8 & 2758.4 & 2819.3 & 2820.2 & 2827.4 & 2846.0 & 2848.4 \\
\hline Lithology ${ }^{+}$ & Halite & Halite & Halite & Halite & Anhydr. & Halite & Anhydr. & Anbydr. \\
\hline \multicolumn{9}{|c|}{ Weight Percent } \\
\hline $\mathrm{SiO}_{2}$ & 37. & 61. & 70 & 67. & 52 . & 33. & 42. & 44 \\
\hline $\mathrm{TiO}_{2}$ & .8 & .8 & .8 & .8 & .1 & .3 & .2 & .2 \\
\hline A] $2_{2}{ }_{3}$ & 13 & 12 . & 12 . & 12. & 3.4 & 5.0 & 3.1 & 3.6 \\
\hline $\mathrm{FeO}{ }^{\mathrm{a}}$ & 3.4 & 4.4 & 3.4 & 3.3 & .7 & 1.4 & 2.6 & 1.5 \\
\hline MgO & 30. & 17 . & 11 & 13. & 33. & 29 . & 35. & 37. \\
\hline $\mathrm{CaO}$ & .002 & .01 & .1 & .06 & .007 & 1.0 & .003 & .003 \\
\hline $\mathrm{Na}_{2} \mathrm{O}$ & 1.0 & 2.9 & 2.3 & 2.1 & 1.6 & .9 & 2.6 & 1.9 \\
\hline $\mathrm{K}_{2} \mathrm{O}$ & 1.7 & 1.8 & 1.4 & 1.8 & .6 & .9 & 3.3 & .7 \\
\hline
\end{tabular}


TABLE 7.10 , continued

Semiquantitive* chemical analysis of EDTA-insoluble fractions from ERDA-9 Core.

\begin{tabular}{|c|c|c|c|c|c|c|c|c|}
\hline & $\mathrm{MB}-\mathrm{CS}-32$ & $\underline{M B}-\mathrm{CS}-10$ & $\mathrm{MB}-\mathrm{CS}-36$ & $\mathrm{MB}-\mathrm{CS}-39$ & $M B-C S-15$ & $\mathrm{MB}-\mathrm{CS}-40$ & $\mathrm{MB}-\mathrm{CS}-9$ & $\mathrm{MB}-\mathrm{CS}-3$ \\
\hline Depth ( $f t)$ & 2541.5 & 2705.8 & 2758.4 & 2819.3 & 2820.2 & 2827.4 & 2846.0 & 2848.4 \\
\hline Lithology ${ }^{+}$ & Halite & Hal ite & Halite & Halite & Anhydr. & Ha] ite & Anhydr. & Anhydr. \\
\hline
\end{tabular}

Atom proportions $(A I=1.0)$

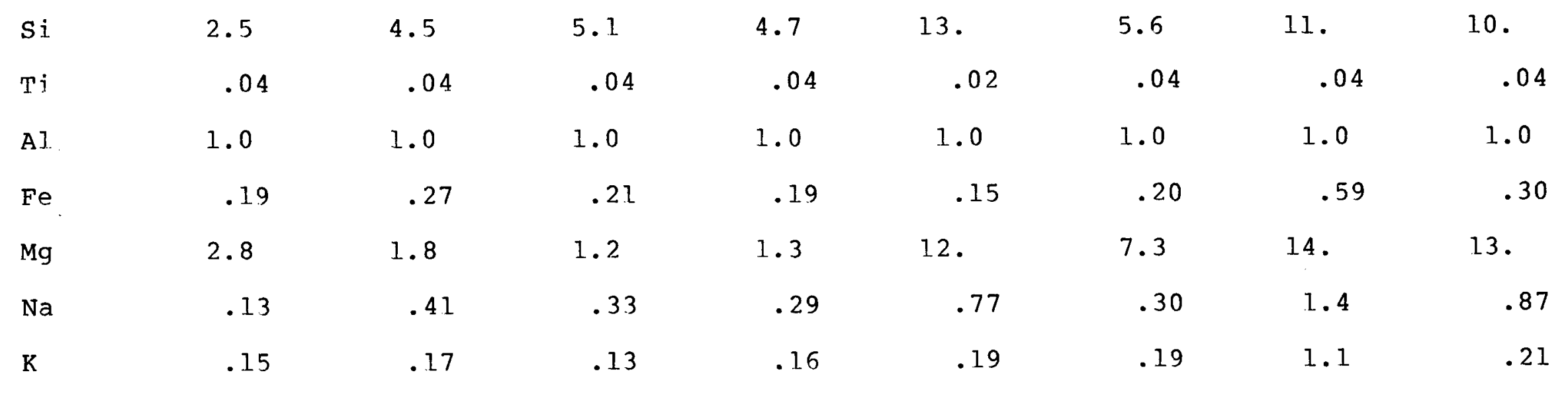

* Calculated from 1:l linear regression; matrix effects and other than unit regression slope not yet included.

+ Anhydr. = anhydrite; polyhal. = polyhalite .

(a) Total iron as Feo. 
Mineralogy of Cores from ERDA No. 9

\begin{tabular}{|c|c|c|}
\hline $\begin{array}{l}\text { Core } \\
\text { Footage } \\
\end{array}$ & $\begin{array}{r}\text { Gross Lithology } \\
\text { (1isted in decreasing order of } \\
\text { (trace }\end{array}$ & $\begin{array}{l}\text { Bulk } \\
\text { Mineralogy by X-ray Diffraction } \\
\text { abundance, lower case indicates } \\
\text { amount) }\end{array}$ \\
\hline 1168.1 & $\begin{array}{l}\text { Anhydrite } \\
\text { Halite } \\
\text { Magnesite }\end{array}$ & $\begin{array}{l}\text { Anhydrite } \\
\text { Magnesite }\end{array}$ \\
\hline 1168.55 & $\begin{array}{l}\text { Anhydrite } \\
\text { Halite } \\
\text { Polyhalite }\end{array}$ & $\begin{array}{l}\text { Anhydrite } \\
\text { Halite } \\
\text { Polyhalite }\end{array}$ \\
\hline 1173.5 & $\begin{array}{l}\text { Halite } \\
\text { "Brown Material" }\end{array}$ & $\begin{array}{l}\text { Halite } \\
\text { Polyhalite } \\
\text { trace } 12 \mathrm{~A} \text { (expandable) clay }\end{array}$ \\
\hline 1173.5 & silty claystone or anhyarite & $\begin{array}{l}\text { Anhydrite } \\
\text { Polyhalite }\end{array}$ \\
\hline 1584.4 & $\begin{array}{l}\text { Halite } \\
\text { "brown material" } \\
\text { anhyarite }\end{array}$ & $\begin{array}{l}\text { Halite } \\
\text { polyhalite }\end{array}$ \\
\hline 1649.7 & $\begin{array}{l}\text { Halite } \\
\text { polyhalite } \\
\text { anhydrite }\end{array}$ & $\begin{array}{l}\text { Halite } \\
\text { polyhalite }\end{array}$ \\
\hline 2066.8 & $\begin{array}{l}\text { Halite } \\
\text { "brown material" }\end{array}$ & $\begin{array}{l}\text { Halite } \\
\text { Anhydrite } \\
\text { quartz } \\
\text { magnesite } \\
\text { trace } 10 \mathrm{~A}^{\circ} \text { clay (illite) } \\
\text { trace } 14 \mathrm{~A}^{\mathrm{O}} \text { clay (chlorite) }\end{array}$ \\
\hline
\end{tabular}


TABLE 7.11, continued

Mineralogy of Cores from ERDA No. 9

\begin{tabular}{|c|c|c|}
\hline $\begin{array}{l}\text { Core } \\
\text { Footage }\end{array}$ & $\begin{array}{r}\text { Gross Lithology } \\
\text { (1isted in decreasing order of } \\
\text { (trace }\end{array}$ & $\begin{array}{l}\text { Bulk } \\
\text { Mineralogy by } x-r a y \text { Ditfraction } \\
\text { abundance, lower case indicates } \\
\text { amount) }\end{array}$ \\
\hline 2067.4 & see 2066.8 & $\begin{array}{l}\text { Halite } \\
\text { polyhalite } \\
\text { quartz? } \\
\text { trace } 12 \mathrm{~A}^{\circ} \text { (expandable) clay }\end{array}$ \\
\hline 2302 & $\begin{array}{l}\text { Polyhalite } \\
\text { "White Material" }\end{array}$ & $\begin{array}{l}\text { Anhydrite } \\
\text { Polyhalite }\end{array}$ \\
\hline $24 \perp 4.7$ & $\begin{array}{l}\text { Polynalite } \\
\text { Halite } \\
\text { Anhydrite }\end{array}$ & $\begin{array}{l}\text { Halite } \\
\text { Polyhalite }\end{array}$ \\
\hline 2415.0 & see 2414.7 & $\begin{array}{l}\text { Polyhalite } \\
\text { Anhydrite }\end{array}$ \\
\hline $24 \perp 5.4$ & see 2414.7 & Anhydrite \\
\hline 2529.5 & $\begin{array}{l}\text { Anhydrite } \\
\text { magnesite? }\end{array}$ & $\begin{array}{l}\text { Anhydrite } \\
\text { Halite } \\
\text { Magnesite }\end{array}$ \\
\hline 2538.5 & $\begin{array}{l}\text { Anhydrite } \\
\text { Halite }\end{array}$ & $\begin{array}{l}\text { Anhydrite } \\
\text { Halite }\end{array}$ \\
\hline 2619.5 & $\begin{array}{l}\text { Halite } \\
\text { anhydrite or magnesite }\end{array}$ & $\begin{array}{l}\text { HaLite } \\
\text { Anhydrite }\end{array}$ \\
\hline $2820 \mathrm{~B}$ & $\begin{array}{l}\text { Anhydrite } \\
\text { Halite } \\
\text { magnesite }\end{array}$ & $\begin{array}{l}\text { Anhydrite } \\
\text { Halite }\end{array}$ \\
\hline
\end{tabular}


TABLE 7.12

Weight Losses Observed Upon Heating of ERDA No. 9 Cores

Specimen

No.

(depth)

2034.7

2035.7

2065.0

2067.5

2302.6

2413.7

2414.2

2415.6

2512.0

2516.3

2518.8

2528.7

2529.0

2538.5

2542.0

2593.2

2594.5

2597.0

2608.9

2614.4

2619.6

2658.5

2663.3

2696.4

2706.5

2711.9

2759.0

2786.5

$2820.7 \mathrm{~A}$

$2820.6 \mathrm{~B}$

2821.0

2826.5

2845.3

2848.8
Total

Weight-Loss

$(8)$

0.20

0.35

0.52

5.40

1. 38

3.13

0.10

0.14

2.15

0.32

2.12

3.12

1.55

6.39

1.47

0.36

0.37

0.17

0.13

0.22

0.48

0.50

1. 12

0.37

0.47

0.28

3.64

0.36

0.35

0.40

0.36

1.42

0.86
Mass-Loss

(z)

At Mean Temperature Ranges

\begin{tabular}{lll}
\hline $100{ }^{\circ} \mathrm{C}$ & $300^{\circ} \mathrm{C}$ & $450^{\circ}$
\end{tabular}

0.36

$----$

$----$

5.10

1.00

2.90

$---$

$---$

$---$

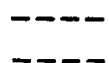

$---$

6.19

$---$

- -

---

$---$

0.10

$----$

-- -

$---$

---

- - -

---

0.19

0.27

---
.057

$-\cdots$

$---1$

0.17

- - -

$---$

$---1$

1.55

1.52

2.94

1.20

0.20

1.20

$--\infty$

$---$

----

0.17

0.29

0.80

$---$

0.21

0.90

0.17

0.12

---

1. 21

0.53 
TABJEE 7.13

Data on the volume percent of fluid now present in the salt cores from ERDA No. 9.

\begin{tabular}{|c|c|c|c|c|c|c|c|c|}
\hline $\begin{array}{l}\text { Depth } \\
\text { interval } \\
\text { (feet) }\end{array}$ & $\begin{array}{c}\text { Type } \\
\text { Sampied }\end{array}$ & $\begin{array}{l}\text { Volume } \\
\text { sampled } \\
\left(\mathrm{mm}^{3}\right)\end{array}$ & $\underset{(\mathrm{mm}}{\operatorname{App}}$ & $\begin{array}{l}\text { box } \\
\text { n s }\end{array}$ & $\begin{array}{l}\text { x. } \\
\text { size }\end{array}$ & $\begin{array}{l}\text { Fraction } \\
\text { of total } \\
\text { sljde }\end{array}$ & $\begin{array}{l}\text { Fluid } \\
\text { o by } \\
\text { vol. }\end{array}$ & $\begin{array}{c}\text { Total. } \\
\text { \% by vol. } \\
\text { whole sljde }\end{array}$ \\
\hline $1799.0-1799.5$ & $\begin{array}{l}B \\
A\end{array}$ & $\begin{array}{l}500 \\
500\end{array}$ & $\begin{array}{l}5 \\
1\end{array}$ & $\begin{array}{l}\text { to } \\
\text { to }\end{array}$ & $\begin{array}{r}10 \\
5\end{array}$ & $\begin{array}{l}1 / 4 \\
3 / 4\end{array}$ & $\begin{array}{l}1.66 \\
0.17\end{array}$ & 0.54 \\
\hline $1902.0-1902.3$ & $\begin{array}{l}B \\
A\end{array}$ & $\begin{array}{l}500 \\
500\end{array}$ & $\begin{array}{r}2 \\
0.5\end{array}$ & $\begin{array}{l}\text { to } \\
\text { to }\end{array}$ & $\begin{array}{l}8 \\
3\end{array}$ & $\begin{array}{l}1 / 5 \\
4 / 5\end{array}$ & $\begin{array}{l}0.866 \\
0.11\end{array}$ & 0.26 \\
\hline $2065.0-2065.4$ & $\begin{array}{l}B \\
A\end{array}$ & $\begin{array}{l}500 \\
500\end{array}$ & $\begin{array}{l}20 \\
20\end{array}$ & $\begin{array}{l}\text { to } \\
\text { to }\end{array}$ & $\begin{array}{l}50 \\
50\end{array}$ & $\begin{array}{l}5 / 6 \\
1 / 6\end{array}$ & $\begin{array}{l}3.4 \\
0.20\end{array}$ & 2.86 \\
\hline $2095.1-2095.5$ & $\begin{array}{l}B \\
A\end{array}$ & $\begin{array}{l}500 \\
500\end{array}$ & $\begin{array}{l}3 \\
3\end{array}$ & $\begin{array}{l}\text { to } \\
\text { to }\end{array}$ & $\begin{array}{l}15 \\
15\end{array}$ & $\begin{array}{l}1 / 10 \\
9.10\end{array}$ & $\begin{array}{l}2.58 \\
0.039\end{array}$ & 0.29 \\
\hline $2274.4-2272.7$ & $\begin{array}{l}\text { (B } \\
(\mathrm{A}\end{array}$ & $\begin{array}{l}470 \\
470\end{array}$ & $\begin{array}{r}10 \\
5\end{array}$ & to & 15 & $\begin{array}{l}1 / 2 \\
I / 2\end{array}$ & $\begin{array}{l}2.29 \\
0.17\end{array}$ & 1.23 \\
\hline$"$ & (B & $\begin{array}{l}510 \\
520\end{array}$ & $\begin{array}{l}5 \\
1\end{array}$ & $\begin{array}{l}\text { to } \\
\text { to }\end{array}$ & $\begin{array}{l}7 \\
3\end{array}$ & $\begin{array}{l}2 / 5 \\
3 / 5\end{array}$ & $\begin{array}{l}0.86 \\
0.02\end{array}$ & 0.36 \\
\hline$"$ & $\begin{array}{l}(\mathrm{B} \\
(\mathrm{A}\end{array}$ & $\begin{array}{l}520 \\
520\end{array}$ & $\begin{array}{l}5 \\
1\end{array}$ & $\begin{array}{l}\text { to } \\
\text { to }\end{array}$ & $\begin{array}{l}7 \\
3\end{array}$ & $\begin{array}{l}1 / 3 \\
2 / 3\end{array}$ & $\begin{array}{l}0.55 \\
0.02\end{array}$ & 0.20 \\
\hline $2391.0-2391.3$ & $\begin{array}{l}\mathrm{B} \\
\mathrm{A}\end{array}$ & $\begin{array}{l}460 \\
460\end{array}$ & $\begin{array}{r}10 \\
3\end{array}$ & $\begin{array}{l}\text { to } \\
\text { to }\end{array}$ & $\begin{array}{l}15 \\
10\end{array}$ & $\begin{array}{l}1 / 10 \\
9 / 10\end{array}$ & $\begin{array}{l}1.17 \\
0.12\end{array}$ & 0.22 \\
\hline $2611.5-2611.8$ & $\begin{array}{l}\mathrm{B} \\
\mathrm{A}\end{array}$ & $\begin{array}{l}530 \\
530\end{array}$ & $\begin{array}{l}5 \\
2\end{array}$ & $\begin{array}{l}\text { to } \\
\text { to }\end{array}$ & $\begin{array}{r}25 \\
5\end{array}$ & $\begin{array}{l}1 / 5 \\
4 / 5\end{array}$ & $\begin{array}{l}0.79 \\
0.015\end{array}$ & 0.17 \\
\hline $2658.7-2659.0$ & $\begin{array}{l}\mathrm{B} \\
\mathrm{A}\end{array}$ & $\begin{array}{l}360 \\
360\end{array}$ & $\begin{array}{l}5 \\
2\end{array}$ & $\begin{array}{l}\text { to } \\
\text { to }\end{array}$ & $\begin{array}{r}10 \\
8\end{array}$ & $\begin{array}{l}1 / 4 \\
3 / 4\end{array}$ & $\begin{array}{l}1.18 \\
0.039\end{array}$ & 0.32 \\
\hline
\end{tabular}




\section{TABLE 7.13 , continued}

Data on the volume percent of fluid now present in the salt cores from ERDA No. 9.

\begin{tabular}{|c|c|c|c|c|c|c|c|}
\hline $\begin{array}{l}\text { Depth } \\
\text { interval } \\
\text { (feet) }\end{array}$ & $\begin{array}{c}\text { Type } \\
\text { Sampled }\end{array}$ & $\begin{array}{l}\text { Volume } \\
\text { sampled } \\
\left(\mathrm{mm}^{3}\right)\end{array}$ & $\begin{array}{l}\text { Approx } \\
\text { grain } 5 \\
\text { (mm) }\end{array}$ & jze & $\begin{array}{l}\text { Fraction } \\
\text { of total } \\
\text { s. ide }\end{array}$ & $\begin{array}{l}\text { Fluid } \\
\text { \& by } \\
\text { vol. }\end{array}$ & $\begin{array}{c}\text { Total } \\
\text { \& by vol. } \\
\text { whole slide }\end{array}$ \\
\hline $2760.0-2760.2$ & $\begin{array}{l}\mathrm{B} \\
\mathrm{A}\end{array}$ & $\begin{array}{l}460 \\
450\end{array}$ & $\begin{array}{ll}5 & \text { to } \\
3 & \text { to }\end{array}$ & $\begin{array}{l}8 \\
5\end{array}$ & $\begin{array}{l}1 / 5 \\
4 / 5\end{array}$ & $\begin{array}{l}0.96 \\
0.27\end{array}$ & 0.40 \\
\hline $2820.8-2821.2$ & $\begin{array}{l}\mathrm{B} \\
\mathrm{A}\end{array}$ & $\begin{array}{l}490 \\
490\end{array}$ & $\begin{array}{ll}3 & \text { to } \\
2 & \text { to }\end{array}$ & $\begin{array}{l}8 \\
5\end{array}$ & $\begin{array}{l}3 / 4 \\
3 / 4\end{array}$ & $\begin{array}{l}0.87 \\
0.31\end{array}$ & 0.45 \\
\hline
\end{tabular}


TABLE 7.14

Homogenization temperatures $\left({ }^{\circ} \mathrm{C}\right)$ of two-phase

1 iquid + gas inclusions from ERDA No. 9 core

(numbers of inclusions run given in parentheses)

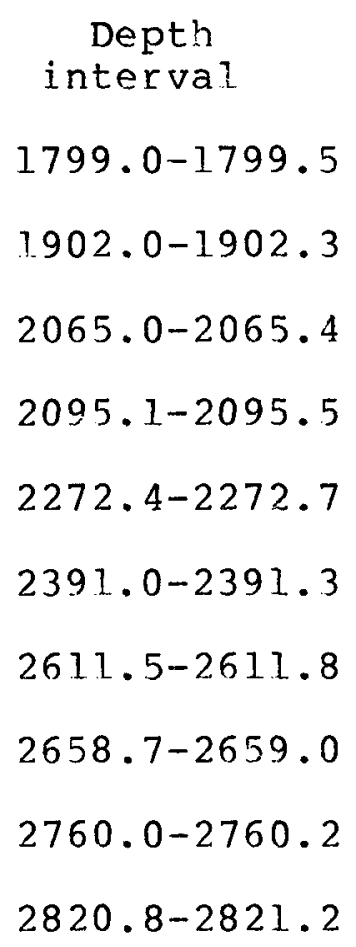

Homogenization temperatures

$20.5(1), 21.0(1), 25(3)$

$25.1(1)$

(none)

$25.6(2), 34.5(1), 44.0(1), 45.5(2)$

$41.25(1), 42.5(1), 42.6(3)$

$23(4), 39(2)$

(none)

$43.0(1), 43.25(l), 43.5(1), 44(2), 45.0(1)$

$20.4(1), 21.6(1), 21.8(2)$

$22.5(1), 23.0(1), 25.5(1)$ 
TABT,E 7.15

Summary of freezing data $\left({ }^{\circ} \mathrm{C}\right)$, mainly on

type $B$ inclusion in samples from ERDA No. 9 core

\begin{tabular}{|c|c|c|c|}
\hline Depth & $\begin{array}{l}\text { First } \\
\text { nelting } \\
\text { temp. }\end{array}$ & Freezing temp. & Notes \\
\hline 1799 & $<-31.9$ & $>\quad+10$ & $\sim 20 \%$ Iiquid at -31.9 \\
\hline 1902 & $<-32$ & $>+10$ & \\
\hline 2095 & $<-28.4$ & +15 & $\sim 20-25 \% \mathrm{x}$ Is at $0^{\circ} \mathrm{C}$ \\
\hline$n$ & -32.2 & $"$ & \\
\hline 2272 & $<-32.8$ & +11.8 & $\sim 50 \%$ xls at $0^{\circ} \mathrm{C}$ \\
\hline 2391 & $<-26.1$ & $>\quad+12.8$ & \\
\hline 2760 & $<-32$ & $>+12.7$ & \\
\hline
\end{tabular}


TABLE 7.16

Test data and wejght loss (in $\%$ ) from decrepitation tests. Roman numerals indicate amount of sample breakup after run: I - unbroken; II - broken into 2 or 3 pieces; IIT - broken into more than 3 pieces.

Temperature, ${ }^{\circ} \mathrm{C}$

Core interval (ft)

$2058.8-2059.0$

$2070.4-2070.6$

$2606.5-2606.9$

$2617.2-261.7 .7$

$2626.7-2627.0$

$2659.0-2659.2$

$2665.0-2665.1$

$2692.4-2692.6$

$2699.8-2700.0$

Average
150

0.16 IT

0.16 I I

$0.02 \mathrm{I}$

$0.06 \mathrm{I}$

$0.19 \mathrm{~T}$

$0.14 \mathrm{I}$

$0.19 \mathrm{I}$

$0.06 \mathrm{~T}$

$0.19 \mathrm{I}$

0.13

\section{0}

0.23 IT

$0.12 \mathrm{~T}$

0.24 II

$0.30 \mathrm{I}$

$0.28 \mathrm{I}$

$0.13 \mathrm{I}$

$0.18 I$

$0.25 \mathrm{I}$

0.24 I T

0.22
250

0.76 III

0.35 r T r

0.95 III

0.62

1.04 IIT

0.59 LTT

0.75 IIJ

0.83 ז. T

0.65 IJI

0.73

Heating schedule (hours)

Room $T$ to run $T$
Hold at run $T$
Run $T$ to room $T$

9.5

8

79

95

79

Run $T$ to room $T$

$\sim 9$

$\sim 9$

$\sim 10$ 


\section{TABILE 7.17}

Temperature of homogenization and volume $z$ vapor of two-phase inclusions in salt of samples after decrepitation tests.

Decrepitation

run temp. $\left({ }^{\circ} \mathrm{C}\right)$

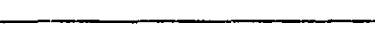

150

200

250

\author{
Homogenization \\ temp. $\left({ }^{\circ} \mathrm{C}\right)$ \\ Minimum \\ Maximum
}

120

180

180

90

110

273
Number of inclusions
runs

\section{Volume o vapor phase; avg. for $\sim 25$ inclusions}

16

21

28
0.8

1.8

5.0

Note: Birefringent crystals, present in some of these inclusions, do not disappear during homogenization runs. 
TABLE 7.18

Temperature of homogenization of two-phase inclusions in salt from near dike in Kerr-McGee mine, Lea county, New Mexico.

Sample no. Distance from dike (m)
Temp. of homogenization (OC)
Minimum

71

85
Number of inclusions run

MB $-77-8$

0.2

2.5

MB- $76-4$

* Two birefringent crystals remained unchanged, and a cubic crystal (KC] ?) dissolved at $82^{\circ} \mathrm{C}$. (See Plate $7-42$ for a similar inclusion.) 
TABLE 7.19

INVENTORY OF FLUIDS SAMPLED FOR GEOCHEMICAL STUDIES OF DELAWARE BASIN GROUNDWATERS

\begin{tabular}{c}
$\begin{array}{c}\text { Sample } \\
\text { No. }\end{array}$ \\
\hline \\
1 \\
2 \\
3 \\
4 \\
5 \\
6 \\
7 \\
8 \\
9 \\
10 \\
11 \\
12 \\
13 \\
14 \\
15 \\
16 \\
17 \\
18 \\
19 \\
20 \\
21 \\
22 \\
23 \\
24 \\
25 \\
26 \\
27 \\
28 \\
29
\end{tabular}

Sample Name

Formation

Sampled

Location

Stable

Isotopes

Solute

Capitan T22S-R26E-S1

Carlsbad City \#7

Duval Mine/Collector Ring

Capitan

Salado

Salado

Duval Mine/Seep-BT58

James Ranch

Fairview

Todd state 36-1

Todd Federal 26-4

Todd Federal 26-1

Shell No. 28

Middleton

Hackberry

ERDA \#6

Shell Bootleg

Duval Mine/Vent Hole

UNM Pokorny

Smith Livingston Ridge

Rustler

T22S-R30E-S 33

T22S-R30E-S33

T22S-R30E-S 33

T2 3S-R32E-S 36

Morrow T23S-R31E-S36

Bell Canyon T23S-R31E-S26

Morrow T23S-R31E-S26

Capitan PSL Blk 74-S34 (Texas)

Capitan

Capitan

Castile

Castile

Salado

Castile

Indian

Santa Rosa

Rustler

T19S-R32E-S21

T19S-R31E-S 31

T21S-R31E-S35

T22S-R32E-S 36

T22S-R30E-S 33

PSL Blk 6I-S3 (Texas)

T22S-R31E-S15

Rustler

T23S-R30E-S21

Mobley

Mobley \#3

Hl-Magenta

Hl-Culebra

Rustler

Rustler

Rustler

T23S-R30E-SI

T23S-R30E-S2

R22S-R31E-S29

T22S-R31E-S29

T22S-R31E-S29

3-Culebra

Rustler

Green Lake

Capitan

Mirror Lake

Capitan

Capitan

Celery Stalk Pool

Capitan

T22S-R31E-S29

Carlsbad Caverns

Carlsbad Caverns

Carbsbad Caverns

Carlsbad Caverns

Solutes Isotopes *Analyst

\footnotetext{
* Analysts: $\quad M$ - Martin Water Laboratories

$S$ - Sandia

Sh - Shell

U - U.S. Geological Survey
} 
TABLE 7.20

GMOCHEMICAL ANALYSES OF DELAWARE BASIN GROUNDWATERS (Solutes in $\mathrm{mg} / \mathrm{l}$ )

\begin{tabular}{|c|c|c|c|c|c|c|c|c|c|c|c|c|c|}
\hline No. & pH & ${ }_{0 / \infty}^{18} 0$ & $0 \%$ & $\mathrm{Ca}^{++}$ & $\mathrm{Mg}^{++}$ & $\mathrm{Na}^{+}$ & $\mathrm{K}^{+}$ & $\mathrm{Cl}^{-}$ & $\mathrm{Br}^{-}$ & $\mathrm{SO}_{4}^{+}$ & $\mathrm{HCO}_{3}^{-}$ & TDS & $\begin{array}{c}\text { Other } \\
\text { Information }\end{array}$ \\
\hline$T 1$ & 7.2 & -7.9 & -54 & 74 & 29 & 8 & 1 & 10 & 0 & 72 & 285 & 474 & $\mathrm{NO}_{3}: 5$ \\
\hline 2 & 7.4 & -6.4 & -48 & 1100 & 280 & 3600 & 405 & 6400 & 0 & 2500 & 122 & 14380 & $S r: 30$ \\
\hline 3 & 5.5 & +3.0 & -10 & 640 & 55400 & 27500 & 3000 & 236500 & 305 & 3650 & 1090 & 355085 & $\mathrm{BO}_{3}: 660$ \\
\hline 4 & 5.4 & +2.6 & -12 & 500 & 62600 & 44400 & 30250 & 251500 & 530 & 3300 & 1170 & 395000 & $\mathrm{BO}_{3}: 840$ \\
\hline 5 & 5.5 & 1200 & & 520 & 62000 & 46300 & 30250 & 250000 & 582 & 3100 & 1170 & 395000 & $\mathrm{BO}_{3}: 990$ \\
\hline 6 & 7.6 & -5.0 & -40 & 590 & 175 & 68 & 5 & 400 & 0 & 1570 & 190 & 3240 & $\mathrm{NO}_{3}: 225$ \\
\hline 7 & 7.6 & -7.1 & -53 & 590 & 200 & 120 & 3 & 142 & 0 & 2140 & 130 & 3350 & \\
\hline 8 & 6.4 & +2.7 & -15 & 1600 & 240 & 11300 & 500 & 20600 & 23 & 300 & 380 & 35600 & Sr $: 240$ \\
\hline 9 & 7.1 & +2.2 & -13 & 27600 & 6075 & 76700 & 1700 & 18500 & 410 & 210 & 215 & 295400 & Sr $: 1750$ \\
\hline 10 & 6.6 & +9.2 & -18 & 4880 & 920 & 28700 & 200 & 55400 & 90 & 30 & 300 & 92400 & Sr : 1750 \\
\hline 11 & 7.1 & -7.7 & -56 & 940 & 280 & 2280 & 57 & 3900 & 0 & 2400 & 550 & 11300 & \\
\hline 12 & 7.4 & -7.5 & -55 & 1100 & 570 & 10600 & 330 & 17050 & & 3720 & 300 & 33800 & Sr: 64 \\
\hline 13 & 6.0 & -6.5 & -46 & 2200 & 1680 & 68700 & 2950 & 110800 & & 5150 & 132 & 192000 & Sr $: 140$, Fe: 312 \\
\hline 14 & 7.3 & +10.3 & 0 & 130 & 350 & 112000 & 5100 & 186100 & 240 & 16000 & 1310 & 321000 & $\mathrm{B0}_{3}: 650, \mathrm{Li}: 160$ \\
\hline 15 & 7.7 & & & 550 & 1860 & 124500 & & 185000 & & 16800 & 1480 & 330700 & \\
\hline 16 & 5.8 & & & 1260 & 38500 & 49000 & 52500 & 241500 & 385 & 3600 & 700 & 388650 & $\mathrm{BO}_{3}: 1160$ \\
\hline 17 & 1.6 & -6.0 & -50 & 190 & 100 & 200 & 18 & 2700 & 0 & 570 & 0 & 3800 & \\
\hline 18 & & -7.2 & -52 & & & & & & & & & & \\
\hline 19 & & -6.3 & -46 & & & & & & & & & & \\
\hline 20 & & -6.9 & -44 & & & & & & & & & & \\
\hline 21 & & -5.9 & -44 & & & & & & & & & & \\
\hline 22 & 7.4 & -6.8 & -48 & 890 & 270 & 5700 & 70 & 8000 & & 3900 & 92 & 18922 & \\
\hline 23 & 7.6 & -7.0 & -50 & 780 & 280 & 9400 & 190 & 12000 & & 7400 & 105 & 30155 & \\
\hline 24 & 7.4 & -7.3 & -53 & 760 & 190 & 4200 & 100 & 5800 & & 2600 & 1150 & 14800 & \\
\hline 25 & 7.4 & -7.0 & -53 & 1500 & $720^{\circ}$ & 19000 & 450 & 33000 & & 5200 & 88 & 60000 & \\
\hline 26 & & -3.6 & -24 & & & & & & & & & & \\
\hline 27 & & -4.3 & -28 & & & & & & & & & & \\
\hline 28 & & -4.2 & -29 & & & & & & & & & & \\
\hline 29 & & -3.0 & -20 & & & & & & & & & & \\
\hline
\end{tabular}


TABI,E 7.21

DUVAL MINE VENT HOLE WATER \#16

One liter of solution might be expressed as the following amounts of common evaporite minerals:

$\begin{array}{lllll}0.006 \text { moles } & (1 & \mathrm{gm}) & \mathrm{CaMg}\left(\mathrm{CO}_{3}\right)_{2} & \text { Dolomite } \\ 0.026 \text { moles } & (4 \mathrm{gm}) & \mathrm{CaSO}_{4} & \text { Anhydrite } \\ 0.012 \text { moles } & (3 \mathrm{gm}) & \mathrm{KMgClS} \mathrm{C}_{4} \cdot 11 / 4 \mathrm{H}_{2} \mathrm{O} & \text { Kainite } \\ 1.343 \text { moles } & (370 \mathrm{gm}) & \mathrm{KMgCl} \cdot 6 \mathrm{H}_{2} \mathrm{O} & \text { Carnallite } \\ 0.224 \text { moles } & (46 \mathrm{gm}) & \mathrm{MgCl}_{2} \cdot 6 \mathrm{H}_{2} \mathrm{O}_{2} & \text { Bischofite } \\ 0.005 \text { moles } & (2 \mathrm{gm}) & \mathrm{Na} 2 \mathrm{~B}_{4} \mathrm{O}_{7} \cdot 10 \mathrm{H}_{2} \mathrm{O} & \text { Borax } \\ 2.121 \text { moles } & (121 \mathrm{gm}) & \mathrm{NaCl} & \text { Halite }\end{array}$


TABILE 7.22

TODD FEDERAI $26-4$ WATER \#9

One liter of solution might be expressed as the following amounts of common evaporite minerals:

$\begin{array}{llll}0.10 \text { moles } & (52 \mathrm{gm}) & \mathrm{CaMg}_{2} \mathrm{Cl}_{6} \cdot 12 \mathrm{H}_{2} \mathrm{O} & \text { Tachyhydrite } \\ 0.04 \text { moles } & (4 \mathrm{gm}) & \mathrm{KMgCl}_{3} \cdot 6 \mathrm{H}_{2} \mathrm{O}^{2} & \text { Carnalite } \\ 0.59 \text { moles } & (129 \mathrm{gm}) & \mathrm{CaCl}^{2} \cdot 6 \mathrm{H}_{2} \mathrm{O} & \text { Antarcticite } \\ 3.34 \text { moles } & (195 \mathrm{gm}) & \mathrm{NaCl} & \text { Halite }\end{array}$


TABILE 7.23

ERDA 6 WATER \# 14

One liter of solution might be expressed as the following amounts of common evaporite minerals:
0.003 moles
0.009 moles
0.011 moles
0.130 moles
0.155 moles
0.048 moles
4.521 moles

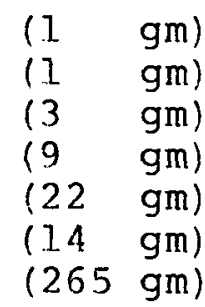
$\mathrm{CaMg}\left(\mathrm{CO}_{3}\right)_{2}$
$\mathrm{MgCO}_{3}$
$\mathrm{KMgCiSO}_{4} \cdot 11 / 4 \mathrm{H}_{2} \mathrm{O}$
$\mathrm{KCl}$
$\mathrm{Na}_{2} \mathrm{SO}_{4}$
$\mathrm{I} \mathrm{iCl}$
$\mathrm{NaCl}$

Dolomite

Magnesite

Kainite

Sylvite

Thenardite ?

Hal ite 
TABLE 7.24

Rb-Sr Data for Evaporites from the Salado Formation

A. Wholle Rocks

Core hole

Interval.

AEC- 8

$1622.4-1622.9$

$1636.6-1637.1$

(sylvite rich

portion)

$1645.0-1645.3$

$1671.2-1671.8$

$1715.4-171.15 .7$

$1762.0-1762.3$

$1782.2-1782.4$

ERDA-9

$1404.8-1405.8$

$1648.5-1549.0$

1759.l-1.759.8

(polyhalite rich

portion)

$\left({ }^{87} \mathrm{Sr} /{ }^{86} \mathrm{Sr}\right)_{\mathrm{N}}$

0.7056

0.7816

0.7150

0.7097

0.7089

0.7099

0.7137

0.7934

0.7079

0.7064

ERDA- 6

$1421.0-1421.7$

0.7095

0.60

156.2

8.0

48.2

39.8

90.9

37.9

5.7

67.1.

0.47

5.1

44.7

793.5

0.02

4.9

B. Water soluble portions

ERDA-8

$1607.0-1608.0$

0.7173

0.8601

0.7094

0.7072

$1713.6-1714.0$

0.7067

$1772.0-1772.4$

c. <2 Micron Fractions (clays)

AEC -3

$1.607 .0-1608.0$

$167 l .2-1671.8$

0.7229

0.7273

ERDA-9

$1404.8-1405.8$

$1772.0-1772.4$

0.7608

0.7181
42.9

43.9

84.5

29.4
70.8

0.99

2.0

1.5
44.7

1.73

0.01

8.41
0.03

38.41
0.03

43.77
0.02
0.41
0.02
0.10
0.15

43.77
0.02
0.41
0.02
0.10
0.15

43.77
0.02
0.41
0.02
0.10
0.15

43.77
0.02
0.41
0.02
0.10
0.15

43.77
0.02
0.41
0.02
0.10
0.15

${ }^{87} \mathrm{Rb} /{ }^{86} \mathrm{Sr}$

0.13 
\& Insoluble Residue in whole Rock

Core hole Interval

AEC-8

$1607.0-1608.0$

$1610.8-1611.3$

$1622.4-1622.9$

$1636.6-1637.1$

$1645.0-1645.3$

$1671.2-1671.8$

$1715.4-1715.7$

$1782.2-1782.4$

\section{ERDA-9}

$1404.8-1.405 .8$

$1621.9-1622.2$

$1633.6-1634.1$

$1648.5-1649.0$

$1652.8-165.3 .1$

$1709.0-1709.5$

$1713.6-1714.0$

$1759.1-1759.8$

$1772.0-1772.4$
Insoluble Residue (percent)

$$
\begin{array}{r}
9.0 \\
9.0 \\
2.0 \\
3.7 \\
0.8 \\
11.3 \\
1.1 \\
12.5
\end{array}
$$

$$
\begin{array}{r}
7.2 \\
0.8 \\
0.4 \\
2.1 \\
0.3 \\
1.1 \\
18.2 \\
0.7
\end{array}
$$$$
12.5
$$ 
TABI_E 7.26

\section{Mineralogica] Data}

Core hole

Interval.

Halite

sylvite

Polyhalite

Langbeinite

A. Whole Rocks (Evaporite Mineralogy by XRD)

AEC- 8

$1607.0-1608.0$

$1610-8-1611-3$

$1622.4-1622.9$

$1636.6-1637.1$

$1645.0-1645.3$

$1671.2-1671.8$

$1715.4-1715.7$

$1762.0-1762.3$

$1782.2-1782.4$

VA

VA

VA

VA

VA

VA

VA

VA

$A$

VA
$A$
$A$
$V A$
$t$
$t$
$t$
$t$
$A$

ERDA-9

$1404.8-1405.8$

$1621.9-1622.2$

$1633.6-1634.1$

$1648.5-1649.0$

$1652.8-1653.1$

$1709.0-1709.5$

$1.713 .6-1714.0$

$1759.1-1.759 .8$

$1.772 .0-1772.4$

$A$

VA

VA

VA

VA

VA

VA

VA

VA

-
-
$t$
-
$t$
-
A

-

A

$-$

-

-

$\cdots$

$-$

t

ERDA- 6

$1421.0-1421.7$

VA

$t$
$t$
$t$
$A$
$t$
$A$
$A$
$A$
$A$

VA

VA

$-$

$-$

$-$

-

-

-.

$-$

-

t

$-$ 
TABLE 7.26, continued

\section{Mineralogical Data}

Core hole Interval.

Halite

sylvite

Polyhalite

Langbeinite

B. 2 Micron Fractions (Clays, Minerals)

Core Hole

Interval

AEC -8

$1607.0-1608.0$

$1610.8-1611.3$

$1622.4-1622.9$

$1636.6-1637.1$

$1645.0-1645.3$

$1671.2-1671.8$

$1715.4-1715.7$

$1762.0-1762.3$

$1782.2-1782.4$

ERDA-9

$1404.8-1405.8$

$1648.5-1649.0$

$1713.6-1714.0$

$1772.0-1772.4$

ERDA- 5

$1421.0-1421.7$

\section{Chlorite \\ Saponite \\ Chlorite/ \\ Saponite}

I11.ite

Talc

Serpentine

-
$t$
-
-
$t$
-
$A$
$t$
$A$

$\begin{array}{ll}- & \text { VA } \\ - & A \\ - & t \\ - & A \\ - & A \\ - & \text { VA } \\ - & t \\ t & - \\ - & t\end{array}$

-

A

$-$

-
-
-

A
A
VA
VA

A

A

A

VA

A

A

A

VA

VA

VA

A

A

$t$

$t$
A

A

$t$

t

A

VA

$t$

A

VA

$V A$

A

$t$

$\begin{array}{ll}\text { VA: } & \text { very abundant } \\ A: & \text { abundant } \\ t: & \text { trace } \\ -: & \text { not detected }\end{array}$


TABLE 7.27

URANIUM CONCENTRATIONS AND ISOTOPIC RATIOS IN DELAWARE BASIN WATERS

$\begin{array}{llcl}\text { Sample } & \text { U Concentration } & \alpha\left({ }^{234} \mathrm{U} /{ }^{238} \mathrm{U}\right) & \delta^{18} 0(\mathrm{SMOW}) \\ \text { Shell } & 0.60 \text { parts in } 10^{9} & 2.75 & -7.7 \\ \text { Middleton } & 0.54 \text { parts in } 10^{9} & 1.81 & -7.5 \\ \text { Hackberry } & 0.02 \text { parts in } 10^{9} & 1.22 \pm 0.05 & -6.5 \\ \text { Carlsbad } 7 & 0.05 \text { parts in } 10^{9} & 5.14 & -7.9 \\ \text { ERDA } 61140 \mathrm{hr} & 89 \text { parts in } 10^{9} & 1.11 \pm 0.04 & -46 \\ \text { ERDA } 61212 \mathrm{hr} & 4.8 \text { parts in } 10^{9} & 1.26 \pm 0.05 & -54 \\ \text { ERDA } 61445 \mathrm{hr} & 2.14 \text { parts in } 10^{9} & 1.37 \pm 0.07 & +10.3 \\ \text { ERDA } 61520 \mathrm{hr} & 1.88 \text { parts in } 10^{9} & 1.33 \pm 0.07 & 0 \\ \text { ERDA 6 Drill Mud } & 67.2 \text { parts in } 10^{9} & 1.19 & 2.04 \\ \text { Brine Lake } & 56.3 \text { parts in } 10^{9} & \end{array}$

(Mud Ingredient) 
Arrows in these photographs point stratigraphically upward.

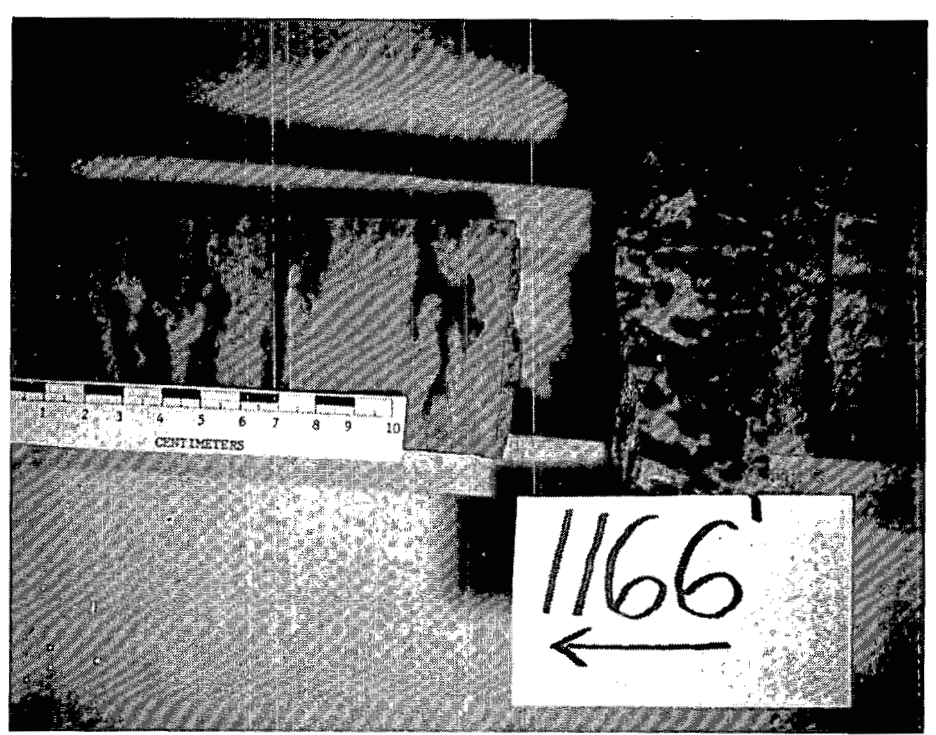

Plate 7.1. Core footage: 1165.4 to $1177.1 \mathrm{ft}$. (including 0.1 ft. gap) Brownish halite in gray anhydrite. Halite occurs as a thin bed at top of specimen, then as irregular lenses and thin laminae, finally as vertically elongate crystals, some with "swallow tail" form, near bottom of specimen. Locally horizontal laminae occur within the anhydrite due either to color change of the anhydrite or laminae of magnesite.

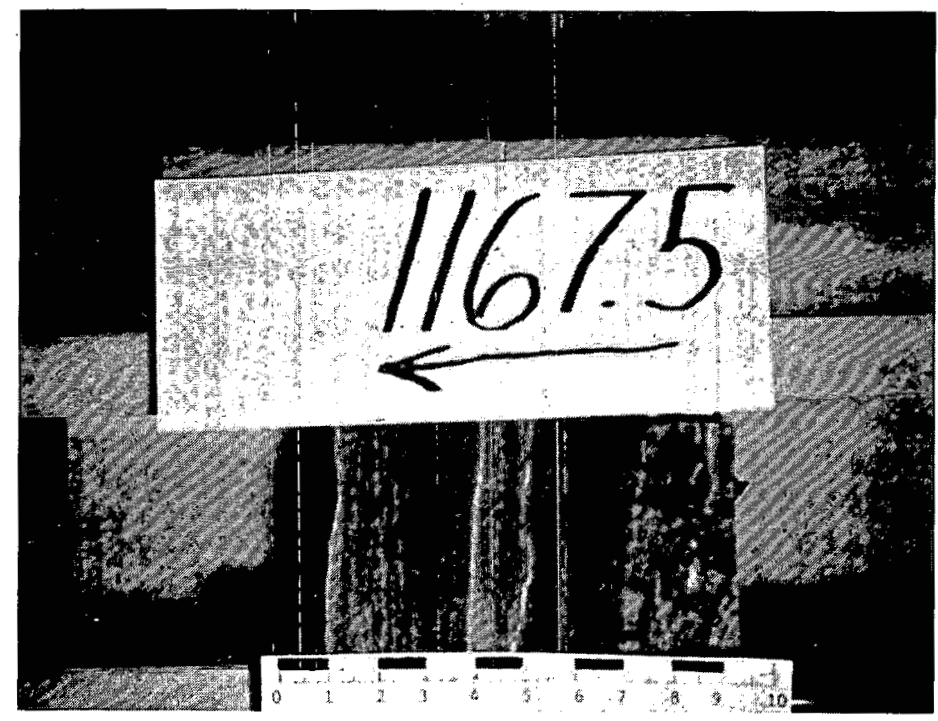

Plate 7.2. Core footage: $1167.5 \mathrm{ft}$. Dominantly light to dark gray, laminated anhydrite with thin, locally discontinuous, laminae of white magnesite and brownish, elongate halite oriented perpendicular to convex-upward, discontinuous laminae of light gray to white anhydrite. 


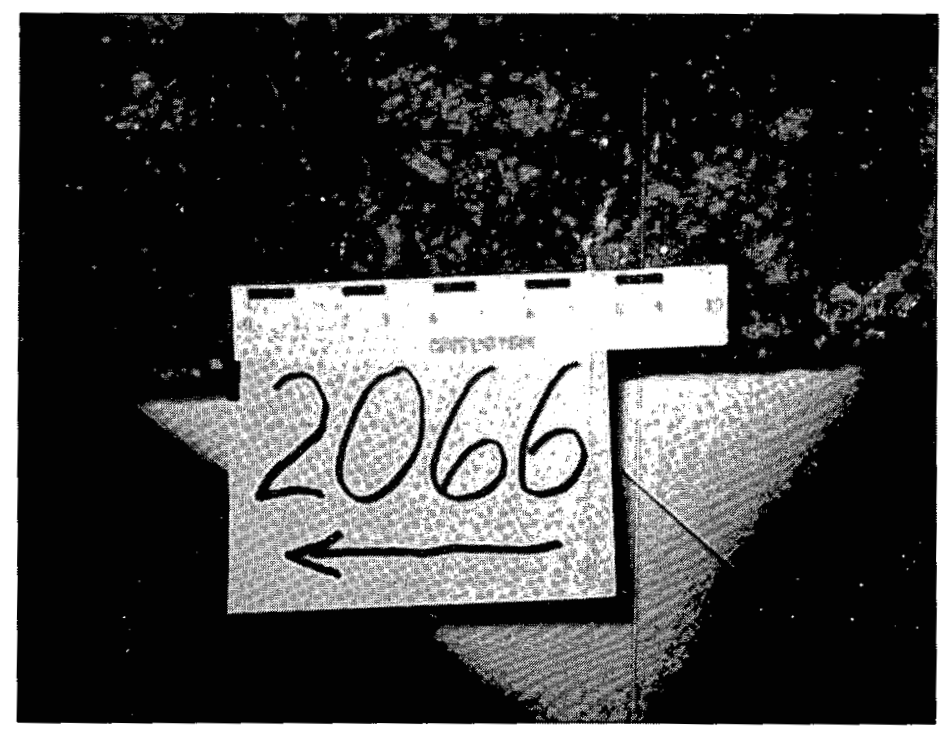

Plate 7.3. Core footage: 2065.8 to $2066.6 \mathrm{ft}$. Dominantly clear to milky white halite crystals, approximately $10 \mathrm{~mm}$ in size, and reddish brown to pinkish brown polyhalite. Note rectangular outline of polyhalite body stratigraphically above the first 6 in 2066 ; but most polyhalite occurs around halite crystal boundaries below 2066 label.

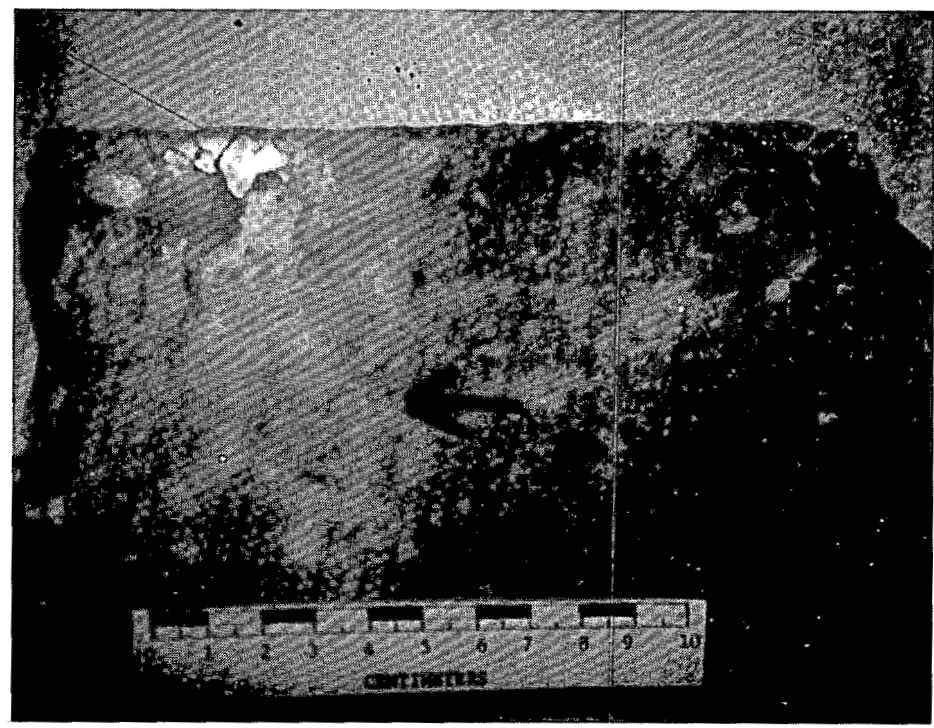

Plate 7.4. Core footage: 2615.0 to $2615.6 \mathrm{ft}$. Dominantly coarse (ranging from 3 to 40 , average $20 \mathrm{~mm}$ in size) halite crystals, some with cubic form but most anhedral, locally separated by microcrystalline white anhydrite. 


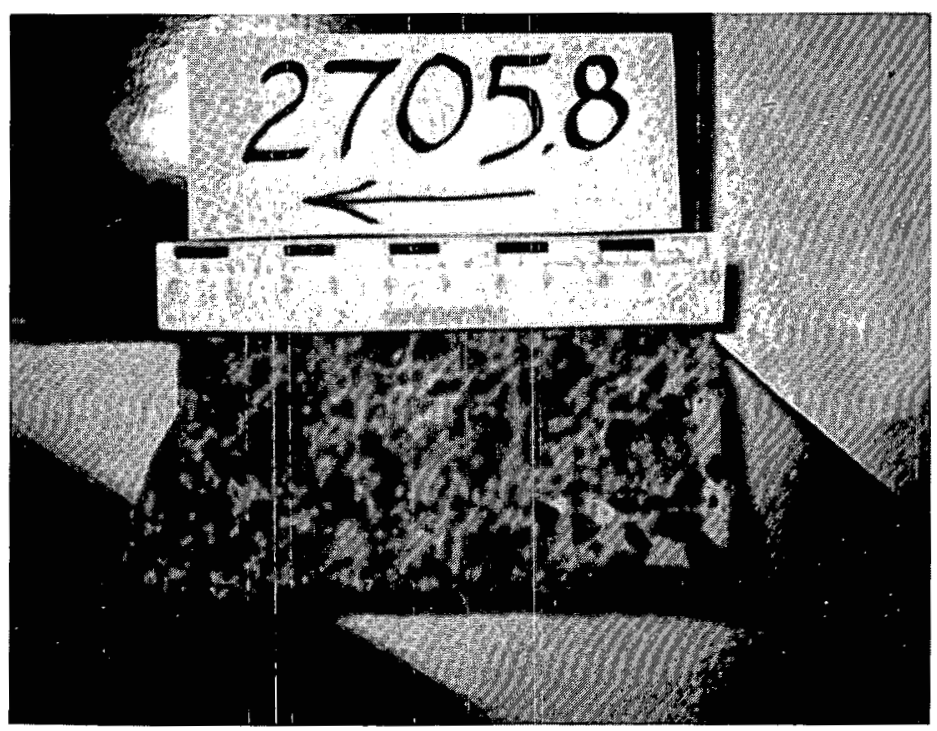

Plate 7.5. Core footage: $2705.8 \mathrm{ft}$. Coarse, ranging from 2 to $15 \mathrm{~mm}$, light gray to black halite in white microcrystalline anhydrite and rare 1 to $2 \mathrm{~mm}$ bodies of pure white magnesite.

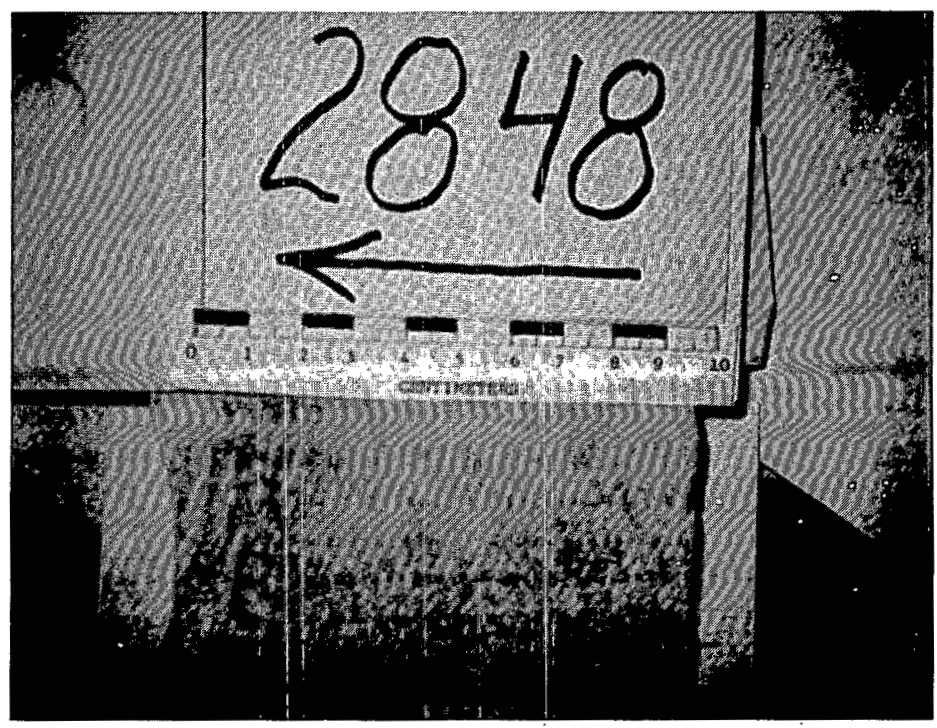

Plate 7.6. Core footage: $2848 \mathrm{ft}$. Varicolored (white and all shades of gray) anhydrite, some crystals near stratigraphic top of sample exhibit "swallow tail" form. 


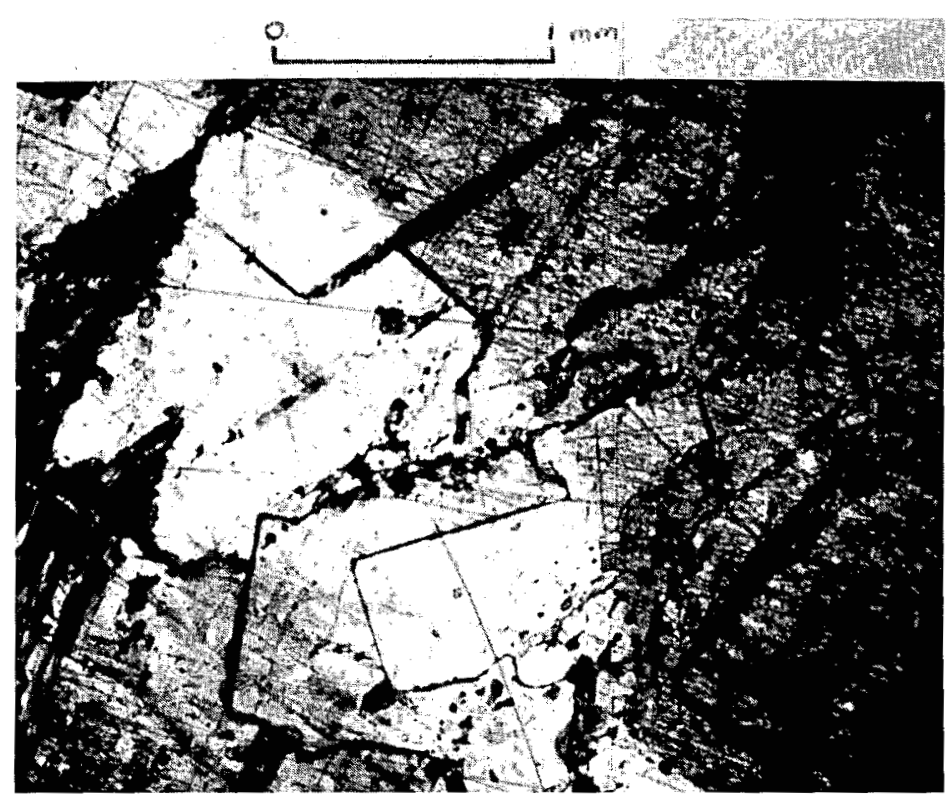

Plate 7.7. Photomicrograph (25X, plane light) of halite: many euhedral (cubic) to subhedral, relatively clear crystals locally containing fluid inclusions. Crystal size ranges from 0.5 to $1.5 \mathrm{~mm}$. Compare with Plate 7.8 .

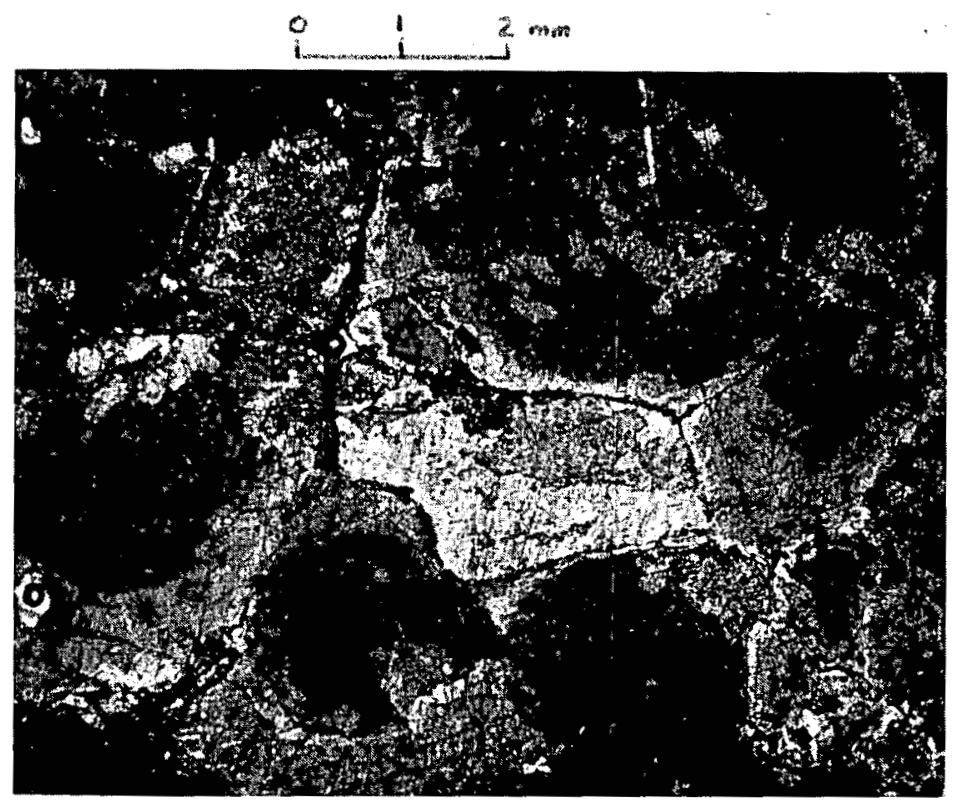

Plate 7.8. Photomicrograph (10x, plane light) of halite: subhedral to anhedral, cloudy crystals devoid of fluid inclusions. Crystal size ranges from 1.5 to $4.5 \mathrm{~mm}$. 


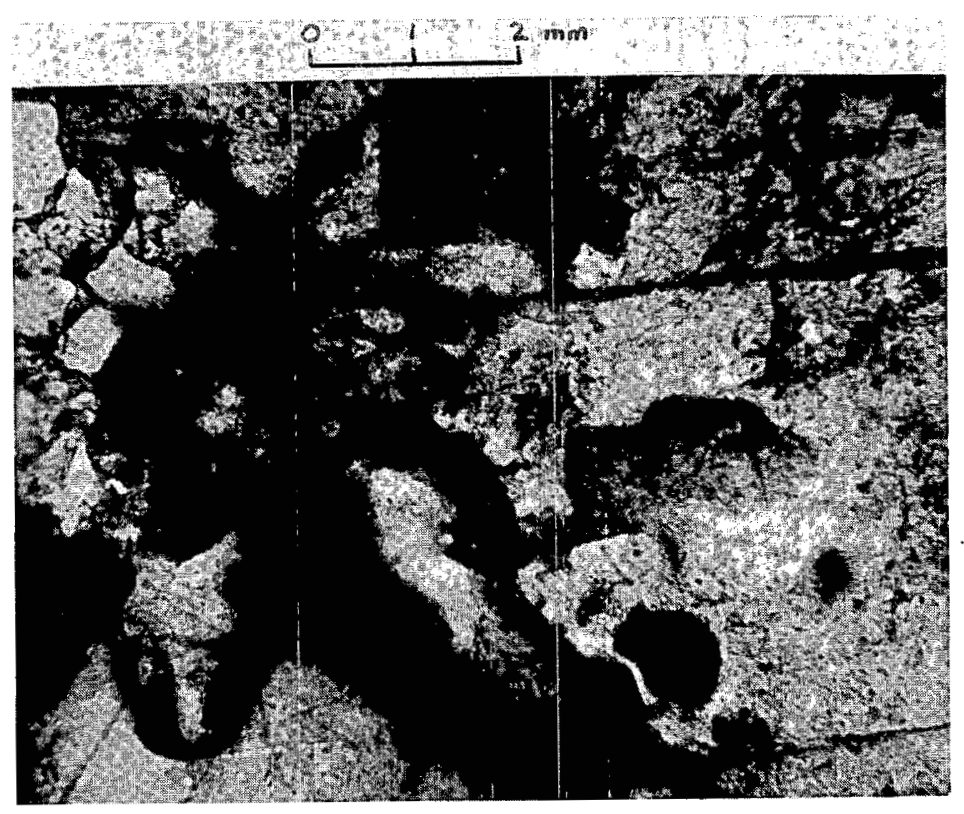

Plate 7.9. Photomicrograph (10x, plane light) of sylvite (reddish, translucent to black, opaque in photo) and halite: halite anhedra size ranges from 0.4 to $5 \mathrm{~mm}$. Two subhedra dominantly of sylvite occur within halite anhedra, one subhedron/anhedron of mixed sylvite and halite occurs within a coarse halite subhedron, but most sylvite occurs as anastomosing bodies having gradational contacts with halite between halite anhedra. 

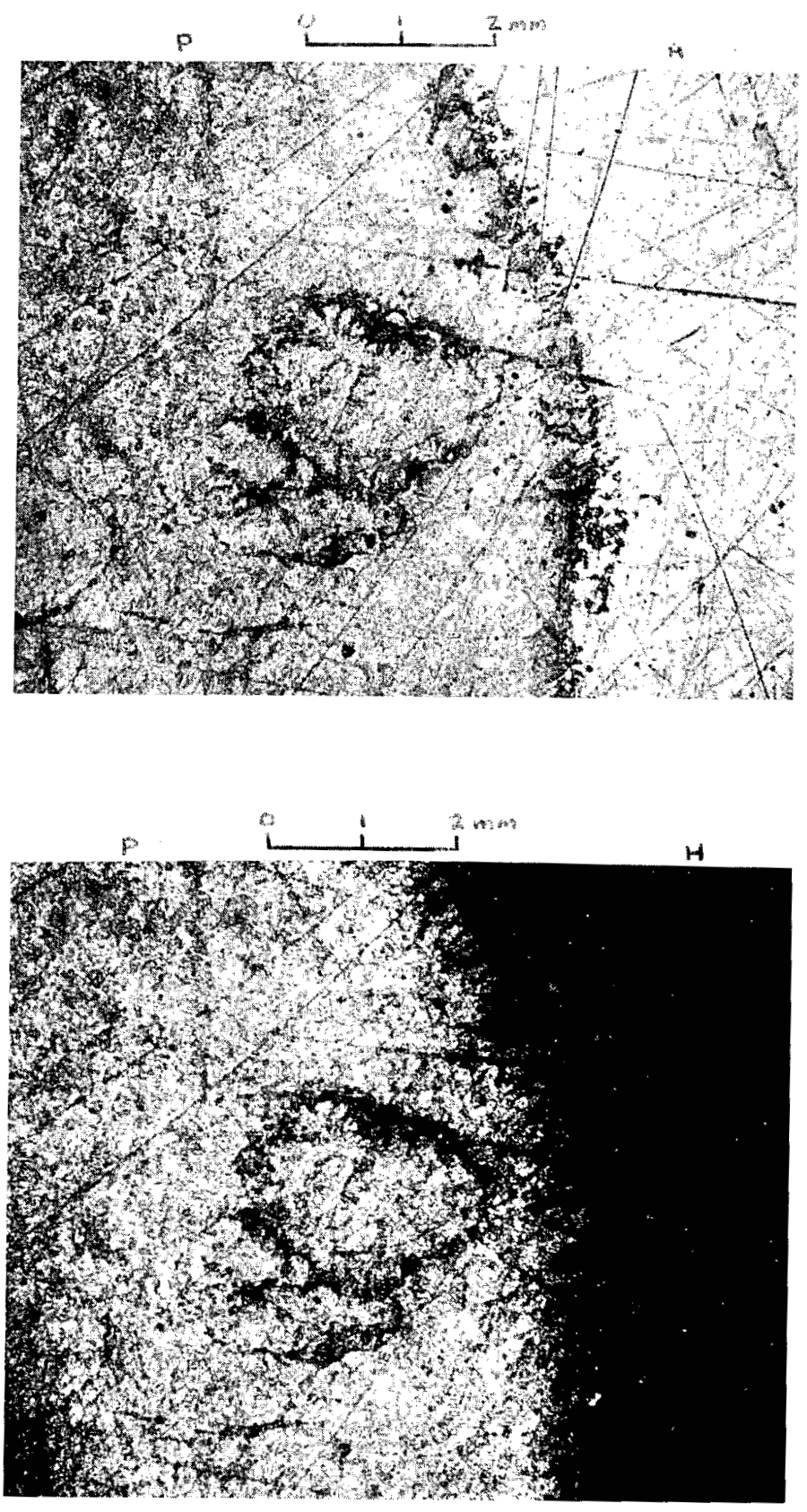

Plates 7.10A and 7.10B. Photomicrographs (10X, plane light in $7.10 \mathrm{~A}$, crossed nicols in $10 \mathrm{~B}$ ) of polyhalite (P) and halite (H) : Polyhalite occurs as a cloudy anhedron (pinkish in hand specimen) locally containing smaller anhedra which are apparent due to concentrations of opaque (black in the photo, red under microscope reflected light) material, probably hematite. Concentrations of hematite also occur along the contact of polyhalite with halite which becomes extinct (black in 10B) under crossed nicols. The contact is irregular and gradational. 


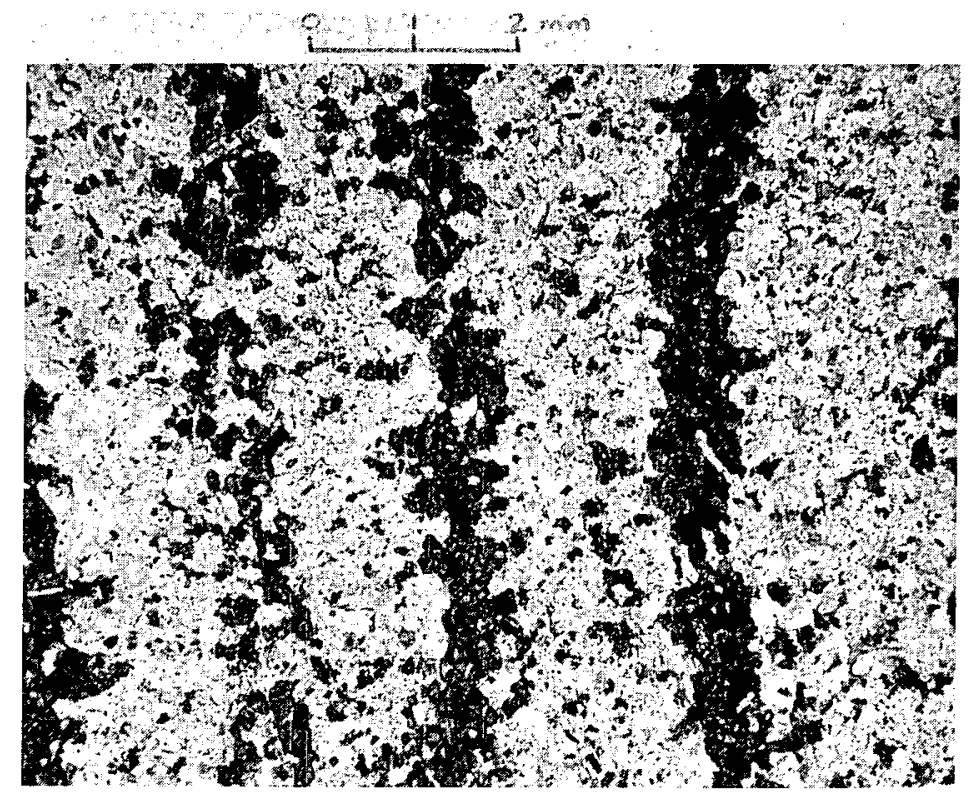

Plate 7.11. Photomicrograph (10x, plane light) of laminated anhydrite and calcium or magnesium carbonate: Dark thin laminae (approximately $1 \mathrm{~mm}$ thick) of dominantly carbonate anhedra separate thin laminae (approximately $2 \mathrm{~mm}$ thick) of dominantly anhydrite anhedra. 

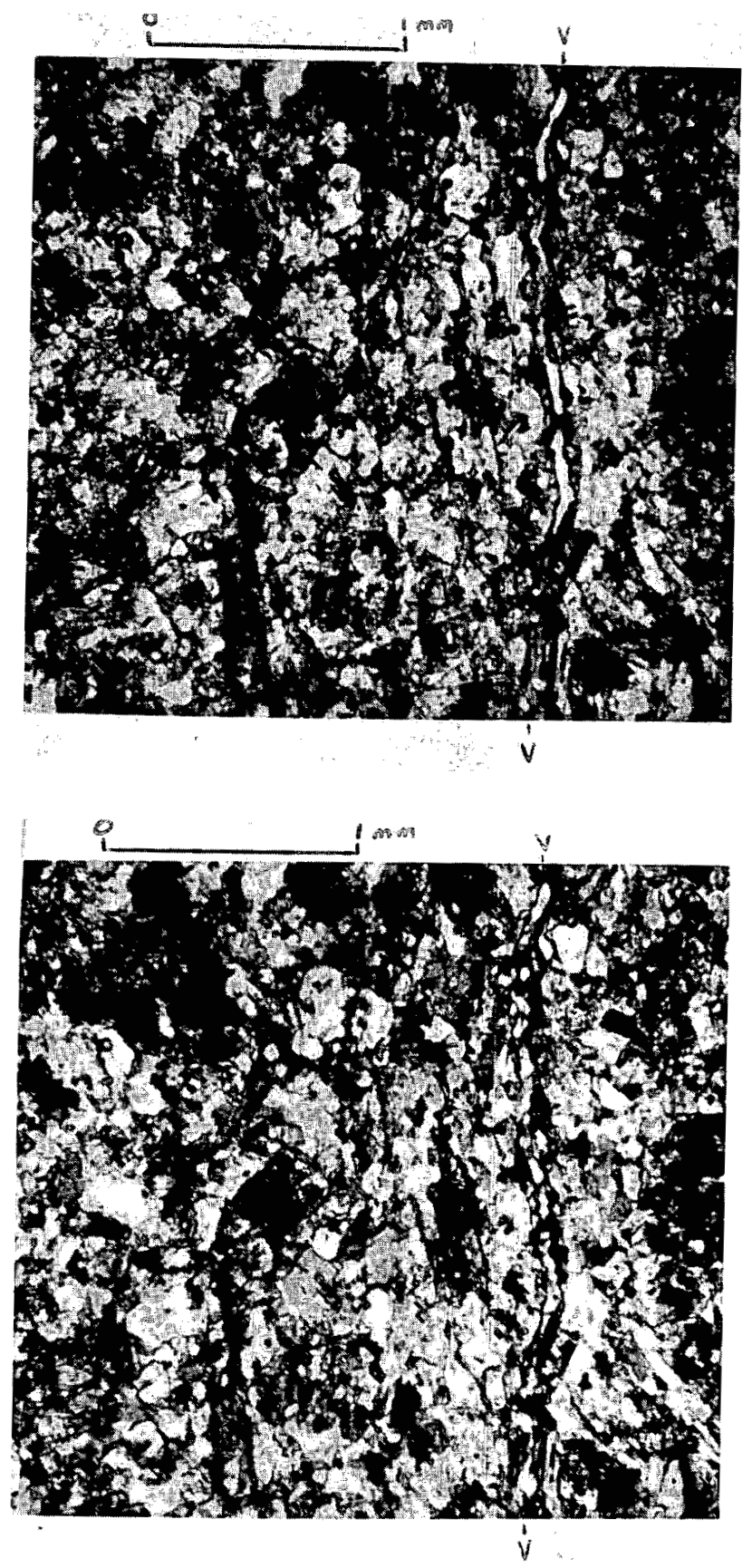

Plates 7.12A and 7.12B. Photomicrographs (25X, plane light in Plate 7.12A, crossed nicols in Plate 7.12B) of anhydrite with veinlet (V) of gypsum. Anhydrite occurs as a mosaic of 0.04 to $0.4 \mathrm{~mm}$ anhedra and subhedra with high order interference colors in 12B. Veinlet somewhat discontinuous, is more apparent in $12 \mathrm{~A}$ and consists of very elongate irregular anhedra of relatively clear gypsum with lower order interference colors than the anhydrite in 12B. The veinlet is approximatedly stratigraphically horizontal and is $0.06 \mathrm{~mm}$ thick, the width of a single elongate gypsum anhedron. 


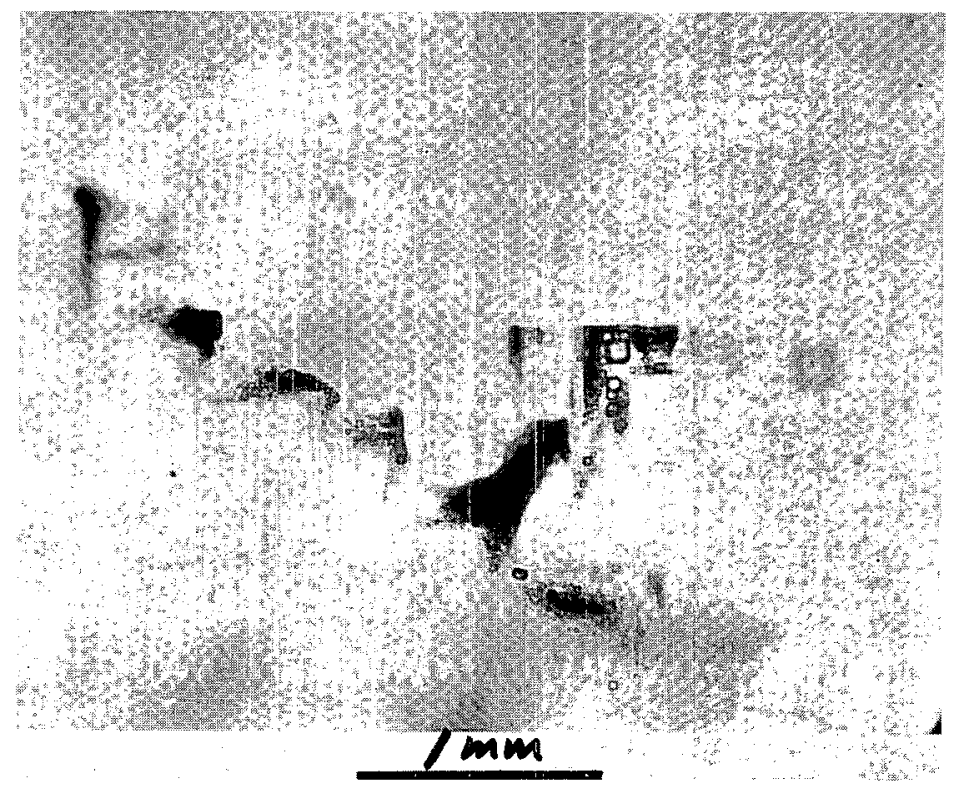

Plate 7.13 Group of cark unrecrystallized zones in essentially inclusion-free single crystal of halite of sample 2065. For detail on central area see plate 7.14.

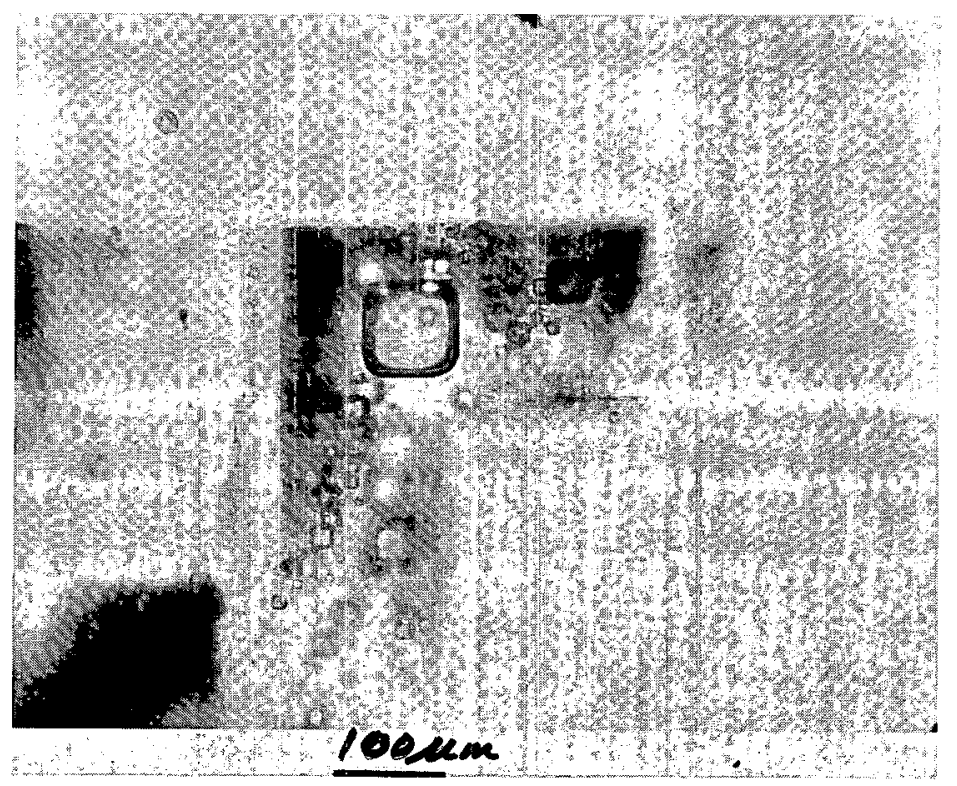

Plate 7.14 Detail of area in Plate 7.13 showing sharp crystallographically controlled boundaries of inclusion-rich zones (type A). Such boundaries may represent primary crystallization features rather than recrystallization fronts. 


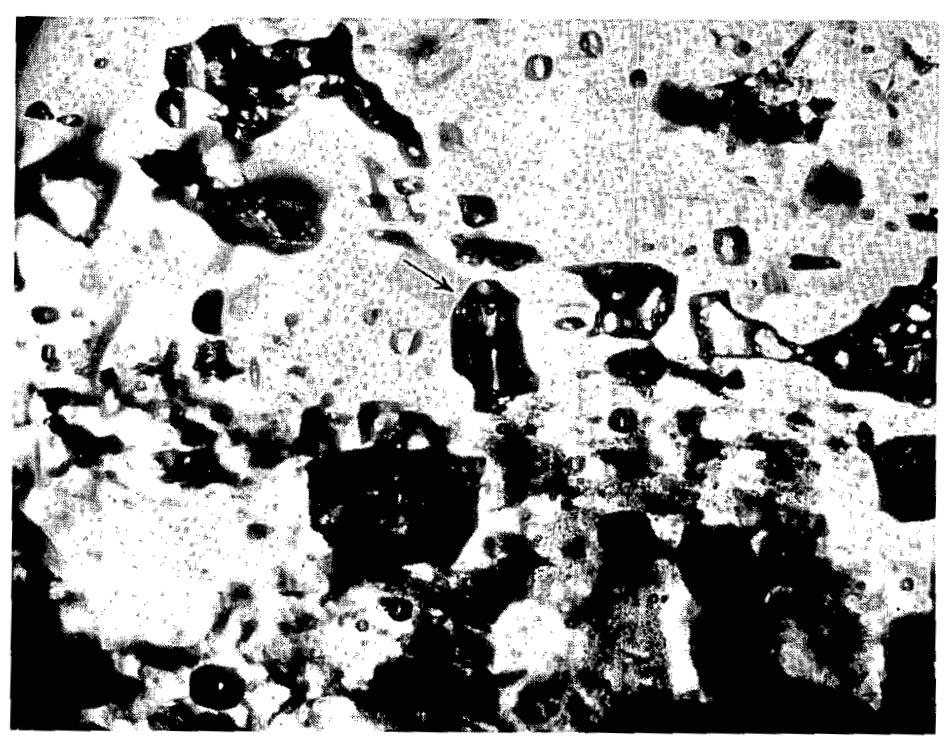

Plate 7.15 Recrystallized part of sample 2065 with large numbers of type $B$ inclusions with small bubbles (e.g., see arrow) and some dark, cloudy unrecrystallized portions (details in Plate 7.16).

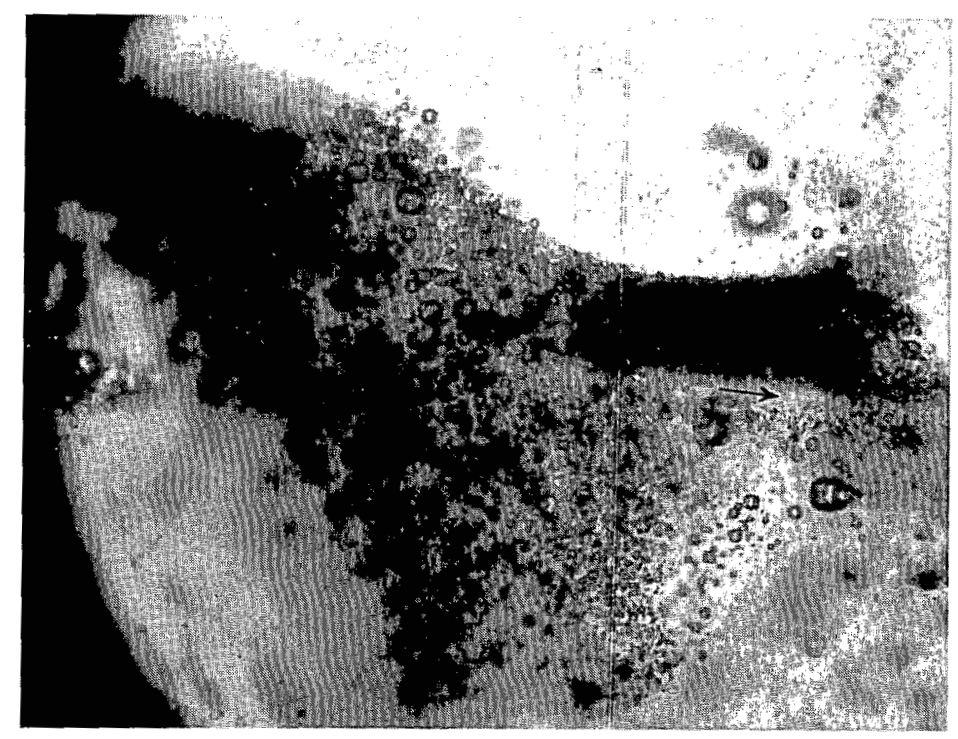

Plate 7.16 One of the dark areas in Plate 7.15 showing dense cloud of primary type A inclusions with some primary - ejre banding (arrow), and sharp but curving (solution?) contact with crystallographically parallel but almost inclusion-free recrystallized salt (at top). 


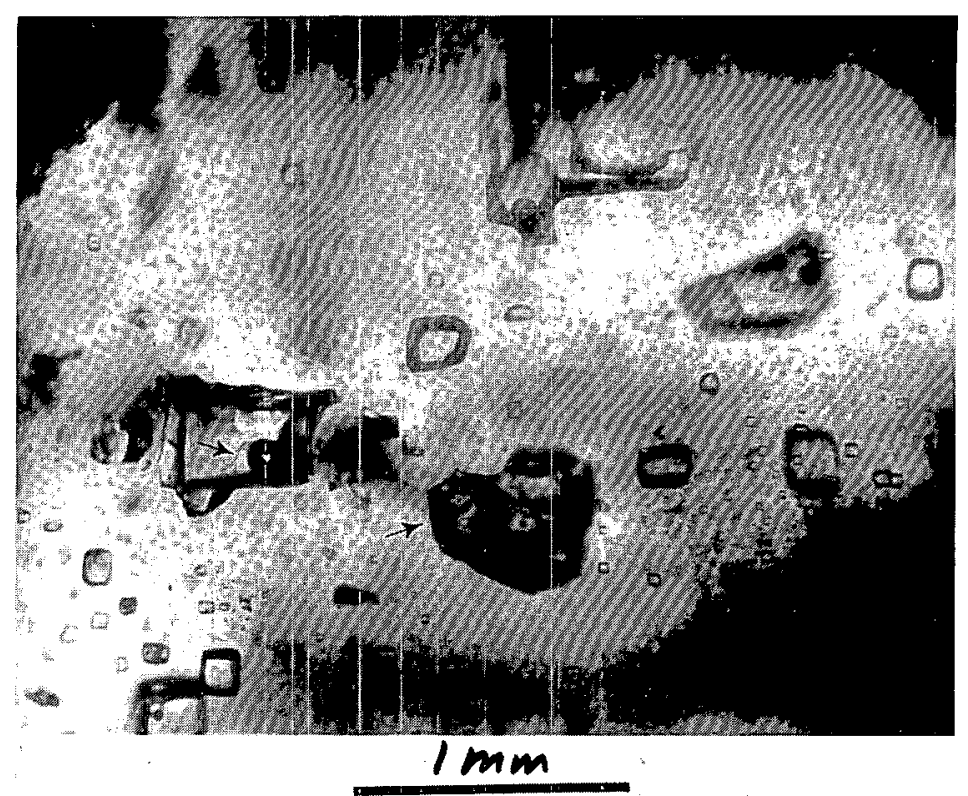

Plate 7.17 Coarsely recrystallized part of sample 2760, with many large type $B$ inclusions, each with bubbles (arrows). Dark clouds are masses of unrecrystallized salt with large numbers of tiny type A primary inclusions (see Plates 7.18 and 7.19 ).

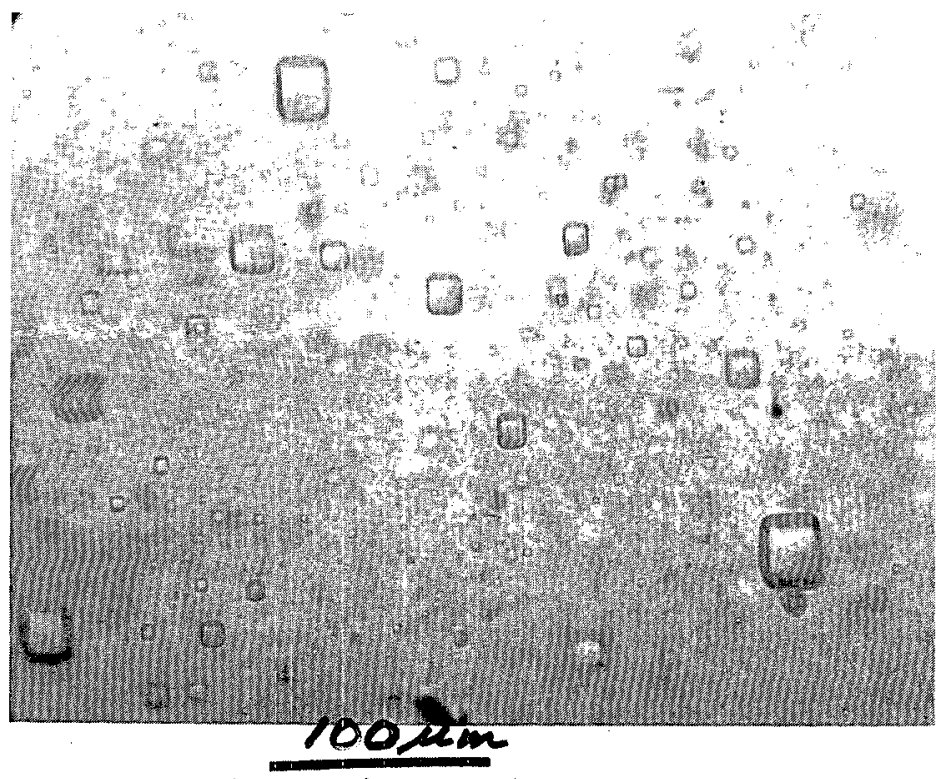

Plate 7.18 Detail of one of the cloudy areas in Plate 7.17, showing high concentration of tiny type A inclusions. Most of these inclusions are < lum (see Plate 7.19). 


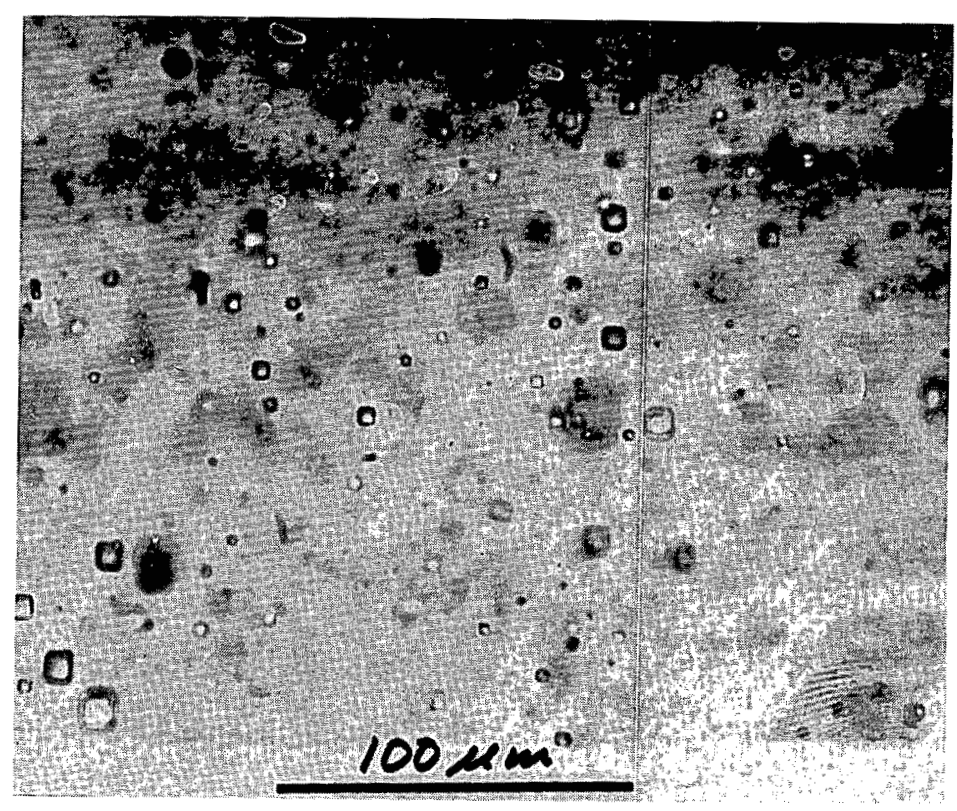

Plate 7.19 Detail of portion of Plate 7.18 that is relatively free of larger inclusions. The smallest inclusions are $\approx 0.5 \mu \mathrm{m}$. All are type A. None of these inclusions contain a bubble.

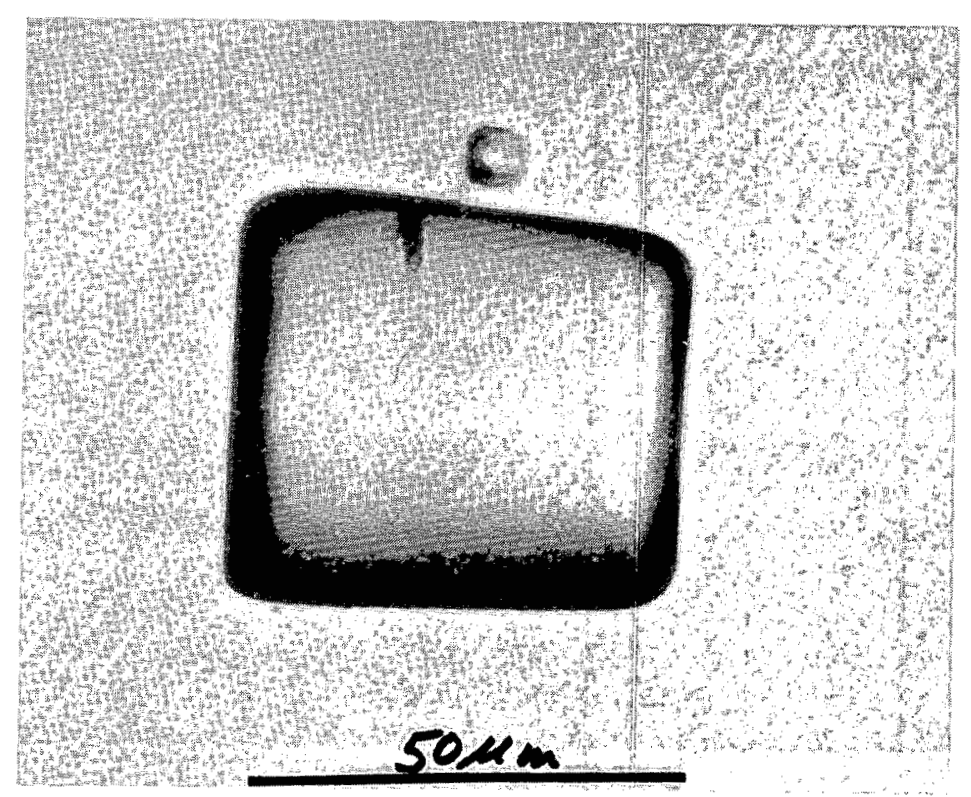

Plate 7.20 Inclusion in sample 2272.5 that contains only liquid, with no bubble, even though fairly large. Type $B$. 


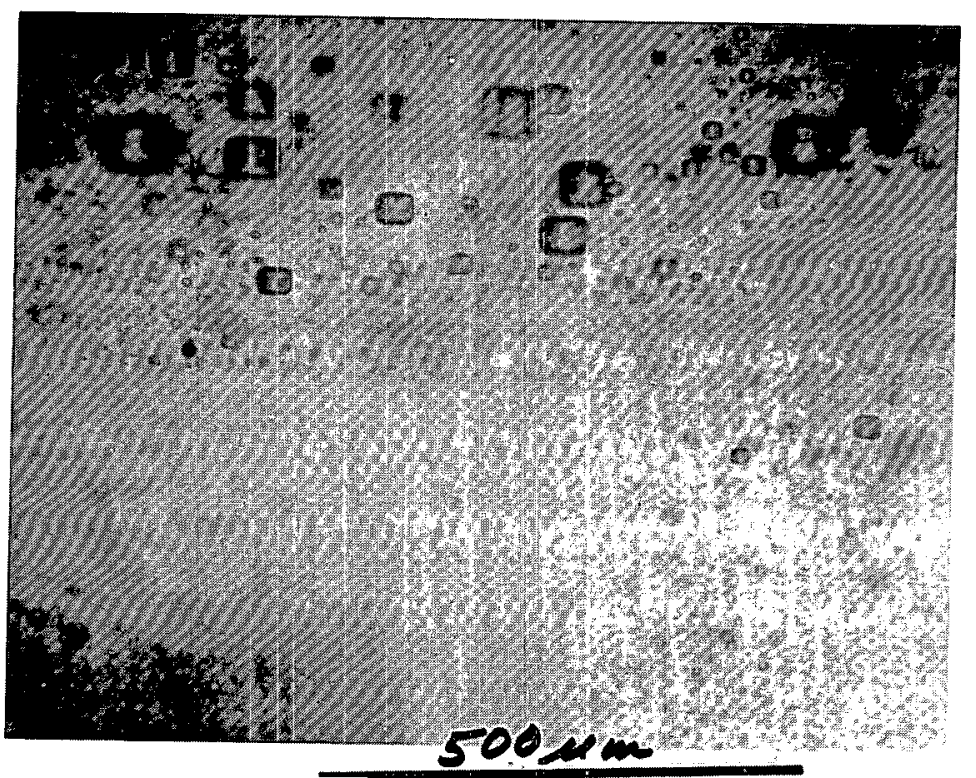

Plate 7.21 Unrecrystallized part of sample 1902 showing primary cubic growth zone feature, delineated by a cloud of tiny type A primary inclusions.

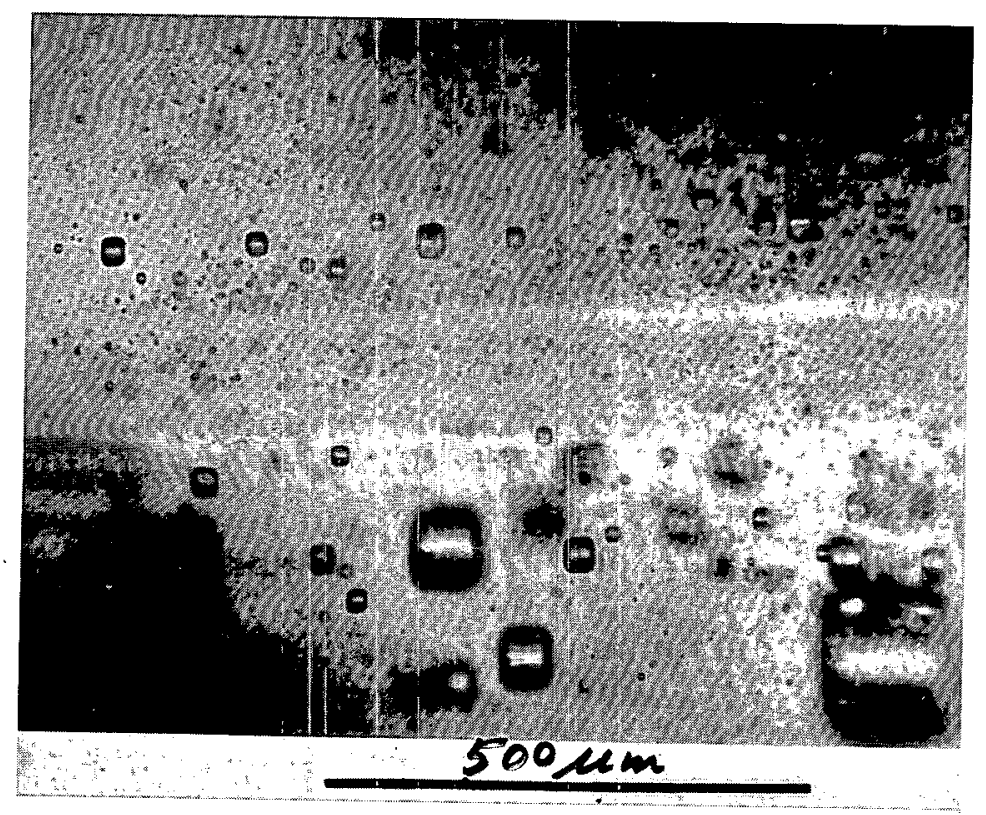

Plate 7.22 Unrecrystallized part of sample 1902 showing thin inclusion-free zone through dense cloud of tiny type $A$ primary inclusions. 


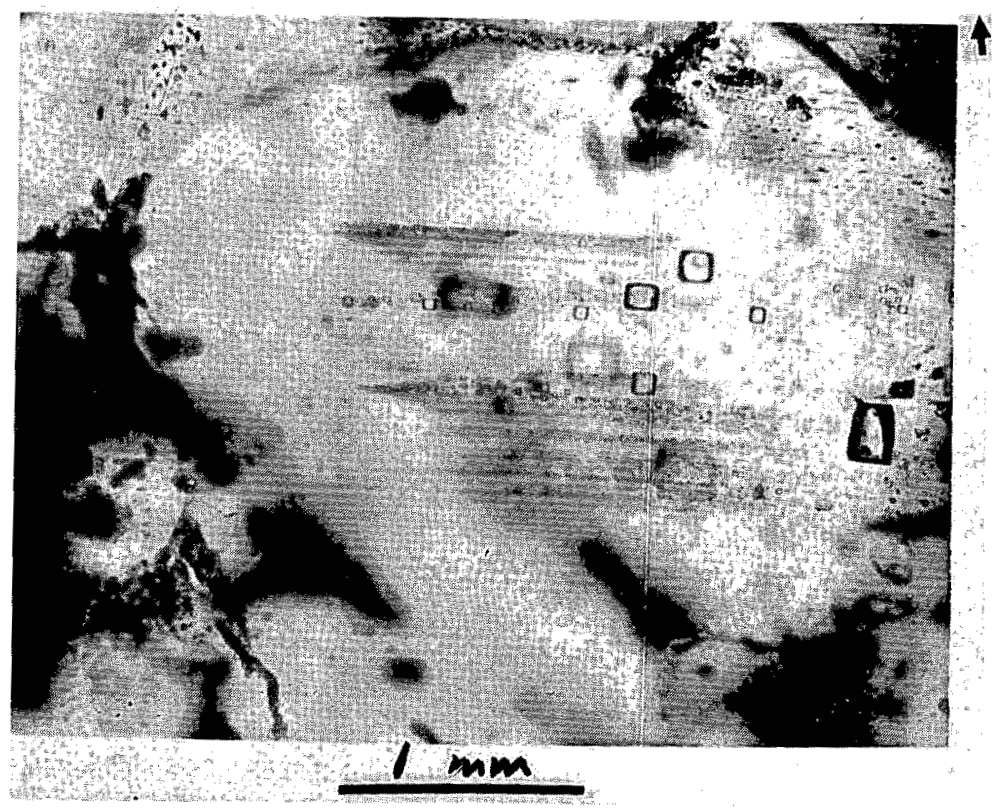

Plate 7.23 Oval grain of salt from sample 2760 containing unrecrystallized core with tiny type A primary inclusions. see plate 7.24 for detail. Top of core is shown by arrow.

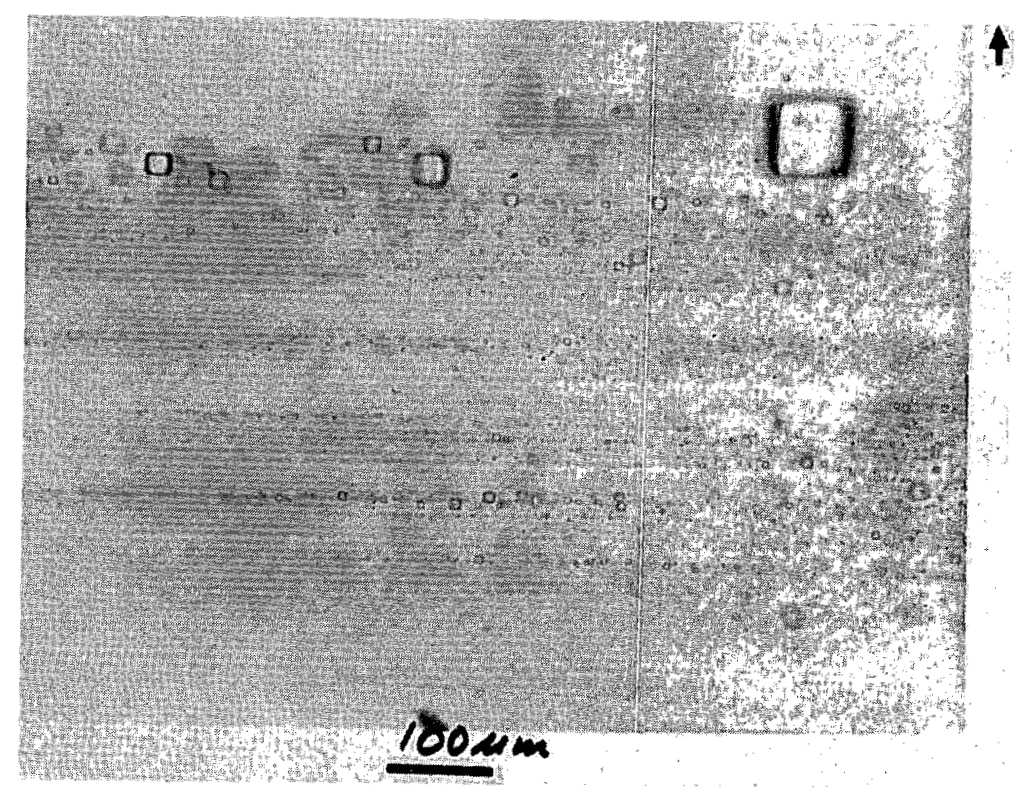

Plate 7.24 Enlgarged view of right central portion of Plate 7.23, showing extremely fine banding of primary type $A$ inclusions, with inclusion-free zones between. Top of core is shown by arrow. 


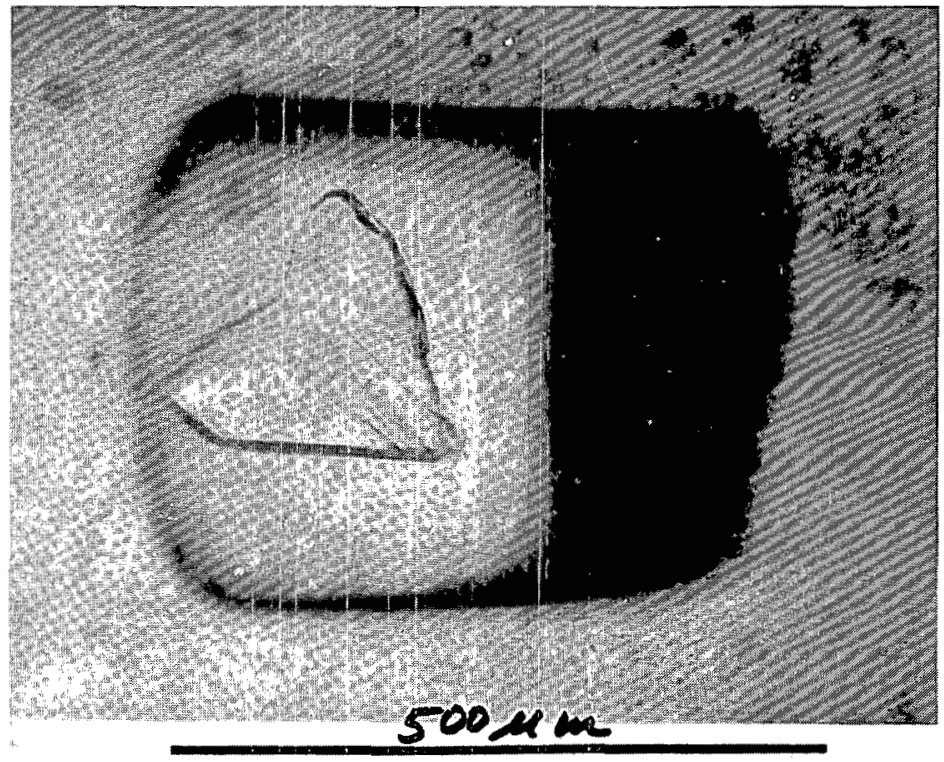

Plate 7.25 Inclusion (type B) in sample 1902 showing twinned birefringent daughter crystal of unidentified phase.

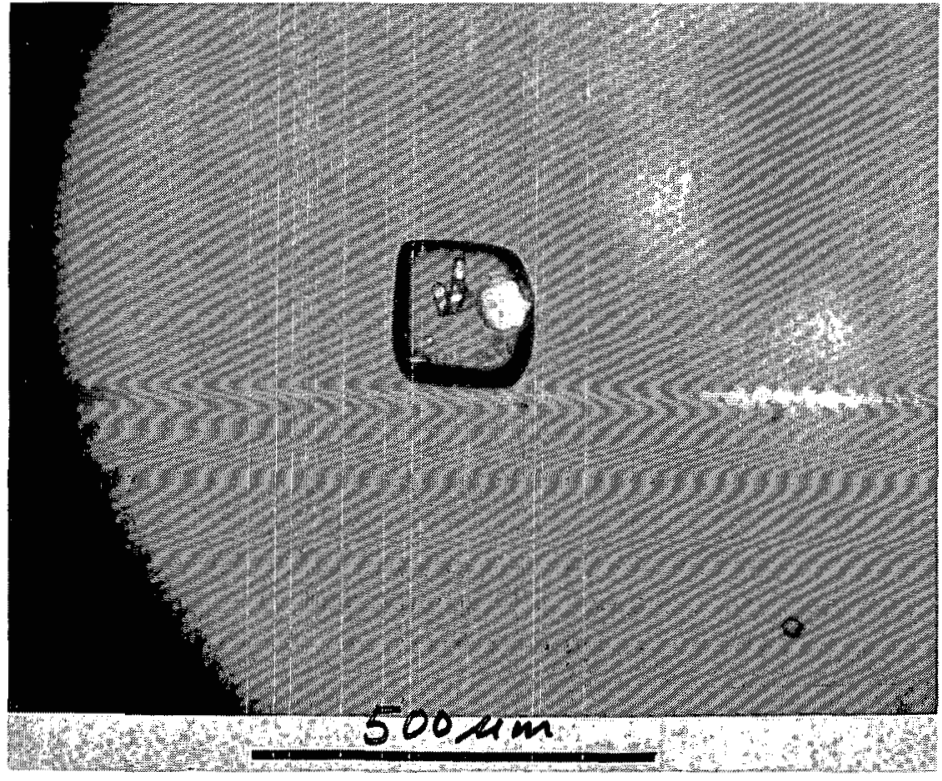

Plate 7.26 Daughter crystals of unidentified phase in type B inclusion in sample 1902.2, with partly crossed polarizers. Note twinning in largest crystal. Many inclusions in this same sample have no daughter crystal or just a few tiny crystals (see Plate 7.28 ). 


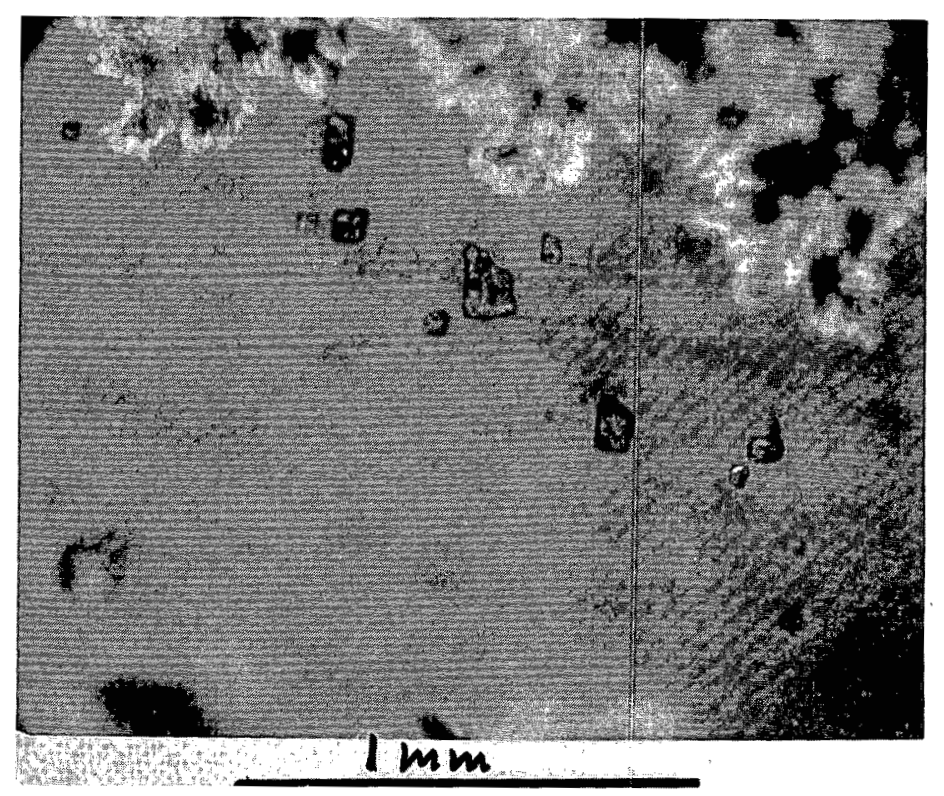

Plate 7.27 Plane of type B liquid inclusions each with a large number of unidentified bladed birefringent daughter crystals, just $400 \mathrm{\mu m}$ below another plane of inclusions with no daughter crystals (Plate 7.28). Inclusion in Plate 7.26 with daughter crystals is similar in phase ratio but not in same plane (out of focus in lower left here). Sample 1902.2 partly crossed polarizers; birefringent mass embedded in salt crystal at top may be the same phase.

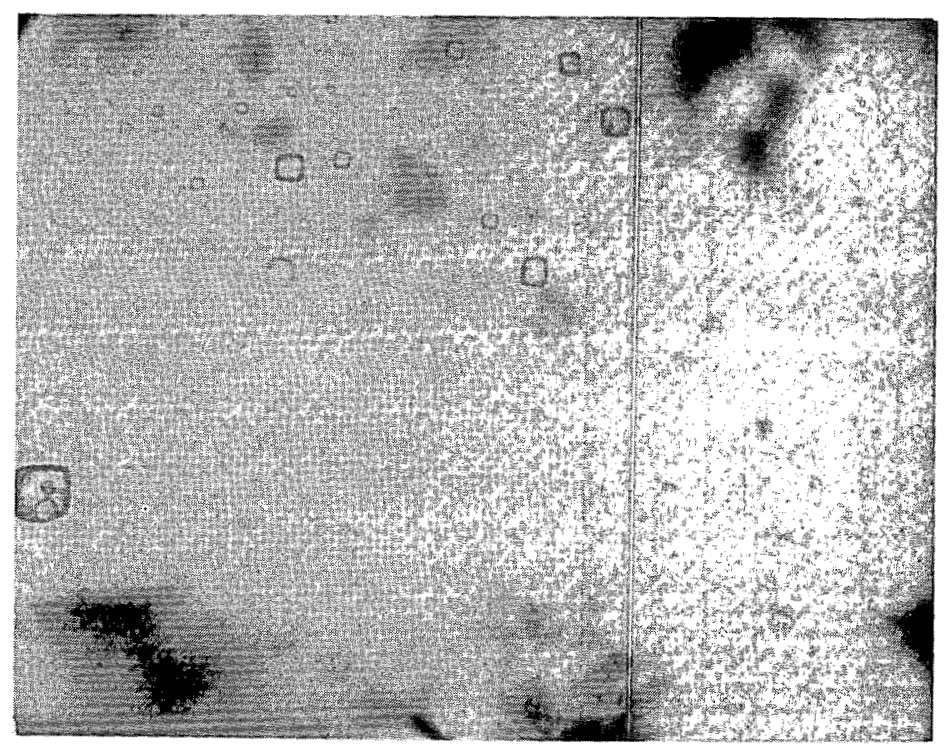

Plate 7.28 Plane of liquid type B inclusions, several with bubble, but without daughter crystals, about $400 \mu \mathrm{m}$ above a plane of type B inclusions with a large number of unidentified daughter crystals (Plate 7.27). This lower plane is visible but out of focus. Sample 1902.2. Inclusion of Plate 7.26 is visible in lower left. 


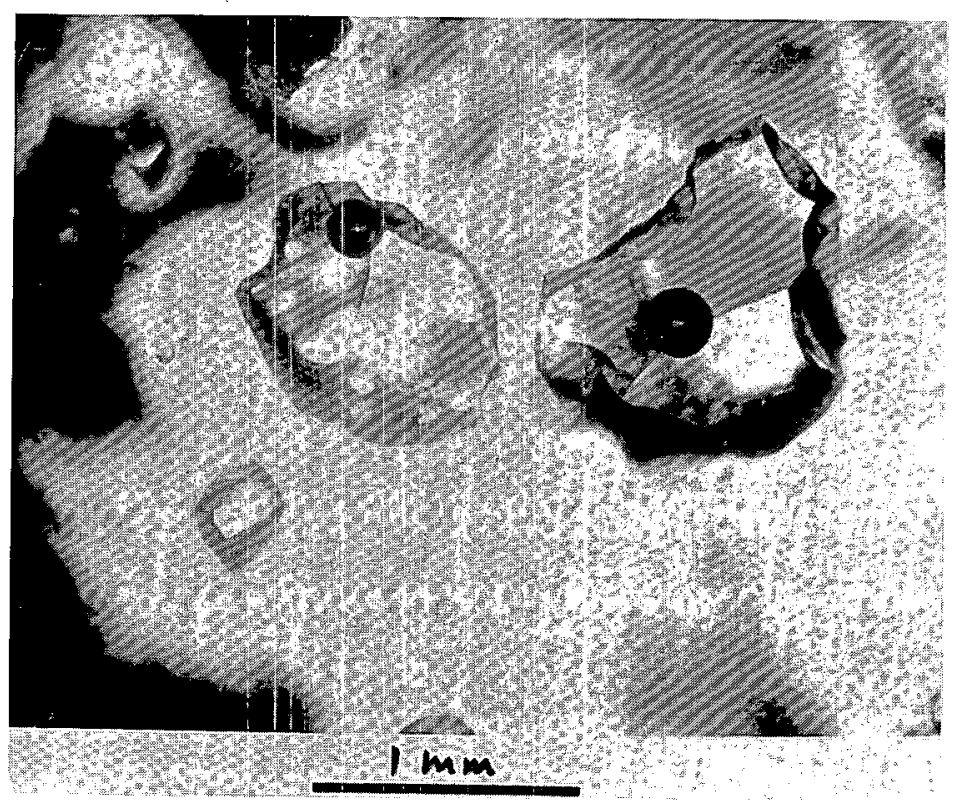

Plate 7.29 Large irregular type C inclusions in sample 2065 with "too large" bubbles.

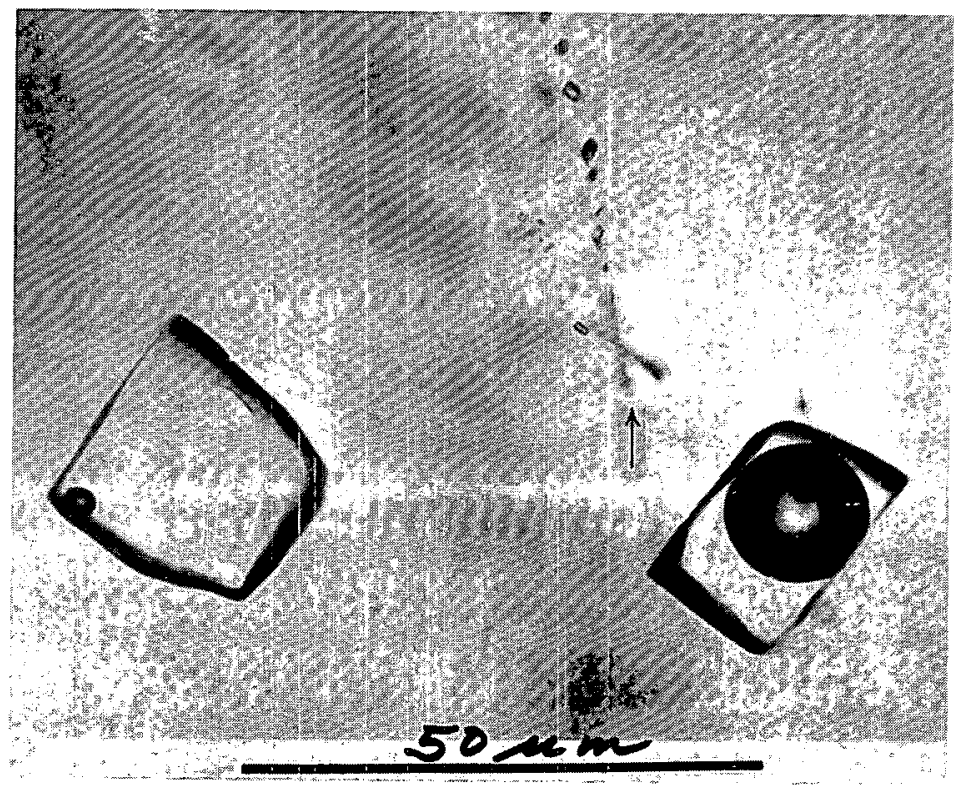

Plate 7.30 Pair of inclusions in sample 1902. The one on left (Type B) with small bubble is typical of those in this sample; that on right (Type C) is on a healed fracture (see arrow) and has apparently been opened and the original fluid replaced with a gas-rich mixture under pressure. 


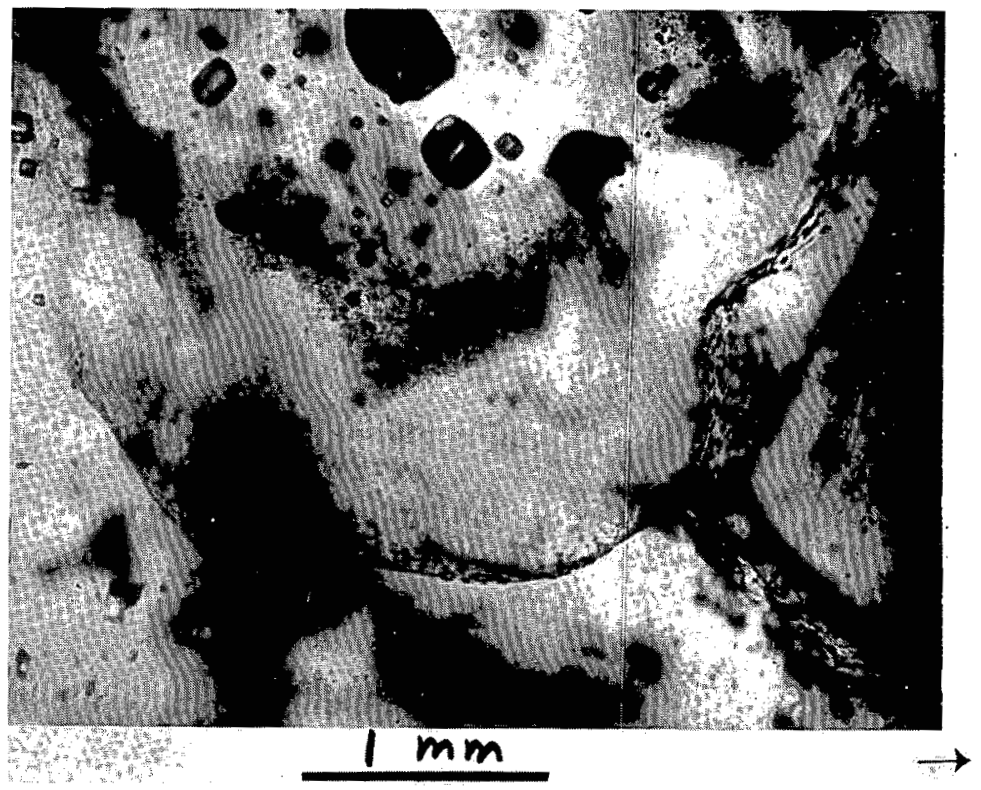

Plate 7.31 Single crystal of salt in sample 2760 with curving planes, outlined by type D inclusions, separating it from adjacent grains. Note also large type $B$ inclusions and mass of tiny type A primary inclusions in central core of crystal. Sample has probably undergone two stages of recrystallization (see text). Top of core is shown by arrow.

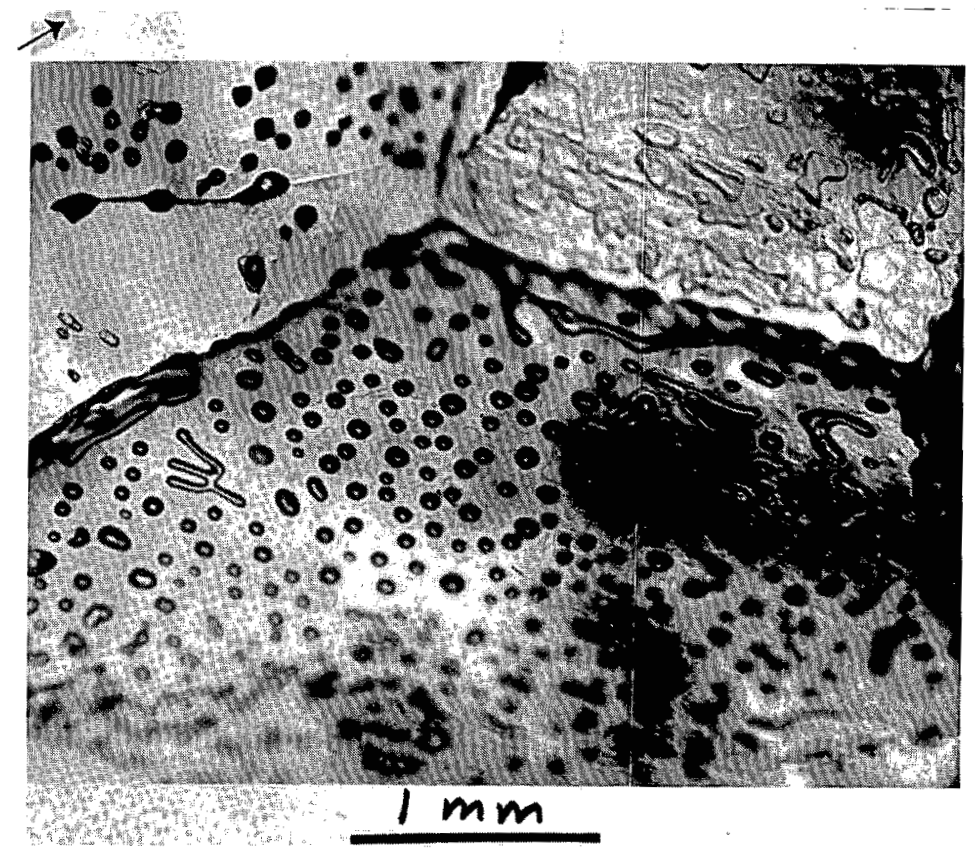

Plate 7.32 Fluid inclusions (gas; type D) on interface between recrystallized salt crystals in sample 2760 . Note $120^{\circ}$ junction. Top of core is shown by arrow. 


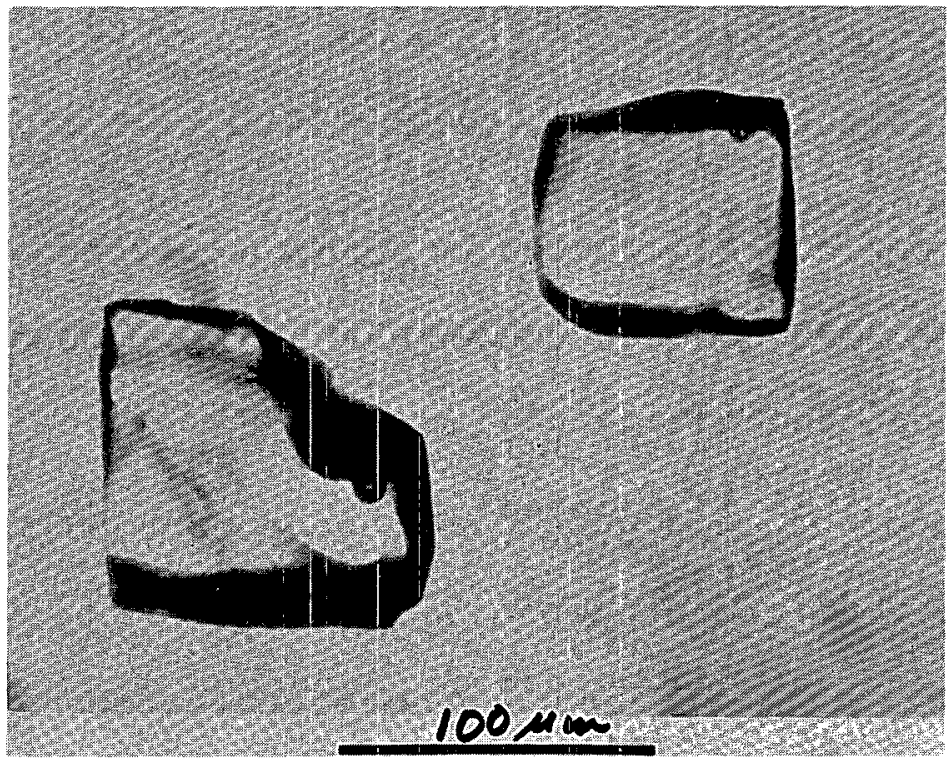

Plate 7.33 Large type B inclusions in sample 1799.1 homogenizing at $20.5^{\circ} \mathrm{C}$ (lower left) and $21^{\circ} \mathrm{C}$ (upper right). Photographed at $\approx 19^{\circ} \mathrm{C}$.

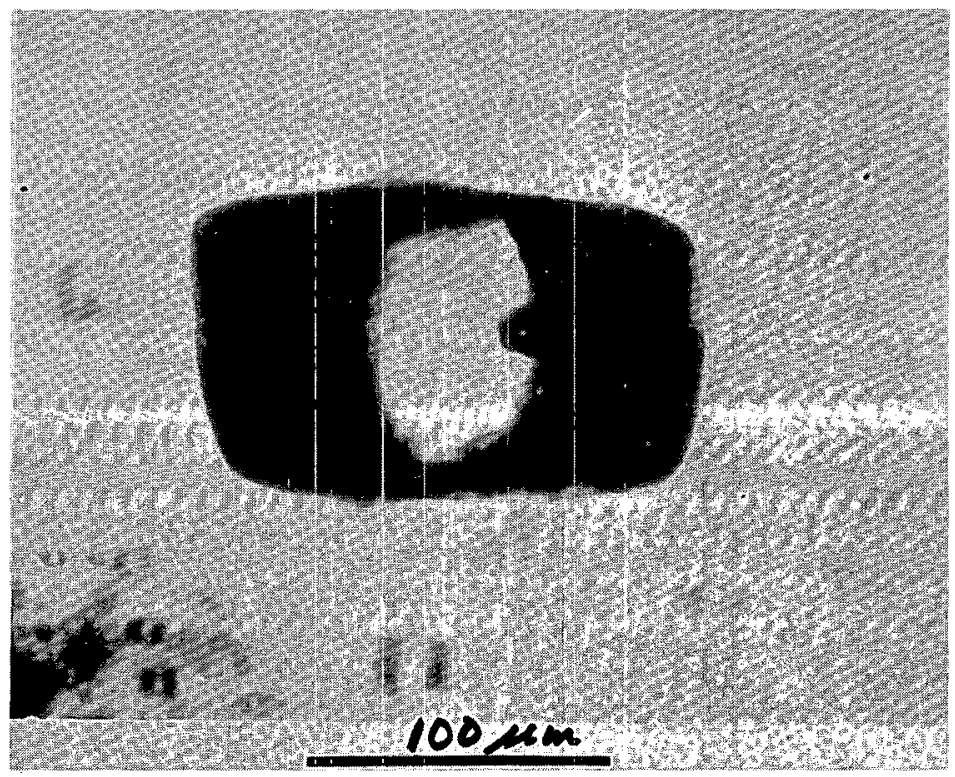

Plate 7.34 Large type B inclusion in sample 2760.1 homogenizing at $20.5^{\circ} \mathrm{C}$. Photographed at $19^{\circ} \mathrm{C}$. 


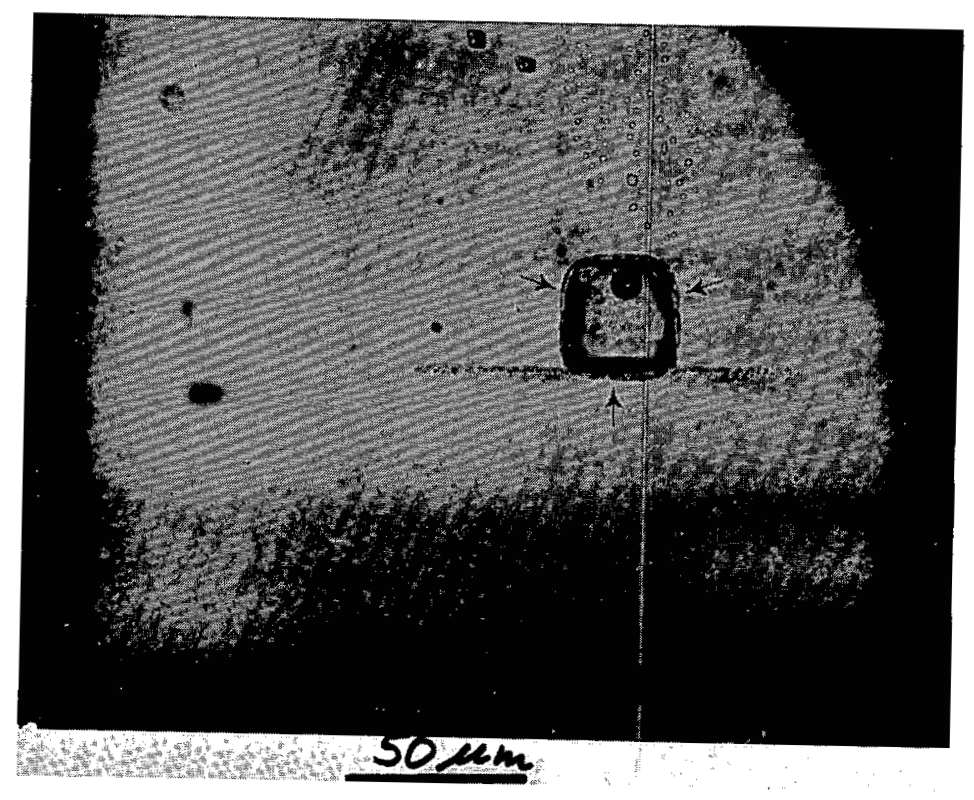

Plate 7.35 Inclusion (type B) in sample 1902 after freezing run, showing horizontal crack formed by expansion on freezing, that is now a plane of tiny secondary fluid inclusions; larger bubble than originally was present (due to volume increase); and rounded halo of tiny inclusions formed during freezing run (arrows), as a result of water in inclusion reacting with halite of walls to form $\mathrm{NaCl} \cdot 2 \mathrm{H}_{2} \mathrm{O}$, thus increasing inclusion volume. See text.

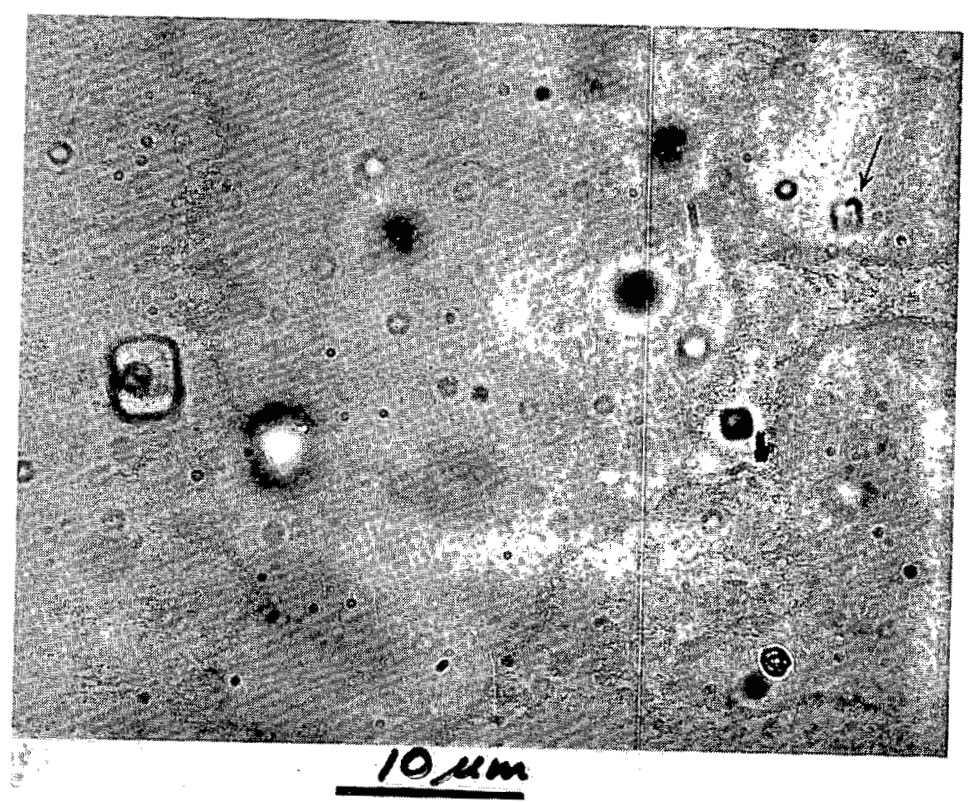

Plate 7.36 Minute primary inclusion in unrecrystallized salt from sample 1902 at high magnification (1560 X). The inclusion in upper right is about $1.8 \mu \mathrm{m}$ on an edge, and contains a bubble of $<0.5 \mu \mathrm{m}$. Resolution of bubble is poor as it is generally in rapid motion even with an IR filter in optical system and exposures must be long. Many inclusions with no bubble area are $\approx 0.5 \mu \mathrm{m}$ on an edge. 
Plate 7.37 sequence of photographs of type B inclusions in sample 2095.3 taken at the temperatures indicated during a freezing run. At $-75.5^{\circ} \mathrm{C}$ the inclusions contain a partiy opaque mixture of solid grains of ice and salts. No change was visible on warming to $-34.5{ }^{\circ} \mathrm{C}$, but at $-32.2{ }^{\circ} \mathrm{C}$ the mixture suddenly became more translucent and the grain size started to increase, indicating first melting. Extensive melting occurred around $-4{ }^{\circ} \mathrm{C}$, and the remaining crystals decreased to $\approx 20-25 \%$ at $0{ }^{\circ} \mathrm{C}$. These were probably a hydrate but not al1 $\mathrm{Nacl} 2 \mathrm{H}_{2} \mathrm{O}$, since a few were present at $+12^{\circ}$, and the last dissolved at $+15^{\circ} \mathrm{C}$. The room temperature photo was taken after the run. The bubble size varies with phases present and temperature. 


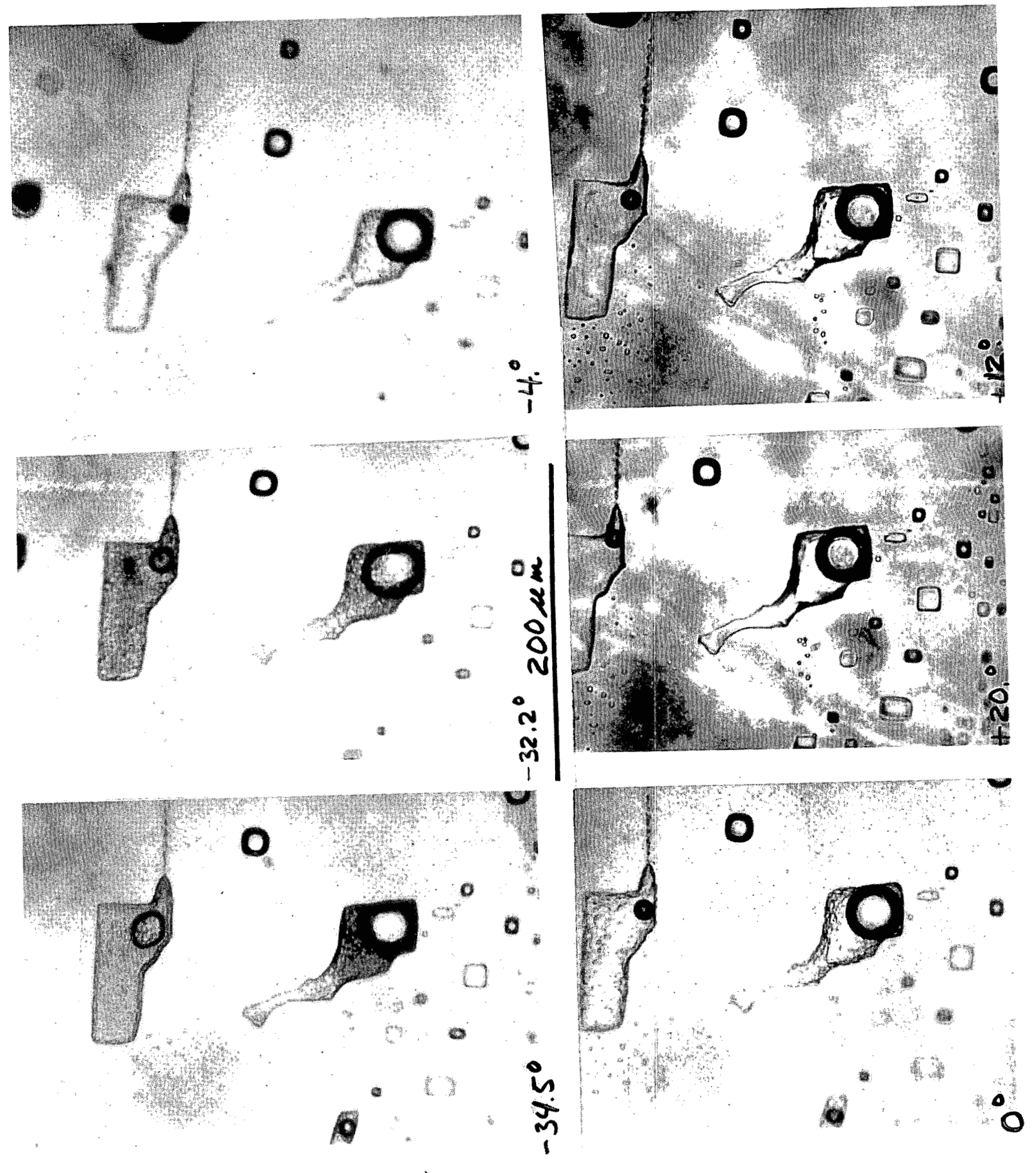




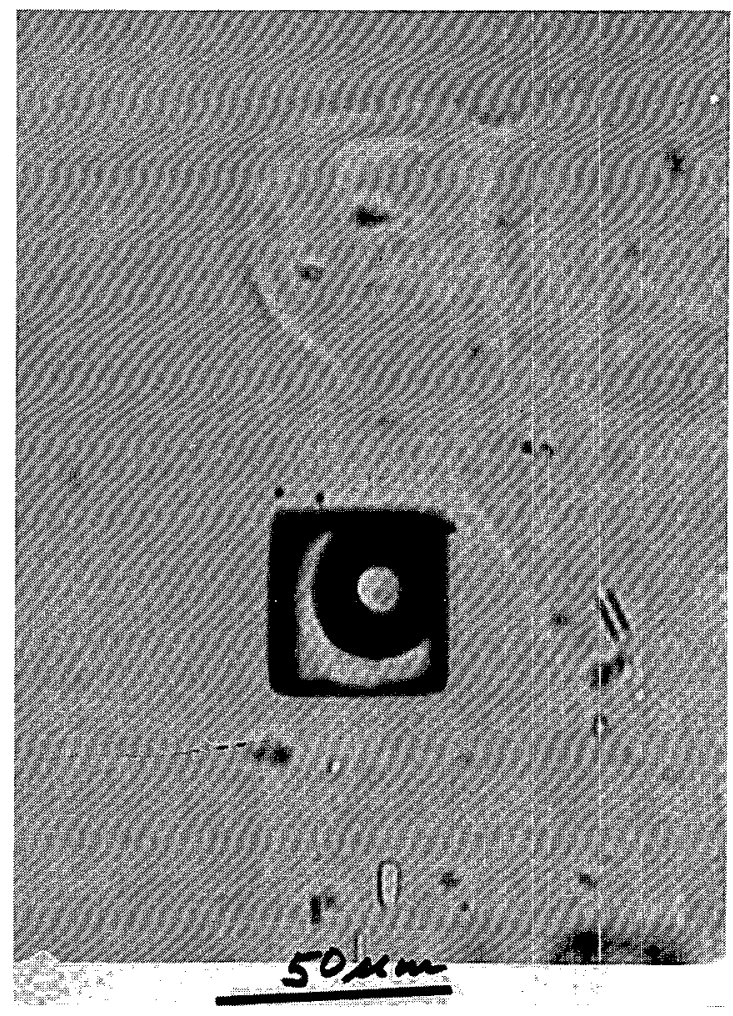

Plate 7.38 Inclusion from sample 2760, as found, with large bubble, viewed on crushing stage. The bubble contains gas under pressure (see Plate 7.39).

Plate 7.39 Same inclusion as seen in Plate 7.38 , on crushing stage, after fracture has reached it. The bubble has expanded approximately $270 \%$ (Vol) on pressure release.

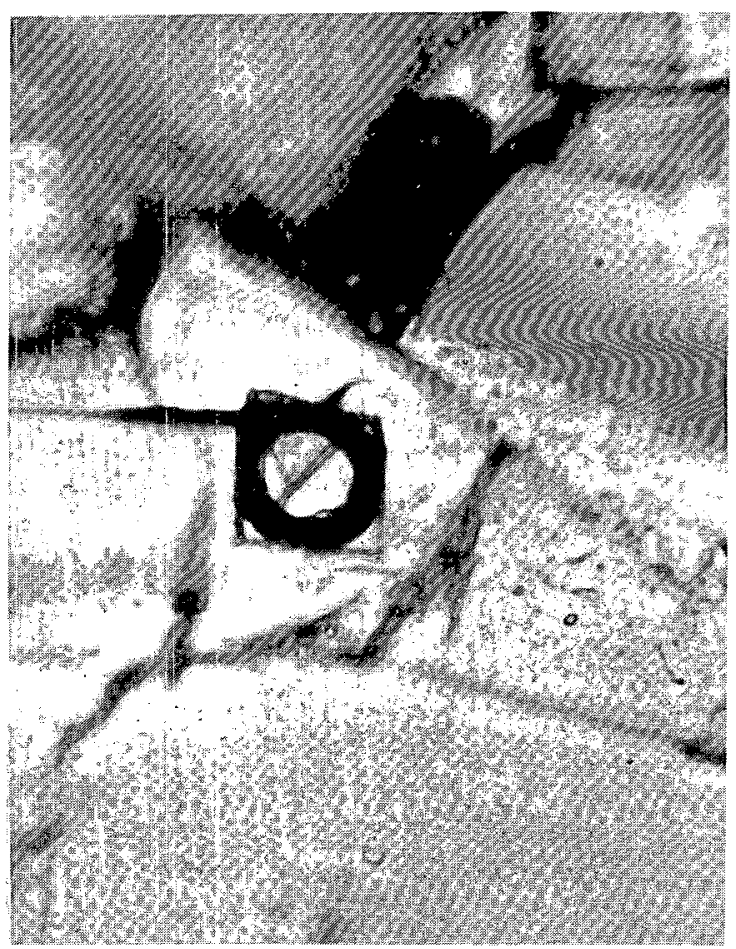



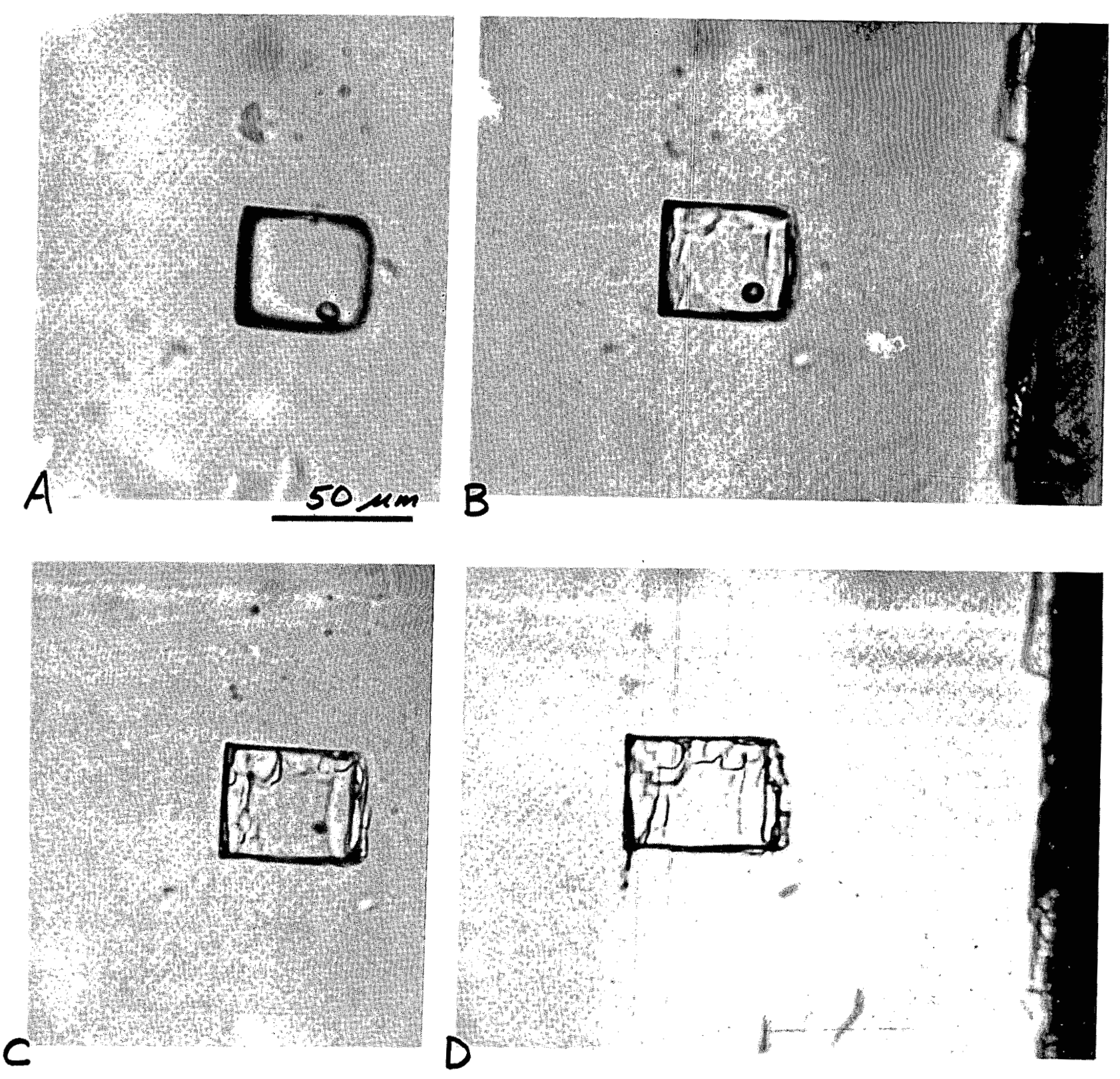

Plate 7.40 Sequence of photographs of inclusion in sample 2760 on crushing stage. A shows the inclusion as found. The sample was then stressed and immediately cracked (at right in $B$ ), but the area of inclusion was still under stress, since changes took place along edges of inclusion during next 10 minutes at constant stress (photo B). After 16 minutes at constant stress (C) changes are more pronounced and bubble is smaller; after 18 minutes bubble is gone (D). 
In each of the following plates, the length of the scale bar is $100 \mu \mathrm{m}$.

Plate 7.41 (Photo I) Group of small primary hoppergrowth inclusions in ERDA-9 sample 2699.8-2700.0, after $250^{\circ} \mathrm{C}$ decrepitation run. These inclusions probably had no bubble originally, and now have one as a result of plastic deformation of the host salt. They now homogenize at temperatures as high as $273^{\circ} \mathrm{C}$ (Table 7.17).

Plate 7.42 (Photo 2) Solid phases (daughter crystals?) in inclusion in Kerr-McGee mine sample MB-76-4. The small rod-like crystal has parallel extinction, and the large cubic(?) crystal (KCl?) appears isotropic.

Plate 7.43 (Photo 3) Dense gas inclusion in Kerr-McGee mine sample $M B-77-8$, photographed at the approximate temperatures indicated $\left({ }^{\circ} \mathrm{C}\right)$. See text, subchapter 7.5.

Plates 7.44 and 7.45 (Photos 4 and 5) Steam inclusions (arrows) in Kerr-McGee mine samples MB-76-3 (7.44) and MB-77-8 (7.45), now containing essentially vacuum, before (a) and after (b) being intersected by a fracture during crushing tests. The surrounding oil has filled the inclusions completely in (b).

Plates 7.46 and 7.47 (Photos 6 and 7) Gas inclusions in Kerr-McGee mine sample MB-77-8 containing gas at less than one atmosphere pressure, before (a) and after (b) being intersected by a fracture during crushing tests.

Plate 7.48 (Photo 8) High pressure gas inclusion in Kerr-MCGee mine sample MB-76-4 before (a) and after (b) being intersected by a fracture during crushing.

Plates 7.49, 7.50 and 7.51 (Photos 9, 10, and 11) High pressure gas inclusions in Kerr-McGee mine samples $M B-77-8$ (7.49 and 7.51) and $M B-76-3$ (7.50), before (a) and after (b) being intersected by a fracture during crushing. The approximate volume expansion is 30-fold in 7.49, 40-fold in 7.50, and 100-fold in 7.51. Two bubbles formed in 7.49 , and one in 7.50 (arrows). 


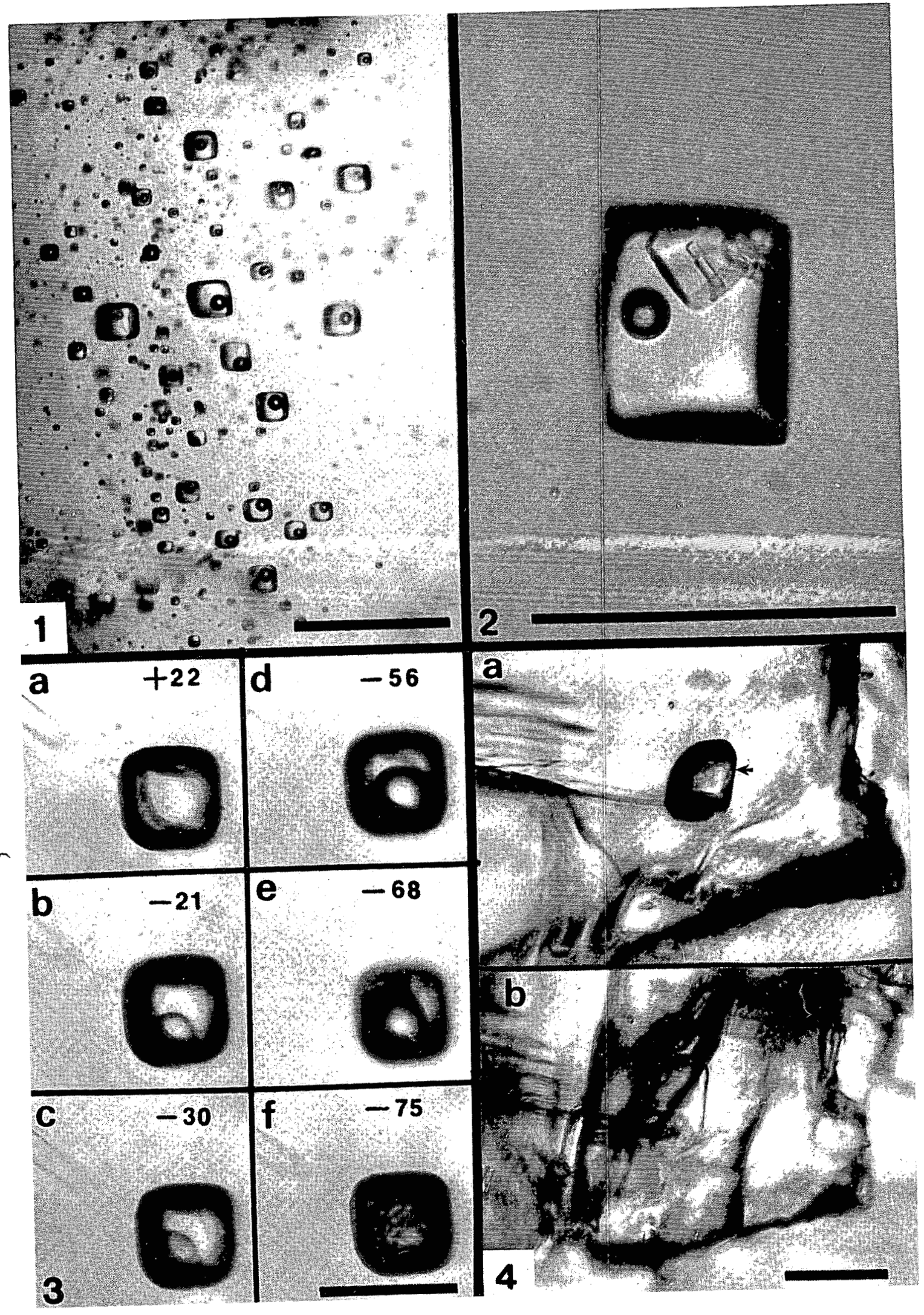



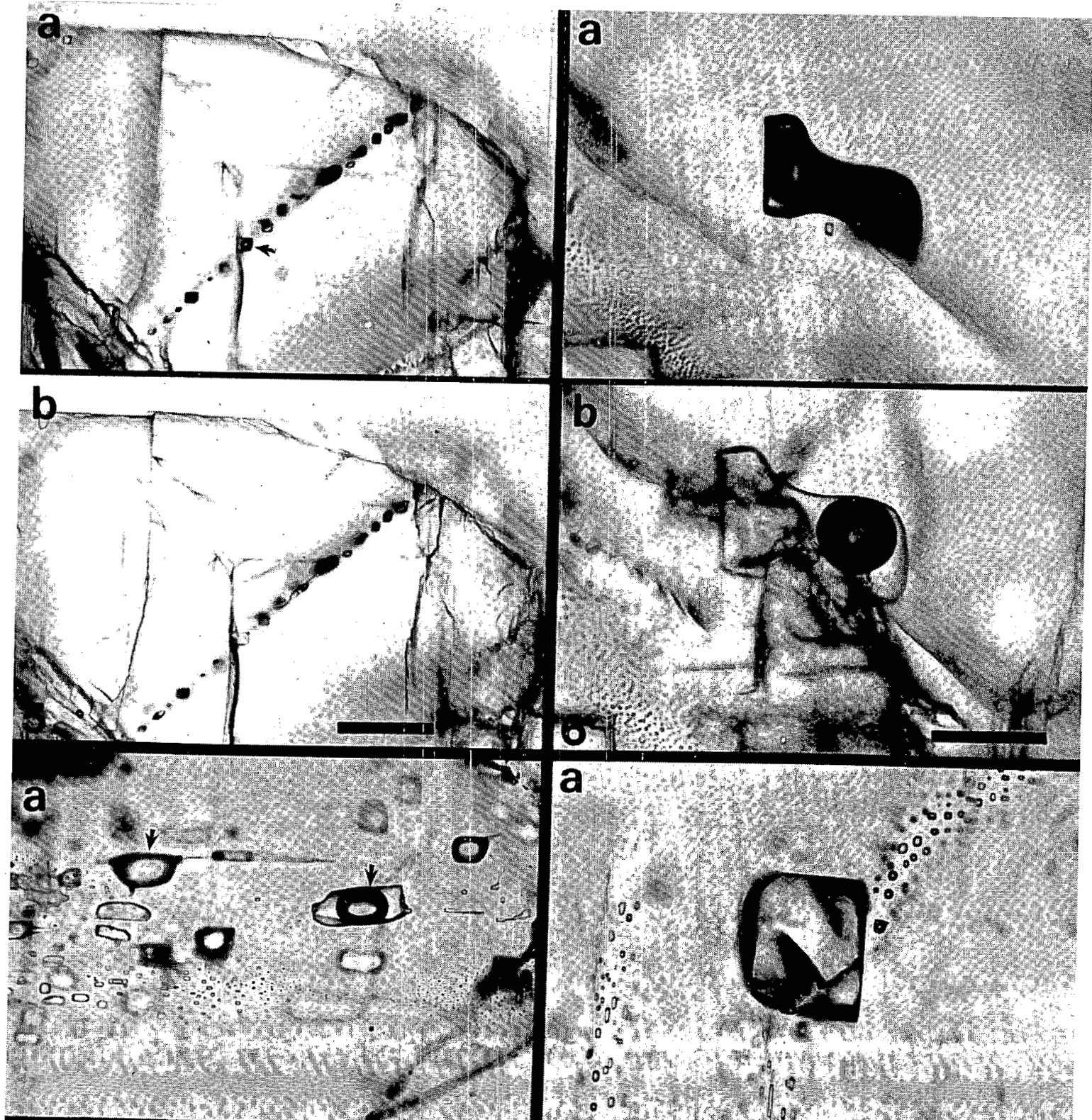

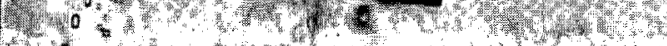

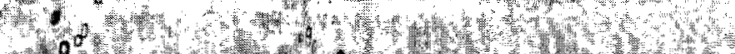

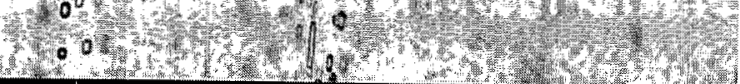
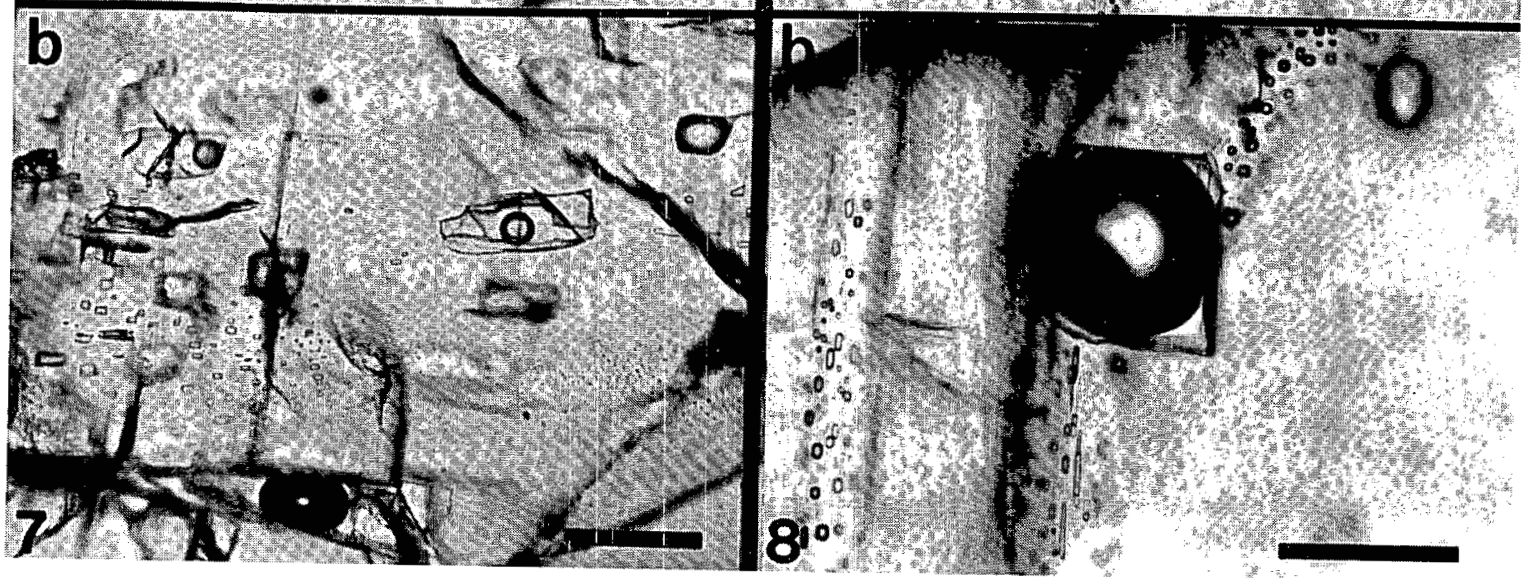

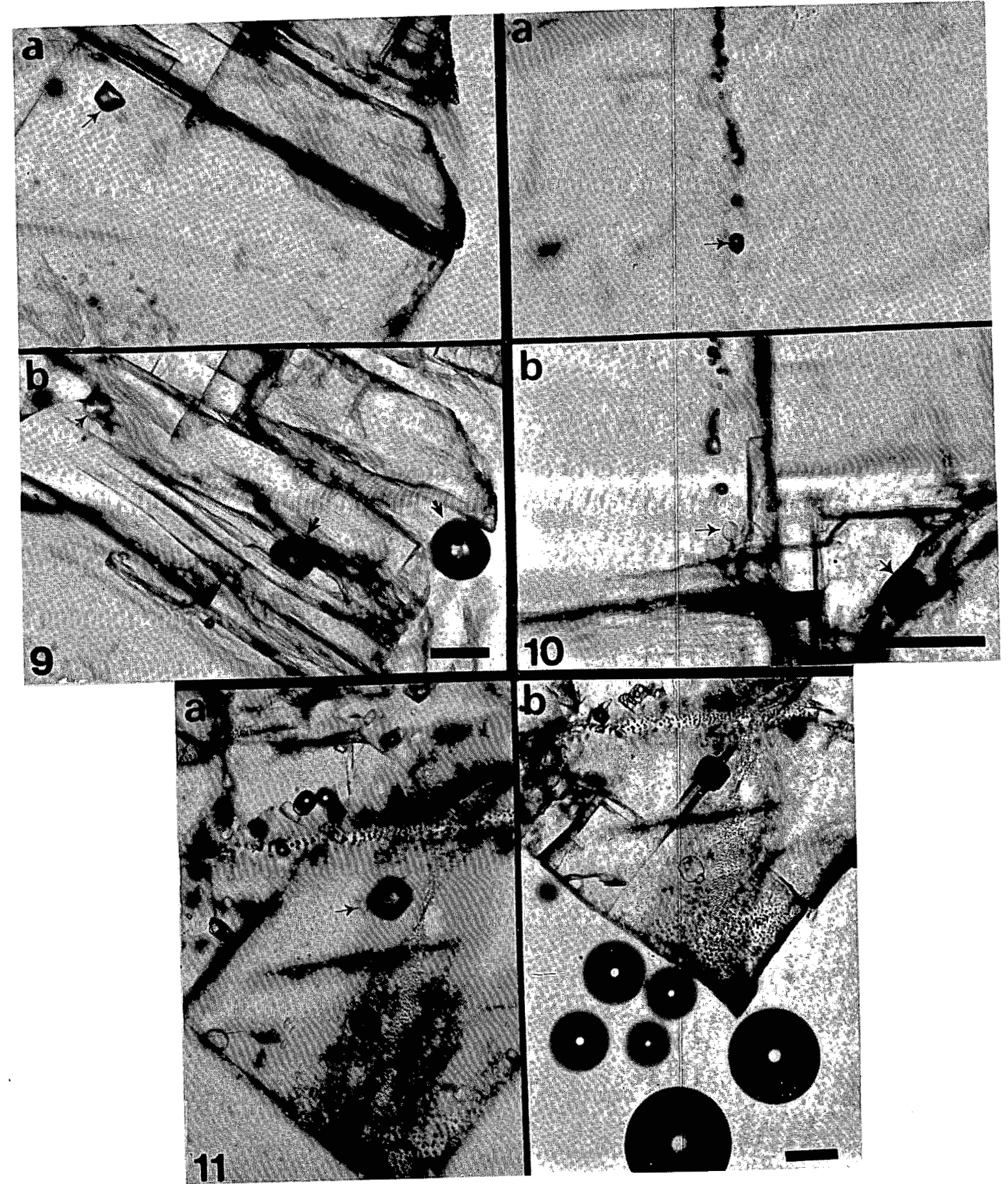


\section{PLATE CAPTION}

Plate 7.52 and Overleaf: Core fragments from Castile anhydrite serving as host rock for the ERDA No. 6 brine reservoir. Depths of origin, uranium contents and ${ }^{23}{ }^{34} \mathrm{U} /{ }^{238} \mathrm{U}$ ratios are given in the overleaf for various parts of the core fragments. 


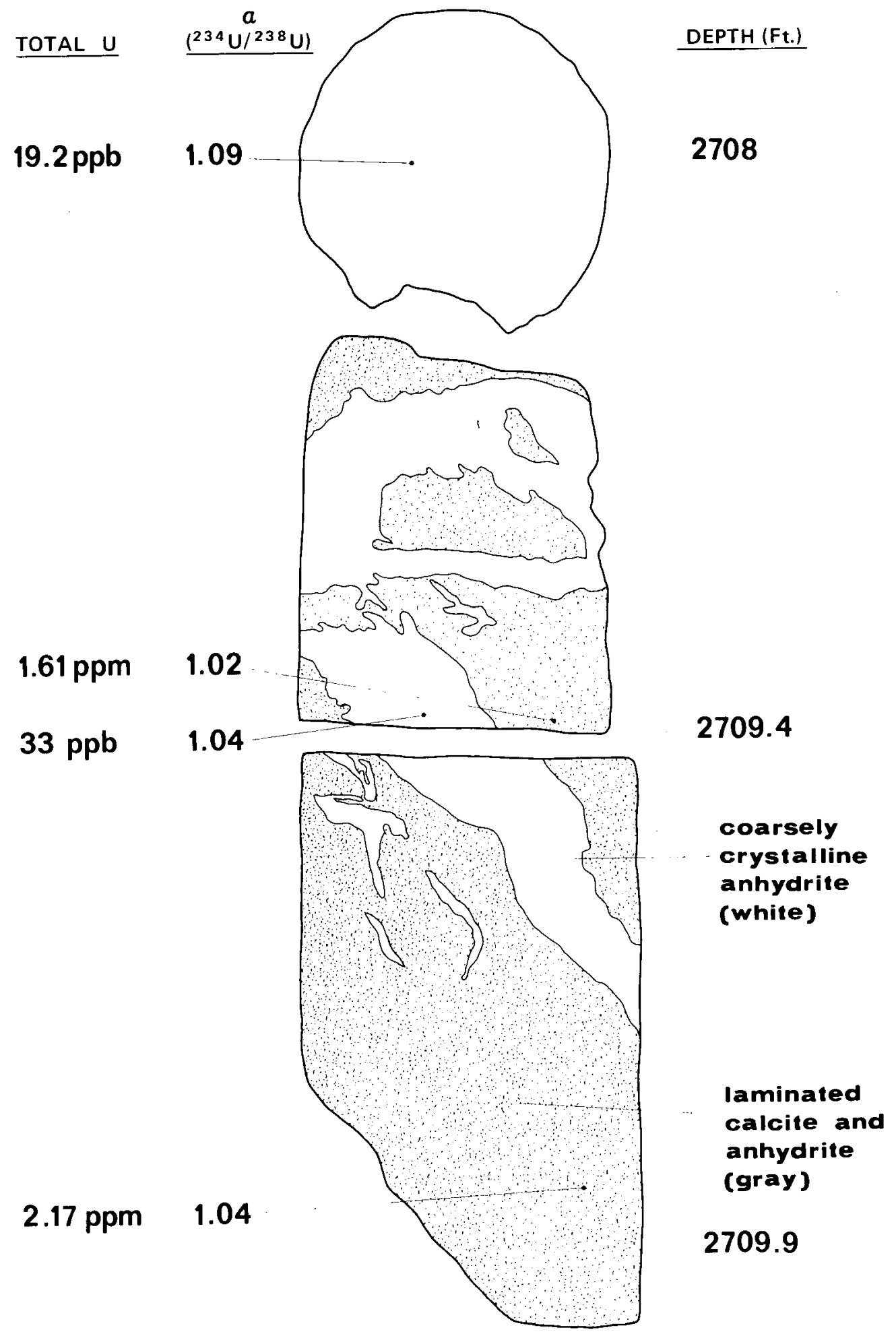




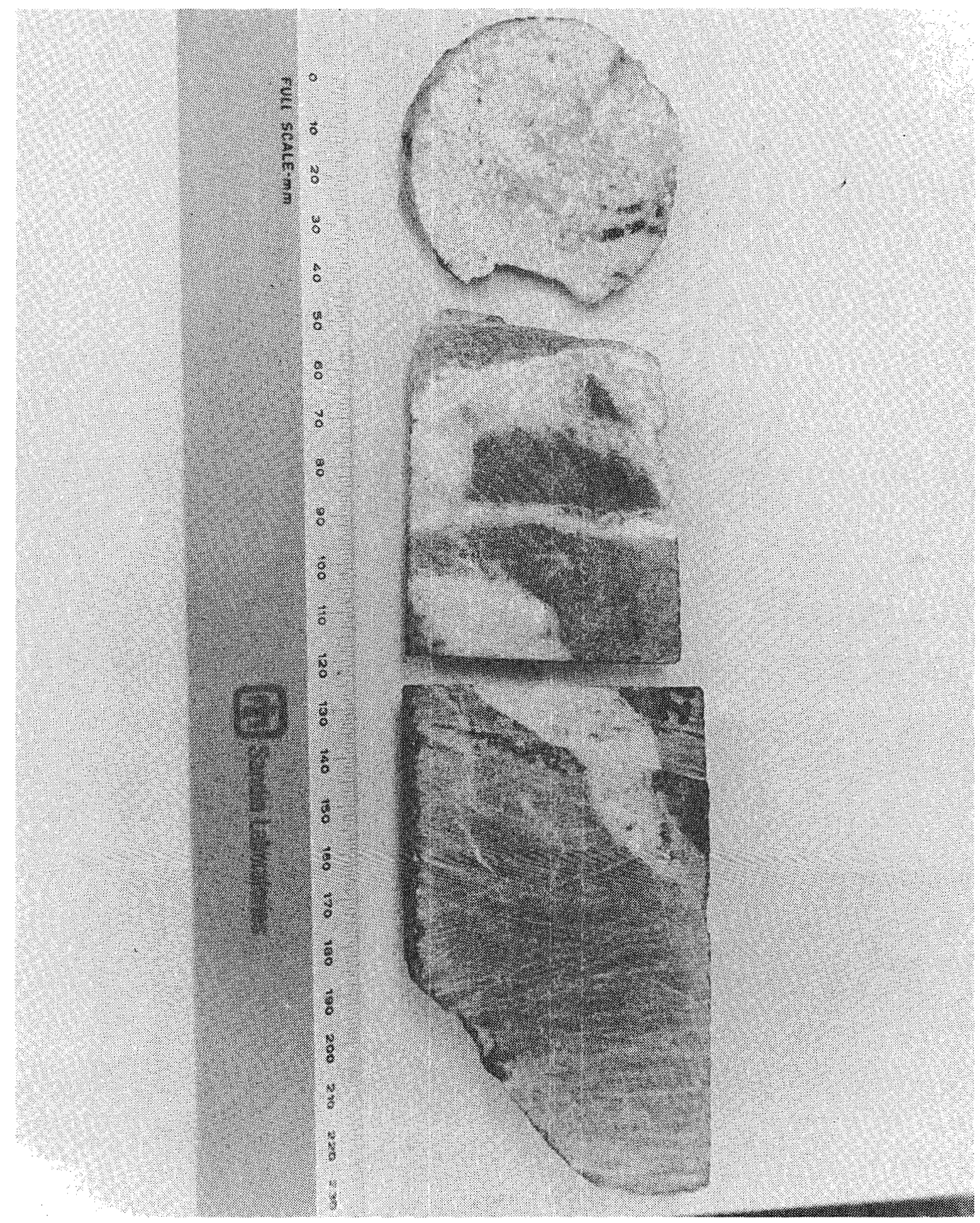

PLATE 7.52 
GCR CHAPTER 8

RESOURCES

\subsection{INTRODUCTION}

The northern portion of the Delaware Basin is known for production of potassium salts and fluid hydrocarbons. An effort was made to select a location for the WIPP that would minimize conflict with these resources. It is likely, however, that some of these potash and hydrocarbon resources underlie the site. The extent of potash mineralization has been fairly well established because the potash mining industry has released information concerning their exploratory drilling in the area. Those findings were supplemented by information from 21 additional holes drilled by the Department of Energy. Site selection criteria described in Chapter 2 prescribe that the site be no closer than one mile from a deep drill hole. This means that the potential hydrocarbon resource must be evaluated by inference utilizing subsurface information from surrounding areas. An investigation was also carried out to determine the significance of other possible industrial minerals such as caliche, gypsum, salt, uranium, sulfur, and lithium at or very near the WIPP site. Table 8-1 summarizes the principal findings of resource studies. Only potash and natural gas are considered to be significant exploitable deposits as shown in Table 8-2. The economic resources denied in zones I-III are shown in Table 8-3.

\subsection{ORGANIZATIONS INVOLVED IN RESOURCE EVALUATION, AND THEIR REPORTS}

Numerous contractors representing both government and private companies were engaged in the resource evaluation at the WIPP site. An outline of work accomplished during this phase of the site characterization is given in Table 8-4.

The listed studies quantify in-place resources and evaluate what portion of those resources would be extractable. A legal determination is now under way to establish values to the various mineral and oil and gas 
lease holders within the site area. However, these studies deal with the present value of specific land tracts and as such are not pertinent to site chacterization.

8.3 POTENTIAL RESOURCES IN RELATIONSHIP TO STRATIGRAPHY AT THE WIPP SITE

Resource evaluation at the WIPP site took into consideration the existing stratigraphy of the site area. Each formation was evaluated for mineral deposits that were either known or that could exist based on the characteristics of the sediments present.

A stratigraphic column is given in Table 8-5 that indicates where in the geologic section specific types of deposits are considered to have a reasonable likelihood of occurrence. The table briefly describes the character, thickness, and median depth of each formation.

\subsection{RESOURCE DESCRIPTION BY SPECIFIC COMMODITIES}

The description of resources commences with the shallowest formation and proceeds down the stratigraphic column to the Precambrian.

\subsubsection{Caliche}

A thin layer of caliche (a whitish, calcium carbonate-rich material) underlies most of the site area. Exposures are normally obscured by dune sand, but it has been estimated that the caliche blanket covers approximately $80 \%$ of the site area. The average thickness is 4.3 feet, and the total resource has been estimated at $185 \mathrm{million}$ tons (Siemers et al., 1978). The quality of caliche as determined by insoluble content (ranging from 21 to $69 \%$ ) appears to be typical for caliche for this region. 
Caliche is often used to surface dirt roads in southeast New Mexico. Small quarries dot the landscape, and several provided material for road construction to various drill locations within the WIPP site. This is the sole use for caliche in this region. Caliche is so extensive in this region that it can not be considered as either a limited resource or one that has significance to road construction of surrounding areas if land is withdrawn for the WIPP site.

\subsubsection{Uranium}

Uranium could occur in sediments such as those of the Gatuna, Santa Rosa or Dewey Lake Formations. However, no significant occurrence of uranium has been found within the Delaware Basin. Reducing environments favoring uranium deposition are absent as evidenced by the lack of organic debris, pyrite or humates in these formations. No signal indicative of economic or even marginal uranium concentrations was observed on gamma ray logs of the 36 holes drilled through these beds during site evaluation. The conclusion is that significant uranium deposits are most unlikely, even in beds which are considered to be the most favorable.

\subsubsection{Gypsum}

Dissolution of salt from the Rustler Formation has occurred over much of the site area. Waters accompanying this dissolution have caused partial conversion of anhydrite within the Rustler to gypsum. The conversion is not complete, however, and it is doubtful that high-quality gypsum would be persistent in any single bed. The maximum amount that could be present, assuming an aggregate thickness of 40 feet, amounts to 1.3 billion tons (Siemers et al., 1978). The quality and bed thickness are inferior to those in beds west of the WIPP site. Still farther west and south, extensive outcrops of high quality gypsum of the Castile Formation occur. The nearby availability of superior quality gypsum that can be mined by open pit methods leads to the conclusion that gypsum in the Rustler Formation can not be considered a likely economic resource. 


\subsubsection{Halite (Salt)}

Halite is the dominant constituent of the Ochoan evaporites. The shallowest salt is in the Rustler, but dissolution of this formation has removed much of the Rustler salt except in the southeast quadrant of the WIPP site. On the other hand, salt beds persist under the site in the Salado and Castile Formations. The thickest and purest salt beds in the region are in the Castile. The State Bureau of Mines and Mineral Resources estimated 118 billion tons of salt in the Salado within the WIPP boundary (Siemers et al., 1978). The Castile Formation would add approximately 80 billion tons of additional salt resource.

As with gypsum and caliche, the immense halite deposits are not considered to have economic significance because of the prevalence of these deposits throughout the general area and the existence of adequate supplies closer to areas where salt is in demand.

\subsubsection{Sulfur}

A significant deposit of native sulfur is being exploited by the Frasch process approximately 50 miles south of the WIPP site in northeastern Culberson county, Texas. The occurrence is associated with brecciated and carbonatized anhydrite beds of the Castile Formation. Considerable exploration has been under way since discovery of the culberson deposit, but that exploration has been aligned along the southern and western parts of the Delaware Basin where the Castile Formation either lacked halite during deposition or the halite has been removed by dissolution. The genesis of the deposits is believed to depend on a combination of bacterial action, induced fracture permeability and a source of hydrocarbons (presumably from upward escape of natural gas or crude oil along fractures from the Delaware Mountain Group). The closest analogy to such a setting in the northern part of the Delaware Basin and the vicinity of the WIPP site would be either "breccia pipes" or $\mathrm{H}_{2} \mathrm{~S}$-laden brine reservoirs. Careful attention was given in selecting the wrPP site to avoid such structures; further investigation has not revealed any such structures, therefore, no sulfur deposits are expected. 


\subsubsection{Lithium}

Lithium occurs in a concentration of $140 \mathrm{mg} / \mathrm{L}$ in a saturated brine reservoir that was encountered during the drilling of ERDA 6 . The hole was located 2 miles northeast of the outer boundary of the WIPP site. A similar reservoir was found in the Belco Hudson Federal No.1 gas well 1/4 mile outside Zone IV on the southwest side of the site. No analyses were done for lithium in the latter well, but both reservoirs were at equivalent stratigraphic positions (middle Castile), contained $\mathrm{H}_{2} \mathrm{~S}$, and were fully saturated brines. The concentration of $140 \mathrm{ppm}$ lithium in ERDA 6 verges on being economically extractable if the reservoir is of sufficient size. Griswold (1977) estimated the reservoir volume at ERDA 6 to be on the order of 100,000 to 1 million bbl. If reservoirs are limited to this size, they would not warrant development. At current market price the in-place value of the lithium would not exceed $\$ 1$ million.

There has been a deliberate attempt to locate the WIPP site in an area free of brine reservoirs in the Castile. Extensive seismic surveys have been run across the area to ensure that no anomalous structures occur in the Castile Formation. The occurrences at ERDA 6 and at the Belco well are associated with complex anticlinal structures and are easily recognizable on seismic survey traces.

\subsubsection{Potash}

Method of Evaluation. Sylvite ( $\mathrm{KCl}$ ) and langbeinite $\left(\mathrm{K}_{2} \mathrm{Mg}_{2}\left(\mathrm{SO}_{4}\right)_{3}\right)$ exist under portions of the WIPP site (see Figures 8.2, 8.3, 8.4). Although an attempt was made to avoid such deposits during the site selection process, it was not possible to do so completely because other site selection factors such as avoiding deep oil and gas test wells and the desire for uniform and thick salt beds at reasonable depth took precedence. 
The potash evaluation commenced in August, 1976, after the site was chosen for detailed characterization. When chosen, the site was located mostly outside the Known Potash Area defined by the Conservation Division of the U.S. Geological Survey. Considerable potash exploratory drilling had been done on the flanks of the site area by private industry, but it is a requirement that the results of that drilling be held in confidence by the USGS. However, Sandia Laboratories contacted each mining company that had drilled in the vicinity and was granted access to the drill records on a private basis. These records indicated that deposits of commercial quality probably extended into the site area. The Department of Energy (then ERDA) authorized an exploratory drilling program to evaluate the potash deposits within the WIPP site. Technical direction of this exploratory drilling program was given to the USGS. The drilling program commenced in August and was completed by the end of November, 1976.

The Roswell, New Mexico, office of the Conservation Division of the USGS was given the task of determining potash resources by combining the results of DOE-sponsored drilling with records of drilling in the vicinity of the site. Findings have been reported by John et al. (1978).

The DOE also engaged the services of the U.S Bureau of Mines (USBM) to evaluate the extent to which the resources defined by the USGS could be produced at a profit using existing mining and beneficiation practices. The results of the study have been reported by the USBM (1977). The essential conclusion was that langbeinite in the 4 th ore zone could be profitably mined in the northeast quadrant of the WIPP site. A band of sylvite, contained mostly within the loth ore zone on the north and west sides of the sites, verged on being economically exploitable. Profitable mining of the sylvite would require a higher price for muriate (KCl) than current market value ( $\$ 52 /$ ton versus a current price of $\$ 43 /$ ton).

Description of the Potash Exploration Drilling Phase. Figure 8-1 is a map showing a land block, centered on the WIPP site, that measures 8 miles on a side. This land block constitutes the area investigated by 
the USGS and USBM. All locations of drill holes are shown from which information was available as to the depth, thickness, grade, and mineral suite of ore beds. Note that a different symbol is used to denote holes drilled by DOE from those drilled by mining companies. Examination of the distribution of hole locations reveals that the drilling plan directed by the USGS included testing the entire WIPP area on a spacing of not less than one hole per square mile. The objective was to completely cover the site area following industry practice for reconnaisance exploration. The density of the holes is judged to be quite adequate for resource appraisal.

Drilling closely followed standard industry practices (Jones, 1978). Rotary techniques were used from the surface down to a point just above the uppermost ore zone. Drilling operations were then converted to coring using a brine saturated with potassium chloride as the drilling fluid. Core recovery was excellent in all 21 holes. The core recovered was examined, and zones of interest were "split" for chemical analysis. Routine check analyses were done by an independent laboratory. All cores, including the remaining half of sample splits and sample rejects (excess after assay), have been permanently stored.

The results of the analyses of the 21 exploratory holes are attached as Appendix 8A. Included in the list are hole AEC 8 (drilled at the old ORNL site) and 17 holes for which information is available for release either by permission of the mining company involved or because the lease or permit on which the hole was drilled has expired.

\section{Calculation of Potash Resource Distribution, Volume and Grade. As} previously stated, calculation of the in-place volume and grade was undertaken by the Roswell office of the Conservation Division of the USGS. Technical assistance was also provided by the special projects Branch of the USGS.

There are 61 exploratory holes in the $8 \times 8$ mile land block shown in Figure 8-1. Ore intercept information was available to the uSGS on all 
of these holes. Thus, while their calculations used all available data, some specific information pertaining to 22 industry drilled holes is not reported in Appendix $8 \mathrm{~A}$ to protect proprietary information of individual companies as they so requested.

The reserve calculation commenced with assigning depth intercepts to significant mineralization within the various ore zones. There are 11 such ore zones within the McNutt member of the Salado Formation (see Figure 4.3-3b). The next step consisted of extrapolating continuity of individual ore zones between holes. The final step was to calculate the volume and grade for continuous blocks of mineralization. In addition, the Conservation Division utilized criteria they have established for classifying resources as either measured, indicated, unevaluated, or barren. The criteria are:

Measured potash reserves - Tonnage is computed from dimensions revealed in workings and drill holes. The grade is computed from the results of detailed sampling and analyses. A minimum of three data points in any one ore zone meeting quality and thickness standards, no more than $11 / 2$ miles $(2.4 \mathrm{~km})$ apart, have been used to delineate measured reserves.

Indicated potash reserves - Tonnage and grade are computed partly from specific measurements, samples, or production data and partly from projection for a reasonable distance on geologic evidence. The sites available for inspection, measurement, and sampling are too widely or inappropriately spaced to permit the mineral bodies to be outlined completely or the grade established throughout.

Unevaluated potash areas - Tonnage and grade have not been computed due to low density drilling and sampling, but are surrounded by measured and (or) indicated reserves.

Barren and/or minor potash mineralization areas - Subeconomic resources that would require a substantially higher market value or a major cost-reducing technology for economical production. 
Subeconomic resources also include other bittern minerals not presently being recovered.

Potash resources were then quantified at three minimum grade and thickness levels. Standard conditions for each class are shown in Table 8.6 .

The intermediate conditions, termed "lease", conform with established policy of the Department of Interior that any area known to contain potash mineralization meeting or exceeding that standard and located on Federal land can be acquired only through competitive bid. The standard is based on judgment along with recognition that ores as low as these grades have been successfully treated from time to time at one or more of the potash refineries in the Carlsbad district. The conditions termed "high" are roughly equivalent to the grade of langbeinite and sylvite ores currently being mined in the district.

Results of the USGS Resource Estimate. The essential results of the USGS resource calculations are best shown by three consecutive maps (Figures $8-2,3$ and 4) which commence with the lowest resource grade standards and progress to the highest. For simplicity, measured and indicated resources were combined. The majority of the resource meets the criteria for "measured" because the entire WIPP site has been drilled on one mile centers. The resource maps do not segregate the several mineralized ore zones, and at times they are "stacked", e.g. the $4 \mathrm{th}$ and $10 \mathrm{th}$ may be mineralized in the same area in plan even though they are stratigraphically separated by about 180 feet.

Most of the WIPP site area is underlain by potash resources that meet the low standards. No significant planimetric change occurs on raising the standard to lease grades. However, at the high standard, which is roughly equivalent to the current standard of producing mines, the WIPP is nearly clear of potash deposits of interest (particularly zones I-III). Mining operations may be allowed in zone IV, the outer boundary of the WIPP site, under controlled conditions. 
As grade standards are increased, the potash resources reduce, at more rapid rate on a mass weight basis than on a planimetric basis. Table 8-7 lists the tonnage of by ore zone, type, and location by zone boundaries within the WIPP site.

For ease in interpretation, the data in Table 8-7 has been charted on Figures 8-5 and 8-6 for langbeinite and sylvite resources, respectively. The USGS recognized the 4 th ore zone (langbeinite) and the 10th (mainly sylvite) as the two major mineralized ore zones in the WIPP site area (John et al., 1977). At lease grade, the 4 th ore zone contains 115.4 million tons of langbeinite resource, of which only 24 million tons (218) lies inside the outer boundary of zone III. At the higher grade (88 $\mathrm{K}_{2} \mathrm{O}$ as langbeinite) the tonnage under the WIPP reduces to 59 million tons, of which only $14.6 \mathrm{million}$ tons (258) lies inside the outer boundary of zone III.

The loth ore zone contains mostly sylvite, but a mixed assemblage containing both langbeinite and sylvite exists on the east side of the withdrawal area. At present only one operator in the Carlsbad district has a refinery capable of handling such ores. This operator is the leaseholder over part of this mixed ore zone. However, the langbeinite in the loth ore zone would be difficult to beneficiate according to the USBM study (USBM, 1977, p.103). Therefore, the loth ore zone is considered to be viable only for its sylvite content. With this restriction, the 10 th ore zone contains $53.5 \mathrm{million}$ tons of ore at lease standard under the entire WIPP site, of which 30.4 million tons (578) are located within the outer boundary of zone III. At the high standard, the total tonnage reduces to 38.8 million tons, of which only 9.8 million tons (258) are inside zone III.

Results of the USBM Valuation of Potash Resources. The USBM has performed an economic assessment of the potash resources that were defined by the USGS. The USBM study included beneficiation testing to determine the amenability of the various mineral assemblages to refining into marketable products. The USBM engineers visited most of the mines in the district to gather data concerning mining and refining techniques, power consumption, water use, etc. Then, knowing the location and grade 
of potash deposits in the WIPP site area, they devised conceptual designs of various mining and processing facilities that would provide both the highest profit and efficient recovery of marketable products from the potash deposits. The approach followed what private industry would do in an evaluation of a potash prospect. No restriction was placed as to where physical mining could be done, or problems related to land acquisition or permitting. Resources adjacent to the WIPP site were considered in the mine development plans. In all, the USBM conceived 12 different conceptual plans for exploiting potash in this area. Each plan, called a mining unit, was evaluated leading to a conclusion that 8 were worthy of full cost analysis. The full findings have been reported by the USBM (1977).

The USBM concluded that only one mining unit (Unit B-1) could be considered economic under existing market conditions and technology (see Table 8.8).

Unit A-1 almost meets the economic requirement of 158 rate of return on invested capital set by the USBM. To make it viable one needs a price of $\$ 52.04$ per ton of muriate without any increase in production costs. Muriate is currently selling at $\$ 43.40$ for standard grade containing $62 \%$ $\mathrm{K}_{2} \mathrm{O}$ (Source: July 1978 issue of Engineering and Mining Journal); however, the price for muriate has exceeded $\$ 60$ per ton in the past.

Data within the USBM report indicate that the langbeinite resources associated with the Unit B-1 that lie within the boundary of WIPP amount to 48.46 million tons, of which only 13.33 million tons (27.58) lie inside the outer boundary of zone III. For Unit A-l the corresponding numbers are 27.41 million and 0.9 million tons.

Summary of Conclusions Concerning Potash Resources in the WIPP Site. The site contains economically mineable reserves of langbeinite and possibly sylvite. If total rights withdrawal is a requirement to satisfy waste isolation, then the relevant quantities of potash resources are much greater than if mining is allowed in the zone IV, the outer buffer zone. The relevant quantities are presented in Table 8-9. 
The USGS has estimated that potash resources in southeast New Mexico (excluding the WIPP site) that meet lease standards are on the order of 5000 million tons of combined sylvite and langbeinite ores. Therefore, total withdrawal of potash lease rights at the WIPP site would account for about 78 of those resources; withdrawal of zone I, II, and III rights would account for about 28 . No data are available for the Carlsbad potash district regarding what percentage of these resources would meet the standards deemed by the USBM to be mineable under today's conditions. In addition, the principal potash resource at the WIPP site consists of langbeinite. No estimates, either by USGS or USBM standards, are available for this ore alone. The Carlsbad district is the only area mining langbeinite in the free world. Langbeinite equivalent is produced in quantity, however, by combining sulfates of potassium and magnesium obtained from brine lakes. When the site was initially selected, most of the WIPP lay outside the known Potash Area, however the 21 hole drilling program conducted as part of the WIPP potash evaluation resulted in discoveries sufficient to warrant expansion of that boundary (see Figure 8-1). The expansion conforms with USGS policy that potash resources meeting the lease standard must be placed within the enclave.

\subsubsection{Hydrocarbons}

Method of Evaluation. The WIPP site selection criteria dictated that deep drill holes (defined as those that penetrate through the Ochoan) be excluded from zones I, II, and III. The objective was to maintain a one mile buffer between deep holes and zone II, the zone in which waste is to be stored. This particular criterion is restrictive, because much of the Delaware Basin has been penetrated by wildcat test holes with an average density of about one hole per square mile. The present site is one of the few remaining portions of the Delaware Basin in New Mexico which will satisfy the criterion pertaining to deep holes. The absence of extensive drilling is due in part to the great depth (greater than 10,000 feet) to potentially favorable gas formations. In addition, potash deposits north and west of the site area precluded oil and gas exploration in those directions. Federal and state regulations have set aside potash 
mineralized areas to protect underground mining operations from accidental entrance of methane gas. Therefore, most of the WIPP site is untested for deep reservoirs that might contain crude oil and natural gas. The evaluation must rely on projection of surrounding subsurface geologic information into the site area. There are four petroleum test holes in Zone IV of the WIPP site. Three holes tested the Delaware sands and were unproductive. The fourth was a deep gas test $(15,000$ feet $)$ that was also unproductive.

The State Bureau of Mines and Mineral Resources performed a regional evaluation of the hydrocarbon resources in southeast New Mexico which was then used to further evaluate a four township area centered on the original ORNL site (Foster, 1974). This report is useful for the current WIPP site because, as indicated in Figure $8-7$, the present site is still within the area studied.

Data contained in Foster's report provide a basis for estimating total hydrocarbon resources that might underlie the site area. By using a statistical approach, Foster arrived at a possible hydrocarbon content for each potential productive zone, commencing with the "Ramsey Sand," down to the top of the Precambrian basement. The Ramsey, the first potential pay zone, is located in the upper part of the Delaware Mountain Group. The lowest zones he considered to be potentially productive were dolomitic reservoirs in the Silurian/Devonian. His estimate was based on full development of any prospective area; therefore, total resources were estimated rather than the economics associated with their extraction. His resource estimate was based on the premise that geologic conditions beneath the site were as favorable as elsewhere in the study area and that each potential zone beneath an untested section would contain a proportionate share of the statistical average of hydrocarbons for that zone. The average was derived from success ratios and a conservative estimate of primary recovery of hydrocarbons as established by past exploration, development and production. 
A consulting petroleum engineering firm, Sipes, Williamson and Aycock, Inc (SW\&A), was engaged by Sandia Laboratories to conduct an economic evaluation of hydrocarbons in the site area. Based on known drilling costs and market conditions, they made a judgment as to what portion and which formations under the site were worthy of testing. The basic criterion was reasonable prospect for discovery with an economic reward to the operator of at least 108 return on his investment plus full recovery of costs. The essential conclusion of the SW\&A study was that the Morrow unit has a high potential for successful discovery of natural gas. All other formations present were considered too high a risk to be the objective of a prudent wildcat test. Naturally, once a Morrow well was drilled it could encounter shallower productive pay zones, but the odds of such happening were deemed too speculative to be considered in the overall economics. The full findings of this study have been reported by Keesey (1976).

Structure maps of several horizons beneath the Ochoan evaporites have been compiled from seismic surveys that were either purchased from existing surveys or conducted as part of the WIPP site study. While the main purpose of these seismic surveys has been to understand the geologic aspects of the site area, they are also valuable for interpretation of potential hydrocarbon reservoirs. These structure maps were not available to Foster for his 1974 study, but they were to SW\&A during their 1976 evaluation. The seismic studies have been reported by McMillan (1976) and G. J. Long \& Associates (1976). Updated structural interpretations based on later seismic studies are now available. The recent changes have had little impact on the overall hydrocarbon evaluation.

Total Hydrocarbon Resources at the WIPP Site. The New Mexico Bureau of Mines study forms the basis of the evaluation of the total hydrocarbon resources in the site area (Foster, 1974). We assume there is a reasonable probability that Foster's estimated resources could exist under the site. However, this probably represents the upper bound of exploitable hydrocarbons. 
The validity of the resource estimate rests on the subsurface geology and statistical probability. The geologic setting under the Ochoan evaporites is considered to be quite typical for this portion of the Delaware Basin; therefore the chance of finding oil or gas should approximate what has been found in similar areas near the site which have been more fully tested. However, since it is a regional statistical approach, it is possible that much more or much less than the average expected resource would be found if the site was actually drilled. The hydrocarbon evaluation is not as definitive as that for potash, which was actually confirmed by exploratory drilling. This would be self-defeating in the case of the deeper hydrocarbon resources since the area was selected to avoid such deep drill holes.

Foster's evaluation (Foster, 1974) took into account the occurrence of all known oil and gas accumulations in much of southeast New Mexico (Figure 8-7). The statistical base encompassed about 42 full townships equivalent to almost 1 million acres. The reserves for each oil pool or gas reservoir were estimated from the standpoint of actual or, where possible, projected production. Areas were then classed as developed or undeveloped based on the density and depth of drilling. From these data, Foster (1974) then determined the expected resource per section of land by assuming that the success of future drilling would have the same success ratio as in the past. A coincident assumption was that, while past wildcat drilling avoided the current WIPP site, the past economic incentive for drilling was low. Also, drilling restrictions pertaining to the Known Potash Enclave have prevented drilling, particularly on the west side of the WIPP area. There were more attractive areas available throughout the basin that satisfied the availability of private venture for exploration capital. These past constraints do not enter into the hydrocarbon potential estimates because the characterization of the site must take into consideration the long-term needs for mineral resources.

Figure 8-8 is taken from Foster (1974). Formations that he considered as potentially productive are shown opposite the stratigraphic column of sedimentary rocks underlying the Ochoan evaporites. Table 8-10 then 
shows the potential resource he assigned to the various specific intervals but which were composited to more gross intervals. Further explanation is required pertaining to "wildcat" and "acreage" assignment of reserves.

The acreage method tests the success ratio of producing acreage versus the acreage considered to have been tested by wildcat drilling. The wildcat method considered a field, regardless of the number of wells in that field, as a single discovery. A success ratio was then determined by dividing the number of wildcat discoveries by the number of dry holes that were drilled to that formational depth. The acreage method normally results in a higher success ratio and, therefore, higher reserve estimates. In-place hydrocarbon resources for each zone within the WIPP site can be readily calculated from Foster's data by combining his estimate of in-place hydrocarbon resources per section (640 acres) with the known area for each zone of the WIPP site. The acreage method was used to prepare Table 8-11.

While the quantities given in Table 8-11 may appear large, they are brought into perspective by stating that all of the nearby region, i.e., the area studied by Foster, would contain 51 times the resource quantity under the WIPP site. The factor is simply the ratio of the total area evaluated by Foster (1512 square miles) divided by the area of the WIPP site (29.62 square miles). In addition, if hydrocarbon development is allowed in zone IV, e.g., by deviated drilling, then the resource that would be withdrawn is reduced in proportion to the excluded area, i.e., from 29.62 square miles down to 12.73 square miles for a 438 reduction in restricted resources. The hydrocarbon resources remaining in zones $I$, II, and III would account for only 0.848 of the total hydrocarbon resources Foster has estimated in the area immediately surrounding the WIPP site.

Estimate of the Economically Recoverable Hydrocarbon Resources. Sipes, Williamson, and Aycock, Inc. (SW\&A) estimated the potentially economic hydrocarbon resources (Keesey, 1976). Their approach was to review the 
existing geologic information pertaining to the area in and around the site and then to determine if the probability of oil and gas occurrences justified the risk of drilling and completing a well. The base area studied by SW\&A consisted of a $20 \times 20$ mile block centered on the WIPP site (Figure 8-7). All available data were evaluated on each test that had been drilled within this 400 square mile area, with particular emphasis placed on deliverability and recoverable reserves.

SW\&A found that 60 wells in this area were producing oil and/or gas from reservoirs in the Delaware Mountain, Bone Spring, Wolfcamp, Strawn, Atoka and Morrow. With the exception of the Atoka and Morrow, all other zones were considered as presenting too high a risk to justify the cost of wildcat drilling. Furthermore, even though an Atoka reservoir is being produced from a well located near the southwest corner of the WIPP site, SW\&A concluded that that particular reservoir is being effectively drained by the single well. Offset drilling would enhance recovery $r$ ate but not total recovery.

The Morrow was considered to be worthy of testing, because of the high success ratio of wells drilled to that formation in the area around the site. Of 26 wells drilled to sufficient depth to test the Morrow, 23 were successfully completed as gas wells. A study of these wells revealed that the projected ultimate recovery ranged from insignificant to as much as 5.20 billion cubic feet (bcf) of natural gas. From the distribution of recoveries they concluded that the average successful Morrow well would recover 2.074 bcf of gas. This is in fair agreement with Foster's estimate for Pennsylvanian gas wells; he estimated 3.2 bcf per Morrow gas well if spaced at 320 acres per well.

Drilling and completion costs were then estimated for wells drilled to the Morrow (approximately 14,000 ft.). The estimate was $\$ 1.4$ million. Using discounted cash flow analysis and the expected delivery rate and current gas price ( $\$ 1.42$ per $1,000 \mathrm{cu}$. ft. with 48 yearly escalation) they concluded that if a well produced 0.7 bcf over its lifetime it would 
recover costs. Since the average well was more than twice this production, it was apparent that drilling in the site area could be justified.

Use was then made of the structure map on a limestone reflector horizon in the Morrow based on data from seismic surveys (Figure 8-9) (Long, 1976). Tentative drilling sites were picked with weight given to the flanks of anticlines because local experience indicates that productive sand lenses would more likely occur at such localities. A total of 20 drill sites was selected (Figure 8-9). In favorable structural areas wells were placed on a spacing of 320 acres per well. This spacing is standard practice for wells of this depth in New Mexico. Depending on proximity to producing wells and structural favorability, the 20 wells were ranked as proven, probable or possible. The proven category was limited to locations that would offset producing wells in the Los Medanos field. Two locations were designated as proven, nine as probable, and nine as possible.

The ultimate recovery of wells was adjusted to take into account the risk factor associated with wildcat drilling. Proven wells were assigned production of 2.07 bcf, probable wells 1.64 bcf, and possible wells 1.33 bcf per well for the southwest quadrant of the WIPP site. The estimated reserves for locations in other parts were placed at 2.09 bcf for probable and 1.67 bcf for possible reserves. No locations could be considered as proven. The higher reserves assigned to these locations were considered justifiable because shallower pay zones may be discovered on the way down to the Morrow. This calculation yielded a total reserve of 36.85 bcf of natural gas under the WIPP site (Table 8-12). Some distillate would accompany this gas production. Foster (1974) estimated that Pennsylvanian gas is accompanied by 14,950 barrels of distillate per bcf of natural gas produced. Therefore, the 36.85 bcf of reserve under the site should be expected to be accompanied by 550,900 bbl distillate.

Of the 20 drilling sites selected, 7 lie in Zone IV, 2 of which are ranked as proven, 4 as probable, and 1 as possible. The aggregate 
reserve of these 7 wells is 13.38 bcf of natural gas and $200,000 \mathrm{bbl}$ of distillate. If drilling is allowed into zone IV these hypothetical reserves could be recovered. The net balance that would be non-recoverable because of restrictions on drilling in zones I, II, and III is 23.47 bcf of natural gas and $350,000 \mathrm{bbl}$ of distillate.

\section{Summary of Conclusion Concerning Hydrocarbon Resources. Table 8-13}

summarizes the findings of the New Mexico Bureau of Mines resource study and the SW\&A economic evaluation of the part of those resources considered attractive enough to be developed by the petroleum industry at 1977 prices and drilling costs.

The hydrocarbon resources remaining under the WIPP, if zone IV is developed, amount to about $0.84 \%$ of that projected by Foster for the vicinity of the WIPP site. The total economic reserve, including zone IV, amounts to approximately 90 days production of dry gas from southeast New Mexico.

\subsubsection{Metalliferous Deposits in the Precambrian}

Even the deepest oil/gas test near the WIPP site has not penetrated deep enough to encounter the Precambrian basement. A regional survey of test holes has been done by Foster and Stipp (1961). The basement may consist of slightly metamorphosed rhyolites and tuffs known as the Panhandle Volcanic Complex (Flawn, 1954). Such rocks hold potential for sulfide deposits. Geophysical techniques (induced polarization or electromagnetics) have a detection capability scarcely exceeding 1000 feet, while the Precambrian is' at median depth of 18,000 feet beneath ground level at the WIPP site. No evaluation, therefore, is feasible for sulfide deposits. The depth is greater by a factor of almost two over the deepest mines in the world. Therefore, resources in the basement rocks, should they exist, are not likely to be attractive targets for exploitation. 


\subsection{SUMMARY}

Potassium salts and fluid hydrocarbons are the only two resources thought to be economically significant in the WIPP site area. The depth, volume and richness of the deposits are the principal factors which will determine when and if they might be exploited by a free-enterprise system. Such economic evaluation has been conducted and reported in the WIPP Environmental Impact statement. Because economic aspects change, they are not so relevant to site characterization as they are to assessing the impacts of constructing the WIPP facility. Hence, in this chapter, amounts and types of resources will be discussed rather than their present economic value. The principal findings of resource studies are summarized in Table $8-1$.

If reasonable technologic and economic restraints are considered for extracting, processing and marketing the resources then both the amounts and types of exploitable deposits are greatly reduced. Only potash and natural gas are considered to be significant in this respect (see Table 8.2). Even these reduced quantities should be considered as upper estimates because of these assumptions: 1) complete mineral lease ownership by a single company and 2) no conflict between the simultaneous development of the shallow potash deposits and the deep gas reservoirs.

Economic resources are further reduced by allowing the mining of potash and recovery of $O i l$ and gas by deviated drilling in zone IV, the outer buffer zone. If this is the case, then economic resources lying in the inner zones are limited to those given in Table 8-3.

Caliche, salt, and gypsum are also present, but the abundance of these minerals throughout the region leads to the conclusion that land withdrawal for the WIPP will have little effect on present or future requirements for them. Consideration was also given to the possible presence of uranium in redbed-type sediments that overlie the evaporites. The conclusion is that no significant uranium deposit exists. Lithium occurs in a brine reservoir within the Castile Formation 
northeast of the present site and may be present in a similar reservoir to the southwest. However, care has been taken to avoid such brine reservoirs within the site area. Consideration was also given to the possible existence of metalliferous deposits in the precambrian basement under the site. However, the depth (about 18,000 feet below the ground surface) to Precambrian rocks would preclude mining even if mineral concentrations were present. No geologic or geophysical evidence exists to suggest that deposits are any more likely in the basement rock of the WIPP area than elsewhere in the region. 


\subsection{REFERENCES}

Flawn, P. T., 1954, Summary of Southeast New Mexico Basement Rocks: Guidebook of Fifth Field Conference, New Mexico Geological Society, p 114-116.

Foster, R. W., 1974, Oil and Gas Potential of a Proposed site for the Disposal of High-Level Radioactive Waste: Open-file report, New Mexico Bureau of Mines and Mineral Resources (work done under Contract No. $\mathrm{AF}(40-1)-4423$ to ORNL).

Foster, R. W. and Stipp, T. F., 1961, Preliminary Geologic and Relief Map of the Precambrian Rocks of New Mexico: New Mexico Bureau of Mines and Mineral Resources, Circular 57.

Griswold, G. B., 1977, Site Selection and Evaluation Studies of The Waste Isolation Pilot Plant (WIPP), Los Medanos, Eddy County, New Mexico: SAND77-0946, Sandia Laboratories.

John, C. B., Cheeseman, R. J., Lorenz, J. C. and Millgate, M. L., 1978, Potash Ore Reserves in the Proposed Waste Isolation Pilot Plant Area, Eddy County, New Mexico: U. S. Geol. Surv. Open-file report 78-828.

Jones, C.L., 1978, Test Drilling for Potash Resources: Waste Isolation Pilot Plant Site, Eddy County, New Mexico: U.S. Geol. Surv. Open-file report $78-592$.

Keesey, J. J., 1976, Hydrocarbon Evaluation Proposed Southeastern New Mexico Radioactive Material Storage Site, Eddy County, New Mexico: Sipes, Williamson and Aycock, Inc., Vols. I and II.

G. J. Long and Associates, Inc., 1976, Interpretation of Geophysical Data, Los Medanos and Vicinity: Report to Sandia Laboratories.

MaMillan, C., 1976, Los Medanos Area: Permian Exploration Co., Report to Sandia Laboratories.

Siemers, W. T., Hawley, J. W., Rautman, C., and Austin, G., 1978, Evaluation of the Mineral Potential (excluding hydrocarbons, potash and water) of the Waste Isolation Pilot Plant Site, Eddy County, New Mexico: New Mexico Bureau of Mines and Mineral Resources, Report to Sandia Laboratories.

U. S. Bureau of Mines, 1977, Valuation of Potash Occurrences Within the Waste Isolation Pilot Plant Site in Southeastern New Mexico: Prepared for the ERDA. 


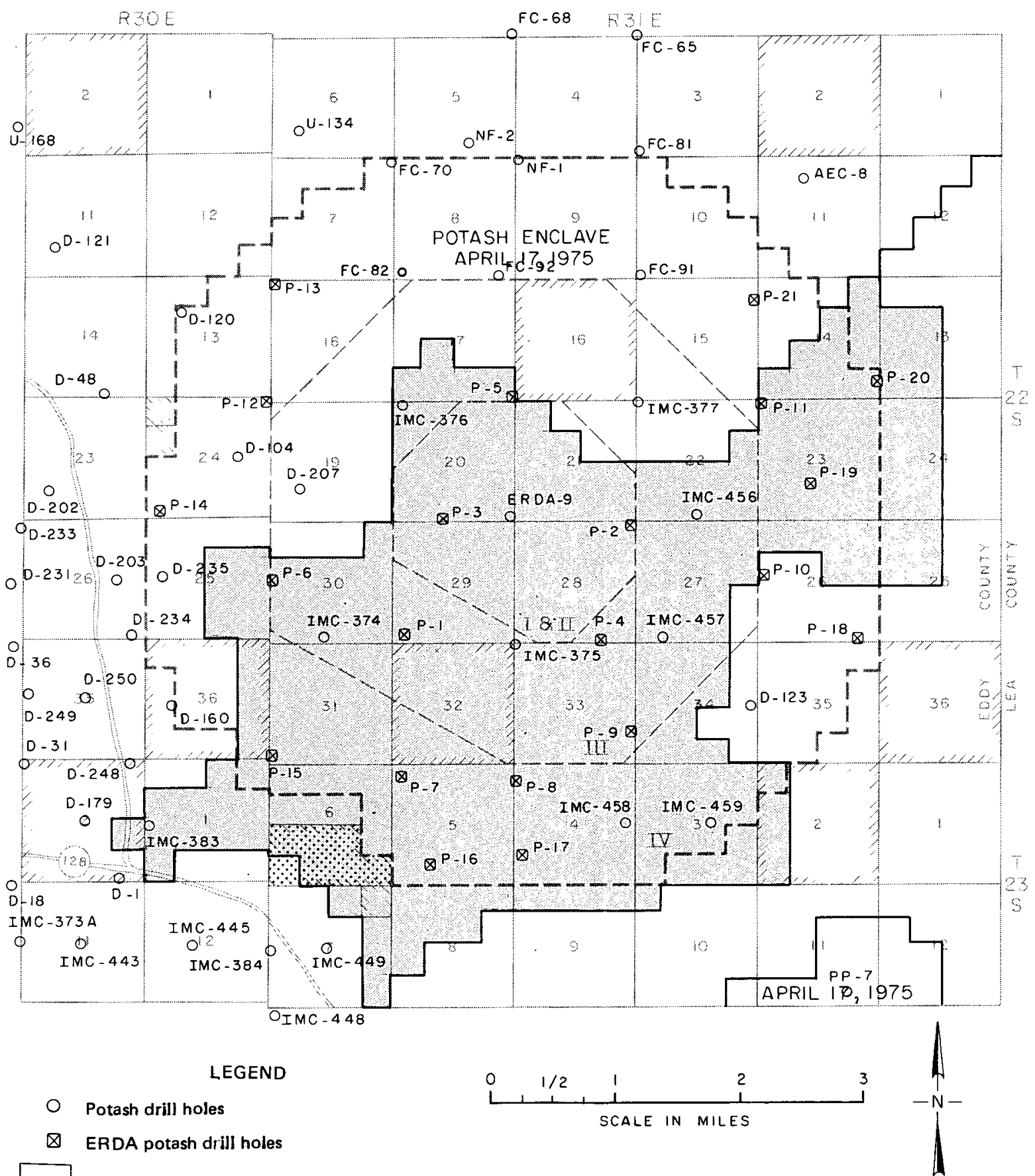

Federal surface and mineral rights

Frग state surface and mineral rights

$21, \hat{y}$

Private surface and mineral rights

Potash Enclave Boundary Extension, July, 1977

TIT Private surface, all mineral rights owned by Federal Government
- - _. Proposed WIPP site outline

- _ _ Z Zone boundaries and areas provided by ERDA

Private surface and mineral rights, except oil and gas federally owned

FIGURE 8-1

LOCATION OF POTASH EXPLORATION DRILL HOLES IN THE VICINITY OF WIPP SITE 


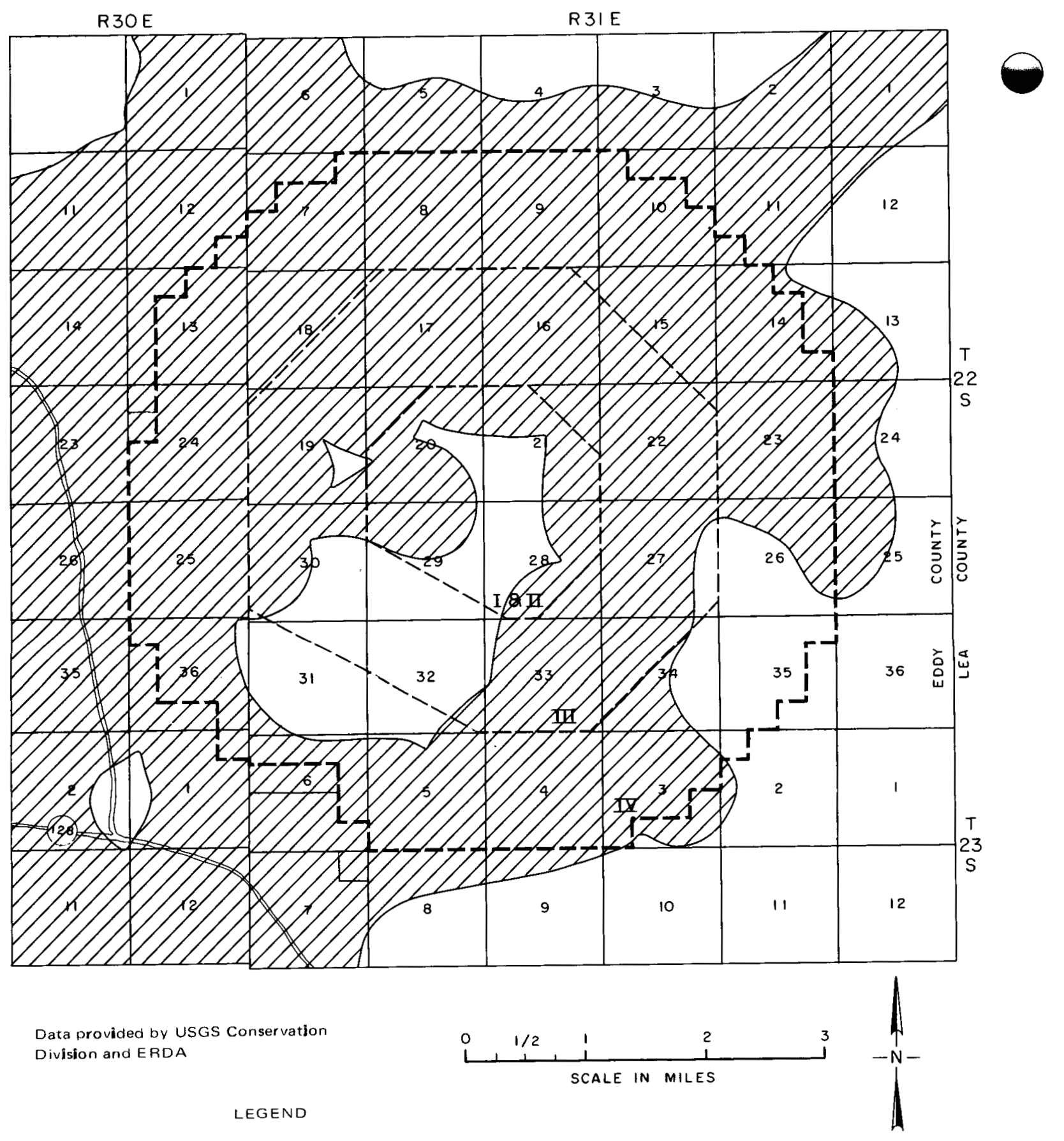

\footnotetext{
- - Proposed WIPP site outline

— _ Zone boundarles and areas provided by ERDA

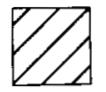

Measured and indicated mineralizzation

Measured and indicated mineralization are at a cut off

of $3 \% \mathrm{~K}, \mathrm{O}$ as langbeinite or $8.0 \% \mathrm{~K}_{2} \mathrm{O}$ as sylvite

or equivalent grade of mixed langbeinite-sylvite

occurring in a minimum 4 -foot interval
} 


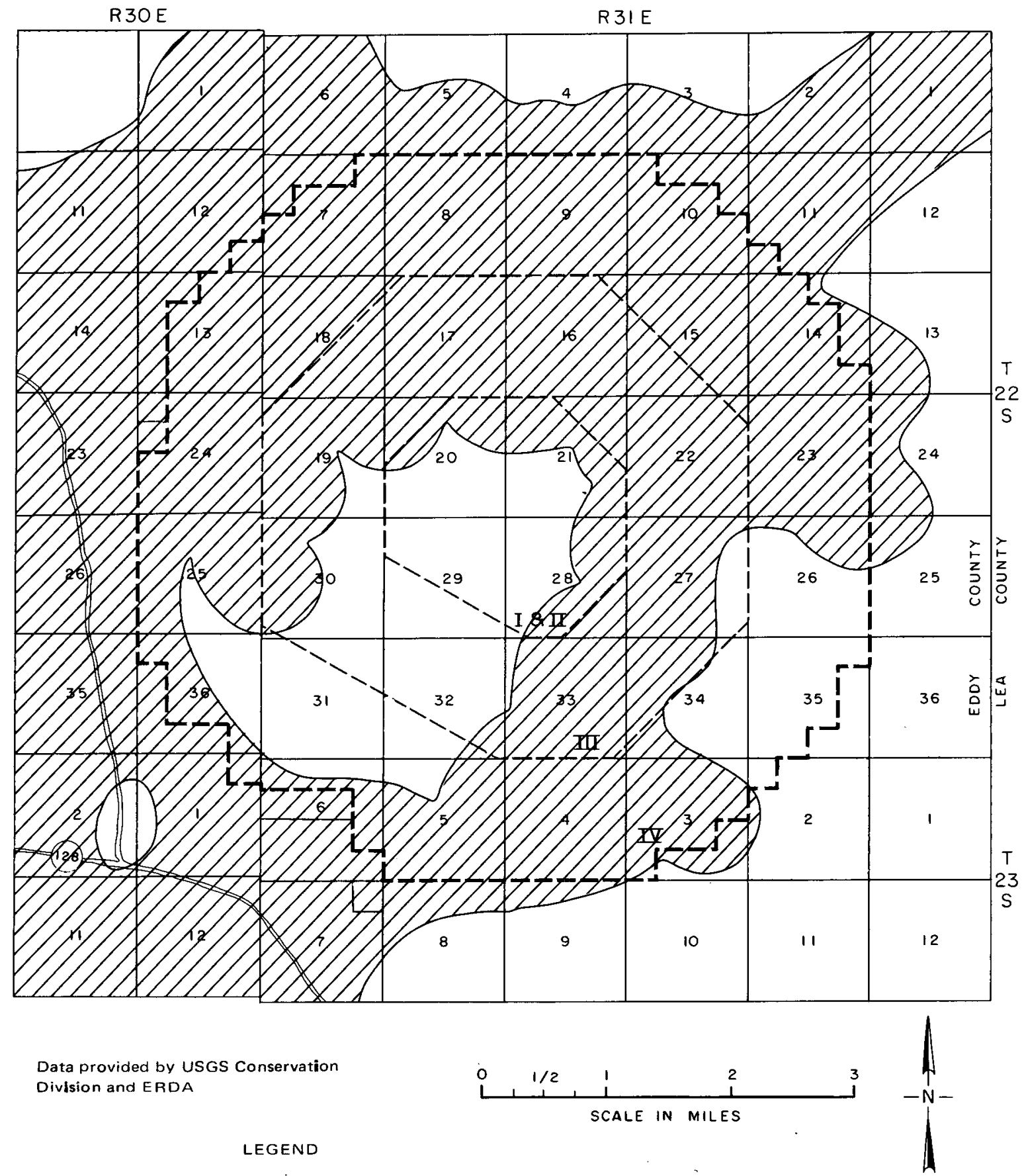

- - Proposed WIPP site outline

- Zone boundaries and areas provided by ERDA

7 Measured and indicated mineralization

Measured and indicated mineralization are at a cut of of $4 \% \mathrm{~K}_{2} \mathrm{O}$ as langbeinite or $10.0 \% \mathrm{~K}_{2} \mathrm{O}$ as sylvite or equivalent grade of mixed langbeinite-sylvite occurring in a minimum 4-foot interval 


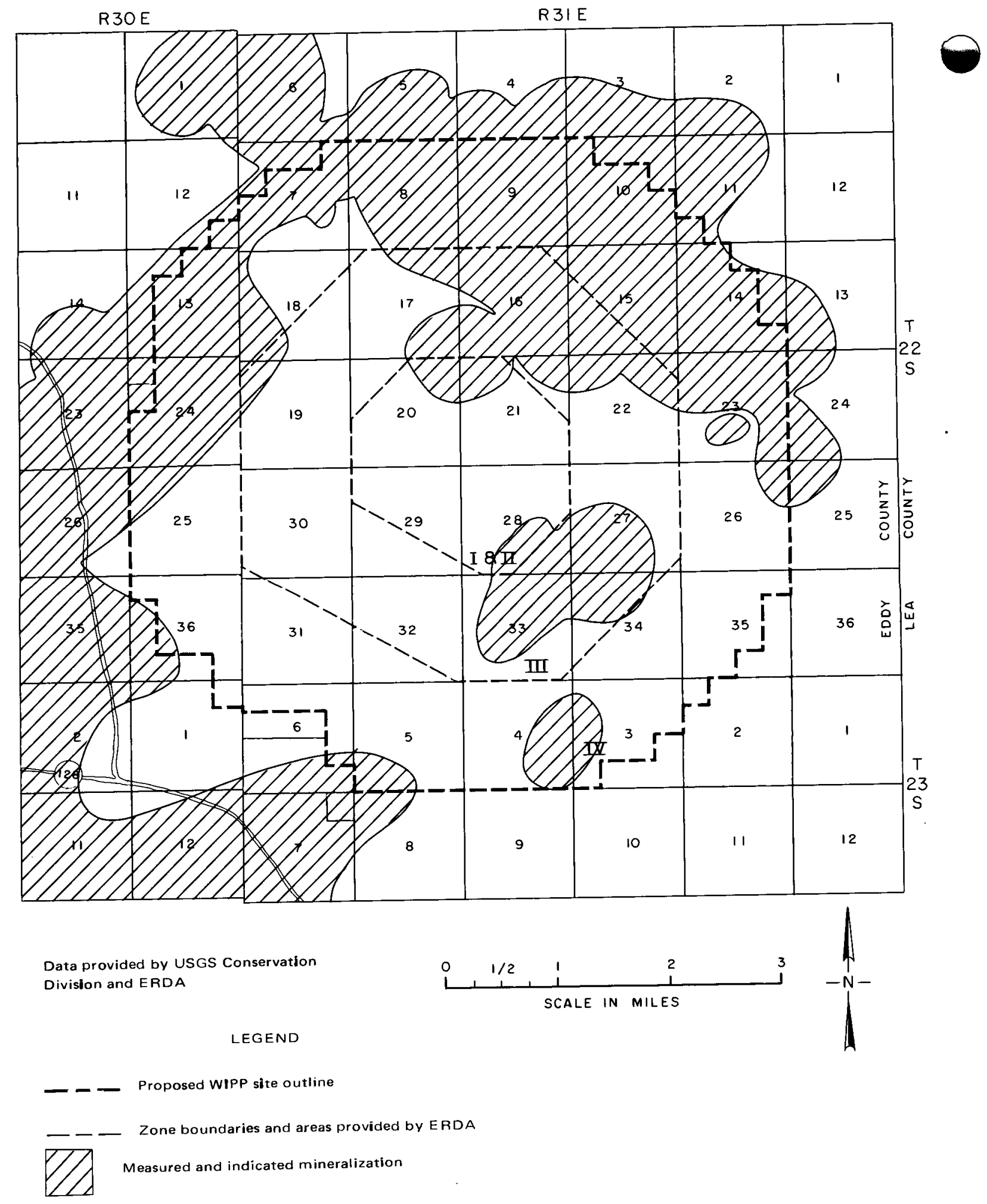

Measured and indicated mineralization are at a cutoff of $8 \% \mathrm{~K}_{2} \mathrm{O}$ as langbeinite or $14.0 \% \mathrm{~K}_{2} \mathrm{O}$ as sylvite or equivalent grade of mixed langbeenite-sylvite occurring in a minimum 4-foot interval 


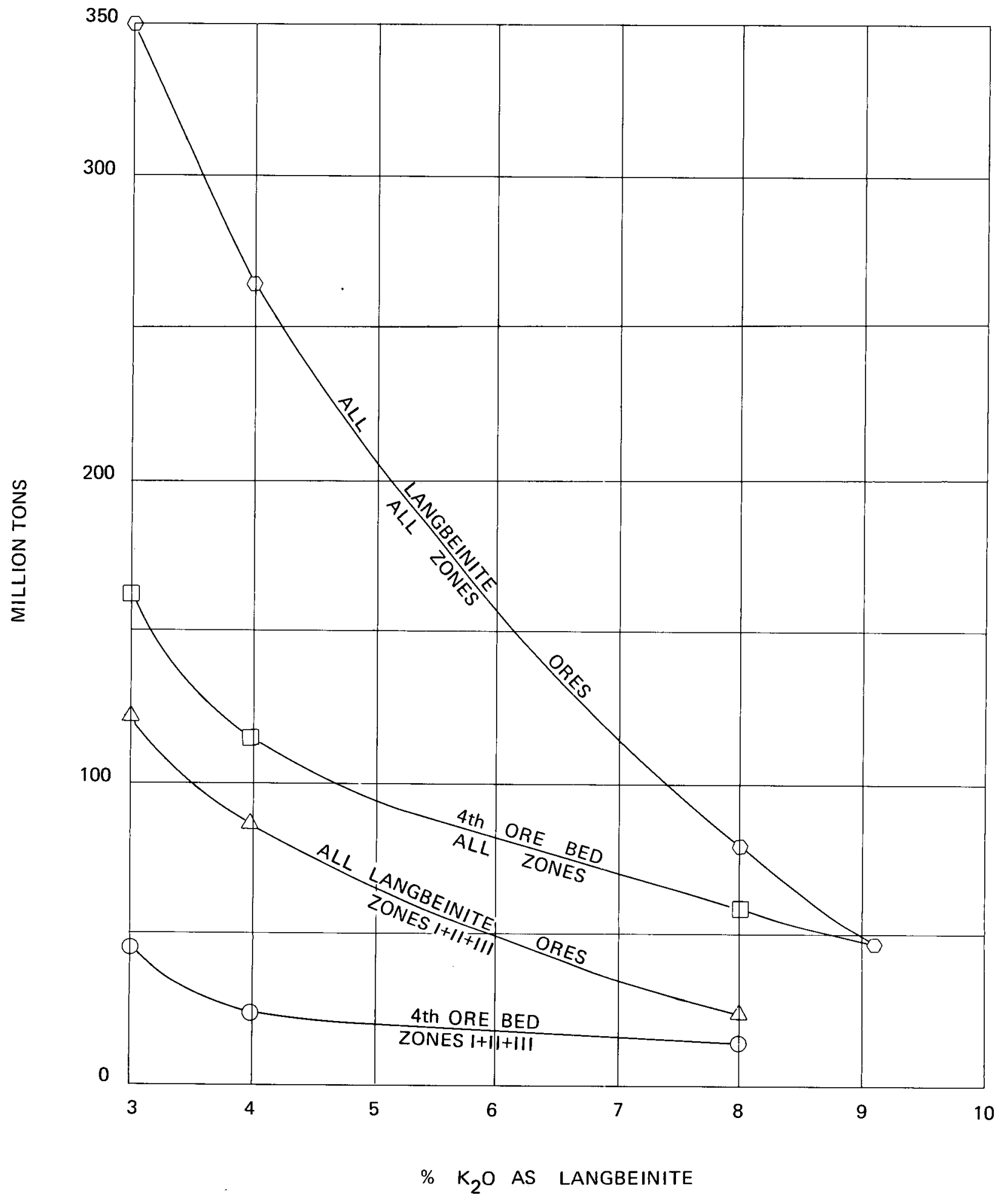

FIGURE 8-5. LANGBEINITE RESOURCES 


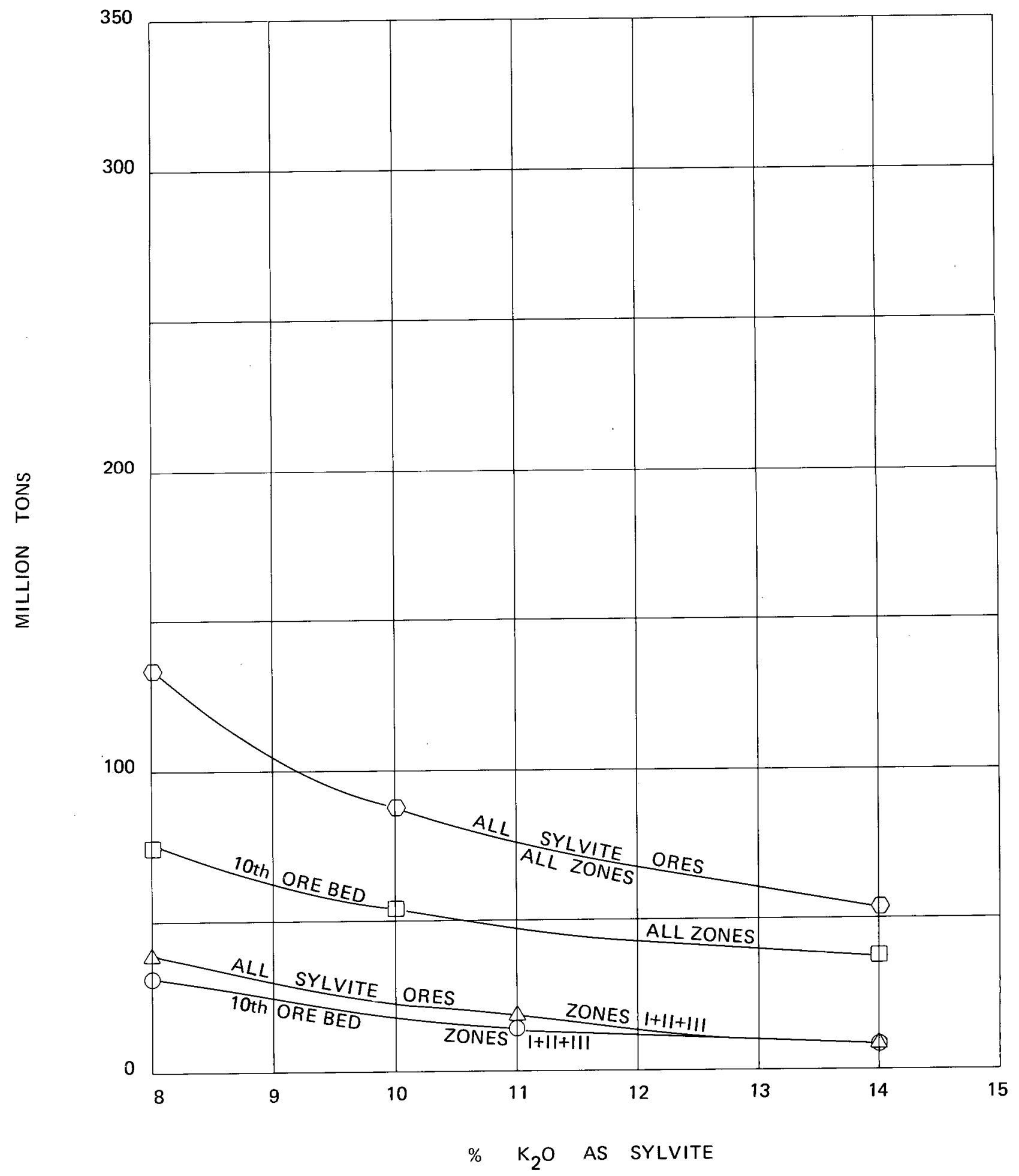

FIGURE 8-6. SYLVITE RESOURCES 


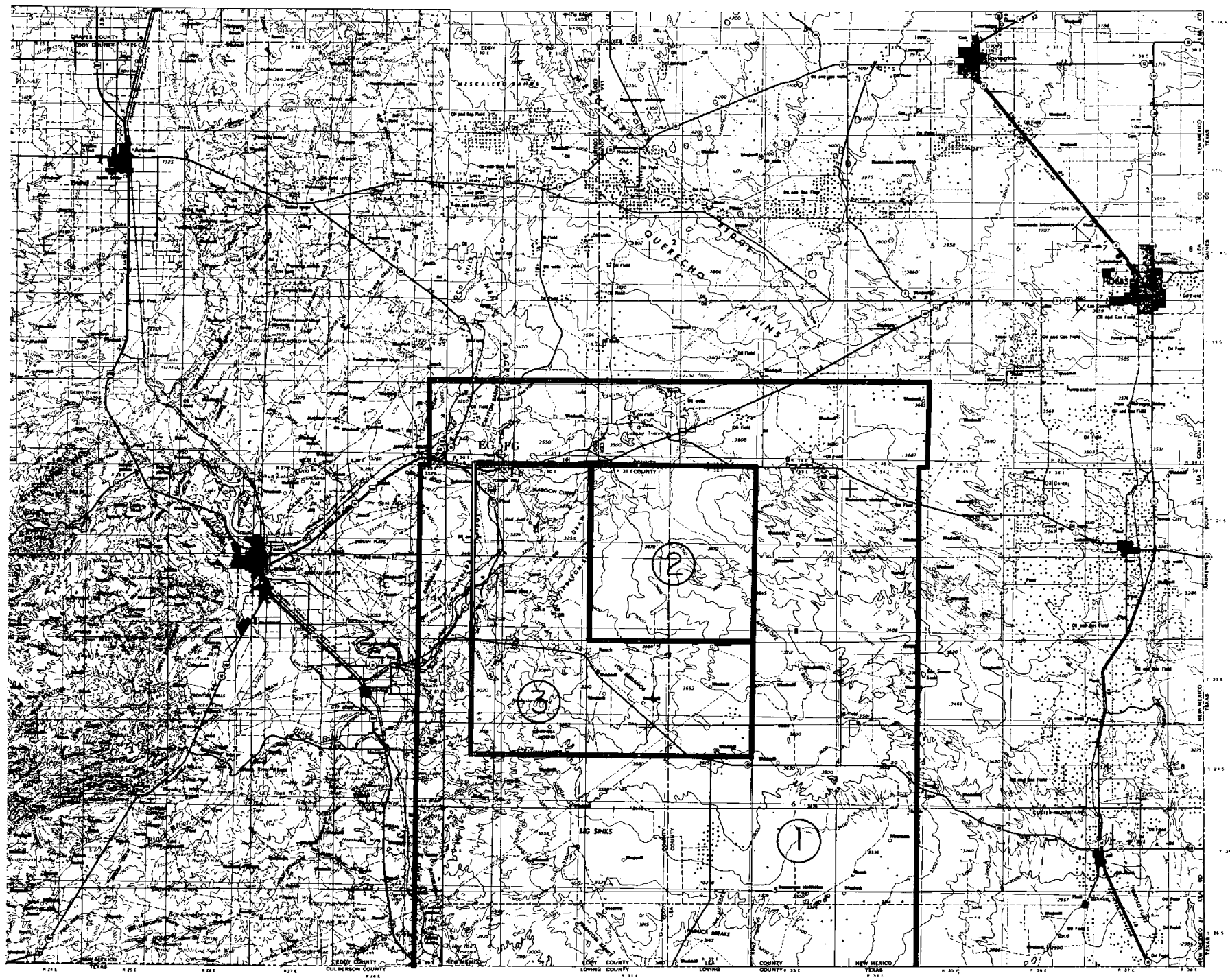

(1) NEW MEXICO BUREAU OF MINES STUDY AREA

(2) NEW MEXICO BUREAU OF MINES DETAILED STUDY CENTERED ON OLD ORNL SITE

(3) SIPES, WILLIAMSON AND AYCOCK STUDY AREA CENTERED ON WIPP SITE

FIGURE $\quad 8-7$

LOCATION OF HYDROCARBON RESOURCE STUDY AREAS 


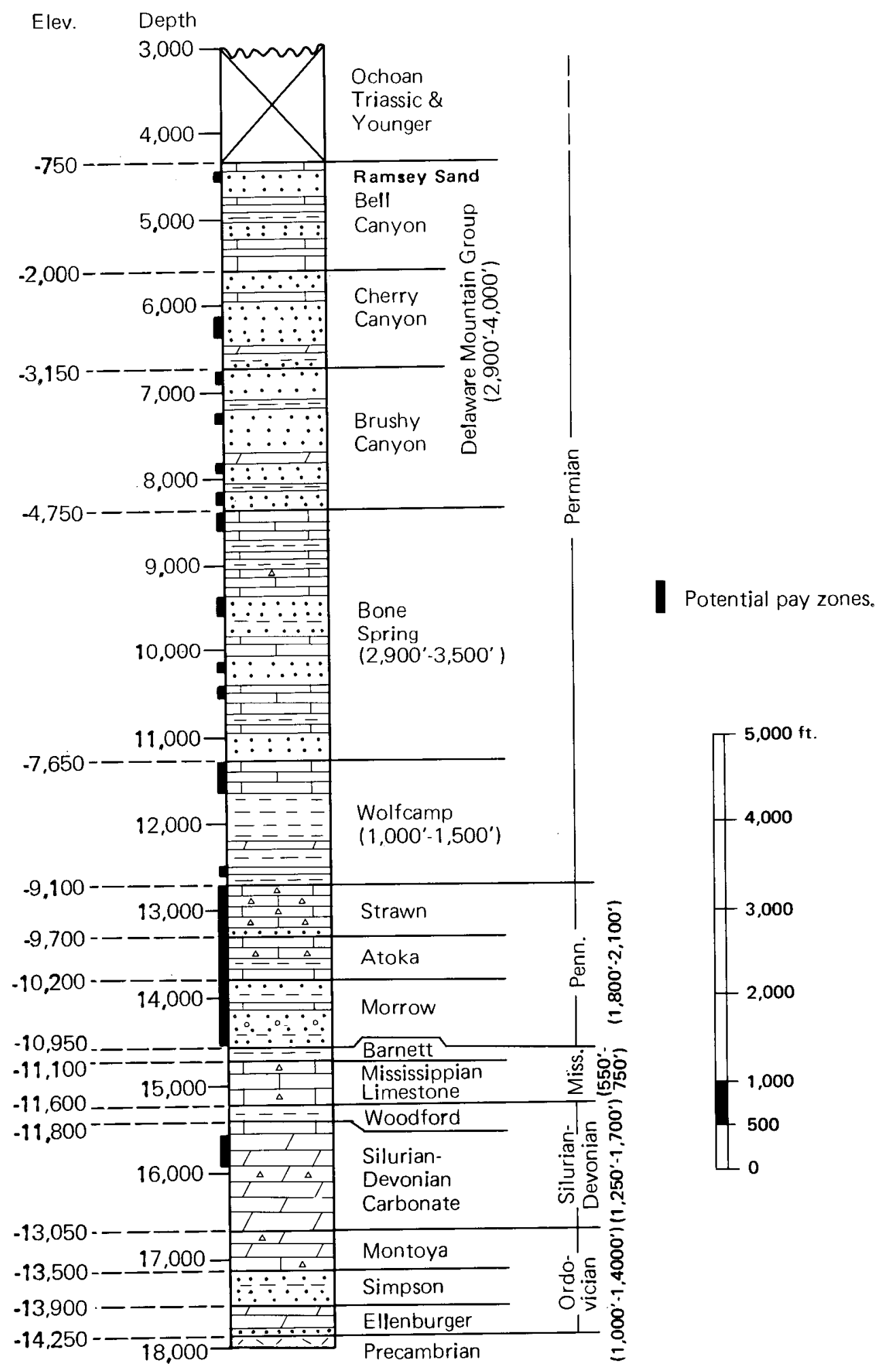

FIGURE 8-8. GEOLOGIC COLUMN AND POTENTIAL HYDROCARBON RESERVOIRS (ADAPTED FROM FOSTER, 1974) 


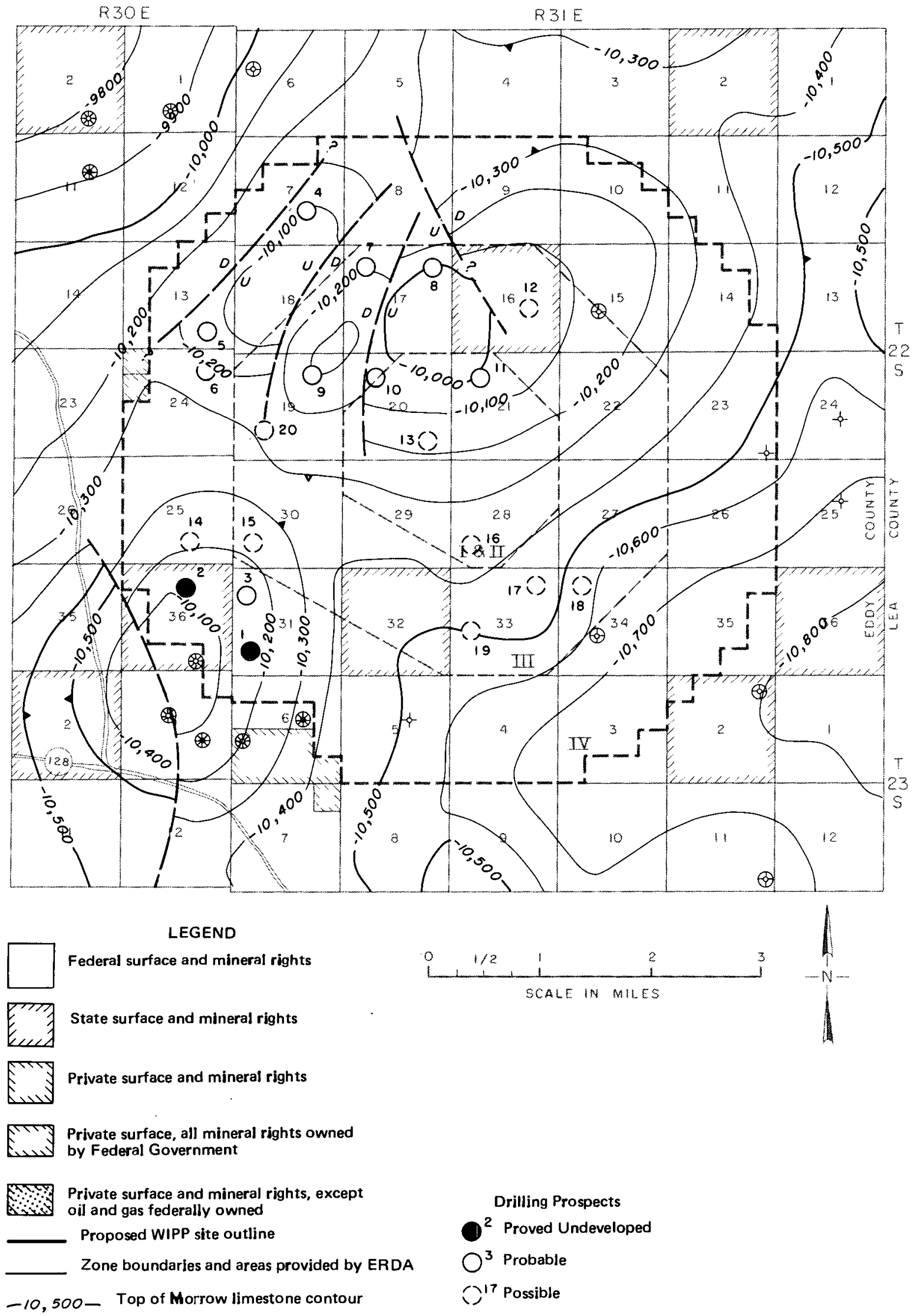

FIGURE 8-9 
TABLE 8-1

TOTAL ESTIMATED RESOURCES AT WIPP SITE

\begin{tabular}{|c|c|c|c|}
\hline Resource & Quantity & Depth & Richness \\
\hline Caliche & $185 \times 10^{6}$ tons & at surface & 2I-698 Insol. \\
\hline Gypsum & $1.3 \times 10^{9}$ tons & $300-1,500$ feet & Pure to mixed \\
\hline Salt & $198 \times 10^{9}$ tons & $500-4,000$ feet & Pure to mixed \\
\hline Sylvite & $88.5 \times 10^{6}$ tons & 1600 feet & $11.8 \mathrm{~K}_{2} \mathrm{O}$ \\
\hline Langbeinite & $264.8 \times 10^{6}$ tons & 1800 feet & $6.10 \mathrm{~K}_{2} \mathrm{O}$ \\
\hline Crude Oil & $37.7 \times 10^{6} \mathrm{bbls}$ & $4,000-20,000$ feet & $31-46^{\circ}$ API \\
\hline Natural Gas & $490 \times 10^{9} \mathrm{cu} . \mathrm{ft}$. & $4,000-20,000$ feet & $1100 \mathrm{BTU} / \mathrm{Cu} \mathrm{ft}$ \\
\hline Distillate & $5.72 \times 10^{6} \mathrm{bbls}$ & $4,000-20,000$ feet & $53-56^{\circ}$ API \\
\hline
\end{tabular}


TABLE 8-2

POTENTIAL ECONOMIC RESOURCES AT WIPP SITE

$\begin{array}{lllll}\text { Resource } & \text { Quantity } & \text { Depth } & \text { Richness } \\ \text { Sylvite } & 27.43 \times 10^{6} \text { tons } & & 1,600 \mathrm{feet} & 13.338 \mathrm{~K}_{2} \mathrm{O} \\ \text { Langbeinite } & 48.46 \times 10^{6} \mathrm{tons} & & 1,800 \mathrm{feet} & 9.118 \mathrm{~K}_{2} \mathrm{O} \\ \text { Natural Gas } & 36.85 \times 10^{9} \mathrm{cu} \mathrm{ft} & & 14,000 \mathrm{feet} & 1,100 \mathrm{BTU} / \mathrm{cu} \mathrm{ft} \\ \text { Distillate } & 0.55 \times 10^{6} \mathrm{bbls} & & 14,000 \mathrm{feet} & 53^{\circ} \mathrm{API}\end{array}$


TABLE 8-3

ECONOMIC RESOURCES WITHIN ZONE I, II AND III AT WIPP SITE

\begin{tabular}{lllll} 
Resource & Quality & Depth & Richness \\
\cline { 3 - 5 } Langbeinite & $10 \times 10^{6}$ tons & $1,800 \mathrm{feet}$ & $10 \% \mathrm{~K}_{2} \mathrm{O}$ \\
Natural Gas & $20 \times 10^{9} \mathrm{cu} \mathrm{ft}$ & $14,000 \mathrm{feet}$ & $1,100 \mathrm{BTU} / \mathrm{cu} \mathrm{ft}$ \\
Distillate & $132 \times 10^{3} \mathrm{bbls}$ & $14,000 \mathrm{feet}$ & $53^{\circ} \mathrm{API}$
\end{tabular}


TABLE $8-4$

ORGANIZATIONS RESPONSIBLE FOR RESOURCE EVALUATION AND

KEY REPORTS CONCERNING RESOURCES

\begin{tabular}{|c|c|c|}
\hline Organization & Responsibility & Reports \\
\hline U.S. Geol Surv. & $\begin{array}{l}\text { Potash Resources as } \\
\text { related to ore grade and } \\
\text { volume }\end{array}$ & $\begin{array}{l}\text { John et al. (1978) } \\
\text { Jones (1978) }\end{array}$ \\
\hline U.S. Bur. of Mines & $\begin{array}{l}\text { Determination as to what } \\
\text { extent the potash resources } \\
\text { reported by U.S.G.S could } \\
\text { be economically mined and } \\
\text { refined under today's technol } \\
\text { and market }\end{array}$ & USBM (1977) \\
\hline N.M. Bur. of Mines & $\begin{array}{l}\text { Definition of resources } \\
\text { and economics for caliche, } \\
\text { salt, gypsum, brine, sulfur } \\
\text { and uranium }\end{array}$ & Siemers et al. (1978) \\
\hline N.M. Bur. of Mines & $\begin{array}{l}\text { Oil and gas resources of a } \\
\text { four township area which } \\
\text { includes the WIPP site }\end{array}$ & Foster (1974) \\
\hline $\begin{array}{l}\text { Sipes, Williams and } \\
\text { Aycock, Inc. }\end{array}$ & $\begin{array}{l}\text { Determination of the } \\
\text { economic viability of } \\
\text { hydrocarbons under the WIPP } \\
\text { site }\end{array}$ & Keesey (1976) \\
\hline $\begin{array}{l}\text { G.J. Long \& Assoc. } \\
\text { Inc., Permain } \\
\text { Exploration Co. }\end{array}$ & $\begin{array}{l}\text { Intrepretation of structure } \\
\text { of Paleozoic sediments } \\
\text { beneath Ochoan evaporites. } \\
\text { These studies were useful } \\
\text { in evaluation of hydrocarbons }\end{array}$ & $\begin{array}{l}\text { Long (1976), } \\
\text { McMillan (1976) }\end{array}$ \\
\hline
\end{tabular}


Table 8-5

POTENTIAL RESOURCES CORRELATED WITH STRATIGRAPHY

\section{Formation}

Mescalero sand

Caliche

Gatuna

Santa Rosa

Sandstone

Dewey Lake

Rustler

Salado
Thickness ( $\mathrm{ft}$ ) General Character

$0-15$

Dune sand, fine grained

$0-5$

$0-375$

Sandstone and siltstone

Sandstone

487

Siltstone and sandstone some claystone

with subordinate dolo-

mite, sandstone, clay-

stone and polyhalite
Uranium

Potential Resources

None

Caliche (in road construction)

Uranium

Uranium
Anhydrite and rock salt Gypsum and salt

Rock salt with subordinate anhydrite, poly-

halite, potassium ores

sandstone, and magnesite

\section{Evaluation}

No resource

Caliche is abundant throughout the area

Conditions apparently were oxidizing during deposition, and no uranium is apt to occur in the vicinity

Conditions apparently were oxidizing during deposition, and no uranium is apt to occur in this vicinity

Minor occurrences have been reported outside the WIPP site area. Gamma ray logs of 36 holes drilled within the site area showed no anomalies.

Abundant throughout the area, no advantage for site resources.

Langbeinite and sylvite occur in commercial

quantities 


\section{Formation}

Castile
Thickness(ft) General Character

1400

Anhydrite and rock salt with subordinate limestone

Sulfur, salt, lithium in brine

Delaw

Bone Spring

3400

Wolfcamp (Hueco)

1480

Strawn

300

Atoka

640

3800

Fine grained sandstone (possibly a siltstone), shale, limestone, and dolomite

Limestone, fine-grained sandstone, and black shale

Limestone, black shale, $0 i 1$ and gas red or green shale, sandstone, and conglomerate

Limestone, oolitic limestone and gray to black shale

Limestone, oolitic limestone and gray to black shale
Potential Resources reservoirs

OiI and associated gas. Most favorable zone is the Ramsey sand

\section{Evaluation}

Salt is abundant throughout the area. Lithium concentration in brine is subeconomic today. Care has been taken to exclude brine reservoirs from site. Conditions and structures for sulfur deposits not known to exist at site.

Reservoirs may exist, but small in comparison with the Morrow Formation

Reservoirs may exist, but are small in comparison to the Morrow Formation

Reservoirs may exist, but are small in comparison to the Morrow Formation

$0 i l$ and associated gas

Natural gas

Natural
Reservoirs may exist, but are small in comparison to the Morrow Formation

Commercial gas is being produced from near site. Atoka reservoirs are restricted in size, therefore, small

likelihood of existence under the site

Commercial quantities of gas probably exist

Morrow

1300
Limestone, oolitic
limestone, gray to
black shale, and

sand stone 
Table 8-5 (Continued)

Formation

Mississippian

Siluro

Ordovician

Precambrian
Potential Resources

None

Black, angillaceous shale, black calcareous

shale or shaly lime-

stone, some sandstone

2100

Limestone, dolomite,

chert, shale, black

shale with rounded

quartz grain inclusions,

and small amounts of

sandstone

Not tested with in the

WIPP site locality.

Regional inference is

that it consists of

acidic volcanics or

metasediments
Oil and gas. Most favorable

zone is beneath the Woodford shale

Sulfide deposits

Considered too deep to exploit.

\section{Evaluation}

None likely

Oil and gas may be present

in anticlinal situations

References: Siemers et al., 1978; Foster, 1974. 
TABLE 8-6

STANDARD CONDITIONS FOR POTASH RESOURCES

\begin{tabular}{|c|c|c|c|}
\hline Class & Type ore & $8 \mathrm{~K}_{2} \mathrm{O}$ & Thickness, ft \\
\hline \multirow[t]{2}{*}{ Low } & Langbeinite & 3 & 4 \\
\hline & Sylvite & 8 & 4 \\
\hline \multirow[t]{2}{*}{ Lease } & Langbeinite & 4 & 4 \\
\hline & Sylvite & 10 & 4 \\
\hline \multirow[t]{2}{*}{$\mathrm{High}$} & Langbeinite & 8 & 4 \\
\hline & Sylvite & 14 & 4 \\
\hline
\end{tabular}

Reference: John et al, 1978. 
Table 8-7

POTASH RESOURCES, TONS $\times 10^{6}$

I. Sylvite Ores

Ore Zone

10
9
8

Total

Ore zone

10
5
4
3
2

Total

Ore Zone

10
9
8
5
4
3
2

Total
Low Grade

\begin{tabular}{|c|c|c|}
\hline$I+I I+I I I$ & IV & Total \\
\hline 30.4 & $\overline{44.4}$ & 74.8 \\
\hline 3.7 & 6.6 & 10.3 \\
\hline$\frac{5.0}{39.1}$ & $\frac{43.1}{94.1}$ & $\frac{48.1}{133.2}$ \\
\hline
\end{tabular}

Low Grade

\begin{tabular}{|c|c|c|}
\hline$I+I I+I I I$ & IV & Total \\
\hline 25.0 & $\overline{30.6}$ & 55.6 \\
\hline 11.6 & 14.6 & 26.2 \\
\hline 46.5 & 114.5 & 161.0 \\
\hline 14.6 & 19.9 & 34.5 \\
\hline 24.2 & 49.5 & 73.7 \\
\hline 121.9 & 229.1 & 351.0 \\
\hline
\end{tabular}

Low Grade

\begin{tabular}{rrr}
\hline I+II+III & \multicolumn{1}{c}{ IV } & $\frac{\text { Total }}{75.4}$ \\
\cline { 1 - 2 } 3.7 & 6.6 & 130.4 \\
5.0 & 43.1 & 48.3 \\
11.6 & 14.6 & 26.2 \\
46.5 & 114.5 & 161.0 \\
14.6 & 19.9 & 34.5 \\
$\frac{24.2}{161.0}$ & $\frac{49.5}{323.2}$ & $\frac{73.7}{484.2}$
\end{tabular}

Lease Grade

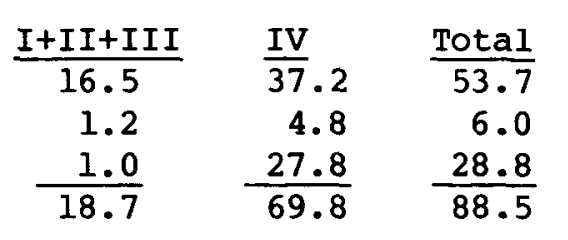

II. Langbeinite ores

\begin{tabular}{|c|c|c|}
\hline$I+I I+I I I$ & IV & Total \\
\hline 24.6 & $\overline{24.8}$ & 49.4 \\
\hline 10.9 & 13.3 & 24.2 \\
\hline 24.0 & 91.4 & 115.4 \\
\hline 9.6 & 16.0 & 25.6 \\
\hline 18.7 & 31.5 & 50.2 \\
\hline 87.8 & $\overline{177.0}$ & $\overline{264.8}$ \\
\hline
\end{tabular}

Lease Grade

\begin{tabular}{|c|c|c|}
\hline$I+I I+I I I$ & IV & Total \\
\hline 41.1 & $\overline{62} .0$ & 103.1 \\
\hline 1.2 & 4.8 & 6.0 \\
\hline 1.0 & 27.8 & 28.8 \\
\hline 10.9 & 13.3 & 24.2 \\
\hline 24.0 & 91.4 & 115.4 \\
\hline 9.6 & 16.0 & 25.6 \\
\hline 18.7 & 31.5 & 50.2 \\
\hline 106.5 & 246.8 & 353.3 \\
\hline
\end{tabular}

High Grade

\begin{tabular}{|c|c|c|}
\hline$I+I I+I I I$ & IV & Total \\
\hline 9.8 & $2 \overline{8.9}$ & 38.7 \\
\hline- & 0.7 & 0.7 \\
\hline- & 13.7 & 13.7 \\
\hline 9.8 & $\overline{43.3}$ & 53.1 \\
\hline
\end{tabular}

High Grade

\begin{tabular}{ccc} 
I+II+III & IV & Total \\
\hline 9.7 & 0.9 & 8.8 \\
-- & 1.6 & 1.6 \\
14.6 & 44.4 & 59.0 \\
-- & -- & -- \\
$\frac{1.9}{24.4}$ & $\frac{7.9}{54.8}$ & $\frac{9.8}{79.2}$
\end{tabular}

High Grade

\begin{tabular}{|c|c|c|}
\hline$I+I I+I I I$ & IV & Total \\
\hline 17.7 & $2 \overline{9.8}$ & 47.5 \\
\hline - & 0.7 & 0.7 \\
\hline -- & 13.7 & 13.7 \\
\hline -- & 1.6 & 1.6 \\
\hline 14.6 & 44.4 & 59.0 \\
\hline- & -- & -1 \\
\hline$\frac{1.9}{34.2}$ & $\frac{7.9}{98.1}$ & $\frac{9.8}{132.3}$ \\
\hline
\end{tabular}

Reference: John et al., 1978. 
Table 8-8

ECONOMIC POTASH RESOURCES, TONS $\times 10^{6}$

\begin{tabular}{|c|c|c|c|c|c|}
\hline $\begin{array}{l}\text { Mining } \\
\text { Unit } \\
\end{array}$ & Products & $\begin{array}{l}\text { Recoverable ore } \\
\text { in } \\
\text { Mining Unit } \\
\end{array}$ & $\begin{array}{c}\text { Recoverable ore } \\
\text { in } \\
\text { WIPP Site } \\
\end{array}$ & $\begin{array}{c}\text { Percent in } \\
\text { zones I,II,III }\end{array}$ & $\begin{array}{c}\text { Price }{ }^{1} \text { that Provides } \\
\text { a } 15 \text { Percent } \\
\text { ROR }^{2}, \$ \\
\end{array}$ \\
\hline$B-1$ & $\begin{array}{l}\text { Langbeinite } \\
\text { Sulphate }\end{array}$ & 79.78 & 48.46 & $\begin{array}{l}27.5 \\
27.5\end{array}$ & $\begin{array}{l}35.00 \\
88.50\end{array}$ \\
\hline$A-1$ & Muriate & 57.60 & 27.41 & 3.2 & 52.04 \\
\hline $\mathrm{D}-2$ & $\begin{array}{l}\text { Langbeinite } \\
\text { Sulphate }\end{array}$ & 87.93 & 23.57 & $\begin{array}{l}0.7 \\
0.7\end{array}$ & $\begin{array}{l}36.51 \\
92.31\end{array}$ \\
\hline$A-2$ & Muriate & 98.32 & 51.80 & 7.6 & 61.73 \\
\hline$C-2$ & Muriate & 57.19 & 36.49 & 54.2 & 61.74 \\
\hline$D-3$ & $\begin{array}{l}\text { Langbeinite } \\
\text { Sulphate }\end{array}$ & 140.27 & 42.45 & $\begin{array}{l}23.5 \\
23.5\end{array}$ & $\begin{array}{r}42.26 \\
106.86\end{array}$ \\
\hline$c-3$ & Muriate & 70.64 & 52.87 & 57.5 & 67.52 \\
\hline$A-3$ & Muriate & 135.02 & 73.77 & 14.9 & 70.28 \\
\hline $\begin{array}{l}{ }^{1} \text { Market } \\
\text { ton of } \\
{ }^{2} \text { Rate o }\end{array}$ & $\begin{array}{l}\text { ce assuming } \\
\text { luct, f.o.b. } \\
\text { turn }\end{array}$ & $\begin{array}{l}\text { increase in } p_{1} \\
\text { rlsbad, New Me }\end{array}$ & $\begin{array}{l}\text { tion costs. Es } \\
\text {, used for eval }\end{array}$ & $\begin{array}{l}\text { ed } w \\
\text { on. }\end{array}$ & dal price per \\
\hline
\end{tabular}




\section{Table 8-9}

SUMMARY OF POTASH RESOURCES, $10^{6}$ TONS

In Place Resources
(USGS Study) $\quad \begin{gathered}\text { Mineable Today } \\ \text { (USBM Study) }\end{gathered}$

Lease Standard

High Standard

\begin{tabular}{|c|c|c|c|c|c|c|}
\hline & Langbeinite & Sylvite & Langbeinite & Sylvite & Langbeinite & Sylvite \\
\hline Total withdrawal & 264.8 & 88.5 & 79.2 & 53.1 & 48.46 & $27.41 *$ \\
\hline Mining Permitted & 87.8 & 18.7 & 24.4 & 9.8 & 13.35 & 0.9 \\
\hline
\end{tabular}

in Zone IV

*The USBM does not consider the sylvite contained in Unit A-1 to be mineable under today's market. To do so would require the price for muriate to be $\$ 52.04$ per ton, or the investor must be willing to accept a rate of return less than $15 \%$. 
Table $8-10$

POTENTIAL HYDROCARBON RESOURCES

EXPECTED IN VARIOUS FORMATIONS WITHIN THE DELAWARE BASIN

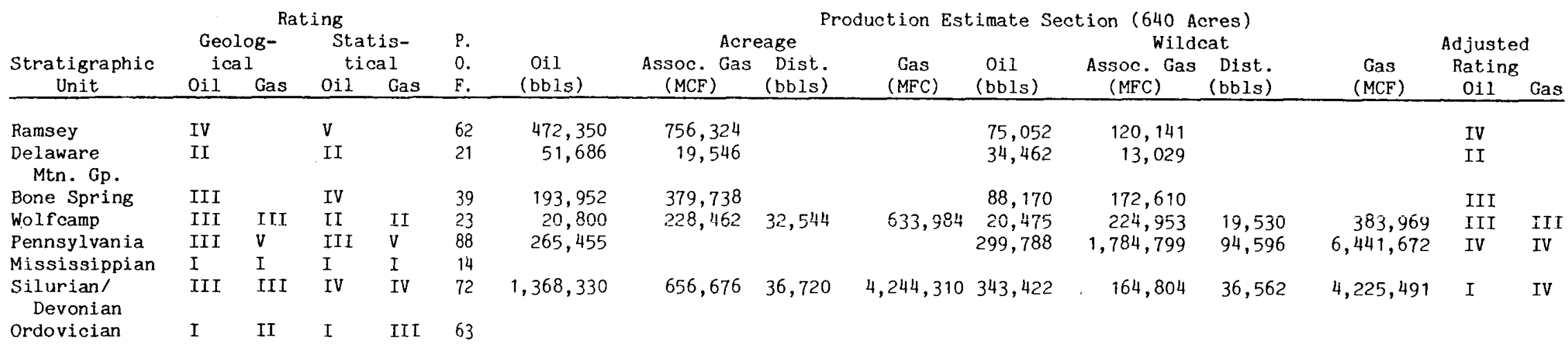

Table 8-10 (Continued)

Adjusted Production Estimate Section (640 Acres)

\section{Ramsey \\ Delaware \\ Mtn. Gp. \\ Bone Spring \\ Wolf camp \\ Pennsylvanian \\ Mississippian \\ Silurian \\ Devonian \\ Ordovician}

$\begin{aligned} & \text { Ratings } \\ \text { I: } & \text { Very low } \\ \text { II: } & \text { Low } \\ \text { III: } & \text { Moderate } \\ \text { IV: } & \text { High } \\ \text { V: } & \text { Very High }\end{aligned}$

Calculated $\%$

25
50
75
100
125

\begin{tabular}{|c|c|c|c|c|c|c|c|}
\hline $\begin{array}{r}472,350 \\
25,843\end{array}$ & $\begin{array}{r}756,324 \\
9,773\end{array}$ & & & $\begin{array}{l}75,052 \\
17,231\end{array}$ & $\begin{array}{r}120,141 \\
6,515\end{array}$ & & \\
\hline $\begin{array}{r}145,464 \\
15,600 \\
265,455\end{array}$ & $\begin{array}{r}284,804 \\
171,347 \\
1,580,826\end{array}$ & $\begin{array}{r}24,408 \\
132,440\end{array}$ & $\begin{array}{r}475,488 \\
8,857,200\end{array}$ & $\begin{array}{r}66,128 \\
15,356 \\
299,788\end{array}$ & $\begin{array}{r}129,458 \\
168,715 \\
1,784,799\end{array}$ & $\begin{array}{r}14,648 \\
118,245\end{array}$ & $\begin{array}{r}287,979 \\
8,052,090\end{array}$ \\
\hline 342,083 & 164,169 & 36,720 & $4,244,310$ & 85,856 & 41,201 & 36,562 & $4,225,495$ \\
\hline 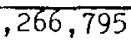 & $\overline{2,967,243}$ & $\overline{193,568}$ & $\overline{13,576,998}$ & $\overline{559,411}$ & $\overline{2,250,829}$ & $\overline{169,455}$ & $\overline{12,565,558}$ \\
\hline
\end{tabular}

Taken from: R. W. Foster, 1974 
Table 8-11

IN PLACE HYDROCARBON RESOURCES AT WIPP SITE*

Formation

Ramsey

Delaware

Group

Bone Spring

Wolf camp

Pennsylvanian

Mississippian

Silurian/ Devonian

Ordovician

Total

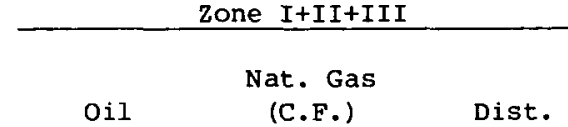

(bbls)
Nat. Gas
(C.F.)

Dist.

(bbls)
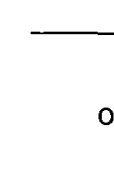

zone IV

\section{Nat. Gas}

$$
\begin{gathered}
\text { Nat. Gas } \\
\text { (C.F.) }
\end{gathered}
$$

$$
\text { (bbls) }
$$

\begin{abstract}
(x $\left.10^{9}\right)$
\end{abstract}
$8.0 \times 10^{6}$

12.8

$4.4 \times 10^{5}$

0.2

$3.3 \times 10^{5}$

$1.9 \times 10^{6}$

0.1

$$
3.6
$$

$2.0 \times 10^{5}$

$3.4 \times 10^{6}$

$$
8.2
$$

132.9

$$
4.4 \times 10^{6}
$$

$$
56.1
$$

$4.7 \times 10^{5}$

$3.1 \times 10^{5}$

$2.5 \times 10^{6}$

4.8

$2.6 \times 10^{5}$

10.9

$4.5 \times 10^{6}$

176.3

$4.0 \times 10^{5}$

$1.7 \times 10^{6}$

$5.8 \times 10^{6}$

74.5

$6.3 \times 10^{5}$

$2.2 \times 10^{6}$

$16.2 \times 10^{6}$

210.5

$2.5 \times 10^{6}$

$21.5 \times 10^{6}$

279.5

$3.2 \times 10^{6}$

$37.7 \times 10^{6}$

490.0

$5.7 \times 10^{6}$

* Based on Adjusted Production Estimate per Section (640 acres), Acreage method, Table 8-10. WIPP site contains 29.6 square miles or sections. 
TABLE 8-12

ESTIMATE OF ECONOMIC HYDROCARBON RESOURCES AT WIPP SITE

\begin{tabular}{|c|c|c|c|}
\hline \multirow[b]{2}{*}{$\begin{array}{c}\text { Well } \\
\text { Number } \\
\end{array}$} & \multicolumn{3}{|c|}{$\begin{array}{c}\text { Natural Gas (BCF) } \\
\text { Zone I, II, III }\end{array}$} \\
\hline & Proven & Probable & Possible \\
\hline 1 & -- & -- & - \\
\hline 2 & --- & --- & -- \\
\hline 3 & -- & -- & -- \\
\hline 4 & -- & -- & -- \\
\hline 5 & -- & --- & -- \\
\hline 6 & --- & --- & -- \\
\hline 7 & -- & 2.09 & --- \\
\hline 8 & -- & 2.09 & -- \\
\hline 9 & -- & 2.09. & -- \\
\hline 10 & -- & 2.09 & -- \\
\hline 11 & -- & 2.09 & --- \\
\hline 12 & -- & -- & 1.67 \\
\hline 13 & -- & -- & 1.67 \\
\hline 14 & $\cdots$ & --- & -- \\
\hline 15 & -- & -- & 1.33 \\
\hline 16 & -- & -- & 1.67 \\
\hline 17 & - & -- & 1.67 \\
\hline 18 & -- & -- & 1.67 \\
\hline 19 & -- & -- & 1.67 \\
\hline \multirow[t]{3}{*}{20} & -- & -- & 1.67 \\
\hline & -- & 10.45 & 13.02 \\
\hline & & Total & 23.47 \\
\hline
\end{tabular}

Plus Distillate 350,900 BBLS
Natural Gas (BCF)

Zone IV

Proven Probable Possible

\begin{tabular}{|c|c|c|}
\hline 2.07 & - & -- \\
\hline 2.07 & --- & --- \\
\hline--- & 1.64 & -- \\
\hline-- & 2.09 & -- \\
\hline-- & 2.09 & -- \\
\hline-- & 2.09 & -- \\
\hline-- & -- & -- \\
\hline--- & -- & -- \\
\hline-- & -- & -- \\
\hline$\cdots$ & -- & $-\infty$ \\
\hline-- & -- & $\cdots$ \\
\hline- & - & -- \\
\hline- & -- & 132 \\
\hline --- & -- & $\begin{array}{l}1.33 \\
---\end{array}$ \\
\hline-- & --- & -- \\
\hline-- & -- & -- \\
\hline--- & --- & -- \\
\hline$-\infty$ & --- & -- \\
\hline--- & -- & -- \\
\hline \multirow[t]{2}{*}{4.14} & 7.91 & 1.33 \\
\hline & Total & 13.38 \\
\hline
\end{tabular}

Plus Distillate 200,000 BBLS
Natural GAS (BCF)

Total

Proven Probable Possible

\begin{tabular}{|c|c|c|}
\hline 2.07 & -- & -- \\
\hline 2.07 & -- & $\cdots$ \\
\hline-- & 1.64 & -- \\
\hline--- & 2.09 & -- \\
\hline--- & 2.09 & -- \\
\hline--- & 2.09 & -- \\
\hline-- & 2.09 & --- \\
\hline--- & 2.09 & -- \\
\hline--- & 2.09 & -- \\
\hline--- & 2.09 & -- \\
\hline--- & 2.09 & -- \\
\hline--- & -- & 1.67 \\
\hline-- & -- & 1.67 \\
\hline --- & -- & 1.33 \\
\hline--- & -- & 1.33 \\
\hline--- & -- & 1.67 \\
\hline-- & -- & 1.67 \\
\hline--- & -- & 1.67 \\
\hline-- & -- & 1.67 \\
\hline-- & --- & 1.67 \\
\hline \multirow[t]{2}{*}{4.14} & 18.36 & 14.35 \\
\hline & Total & 36.85 \\
\hline
\end{tabular}

Plus Distillate 550,960 BBLS

Reference: Keesey, 1976. 
TABLE 8-13

SUMMARY OF IN-PLACE AND ECONOMIC HYDROCARBON RESOURCES AT THE WIPP

IN PLACE RESOURCES

(NMBM STUDY)

Zone I, II, III Zone IV
ECONOMIC RESOURCES

(SW\&A STUDY)

Crude Oil
$10^{6}$ BBLS
Natural Gas
$10^{9}$ CUFT
Distillate
$10^{6}$ BBLS

16.2

21.5

210.5

279.5

490

3.2

5.7

23.47

13.38

36.85

2.5

0.35

0.20

0.55 


\section{GCR Chapter 9}

SPECIAL STUDIES

\subsection{INTRODUCTION}

The special studies presented in Chapter 9 cover issues of particular interest because the site is being characterized for radioactive waste isolation (the WIPP). The first special study presented is that of determining the thermophysical behavior of Southeastern New Mexico (SENM) rocks for mine design and the effects of heat-producing wastes, if placed in the WIPP. The second special study is to determine the site-specific sorptive capacities of SENM rocks for radionuclides flowing with SENM groundwaters. Characterization of the sorptive capacities of SENM rocks is required for safety assessment analysis of hypothetical failure events, not for site selection. Both of these studies are by no means complete and are continuing. The information presented here is an indication of the status of these studies in midyear 1978. Tabulations of test data are left to the references and future reports on specific subjects.

\subsection{THERMOPHYSICAL PROPERTIES}

\subsubsection{Introduction}

The thermophysical properties of New Mexico rock salt are being investigated to support the structural mine design and to evaluate the overall stability of bedded salt for the WIPP. A goal of this program is to develop constitutive relations which can be used in design and long-term stability calculations, commonly by finite element analyses (Dawson and Tillerson, 1977). Specific concerns are the stability of the facility during its life, the influence of ground motions on waste retrieval capabilities, and the effect of waste emplacement on the long term containment potential. The program was initiated in 1975.

Rock salts are weak, anelastic geological materials. They exhibit nonlinear response under practically all loading conditions at temperatures and pressures normally encountered in mining. Since salt 
can experience large strains prior to failure, openings even at very shallow depths have been known to completely close and heal (Baar, 1977).

In long-established active mining districts, careful in situ observations and measurements have provided a basis for making reasonably reliable predictions of room deformation and failure (Baar, 1977). Some of this knowledge is applicable to the WIPP, although it cannot be directly applied to the WIPP because the behavior of rock salt is dependent upon the site, facility design, temperature and time involved. The rock mechanics program considers the particular problems posed by the longevity of the WIPP and by the unusual combination of mechanical and thermal loading anticipated in the repository.

Laboratory experiments have been severely criticized by some for not realistically representing in situ conditions, (Baar, 1977). However, laboratory experiments on rock salt are a useful step in material characterization, to establish limits of behavior. Ultimately, laboratory and in-situ test data coupled with modeling should lead to representative descriptions of material and structural behavior. As the WIPP is developed, in situ monitoring should enhance the validity of laboratory and modeling results.

The thermophysical behavior of rock salt has been modeled through various approaches, (e.g., Bradshaw and McClain, 1975; Fossum, 1977; Langer, 1967; Mraz, 1978; St. John, 1978; Serata, 1966, 1968, 1970; Serata and Cundey, 1978; Thompson and Ripperger, 1964; Thoms et al., 1973; Wahi et al., 1978). A widely accepted model which can translate laboratory data into a prediction of in situ salt behavior has not been developed.

Three broad areas were studied to identify the relative and site specific importance of various southeast New Mexico rock salt thermophysical properties. These three areas of study consist of: 1) petrography relevant to physical and mechanical properties, 2) general physical properties (density, moisture content, resistivity, etc.), and 3) thermal-mechanical properties (quasi-static and creep parameters). 
Petrographic studies were conducted on mineralogically characterized core from AEC 7, AEC 8 and ERDA 9 to investigate structural petrographic changes between natural and experimentally-deformed samples (Callender \& Ingwell, 1977). Identification of failure mechanisms by petrographic analyses will assist in selecting models to describe rock behavior.

Physical properties being measured for selected core include density, moisture content, porosity, permeability, electrical resisitivity, ultrasonic velocity, and thermal conductivity. Additional gas and brine permeability measurements are in progress at Sandia both on experimentally undeformed and deformed samples.

The following mechanical properties are being measured: uniaxial compressive strength, indirect (Brazilian) tensile strength, stress-strain behavior and ultimate stress in quasi-static triaxial compression, elastic moduli, principal strain ratios, elastic limit ("yield" stress), and creep rates. Additional tests address the effects of specimen machining, specimen aging due to stress relief during and after core retrieval, and specimen size, all of which could limit the field applicability of laboratory-determined results. The influence of sample size may be partially inferred from published data (e.g., Uhlenbecker, 1968; Dreyer, 1972; Szeki, 1978).

The data base for physical and thermal properties determined from core from the WIPP study area is still being compiled, and tests are continuing. Moreover, most of the results obtained to date pertain to rock salt alone, as opposed to other members of the stratigraphic column above and below the proposed repository horizons.

\subsubsection{Petrography}

Approximately 35 samples of experimentally undeformed and deformed salt were macroscopically and microscopically examined for mineralogy, fabric, and induced structure by J.F. Callender and T. Ingwell of the University of New Mexico (1977). Mineralogy of rock salt from southeast New Mexico has been described in detail in Chapter 7 . 
Between the depths of 1,000 and 2,000 feet, the samples are predominantly halite (NaCl) (range 47-98 percent) with lesser amounts of anhydrite $\left(\mathrm{CaSO}_{4}\right)$ (range 0-15 percent), polyhalite $\left(\mathrm{K}_{2} \mathrm{MgCa}_{2}\left(\mathrm{SO}_{4}\right)_{4} \cdot 2 \mathrm{H}_{2} \mathrm{O}\right)$ (range 0-18 percent), and clay and silt (range 0-44 percent). Halite is usually present in the core, except in samples from anhydrite layers and polyhalite seams. Anhydrite, clay and silt are generally present, while polyhalite occurs less commonly. Detailed stratigraphy of the WIPP study area is presented in the ERDA 9 corehole lithologic log, Figure 4.3.3.b.

Fabric In general, the undeformed rock salt specimens do not show well-developed linear or planar fabrics, aside from uncommonly-observed bedding. Locally, however, halite crystals show a faint to strong elongation, probably due to readjustment to local stresses. Certain fabric features within the cores may presumably have important local effects on salt deformation. These features include bubble trains, hopper crystals, cleavage, glide planes, grain boundaries, and clay zones (Callender and Ingwell, 1977).

Bubble trains are commonly aligned along cleaveage traces or grain boundaries in halite. The bubbles generally contain fluid, although some may also be gas or partially solid-filled (see section 7.6). Fracturing in experimentally deformed cores locally follows the bubble trains, and they are likely the site of small-scale structural weaknesses within halite. Once such fractures heal, the zones they followed become stronger than before (section 7.6) Hopper crystals, generally filled with clay, also tend to grow and be aligned along halite cleavage planes. In a number of samples, small-scale fracturing, induced by sample preparation or by disturbance during the coring operation in the field, is associated with zones of hopper crystals.

Cleavage, and fracture related to cleavage, is observed in halite. In euhedral, generally recrystallized, halite, the cleavage direction and grain boundary are coincident. In these cases, deformation along trends parallel to grain boundaries should certainly be facilitated. Similar relations, though less common, exist in subhedral halite. Translation 
glide in halite is an important dislocation mechanism and has been described in the literature (c.f., Buerge, 1930; Clabaugh, 1962). Two glide planes, (110) and (001), have been recognized in both undeformed and deformed salt.

In summary, a local concentration of discrete fabric elements (e.g., hopper crystals, bubble trains) may be as statistically significant as planar or linear elements (such as bedding, cleavage alignment, or elongation) for the structural evaluation of the core, and local zones in deformed salt may play an important role in establishing fracture patterns.

Fracture. Analyses of fracture patterns in salt to date have been complicated by induced fracture during sample preparation and the field coring procedures used to obtain samples. The recognition of these induced fractures is generally fairly straightforward; however, the persistent question of local induced fracture arises during detailed study, and is a problem which cannot be easily resolved. Fortunately for the petrographer, many fractures are filled with clay, anhydrite, and polyhalite; these filled fractures give some insight into patterns in material before laboratory testing since they are clearly not a result of sample handling.

In general, fracture in undeformed salt core is relatively minor and is commonly associated with cleavage or grain boundary adjustments. It appears that fractures may have remained open at some stages of diagenesis for a sufficiently long period of time to be filled by sulfate or other solutions. A few unusual fracture geometries have been noted: en echelon fractures, generally with their major trend parallel to cleavage; circular fractures commonly around hopper crystals; fracture refraction across grain boundaries; jog and kink fractures; and fracture and local extension along glide planes. The number of fractures observed in the laboratory resulting from relief of the in situ confining stresses is unknown. Clay, anhydrite, and polyhalite have apparently flowed in some undeformed samples. Perhaps the best evidence for this statement is 
local well-defined linear fabric in polyhalite and anhydrite, and the inclusion of halite in clay along grain boundaries.

In samples severely deformed by laboratory testing, fracture patterns are easily observed. In one sample a well-defined zone of cleavage and glide-plane fracture developed at about $40^{\circ}$ to the compressional axis. Apparently, a network of interconnected fractures has been established in this zone which respects neither grain boundaries nor grain size. In contrast, another sample suggests that local fabric elements, particularly clay-rich zones, may affect fracture geometry and that planar fracture fabrics may not be as well-developed in clay-rich samples.

Fracturing of halite can be generated in the laboratory at relatively low confining pressures $(\leq 1500 \mathrm{psi}$ ) and moderately high strains (5 to 12 percent); this fracturing induces a fracture porosity in the material. At higher confining pressures, rock salt displays ductile behavior and it is difficult to induce fracturing. The position of the fracture pattern observed in the laboratory is related to both the stress direction and the local fabric elements. In addition, the crystal lattice of halite permits, through defects and crystallographic constraints (c.f., Hirth and Lothe, 1968), a complex dislocation system to develop.

\subsubsection{Physical Properties}

Measurements of physical properties of rock salt pertinent to the design of the WIPP have been conducted by several investigators. Some representative data are summarized in Table 9.2.3-1.

Density and Resistivity. Measurements were made on full dimension (4-1/2 inch diameter) core. The density determinations were performed following conventional laboratory procedures for determing bulk rock densities utilizing the buoyancy method. Commercial grade kerosene was used for buoyancy measurements. Direct current resistivity determinations were made using current densities of less than 0.20 microamperes per square centimeter (Elliot, 1976), and by downhole geophysical measurements (Griswold, 1977). 
Volatile Mass Loss. Total volatiles, including water, were obtained by heating samples of salado salt from the proposed repository levels to $300^{\circ} \mathrm{C}$ in several stages. Static weight loss determinations were made at each stage of heating (Kopp \& Combs, 1975) and were reported in section 7.5.3.. In addition, thermogravimetric analyses were made by suspending powdered samples from a microbalance while dry nitrogen flowed over the sample. The samples were heated at $5^{\circ} \mathrm{C} /$ minute until the temperature reached $500^{\circ} \mathrm{C}$ and held there until gas evolution had ceased (see section 7.5.2 for details and data).

Permeability. Gas permeability of SENM rock salt has been measured for pressures up to $5000 \mathrm{psi}$ and at room temperature to determine the tightness of the host rock to any gases evolved in the WIPP. The data developed by Sutherland (1978), are for argon gas at confining pressures to 2000 psi. A plot of permeability test results is shown on Figure 9.2.3-1. Sutherland's data demonstrate the influence of confining pressure (crack closure and healing) on permeability. Preloading of samples to near lithostatic confining pressures is required to obtain reproducible data in laboratory experiments. Other gases (air, nitrogen, argon) were measured by Core Labs (1977), Terra Tek (1978), and Shelby (1978). The Core Labs' tests followed API standards, however, they did not allow for crack healing. Shelby tested single crystal NaCl. The results of these measurements illustrate the following:

(1) There is no correlation between measured permeabilities for as-received (stress-relieved) core samples;

(2) Samples behave as if they are "healing" when subjected to a confining pressure on the order of their original in situ pressure (illustrated on Figure 9.2.3-1).

(3) After an initial "healing" or "consolidation" period, the polycrystalline samples tested by sutherland (1978) and Terra Tek (1978) have measured permeabilities of less than 0.05 microdarcys (the limit of resolution of their permeability measurement systems); 
(4)

There is little or no gas flow through the salt single crystals (less than 1 picodarcy) in the single crystal test apparatus of Shelby (1978). Therefore, the preferred flow channels through a core sample are believed to be along crystalline boundaries.

Thermal Conductivity. The thermal conductivity of several rock salt samples from core of AEC 8 were determined by a longitudinal heat flow apparatus. This apparatus was designed specifically for use with geologic core sections. Constant power is supplied to a heater at one end of the specimen until thermal equilibrium is established. The heat flux transducer and thermocouple outputs are then recorded allowing the thermal conductivity to be calculated from the readings (Acton, 1977). A plot of test results is shown on Figure 9.2.3-2.

Sonic Pulse Velocity. Measurements of compressional wave velocity were made both on laboratory samples (Kent and Wawersik, 1976) and by down hole geophysical methods (Griswold, 1977). Laboratory measurements were made both parallel and perpendicular to the core axis. No signficant variations (less than $0.02 \mathrm{~km} / \mathrm{sec}$ ) were observed between the axial and transverse values of twenty measurements. The laboratory data were within 158 of the downhole geophysical values.

Summary of Data. Some physical properties are summarized in Table 9.2.3-1. In addition, permeability data are plotted on Figure 9.2.3-1 and thermal properties are shown in Figure 9.2.3-2. The experimental data are presented in the referenced documents.

\subsubsection{Thermomechanical Properties}

Introduction. It is the goal of laboratory stress-strain tests to develop constitutive relations which can be used in structural calculations. As the program progresses, a combination of finite element calculations using data obtained in the laboratory, empirical mine design methods and in-situ validation studies will serve to evaluate, in detail, certain aspects of the final WIPP design. 
To achieve a valid and practical description of the behavior of rock salt from experiments in the laboratory, several programs are being conducted. These are: (1) Measurement of the mechanical response of SENM rock salts and other nearby rocks (e.g., anhydrite) over the domain of stresses and temperatures which may be expected in the WIPP; (2) Development of general models based on test results that are applicable to differing stress deformation and/or temperature histories; (3) Determination of mechanisms governing salt response in sufficient detail to allow the extrapolation of laboratory measurement in time; and finally (4) Establishment of relationships between laboratory samples of rock salt and salt masses in-situ.

This report summarizes the first series of laboratory tests, consisting primarily of short term "quasi-static" tests. These tests served to compare the response of WIPP salt with rock salts from other horizons and locations and to effectively scope the rock behavior for planning the long term creep tests. It is recognized that short term test behavior may be only partially indicative of long term behavior. Not all of the data developed is presented, particularly where detailed information has been published elsewhere. Instead, test values have been selected which are felt to best represent the behavior of the WIPP rock salt. Too few repetitive tests have been performed thus far to determine statistical significance of the data. This is due to the long times required to perform tests and the limited amount of rock salt core available to this test program from specific horizons of interest to WIPP.

A deliberate attempt was made to encompass a broad range of parameter variations including confining pressure and principal stress difference, i.e., mean stress and deviator stress, as well as temperature, time, loading rate, loading path, handling history, and specimen size. These variations covered a wider spectrum than might ordinarily be required to support the design of conventional mines or solution cavities. The approach is predicated on the unusual combination of anticipated mechanical and thermal loadings associated with WIPP. The experimental program plan also tried to address specific questions, for example, 
concerning the effect of loading path, which were raised by critics of conventional quasi-static experiments in the past (Baar, 1977).

Testing was primarily conducted on rock salt samples from three horizons in the Salado Formation. The two horizons at 2,100+ feet and 2,600 to 2,700 feet represent the relatively pure halite from the proposed contact-handling $(\mathrm{CH})$ and remote-handling ( $\mathrm{RH})$ levels, while the third horizon at 1,900 feet was chosen for study because it is clay rich salt.

The testing program through the summer of 1978 was generally divided into two segments, quasi-static tests and creep tests. Quasi-static properties were generated over a range of loading rates from $d / d t$ $\left(\sigma_{1}-\sigma_{3}\right)$ of 150 to $215 \mathrm{psi} / \mathrm{min}$ (RE/SPEC Inc. data, Gnirk et al., 1973, Hansen and Mellegard, 1977) to loading rates of 30 to $60 \mathrm{psi} / \mathrm{min}$ (Sandia data, wawersik, 1977, 1978c). The $30 \mathrm{psi} / \mathrm{min}$ loading rate was chosen to match that of published data (Dreyer, 1972, Menzel and Schreiner, 1977). Creep tests were carried over a range of confining pressure $0 \leq \sigma_{3} \leq$ 3,000 psi, deviator stresses $1,500 \leq\left(\sigma_{1}-\sigma_{3}\right) \leq 6,000 \mathrm{psi}$, and temperatures of $24^{\circ} \leq \mathrm{T} \leq 100^{\circ} \mathrm{C}$ with a duration of up to 70 days. These loading rates were arbitrarily chosen as a means of scoping the behavior of SENM rock salt under conditions that may be encountered in the WIPP.

Apparatus, Experiments, Capabilities, and Data Handling. To support the determination of material properties of WIPP site rocks, a new triaxial facility was developed (Wawersik et al., 1976). Based on earlier experience (Wawersik and Brown, 1973; Gnirk et al., 1973; Wawersik, 1975), the present apparatus has the following capabilities.

The apparatus accepts cylindrical specimens up to $4-1 / 4$ inches diameter by 8.5 inches in length to accomodate the coarse grain size or rock salt.

The system has a pressure rating of $10,000 \mathrm{psi}$; this is adequate to perform variable load path tests, for example, in triaxial compression, in triaxial extension, at constant maximum compression, etc. 
The equipment is suitable to conduct both quasi-static tests and creep experiments.

Specimens can be heated uniformly to approximately $250^{\circ} \mathrm{C}$ in short-term tests and to $200^{\circ} \mathrm{C}$ to $220^{\circ} \mathrm{C}$ in long-term experiments.

Controlled, known temperature gradients can be applied for studies of fluid migration.

The equipment provides access to both specimen ends for possible venting or for measurements of pore pressure and permeability and for application of pore pressure, etc.

It provides both axial and radial deformation measurements. For uniform lateral deformation, this combination of strain measurements yields shear and volumetric strains.

The apparatus is equipped with multiple feed-throughs for use of instrumentation inside the pressure vessel.

Normally, hydrostatic and deviatoric loading are decoupled so that the hydrostatic response of all specimens can be defined and, more importantly, so that linear and bulk thermal expansion measurements can be determined as a function of temperature and pressure.

The apparatus and procedures allow for large, relatively unrestrained sample deformation.

Details of the test equipment (ranges, calibration procedures and precisions) are discussed elsewhere (Wawersik, 1975; Wawersik et. al., 1977; Wawersik, 1978a).Material and Test Specimens - The rock salt studied was machined from 4-1/4 inch diameter core obtained from zones at depths of 1,900 feet, 2,100 feet and 2,600 to 2,700 feet. Sample machining consisted of cylindrical and flat-end grinding following documented procedures which were designed to minimize the thickness of any shatter zones at the specimen surfaces. Alternatively, specimens were obtained by means of standard coring tools. Final specimen dimensions were nominally 2 inches or 4 inches in diameter, with a 
length-to-diameter ratio of at least two. After machining, the cylindrical surfaces of all samples were coated with a protective layer of RTV silastic.

Quasi-static Rock Salt Properties. Quasi-static testing was conducted on WIPP salt under hydrostatic pressures to 5,000 psi. Deviatoric loading tests were performed to 3000 psi confining pressure and to temperatures of $200^{\circ} \mathrm{C}$. Variables of interest were: pressure (confining pressure, mean stress), principal stress difference (deviator stress), time (loading rate), temperature and load path. A separate study of the role of the intermediate principal stress will also be initiated. The importance of the foregoing variables was suggested by prior mine measurements and by existing laboratory data (for example schmidt, 1937; U.S. Corps of Engineers, 1963; Le Comte, 1965; Hofer and Thoms, 1968; Schlichta, 1969; Carter and Heard, 1970; Bradshaw and McClain, 1971; Dreyer, 1972; Heard, 1972, Serata et al., 1972; Kern, 1973; Menzel and Schreiner, 1977; Baar, 1977).

The term quasi-static is used in the conventional sense to denote a fixed slow rate of loading. To avoid misunderstandings and undue generalizations of these data, it is emphasized that most quasi-static experiments were carried out at particular loading rates, e.g., 30 psi/min. It is important to realize that any data concerning the mechanical behavior of WIPP rock salt under different loading conditions must be inferred with proper regard to the time-dependent nature of the material (Wawersik and Hannum, 1978).

Quasi-static data available to date include approximately 75 uniaxial compression and indirect Brazilian tension tests at ambient temperature on core from drill holes AEC 7 and 8 (Hansen and Gnirk, 1975). These experiments were performed under the direction of Oak Ridge National Laboratory prior to June, 1975. They include approximately 20 experiments on anhydrite and 5 tests on polyhalite. More recent quasi-static data include approximately 50 tests on selected specimens from the potential WIPP repository horizons (Wawersik et al., 1976; 
Hansen, 1977; Hansen and Mellegard, 1977, Wawersik and Hannum, 1978). Samples were machined from core of drill holes AEC 7 and ERDA 9. Emphasis was placed on the response of rock salt from the storage horizon at 2600 feet because of the added complexities of elevated temperatures if heat producing wastes are placed in WIPP.

Selected representative mechanical properties in uniaxial compression and indirect tension are listed in Table 9.2.4-1.

Quasi-static Triaxial Properties - Representative triaxial data are listed on Table 9.2.4-2 for a range of confining pressures and temperatures. Note that both tables 9.2.4.1 and 9.2.4-2 list secant moduli (stress/total strain) and principal strain ratios $\left(\varepsilon_{3} / \varepsilon_{1}\right)$ rather than the elastic constants, that is, Young's modulus, E, and Poisson's ratio. To calculate the intrinsic elastic constants it is necessary to separate the nonelastic portion from the total deformation or to move through stress states where elastic response dominates. This was accomplished for New Mexico rock salt recently during unload/reload cycles.

The constants obtained were $4.55 \times 10^{6} \leq \varepsilon \leq 5.2 \times 10^{6}$ psi and $0.17 \leq \nu \leq 0.24$ (Wawersik and Hannum, 1978). These values agree to within 158 with those which were determined from borehole geophysical data.

During initial deviatoric loading in the laboratory, nearly all deformation of WIPP salt was nonelastic (Wawersik and Hannum, 1978). The actual magnitude of this nonelastic deformation is likely to be sensitive to the magnitude of the deviatoric stress which the core experienced during drilling (Wawersik and Hannum, 1978), associated core damage and subsequent core "relaxation" during core storage and handling. Combinations of these factors probably account for the variations in secant moduli and principal strain ratios in tables 9.2.4-1 and 9.2.4-2.

It is common practice in engineering to plot triaxial test data in the form of Mohr's circles at the ultimate stress. The plots are made in the 
stress space $(\sigma, T)$ where $\sigma$ and $T$ denote normal and shear stresses, and an envelope is drawn tangent to the circles representing the ultimate shear stress of any value of confining pressure.

When the data from Tables 9.2.4-1 and 9.2.4-2 are plotted, three Mohr's circles which are normal for SENM rock salt are obtained in Figure 9.2.4-2A in stress space $(\sigma, T)$. The ultimate stresses can be approximated by a straight line (Coulomb) envelope of the form $T=C+\sigma \tan \phi$. In conventional engineering terminology, $C$ is called the cohesion and $\phi$, the angle of internal friction. In this case, at ambient temperatures, rock salt from the 2,700 foot level has an apparent cohesion of approximately $1,000 \mathrm{psi}$ and an angle of internal friction of $33^{\circ}$. Similar data for other rocks are being used for mine pillar design. However, it should be recognized that the validity of these ultimate stress analyses rests on two assumptions: (1) failure is independent of the intermediate principal stress, and (2) failure is defined solely in terms of stresses and independent of strain, strain rate and time. Both of these assumptions are currently being evaluated for rock salt.

In contrast to other rocks, it is important to remember that rock salt undergoes large deformations long before the ultimate stress is reached. Since these deformations can exceed 158 even at ambient temperature, it is conceivable that a practial failure condition might incorporate a maximum deformation criterion. To illustrate this case, a coulomb envelope was constructed (Figure 9.2.4-2B) which defines the stress magnitudes at an arbitrarily chosen constant value of strain $\left(\varepsilon_{1}=2.58\right)$. This value is the average strain at the ultimate stress of samples tested in uniaxial compression at ambient temperature and a loading rate of $30 \mathrm{psi} / \mathrm{min}$. It can be seen that Figure $9.2 .4-2 \mathrm{~B}$ is different from the ultimate stress envelope in Figure 9.2.4-2A. Clearly, the shapes of the Mohr envelopes are highly dependent on failure criteria. The values obtained also depend on the manner in which the Mohr's envelope is drawn. In Figure 9.2.4-2A, a "best fit" straight line tangent to the circles was drawn; while in B, a parabola was drawn tangent to the circles. 
Detailed Quasi-static stress-Strain Relationships. Elastic constants, ultimate stresses, and stress or strain envelopes are useful for conventional failure stability analyses where rock is treated either as an elastic or as an elastic-plastic material. While such analyses have proven valuable in combination with careful engineering judgement, they are not always accurate. In view of the time-dependent nature of rock salt it is especially important that design calculations be based on a more comprehensive constitutive model. To initiate the development of such a model, detailed short-term quasi-static stress strain observations were made to identify the effects of pressure, deviatoric stress, (shear stress), temperature, and loading history. The influence of time as a discrete parameter is mainly considered in creep experiments.

Deviatoric Loading at Constant Confining Pressure. Deviatoric loading at constant confining pressure is the process of increasing the principal stress difference (deviator stress) from an initial state of hydrostatic compression. It is a necessary condition to induce substantial salt flow.

Typical quasi-static deviatoric loading data are shown in Figures 9.2.4-3 through 9.2.4-15. The key to these curves indicates sample depth in feet and (confining pressure in $\mathrm{ksi}$ and temperature in degree $\mathrm{c}$ ). These stress strain curves depict complete continuous experimental records which indicate the manner in which all specimens were loaded. Deviator stress was applied incrementally rather than continuously. Actual force was raised quickly by some predetermined amount and then held constant for between 4 and 15 minutes while axial and lateral strains $\varepsilon_{1}$ and $\varepsilon_{2} \quad\left(=\varepsilon_{3}\right)$ were monitored in time. The stepwise loading procedure made it relatively easy to control the mean applied loading rate while monitoring time dependent strains during load hold periods with a minimum of experimental error (Wawersik and Hannum, 1978). In most figures, these details of loading are omitted. As illustrated by the curve for sample 9-2601 in Figure 9.2.4-3, where smooth fits are made to the endpoints of each step in the actual stress strain record. Note that large changes in specimen cross sectional area at constant force during 
all load hold intervals lead to considerable decreases in principal stress difference with time (Wawersik et al., 1977, 1978c). Conventional plots $\left(\sigma_{1}-\sigma_{3}\right)$ versus $\varepsilon_{1}$ such as Figure 9.2.4-3 relate the present data to virtually all similar results for rock salt in the literature (for example, Schmidt, 1937; Heard, 1972; Dreyer, 1972, Menzel and Schreiner, 1977).

Considering Figures 9.2.4-3 through 9.2.4-6, three observations are particularly noteworthy.

1. Laboratory specimens of New Mexico rock salt have an initial elastic limit close to zero. Furthermore, this initial elastic limit appears to be the same following all hydrostatic pressure histories up to 5000 psi (Wawersik and Hannum, 1978).

2. Pressure appears to have a considerable effect on all properties of New Mexico rock salt except the elastic constants (Wawersik and Hannum, 1978). Specifically pressure controls the strain magnitudes, the ultimate stress and the relationships between the principal strain (Figures 9.2.4-5 and 9.2.4-6). Pressure effects are particularly evident at $\left(\sigma_{1}-\sigma_{3}\right)$ greater or equal 1200 psi.

3. New Mexico rock salt subjected to quasi-static laboratory compression can undergo substantial dilatancy which is associated with cataclasis, i.e., microfracturing. The magnitudes of the observed volume changes were significant particularly at low confining pressure and amounted to sizeable fractions of the observed shear strains near the ultimate stress (Wawersik and Hannum, 1978). Isovolumetric conditions of deformation are approached only at 3000 psi confining pressure. However, data at elevated temperature demonstrate that even comparatively minor amounts of dilatancy can have a considerable effect on the rate at which New Mexico rock salt deforms (Wawersik and Hannum, 1978). 
Elevated Temperature Data. Elevated temperature experiments were carried out in two groups. First, the influence of temperature was considered at fixed confining pressures, for example, 500 psi (Figs.9.2.4-7, 8 and 9). Then, the effect of pressure was evaluted at $200^{\circ} \mathrm{C}$ (Figs. 9.2.4-10, 11 and 12). As expected (Bradshaw and McClain, 1971; Heard, 1972: Dreyer, 1972), temperature reduced the ultimate stress and increased the ductility (Fig. 9.2.4-7). Increasing the temperature is qualitatively equivalent to increasing confining pressure at ambient temperature. Cataclastic effects with considerable dilatancy are suppressed in favor of deformation modes which proceed at constant, or nearly constant, volume (Figs. 9.2.4-8 and 9.2.4-9). (Wawersik and Hannum, 1978)

Influence of Loading History. Effects of loading history are noted in several studies in the literature (for example, Schmidt, 1937; Sereta et al., 1972; Baar, 1977). To consider such effects, three sets of experiments were performed early in the experimental program. First, the influence of differing hydrostatic loading histories was tested. The results indicated no measurable effects on the behavior of rock salt from southeastern New Mexico during subsequent deviatoric loading (Wawersik and Hannum, 1978).

In the second group of experiments, quasi-static strains were measured as a function of load path in a conscious effort to separate the influences of load path and loading history as much as possible. The load paths employed are shown in Figure 9.2.4-15. They consist of:

1. Conventional triaxial tests at constant confining pressure (load path I).

2. Triaxial loading at constant mean stress $\left(\sigma \mathrm{m}=\frac{1}{3}\left(\sigma_{1}+\sigma_{2}+\sigma_{3}\right)\right.$ load path II).

3, Deviatoric loading at approximately constant maximum compression (load path III). 
Figure 9.2.4-13 also identifies one test which combined load path III and I passing through points $A, D, E, G$, and $H$ (Wawersik and Hannum, 1978). Table 9.2.4-3 provides a comparison of strains at several common stress states of Figure 9.2.4-13 with the strains $\varepsilon_{1}$ and $\varepsilon_{3}$ are numerically greatest along the path of constant confining pressure (load path I). The smallest $\varepsilon_{1}$ and $\varepsilon_{3}$ were obtained along the path of maximum pressure, either confining pressure or mean stress (load path III) (Wawersik and Hannum, 1978).

To evaluate load history even further, a third set of tests was performed. In these experiments, one sample was deformed in three successive stages at 3000,500 , and again at 3000 psi confining pressure. The response of this specimen was then compared with the strain behavior of individual samples which had been loaded deviatorically at 3000 psi and 500 psi confining pressure (Wawersik and Hannum, 1978). The results of the latter tests are shown in Figures 9.2.4-14 and 9.2.4-15. Notice particularly, that the stress strain record for the third load cycle of sample 7-2740.5 does not immediately converge to the stress strain records of specimens 7-2745 and 9-2601.5. Differences in results are obviously due to the influence of loading history (Wawersik and Hannum, 1978).

Interpretation of Quasi-static Data - In view of the quasi-static testing to date, as illustrated in the figures, the following observations were made repeatedly and establish broad guidelines which should be observed in modeling the thermomechanical behavior of New Mexico rock salt up to fracture and/or massive flow ( $\varepsilon_{1}$ greater or equal 20\%).

Rock salt from SENM in the laboratory is nonlinear under all loading conditions with an initial elastic limit $\left(\sigma_{1}-\sigma_{3}\right)$ approximately zero. Its intrinsic elastic properties can be evaluated accurately only in load/unload/reload cycles provided restrictions are imposed either on the loading (strain) rate or on the range of deviator stresses. However, given comparatively nonelastic strains, the intrinsic elastic behavior does not appear to be very important. 
In the low confining pressure domain $\sigma_{3} \leq 3000$ psi, rock salt behavior depends strongly on pressure and temperature. Both dependencies are reflected in ductility, ultimate stresses and in the variation between maximum and minimum principal strains or in the variations between volumetric strains and shear strains (Figures 9.2.4-4, 5, 8, 11, and 15).

A brittle mode of deformation (microfracturing) dominates rock salt deformation at ambient temperature, low confining pressure, and deviator stress in excess of approximately 1000 to 1500 psi. Accordingly, the overriding pressure effect under these conditions is pressure dependent dilatancy (Figures 9.2.4-4, 6 and 9). Brittle fracture, including creep fracture, i.e., macroscopic collapse and loss in load bearing ability are possible. At low (less than 1,000 to 1,500 psi) deviator stress, high temperature, and/or high pressure, salt deformation proceeds in a predominantly ductile manner at nearly constant volume. Particularly at high temperatures, pressure does not appear to further influence the nature of the governing deformation mechanisms. This is indicated by a pressure invariance (Figure 9.2.4-11) of the relationship between maximum and minimum compressive strains (shear and volumetric strains). However, observed differences in induced strain rate at a fixed loading rate but different confining pressures indicate that pressure influences the rate at which the governing deformation mechanisms, cataclastic or ductile flow, proceed.

It is recognized that available quasi-static stress strain data do not necessarily describe the properties of New Mexico rock salt over long periods of time. However, for lack of other information, quasi-static tests have been used to define the matrices of future creep experiments and to anticipate phenomena which might occur during creep. For example, emphasis is being placed on triaxial creep experiments as opposed to uniaxial tests. Simultaneous measurements are being made of both volumetric strains and shear strains in creep. Similar tests are not conducted routinely elsewhere and the apparatus to perform these tests is at the state-of-the-art in experimental rock mechanics. 
Creep of Rock Salt Creep tests on rock salt are continuing to evaluate the long-term time-dependent behavior of New Mexico rock salt. Since August, 1977, two sets of triaxial creep tests have been performed on core from drill holes AEC 7 and ERDA 9, emphasizing the interval of 2600 to 2800 feet depth. Experiments were carried out over the range

$$
\begin{aligned}
0 & \leq \sigma_{3} \leq 3000 \text { psi, } 1500 \leq\left(\sigma_{1}-\sigma_{3}\right) \\
\leq 6000 \text { psi, and } 24^{\circ} \leq \mathrm{T} & \leq 130^{\circ} \mathrm{C} .
\end{aligned}
$$

Results indicate that in principle WIPP salt can undergo both transient and steady state creep. Furthermore, limited data suggest that steady state creep rates 1 ie in the range from $10^{-10} \mathrm{sec}^{-1}$ to $10^{-7}$ $\sec ^{-1}$, depending strongly on stress state and temperature. Steady state creep may have to be considered in WIPP design calculations; it was not included in earlier wastes repository analyses which were conducted in conjunction with in situ experiments during Project Salt Vault, Kansas (Bradshaw and McClain, 1971).

To evaluate the nature of transient creep of the WIPP salt, 34 tests were carried out on NX sized (two inch nominal diameter) core. Tests durations vary between 0.5 and 500 hours (Hanson, 1977, and Hanson and Mellegard, 1977). Initial efforts served to evaluate the significance of transient creep on the possible repository conditions, to establish upper (conservative) bounds for steady state creep rates at relatively low deviator stress and temperature, and to test the applicability of a pillar creep formula which has been widely used (Bradshaw and McClain, 1971):

$$
E(t)=A\left(\sigma_{1}-\sigma_{3}\right) a_{T}^{b} t^{c}
$$

The results of present transient creep data demonstrate significant pressure effects which are consistant with all quasi-static observations but are not predicted by equation 9.1 . 
Beyond that, however, at least one block of data appears to support equation 9.1 which in its generalized form is:

$$
\varepsilon=F_{1}(p) F_{2}\left(\sigma_{1}-\sigma_{3}\right) F_{3}(T) F(\text { strain or time) }
$$

Work is now in progress to estimate the error magnitudes which are associated with the use of equation 9.2 even under restricted conditions, e.g., $\left(\sigma_{1}-\sigma_{3}\right) \leq 2,500$ psi and $\sigma_{3} \leq 1,000$ psi. To accomplish this, numerical simulations are compared with the results of independent laboratory experiments which combine multiple creep runs with intermittent short-term stress variations at two different temperatures.

Time Dependent Fracture. To determine the long term strength of New Mexico rock salt, two approaches are being take. First, long-term laboratory creep tests are conducted to establish a relationship between strength and time. Obviously such tests are time consuming. Second, failure times may be calculated from creep flow and from estimates of the amount of nonelastic strain at the point of fracture. The nonelastic failure strain can be estimated by means of an empirical procedure which establishes a relationship between creep, time dependent fracture and quasi-static post failure characteristics (Wawersik, 1972). If this technique. is applied to New Mexico rock salt, it appears that the range of stable creep prior to fracture at ambient temperature is:

$$
\begin{aligned}
& \varepsilon_{1} \leq 2.5 \text { to } 6 \% \text { at } \sigma_{3}=0 \mathrm{psi} \\
& \varepsilon_{1} \leq 17 \text { to } 20 \% \text { at } \sigma_{3}=500 \mathrm{psi}
\end{aligned}
$$

Substantially greater stable creep occurs at $\sigma_{3}=3000$ psi confining pressure (Wawersik 1977). On Figure 9.2.4-18, photographs of core samples from ERDA \#9 are shown that were deformed during triaxial testing (Hansen and Mellegard, 1977). Notice the large amount of strain test Numbers 6 and 7 have undergone without apparent major physical damage. 
Applicability of Laboratory Measurements. Several investigations are underway to define the qualitative and quantitative applicability of laboratory experiments on WIPP salt to in-situ design predictions. Apart from numerical validation studies, measurements are in progress to determine the relaxation of core after drilling and to assess whether rock salt is damaged during field coring, recovery and storage. The latter efforts are supported by repeated tests on specimens with known laboratory stress histories to further define the effects of stress history, aging and specimen machine. In addition, numerical simulation are being conducted to balance the magnitude of deviatoric loading of salt core during drilling.

\subsubsection{Summary and Conclusions}

Data from the petrographic and physical properties studies show the WIPP horizon rock salt has low moisture content $(<0.5 \%)$, is essentially impermeable ( $<5 \times 10^{-8}$ darcy) and has a high thermal conductivity ( $\simeq 5.75$ watts $/ \mathrm{m}^{\circ} \mathrm{k}$ ). These properties along with the studies of fabric and fracture indicate this rock salt is ideally suited from a physical standpoint for the storage of high temperature nuclear waste.

The initial elastic limit is close to zero for rock salt for any confining pressure. Although strengths for rock salt are substantial (unconfined compressive strength to $3700 \mathrm{psi}$ and modulus to $2 \times 10^{6}$ psi) the load bearing ability is dependent on time, temperature and confining pressure.

It has been shown that rock salt can experience large creep strains (25z) prior to loss of load bearing capacity. Gradual creep is an acceptable feature in the design of underground openings in rock salt as it allows the structure to close without a sizeable reduction in bearing strength and without the physical damage which is associated with fracture. 
Laboratory testing is continuing to develop a constitutive model to describe the behavior of SENM rocks. The model will be used in computer codes to study the structural response of the geologic media to WIPP.

\subsection{RADIONUCLIDE SORPTION ON WIPP ROCKS}

\subsubsection{Introduction}

An important mechanism in retarding nuclide movement in groundwater is sorption. In the following discussion, this term will be used to encompass all mechanisms pertinent to interaction between nuclides and geomedia which include ion exchange, adsorption, and precipitation.

The ability of rocks to adsorb radionuclides and hinder their migration away from a geologic repository for radioactive waste is not a factor in site selection criteria (Chapter 2 ). Also, since sorptive affinity is not a fundamental invariant property of a rock sample, such as is mineralogy or total volatile content, radionuclide sorption properties were not discussed in Chapter 7 (Geochemistry). Nevertheless, quantification of rocks' affinities for radionuclide sorption, however, is NOT a generic problem which can be solved simply for all rocks. Since the only rational approach to the problem is to conduct experiments to determine radionuclide sorption properties for site-specific rocks and site-specific aqueous solutions, preliminary results of such experiments are reported as special studies. The results of special studies of radionuclide sorption are entirely dependent upon experimental conditions, just as in the measurement of quasistatic mechanical properties.

In some safety assessment modeling scenarios described for the escape of radionuclides from WIPP repository horizons, groundwters contact and leach the waste form, and eventually find their way out of the salt deposit into the surrounding rock and mineral strata. During this exit, the nuclide-bearing liquid would contact clay-containing halite in the repository horizon, polyhalite formations, anhydrite formations, and 
finally the sandstone and dolomite formations which are the bounds of the evaporites. To a rough approximation, the concentration per unit mass of a given nuclide, sorbed on a solid mineral phase $c_{\text {solid }}$ can be related to the concentration per unit volume, in the liquid phase $\mathrm{C}_{1 \text { liquid' }}$ by the relation:

$$
\mathrm{C}_{\text {solid }}=\mathrm{KC}_{\text {liquid }}
$$

where $K$ is generally known as the distribution coefficient, $k d$, with units of $\mathrm{ml} / \mathrm{g}$. The use of the term $\mathrm{Kd}$ implies an equilibrium condition for a given reaction which is both instantaneous and reversible. In the interaction of a nuclide with a complex mineral assemblage, neither condition may apply and the nuclide sorption observed can result from one or more sorption phenomena on one or more phases. To prevent confusion in nomenclature, the term $\mathrm{Kd}$ is used in this report, but with the understanding that what is being measured is a sorption coefficient which applies only to the system described and for the particular set of conditions used in making the measurement. Thus, the measurement of "Kd" does not reflect a fundamental thermodynamic property of rocks and/or solutions; it is rather a function of the experiment in which it is measured.

Ideally, sorptive affinities for radionuclides would be measured in situ in the geological formation of interest using long path lengths and available groundwater. This is not generally feasible and must be supplanted with data generated in a laboratory. Most of this section is an extract of SAND78-0297, "Interaction of Radionuclides with Geomedia Associated with the Waste Isolation Pilot Plant (WIPP) site in New Mexico" by R. G. Dosch and A. W. Lynch. It provides the results of a series of laboratory Kd measurements for various radionuclides and samples of different geological media from the vicinity of the WIPP site, and a discussion of the conditions used in making the measurements. The nuclides chosen for study have either a high potential for leaching and/or migration, a high radiotoxicity, or a chemistry similar to that of a nuclide with these properties. They included ${ }^{137} \mathrm{Cs},{ }^{85} \mathrm{Sr},{ }^{131} \mathrm{I}$, ${ }^{125} \mathrm{Sb},{ }^{144} \mathrm{Ce},{ }^{152} \mathrm{Eu},{ }^{153} \mathrm{Gd},{ }^{106} \mathrm{Ru},{ }^{243} \mathrm{Am},{ }^{244} \mathrm{Cm}$ and ${ }^{238} \mathrm{pu}$. 
A given set of conditions including pH, Eh, particle size, nuclide concentrations, and brine and/or groundwater simulant composition was defined prior to starting the work and maintained throughout. The Kd values reported are considered to be a set of preliminary baseline data for use in evaluating the effects of changes in those conditions which will undoubtedly be necessary as more information about the WIPP site itself and interactions of the waste forms with bedded salt become available.

The results of some parametric studies with lanthanide elements are also given. Significant differences in Kd's were observed as a result of varying $\mathrm{pH}$ and nuclide concentrations, and from the addition of trace quantities of organic contaminants to simulant solutions.

\subsubsection{Geological Media}

Sample selection. The geological samples used in this work were taken from four inch diameter core samples from AEC \#8 and ERDA \#9 boreholes. (See Chapters 4 and 7 for descriptions of stratigraphy and mineralogy.) These include three samples from various rock formations (including the water-bearing rocks above and below the evaporites), four halite samples from the Salado Formation, and samples of polyhalite and Cowden anhydrite also from the Salado Formation.

The selection of the geological media for study was based on both the hydrology of the WIPP site and surrounding area and on a reasonable scenario for radionuclide transport from a bedded salt repository. The Magenta, Culebra, and Bell Canyon formations represent actual or potential aquifers.

Any path to the biosphere for water which may have contacted and leached a waste form would involve migration through halite formations, and also through anhydrite and polyhalite strata interspersed in the halite. Thus, these materials, along with the clay contained in the halite, are included in this study as they represent potential barriers to nuclide migration. 
Sample Preparation. Culebra, Magenta, Bell Canyon, polyhalite, and anhydrite samples were reduced to a powder prior to use. Clays from the halite samples were obtained by dissolving core samples in deionized water, fill tering and washing the insoluble residue, and drying at ambient temperature in air or vacuum.

\subsubsection{Brine and Groundwater Simulants}

The bulk of the $\mathrm{Kd}$ measurements reported herein were done using simulated brines and groundwater of the compositions given in Table 9.3-1. The Brine A composition is based on that expected in an aqueous solution in contact with potash deposits found in the vicinity of the WIPP site. The Brine B composition is typical of water in contact with halite deposits in the repository horizons. The groundwater Solution C composition is based on analyses of shallow groundwaters from the Los Medanos area (Lambert, 1978) above the evaporites and is intended to represent an "average" composition.

In determining $\mathrm{Kd}$ values for halite particles, saturated brines prepared from the particular core sample from which the halite had been taken were used as the liquid phase.

\subsubsection{Solution Chemistry}

Solutes. The use of simulated brines became necessary as both naturally occurring brines and core samples from repository horizons are currently available in very limited quantities. Simulants do offer the advantage of providing a reproducible matrix which allows for direct comparison of Kd data generated in different laboratories.

Potential problems in using simulants could arise from the absence of trace constituents which may be present in natural waters. If these are common inorganic species, the effect on Kd's would probably be negligible. However, trace quantities of organic compounds or dissolved gases such as hydrogen sulfide could produce significant changes in Kd 
values should they tend to form stable complexes with some nuclides. The effect of trace quantities of organics which may be introduced into the repository as radwaste is being addressed and is discussed in section 9.3.8.

Oxidation Potential. In aqueous migration from a deep geologic storage site, nuclides would most likely encounter both anoxic and aerobic conditions, in that order, as the biosphere is approached. The potential effect on Kd values could be many orders of magnitude; however, this should be limited to nuclides such as $U, N p$, and $\mathrm{Pu}$ which may undergo oxidation-reduction reactions in the potential range encountered.

Oxidizing conditions have been used to date as they are believed to produce the "worst case" with respect to migration, i.e., the higher valence states of the previously mentioned actinides tend to have lower Kd's, and they will be encountered in any scenario leading to contamination of the biosphere.

Hydrogen Ion Activity. The effect of the pH is believed to be extremely important in both the solution chemistry and the adsorption mechanism involved in the Kd for a given geological media. Problems encountered in determining $\mathrm{Kd}$ values in systems where solution $\mathrm{pH}$ is varying are discussed in Section 9.3.8. Changes in the adsorption characteristics of clays, oxides, and some zeolite materials as a function of $\mathrm{pH}$ are well documented (Amphlett, 1964).

The initial $\mathrm{pH}$ values of $6.5,6.5$ and 7.5 for Brine $A, B r i n e ~ B$ and solution $C$ simulants, respectively, were chosen as being representative of field pH measurements of natural brines and groundwaters in the Los Medanos area.

Radionuclide Concentation. Ideally, a distribution coefficient should be independent of concentration. This condition usually exists only over a narrow concentration range and, therefore, nuclide concentrations should be chosen which are somewhat representative of those expected in a 
repository. The problem lies in the fact that little or no data exists to aid in estimating leaching rates under conditions expected after closure of a repository. These include glass or other waste forms at elevated temperature $\left(70-200^{\circ} \mathrm{C}\right)$ and lithostatic pressure (2000 psi) in contact with "wet" salt or brine. Another presently unknown variable is the effect of radiolysis on leaching mechanisms and rates. Available leaching data primarily result from laboratory leaching experiments with simulated waste in distilled water at ambient temperature.

In order to simplify both sampling and counting operations in the initial work, an activity of approximately $1 \mu \mathrm{Ci} / \mathrm{ml}$ was used for all determinations unless stated otherwise. The corresponding nuclide concentrations based on the suppliers' analyses of the isotopes used are listed in Table 9.3-2.

Unless otherwise stated, all distribution coefficient measurements were made using a single nuclide in the brines or groundwater to eliminate competing ion effects. The effect of the nuclide concentration on Kd's is of concern and some initial work in this regard is presented in Section 9.3.8.

\subsubsection{Experimental Procedures}

Apparatus, Sample Size and Sampling. Samples of rock, clay, anhydrite, polyhalite, or halite were weighed directly into polyethylene dropping bottles volumes of doped brine or groundwater were added. The ratio of liquid to solid was typically in the range of 30 to 35 . Due to limited quantities of the clay samples, higher ratios (50-150) were used in experiments with clays.

The bottles were sealed by placing a piece of polyethylene film over the opening and replacing the bottle top. Agitation was provided by orbital, reciprocating, or wrist-action shakers. Samples for analysis were taken by replacing the polyethylene film with a $0.8 \mu$ pore size Gelman filter, tightening the dropping bottle top down over the filter, and squeezing 
the bottle to force 0.5 to $1.0 \mathrm{ml}$ volumes into pre-weighed polyethylene vials. Quantitative volumes were determined from weight and density measurements. The filters were replaced with polyethylene film and the agitation continued.

Portions of all "feed" solutions were put in identical polyethylene dropping bottles, agitated, and sampled at the same time and in the same manner. The activity in the filtered "feed" samples were used as the initial solution activity in the $\mathrm{Kd}$ calculations.

Analyses. The activity in solutions containing ${ }^{137} \mathrm{Cs},{ }^{85} \mathrm{Sr},{ }^{106} \mathrm{Ru}$, ${ }^{131} \mathrm{I},{ }^{125} \mathrm{Sb},{ }^{152} \mathrm{Eu},{ }^{144} \mathrm{Ce}$, or ${ }^{153} \mathrm{Gd}$ was determined by $\mathrm{x}$-ray spectroscopy. A Harshaw 3" x 3" NaI(Tl) scintillation crystal or an Ortec VIP Series Coaxial Ge(Li) solid state detector was used. Data was accumulated and processed by a PDP-11/20 computer system. ${ }^{99}$ Tc beta activity was measured using a mica end-window Geiger tube or by liquid scintillation counting. Alpha activities were determined by liquid scintillation counting. Since only relative activities are needed to determine Kd's, units of $\mathrm{cpm} / \mathrm{ml}$ were used in all calculations.

Equilibration Time. Samples of fission product nuclides were generally taken after 14-20 and 30-35 day equilibration periods. In some instances, more frequent sampling was done. Variation in Kd's between the two sampling times were generally within a factor of two and are believed to result from changes in concentration due to adsorption on container walls, filters, or pH changes in both the sample and feed solutions rather than from rock-nuclide sorption kinetics.

Equilibration times of 170 days were used in the actinide experiments. This extended period was dictated by delays in acquiring laboratory facilities rather than by experimental design. 


\subsubsection{Kd Data}

The results of $\mathrm{Kd}$ measurements using the conditions described in previous sections are given in Tables 9.3-3 through 9.3-11. Each table represents a different geological sample and contains th Kd's determined for the various brine/groundwater-nuclide combinations listed and a $\mathrm{pH}$ range including the initial feed $\mathrm{pH}$ and final sample $\mathrm{pH}$ values. The Kd ranges given for the fission product nuclides include two or more measurements made during the course of the experiment. Error associated with these measurements is certainly the most significant at the high $\left(>10^{4}\right)$ and low $(<1)$ ends of the kd range, where background to signal ratios are high or calculations are based on small differences in large numbers. Two-to-fivefold variations of $\mathrm{Kd}$ 's between duplicate analyses in these regions were not uncommon. Another obvious source of uncertainty is sampling, both in picking a section of core to represent a geological formation and in taking small samples to represent the core. The magnitude of error due to heterogeneity in a given core sample is unknown, as multiple samples were not used in this survey.

\subsubsection{Discussion of Kd Data}

Cesium. Cesium adsorption from brines " $A$ " and " $B$ " on Culebra and Magenta samples, representing a potential aquifer region overlying the repository horizons, is minimal or non-existent with kd's ranging from 0 to 2 . Adsorption from groundwater $C$ is slightly higher (Kd's from 4 to 10). In the potential aquifer underling the repository, the Bell Canyon Formation, Cs adsorption is significantly higher in the groundwater " $\mathrm{C}$ " simulant than in brine "B". This trend tends to support an ion exchange mechanism for Cs adsorption.

Similar results are observed on the samples associated with the repository horizons, with the exception of the polyhalite sample, which did not adsorb Cs from any of the solutions used. 
Strontium. The adsorption of $\mathrm{Sr}$ on the rock samples from potential aquifer regions was very low with a Kd of 5 being the highest value observed in both brines and groundwater simulant.

of the materials associated with the repository horizons, only the polyhalite sample showed any appreciable adsorption of Sr from the brine solutions that would be associated with the region.

The interstitial clay in the halite formation shows no tendency to adsorb Sr from the brine solutions (Tables 9.3-6 and (.3-9), and this may be attributed in part to the relatively high concentration of stable $\mathrm{Sr}$ used in the simulants. However, the same behavior was observed in an experiment where a brine prepared by dissolving a halite core and doped with $<0.3 \mathrm{ppm}{ }^{85} \mathrm{Sr}$ was cycled through a column of the halite particles from the same core (Tables 9.3-1 and 9.3-11). In this case, only a slight reduction in Sr activity was observed (which may have resulted from adsorption on the glass column or Tygon tubing used to circulate the brine), while ${ }^{144}$ Ce was quantitatively removed by the halite.

Europium, Gadolinium and Cerium. These nuclides have been grouped together for discussion because their chemistries are very similar, particularly with respect to hydrolysis, and secondly, because they exhibited similar behavior in their interactions with the geomedia from the WIPP site.

With the exception of polyhalite samples, Kd's of greater than $10^{3}$ for these nuclides were observed on all the geological samples with which they were contacted. Any interpretation of these data with respect to mechanism or comparison of the effects of different brines or geological media is difficult because of the contribution of hydrolysis and subsequent precipitation to the overall adsorption observed in the experiments.

For example, the polyhalite sample which was singled out as having Kd's of less than $10^{3}$ for these nuclides (Table 9.3-7), also had final pH values which were lower than the rock or clay samples. Thus, the 
apparent difference in Kd's may be a hydrolysis effect rather than be related to the polyhalite. The effect of hydrolysis is further discussed in section 9.3 .8 .

Technetium and Iodine. Both of these nuclides are expected to exist as anionic species in natural groundwaters or brines and were used in the form of pertechnetate, $\mathrm{TCO}_{4}$, and iodide, I, in this work.

Natural ion exchangers typically exhibit extremely low anion capacities, particularly in neutral or basic solution. In this work, the only material which showed significant adsorption of pertechnetate and iodide was a clay sample taken from a halite core (Table 9.3-9). The adsorption was observed in Brine $A$ and groundwater $C$, but neither species appeared to be adsorbed from Brine $B$. The relatively high concentration of TC used may have far exceeded the anion exchange capacity of some or all of the samples and this possibility is being investigated.

Ruthenium and Antimony. Difficulty was encountered in preparing the doped " $A$ ", "B", and " $C$ " solutions due to the high concentrations of stable $\mathrm{Ru}$ and acid (4NHCl) in the ${ }^{106} \mathrm{Ru}$ solution used. Adjustment of $\mathrm{pH}$ after doping resulted in precipitation of $>958$ of the $\mathrm{Ru}$. The final feed solutions were estimated to contain approximately $0.10 \mu \mathrm{Ci} / \mathrm{ml}$ of ${ }^{106} \mathrm{Ru}$ in "B" and "C" or $25 \mathrm{ppm}$ total $\mathrm{Ru}$.

General trends observed in the Kd measurements include: 1 ) higher Kd's for the clay minerals than for the rock samples, 2) higher Kd's in simulants "B" and "C" than observed in "A". The latter effect may be the result of brine composition, but more likely is a hydrolysis effect as the final equilibrium pH of " $\mathrm{B}$ " and " $\mathrm{C}$ " is higher than that in the " $\mathrm{A}$ " brine.

Antimony was added to the group of nuclides being studied late in this work, and there are not sufficient data available on which to base any general statements. 
Actinides. The actinides used in this work were supplied as Am(III), $\mathrm{Cm}$ (III), and Pu(IV) solutions and used at Eace value. No attempts were made to determine the $\mathrm{Pu}$ species present in the simulant solutions after doping. The nominal activity of the actinides in the solutions used in this work was $1 \mu \mathrm{Ci} / \mathrm{ml}$, however, the final activities in the "feed" solutions were lower. The doping was done by adding the isotope solutions to containers and evaporating to dryness at room temperature. The brines or groundwater solutions were then added to the containers and the solutions were set aside for several days. The amount of isotope used was sufficient to provide an activity of $1.0 \mu \mathrm{Ci}$ per milliliter of solution if the entire amount was dissolved.

In general, the actinide concentrations in groundwater " $\mathrm{C}$ " at a $\mathrm{pH}$ of 7.3-7.4 are greater than those in the brine solutions in the $6.9-7 \mathrm{pH}$ range. This is particularly true for ${ }^{244} \mathrm{Cm}$, where the concentrations are 2 to 3 orders of magnitude lower in the brine solutions.

Kd values for the actinides of 300 or greater are observed for all the geological samples if the halite Kd's are based on weight of insoluble material rather than the weight of the total halite sample. In general, the $\mathrm{Kd}$ values in the groundwater " $\mathrm{C}$ " are higher than in Brine "B" which could result from hydrolysis due to higher $\mathrm{pH}$ in the " $\mathrm{C}$ " solutions; however, there are some cases where this $\mathrm{kd}$ order is reversed.

The reasonably good agreement between the $K d$ values for the clay samples (Table 9.3-6) and the halite containing interstitial clay particles (Tables 9.3-5 and 9.3-11) suggests that the halite in the vicinity of the repository can serve as a barrier to actinide migration.

\subsubsection{Parametric Effects}

$\mathrm{pH}$ and Nuclide Concentration Effects on $\mathrm{Kd}$. The first investigation into the contribution of the $\mathrm{pH}$ of the aqueous phase and effect of nuclide concentration on the sorption coefficient involved ${ }^{152} \mathrm{Eu}$ sorption from brines $\mathrm{A}$ and $\mathrm{B}$ and groundwater $\mathrm{C}$ on samples from the Magenta and Culebra Formations. 
The experimental procedure used was the same as that described previously, except two blank samples of each feed solution were included instead of one. At the end of a two week equilibration period, the pH of the samples and feed solutions were measured. One of the feed $B$ and $C$ solutions was then adjusted so that its $\mathrm{pH}$ was equal to that observed in sample solutions containing that feed. A sodium carbonate solution was used for the $\mathrm{pH}$ adjustment, which was done over a period of three days. By the time analytical samples of the adjusted feeds were taken, the pH of some of them had increased and was higher than the corresponding sample. The pH of the Brine A feeds was not adjusted as the final values were the same as those in the samples.

The $\mathrm{pH}$ of the adjusted feeds decreased significantly during the first three months, probably due to adsorption of atmospheric carbon dioxide (Garrels and Christ, 1965). The pH of the solutions contacting the rock also varied with some increasing and others decreasing; however, the change was consistent within a given set of samples containing the same rock and solution.

Distribution coefficients calculated from both the feed activities and pH adjusted feed activities after two week and three month periods are listed in Table 9.3-12.

Europium is apparently more soluble in Brine A than in Brine B at the same pH or in the C composition at higher pH. The effect of adjusting the $\mathrm{pH}$ in $\mathrm{B}$ and $\mathrm{C}$ solutions definitely resulted in hydrolysis and formation of some species which did not pass through a $0.8 \mu$ filter. It is also of interest that significant decreases in activity in the pH-adjusted feeds were observed for all Eu concentrations used.

The Effect of Trace Organic Contaminants of Kd's of ${ }^{152} \mathrm{Eu},{ }^{153} \mathrm{Gd}$ and ${ }^{144} \mathrm{Ce}$. One of the concerns in estimating migration rates of radionuclide in aqueous media is the ionic form of the nuclide of interest. Experiments have shown that the simple ionic forms of most polyvalent cations interact quite readily with geologic media from the 
WIPP site via ion exchange or other sorption phenomena. These interactions serve to retard the movement of the ionic species relative to the aqueous matrix containing them.

The extent of the nuclide-geologic media interaction can be significantly altered by changes in the ionic form of the nuclide. Examples of such changes are redox reactions which may result in species of zero or negative charge types and reactions with available inorganic or organic ligands to form complex species with different chemical properties. One such change in properties might be enhanced mobility over that of the bare ion.

Investigations of the sorption changes due to complexation between organic ligands and radionuclides have been initiated by Robert $T$. Paine of the University of New Mexico. One source of organic ligands which may be present in large quantities in the repository is the plywood used in containers for shipping TRU waste. Samples of these containers are being refluxed in synthetic Brine $B$ at $70^{\circ} \mathrm{C}$, the maximum temperature expected in the transuranic (TRU) waste horizon in the repository. The initial samples of this brine, subsequently referred to as $B^{*}$, were taken after 5 weeks of refluxing.

Although no significant physical degradation of the plywood was observed after this time period, chemical leaching did occur as evidenced by the coffee brown appearance of the brine. Gas chromatograph-mass spectrometer analysis of the brine indicated the presence of organic material, but identificaton was inconclusive. Infrared spectroscopy was used to examine carbon tetrachloride and benzene-acetone extracts from the brine. The extracted organic material fell into the general class of esterified rosin compounds, but no specific indentification was possible. Qualitative observation indicated that the brine contained extremely small amounts of organic material. Neither solvent system extracted the colored species from the brine. 
The effect of plywood extract on lanthanide distribution coefficients (Kd's) was determind by measuring Kd's for ${ }^{153} \mathrm{Gd},{ }^{144} \mathrm{Ce}$ and ${ }^{152} \mathrm{Eu}$ between five geologic media from the WIPP site and the brine $B^{*}$ containing the plywood extract, and comparing these values with Kd's obtained in identical experiments using pure Brine B. The results are given in Table 9.3-13.

Although both the $B$ and $B *$ brines were doped initially with the same concentrations of tracers, there is a significant difference in the activity of the final samples taken. This could result from adsorption on the polyethylene containers or hydrolysis and subsequent filtration of hydrated oxides of the tracer elements through the $0.8 \mu$ filters. In either case, the effect occurs to a significantly lesser extent in the brine $B^{*}$, which is probably the result of interaction between the tracers and some ligand extracted from the plywood to form complexes which are less susceptible to hydrolysis.

The difference in $\mathrm{Kd}$ values could also result from complex formation. The complexing ligand may be a rosin derivative, many of which form very stable compounds with heavy metals. It may also be the species which causes the brown coloration of the brine. Observation of the analytical samples taken from the brine $B^{*}$ samples showed that the clay material had completely decolorized the brine. The other materials decolorized the $\mathrm{B}^{*}$ samples to varying degrees, as given below in order of decreasing color intensity remaining in solution:

Feed > Magenta $>$ Culebra $\approx$ Bell Canyon $>$ Cowden $>$ Clay solution

Similar work will be done using extracts which are being prepared from other organic materials expected to be associated with TRU waste such as rubber gloves, swipes, detergents, etc. Based on lanthanide results, an experimental matrix will be designed to study the actinide elements.

The Effect of Oxidation State on Radionuclide Sorption. An additional approach to understanding the behavior of actinides under site specific conditions in WIPP is the study of the behavior of various oxidation 
states of the actinides (particularly plutonium) in the presence of various components of the WIPP strata. This work is being performed at Argonne National Laboratory by Sherman Fried and Arnold Friedman.

Relatively concentrated solutions of actinides $(0.01 \mathrm{M})$ whose oxidation states were determined by inspection of their optical absorption spectra were prepared and allowed to react with saturated WIPP brines, and with rocks from the WIPP site. Since it was assumed that in the final stages of a WIPP repository oxygen might be absent in the rock salt, the preparations were made in vacuo to identify species present under such conditions.

Solutions of plutonium were prepared in such a way that samples sealed in optical absorption cells at approximately $10^{-6}$ atmosphere of $\mathrm{O}_{2}$ could be examined from time to time to observe changes in absorption peaks (if any) and thus determine the stability of the particular oxidation state as a function of time.

In the case of plutonium preparations, the isotope ${ }^{242} \mathrm{Pu}$ was employed. This was done to minimize radiolysis effects (specific activity $\mathrm{Pu}^{242}=$ $4.5 \times 10^{3} \mathrm{~d} / \mathrm{m} / \mu \mathrm{g}$ vs. $1 / 15 \times 10^{5} \mathrm{~d} / \mathrm{m} / \mu \mathrm{g}$ for $\left.{ }^{239} \mathrm{Pu}\right)$. It is felt that while the behavior of plutonium in these concentrated solutions may be substantially different than tracer Pu migrating in an aquifer where the radiation field will be much less, it is nevertheless a good approximation to the conditions immediately in the vicinity of the canister when an amount of radioactivity has just leached out.

The various oxidation states of $\mathrm{Pu}$ were prepared by electrolytic means or oxidation by ozone as the case required, in order to avoid the introduction of extraneous ions which might affect the results.

The solutions of $\mathrm{Pu}$ compounds $\left(\mathrm{PuCl}_{3}, \mathrm{PuCl}_{4}\right.$, and $\mathrm{PuO}_{2} \mathrm{Cl}_{2}$ ) were prepared directly in the absorption cell. The concentrations were generally of the order of $0.01 \mathrm{M}$. In a typical case, $4 \mathrm{ml}$ of saturated WIPP brine "A" (Table 9.6-1) was introduced into the optical cell and 
evaporated to dryness in a stream of nitrogen. After this operation, the proper amount of $\mathrm{Pu}$ compound was pipetted in the cell and evaporated to dryness with the salts from the WrPP brine.

The cell was attached to the vacuum line and evacuated until the pressure was $\sim 10^{-6} \mathrm{~atm}$. De-aerated water was then distilled under vacuum until the amount of solution equals that which originally pipetted into the cell.

These samples of various $\mathrm{Pu}$ compounds were examined from time to time observing any changes in intensity or wavelength of absorption peaks corresponding to the oxidation state in question.

The resulting samples prepared for measurement of changes in intensity of the optical absorption spectra are $\mathrm{Pu}(\mathrm{III}), \mathrm{Pu}(\mathrm{IV})$ and $\mathrm{Pu}(\mathrm{VI})$ in water, and in saturated WIPP brine solution.

No definite changes in absorption peaks corresponding to changes in oxidation state were observed. The Pu(IV) solutions were so dilute, because of precipitation from the hydrolysis of $\mathrm{Pu}(\mathrm{IV})$, that little or no characteristic absorption peaks could be observed at all. The Pu(III) solutions, whose absorption peak is at about $6000 \AA$, also showed little or no detectable change over the time interval of the experiment (2-4 months).

The $\mathrm{Pu}(\mathrm{VI})$ as $\mathrm{PuO}_{2} \mathrm{Cl}_{2}$, surprisingly, is insoluble in saturated WIPP brine. The level of solubility is so small that no absorption peaks could be seen at all. In order to be sure that this case is not one of very slow rate of solution, the sealed absorption cells are being rotated with periodic abosorption spectrum determinations.

Some absorption studies have already been carried out with $\mathrm{Pu(IV)}$ and Am(III) on anhydrite and dolomite from the WIPP site (see previous sections). 
Work is presently underway with the Argonne National Laboratory Analytical Chemistry Group to develop procedures for the determination of the oxidation potential of WIPP salt, dolomite and anhydrite slurries, particularly those employing oxidation-reduction indicators.

Crude reaction rates and $K_{D}$ values of $P u(I I I)$ and Am(III) with Magenta and Culebra dolomites in waters that have been equilibrated with the individual rock are in the table.

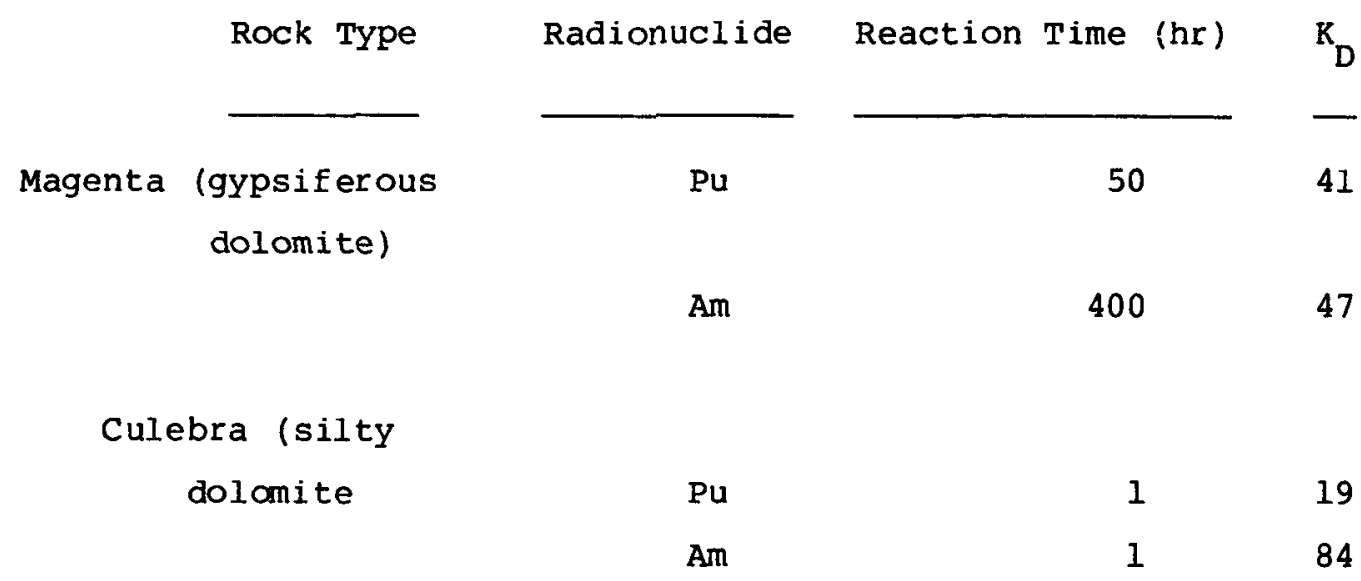

It should be understood that these reaction rates are crude and that the $K_{D}$ values are somewhat indeterminable because of varying quantities of radionuclides "plating out" on the walls of the containers. These experiments will be repeated as a function of temperature. Since these determinations were made on tablets of rock of known dimensions, the surface absorption coefficients can be calculated, these perhaps being more applicable to migration along fissures and cracks, where the surface absorption coefficient is

$$
s_{C}=\frac{\text { activity } / \mathrm{ml} \text { liquid }}{\text { activity/cm }{ }^{2} \text { solid }}
$$

The installation of a controlled atmosphere box has made it possible to study the absorption of the various oxidation states of $\mathrm{Pu}$ without the perturbing effects of atmospheric oxygen. 


\subsubsection{Summary}

A survey of the potential of geological media from the vicinity of the Waste Isolation Pilot Plant site in Southeastern New Mexico for retardation of radionuclide migration via an aqueous carrier has been completed. Solution simulants representing water in equilibrium with potash minerals or halite zones and a typical groundwater were spiked with radionuclides and contacted with geological samples to obtain sorption coefficients, Kd's. The samples were taken from potential aquifers above and below the repository horizons and from bedded salt deposits in the repository horizons. The nuclides chosen for study represent those with a high potential for leaching and/or migration, high radiotoxicity, or those with a chemistry similar to nuclides with the aformentioned properties. They included ${ }^{137} \mathrm{Cs},{ }^{85} \mathrm{Sr},{ }^{131} \mathrm{I},{ }^{99} \mathrm{Tc}$, ${ }^{125} \mathrm{Sb},{ }^{144} \mathrm{Ce},{ }^{152} \mathrm{Eu},{ }^{153} \mathrm{Gd},{ }^{106} \mathrm{Ru},{ }^{243} \mathrm{Am},{ }^{244} \mathrm{Cm}$ and ${ }^{238} \mathrm{Pu}$.

A very general summation of the $\mathrm{Kd}$ results in brine simulants is as follows: Anionic species, $\mathrm{TCO}_{4}{ }^{-}$and $\mathrm{I}^{-}$, showed little or no tendency to adsorb on any of the geological media (Kd's $\leq 1$ ), with the possible exception of a clay material from a halite stratum (Kd < 5). Cs and $\mathrm{Sr} \mathrm{Kd's}$ were also generally less than 1 , but values in the range of 10-20 were observed on several minerals. Ru Kd's ranged from 25 to $>10^{3}$, depending on the brine and geological materials. The lanthanide and actinide Kd's were typically $>10^{3}$, with only polyhalite showing significantly lower adsorption.

In the groundwater simulant, TC and I showed the same behavior. The Kd's of the other nuclides were slightly higher, particularly those of Cs and Sr. This would be expected if the sorption were due to an ion exchange mechanism, but, in the case of the Ianthanides and actinides, may also result from an increased contribution of hydrolysis to the $\mathrm{Kd}$ due to the higher $\mathrm{pH}$ of the groundwater simulant. 
Important parameters in Kd measurements include solid sample form, simulant compositon, Eh and $\mathrm{pH}$, and radionuclide concentration. In the Kd survey measurements, an initial set of these parameters was selected and, wherever possible, was used throughout the work. Parametric studies with Eu involving $\mathrm{pH}$, trace organic constituents in the simulant solutions, and radionuclide concentrations have shown that significant differences in Kd's can be observed by varying any of those parameters.

A general observation which can be made from data obtained to date is that a Kd represents an empirical value for nuclide adsorption, which includes the effects of physical adsorption, ion exchange, and hydrolysis or other precipitation processes. The utility of a given kd value is unambiguous only for that set of conditions used in making the measurement. Kd information which is used in modeling radionuclide migration should be in the form of a range of values generated in parametric studies under the variety of conditions postulated for a specific repository site.

For the WIPP site, rock salt, anhydrite, polyhalite and water-bearing dolomites and sandstones show an affinity for radionuclide sorption. Sorptive capacity as measured by batch Kd experiments generally expressed $\mathrm{Kd}>0$. Even small values of $K d(0<\mathrm{Kd}<1)$ are effective in retarding the movement of radionuclides in groundwater. 


\subsection{REFERENCES}

Acton, R.V., 1977, Thermal conductivity of SE New Mexico rocksalt and anhydrite: unpublished Sandia Laboratories preliminary report.

Amphlett, C.B., 1964, Inorganic Ion Exchangers, Elsevier, Amsterdam.

Baar, C.A., 1977, Applied Salt-Rock Mechanics 1: Elsevier Scientific, New York.

Bradshaw, R.L. and McClain, W.C., 1971, Project salt Vault, a demonstration of the disposal of high-activity solidified waste in underground salt mines: Oak Ridge National Laboratories \#4555.

Buerger, M.J., 1930, Translation-gliding in crystals of the $\mathrm{NaCl}$ structural type: Am. Mineralogist, v. 15, p. 174-187; p. 226-238.

Callender, J.F. and Ingwe11, T., 1977, Structural Petrology of Undeformed and Experimentally Deformed Halite samples from USERDA Site \#7 and \#9, Report, SAND78-7076, Department of Geology, University of New Mexico.

Carter, N.L. and Heard, H.C., 1970, Temperature and rate dependent deformation of halite: Amer. Jour. Sci. 269, 193.

Clabaugh, P.S., 1962, Petrofabric study of deformed salt: Science, v. 136 , p. 389-391.

Core Laboratories, 1977, Special core analysis study for Sipes, Williamson and Aycock, unpubl. consulting report to Sandia Laboratories by Sipes, Williamson and Aycock, Inc.

Dawson, P.R. and Tillerson, J.R., 1977, Comparative evaluations of the thermomechanical responses for three high level waste canister emplacement alternatives: Report, SAND77-0388, Sandia Laboratories.

Dreyer, W.E., 1974, Results of recent studies on the stability of crude oil and gas storage in salt caverns. 4 th Symp. on Salt, A. H. Coogan, Ed.

Dreyer, W., 1972, The Science of Rock Mechanics: Trans. Tech. Publ. Cleveland, Ohio.

Elliot Geophysical Company, 1976, A laboratory investigation of the density and resisitivity physical properties of drill core sample ERDA \#9: consulting report to Sandia Laboratories.

Fossum, A.F., 1977, On the structural behavior of progressively mined solution cavities in salt, Journal of Applied Mechanics, v. 44, Series E, No. 4 , p. 565-570.

Garrels, R.M. and Christ, C.L., 1965, "Solutions, Minerals and Equilibria," Freeman, Cooper \& Co., San Francisco. 
Gnirk, P.F., Pariseau, W.G., Russel, J.E., Wawersik, W.R., and Hovland, H.V., 1973, Analysis and evaluation of the rock mechanics aspects of the proposed salt mine repository: Report, RSI-005, RE/SPEC, Inc.

Griswold, G.B., 1977, Site selection and evaluation studies of the waste isolation pilot plant (WIPP), Los Medanos, Eddy County, New Mexico: Sandia Laboratories report 77-0946, Albuquerque, New Mexico.

Hansen, F.D. 1977, Triaxial Quasi-Static Compression and Creep Bahavior of Bedded Salt from Southeastern New Mexico: Technical Memorandum Report RSI-0055, For Sandia Laboratories, Albuquerque, New Mexico.

Hansen, F.D., and Gnirk, P.F., 1975, Design Aspects of Radioactive Waste Repository: III Uniaxial Quasi-static and Creep Properties of the Site Rock, Tech. Memorandum Report RSI-0029.

Hansen, F.D. and Mellegard, K.D., 1977, Creep behavior for bedded salt from southeastern New Mexico at elevated temperatures: Tech Memo to Sandia Laboratory, RSI-0062, Albuquerque, New Mexico.

Heard, H.C., 1972, Steady-state flow in polycrystalline halite at pressure of $2 \mathrm{~Kb}$ : Geophys. Monograph Series, p. 16, 191, 1972.

Hirth, J.P. and Lothe, H., 1968, Theory of dislocations: New York, McGraw-Hill, 780 p.

Hofer, K.H. and Thomas, K., 1968, Triaxial tests on rock salt: Int. J. Rock Mech. Min. Sci., 5, 195.

Kent, D., and Wawersik, W.R., 1976, Laboratory velocity measurements on rock salt core samples: Sandia Laboratories interoffice memo, Albuquerque, New Mexico.

Kopp, O.D., and Combs, D.W. 1975, Mineral sources of water in evaporite sequences, Report, ORNL subcontract No. 3670, Dept. of Geol. Sci., Univ. of Tennessee.

Lambert, S.J., 1977, "The Geochemistry of Delaware Basin Groundwaters," SAND77-0420.

Langer, M., 1969, Rheologie der Gesteine, z deutsch. geol. Ges., 119.

Le Comte, P., 1965, Creep of rock salt: J. Geol., 73, 469.

Levy, H.B., 1972, "On Evaluating the Hazards of Groundwater Contamination by Radioactivity from An Underground Nuclear Explosion," Lawrence Livermore Laboratory Rept. UCRL-51278.

Menzel, w. and Schreiner, W., 1977, Zum Geomechanischen verhalten von steinsalz verschiedener lagerstatten der DDR, Teil II: das Verformungsverhalten: Neue Bergbautechnik, 7, 585. 
Mraz, D., 1978, Theoretical predictions confirmed by in-situ rock behavior in a deep potash mine: in 19th U.S. Rock Mechanics Symp., ed Y.S. Kim, Reno, Nevada.

Russel, J.E., 1978, A Creep Model for Rock Salt, Fifth Int. Salt Symps., Hamburg, Germany.

Schlichta, P.J., 1969, Growth, deformation, and defect structure of salt crystals: Geol. Soc. Am., Sp. Paper 88, 598.

Schmidt, W., 1937, Festigkeit and Verfestigung von Steinsalz: Zeitschr. Angew. Min., 1., 1.

Serata, S., 1966, Continuum theory and model of rock salt structure: in second symposium on salt, ed Jon L. Rau, Cleveland, Ohio.

Serata, S., 1968, Application of continuum mechanics to design of deep potash mines in Canada: Int. J. Rock Mech. Min. Sci., 5:293-314.

Serata, S., 1970, Prerequisites for application of finite-element method to solution cavities and conventional mines: in Third symposium on Salt, ed., J.L. Rau and L.F. Dellwig, Cleveland Ohio.

Serata, S., 1972, The Serata stress control method of stabilizing undergound openings: Proc. 7 Can. Rock Mech. Symp. Edmonton, March 1971, pp. 99-118.

Serata, S., and Cundey, T.E., 1978, Rheological method of salt county design for underground storage of solid liquid, and gaseous matters: in 19 th U.S. Symp. on Rock Mech. ed. Y.S. Kim, Reno, Nevada.

Serata, S., Sakuri, S., and Adachi, T., 1972, Theory of aggregate rock behavior based on absolute three-dimensional testing (ATT) of rock salt: in Basic and Applied Rock mechanics, Proc. 10th U.S. Symp. Rock Mech., K.E. Gray (ed.), AIME.

Shelby, J.E., 1978, Permeability of Sodium Cloride: Sandia Laboratories interoffice memo, Albuquerque, New Mexico.

St. John, C.M., 1978, Computer models and the design of underground radioactive waste repositories, M.I.T. Special Summer Session on Rock Engineering, June 1978.

Sutherland, H.J., 1978, Permeability of SENM rock salt: Sandia interoffice memo, Albuquerque, New Mexico.

Szeki, A, 1978, Influence of Volume on Creep Behavior of Rocksalt Pillars, Fifth. Int. Salt Sympos., Hamburg, Germany.

Terra Tek Inc., 1978, Gas permeabilities of SENM salt: consulting memo to Sandia Laboratories, Albuquerque, New Mexico. 
Thompson, E., and Ripperger, E.A., 1964, An Experimental Technique for the Investigation of the Flow of Halite and Sylvinite, Proc. 6th Symp. Rock Mech., E.M. Spokes and C.R. Christiansen, eds., AIME.

Thoms, R.L., Char, C.V., and Bergeron, W.J., 1973, Finite Element Analysis of Creep in Rock-Salt Pillar Models, Proc. $14 \mathrm{th}$, Symp. Rock Mech., H.R. Hardy and R. Stefanko eds., AIME.

Uhlenbecker, F.W., 1968, Verformungsmessungen in der Grube und erganzende Laboruntersuchungen auf dem Kaliwerk Hattorf (Werra-Revier) im Hinblick auf eine optimale Festlegung des Abbauverlustes bei grobtmoglicher Sicherheit der Grubenbaue, PhD Thesis, TH Clausthal.

U.S. Corps. of Engineers, 1963, Project Dribble, Petrographic examination and physical tests of cores, Tatum Salt Dome, Mississippi: Army Engineers Waterway Experiment Station, Techn. Rep. No. 6-614.

Wahi, K.K., Maxwell, D.F., Hofmann, 1978, Explicit finite-difference simulations of Project Salt Vault: in 19th U.S. Rock Mech. Symp., ed. Y.S. Kim, Reno, Nevada.

Wawersik, W.R. and Brown, W.s., 1973, Creep Fracture of Rock, Techn. Report UTEC 73-197, Univ. of Utah,

Wawersik, W.R., 1975, Technique and apparatus for strain measurements on rock in constant confining pressure experiments. Rock Mech. v. 7, 231.

Wawersik, W.R., 1977, Sandia Laboratories Albuquerque, New Mexico, Inter office memos, August and November.

Wawersik, W.R., 1978a, Large specimen triaxial apparatus for rock testing to $70 \mathrm{MPa}$ confining pressure and $2250^{\circ} \mathrm{C}$ : to be published.

Wawersik, W.R., 1978b, Effects of pressure, deviator stress and temperature on transient creep of rock salt at low confining pressure: AGU, Vol 59 No. 4, Apr. 78 p. 376.

Wawersik, W.R., 1978c, Sandia Laboratories, Albuquerque, New Mexico, Inter Office Memo, January.

Wawersik, W.R., Callender, J.F., Weaver, R., and Dropek, R.K., 1976, Preliminary determination of mechanical properties on rock salt from southeastern New Mexico. Pre-Proc., 17th U.S. Symp. Rock Mech., Univ. Utah Exp. St..

Wawersik, W.R. and Hannum, D.W., 1978, Mechanical behavior of New Mexico rock salt in triaxial compression up to 2000C: 5th Int'1 Salt Symp. Hamburg, Germany, June 1978. 


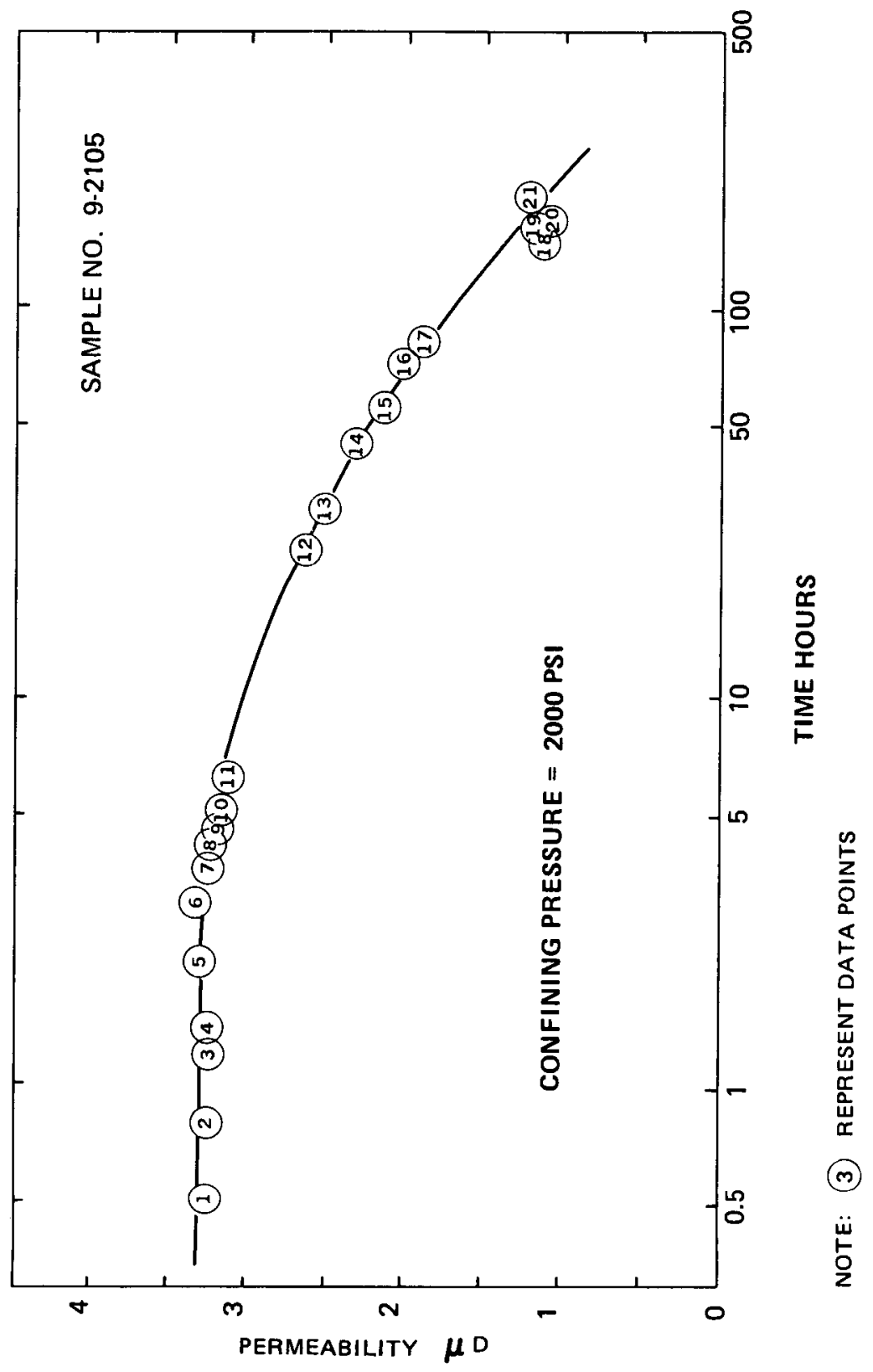

ARGON PERMEABILITY OF ROCK SALT SAMPLE AT 2000 PSI CONFINING PRESSURE 


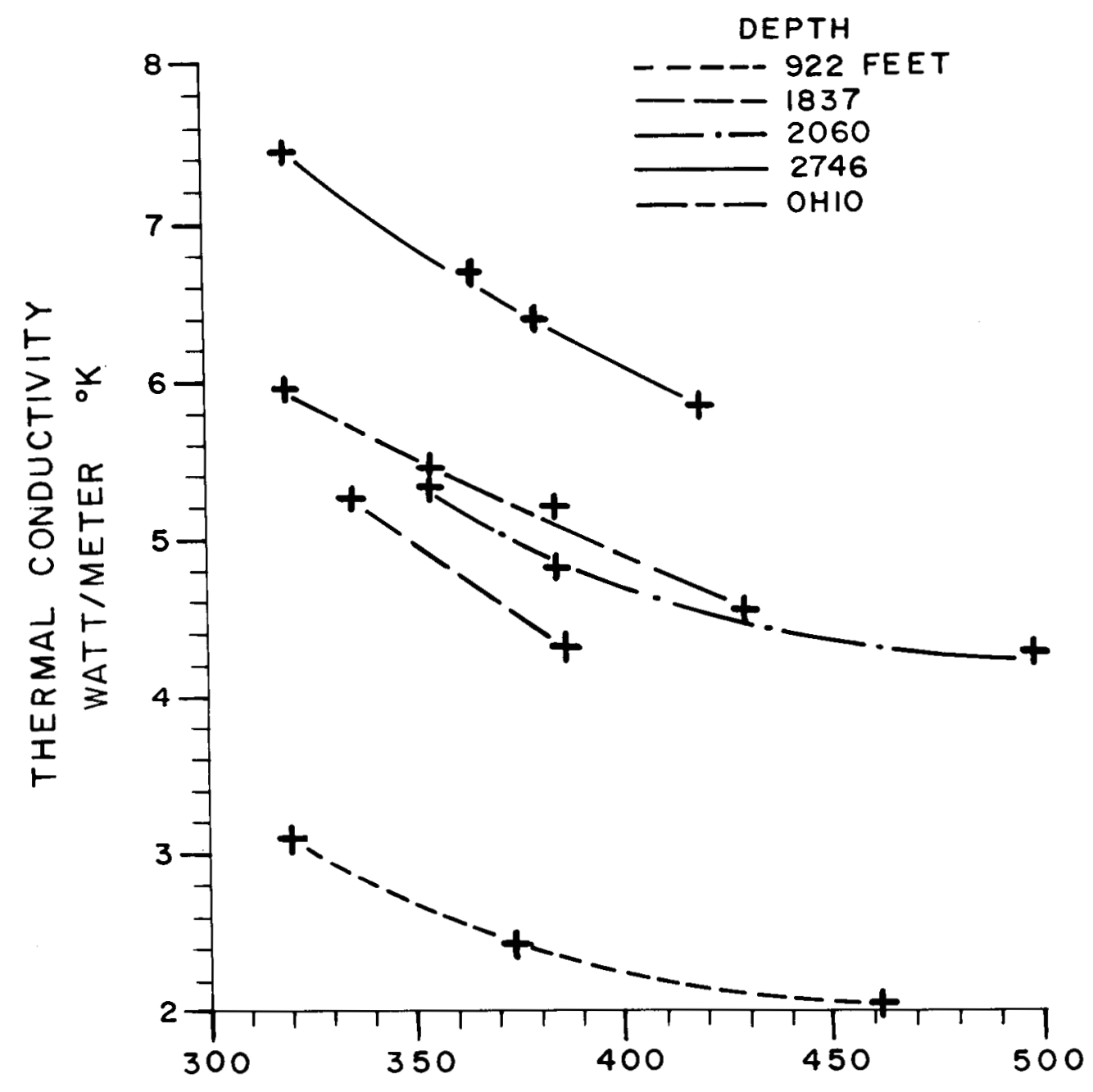

TEMPERATURE ${ }^{\circ} \mathrm{K}$.

THERMAL CONDUCTIVITY OF ROCKSALT CORE SECTIONS CONTAINING 50\% OR MORE HALITE, WELL AEC 8

From: Acton, 1977 


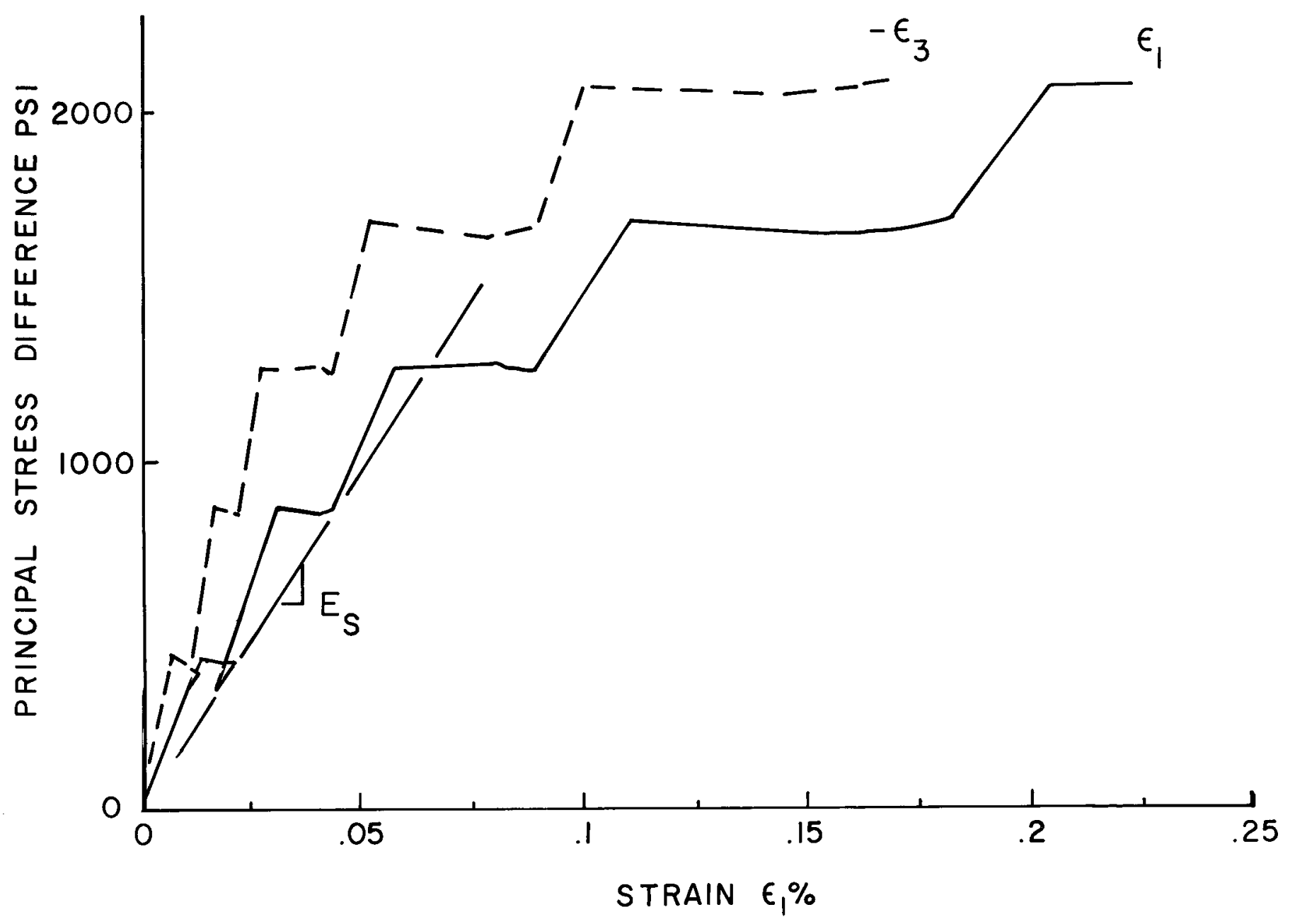

KEY

ニ-ーーー $7-2745(3.0,23)$

Hole No. - Sample depth in ft. (Conf. pressure in ksi, Temp. in ${ }^{\circ} \mathrm{C}$ )

TRIAXIAL STRESS-STRAIN CURVES IN

REGIME OF SMALL PRINCIPAL STRESS DIFFERENCES

$$
\text { AND STRAIN }
$$

From: Wawersik and Hannum, 1978

FIGURE $\quad 9.2 .4-1$ 


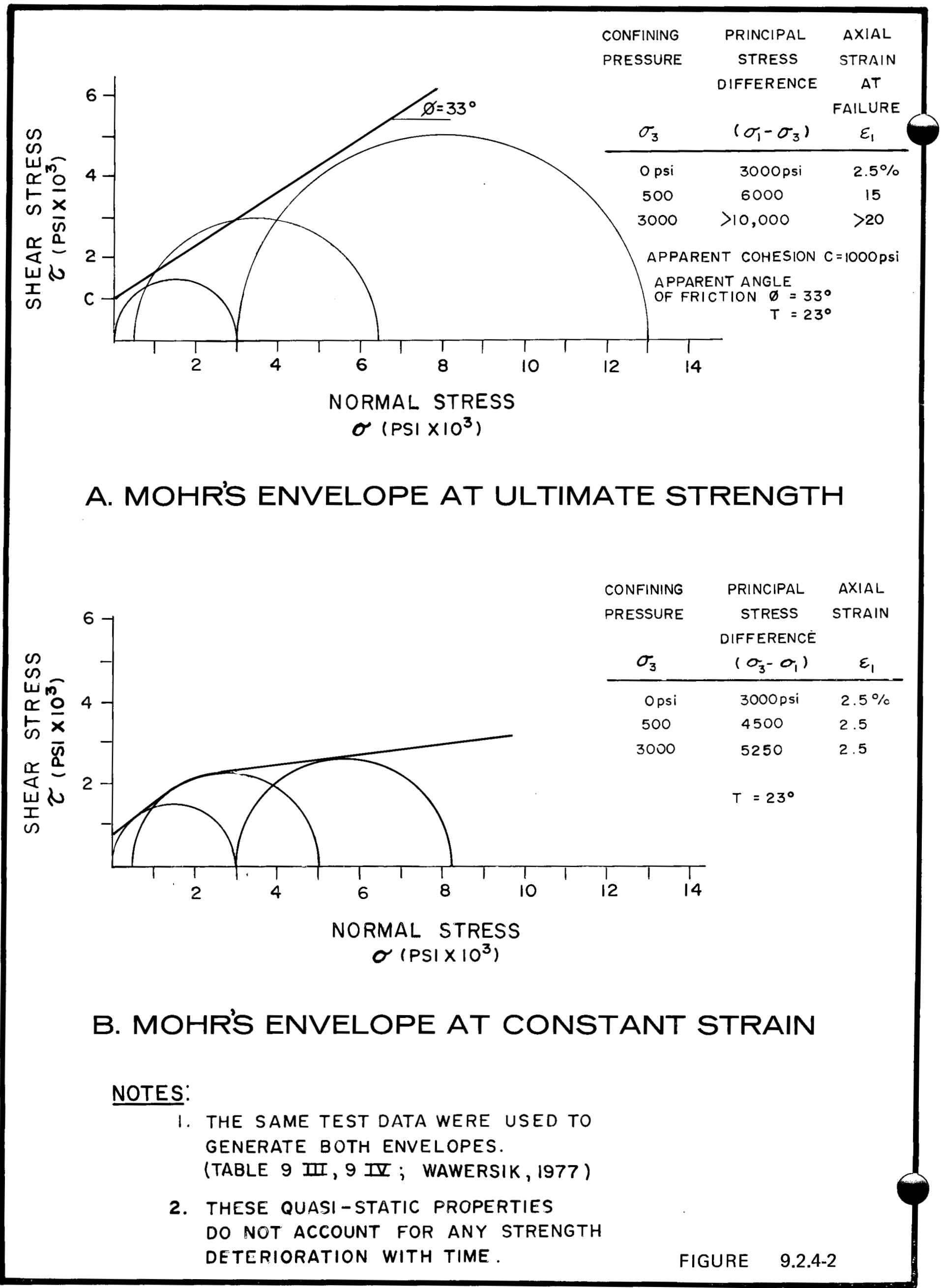




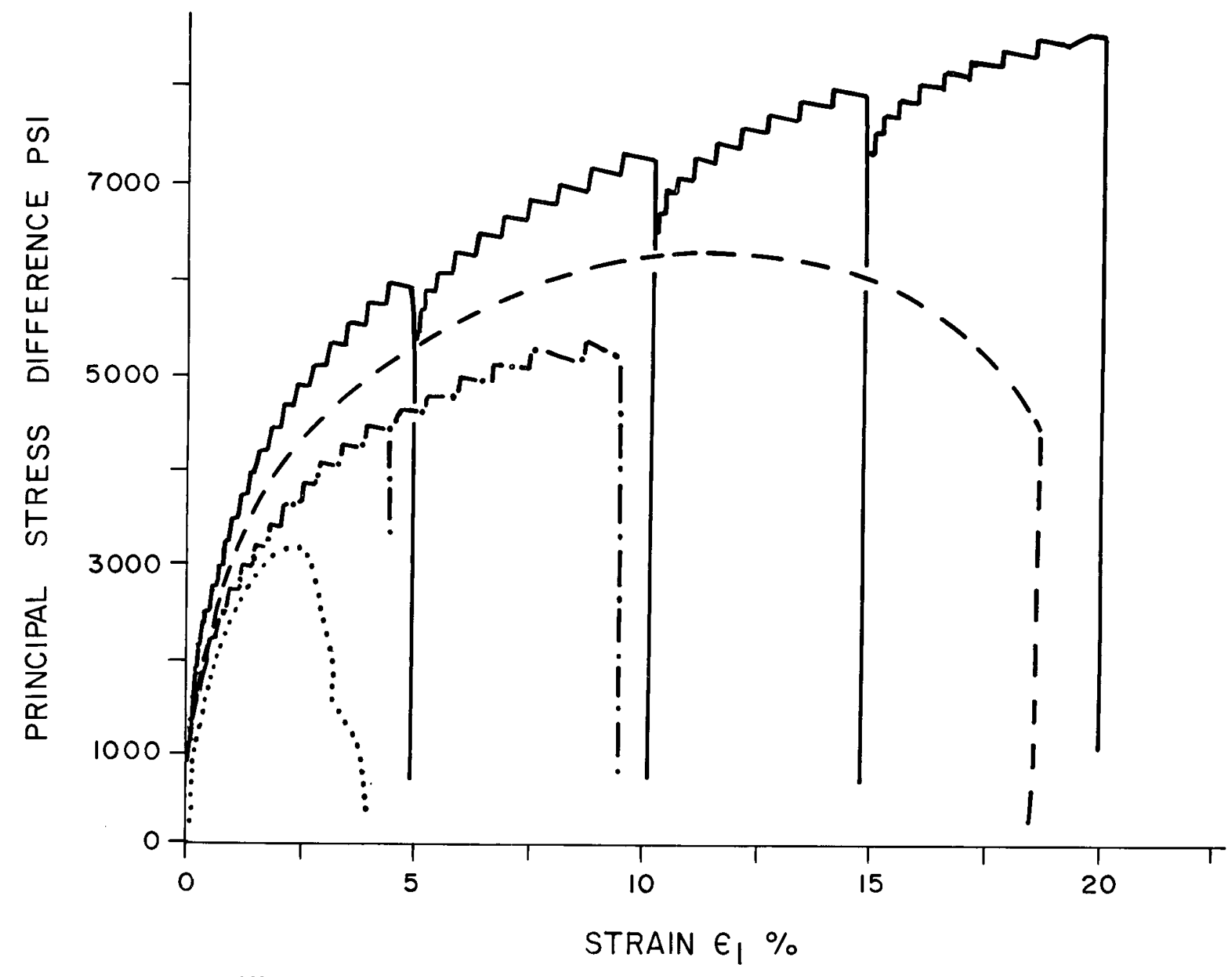

KEY

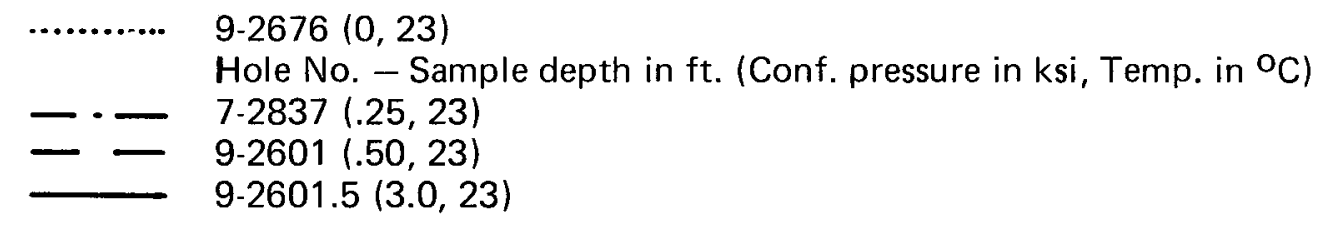

CONVENTIONAL QUASI-STATIC TRIAXIAL

STRESS-STRAIN DATA AT AMBIENT TEMPERATURE EFFECT OF PRESSURE

From: Wawersik and Hannum, 1978. 


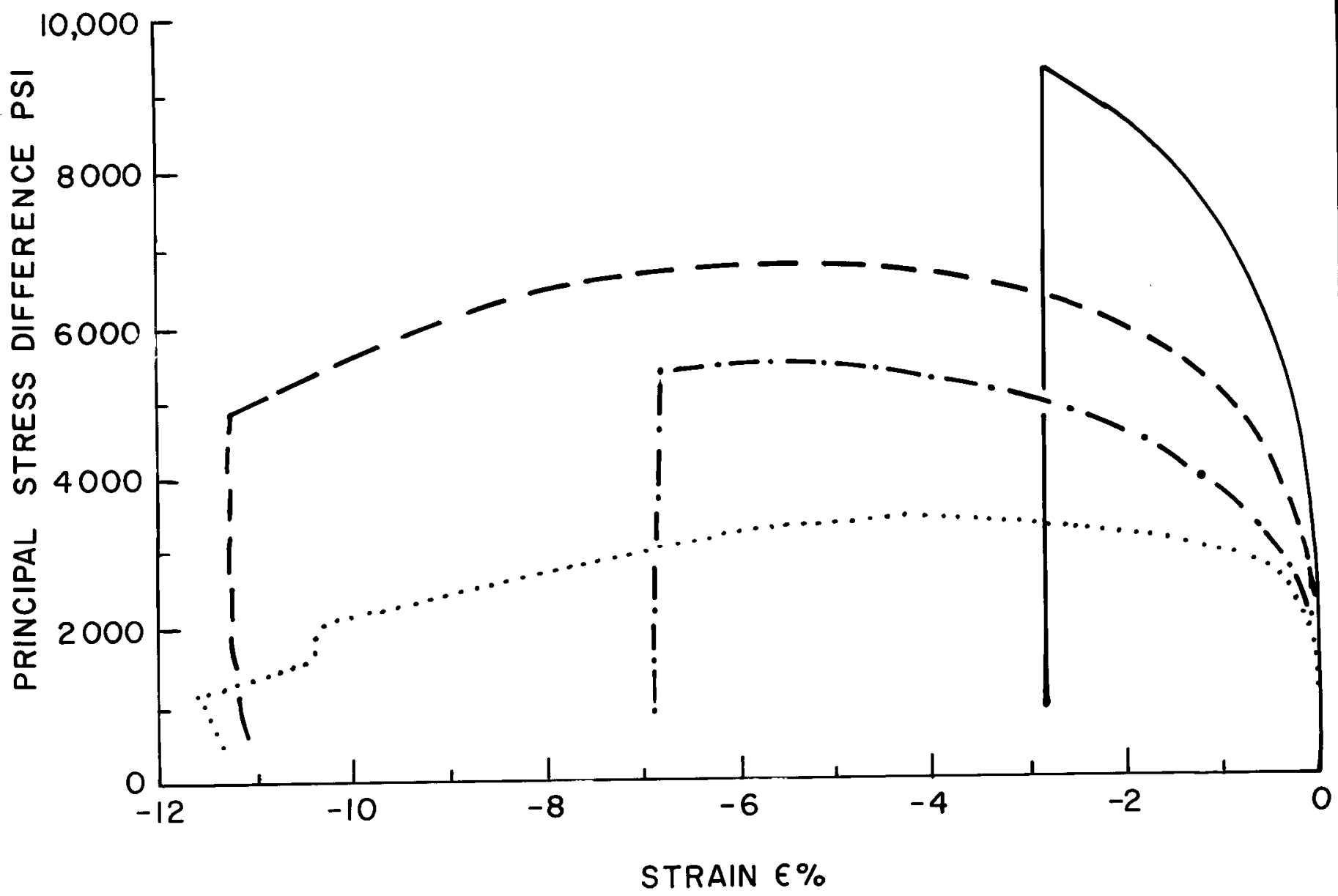

KEY

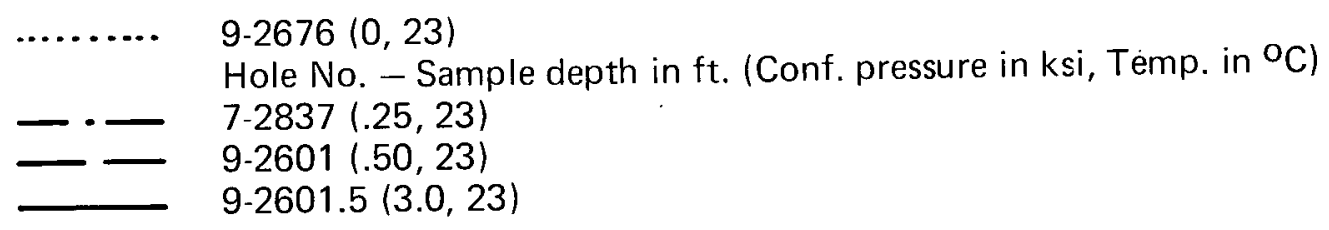

PRINCIPAL STRESS DIFFERENCE VS. VOLUMETRIC STRAIN FOR TEST OF FIGURE 9.2.4-3 


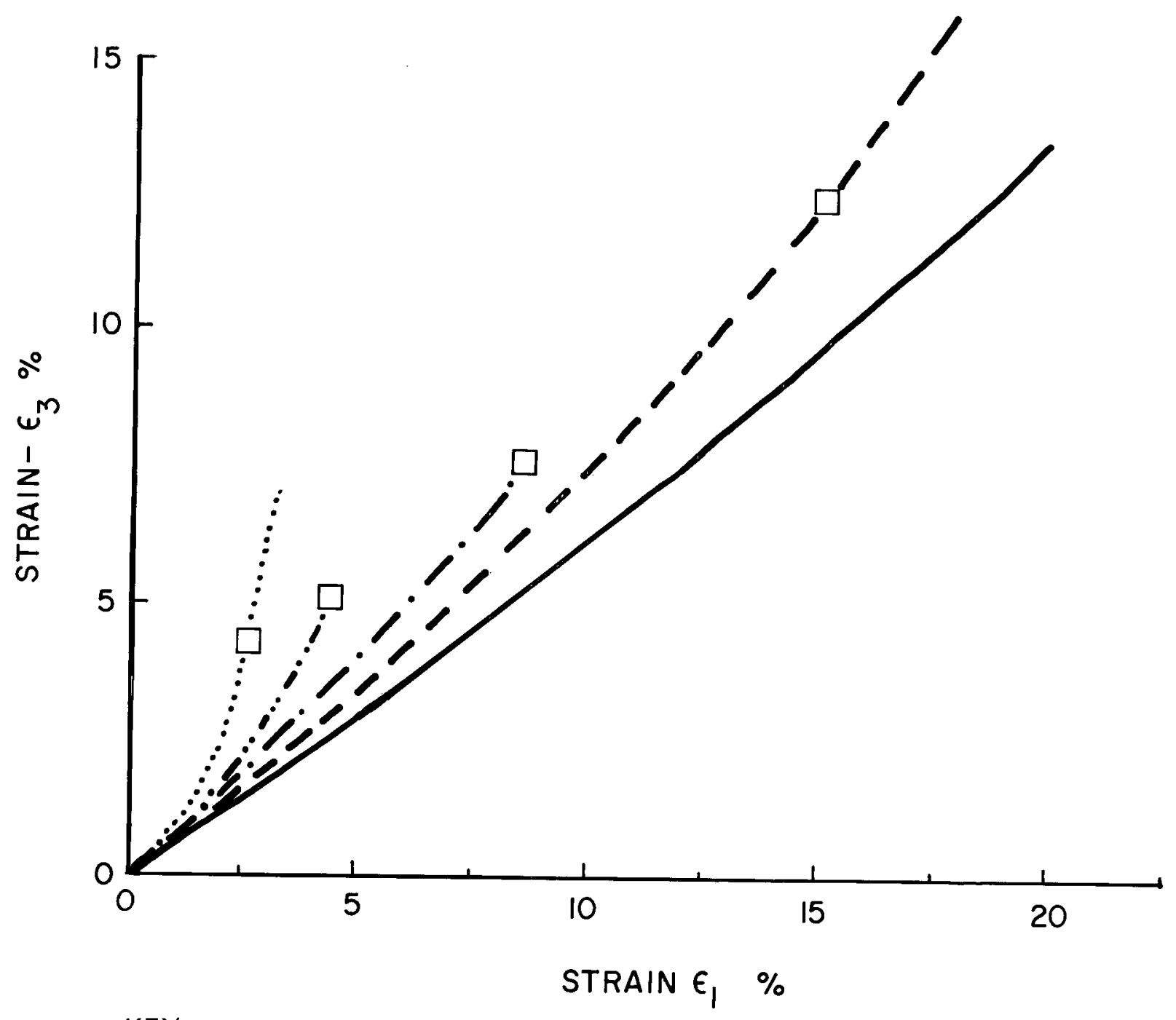

KEY

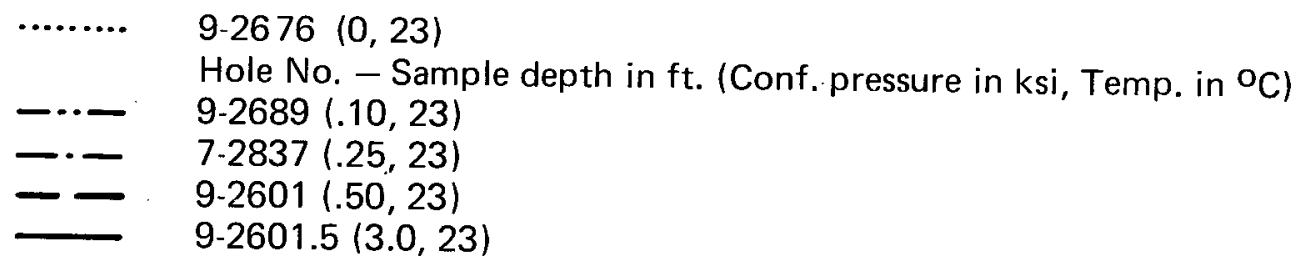

NOTE: Open squares identify approximate strains at ultimate stresses.

TRIAXIAL VARIATION OF LATERAL STRAIN VS. AXIAL STRAIN FOR TEST OF FIGURE 9.2.4-3 


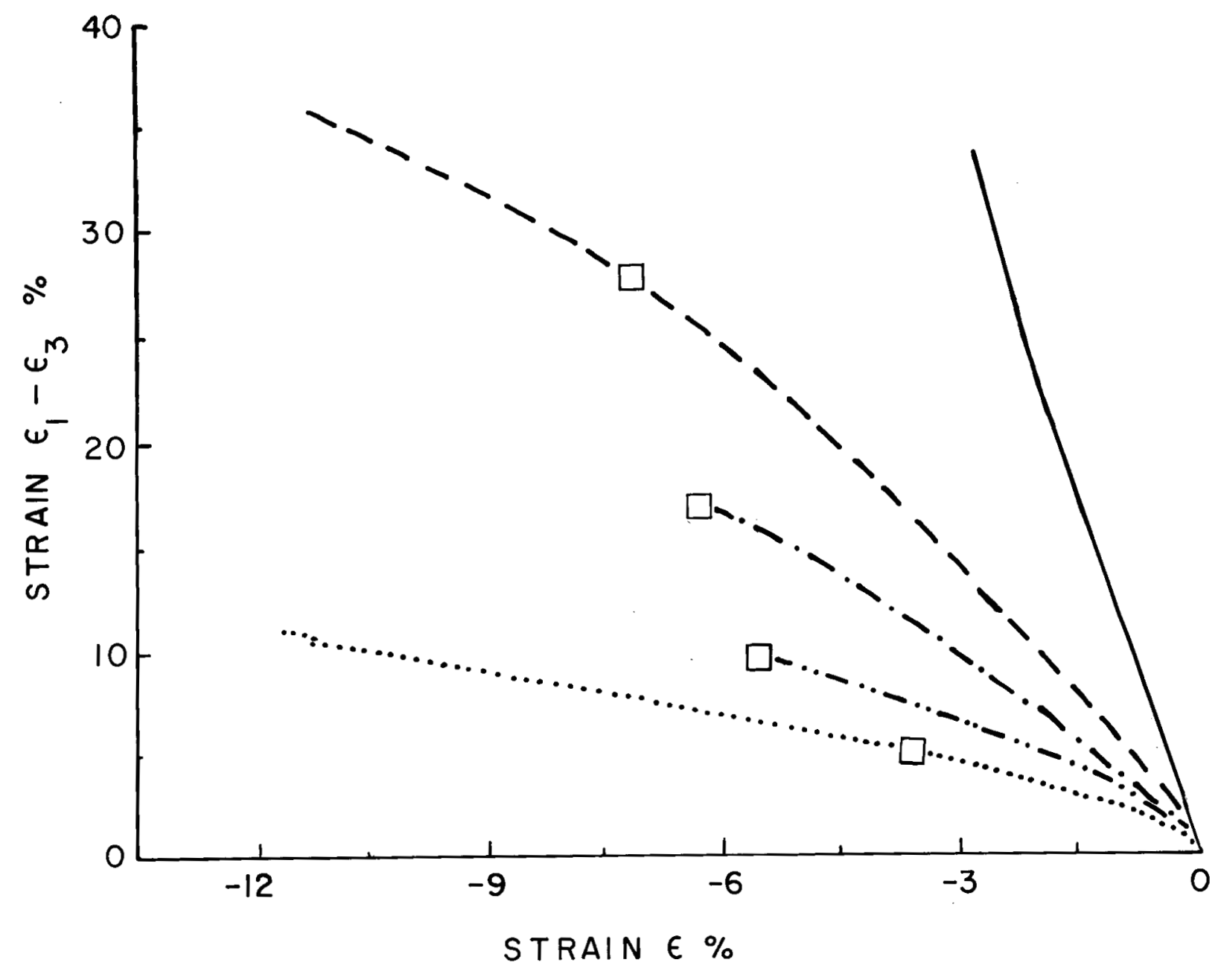

KEY

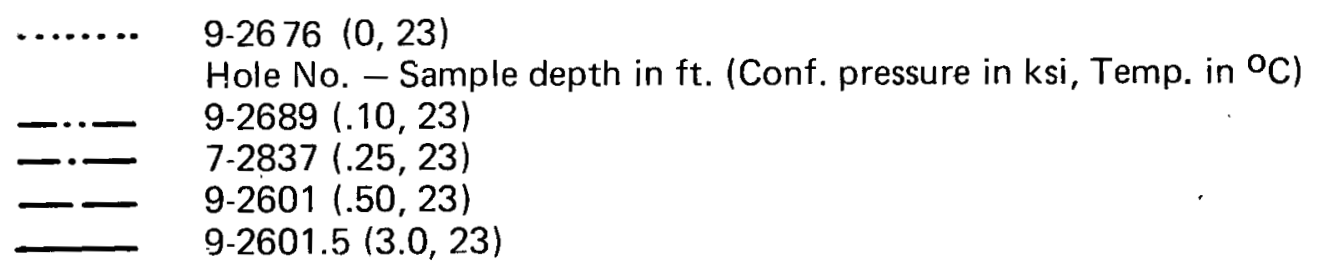

NOTE: Open squares identify approximate strains at ultimate stresses.

\section{TRIAXIAL VARIATION OF SHEAR STRAIN VS}

VOLUMETRIC STRAIN FOR TESTS OF FIGURE 9.2.4-3 


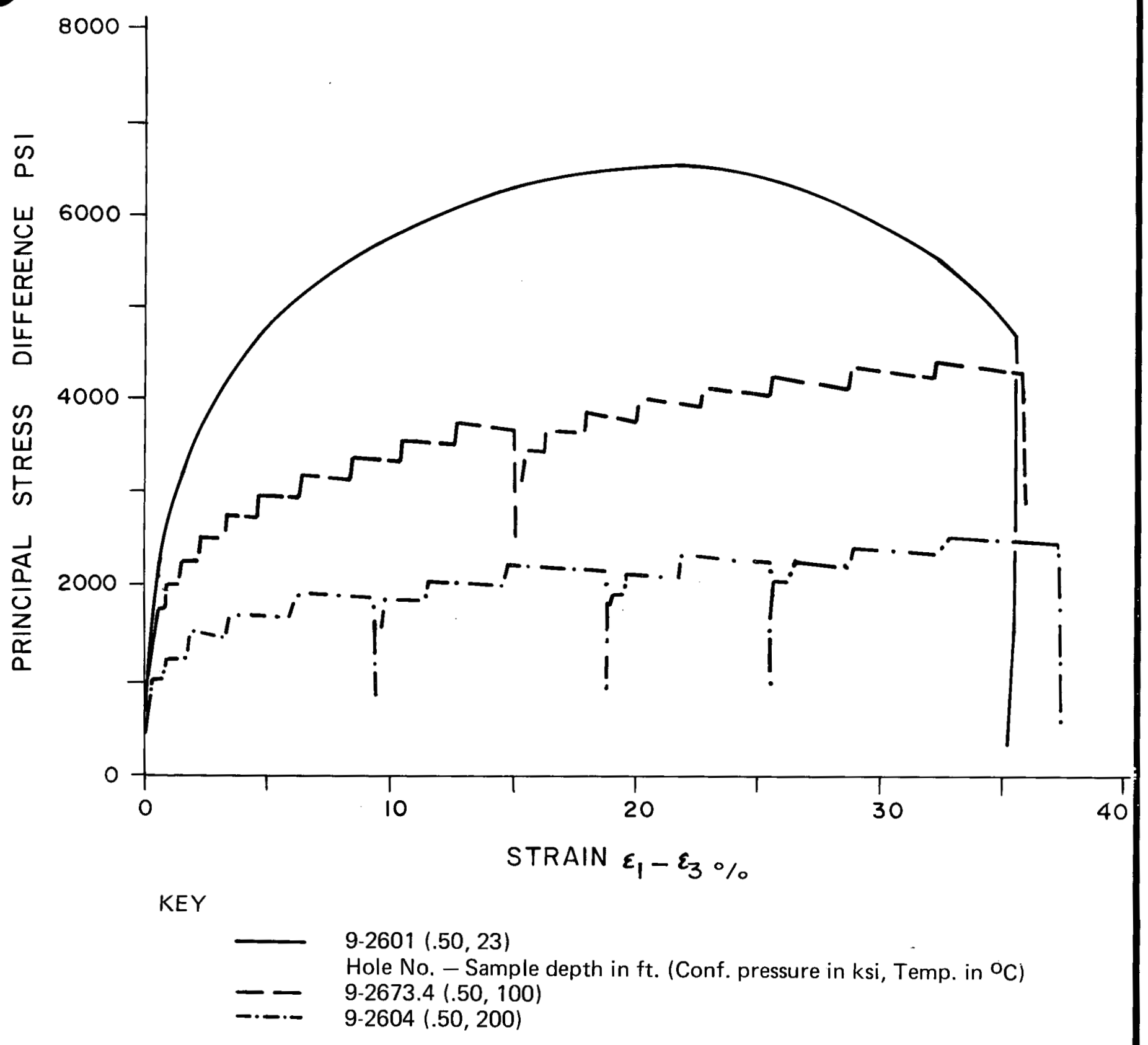

\section{TRIAXIAL STRESS-STRAIN CURVES AS A FUNCTION} OF TEMPERATURE AT CONSTANT CONFINING PRESSURE 


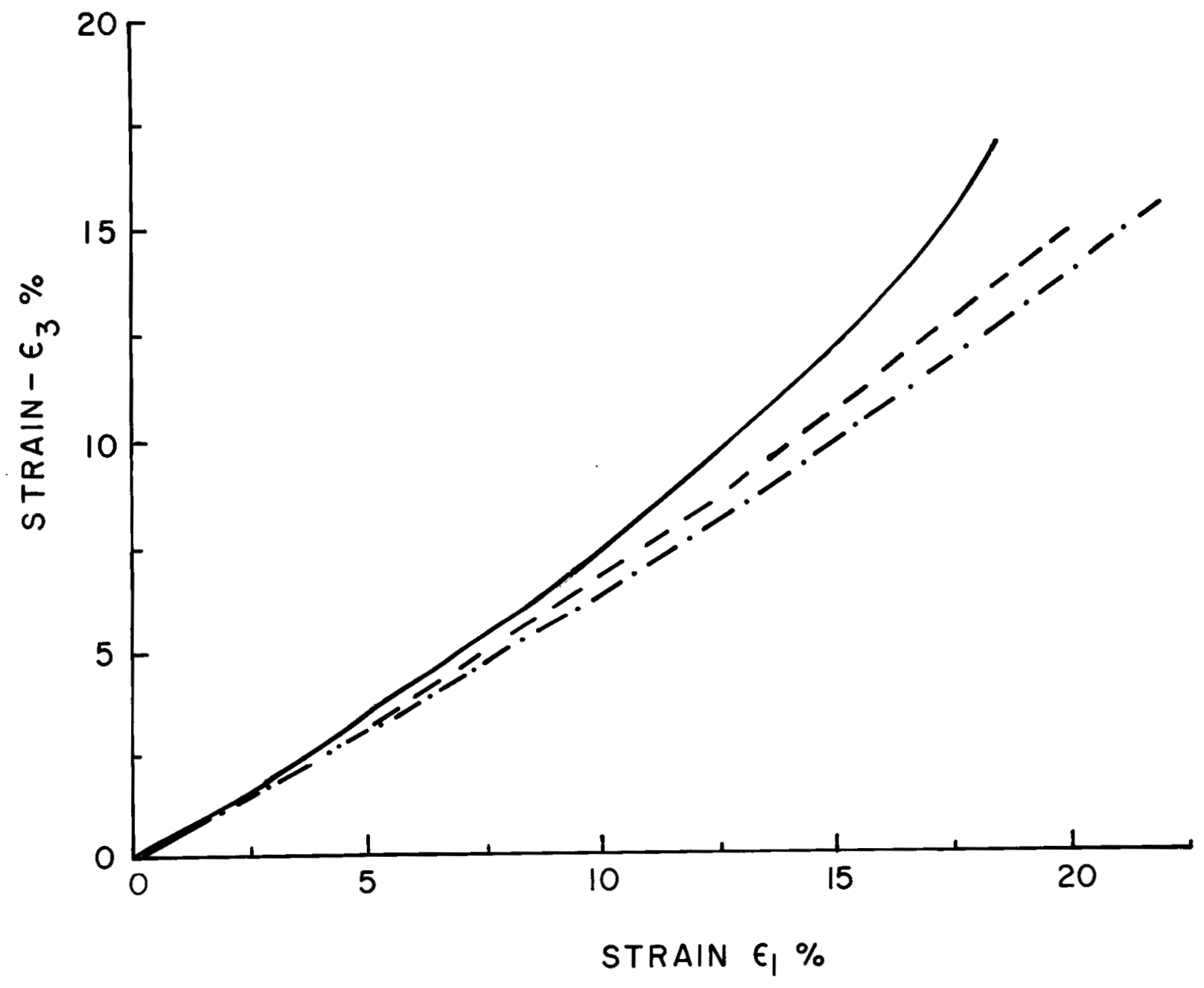

KEY

- $9-2601(.50,23)$

Hole No. - Sample depth in $\mathrm{ft}$. (Conf. pressure in ksi, Temp. in ${ }^{\circ} \mathrm{C}$ )

- $9-2673.4(.50,100)$

-.. $9-2604(.50,200)$

\section{VARIATION OF LATERAL VS. AXIAL STRESS FOR TESTS OF FIGURE 9.2.4-7}




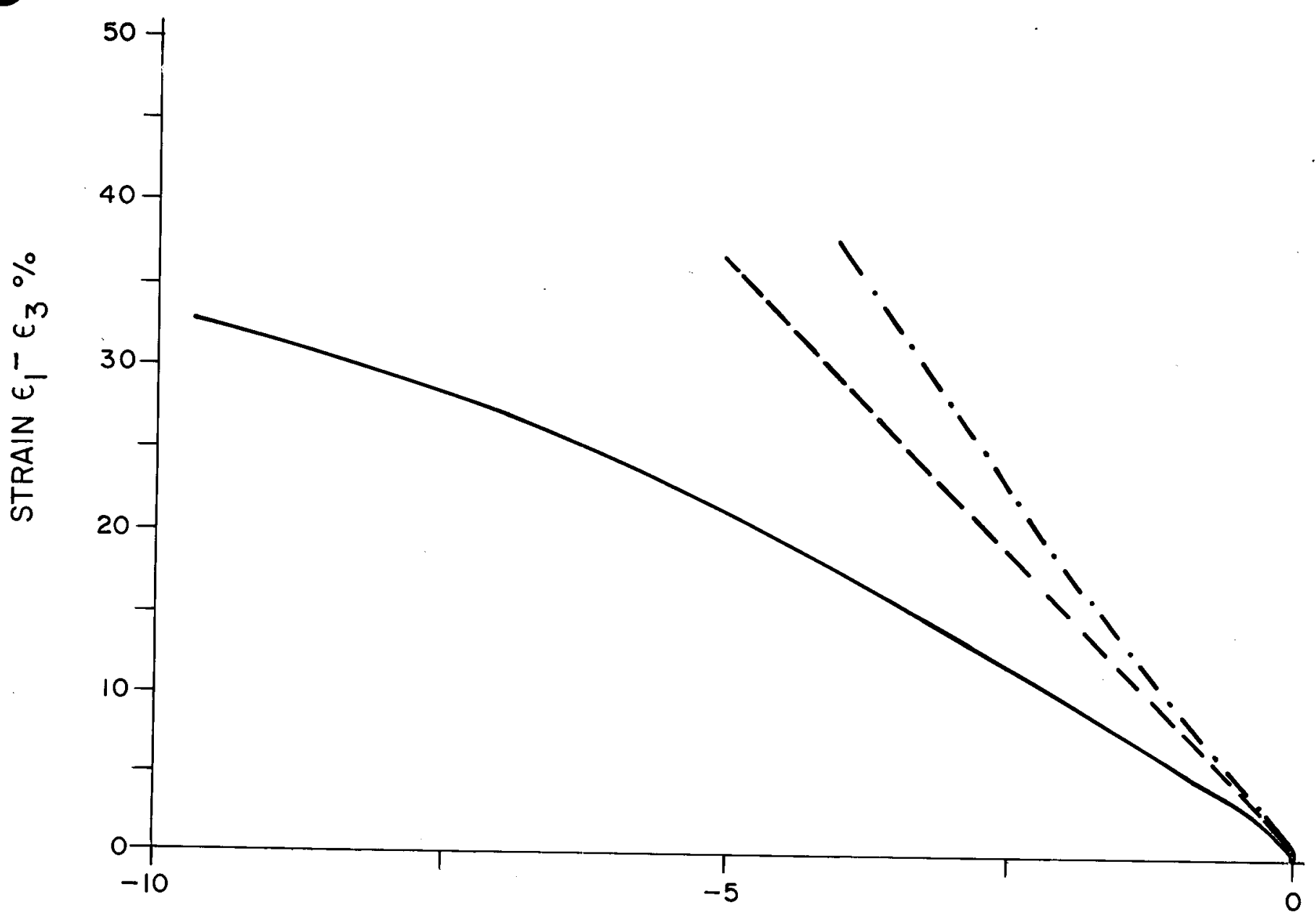

STRAIN E \%

KEY

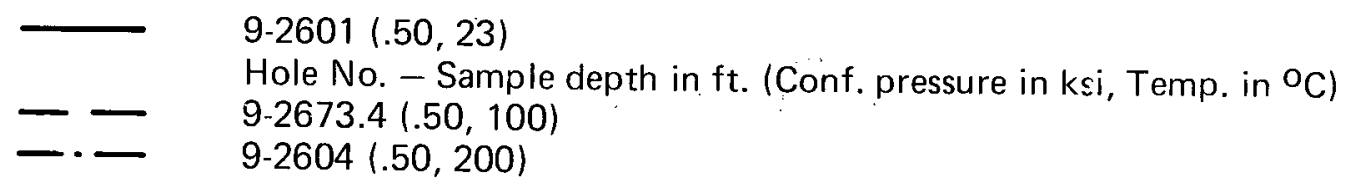

VARIATION OF SHEAR-STRAIN VS. VOLUMETRIC STRAIN FOR TESTS OF FIGURE 9.2.4.7

From: Wawersik and Hannum, 1978

FIGURE 9.2.4-9 


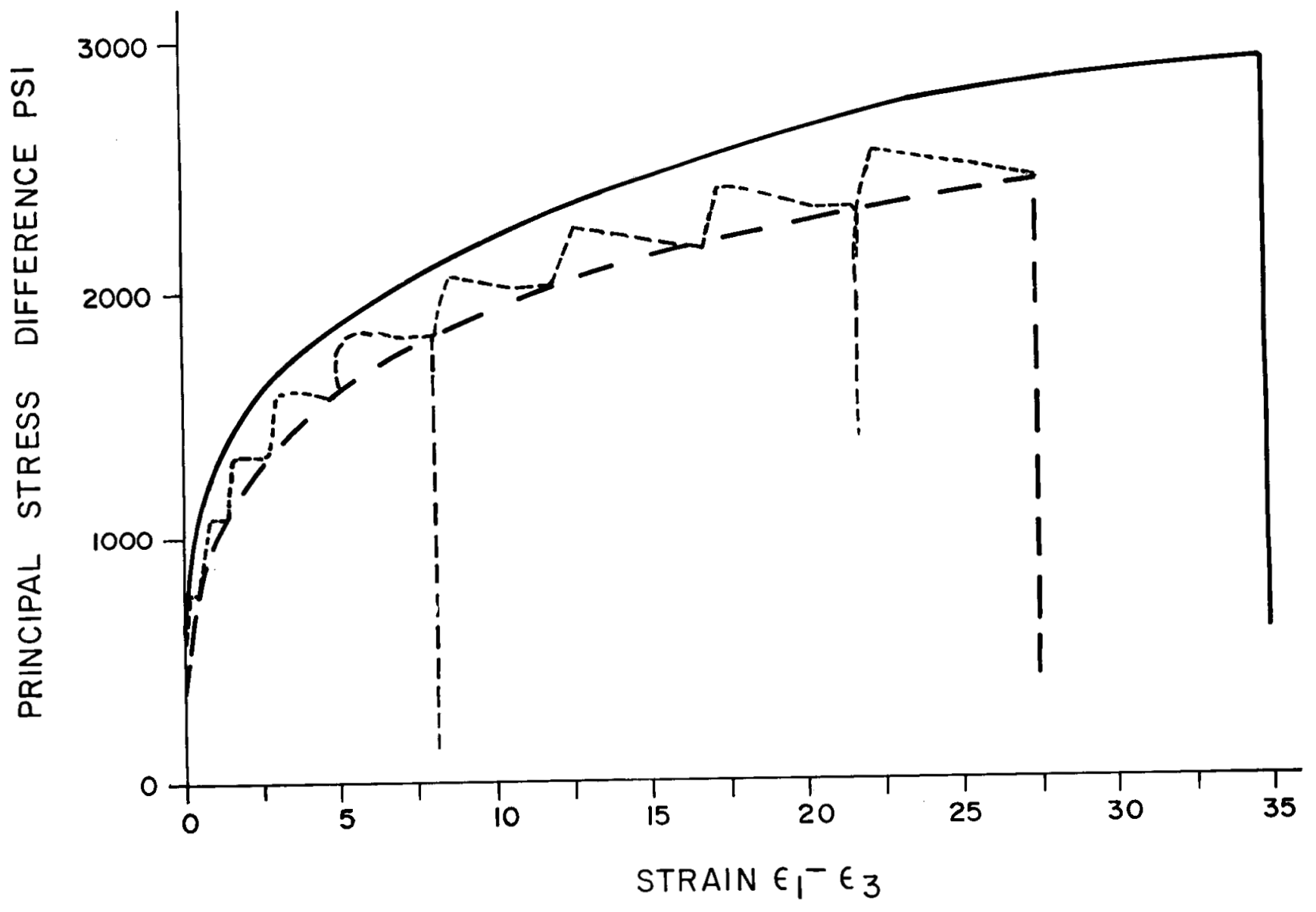

KEY

$-\quad 7-2740(.50,200)$

Hole No. - Sample depth in $\mathrm{ft}$. (Conf. pressure in ksi, Temp. in ${ }^{\circ} \mathrm{C}$ )

$\begin{array}{ll}\text { 7-2744 }(3.0,200) \\ --\infty & \text { Actua! ioad path }\end{array}$

TRIAXIAL STRESS STRAIN CURVES AS A FUNCTION OF CONFINING PRESSURE AT $200^{\circ} \mathrm{C}$

From: Wawersik and Hannum, 1978 


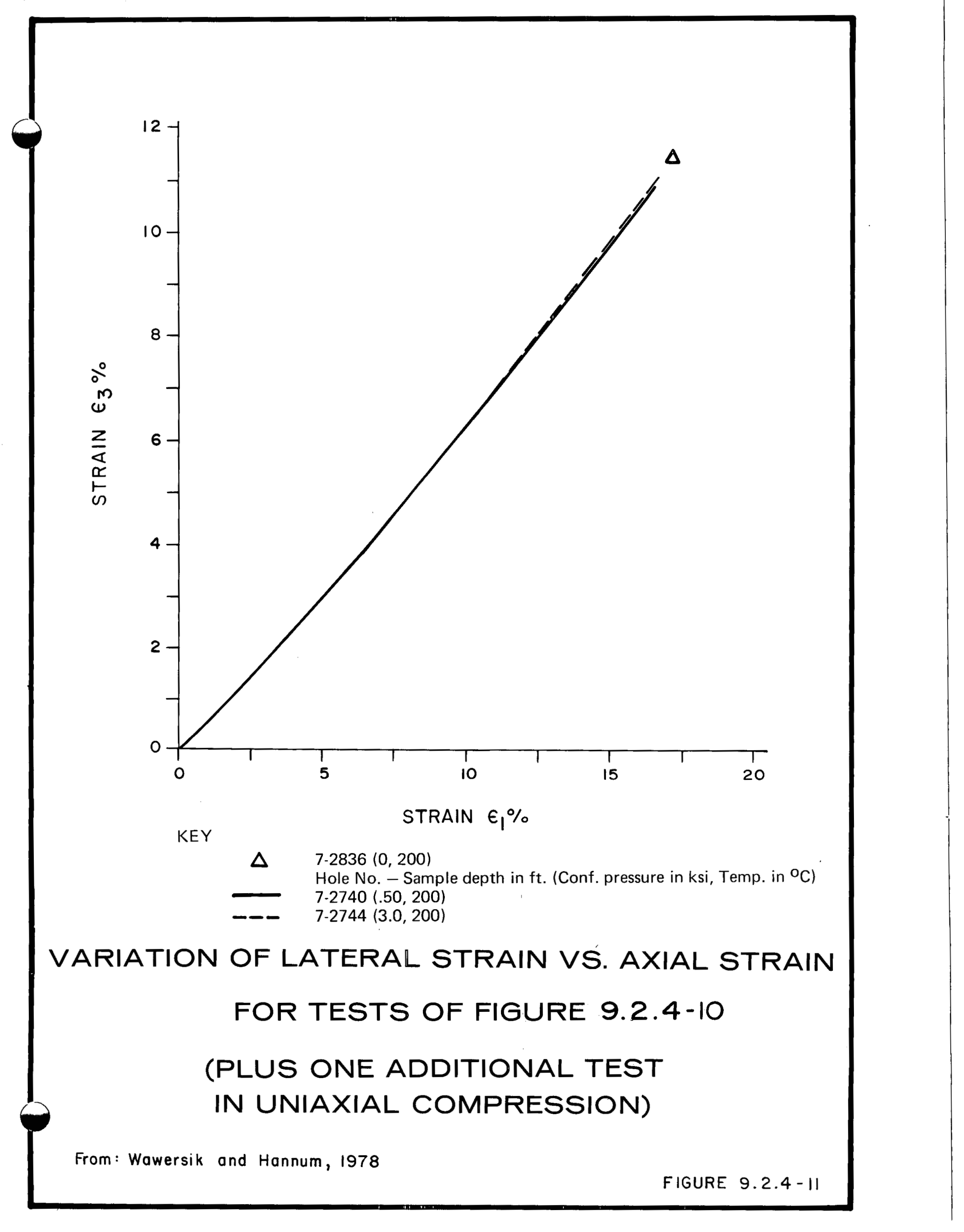




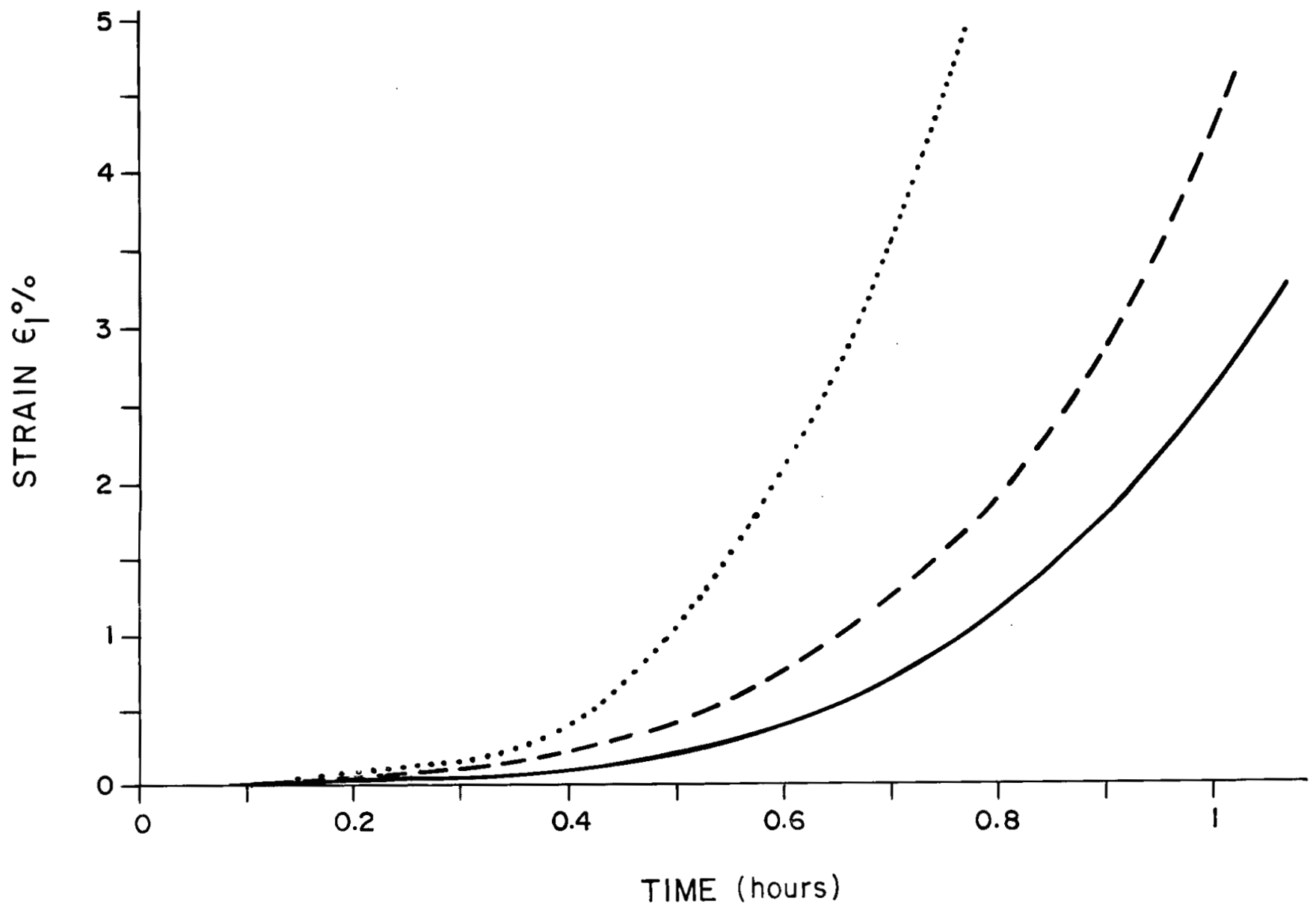

KEY

AXIAL STRAIN VS. TIME FOR TEST OF FIGURES 9.2.4-10 AND 9.2.4-11 


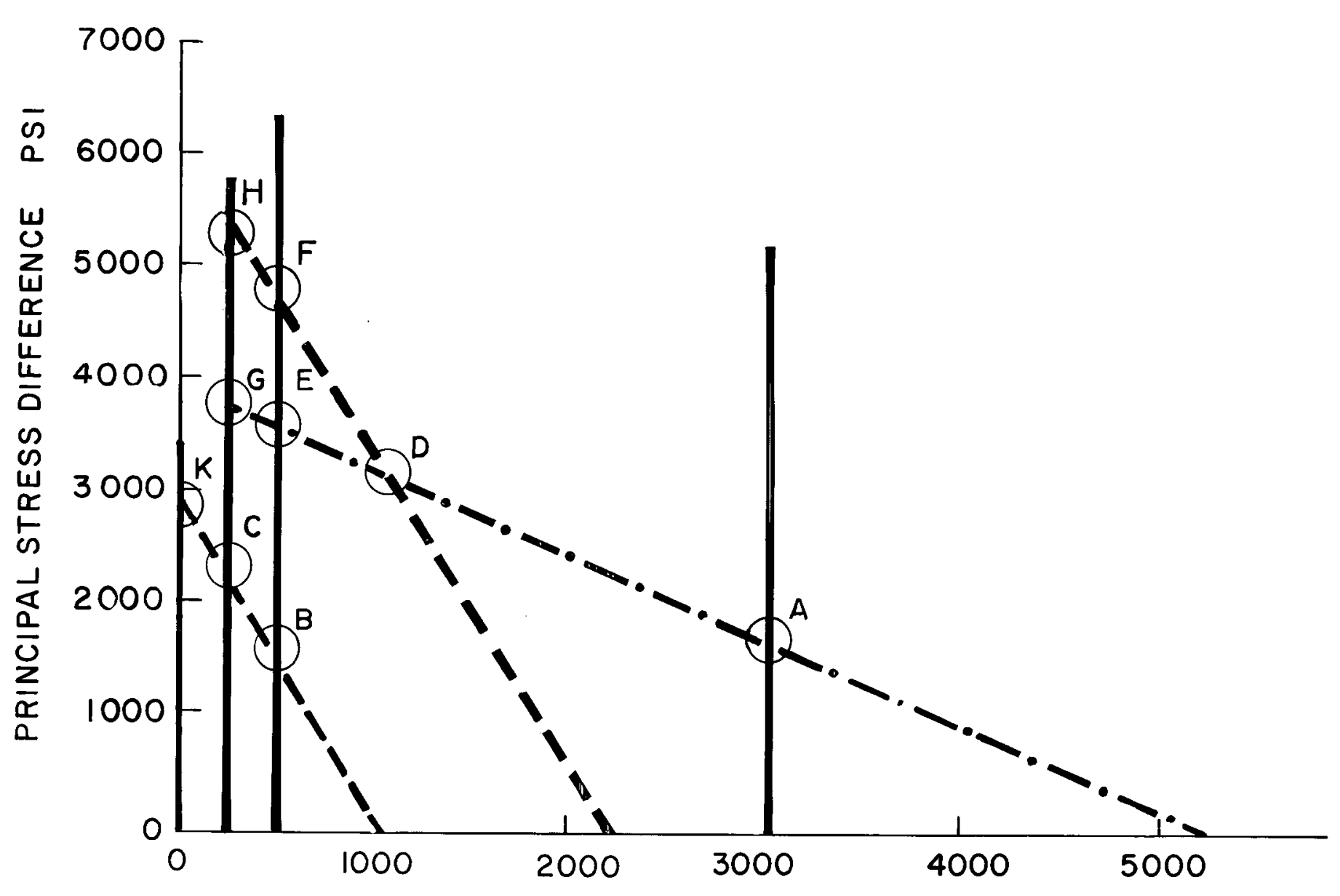

CONFINING PRESSURE PSI

KEY

$$
\begin{aligned}
& \text { Load Path I }\left(\sigma_{2}=\sigma_{3}=\text { const. }\right) \\
& \text { Load Path II }\left(\sigma_{\mathrm{m}}=\text { const. }\right) \sigma_{\mathrm{m}}=\frac{\sigma_{1}+\sigma_{2}+\sigma_{3}}{3} \\
& \text { Load Path III ( } \left.\sigma_{1} \approx \text { const. }\right)
\end{aligned}
$$

NOTE: See table 9.2.4-3 for tabulated data.

MAP OF THREE NON-PROPORTIONAL LOAD PATHS AND COMMON STRESS STATES (POINTS A THROUGH K) 


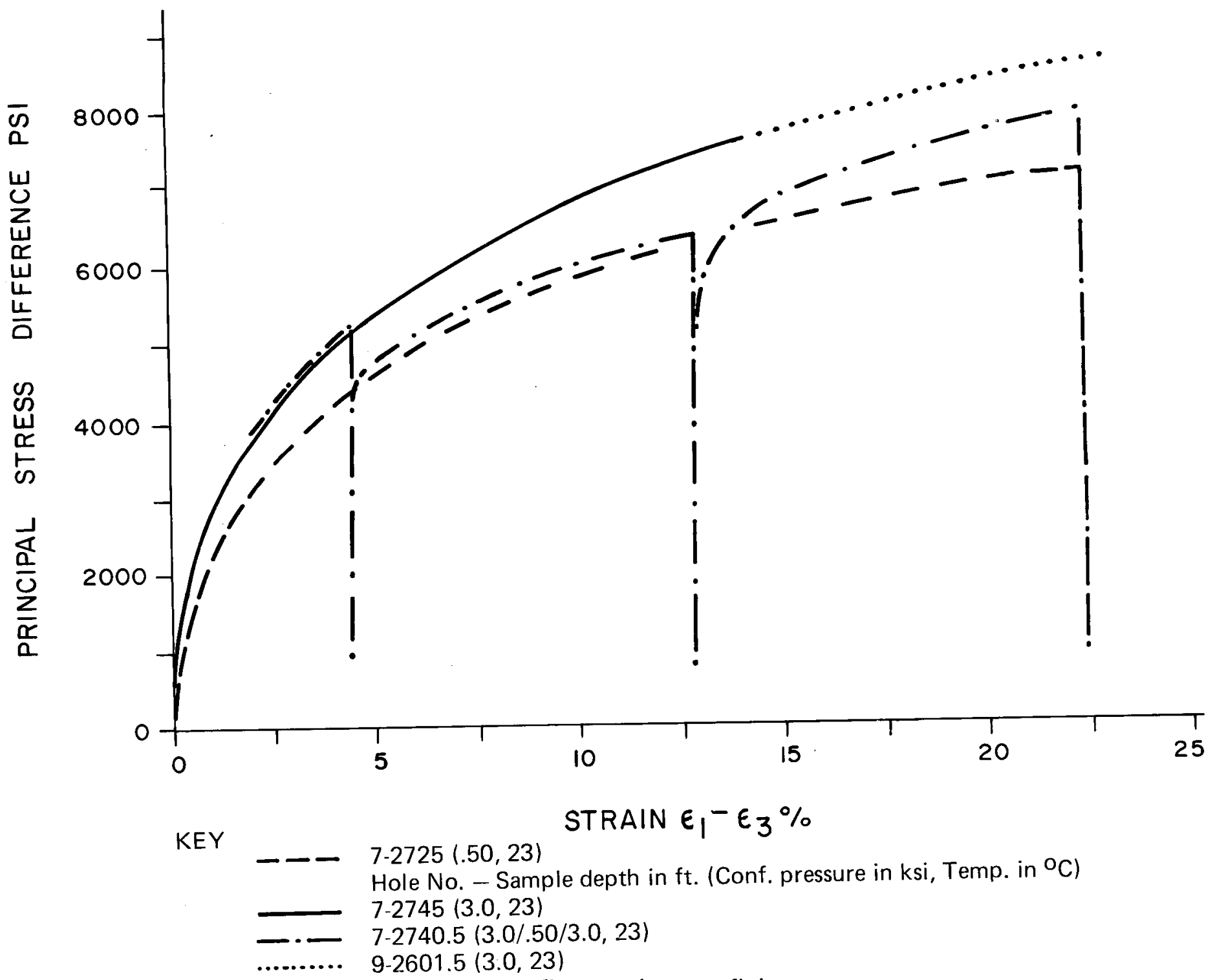

NOTE: The partial code 3.0/.50/3.0 identifies prevailing confining pressures between $\left(\sigma_{1}-\sigma_{3}\right)=0$ and first unload $/ \mathrm{reload}$ cycle, first and second unload/reload cycle, and between second unload/reload cycle and final unloading trace.

\section{STRESS-STRAIN CURVES}

\section{FOR SAMPLE SUBJECTED TO}

\section{ONE OR MORE CONFINING PRESSURES}




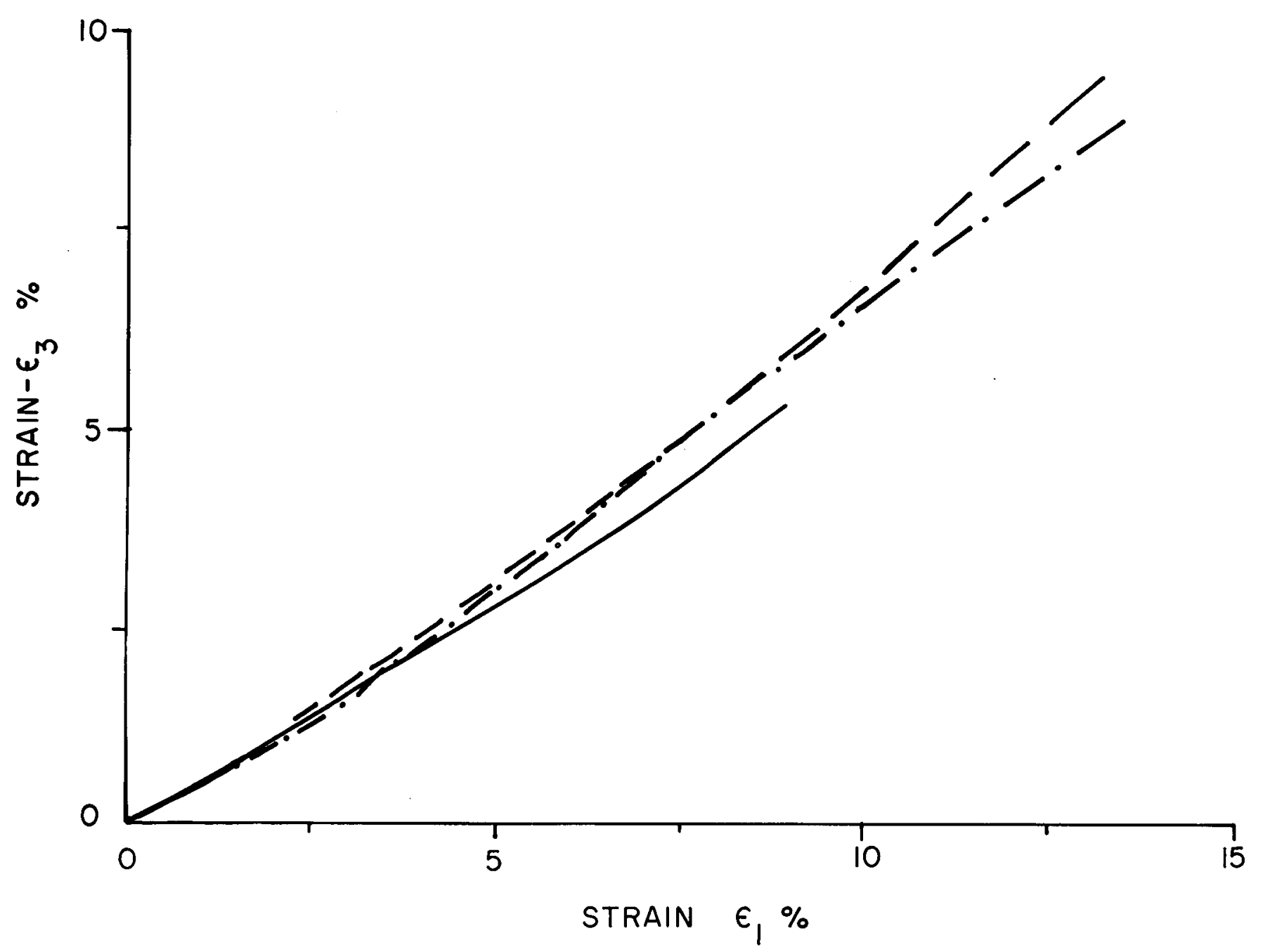

KEY

- $7.2725(.50,23)$

Hole No. - Sample depth in ft. (Conf. pressure in ksi, Temp. in ${ }^{\circ} \mathrm{C}$ )

$-\quad 7-2745(3.0,23)$
$-\quad 7-2740.5(3.0 / .50 / 3.0,23)$

VARIATION OF LATERAL STRAIN VS.

AXIAL STRAIN FOR TESTS OF FIGURE 9.2.4-14

From : Wawersik and Hannum, 1978

FIGURE 9.2.4-15 

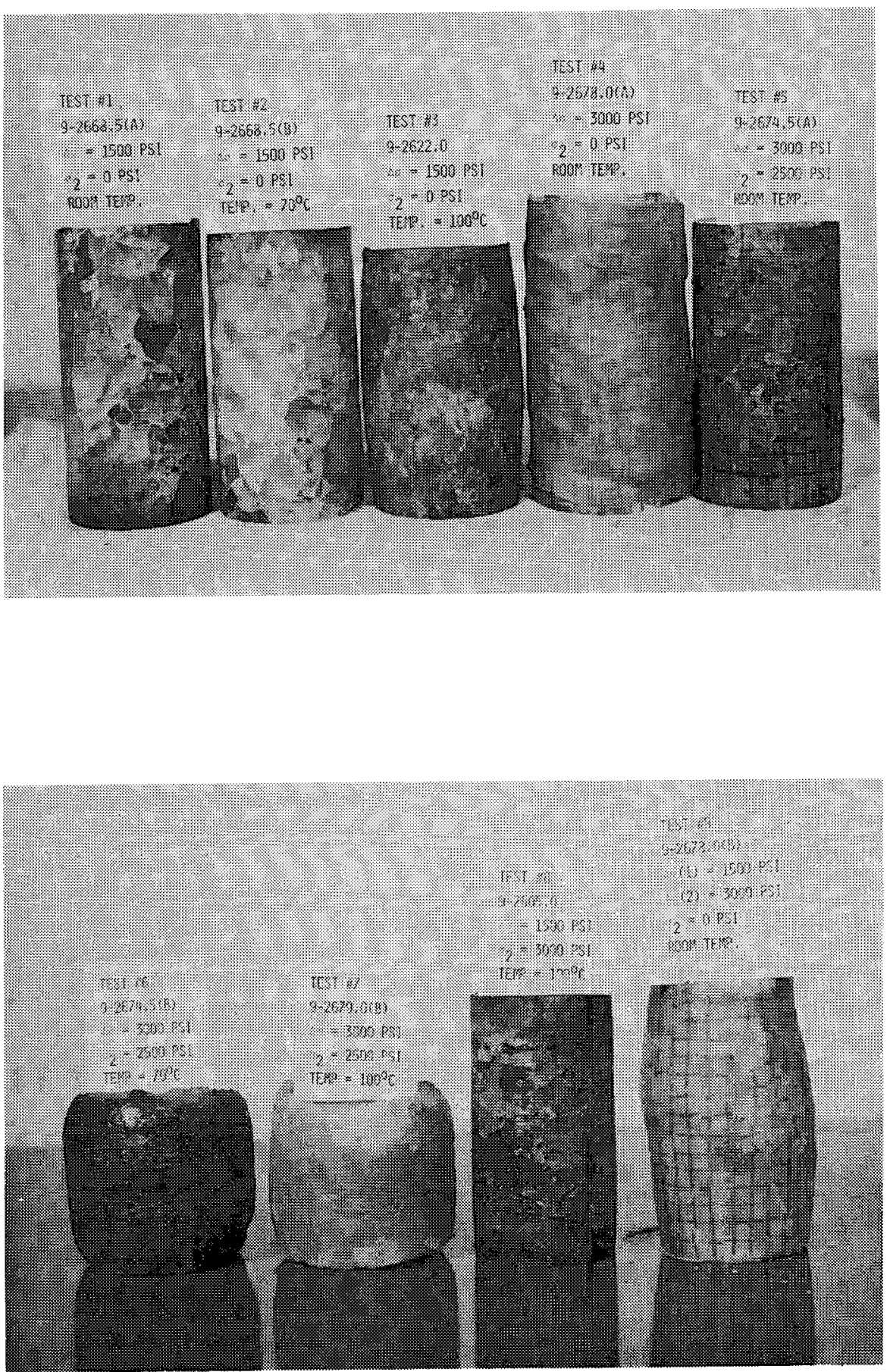

DEFORMED CORE SAMPLES OF ROCK SALT

FROM DRILL HOLE ERDA \#9

FROM: HANSEN and MELLEGARD, 1977

FIGURE 9.2.4-16 
Table 9.2.3-1: Physical properties of rock from WIPP study area

\begin{tabular}{|c|c|c|c|c|c|c|c|c|}
\hline Material & $\begin{array}{l}\text { Depth } \\
(\mathrm{ft})\end{array}$ & $\begin{array}{l}\text { Density } \\
(\mathrm{gm} / \mathrm{cc})\end{array}$ & $\begin{array}{l}\text { Avg. } \\
\text { Porosity } \\
\text { (Range) } \\
(8)\end{array}$ & $\begin{array}{l}\text { Mass } \\
\text { (8 to }\end{array}$ & $\begin{array}{l}\text { (Moisture) } \\
\text { Loss } \\
\left.\leq 300^{\circ} \mathrm{C}\right)\end{array}$ & $\begin{array}{l}\text { Resistivity } \\
\text { in Ohm Meters }\end{array}$ & $\begin{array}{l}\text { Avg. Air } \\
\text { Permeability } \\
\text { (Range) in (md) } 2\end{array}$ & $\begin{array}{l}\text { (P) } \text { Wave }^{3} \\
\text { Velocity } \\
(\mathrm{Km} / \mathrm{sec})\end{array}$ \\
\hline Rock Salt & $2000-2100$ & 2.18 & $\begin{array}{l}0.4 \\
(0.1-0.8)\end{array}$ & $\mathrm{N}^{1}$ & -1.0 & 58,100 & $\begin{array}{c}0.01 \\
(0.0003-0.17)\end{array}$ & $(4.42-4.62)$ \\
\hline Anhydrite & & 2.80 & - & & - & - & - & - \\
\hline Polyhalite & - & 2.70 & - & & - & - & - & - \\
\hline Siltstone & - & 2.26 & - & & - & - & - & - \\
\hline
\end{tabular}


Table 9.2.4.-1 - Representative unconfined mechanical properties of rock salt from the wIPP study area

\begin{tabular}{|c|c|c|c|c|c|c|c|c|}
\hline Material & $\begin{array}{l}\text { Drillhole/ } \\
\text { Approx. } \\
\text { Depth ( } f t)\end{array}$ & $\begin{array}{l}\text { Uniax. } \\
\text { Compr. } \\
\text { Strength } \\
\text { (psi) }\end{array}$ & $\begin{array}{l}\text { Strain } \\
\text { at failure } \\
\text { percent }\end{array}$ & $\begin{array}{c}\text { Brazilian } \\
\text { Tensile Strength } \\
\text { (psi) }\end{array}$ & $\begin{array}{c}\text { Initial } \\
\text { Elastic Limit } \\
\left(\sigma_{1}-\sigma_{3}\right) \\
(\text { psi) }\end{array}$ & $\begin{array}{l}\text { Secant } \\
\text { Modulus } \\
\times 10^{6} \text { (psi) }\end{array}$ & $\begin{array}{c}\text { Principal } \\
\text { Strain } \\
\text { Ratio }\end{array}$ & $\begin{array}{l}\text { Principal Strain } \\
\text { Ratio, } \varepsilon_{3} / \varepsilon_{1} \\
\text { at Failure }\end{array}$ \\
\hline Rock Salt & AEC $7,8 / 1900$ & 2450 & $\geq 1.7$ & 200 & $\leq 750$ & 1.94 & 0.33 & - \\
\hline Rock Salt & $\operatorname{AEC} 7,8 / 2700$ & 3700 & 3.6 & 240 & $\leq 750$ & 1.94 & 0.34 & - \\
\hline Rock Salt & ERDA $9 / 2100$ & 2400 & 1.6 & - & $<200$ & - & - & 1.6 \\
\hline Rock Salt & ERDA $9 / 2700$ & 3300 & 2.9 & - & $<200$ & - & - & 2.1 \\
\hline
\end{tabular}

Note: Loading rates $-30 \leq \frac{\mathrm{d}}{\mathrm{d} t}\left(\sigma_{1}-\sigma_{3}\right) \leq 215 \mathrm{psi} / \mathrm{min}$

1 Megapascal (MPa) equals about 145 psi

Symbols < and > denote experimental uncertainty. 
Table 9.2.4-2 - Representative triaxial compression data for rock salt from the wIPP study area

\begin{tabular}{|c|c|c|c|c|c|c|c|c|}
\hline $\begin{array}{l}\text { Drill hole/ } \\
\text { Depth (ft) }\end{array}$ & $\begin{array}{c}\text { Confining } \\
\text { Pressure } \\
\text { (psi) }\end{array}$ & $\begin{array}{l}\text { Temp. } \\
\left({ }^{\circ} \mathrm{C}\right)\end{array}$ & $\begin{array}{l}\text { Ultimate } \\
\text { (max) Princ. } \\
\text { Stress Diff. } \\
\text { (psi) }\end{array}$ & $\begin{array}{l}\begin{array}{l}\text { Ultimate } \\
\quad \text { (max) }\end{array} \\
\text { Strain, } \varepsilon_{1} \\
\text { Percent }\end{array}$ & $\begin{array}{c}\text { Initial } \\
\text { Elastic } \\
\text { Limit } \\
\left(\sigma_{1}-\sigma_{3}\right) \\
\text { (psi) }\end{array}$ & $\begin{array}{l}\text { Secant } \\
\text { Modulus } \\
\times 10^{6} \text { (psi) }\end{array}$ & $\begin{array}{l}\text { Principal } \\
\text { Strain } \\
\text { "Poissons'" } \\
\text { Ratio }\end{array}$ & $\begin{array}{l}\text { Max. Obs. Princ. } \\
\text { Strain Ratio }\end{array}$ \\
\hline ERDA $9 / 2100$ & 500 & 23 & 6000 & 12 & $\leq 100$ & 2.7 & 0.20 & -0.72 \\
\hline ERDA $9 / 2100$ & 3000 & 23 & $>9000$ & $>20$ & $\leq 100$ & 2.7 & 0.20 & -0.65 \\
\hline $\begin{array}{r}\text { ERDA } 9 / 2600- \\
2700\end{array}$ & 500 & 23 & 6300 & 15 & $\leq 100$ & 2.7 & 0.20 & -0.80 \\
\hline $\begin{array}{c}\text { ERDA } 9 / 2600- \\
2700\end{array}$ & 3000 & 23 & $>8900$ & $>20$ & $\leq 100$ & 2.7 & 0.20 & -0.67 \\
\hline $\begin{array}{c}\text { AEC } 7 / 2700- \\
2800\end{array}$ & 500 & 23 & $>6200$ & $>13$ & $\leq 100$ & 2.7 & 0.21 & -0.71 \\
\hline $\begin{array}{c}\mathrm{AEC} 7 / 2700- \\
2800\end{array}$ & 500 & 100 & $\approx 4200$ & $\geq 18$ & $\leq 100$ & - & - & -0.69 \\
\hline $\begin{array}{c}\text { AEC } 7 / 2700- \\
2800\end{array}$ & 500 & 200 & $\approx 2400$ & $>17$ & $\leq 100$ & 2.4 & - & -0.68 \\
\hline $\begin{array}{c}A E C 7 / 2700- \\
2800\end{array}$ & 300 & 200 & $>2750$ & $>17$ & $\leq 100$ & - & - & - \\
\hline ERDA $9 / 2600$ & 500 & 200 & $>2500$ & $>22$ & $\leq 100$ & - & - & -0.68 \\
\hline Note: Loadi & rate $d / d t$ & $\sigma_{1}-$ & $=30$ to 60 & in. & & & & \\
\hline
\end{tabular}


Table 9.2.4-3 Deviatoric Load Path Data For Figure 9.2.4-13

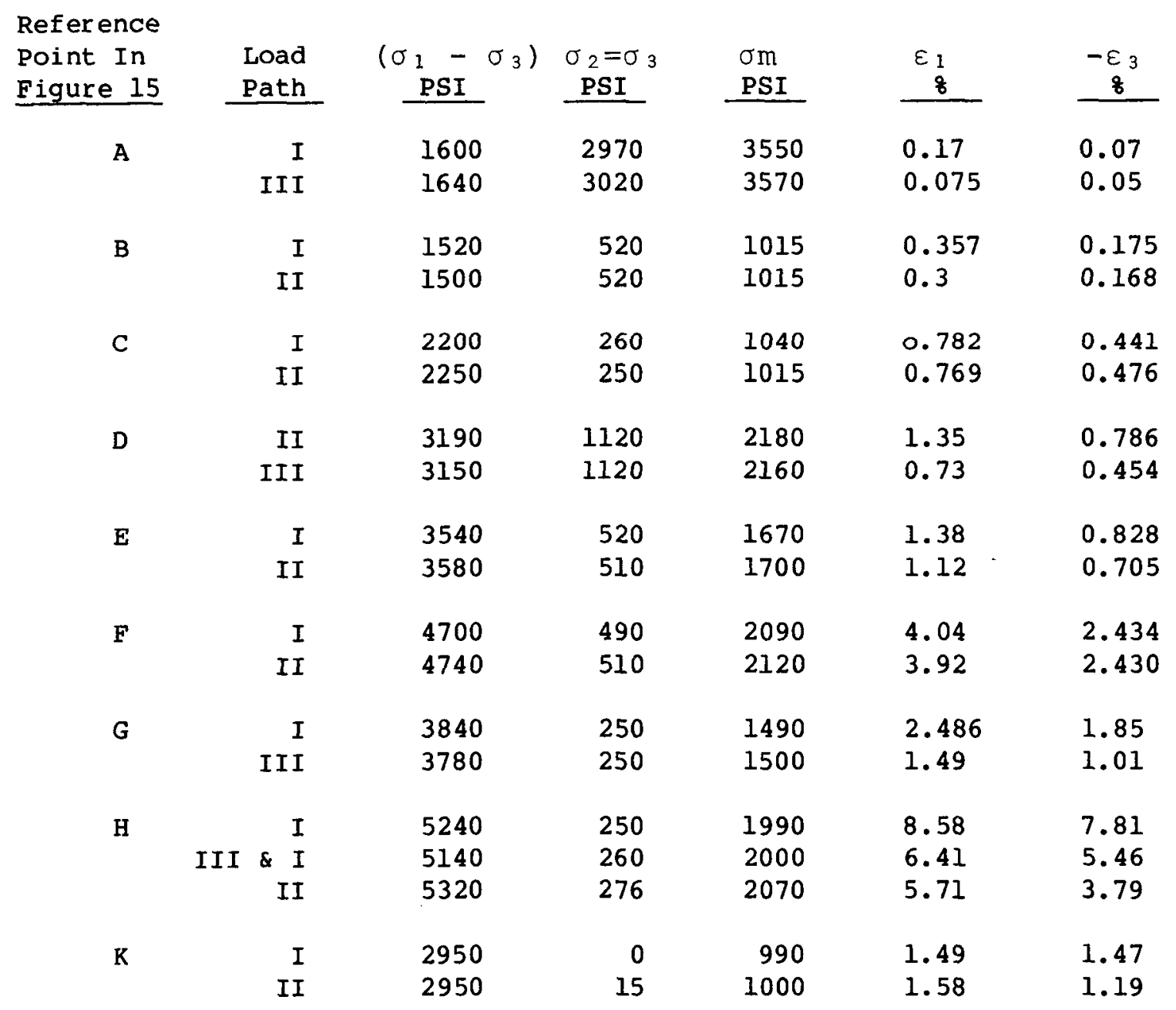




\section{REPRESENTATIVE BRINES/SOLUTIONS FOR \\ WIPP EXPERIMENTATION}

Ion

$\mathrm{Na}^{+}$

$\mathrm{K}^{+}$

$\mathrm{Mg}^{++}$

$\mathrm{Ca}^{++}$

$\mathrm{Fe}^{+++}$

$\mathrm{Sr}^{++}$

$\mathrm{Li}^{+}$

$\mathrm{Rb}^{+}$

$\mathrm{Cs}^{+}$

$\mathrm{Cl}^{-}$

$\mathrm{SO}_{4}^{--}$

$\mathrm{B}\left(\mathrm{BO}_{3}{ }^{---}\right)$

$\mathrm{HCO}_{3}^{-}$

$\mathrm{NO}_{3}^{-}$

$\mathrm{Br}^{-}$

$1^{-}$

$\mathrm{pH}$ (adjusted)

specific gravity $\frac{\text { Brine "A" }}{\text { (mg/liter) }}$

$( \pm 3 \%)$

42,000

30,000

35,000

600

2

5

20

20

1

190,000

3,500

1, 200

700

-

400

10 $\frac{\text { Brine "B" }}{\text { (mg/liter) }} \quad \frac{\text { Solution "C" }}{\text { (mg/liter) }}$

$( \pm 3 \%)$

115,000

15

10

900

2

15

-

1

1

175,000

3,500

10

10

-

400

10

6.5

1.2
$( \pm 3 \%)$

100

5

200

600

1

15

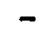

1

1

200

1, 750

100

20

-

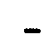

7.5

1.0 
Table $9 \cdot 3-2$

Nominal Concentration of Nuclides Used in Kd Measurements

$\begin{array}{lc}\text { Nuclide }^{137_{\mathrm{Cs}}} & 0.012 \\ { }_{\text {Stable Cs }} & 1.0 \\ { }^{85} \mathrm{Sr} & 0.03-0.3 \\ \mathrm{Stable} \mathrm{Sr} & 5-15 \\ 106_{\mathrm{Ru}} & 2500 \\ 99_{\mathrm{Tc}} & 59 \\ 152_{\mathrm{Eu}} & 0.1-1.0 \\ 144_{\mathrm{Ce}} & 3 \times 10^{-4} \\ 131_{\mathrm{I}} & 5 \times 10^{-5} \\ 153_{\mathrm{Gd}} & 0.2-2.0 \\ 125 \mathrm{Sb} & \leq 0.01 \\ 243_{\mathrm{Am}} & 5.4 \\ 244_{\mathrm{Cm}} & 0.012 \\ 238_{\mathrm{Pu}} & 0.058\end{array}$


Table $9 \cdot 3-3$

Distribution Coefficients on Samples From the Magenta Dolomite

Fission Product

Distribution Coefficients

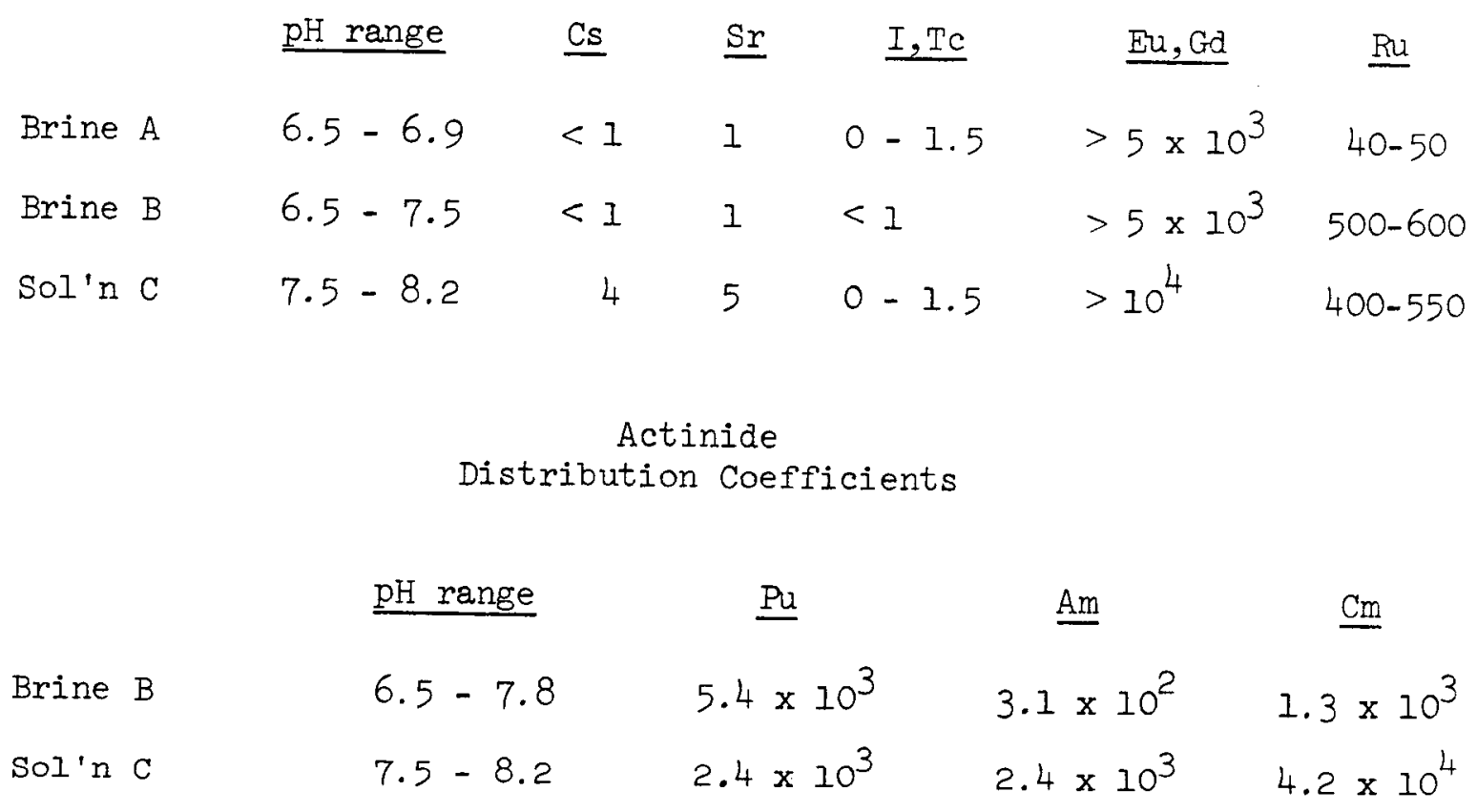


Table $9 \cdot 3-4$

Distribution Coefficients on Samples From the Culebra Dolomite

Fission Product

Distribution Coefficients

$\begin{array}{lllllll} & \underline{\mathrm{pH} \text { range }} & \underline{\mathrm{Cs}} & \underline{\mathrm{Sr}} & \underline{\mathrm{I}, \mathrm{Tc}} & \underline{\mathrm{Eu}, \mathrm{Gd}} & \underline{\mathrm{Ru}} \\ \text { Brine A } & 6.5-6.9 & <1 & <1 & <1 & >10^{4} & 25-35 \\ \text { Brine B } & 6.5-7.6 & 1-2 & 1-2 & <1 & >10^{4} & 640-660 \\ \text { Sol'n } & 7.5-8.2 & 7-10 & 4-5<<1 & >10^{4} & 240-400 \\ \text { Actinide } \\ \text { Distribution Coefficients }\end{array}$

$\underline{\text { pH range }}$

$\underline{P u}$

$\underline{\mathrm{Am}}$

$\underline{\mathrm{Cm}}$

Brine $B$

$6.5-7.8$

$2.1 \times 10^{3}$

$2.6 \times 10^{3}$

$1.2 \times 10^{4}$

Sol'n $C$

$7.5-8.3$

$7.3 \times 10^{3}$

$2.2 \times 10^{4}$

$1.1 \times 10^{5}$

Table $9 \cdot 3-5$

Distribution Coefficients on Halite From The 2056' Horizon of ERDA \#9 Borehole

\section{Actinide Distribution \\ Coefficients 1}
pH range
$\underline{P u}$
Am
$\underline{\mathrm{Cm}}$
$7.0-7.1$
17
306
354
$\left(1.0 \times 10^{4}\right)$
$\left(1.8 \times 10^{5}\right)$
$\left(2.1 \times 10^{5}\right)$
1) The $\mathrm{Kd}$ values in parentheses were calculated from the weight of water insoluble material in the halite. The lower values are based on the total weight of halite taken.




$$
\text { Table } 9.3-6
$$

\section{Distribution Coefficients on Samples of Clay From The 2186.6' Horizon of AEC \#8 Borehole}

\section{Fission Product \\ Distribution Coefficients}

$\begin{array}{lcccccc} & \underline{\mathrm{pH} \text { range }} & \underline{\mathrm{Cs}} & \underline{\mathrm{Sr}} & \underline{\mathrm{I}, \mathrm{Tc}} & \underline{\mathrm{Gd}, \mathrm{Eu}} & \underline{\mathrm{Ru}} \\ \text { Brine A } & 6.5-7.0 & <1 & <1 & <2 & >2.5 \times 10^{3} & 150-180 \\ \text { Brine B } & 6.5-7.7 & 4-6 & <1 & <1 & >10^{4} & >2 \times 10^{3} \\ \text { Sol'n C } & 7.5-7.8 & 80-120 & 3-6 & <1 & >10^{4} & >1 \times 10^{3}\end{array}$

\section{Actinide}

Distribution Coefficients

$\underline{\mathrm{pH} \text { range }}$

Brine B

Sol'n $\mathrm{C}$
$6.5-8.0$

$7.5-8.4$
$\underline{\mathrm{Am}}$

$1.1 \times 10^{3}$

$3.5 \times 10^{3}$

Table $9 \cdot 3-7$
Pu $\quad$ Cm

$4 \times 10^{4} \quad 1.9 \times 10^{4}$

$1.8 \times 10^{5} 4.2 \times 10^{5}$

tribution Coefficients on Samples of Polyhalite From the 2304' Horizon of ERDA \#9 Borehole

Fission Product

Distribution Coefficients

\begin{tabular}{|c|c|c|c|c|c|c|}
\hline & $\underline{\mathrm{pH}}$ range & Cs & $\underline{\mathrm{Sr}}$ & $\underline{E u}, \mathrm{Ce}^{1}$ & $\underline{\mathrm{Sb}}$ & $\underline{T c}$ \\
\hline Brine A & $6.5-7.0$ & $<1$ & $5-10$ & $10-20$ & $<1$ & $<1$ \\
\hline Brine $B$ & $6.5-7.2$ & $<1$ & $19-22$ & $\begin{array}{c}430-700 \\
50-55\end{array}$ & $0.9-1.5$ & $<1$ \\
\hline Sol'n $\mathrm{C}$ & $7.5-7.6$ & $<1$ & $35-40$ & $\begin{array}{c}100-200 \\
40-60\end{array}$ & $3-4$ & 1 \\
\hline
\end{tabular}

1) Where two ranges of values are given, the first refers to $\mathrm{Eu}$ and the second to $\mathrm{Ce}$. 
Table $9 \cdot 3-8$

Distribution Coefficients on Sample of Cowden Anhydrite From the 2562' Horizon of AEC \#8 Borehole

\begin{tabular}{|c|c|c|}
\hline & $\begin{array}{r}\text { Fissio } \\
\text { Distributio }\end{array}$ & \\
\hline & $\mathrm{pH}$ range & $\mathrm{Gd}, \mathrm{Eu}, \mathrm{Ce}$ \\
\hline Brine $B$ & $6.5-7.9$ & $>10^{3}$ \\
\hline
\end{tabular}

Actinide Distribution Coefficients

$\underline{\mathrm{pH} \text { range }} \quad \underline{\mathrm{Am}} \quad \underline{\mathrm{Pu}} \quad \underline{\mathrm{Cm}}$

$\begin{array}{lllll}\text { Brine B } & 6.5-7.9 & 2.9 \times 10^{2} & 6.7 \times 10^{3} & 4.2 \times 10^{3} \\ \text { Sol'n C } & 7.5-8.2 & 2.2 \times 10^{3} & 7.7 \times 10^{4} & 1.8 \times 10^{5}\end{array}$


Table 9.3-9

Distribution Coefficients on Samples of Clay from the 2725' Horizon of AEC \#8 Borehole

Fission Product

Distribution Coefficients

\begin{tabular}{|c|c|c|c|c|c|c|}
\hline & $\mathrm{pH}$ range & $\underline{\mathrm{Cs}}$ & $\underline{\mathrm{Sr}}$ & $\mathrm{Eu,Gd}{ }^{1}$ & ${\underline{T C}, I^{I}}^{1}$ & $\underline{R u}$ \\
\hline Brine A & $6.6-7.0$ & $4-9$ & $<1$ & 2. $8-4 \times 10^{3}$ & $\begin{array}{l}3 \cdot 5-4 \cdot 5 \\
0-3 \cdot 5\end{array}$ & $90-120$ \\
\hline Brine $B$ & $6.7-7.4$ & $3-6$ & $<1$ & $>10^{4}$ & $<1$ & $>10^{3}$ \\
\hline Sol'n C & $7.5-8.0$ & $34-40$ & $30-45$ & $\begin{array}{l}>10^{4} \\
>3 \times 10^{3}\end{array}$ & $\begin{array}{l}0.7-1.5 \\
0.5-4\end{array}$ & $>10^{3}$ \\
\hline \multicolumn{7}{|c|}{$\begin{array}{c}\text { Actinide } \\
\text { Distribution Coefficients }\end{array}$} \\
\hline & pH range & & $\mathrm{Am}$ & \multicolumn{2}{|c|}{$\underline{P u}$} & $\mathrm{Cm}$ \\
\hline Brine $B$ & $6.5-7.8$ & & 310 & 7.2 & $\times 10^{4}$ & $2.7 \times 10^{3}$ \\
\hline Sol'n C & $7.4-8.4$ & & $2.3 \times 1$ & 4. & $\times 10^{4}$ & $1.6 \times 10^{5}$ \\
\hline
\end{tabular}

1) Where two ranges of values are given, the first refers to the first element listed and the second range is for the second element listed.

Table 9.3-10

Distribution Coefficients on Samples of Bell Canyon Formation

Fission Product

Distribution Coefficients

$\underline{\mathrm{pH}}$ range

Cs

$\underline{\text { Sr }}$

Eu

$\underline{\mathrm{Sb}}$

$\underline{T C}$

Brine $B$

$6.5-7.4$

$14-16$

$<1>10^{4}$

$5-8$

$<1$

Sol'n C

$7.5-7.9$

$130-140$

$1-5>10^{4}$

$20-25$

$<1$ 
Table $9 \cdot 3-11$

Distribution Coefficients on Halite Samples From the 2611' Horizon of ERDA \#9 Borehole

\section{Column Experiment}

Column Bed: $7.5 \mathrm{~g}$ of Halite in $1 \mathrm{~cm}$ diameter column Solution: Saturated Halite Solution, $200 \mathrm{ml}$ Flow: I Bed volume/min.

\begin{tabular}{ccc} 
Time (days) & \multicolumn{2}{c}{ of Initial Activity in Solution } \\
\hline 0 & $\frac{{ }^{85} \mathrm{Sr}}{144}$ & $\frac{10 \mathrm{Ce}}{100}$ \\
1 & 98.0 & 26.7 \\
4 & 96.8 & 0.9 \\
8 & 98.4 & 0
\end{tabular}

\section{Actinide
Distribution Coefficients}

$\underline{\mathrm{pH}}$ range

$\underline{\text { Am }}$

11
Pu

59
$\underline{\mathrm{Cm}}$

56

$$
\left(3.8 \times 10^{3}\right) \quad\left(2.11 \times 10^{4}\right) \quad\left(2 \times 10^{4}\right)
$$

(1) The $\mathrm{Kd}$ values in parentheses were calculated using the weight of water insoluble material in the clay. The lower values are based on the weight of halite taken. 
Table $9 \cdot 3-12$

${ }^{152}$ Eu Distribution Coefficients (Kd's)

\begin{tabular}{|c|c|c|c|c|c|c|}
\hline Rock & Simulant & $152_{\mathrm{Eu}(\mu \mathrm{Ci} / \mathrm{ml})}^{\text {Nominal }}$ & \multicolumn{2}{|c|}{$\mathrm{Kd}(1)$} & \multicolumn{2}{|c|}{$K d^{(2)}$} \\
\hline Culebra & A & 0.01 & $1.7 \times 10^{4}$ & $1.5 \times 10^{4}$ & -- & -- \\
\hline$" 1$ & A & 0.1 & $3.6 \times 10^{4}$ & $2.1 \times 10^{4}$ & -- & -- \\
\hline$"$ & $A$ & 1.0 & $1.8 \times 10^{4}$ & $4.3 \times 10^{4}$ & -- & -- \\
\hline$"$ & B & 0.01 & $3.4 \times 10^{3}$ & $1.6 \times 10^{3}$ & -- & $7.6 \times 10^{3}$ \\
\hline$"$ & B & 0.1 & $1.1 \times 10^{4}$ & $3.6 \times 10^{3}$ & -- & $1.3 \times 10^{3}$ \\
\hline$"$ & $B$ & 1.0 & $3.7 \times 10^{3}$ & $3.9 \times 10^{3}$ & $8.8 \times 10^{2}$ & $1.4 \times 10^{3}$ \\
\hline$"$ & $\mathrm{C}$ & 0.01 & $2.8 \times 10^{4}$ & $1.3 \times 10^{4}$ & -- & $1.1 \times 10^{4}$ \\
\hline " & $\mathrm{C}$ & 0.1 & $2.7 \times 10^{4}$ & $2.6 \times 10^{4}$ & -- & $1.9 \times 10^{4}$ \\
\hline$"$ & $\mathrm{C}$ & 1.0 & $2.0 \times 10^{4}$ & $1.4 \times 10^{4}$ & $1.2 \times 10^{3}$ & $9.6 \times 10^{3}$ \\
\hline
\end{tabular}

Magenta
A
0.01
$1.4 \times 10^{4}$
$6 \times 10^{3}$

$"$

A

0.1

$1.9 \times 10^{4}$

$2.0 \times 10^{4}$

$"$

A

1.0

$1.2 \times 10^{4}$

$1.4 \times 10^{4}$

$"$

B

0.01

$2.8 \times 10^{3}$

$8.6 \times 10^{2}$

$-$

$4 \times 10^{2}$

" B

0.1

$8.3 \times 10^{3}$

$3.7 \times 10^{3}$

$-$

$1.3 \times 10^{3}$

$"$

$1.0 .1 .1 \times 10^{3}$

$1.2 \times 10^{3}$

$3.5 \times 10^{2}$

4. $0 \times 10^{2}$

" C

0.01

$2.0 \times 10^{4}$

$1.7 \times 10^{4}$

$1.3 \times 10^{4}$

$" \quad \mathrm{C}$

0.1

$3.6 \times 10^{4}$

$2.2 \times 10^{4}$

$1.6 \times 10^{4}$

$"$

1.0

$1.4 \times 10^{4}$

$1.5 \times 10^{4}$

$1.3 \times 10^{4}$

(1) Kd based on activity in feed solutions.

(2) Kd based on activity in $\mathrm{pH}$ adjusted feed solutions. 
Table 9.3-13

Comparison of ${ }^{153} \mathrm{Gd},{ }^{144} \mathrm{Ce}$, and ${ }^{152} \mathrm{Eu} \mathrm{Kd}$ 's in Brine $B$ and Brine $B^{*}$ Containing Plywood Extract

14 Day Equilibration

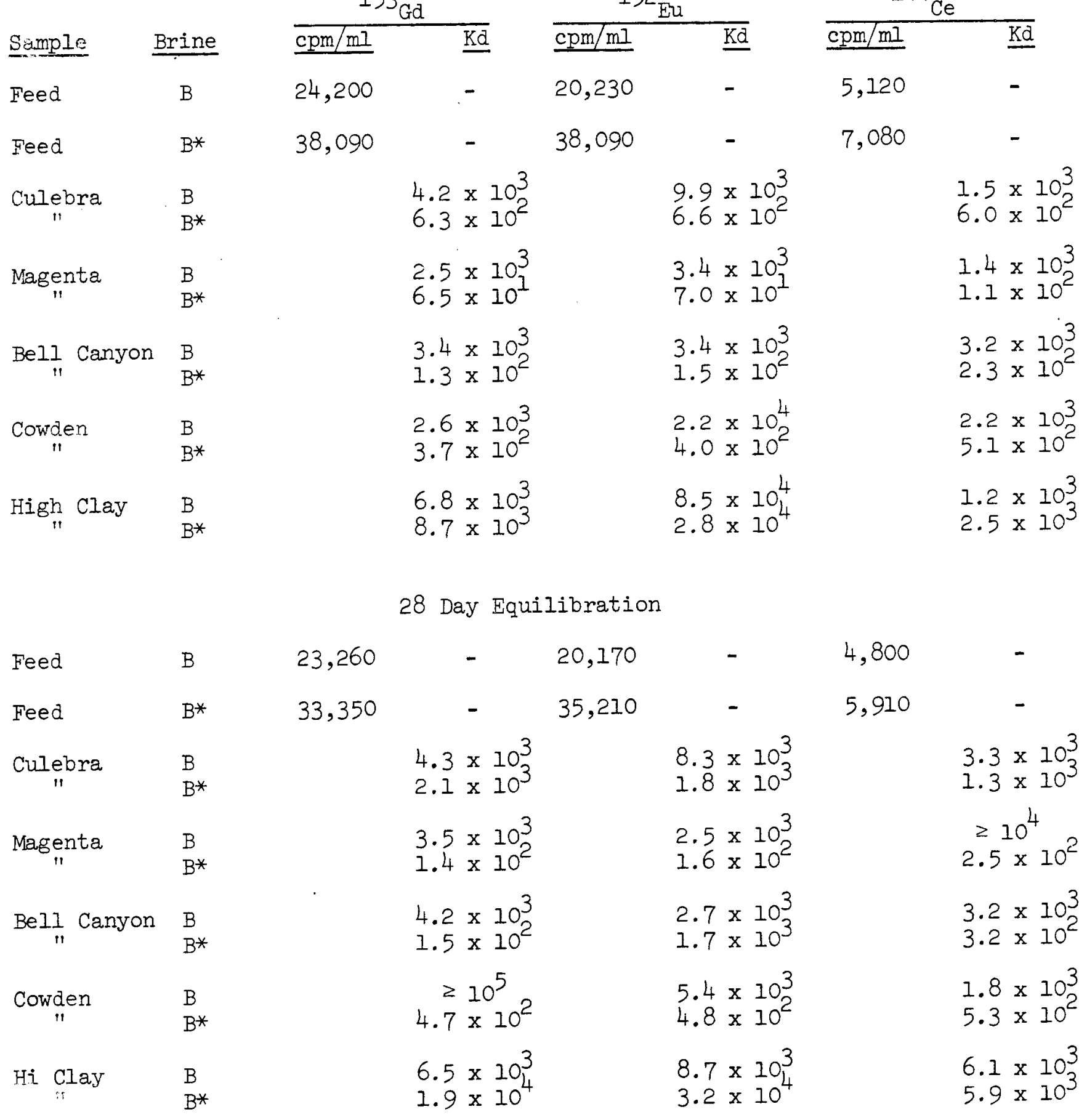


GCR CHAPTER 10

CONTINUING STUDIES

\subsection{INTRODUCTION}

Continuing studies for the WIPP primarily encompass those geological processes that need to be understood in order to more quantitatively assess the safety of converting the WIPP to a repository. The processes of importance are tectonic, geochemical, hydrologic, and climatic. The studies indicated within this chapter generally relate to these major processes. In addition, a few studies indicated in this chapter relate to minor continuing efforts of site characterization. This chapter will serve to enumerate issues which remain to be addressed relevant to the safety of converting WIPP to a repository. It is not intended here that specific plans and schedules be presented.

The organization of Chapter 10 follows that of previous chapters.

\subsection{SITE SELECTION}

In line with the differentiation made in Chapter 2 between site selection, site characterization, and site confirmation, the activities of site selection and site characterization are nearly complete. The confirmation of the WIPP site for a repository will necessitate the continuing studies indicated in Sections 10.3 through 10.9 .

\subsection{REGIONAL GEOLOGY}

Continuing studies of the regional geology focus mainly on the processes of tectonics and climate through studies of paleoclimates and various manifestations of past tectonic activity. 


\subsubsection{Paleoclimatology}

The purpose of paleoclimatic studies in southeastern New Mexico is to develop the local timing and magnitude of past climatic changes and their relation to observed geology to help assess the possible effects of future changes on a repository.

The primary method of paleoclimatic study is to examine cores of Pleistocene or Recent sediments for fauna and flora which are indicative of past climatic conditions. In addition, organic matter or ash falls may, if suitable, be dated radiometrically to provide time control.

Studies of paleoclimate are underway with preliminary analysis of core taken in San Simon Sink from borehole WIPP 15. Fauna and flora are being separated from the sediment for paleontological analyses, and suitable organic material is being separated for radiocarbon analysis. These studies of the San Simon material will be completed in 1979 to yield an initial profile of climatic changes. Further coring in other locations may be undertaken at that time, if necessary, to supplement the record. The final stage of this study will be to integrate the local climatic changes into the information about regional climates and to determine the relationship between climatic changes and related processes such as subsurface salt dissolution and resultant subsidence (see Section 10.6).

\subsubsection{Regional Tectonic Studies}

The purpose of various studies of regional tectonics is to assess the long-term effects of tectonic forces on a repository.

Several studies together contribute to information about regional tectonics and include the seismological studies discussed in section 10.5 .

LANDSAT. A preliminary examination of LANDSAT photos has been completed and is reported in chapter 3. In addition, the WIPP site and surrounding regions will be re-examined in 1979 with more sophisticated image 
enhancement to determine the presence and location of more subtle lineaments. Field evaluation of the interpretations will be undertaken as required.

Leveling Surveys. Releveling of some existing first-order vertical control lines was carried out in 1977, and about $300 \mathrm{~km}$ of new lines were established. These new lines, some of which traverse Nash Draw and the WIPP site, will be periodically releveled to establish a data base for separating regional tectonic effects from local effects perhaps due to dissolution (see Section 10.6).

West Texas Salt Flats Graben. Releveling and seismology studies indicate active tectonic displacement on the west Texas salt flats graben. Seismic reflection records will be examined and test coring conducted in 1979 to determine if the sediments will yield a record of tectonic disturbance that will contribute to information about the tectonic forces likely to affect a repository located in the Delaware Basin.

\subsection{SITE GEOLOGY}

The purpose of continuing studies of site geology are to refine the data base for assessment of the safety of a repository there, and to contribute some additional details of site characterization. The methods and studies as such are quite varied.

\subsubsection{Geologic Mapping}

Geologic mapping continues on the WIPP site and in the area, particularly under a study of the stability of the WIPP site. This study, being conducted by the USGS, is concerned with mapping caliche and related sediments to provide more conclusive data on the length of time the area has been stable, and the rates at which areas around the site have been disturbed. 


\subsubsection{Aeromagnetic Survey}

A very high resolution aeromagnetic survey will be initiated during FY79 to examine the WIPP site and several special features. The survey of the site will primarily be to determine if any dikes have intruded the evaporites at the site since dikes might form a pathway for fluid flow. Several of the domal features mentioned in chapters 3,4 , and 6 , two of which are considered to be breccia pipes, will be examined to determine if a magnetic signature is associated with disturbance of the magnetic red beds. The tool, if proven applicable, might then be used for prospecting to support continuing studies of breccia pipes as indicated in 10.6 .

\subsection{SEISMOLOGY}

The purpose of continuing seismological studies is to provide data for facility design and to expand the data base contributing to an understanding of tectonic processes affecting a repository in the Delaware Basin. Seismological studies are supported by arrays of stations near points of interest.

\subsubsection{Near-Site Activity}

The careful characterization of near-site background activity, as indicated in chapter 5 , is the dominant seismic issue affecting the WIPP site. Station CLN has been operating near the site since 1974, and continues to operate. It is planned to augment this station so that at least three stations will be operating at the site to better define near-site seismicity.

\subsubsection{Central Basin Platform}

An array of stations has been operating near Kermit, Texas, since 1976 to evaluate the seismic activity on the Central Basin Platform and to explore the relationship, if any, between this activity and the massive 
fluid injection for secondary oil recovery operations occurring in that area. This array will continue to operate both for this purpose and because the assessment of seismic activity at the WIPP site may partly depend on an understanding of the relationship between fluid injection and seismic activity should injection occur in oil fields near the site.

\subsection{CONTINUING STUDIES IN HYDROLOGY}

\subsubsection{Introduction}

Hydrology is a major consideration when examining the feasibility for locating a nuclear waste disposal site. Two factors are directly related to hydrology: (1) the geologic stability of the formation in which the waste products will be stored, and (2) the occurrence of water as a transport medium for radionuclides. Unsaturated waters migrating along the surfaces of the salt beds will dissolve salt; therefore, an examination of magnitude and direction of fluid flow and fluid chemistry in formations above and below the salt is necessary. Additionally, the direction and rate of fluid movement both above and below the storage horizon should be evaluated to predict the movement of radionuclides should they be accidentally discharged into the aquifers.

\subsubsection{Purpose of Hydrologic Testing}

Two hydrology-related questions are to be answered in evaluating the suitability of the proposed WIPP site.

1. What is the geologic stability of the Salado Formation?

2. Should the primary containment barrier (the salt) fail or an accident occur, where and how rapidly will radionuclides be transported by groundwater?

Three factors need to be investigated to examine the integrity of the Salado within the site: (1) the Rustler-Salado contact is to be examined 
geophysically and petrologically within the WIPP area to determine if dissolution is presently occurring, (2) the dissolution front (as defined by the edge of the shallow dissolution zone in the Nash Draw) needs to be located more precisely, (3) the estimated rate of dissolution is to be refined.

The hydraulic gradients and rates of fluid movement in the series of fluid bearing zones that overlie the salado require further definition. Estimates of concentrations of aqueous species (and when and where they might appear) may then be refined for specific safety-assessment modeling scenarios describing radionuclide escape into these groundwater systems and migration out of the area. In addition, formations which do not presently contain water but exhibit some degree of permeability are to be tested to see what rates of movement would be, should they contain water or other fluids at some later time.

\subsubsection{Direction and Rate of Fluid Migration}

If radionuclides were to reach fluid bearing zones in the Rustler, they would be transported away from the site by the groundwater system. To evaluate the impact of such an accident on the surrounding area, hydraulic gradients and hydraulic conductivities of fluid bearing zones overlying the salt beds will be determined or modified. Data for these determinations will be acquired by pumping tests on hydrologic test holes or measurements of the recovery time of fluid levels in bailed holes. Tracer tests will be conducted where they may contribute useful information.

A series of hydrologic tests is planned in holes placed near the periphery of the proposed land withdrawal area. After additional testing of some existing holes, control points for the potentiometric surfaces and for hydraulic conductivities will have been established for the periphery with a spacing of 2 to 3 miles. These data will allow construction of more detailed potentiometric surface maps for the site area. The potentiometric contours will be meshed with the results from 
the Nash Draw program to the west. Consequently, the potentiometric surface and hydraulic conductivity data required for modeling efforts of long-term safety assessment will be obtained for an area extending from the northeast part of the study area to Malaga Bend on the Pecos River (an area of about 200 square miles).

The borehole plugging program requires data from both laboratory and in situ permeability measurements. These permeability measurements, both in the evaporites and in aquifers, will provide additional data for the safety assessment work.

\subsubsection{Dewey Lake Redbeds}

The Rustler Formation and the shallow dissolution zone in Nash Draw have demanded the attention of this program because they are fluid-bearing. The Dewey Lake Redbeds are also of some significance since fluids are present in sandstone lenses. Although the redbeds are only locally saturated, two possibilities exist for additional water to enter the formation: a climatic change to a high rainfall period, or migration of fluids from below into the redbeds.

Tests in two types of holes are being considered: existing holes, and at least one new hole specifically designed for Dewey Lake testing. The casing in existing holes will be perforated opposite permeable zones as identified from analyses of logging and drilling records.

The standard hydrologic testing procedures will allow calculation of the transmissivity of fluid bearing strata in the Dewey Lake Redbeds or other permeable zones that might be expected to contain fluids at some future time.

\subsubsection{Long-Term Monitoring}

The peripheral hydrologic test holes, which now include four potash holes, will be configured for long-term monitoring. This long-term 
monitoring may show what changes are taking place in the hydraulic gradients which in turn may indicate increased or decreased flow, and variations in rates of recharge or discharge. Moreover, depending on the extent of the monitoring system, a warning network for information on fluid threats to the integrity of the repository is obtained.

The Dewey Lake Redbed hole(s) can be monitored to detect fluid movement that may not be present except during high precipitation cycles of long or short duration.

The test holes drilled in Nash Draw would be monitored to detect changes in the hydrologic regime along the Rustler-salado contact. Because the Culebra is the main producer of water west and south of the WIPP area, it is desirable to monitor this fluid-bearing strata to determine its relationship with the shallow dissolution zone and to provide additional data for modeling the safety assessment modeling scenarios.

\subsubsection{Surface Hydrology}

Surface hydrology must be examined climatologically with the aid of surface mapping. Records of annual rainfall and intensity and duration of storms (particularly high intensity, 24 hour, 50 and 100 year recurring storms) are available. This information, in conjunction with surface mapping (from aerial photographs, topographic maps, or both) of contributory drainage will provide the basis to estimate amounts of runoff and amounts of infiltration in the study area. Because of the high evapotranspiration and the caliche layer below surficial sands, infiltration estimates are expected to be only a small portion of the calculated recharge.

Photogrammetric and field mapping is planned to locate and describe springs which may issue from the Dewey Lake Redbeds or the shallow dissolution zone. Several springs are suspected to be located west of the site, and discharge measurements could aid in the identification of the formations from which they issue. Geochemical monitoring of many 
such springs, including the Malaga Bend seeps and the Pecos River salt load, will add to this overall understanding of hydrologic system dynamics.

\subsubsection{Overview of Deep Hydrologic Testing}

Three objectives for deep aquifer testing to complement the site-specific shallow aquifer investigations in the WIPP study area are:

(1) To obtain static bottom-hole pressure measurements in the deep aquifer zones, for the refinement of previous estimates of local potentiometric surfaces, hydraulic gradients, and hydraulic conductivities.

(2) To determine the bounds of the formational reservoirs.

(3) To obtain fluid samples for geochemical analyses.

Three wells suitable for hydrologic testing (Badger, Cabin-Baby, Cotton-Baby) are located within the site area. Each well will have to be re-entered and plugged, in accordance with methods now under study, or maintained as monitoring wells. Deep hydrologic data will be developed from these well to obtain site-specific information on the Delaware zones. Testing outside the study area involves two additional wells (AEC No. 8 and ERDA No. 6).

\subsubsection{Long-Term Monitoring of Deep Wells}

A number of wells could be equipped for long-term monitoring of the Delaware zone to show what changes, if any, are taking place in the hydraulic gradient, which in turn indicate fluid movement in the reservoir. Periodic fluid samples can be obtained to identify increased flow or chemical changes in the ground water system. 
10.6.9 Continuing Studies in Salt Dissolution and Overburden Subsidence

Program Objectives. The program of investigation of dissolution and subsidence has four fundamental purposes, and one special-case consideration:

1. To correlate surficial collapse features and deposits with subsurface dissolution, in order to develop criteria for an evolutionary pattern of collapse.

2. To characterize subsurface dissolution products adjacent to the WIPP site.

3. To determine the behaviour of fluids in dissolution products adjacent to the WIPP site.

4. To analyze potential impacts of evolution of dissolution products at and near the WIPP site with respect to repository breachment and radionuclide transport.

The special case is to determine the nature of subsidence over mines in salt, and its effects on the overlying groundwater system.

An elaboration of these purposes follows.

Nash Draw Investigations. Nash Draw is believed to have originated by some combination of surface erosion and subsidence following subsurface dissolution. If the process of formation is overwhelmingly exosion, then the potential for removal of overburden at the WIPP site is probably about the same as it has been in Nash Draw. If, however, the process is overwhelmingly dissolution of salt and subsequent collapse of the overburden, the potential extension of Nash Draw toward the WIPP by dissolution will be more quantitatively described. At present, there is no conclusive way of defining an instantaneous rate of growth of Nash Draw toward the WIPP site; therefore, the only alternative is to 
understand the processes which have resulted in Nash Draw, and incorporate their implications into the mathematical modeling efforts directed toward safety assessment involving the WIPP site in general, and radionuclide escape and migration in particular.

First, the Nash Draw program is a series of core holes, which will be geophysically logged. This operation will obtain data to serve three purposes: 1) reveal the subsurface of Nash Draw stratigraphy at carefully chosen points, 2) reveal the relationships between the subsurface structure and surface features and deposits, 3) reveal how much halite and anhydrite (or gypsum) has been removed by dissolution.

Second, the Nash Draw program is a source of geologic material for petrographic and geochemical examination. Examination of thin sections of recovered rock will allow the mineralogy of dissolution products to be determined, i.e. identification of what was dissolved and what remains. Mineralogy and textures of dissolution residues and cemented collapse fill can then be compared with those of dissolution features sampled in other programs, such as the one to investigate the cemented rubble chimneys (often called "karstic domal features" or "breccia pipes"). Geochemical analyses of core materials for trace constituents will reveal their degree of interaction with groundwaters, and possibly an age of formation. Also, permeabilities to fluids can be obtained from cores.

Third, the Nash Draw core holes will become a series of hydrology test holes. The brine flow underlying Nash Draw has been attributed responsibility for much of the dissolution and collapse observed today. The safety assessment scenarios for radionuclide escape and migration involve movement from WIPP into Rustler Formation waters into the shallow dissolution zone and out at Malaga bend on the Pecos River. It behooves us to understand the hydrologic relationships between the shallow dissolution zone and the Rustler water-bearing rocks in Nash Draw in order to verify that models of radionuclide transport are representative of the physical system. 
Cemented Rubble Chimney Investigations. One of the "karstic domal features" described by J. D. Vine (called Hill "C") was encountered at the level of the McNutt potash zone by Mississippi Chemical Corporation. It was found to be a chimney in the salado Formation filled with clay-cemented brecciated rock belonging to strata above the McNutt. Similarly a breccia-filled chimney was encountered in drilling near a circular hill near the Wills-Weaver Mine. There are numerous other erosion-breached domes such as Vine's Hill " $\mathrm{C}$ " in the vicinity of Nash Draw; the subsurface expression of them, if any, is virtually unknown. It is desirable that a hole be drilled to a depth at which no more brecciated rock is found. Hydrologic observation (including water sampling and static water-level measurements) in fluid-bearing zones of the structure itself and in "bedrock" and in nearby rocks will help to determine the degree of hydraulic connection of the structure with aquifers of regional extent.

Petrographic analyses of recovered core will allow comparisons to be made with dissolution products recovered from Nash Draw investigations, described previously. Such material also lends itself to geochemical analyses for the determination of rock-water interaction history and age. Similarly, fluid analyses will provide an indication of how the fluids have interacted with their host rocks, helping to determine the processes at work in such structures.

Since modeling of radionuclide escape and migration must take into account fluid movement, cemented rubble chimneys should be evaluated for their potential as paths for such movement. They should also be evaluated as members of the evolutionary pattern of dissolution and collapse features, and might be generically related to the development of Nash Draw. Consequently, it is desirable to measure in situ the permeability of the structure. In addition, the hydrologic relationships between the chimney and surrounding rocks should be understood in order to formulate a complete hydrologic model for risk assessment. 
Mine Subsidence Investigations. The potash producers in southeastern New Mexico mine in two stages -- the primary recovery which leaves rooms separated by large pillars, and the secondary recovery in which they may "rob the pillars" and ultimately remove almost 958 of the ore. Second-mining requires abandonment almost immediately thereafter, because there is no longer a large enough local pillar system to hold up the roof. And so, the roof slowly sags, and subsidence is propagated to the surface.

While investigations of subsidence over mines do not bear directly on the four program objectives, mining is certainly a particular cause of subsidence and perhaps an indirect agent for initiating dissolution. If subsidence over a mine causes fracturing of water bearing rocks above, locally increased permeability might allow circulation of groundwater to underlying evaporites through the fractures to start dissolution.

The amount of subsidence and its potential for enhancement of salt dissolution of the Salado Formation over the WIPP if the McNutt potash zone were to be mined is unknown. If this subsidence program were to lead to a satisfactory means to predict subsidence and its effects, in particular dissolutioning, the control zone restrictions currently prescribed around the WIPP could possibly be relaxed. It is possible that minor subsidence will occur over the closed WIPP mine because it will not be possible to backfill the repository to the same packing density as original rock. Therefore, it is desirable to evaluate the effect of mining and subsequent subsidence on the local groundwater system in the subsiding overburden.

\subsubsection{Modeling of Regional Hydrology}

Hydrologic modeling has one basic objective, to support risk assessment work by describing the movement of fluids in this region in as much detail as possible. The movement of fluids affects the expected period of integrity of the repository and the movement of radionuclides from the repository. To fulfill this objective, the modeling emphasizes several 
aspects. The first aspect is interpretation and explication of the data collected in field programs designed to delineate the regional flows. The second is to suggest where data are insufficient and more field or laboratory work is required. The third aspect is the simulation of experiments which cannot be performed in the field. Two examples for simulations are: consequences of perturbations to regional flow patterns caused by the existence of a repository, and consequences of changes in regional flow patterns due to alterations in rainfall patterns or due to man's activities.

The fourth aspect is prediction of the movement and concentrations of radionuclides consistent with fluid movement determined in part by the release scenarios developed for WIPP.

Implementation is based on the modification and use of certain 2-D and 3-D computer codes available for hydrologic modeling. Code verification based on field data already collected is in process. Supporting laboratory programs designed to provide parameters as absorption coefficients, permeabilities, etc., are already underway.

\subsection{CONTINUING STUDIES IN GEOCHEMISTRY}

\subsubsection{Introduction}

Detailed accounts of geochemical data reported in Chapter 7 have provided the pressing need of fundamental information for (1) conceptual design of WIPP operational facilities, and (2) Eormulation of site-specific process scenarios to be used in the consequence safety assessment effort. An evaluation of the available data has shown that the completed studies are not entirely sufficient to support WIPP experimental programs. These programs include borehole plugging, laboratory rock mechanics, in-mine rock mechanics, in-mine heater experiments, in-mine high-level waste emplacement experiments, laboratory waste-rock interaction experiments, radionuclide transport through rocks, and waste encapsulation studies. 
In addition, the long-term safety assessment effort has lacked information about geological processes associated with so-called "geological anomalies" such as igneous dikes and cemented rubble chimneys.

\subsubsection{Mineralogy and Petrology}

The data concerning assemblages of evaporite minerals in the Salado Formation which were presented in Chapter 7 have addressed the types of minerals found and their relative (qualitative) abundances. While this has been useful in selection of candidate horizons for waste emplacement, it has been of limited use to the quantitative measurements of thermal and physical properties of evaporite rocks (see Chapter 9).

It has been found that a small change in the quantitative mineralogical proportions in a rock sample has a large non-linear effect on thermal properties, for example. Chapter 7, together with its executive summary in Chapter 1, has pointed out the variability in the mineralogical composition of rocks in the Permian evaporite section.

In addition, quantitative mineralogy and petrology is required for development of materials to be used in the plugging of shafts and boreholes. The long-term thermodynamic stability of a grout plug, for example, cannot be evaluated without an intimate knowledge of mineral phases in both grout and rock, so that free energy calculations can be made for degradation reactions which might occur between the two. Compatibility of grout with rock and groundwater will be an essential factor requiring thorough evaluation to provide confidence in the long-term sealing of boreholes and shafts which penetrate from surface to repository horizons.

\subsubsection{Volatiles Characterization}

Chapters 7 and 9 have alluded to the variability in volatile content of evaporites and how the variation affects fundamental rock properties. Chapter 7 has addressed the volatile component in detail mostly in view 
of mass loss experienced by heated rock. The entire mass loss cannot be ascribed to water alone. Indeed, chapter 7 briefly addressed the chemical species which were found in a few selected rock samples, and even so, considerable variation was observed. Experiments are planned to simulate high-level-waste-canister heat in a potash mine, in order to quantize the devolatilization products. Unambiguous interpretations of the experimental results derived therefrom require an understanding of the volatile components native to the rock before heating begins. Furthermore, the interpretations also require an understanding of the fundamental differences between potash ore zones and actual repository zones, since the results of devolatilization in one will certainly not be directly applicable to the other without taking into consideration the native differences.

\subsubsection{Origins of Evaporite Assemblages}

It was pointed out in Chapter 7 that many of the evaporite mineral assemblages observed in the Permian section cannot have precipitated from a seawater-like solution. Furthermore, the thermodynamic properties of some minerals, such as the almost ubiquitous polyhalite, are virtually unknown. Similarly its mode of origin is entirely unknown, and has been long regarded wholly as a product of recrystallization, commonly replacing anhydrite.

The present assemblages not only contain non-primary evaporite minerals, but also have a magnesium deficiency relative to other evaporites in the world. The sink for this magnesium presumably lost during recrystallization has not been identified. The observations of chapter 7 urge that a thermodynamic understanding of the environments and processes of evaporite recrystallization be sought. In this way the water loss that the evaporites have experienced (during recrystallization) can be estimated, and confidence can be gained regarding what mineralogical changes (if any) are likely to take place in response to waste emplacement. 
The techniques used in deducing the origins of evaporite assemblages include chemical quantitative analyses of minerals, petrographic paragenetic examination, and stable isotope, radioisotope and trace element analyses.

\subsubsection{Igneous Dike}

In Chapter 4, there was mention of a northeast-trending igneous dike intruding the evaporites on the west side of Nash Draw west of the WIPP study area. The characterization of the dike was based on the Yeso Hills and Kerr-McGee mine occurrences, together with an aeromagnetic survey. In order to come to an understanding of the marginal effects (i.e., dike-salt-fluid interactions), the following pursuits are recommended:

1. Collection and study of additional samples from farther away from the Kerr-McGee dike occurrence.

2. Determination of:

a. K-Ar ages of the alteration micas in the dikes

b. Drilling angle holes with coring at appropriate intervals, to sample the dike and the effects of the dike upon the host rock system.

The dike appears to be a natural laboratory experiment involving high-temperature interactions among salts, groundwaters, and "alien" mineralogies such as emplaced waste would also represent.

\subsubsection{Trace Elements and Age-Dating}

A continued effort is desirable in age-dating and trace element studies, in order to support investigative efforts contemplated for the so-called "geologic anomalies." The activities are, specifically:

1. Chemical and isotopic study of exposed collapse structure in underground workings of Mississippi Chemical Mine. 
a. If waters have percolated through this structure in very recent times then this may be reflected in oxygen isotopic study of grain coatings, etc. Rb-Sr studies of clay minerals should give an indication of $\mathrm{Rb}, \mathrm{Sr}$ and $\left({ }^{87} \mathrm{Sr} / 86 \mathrm{Sr}\right)$ redistribution relative to clay minerals removed from the collapse structure.

b. Scanning electron microscope/microprobe study of grain boundaries: supplemented by instrumental neutron activation analysis (INAA) for adsorbed elements (alkalies, alkaline earths, rare earth elements).

c. Rare Earth Elements (REE) distribution in all primary and secondary phases most likely to have been affected by solutions.

2. REE (and other key trace element) abundance in major facies of drill core from WIPP site. At present trace element data are very sporadic and obtained by different techniques so that real differences due to analytical precision and accuracy are suspect. Detailed INAA study of various phases from the same stratigraphic horizons over a wide lateral extent are desirable to establish realistic background data for the REE (i.e. because the REE are commonly used as analogues for the transuranics) so that REE data from dike-salt contact zones and elsewhere can be proprly assessed. If the REE distribution is extremely variable then local variations due to solution, recrystallization, contact effects will be difficult to interpret; if the REE show a more or less uniform distribution pattern and abundance then such effects can be closely scrutinized.

3. Dike-evaporite contact effects. Samples from the lamprophyre dike $(T=\sim 35$ MYBP) which is observed in the underground workings of the Kerr-MaGee Mine offers a unique chance to examine the effects of a local, high temperature source in contact with several evaporite phases. 


\subsubsection{Reef and Back-Reef Waters}

There is at present some degree of confusion surrounding the source and discharge of water in the Capitan Reef surrounding the Delaware Basin. Chapter 7 has shown that the greater portion of the water in the Reef cannot have come from direct infiltration into outcrops in the Guadalupe and Glass Mountains, nor from rocks in the Basin. Therefore, the relationships between the Reef and its lagoonal facies (back-reef) stratigraphic equivalents are likely source and sink candidates. These relationships are best deduced by combinations of stable isotope, uranium isotope, and solute analyses of reef and back-reef waters. An extensive water-sampling of these areas is required for this. The results of this geochemical mapping of regional groundwater flow would be used in the long-term safety assessment modelling effort and the final publication of the regional groundwater mathematical model.

\subsubsection{Future Work on Fluid Inclusions}

In addition to the obvious necessity of making studies on samples from the actual strata to be used for high level waste storage, a variety of approaches need to be explored. Fluid inclusions near the waste canisters might decrepitate in the thermal pulse; the conditions under which this will occur can and should be explored experimentally. (studies are continuing of inclusions in a suite of salt samples collected at various distances from a dike penetrating the salt horizons; this provides a natural analog.) The identification of the daughter minerals in some inclusions, and their thermal behavior, as well as bubble movement in a thermal gradient, will provide additional compositional information. The gases released on crushing or heating should be explored, as well as the leakage of gases (or water) out of inclusions. This would be pertinent both for interpretation of $\mathrm{K} / \mathrm{Ar}$ ages and in corrosion problems. The actual chemical composition of the larger inclusions and their isotopic composition (particularly H/D and $0^{16} / 0^{18}$, can be determined by existing methods. This would help in 
understanding the complex sequence of interactions of pore (and inclusion) fluid with the original salt beds to yield the present mineralogy.

\subsection{RESOURCES}

Sandia Laboratories has no continuing studies of resources at the WIPP site.

\subsection{SPECIAL STUDIES}

10.9.1 Purpose. The objective of thermophysical and radionuclide sorption studies on SENM rocks is to determine their characteristics as required by the structural mine design, in situ experimental, and long-term safety analyses programs. As with other continuing studies, these special studies are a means to an end, not an end in themselves.

\subsubsection{Thermophysical Properties}

Scope. A continuing assessment of the thermophysical properties of SENM rocks is envisioned because of the broad range of questions posed about radioactive waste isolation. These problems range from the plasticity of salt to the migration of brine in salt; many are not answered by a cursory investigation. Establishing a data base, for instance, for the analyses of long-term creep, is time consuming. It is not anticipated that evaluation of physical rock properties will be pivotal in mine, experiment or repository design; however, that is intrinsically impossible to guarantee. Such evaluations may very well be pivotal in considerations of retrievability of high-level waste experiments, in which high temperatures tend to accelerate creep. Thus, physical rock property determinations, such as the micromechanics of rock deformation, are a prudent pursuit to provide additional confidence in geologic isolation. 
Continuing studies. The primary object of the continuing experimental rock mechanics program is to understand and model the thermomechanical behavior of the WIPP salt. This will be accomplished through studies of transient creep data at pressures exceeding $1500 \mathrm{psi}$ and at a principal stress difference less than 2000 psi where there is a paucity of data. In addition, petrographic investigations will continue to identify the governing deformation mechanisms.

Other studies relevant to the long-term stability of the WIPP include measurements of gas and brine permeabilities on previously deformed core and measurements of gas permeabilities at elevated temperatures. Studies are also planned in the area of thermal expansion coefficients and brine migration in salt under thermal gradients. Migration of fluid inclusions is being given attention, because of the brine's corrosive potential and because the capacity of fluid inclusions to carry radionuclides through rock salt is not known.

Rock mechanic programs will also be initiated to determine the mechanical properties of the WIPP site rock other than rock salt. These studies will be directed toward the engineering performance and construction characteristics of the non-salt rock which will influence the design and construction of shafts to the repository levels.

Mineralogic and petrographic studies will be conducted on core to support the physical rock properties determinations as required. This information is required to determine the phase systems in the rocks being investigated. A similar set of studies support the geochemical analyses, Chapter 7. The variations in mineral assemblage, grain size, fluid inclusion content, and petrofabric which have been observed in evaporite rocks have also given rise to variations in physical properties, which could only qualitatively be taken into account in the investigations reported here.

The arbitrary separation of mineralogical and physical rock properties from geology and hydrology that has of ten occurred in other studies is 
being avoided in the comprehensive studies being performed for the WIPP. The relations of rocks found at the proposed repository horizons to those found in an in situ test bed located elsewhere (e.g., nearby potash mine) are being evaluated. Quite possibly, mineralogic and fabric changes may cause discrepancies in results from one site to another.

\subsubsection{Radionuclide Sorption Properties}

Scope. A continuing assessment of WIPP rocks ability to inhibit the migration of radionuclides away from the repository is envisioned to augment the batch Kd determinations, which were used in preliminary calculations of radionuclide travel time in site-specific escape scenarios. A realistic approach to safety assessment requires data to be generated (mostly in the laboratory) under simulated physiochemical conditions anticipated in subsurface evaporites and related rocks of southeast New Mexico. The laboratory experiments in radionuclide migration would ultimately be evaluated by SENM field experiments involving the emplacement and observation of movement of non-radioactive tracers which are chemically analogous to radionuclides.

Continuing s.tudies. Whereas previous "Kd" measurements reflect the degree to which radionuclide soprtion on rocks takes place in static, closed systems, scenarios involving the entrainment of radionuclides in moving groundwater imply that a variety of physiochemical conditions will be encountered in the subsurface.

Now that the radionuclides of interest have been identified, different oxidation states of those radionuclides which might give rise to different mobilities in WIPP environments will next be identified. Investigations of effects on sorption of parameters such as $\mathrm{pH}$, radionuclide concentration in solution, and oxidation potential will then proceed with the oxidation states of species of interest. These parameterization experiments will culminate in the simulation of radionuclide migration in flow-through experiments involving actual WIPP rocks and solutions, at the anticipated physiochemical conditions. 
Appendix 7.A (Ref. sec. 7.3)

Whole Rock Chemical Analyses, Soluble-Insoluble

Fractions, Mineralogy, and Weight Losses

upon Heating. 


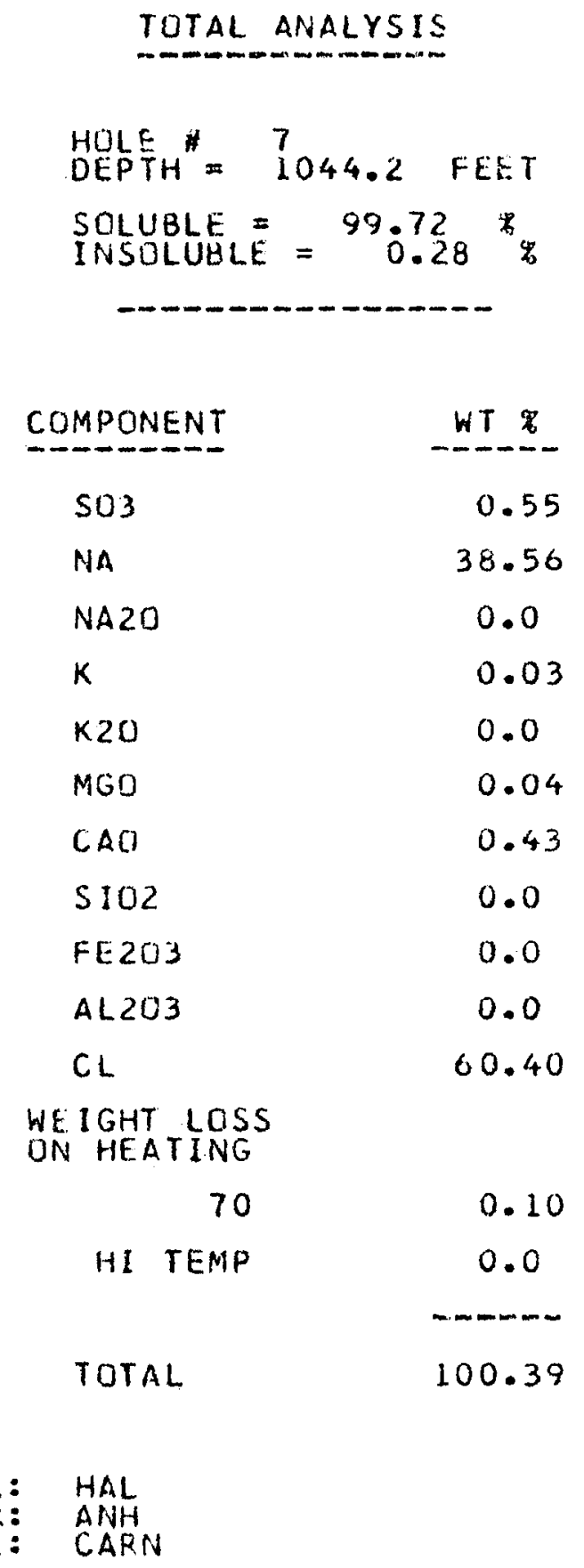


TOTAL ANALYSIS

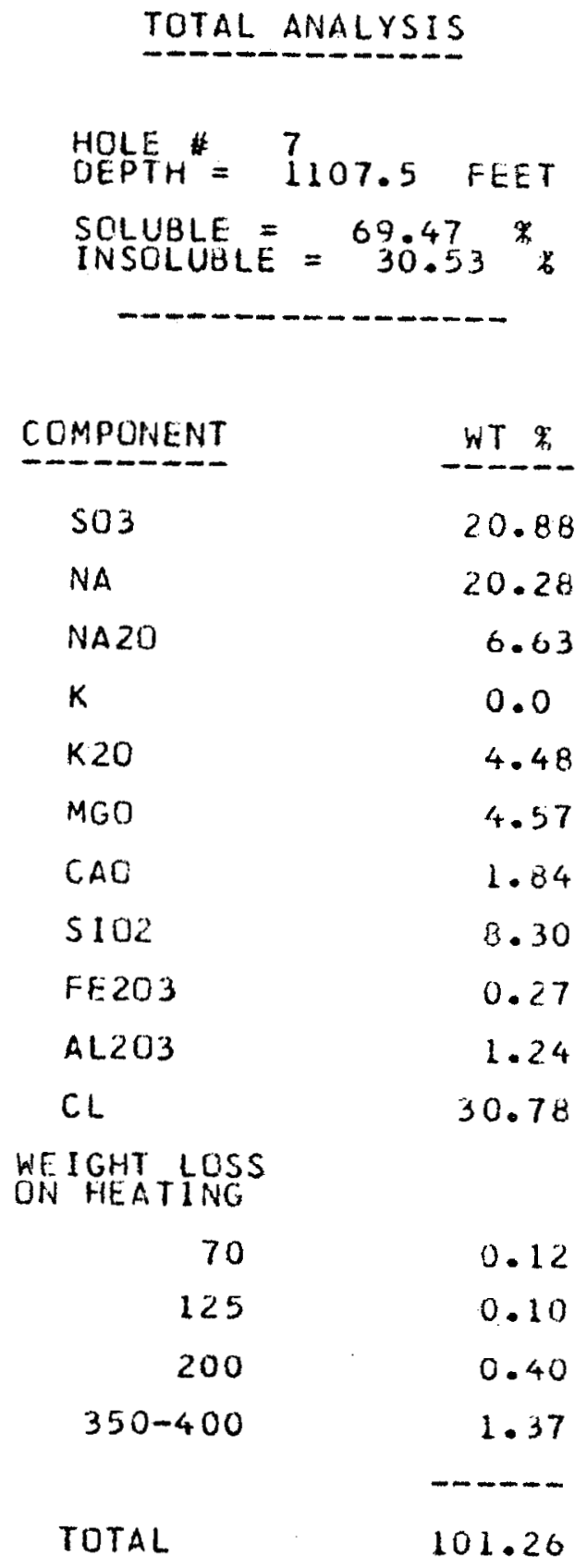

MAJOR: HAL

MINOR: PQLY, LANG, KFELD, TALC, OTZ 
TOTAL ANALYSIS

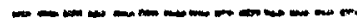

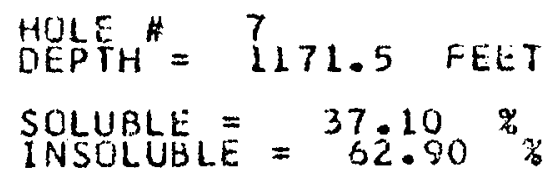

\section{COMPONENT}

503

NA

NA2O

$\mathrm{K}$

$K 20$

$M G O$

CAO

5102

FE2013

AL 203

$\mathrm{CL}$

WE IGHT LOSS

ON HEATING

$\begin{array}{rr}70 & 0.14 \\ 300-400 & 0.58 \\ 425 & 0.08 \\ & ---- \\ \text { TUTAL } & 101.27\end{array}$

MAJOR: HAL, ANH

MINOR: POLY

TRACE: SYL, BLUED, QTZ, FEOX 


\section{TOTAL ANALYSIS}

$$
\begin{aligned}
& \text { HULE \# } \\
& \text { OEPTH }=7221.0 \text { FEET } \\
& \text { SOLUBLE }=99.51 \\
& \text { INSOLUBLE }=0.49
\end{aligned}
$$

\begin{tabular}{lc} 
COMPONENT & $W T$ \\
\hline SO3 & 2.02 \\
NA & 38.79 \\
NA2O & 0.0 \\
$K$ & 0.06 \\
K2O & 0.0 \\
MGO & 0.10 \\
CAO & 0.88 \\
S102 & 0.01 \\
FE203 & 0.0 \\
AL203 & 0.0 \\
CL & 58.31
\end{tabular}

WEIGHT LOSS

ON HEATING

$$
\begin{array}{rr}
70 & 0.30 \\
100-200 & 0.14 \\
375-425 & 0.07 \\
& - \\
\text { TOTAL } & 101.17
\end{array}
$$

MAJOR: HAL

MINOR: $\quad$ ANH

TRACE: POLY, LANG, OTL 


\section{TOTAL ANALYSIS}

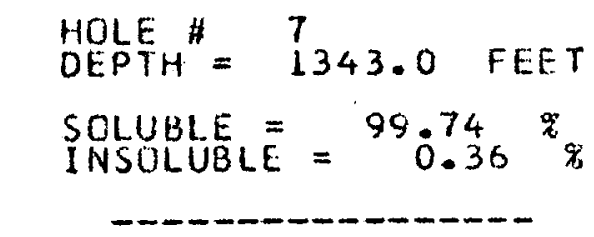

\begin{tabular}{|c|c|}
\hline COMPONENT & WT \\
\hline 503 & 0.99 \\
\hline NA & 38.60 \\
\hline NA2O & 0.0 \\
\hline$k$ & 0.35 \\
\hline$K 20$ & 0.0 \\
\hline MGO & 0.15 \\
\hline $\mathrm{CAO}$ & 0.66 \\
\hline 5102 & 0.01 \\
\hline FE2O3 & 0.0 \\
\hline$A L 203$ & 0.0 \\
\hline $\mathrm{CL}$ & 59.40 \\
\hline \multicolumn{2}{|l|}{$\begin{array}{l}\text { WEIGHT LOSS } \\
\text { ON HEATING }\end{array}$} \\
\hline 70 & 0.27 \\
\hline $300-350$ & 0.16 \\
\hline TOTAL & 100.95 \\
\hline
\end{tabular}

MAJOR: HAL

MINOR: ANHT, POLY

TRACE: OTL 
TOTAL ANALYSIS

$$
\begin{aligned}
& \text { HOLE } \#=7 \\
& \text { DEPTH }=1402.5 \text { FEET } \\
& \text { SOLUBLE }=99.97 \% \\
& \text { INSOLUBLE }={ }^{99} 0.03 \%
\end{aligned}
$$

\begin{tabular}{lc} 
COMPONENT & $W T \%$ \\
\hline SOS & 0.11 \\
NA & 39.67 \\
NA2O & 0.0 \\
K & 0.06 \\
KO & 0.0 \\
MG & 0.06 \\
CAD & 0.02 \\
S1O2 & 0.0 \\
FE2O3 & 0.0 \\
AL 2O3 & 0.0 \\
CL & 59.78 \\
WEIGHT LOSS & \\
ON HEATING & \\
TO & 0.19 \\
4OO-5OO & 0.12 \\
TOTAL & ---10 \\
HAL & 100.04 \\
POLY &
\end{tabular}


TOTAL ANALYSIS

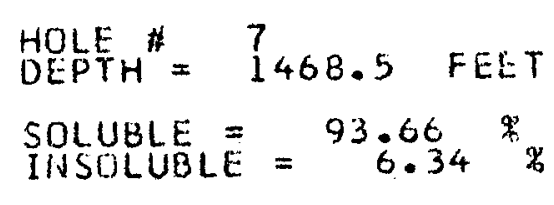

\begin{tabular}{lc} 
COMPONENT & $W T$ 类 \\
\hline SO3 & 2.88 \\
NA & 34.44 \\
WA2O & 0.0 \\
$K$ & 0.37 \\
K2O & 0.07 \\
MGO & 1.85 \\
CAO & 0.19 \\
S1O2 & 2.15 \\
FE203 & 0.24 \\
AL203 & 0.07 \\
CL & 53.61
\end{tabular}

WEIGHT LOSS

ON HEATING

$\begin{array}{rr}70 & 1.27 \\ 100-150 & 0.36 \\ 175 & 0.10 \\ 250 & 0.07 \\ 375 & 0.34 \\ 400-500 & 0.45 \\ \text { TOTAL } & ----- \\ \end{array}$

MAJOR: HAL

MINUK: KAIN, KIES 


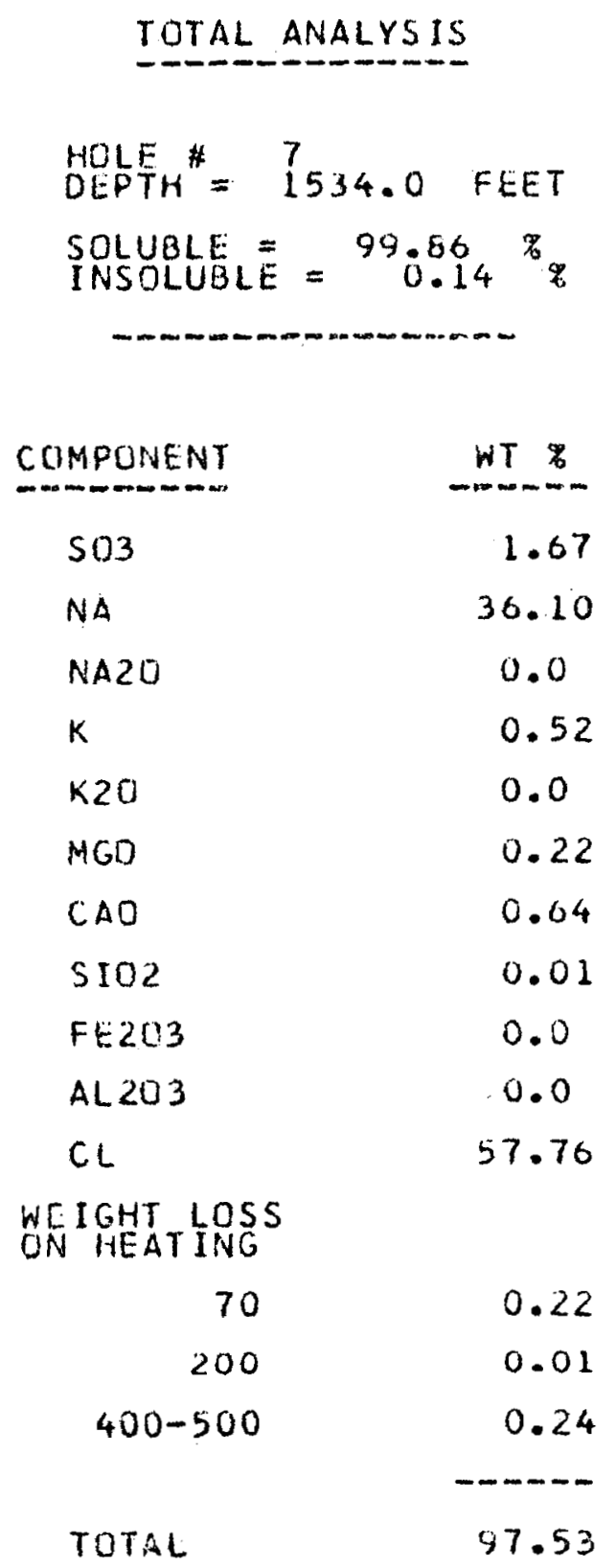

MAJOR: HAL

MINOR: POLY

TRACE: KAIN, QTL 


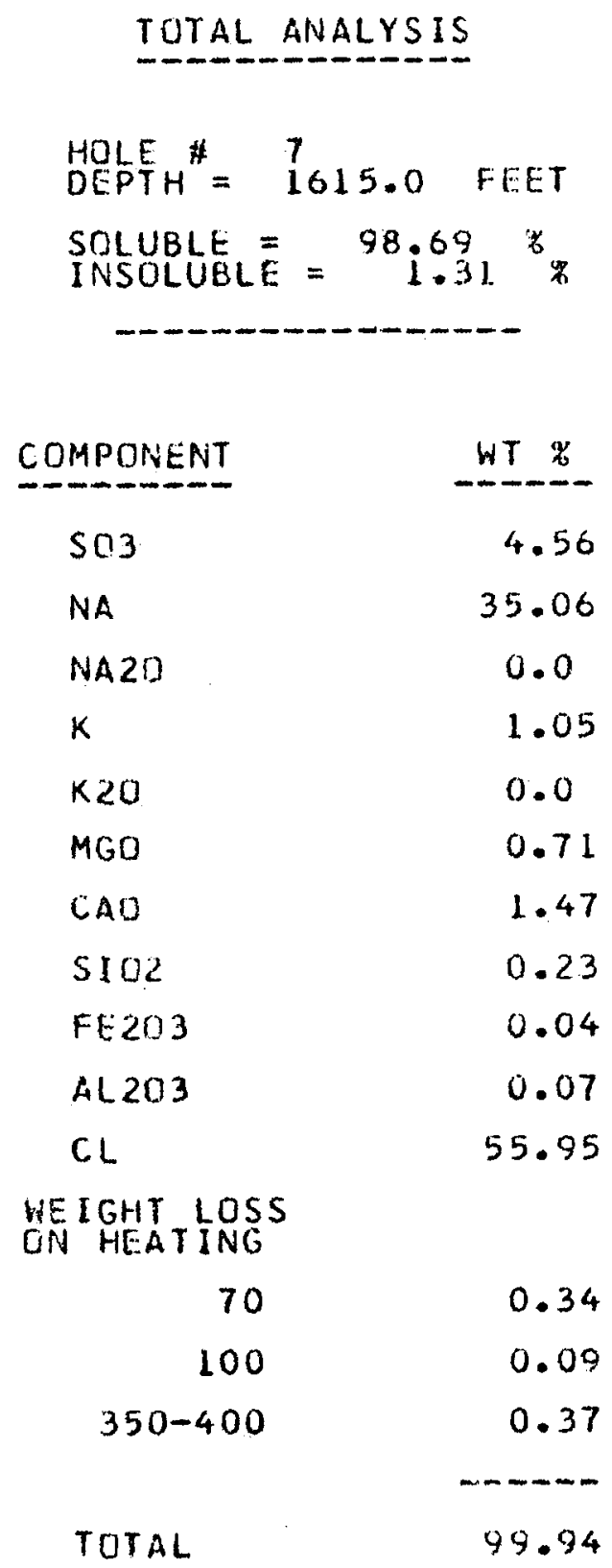

MAJOR: HAL

MINOR: POLY, KAIN

TRACE: CHLDR, MONT 


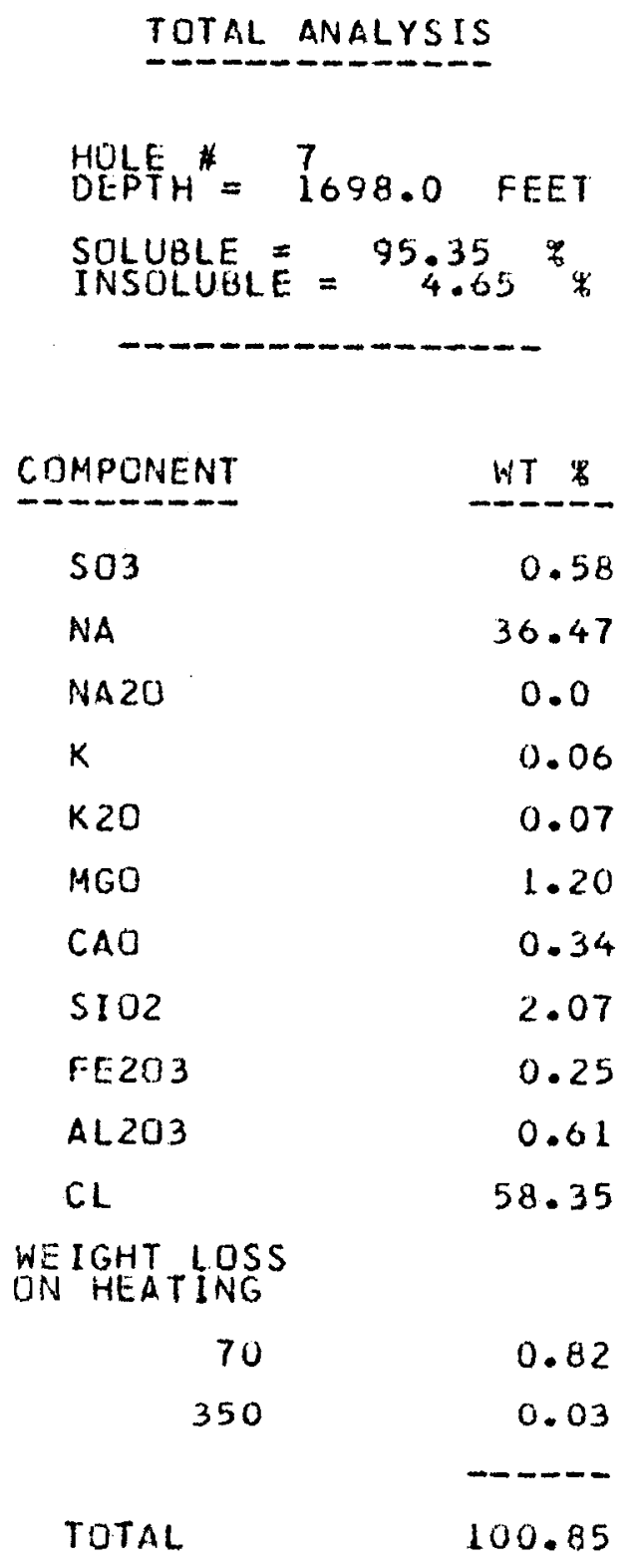

MAJDR: HAL

MINOR: ANH, CARN, KIES

TRACE: POLY, ILL, QTZ, FEOX 
TOTAL ANALYSIS

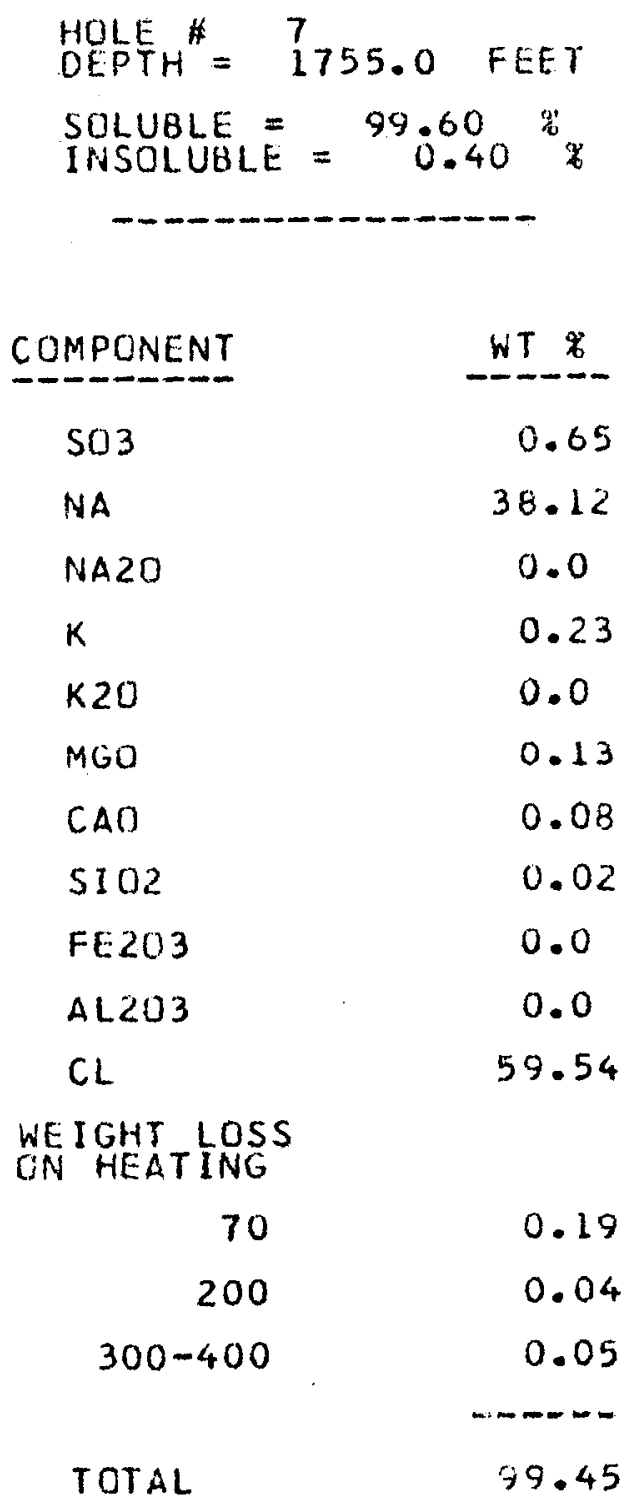

MAJOR: HAL

MINOR:

TRACE: LEON, OTZ 
TOTAL ANALYSIS

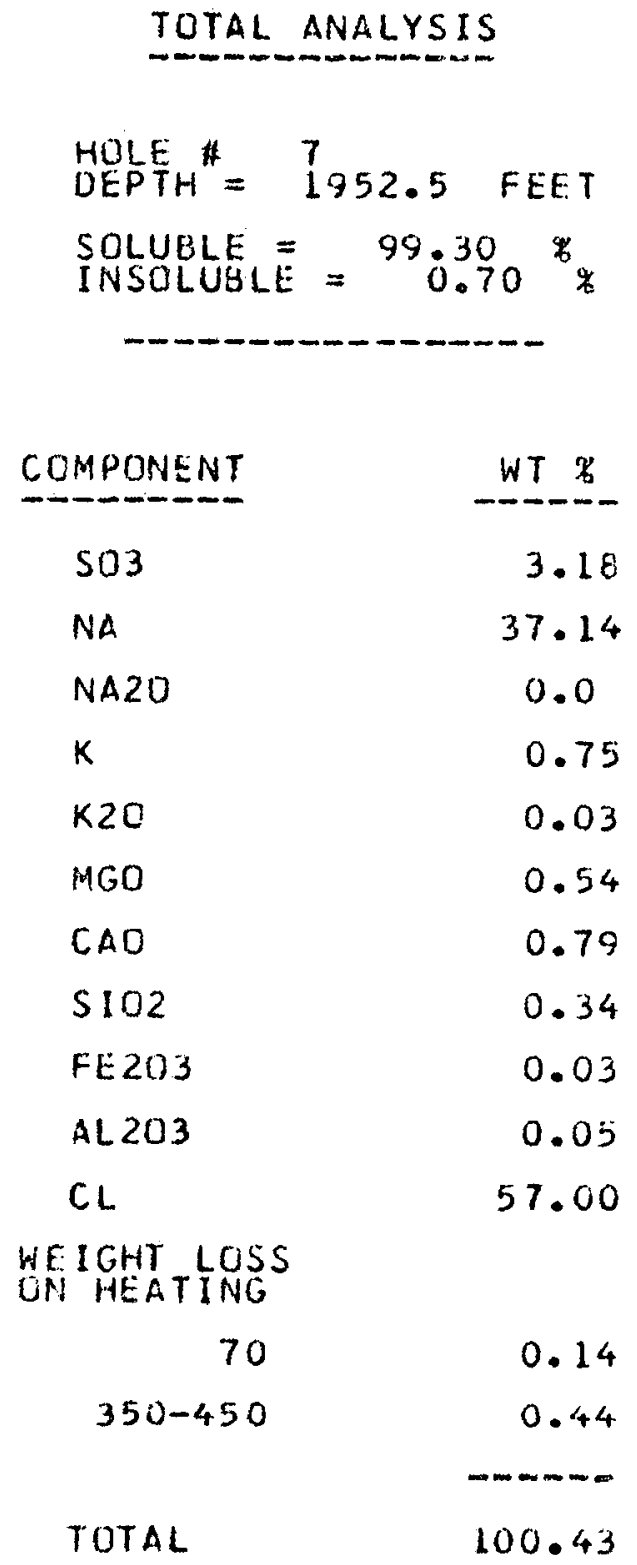

MAJOR: HAL

MINOK: PULY

TRACE: LEON, CHLOR, KFELD, FEOX 


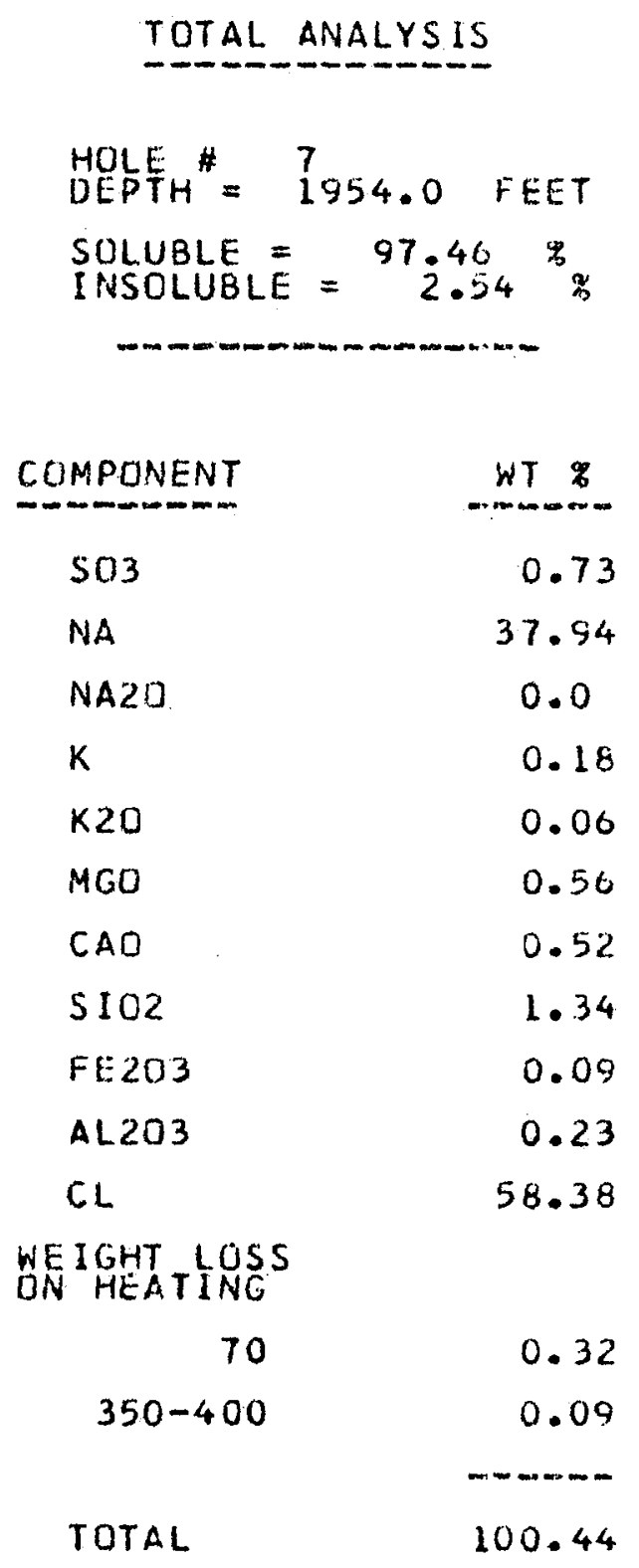

MAJUR: HAL

MINUR: POLY

TRACE: ANH, CHLOR, KFELO, TALC, FEOX 


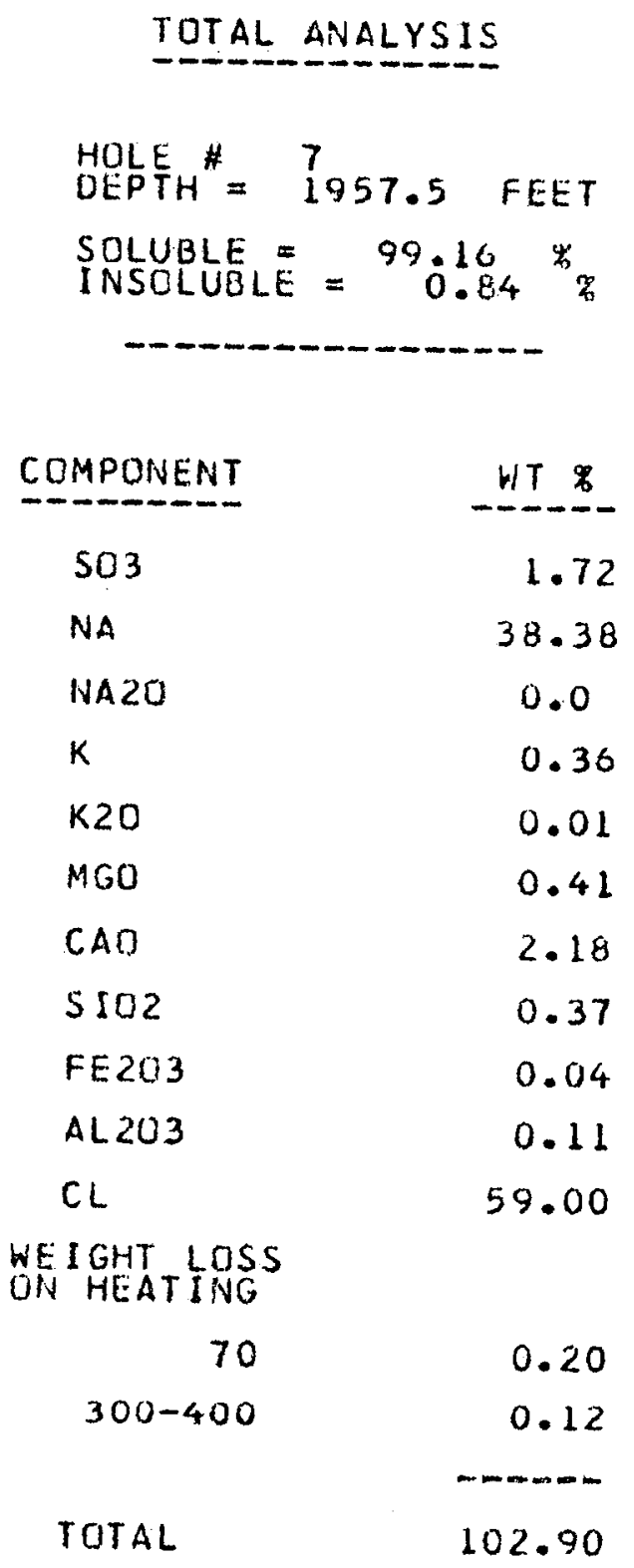

MAJOR: HAL

MINDR: ANH

TRACE: POLY, CHLOR, KFELD, FEOX 


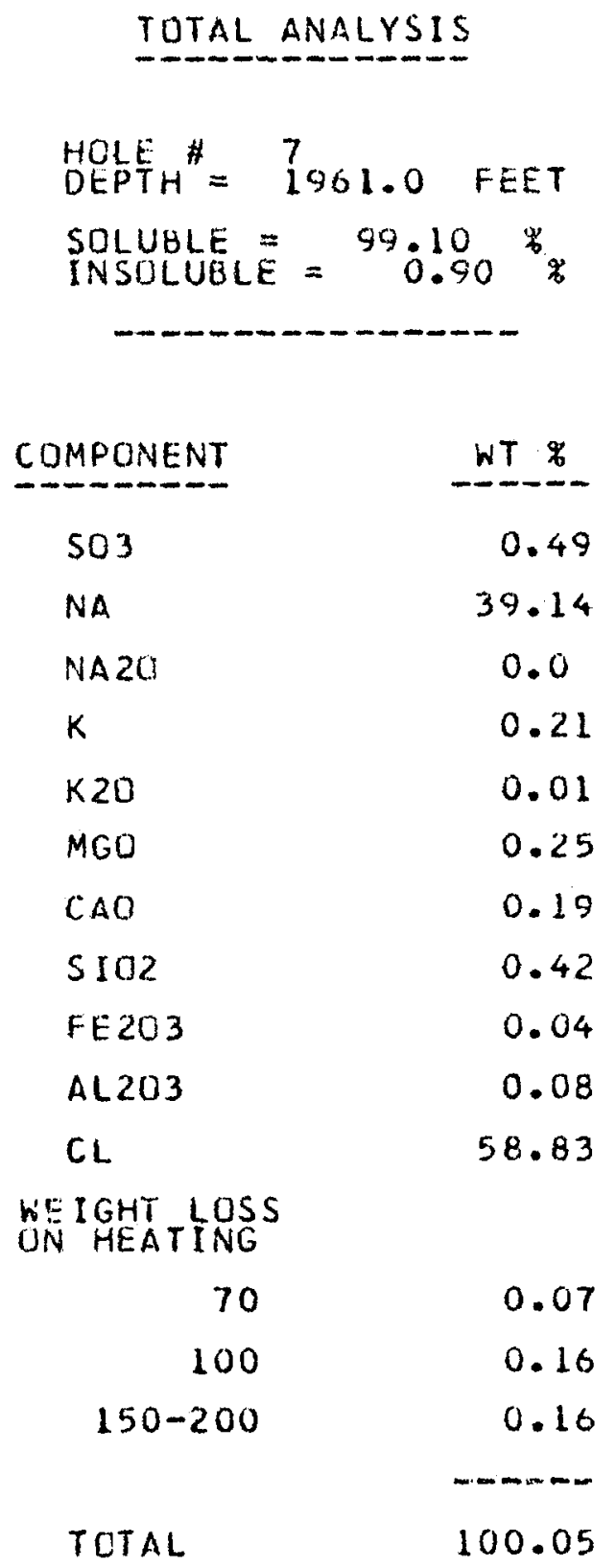

MAJOR: HAL

MINOR: POLY

TRACE: CHLOR, KFELD, TALC, OTZ, FEOX 
TOTAL ANALYSIS

HOLE ${ }^{*} 7$
DEPTH $=1967.0$ FEET
SOLUBLE $=99.94$ \%
INSOLUBLE $=9.06$

COMPONENT

$\mathrm{SO}_{3}$

NA

NA2O

$K$

$\mathrm{K} 2 \mathrm{O}$

$M G O$

$C A D$

$\$ 102$

FE203

AL 203

$\mathrm{CL}$

WEIGHT LOSS

UN HEATING

$\begin{array}{rr}70 & 0.20 \\ 300-350 & 0.28 \\ 450-500 & 0.65 \\ & ----- \\ \text { TOTAL } & 104.62\end{array}$

MAJOR: HAL

MINOR: POLY

TKACE: FEOX 


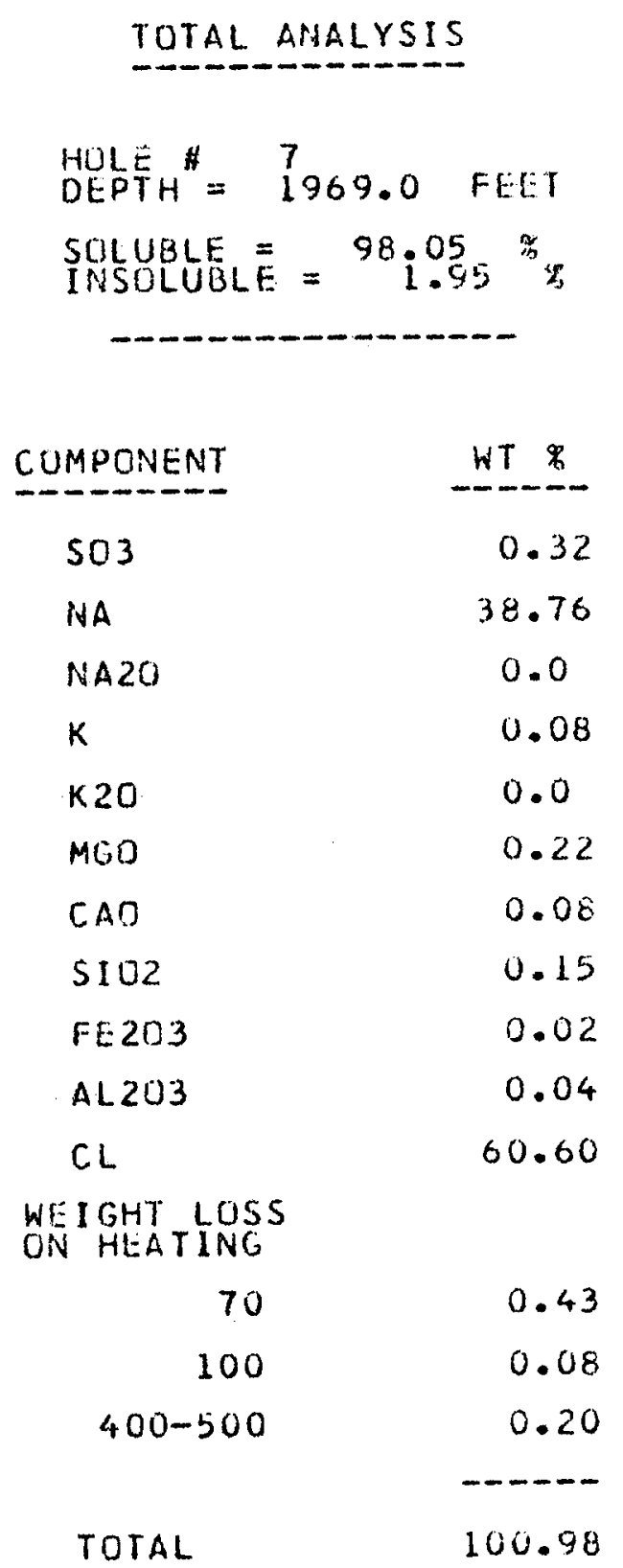

MAJOR: HAL

MINOR:

TRACE:

ANH, KAIN, CHLOR, TALC, QTL, FEOX 
TOTAL ANALYSIS

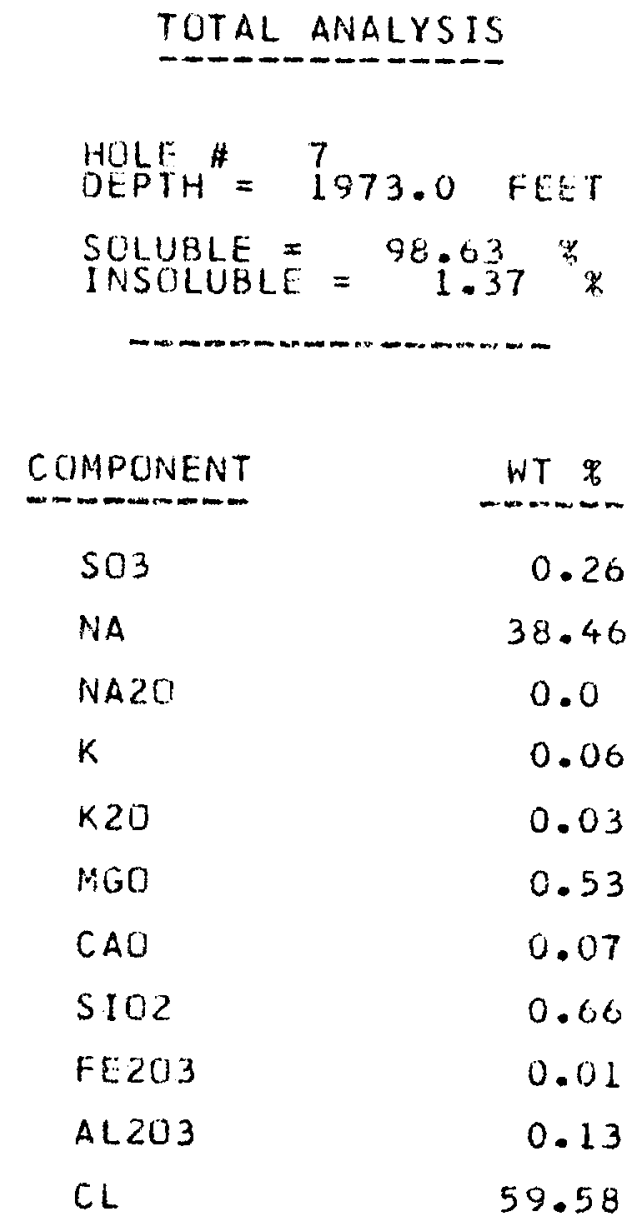

WE IGHT LOSS

ON HEATING

$\begin{array}{rr}70 & 0.19 \\ 170 & 0.07 \\ 380 & 0.02 \\ 450+ & 0.12 \\ & \\ \text { TOTAL } & 100.19\end{array}$

MAJUR: HAL

MINOR: POLY, KIES

TRACE: KAIN, CHLDR, FKELD, TALC, QTZ, FEOX 


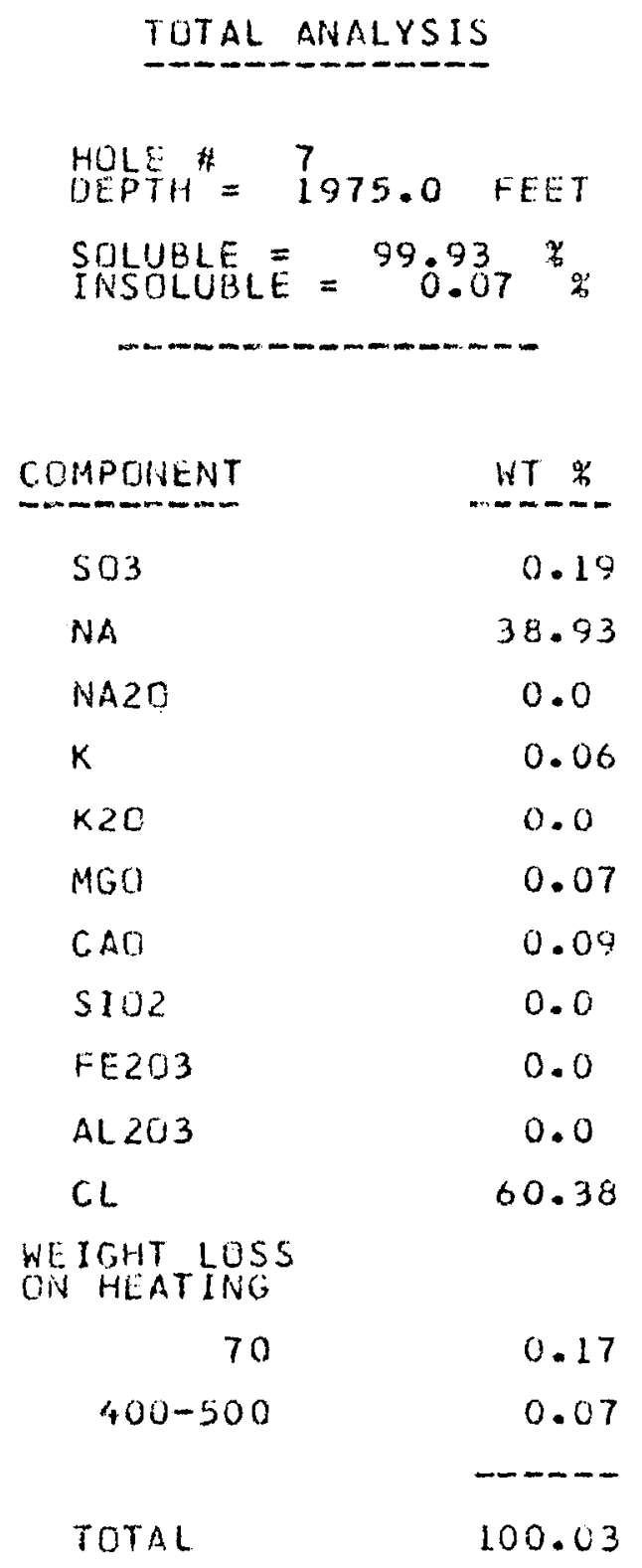

MAJUR: HAL

MINDR: ANH, KAIN 


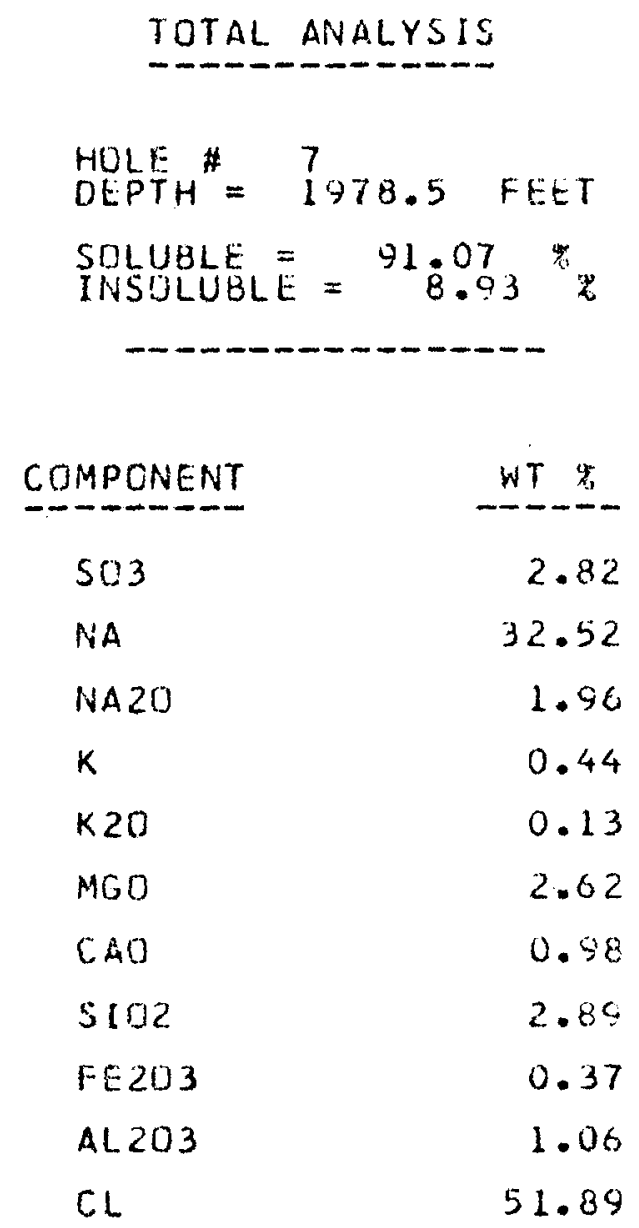

WE IGHT LOSS

ON HEATING

$\begin{array}{rr}70 & 0.30 \\ 200 & 0.04 \\ 300-400 & 0.17 \\ 450.550 & 1.10 \\ & \\ \text { TOTAL } & 99.35\end{array}$

MAJUR: HAL

MINOR: POLY, CHLCK

TRACE: ANH: LANG, BLOED, FEOX 


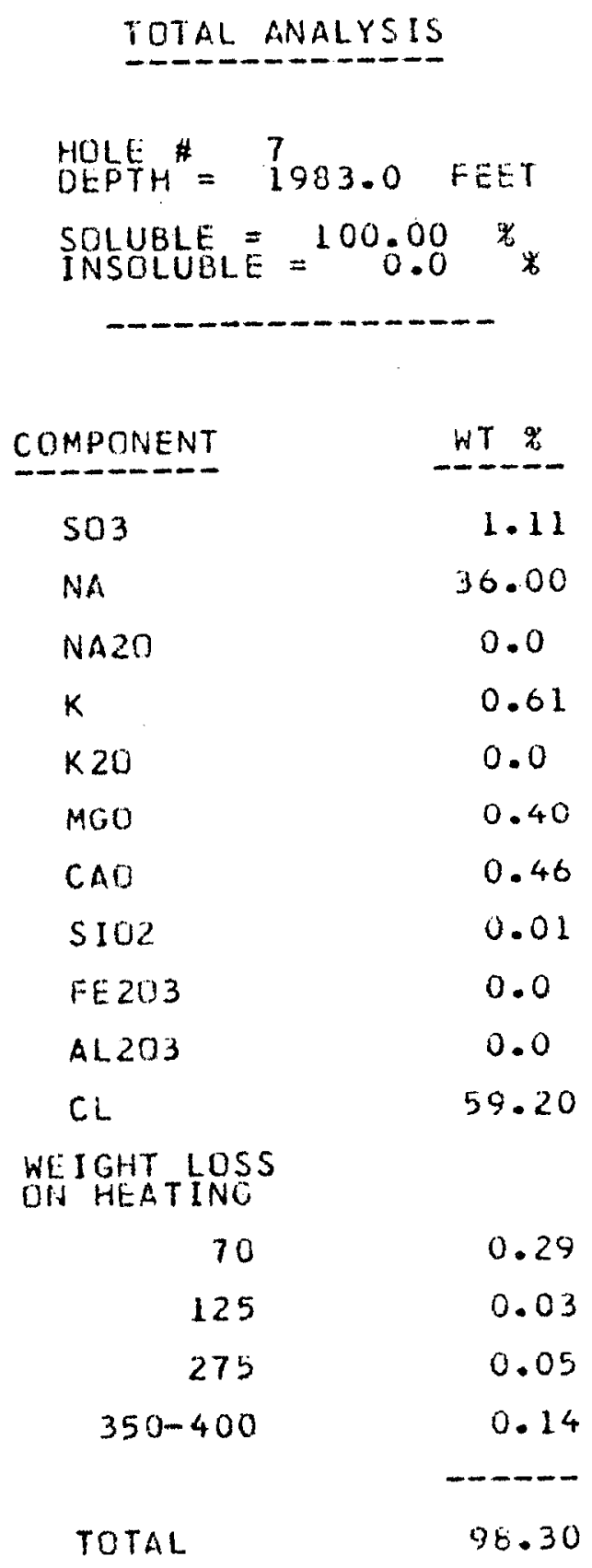

MAJOR: HAL

MINOR: DOLY, KAIN

TRACE: QTZ 
TOTAL ANALYSIS

HOLE H
OEPTH $=1996.5$ FEET
SOLUBLE $=99.71$
INSCLUBLE $=9.29$

COMPONENT

CIOMPONENT

503

NA

NA2O

$\mathrm{K}$

$K 20$

MGO

CAO

$\mathrm{SIOL}$

FE203

AL2O3

$\mathrm{CL}$

WEIGHT LOSS

UN HEATINC

$\begin{array}{cc}70 & 0.10 \\ \text { TO } 500 & 0.0 \\ & - \\ \text { TOTAL } & 99.71\end{array}$

MAJOR: HAL

MINOR: ANH, POLY

TRACE: KAIN, QTL 


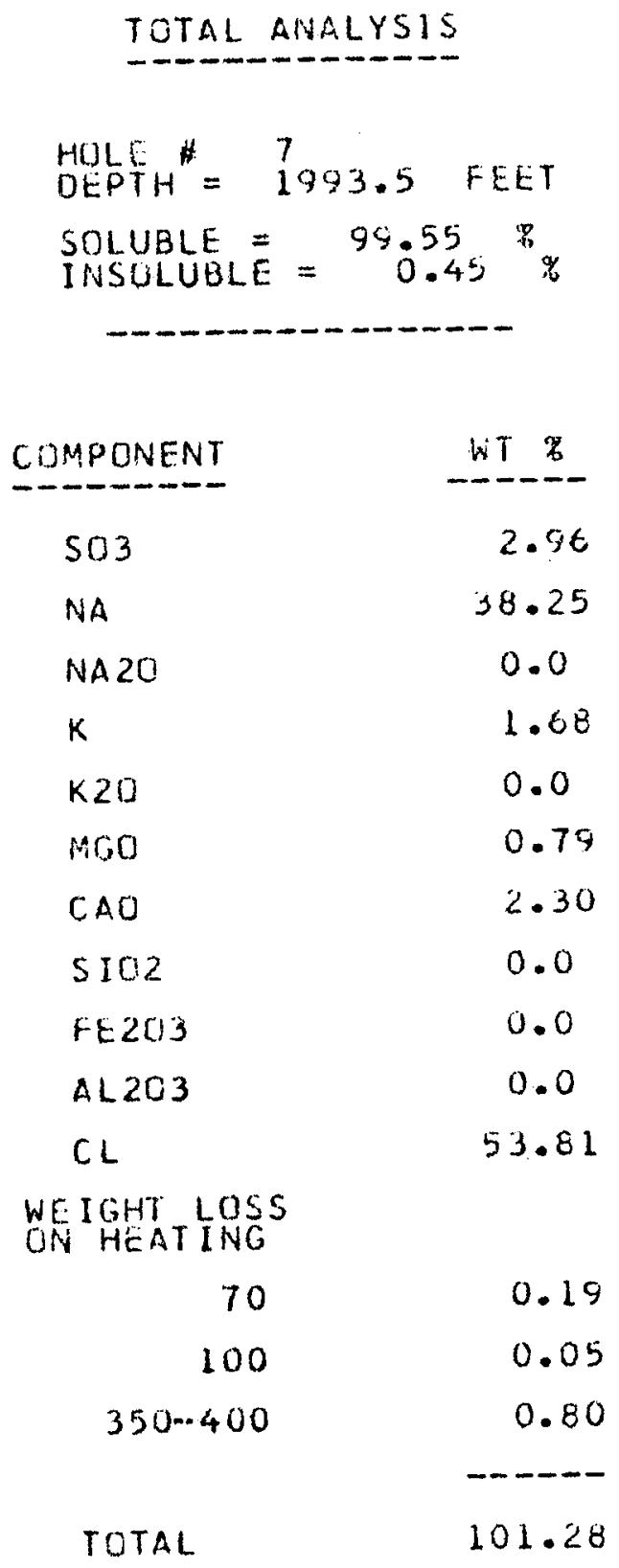

MAJOR: HAL

MINOR: POLY

TRACE: 


\section{TOTAL ANALYSIS}

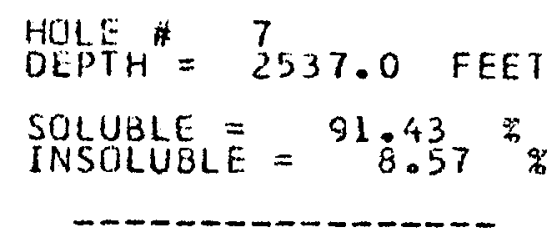

$\begin{array}{lc}\text { COMPUNENT } & \text { WT } \\ \text { SO3 } & 46.62 \\ \text { NA } & 0.93 \\ \text { NA2O } & 4.93 \\ \text { K } & 0.90 \\ \text { K2O } & 0.0 \\ \text { MGO } & 13.02 \\ \text { CAO } & 4.37 \\ \text { SIO2 } & 13.98 \\ \text { FE2O3 } & 1.13 \\ \text { AL2O3 } & 3.26 \\ \text { CL } & 2.63\end{array}$

WEIGHT LOSS

DN HEATING

$\begin{array}{rc}70 & 0.47 \\ 100 & 0.09 \\ \text { TO } 500 & 0.0 \\ \text { HI TEMP } & 8.68 \\ \text { TOTAL } & 109.58\end{array}$

MAJIIR: ANH

MINOR: HAL, KIES

TRACE: BLOEO, FEOX 
TOTAL ANALYSIS

$$
\begin{aligned}
& \text { HOLE H } \\
& \text { DEPTH }=2703.0 \text { FEET } \\
& \text { SOLUBLE }=98.97 \% \\
& \text { INSOLUBLE }=9.03 \%
\end{aligned}
$$

COAPONENT

$\mathrm{SO} 3$

NA

NA2O

$k$

$K 20$

MGO

CAO

5102

FE2013

AL.203

C.L

WEIGHT LOSS

$\begin{array}{rr}70 & 0.24 \\ 150 & 0.03 \\ 550 & 0.12 \\ & \cdots-2 . \cdots-\cdots \\ \text { TUTAL } & 100.54\end{array}$

MAJOR: HAL

MINDP: $\quad A N H$

TRACE: POLY, CHLOR, KFELD, TALC, FEOX
WT

1.40

38.36

0.0

0.02

0.01

0.26

0.79

0.25

0.06

0.05

58.89 


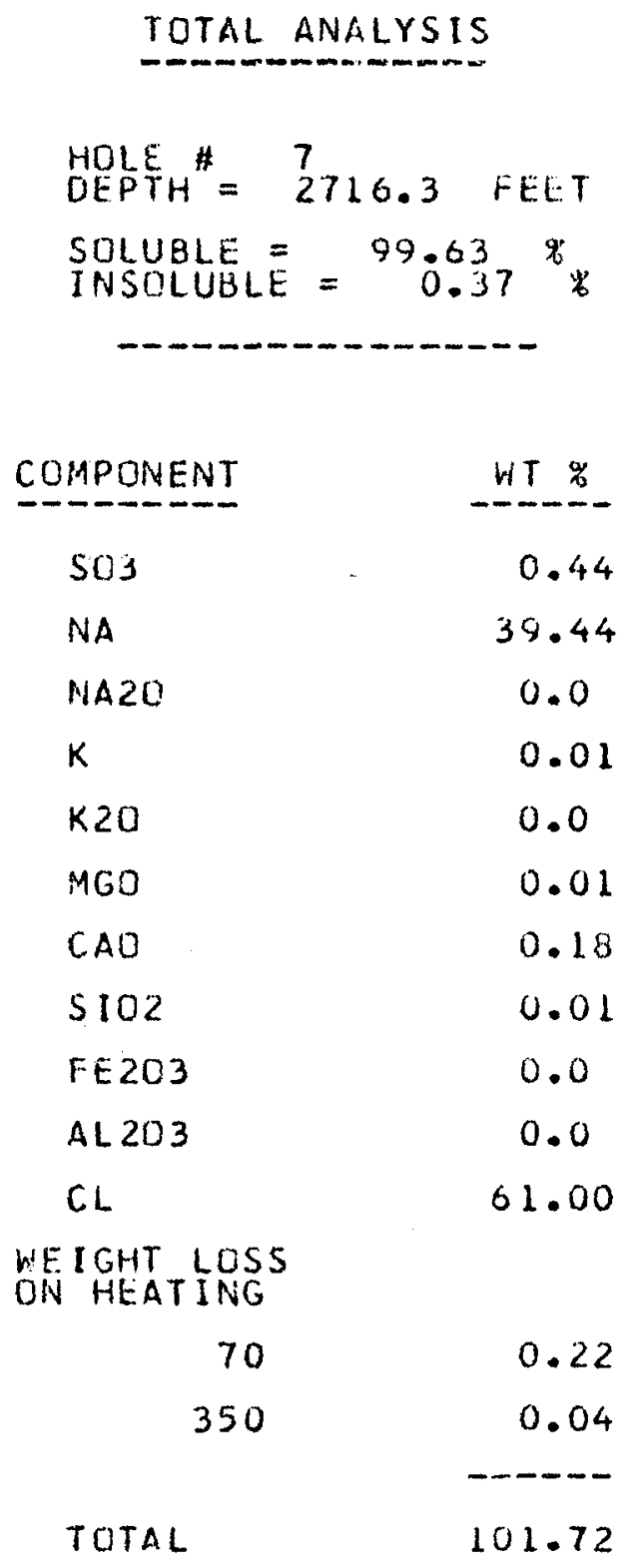

MAJOR: HAL

MINOR: ANH

TRACE: POLY, TALC 
TOTAL ANALYSIS

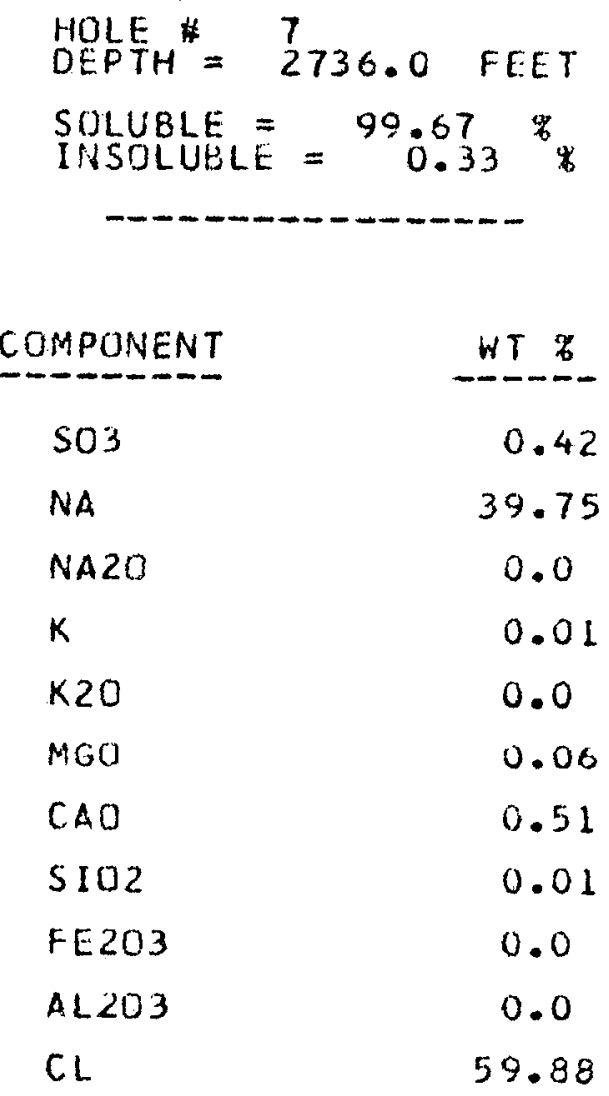

WEIGHT LOSS

UN HEATING

$\begin{array}{rr}70 & 0.08 \\ \text { TO } 450 & 0.03 \\ & \\ \text { TOTAL } & 101.08\end{array}$

MAJOR: HAL

MINUR: ANH

TRACE: 


\section{TUTAL ANALYSIS}

HOLE
DEPTH

SULUBLE $=98.99 \%$

\begin{tabular}{lr} 
COMPONENT & WT \\
\hline SO3 & 1.14 \\
NA & 39.34 \\
NA2O & 0.0 \\
K & 0.31 \\
K2O & 0.02 \\
MGO & 0.27 \\
CAO & 0.53 \\
SIO2 & 0.40 \\
FE203 & 0.27 \\
AL203 & 0.10 \\
CL & 58.07
\end{tabular}

WE IGHT LOSS

ON HEATING

$\begin{array}{rr}70 & 0.04 \\ 110 & 0.03 \\ 350-400 & 0.19 \\ & -70-7- \\ \text { TOTAL } & 100.71\end{array}$

MAJOR: HAL

MINOR: POLY

TRACE: CHLOR, ILL, QTZ, FLUX 


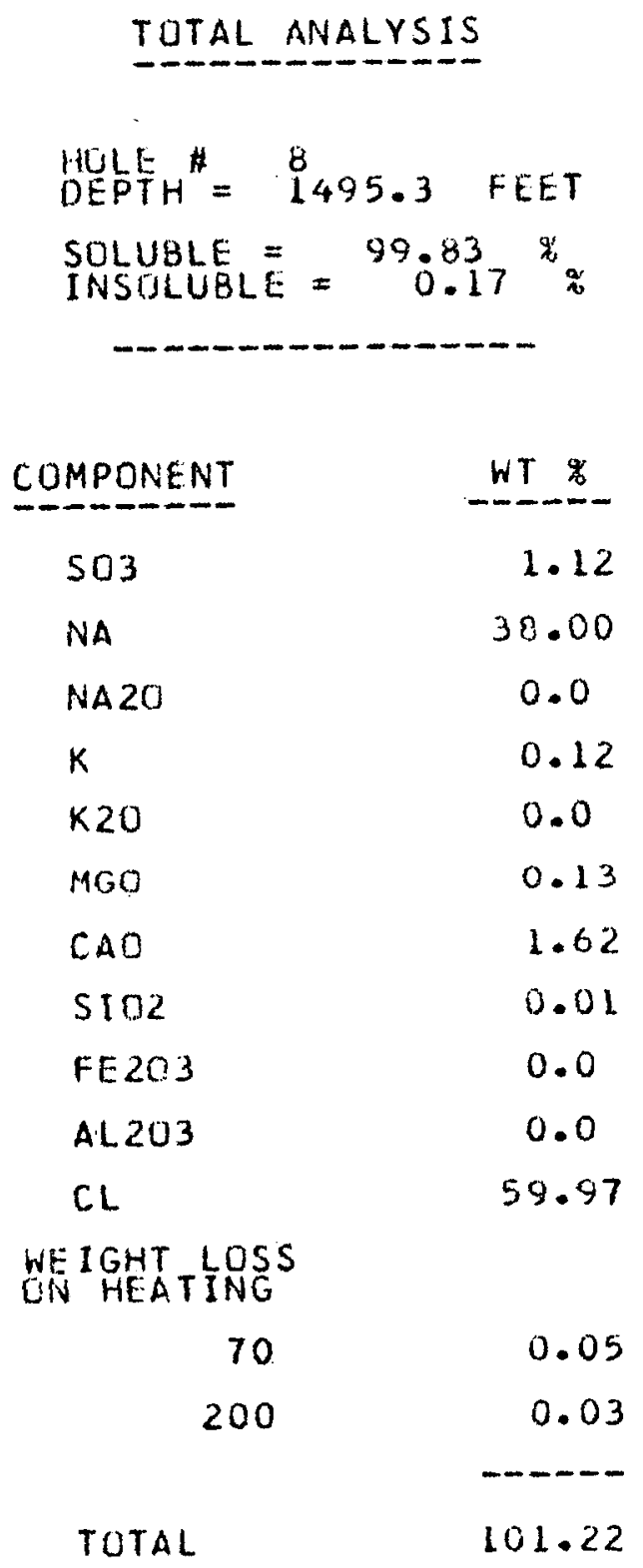

MAJUR: HAL

MINOPE: CARN 
TOTAL ANALYSIS

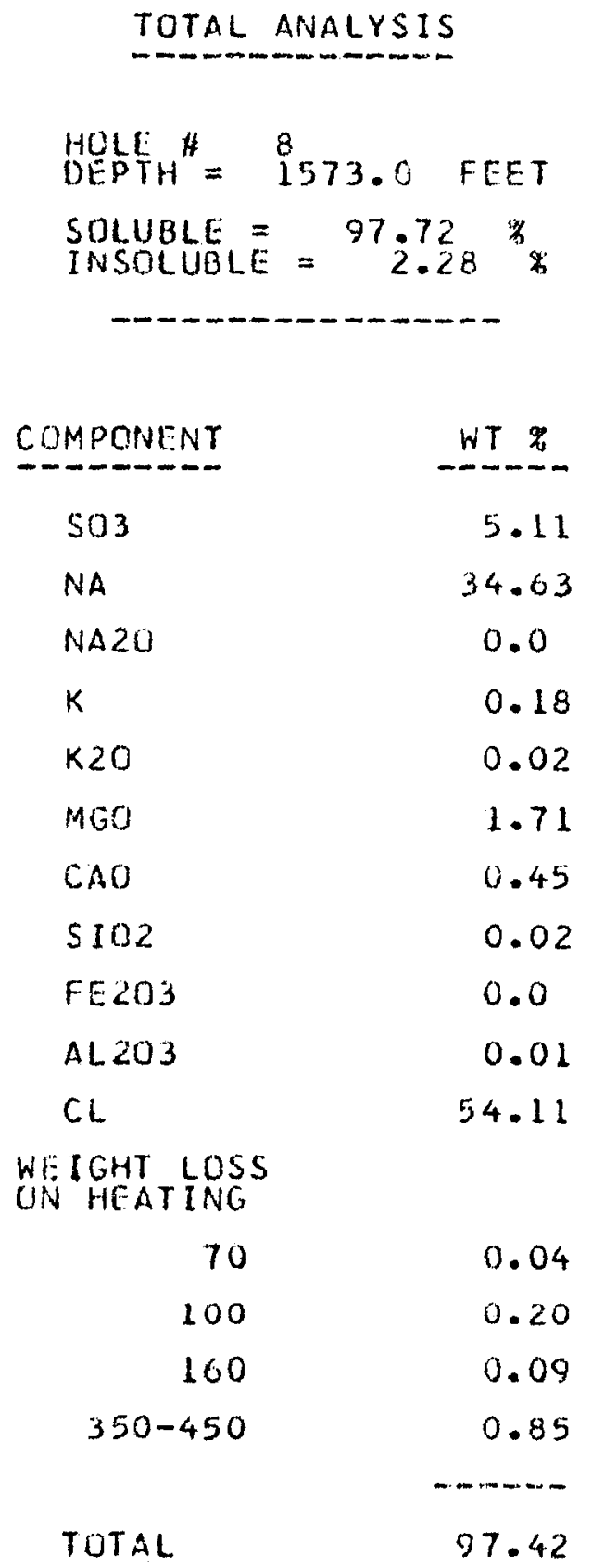

MAJOR: HAL

MINUR: (?) POLY, KIES

TRACE: (?) ILL 


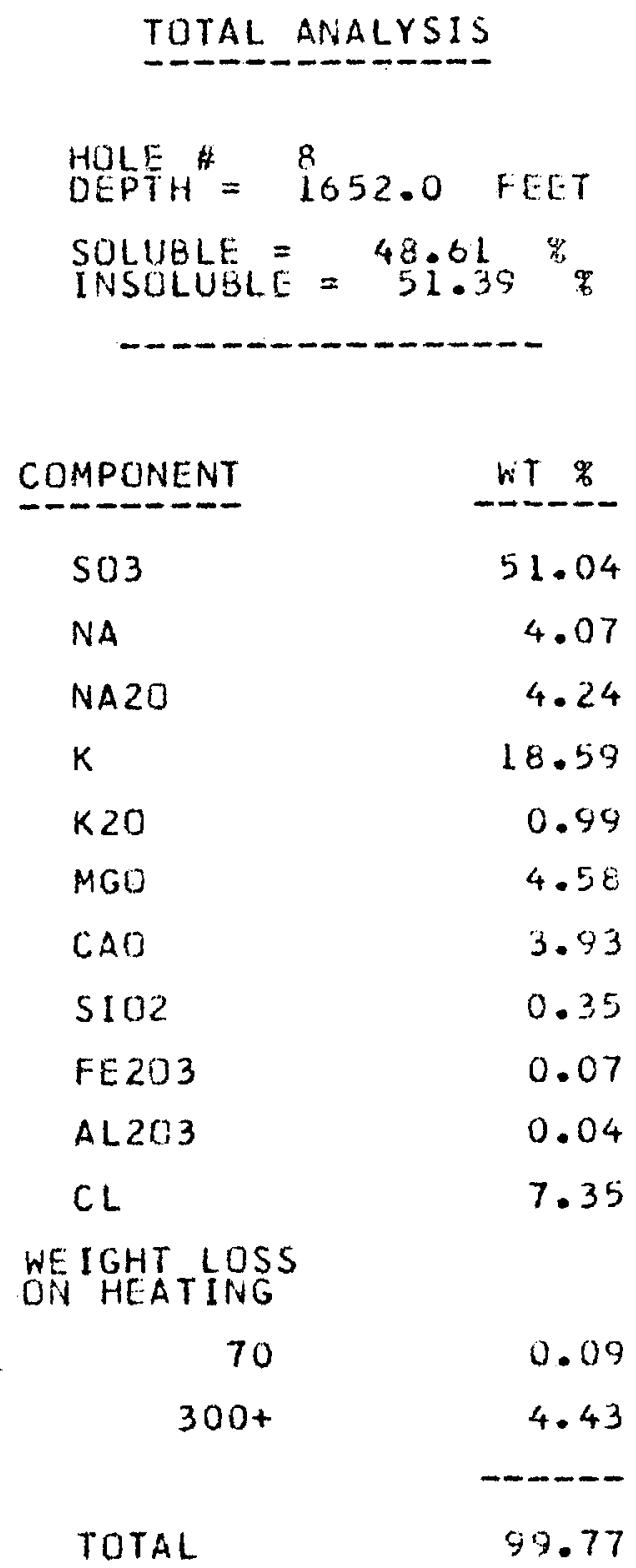

MAJOK: HAL

MINOR: POLY - P? SYLELLON, GLAS 


\section{TOTAL ANALYSIS}

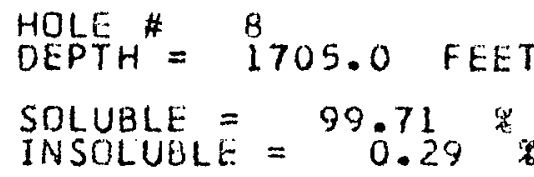

\begin{tabular}{lc} 
COMPONENT & WT \\
\hline SO3 & 1.18 \\
NA & 38.79 \\
NA2O & 0.0 \\
$K$ & 0.35 \\
K2O & 0.0 \\
MGO & 0.17 \\
CAO & 0.44 \\
SIO2 & 0.01 \\
FE2O3 & 0.0 \\
AL203 & 0.0 \\
CL & 58.64
\end{tabular}

WEIGHT LOSS

ON HEATING

$\begin{array}{rr}70 & 0.15 \\ 170 & 0.02 \\ 400-500 & 0.15 \\ & ---- \\ \text { TOTAL } & 100.19\end{array}$

MAJOR: HAL

MINOR:

TFACE: POLY 


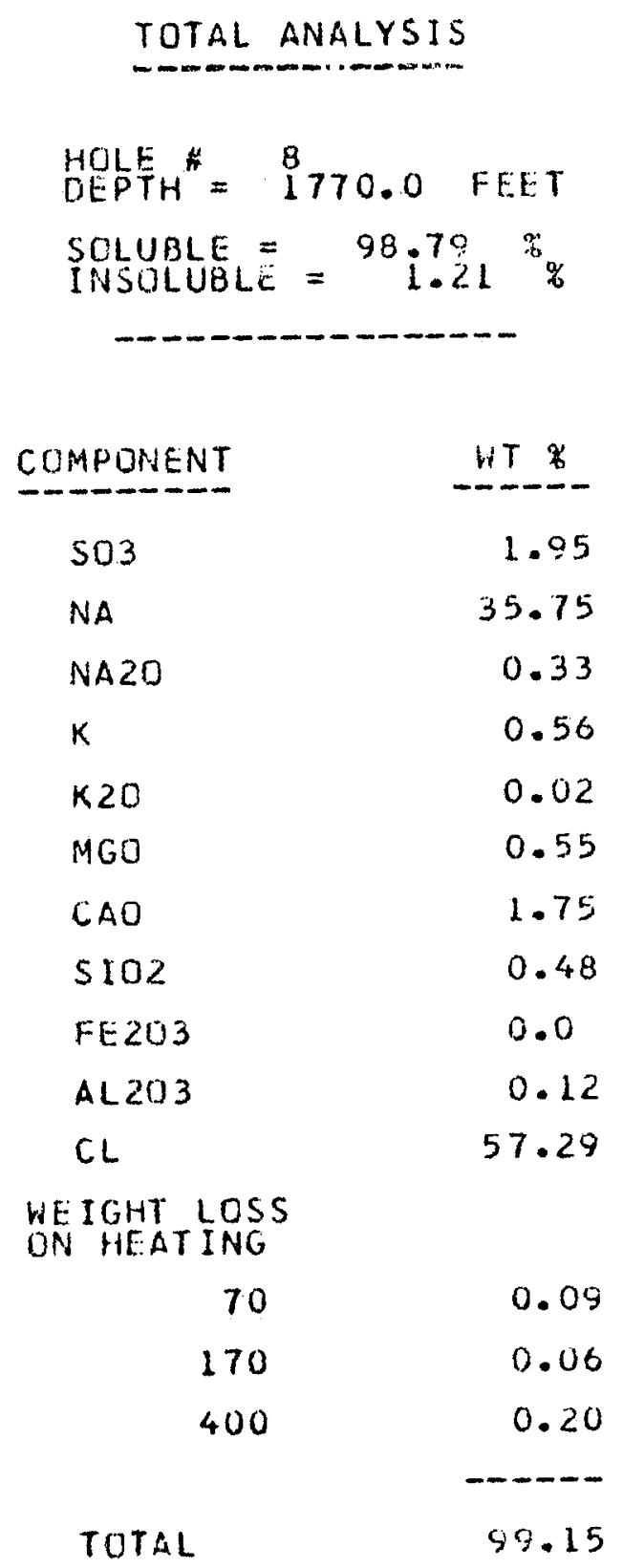

MAJOR: HAL

MINDR: ANH, KAIN

TRACE: ILL, QTZ 
TOTAL ANALYSIS

HOLETH ${ }^{\#}{ }_{1787.0 \quad \text { FEET }}^{8}$ SOLUBLE $=99.43 \%$

COMPONENT

$\mathrm{SO} 3$

NA

NA2O

$x$

$\mathrm{K} 2 \mathrm{O}$

MGO

CAO

$\mathrm{SIO} 2$

FE 203

AL 203

$C L$

WEIGHT LOSS

ON HEATING

$\begin{array}{rr}70 & 0.32 \\ 100 & 0.04 \\ 300-400 & 0.23 \\ & - \\ \text { TOTAL } & 101.06\end{array}$

MAJUR: HAL

MINIR: POLY, KAIN

TRACE: CHLOR, QTZ, FEOX 


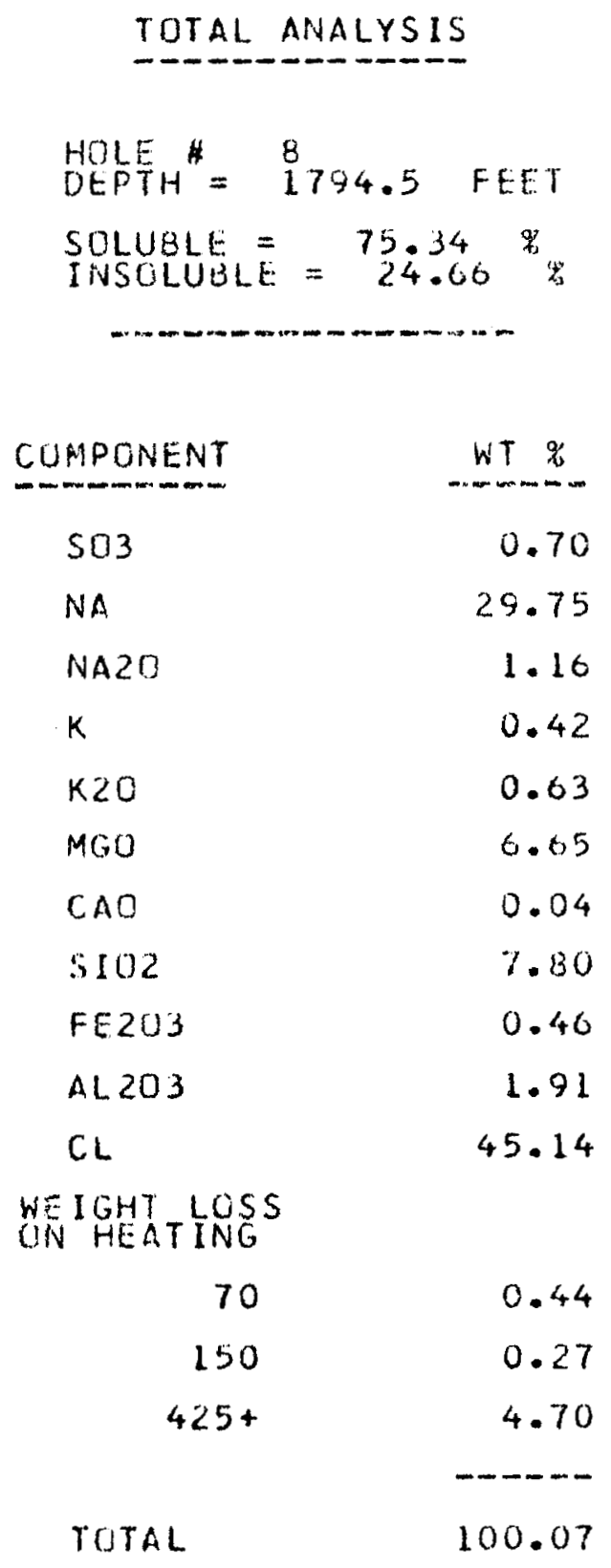

MAJOR: HAL

MINOR: CARN, CHLOR, KFELD, TALC, OTL TKACE: POI.Y, FEOX 


\section{TDTAL ANALYSIS}

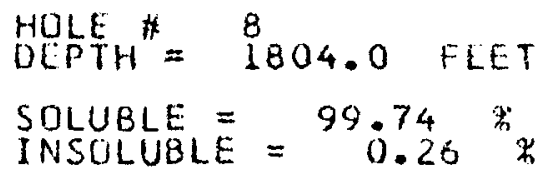

\begin{tabular}{lc} 
COMPONENT & WT \\
\hline SO3 & 0.28 \\
NA & 30.43 \\
NA2O & 0.0 \\
K & 0.06 \\
K2O & 0.0 \\
MGO & 0.04 \\
CAO & 0.70 \\
SIOZ & 0.01 \\
FE203 & 0.0 \\
AL203 & 0.0 \\
CL & 59.94
\end{tabular}

WEIGHT LOSS

ON HEATING

$\begin{array}{rr}70 & 0.02 \\ 200 & 0.05 \\ & \\ \text { TOTAL } & 100.79\end{array}$

MAJOR: HAL

MINOR: $\quad A N H$

TRACE: CARN 
TOTAL ANALYSIS

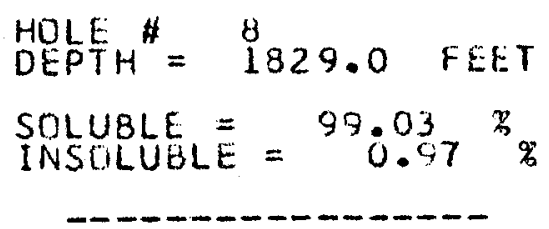

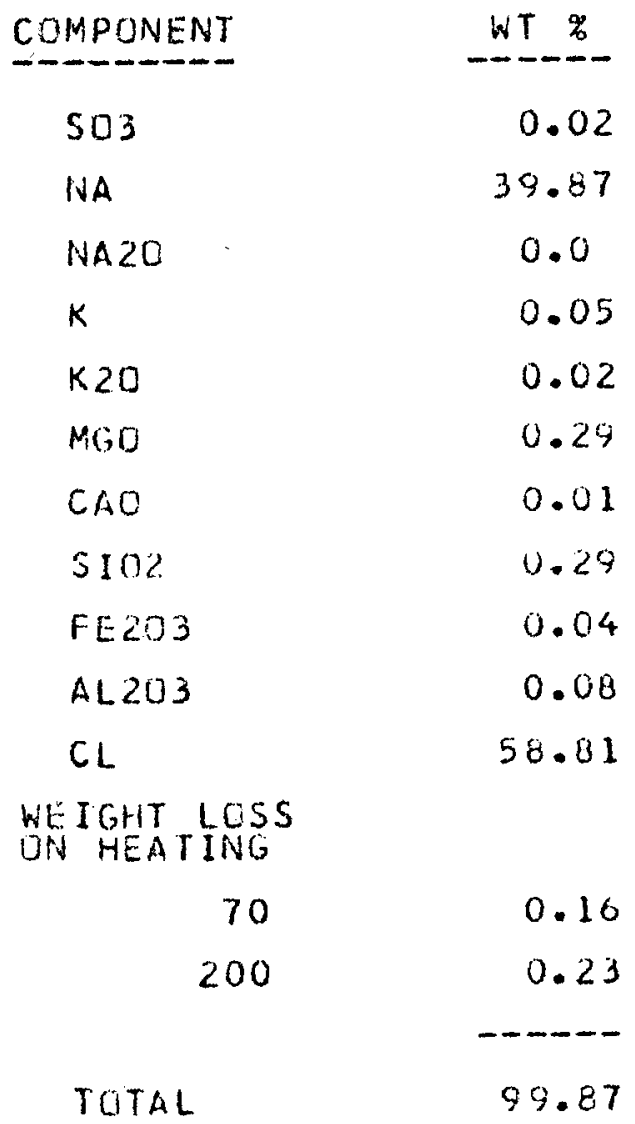

MAJOR: HAL

MINGR: APH, CAPN, CHLOR, KFELD, TALC, FEOX 


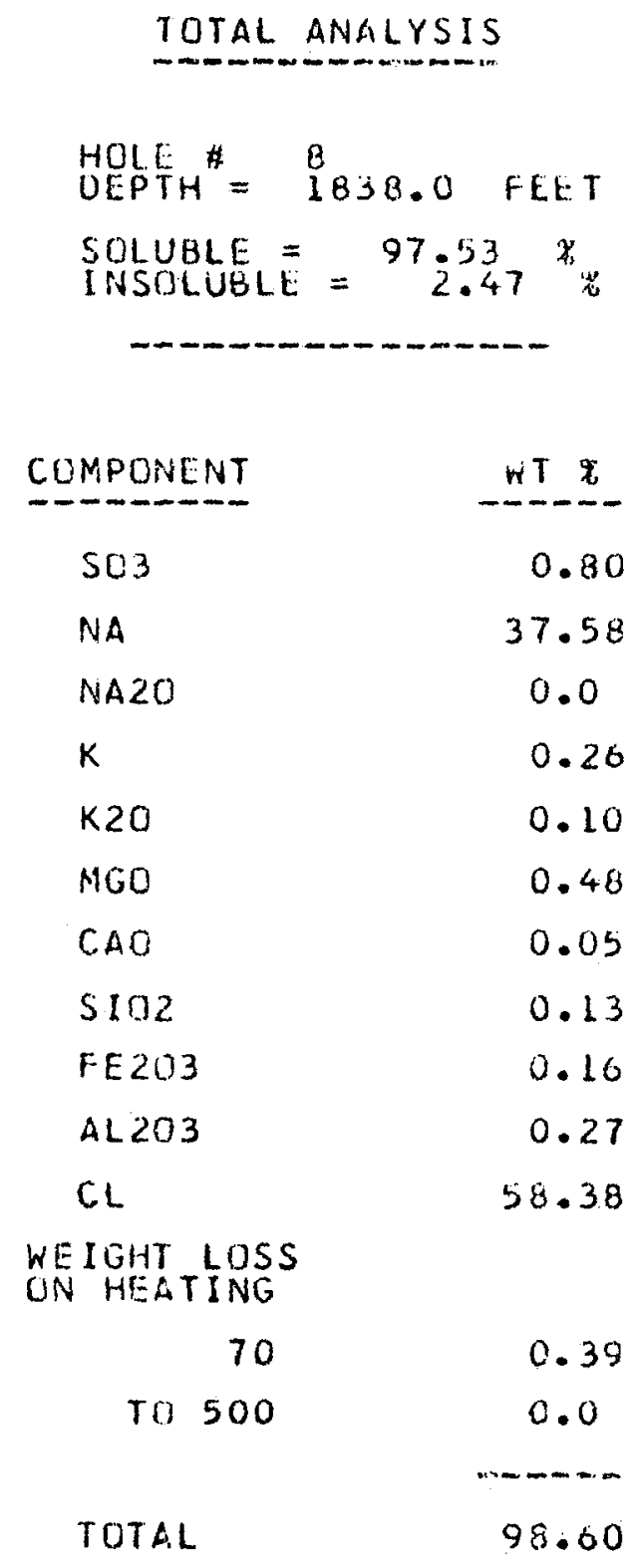

MAJUR: HAL

MINOCE: POLY, SLY, LEON, CHLOR, KFELD, FEOX 


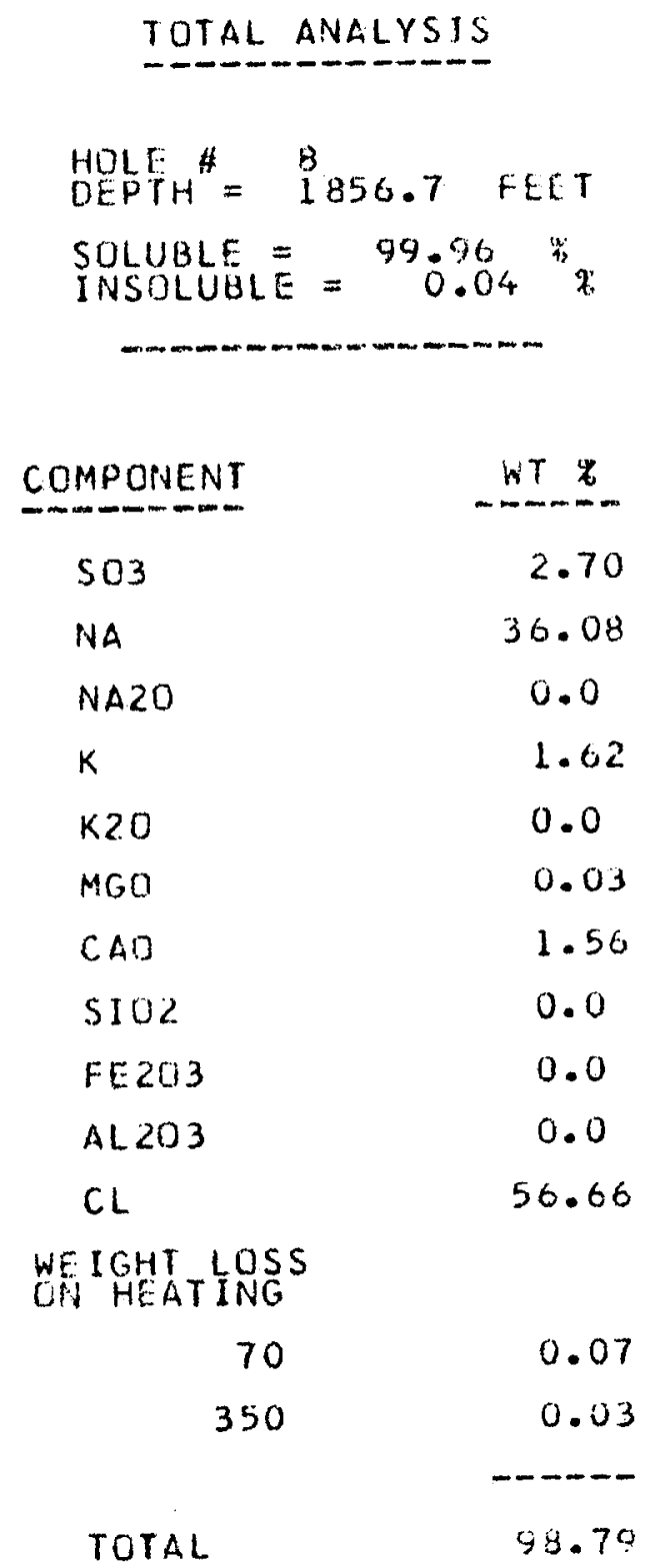

MAJOR: HAL

MINOR: ANH, SYL, POLY

TRACE: 


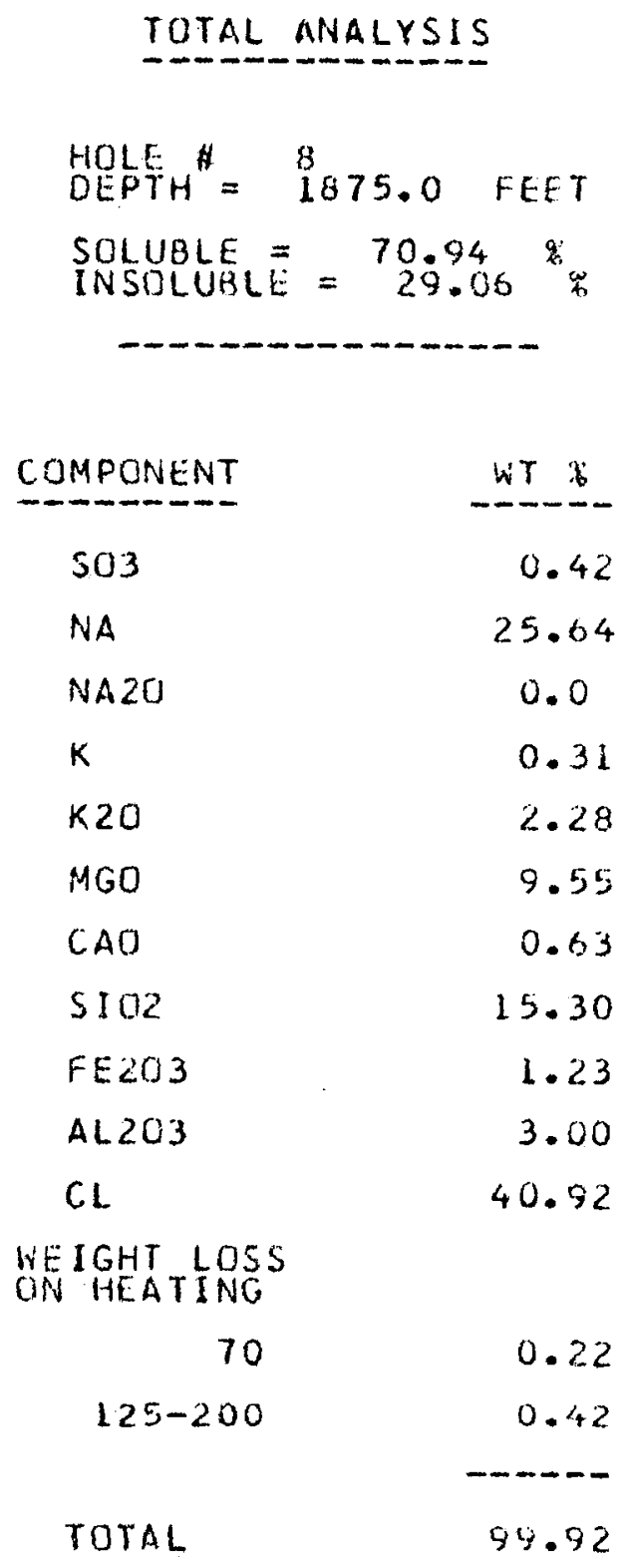

MAJOR: HAL

MINOR: CARN, KFELD, TALC

TRACE: POLY; CHLOR 
TDTAL ANALYSIS

$\begin{array}{lr}\text { HOLE H } & 8 \\ \text { DEPTH } & 1884.0 \mathrm{FEET} \\ \text { SOLUBLE }=90.582^{*} \\ \text { INSOLUBLE }=19.42 \\ \end{array}$

WEIGHT LOSS

ON HEATING

$\begin{array}{rr}70 & 0.36 \\ 350-400 & 0.44 \\ & ----- \\ \text { TOTAL } & 102.86\end{array}$

MAJUR: HAL

MINOF: ANH, CARN, KFELD, TALC, FEOX TPACE: CHLOR 


\section{TOTAL ANALYSIS}

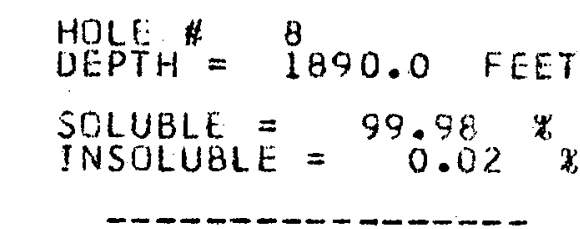

\section{CDMPONENT \\ $\mathrm{SO}_{3}$}

NA

NA2O

$\mathrm{K}$

$K 20$

MGO

$\mathrm{CAO}$

5102

$\mathrm{FE} 203$

AL 203

$\mathrm{CL}$

HEIGHT LOSS

GIN HEATING

$\begin{array}{rr}70 & 0.05 \\ 300-400 & 0.08 \\ & ----- \\ \text { TOTAL } & 100.18\end{array}$

$$
\begin{gathered}
\text { W.T } \\
0.77 \\
38.78 \\
0.0 \\
0.10 \\
0.0 \\
0.10 \\
0.95 \\
0.0 \\
0.0 \\
0.0 \\
59.33
\end{gathered}
$$

MAJOR: HAL

MINOR: ANH, CARN

TRACE: ANH, CARN 


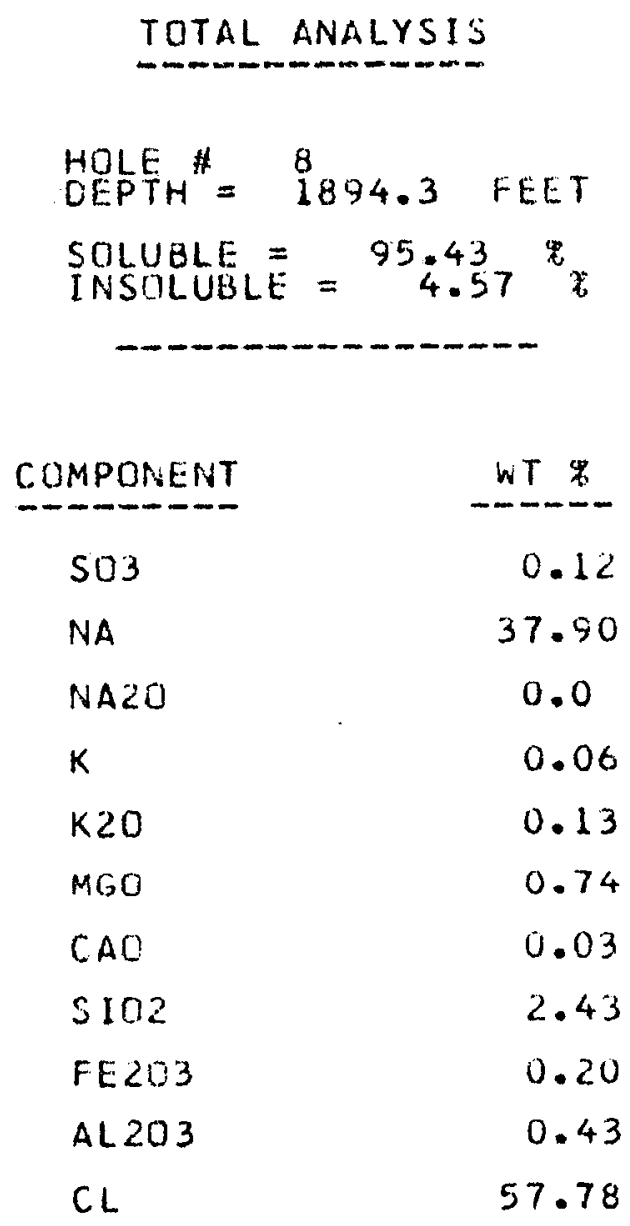

WEIGHT LOSS

DIV HEATING

$\begin{array}{cc}70 & 0.30 \\ \text { TO } 500 & 0.0 \\ & \\ \text { TOTAL } & 100.12\end{array}$

MAJUR: HAL

MINUR: OTZ 


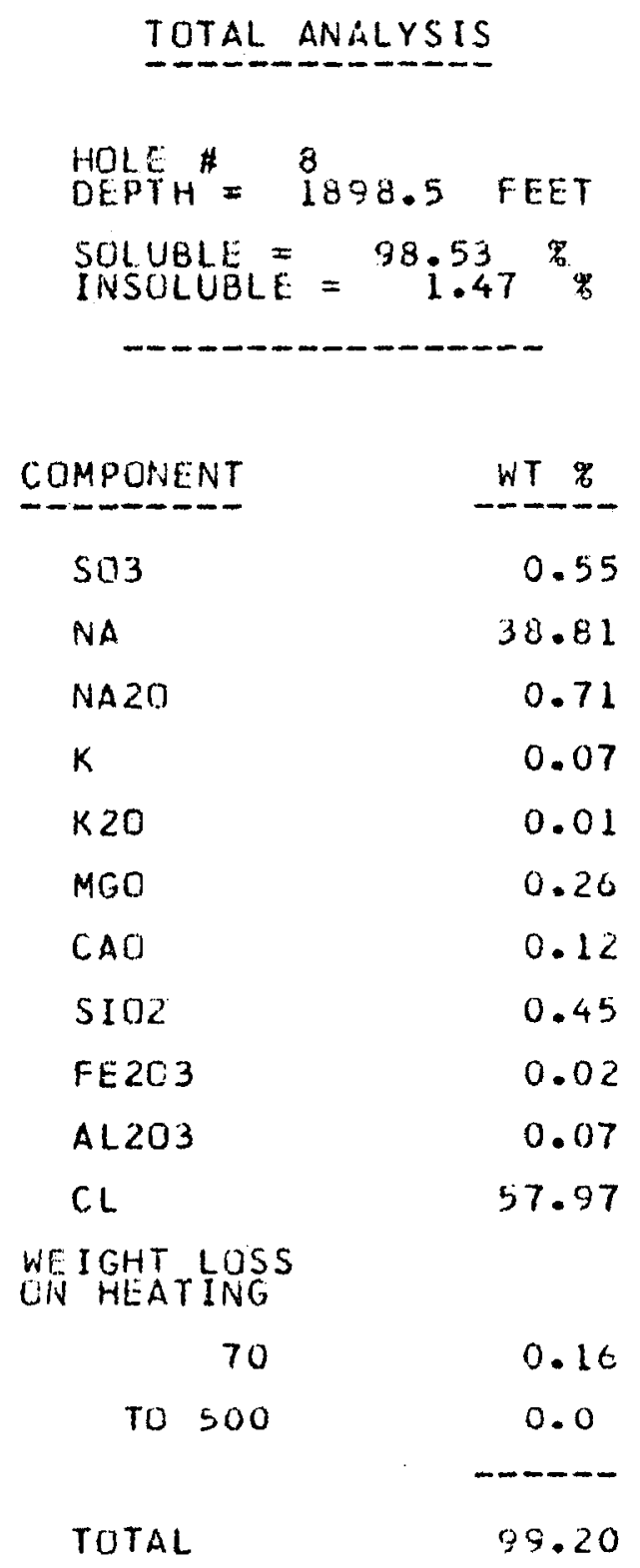

MAJOR: HAL

MINUR:

TRACE: POLY, BLOED, CHLQR, TALC, FEOX 
TOTAL ANALYSIS

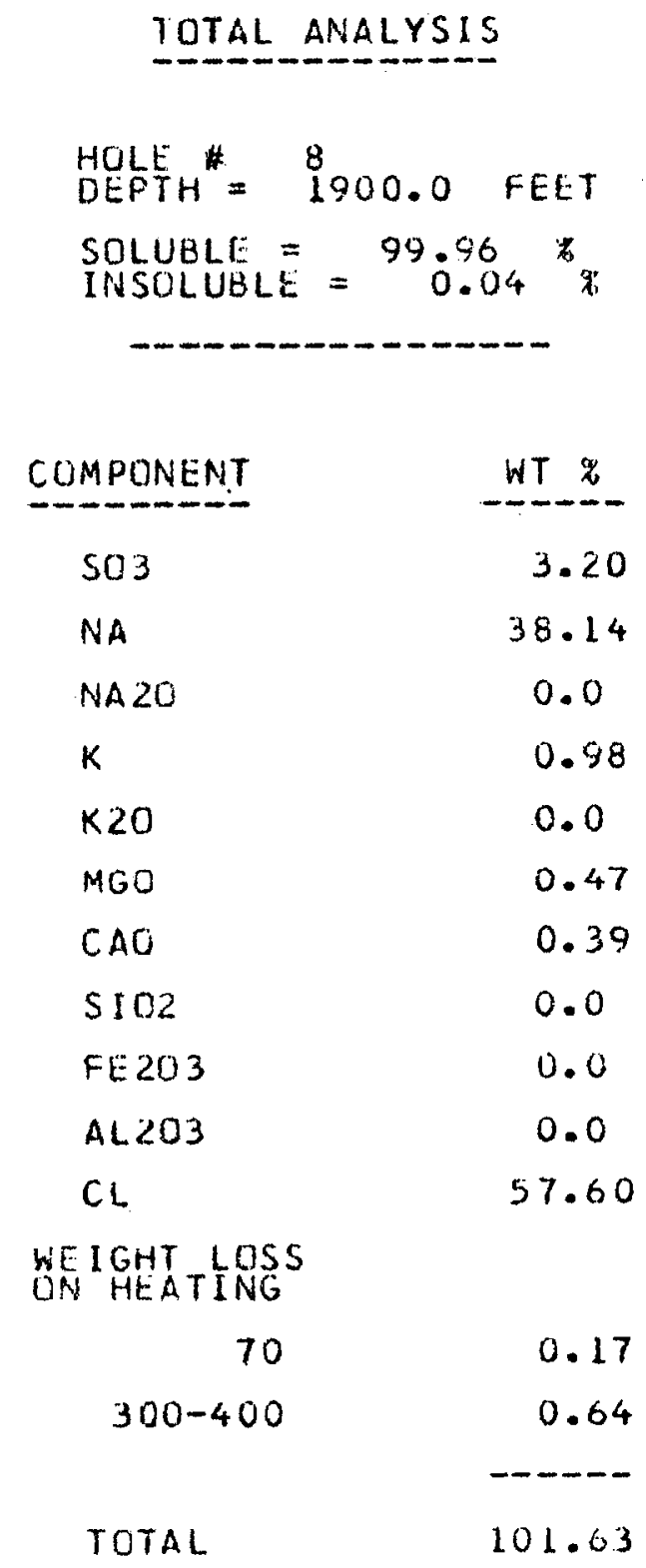

MAJOK: HAL

MINOR: LEON 
TOTAL ANALYSIS

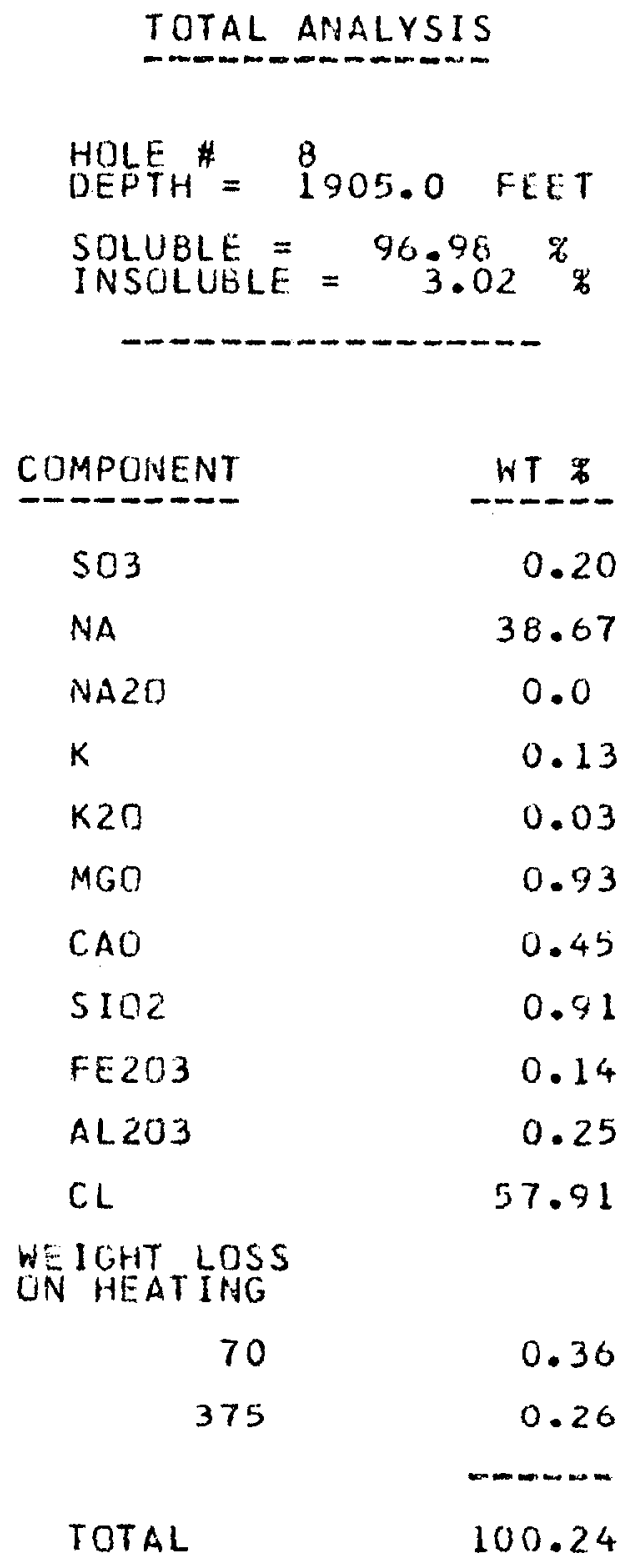

MAJUR: HAL

MINOR:

TRACE: POLY, CHLOR, KFELD, TALC 
TOTAL ANALYSIS

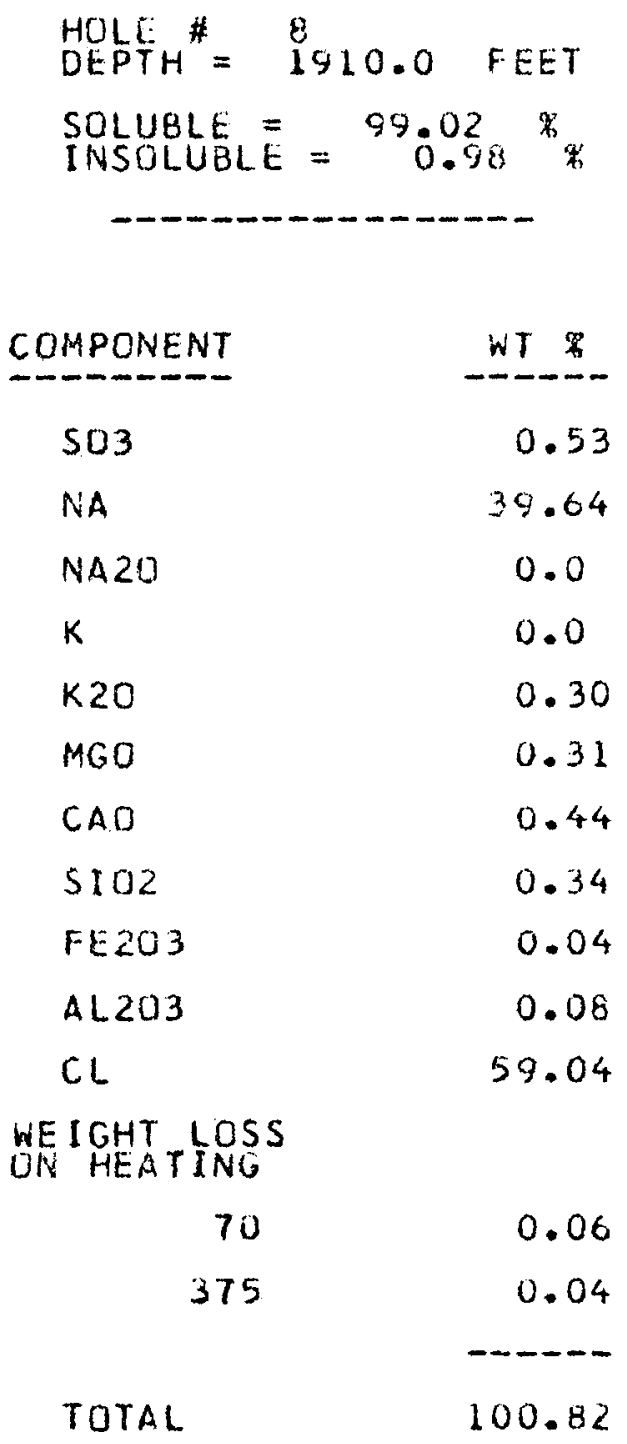

MAJOR: HAL

MINUR: PULY 


\section{TOTAL ANALYSIS}

$$
\begin{aligned}
& \text { HOLE H" } \\
& \text { DEPTH }=1913.1 \text { FELT } \\
& \text { SOLUBLE }=97.71 \% \\
& \text { INSOLUBLE }=2.29 \%
\end{aligned}
$$

\section{COMPONENT}

$\mathrm{SO} 3$

NA

NA20

$\mathrm{K}$

$k 20$

MGO

CAO

5102

FE 203

AL 203

$C L$

WEIGHT LOSS

ON HEATING

$\begin{array}{rr}70 & 0.11 \\ 120 & 0.03 \\ 260 & 0.03 \\ 400+ & 0.04 \\ & -9.79-9\end{array}$

MAJUR: HAL

MINOR:

TRACE: KAIN, CHLOR, KFELD, TALC, QTZ, FEOX 
TOTAL ANALYSIS

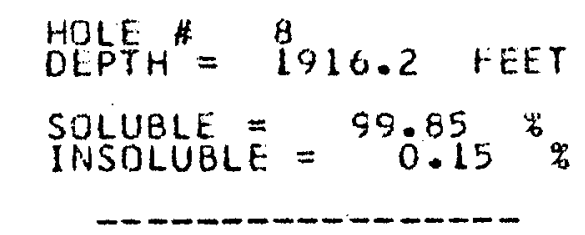

COMPONENT

$\mathrm{SO} 3$

NA

NA 20

$\mathrm{K}$

$K 20$

MGO

CAO

5102

FE: 203

AL203

CL

WEIGHT LOSS

ON HEATING

$\begin{array}{rr}70 & 0.13 \\ 250 & 0.02 \\ 350-400 & 0.10 \\ & \ldots .0 .29\end{array}$

$W T$
0.92
38.48
0.0
0.21
0.0
0.13
0.44
0.0
0.0
0.0
57.71

MAJOR: HAL

MINOR: POLY

TRACE: ANH 


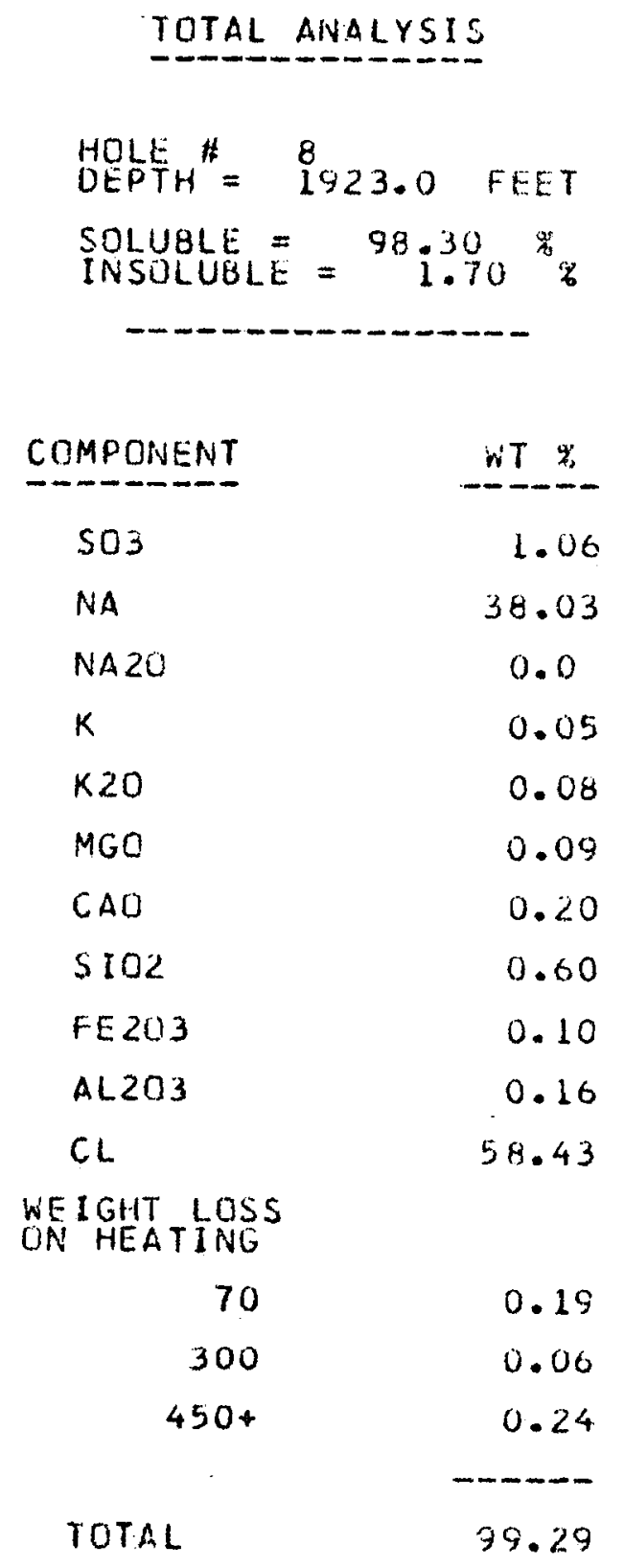

MAJUR: HAL

MINOR: POLY

TRACE: KAIH, CHLOR, ILL, KFELO, OTZ, FEOX 
TOTAL ANALYSIS

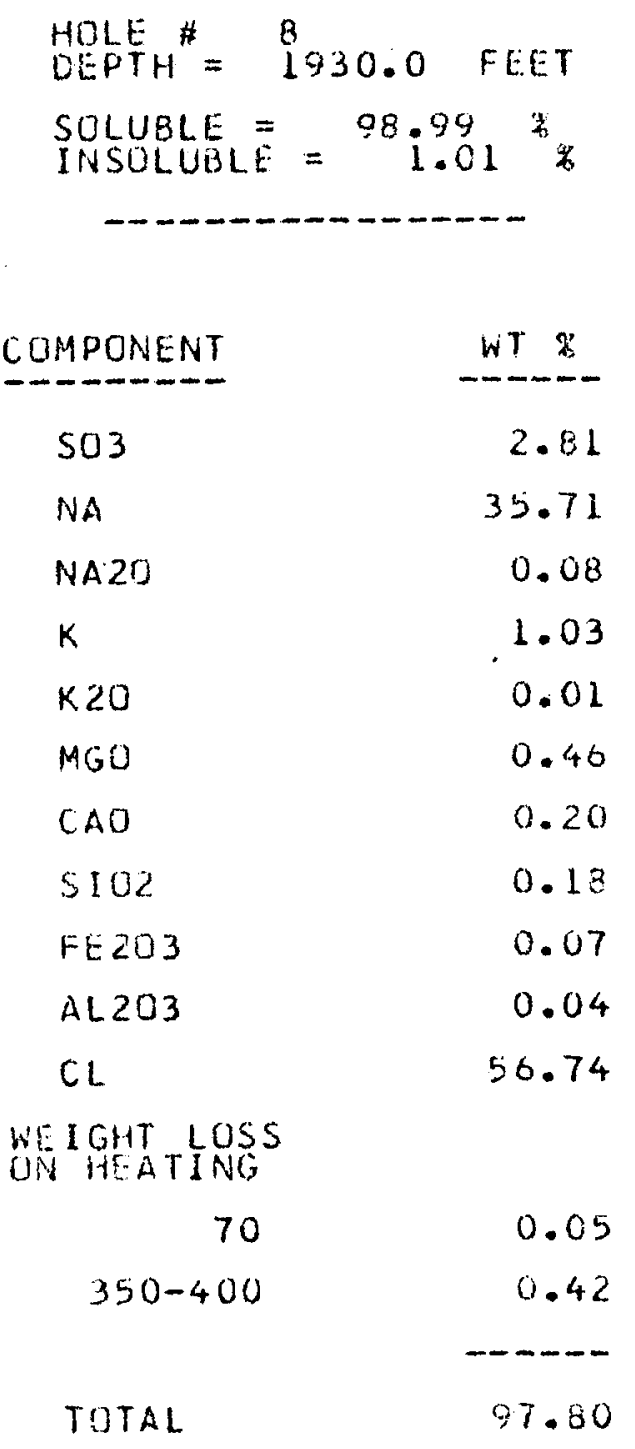

MAJUR: HAL

MINCER: POLY 


\section{TOTAL ANALYSIS}

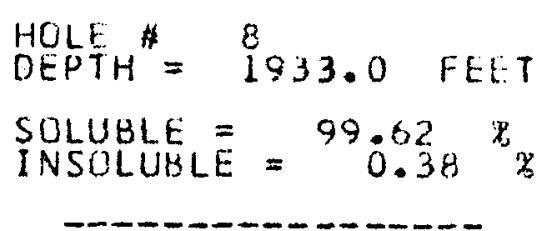

\begin{tabular}{lc} 
COMPONENT & WT \\
\hline S03 & 0.78 \\
NA & 38.03 \\
NA2O & 0.0 \\
K & 0.15 \\
K20 & 0.0 \\
MGO & 0.09 \\
CAD & 0.65 \\
SIO2 & 0.01 \\
FE203 & 0.01 \\
AL203 & 0.0 \\
CL & 59.61
\end{tabular}

WEIGHT LOSS

UN HEATING

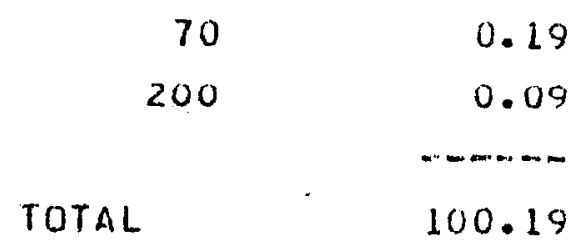

MAJOR:

MINUOR:

TRACE:

HAL

ANH, POLY, KAIN

QT2, FEDX 
TOTAL ANALYSIS

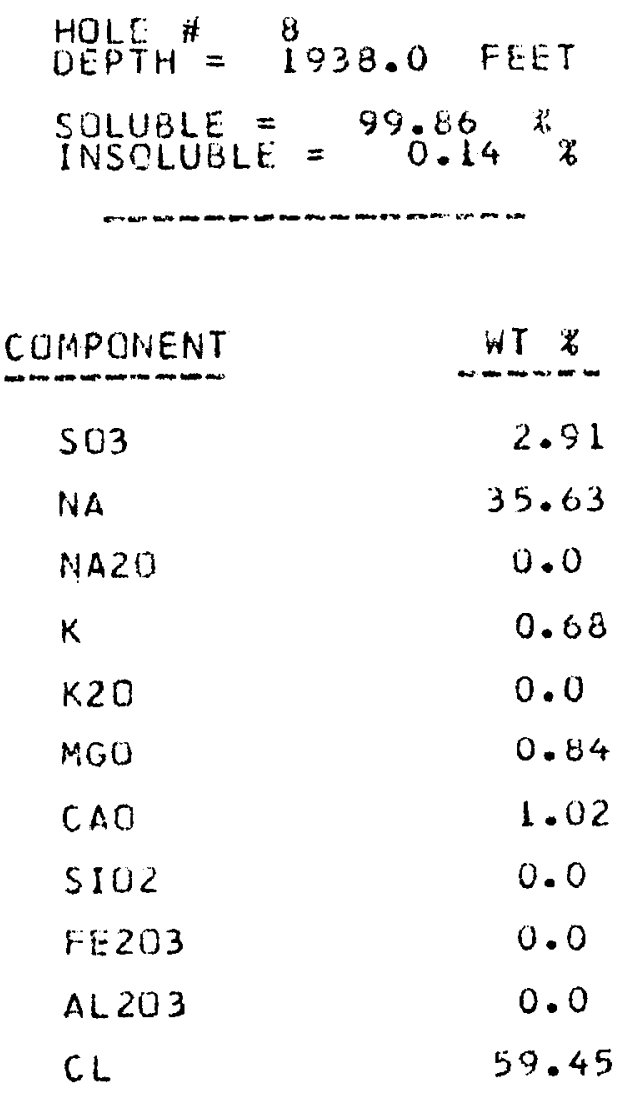

WEIGHT LOSS

UN HEATING

$\begin{array}{rr}70 & 0.13 \\ 125 & 0.14 \\ 275 & 0.05 \\ 350-400 & 0.17 \\ & - \\ \text { TOTAL } & 101.16\end{array}$

MAJUR: HAL

MINOR: POLY, KAIN

TRACE: 


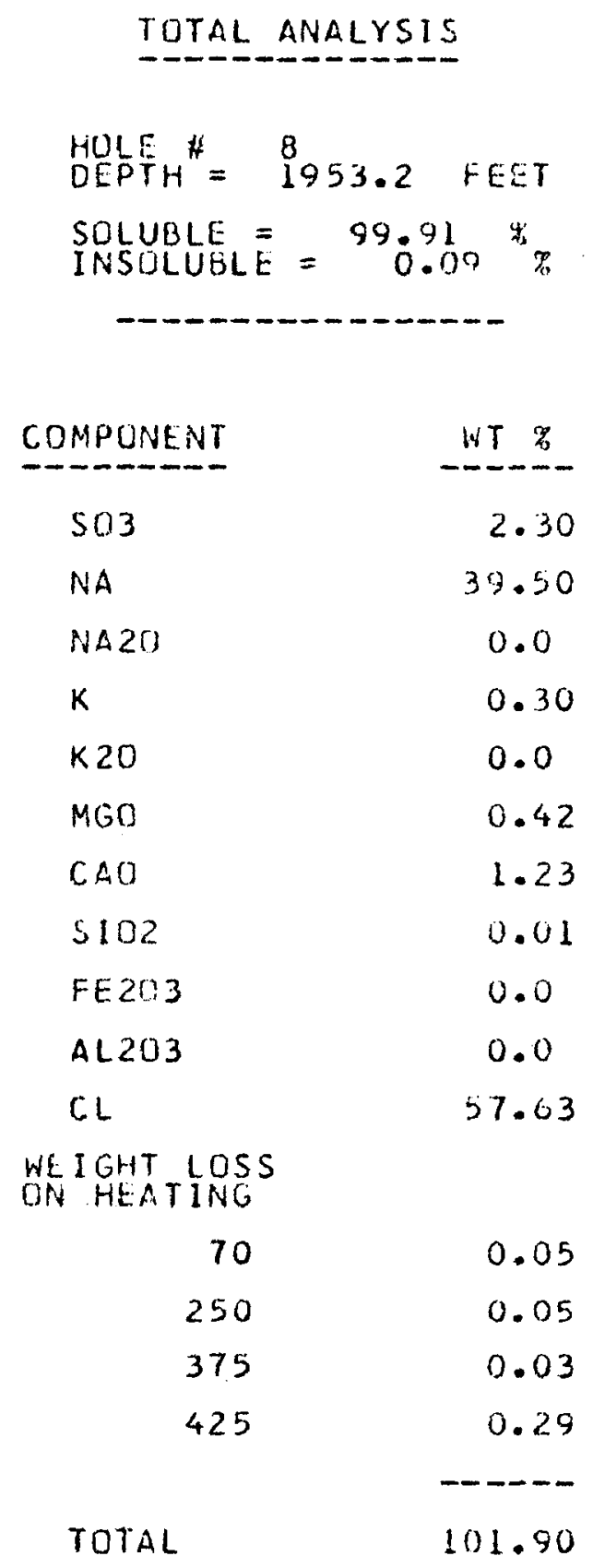

MAJUR: HAL

MINOR: ANH, POLY

TRLCE: BLOED, TALC 


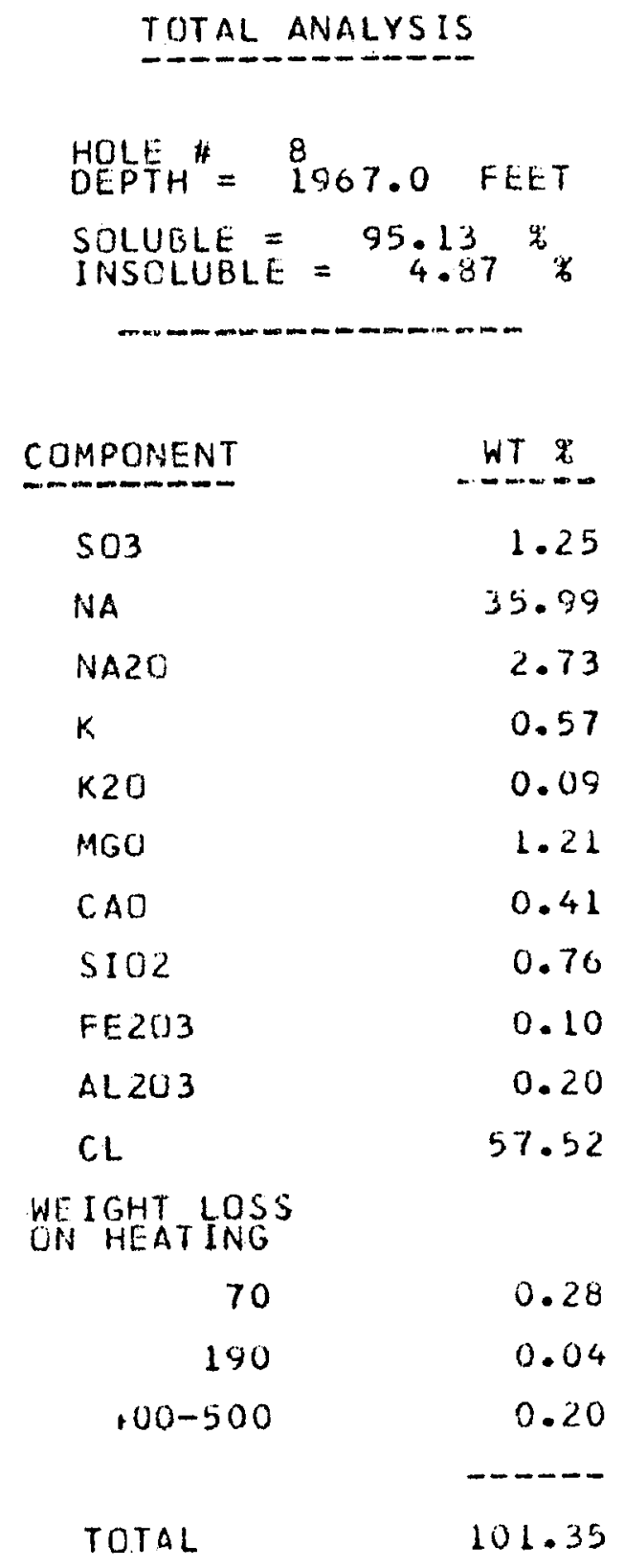

MAJOR: HAL

MINGR: POLY, KAIN, TALC

TRACE: CHLOR, FEOX 


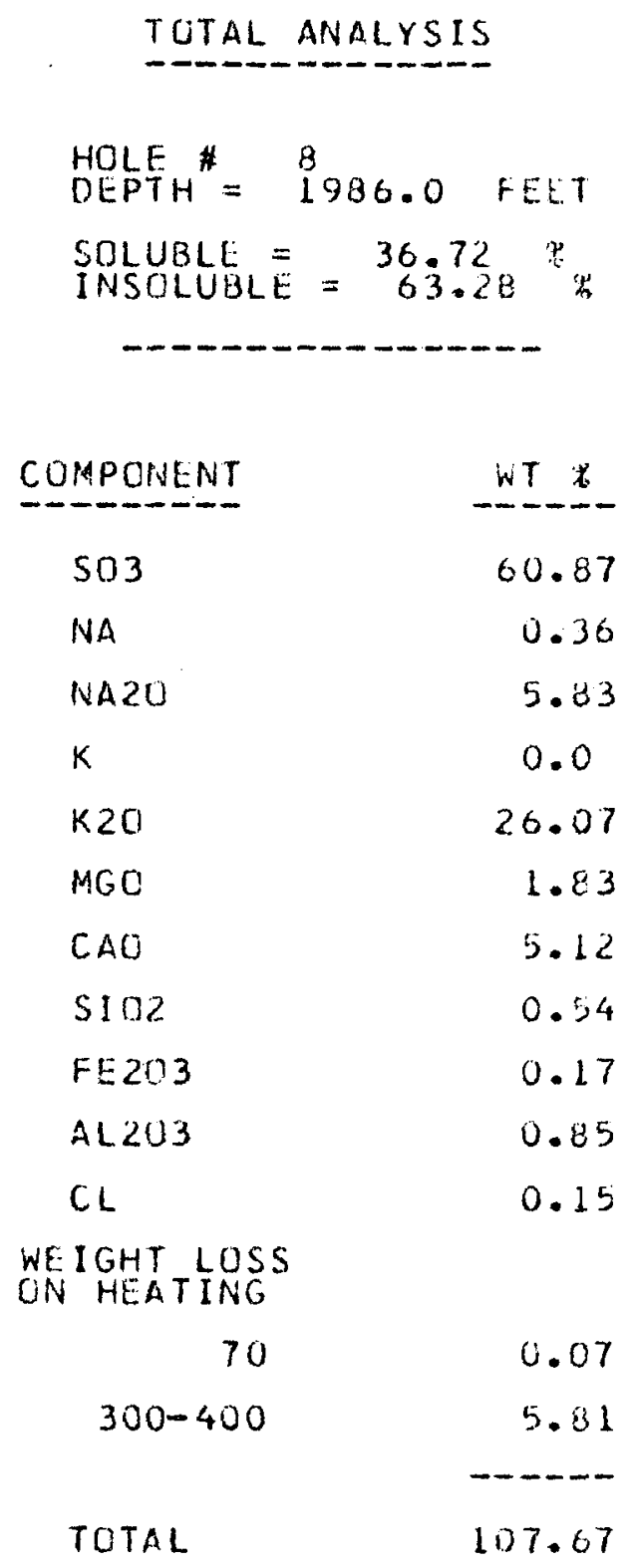

MAJUR: (?) GLAS, ANH, LEON

MINOOR: HAL FEOX 
TOTAL ANALYSIS

HULE ${ }^{*}=8$
OEPTH $=2006.0$ FEET
SOLUBLE $=99.50$ 尘
INSOLUBLE $=9.50 \%$

COMPONENT

503

NA

NA20

$\mathrm{K}$

$K 20$

$\mathrm{MGO}$

CAO

5102

FE203

$\mathrm{AL}_{2} \mathrm{O}_{3}$

$\mathrm{CL}$

WEIGHT LOSS

ON HEATING

$$
\begin{array}{r}
70 \\
350-400 \\
450 \\
475
\end{array}
$$

TOTAL

MAJUR: HAL

MIHOR: KAIN, BLOED

TRACE: POLY, QTL
WT 籴

2.37

37.59

0.0

1.03

0.0

0.31

0.06

0.01

0.0

0.0

57.17

$$
\begin{aligned}
& 0.20 \\
& 0.25 \\
& 0.13 \\
& 0.04 \\
& 99.70
\end{aligned}
$$




\section{TOTAL ANAI.YSIS}
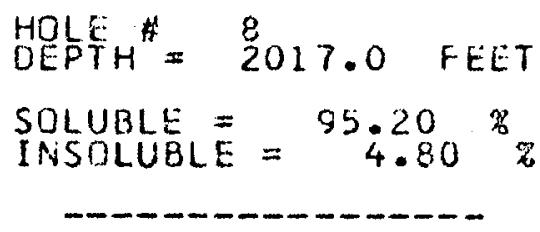

$\begin{array}{lc}\text { COMPONENT } & \text { WT } \\ \text { SO3 } & 0.02 \\ \text { NA } & 35.00 \\ \text { NA2O } & 0.0 \\ \text { K } & 0.06 \\ \text { K2O } & 0.04 \\ \text { MGO } & 0.33 \\ \text { CAO } & 1.02 \\ \text { S102 } & 2.02 \\ \text { FE 203 } & 0.28 \\ \text { AL203 } & 0.70 \\ \text { CL } & 57.09\end{array}$

WEIGHT LOSS

DN HEATING

$\begin{array}{rr}70 & 0.22 \\ 100 & 0.02 \\ 300-400 & 0.17 \\ \text { ORGANIC } & 1.59 \\ \text { TOTAL } & - \\ & 100.02\end{array}$

MAJOR: HAL

MINOR: ANH

TRACE: SYL, CAIN, CHLOR, FEOX, ILL 
TOTAL ANALYSIS

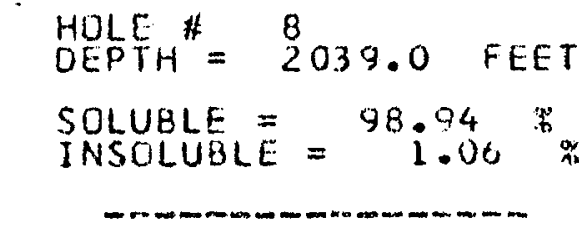

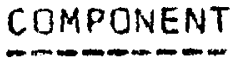

503

NA

NA20

K

$\mathrm{K} 20$

$M G O$

CAO

5102

$\mathrm{FE} 203$

AL 203

$\mathrm{CL}$

WE IGHT LOSS

ON HEATING

$\begin{array}{rr}70 & 0.21 \\ 100 & 0.05 \\ 300-400 & 0.49 \\ 425 & 0.27 \\ & ----- \\ \text { TOTAL } & 49.81\end{array}$

$W T$
5.50
35.02
0.0
1.56
0.03
0.70
1.58
0.27
0.07
0.05

54.01

MAJOR: HAL

MINOK: PULY, KAIN 


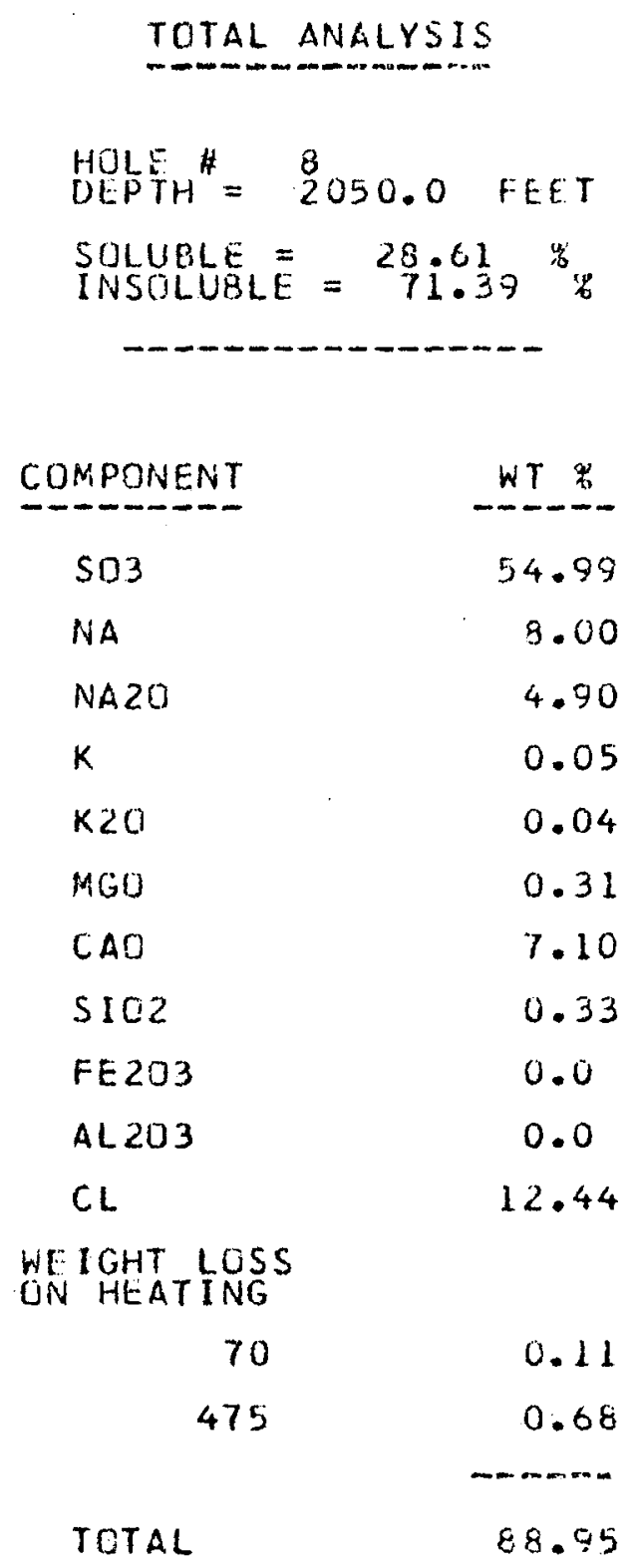

MAJDR: ANH

MINOR: HAL

TRACE: $\quad$ QTZ 


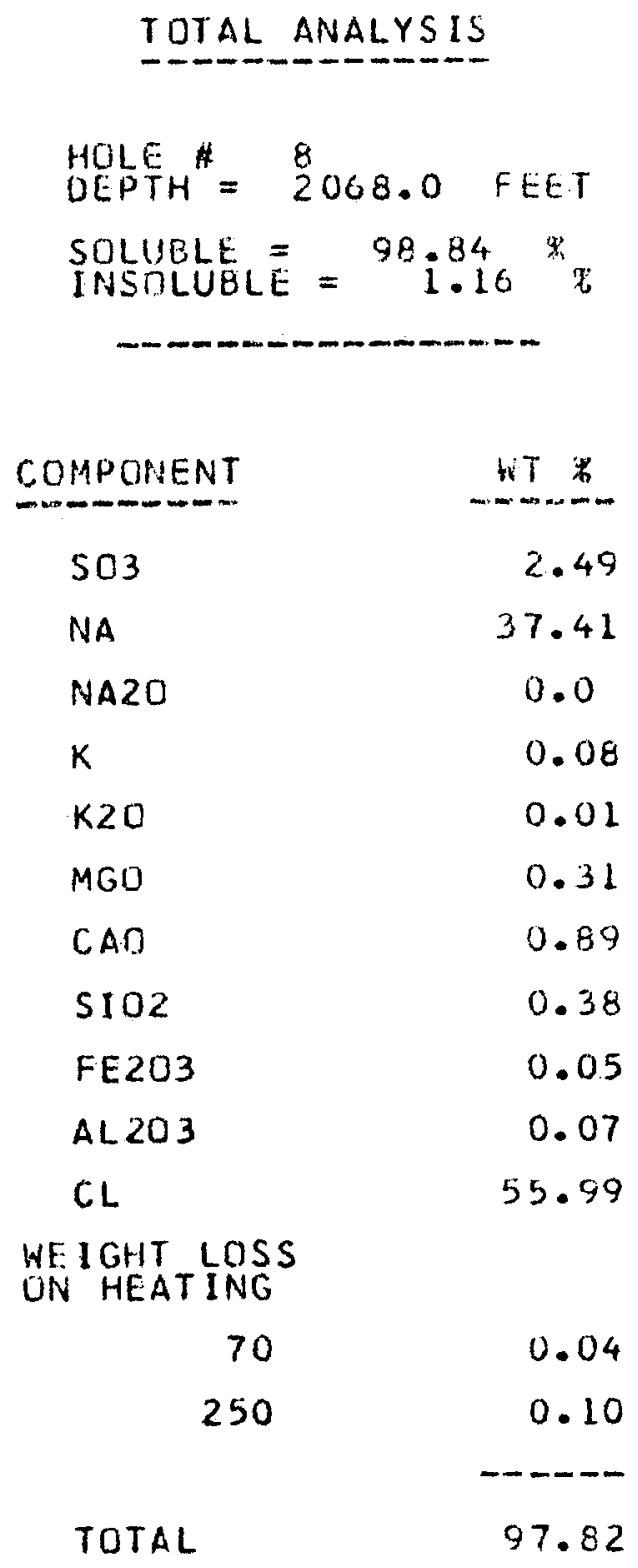

MAJOR: HAL

MINOR: ANH, TALC, BLOED

TRACE: PULY, CHLOR, FEOX 


\section{TOTAL ANALYSIS}

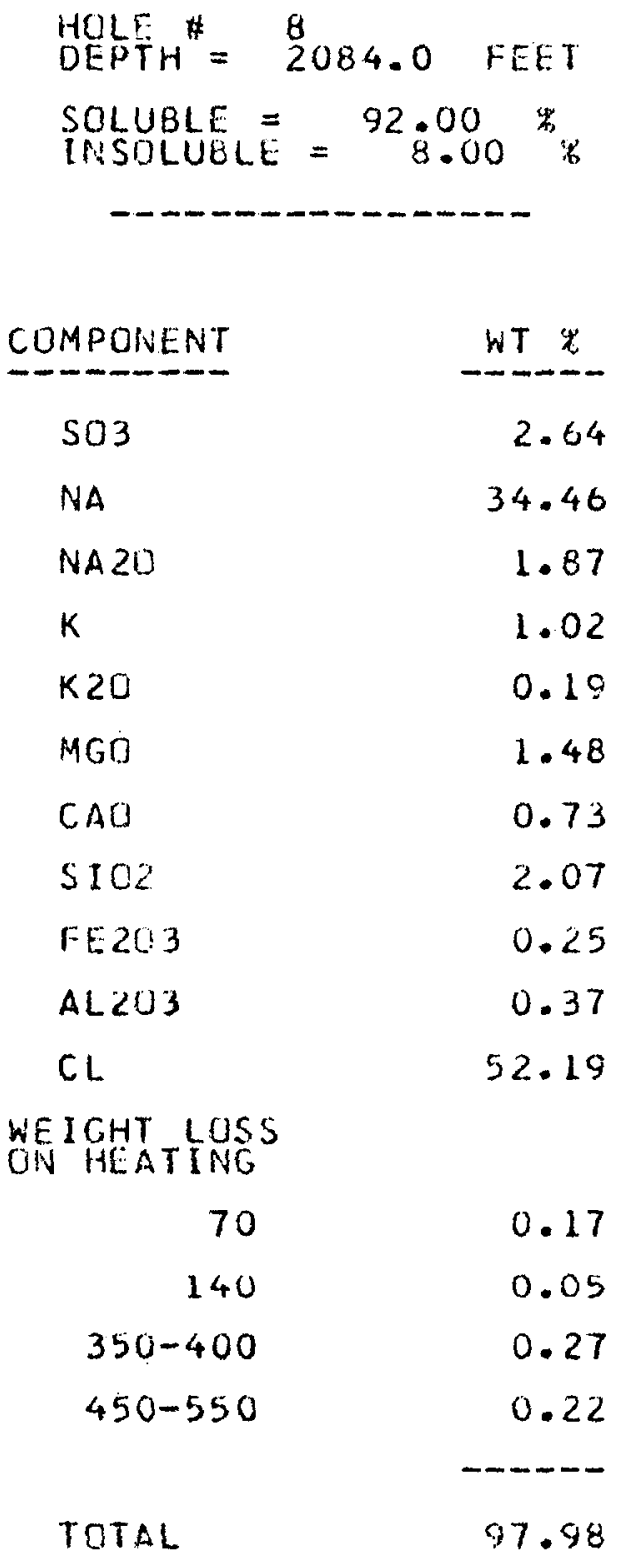

MAJUR: HAL

MINOR: CHLOR, TALC, QTL 
TOTAL ANALYSIS

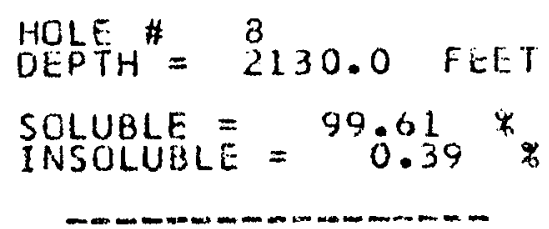

\begin{tabular}{|c|c|}
\hline COMPONENT & WT $\mathscr{E}$ \\
\hline $\mathrm{SO3}$ & 2.31 \\
\hline NA & 37.79 \\
\hline NA2O & 0.0 \\
\hline$k$ & 0.42 \\
\hline$k 20$ & 0.0 \\
\hline MGO & 0.25 \\
\hline CAD & 0.75 \\
\hline 5102 & 0.03 \\
\hline$F E 2013$ & 0.0 \\
\hline$A L 203$ & 0.0 \\
\hline$C L$ & 57.16 \\
\hline \multicolumn{2}{|l|}{$\begin{array}{l}\text { WEIGHT LOSS } \\
\text { ON HEATING }\end{array}$} \\
\hline 70 & 0.11 \\
\hline 125 & 0.07 \\
\hline $350-400$ & 0.10 \\
\hline & \\
\hline TOTAL & 99.38 \\
\hline
\end{tabular}

MAJOR: HAL

MINOR: POLY
TRACL: 
TOTAL ANALYSIS

HOLE \#
DEPTH $=8$
SOLUBLE $=98.0$ FEET
INSOLUBLE $=98.90$
1.10

\begin{tabular}{lr} 
CUMPONENT & WT \\
\hline SO3 & 1.56 \\
NA & 36.77 \\
NA2O & 0.55 \\
K & 1.23 \\
K2O & 0.03 \\
MGO & 0.65 \\
CAO & 0.93 \\
S1O2 & 0.23 \\
FE203 & 0.06 \\
AL2O3 & 0.05 \\
CL & 59.99
\end{tabular}

WEIGHT LOSS

ON HEAT ING

$\begin{array}{rr}70 & 0.14 \\ 300-400 & 0.48 \\ \text { TOTAL } & - \\ & 102.67\end{array}$

MAJOR: HAL

MINOR: ANH, POLY, SYL 


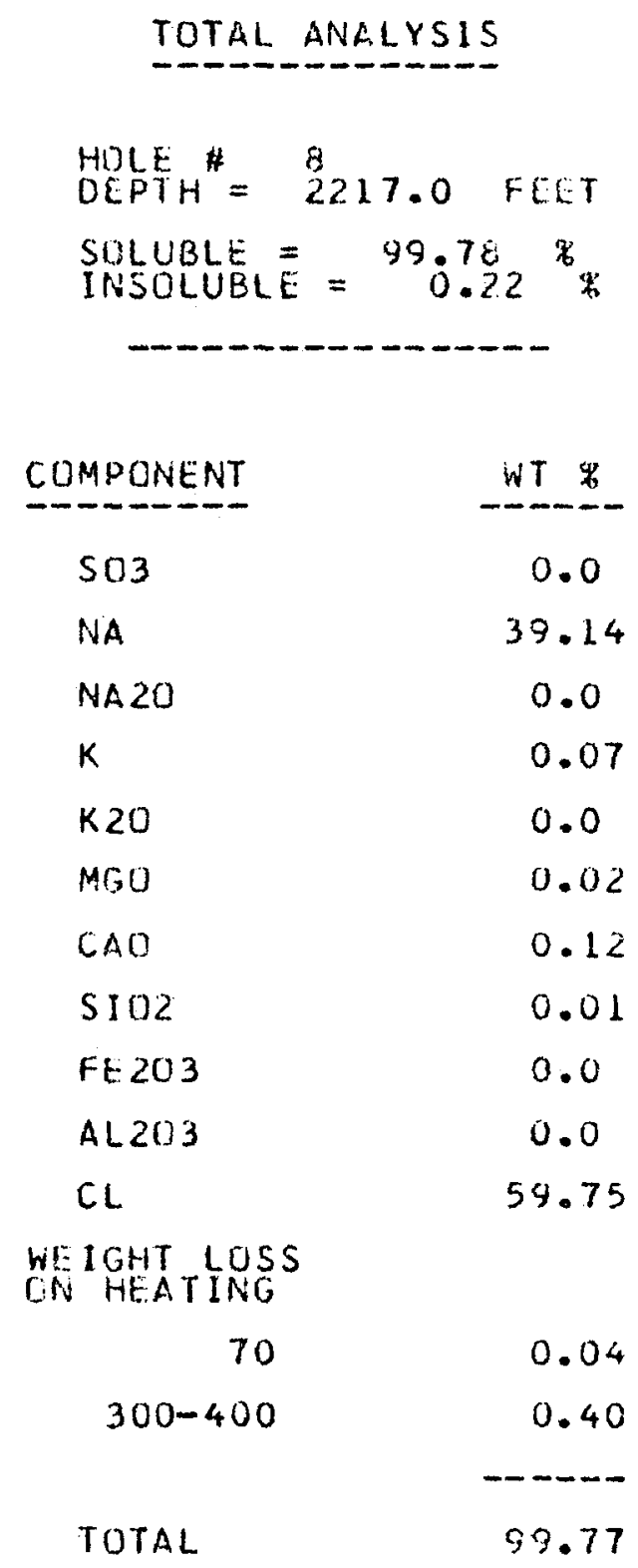

MAJOR: HAL

MINUR: ARAE POLY, SLY, GTL 
TOTAL ANALYSIS

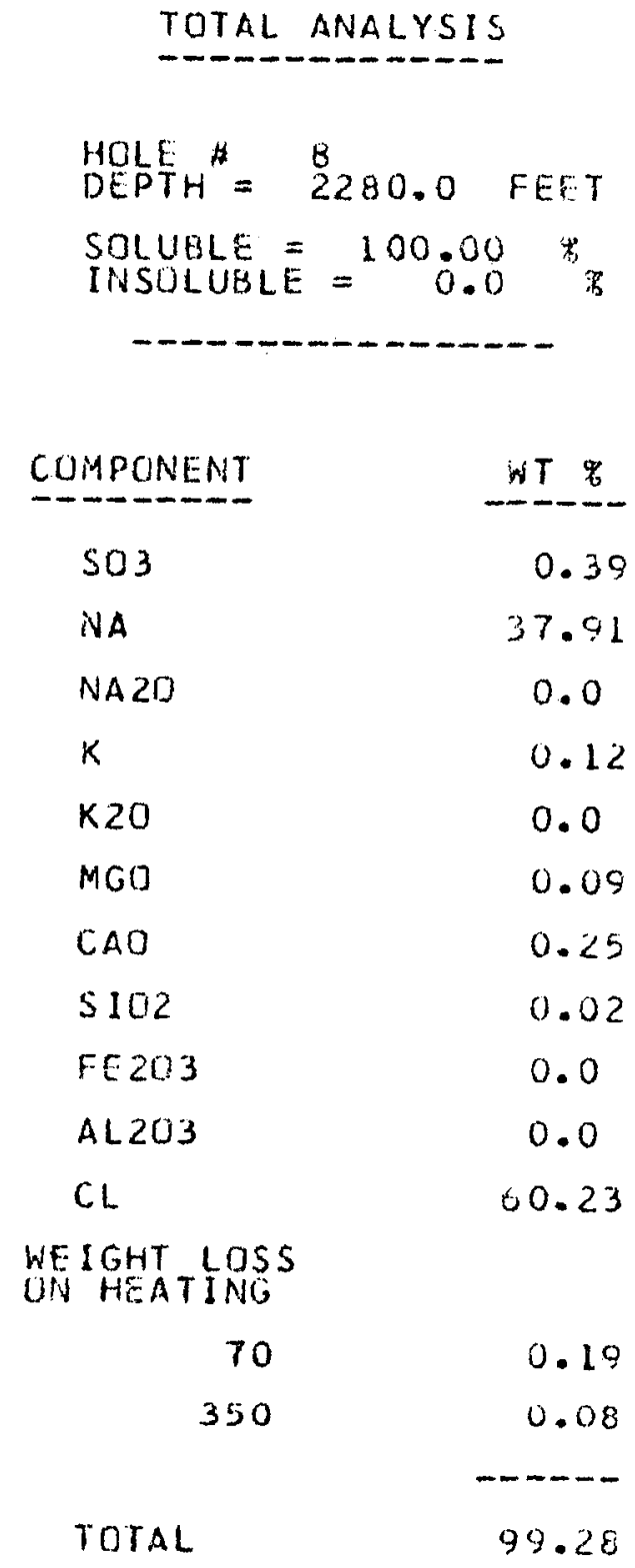

MAJUR: HAL

MINGR: ANH, CARN

TPACE: POLY, QTZ 


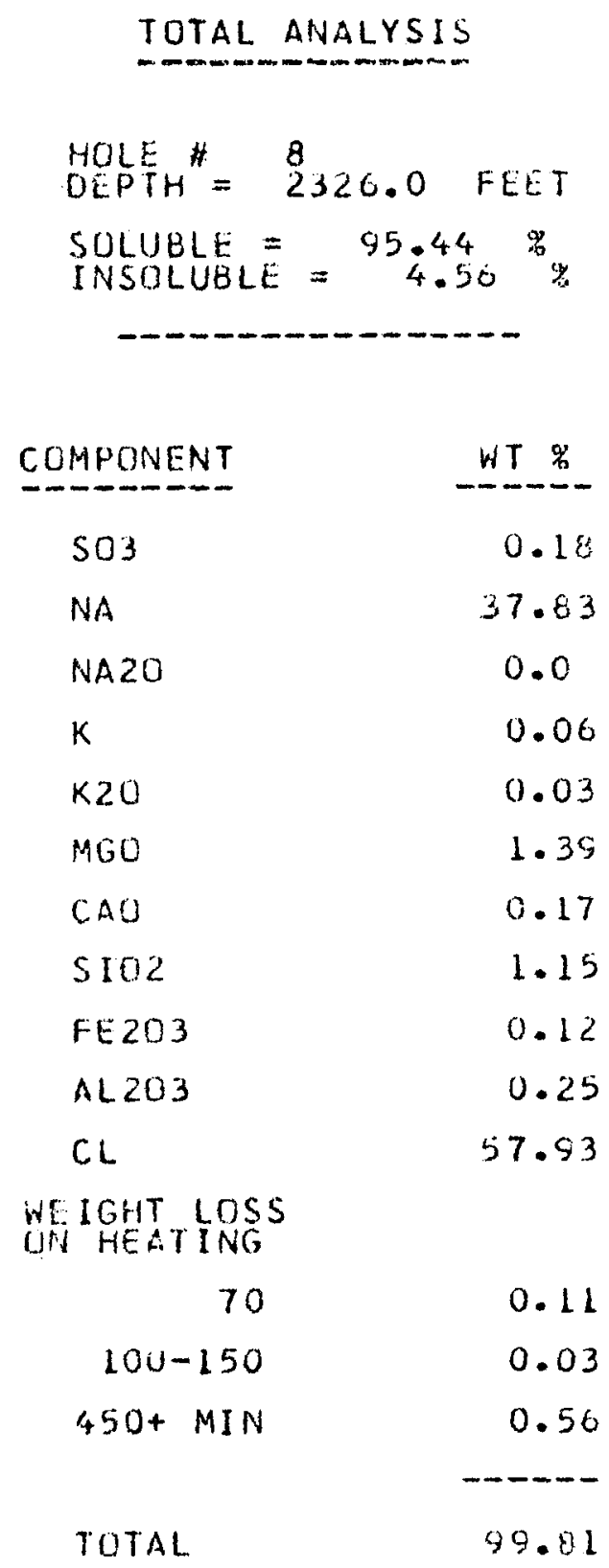

MAJOR: HAL

MINOR: TALC

TRACE: HAL, CARN, CHLOF, FLOX 


\section{TOTAL ANALYSIS}

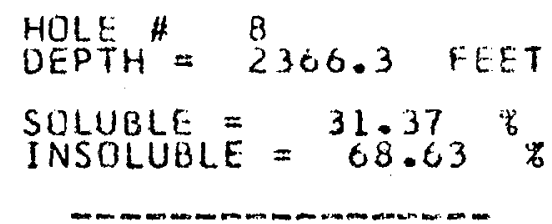

\begin{tabular}{lc} 
COMPONENT & WT \\
\hline SO3 & 47.32 \\
NA & 0.62 \\
NA2O & 3.76 \\
$K$ & 0.0 \\
K2O & 10.67 \\
MGO & 0.40 \\
CAO & 3.37 \\
SIO2 & 10.68 \\
FE2O3 & 0.01 \\
AL2O3 & 1.57 \\
CL & 1.17
\end{tabular}

WE I GHT LOSS

ON HEATING

$\begin{array}{rr}70 & 0.43 \\ 200-375 & 4.81 \\ 375-500 & 1.60 \\ & --0- \\ \text { TOTAL } & 92.41\end{array}$

MAJOR:

MINOR: KAIN, KFELU, TALC, GTL TRACE: HAL, SYL 


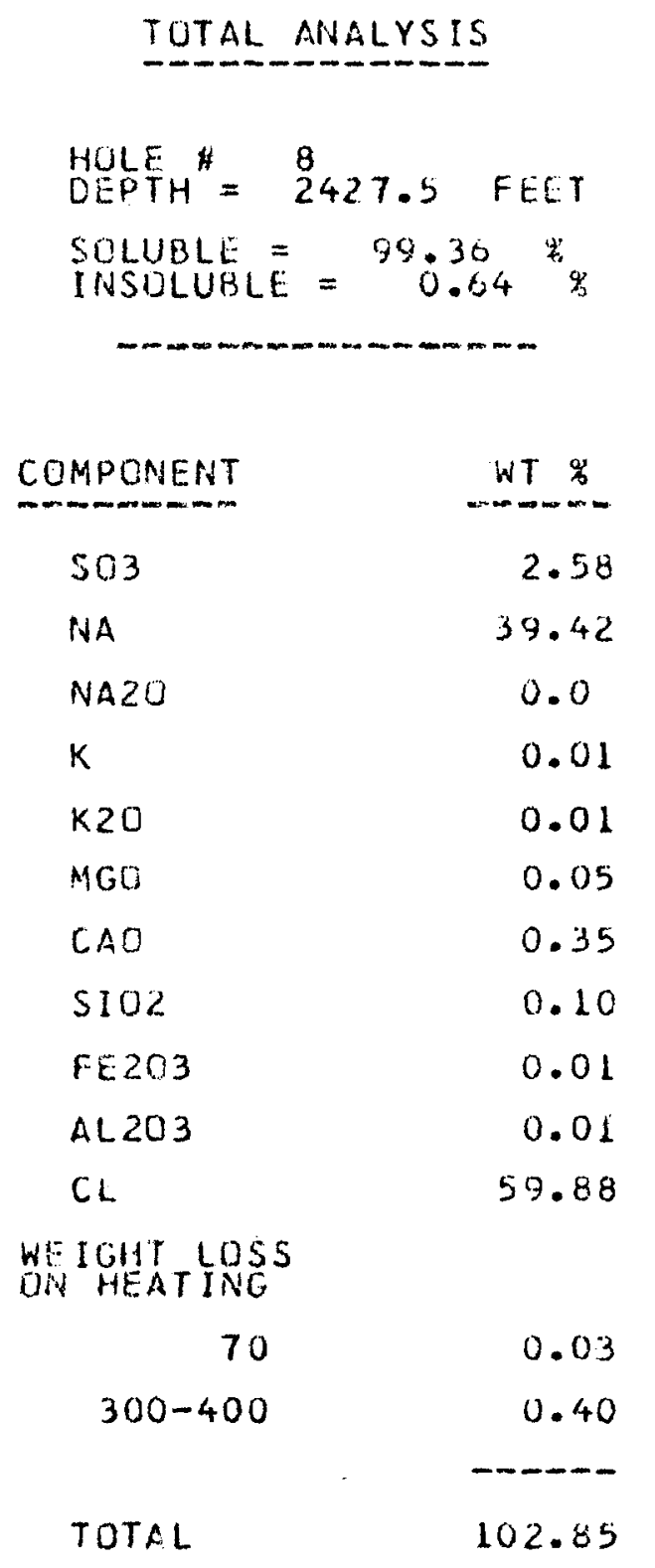

MAJOR: HAL

MINOR: $A N H$

TRACE: POLY, BLOEO, KFELO, TALC, QTZ, FEOX 


\section{TOTAL ANALYSIS}

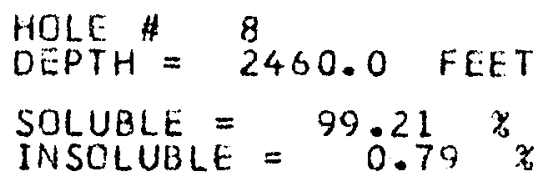

$\begin{array}{lc}\text { COMPONENT } & \text { WT } \\ \text { SO3 } & 1.14 \\ \text { NA } & 38.75 \\ \text { NA2O } & 0.0 \\ K & 0.03 \\ \text { K2O } & 0.01 \\ \text { MGO } & 0.20 \\ \text { CAO } & 0.02 \\ \text { S102 } & 0.19 \\ \text { FE203 } & 0.03 \\ \text { AL203 } & 0.06 \\ \text { CL } & 57.00\end{array}$

WE I GHT LOSS

ON HEATING

$\begin{array}{rr}70 & 0.17 \\ 125 & 0.05 \\ 350 & 0.08 \\ 450 & 0.07 \\ & \\ \text { TOTAL } & 98.40\end{array}$

MAJUR: HAL

MINOR: ANH

TRACE: KAIN, CHLUR, KFELD, TALC, FEOX 


\section{TOTAL ANALYSIS}

HOLE $\#=8$
DEPTH $=2519.0$ FEET
SOLUBLE $=99.36 \%$
INSOLUBLE $=0.64 \%$

COMPONENT

503

NA

NA2O

$\mathrm{K}$

$K 20$

MGO

CAO

5102

FE203

AL 203

$\mathrm{CL}$

WEIGHT LOSS

ON HEATING

$\begin{array}{rr}70 & 0.08 \\ 480 & 0.06 \\ & - \\ \text { TOTAL } & 101.74\end{array}$

MAJOR: HAL

MINOR:

TRACE: POLY 
TOTAL ANALYSIS

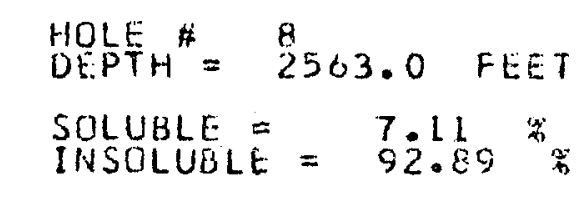

\begin{tabular}{lr} 
CUMPONENT & WT \\
\hline SO3 & 40.59 \\
NA & 1.47 \\
NA2O & 6.06 \\
$K$ & 0.05 \\
K2O & 0.54 \\
MGO & 14.73 \\
CAO & 24.37 \\
SIO2 & 0.25 \\
FE2O3 & 0.96 \\
AL2O3 & 1.86 \\
CL & 1.05
\end{tabular}

WEIGHT LOSS

ON HEATING

$\begin{array}{rr}70 & 1.87 \\ 100-150 & 0.19 \\ 175 & 0.07 \\ 450+\text { MIN } & 0.11 \\ & - \\ \text { TOTAL } & 100.17\end{array}$

MAJOR: ANH

MINUR: CHLOR, KFELD, TALG, FEOX

TRACE: HAL, LANG 


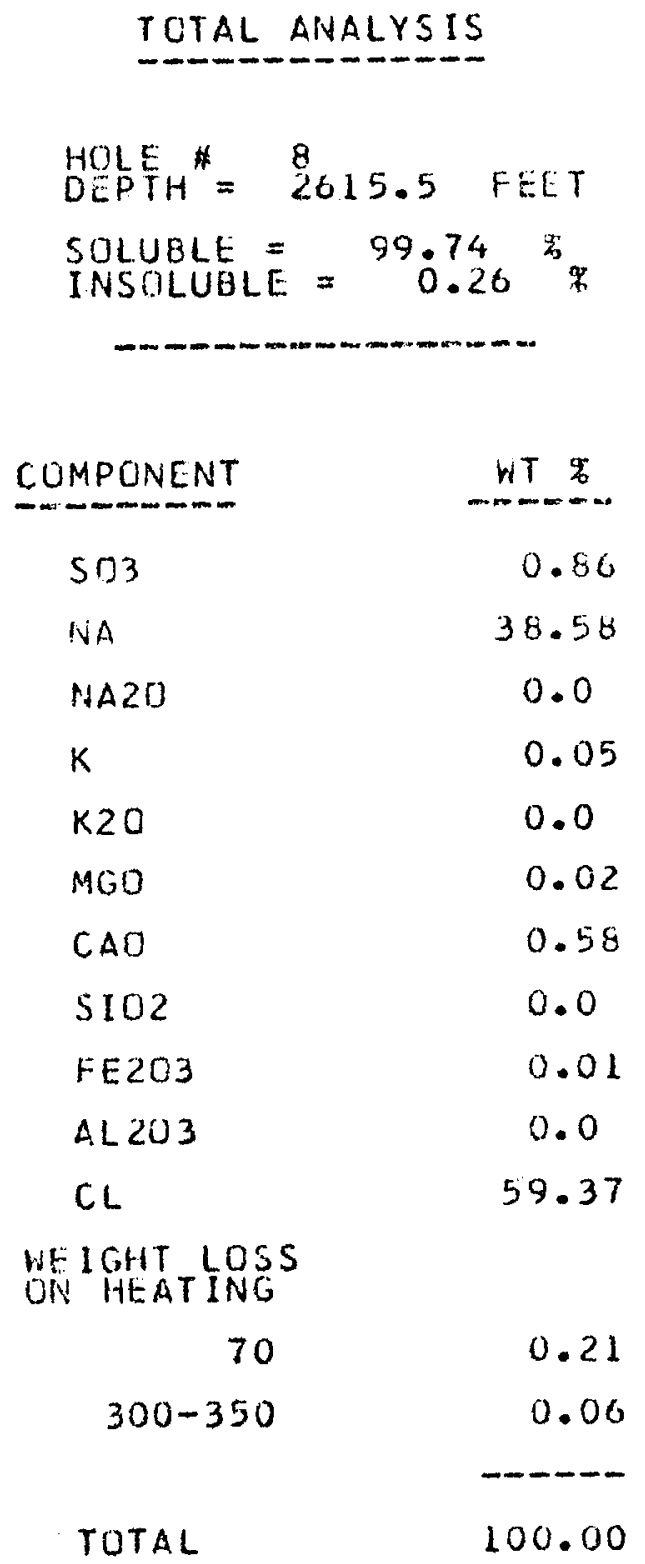

MAJOR:

MINOR:

TRACE:

HAL

ANH

POLY, FEOX 
TOTAL ANALYSIS

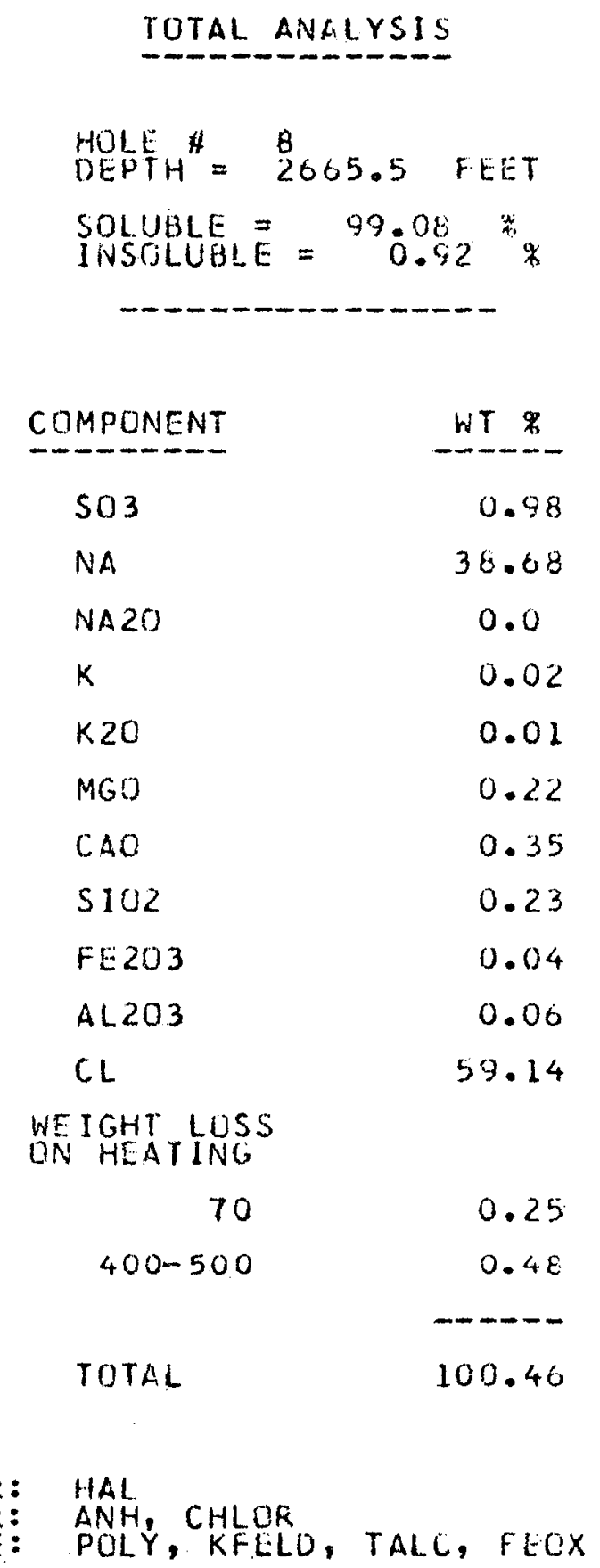

MAJUR: HAL

MRACE: POLY, KFELO, TALC, FEOX 


\section{TUTAL ANALYSIS}

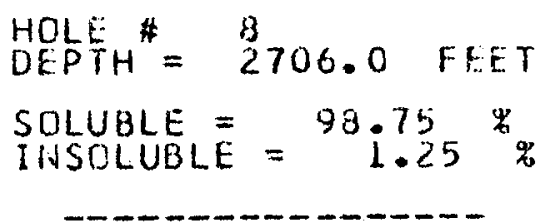

\begin{tabular}{lr} 
CUMPONENT & \multicolumn{1}{c}{ WT } \\
\hline SO3 & 1.13 \\
NA & 37.09 \\
NA2O & 0.64 \\
K & 0.03 \\
K2O & 0.03 \\
MGO & 0.19 \\
CAO & 0.68 \\
SIO2 & 0.27 \\
FE203 & 0.27 \\
AL203 & 0.07 \\
CL & 58.60
\end{tabular}

WE IGHT LOSS

ON HEATING

$\begin{array}{rr}70 & 0.16 \\ 300 & 0.05 \\ 380 & 0.75 \\ 400+ & 0.70 \\ & \\ \text { TOTAL } & 100.66\end{array}$

MAJOR: HAL

MINOR: ANH

TRACE: PGLY, CHLOR, KFELD, TALC, FEOX 


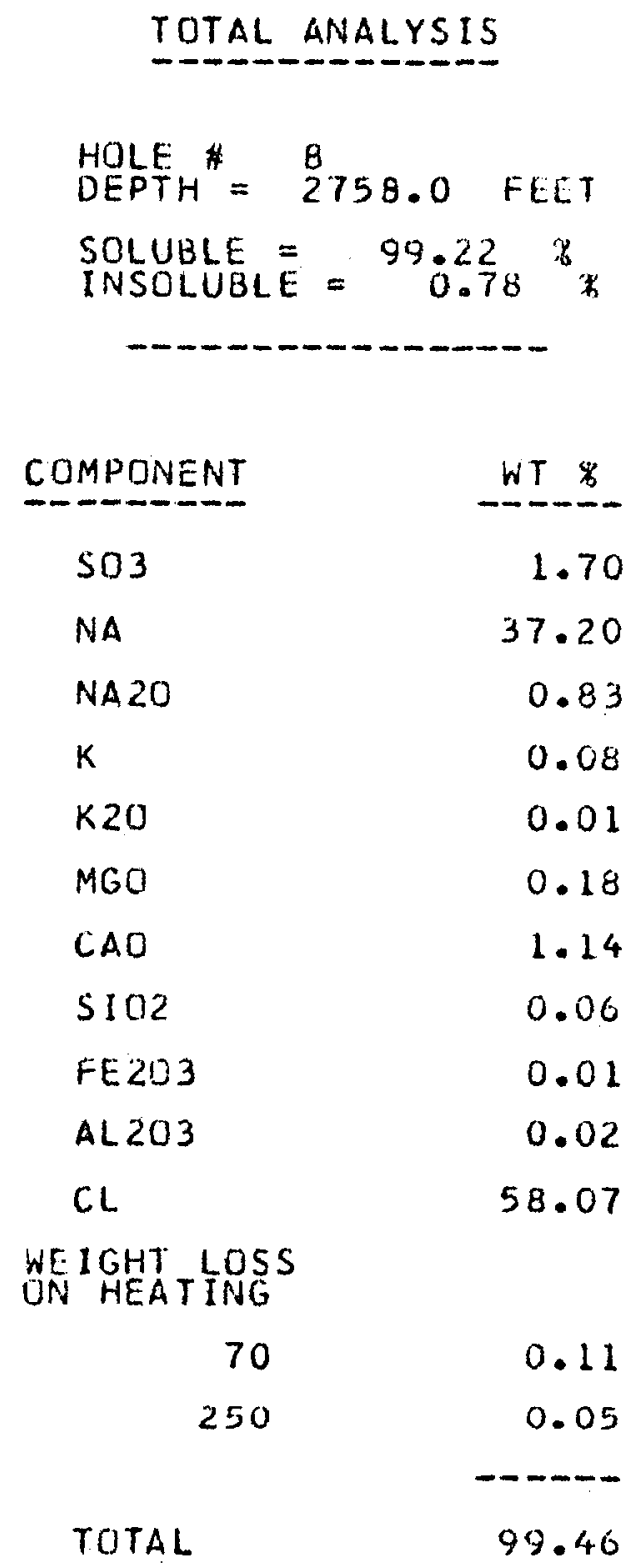

MAJOR: $\quad H A L$

MINUR: ANH

TRACE: POLY, CHLOR, KFELD, TALC, FEOX 


\section{TOTAL ANALYSIS}

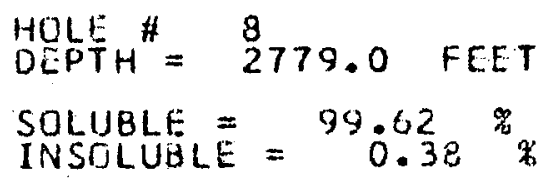

\section{COMPONENT}

$\mathrm{SO} 3$

NA

NA2O

$k$

$K 20$

MGO

CAO

5102

FE 203

AL 203

$C L$

WEIGHT LOSS

UN HEATING

$\begin{array}{cc}\text { TO } & 0.21 \\ \text { HI TEMP } & 0.0 \\ & --0- \\ \text { TOTAL } & 99.46\end{array}$

$$
\begin{aligned}
& 1.09 \\
& 37.41 \\
& 0.0 \\
& 0.01 \\
& 0.0 \\
& 0.03 \\
& 1.80 \\
& 0.0 \\
& 0.0 \\
& 0.0 \\
& 58.53
\end{aligned}
$$

99.40

MAJUR: HAL

MINOP: CARN, ANH

TRACE: 
TOTAL ANALYSIS

-

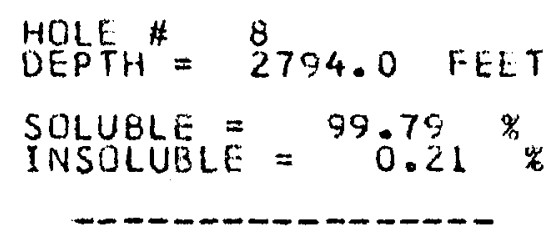

\begin{tabular}{lc} 
COMPONENT & WT \\
\hline SO3 & 0.99 \\
NA & 37.86 \\
NA2O & 0.0 \\
K & 0.02 \\
K2O & 0.0 \\
MGO & 0.01 \\
CAO & 0.68 \\
S102 & 0.0 \\
FE203 & 0.0 \\
AL203 & 0.0 \\
CL & 60.58
\end{tabular}

WEIGHT LOSS

ON HEATING

$\begin{array}{cc}70 & 0.18 \\ \text { HI TEMP } & 0.0 \\ & \\ \text { TOTAL } & 100.53\end{array}$

MAJOR: HAL

MINUR: ANH

TRACE: POLY 


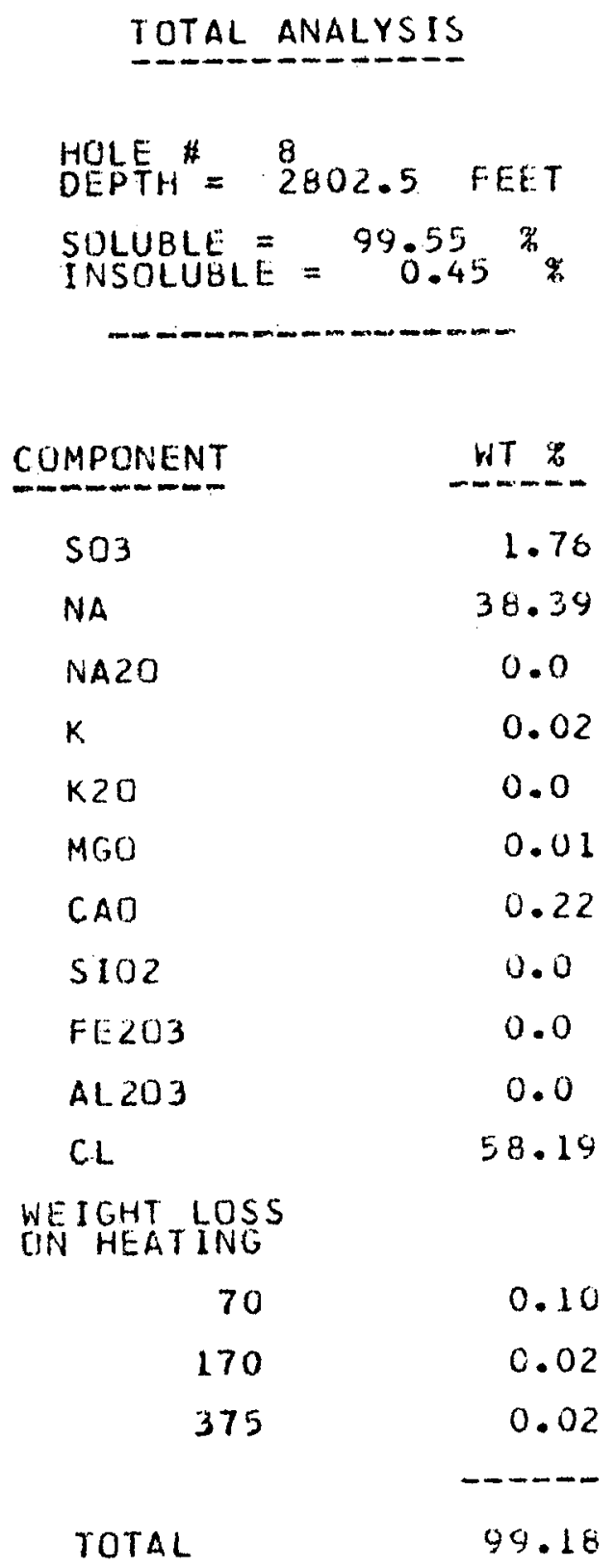

MAJOR: HAL

MINUR: ANH

TRACE: BLDED, POLY 
TOTAL ANALYSIS

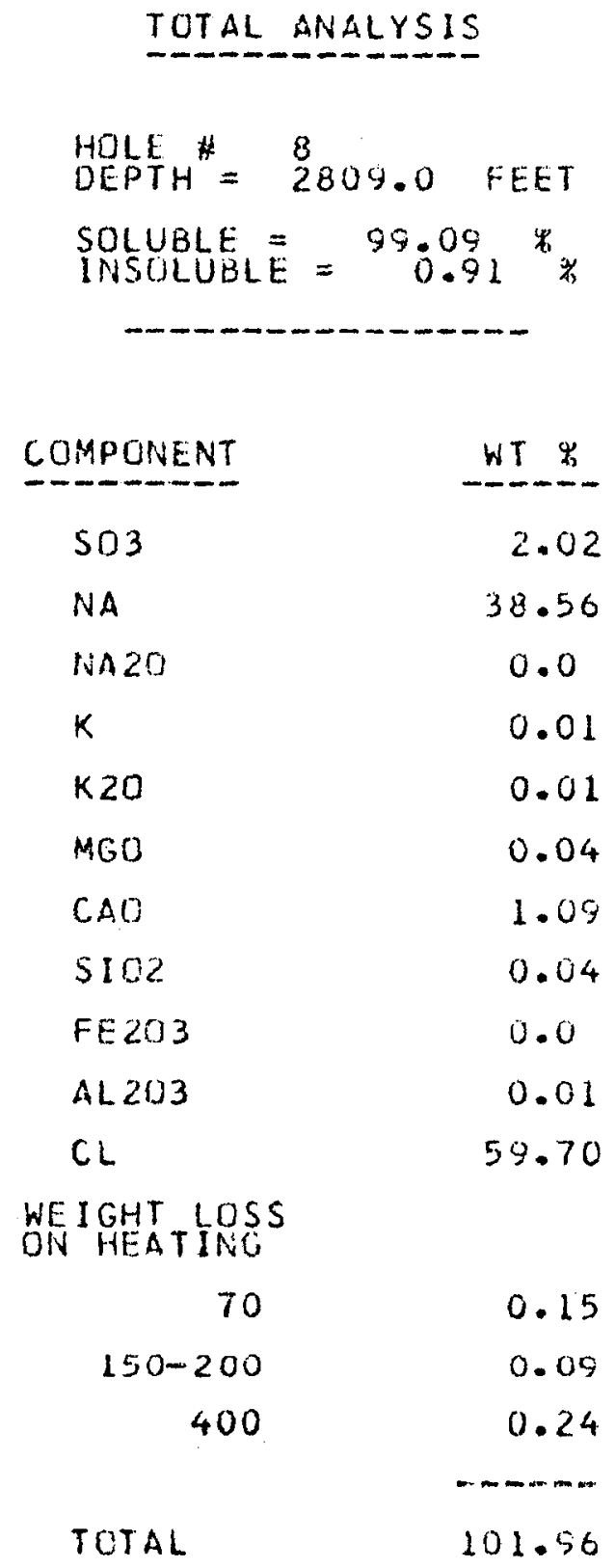

MAJUR: HAL

MINOR: $\triangle N H$

TRACE: POLY, BLOED, POLY, KFELO, QTZ 


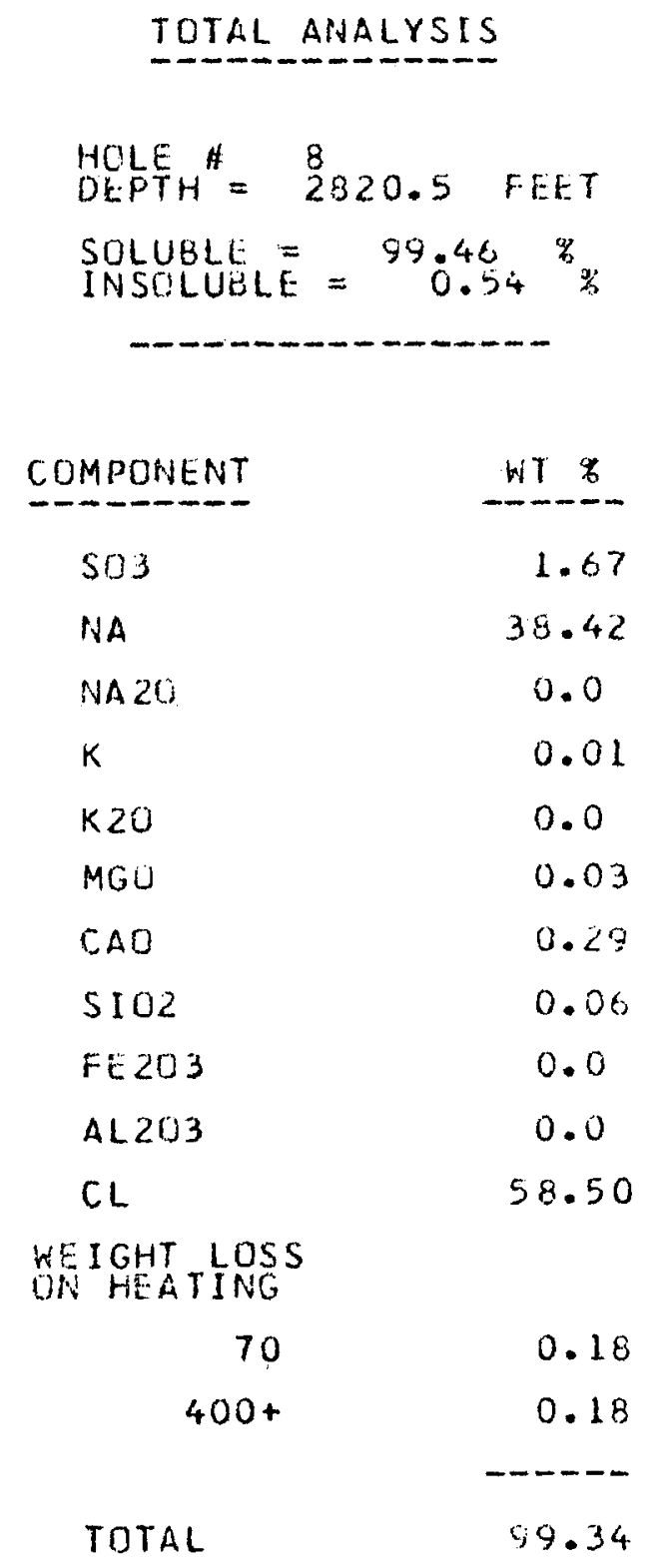

MAJOR: HAL

MIRUR: THEN, ARH

TRACE: POLY, TALC 


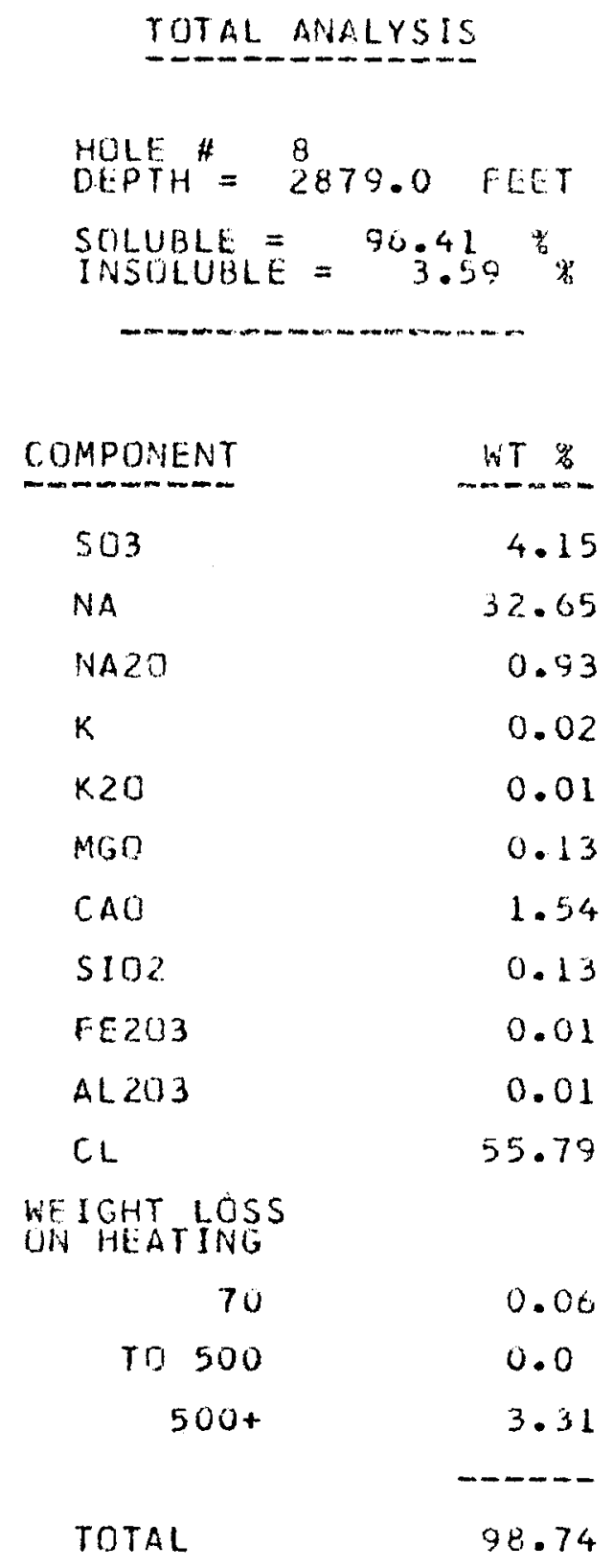

MAJGR: HAL

MINOR: GLAYB, ANH

TRACE: PULY, KFELO, TALC, FEOX 
TOTAL ANALYSIS

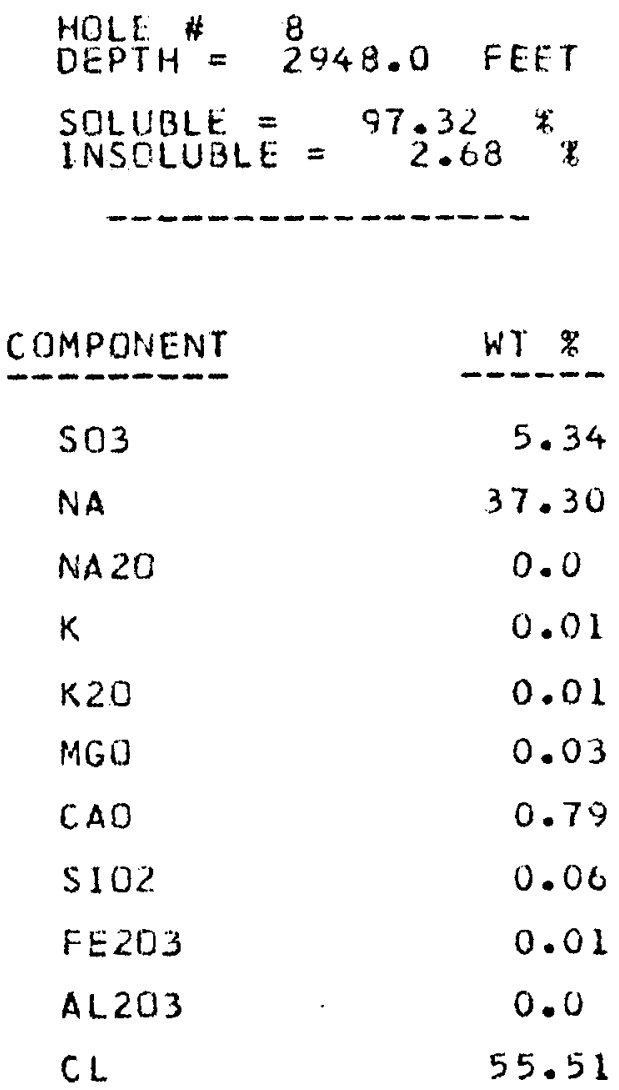

WE IGHT LOSS

ON HEATING

$\begin{array}{rr}70 & 0.20 \\ 150 & 0.02 \\ 450 & 0.02 \\ 500 & 0.02 \\ & \\ \text { TOTAL } & 99.32\end{array}$

MAJUR:

MINOR:

HAL

TRACE:

GLAMB, ANH

LANG, TALC, QTL, FECX 
Appendix 7.B (Ref. sec. 7.3$)$

Whole Rock Chemical Analyses in Soluble and Insoluble Fractions \& Moles times 1000 


$$
\begin{aligned}
& \text { HOLE H' } \\
& \text { OLPTH } \\
& \text { TOTAL }
\end{aligned}
$$

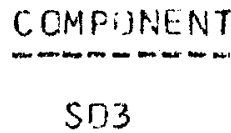

NA

NA2O

$k$

$K 20$

MCU

CAO

$510 ?$

$\mathrm{FE}<03$

AL 203

$\mathrm{CL}$

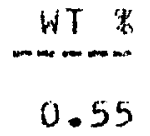

38.56

0.0

0.03

0.0

0.04

0.43

0.0

0.0

0.0

60.40
MOLES

0.87
1077.25
0.0
0.77
0.0
0.99
7.67
0.0
0.0
0.0

1703.81 


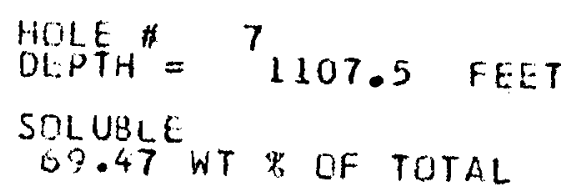

COPPONEN
503
$\mathrm{NA}$
$\mathrm{NA2O}$
$\mathrm{K}$
$\mathrm{K} 2 \mathrm{O}$
$\mathrm{MGO}$
$\mathrm{CAO}$
$\mathrm{S102}$
$\mathrm{FE} 203$
$\mathrm{AL} 203$
$\mathrm{CL}$

SUETUTAL.

MEASUREO =

\begin{tabular}{cc} 
WT $x$ & MOLES \\
\hline 9.24 & 125.41 \\
20.28 & 882.12 \\
0.0 & 0.0 \\
0.0 & 0.0 \\
3.70 & 39.28 \\
2.24 & 55.57 \\
1.61 & 28.71 \\
0.0 & 0.0 \\
0.0 & 0.0 \\
0.01 & 0.10 \\
30.78 & 868.26 \\
07.36 & \\
69.47 &
\end{tabular}

\begin{tabular}{|c|c|c|}
\hline \multicolumn{3}{|c|}{$\begin{array}{l}\text { HOLE }{ }^{*} 7 \\
\text { DEPTH }=7,1,075\end{array}$} \\
\hline $\begin{array}{l}\text { HOLE } \\
\text { DEPTH } \\
\text { INSOLUBLE } \\
30.53 \text { WT }\end{array}$ & $\not B \quad O F$ & TOTAL \\
\hline WT & & MCLES \\
\hline 11.63 & & 145.27 \\
\hline 0.0 & & 0.0 \\
\hline 6.63 & & 106.97 \\
\hline 0.0 & & 0.0 \\
\hline 0.77 & & 8.17 \\
\hline 2.33 & & 57.80 \\
\hline 0.23 & & 4.10 \\
\hline 8.30 & & 138.13 \\
\hline 0.27 & & 1.69 \\
\hline 1.24 & & 12.10 \\
\hline 0.0 & & 0.0 \\
\hline 31.40 & & \\
\hline 30.53 & & \\
\hline
\end{tabular}




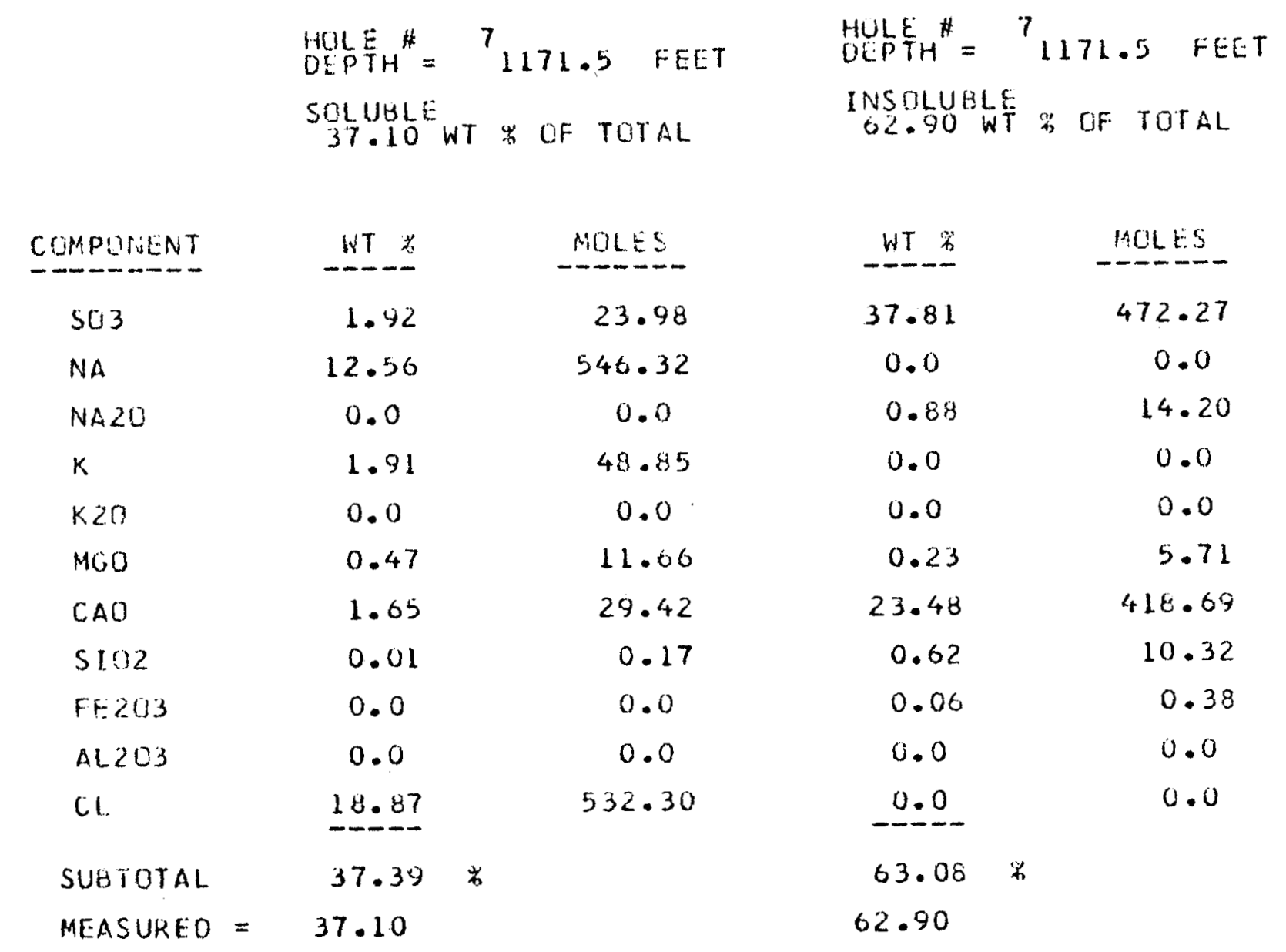




$$
\begin{aligned}
& \text { HOLE \# } \\
& \text { DEPTH } \\
& \text { TOTAL }
\end{aligned}
$$

\begin{tabular}{lcc} 
COMPGNENT & WT & MLLES \\
\hline SO3 & 2.02 & 25.23 \\
NA & 38.79 & 1687.26 \\
NA2O & 0.0 & 0.0 \\
K & 0.06 & 1.53 \\
K2O & 0.0 & 0.0 \\
MGO & 0.10 & 2.48 \\
CAO & 0.88 & 15.69 \\
S102 & 0.01 & 0.17 \\
FE2O3 & 0.0 & 0.0 \\
AL203 & 0.0 & 0.0 \\
CL & 58.31 & 1644.85
\end{tabular}




$$
\begin{aligned}
& \text { HQLE H } \\
& \text { UEPTH }
\end{aligned}
$$

\begin{tabular}{lcc} 
COMPCNENT & WT & MOLES \\
\hline SOS & 0.99 & 12.37 \\
NA & 38.60 & 1678.99 \\
NA2O & 0.0 & 0.0 \\
$K$ & 0.35 & 3.95 \\
K2O & 0.0 & 0.0 \\
MGO & 0.15 & 3.72 \\
CAO & 0.66 & 11.77 \\
SIO2 & 0.01 & 0.17 \\
FE203 & 0.0 & 0.0 \\
AL2U3 & 0.0 & 0.0 \\
CL & 59.40 & 1075.60
\end{tabular}




$$
\begin{aligned}
& \text { HOLE HA } \\
& \text { DEPTH }={ }_{1402.5} \text { FEET } \\
& \text { TOTAL }
\end{aligned}
$$

$\begin{array}{lcc}\text { COMPONENT } & \text { WT } & \text { MOLES } \\ \text { SO3 } & 0.11 & 1.37 \\ \text { NA } & 39.67 & 1725.53 \\ \text { NA20 } & 0.0 & 0.0 \\ \text { K } & 0.06 & 1.53 \\ \text { K2O } & 0.0 & 0.0 \\ \text { MGO } & 0.06 & 1.49 \\ \text { CAO } & 0.02 & 0.36 \\ \text { SIO2 } & 0.0 & 0.0 \\ \text { FE2O3 } & 0.0 & 0.0 \\ \text { AL 203 } & 0.0 & 0.0 \\ \text { CL } & 59.78 & 1686.32\end{array}$




\begin{tabular}{|c|c|c|c|c|}
\hline \multirow[b]{3}{*}{ COMPONENT } & HOLE ${ }_{\text {OEPH }}^{H}=$ & ${ }^{7} 1408.5$ FEET & \multicolumn{2}{|c|}{ HOLEEH ${ }^{7}{ }^{7} 1468.5 \mathrm{FEE}$} \\
\hline & $\underset{G 3.66 \mathrm{~W}}{\text { SOLUBLE }}$ & $T:$ UF TOTAL & $\begin{array}{l}\text { INSSOLUBL } \\
6.34\end{array}$ & T $\%$ OF TOTAL \\
\hline & WT & MOLES & WT 8 & MOLES \\
\hline $\mathrm{SO} 3$ & 0.98 & 12.24 & 1.89 & 23.61 \\
\hline NA & 34.44 & 1498.04 & 0.0 & 0.0 \\
\hline $\mathrm{NA} 20$ & 0.0 & 0.0 & 0.0 & 0.0 \\
\hline k & 0.37 & 9.46 & 0.0 & 0.0 \\
\hline$k 20$ & 0.0 & 0.0 & 0.07 & 0.74 \\
\hline MGO & 0.52 & 12.90 & 1.32 & 32.75 \\
\hline CAO & 0.18 & 3.21 & 0.01 & 0.18 \\
\hline 5102 & 0.03 & 0.50 & 2.12 & 35.28 \\
\hline Fe203 & 0.0 & 0.0 & 0.24 & 1.50 \\
\hline$A L 203$ & 0.0 & 0.0 & 0.07 & 0.69 \\
\hline $\mathrm{Cl}$ & 53.61 & 1512.27 & 0.0 & 0.0 \\
\hline SUETOTAL & 90.13 & $x$ & 5.72 & 6 \\
\hline MEASURED = & 93.66 & & 0.34 & \\
\hline
\end{tabular}


HOLE ${ }^{H}={ }^{7} 1534.0 \quad$ FEET
DETAL

$\begin{array}{lcc}\text { COMPONENT } & \text { WT } & \text { MOLES } \\ \text { S03 } & 1.67 & 20.86 \\ \text { NA } & 36.10 & 1570.25 \\ \text { NA20 } & 0.0 & 0.0 \\ K & 0.52 & 13.30 \\ \text { K2U } & 0.0 & 0.0 \\ \text { MGO } & 0.22 & 5.46 \\ \text { CAO } & 0.64 & 11.41 \\ \text { S102 } & 0.01 & 0.17 \\ \text { FE2O3 } & 0.0 & 0.0 \\ \text { AL203 } & 0.0 & 0.0 \\ \text { CL } & 37.76 & 1629.34\end{array}$




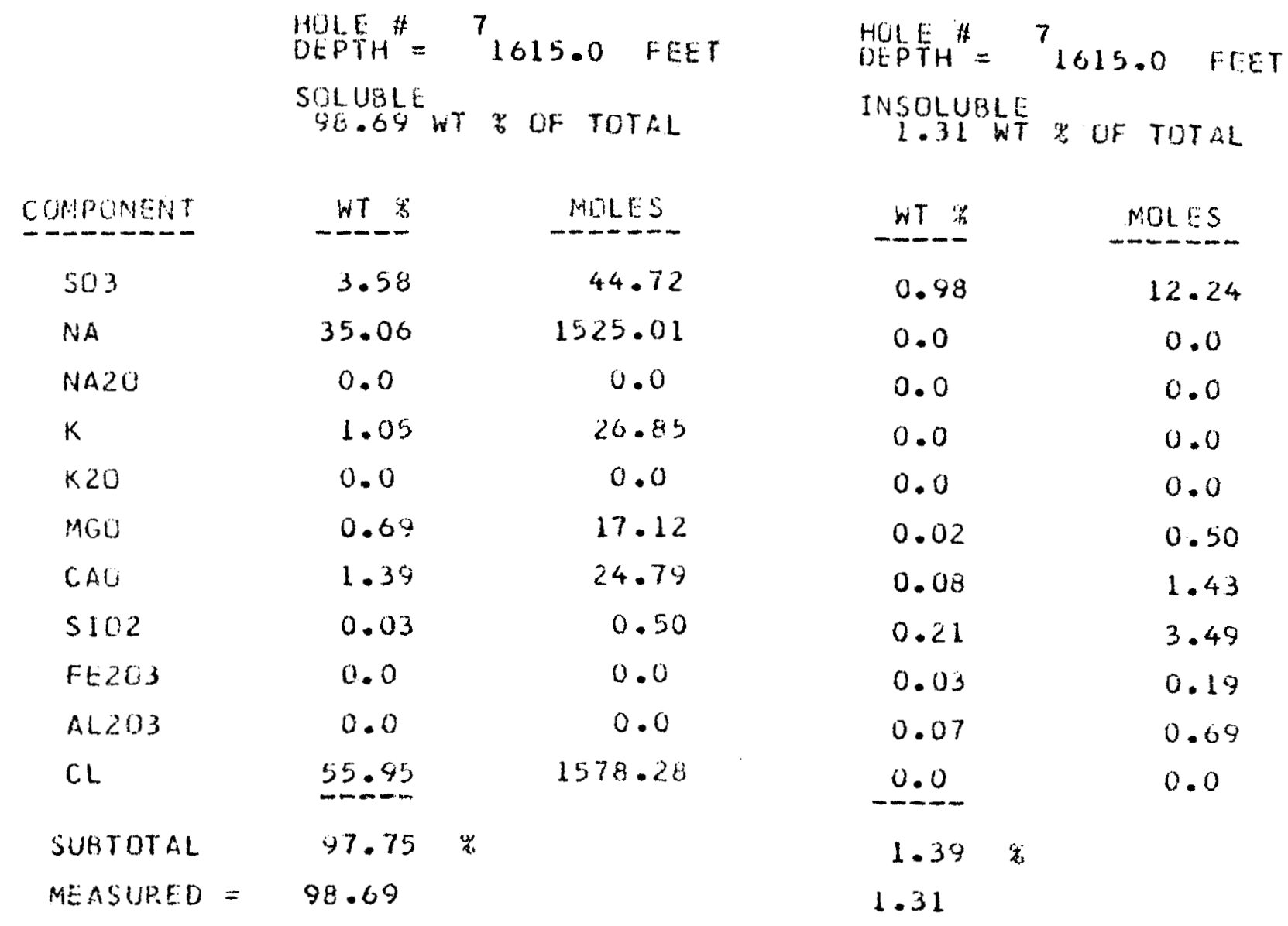




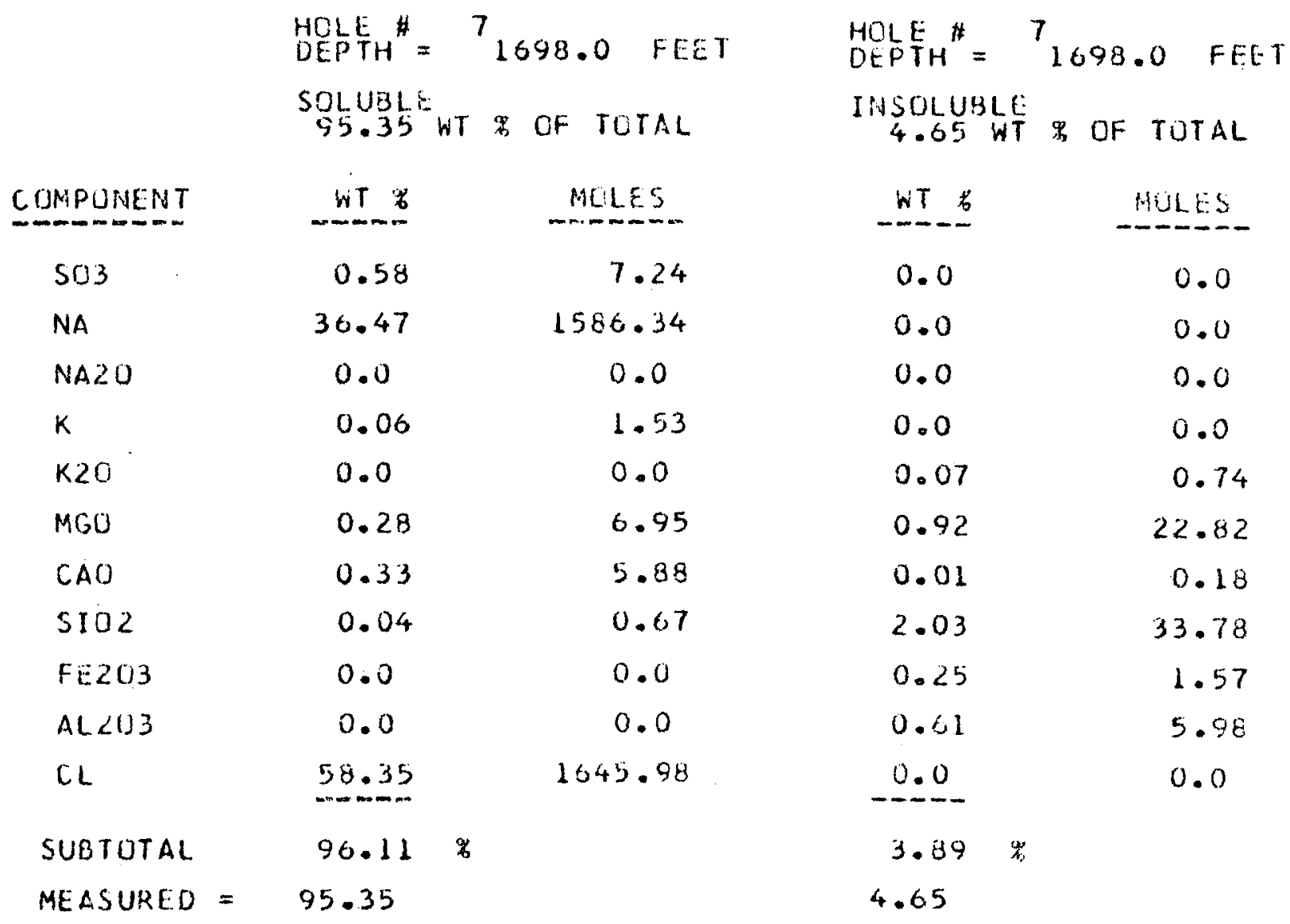




$$
\begin{aligned}
& \text { HOLE } \\
& \text { OEPTH }
\end{aligned}
$$

\begin{tabular}{lcc} 
COMPUNENT & WT & MOLES \\
\hline 503 & 0.65 & 8.12 \\
NA & 38.12 & 1658.11 \\
NA2O & 0.0 & 0.0 \\
$K$ & 0.23 & 5.88 \\
K2O & 0.0 & 0.0 \\
MGO & 0.13 & 3.23 \\
CAOS & 0.08 & 1.43 \\
S102 & 0.02 & 0.33 \\
FE203 & 0.0 & 0.0 \\
AL203 & 0.0 & 0.0 \\
CL & 59.54 & 1679.55
\end{tabular}




\begin{tabular}{|c|c|c|c|c|c|}
\hline \multirow[b]{3}{*}{ COMPUNENT } & \multirow{2}{*}{$\begin{array}{l}\text { HOLE }{ }^{\#}=7 \\
\text { OLDTH }= \\
\text { SOLUBLE } \\
99.30 \text { WT }\end{array}$} & 7 1952.5 FEET & \multirow{2}{*}{$\begin{array}{l}\text { HULE } \\
\text { OEPTH }=7 \\
\text { INSOLUBLE } \\
0.70 \text { WT }\end{array}$} & 1952.5 & \multirow{2}{*}{$\begin{array}{l}5 \text { FEE } \\
\text { TOTAL }\end{array}$} \\
\hline & & D OF TOTAL & & UF & \\
\hline & $-W T$ 岁 & MULES & WT & & MULES \\
\hline $\mathrm{SO} 3$ & 3.03 & 37.85 & 0.15 & & 1.87 \\
\hline NA & 37.14 & 1615.49 & 0.0 & & 0.0 \\
\hline NA20 & 0.0 & 0.0 & 0.0 & & 0.0 \\
\hline K & 0.75 & 19.18 & 0.0 & & 0.0 \\
\hline$k 20$ & 0.0 & 0.0 & 0.03 & & 0.32 \\
\hline$M G O$ & 0.42 & 10.42 & 0.12 & & 2.58 \\
\hline $\mathrm{CAO}$ & 0.78 & 13.91 & 0.01 & & 0.18 \\
\hline 5102 & 0.01 & 0.17 & 0.33 & & 5.49 \\
\hline FE: 203 & 0.01 & 0.06 & 0.02 & & 0.13 \\
\hline AL. 203 & 0.0 & 0.0 & 0.05 & & 0.49 \\
\hline $\mathrm{CL}$ & 57.00 & 1607.90 & 0.0 & & 0.0 \\
\hline SUBTOTAL & $99.14-x$ & & 0.71 & & \\
\hline MEASURED = & $99 \cdot 30$ & & 0.70 & & \\
\hline
\end{tabular}




\begin{tabular}{|c|c|c|c|c|}
\hline \multirow[b]{3}{*}{ COMPONENT } & \multicolumn{2}{|c|}{${ }_{\text {OEPTH }}^{\text {HDLE }}=$} & 1954.0 & .0 FEET \\
\hline & $\begin{array}{l}\text { SOLUBLE } \\
97.46\end{array}$ & VT & OF & TOTAL \\
\hline & WT $*$ & & & MOLES \\
\hline $\mathrm{SO3}$ & 0.73 & & & 9.12 \\
\hline NA & 37.94 & & & 650.28 \\
\hline NA2O & 0.0 & & & 0.0 \\
\hline K & 0.18 & & & 4.60 \\
\hline$K 20$ & 0.0 & & & 0.0 \\
\hline MGO & 0.17 & & & 4.22 \\
\hline CAO & 0.51 & & & 0.09 \\
\hline 5102 & 0.02 & & & 0.33 \\
\hline$F E 203$ & 0.0 & & & 0.0 \\
\hline$A L 203$ & 0.0 & & & 0.0 \\
\hline $\mathrm{CL}$ & 58.38 & & & 640.83 \\
\hline SUETOTAL & 97.93 & 学 & & \\
\hline MEASURED = & 97.46 & & & \\
\hline
\end{tabular}

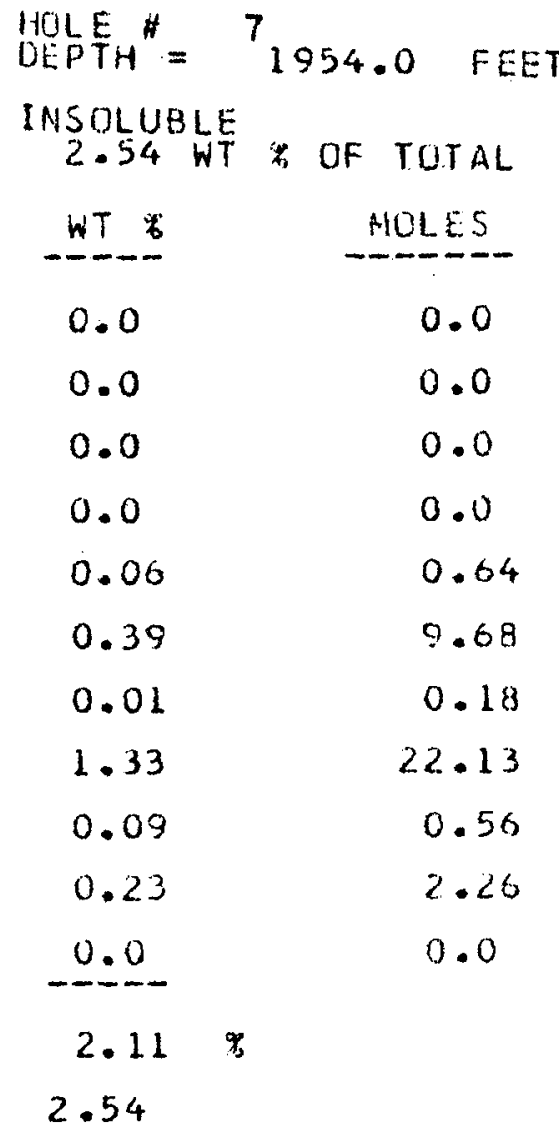




\begin{tabular}{|c|c|c|c|c|c|c|}
\hline & $\begin{array}{l}\text { HOLE } \\
\text { OLPTH }\end{array}$ & $7_{1}$ & 1957.5 FEET & $\begin{array}{l}\text { HOLE }{ }^{H} \\
\text { DEPTH }\end{array}$ & 7957 & .5 FEET \\
\hline & $\begin{array}{c}\text { SELUBLE } \\
99.16\end{array}$ & WT & $\because$ UF TOTAL & $\begin{array}{c}\text { INSOLUBLE } \\
\text { O.84 WT }\end{array}$ & OF & TOTAL \\
\hline COMPONEMT & 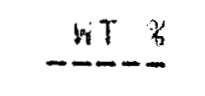 & & MULES & WT & & $\because 0 L 55$ \\
\hline 503 & 1.32 & & 10.49 & 0.41 & & 5.12 \\
\hline NA & 38.38 & & 1669.42 & 0.0 & & 0.0 \\
\hline NAA 20 & 0.0 & & 0.0 & 0.0 & & 0.0 \\
\hline$k$ & 0.36 & & $9 \cdot 21$ & 0.0 & & 0.0 \\
\hline $\mathrm{k} 20$ & 0.0 & & 0.0 & 0.01 & & 0.11 \\
\hline$M G O$ & 0.24 & & 5.95 & 0.17 & & $4 \cdot 22$ \\
\hline CAO & 2.18 & & 38.87 & 0.0 & & 0.0 \\
\hline 5102 & 0.03 & & 0.50 & 0.35 & & 5.82 \\
\hline$F E 203$ & 0.0 & & 0.0 & 0.04 & & 0.25 \\
\hline D.1.203 & 0.0 & & 0.0 & 0.10 & & 0.98 \\
\hline$C L$ & 59.00 & & 1604.32 & $\underline{0.0}$ & & 0.0 \\
\hline SUETOTAL & 101.51 & 㟧 & & $1.08 \quad \mathrm{z}$ & & \\
\hline MEASUREO = & 99.16 & & & 0.84 & & \\
\hline
\end{tabular}




\begin{tabular}{|c|c|c|c|c|}
\hline \multirow[b]{3}{*}{ COMPUNENT } & \multicolumn{2}{|c|}{ HULE \# 7} & 1961.0 & .0 \\
\hline & $\begin{array}{l}\text { SOL UBLE } \\
\text { YG.1O }\end{array}$ & $N T$ & $\%$ of & TOTALL \\
\hline & WT & & & MOLES \\
\hline SU3 & 0.49 & & & 6.12 \\
\hline NA & 39.14 & & & 702.48 \\
\hline NA2O & 0.0 & & & 0.0 \\
\hline$k$ & 0.21 & & & 5.37 \\
\hline $\mathrm{K} 2 \mathrm{O}$ & 0.01 & & & 0.11 \\
\hline MGO & 0.07 & & & 1.74 \\
\hline CAO & 0.19 & & & 3.39 \\
\hline 5102 & 0.01 & & & 0.17 \\
\hline$F E 203$ & 0.0 & & & 0.0 \\
\hline AL2013 & 0.0 & & & 0.0 \\
\hline$C L$ & 56.83 & & & 659.52 \\
\hline SUBTOTAL & 98.95 & \% & & \\
\hline MEASURED = & 99.10 & & & \\
\hline
\end{tabular}

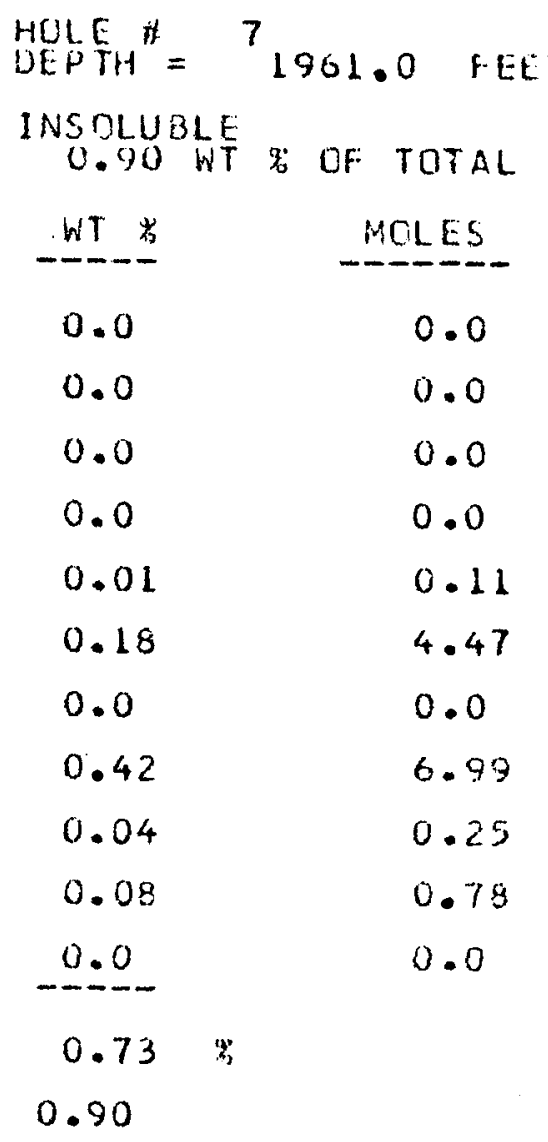




$$
\begin{aligned}
& \text { HOLE \# } \\
& \text { OLPTH } \\
& \text { TOTAL }
\end{aligned}
$$

\begin{tabular}{lcc} 
CLMPONENT & WT & MCLES \\
\hline SO3 & 3.03 & 37.85 \\
NA & 39.53 & 1721.62 \\
NA2O & 0.0 & 0.0 \\
K & 0.90 & 23.02 \\
K2O & 0.0 & 0.0 \\
MGD & 0.23 & 5.71 \\
CAD & 0.94 & 16.76 \\
S102 & 0.0 & 0.0 \\
FE2O3 & 0.01 & 0.06 \\
AL203 & 0.0 & 0.0 \\
CL & 58.74 & 1056.90
\end{tabular}




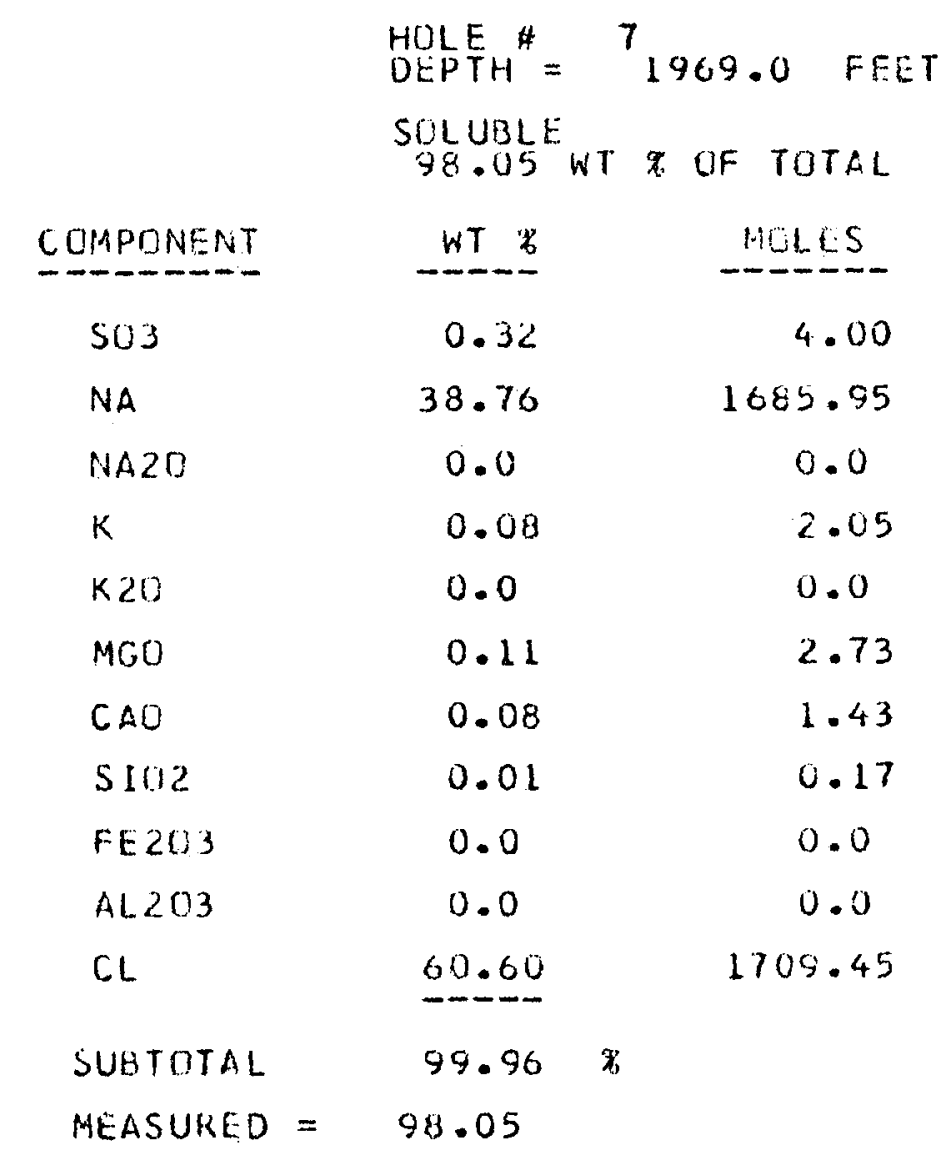

HOLEFH ${ }^{*}=7_{1969.0 \quad \text { FEET }}$

INSOLUSLF

1.95 WT OF TOTAL

\begin{tabular}{ll} 
WT & NOLES \\
\hline 0.0 & 0.0 \\
0.0 & 0.0 \\
0.0 & 0.0 \\
0.0 & 0.0 \\
0.0 & 0.0 \\
0.11 & 2.73 \\
0.0 & 0.0 \\
0.14 & 2.33 \\
0.02 & 0.13 \\
0.04 & 0.39 \\
0.0 & 0.0 \\
\hline 0.31 & \\
1.95 &
\end{tabular}



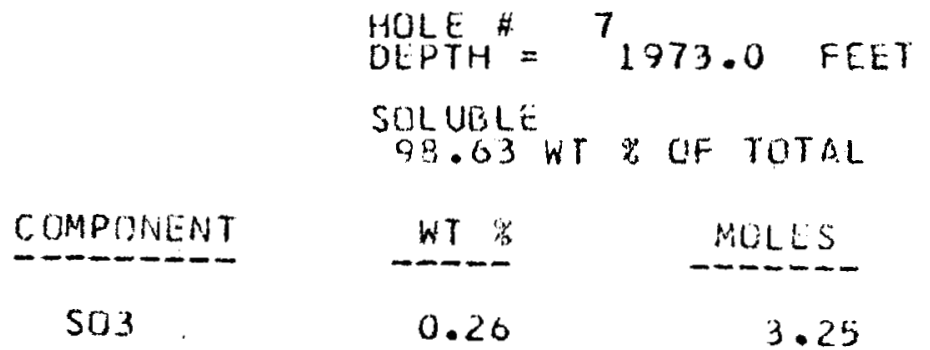

IVA

NA20

$k$

$\mathrm{K} 2 \mathrm{O}$

$\mathrm{MGO}$

$\mathrm{CAO}$

5102

$\mathrm{FE} 2 \mathrm{O} 3$

AL 203

$C L$

SUBTUTAL

MEASURED =
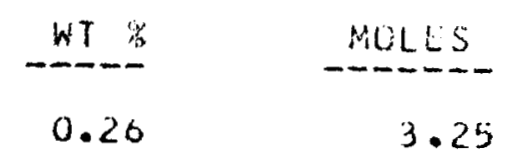

38.46

0.0

0.06

0.0

0.13

0.06

0.03

0.0

0.0

59.58

$98.58 x$

98.63

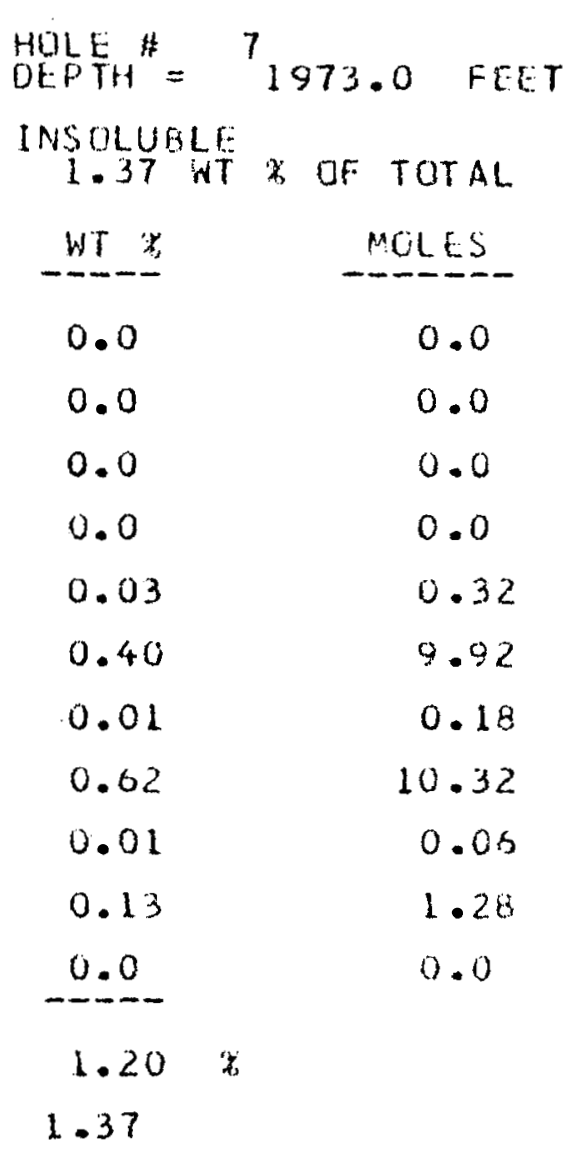




HOLE \#
DEPTH
TOTAL

\begin{tabular}{lcc} 
CCMPONENT & WT & MOLES \\
\hline SO3 & 0.19 & 2.37 \\
NA & 38.93 & 1693.35 \\
NA2O & 0.0 & 0.0 \\
$K$ & 0.06 & 1.53 \\
K2O & 0.0 & 0.0 \\
MGO & 0.07 & 1.74 \\
CAO & 0.09 & 1.60 \\
SIO2 & 0.0 & 0.0 \\
FE203 & 0.0 & 0.0 \\
AL203 & 0.0 & 0.0 \\
CL & 00.30 & 1703.24
\end{tabular}




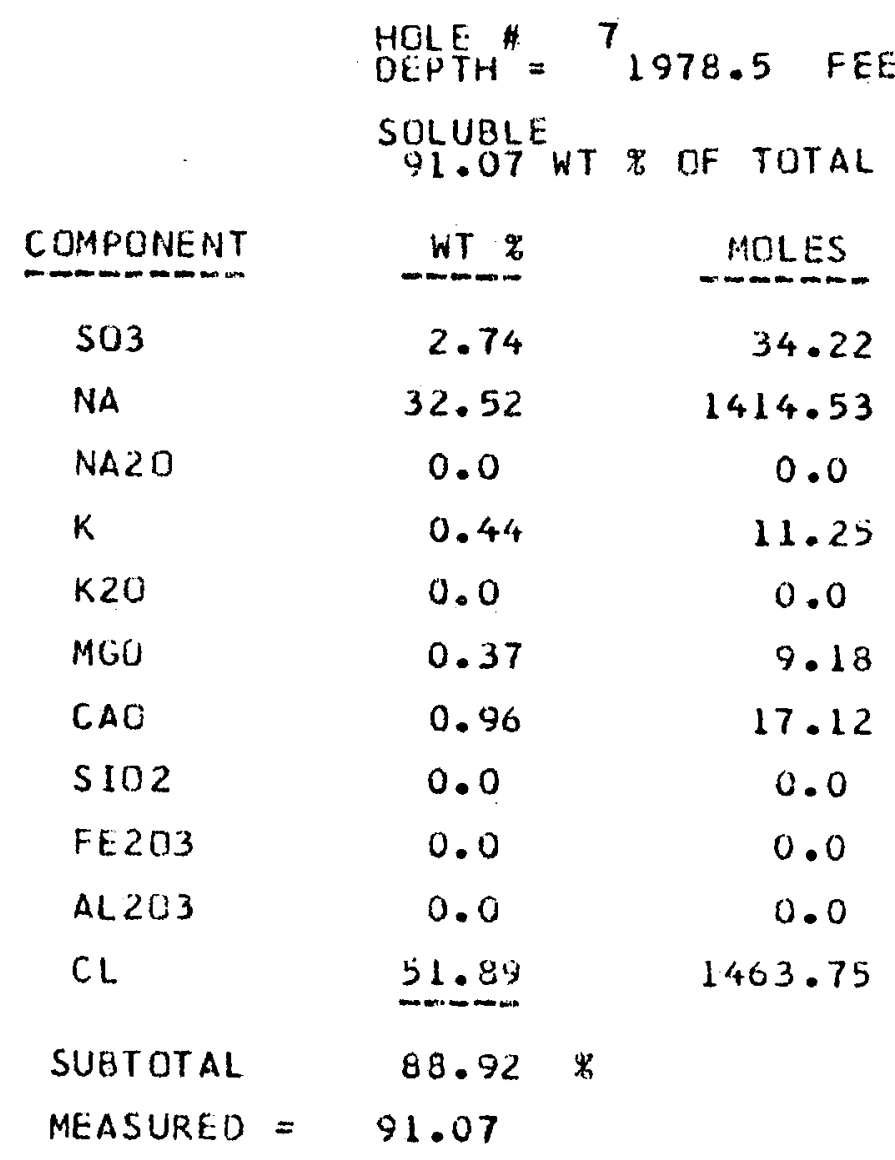

\begin{tabular}{cc} 
HOLE & 7 \\
DEPTH & 71978.5 \\
INSOLUBLE & FEET \\
8.93 WT & OF TOTAL \\
$W T \%$ & MOLES \\
\hline 0.08 & 1.00 \\
0.0 & 0.0 \\
1.96 & 31.62 \\
0.0 & 0.0 \\
0.13 & 1.38 \\
2.25 & 55.82 \\
0.02 & 0.36 \\
2.89 & 48.09 \\
0.37 & 2.32 \\
1.06 & 10.40 \\
0.0 & 0.0 \\
-8.76 & \\
8.93 &
\end{tabular}




$$
\begin{aligned}
& \text { HULE \#\# } \\
& \text { OEPTH } \\
& \text { TOTAL }
\end{aligned}
$$

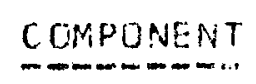

503

NA

NA2O

$K$

$K 20$

MGO

CAO

5102

FE 203

AL2O3

$\mathrm{CL}$

WT
1.11
36.00
0.0
0.61
0.0
0.40
0.46
0.01
0.0
0.0
59.20

59.20
MOLES

$$
13.86
$$$$
1505.90
$$

0.0

15.60

0.0

9.92

8.20

0.17

0.0

0.0

1669.96 


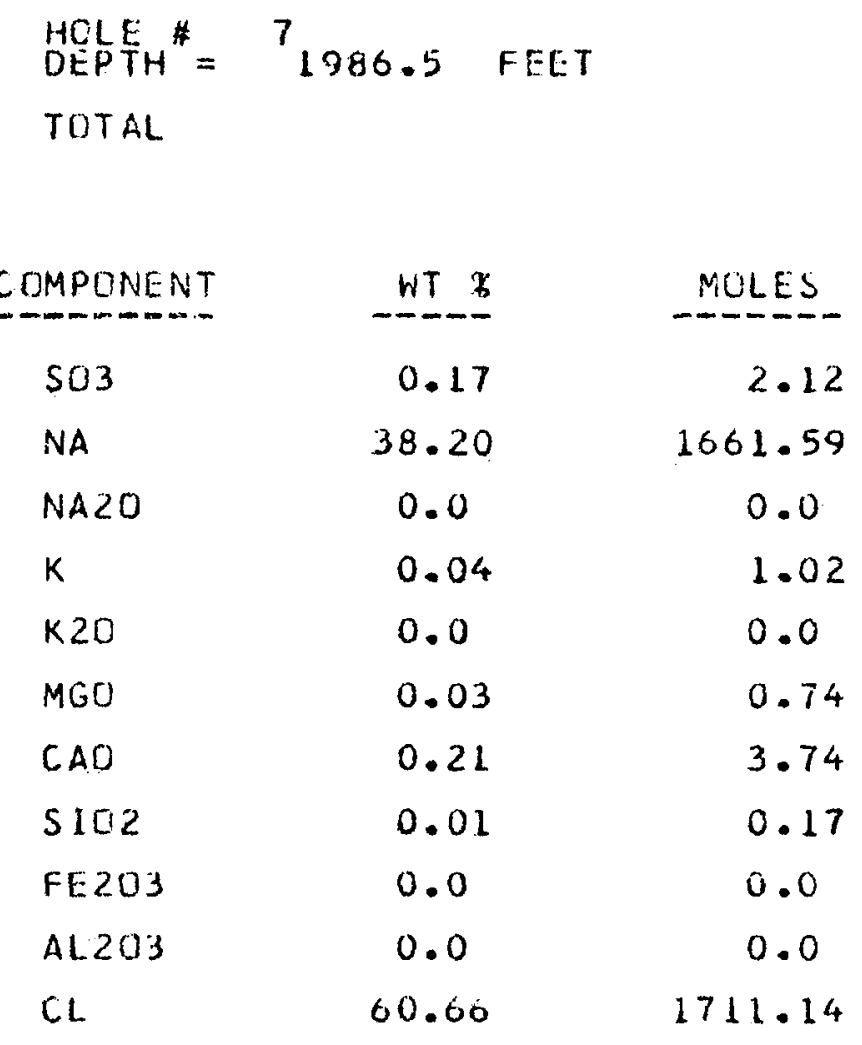




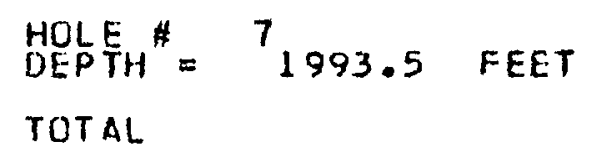

NA

NA 20

$K$

$K 20$

MGD

CAO

$S I 02$

FE:203

AL203

$\mathrm{CL}$

0.0

1.68

0.0

0.79

2.30

0.0

0.0

0.0

53.81

MOLES

36.97

1663.77

0.0

42.97

0.0

19.60

41.01

0.0

0.0

0.0

1517.91 


$$
\begin{aligned}
& \text { HOLE } \\
& \text { DEPTH }
\end{aligned}
$$

COMPONENT

$\mathrm{SO} 3$

NA

NA 20

$K$

$K 20$

MGO

CAO

SIO2

$\mathrm{FE}_{2} \mathrm{OS}_{3}$

AL 203

$\mathrm{Cl}$

WT
40.62
0.93
4.93
0.90
0.0

13.02

4.37

13.98

1.13

3.26

2.63
MOLES

582.31

40.45

79.54

23.02

0.0

323.00

77.92

232.65

7.08

31.97

74.19 


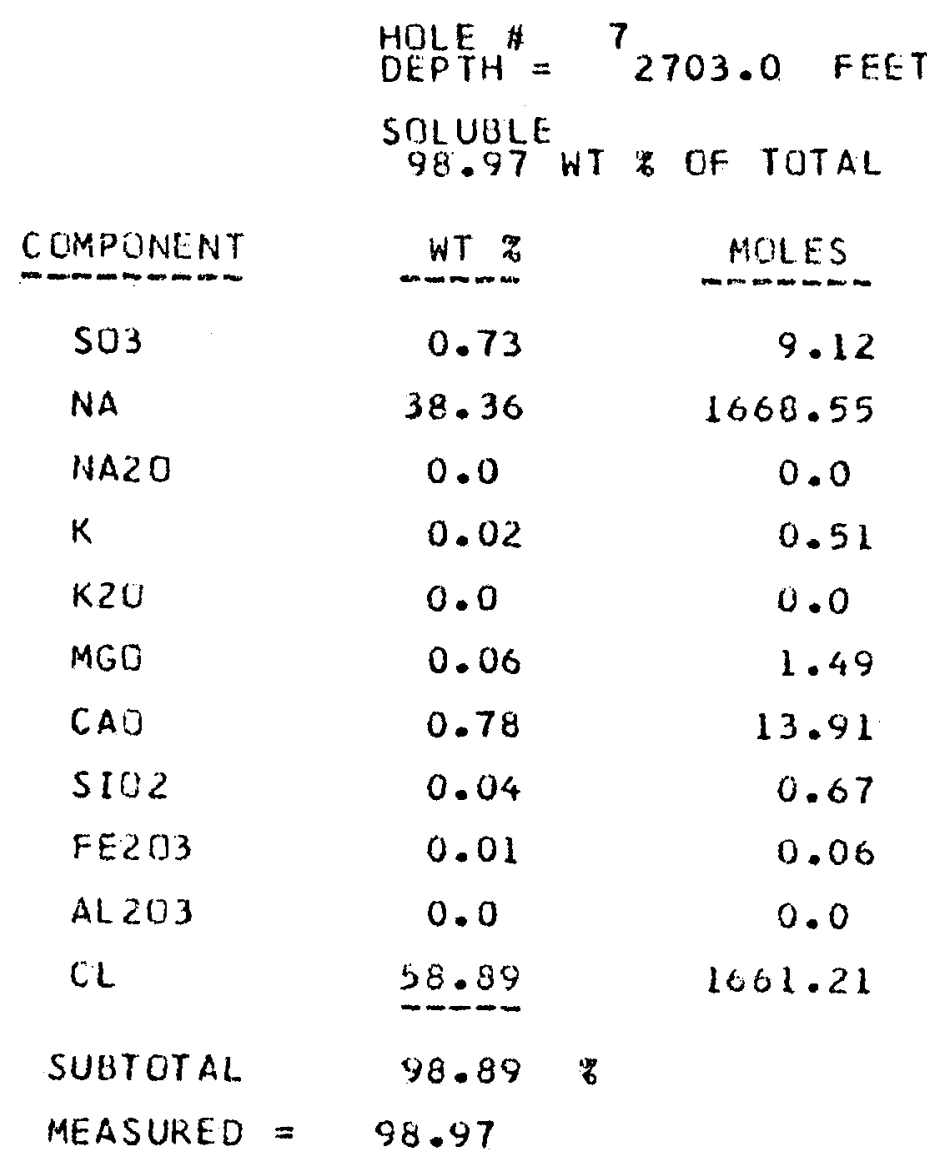

DELPTH ${ }^{H}=7_{2703.0 \quad \text { FEET }}$

INSOLUBLE 1.03 WT $\%$ OF TOTAL

\begin{tabular}{cc} 
WT $\%$ & NULES \\
0.74 & 9.24 \\
0.0 & 0.0 \\
0.0 & 0.0 \\
0.0 & 0.0 \\
0.01 & 0.11 \\
0.20 & 4.96 \\
0.01 & 0.18 \\
0.21 & 3.49 \\
0.05 & 0.31 \\
0.05 & 0.49 \\
0.0 & 0.0 \\
\hline 1.27 & \\
1.03 &
\end{tabular}




\begin{tabular}{lcr} 
HOLE H & \multicolumn{2}{l}{${ }^{7} 2716.3 \mathrm{FEET}$} \\
TOTAL & & \\
& & MOLES \\
COHPONEHT & WT & 5.50 \\
SO3 & 0.44 & 1715.53 \\
NA & 39.44 & 0.0 \\
NA2O & 0.0 & 0.26 \\
K & 0.01 & 0.0 \\
K2O & 0.0 & 0.25 \\
MGO & 0.01 & 3.21 \\
CAO & 0.18 & 0.17 \\
S102 & 0.01 & 0.0 \\
FE203 & 0.0 & 0.0 \\
AL203 & 0.0 & 1720.73 \\
CL & 61.00 &
\end{tabular}




$$
\begin{aligned}
& \text { HOLEE } \\
& \text { DEPTH } \\
& \text { TOTAL }
\end{aligned}
$$

\begin{tabular}{lcc} 
COMPUNENT & WT $\$$ & MOLES \\
\hline SO3 & 0.42 & 5.25 \\
NA & 39.75 & 1729.01 \\
NA20 & 0.0 & 0.0 \\
$K$ & 0.01 & 0.26 \\
K2O & 0.0 & 0.0 \\
MGO & 0.06 & 1.49 \\
CAO & 0.51 & 9.09 \\
S102 & 0.01 & 0.17 \\
FE203 & 0.0 & 0.0 \\
AL203 & 0.0 & 0.0 \\
CL & 59.88 & 1689.14
\end{tabular}




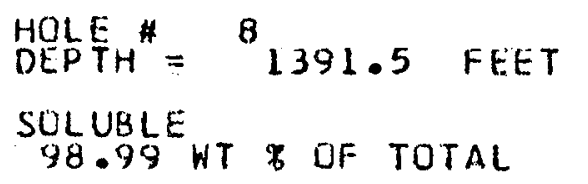

\begin{tabular}{lcc} 
COMPONENT & WT & MOLES \\
\hline SO3 & 1.07 & 13.36 \\
NA & 39.34 & 1711.18 \\
NA2O & 0.0 & 0.0 \\
K & 0.31 & 7.93 \\
K2O & 0.0 & 0.0 \\
MGO & 0.21 & 5.21 \\
CAO & 0.52 & 9.27 \\
S102 & 0.0 & 0.0 \\
FE203 & 0.0 & 0.0 \\
AL203 & 0.0 & 0.0 \\
CL & 58.07 & 1638.08 \\
SUBTOTAL & 99.52 &
\end{tabular}

MEASURED $=98.99$

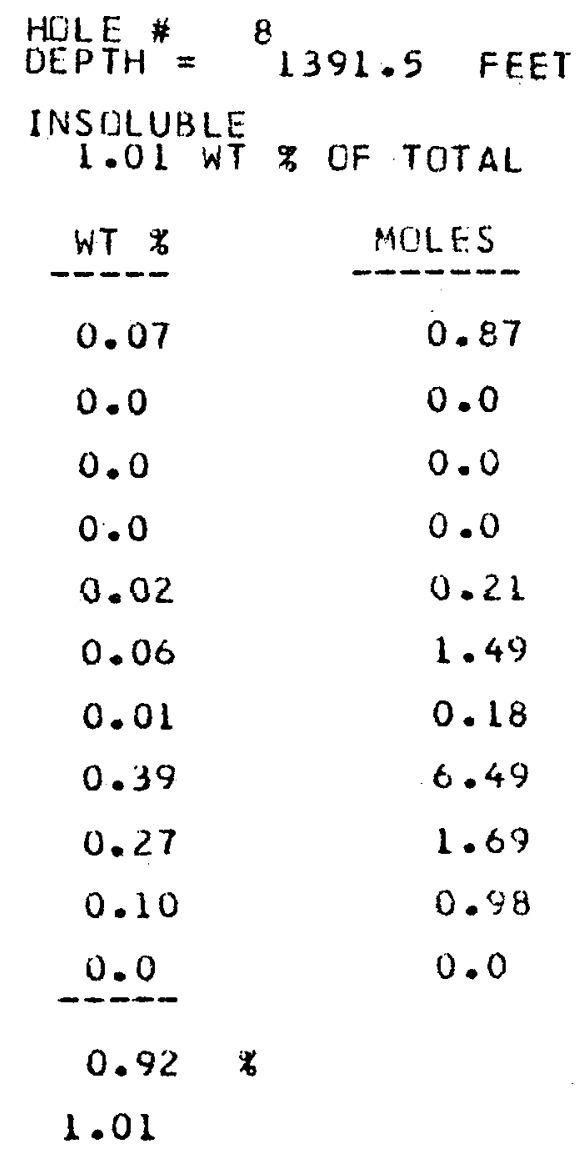




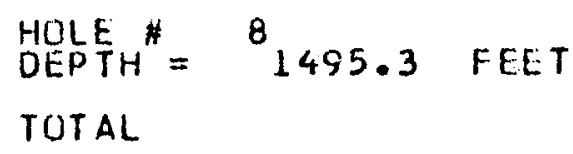

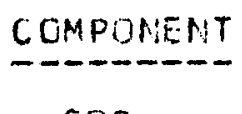

503

NA

NA2O

K

$K 20$

MGO

$C A D$

5102

FE203

AL203

$\mathrm{CL}$

$$
\begin{gathered}
W T x \\
1.12 \\
38.00 \\
0.0 \\
0.12 \\
0.0 \\
0.13 \\
1.62 \\
0.01 \\
0.0 \\
0.0 \\
59.97
\end{gathered}
$$

MOLES
13.99
1652.89
0.0
3.07
0.0
3.23
28.89
0.17
0.0
0.0
1691.68




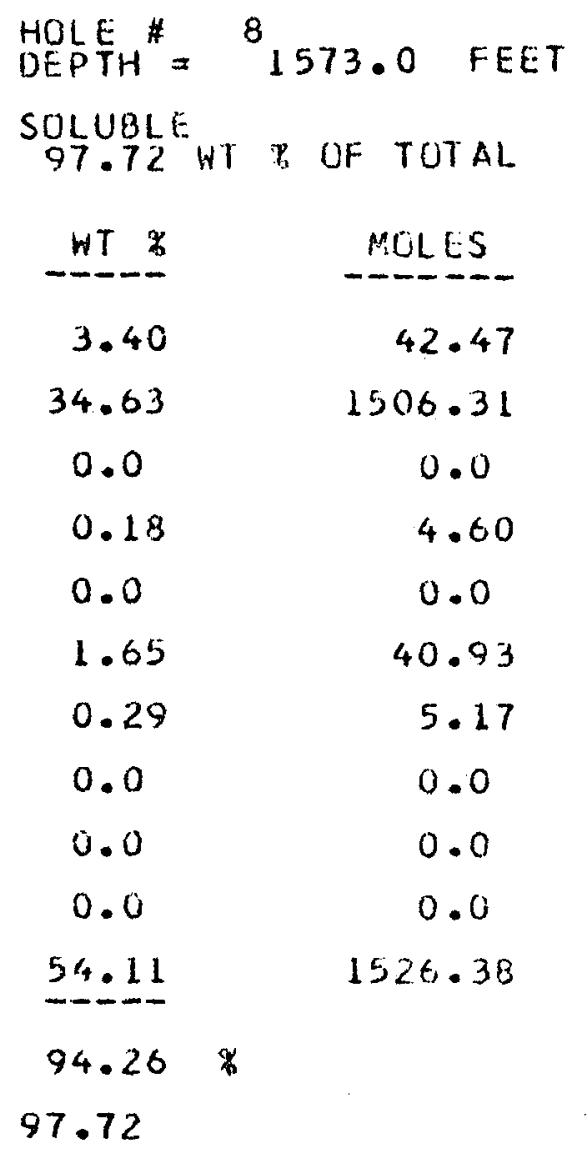

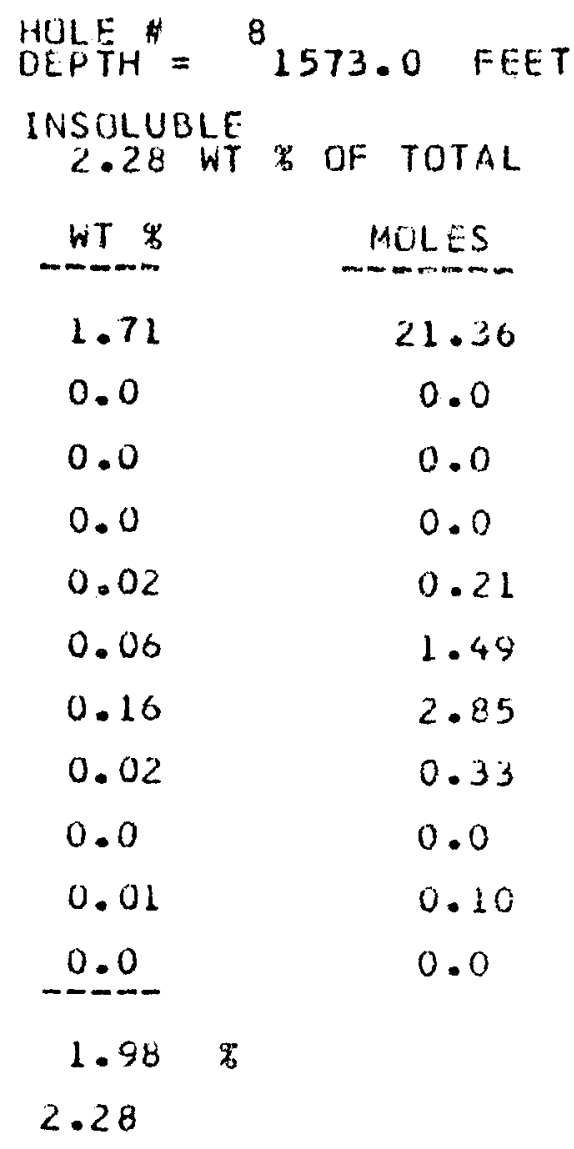




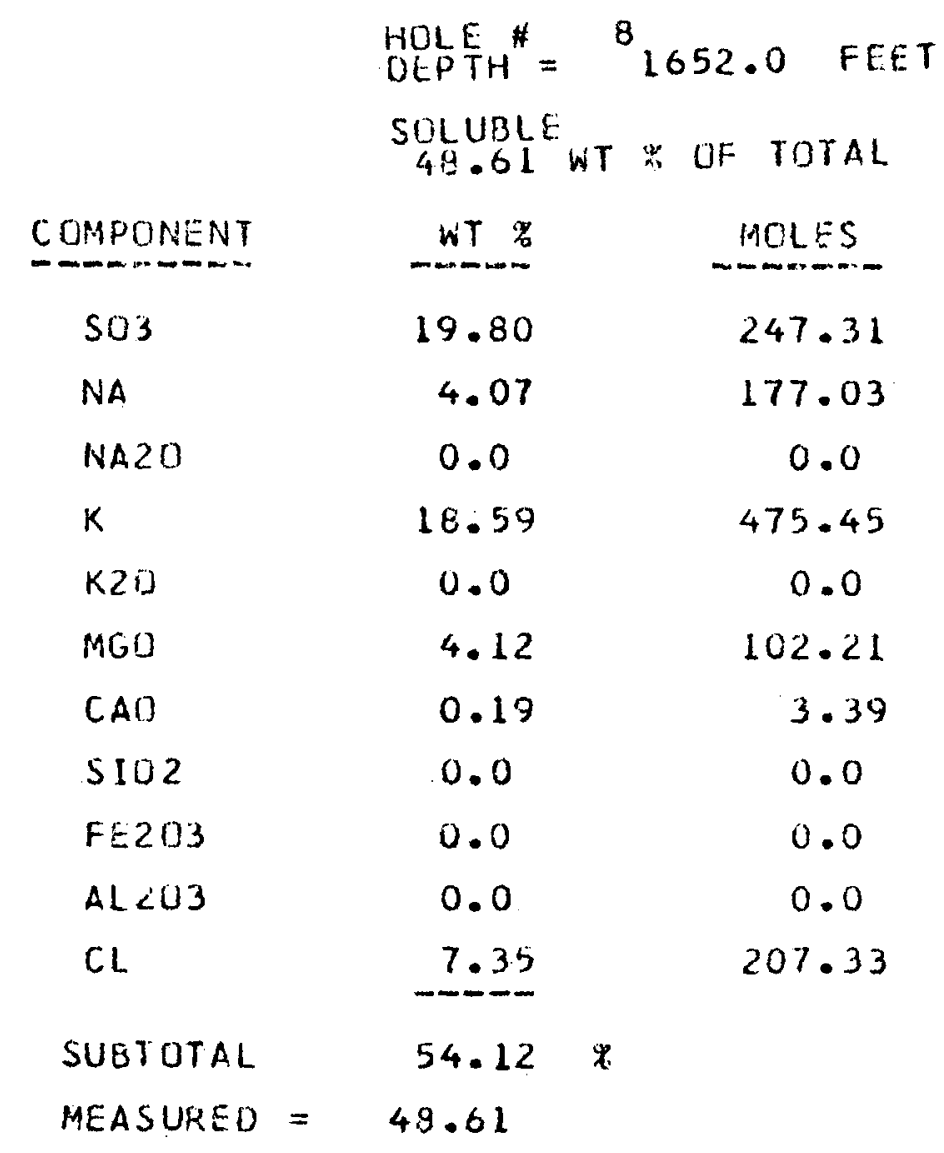

HOLE $\#{ }^{\#}={ }^{8} 1652.0$ FEET

INSOLUBLE

51.39 WT OF TOTAL

$\begin{array}{cc}W T z & \text { MOLES } \\ 31.24 & 390.21 \\ 0.0 & 0.0 \\ 4.24 & 68.41 \\ 0.0 & 0.0 \\ 0.99 & 10.51 \\ 0.46 & 11.41 \\ 3.74 & 66.09 \\ 0.34 & 5.60 \\ 0.07 & 0.44 \\ 0.04 & 0.39 \\ 0.0 & 0.0 \\ -0.0 & \\ 41.12 & \\ 51.39 & \end{array}$




$$
\begin{aligned}
& \text { HOLE H } \\
& \text { DEPTH } \\
& \text { TOTAL }
\end{aligned}
$$

\begin{tabular}{lcc} 
COMPONENT & WT & MOLES \\
\hline SO3 & 1.18 & 14.74 \\
NA & 38.79 & 1687.26 \\
NA2O & 0.0 & 0.0 \\
K & 0.35 & 8.95 \\
K2O & 0.0 & 0.0 \\
MGO & 0.17 & 4.22 \\
CAO & 0.44 & 7.85 \\
S102 & 0.01 & 0.17 \\
FE203 & 0.0 & 0.0 \\
AL203 & 0.0 & 0.0 \\
CL & 58.64 & 1654.16
\end{tabular}




\begin{tabular}{|c|c|c|c|c|}
\hline \multirow[b]{3}{*}{ COMPONENT } & \multicolumn{2}{|c|}{$\begin{array}{l}\text { HOLE } \\
\text { DEPTH }\end{array}$} & 1770.0 & $.0 \quad F E E$ \\
\hline & $\begin{array}{c}\text { SOLUBLE } \\
90.79\end{array}$ & WT $:$ & DF & TOTAL \\
\hline & WT $\%$ & & & MOLES \\
\hline 503 & 1.78 & & & 22.23 \\
\hline NA & 35.75 & & & 555.02 \\
\hline $\mathrm{NA} 2 \mathrm{O}$ & 0.0 & & & 0.0 \\
\hline K & 0.56 & & & 14.32 \\
\hline $\mathrm{K} 20$ & 0.0 & & & 0.0 \\
\hline MGO & 0.52 & & & 12.90 \\
\hline CAO & 1.75 & & & 31.21 \\
\hline$S I 02$ & 0.01 & & & 0.17 \\
\hline FE203 & 0.0 & & & 0.0 \\
\hline$A L 203$ & 0.0 & & & 0.0 \\
\hline $\mathrm{CL}$ & 57.29 & & & 016.08 \\
\hline SUBTOTAL & 97.66 & 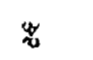 & & \\
\hline MEASURED $=$ & 98.79 & & & \\
\hline
\end{tabular}

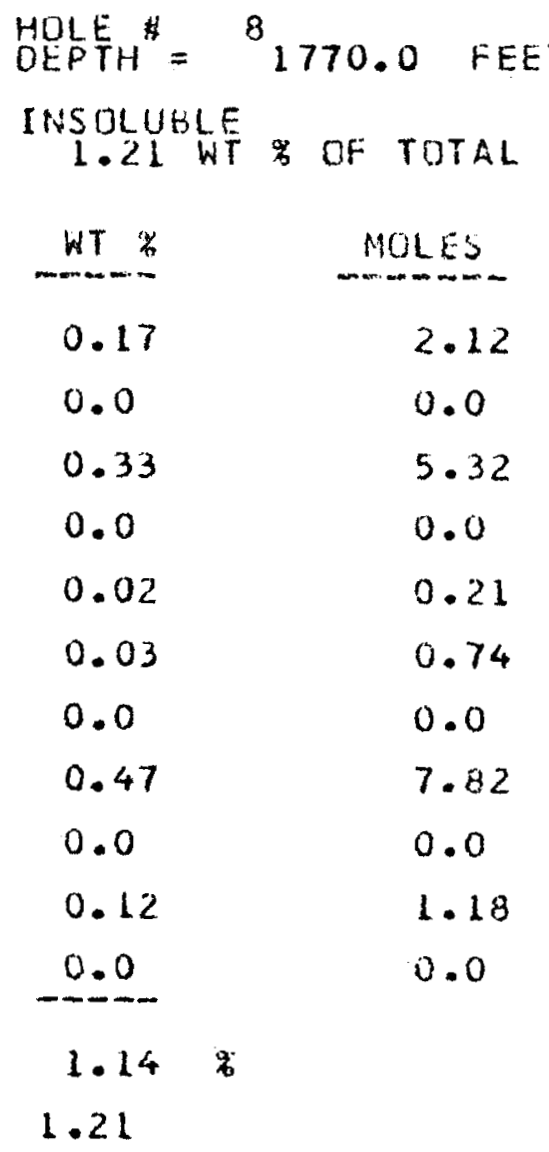




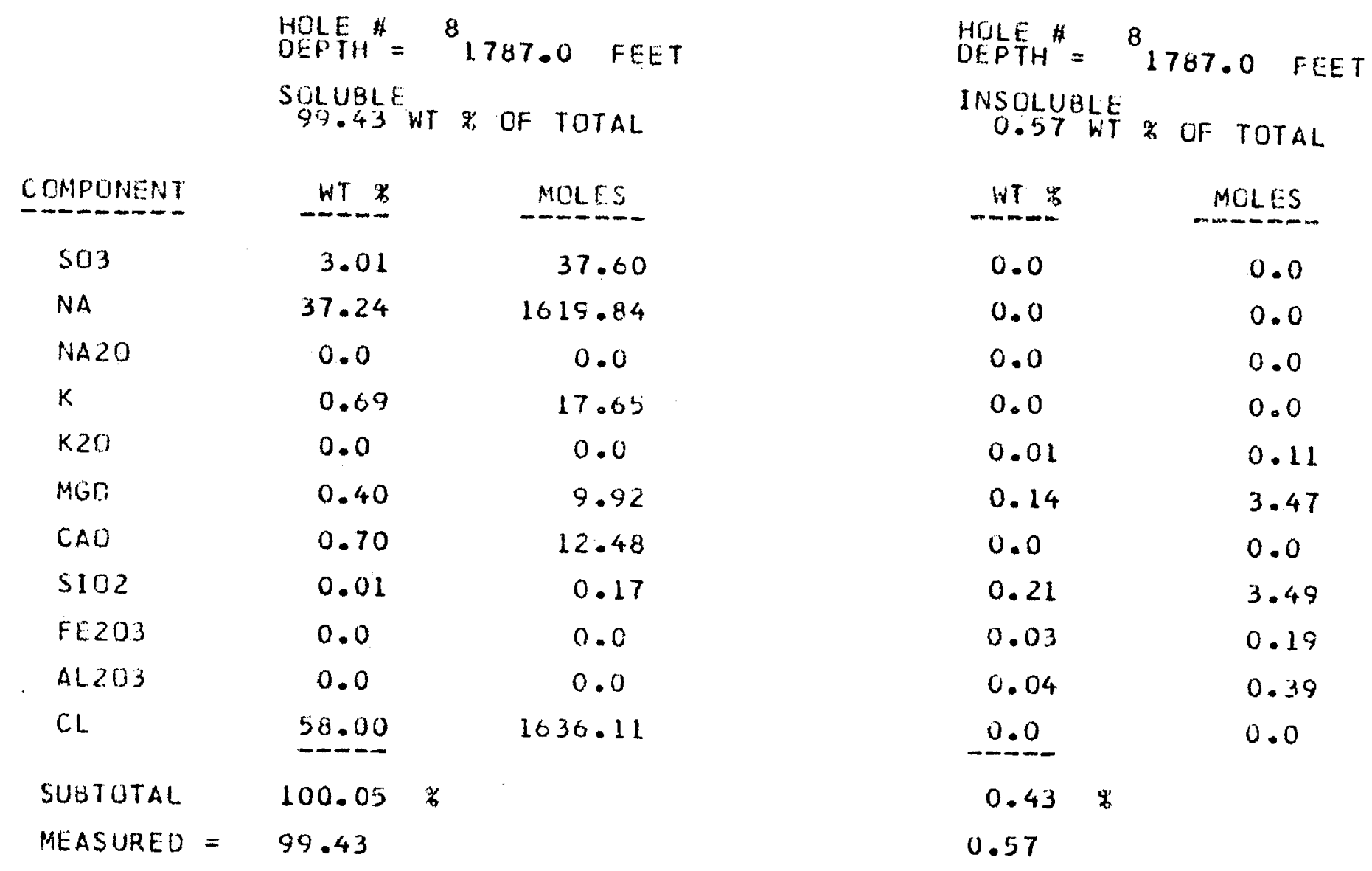




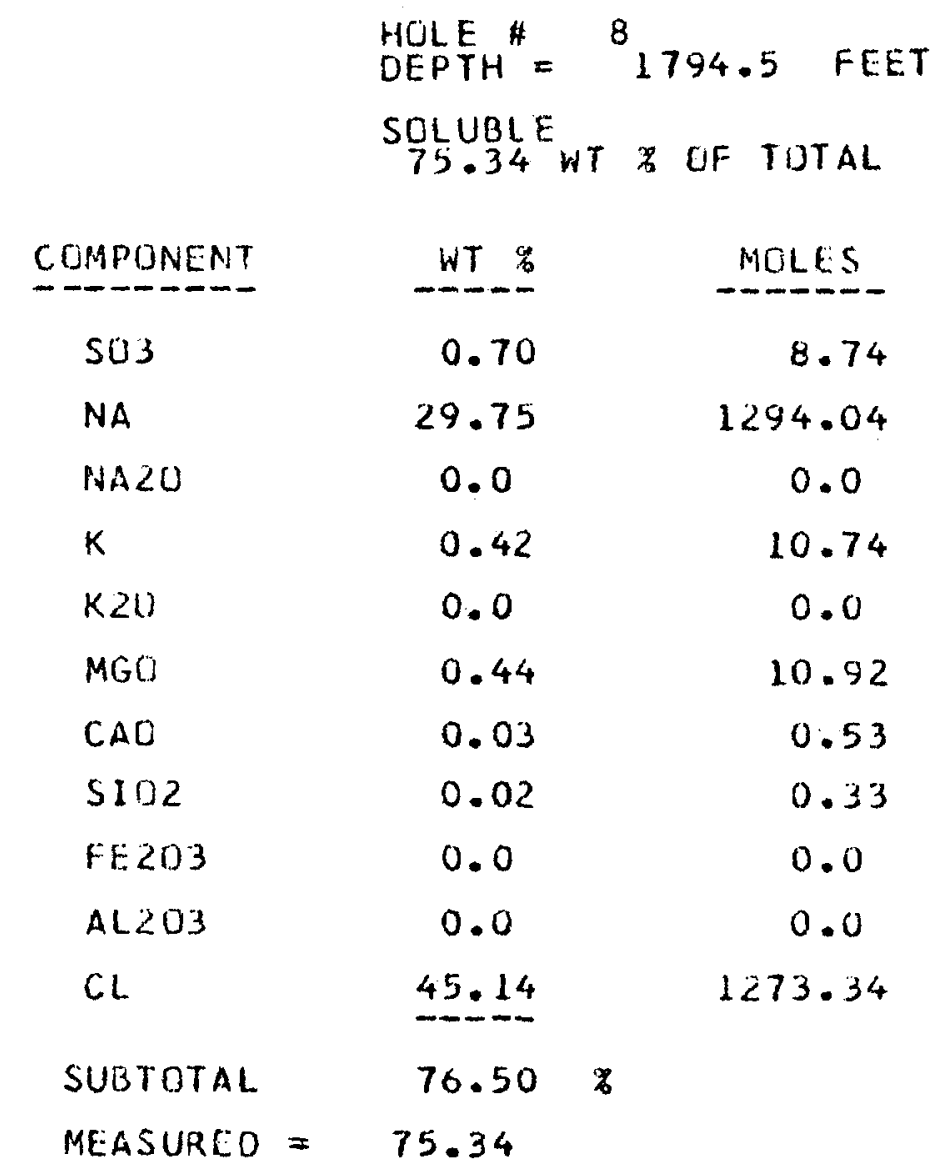

HOLE
OEPTH ${ }^{8} 1794.5$ FEET

INSOLUBLE 24.66 WT OF TOTAL

$\begin{array}{cc}W T & \text { MOLES } \\ 0.0 & 0.0 \\ 0.0 & 0.0 \\ 1.16 & 18.72 \\ 0.0 & 0.0 \\ 0.63 & 6.69 \\ 6.20 & 153.81 \\ 0.01 & 0.18 \\ 7.78 & 129.47 \\ 0.46 & 2.88 \\ 1.91 & 18.73 \\ 0.0 & 0.0 \\ -28.15 & \\ 24.66 & \end{array}$




$$
\begin{aligned}
& \text { HOLE } \\
& \text { DEPTH }
\end{aligned}
$$

$\begin{array}{lcc}\text { COMPONENT } & \text { WT } & \text { MOLES } \\ \text { SO3 } & 0.28 & 3.50 \\ \text { NA } & 39.43 & 1715.09 \\ \text { NA2O } & 0.0 & 0.0 \\ \text { K } & 0.06 & 1.53 \\ \text { K2D } & 0.0 & 0.0 \\ \text { MGO } & 0.04 & 0.99 \\ \text { CAD } & 0.70 & 12.48 \\ \text { S1O2 } & 0.01 & 0.17 \\ \text { FE203 } & 0.0 & 0.0 \\ \text { AL203 } & 0.0 & 0.0 \\ \text { CL } & 59.94 & 1690.83\end{array}$




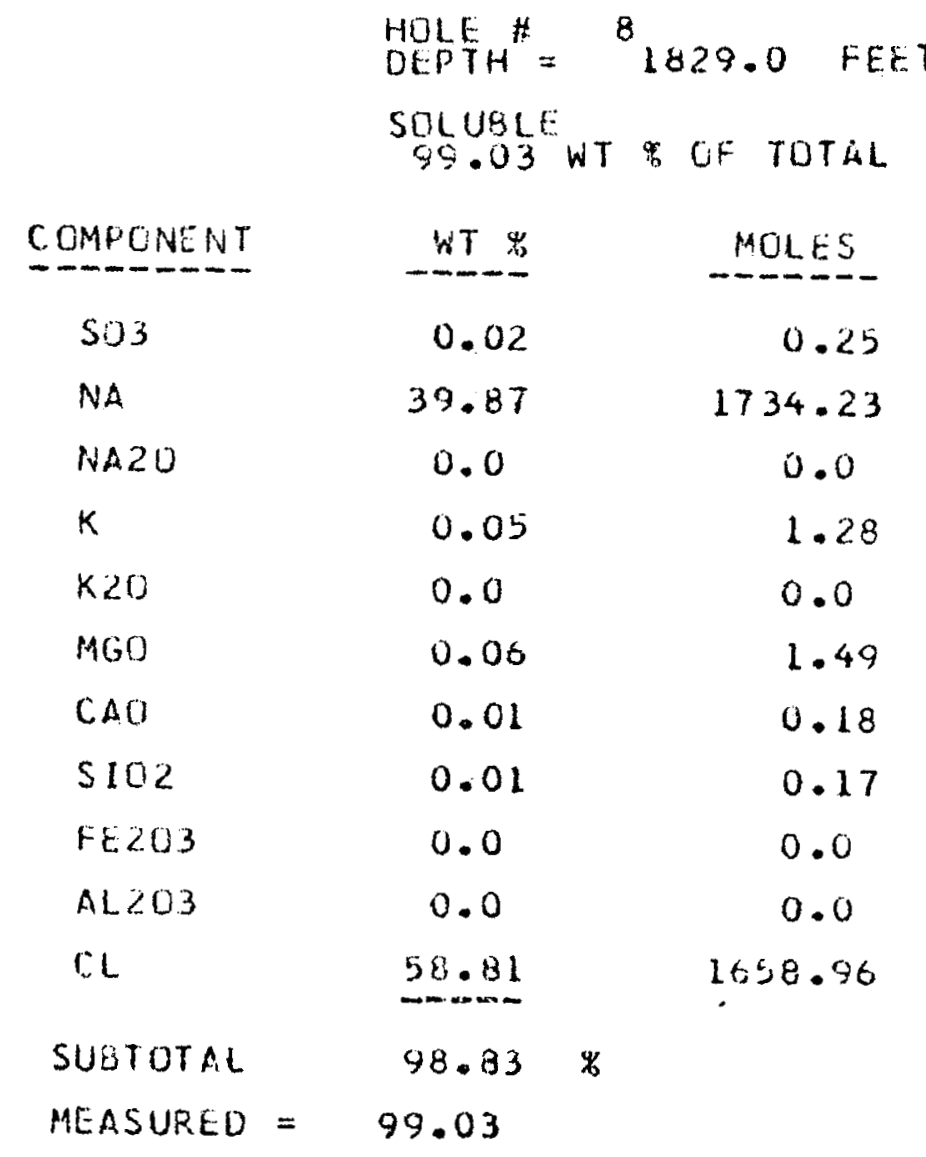

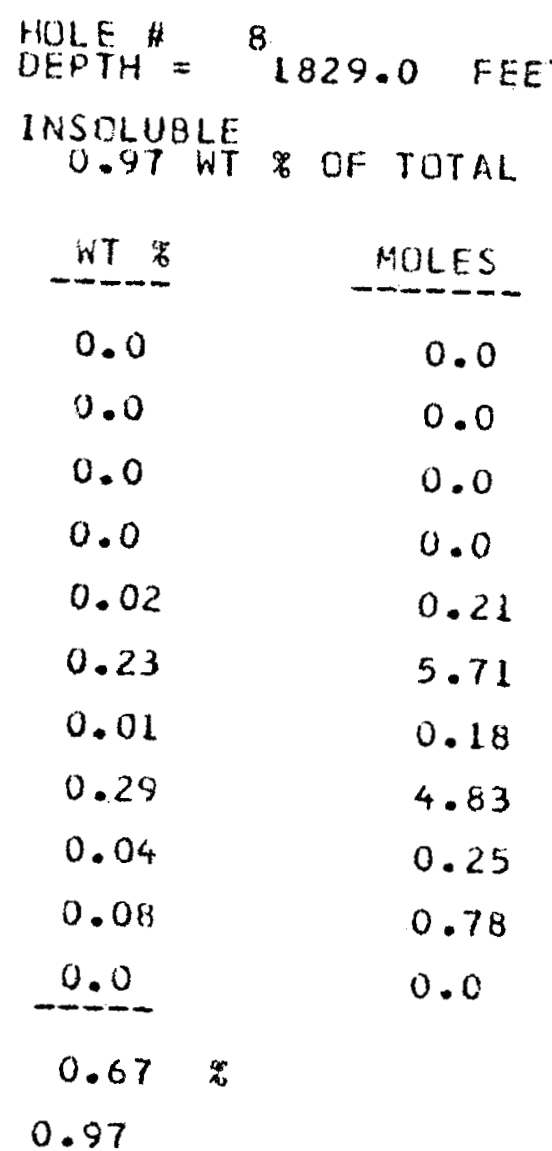


DOLEFH ${ }^{H}={ }^{8} 1838.0$ FEET

SOLUBLE

97.53 WT $\$$ OF TOTAL

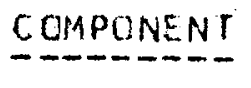

503

NA

NA2O

$K$

K20

$M G O$

$\mathrm{CAO}$

5102

FE203

AL 203

$\mathrm{CL}$

-WT

0.80

37.58

0.0

0.26

0.0

0.11

0.05

0.01

0.0

0.0

58.38

97.19

SUBTOTAL

MEASURED =
HOLE \#H ${ }^{8} 1838.0$ FEET

INSOLUBLE 2.47 WT $\%$ UF TOTAL

WT MOLES

0.0

0.0

0.0

0.0

0.0

0.0

0.0

0.0

0.10

1.06

0.37

9.18

0.0

0.0

0.12

2.00

0.16

1.00

0.27

2.65

0.0

0.0

1.02

2.47 


$$
\begin{aligned}
& \text { HOLE } \\
& \text { DEPTH }
\end{aligned}
$$

\begin{tabular}{lcc} 
CUMPONENT & WT & MOLES \\
\hline SO3 & 2.70 & 33.72 \\
NA & 36.08 & 1569.38 \\
NA2O & 0.0 & 0.0 \\
K & 1.62 & 41.43 \\
K2O & 0.0 & 0.0 \\
MGO & 0.03 & 0.74 \\
CAO & 1.56 & 27.82 \\
S102 & 0.0 & 0.0 \\
FE2O3 & 0.0 & 0.0 \\
AL2O3 & 0.0 & 0.0 \\
CL & 56.66 & 1598.31
\end{tabular}




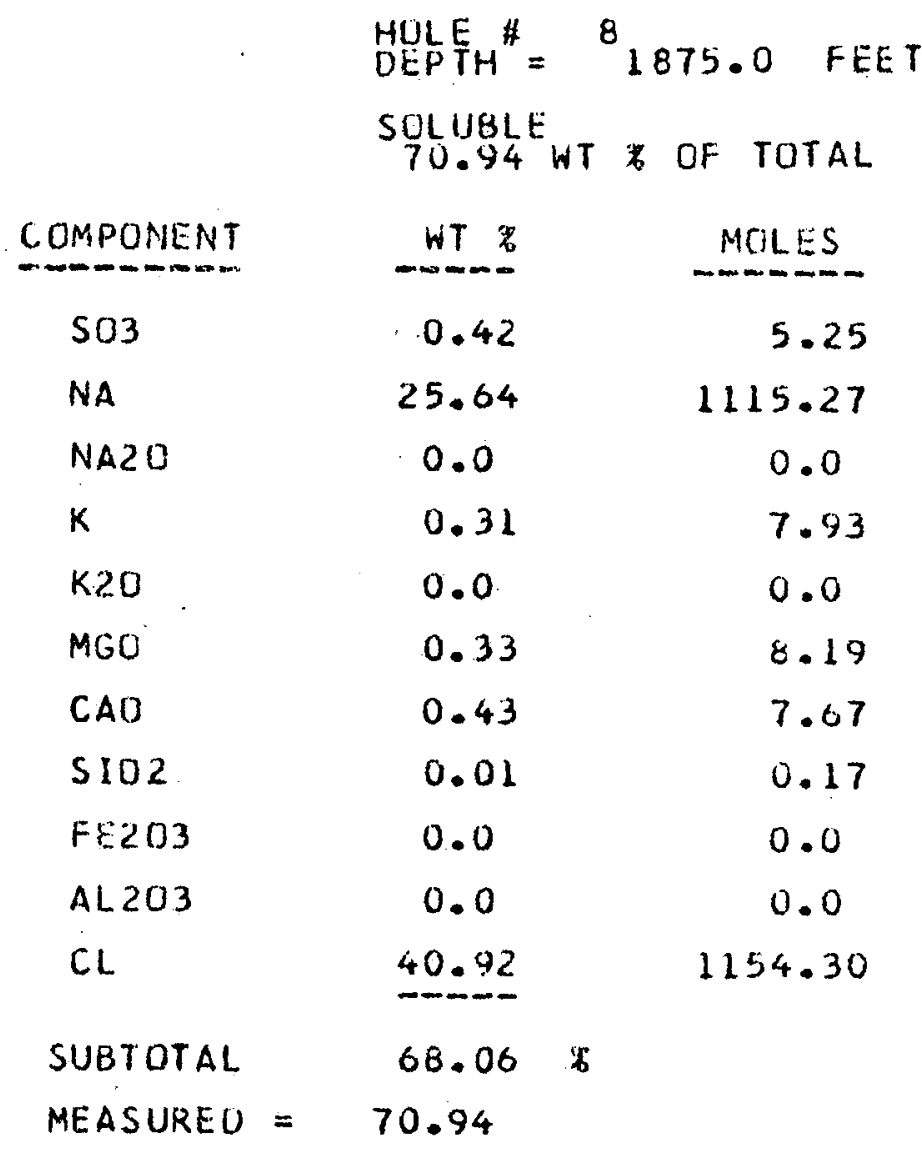

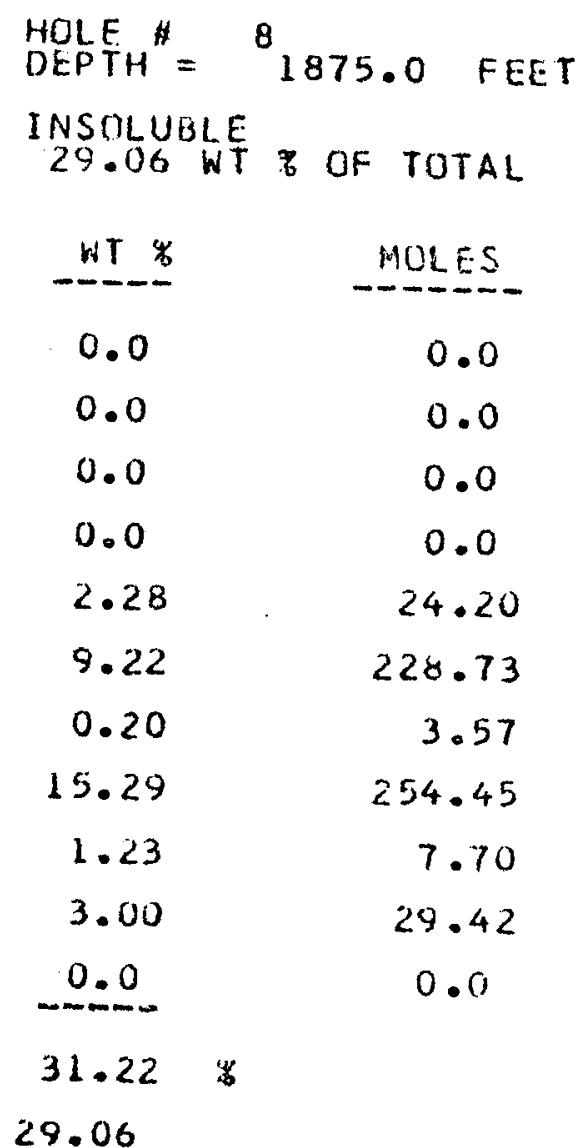




\begin{tabular}{|c|c|c|c|c|}
\hline \multirow[b]{3}{*}{ COMPONENT } & \multicolumn{3}{|c|}{$\begin{array}{l}\text { HOLEEH } \\
\text { DEPTH }{ }^{8}{ }_{1884.0}\end{array}$} & FEET \\
\hline & $\begin{array}{c}\text { SOLUBLE } \\
80.58\end{array}$ & IT $\%$ & OF & TUTAL \\
\hline & WT & & & 10LES \\
\hline $\mathrm{SO} 3$ & 3.76 & & & 46.96 \\
\hline NA & 27.10 & & & 178.77 \\
\hline NA 20 & 0.0 & & & 0.0 \\
\hline$k$ & 6.98 & & & 178.52 \\
\hline$k 20$ & 0.0 & & & 0.0 \\
\hline MGO & 1.44 & & & 35.72 \\
\hline CAO & 1.65 & & & 29.42 \\
\hline $\mathrm{SIOZ}$ & 0.01 & & & 0.17 \\
\hline FEE 203 & 0.0 & & & 0.0 \\
\hline AL2O3 & 0.0 & & & 0.0 \\
\hline$C L$ & 44.06 & & & 242.88 \\
\hline SUBTOTAL & 85.00 & 名 & & \\
\hline MEASURED $=$ & 80.58 & & & \\
\hline
\end{tabular}

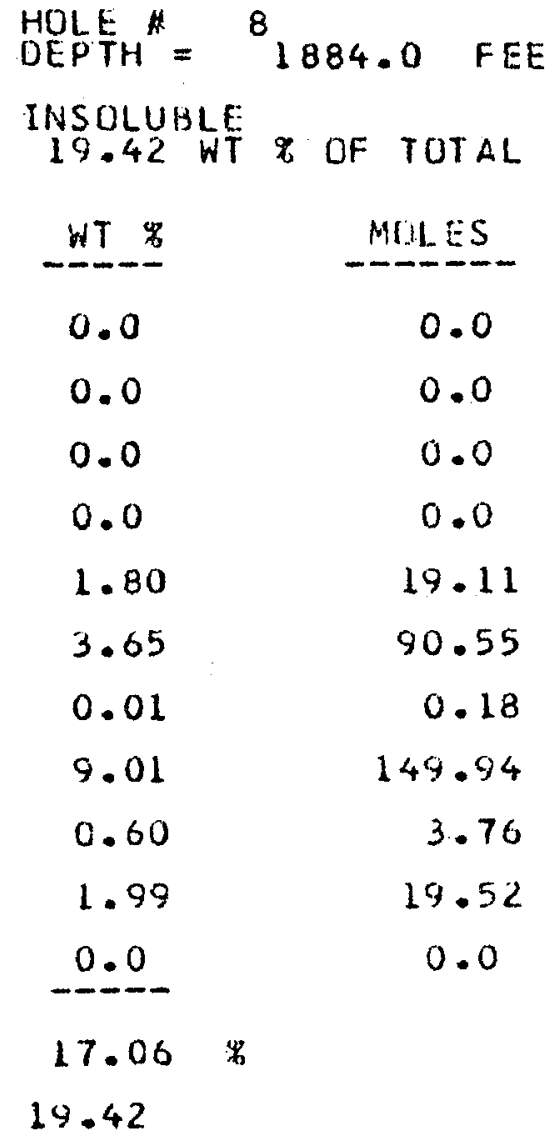




$$
\text { DELETH }{ }^{*}{ }^{8} \text { L } 890.0 \text { FEET }
$$

TOTAL.

\begin{tabular}{lcr} 
COMPONENT & WT & MOLES \\
\hline$S 03$ & 0.77 & 9.62 \\
NA & 38.78 & 1686.82 \\
NA2O & 0.0 & 0.0 \\
$K$ & 0.10 & 2.56 \\
K2O & 0.0 & 0.0 \\
MGO & 0.10 & 2.48 \\
CAO & 0.95 & 16.94 \\
S1O2 & 0.0 & 0.0 \\
FE2O3 & 0.0 & 0.0 \\
AL203 & 0.0 & 0.0 \\
CL & 59.33 & 1673.62
\end{tabular}




\begin{tabular}{|c|c|c|c|c|}
\hline \multirow[b]{3}{*}{ COHPONENT } & \multicolumn{3}{|c|}{$\begin{array}{l}\text { HOLE: } \\
\text { DEPTH }\end{array}{ }^{8}{ }^{8} 1894.3$} & FEET \\
\hline & $\operatorname{SOLUBLE}_{93.43} W T$ & T $\%$ & of & TOTAL \\
\hline & \multicolumn{2}{|l|}{ WT } & \multicolumn{2}{|c|}{ MOLES } \\
\hline $\mathrm{SO}_{3}$ & 0.12 & & & 1.50 \\
\hline NA & 37.90 & & & 648.54 \\
\hline NA2 20 & 0.0 & & & 0.0 \\
\hline$k$ & 0.06 & & & 1.53 \\
\hline $\mathrm{K} 20$ & 0.0 & & & 0.0 \\
\hline MGO & 0.08 & & & 1.98 \\
\hline CAO & 0.03 & & & 0.53 \\
\hline $\mathrm{S} 102$ & 0.0 & & & 0.0 \\
\hline$F E 2013$ & 0.0 & & & 0.0 \\
\hline$A L 203$ & 0.0 & & & 0.0 \\
\hline $\mathrm{CL}$ & 57.78 & & & 629.90 \\
\hline SUBTOTAL & 95.97 & $z$ & & \\
\hline MEASURED = & 95.43 & & & \\
\hline
\end{tabular}

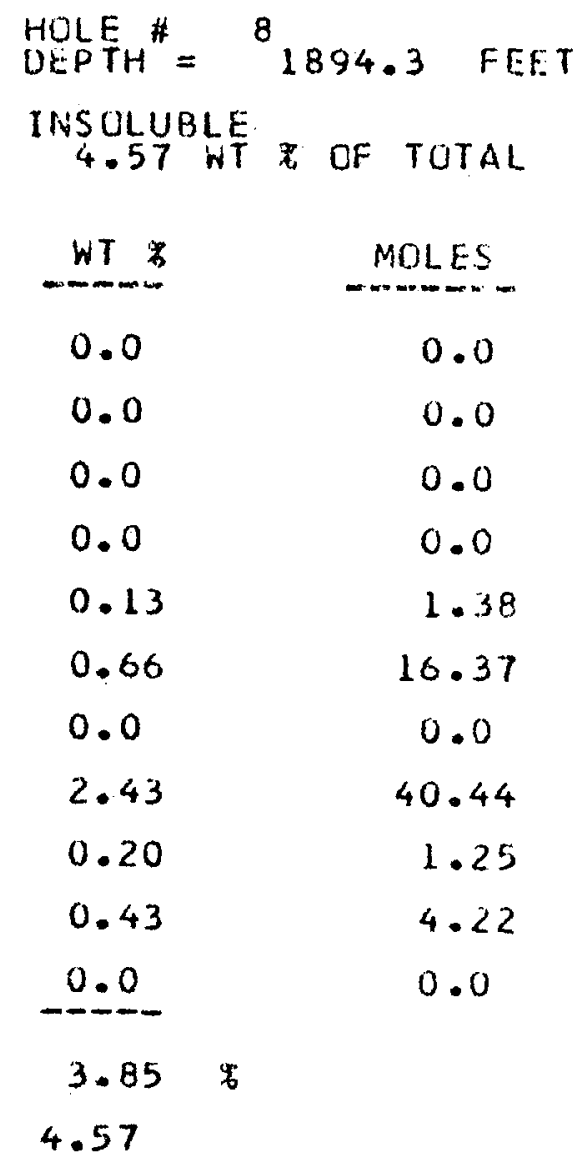




\begin{tabular}{cc} 
HOLE & ${ }^{8}$ LEPH \\
SULUBLE & \\
98.53 WT $\%$ OF TOTAL & FEET \\
WT & MOLES \\
\hline 0.55 & 6.87 \\
38.81 & 1688.13 \\
0.0 & 0.0 \\
0.07 & 1.79 \\
0.0 & 0.0 \\
0.08 & 1.96 \\
0.11 & 1.90 \\
0.01 & 0.17 \\
0.0 & 0.0 \\
0.0 & 0.0 \\
57.97 & 1635.26 \\
97.60 & 8 \\
98.53 &
\end{tabular}

\begin{tabular}{lc} 
HULE & ${ }^{8}$ 1898.5 FEET \\
INSOLUBLE & \\
1.47 WT & OF TOTAL \\
WT 8 & MULES \\
\hline 0.0 & 0.0 \\
0.0 & 0.0 \\
0.71 & 11.46 \\
0.0 & 0.0 \\
0.01 & 0.11 \\
0.18 & 4.47 \\
0.01 & 0.18 \\
0.44 & 7.32 \\
0.02 & 0.13 \\
0.07 & 0.69 \\
0.0 & 0.0 \\
\hline 1.44 & \\
1.47 &
\end{tabular}




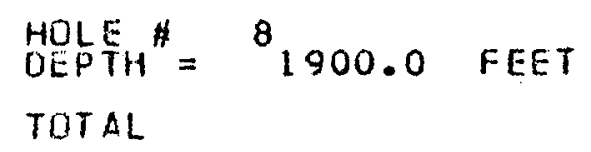

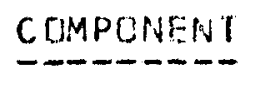

503

NA

NAZO

$K$

$K 20$

1460

CAO

5102

FE203

AL 203

$C L$

$W T \$$
3.20
38.14
0.0
0.98
0.0
0.47
0.39
0.0
0.0
0.0
57.60

NOI ES

39.97
1658.98
0.0
25.06
0.0
11.66
6.35
0.0
0.0
0.0
1624.82




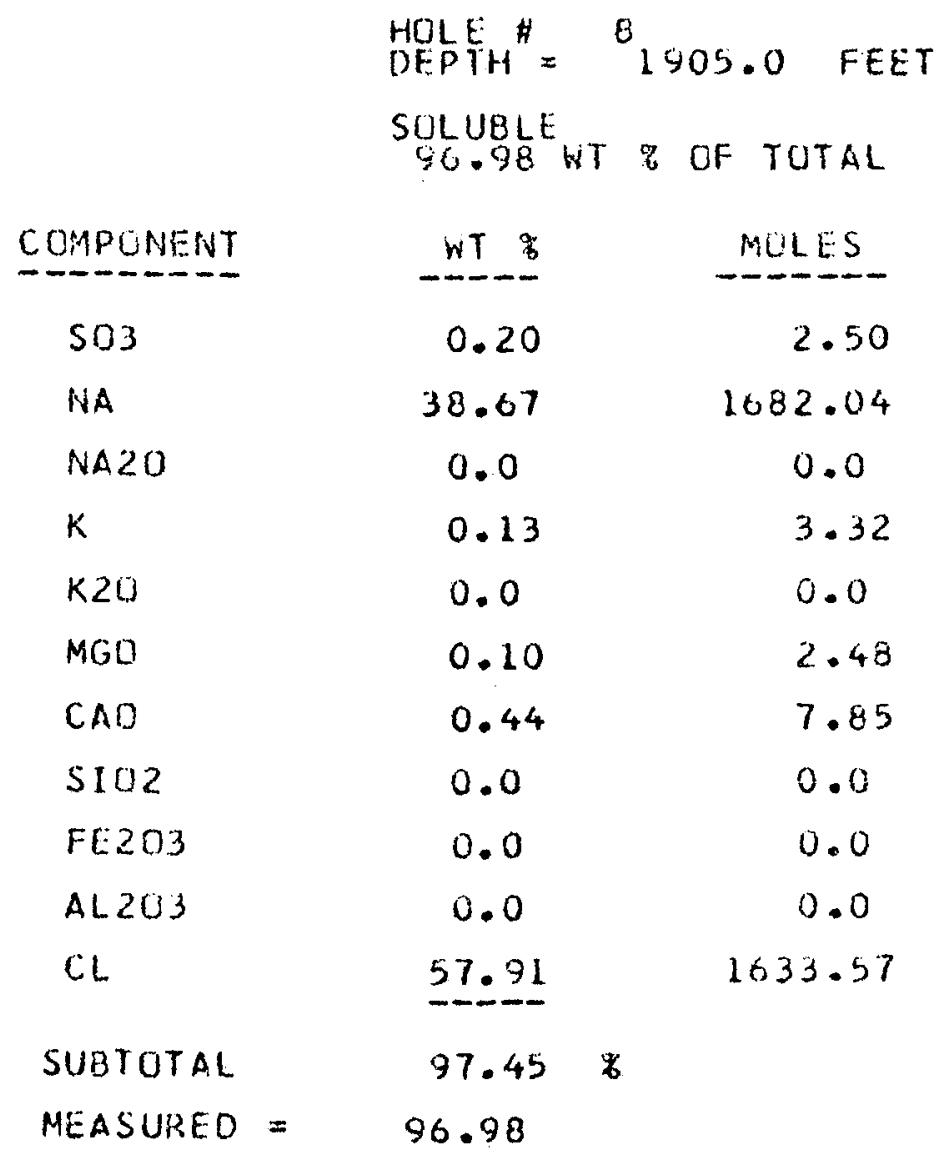

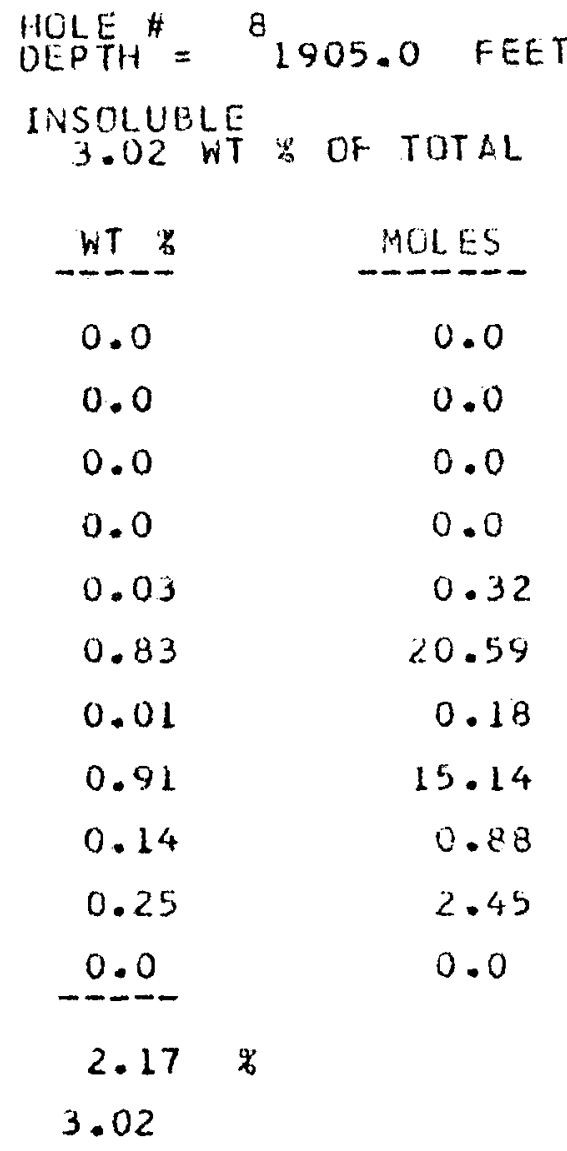




\begin{tabular}{|c|c|c|c|c|}
\hline \multirow[b]{3}{*}{ COMPONENT } & \multicolumn{2}{|c|}{$\begin{array}{l}\text { HULEF } \\
\text { DEPTH }\end{array}$} & 1910.0 & .0 \\
\hline & $\begin{array}{c}\text { SOLUBLE } \\
99.02\end{array}$ & WT $\%$ & of & TOTAL \\
\hline & WT 苦 & & & MOLES \\
\hline 503 & 0.53 & & & 6.62 \\
\hline NA & 39.64 & & & 724.23 \\
\hline NA.2O & 0.0 & & & 0.0 \\
\hline$k$ & 0.0 & & & 0.0 \\
\hline$k 20$ & 0.29 & & & 3.08 \\
\hline$M G O$ & 0.10 & & & 2.48 \\
\hline$C A D$ & 0.44 & & & 7.85 \\
\hline $\mathrm{S} 102$ & 0.01 & & & 0.17 \\
\hline FE203 & 0.0 & & & 0.0 \\
\hline$A L 203$ & 0.0 & & & 0.0 \\
\hline $\mathrm{Cl}$ & 59.04 & & & 665.44 \\
\hline SUBTDTAL & 100.05 & $x$ & & \\
\hline MEASUREU = & 99.02 & & & \\
\hline
\end{tabular}

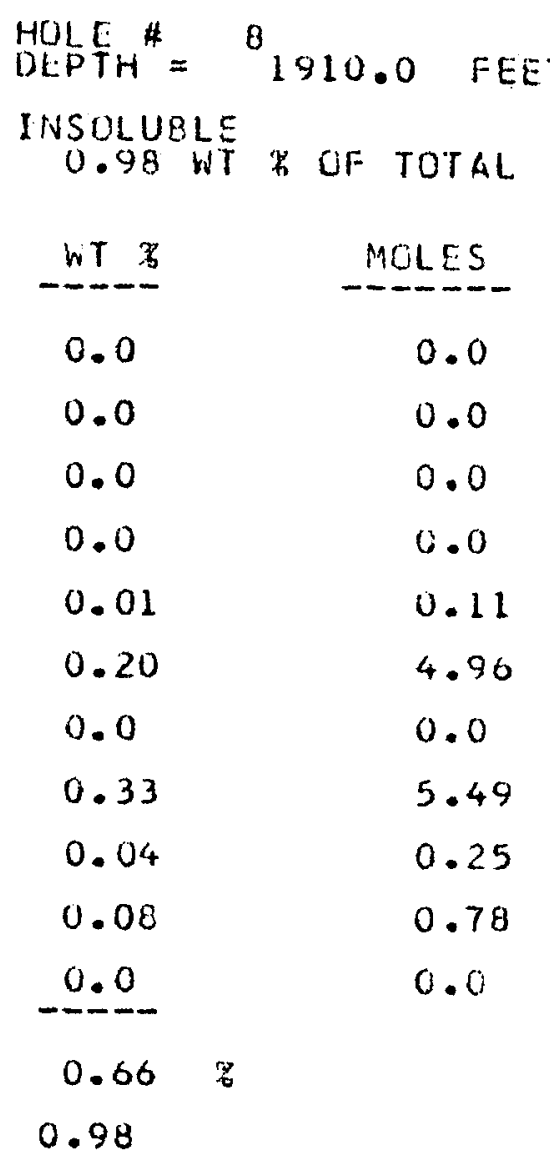


HOLE ${ }_{\text {DEPTH }}{ }^{8}{ }^{8} 1913.1$ FEET

SOLUBLE WT \% OF TOTAL

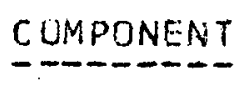

$\mathrm{SO} 3$

NA

NA2O

$\mathrm{K}$

$K 20$

MGO

CAD

5102

$\mathrm{FE} 203$

ALZO3

$\mathrm{Cl}$

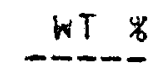

MOLES

0.06

38.48

0.0

0.06

0.0

0.06

0.0

0.01

0.0

0.0

59.27

0.75

1673.77

0.0

1.53

0.0

1.49

0.0

0.17

0.0

0.0

SUBTOTAL

97.94 *

MEASURED =
HOLE $\#{ }^{\#}={ }^{8} 1913.1$ FEET

INSOLUBLE

2.29 WT $\%$ OF TOTAL

WT 8

0.0

0.0

MOLES

0.0

0.0

$$
0.0
$$

0.0

0.05

0.0

0.05

0.48

0.0

0.90

0.13

0.21

0.0

$1.77 \%$

2.29 


$$
\begin{aligned}
& \text { HOLE H } \\
& \text { DEPTH } \\
& \text { TOTAL }
\end{aligned}
$$

$\begin{array}{lcc}\text { COMPONENT } & \text { WT } & \text { MOLES } \\ \text { SO3 } & 0.92 & 11.49 \\ \text { NA } & 38.48 & 1673.77 \\ \text { NA2O } & 0.0 & 0.0 \\ \text { K } & 0.21 & 5.37 \\ \text { K2O } & 0.0 & 0.0 \\ \text { MGO } & 0.13 & 3.23 \\ \text { CAD } & 0.44 & 7.85 \\ \text { S1O2 } & 0.0 & 0.0 \\ \text { FE2O3 } & 0.0 & 0.0 \\ \text { AL203 } & 0.0 & 0.0 \\ \text { CL } & 57.71 & 1027.03\end{array}$




\begin{tabular}{|c|c|c|c|c|}
\hline \multirow[b]{3}{*}{ COMPONENT } & \multicolumn{2}{|c|}{$\begin{array}{l}\text { HOLEE } \\
\text { DLLP }\end{array}$} & 1923.0 & FEE \\
\hline & $\begin{array}{l}\text { SOLUBLE } \\
98.30\end{array}$ & WT & $*$ OF & TUTAL \\
\hline & WT 8 & & & MOLES \\
\hline $\mathrm{SO} 3$ & 0.10 & & & 1.25 \\
\hline NA & 38.03 & & & 654.20 \\
\hline $\mathrm{NA} 2 \mathrm{O}$ & 0.0 & & & 0.0 \\
\hline$k$ & 0.05 & & & 1.28 \\
\hline $\mathrm{K} 20$ & 0.0 & & & 0.0 \\
\hline $\mathrm{MGO}$ & 0.05 & & & 1.24 \\
\hline $\mathrm{CAO}$ & 0.08 & & & 1.43 \\
\hline 5102 & 0.01 & & & 0.17 \\
\hline FE:203 & 0.0 & & & 0.0 \\
\hline$A L 203$ & 0.0 & & & 0.0 \\
\hline$C L$ & 58.43 & & & 048.24 \\
\hline SUBTOTAL & 96.75 & 要 & & \\
\hline MEASUPEED & 98.30 & & & \\
\hline
\end{tabular}

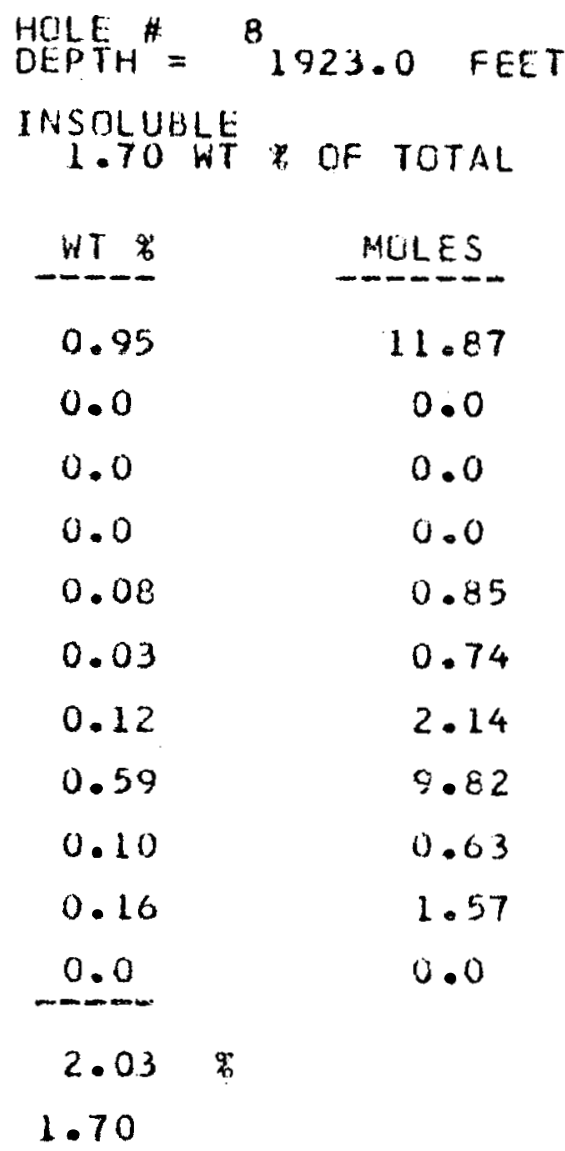




\begin{tabular}{|c|c|c|}
\hline \multirow[b]{3}{*}{ COMPUNENT } & \multirow{2}{*}{$\begin{array}{l}\text { HOLE } \\
\text { OEPTH } \\
\text { SOLUELE } \\
\text { SB.99 WT }\end{array}$} & 1930.0 \\
\hline & & \% OF TOTAL \\
\hline & WT & MCLES \\
\hline $\mathrm{SO} 3$ & 2.81 & 35.10 \\
\hline NA & 35.71 & 1553.28 \\
\hline NA2O & 0.0 & 0.0 \\
\hline$k$ & 1.03 & $26 \cdot 34$ \\
\hline$k 20$ & 0.0 & 0.0 \\
\hline$M G O$ & 0.33 & 8.19 \\
\hline CAO & 0.19 & 3.39 \\
\hline $\mathrm{S} 102$ & 0.0 & 0.0 \\
\hline FE: 203 & 0.0 & 0.0 \\
\hline AL 203 & 0.0 & 0.0 \\
\hline C.L & 50.74 & 1600.56 \\
\hline SUBTOTAL & 96.81 & \\
\hline MEASURED = & 98.99 & \\
\hline
\end{tabular}

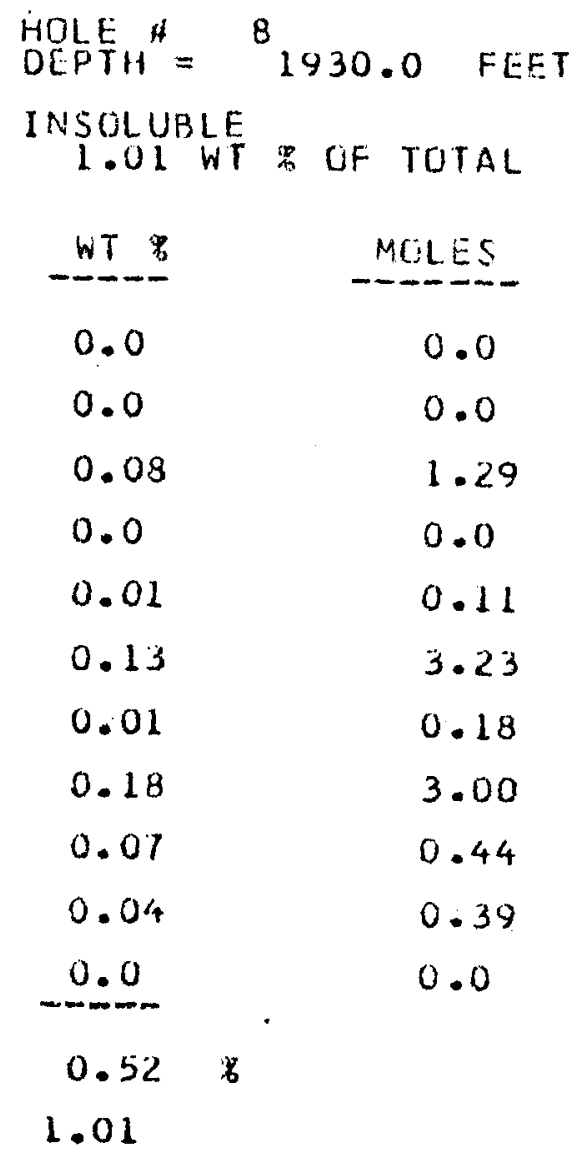




\section{HOLE EHH ${ }^{\#}{ }^{8} 1933.0$ FEET \\ TOTAL.}

\begin{tabular}{lcc} 
CGMPONENT & WT 6 & MOLES \\
\hline SO3 & 0.78 & 9.74 \\
NA & 38.03 & 1654.20 \\
NA2O & 0.0 & 0.0 \\
$K$ & 0.15 & 3.84 \\
K2O & 0.0 & 0.0 \\
MGO & 0.09 & 2.23 \\
CAO & 0.65 & 11.59 \\
SIO2 & 0.01 & 0.17 \\
FE203 & 0.01 & 0.06 \\
AL203 & 0.0 & 0.0 \\
CL & 59.81 & 1687.17
\end{tabular}




$$
\begin{aligned}
& \text { HOLE }{ }^{*}={ }^{8} 1938.0 \text { FEET } \\
& \text { TOTAL }
\end{aligned}
$$

\begin{tabular}{lcc} 
COMPONENT & HT $\%$ & MOLES \\
\hline$S 03$ & 2.91 & 36.35 \\
NA & 35.63 & 1549.80 \\
NA2O & 0.0 & 0.0 \\
$K$ & 0.08 & 17.39 \\
$K 20$ & 0.0 & 0.0 \\
$M G O$ & 0.84 & 20.84 \\
$C A O$ & 1.02 & 18.19 \\
$S 102$ & 0.0 & 0.0 \\
FE2O3 & 0.0 & 0.0 \\
AL203 & 0.0 & 0.0 \\
CL & 59.45 & 1677.01
\end{tabular}




\section{HOLETH ${ }^{*}={ }^{8}{ }_{1953.2}$ FEET \\ TOTAL}

\begin{tabular}{lcc} 
COMPONENT & WT & MCLES \\
\hline SO3 & 2.30 & 28.73 \\
NA & 39.50 & 1718.14 \\
NA2O & 0.0 & 0.0 \\
$K$ & 0.30 & 7.67 \\
K2O & 0.0 & 0.0 \\
MGO & 0.42 & 10.42 \\
CAO & 1.23 & 21.93 \\
S102 & 0.01 & 0.17 \\
FE2O3 & 0.0 & 0.0 \\
AL2O3 & 0.0 & 0.0 \\
CL & 57.63 & 1625.67
\end{tabular}




\begin{tabular}{|c|c|c|c|c|}
\hline \multirow[b]{3}{*}{ CUMPONENT } & $\begin{array}{l}\text { HOLE } \\
\text { DEP }\end{array}{ }^{\#}=$ & \multicolumn{2}{|c|}{${ }^{8} 1967.0$} & .0 \\
\hline & SOLUBLE & IT & $\%$ OF & TOTAL \\
\hline & WT $\%$ & & & MOLES \\
\hline $\mathrm{SO} 3$ & 1.25 & & & 15.61 \\
\hline NA & 35.99 & & & 565.46 \\
\hline$N A 20$ & 0.0 & & & 0.0 \\
\hline$k$ & 0.57 & & & 14.58 \\
\hline$k 20$ & 0.0 & & & 0.0 \\
\hline MGO & 0.23 & & & 5.71 \\
\hline$C A D$ & 0.40 & & & 7.13 \\
\hline 5102 & 0.0 & & & 0.0 \\
\hline FE: 20.3 & 0.0 & & & 0.0 \\
\hline AL 203 & 0.0 & & & 0.0 \\
\hline$C L$ & 57.52 & & & 622.57 \\
\hline SUETOTAL & 95.96 & $\mathscr{z}$ & & \\
\hline MEASURED & 95.13 & & & \\
\hline
\end{tabular}

HOLEFH ${ }_{\text {OEPTH }}{ }^{8} 1967.0$ FEET

INSOLUELE 4.87 WF TOTAL

\begin{tabular}{cc}
$W T$ & MOLES \\
\hline 0.0 & 0.0 \\
0.0 & 0.0 \\
2.73 & 44.05 \\
0.0 & 0.0 \\
0.09 & 0.96 \\
0.98 & 24.31 \\
0.0 & 0.0 \\
0.76 & 12.65 \\
0.10 & 0.63 \\
0.20 & 1.96 \\
0.0 & 0.0 \\
-0.0 & \\
4.86 & \\
4.87 &
\end{tabular}




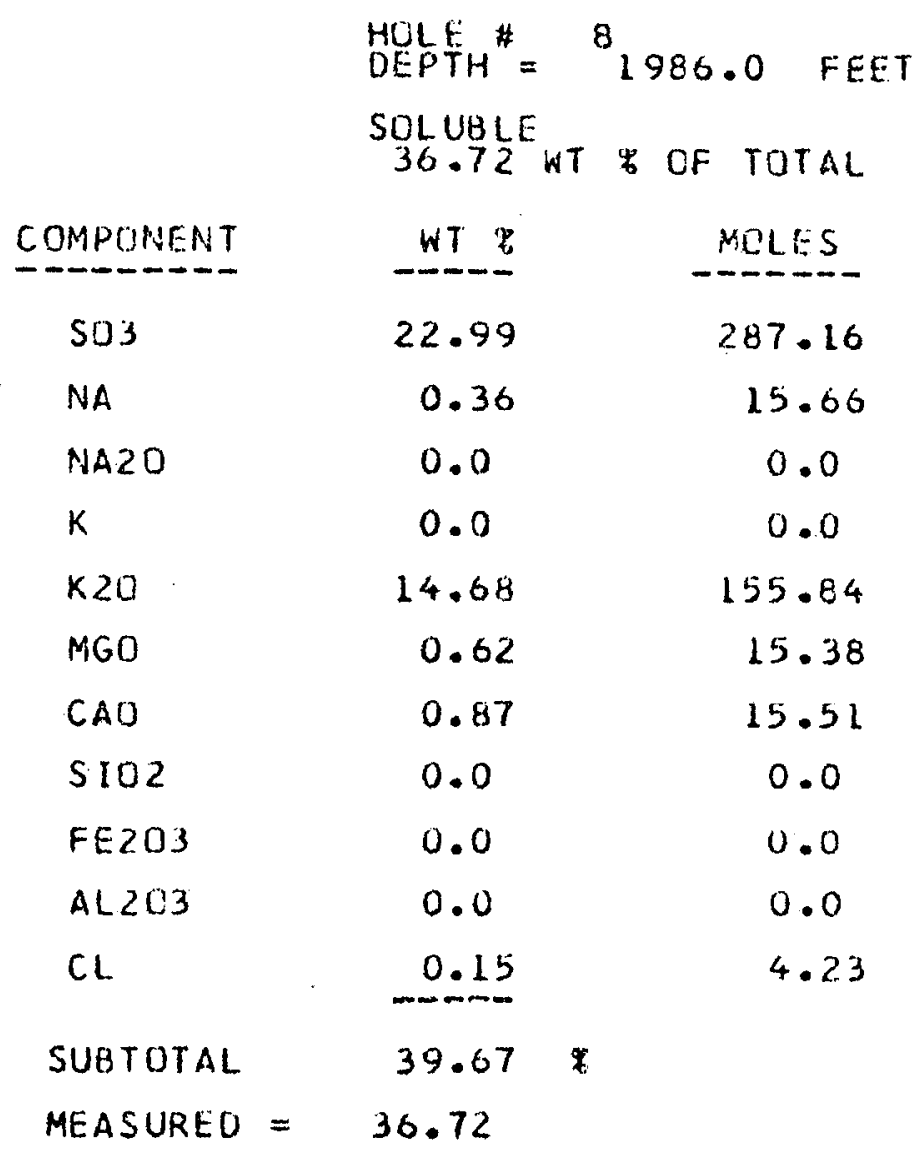

HOLE ${ }^{*}{ }^{*}{ }^{8} 1986.0$ FEET INSULUBLE 63.28 WT $\%$ OF TOTAL

WT MOLES

37.88

473.15

0.0

0.0

5.83

94.06

0.0

0.0

11.39

120.91

1.20

29.77

4.25

75.78

0.54

8.99

0.17

1.06

0.85

8.34

0.0

0.0

02.11 b

63.28 


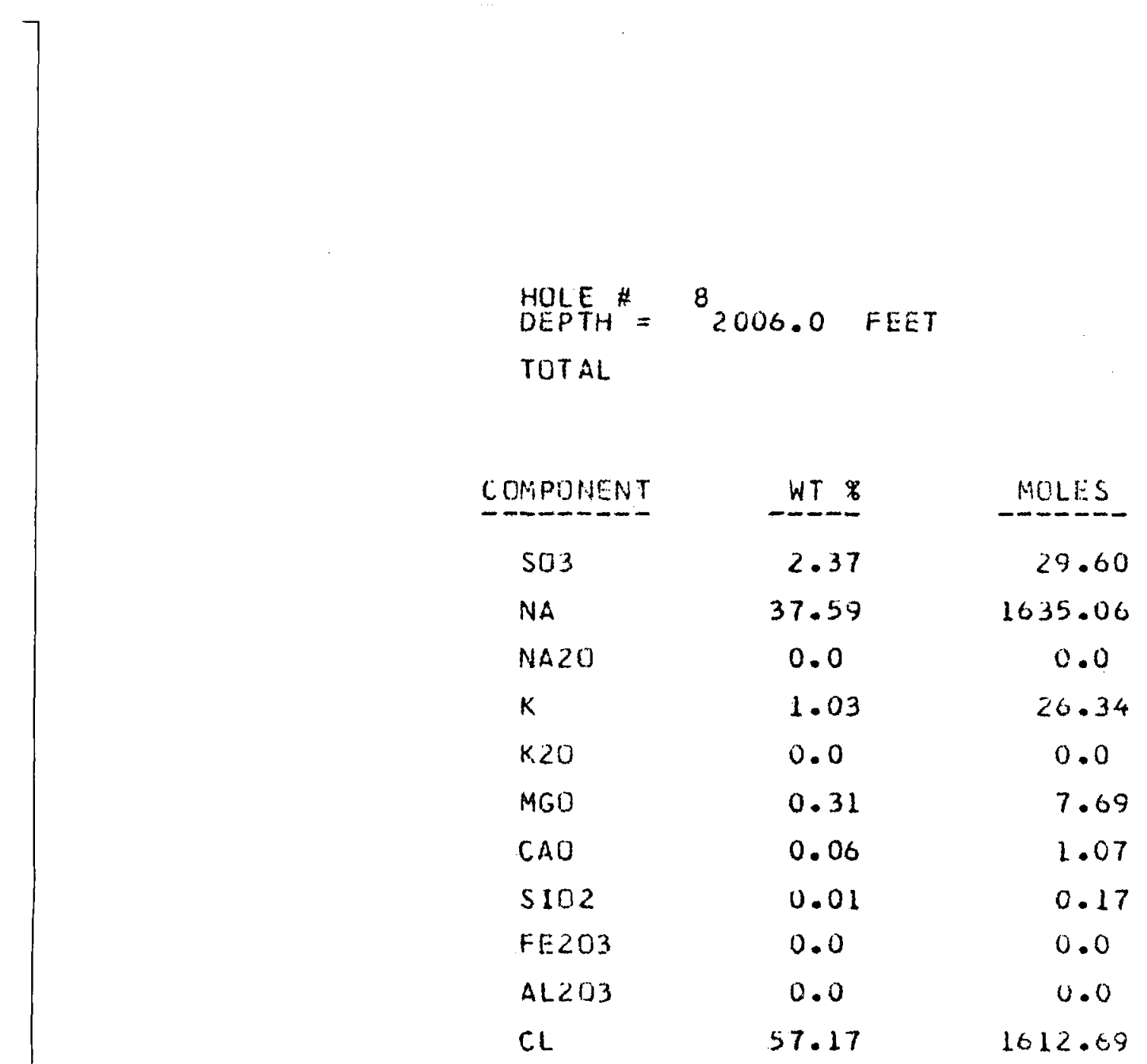




\begin{tabular}{|c|c|c|c|c|}
\hline \multirow[b]{3}{*}{ COMPONENT } & \multicolumn{2}{|c|}{$\begin{array}{l}\text { HOLEEH } \\
\text { DEPTH }=8\end{array}$} & \multicolumn{2}{|c|}{2017.0} \\
\hline & $\begin{array}{c}\text { SOLUBLE } \\
95.20\end{array}$ & WT & of & $=$ TUTAL \\
\hline & WT $\%$ & & & MOLES \\
\hline $\mathrm{SO} 3$ & 0.55 & & & 6.87 \\
\hline NA & 35.66 & & & 551.11 \\
\hline NA2O & 0.0 & & & 0.0 \\
\hline K & 0.06 & & & 1.53 \\
\hline$k 20$ & 0.0 & & & 0.0 \\
\hline$M G O$ & 0.08 & & & 1.98 \\
\hline CAO & 0.96 & & & $17 \cdot 12$ \\
\hline 5102 & 0.02 & & & 0.33 \\
\hline FE 203 & 0.0 & & & 0.0 \\
\hline Al.203 & 0.0 & & & 0.0 \\
\hline$C L$ & 57.09 & & & 610.44 \\
\hline SUBTOTAL & 94.42 & 岕 & & \\
\hline MEASURED = & 95.20 & & & \\
\hline
\end{tabular}

HOLETH ${ }^{*}={ }^{8} 2017.0$ FEET

INSOLUBLE

4.80 WT $\$$ OF TOTAL

\begin{tabular}{cc}
$W T$ & MOLES \\
\hline 0.07 & 0.87 \\
0.0 & 0.0 \\
0.0 & 0.0 \\
0.0 & 0.0 \\
0.04 & 0.42 \\
0.44 & 10.92 \\
0.06 & 1.07 \\
2.01 & 33.45 \\
0.28 & 1.75 \\
0.70 & 6.87 \\
0.0 & 0.0 \\
-9.0 & \\
3.60 & \\
4.80 &
\end{tabular}




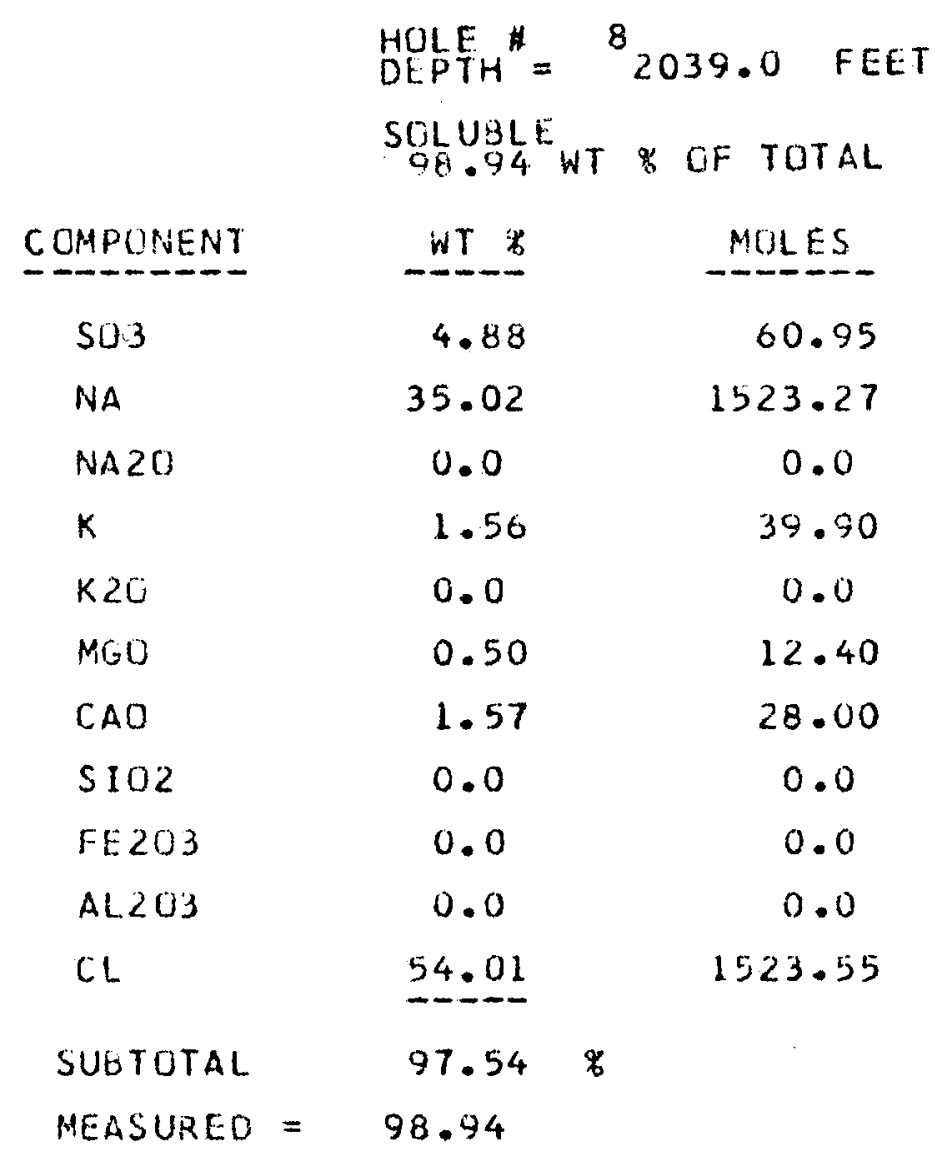

OELPTH ${ }^{*}={ }^{8} 2039.0$ FEET INSOLUBLE 1.06 HT OF TOTAL

$\begin{array}{ll}W T & \text { MOLES } \\ 0.62 & 7.74 \\ 0.0 & 0.0 \\ 0.0 & 0.0 \\ 0.0 & 0.0 \\ 0.03 & 0.32 \\ 0.21 & 5.21 \\ 0.01 & 0.18 \\ 0.26 & 4.33 \\ 0.07 & 0.44 \\ 0.05 & 0.49 \\ 0.0 & 0.0 \\ -1.25 & \\ 1.06 & \end{array}$




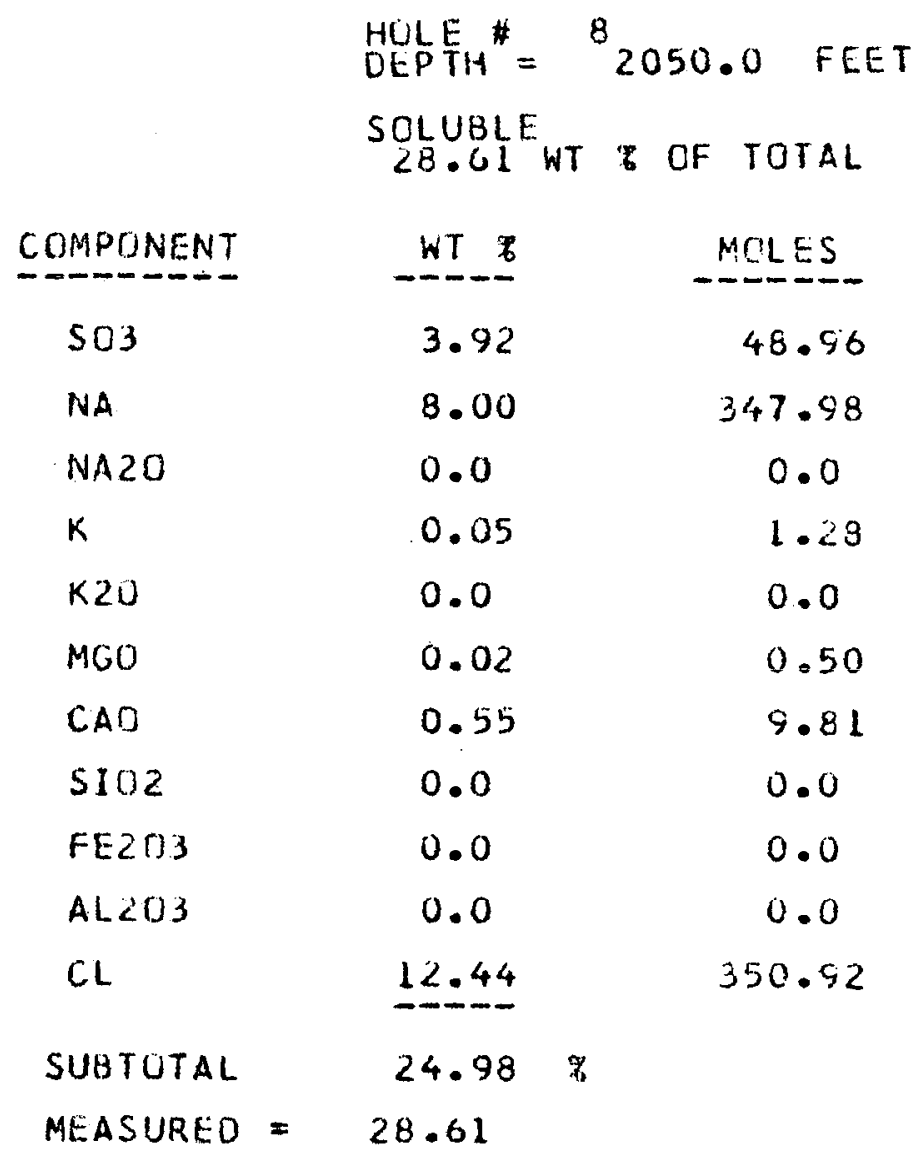

HOLE HE ${ }^{8}{ }^{8} 2050.0$ FEET

INSOLUBLE 71.39 WF TOTAL

$\begin{array}{cc}W T .6 & \text { MOLES } \\ 51.08 & 638.02 \\ 0.0 & 0.0 \\ 4.90 & 79.00 \\ 0.0 & 0.0 \\ 0.04 & 0.42 \\ 0.29 & 7.19 \\ 6.55 & 116.80 \\ 0.33 & 5.49 \\ 0.0 & 0.0 \\ 0.0 & 0.0 \\ 0.0 & 0.0 \\ -03.19 & \end{array}$

71.39 


\begin{tabular}{|c|c|c|c|c|}
\hline \multirow[b]{3}{*}{ COHPONENT } & \multicolumn{2}{|c|}{$\begin{array}{l}\text { HOLE } \\
\text { DEPTH }\end{array}$} & ${ }^{8} 2068.0$ & 3.0 FEE \\
\hline & $\begin{array}{l}\text { SOLUBLE } \\
98.84\end{array}$ & WT & $\%$ OF & $=$ TOTAL \\
\hline & WT & & & MOLES \\
\hline $\mathrm{SO} 3$ & 2.49 & & & 31.10 \\
\hline NA & 37.41 & & & 1627.23 \\
\hline 1420 & 0.0 & & & 0.0 \\
\hline k & 0.08 & & & 2.05 \\
\hline$K 20$ & 0.0 & & & 0.0 \\
\hline $\mathrm{MCO}$ & 0.03 & & & 0.74 \\
\hline $\mathrm{CAO}$ & 0.87 & & & 15.51 \\
\hline $5 \mathrm{IOZ}_{2}$ & 0.02 & & & 0.33 \\
\hline$F: 2 n 3$ & 0.0 & & & 0.0 \\
\hline AL.203 & 0.0 & & & 0.0 \\
\hline $\mathrm{CL}$ & 55.99 & & & 1579.41 \\
\hline SUBTUTAL & 90.89 & 必 & & \\
\hline MEASURED = & 98.84 & & & \\
\hline
\end{tabular}

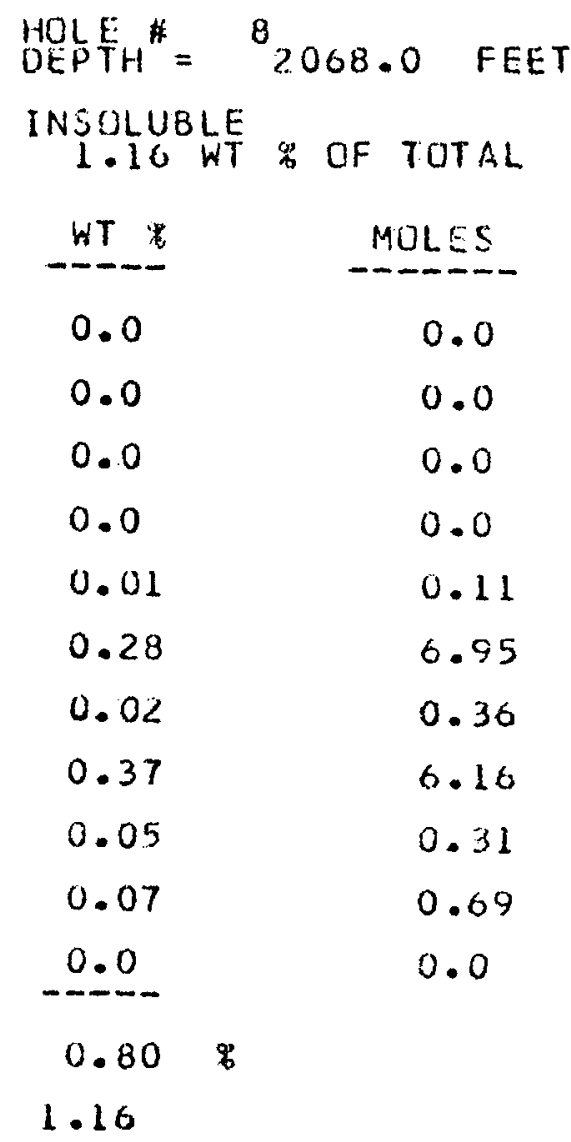




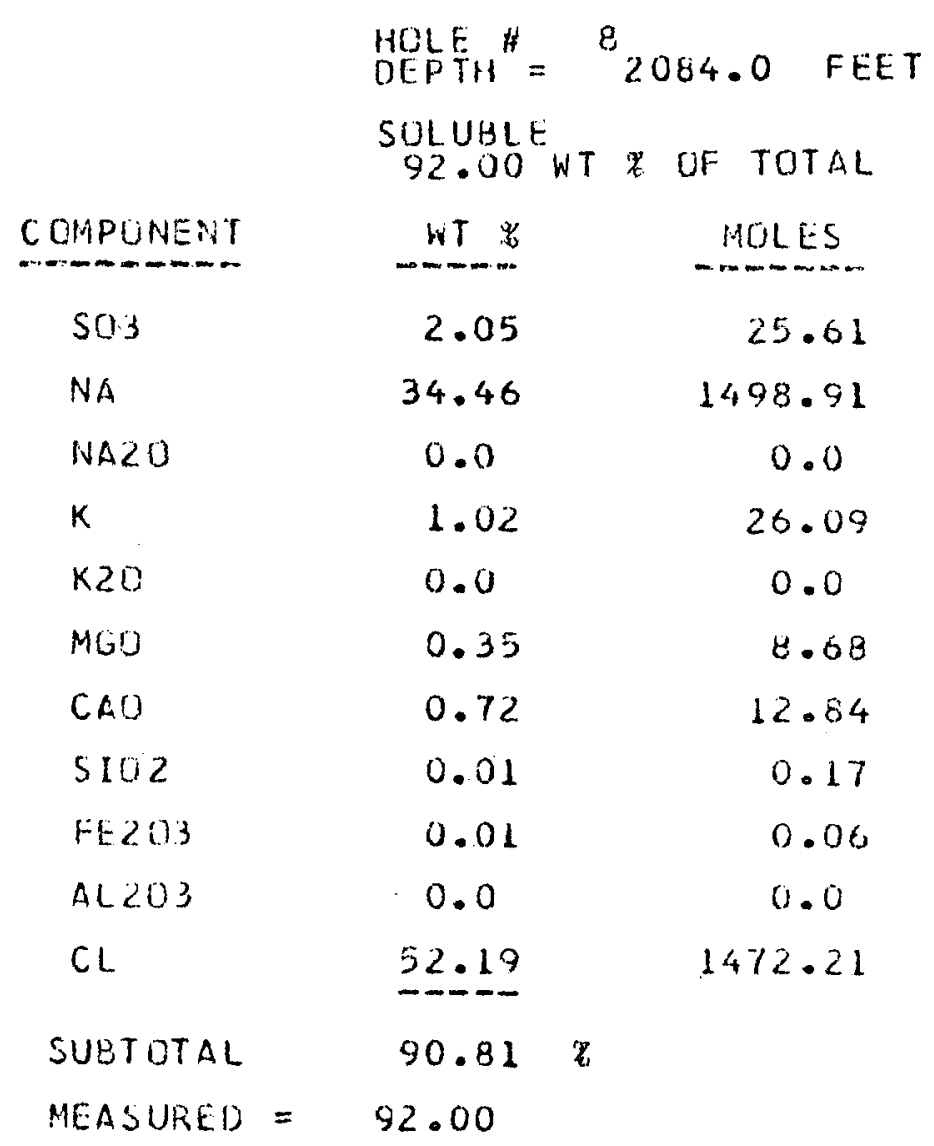

HELETH ${ }^{H}{ }^{8} 2084.0$ FEET INSULUBLE 8.00 WT OF TOTAL

$\begin{array}{cc}W T .8 & \text { MULES } \\ 0.59 & 7.37 \\ 0.0 & 0.0 \\ 1.87 & 30.17 \\ 0.0 & 0.0 \\ 0.19 & 2.02 \\ 1.13 & 28.03 \\ 0.01 & 0.18 \\ 2.07 & 34.45 \\ 0.24 & 1.50 \\ 0.37 & 3.63 \\ 0.0 & 0.0 \\ 0.00 & \\ 8.00 & \end{array}$




$$
\begin{aligned}
& \text { HOLE } \\
& \text { DEPTH }{ }^{8}{ }^{8} 2130.0 \quad \text { FEET } \\
& \text { TOTAL }
\end{aligned}
$$

$\begin{array}{lcc}\text { COMPONENT } & \text { WT } & \text { MOLES } \\ \text { SO3 } & 2.31 & 28.85 \\ \text { NA } & 37.79 & 1643.76 \\ \text { NA2O } & 0.0 & 0.0 \\ K & 0.42 & 10.74 \\ \text { K2O } & 0.0 & 0.0 \\ \text { MGO } & 0.25 & 6.20 \\ \text { CAO } & 0.75 & 13.37 \\ \text { S102 } & 0.03 & 0.50 \\ \text { FE203 } & 0.0 & 0.0 \\ \text { AL203 } & 0.0 & 0.0 \\ \text { CL } & 57.16 & 1612.41\end{array}$




\begin{tabular}{|c|c|c|c|c|}
\hline \multirow[b]{3}{*}{ COMPONENT } & \multicolumn{2}{|c|}{$\begin{array}{l}\text { HOLE } \\
\text { DEPTH }\end{array}$} & \multicolumn{2}{|c|}{2162.0} \\
\hline & $\begin{array}{l}\text { SOLUBLE } \\
98.90\end{array}$ & WT & $\because 0 F$ & JF TOTAL \\
\hline & WT B & & & MCLES \\
\hline$\$ 03$ & 1.31 & & & 16.36 \\
\hline NA & 36.77 & & & 1599.39 \\
\hline$N A 20$ & 0.0 & & & 0.0 \\
\hline$k$ & 1.23 & & & $31 \cdot 46$ \\
\hline $\mathrm{k} 20$ & 0.0 & & & 0.0 \\
\hline MGO & 0.45 & & & 11.16 \\
\hline $\mathrm{CAO}$ & 0.93 & & & 16.58 \\
\hline$\$ 102$ & 0.0 & & & 0.0 \\
\hline$F E 203$ & 0.0 & & & 0.0 \\
\hline A1.203 & 0.0 & & & 0.0 \\
\hline $\mathrm{CL}$ & 59.99 & & & $16,92.24$ \\
\hline SUBTOTAL & 100.68 & $x$ & & \\
\hline MEASUREO = & 98.90 & & & \\
\hline
\end{tabular}

$\begin{array}{lc}\text { HOLE } & \\ \text { DEPH } & 8 \\ \text { INSOLUBLE } & \\ 1.162 .0 \text { WT } & \text { FEET } \\ \text { OF TOTAL } & \text { MOLES } \\ 0.25 & 3.12 \\ 0.0 & 0.0 \\ 0.55 & 8.87 \\ 0.0 & 0.0 \\ 0.03 & 0.32 \\ 0.20 & 4.96 \\ 0.01 & 0.18 \\ 0.23 & 3.83 \\ 0.06 & 0.38 \\ 0.05 & 0.49 \\ 0.0 & 0.0 \\ -1.38 & \\ 1.10 & \end{array}$




$$
\begin{aligned}
& \text { HOLE TH } \\
& \text { DEP } \\
& \text { TOTAL }
\end{aligned}
$$

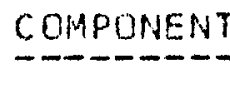

503

NA

NA2O

$k$

$K 20$

$M G O$

CAO

5102

FE 203

AL2O3

CL

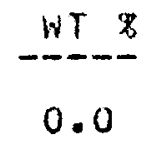

39.14

0.0

0.07

0.0

0.02

0.12

0.01

0.0

0.0

59.75
MOLES

0.0

1702.48

0.0

1.79

0.0

0.50

2.14

0.17

0.0

0.0

1685.47 


HOLE \#H
DEPTH
TOTAL

\begin{tabular}{lcc} 
COMPONENT & WT & MOLES \\
\hline SO3 & 0.39 & 4.87 \\
NA & 37.91 & 1648.98 \\
NA2O & 0.0 & 0.0 \\
K & 0.12 & 3.07 \\
K20 & 0.0 & 0.0 \\
MGO & 0.09 & 2.23 \\
CAO & 0.25 & 4.46 \\
S102 & 0.02 & 0.33 \\
FE203 & 0.0 & 0.0 \\
AL203 & 0.0 & 0.0 \\
CL & 60.23 & 1699.01
\end{tabular}


${ }_{D E P T H}^{\text {HOLE }}={ }^{8} 2326.0$ FEET

INSOLUBLE

4.56 WT OF TOTAL

\begin{tabular}{lcc} 
COMPONENT & WT & MOLES \\
\hline SO3 & 0.0 & 0.0 \\
NA & 0.0 & 0.0 \\
NA2O & 0.0 & 0.0 \\
K & 0.0 & 0.0 \\
K2O & 0.03 & 0.32 \\
MGO & 1.31 & 32.50 \\
CAO & 0.03 & 0.53 \\
SIO2 & 1.14 & 18.97 \\
FE2O3 & 0.12 & 0.75 \\
AL203 & 0.25 & 2.45 \\
CL & 0.0 & 0.0 \\
SUBTOTAL & 2.88 & \\
MEASURED & 4.56 &
\end{tabular}




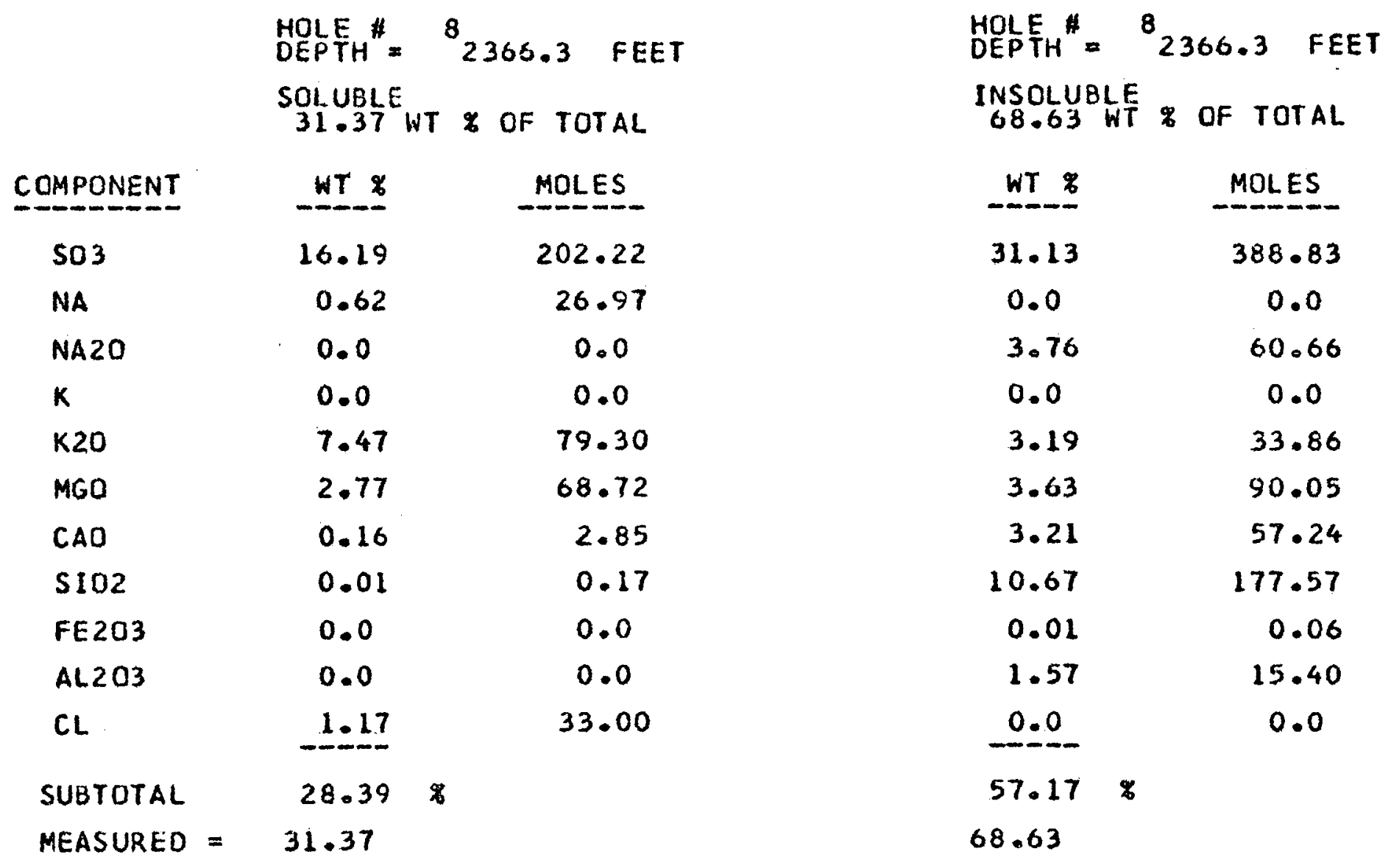




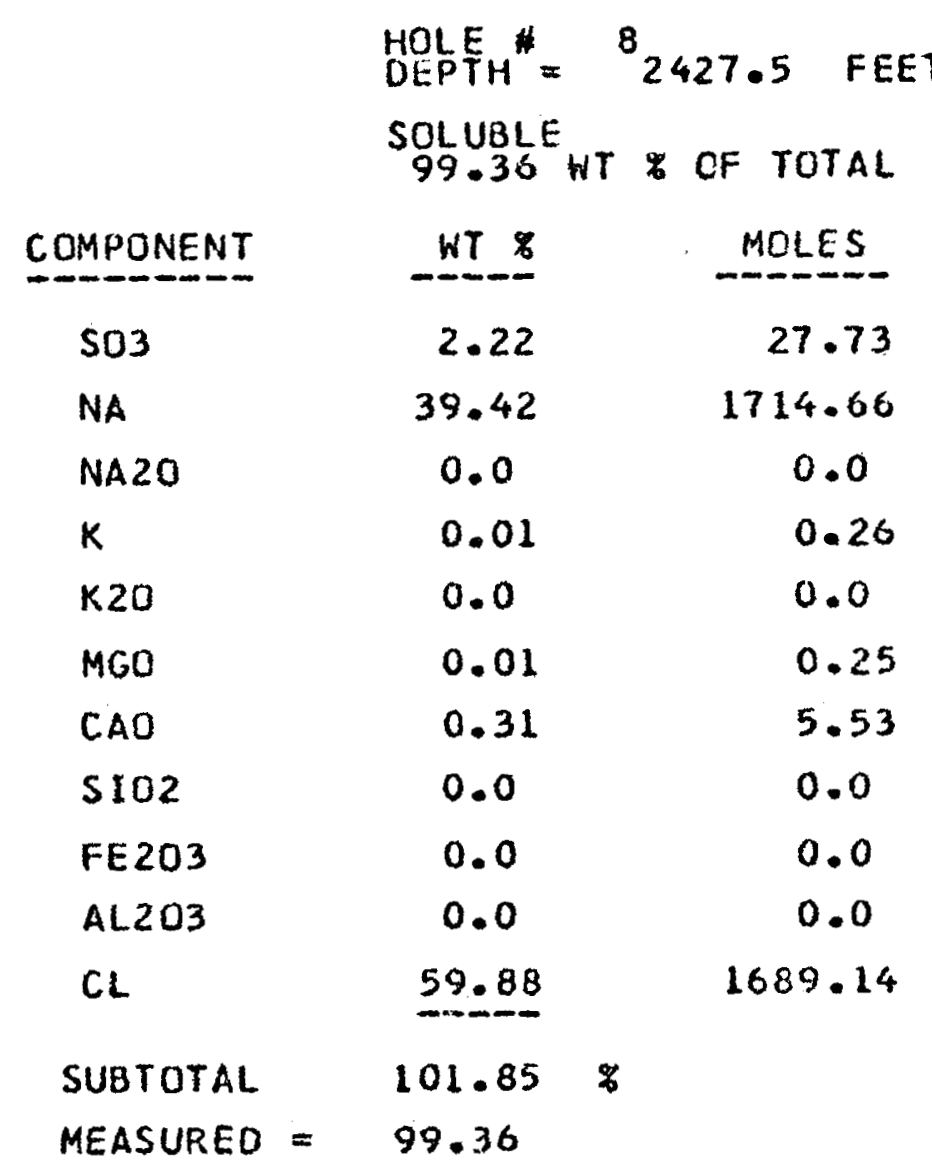

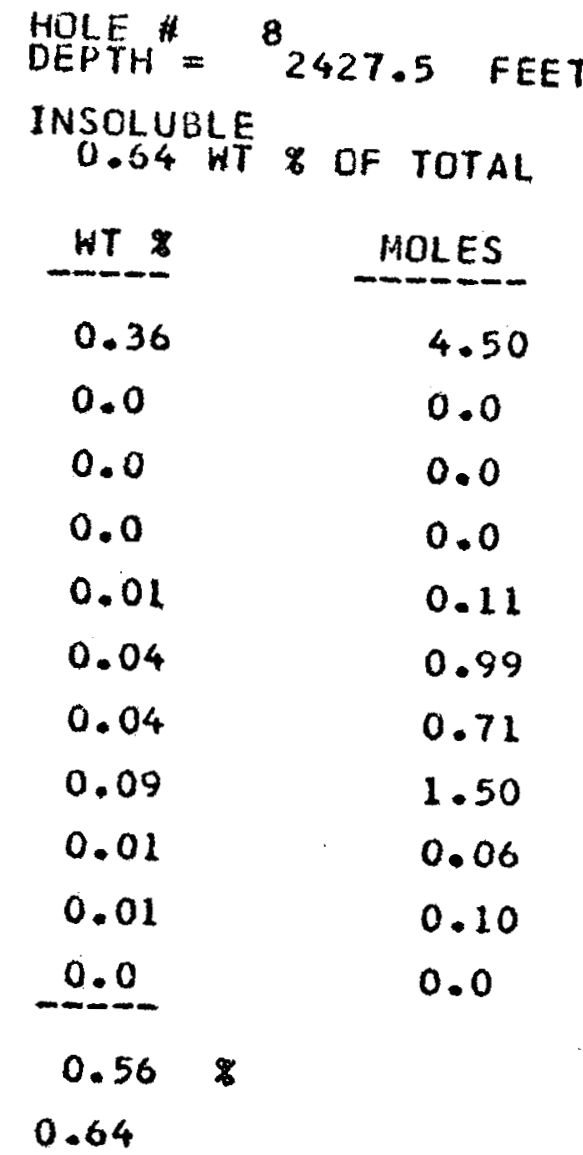




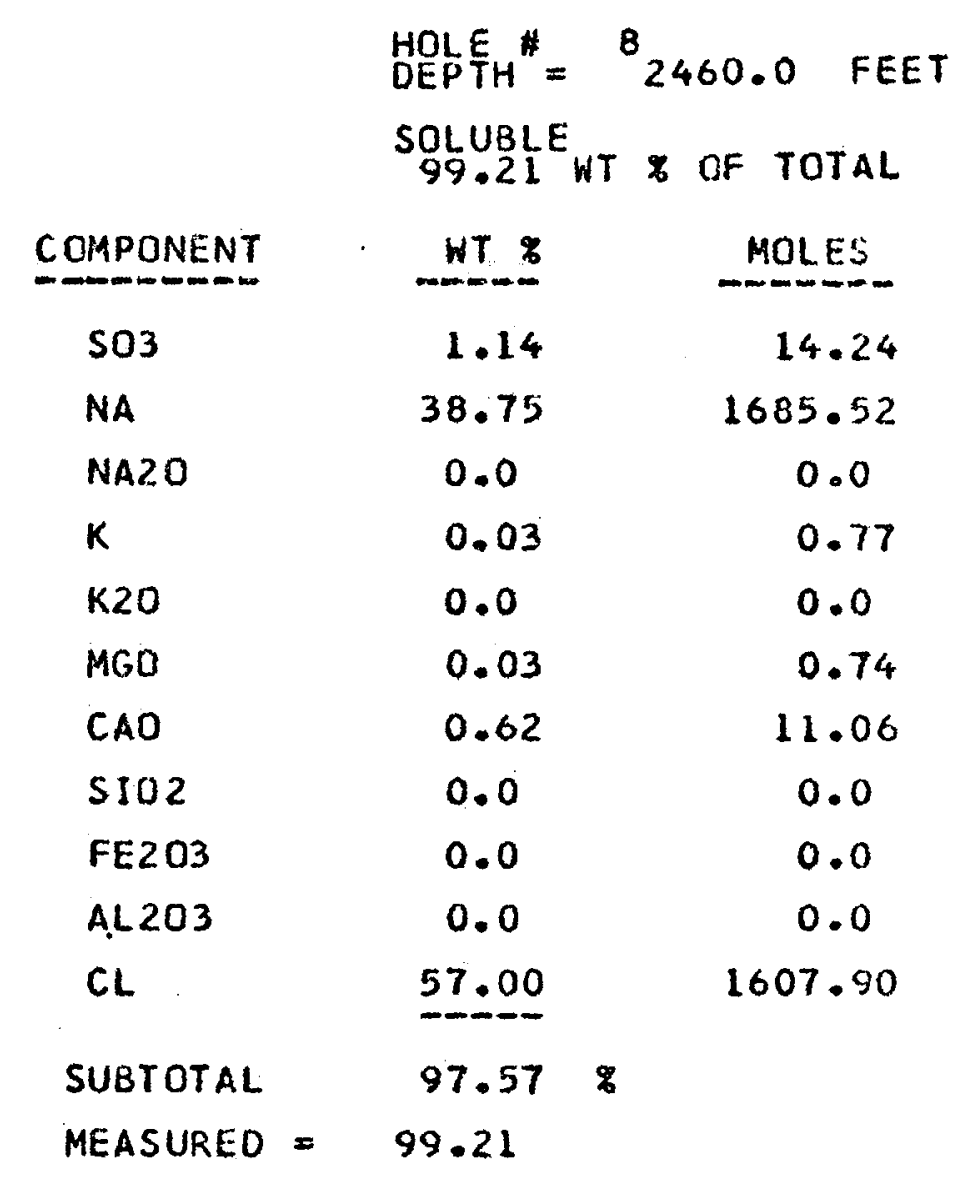

\begin{tabular}{cc} 
HOLE & \\
OEPTH & ${ }^{8} 2460.0$ \\
INSOLUBLE & FEET \\
0.79 WT & OF TOTAL \\
WT $\%$ & MOLES \\
\hline 0.0 & 0.0 \\
0.0 & 0.0 \\
0.0 & 0.0 \\
0.0 & 0.0 \\
0.01 & 0.12 \\
0.17 & 4.22 \\
0.0 & 0.0 \\
0.19 & 3.16 \\
0.03 & 0.19 \\
0.06 & 0.59 \\
0.0 & 0.0 \\
\hline 0.46 & \\
0.79 &
\end{tabular}




\section{HOLEF" ${ }_{\text {DEPTH }}{ }^{8} 2519.6$ FEET \\ TOTAL}

\begin{tabular}{lcc} 
COMPONENT & WT $\%$ & MOLES \\
\hline SO3 & 0.17 & 2.12 \\
NA & 40.42 & 1758.16 \\
NA20 & 0.0 & 0.0 \\
K & 0.02 & 0.51 \\
K2O & 0.0 & 0.0 \\
MGO & 0.01 & 0.25 \\
CAO & 0.03 & 0.53 \\
S102 & 0.0 & 0.0 \\
FE203 & 0.0 & 0.0 \\
AL203 & 0.0 & 0.0 \\
CL & 60.31 & 1701.27
\end{tabular}




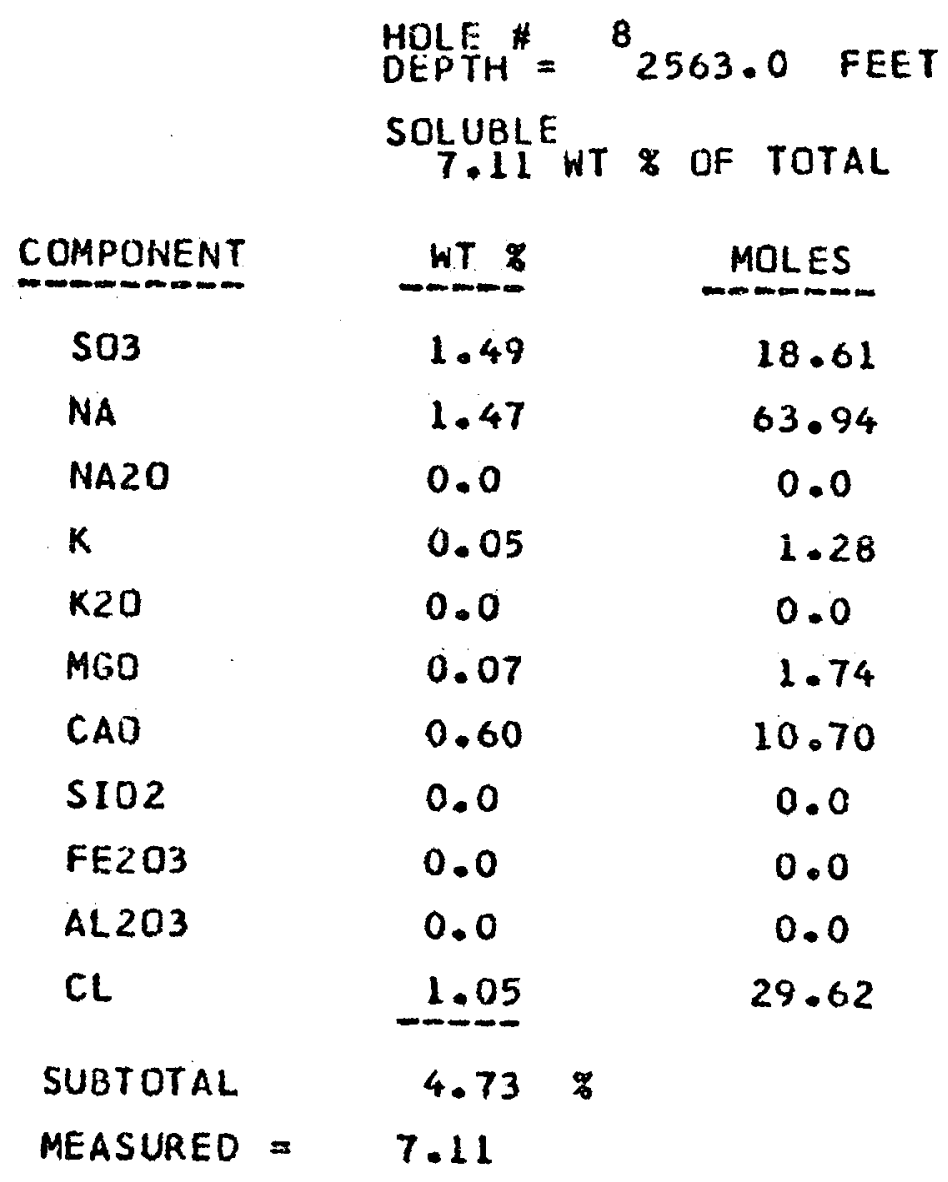

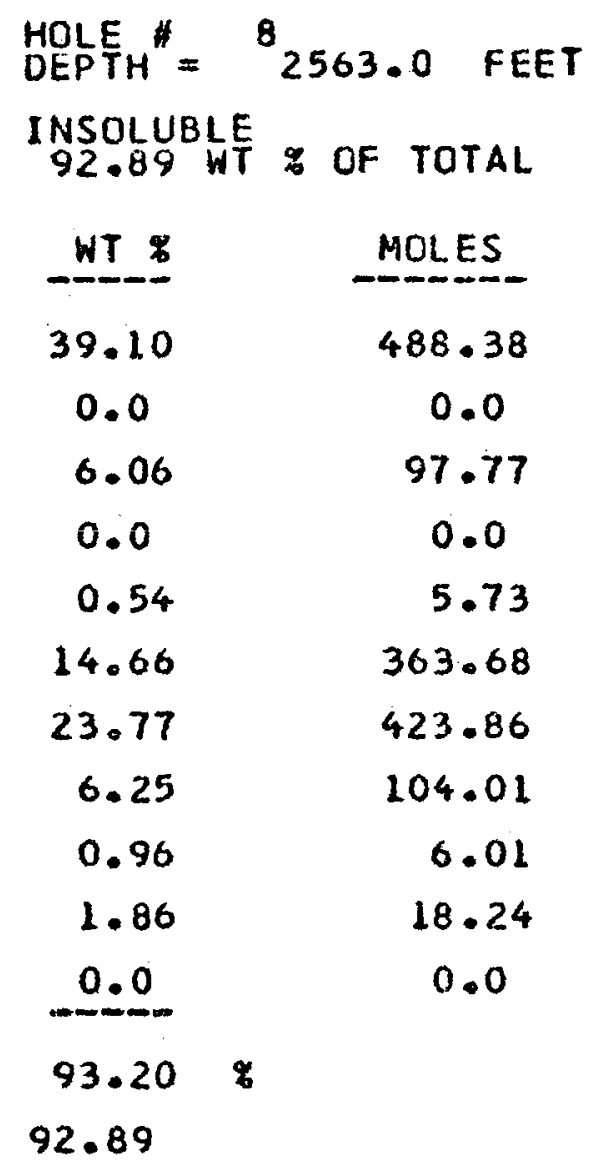




$$
\begin{aligned}
& \text { HOLE \# }{ }^{*}{ }^{6} 2615.5 \text { FEET } \\
& \text { TOTAL }
\end{aligned}
$$

\begin{tabular}{lcc} 
COMPONENT & WT & MOLES \\
\hline SO3 & 0.86 & 10.74 \\
NA & 38.58 & 1678.12 \\
NA20 & 0.0 & 0.0 \\
K & 0.05 & 1.28 \\
K2O & 0.0 & 0.0 \\
MGO & 0.02 & 0.50 \\
CAO & 0.58 & 10.34 \\
SIO2 & 0.0 & 0.0 \\
FE203 & 0.01 & 0.06 \\
AL203 & 0.0 & 0.0 \\
CL & 59.37 & 1674.75
\end{tabular}




\begin{tabular}{|c|c|c|c|c|}
\hline \multirow{3}{*}{ COMPONENT } & \multirow{2}{*}{$\begin{array}{l}\text { HOLE } \\
\text { DEPTH } \\
\text { SOLUBLE } \\
99.08\end{array}$} & \multicolumn{2}{|c|}{${ }_{2665.5}$} & FEET \\
\hline & & VT & of $T$ & TOTAL \\
\hline & WT $\%$ & & MO & ILES \\
\hline$\$ 03$ & 0.98 & & & 12.24 \\
\hline NA & 38.68 & & 168 & 32.47 \\
\hline NA2D & 0.0 & & & 0.0 \\
\hline$k$ & 0.02 & & & 0.51 \\
\hline $\mathrm{K} 20$ & 0.0 & & & 0.0 \\
\hline MGO & 0.01 & & & 0.25 \\
\hline CAO & 0.35 & & & 6.24 \\
\hline 5102 & 0.01 & & & 0.17 \\
\hline FE203 & 0.0 & & & 0.0 \\
\hline AL 203 & 0.0 & & & 0.0 \\
\hline$C L$ & 59.14 & & 166 & 68.27 \\
\hline SUBTOTAL & 99.19 & $\%$ & & \\
\hline MEASURED $=$ & 99.08 & & & \\
\hline
\end{tabular}

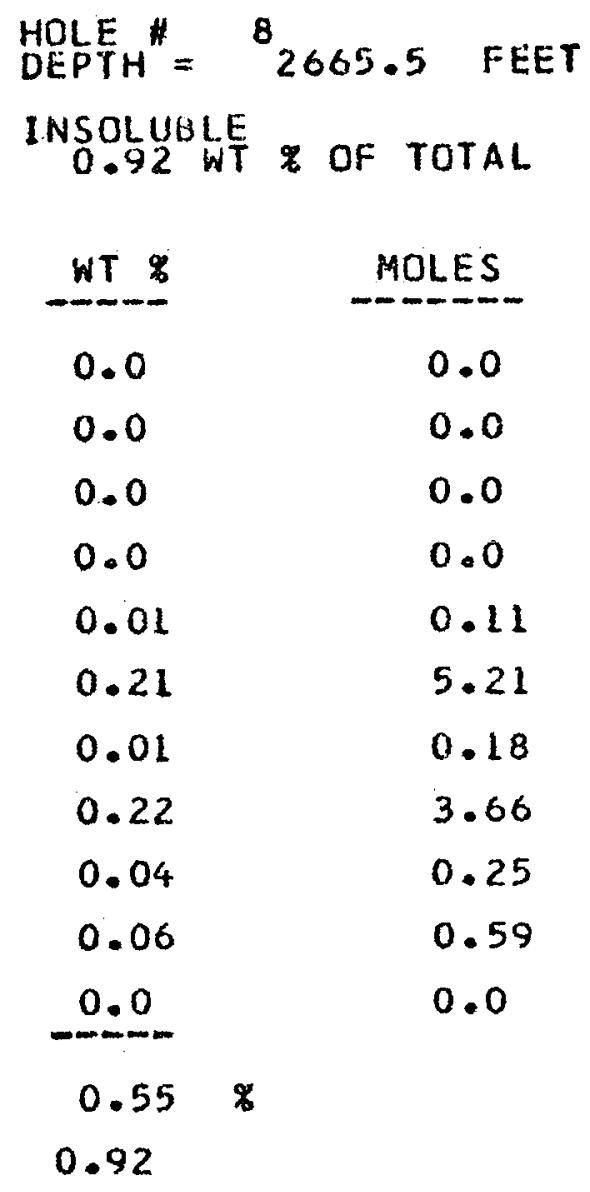




\begin{tabular}{lcc} 
& $\begin{array}{c}\text { HOLE } \\
\text { DEPTH }\end{array}$ & 8706.0 FEET \\
& $\begin{array}{c}\text { SOLUBLE } \\
98.75\end{array}$ & WT $\%$ OF TOTAL \\
COMPONENT & WT & MOLES \\
\hline SO3 & 1.12 & 13.99 \\
NA & 37.09 & 1613.31 \\
NA20 & 0.0 & 0.0 \\
K & 0.03 & 0.77 \\
K2O & 0.0 & 0.0 \\
MGO & 0.01 & 0.25 \\
CAO & 0.68 & 12.13 \\
SI02 & 0.01 & 0.17 \\
FE203 & 0.0 & 0.0 \\
AL203 & 0.0 & 0.0 \\
CL & 58.60 & 1653.03 \\
SUBTOTAL & 97.54 & \\
MEASURED & 98.75 &
\end{tabular}
${ }_{\text {DELPTH }}^{\text {HOLE }}={ }^{8} 2706.0$ FEET INSOLUBLE
1.25 WT \& OF TOTAL

\begin{tabular}{lc} 
WT \% & MOLES \\
0.01 & 0.12 \\
0.0 & 0.0 \\
0.64 & 10.33 \\
0.0 & 0.0 \\
0.03 & 0.32 \\
0.18 & 4.47 \\
0.0 & 0.0 \\
0.27 & 4.49 \\
0.27 & 1.69 \\
0.07 & 0.69 \\
0.0 & 0.0 \\
\hline 1.47 & $\$$ \\
1.25 &
\end{tabular}




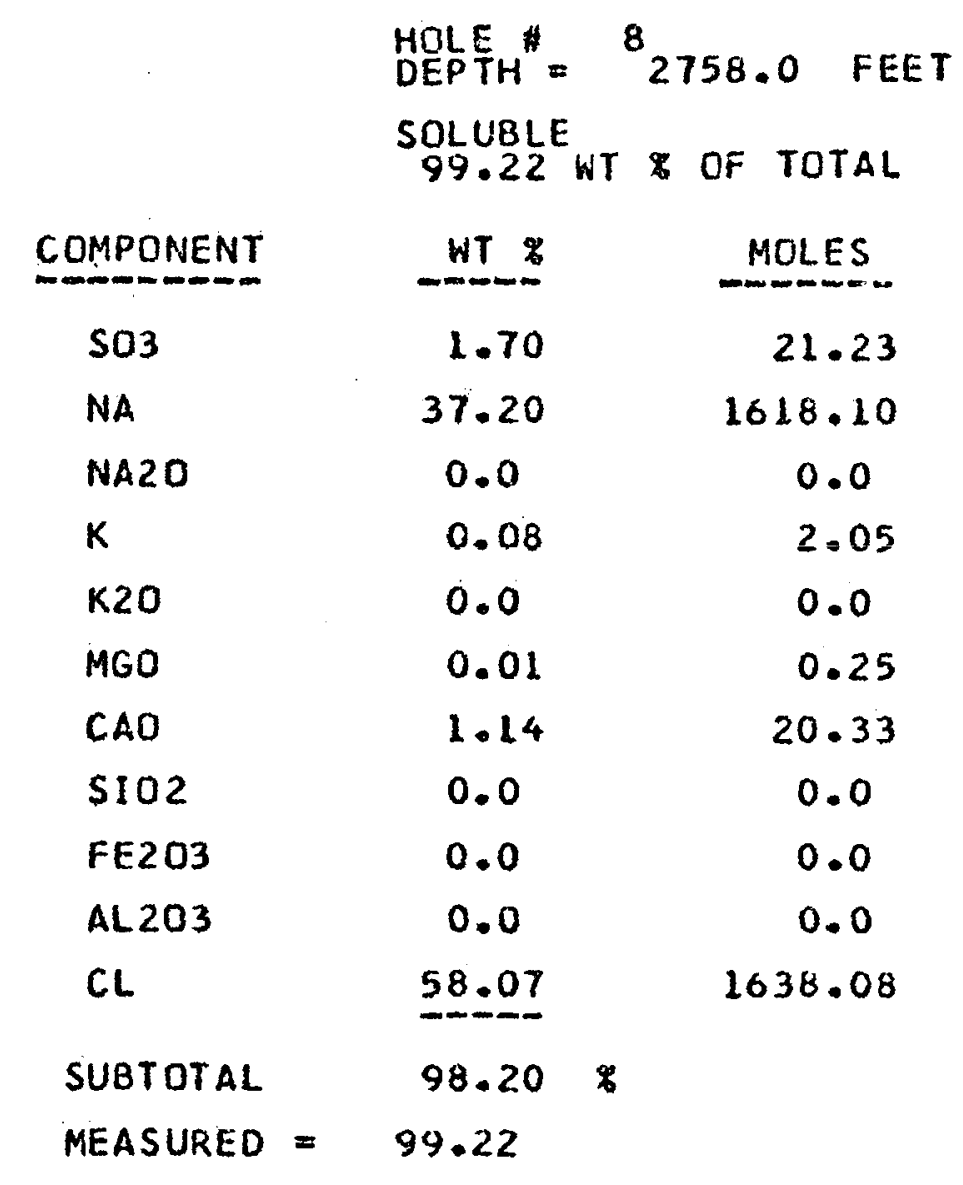

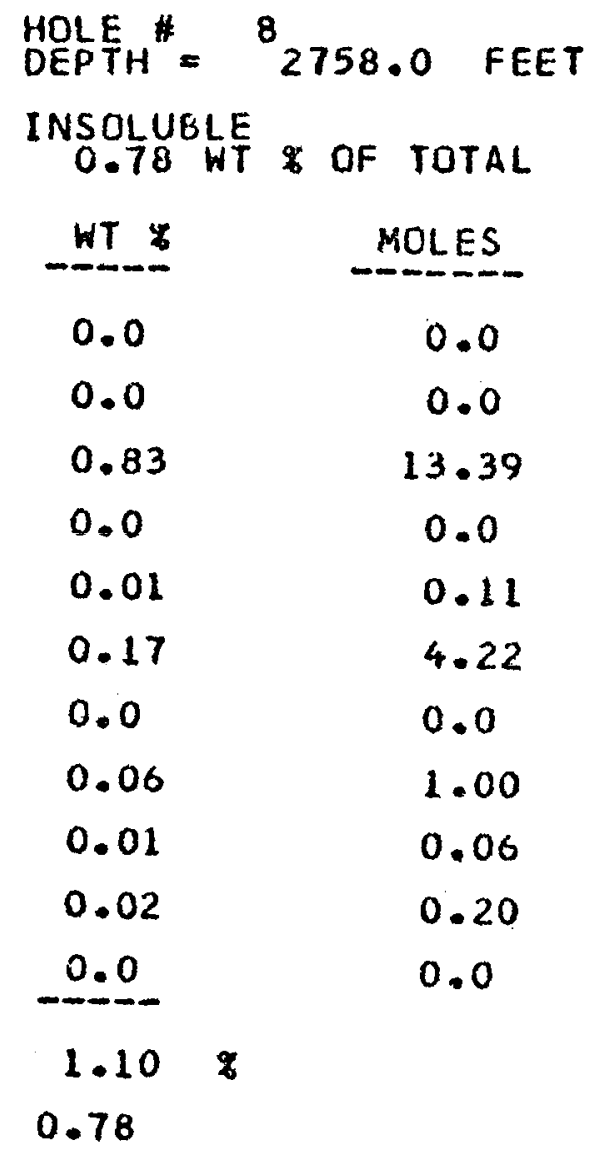




\section{HOLE " ${ }^{8} 2779.0$ FEET \\ TOTAL}

\begin{tabular}{lcr} 
COMPONENT & WT $\%$ & MOLES \\
\hline SO3 & 1.09 & 13.61 \\
NA & 37.41 & 1627.23 \\
NA2O & 0.0 & 0.0 \\
K & 0.01 & 0.26 \\
K2O & 0.0 & 0.0 \\
MGO & 0.03 & 0.74 \\
CAO & 1.80 & 32.10 \\
SIO2 & 0.0 & 0.0 \\
FE203 & 0.0 & 0.0 \\
AL203 & 0.0 & 0.0 \\
CL & 58.53 & 1651.06
\end{tabular}




$$
\begin{aligned}
& \text { HOLE } \\
& \text { DEPTH" } \\
& \text { TOTAL }
\end{aligned}
$$

\begin{tabular}{lcc} 
COMPONENT & WT $\%$ & MOLES \\
\hline SO3 & 0.99 & 12.37 \\
NA & 37.86 & 1646.80 \\
NA20 & 0.0 & 0.0 \\
K & 0.02 & 0.51 \\
K20 & 0.0 & 0.0 \\
MGO & 0.01 & 0.25 \\
CAO & 0.68 & 12.13 \\
S102 & 0.0 & 0.0 \\
FE203 & 0.0 & 0.0 \\
AL203 & 0.0 & 0.0 \\
CL & 60.58 & 1708.89
\end{tabular}




$$
\begin{aligned}
& \text { MOLE \# }{ }^{8} 2802.5 \text { FEET } \\
& \text { TOTAL }
\end{aligned}
$$

\begin{tabular}{lcc} 
COAPONENT & NT & MOLES \\
\hline SO3 & 1.76 & 21.98 \\
NA & 38.39 & 1669.86 \\
NA20 & 0.0 & 0.0 \\
K & 0.02 & 0.51 \\
K2O & 0.0 & 0.0 \\
MGO & 0.01 & 0.25 \\
CAO & 0.22 & 3.92 \\
SIO2 & 0.0 & 0.0 \\
FE203 & 0.0 & 0.0 \\
AL203 & 0.0 & 0.0 \\
CL & 58.19 & 1641.47
\end{tabular}




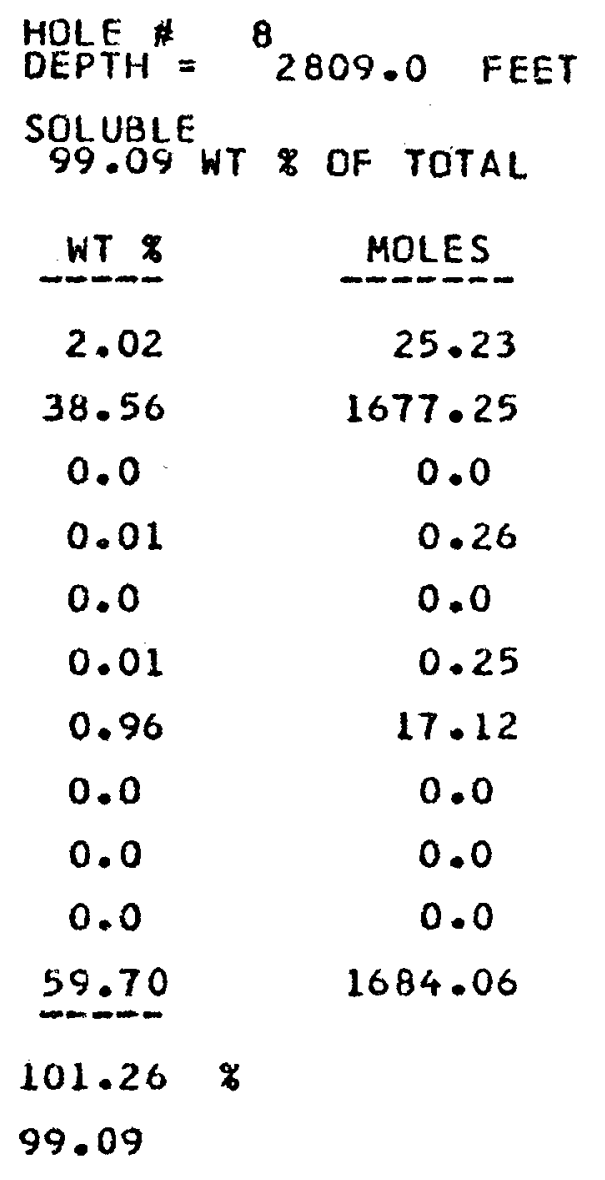

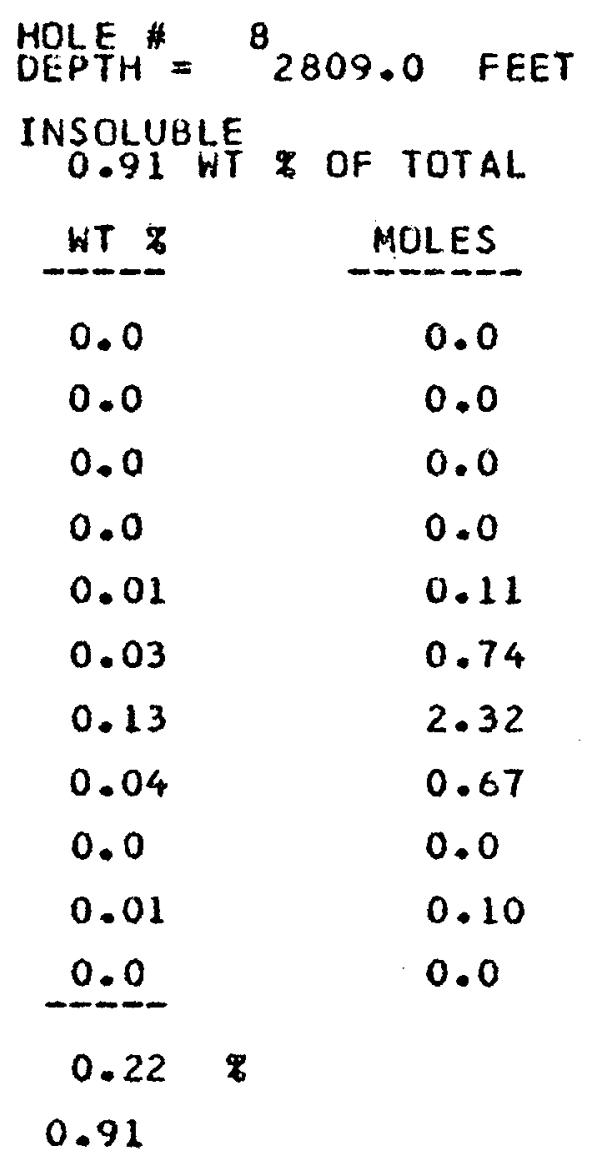




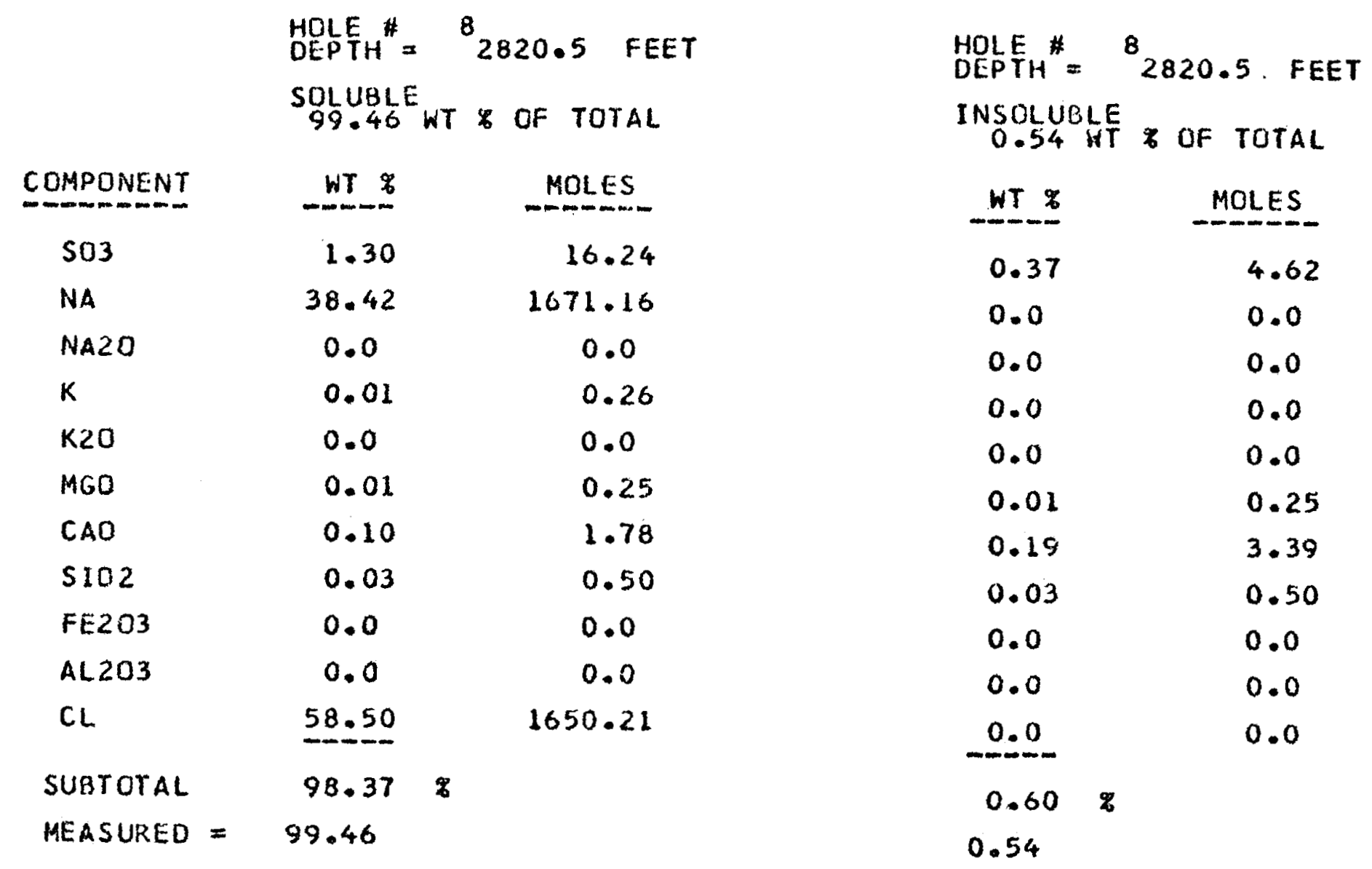




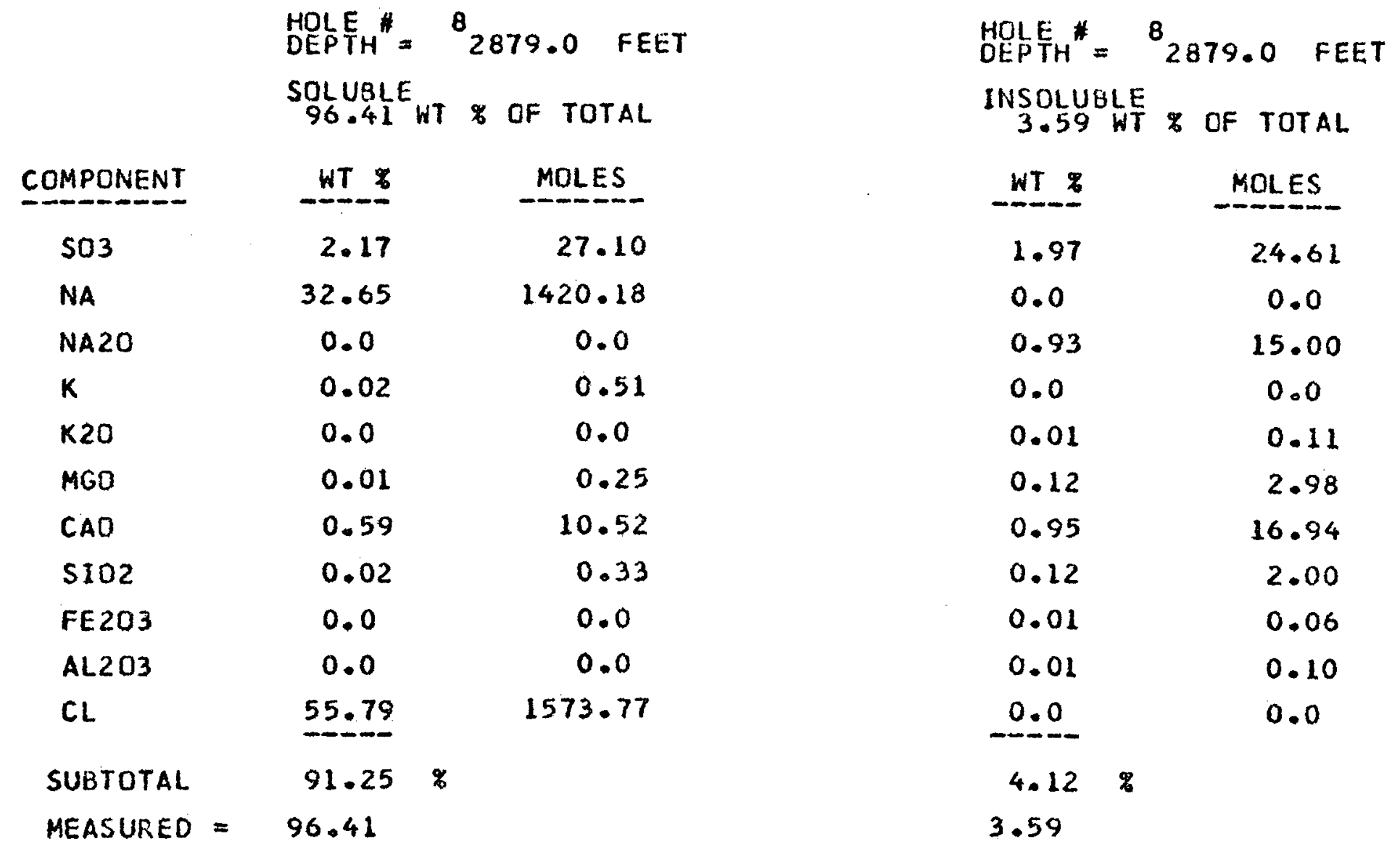




\begin{tabular}{lcc} 
& $\begin{array}{c}\text { HOLEEH } \\
\text { DEPTH } \\
\text { SOLUBLE } \\
97.32\end{array}$ WT 8948.0 FF TOTAL \\
COMPONENT & WT & MOLES \\
\hline SO3 & 3.41 & 42.59 \\
NA & 37.30 & 1622.45 \\
NA2O & 0.0 & 0.0 \\
K & 0.01 & 0.26 \\
K2O & 0.0 & 0.0 \\
MGO & 0.01 & 0.25 \\
CAD & 0.54 & 9.63 \\
SIO2 & 0.01 & 0.17 \\
FE203 & 0.0 & 0.0 \\
AL203 & 0.0 & 0.0 \\
CL & 55.51 & 1565.87 \\
SUBTOTAL & $96.79 \%$ & \\
MEASURED $=$ & 97.32 &
\end{tabular}

HOLEFH" ${ }^{*} 2948.0$ FEET

INSOLUBLE

2.68 WT $\%$ OF TOTAL

\begin{tabular}{cc} 
WT $~$ & MOLES \\
\hline 1.92 & 23.98 \\
0.0 & 0.0 \\
0.0 & 0.0 \\
0.0 & 0.0 \\
0.01 & 0.11 \\
0.02 & 0.50 \\
0.25 & 4.46 \\
0.05 & 0.83 \\
0.01 & 0.06 \\
0.0 & 0.0 \\
0.0 & 0.0 \\
\hline 2.26 & \\
2.68 &
\end{tabular}


Appendix 7.C (Ref. sec. 7.4)

Selected $x$-ray diffraction traces of EDTA-insoluble residues from the ERDA-9 core.

I-2. MB-CS-42: Serpentine and saponite; the sharp maxima at 12.2 and $24.5^{\circ} 2 \theta$ are basal spacings of serpentine's $7 \AA$ periodicity. The broad peak at $7.25^{\circ} 2 \theta$ (air-dried) becomes a broad weak shoulder at $\sim 5^{\circ} 2 \theta$ upon glycol saturation and is saponite.

A. $<2 \mu \mathrm{m}$ EDTA-insoluble residue, air-dried.

B. Bulk EDTA-insoluble residue, glycol-saturated.

I-3. MB-CS-15: Talc and smectite (saponite); sharp peaks at 9.5 and $28.5^{\circ} 2 \theta$ are basal spacings of talc's $9.5 \AA$ periodicity; they do not shift with glycol-saturation. The broad low-angle peak again is saponite; accessory amounts of serpentine also present.

A. $<2 \mu m$ EDTA-insoluble residue, air-dried.

B. Bulk EDTA-Insoluble residue, glycol-saturated.

I-4. MB-CS-17: Regularly interstratified mixed-layer chlorite-saponite (corrensite); distinct strong superlattice reflection at $2.9^{\circ} 2 \theta$ (air-dried) which expands to $2.7^{\circ} 2 \theta$ with glycol-saturation. The peak at $6.4^{\circ} 2 \theta$ (air-dried) expands to $5.6^{\circ} 2 \theta$.

A. $<2 \mu \mathrm{m}$ EDTA-insoluble residue, air-dried.

B. $<2 \mu m$ EDTA-insoluble residue, glycol-saturated.

I-5. JL-CS-9: Randomly interstratified mixed-layer chlorite-saponite; airdried peak at $6.1^{\circ} 2 \theta$ expands to $5.5^{\circ} 2 \theta$ with glycol saturation. Illite $\left(8.7,17.6\right.$, and $\left.26.6^{\circ} 2 \theta\right)$, minor serpentine (12.3 and $\left.13.1^{\circ} 2 \theta\right)$, and minor feldspar $\left(27.4^{\circ} 2 \theta\right)$ also present.

A. $<2 \mu \mathrm{m}$ EDTA-insoluble residue, air-dried.

B. $<2 \mu \mathrm{m}$ EDTA-insoluble residue, glycol-saturated.

I-6. MB-CS-13: Saponite; reflections at 6.1 and $27.3^{\circ} 2 \theta$ which expand to $5.2^{\circ}$ $2 \theta$ upon glycol saturation. A small quantity of a regularly Interstratified mixed-1ayer clay (small superlattice peak at $2.4^{\circ} 2 \theta$ ) also present.

A. $<2 \mu \mathrm{m}$ EDTA-insoluble residue, air-dried.

B. $<2 \mu \mathrm{m}$ EDTA-insoluble residue, glycol saturated.

I-7. JL-CS-2: Randomly interstratified mixed-layer clay, either talc-saponite or illite-saponite; single strong maximum at $8.6^{\circ} 2 \theta$ becomes pronounced doublet at 9.6 and $7.6^{\circ} 2 \theta$ with glycol saturation.

A. <2um EDTA-1nsoluble residue, air-dried.

B. $<2 \mu \mathrm{m}$ EDTA-insoluble residue, glycol-saturated. 


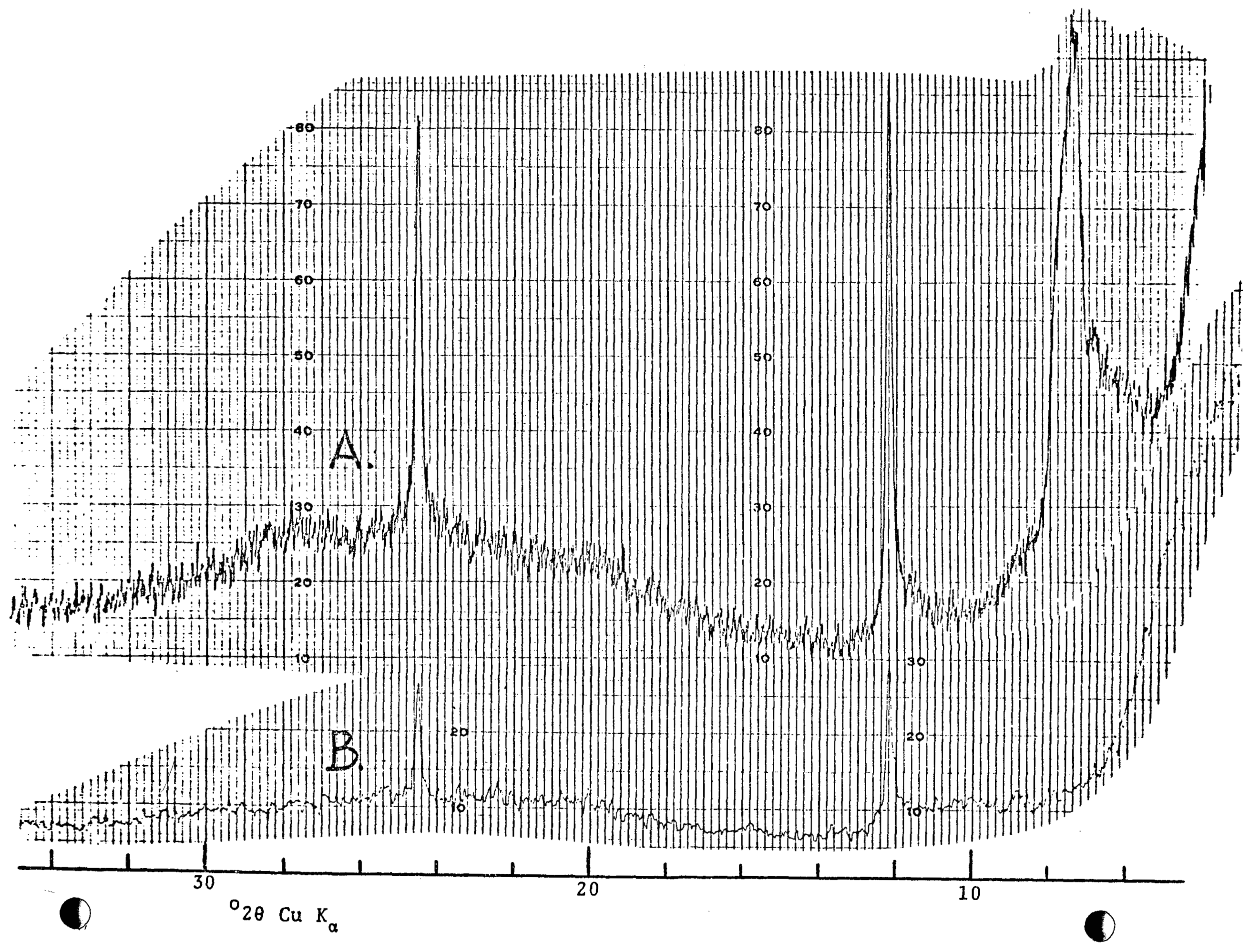




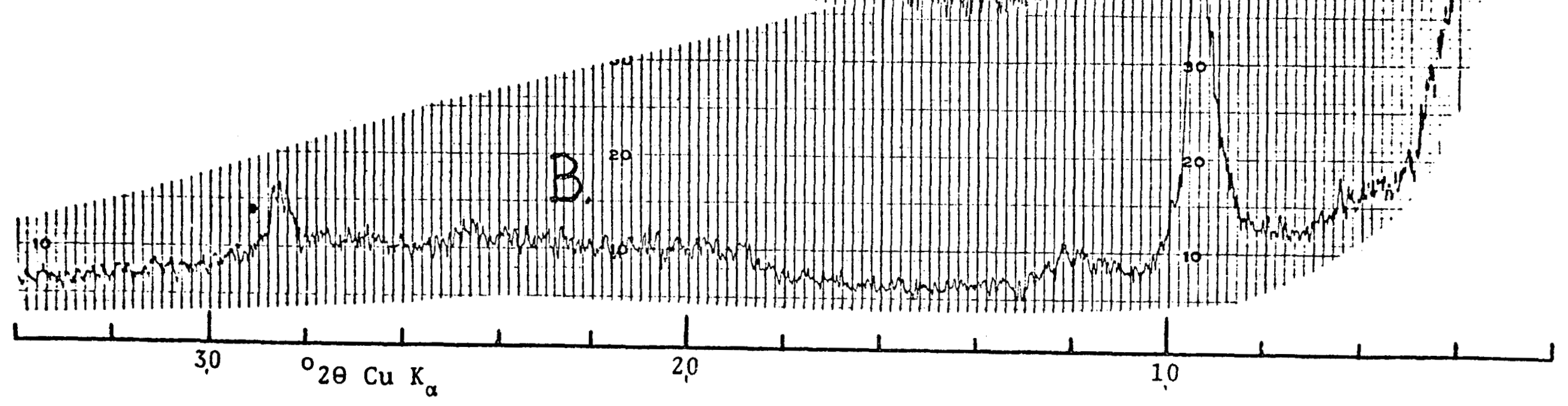




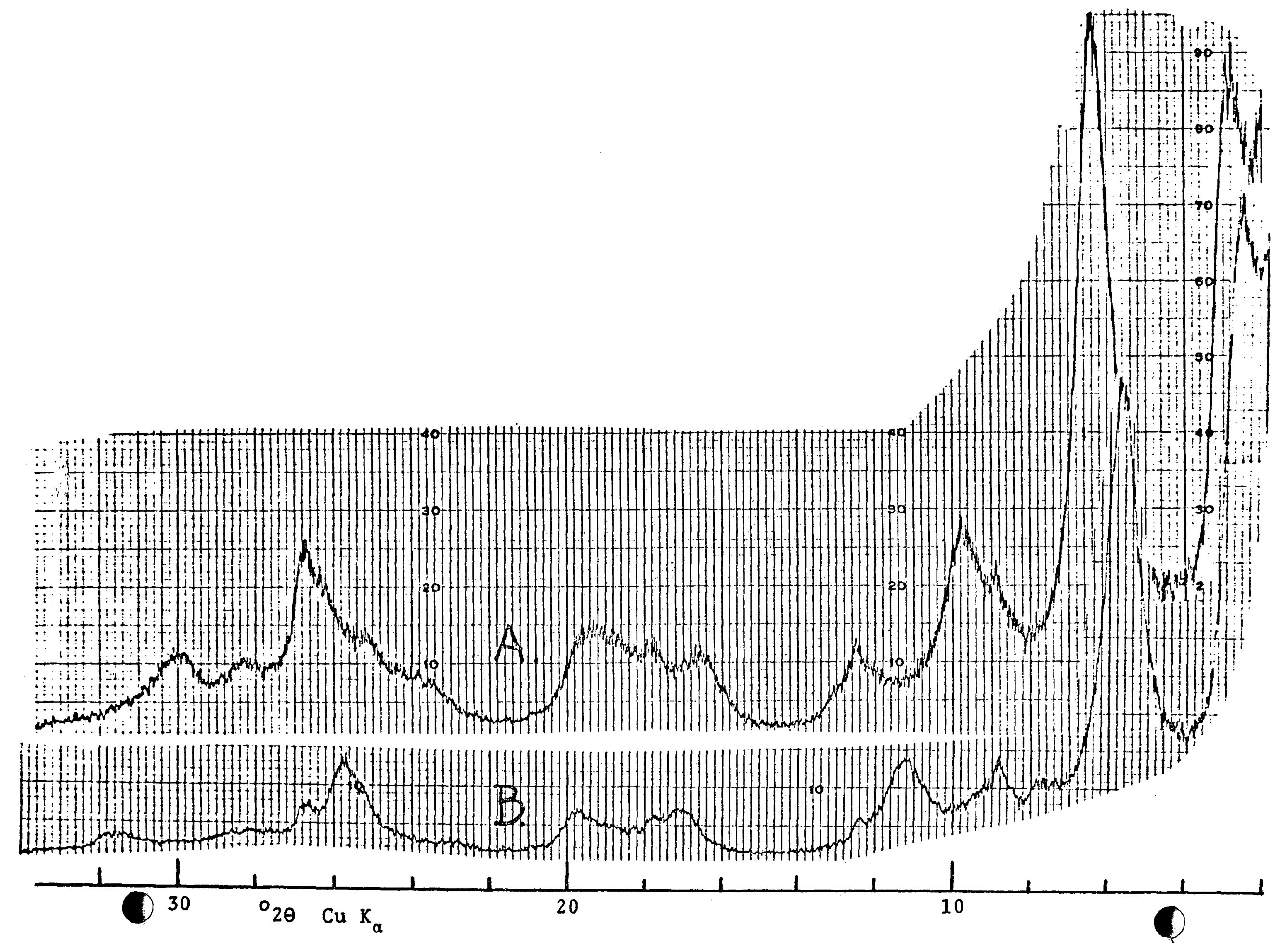




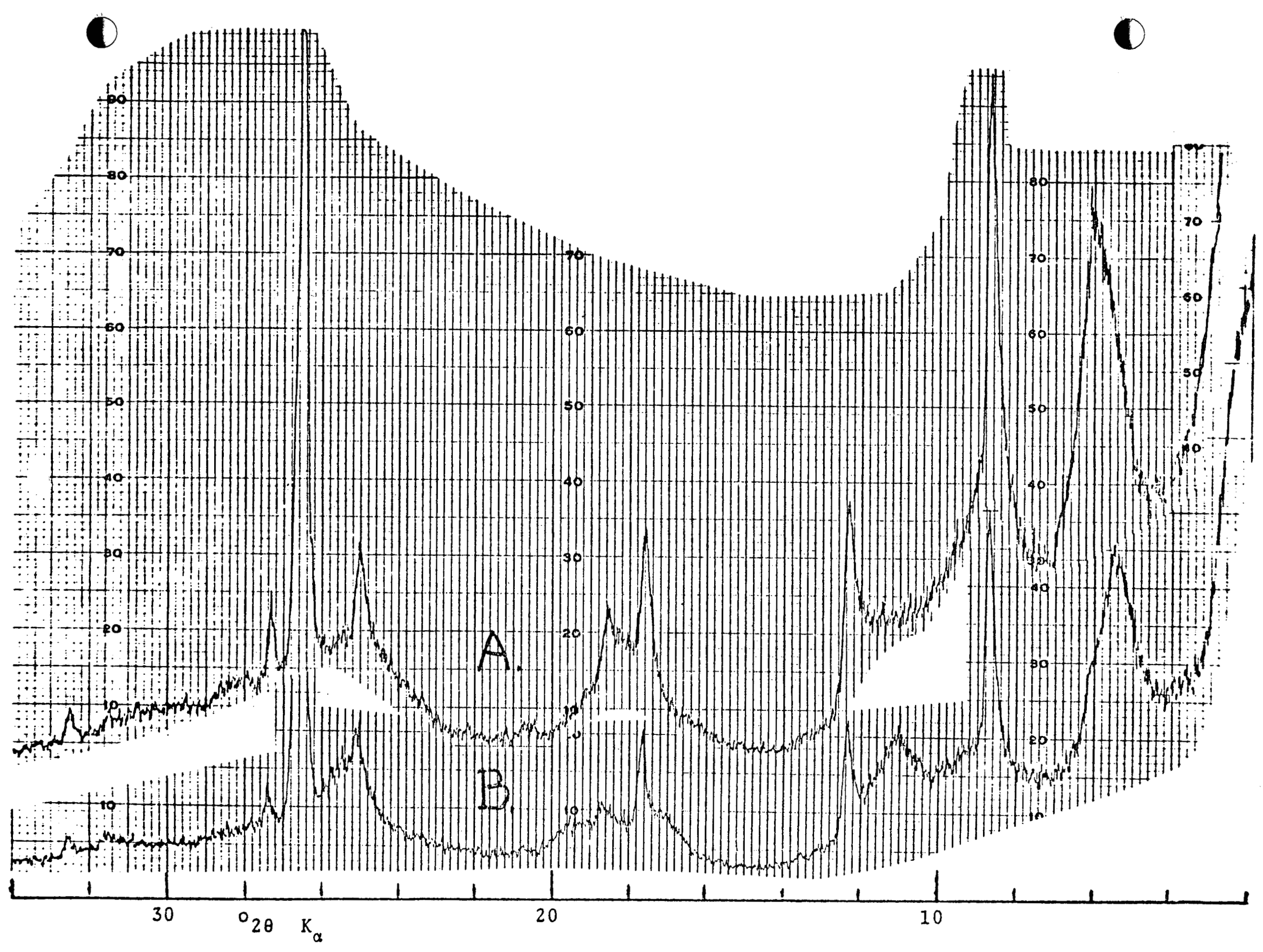




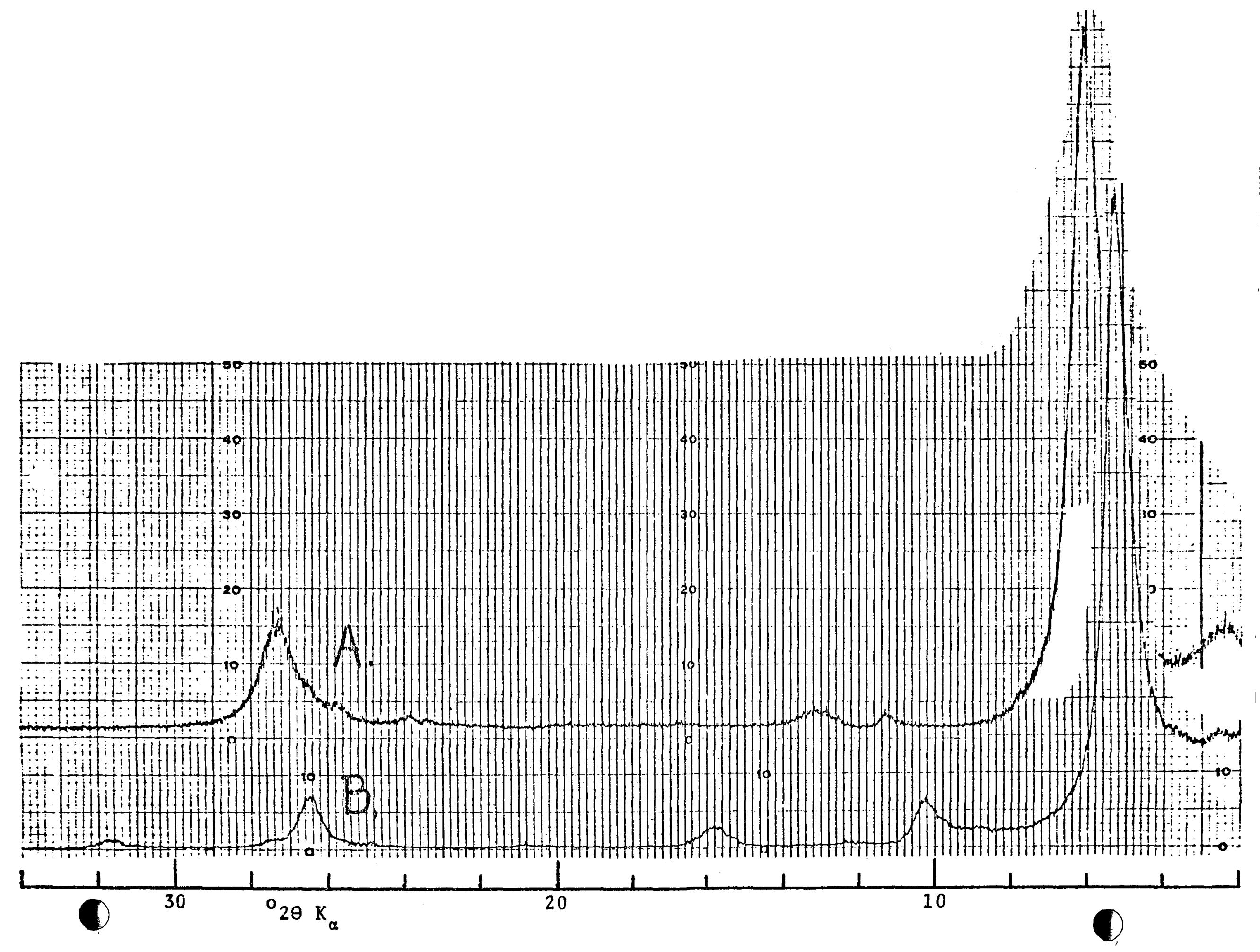


1
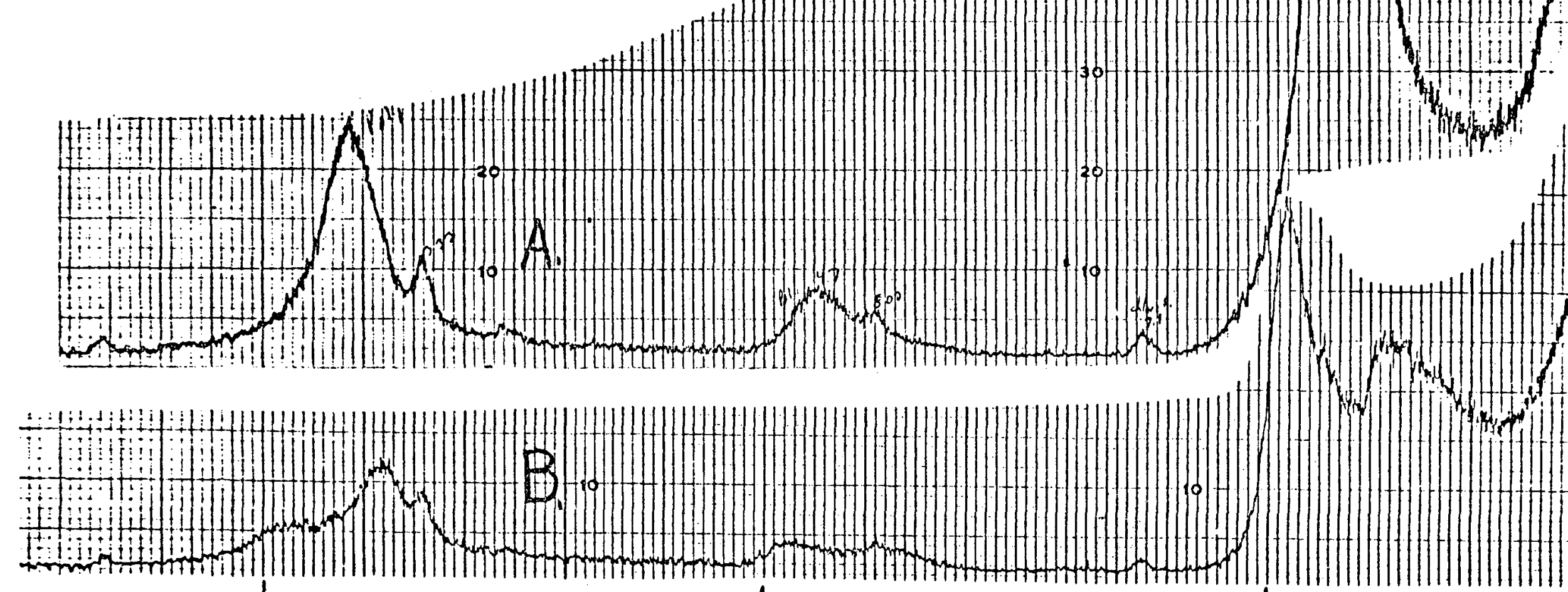
APPENDIX 7.D (Ref. sec. 7.4)

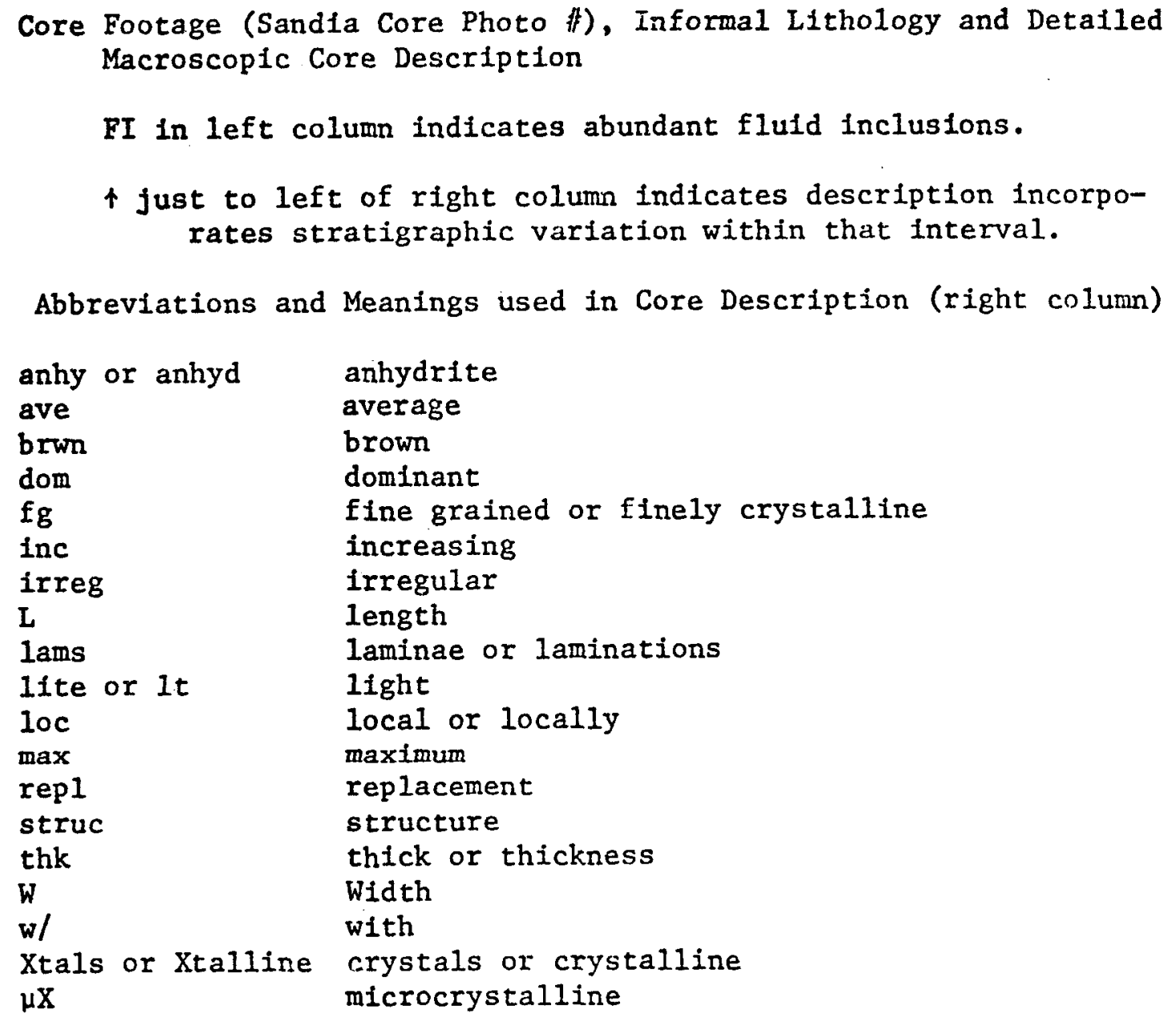

FI in left column indicates abundant fluid inclusions.

$\uparrow$ just to left of right column indicates description incorporates stratigraphic variation within that interval.

Abbreviations and Meanings used in Core Description (right column)

anhy or anhyd anhydrite

ave average

brwn brown

dom dominant

$\mathrm{fg}$ fine grained or finely crystalline

inc increasing

irreg irregular

L length

lams laminae or laminations

lite or it light

loc local or locally

max maximum

repl replacement

struc structure

thk thick or thickness

W Width

w/ with

Xtals or Xtalline crystals or crystalline

$\mu \mathrm{X}$

microcrystalline 


\begin{tabular}{|c|c|c|}
\hline $\begin{array}{c}\text { Core Footage } \\
\text { (Sandia Photo \#) }\end{array}$ & $\begin{array}{l}\text { Informal } \\
\text { L1thology }\end{array}$ & $\begin{array}{c}\text { Macroscoplc (aided by binocular microscope) Core } \\
\text { Description }\end{array}$ \\
\hline $\begin{array}{l}1162.7 \\
(27) \\
1163.7\end{array}$ & Halite & $\begin{array}{l}\text { lite brwn, clear, anhedral Xtals }(1 \mathrm{~cm}) \text {, sharp Xtal } \\
\text { boundaries of halite } \\
\text { minor } 1-4 \mathrm{~mm} \text { thk, lenses of 1ite gray, } \mu \mathrm{X} \text {, anhydrite } \\
\text { rimmed with polyhalite }\end{array}$ \\
\hline $\begin{array}{l}1165.2 \\
(28) \\
1166.6\end{array}$ & $\begin{array}{l}\text { Anhydrite w/ } \\
\text { halite "crystal } \\
\text { growth" }\end{array}$ & $\begin{array}{l}\text { dominantly gray, } \mu \text { anhydrite w/ slight color banding } \\
\text { (gray-lite gray) with: lenses }(1 / 2 \text { to } 1 \mathrm{~cm} \text { thk.) of } \\
\text { brown, clear to opaque, poorly defined anhedral Xtals } \\
\text { of halite } \\
\text { layers ( } 1 \text { to } 4 \mathrm{~cm} \text { thk) of vertically elongate } \\
\text { (L/W=2 to } 3 \text {, } L=2 \mathrm{~mm} \text { to } 31 / 2 \mathrm{~cm}) \text {, locally swallow- } \\
\text { tail, Xtals of halite }\end{array}$ \\
\hline $\begin{array}{l}1167.3 \\
(28) \\
1168\end{array}$ & $\begin{array}{l}\text { Banded } \\
\text { Anhydrite }\end{array}$ & $\begin{array}{l}\text { banding of dominantly gray, } \mu \mathrm{X} \text { anhydrite laminae } \\
\text { ( } 5-10 \mathrm{~mm} \text { thk) with white, thin (<1mm) laminae of } \mu \mathrm{X} \\
\text { magnesite } \\
\text { locally a few anhedral (some swallow tail) Xtals of } \\
\text { halite, locally vertically elongate or radiating }\end{array}$ \\
\hline $\begin{array}{l}1168 \\
(29) \\
1168.25\end{array}$ & Anhydrite & $\begin{array}{l}\text { similar to } 1165.2 \text { - } 1166.6 \text { but including laminae } \\
(\sim \mathrm{mm} \text { thick) of magnesite }\end{array}$ \\
\hline $\begin{array}{l}1168.25 \\
(2.9) \\
1169.9\end{array}$ & $\begin{array}{l}\text { brick-red } \\
\text { Polyhalite } \\
\text { and Halite }\end{array}$ & $\begin{array}{l}\text { dominantly anhedral (rare euhedral) } 1 / 2 \mathrm{~cm} \text { Xtals of } \\
\text { halite, clear to cloudy with red, } \mu \mathrm{X} \text { polyhallte } \\
\text { between and in halite crystals }\end{array}$ \\
\hline $\begin{array}{l}1172.6 \\
(30) \\
1173.5\end{array}$ & $\begin{array}{l}\text { Banded } \\
\text { Polyhalite }\end{array}$ & $\begin{array}{l}\text { prominant banding but mineralogy obscure - "brown } \\
\text { mineral" typically opaque, microcrystalline or } \\
\text { massive halite, orange to orange brown poorly bounded } \\
\text { anhedra }-1 / 2 \mathrm{~cm}-\text { silty claystone or anhydrite? } \\
\text { locally contorted banding }\end{array}$ \\
\hline
\end{tabular}




\begin{tabular}{|c|c|c|}
\hline $\begin{array}{l}\text { Core Footage } \\
\text { (Sandia Phote \#) }\end{array}$ & $\begin{array}{l}\text { Informal } \\
\text { Lithology }\end{array}$ & $\begin{array}{c}\text { Macroscopic (aided by binocular microscope) Core } \\
\text { Description }\end{array}$ \\
\hline $\begin{array}{l}1173.5 \\
(31) \\
1174.7\end{array}$ & Halite & $\begin{array}{l}\text { halite - clear to red, anhedral Xtals (ave } 1 / 2 \mathrm{~cm} \text {, } \\
\text { max } 2 \mathrm{~cm} \text { ) red from polyhalite stain; } \\
\text { minor anhydrite }\end{array}$ \\
\hline $\begin{array}{l}1404.7 \\
(103) \\
1405.7\end{array}$ & $\begin{array}{l}\text { 11th ore zone } \\
\text { (leonite, } \\
\text { kainite?) }\end{array}$ & $\begin{array}{l}\text { polyhalite ( } \pm \text { halite?) white \& cloudy to blood red, } \\
\text { massive w/ irreg. patches of dark gray claystone and } \\
\text { irreg patches of pale yellow mineral (kainite- } \\
\text { leonite?) massive patches are both vertically and } \\
\text { horizontally elongate }\end{array}$ \\
\hline $\begin{array}{l}1418 \\
(106-107) \\
1418.8\end{array}$ & $\begin{array}{l}\text { Marker Bed } 117, \\
\text { polyhalite plus } \\
\text { mud }\end{array}$ & $\begin{array}{l}\text { dominantly massive red polyhalite (w/ microscopic } \\
\text { granular texture) laminations } 1 / 2 \text { to } 11 / 2 \mathrm{~cm} \text { thk } \\
\text { alternating w/ clay laminae (<2m thk) which are } \\
\text { black \& wavy [near } 1418 \text { - claystone w/ poor hori- } \\
\text { zontal fissility plus "brown mineral" which looks } \\
\text { like halite but has bitter taste] }\end{array}$ \\
\hline $\begin{array}{l}1584 \\
(160) \\
1584.9\end{array}$ & $\begin{array}{l}\text { 5th ore zone, } \\
\text { very dirty }\end{array}$ & $\begin{array}{l}\text { dominantly hallte - clear anhedra }-1 \mathrm{~cm} \text { (max } 2 \mathrm{~cm} \text { ) } \\
\text { locally stained by "brown mineral" } \mu X t a 11 \text { ine coatings } \\
\& \text { locally patches a few mm in size; minor patches of } \\
\text { gray } \mu X \text { anhydrite }\end{array}$ \\
\hline $\begin{array}{l}1609.1 \\
(168) \\
1610.3\end{array}$ & $\begin{array}{c}\text { Clear Halite } \\
\text { ( } 2 \text { ft above } \\
\text { polyhalite) }\end{array}$ & $\begin{array}{l}\text { dominantly halite - brwn (due to polyhalite stain?) } \\
\text { indistinct anhedral about } 11 / 2 \mathrm{~cm} \text {; minor evenly } \\
\text { dispersed polyhalite stain, and patches ( } 2 \mathrm{~mm} \text { ) of } \\
\text { gray material (anhydrite or clay?) }\end{array}$ \\
\hline $\begin{array}{l}1632 \\
(175) \\
1632.8\end{array}$ & Mudstone & $\begin{array}{l}\text { near top: banded anhydrite - claystone; } \\
\text { anhydrite dark gray, } \mu X \text { - laminae up to } 2 \mathrm{~mm} \text { thk, } \\
\text { locally vertically elongate masses or Xtals; } \\
\text { claystone lite grey, laminae from } 1 / 2 \mathrm{~mm} \text { to } 1 / 2 \mathrm{~cm} \\
\text { (thk Inc. upward) } \\
\text { near base: polyhalite w/ gray clay }\end{array}$ \\
\hline
\end{tabular}




\begin{tabular}{|c|c|c|c|}
\hline $\begin{array}{l}\text { Core Footage } \\
\text { (Sandia Photo }(\text { ) }\end{array}$ & $\begin{array}{l}\text { Informal } \\
\text { Lithology }\end{array}$ & & $\begin{array}{c}\text { Macroscopic (aided by binocular microscope) Core } \\
\text { Description }\end{array}$ \\
\hline $\begin{array}{l}1648.5 \\
(180-181) \\
1649.7\end{array}$ & $\begin{array}{l}4 \text { th ore zone } \\
\text { halite, bloedite, } \\
\text { vanthoffite }\end{array}$ & & $\begin{array}{l}\text { dominantly halite - lite brown anhedra }-3 / 4 \mathrm{~cm} \\
\text { locally red, } \mu X t a 1 \text { polyhallte as stain \& repl. of } \\
\text { halite - some lenses and Xtal coatings of gray } \mu \mathrm{X} \\
\text { anhydrite? }\end{array}$ \\
\hline $\begin{array}{l}2034.3 \\
2037.3\end{array}$ & Halite & $\uparrow$ & $\begin{array}{l}\text { dominantly halite: finely crystalline \& clayey near } \\
\text { top - coarsely crystalline \& banded anhydrite \&/or } \\
\text { polyhalite near center - finely crystalline \& banded } \\
\text { w/ anhydrite near base }\end{array}$ \\
\hline 2065.2 & Halite & & $\begin{array}{l}\text { dominantly coarsely Xtalline }(-2 \mathrm{~cm}) \text { clear, anhedral } \\
\text { halite w/ patches, lenses \& stains of "brown materlal" } \\
\text { (polyhalite, carnallite, glauberite?) loc w/ radiating } \\
\text { actcular texture }\end{array}$ \\
\hline $\begin{array}{l}2301.6 \\
(384) \\
2302.7\end{array}$ & $\begin{array}{l}\text { lite colored } \\
\text { Polyhalite }\end{array}$ & & $\begin{array}{l}\text { dominantly red, } \mu \text { x polyhalite - locally crinkly } \\
\text { flakes \& irreg. patches of white fg. material }\end{array}$ \\
\hline $\begin{array}{l}2413.6 \\
(418-419) \\
2415.7\end{array}$ & $\begin{array}{l}\text { pure \& impure } \\
\text { Polyhalite }\end{array}$ & $\uparrow$ & $\begin{array}{l}\text { dominantly poorly thickly banded polyhalite w/ sub- } \\
\text { equal lenses of anhydrlte \& hallte } \\
\text { polyhalite: pinkish brown to red, } \mu X \\
\text { halite: med. to coarsely Xtal, usually anhedral but } \\
\text { some euhedra, typically clear } \\
\text { anhydrite: layers, lenses and interXtalline patches, } \\
\text { gray, } \mu X, \text { locally brown }\end{array}$ \\
\hline $\begin{array}{l}2512 \\
(450) \\
2512.5\end{array}$ & dirty Halite & & $\begin{array}{l}\text { dominantly halite-gray, clear to cloudy, anhedral, } \\
1 \mathrm{~cm} \text { Xtal; minor light gray anhydrite as interXtalline } \\
\text { patches }\end{array}$ \\
\hline $\begin{array}{l}2515.6 \\
(452+) \\
2519.2\end{array}$ & $\begin{array}{l}\text { typical massive } \\
\text { Cowden Anhy. }\end{array}$ & $\uparrow$ & $\begin{array}{l}\text { (halite above } 2516.9 \text { ) } \\
\text { faintly banded gray, } \mu \mathrm{X} \text {, anhydrite } w / \text { wispy lenses } \\
\text { of magnesite } \\
\text { very minor halite }\end{array}$ \\
\hline
\end{tabular}




\begin{tabular}{|c|c|c|c|}
\hline $\begin{array}{l}\text { Core Footage } \\
\text { (Sandia Photo \#) }\end{array}$ & $\begin{array}{l}\text { Informal } \\
\text { Lithology }\end{array}$ & & $\begin{array}{c}\text { Macroscopic (aided by binocular microscope) Core } \\
\text { Description }\end{array}$ \\
\hline $\begin{array}{l}2527.7 \\
(456+) \\
2529.2\end{array}$ & $\begin{array}{l}\text { typical } \\
\text { laminated } \\
\text { Cowden Anhy. }\end{array}$ & & $\begin{array}{l}\text { laminations of gray, } \mu \mathrm{X} \text {, anhydrite - lam up to } 11 / 2 \\
\mathrm{~cm} \text { (some needle like \& loc radiating into magnesite) } \\
\text { white, opaque } \mu \mathrm{X} \text { magnesite lams, wavy, <1mm to } 3 \mathrm{~mm} \text { thk }\end{array}$ \\
\hline $\begin{array}{l}2538.5 \\
(459) \\
2539.4\end{array}$ & $\begin{array}{l}\text { base of } \\
\text { Cowden Anhy. }\end{array}$ & $\uparrow$ & $\begin{array}{l}\text { top: faintly banded (color) } \mu X \text { anhydrite, minor } \\
\text { patches of halite } \\
\text { dominantly coarsely Xtalline }(\sim 1 \mathrm{~cm}) \text { clear, anhedral } \\
\text { halite w/ lenses \& interXtalline anhydrite } \\
\text { base: similar to middle but hallte Xtal size decreases } \\
\text { to } \sim 1 \mathrm{~mm}\end{array}$ \\
\hline $\begin{array}{l}2541 \\
(460) \\
2542.5\end{array}$ & $\begin{array}{l}\text { dirty halite } \\
\text { just below } \\
\text { Cowden }\end{array}$ & & $\begin{array}{l}\text { dominantly halite - gray, clear to cloudy, anhedral } \\
\text { Xtals (ave } 1 \mathrm{~cm},<1 \mathrm{~mm} \text { to } 3 \mathrm{~cm} \text { ) } \\
\text { minor anhydrite (or magnesite?) - interXtalline } \\
\text { patches ( } 1 \text { or } 2 \mathrm{~cm} \text { by } 2 \mathrm{~mm})\end{array}$ \\
\hline $\begin{array}{l}2606.5 \\
2608.8\end{array}$ & Halite & & $\begin{array}{l}\text { dominantly halite - typically clear but some cloudy, } \\
\text { white to gray anhedra typically }-1 \mathrm{~cm} \text { but three } 3 \mathrm{~cm} \\
\text { thk zones of ave size - } 2 \mathrm{~mm} \text { which tend to be gray; } \\
\text { minor anhydrite - interXtalline gray, } \mu \mathrm{X}\end{array}$ \\
\hline $\begin{array}{l}2614.7 \\
2615.6\end{array}$ & Halite & & $\begin{array}{l}\text { dom. halite }- \text { clear white euhedra \& subhedra, most } \\
\text { anhedra, ave } 2 \mathrm{~cm}(<1 \mathrm{~mm} \text { to } 4 \mathrm{~cm}) ; \\
\text { minor anhydrite - } 1 \text { t gray to white, } \mu \mathrm{x} \text {, interXtalline }\end{array}$ \\
\hline $\begin{array}{l}2615.9 \\
2619.5\end{array}$ & Halite & $\uparrow$ & $\begin{array}{l}15.9-16.5 \text { dom halite }- \text { clear, white to gray, anhedra, } \\
\text { ave } 2 \mathrm{~cm}(1 / 2-6 \mathrm{~cm}) \mathrm{w} / \mathrm{v} \text { minor gray-white, } \mu \mathrm{X} \text {, } \\
\text { interXtalline anhyd or magnesite } \\
16.5-18.4 \text { dom halite }- \text { clear to cloudy, white to } \\
\text { gray anhedra, ave } 1 \mathrm{~cm}(<1 \mathrm{~mm}-2 \mathrm{~cm}) \text { locally } \\
\text { "chevron struc" within ( } 8 \text { across) Xtals } \\
\text { w/ minor gray-white, } \mu x \text {, interXtalline anhyd or } \\
\text { magnesite } \\
18.4-19.5 \text { similar to } 15.9-16.5\end{array}$ \\
\hline
\end{tabular}




\begin{tabular}{|c|c|c|}
\hline $\begin{array}{l}\text { Core Footage } \\
\text { (Sandia Photo }{ }^{\text {(Sa) }}\end{array}$ & $\begin{array}{l}\text { Informal } \\
\text { Lithology }\end{array}$ & $\begin{array}{c}\text { Macroscopic (aided by binocular microscope) Core } \\
\text { Description }\end{array}$ \\
\hline $\begin{array}{l}(2705.7) \\
2704.8 \\
(509) \\
(2706.8) \\
2706.5\end{array}$ & $\begin{array}{l}\text { mottled } \\
\text { Anhy \& } \\
\text { Halite }\end{array}$ & $\begin{array}{l}\text { dominantly halite - coarsely Xtalline ( } 1 \text { to } 11 / 2 \mathrm{~cm}) \\
\text { anhedral, clear to white cloudy cut at }-45^{\circ} \text { by zones } \\
\text { more finely Xtalline halite and mixed w/ up to } 30 \% \\
\text { interXtalline gray, } \mu \mathrm{X} \text {, anhydrite (w/ minor magnesite) }\end{array}$ \\
\hline $\begin{array}{l}2758 \\
(526) \\
2759.3\end{array}$ & $\begin{array}{l}\text { dirty } \\
\text { Halite }\end{array}$ & $\begin{array}{l}\text { dom halite }- \text { light to dk gray, anhedra, ave }-1 \mathrm{~cm} \\
\text { ( }<1 \mathrm{~mm} \text { to } 3 \mathrm{~cm} \text { ) } \mathrm{w} / \mathrm{minor} \text { anhydrite }-\mathrm{dk} \text { gray, } \mu \mathrm{X} \\
\text { (but some microlites) as interXtall material }\end{array}$ \\
\hline $\begin{array}{l}2819.1 \\
(545) \\
2819.8\end{array}$ & $\begin{array}{l}\text { clean } \\
\text { Halite, } \\
\text { slightly } \\
\text { banded }\end{array}$ & $\begin{array}{l}\text { dom halite - cloudy, white to } 1 t \text {. gray, anhedral; } \\
\text { faint banding by ave Xtal size variation from } 1 / 2 \text { to } \\
1 \mathrm{~cm} \text {, finer Xtalline tends to be whiter; minor thin } \\
\text { horlzontal lenses (rare patches), white, } \mu X \text { (rare } \\
\text { microlites) }\end{array}$ \\
\hline $\begin{array}{l}2819.9 \\
(545) \\
2820.9 A\end{array}$ & see above & $\begin{array}{l}\text { dom anhydrite }-1 \text { gray to dk gray (locally banded), } \mu \mathrm{x} ; \\
\text { subordinate halite - irreg lenses \& patches } \\
\text { (frequently thin \& horiz elongate) } \\
\text { unusually sharp contacts between anhydrite \& halite }\end{array}$ \\
\hline $\begin{array}{l}2820 \text { B } \\
(545-546) \\
2820.6 B\end{array}$ & see above & $\begin{array}{l}\text { same as } 19.9-20.9 \mathrm{~A} \text { except } \\
\text { anhydrite locally brown and may contain magnesite }\end{array}$ \\
\hline $\begin{array}{l}2820.6 B \\
(546) \\
2821.9\end{array}$ & see above & $\begin{array}{l}\text { dom halite - cloudy, white, anhedral, ave } 1 \mathrm{~cm} \\
(<1 \mathrm{~mm} \text { to } 2 \mathrm{~cm}) \text {; very rare lense of wh to } 1 \mathrm{t} \text { gray, } \\
\mu \mathrm{X} \text { anhydrite possibly } \mathrm{w} / \text { magnesite }\end{array}$ \\
\hline $\begin{array}{l}2826.5 \\
2827.5\end{array}$ & $\begin{array}{l}\text { dirty } \\
\text { Halite }\end{array}$ & $\begin{array}{l}\text { dom halite - poorly developed banding from clear, to } \\
\text { cloudy white, to opaque dk gray, anhedral crystals ave } \\
1 / 2-1 \mathrm{~cm} \\
\text { some magnesite (or anhydrite) - thin Irreg seams \& } \\
\text { wavy lams (both horiz), white, } \mu \mathrm{X}\end{array}$ \\
\hline
\end{tabular}




\begin{tabular}{|c|c|c|}
\hline $\begin{array}{l}\text { Core Footage } \\
\text { (Sandia Photo \#) }\end{array}$ & $\begin{array}{l}\text { Informal } \\
\text { Lithology }\end{array}$ & $\begin{array}{c}\text { Macroscopic (aided by binocular microscope) Core } \\
\text { Description }\end{array}$ \\
\hline $\begin{array}{l}2845.6 \\
2846.4\end{array}$ & $\begin{array}{l}\text { massive light } \\
\text { Anhydrite } \\
\text { (in Castile) }\end{array}$ & $\begin{array}{l}\text { dom anhydrite - mottled from clear to white \& cloudy } \\
\text { to gray to dk gray } \\
\text { sub. magnesite - thin seams and irreg patches, } \mu \mathrm{X}\end{array}$ \\
\hline $\begin{array}{l}2847.8 \\
2849.1\end{array}$ & $\begin{array}{l}\text { banded } \\
\text { light } \\
\text { Anhydrite }\end{array}$ & $\begin{array}{l}\text { dom anhydrite - banded from clear, to white \& cloudy, } \\
\text { to gray to dk gray, to black; clear tends to occur } \\
\text { in laminae \& lenses, locally "enterolithic" contor- } \\
\text { tions and w/ smooth lower contacts \& irreg "swallow- } \\
\text { tail" upper contacts; } \\
\text { subordinate magnesite }\end{array}$ \\
\hline
\end{tabular}




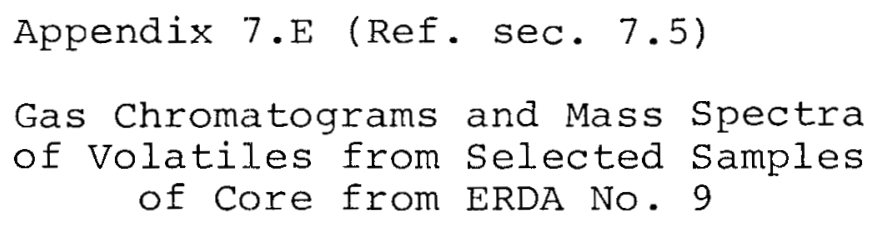

Mass spectra are reported as intensity (normalized to the highest mass peak) as a function of mass/charge ratio (in atomic mass units). Gas chromatograms are reported as intensity of elution peaks (normalized to the highest elution peak) as a function of relative elution time (in arbitrary units). 


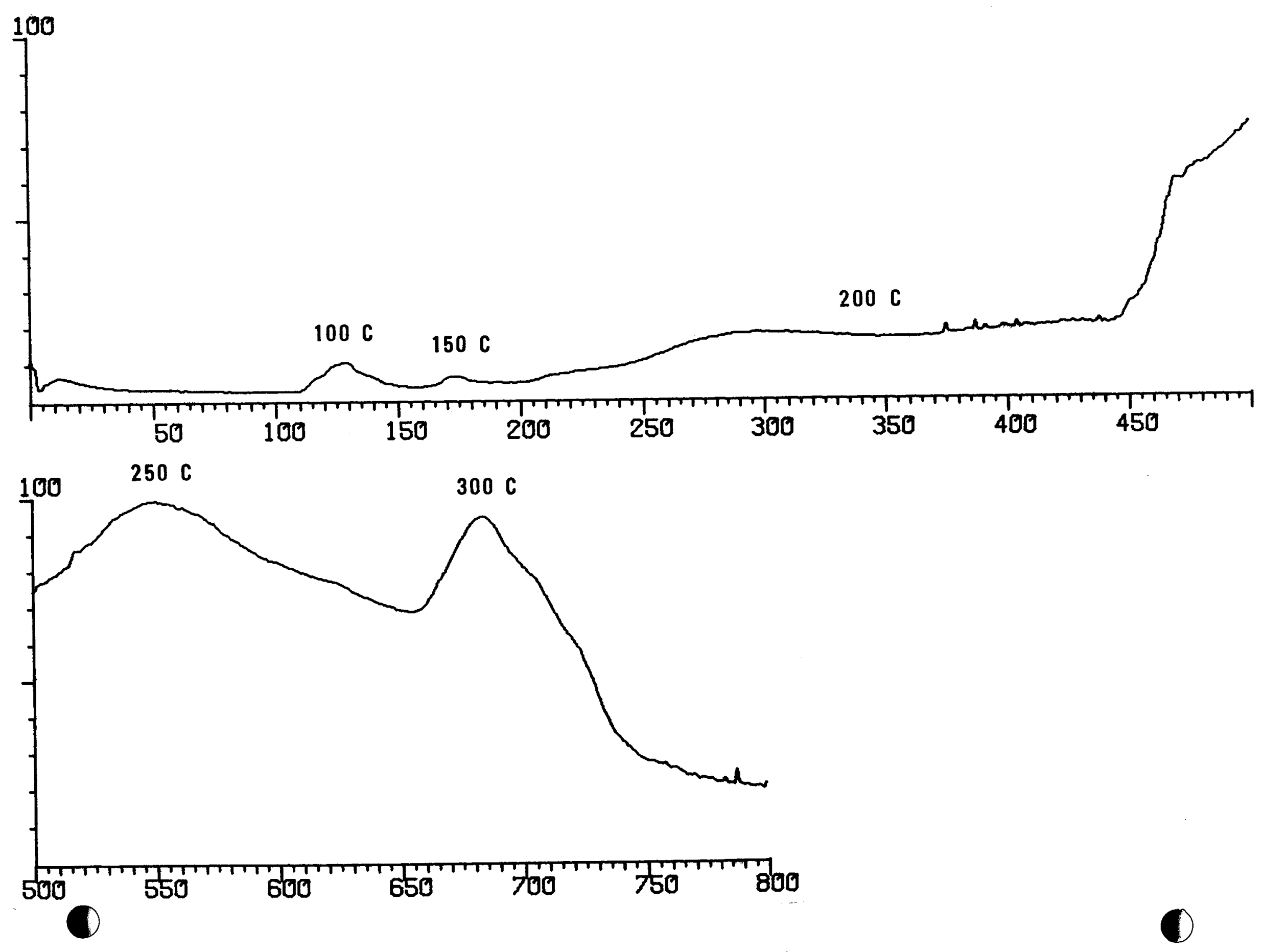


SALT SAMPLE

* 12

MASS SPECTRA $50 \mathrm{C} \times 3$

100

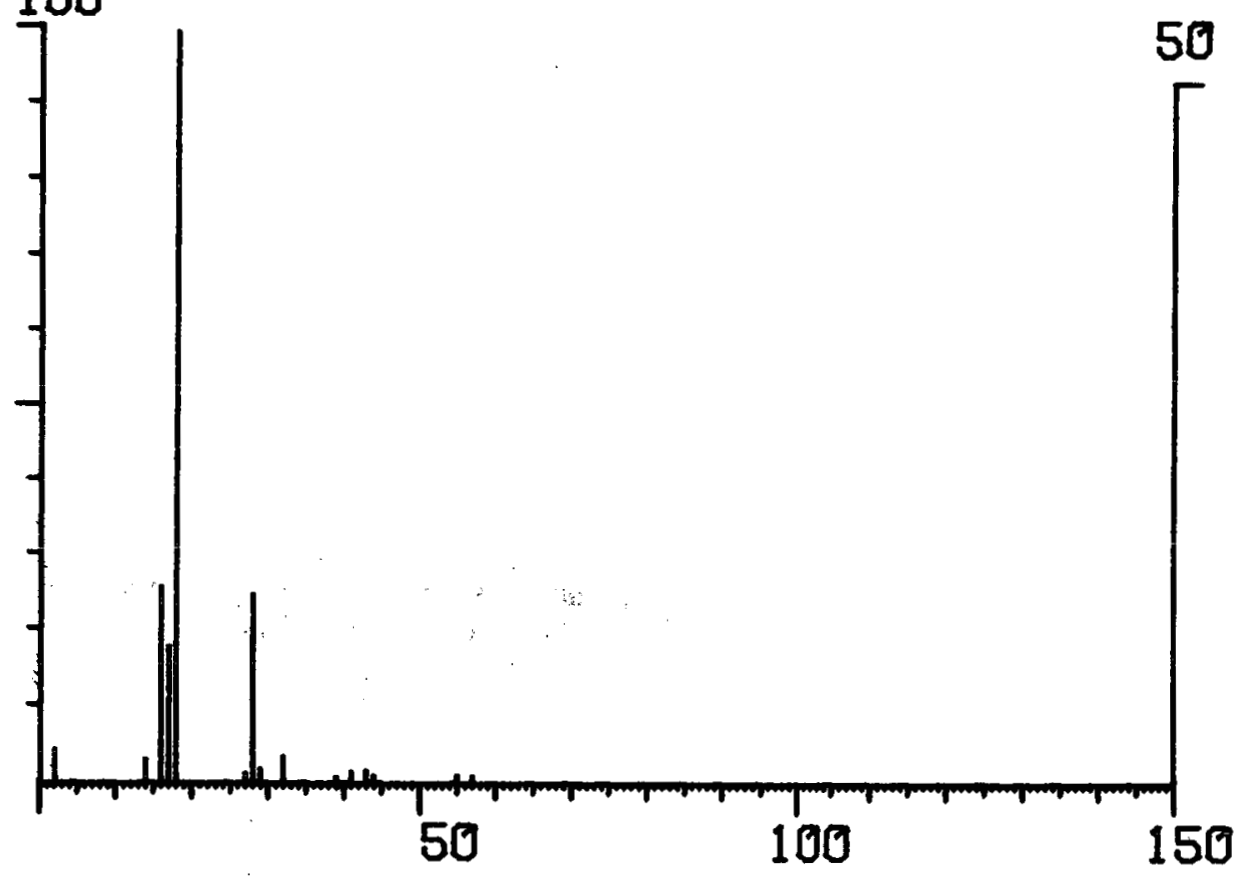




\section{SALT SAMPLE}

\# 128 MASS SPECTRA 100C X3

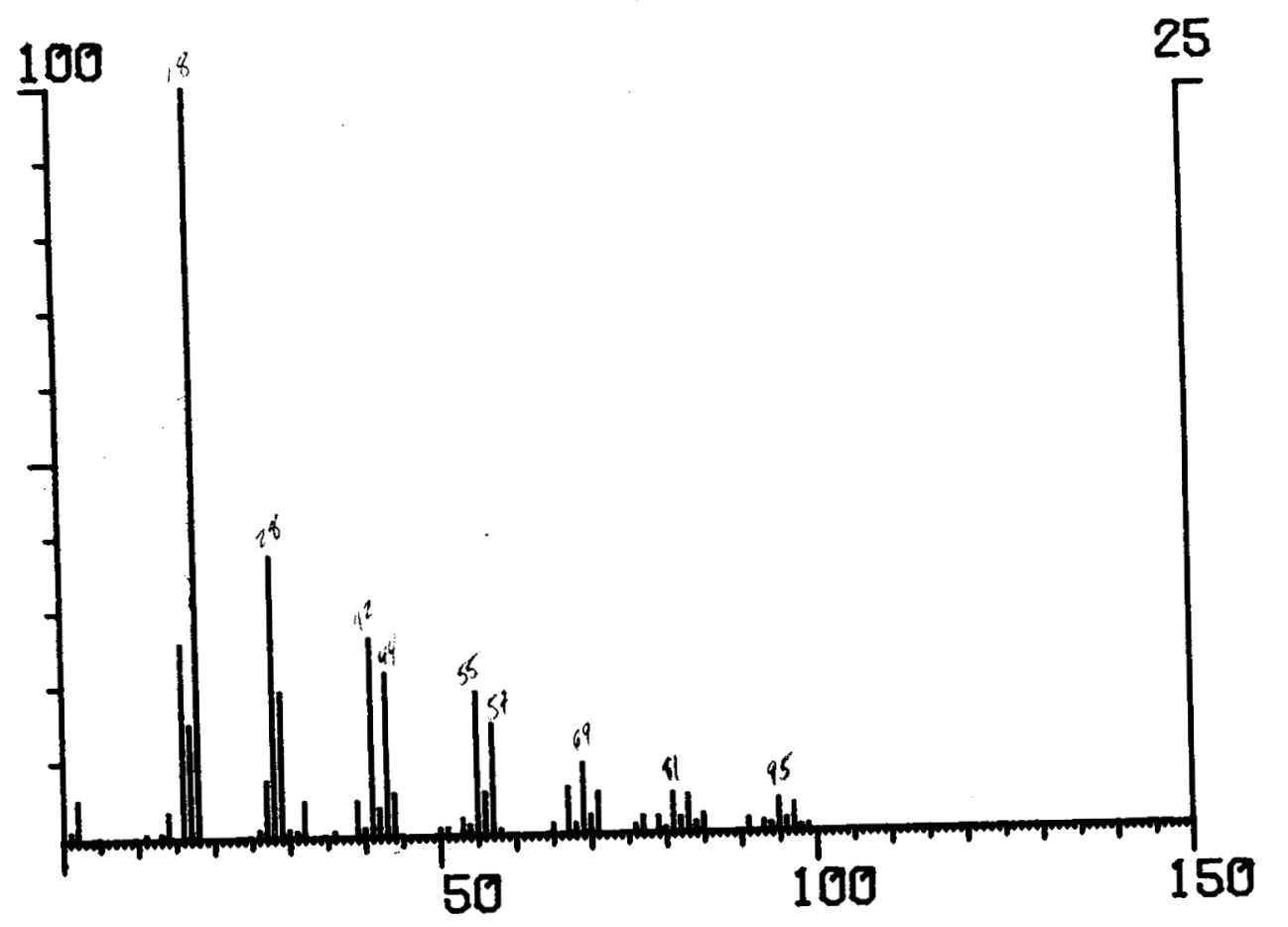

2302.6 
SALT SAMPLE

2302.6

* 174 MASS SPECTRA 150C $\times 3$

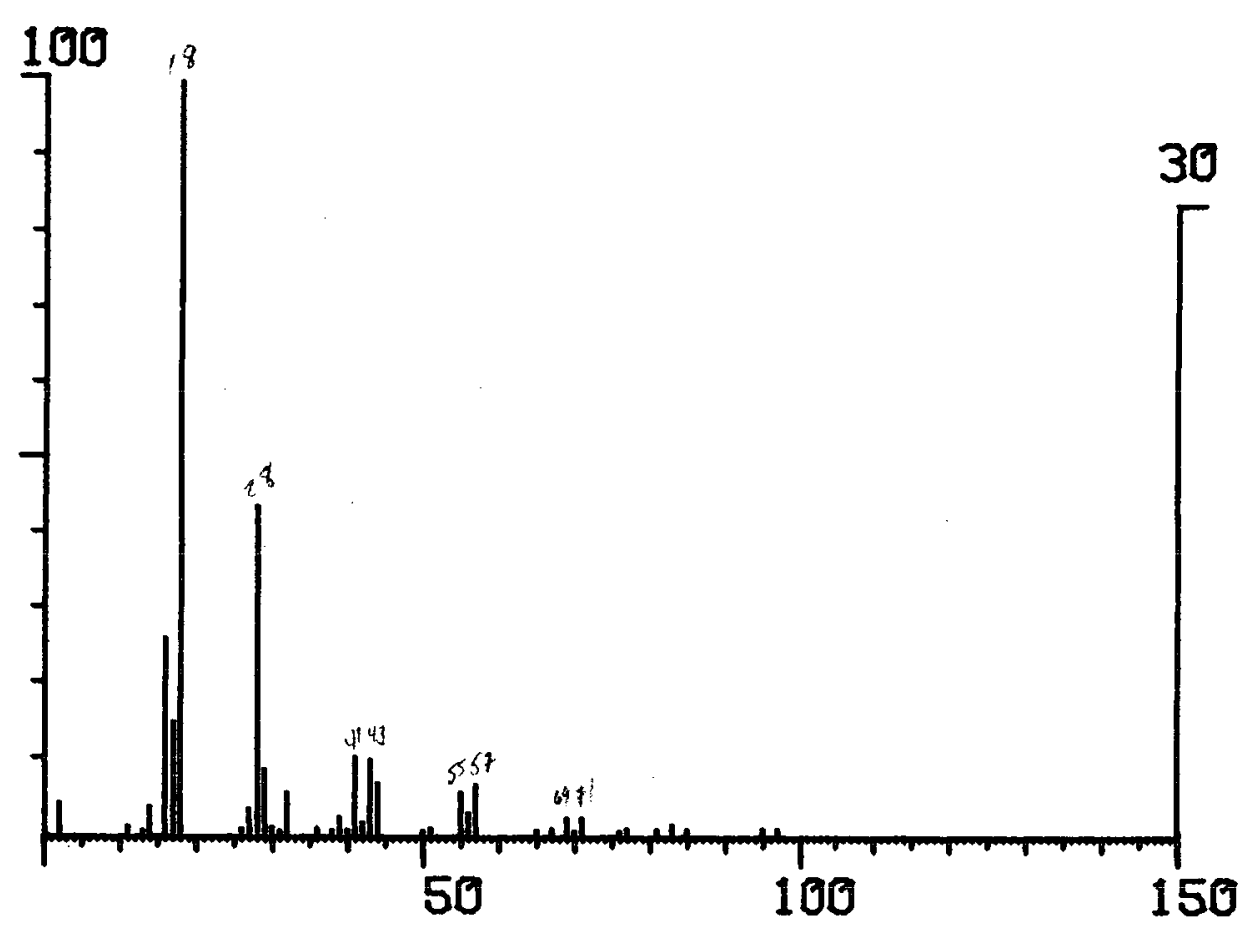


SALT SAMPLE

* 297 MASS SPECTRA 200C X4

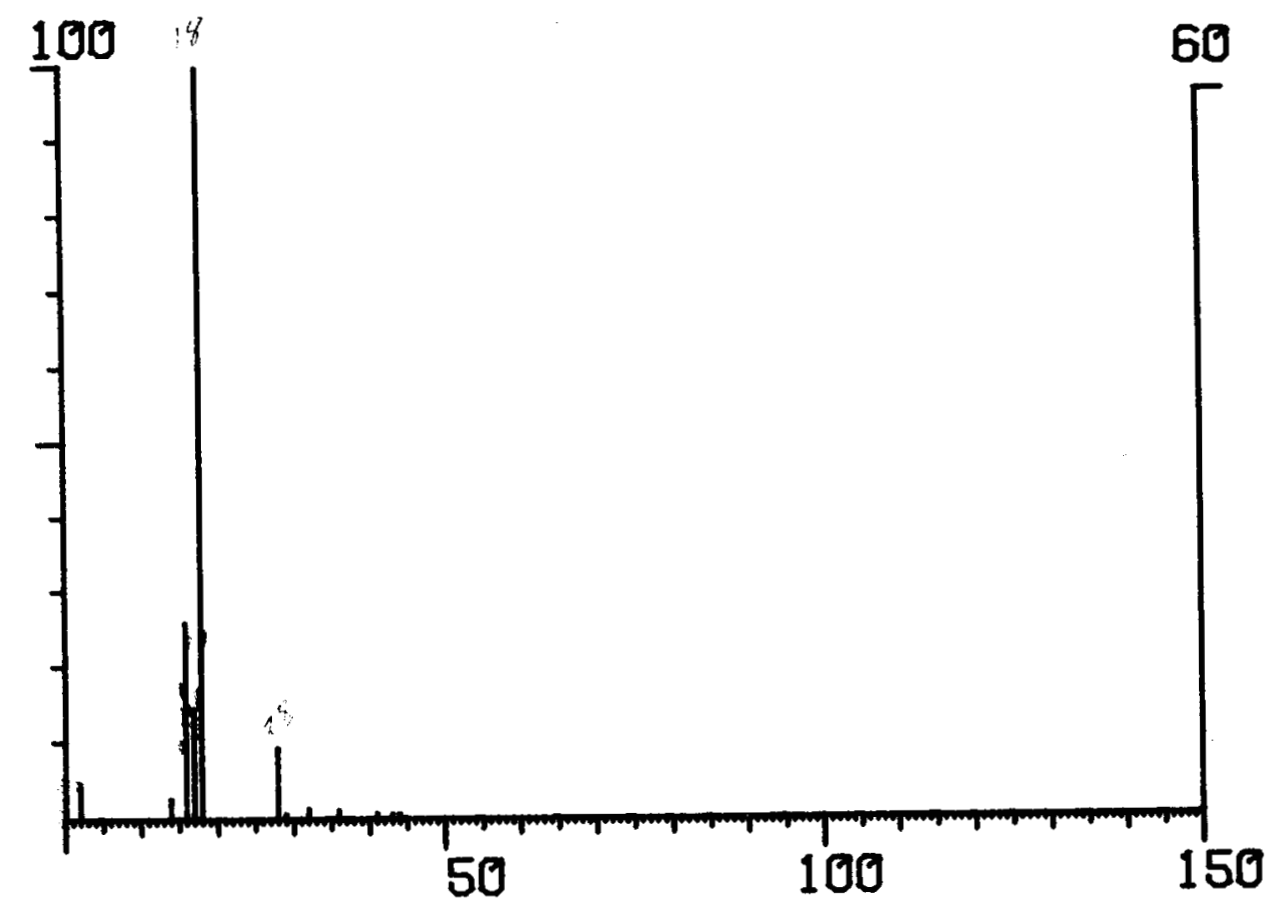


1

SALT SAMPLE

\# 550

MASS SPECTRA $250 C \times 4$

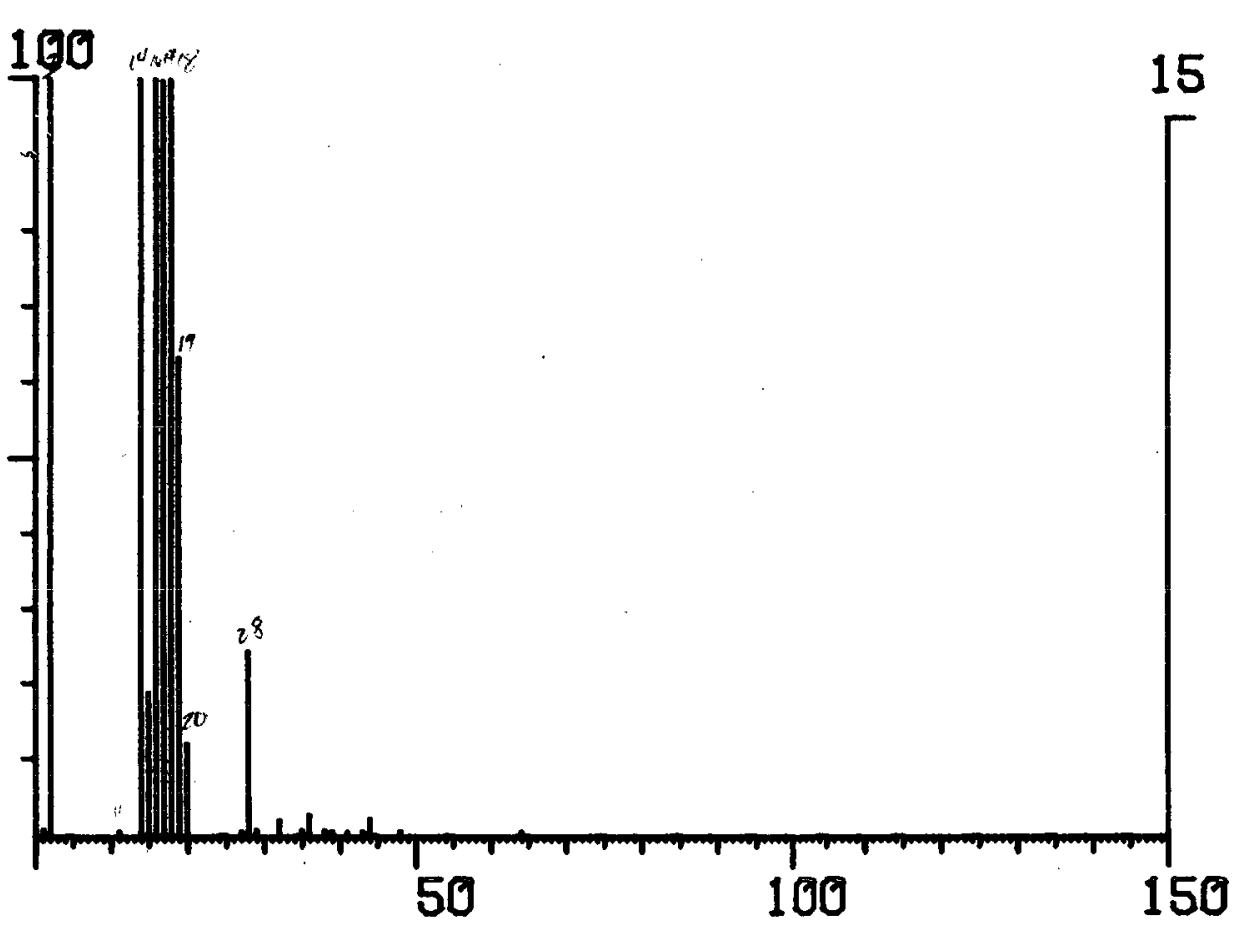


SALT SAMPLE

2302.6

* 686

MASS SPECTRA $300 C \times 4$

100

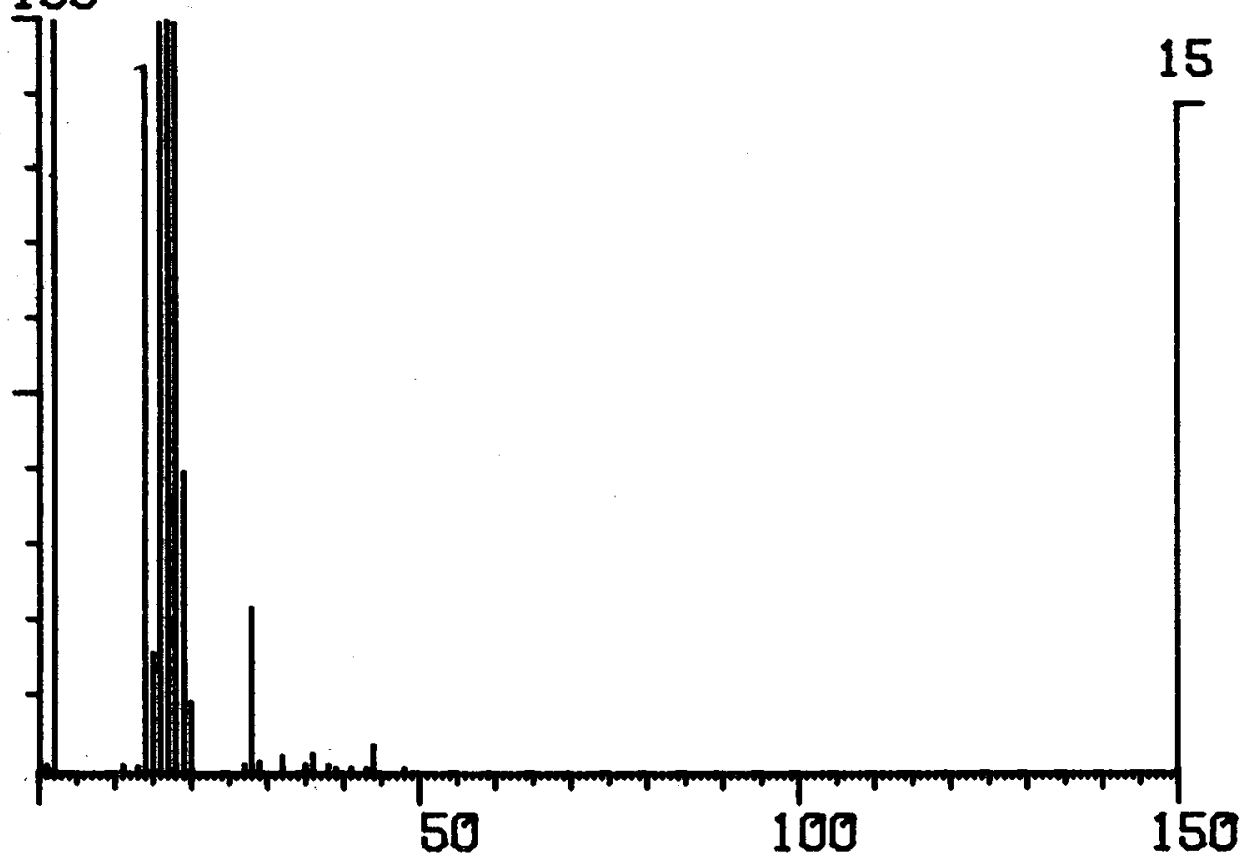


MASS 14 SEARCH $\times 5$
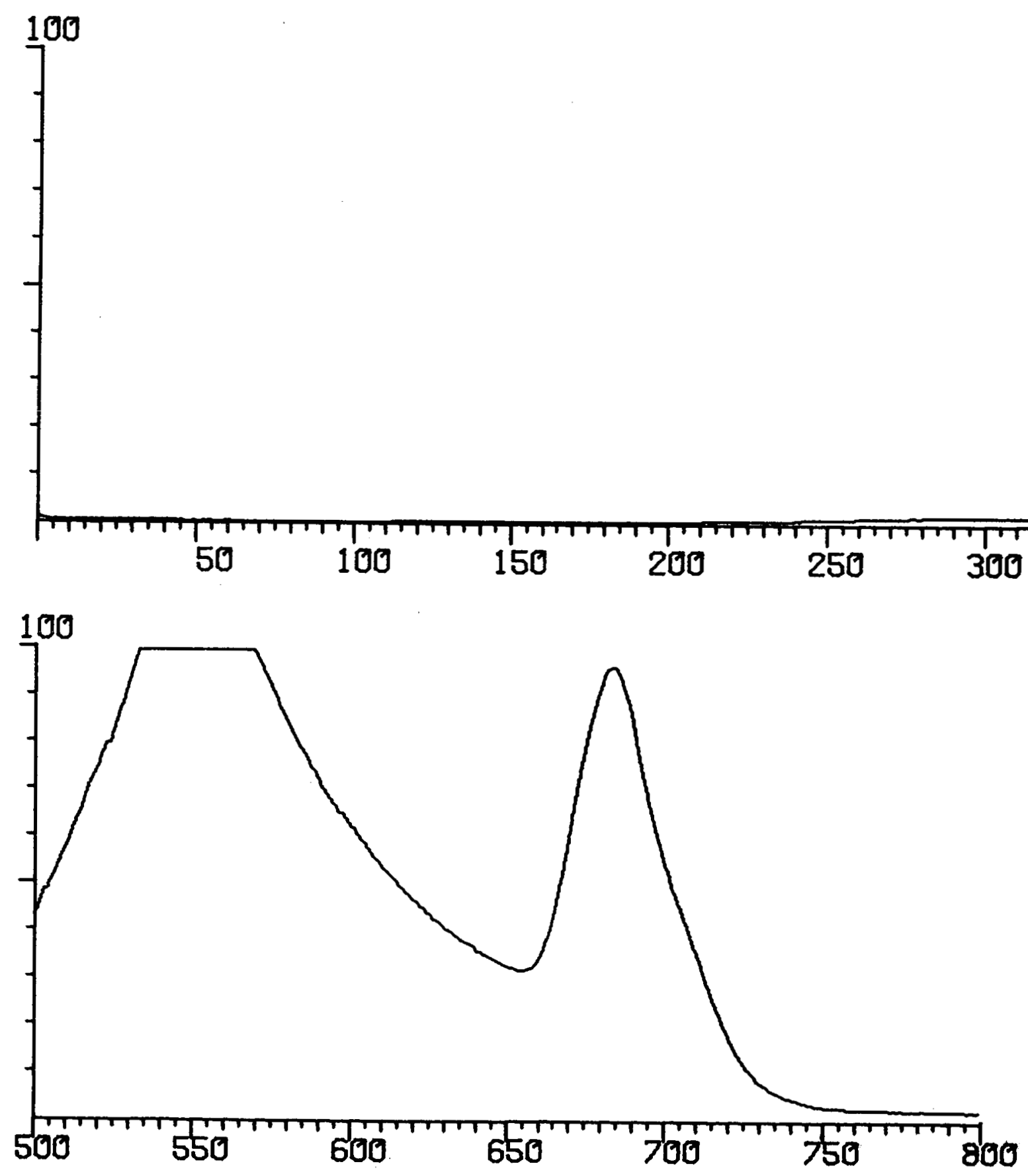
SALT SAMPLE

2302.6

MASS 18 SEARCH $\times 4$
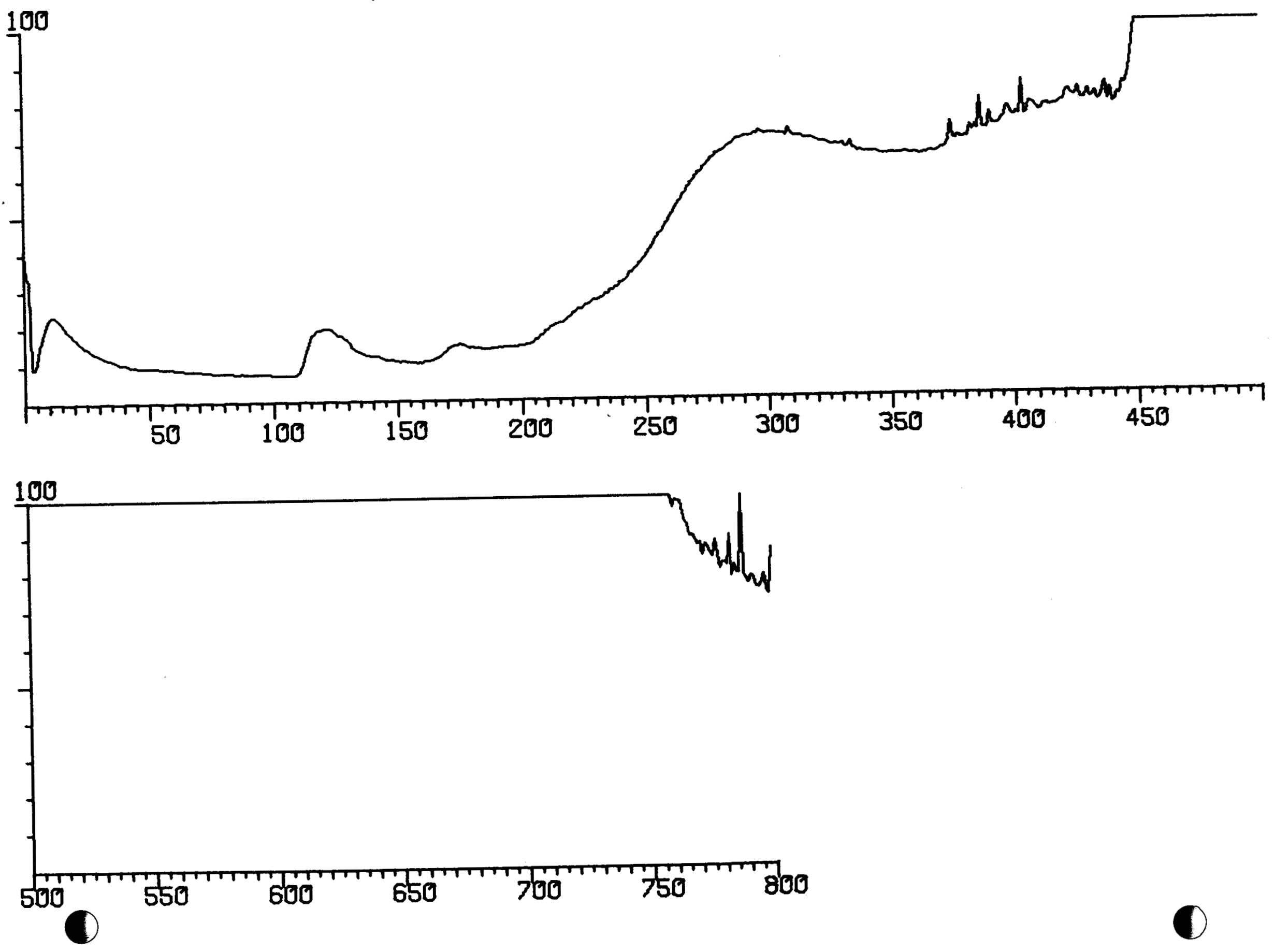
1

SALT SAMPLE

MASS 19 SERRCH $\times 4$
2302.6

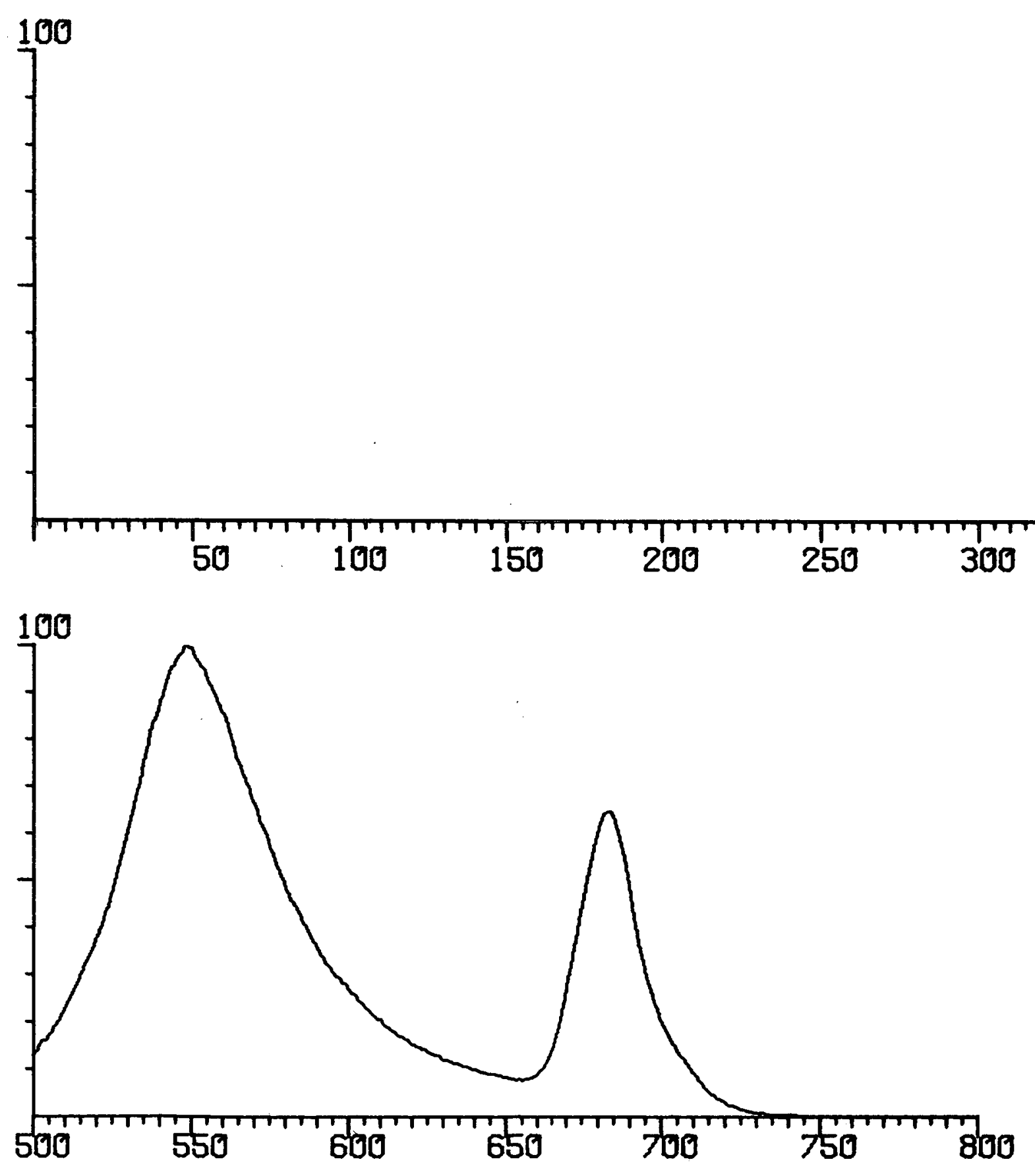




\section{MASS 20 SEARCH $\times 3$}

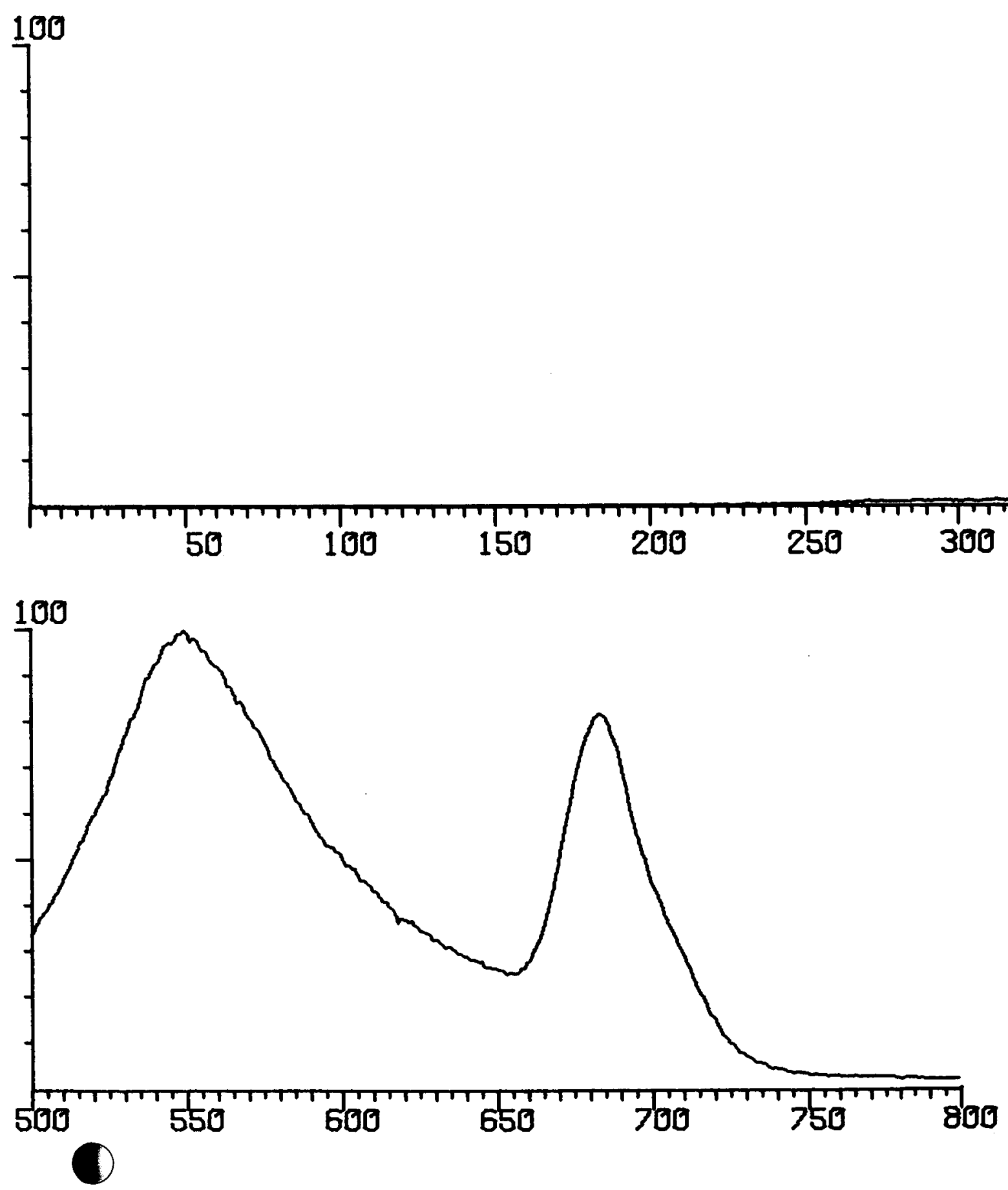


MASS 32 SEARCH $\times 2$
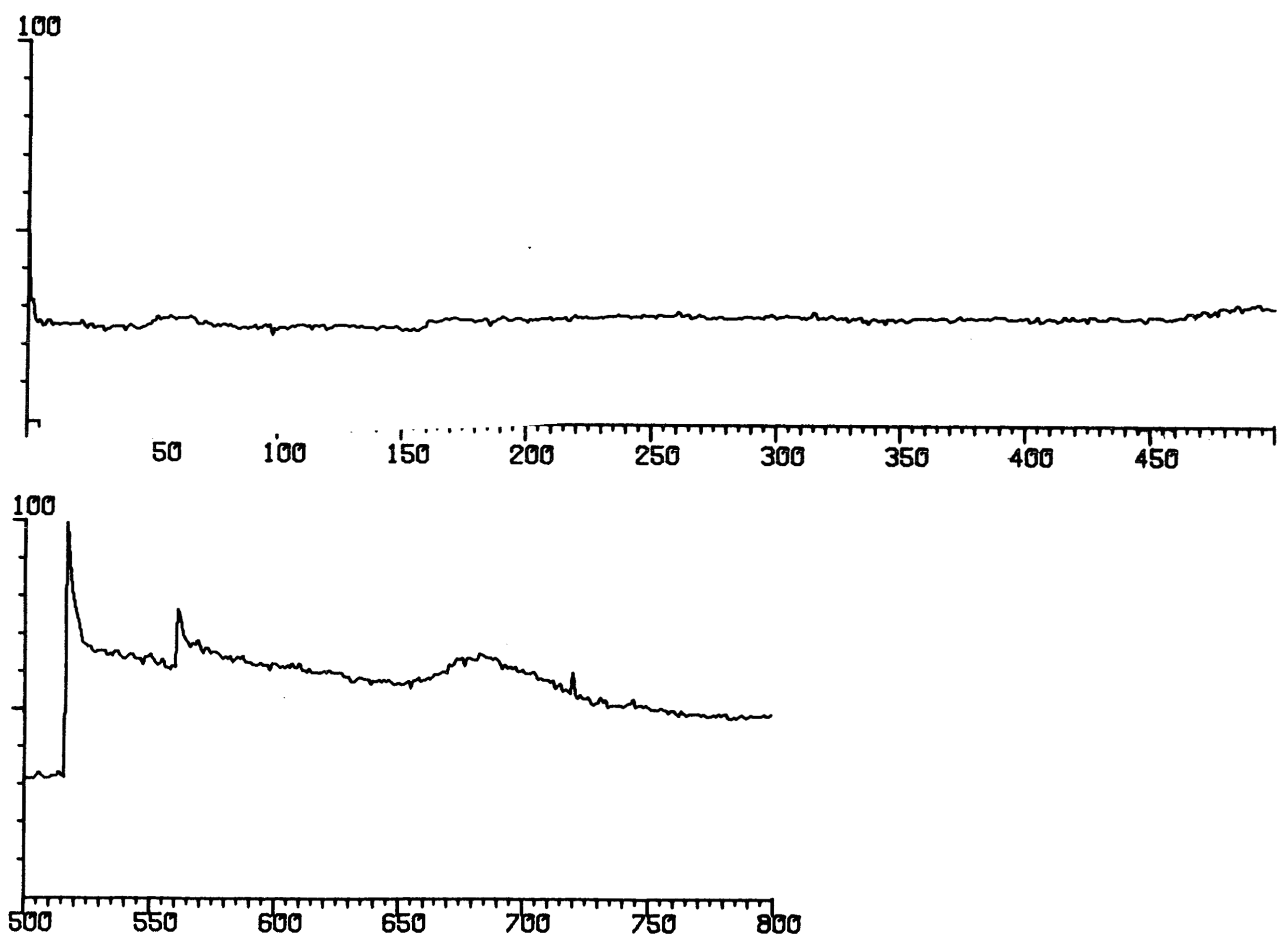
SALT SAMPLE

MASS 36 SEARCH $\times 2$

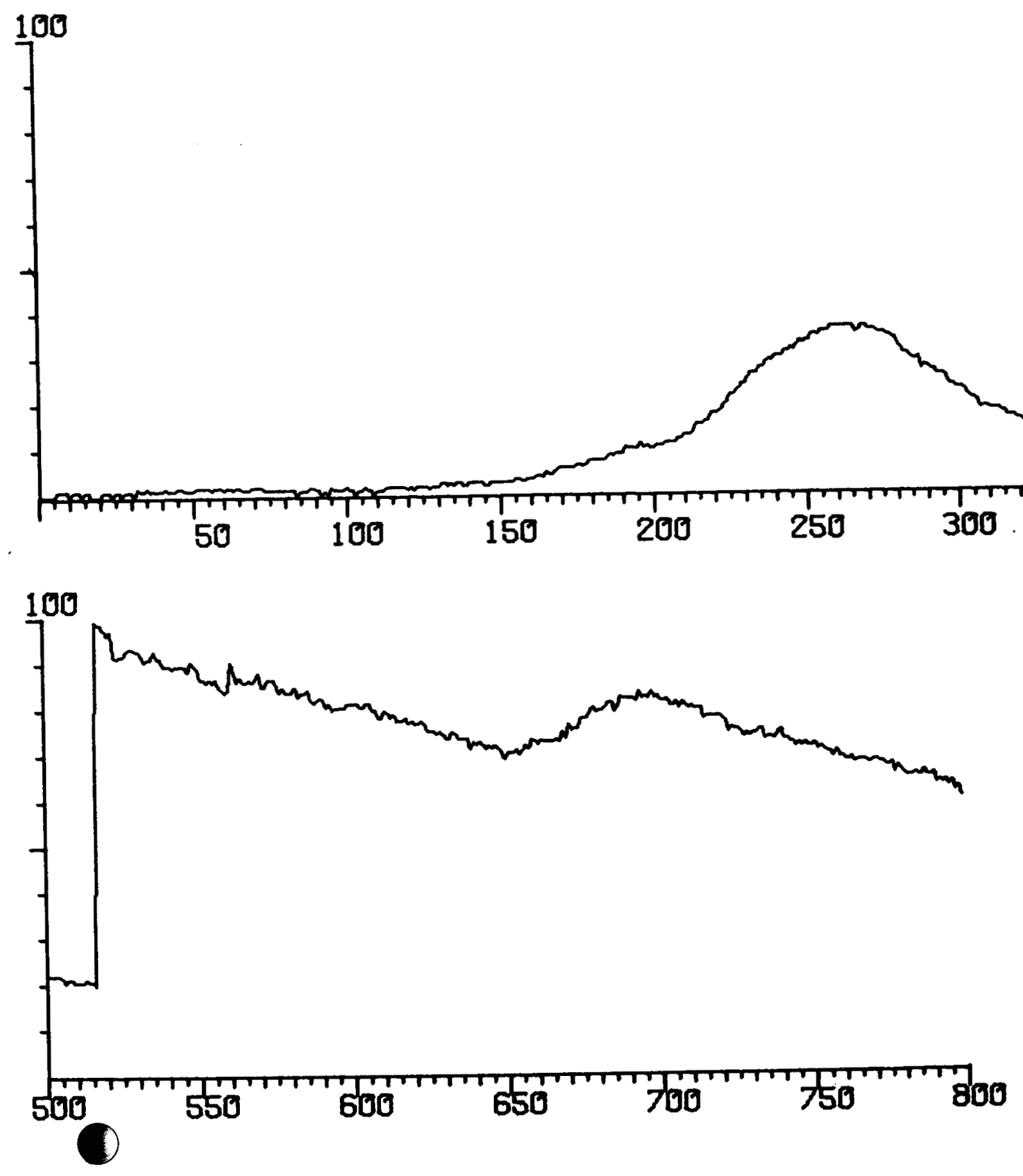


MASS 44 SEARCH X2
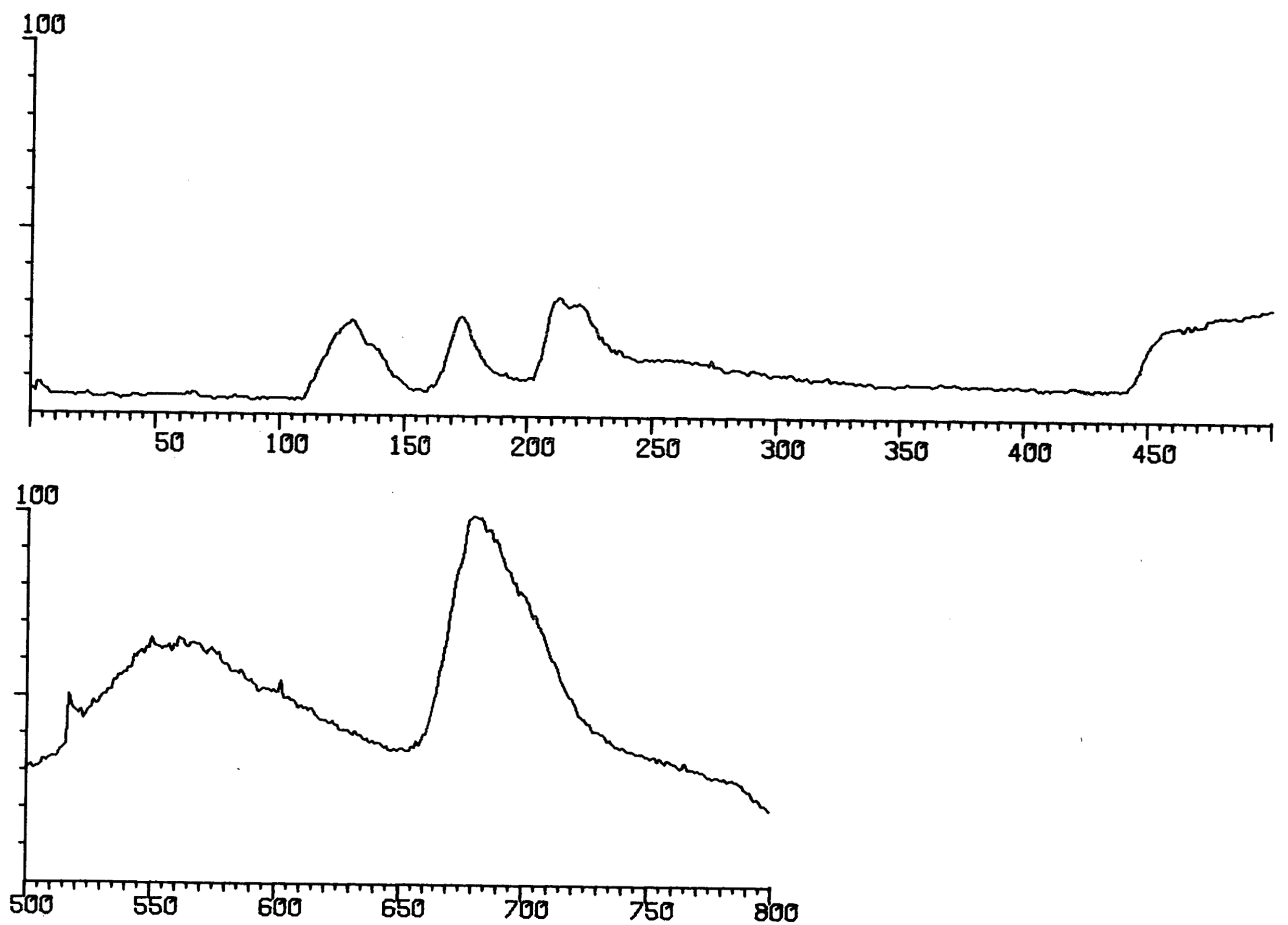
MASS 48 SEARCH $X 1$

\section{0}

1
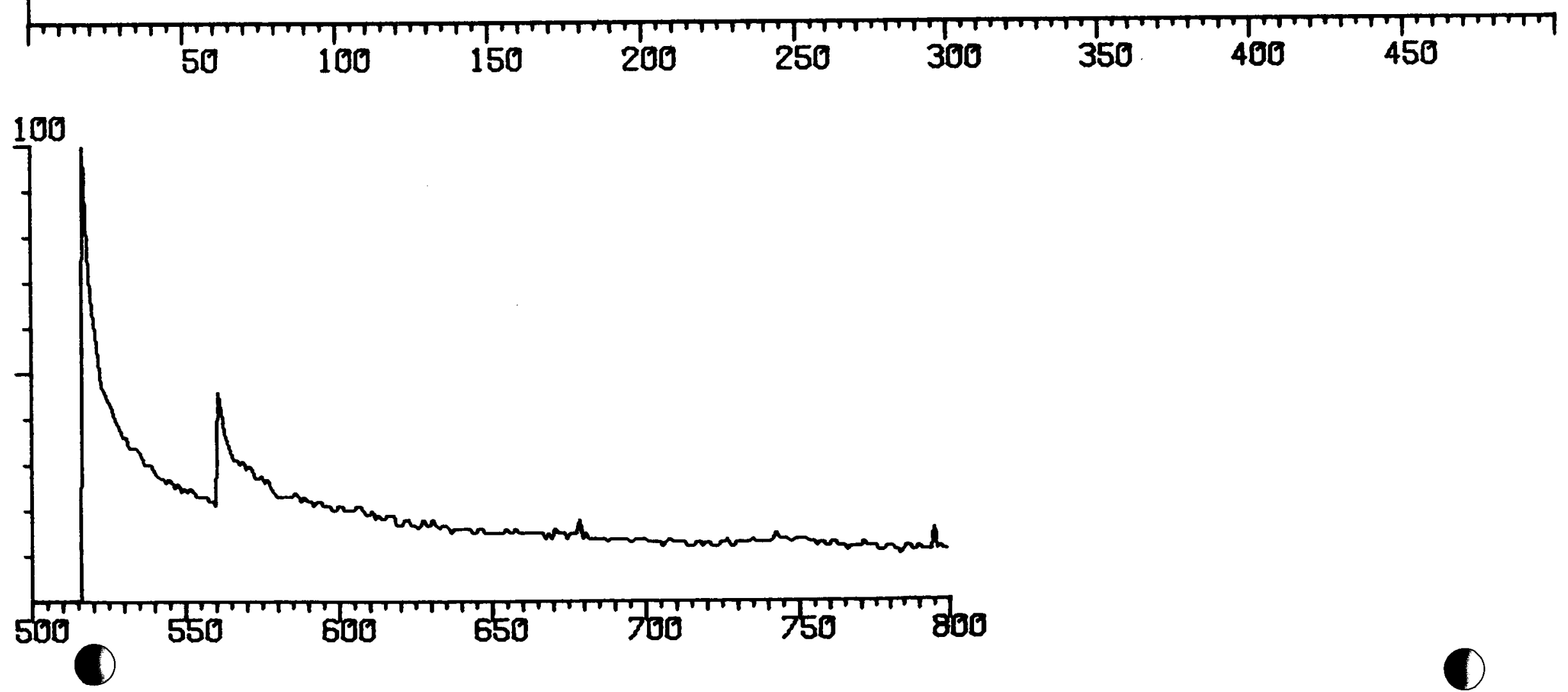
SAL SAMPLE

MASS 64 SEARCH $X 1$
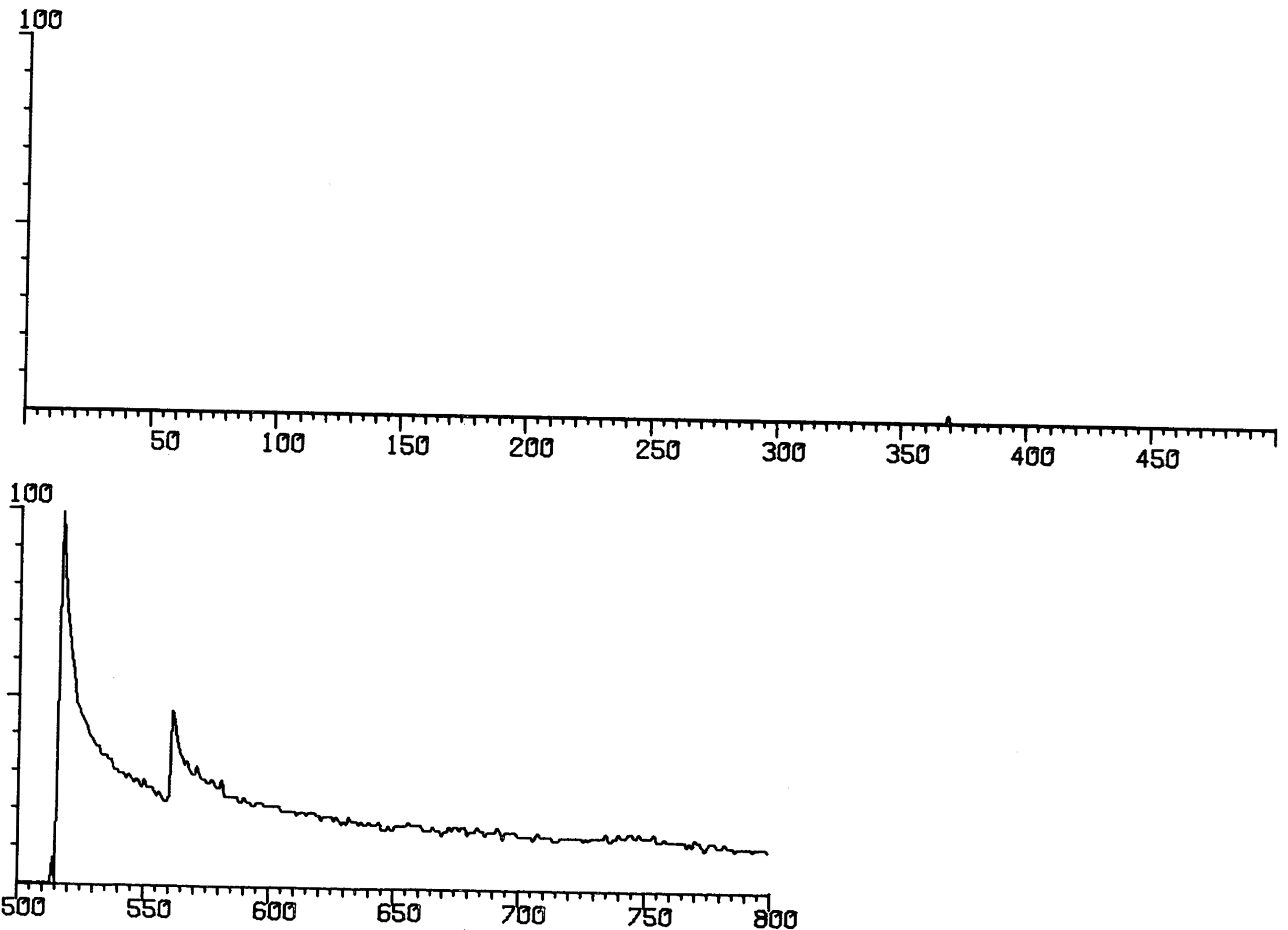
MASS 80 SEARCH $X 1$
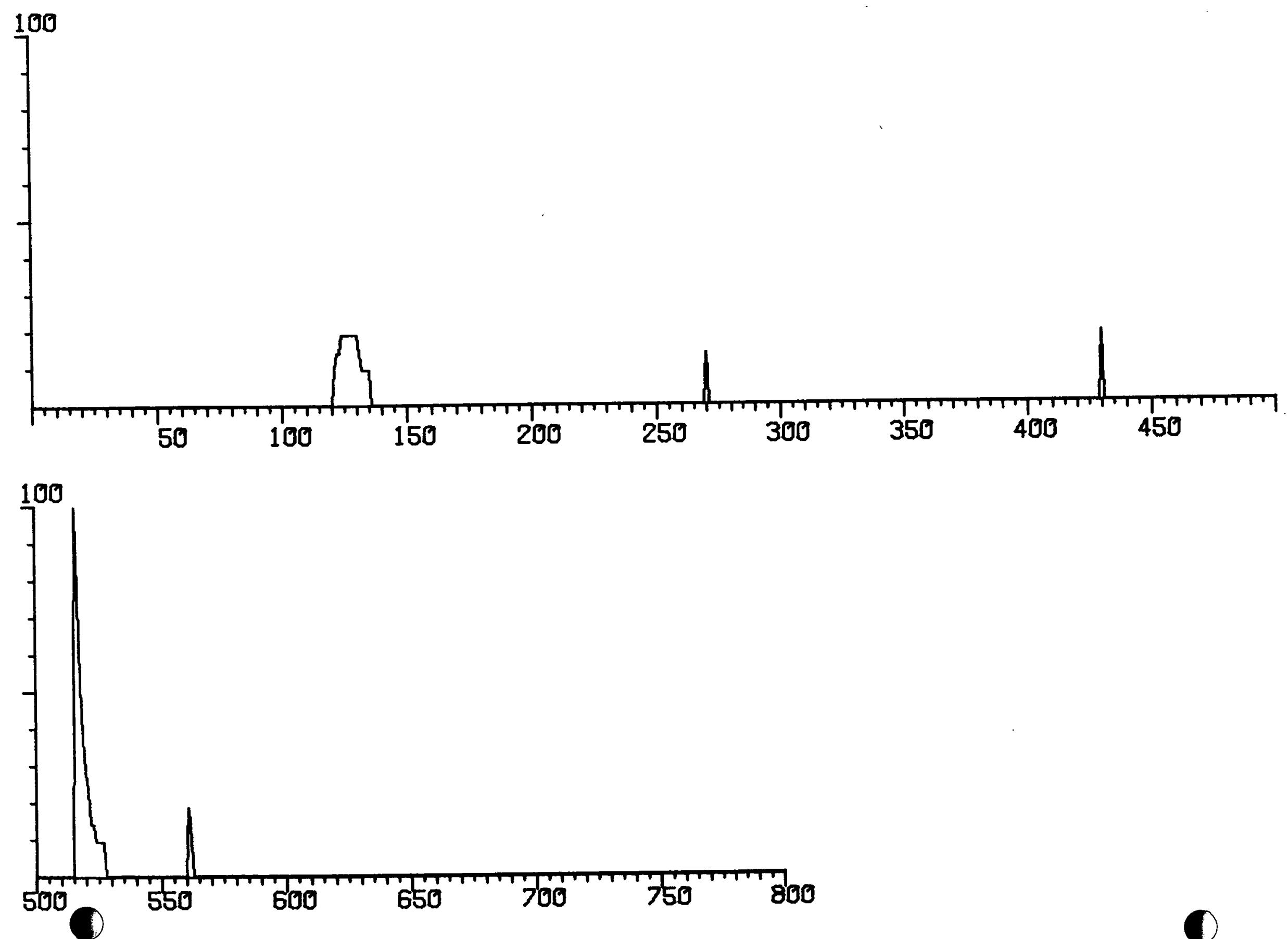
0

SALT SAMPLE

\# $517 \quad \mathrm{CH} 517-\mathrm{CH} 522 \times 1$

100

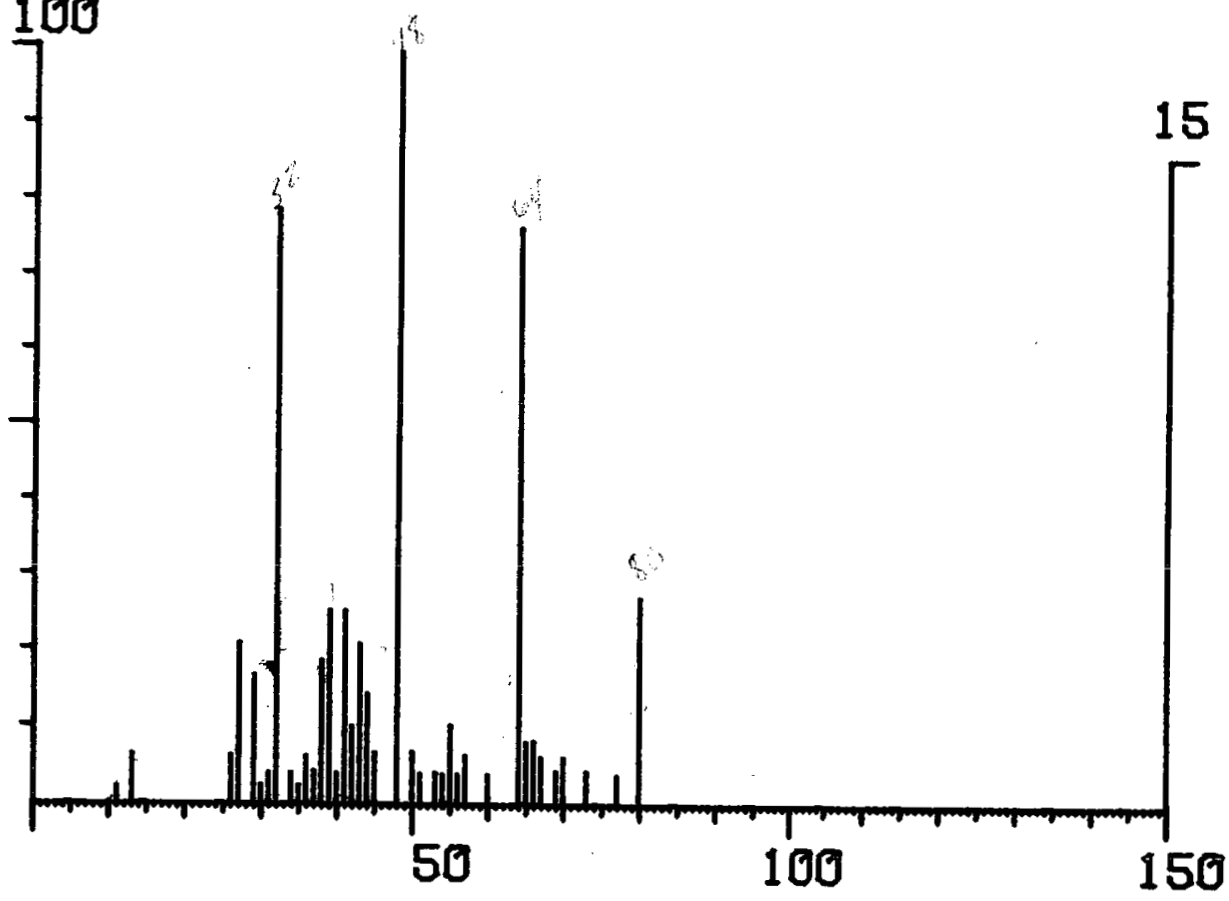

2302.6

15 50 
SALT SAMPLE 2516.3

TOTAL ION CHROMATOGRAM

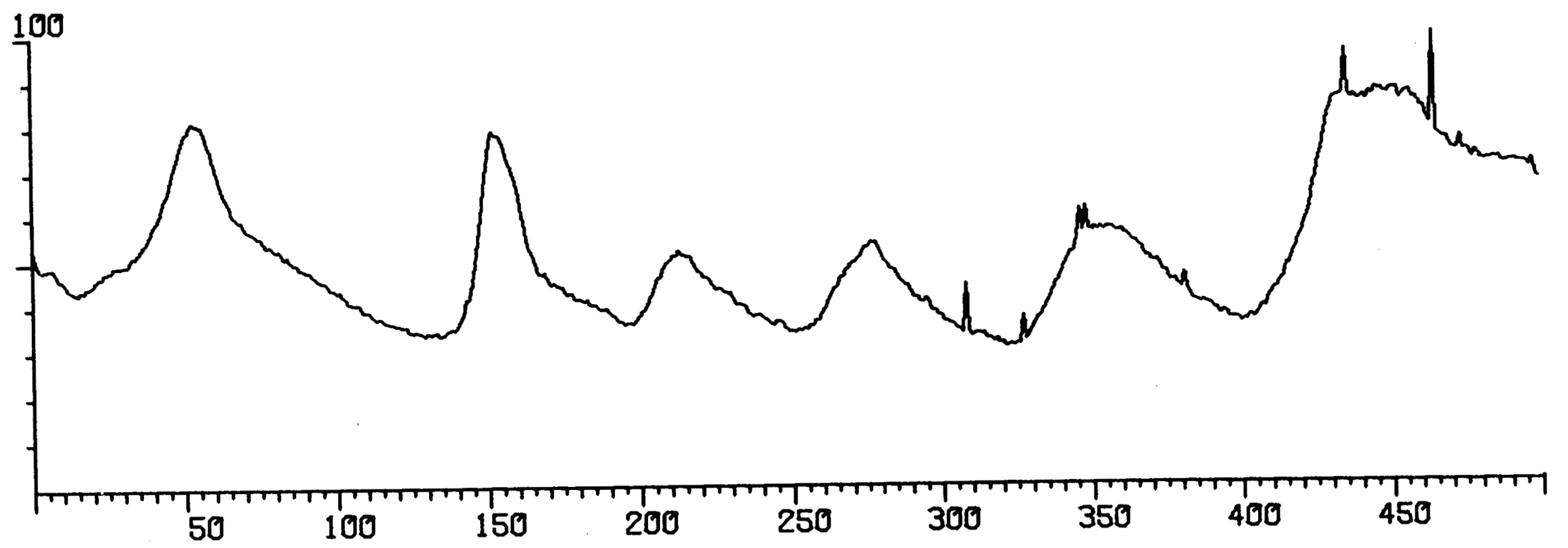


SALT SAMPLE

$2516 \cdot 3$

MASS 18 SEARCH $\times 3$

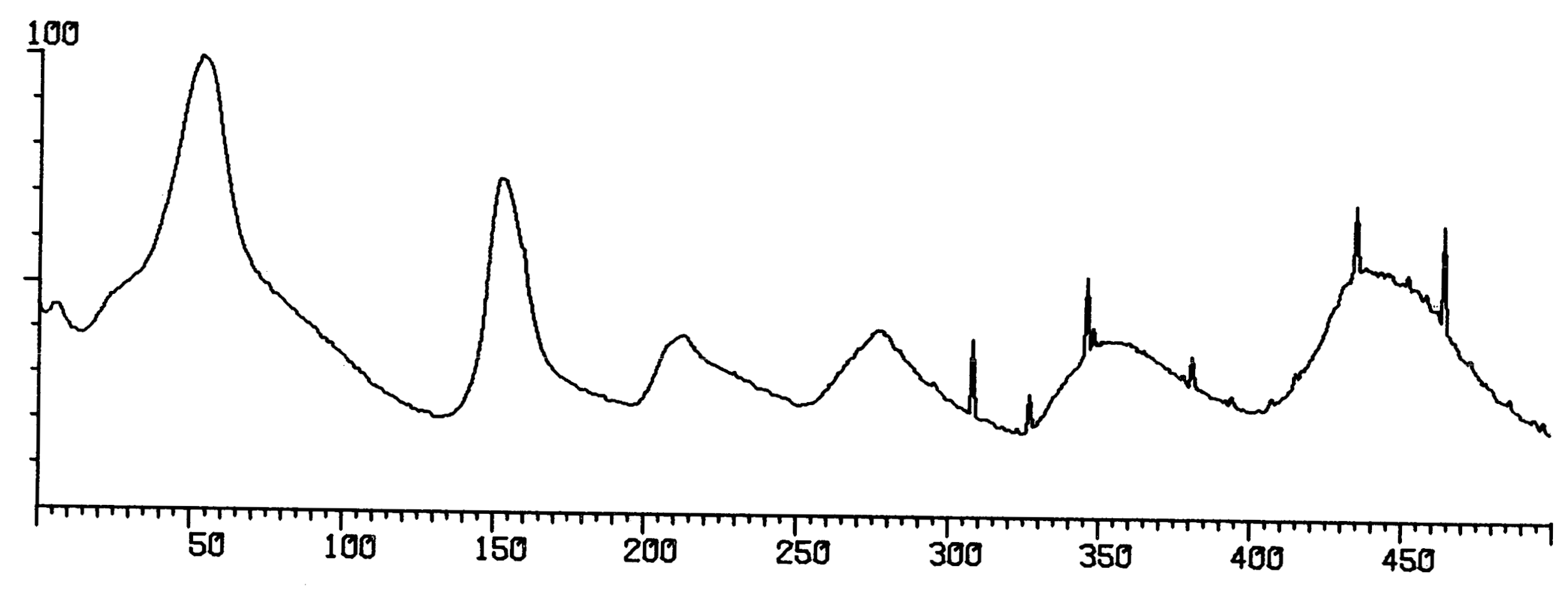


SALT SAMPLE

2516.3

MASS 28 SEARCH $\times 3$

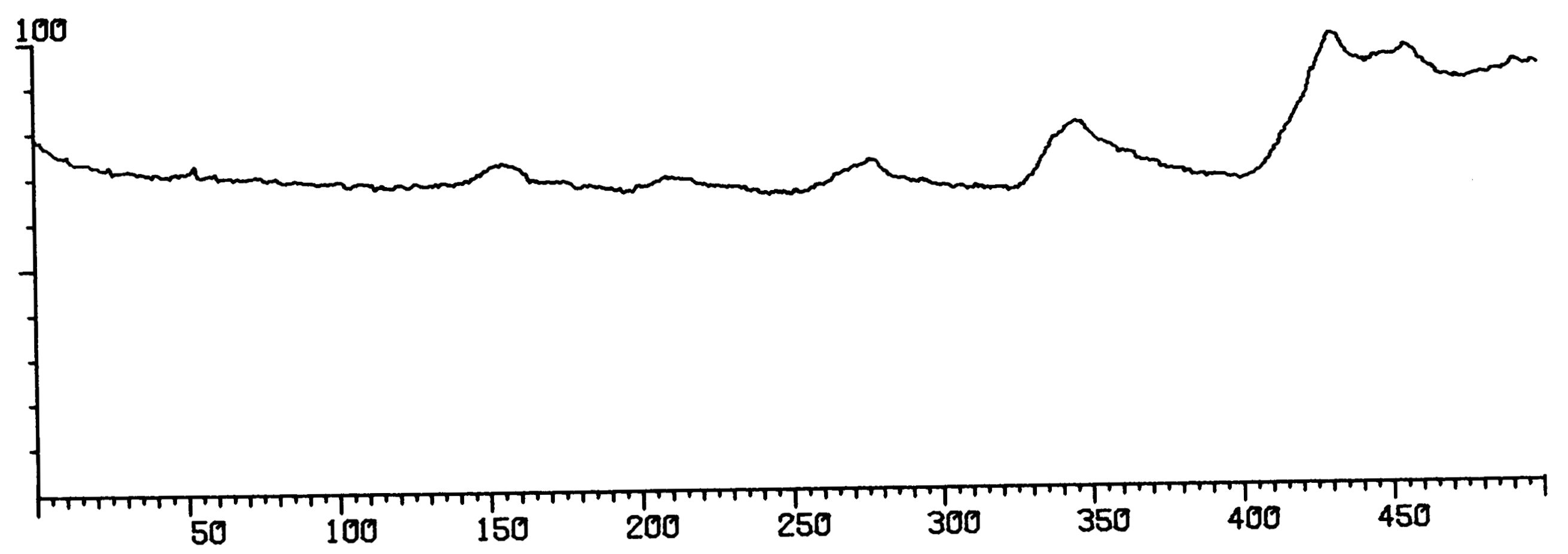


SALT SAMPLE

2516.3

MASS 32 SERRCH X2

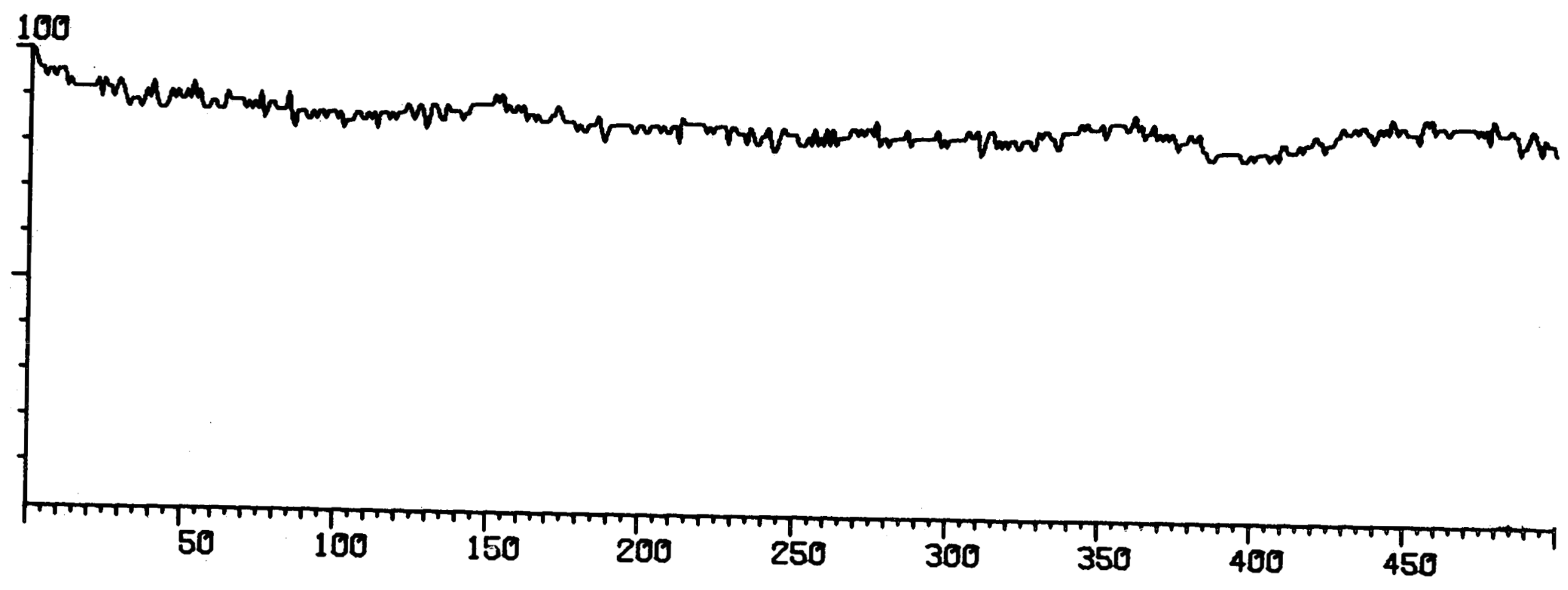


SALT SAMPLE

MASS 36 SEARCH $\times 2$
2516.3

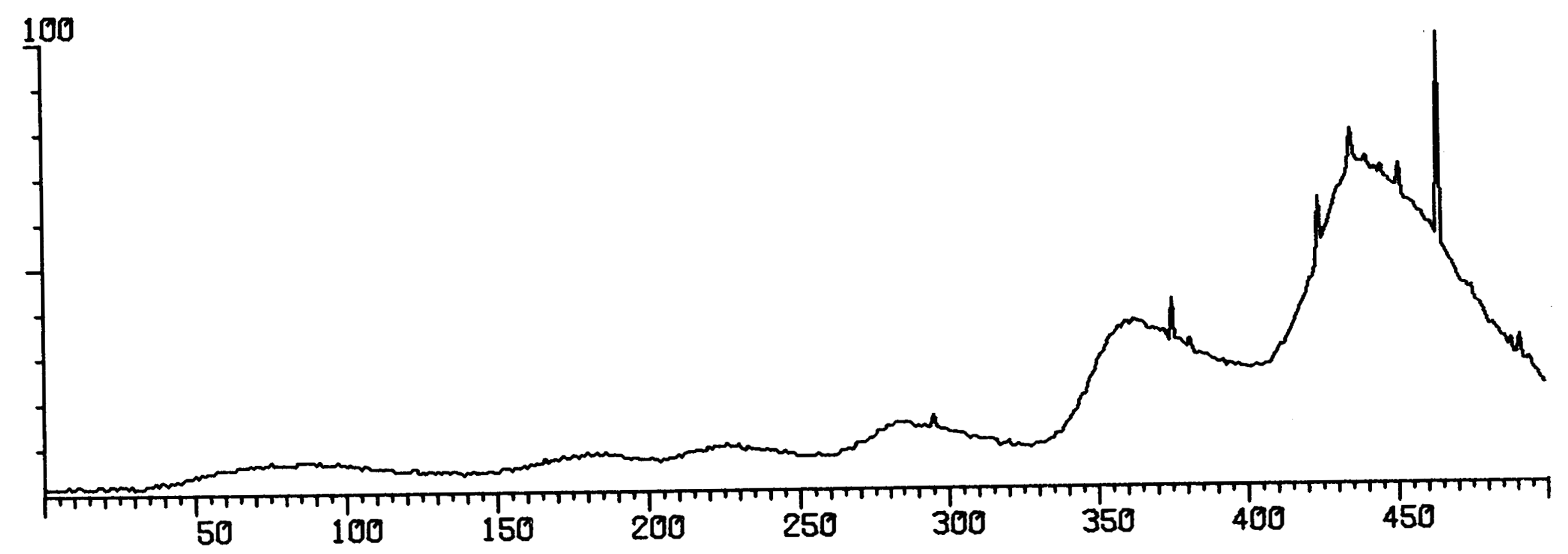


SALT SAMPLE

2516.3

MASS 44 SEARCH $\times 3$

100

7

1
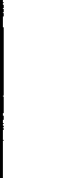

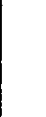
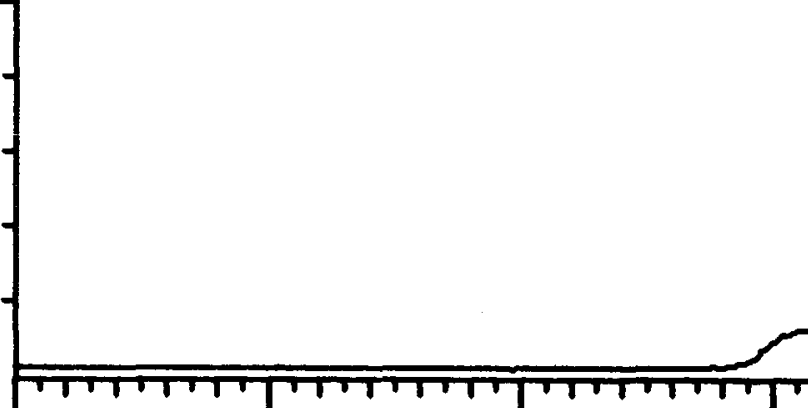

50

100

150

200

250

300

350

400

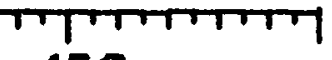


2516.3

MASS 48 SEARCH $X 1$

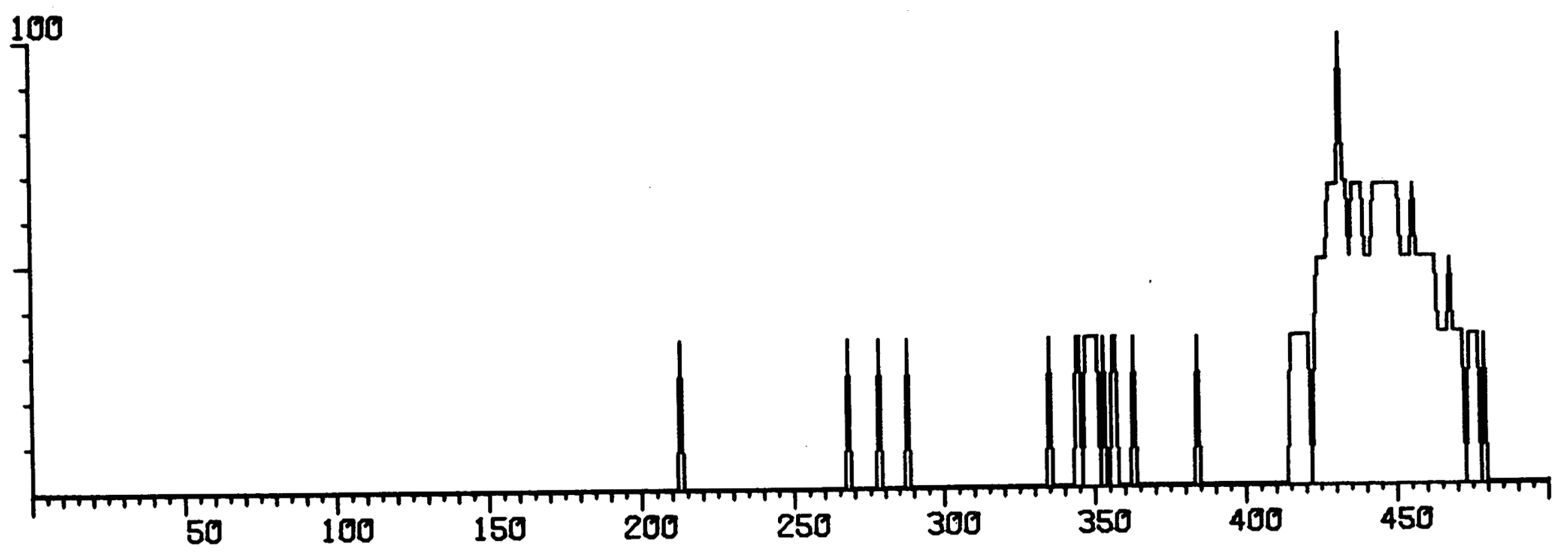




\section{SALT SAMPLE 2658.5 \\ TOTAL ION CHROMATOGRAM}

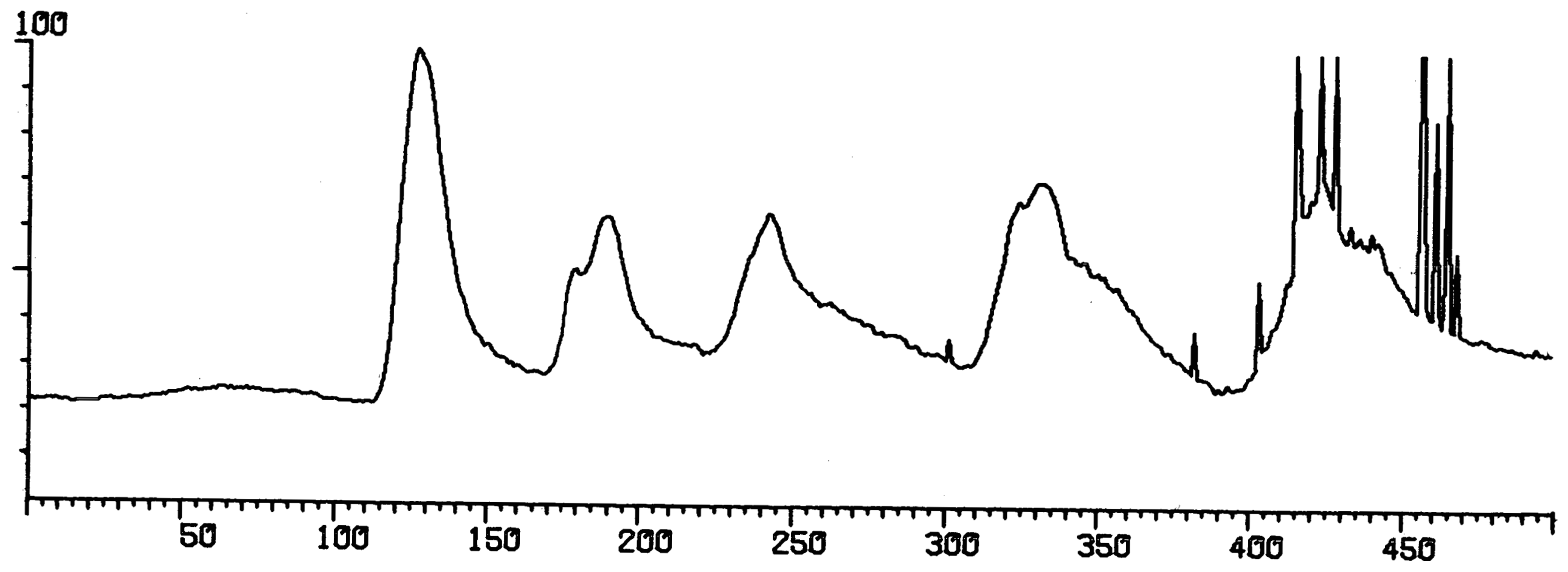


2658.5

IASS 14 SEARCH X1

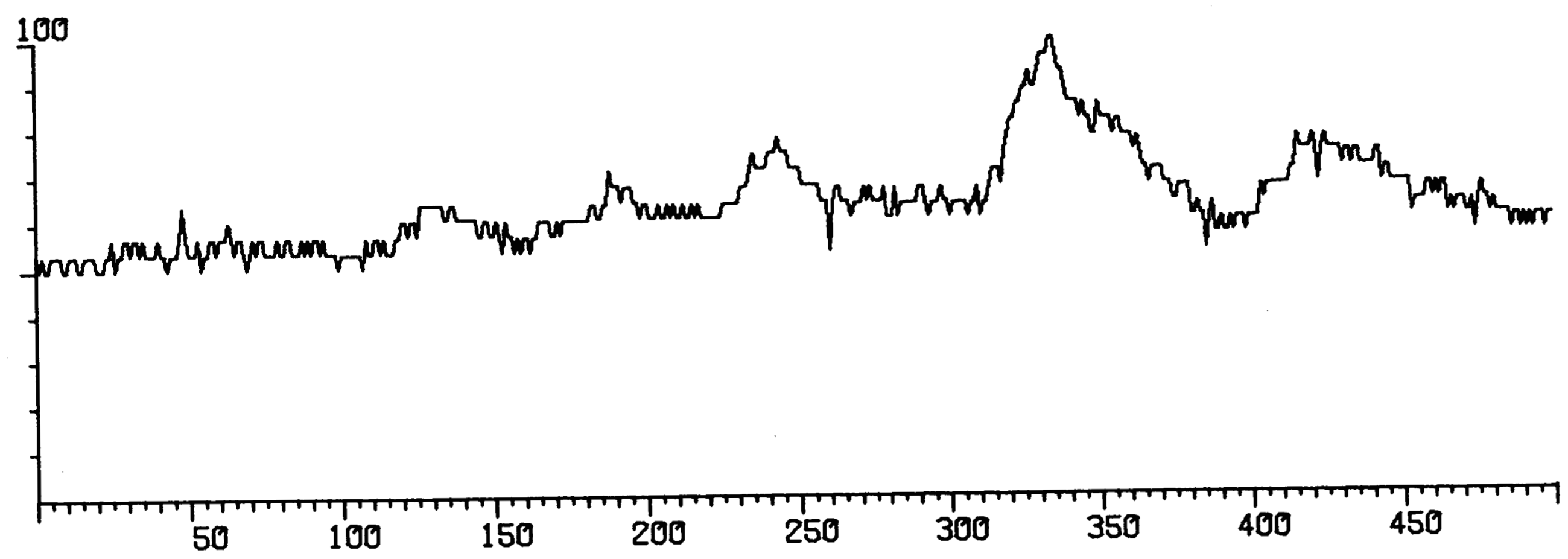


MASS 18 SEARCH $\times 4(\mathrm{CH} 127=100 \%)$

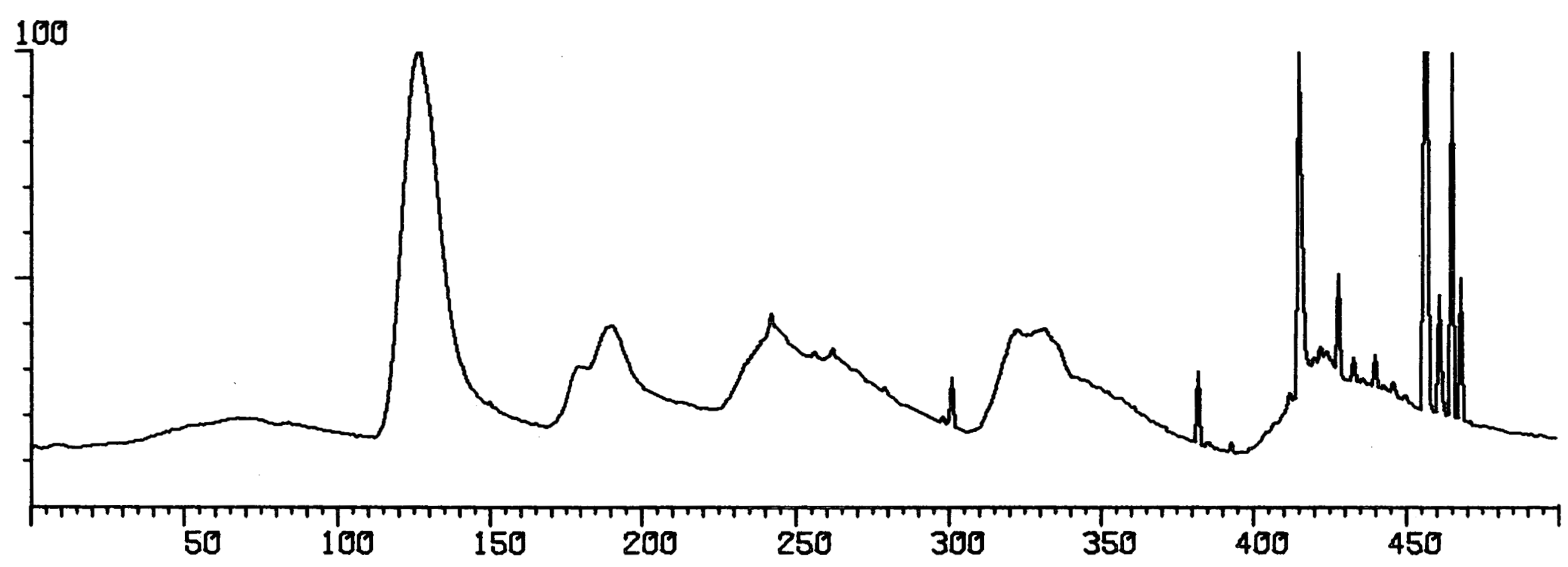


MASS 28 SEARCH $X 3$

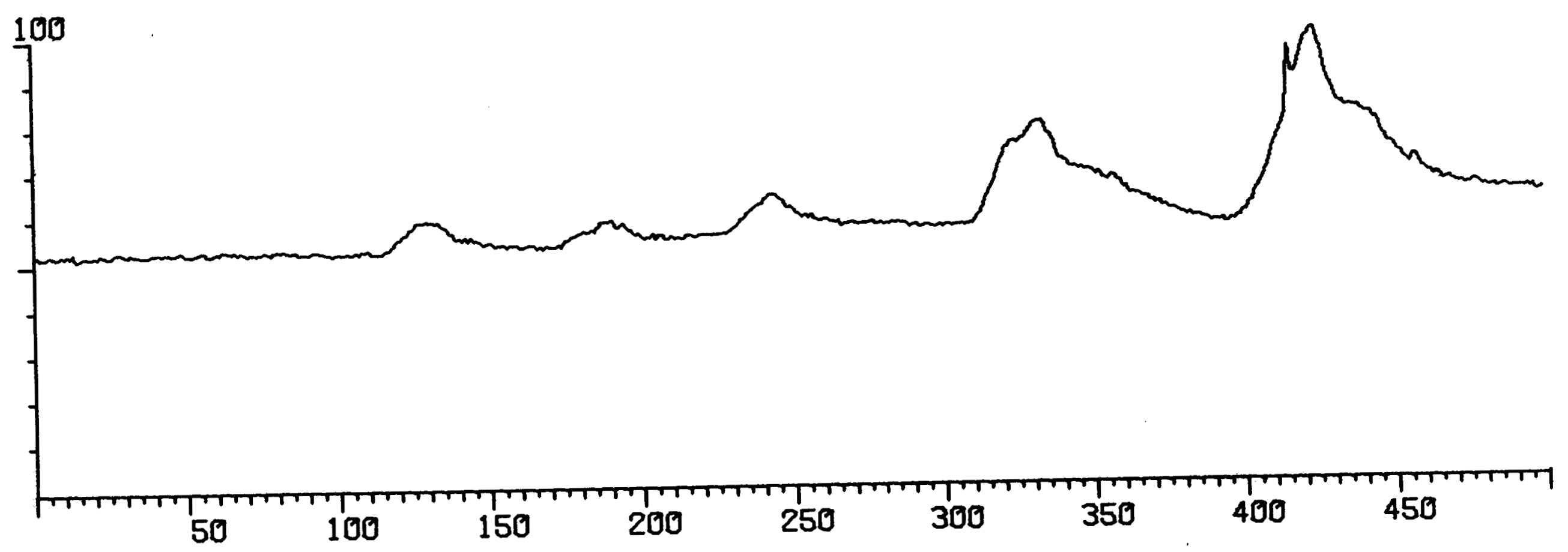


SALT SAMPLE

2658.5

MASS 32 SEARCH $X 1$

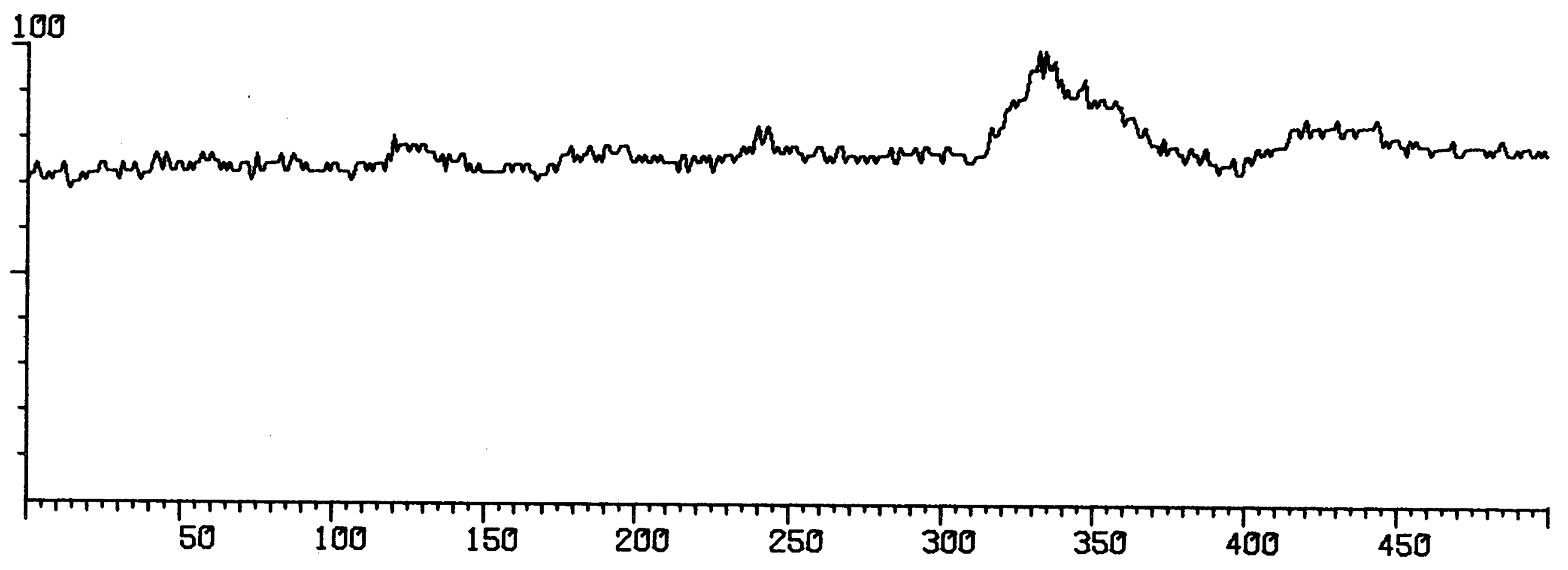


MASS 36 SERRCH $\times 2$ ( $\mathrm{CH} 415=100 \%)$

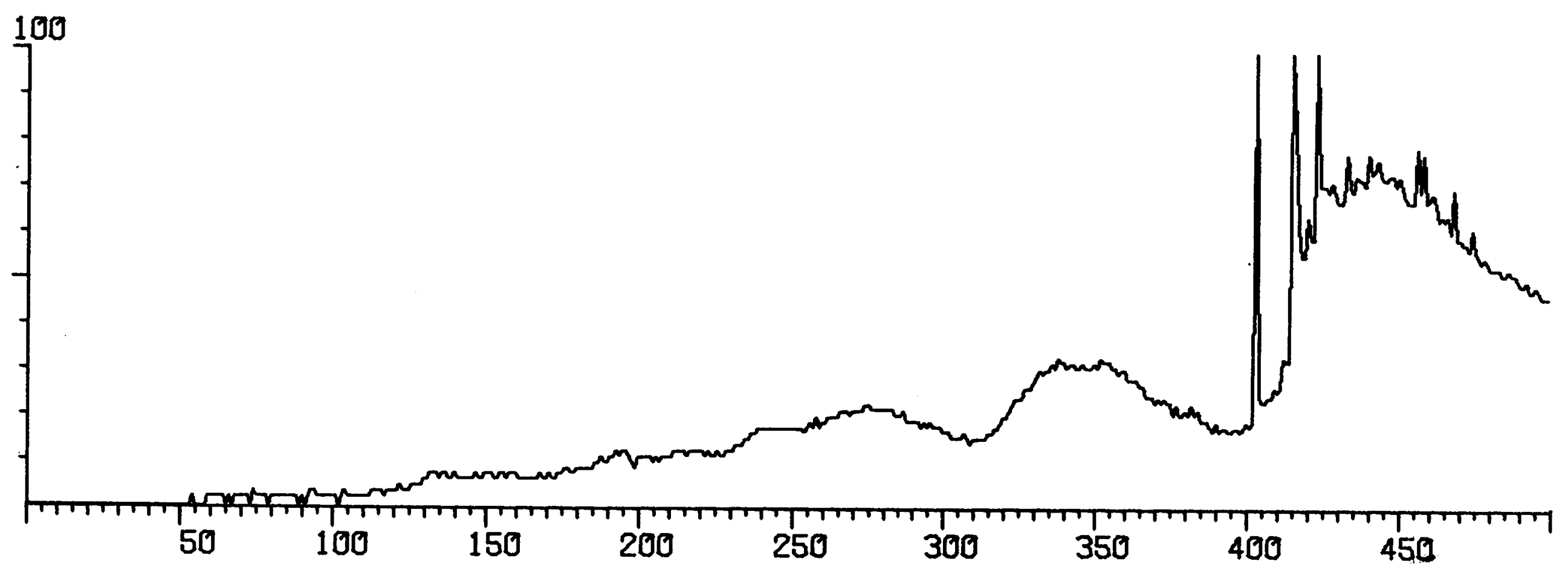


MASS 44 SEARCH X2

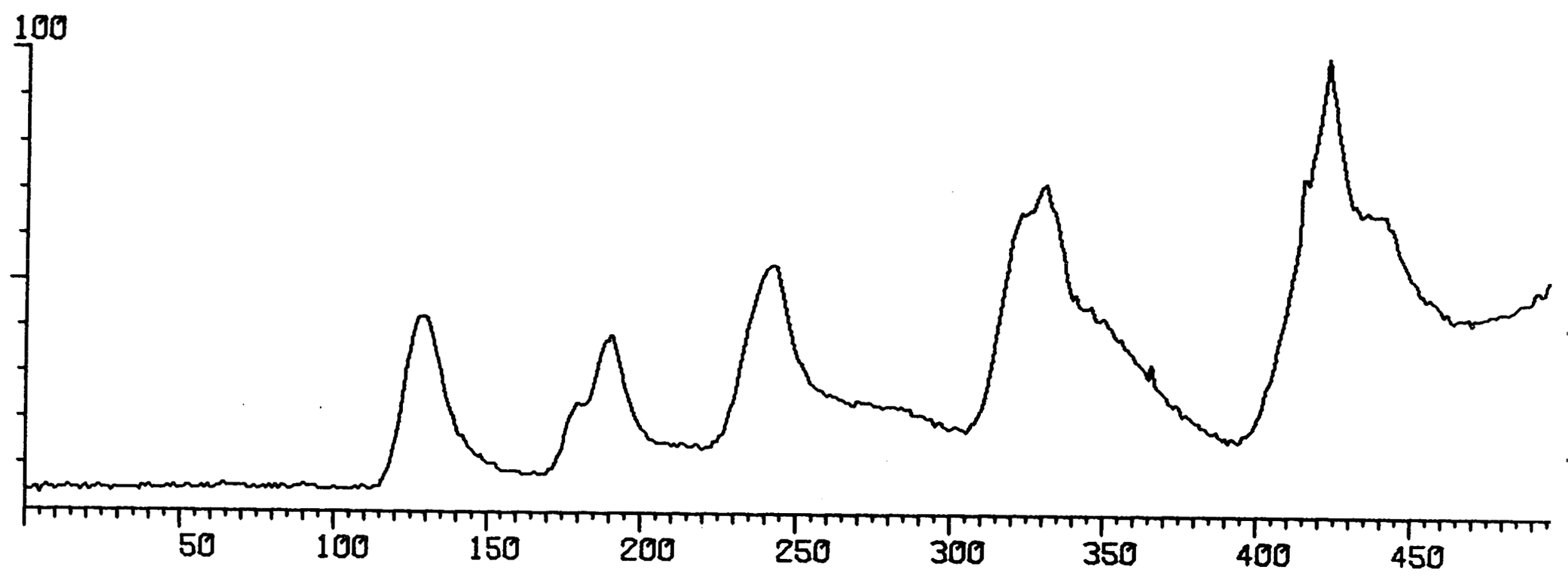


SALT SAMPLE

2658.5

MASS 48 SEARCH $X 1$

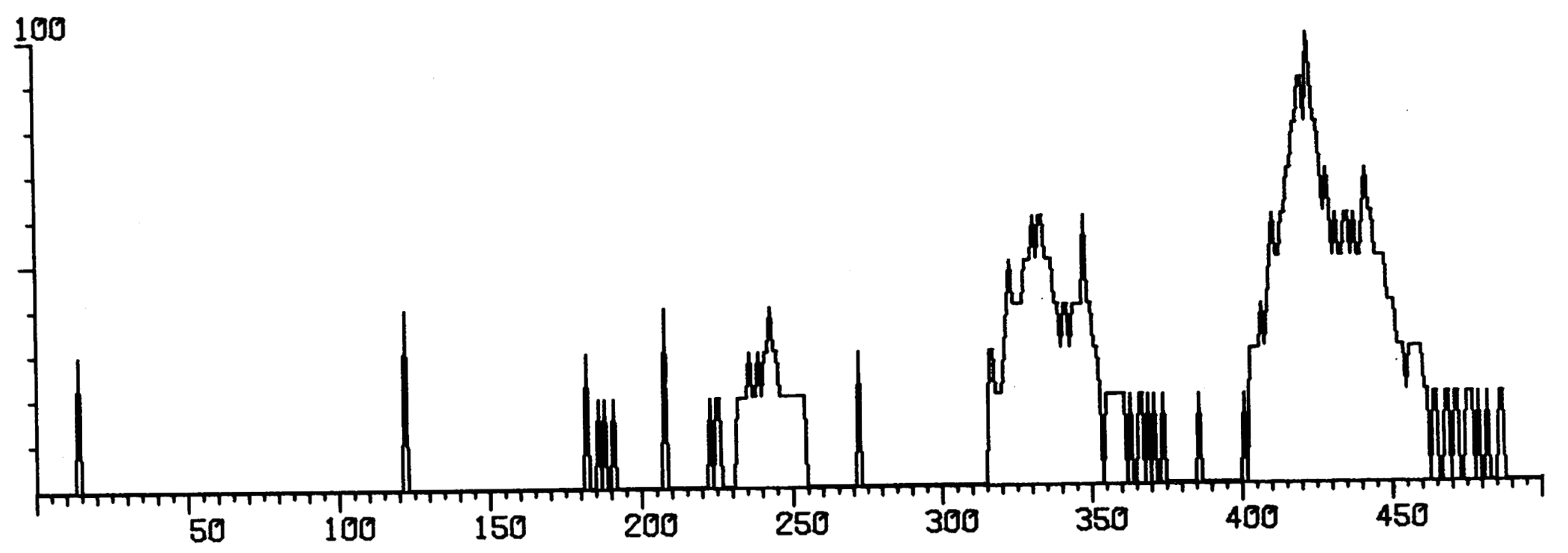


SALT SAMPLE

2786.5

TOTAL ION CHROMATOGRAM
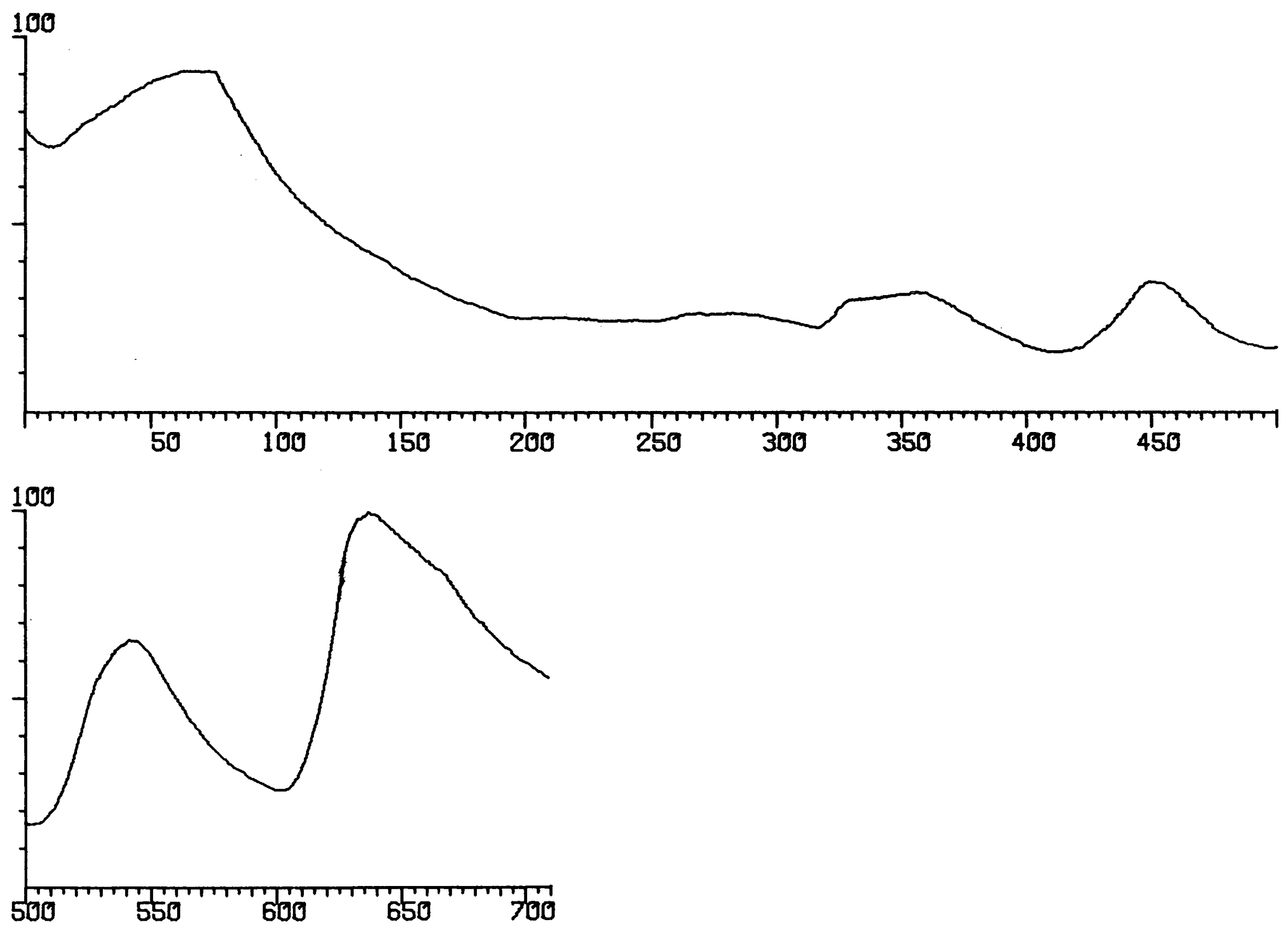
SALT SAMPLE

MASS 14 SEARCH $\times 1$

2786.5
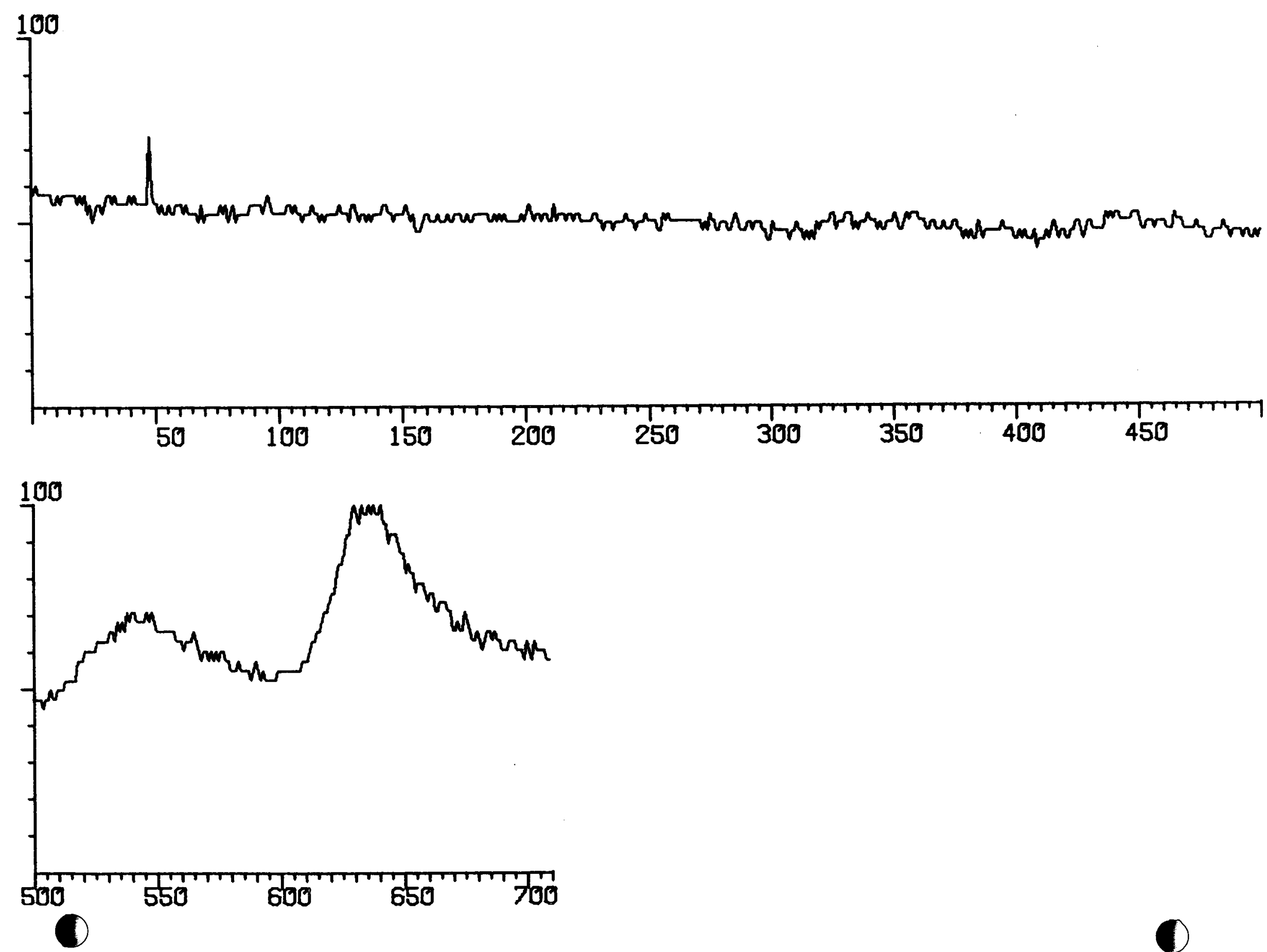
1

SALT SAMPLE

2786.5

MASS 18 SEARCH $X 4$
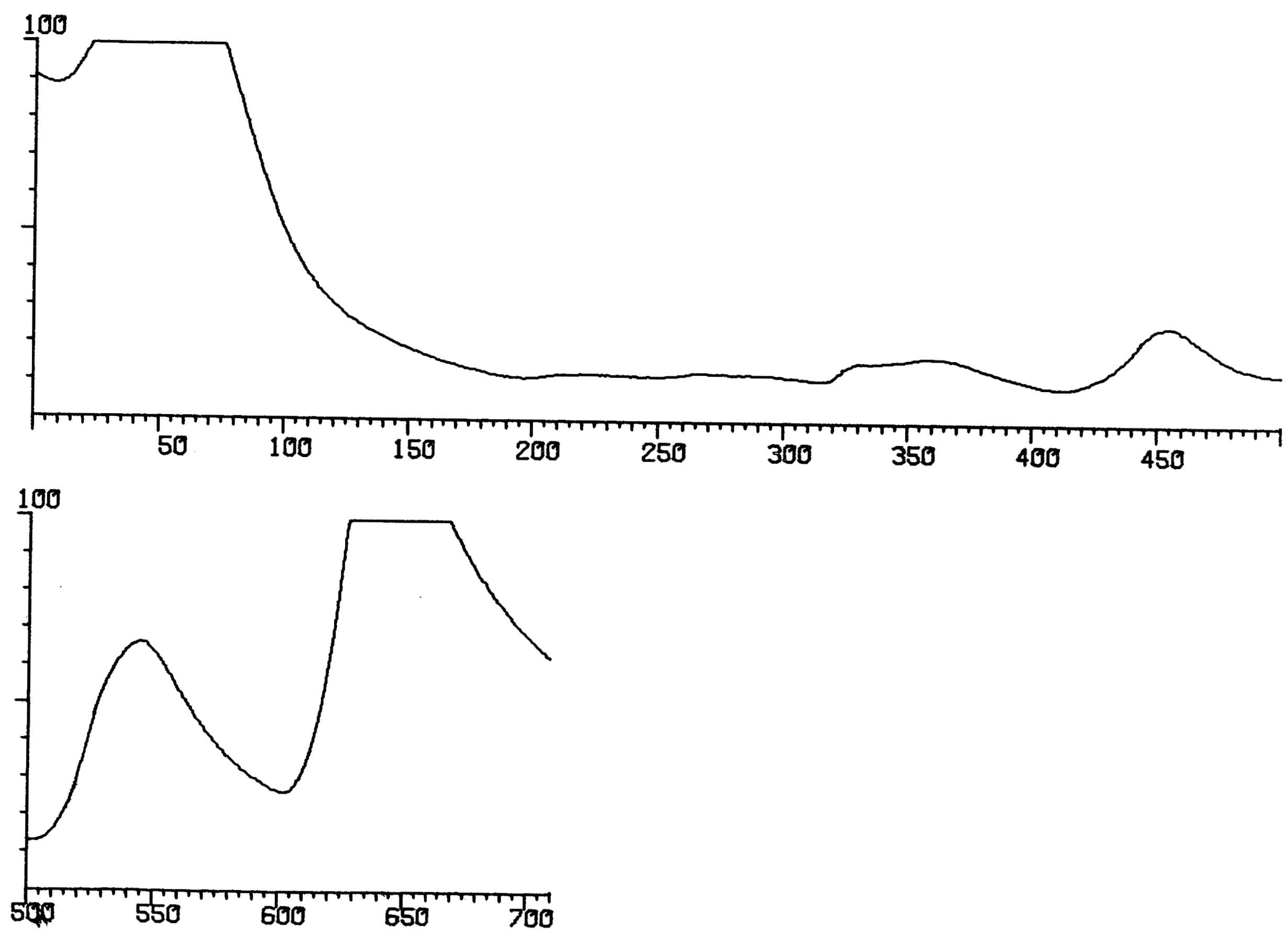
SALT SAMPLE

2786.5

MASS 19 SEARCH $\times 1$
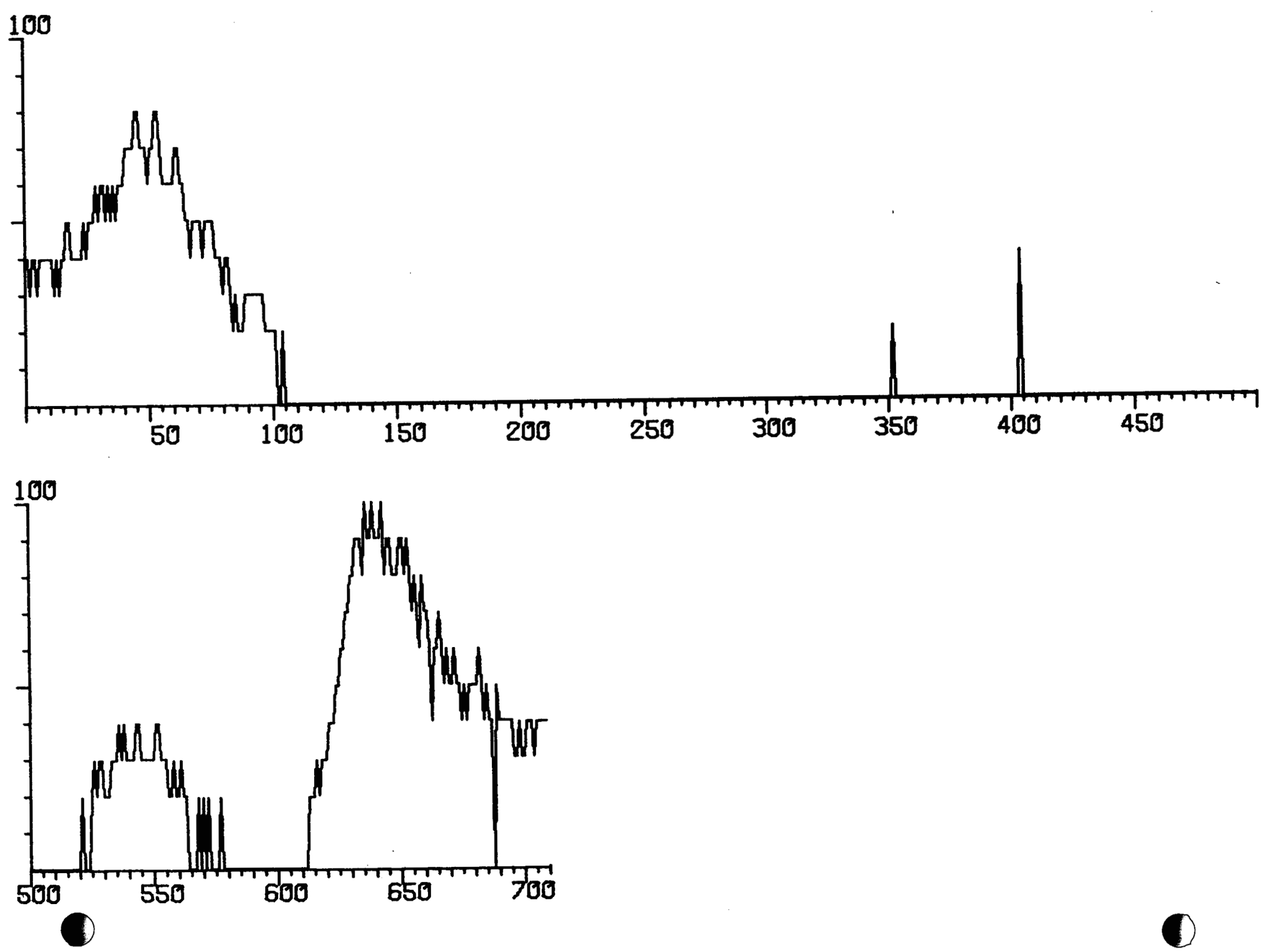
0

SALT SAMPLE

2786.5

\section{MASS 28 SEARCH $\times 3$}

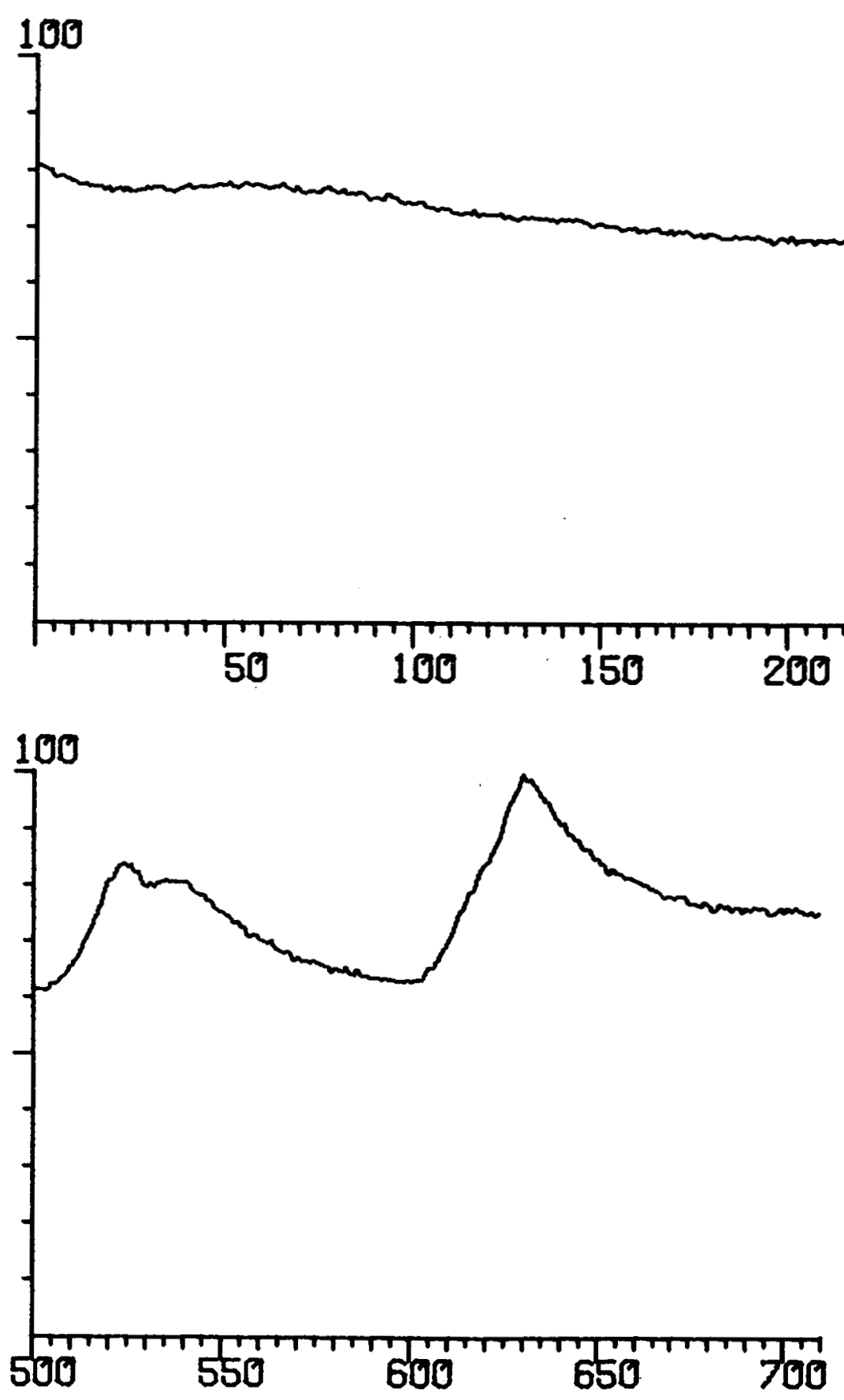


MASS 32 SEARCH X1
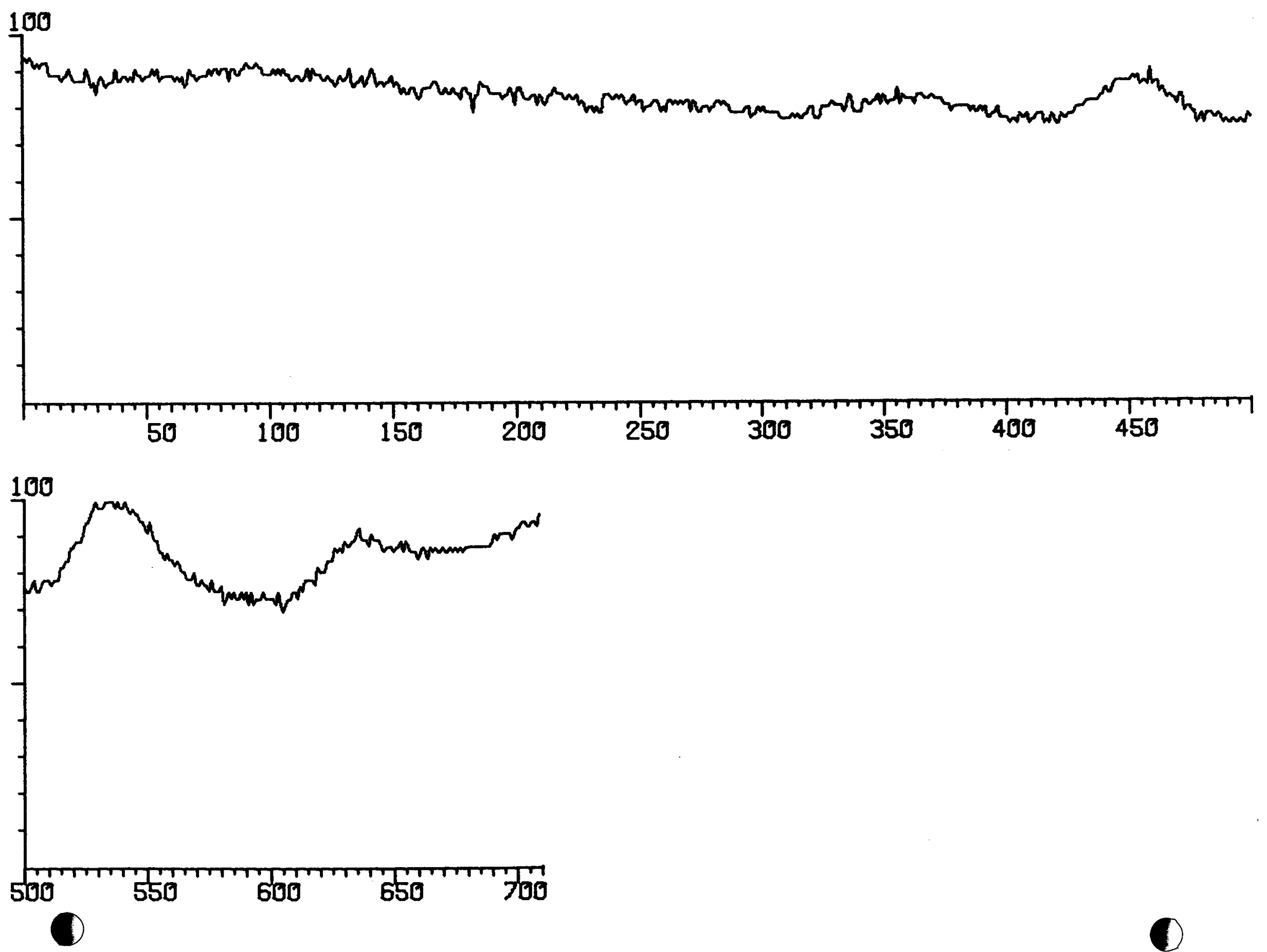
0

SALT SAMPLE

MASS 36 SERRCH $\times 2$

\section{5}

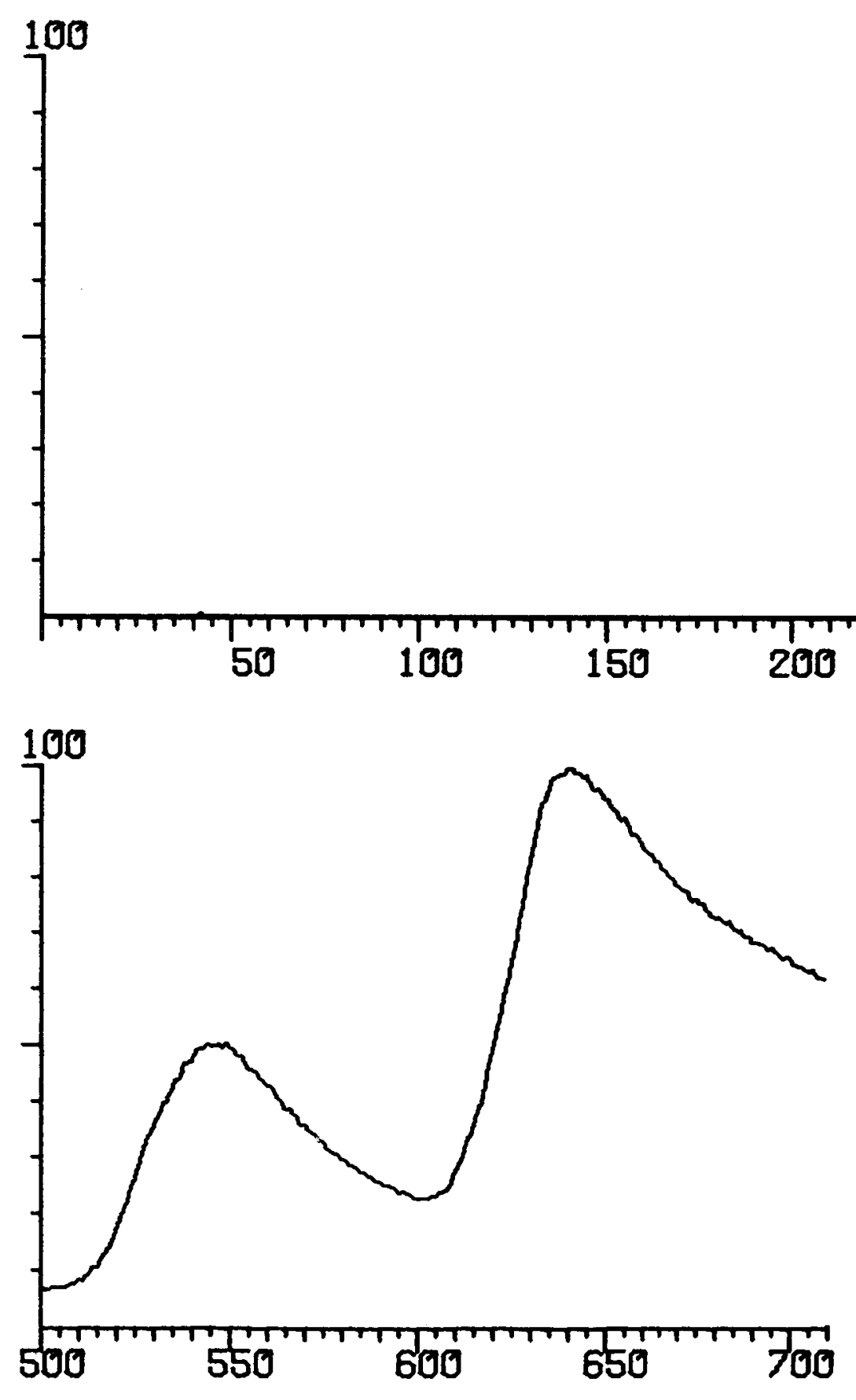


SALT SAMPLE

MASS 44 SEARCH $\times 2$
2786.5

100

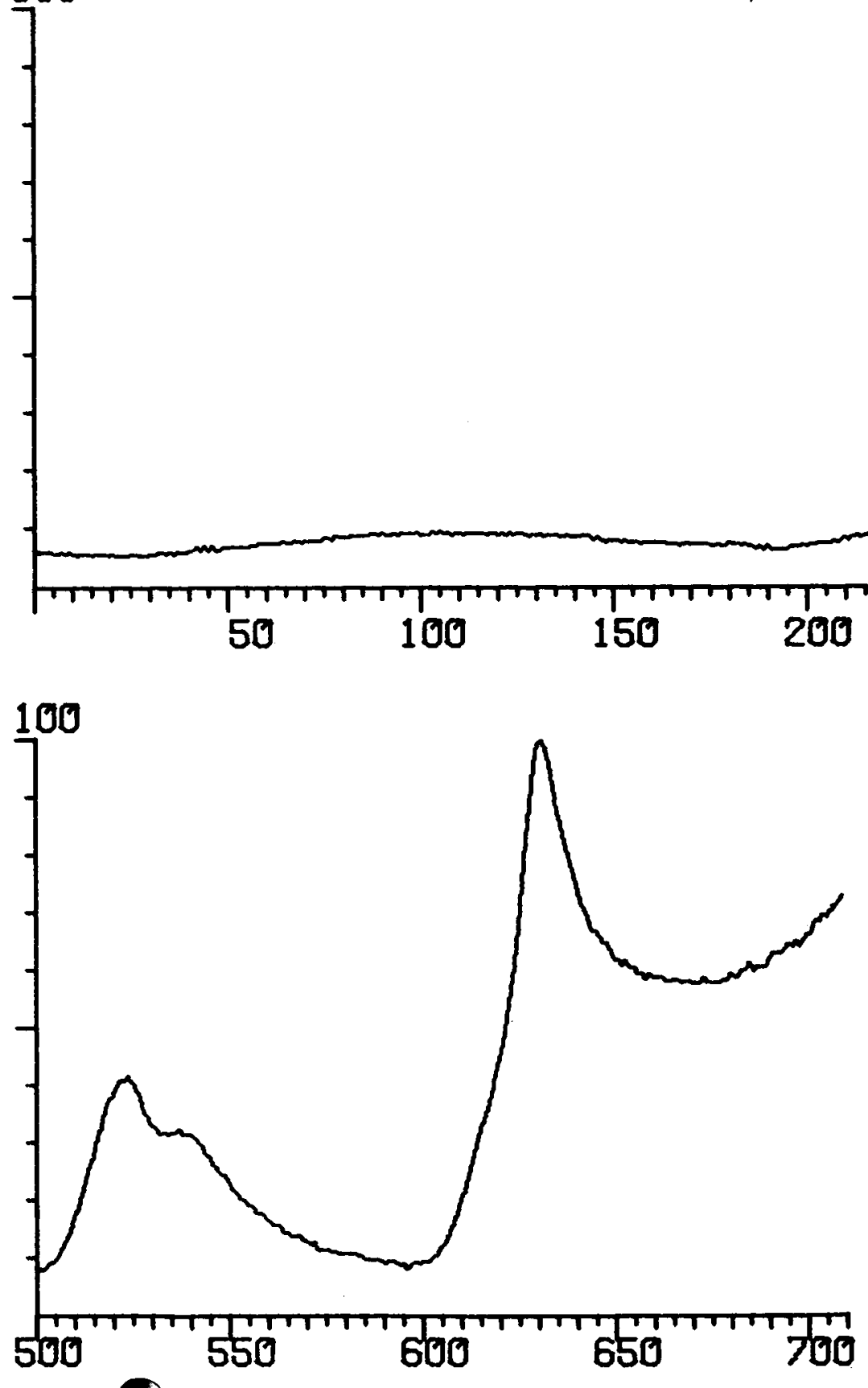


D

SALT SAMPLE

MASS 48 SEARCH $X_{1}$
$2786-5$

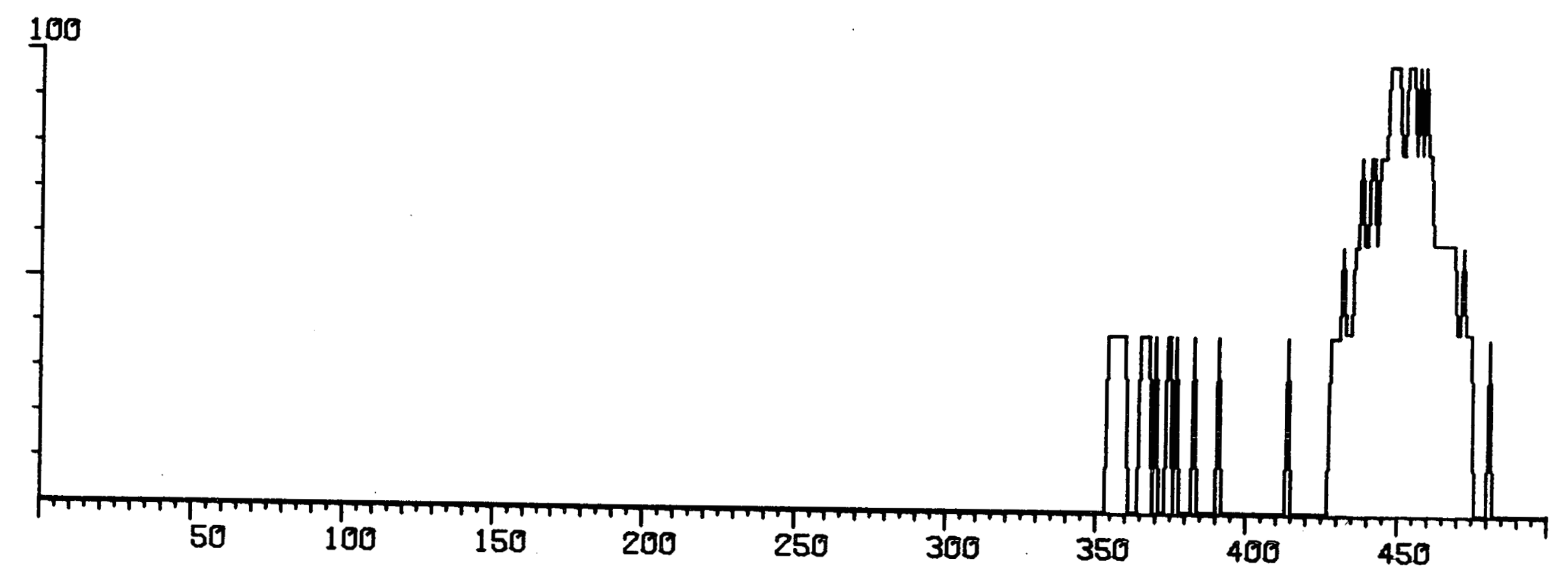


SALT SAMPLE

2821.0

TOTAL ION CHROMATOGRAM

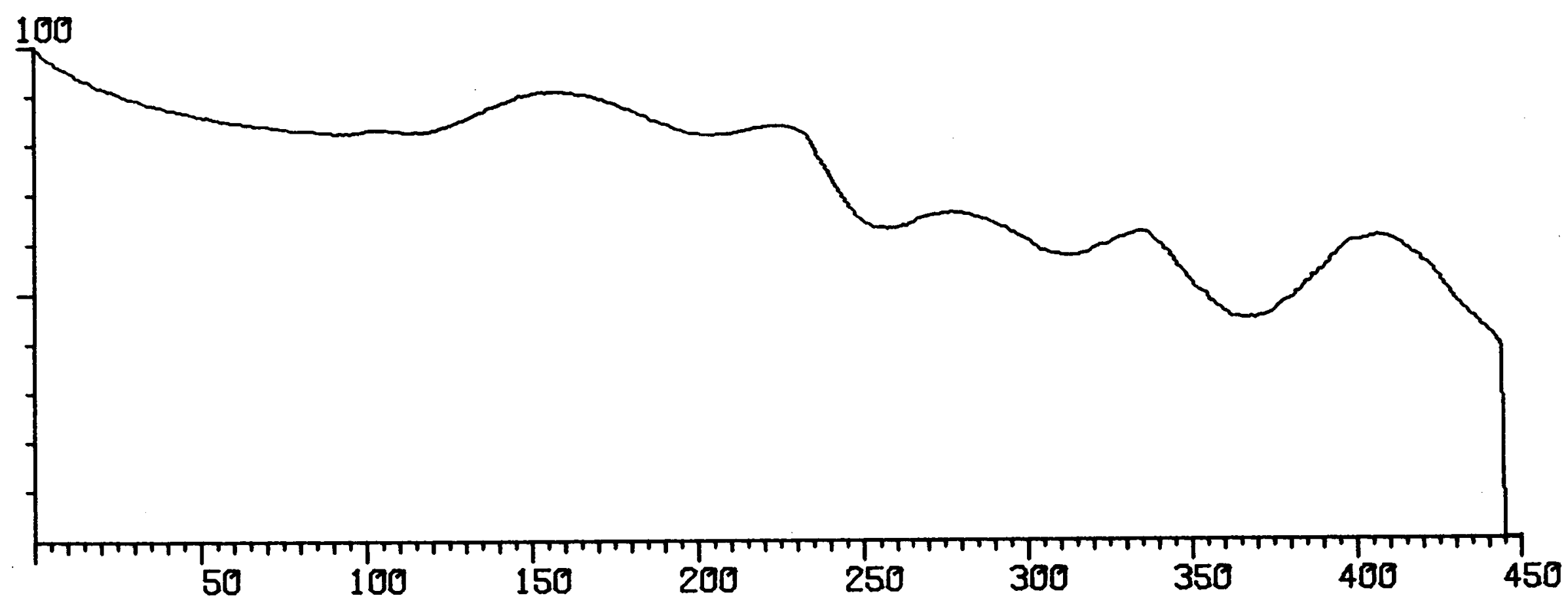


SALT SAMPLE

2821.0

100

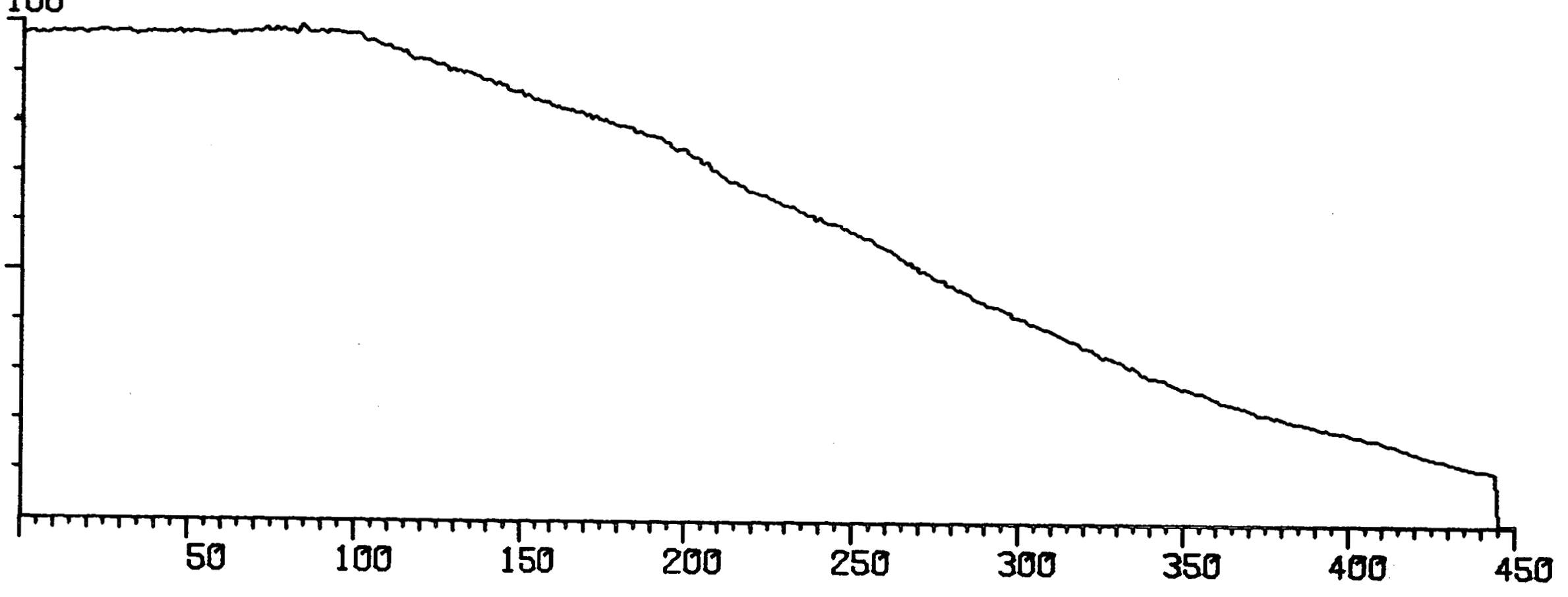


SALT SIYMPIE

2821.0

ISSS 18 SEARCH $X_{4}$

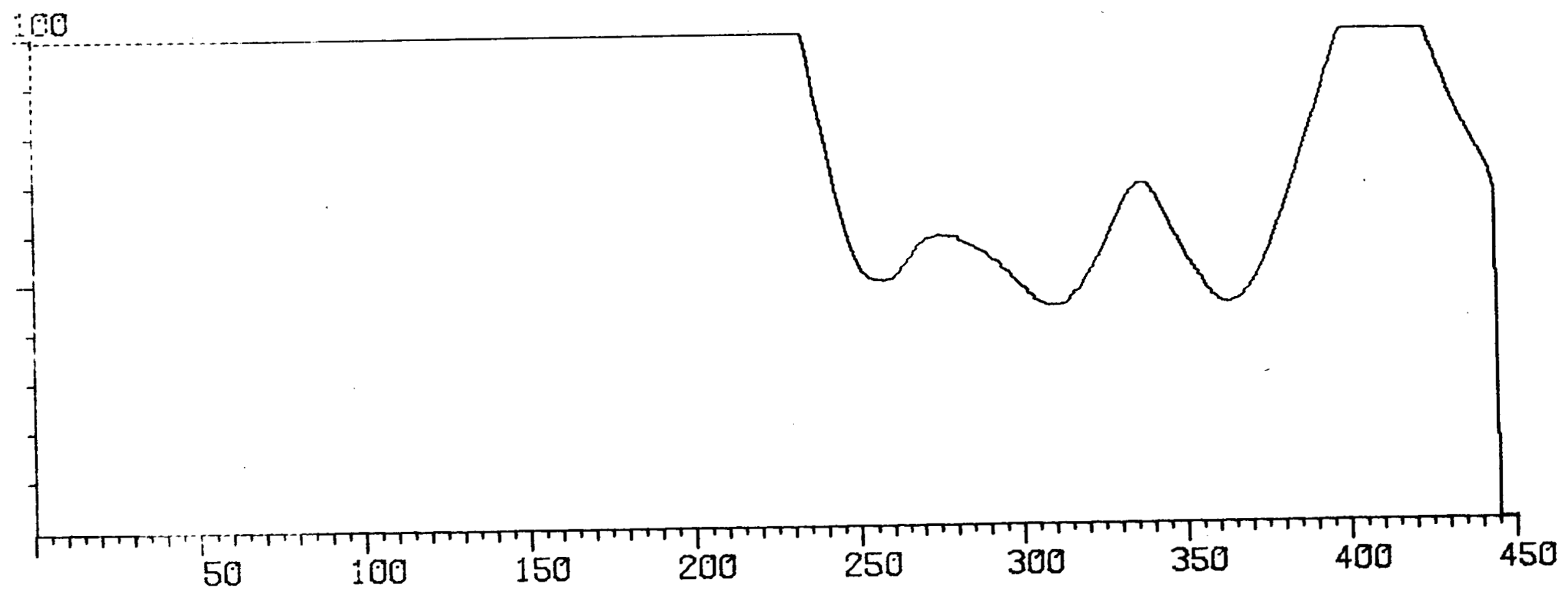


MASS 28 SEARCH $X 4$

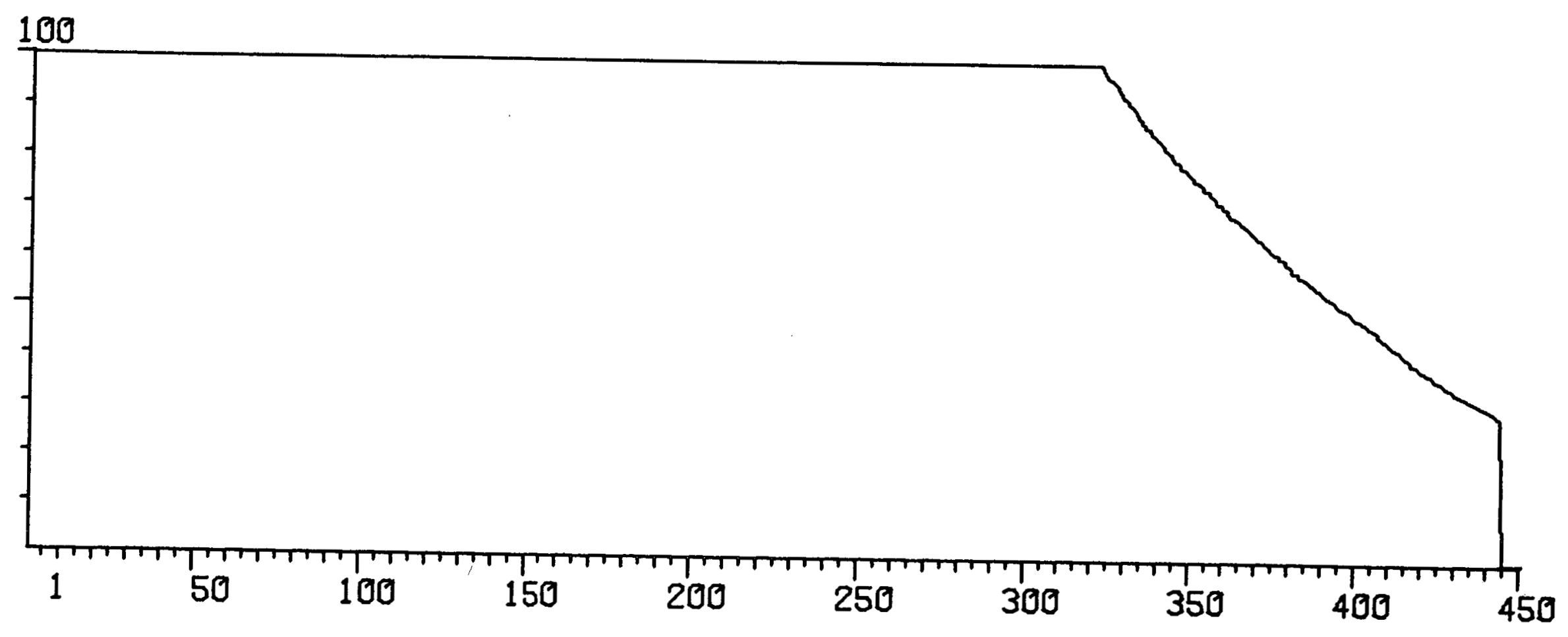


SALT SAMPLE

2821.0

MASS 32 SERRCH $\times 4$

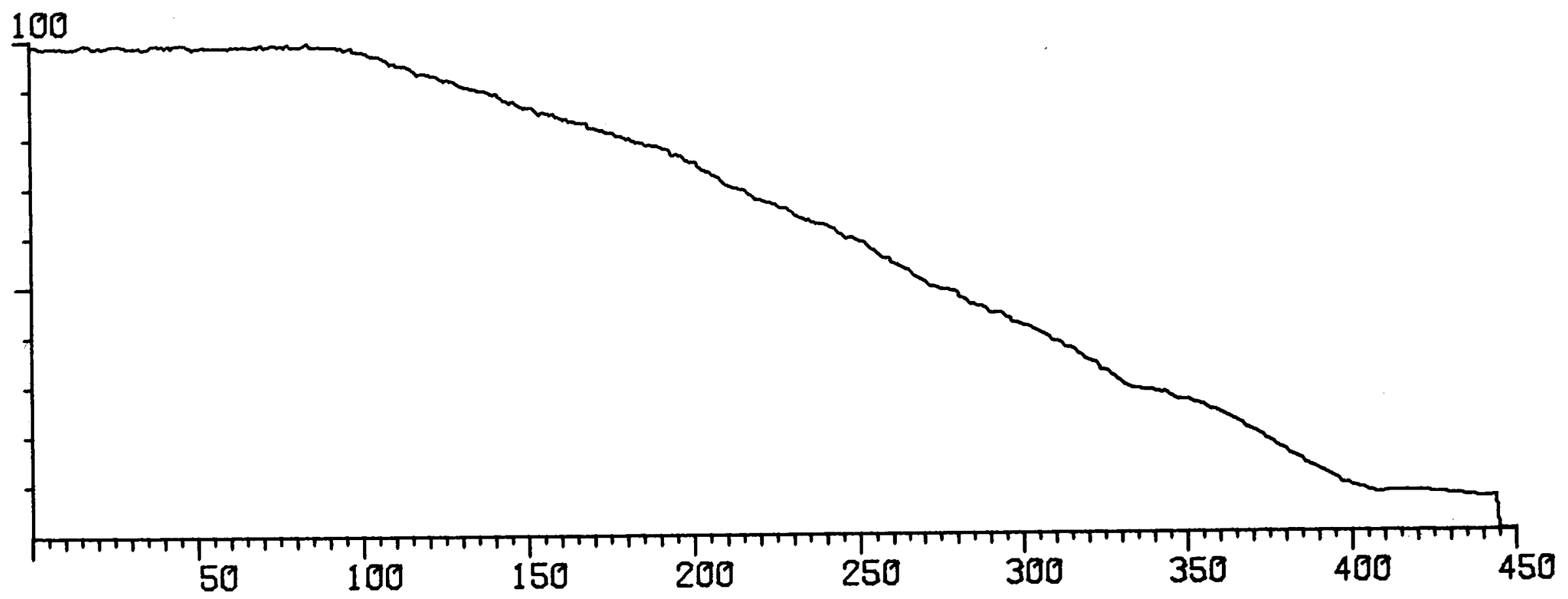


1

SALT SAMPLE

2786.5

MASS 18 SEARCH $X 4$
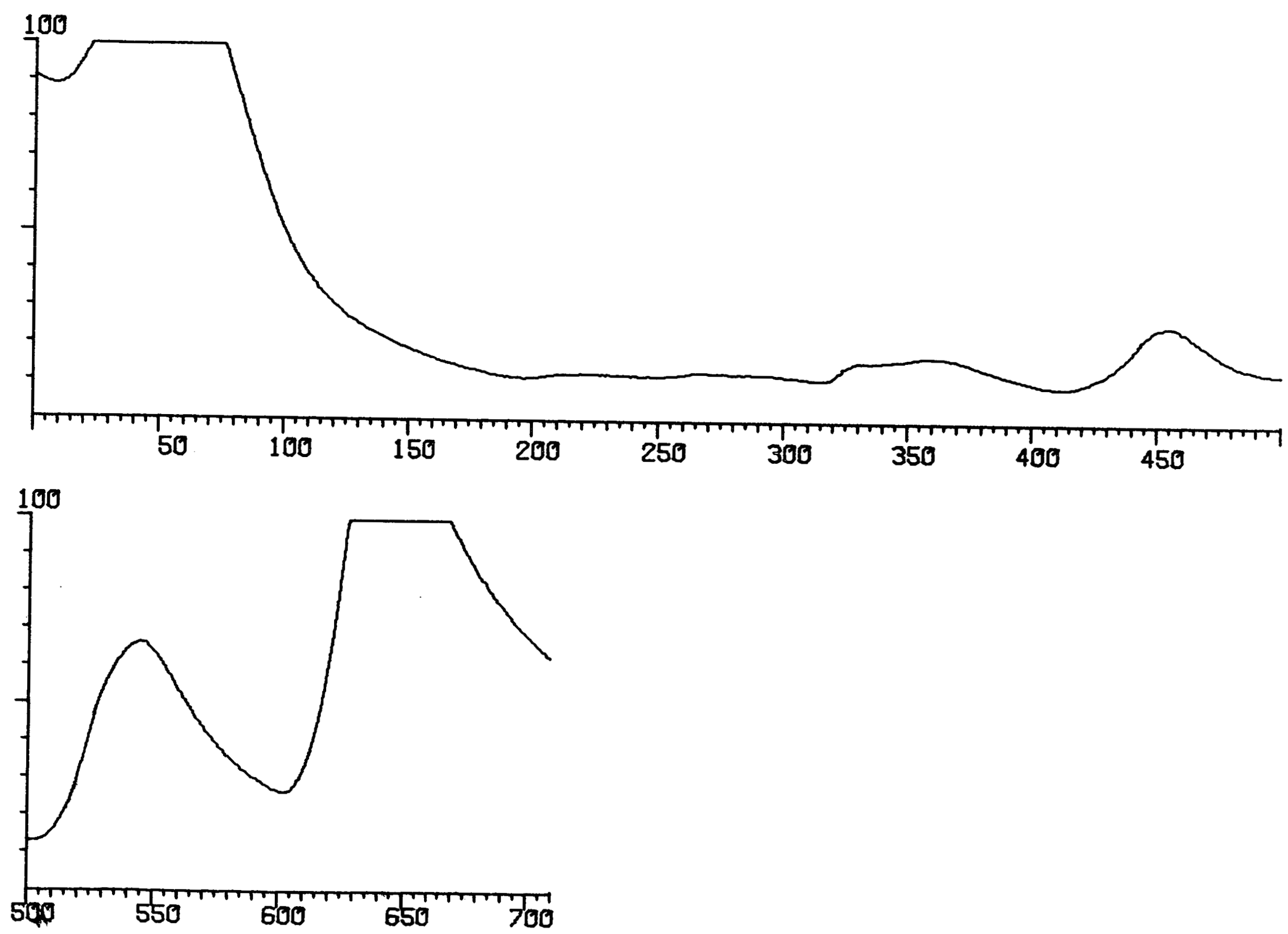
SALT SAMPLE

2786.5

MASS 19 SEARCH $\times 1$
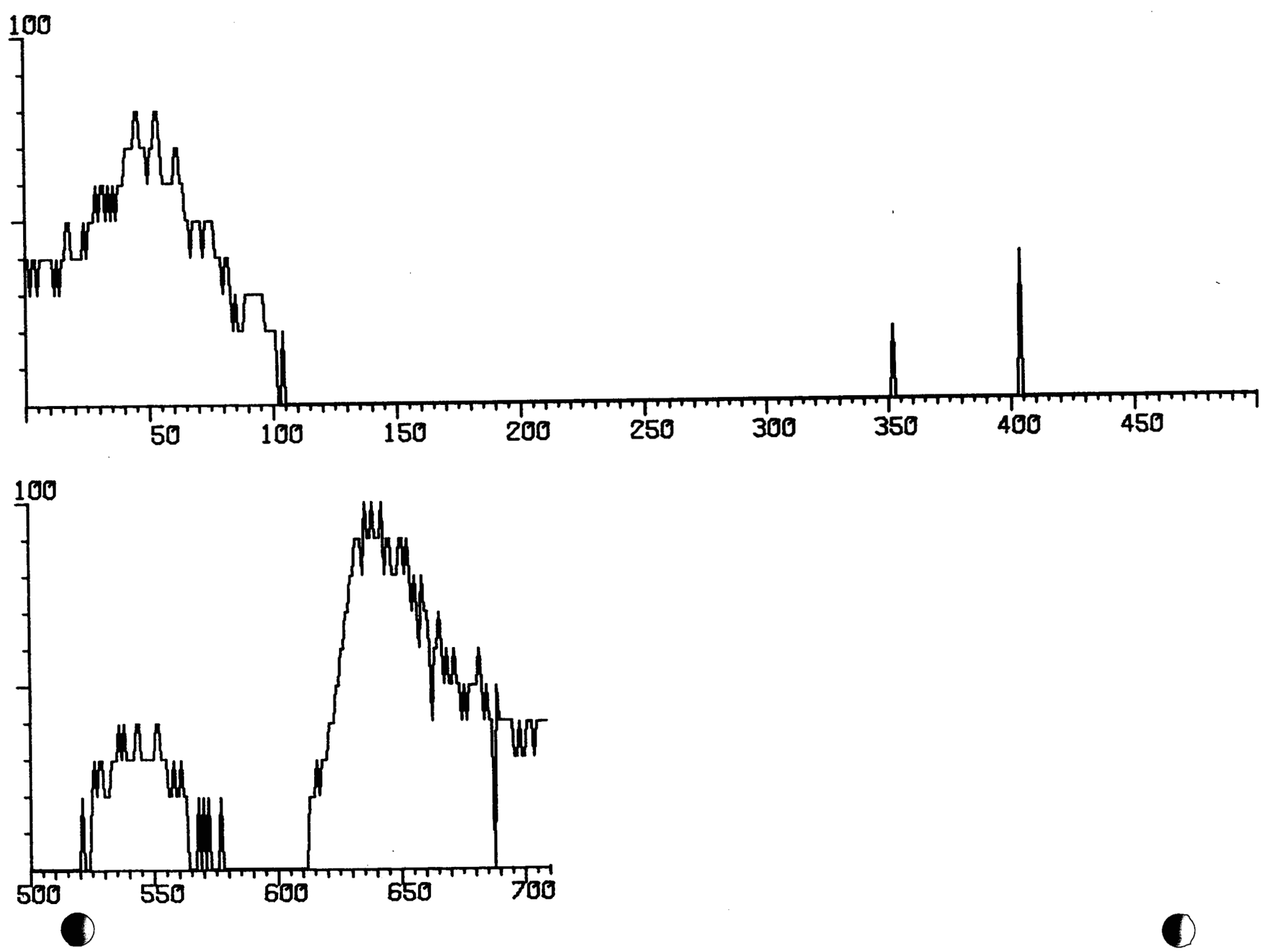
0

SALT SAMPLE

2786.5

\section{MASS 28 SEARCH $\times 3$}

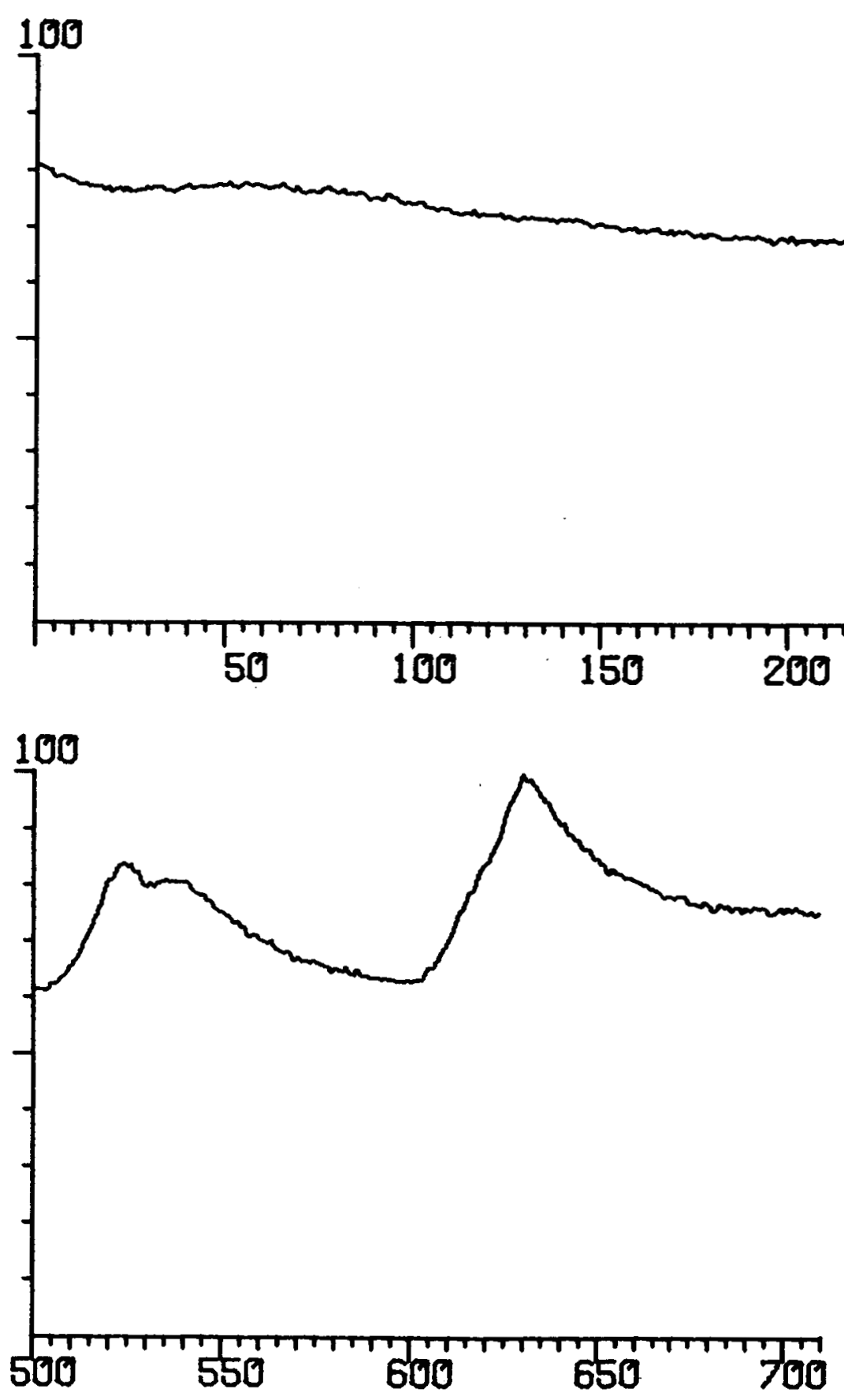


MASS 32 SEARCH X1
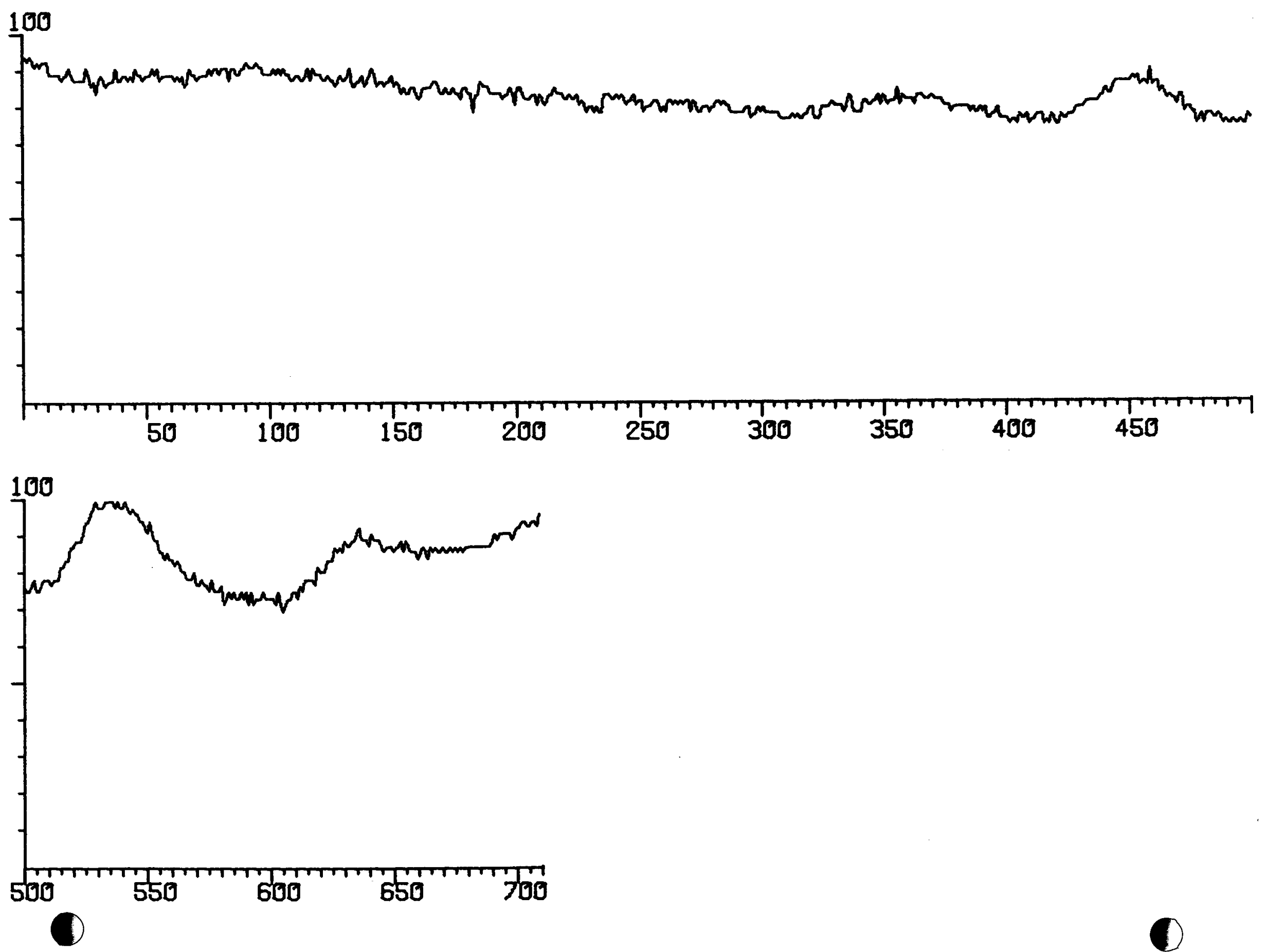
0

SALT SAMPLE

MASS 36 SERRCH $\times 2$

\section{5}

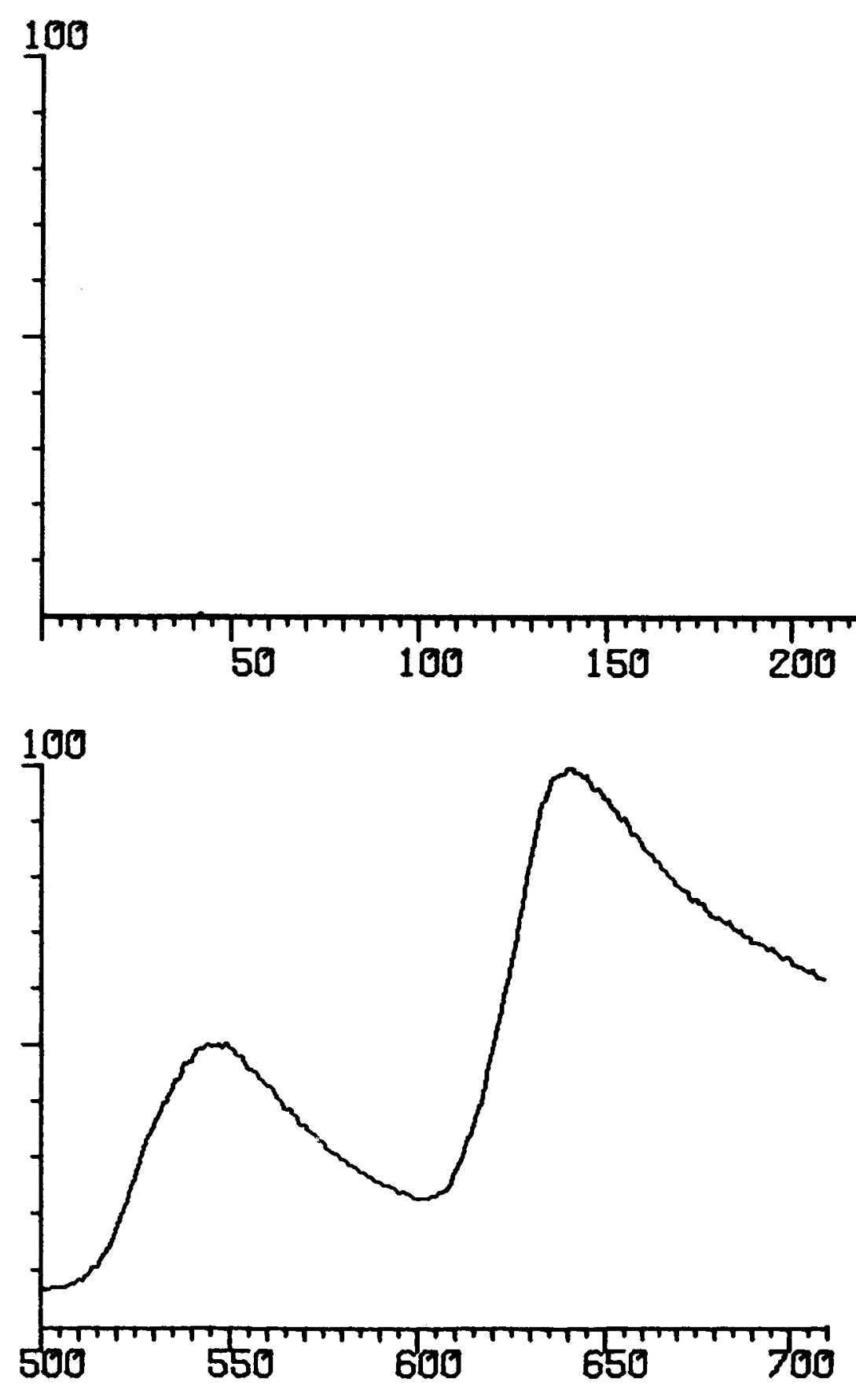


SALT SAMPLE

MASS 44 SEARCH $\times 2$
2786.5

100

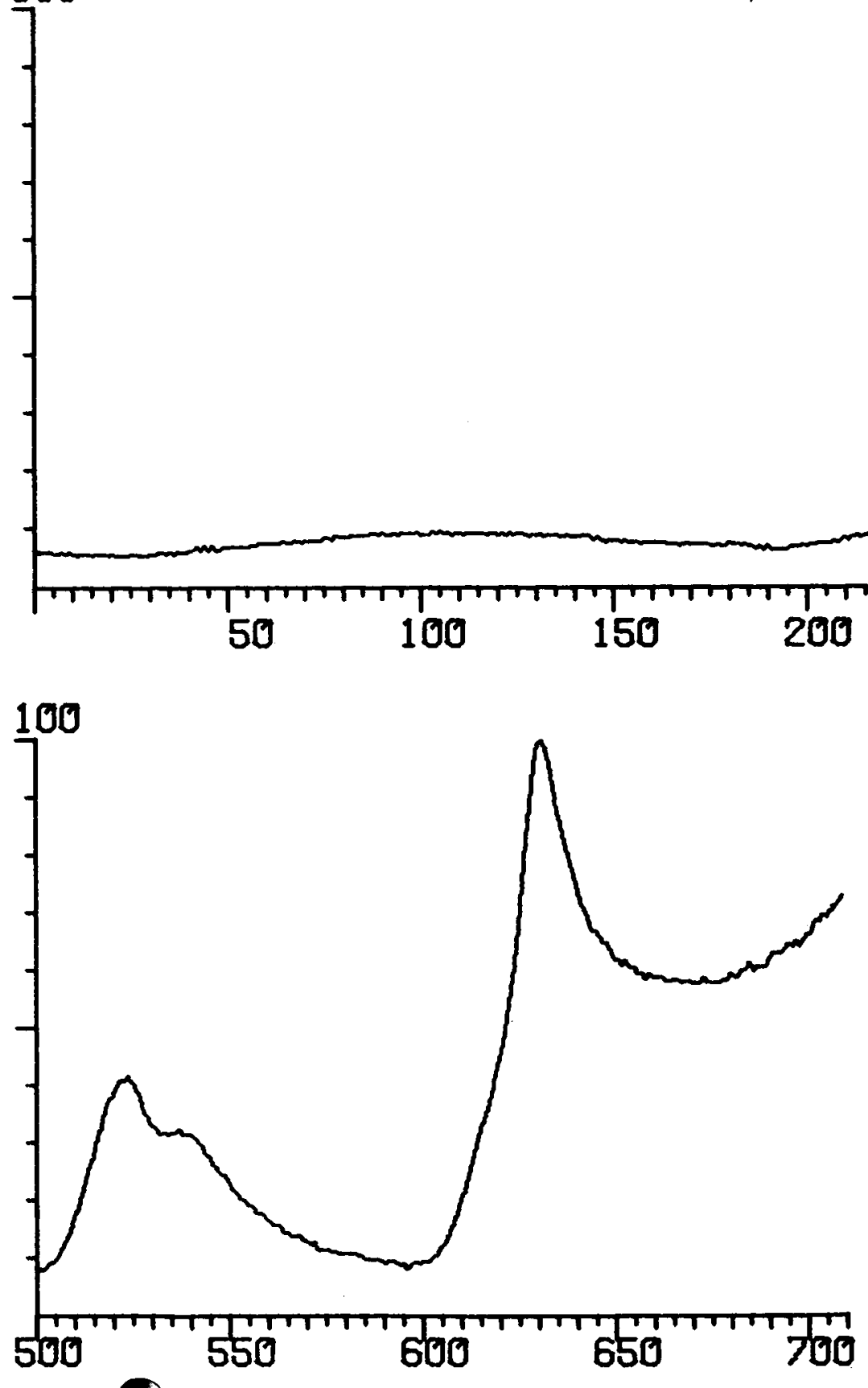


D

SALT SAMPLE

MASS 48 SEARCH $X_{1}$
$2786-5$

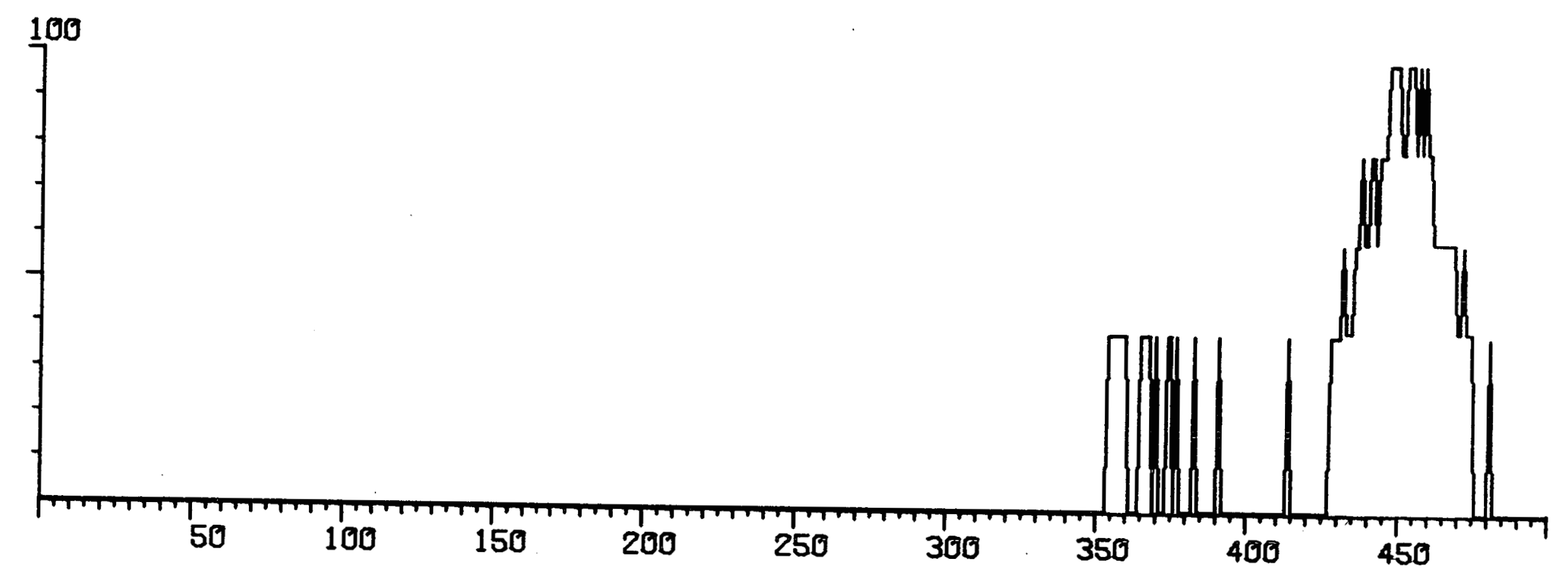


SALT SAMPLE

2821.0

TOTAL ION CHROMATOGRAM

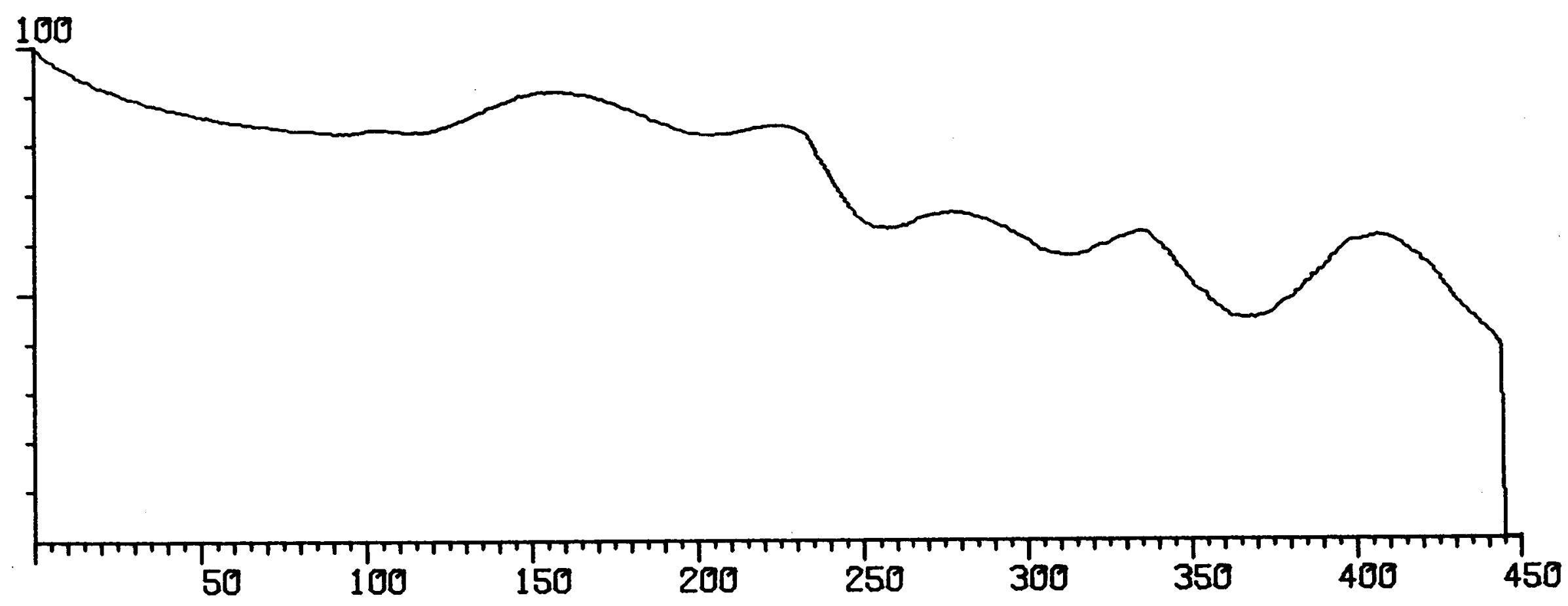


SALT SAMPLE

2821.0

100

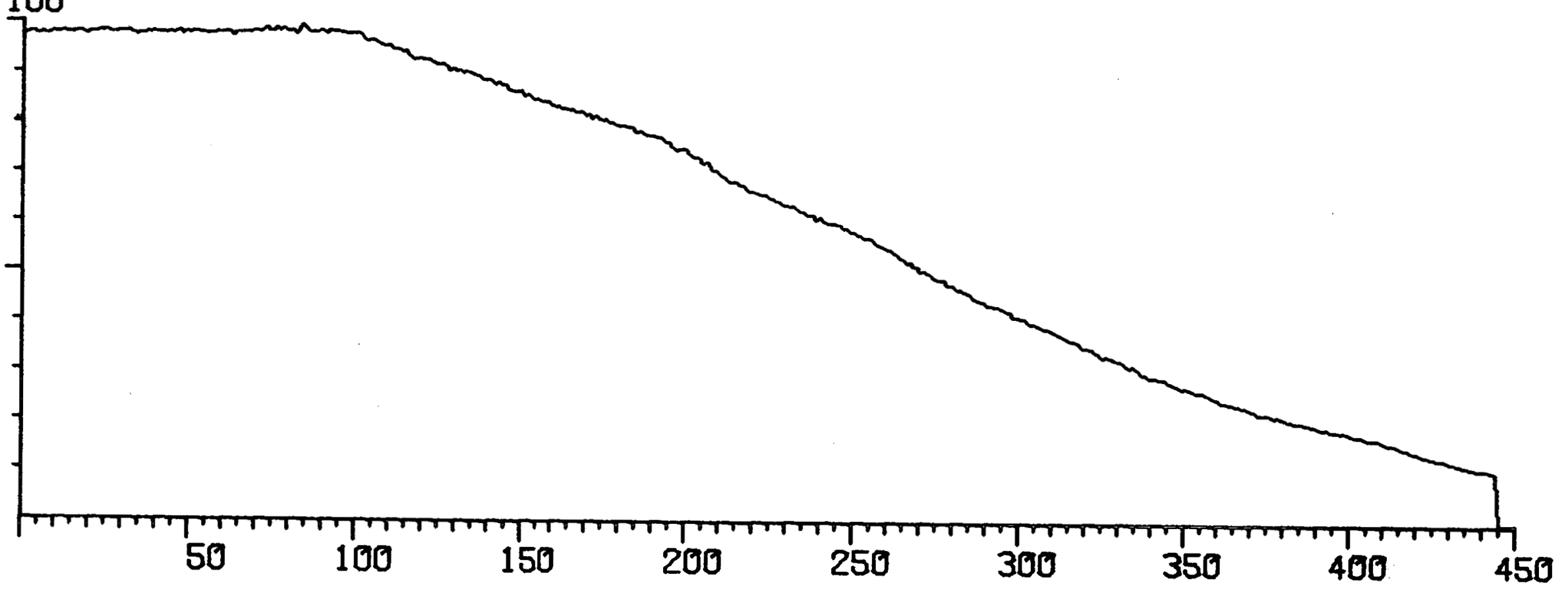


SALT SIYMPIE

2821.0

ISSS 18 SEARCH $X_{4}$

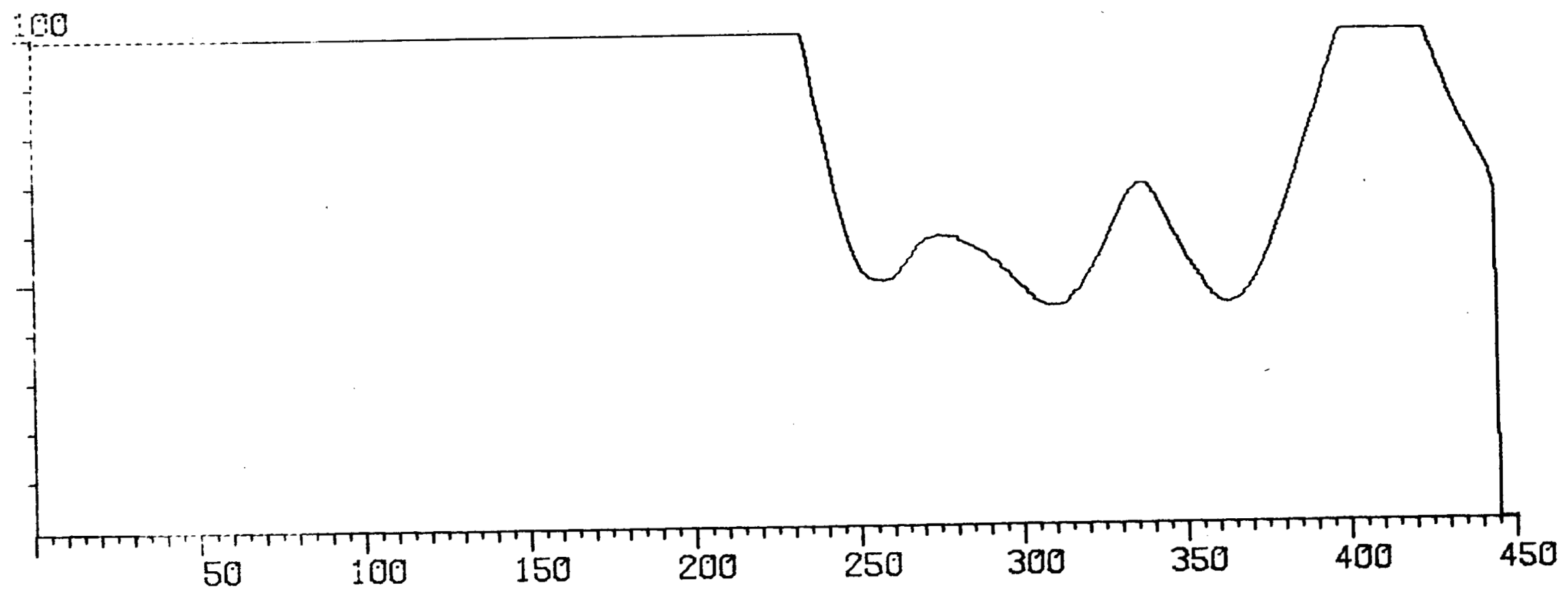


MASS 28 SEARCH $X 4$

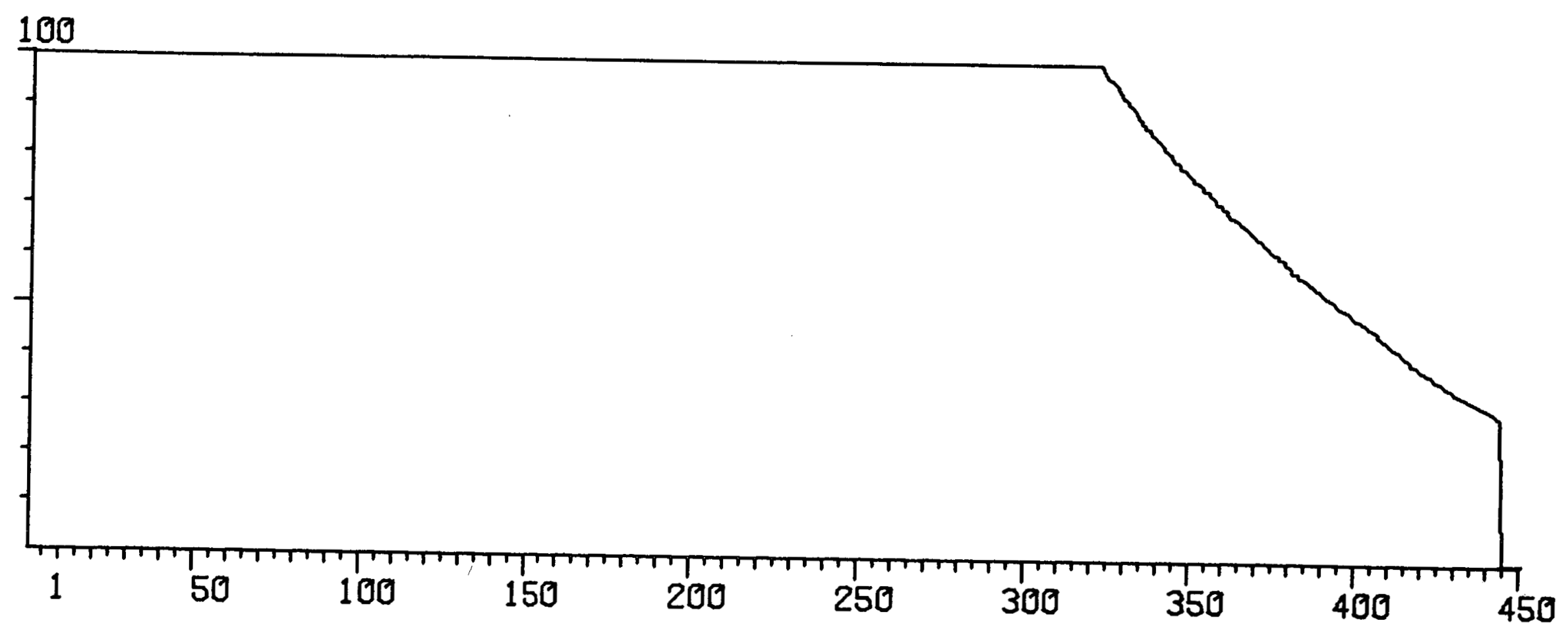


SALT SAMPLE

2821.0

MASS 32 SERRCH $\times 4$

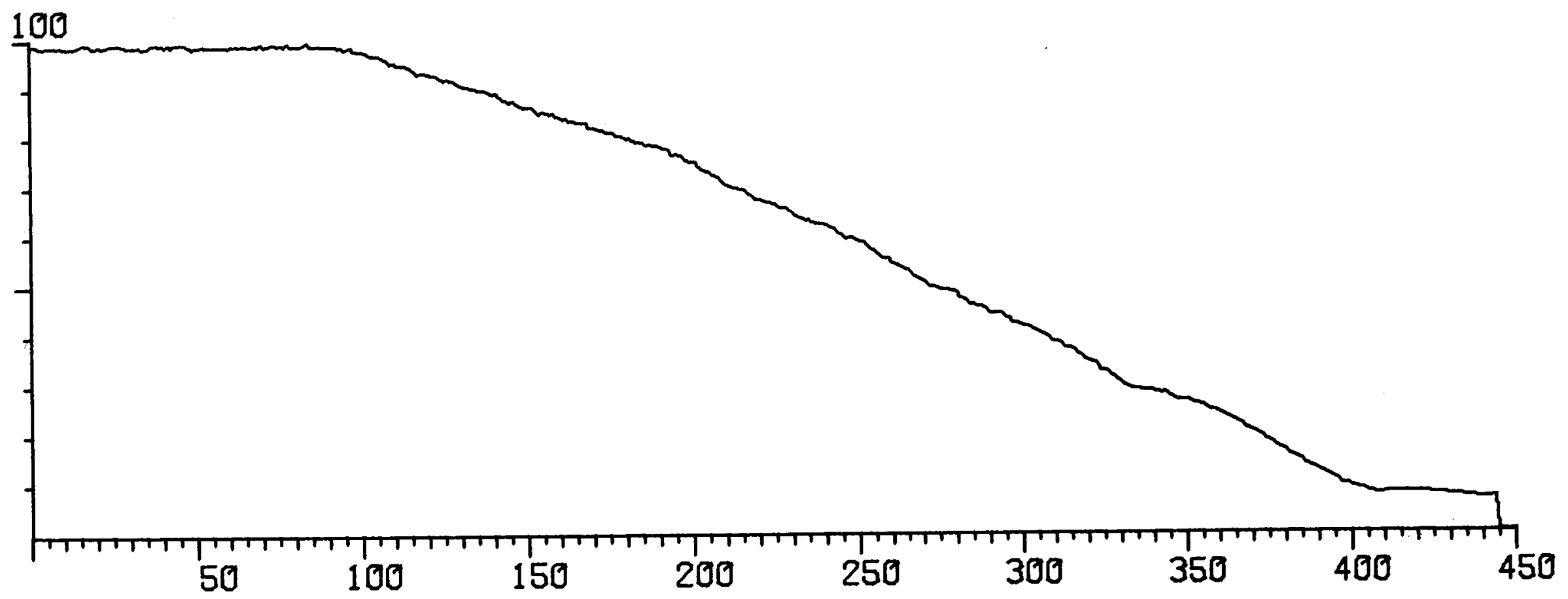


SALT SAMPLE

2821.0

MASS 36 SEARCH $\times 2$

\section{0}

1

50 
SALT SAMPLE

2821.0

MASS 36 SEARCH $\times 2$

\section{0}

1

50 
SALT SAMPLE

2821.0

MASS 44 SEARCH X2

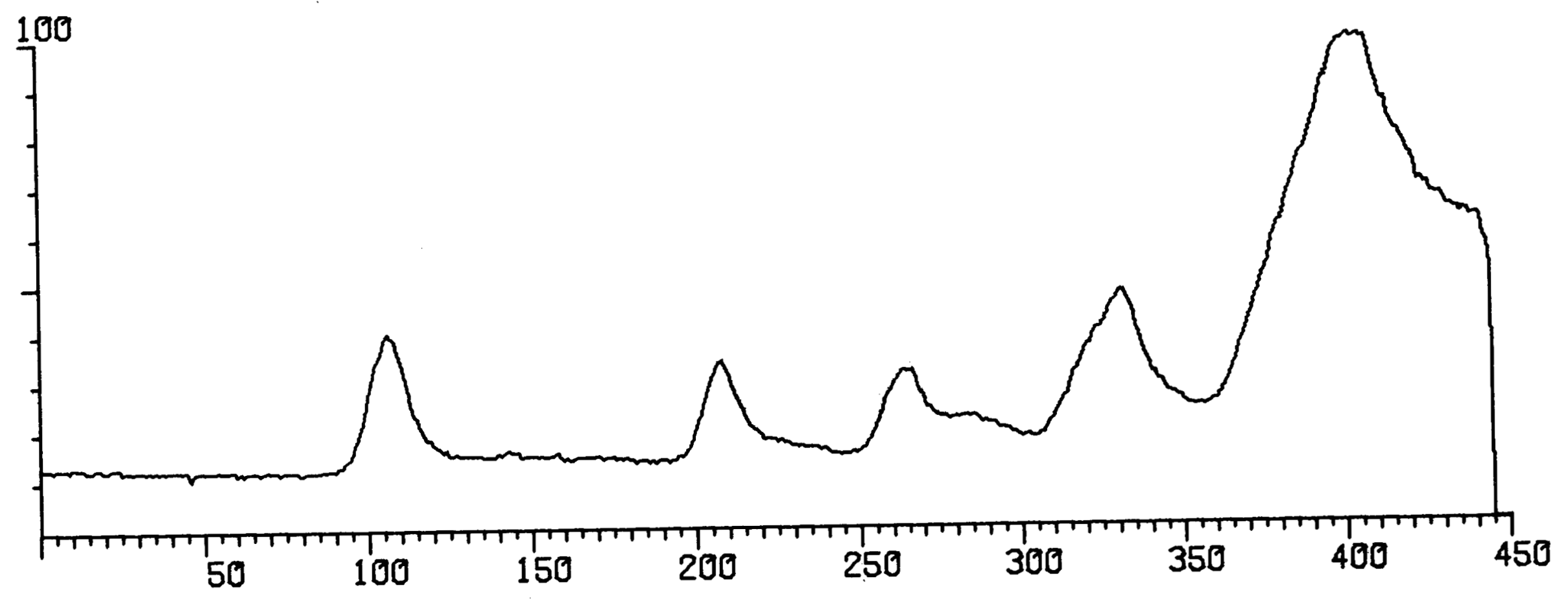


APPENDIX 7.F. Analytical Precision. (Ref. Sec. 7.5)

1. General statement concerning sample sizes, weighing errors, etc.

The sample weights used in this study ranged from approximately 0.5 to 2.5 grams, but typically were from 1.5 to 2.0 grams. The sample bottles were weighed before each new batch of samples was prepared, and both the sample bottles and the combined sample bottle and sample were weighed two times or more. Replicate weighings errors should result in a precision of no worse than \pm 0.1 to 0.2 weight 8 .

2. Results of triplicate analyses on selected samples.

Triplicate analyses were performed on separate splits taken from the sample vial using different initial sample weights each time. The results are tabulated below:

Sample Weight Losses Determined (Wt. $\%$ ) Mean to Nearest $0.1 \%$

$\begin{array}{lllll}7-1044 & 0.1 & 0.1 & 0.3 & 0.2\end{array}$

$\begin{array}{lllll}7-1296 & 1.3 & 0.9 & 1.3 & 1.2\end{array}$

$\begin{array}{lllll}8-1794 & 1.2 & 1.4 & 1.2 & 1.3\end{array}$

$\begin{array}{lllll}8-1986 & 0.0 & 0.0 & 0.1 & 0.0\end{array}$

$\begin{array}{lllll}8-2563 & 2.0 & 2.3 & 1.9 & 2.1\end{array}$

$\begin{array}{lllll}8-2616 & 0.0 & 0.0 & 0.0 & 0.0\end{array}$ 


\section{$7 F-2$}

The results of these analyses indicate that most weight losses determined from replicate samples (taken from the same sample bottle) fall within \pm 0.2 to 0.3 of the mean value. Because of vertical and lateral variation in mineral content typical of sedimentary rocks the range anticipated for different samples of the same core would be larger, but it is not possible to estimate the precision under such non-reproducible conditions. In the case of relatively uniform samples (such as some halite or anhydrite beds) the precision might be anticipated to remain fairly good. On the other hand, samples which contain varying amounts of clays or other hydrous minerals might be expected to show much larger variations in their weight losses upon heating. 
APPENDIX 7.G. Weight Loss Data for Cores \#7 and \#8, Carlsbad, New Mexico, Including Comparisons with the Data of Section 7.3. (Ref. Sec. 7.5)

1. Core \#7.

\begin{tabular}{|c|c|c|}
\hline $\begin{array}{l}\text { Sample } \\
(\mathrm{ft})\end{array}$ & $\begin{array}{l}\text { Depth } \\
\text { (m) }\end{array}$ & $\begin{array}{l}\text { Weight Losses at } \\
102 \pm 5^{\circ} \mathrm{C} \text { (Wt. } 8 \text { ) }\end{array}$ \\
\hline 1044 & 318.2 & 0.1 \\
\hline 1107 & 337.4 & 1.0 \\
\hline 1171 & 356.9 & 0.1 \\
\hline 1221 & 372.2 & 0.2 \\
\hline 1342 & 409.0 & 0.2 \\
\hline 1402 & 427.3 & 0.1 \\
\hline 1468 & 447.4 & 2.2 \\
\hline 1533 & 467.3 & 0.1 \\
\hline 1615 & 492.3 & 0.2 \\
\hline 1697 & 517.2 & 3.4 \\
\hline 1755 & 534.9 & 0.2 \\
\hline 1952 & 595.0 & 0.0 \\
\hline 1954 & 595.6 & 0.6 \\
\hline 1958 & 596.8 & 0.2 \\
\hline 1960 & 597.4 & 0.1 \\
\hline 1967 & 599.5 & 0.1 \\
\hline 1969 & 600.2 & 0.2 \\
\hline 1973 & 601.4 & 0.3 \\
\hline 1975 & 602.0 & 0.2 \\
\hline 1978 & 602.9 & 0.8 \\
\hline 1983 & 604.4 & 0.0 \\
\hline 1986 & 605.3 & 0.0 \\
\hline 1993 & 607.5 & 0.0 \\
\hline 2702 & 823.6 & 0.0 \\
\hline $\begin{array}{l}2716 \\
2736\end{array}$ & $\begin{array}{l}827.8 \\
833.9\end{array}$ & 0.2 \\
\hline
\end{tabular}

\begin{tabular}{c} 
a70 ${ }^{\circ} \mathrm{C}$ \\
\hline 0.10 \\
0.12 \\
0.14 \\
0.30 \\
0.27 \\
0.19 \\
1.27 \\
0.22 \\
0.34 \\
0.82 \\
0.19 \\
0.14 \\
0.32 \\
0.20 \\
0.07 \\
0.20 \\
0.43 \\
0.19 \\
0.17 \\
0.36 \\
0.29 \\
0.10 \\
0.19 \\
0.24 \\
0.22 \\
0.08
\end{tabular}

Data from section 7.3 To $200^{\circ} \mathrm{C}$

To Above $400^{\circ} \mathrm{C}$

0.10
0.22
0.14
0.44
0.27
0.19
1.73
0.23
0.43
0.82
0.23
0.14
0.32
0.20
0.39
0.20
0.51
0.26
0.17
0.40
0.32
0.10
0.24
0.27
0.22
0.08

0.10

1.99

0.80

0.51

0.43

0.31

2.59

0.47

0.80

0.85

0.28

0.58

0.41

0.32

0.39

1.13

0.71

0.40

0.24

1.67

0.51

0.10

1.04

0.39

0.26

0.11 
APPENDIX 7.G. Weight Loss Data, Continued.

\section{Core \#8}

\begin{tabular}{|c|c|c|}
\hline $\begin{array}{l}\text { Sample } \\
\text { (ft) }\end{array}$ & $\begin{array}{l}\text { Depth } \\
\text { (m) }\end{array}$ & $\begin{array}{l}\text { Weight Losses at } \\
102 \pm 5^{\circ} \mathrm{C} \text { (Wt. } 8 \text { ) }\end{array}$ \\
\hline $\begin{array}{l}1391 \\
1495 \\
1573 \\
1652 \\
1705 \\
1769 \\
1787 \\
1794 \\
1804 \\
1829 \\
1838 \\
1857 \\
1875 \\
1884 \\
1890 \\
1894 \\
1899 \\
1900 \\
1905 \\
1911 \\
1913 \\
1916 \\
1923 \\
1930 \\
1933 \\
1938 \\
1953 \\
1967 \\
1986\end{array}$ & $\begin{array}{l}424.0 \\
455.7 \\
479.5 \\
503.5 \\
519.7 \\
539.2 \\
544.7 \\
546.8 \\
549.9 \\
557.5 \\
560.2 \\
566.0 \\
571.5 \\
574.2 \\
576.1 \\
577.3 \\
578.8 \\
579.1 \\
580.6 \\
582.5 \\
583.1 \\
584.0 \\
586.1 \\
588.3 \\
589.2 \\
590.7 \\
595.3 \\
599.5 \\
605.3\end{array}$ & $\begin{array}{l}0.1 \\
0.1 \\
0.2 \\
0.1 \\
0.0 \\
0.1 \\
0.2 \\
1.4 \\
0.0 \\
0.1 \\
0.3 \\
0.1 \\
1.2 \\
0.9 \\
0.1 \\
0.4 \\
0.1 \\
0.1 \\
1.0 \\
0.2 \\
0.2 \\
0.0 \\
0.1 \\
0.4 \\
0.1 \\
0.0 \\
0.1 \\
0.5 \\
0.0\end{array}$ \\
\hline
\end{tabular}

a $70^{\circ} \mathrm{C}$

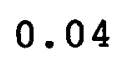

0.05

0.04

0.09

0.15

0.09

0.32

0.44

0.02

0.16

0.39

0.07

0.22

0.36

0.05

0.30

0.16

0.17

0.36

0.06

0.11

0.13

0.19

0.05

0.19

0.13

0.05

0.28

0.07
Data from Section 7.3 To $200^{\circ} \mathrm{C}$

To Above $400^{\circ} \mathrm{C}$

0.07
0.08
0.33
0.09
0.17
0.15
0.36
0.71
0.07
0.39
0.39
0.07
0.64
0.36
0.05
0.30
0.16
0.17
0.36
0.06
0.14
0.13
0.19
0.05
0.28
0.27
0.10
0.32
0.07

\subsection{6}

0.08

1.18

4.52

0.32

0.35

0.59

5.41

0.07

0.39

0.39

0.10

0.64

0.80

0.13

0.30

0.16

0.81

0.62

0.10

0.21

0.25

0.49

0.47

0.28

0.49

0.42

0.52

5.81 
APPENDIX 7.G. Weight Loss Data, Continued.

\section{Core \#8}

\begin{tabular}{|c|c|c|}
\hline $\begin{array}{l}\text { Sample } \\
\text { (ft) }\end{array}$ & $\begin{array}{l}\text { Depth } \\
\text { (m) }\end{array}$ & $\begin{array}{l}\text { Weight Losses at } \\
102 \pm 5{ }^{\circ} \mathrm{C}(\mathrm{Wt} .8)\end{array}$ \\
\hline $\begin{array}{l}2006 \\
2017 \\
2039 \\
2050 \\
2068 \\
2084 \\
2130 \\
2162 \\
2217 \\
2280 \\
2326 \\
2366 \\
2427 \\
2460 \\
2519 \\
2563 \\
2616 \\
2666 \\
2707 \\
2758 \\
2779 \\
2793 \\
2803 \\
2809 \\
2821 \\
2879 \\
2948\end{array}$ & $\begin{array}{l}611.4 \\
614.8 \\
621.5 \\
624.8 \\
630.3 \\
635.2 \\
649.2 \\
659.0 \\
675.7 \\
694.9 \\
709.0 \\
721.2 \\
739.7 \\
749.8 \\
767.8 \\
781.2 \\
797.4 \\
812.6 \\
825.1 \\
840.6 \\
847.0 \\
851.3 \\
854.4 \\
856.2 \\
859.8 \\
877.5 \\
898.6\end{array}$ & $\begin{array}{l}0.1 \\
0.2 \\
0.1 \\
0.0 \\
0.1 \\
0.3 \\
0.0 \\
0.1 \\
0.1 \\
0.0 \\
0.1 \\
1.9 \\
0.0 \\
0.0 \\
0.0 \\
2.3 \\
0.0 \\
0.0 \\
0.6 \\
0.0 \\
0.2 \\
0.0 \\
0.0 \\
0.0 \\
0.2 \\
0.2 \\
0.1\end{array}$ \\
\hline
\end{tabular}

\begin{tabular}{l} 
Q70 \\
\hline 0.20 \\
0.22 \\
0.21 \\
0.11 \\
0.04 \\
0.17 \\
0.11 \\
0.14 \\
0.04 \\
0.19 \\
0.11 \\
0.43 \\
0.03 \\
0.17 \\
0.08 \\
1.87 \\
0.21 \\
0.25 \\
0.16 \\
0.11 \\
0.21 \\
0.18 \\
0.10 \\
0.15 \\
0.18 \\
0.06 \\
0.20
\end{tabular}

Data from section 7.3 To $200^{\circ} \mathrm{C}$

To Above $400^{\circ} \mathrm{C}$

0.20
0.24
0.26
0.11
0.04
0.22
0.18
0.14
0.04
0.19
0.14
0.43
0.03
0.22
0.08
2.13
0.21
0.25
0.16
0.11
0.21
0.18
0.12
0.24
0.18
0.06
0.22


APPENDIX 7.G. Weight Loss Data, Continued.

3. Weight losses determined at higher temperatures for selected samples from Core \#8.

\begin{tabular}{|c|c|c|c|c|}
\hline $\begin{array}{l}\text { Sample } \\
(\mathrm{ft})\end{array}$ & $\begin{array}{l}\text { Depth } \\
\text { (m) }\end{array}$ & $\begin{array}{l}\text { Weight Losses } \\
102 \pm 5^{\circ} \mathrm{C}\end{array}$ & $170 \pm 5^{\left(+\bar{\sigma}_{C}\right.} 0.1$ to 0.2 & $\begin{array}{l}\text { Weight } 8) \\
300 \pm 10^{\circ} \mathrm{C}\end{array}$ \\
\hline $\begin{array}{l}1804 \\
1829 \\
1875 \\
1884 \\
1923 \\
1967 \\
2050 \\
2366 \\
2948\end{array}$ & $\begin{array}{l}549.9 \\
557.5 \\
571.5 \\
574.2 \\
586.1 \\
599.5 \\
624.8 \\
721.2 \\
898.6\end{array}$ & $\begin{array}{l}0.0 \\
0.1 \\
1.2 \\
0.9 \\
0.1 \\
0.5 \\
0.0 \\
1.9 \\
0.1\end{array}$ & $\begin{array}{l}0.0 \\
0.2 \\
1.8 \\
1.0 \\
0.1 \\
0.5 \\
0.0 \\
2.0 \\
0.0\end{array}$ & $\begin{array}{l}0.2 \\
0.4 \\
2.2 \\
1.5 \\
0.2 \\
1.4 \\
0.7 \\
7.4 \\
0.2\end{array}$ \\
\hline
\end{tabular}

Note: In this set of weight loss determinations, one split from each sample selected was heated to successively higher temperatures. 
APPENDIX 7.H. Mineralogy and Petrology of Core \#7 and \#8.

1. Abbreviations used.

Minerals In the summaries which follow the approximate amounts of the minerals present are indicated by upper and lower case letters. AN + MAJOR

$(>258) ;$ An + Minor (5 to 258); an = trace

$(<5 \%$. Often less than $1 \%)$

$\begin{array}{llll}\text { AN } & \text { Anhydrite } & \text { HA } & \text { Halite } \\ \text { CAR }= & \text { Carnallite } & \text { KAIN } & \text { Kainite } \\ \text { CEL } & \text { Celestite } & \text { PH } & \text { Polyhalite } \\ \text { CSSM }= & \text { Clay and silt-sized } & \text { QTZ } & \text { Quartz } \\ & \text { minerals (often magnesitic) } & \text { SYL }=\text { Sylvite } \\ \text { FELD }= & \text { Feldspar (s) } & & \\ \text { GLAU }= & \text { Glauconite } & & \\ \text { GYP }= & \text { Gypsum }\end{array}$

Grain Sizes

$\mathrm{fg}=$ Fine grained $(<1 \mathrm{~mm})$
$\mathrm{mg}+$ medium grained $(1 \mathrm{~mm}$ to $1 \mathrm{~mm})$
$\mathrm{cg} \quad=\quad$ coarse grained $(>1 \mathrm{~cm})$

With the exception of halite, which shows a wide range of grain sizes, most of the minerals observed are fine grained. 
APPENDIX 7.H. Mineralogy and Petrology, Continued.

2. Core \#7

Depth (ft)

1044

1107

1171

1221

1296

1342

1402

1468

1533

1615

1697
Description

cg HA with An and cssm in patches and stringers. An also in isolated crystals and crystal clusters.

fg to mg HA with mg gyp which is partially replaced by $\mathrm{An}$. $\mathrm{fg}$ to $\mathrm{mg} \mathrm{ph}$ in patches and stringers along with cssm.

Appears macroscopically bedded. Primarily vuggy AN. Voids filled with radial ("starbursts") of ph and also with ha and cssm.

cg HA. Patches and stringers filled with ph (radial in part) and an. Some evidence of ph replacing an.

mg to cg HA with Cssm, ph and possibly some an in patches and stringers. Some of the Cssm appears intergranular among $\mathrm{HA}$ crystals. May represent subaerial deposition.

mg to cg HA with ph and cssm in patches and stringers.

mg HA. ph (radial in part) and an in patches and stringers and as crystal clusters.

mg HA with much intergranular Cssm. Possibly represents subaerial deposition. Trace an and ph as isolated crystals and crystal clusters. Some authigenic quartz and feldspar.

mg to cg HA with poorly preserved hoppers. $\mathrm{Ph}$ in patches and stringers, some possibly intergranular with HA. Trace Cssm associated with the Ph.

mg to $\mathrm{cg}$ HA with hoppers. fg to $\mathrm{mg}$ An and $\mathrm{ph}$ in patches and stringers. ph appears to be replacing An, some of which may be psuedomorphic after gypsum.

Appears to be macroscopically bedded. Large, nodular masses of AN (possibly pseudomorphic after gypsum nodules) with voids filled with Cssm, Ph, ha and syl. Ph associated with Cssm; syl associated with $\mathrm{Ph}$. 
APPENDIX 7.H. Mineralogy and Petrology, Continued.

2. Core \#7, continued

Depth (ft)

1755

1952

1954

1958

1960

1967

1969

1973

1975

1978

Description

$\mathrm{mg}$ to $\mathrm{cg}$ Ha with poorly preserved hoppers. ph and an in patches and stringers. ph replaces an in part. Perhaps a little syl is present.

Appears macroscopically bedded. mg to cg HA with hoppers. $\mathrm{Ph}$ and an in patches, stringers and as isolated crystals and clusters. Ph replacing an in part.

mg to cg HA with Cssm in patches and stringers. Some Cssm is intergranular with HA. May represent subaerial deposition. Some isolated crystals and clusters of ph associated with Cssm.

$\mathrm{mg}$ to $\mathrm{cg} \mathrm{HA}$. cssm in patches and stringers. (Some cssm may be intergranular). ph and possible an in patches and stringers associated with cssm and also in isolated crystals and clusters.

Possibly macroscopically bedded. fg to cg HA with hoppers. Intergranular Cssm with associated authigenic qtz and feld. May represent suberial deposition. Some isolated crystals and clusters of ph and an.

mg to cg HA with poorly preserved hoppers. ph in patches and stringers shows some evidence of flow or deformation. A few isolated crystals and clusters of an.

fg to $\mathrm{cg} H A$ with poorly preserved hoppers. Intergranular Cssm with associated authigenic qtz and feld. Isolated crystals and clusters of an and lesser ph.

cg HA with very few patches and stringers of cssm, $\mathrm{ph}$ and even some ha crystals.

cg HA with ph, cssm and an in patches and stringers. ph appears to be replacing an. ph associated with cssm.

$\mathrm{mg}$ to $\mathrm{cg} \mathrm{HA}$ with intergranular Cssm and ph. May represent subaerial deposition. Some ph in patches and stringers and as isolated crystals and clusters. Some ph is $\mathrm{mg}$. Isolated crystals of an are associated with the ph. 
APPENDIX 7.H. Mineralogy and Petrology, Continued.

2. Core \#7, continued

Depth (ft)

1983

1986

1993

2702

2716

2736

\section{Description}

mg to cg HA with hoppers. Ph and an in patches and stringers $\mathrm{Ph}$ replacing an.

$\mathrm{mg}$ to $\mathrm{cg}$ HA with small amounts of $\mathrm{ph}$, an and cssm in patches and stringers.

cg HA with hoppers. $\mathrm{Ph}$ and an in patches and stringers. (Some $\mathrm{Ph}$ and an may be intergranular). $\mathrm{Ph}$ appears to replace an.

mg to cg HA with An and cssm in patches and stringers.

mg to cg HA with hoppers. an and cssm in patches and stringers, some possibly intergranular with HA. May represent subaerial deposition.

mg to cg HA with hoppers. An and cssm in patches and stringers, some possibly intergranular with HA. May represent subaerial deposition. 
APPENDIX 7.H. Mineralogy and Petrology, Continued.

3. Core \#8

Depth $(\mathrm{ft})$

1391

1495

1573

1652

1705

1769

1787

1794

1804

1829

\section{Description}

cg HA with ph and possibly some an in patches and stringers.

mg to cg HA with hoppers. Ph associated with cssm in patches and stringers. Some may be intergranular. $\mathrm{Ph}$ shows evidence of flowage or deformation.

Appears macroscopically bedded. $\mathrm{mg}$ to $\mathrm{cg}$ HA with $\mathrm{Ph}$ and $\mathrm{fg}$ to $\mathrm{mg}$ An in large patches. Ph appers to be replacing An.

Appears macroscopically bedded. fg to mg AN with $\mathrm{Ph}$. $\mathrm{mg} \mathrm{Ha}$ in patches or voids. Some syl associated with Ph. Algal laminations may be present in the An.

fg to $\mathrm{Cg} H A$ with hoppers. Ph in patches and stringers; some may be intergranular. Small amount of an associated with $\mathrm{Ph}$.

mg to $\mathrm{cg}$ HA with poorly preserved hoppers. fg to $\mathrm{mg}$ $\mathrm{Ph}$ in patches and stringers and intergranular with HA. In part, $\mathrm{Ph}$ appears to be replacing HA. Some gyp (?) may be present in very small amounts. There also may be trace amounts of cel (?).

mg to $\mathrm{cg}$ HA with hoppers. Ph in patches and stringers and some intergranular with HA. Some $\mathrm{mg}$, acicular an crystals and $\mathrm{mg}$, acicular cel (?) crystals noted. There may be a small amount of gyp (?) present in this slide.

Appears macroscopically bedded. fg to mg HA with hoppers. CSSM is intergranular with HA. May represent subaerial deposition. Also noted: a few isolated ph crystals, some authigenic qtz and feld, and a trace of glau (?).

fg to cg HA with poorly presrved hoppers. CSSM is intergranular with HA. May represent subaerial deposition. ph in isolated crystals and cluters.

cg HA with hoppers. Cssm in patches and stringers and some intergranular. Possible subaerial

deposition. Trace of ph. 
APPENDIX 7.H. Mineralogy and Petrology, Continued.

3. Core \#8, continued

Depth (ft)

1838

1857

1875

1884

1890

1894

1900

1905

1910

1911

\section{Description}

fg to mg HA with poorly preserved hoppers. Cssm intergranular with $\mathrm{HA}$. $\mathrm{Ph}$ and $\mathrm{An}$ in patches and stringers and associated wtih the Cssm. May represent subaerial deposition.

cg HA with poorly preserved hoppers. ph along stringers.

Apperas macroscopically bedded. fg to mg HA intergranular with CSSM. May represent subaerial deposition. Isolated crystals and clusters of ph and $\mathrm{fg}$ to $\mathrm{mg}$ an. Traces of authigenic qtz and feld.

fg to $\mathrm{mg}$ HA with hoppers, intergranular with CSSM. May represent subaerial deposition. Some isolated crystals and clusters of fg to $\mathrm{mg}$ an (some may be pseudomorphic after gyp). Possible trace of syl.

mg to cg HA with hoppers. ph and an in patches and stringers.

mg to Cg HA with poorly preserved hoppers. ph and an in patches and stringers. cssm in patches and stringers with authigenic qtz and feld.

fg to cg HA with hoppers. $\mathrm{Ph}$, An and cssm in patches and stringers and some intergranular with HA. May represent subaerial deposition. Some Ph appears to be deformed or to have flowed.

mg to $\mathrm{cg} \mathrm{HA}$ with patches and stringers and some intergranular Cssm. (May represent subaerial deposition). Scattered, isolated crystals of ph and an.

mg to $\mathrm{Cg} H A$ with poorly preserved hoppers. $\mathrm{Ph}$, an and cssm intergranular with $\mathrm{HA}$ and in patches and stringers. Ph apperas to be replacing an.

mg to cg HA with hoppers. $\mathrm{Ph}$, An and cssm in patches and stringers, some intergranular with HA. (May represent subaerial deposition). Ph appears to be replacing an. 
APPENDIX 7.H. Mineralogy and Petrology, Continued.

3. Core \#8, continued

Depth (ft)

1913

1916

1923

1930

1933

1938

1953

1967

1986

2006
Description

fg to $\mathrm{Cg} H A$ with intergranular Cssm. Inclusions of ha in Cssm. May represent subaerial deposition. Isolated crystals of ph. A few authigenic grains of qtz and feldspar.

cg HA with poorly preserved hoppers. ph and an in patches and stringers.

fg to cg HA with intergranular Cssm. May represent subaerial deposition. $\mathrm{ph}$ and an in patches and stringers and as isolated crystals. Trace authigenic feld.

mg to cg HA with poorly presrved hoppers. $\mathrm{Ph}$ and an in patches and stringers, some as isolated crystals. cssm in patches and stringers. Possible trace gyp (?).

cg HA with hoppers. cssm, ph and an in patches and stringers. Small amounts of authigenic qtz and feld (?).

cg HA with poorly preserved hoppers. $\mathrm{Ph}$ and an in patches and stringers.

fg to $\mathrm{mg}$ HA with hoppers. Cssm intergranular with $H A$ and in patches and stringers. May represent subaerial deposition. Isolated crystals and clusters of $\mathrm{ph}$ and $\mathrm{an}$.

fg to cg HA with hoppers. Cssm intergranular with HA and in patches and stringers. May represent subaerial deposition. Isolated crystals and clusters of $\mathrm{ph}$ and $\mathrm{an}$.

Appears cross-bedded. PH with $\mathrm{mg}$ AN. Ph appeas to be replacing AN. Some fine laminations may be algal lamination or traces of cssm seams. ha in patches or filling void places.

fg to $\mathrm{Cg} H A$ with hoppers. $\mathrm{Ph}$ and an in patches and stringers. Trace of syl associated with $\mathrm{Ph}$. 
APPENDIX 7.H. Mineralogy and Petrology, Continued.

3. Core \#8, continued

Depth (ft)

2017

2039

2050

2068

2084

2130

2162

2217

2280

2326

2366

Description

$\mathrm{mg}$ to $\mathrm{cg}$ HA with hoppers. Ph and an in patches and stringers. Ph appears to be replacing an. cssm in patches.

mg to cg HA with hoppers. Ph and an with cssm in patches and stringers. Much of the $\mathrm{Ph}$ is radial. $\mathrm{Ph}$ appears to be replacing an.

mg AN with numerous inclusions. AN apperas to be replacing ha with former cubic crystal outlines preserved.

fg to $\mathrm{cg} H A$. Patches and stringers and intergranular An, cssm and possible ph (?). May represent subaerial deposition.

fg to cg HA with much intergranular Cssm, ph and poissible an (?). May represent subaerial deposition. Some Ha crystals appear to be growing in the Cssm.

fg to $\mathrm{mg} H A$ with intergranular An and minor cssm. Some ph (?) may be replacing An.

Cg HA with intergranular Cssm and Ph. May represent subaerial deposition. Trace of an associated with $\mathrm{Ph}$. Trace of syl associated with $\mathrm{Ph}$.

cg $\mathrm{HA}$ with patches and stringers of $\mathrm{Ph}$ and an. Some $\mathrm{Ph}$ radial and replacing an. Possible syl associated with $\mathrm{Ph}$.

fg to cg $\mathrm{HA}$ with patches and stringers of $\mathrm{Ph}$ and an. POssible trace of kain (?).

fg to cg HA with poorly preserved hoppers. Cssm intergranular with HA. May represent subaerial deposition. Isolated crystals and clsuters of ph and an. Trace authigenic feld (?).

Possibly macroscopically bedded. fg, radial PH with minor an. cssm scattered throughout. 
APPENDIX 7.H. Mineralogy and Petrology, Continued.

3. Core \#8, continued

Depth (ft)

2427

2460

2519

2563

2616

2666

2707

2758

2779

2793
Description

fg to $\mathrm{cg} H A$ with poorly preserved hoppers. An and cssm in patchers, stringers, and intergranular with HA. May represent subaerial deposition, in part. Possible fossil (bryozoan) fragment.

mg to cg HA with hoppers. Patches, stringers, and intergranular An and cssm. $\mathrm{mg}$ an in isolated crystals and clusters along the margins of the patches and stringers.

mg to $\mathrm{cg}$ HA with poorly preserved hoppers. Patches, stringers and intergranular an ofter associated with cssm. May represent subaerial deposition.

Possibly macroscopically bedded. Nodular AN with patches of Cssm. Possible mudcrack or burrow along one edge of slide normal to the bedding.

fg to mg HA with poorly preserved hoppers. An intergranular with $\mathrm{HA}$ and as patches and stringers. May represent subaerial deposition.

fg to cg HA with poorly preserved hoppers. Patches, stringers, and intergranular Cssm and an. May

represent subaerial deposition.

cg HA with hoppers. Patches and stringers of Cssm and an.

fg to mg HA with poorly preserved hoppers. An associated wtih cssm in patches, stringers (some intergranular). May represent subaerial

deposition. Some An in isolated crystals.

fg to $\mathrm{cg} H A$ with hoppers. An and cssm in patches, stringers and intergranular with HA. May represent subaerial deposition.

fg to $\mathrm{cg}$ HA with trace evidence of hoppers. Intergranular AN and cssm. May represent subaerial deposition. Patches and stringers of An. Traces of ph and authigenic qtz (?). 
APPENDIX 7.H. Mineralogy and Petrology, continued.

3. Core \#8, continued

Depth (ft)

2803

2809

2821

2879

2948

\section{Description}

fg to $\mathrm{cg}$ HA with hoppers. Intergranular An and cssm. Some An in patches with possible ph (?). A few large, isolated crystals of An. May represent subaerial deposition.

fg to $\mathrm{mg}$ HA with trace evidence of hoppers. An and cssm in patches, stringers and as intergranular material. May represent subaerial deposition.

mg to cg HA with hoppers. Intergranular An and cssm. Some An in patches and stringers. May represent subaerial deposition.

Possible macroscopic evidence of bedding. fg to mg HA with hoppers. Patches and stringers of $A n$ and cssm. POssible trance of ph (?). An unknown minerals with lower birefringence and positive relief was observed. Also present are some large, isolated crystals of An.

Possible macroscopic evidence of bedding. mg to cg HA with hoppers. Some patches and stringers of An present. Some may be nodular (?) (possibly pseudomorphic after gyp). a few isolated crystals of ph (?) were noted. 
APPENDIX 8A

Analyses of Potash for Department of Energy (then ERDA) and Industry Boreholes in the WIPP Area

Source is Table 3, John et al., 1978 
Drill-hole no.: Drill-hole designations; P, Energy Research and Developnent Adninistration;

FC For Corp; TMC, International Yinerals and Chemical Corp;

C, Farm Che Co.

NFU, Farmers Edu. and Coop. Union of America; bischofite; Bl, bloedite; C, carnallite

Gi, glaserite: Gu, glauberite; Ka, kainite; Ki, kieserite; $\mathrm{L}$, langeinite; Le, leonite;

Lo, loewite: S, sylvite; Va, vanthoffite.]

\begin{tabular}{|c|c|c|c|c|c|c|c|c|c|c|c|}
\hline \multirow{2}{*}{$\begin{array}{c}\text { Drill- } \\
\text { hole } \\
\text { no. }\end{array}$} & \multirow{2}{*}{$\begin{array}{l}\text { ore } \\
\text { zone }\end{array}$} & \multirow{2}{*}{$\begin{array}{c}\text { Sample } \\
\text { no. }\end{array}$} & \multirow{2}{*}{$\begin{array}{l}\text { Depths of } \\
\text { interval } \\
\text { (feet) }\end{array}$} & \multirow{2}{*}{$\begin{array}{l}\text { Thickress } \\
\text { (feet) }\end{array}$} & \multicolumn{5}{|c|}{$\begin{array}{c}\text { Calculated minerals present } \\
\text { (weight percent) }\end{array}$} & \multirow{2}{*}{$\mid \begin{array}{c}\mathrm{K}_{2} \mathrm{O} \text { as } \\
\text { ore } \\
\text { minerals } \\
\text { (percent) }\end{array}$} & \multirow{2}{*}{$\begin{array}{l}\text { Weighted average } \\
\mathrm{K}_{2} \mathrm{O} \text { as ore mineral } \\
\text { for all intervals } \\
\text { In ore zone } \\
\text { (feet and percent) }\end{array}$} \\
\hline & & & & & Polyhalite & Halite & sylvite & Langbeinite & minerals & & \\
\hline \multirow[t]{5}{*}{$\mathrm{p}-1$} & 5 & 9 & $1440.47-1441.35$ & 0.88 & 8 & 76 & -- & 15.0 & $\mathrm{Tr} / \mathrm{Ka}^{\mathrm{I}}$ & $3.4 / \mathrm{L}$ & \\
\hline & 5 & 10 & $1441.35-1442.30$ & 0.95 & 9 & 86 & $\cdots$ & 4.4 & & $1.0 / \mathrm{L}$ & \\
\hline & 5 & 11 & $1442.30-1443.50$ & 1.20 & $\cdots$ & 79 & $\cdots$ & -- & $\left|\begin{array}{r}14.0 / \mathrm{Ka} \\
\mathrm{Tr} / \mathrm{BI}\end{array}\right|$ & --- & \\
\hline & 5 & 12 & $1443.50-1444.35$ & 0.85 &.- & 95 & -.. & 2.34 & $-\cdots$ & $0.53 / \mathrm{L}$ & \\
\hline & 5 & 13 & $1444.35-1445.30$ & 0.95 & 1 & 79 & $\cdots$ & 17.07 & -- & $3.87 / \mathrm{L}$ & $4.83-1.67 / \mathrm{L}$ \\
\hline \multirow[t]{9}{*}{$P-2$} & 10 & 14 & $1627.15-1628.35$ & 1.20 & 1 & 39 & $-\cdots$ & 39.9 & $1.9 / \mathrm{Ka}$ & & \\
\hline & & & & & & & & & $5.0 / \mathrm{Le}$ & $9.05 / \mathrm{L}$ & \\
\hline & 10 & 15 & $1628.35-1629.52$ & 1.17 & 1 & 46 & -- & 43.1 & $\begin{array}{l}2.6 / \mathrm{Ka} \\
0.5 / \mathrm{Le}\end{array}$ & $9.78 / \mathrm{L}$ & \\
\hline & 4 & 5 & $1802.70-1804.00$ & 1.30 & 1 & 39 & $\ldots$ & 38.0 & $12.9 / \mathrm{Ka}$ & $8.6 / \mathrm{L}$ & $2.37-9.41 / \mathrm{L}$ \\
\hline & 4 & 6 & $1804.00-1805.00$ & 1.00 & 6 & 80 & -.- & - & - - &.- & \\
\hline & 4 & 7 & $1805.00-1805.85$ & 0.85 & 5 & 89 & $\ldots$ & $\ldots$ & $-\cdots$ & -- & \\
\hline & 4 & 8 & $1805.85-1806.30$ & 0.45 & 6 & 60 & --- & 20,0 & $\begin{array}{l}4.0 / \mathrm{Ka} \\
3.7 / \mathrm{Le}\end{array}$ & $4.54 / \mathrm{L}$ & $3.60-3.67 / \mathrm{L}$ \\
\hline & 2 & 1 & $1833.08-1834.00$ & 0.92 & 2 & 79 &.- & 4.4 & $1.9 / \mathrm{Ka}$ & 3. $14 / \mathrm{L}$ & \\
\hline & 2 & 2 & $1834.00-1834.50$ & 0.50 & $\cdots$ & 38 & $\cdots$ & 52.9 & $0.5 / \mathrm{Ka}$ & $12.0 / \mathrm{L}$ & $1.42-6.26 / \mathrm{L}$ \\
\hline \multirow{3}{*}{$P-3$} & 4 & 3 & $1596.30-1.597 .60$ & 1.30 & 2 & 72 & -- & 24.7 & $0.5 / \mathrm{Ka}$ & $5.6 / L$ & \\
\hline & 4 & 4 & $1597.60-1598.70$ & 1.10 & 2 & 62 & -- & 18.6 & $0.5 / \mathrm{Ka}$ & $4.22 / \mathrm{L}$ & \\
\hline & 4 & 5 & $1598.70-1599.53$ & 0.83 & 34 & 38 & -- & 23.4 & -- & $5.31 / \mathrm{L}$ & $3.23-5.06 / \mathrm{L}$ \\
\hline \multirow[t]{4}{*}{$P-4$} & 10 & 2 & $1572.60-1574.97$ & 2.37 & $\underline{1}$ & 56 & 46.0 & $\ldots$ & $-\ldots$ & $29: 40 / \mathrm{s}$ & \\
\hline & 10 & 3 & $1574.97-1576.17$ & 1.20 & 4 & 64 & 27.6 & -- & $\cdots$ & $17.48 / \mathrm{s}$ & \\
\hline & 10 & 4 & $1576.17-1577.77$ & 1.60 & 3 & 86 & 7.0 & -- & -- & $4.32 / \mathrm{S}$ & \\
\hline & 10 & 5 & $1577.77-1578.69$ & 0.92 & 4 & 64 & 28.0 & -- & --- & $17.46 / \mathrm{s}$ & $6.09-18.66 / \mathrm{s}$ \\
\hline \multirow[t]{4}{*}{$P-5$} & 10 & 6 & $1546.69-1548.65$ & 1.96 & 6 & 65 & 28.0 & -- & -- & $18.28 / \mathrm{s}$ & \\
\hline & 10 & 7 & $1548.65-1549.66$ & 1.01 & 4 & 76 & 13.3 & -- & $\ldots$ & $8.42 / 5$ & \\
\hline & 10 & 8 & $1549.66-1551.40$ & 1.74 & 3 & 60 & 21.0 & $=-$ & -- & $13.41 / \mathrm{s}$ & \\
\hline & 10 & 9 & $1551.40-2552.75$ & 1.35 & 2 & 65 & 14.5 & $\cdots$ & $-\cdot$ & $9.14 / \mathrm{S}$ & $6.06-13.2 / 5$ \\
\hline \multirow[t]{6}{*}{$P-6$} & 4 & 12 & $1476.00-1477.45$ & 1.45 & 6 & 74 & --- & 22.0 & $1.0 / \mathrm{Ki}$ & $5.01 / 1$ & \\
\hline & 4 & 13 & $1477.45-1478.37$ & 0.92 & I & 83 & 2.0 & 8.0 & $6.0 / \mathrm{Ki}$ & $\begin{array}{l}1.90 / \mathrm{L} \\
1.26 / 5\end{array}$ & \\
\hline & 4 & 14 & $1478.37-1480.00$ & 1.63 & 3 & 84 & -- & 12.0 & $\cdots$ & $2.78 / \mathrm{L}$ & $4.00-3.39 / \mathrm{L}$ \\
\hline & 2 & 18 & $1510.50-1511.32$ & 0.82 & 1 & 37 & 2.0 & 54.0 & $6.0 / \mathrm{Ki}$ & $12.31 / \mathrm{L}$ & \\
\hline & 2 & 19 & $1511.32-1512.10$ & 0.78 & $\ldots$ & 53 & $\cdots$ & 42.0 & $\ldots$ & $9.65 / \mathrm{L}$ & \\
\hline & 2 & 20 & $1512.10-1513.05$ & 0.95 & 7 & 79 & 3.0 & 1.0 & $8,6 / K i$ & $0.19 / \mathrm{L}$ & $2.55-6.98 / \mathrm{L}$ \\
\hline \multirow[t]{3}{*}{$\mathrm{F}-7$} & 4 & 2 & $1479.73-1481.20$ & 1.47 & 2 & 65 & 1.0 & 29.0 & - & $6.53 / \mathrm{L}_{4}$ & \\
\hline & 4 & 3 & $1481.20-1483.00$ & 1.80 & -- & 89 & 2.0 & $3.0^{4}$ & $\cdots$ & $0.75 / \mathrm{L}^{4}$ & \\
\hline & 4 & 4 & $1483.00-1483.48$ & 0.48 & 3 & 69 & 2.0 & 3.8 & $\mid \begin{array}{l}5.7 / \mathrm{Ka} \\
1.0 / \mathrm{Le} \\
1.0 / \mathrm{Bl}\end{array}$ & $3.8 / \mathrm{L}$ & $3.75-3.41 / \mathrm{L}$ \\
\hline \multirow[t]{3}{*}{$\mathrm{P}-8$} & 10 & 2 & $1363.70-1365.00$ & 1.30 & -.- & 52 & 29.0 & 25.0 & $\ldots$ & $\begin{array}{l}18.45 / 5 \\
5.62 / \mathrm{L}\end{array}$ & \\
\hline & 10 & 3 & $1365.00-1366.72$ & 1.72 & $I$ & 46 & 3.0 & 45.0 & $\begin{array}{l}4.0 / \mathrm{Ka} \\
\mathrm{Z} .0 / \mathrm{Le}\end{array}$ & $\begin{array}{l}10.3 / \mathrm{L} \\
1.65 / \mathrm{S}\end{array}$ & \\
\hline & 10 & 4 & $1366.72-1368.05$ & 1.33 & 1 & 86 & $\cdots$ & 14.0 & $\cdots$ & $3.23 / \mathrm{L}$ & $\begin{array}{c}4.35-6.74 / \mathrm{L} \\
4.35-6.17 / \mathrm{S} \\
\text { mixed ore equivalent } \\
4.35-9.2 / \mathrm{L}\end{array}$ \\
\hline
\end{tabular}




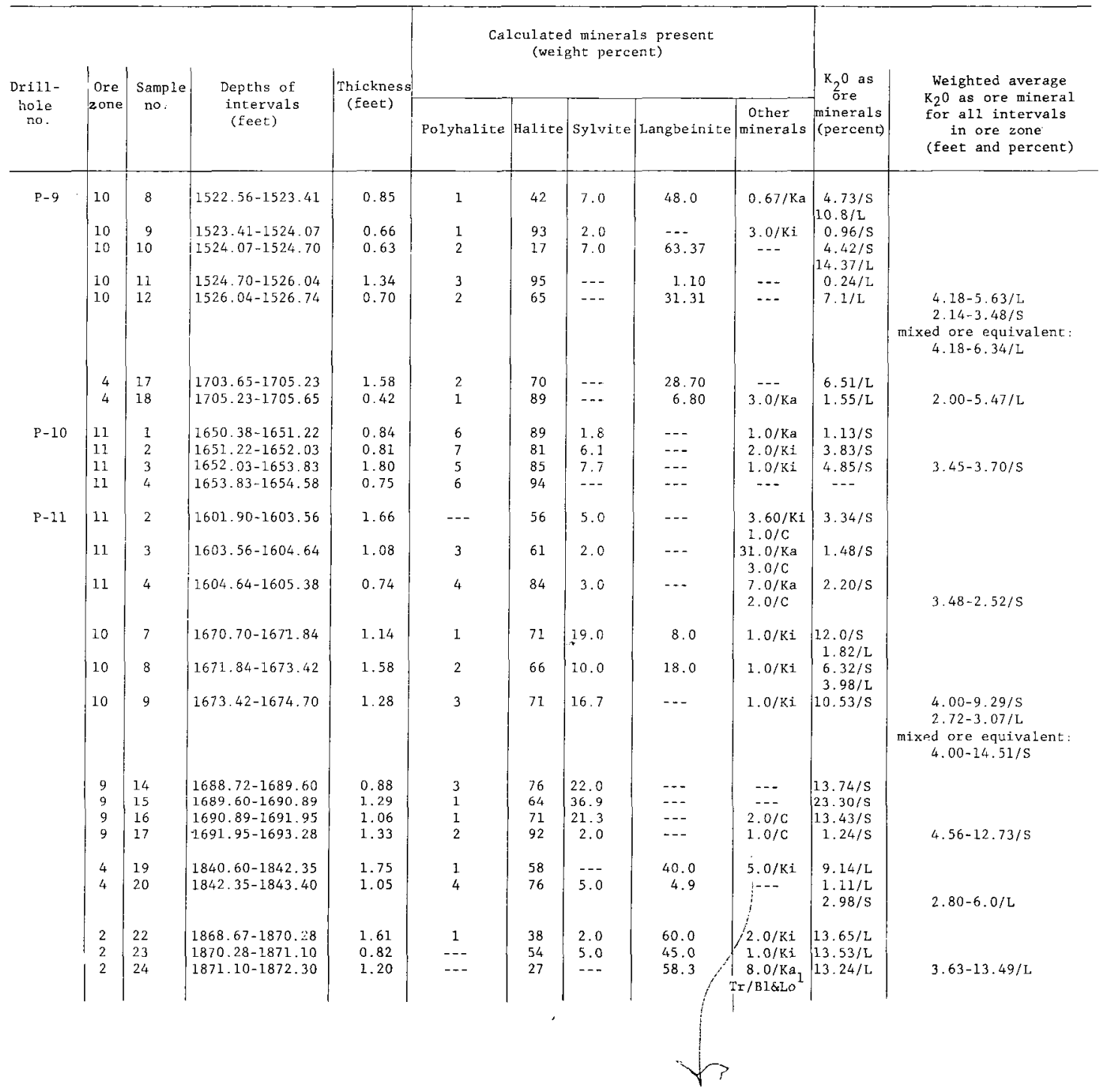




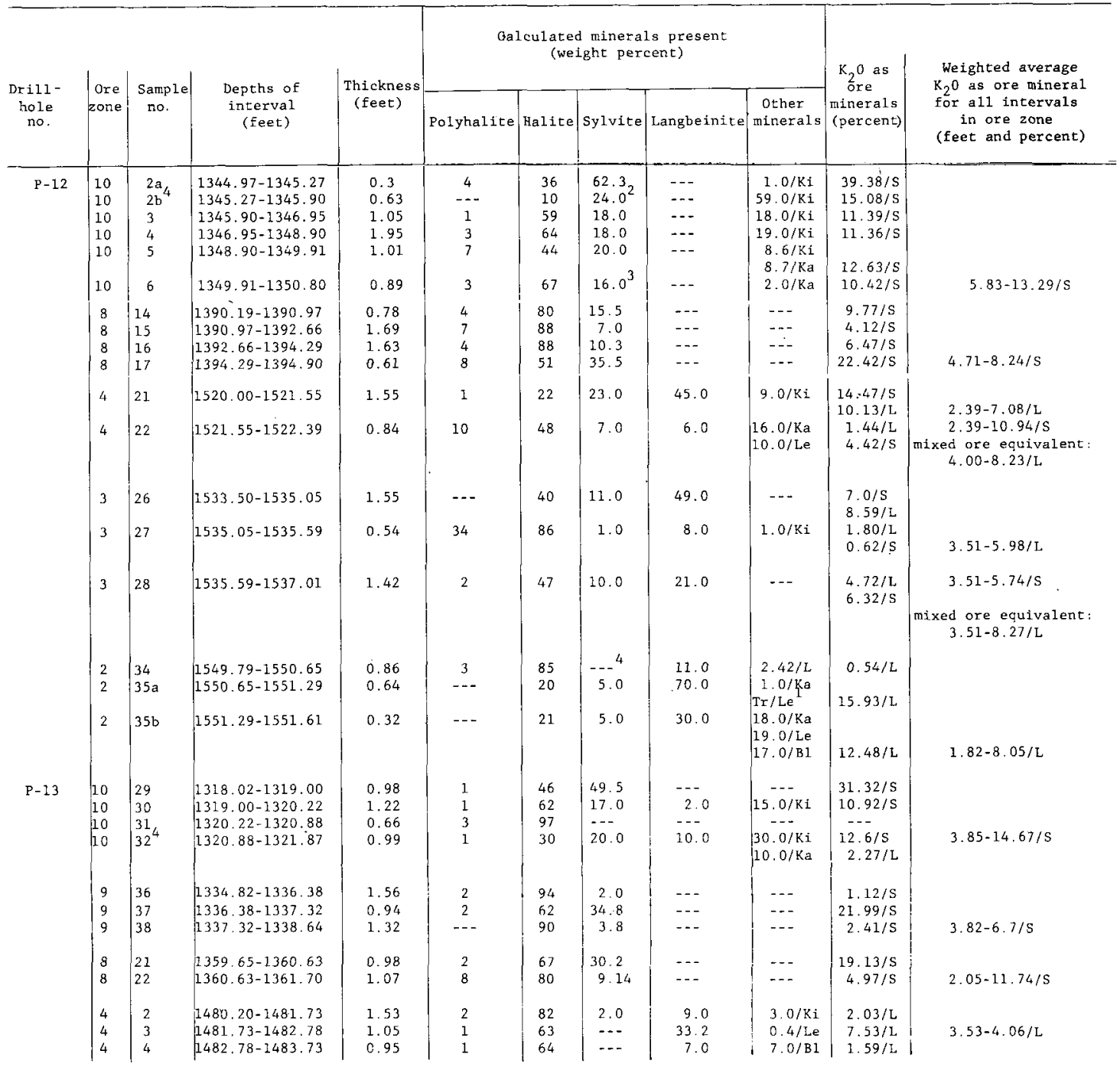




\begin{tabular}{|c|c|c|c|c|c|c|c|c|c|c|c|}
\hline \multirow{2}{*}{$\begin{array}{l}\text { Drill- } \\
\text { hole } \\
\text { no. }\end{array}$} & \multirow{2}{*}{$\begin{array}{l}\text { Ore } \\
\text { zone }\end{array}$} & \multirow{2}{*}{$\begin{array}{l}\text { Sample } \\
\text { no. }\end{array}$} & \multirow{2}{*}{$\begin{array}{l}\text { Depths of } \\
\text { interval } \\
\text { (feet) }\end{array}$} & \multirow{2}{*}{$\begin{array}{l}\text { Thickness } \\
\text { (feet) }\end{array}$} & \multicolumn{5}{|c|}{$\begin{array}{l}\text { Calculated minerals present } \\
\text { (weight percent) }\end{array}$} & \multirow{2}{*}{$\mid \begin{array}{l}\mathrm{K}_{2} 0 \text { as } \\
\text { Ore } \\
\text { minerals } \\
\text { (percent) }\end{array}$} & \multirow{2}{*}{$\begin{array}{l}\text { Weighted average } \\
\mathrm{K}_{2} \mathrm{O} \text { as ore mineral } \\
\text { for all intervals } \\
\text { in ore zone } \\
\text { (feet and percent) }\end{array}$} \\
\hline & & & & & Polyhalite & Halite & Sylvite & Langbeinite & Other & & \\
\hline \multirow{15}{*}{ P-14 } & 3 & 8 & $1493.23-1493.88$ & 0.65 & 2 & 86 &.- & 7.0 & $\ldots$ & $1.59 / \mathrm{L}$ & \\
\hline & 3 & 9 & $1493.88-1494.58$ & 0.70 & $\ldots$ & 15 & --- & 53.0 & -- & $12.06 / \mathrm{L}$ & \\
\hline & 3 & 10 & $1494.58-1495.50$ & 0.92 & 3 & 86 & --- & 10.0 & --- & $2.21 / \mathrm{L}$ & $\begin{array}{l}2.27-5.07 / \mathrm{L} \\
4.00-2.88 / \mathrm{L}^{5}\end{array}$ \\
\hline & 10 & 2 & $1255.24-1.255 .64$ & 0.40 & -- & 41 & 57.0 & -- & -- & $36.03 / 5$ & \\
\hline & 10 & 3 & $1255.64-1257.56$ & 1.92 & -- & 41 & 57.0 & -- & -- & $\begin{array}{r}36.06 / 5 \\
8.84 / 5\end{array}$ & \\
\hline & 10 & 4 & $1257.56-1259.07$ & 1.51 & 3 & 64 & 14.0 & 18.0 & $\operatorname{Tr} / \mathrm{Ka}^{1}$ & $\begin{array}{l}8.84 / \mathrm{S} \\
3.99 / \mathrm{L}\end{array}$ & \\
\hline & 10 & 5 & $1259.07-1260.15$ & I. 08 & 4 & 74 & 7.0 & 22.0 & $\cdots$ & $\begin{array}{l}4.36 / \mathrm{S} \\
4.88 / \mathrm{L}\end{array}$ & \\
\hline & 10 & 6 & $1260.15-1261.05$ & 0.90 & 2 & 55 & $12.0^{6}$ & $\ldots$ & $16.0 / \mathrm{Ka}$ & $6.21 / 5$ & $\begin{array}{c}5.81-18.47 / \mathrm{s} \\
2.59-4.36 / \mathrm{L} \\
\text { mixed ore equivalent: } \\
5.81-23.33 / \mathrm{s}\end{array}$ \\
\hline & 5 & 10 & $1364.44-1366.11$ & 1.67 & 5 & 74 & 5.0 & 15.0 & $1.0 / \mathrm{Ka}$ & $\begin{array}{l}3.35 / \mathrm{L} \\
3.00 / \mathrm{S}\end{array}$ & \\
\hline & 5 & $11_{6}$ & $1366.11-1367.86$ & 1.75 & 3 & 83 & -- & 19.0 & $\mathrm{Tr} / \mathrm{Ka}_{1}^{1}$ & $4.3 / \mathrm{L}$ & \\
\hline & 5 & $12^{6}$ & $1367.86-1369.26$ & 1.40 & 1 & 80 & -- & 13.0 & $\mathrm{Tr} / \mathrm{Ka}^{1}$ & $3.03 / \mathrm{L}$ & $\begin{array}{c}4.82-3.60 / \mathrm{L} \\
1.67-3.0 / \mathrm{S} \\
\text { mixed ore equivalent: } \\
\quad 4.82-4.02 / \mathrm{L}\end{array}$ \\
\hline & 4 & 18 & $1440.79-1441.98$ & 1.19 & 4 & 46 & 6.0 & 38.5 & $\ldots$ & $\begin{array}{l}8.74 / \mathrm{L} \\
3.99 / \mathrm{S}\end{array}$ & \\
\hline & 4 & 19 & $1441.98-1442.84$ & 0.86 & 5 & 95 &.- & $\ldots$ & --- & $\ldots$ & \\
\hline & 4 & 20 & $1442.84-1443.98$ & 1.14 & 16 & 56 & 4.0 & 23.0 & \begin{tabular}{|l}
$\mathrm{Tr} / \mathrm{Le}$ \\
$2.0 / \mathrm{Ka}$
\end{tabular} & $\begin{array}{l}5.22 / \mathrm{L} \\
2.53 / \mathrm{S}\end{array}$ & \\
\hline & 4 & 21 & $1443.98-1444.61$ & 0.63 & 3 & 88 & --- & 11.0 & $\ldots$ & $2.50 / 2$ & $\begin{array}{l}3.82-4.69 / \mathrm{L} \\
3.19-2.39 / \mathrm{S}\end{array}$ \\
\hline \multirow[t]{5}{*}{$P-15$} & 4 & 7 & $1371.94-1372.81$ & 0.87 & 6 & 76 & $\ldots$ & 25.0 & $\ldots$ & $5.59 / \mathrm{L}$ & \\
\hline & 4 & 8 & $1372.81-1374.77$ & 1.96 & 8 & 89 & -- & 4.0 & --- & $1.00 / \mathrm{L}$ & \\
\hline & 4 & 9 & $1374.77-1375.80$ & 1.03 & 9 & 64 & -- & 28.0 & -- & $6.30 / \mathbf{L}$ & $3.86-3.45 / \mathrm{L}$ \\
\hline & 2 & 13 & $1399.66-1400.38$ & 0.72 & 3 & 64 & $\ldots$ & 32.0 & $4.0 / \mathrm{Ka}$ & $7.18 / \mathrm{L}$ & \\
\hline & 2 & 14 & $1400.38-1401.51$ & 1.13 & $\cdots$ & 78 & $\cdots$ & 17.0 & $\begin{array}{l}3.0 / \mathrm{Ka} \\
3.0 / \mathrm{Le}\end{array}$ & $4.28 / \mathbf{L}$ & $1.85-5.41 / \mathrm{L}$ \\
\hline \multirow[t]{9}{*}{$P-16$} & 10 & 4 & $1301.94-1302.57$ & 0.63 & 3 & 93 & 0.7 & 4.0 &.- & $\begin{array}{l}0.47 / \mathrm{s} \\
0.89 / \mathrm{L}\end{array}$ & \\
\hline & 10 & 5 & $1302.57-1303.91$ & 1.34 & 3 & 79 & -.. & 21.0 & $\ldots$ & $4.77 / \mathrm{L}$ & \\
\hline & 10 & 6 & $1303.91-1304.39$ & 0.48 & $-\cdot$ & 61 & -- & 34.0 & $\begin{array}{l}8.1 / \mathrm{Ka} \\
8.0 / \mathrm{Te} \\
\mathrm{Tr} / \mathrm{Ki}^{\mathrm{e}}\end{array}$ & $7.77 / \mathrm{L}$ & $2.45-4.63 / \mathrm{L}$ \\
\hline & 4 & 10 & $1476.76-1478.40$ & 1.64 & --- & 36 & 2.0 & 53.0 & Tr'Ka\&Le ${ }^{1}$ & $\begin{array}{r}12.01 / \mathrm{L} \\
1.26 / \mathrm{S}\end{array}$ & \\
\hline & 4 & 11 & $1478.40-1478.95$ & 0.55 & 2 & 86 & $-m$ & 8.7 & $\cdots$ & $1.98 / \mathrm{L}$ & $2.19-9.49 / \mathrm{L}$ \\
\hline & 4 & 12 & $1490.12-1491.00$ & 0.88 & 1 & 83 & 1.0 & 14.17 & $\ldots$ & $4.94 / \mathrm{L}$ & \\
\hline & 4 & 13 & $1491.00-1491.56$ & 0.56 & 0 & 39 & 7.0 & $19.7^{7}$ & -.- & $\begin{array}{l}4.40 / \mathrm{L} \\
4.12 / \mathrm{S}\end{array}$ & \\
\hline & 4 & 14 & $1491.56-1492.64$ & 1.08 & 7 & 79 & -- & 12.0 & --- & $2.75 / \mathrm{L}$ & \\
\hline & 4 & 15 & $1492.64-1493.89$ & 1.25 & 2 & 56 & 3.0 & 31.0 & $\begin{array}{l}\text { 6.0/Le } \\
2.0 / \mathrm{Ka}\end{array}$ & $\begin{array}{l}7.05 / \mathrm{L} \\
2.09 / \mathrm{S}\end{array}$ & $3.77-4.93 / \mathrm{L}$ \\
\hline
\end{tabular}




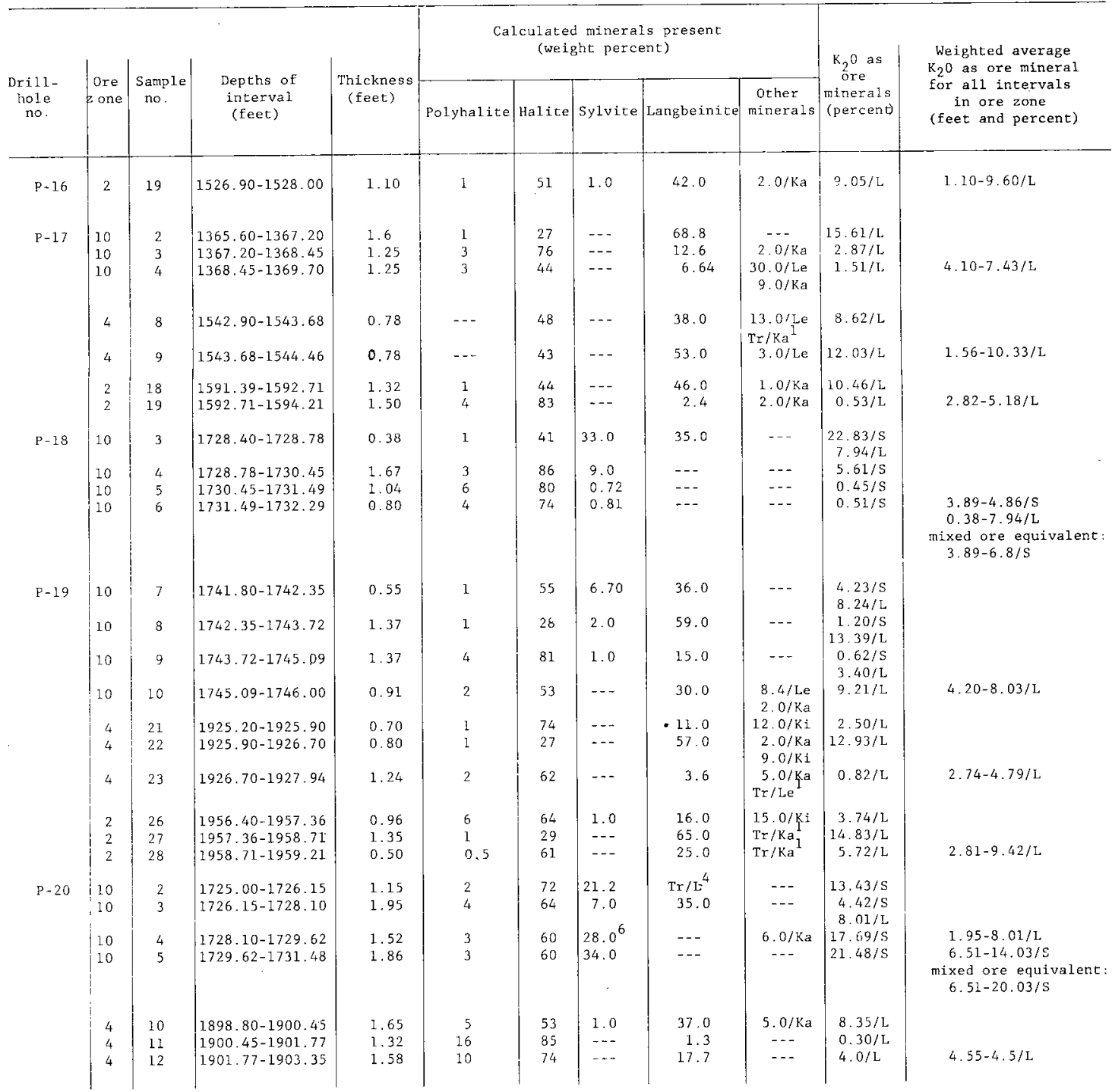




\begin{tabular}{|c|c|c|c|c|c|c|c|c|c|c|c|}
\hline \multirow{2}{*}{$\begin{array}{l}\text { Drill- } \\
\text { hole } \\
\text { no. }\end{array}$} & \multirow{2}{*}{$\begin{array}{l}\text { Tore } \\
\text { pone }\end{array}$} & \multirow{2}{*}{$\begin{array}{c}\text { Sample } \\
\text { no. }\end{array}$} & \multirow{2}{*}{$\begin{array}{c}\text { Depths of } \\
\text { interval } \\
\text { (feet) }\end{array}$} & \multirow{2}{*}{$\begin{array}{l}\text { Thickness } \\
\text { (feet) }\end{array}$} & \multicolumn{5}{|c|}{$\begin{array}{c}\text { Calculated minerals present } \\
\text { (weight percent) }\end{array}$} & \multirow{2}{*}{$\begin{array}{l}\mathrm{K}_{2} \mathrm{O} \text { as } \\
\text { ore } \\
\text { minerals } \\
\text { (percent) }\end{array}$} & \multirow{2}{*}{$\begin{array}{l}\text { Weighted average } \\
\mathrm{K}_{2} \mathrm{O} \text { as ore mineral } \\
\text { for all intervals } \\
\text { in ore zone } \\
\text { (feet and percent) }\end{array}$} \\
\hline & & & & & Polyhalite & Halite & Sylvite & Langbeinite & $\begin{array}{c}\text { Other } \\
\text { minerals }\end{array}$ & & \\
\hline \multirow[t]{2}{*}{$P-20$} & 2 & $14^{4}$ & $1925.08-1926.30$ & 1.22 & 3 & 95 & $\cdots$ & 0.88 & -- & $0.2 / \mathrm{L}$ & \\
\hline & 2 & 15 & $1926.30-1927.75$ & 1.45 & 1 & 61 & $\cdots$ & $35 \cdot 5$ & $\cdots$ & $8.05 / \mathrm{L}$ & $2.67-4.46 / \mathrm{L}$ \\
\hline \multirow[t]{17}{*}{$P-21$} & & 2 & $\begin{array}{l}1644.03-1644.84 \\
1644.84-1646.00\end{array}$ & $\begin{array}{l}0.81 \\
1.16\end{array}$ & $\begin{array}{l}4 \\
4\end{array}$ & 80 & 17.0 & -- & -- & $10.82 / \mathrm{s}$ & \\
\hline & $\begin{array}{l}10 \\
10\end{array}$ & $\begin{array}{l}3 \\
4\end{array}$ & $\begin{array}{l}1644.84-1646.00 \\
1646.00-1646.33\end{array}$ & $\begin{array}{l}1.16 \\
0.33\end{array}$ & $\begin{array}{l}4 \\
1\end{array}$ & 81 & 1.1 .86 & -- & $2.0 / \mathrm{Ki}$ & $7.46 / \mathrm{s}$ & \\
\hline & 10 & 5 & & $\begin{array}{l}0.33 \\
0.87\end{array}$ & $\begin{array}{l}1 \\
1\end{array}$ & $\begin{array}{l}28 \\
41\end{array}$ & $20.2^{6}$ & $\cdots$ & $42.0 / \mathrm{Ki}$ & $12.76 / 5$ & \\
\hline & 10 & 6 & $\begin{array}{l}1646.33-1647.20 \\
1647.20-1648.22\end{array}$ & $\begin{array}{l}0.87 \\
1.02\end{array}$ & 1 & $\begin{array}{l}41 \\
62\end{array}$ & $\begin{array}{l}25.5^{\circ} \\
29.5^{2}\end{array}$ & -- & $\begin{array}{r}18.0 / \mathrm{Ki} \\
1.0 / \mathrm{Ki}\end{array}$ & $\begin{array}{l}16.14 / \mathrm{S} \\
18.66 / \mathrm{S}\end{array}$ & \\
\hline & 10 & 7 & $1648.22-1649.23$ & 1.01 & 3 & 64 & 31.3 & -- & $\cdots$ & $19.81 / \mathrm{S}$ & $5.20-14.37 / \mathrm{S}$ \\
\hline & 8 & 15 & $1685.17-1686.48$ & 1.31 & 0 & 55 & 45.0 & -- & -- & $28.4 / 5$ & \\
\hline & 8 & 16 & $1686.48-1687.20$ & 0.72 & 4 & 83 & $6.0^{6}$ & $\cdots$ & -- & $3.72 / \mathrm{s}$ & \\
\hline & 8 & 17 & $1687.20-1688.24$ & 1.04 & 5 & 92 & 3.0 & $\cdots$ & -- & $1.95 / 5$ & \\
\hline & 8 & 18 & $1688.24-1688.77$ & 0.53 & 4 & 95 & 0.8 & --- & --- & $0.52 / \mathrm{s}$ & \\
\hline & 8 & 19 & $1688.77-1690.19$ & 1.42 & 6 & 86 & 9.9 & -. & $\cdots$ & $6.24 / \mathrm{s}$ & \\
\hline & 8 & 20 & $1690.19-1691.26$ & 1.07 & 8 & 90 & 1. . 0 & --- & --- & $0.75 / \mathrm{s}$ & \\
\hline & 8 & 21 & $1691.26-1692.40$ & 1.14 & 3 & 65 & 33.0 & $\cdots$ & -- & $21.16 / 5$ & \\
\hline & 8 & 22 & $1692.40-1693.34$ & 0.94 & 5 & 65 & 13.0 & -- & -- & $8.18 / \mathrm{s}$ & $8.17-10.24 / \mathrm{s}$ \\
\hline & 4 & 24 & $1809.90-1811.50$ & 1.60 & 0 & 31 & 3.0 & 64.0 & $2.5 / \mathrm{Ka}$ & $14.60 / \mathrm{L}$ & \\
\hline & 4 & 25 & $1811.50-1811.82$ & 0.32 & 0 & 18 & $5.0^{2}$ & 54.66 & $\begin{array}{c}3.9 / \mathrm{Le} \\
9.0 / \mathrm{Ka} \\
10.60 / \mathrm{Le}\end{array}$ & $15.12 / \mathrm{L}$ & $\begin{array}{l}1.92-14.69 / 5 \\
4.00-7.05 / \mathrm{L}\end{array}$ \\
\hline & 4 & 30 & $1815.51-1816,10$ & 0.59 & 11 & 51 & 5 & 27.0 & $9.0 / \mathrm{Ki}$ & $6.08 / \mathrm{L}$ & \\
\hline & 4 & 31 & $1816 \cdot 10-1817.25$ & 1.15 & 3 & 42 & 5 & 44.0 & $8.0 / \mathrm{Ka}$ & $9.95 / 2$ & $\begin{array}{l}1.74-8.64 / L \\
4.00-3 / 76 / L^{5}\end{array}$ \\
\hline \multirow[t]{10}{*}{$A E C-8$} & 10 & 10 & $1589.10-1589.70$ & 0.60 & 1 & 85 & 5 & -- & $\begin{array}{l}5 / \mathrm{Ki} \\
2 / \mathrm{An}\end{array}$ & $2.97 / 5$ & \\
\hline & 10 & $11_{6}$ & $1589.70-1591.70$ & 2.00 & $\cdots$ & 43 & 16 & -. & $40 / \mathrm{Ki}$ & $10.32 / \mathrm{s}$ & \\
\hline & 10 & $12^{\circ}$ & $1591.70-1592.20$ & 0.50 & $-\infty$ & 37 & 24 & $\ldots$ & $\begin{array}{l}6 / C \\
30 / \mathrm{Ki}\end{array}$ & $15.16 / \mathrm{S}$ & \\
\hline & 10 & $13^{6}$ & $1592.20-1594.50$ & 2.30 & $\cdots$ & 49 & 32 & -- & $\begin{array}{l}9.1 / \mathrm{An} \\
7 / \mathrm{C} \\
9 / \mathrm{Ka} \\
9.3 / \mathrm{An}\end{array}$ & $20.31 / \mathrm{s}$ & \\
\hline & 10 & 14 & $1594.50-1594.70$ & 0.20 & $-\cdots$ & 38 & 4 &.- & \begin{tabular}{|l|}
$51 / \mathrm{C}$ \\
$9 / \mathrm{Ka}$ \\
$1 / \mathrm{Ki}$ \\
$2.1 / \mathrm{An}$
\end{tabular} & $2.34 / \mathrm{s}$ & \\
\hline & 10 & $15^{6}$ & $1594.70-1595.50$ & 0.80 & 2 & 85 & 3 & -- & $\begin{array}{l}4 / \mathrm{C} \\
2 / \mathrm{Ki} \\
9 / \mathrm{Ka} \\
0.9 / \mathrm{An}\end{array}$ & $2.18 / \mathrm{s}$ & $6.4-12.33 / \mathrm{s}$ \\
\hline & 4 & 2 & $1752.70-1753,40$ & 0.70 & -- & 95 & $-\ldots$ & 4 & -- & $0.86 / \mathrm{L}$ & \\
\hline & 4 & 3 & $1753.40-1754.00$ & 0.60 & 1 & 69 & 2 & 33 & $3 / \mathrm{Ka}$ & $7.39 / \mathrm{L}$ & \\
\hline & 4. & 4 & $1754.00-1755.00$ & 1.00 & $-\cdot$ & 33 & 2 & 68 & $2 / \mathrm{Ka}$ & $13.90 / \mathrm{L}$ & \\
\hline & 4 & 5 & $1755.00-1756.70$ & 1.70 & $\cdots$ & 24 & -- & 69 & $3 / \mathrm{Le}$ & $15.38 / \mathrm{L}$ & $4-11.27 / L$ \\
\hline
\end{tabular}




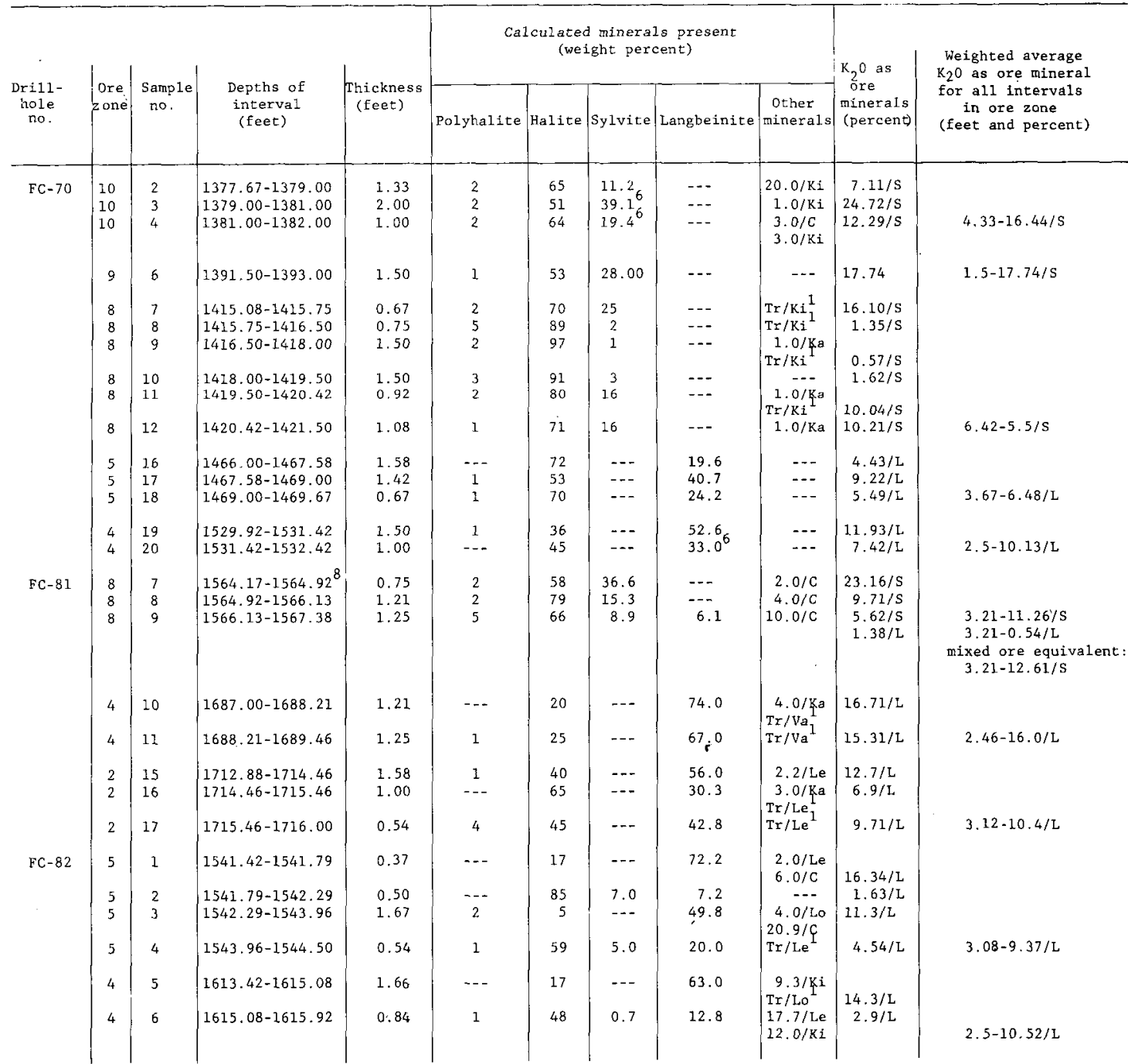




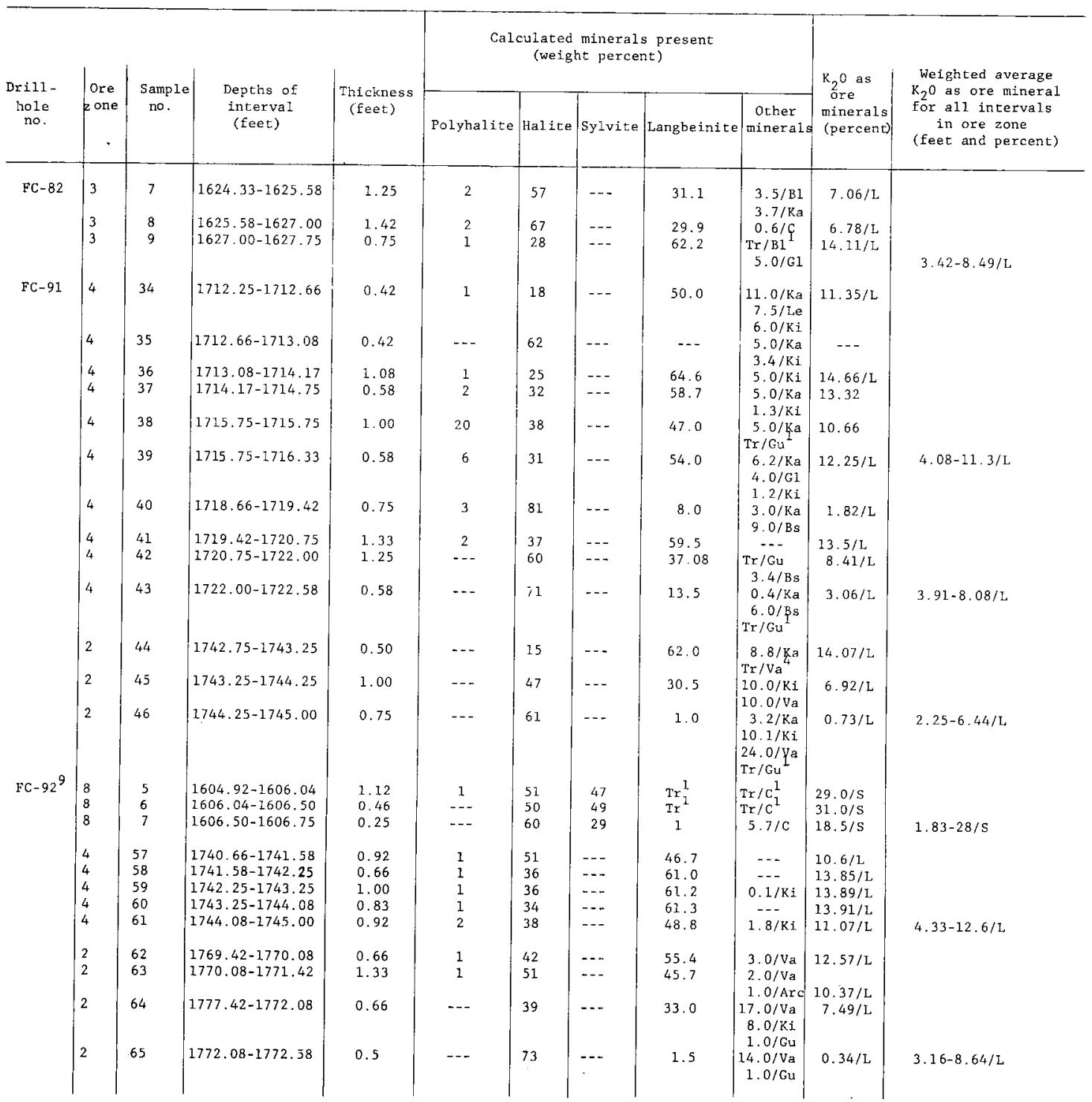




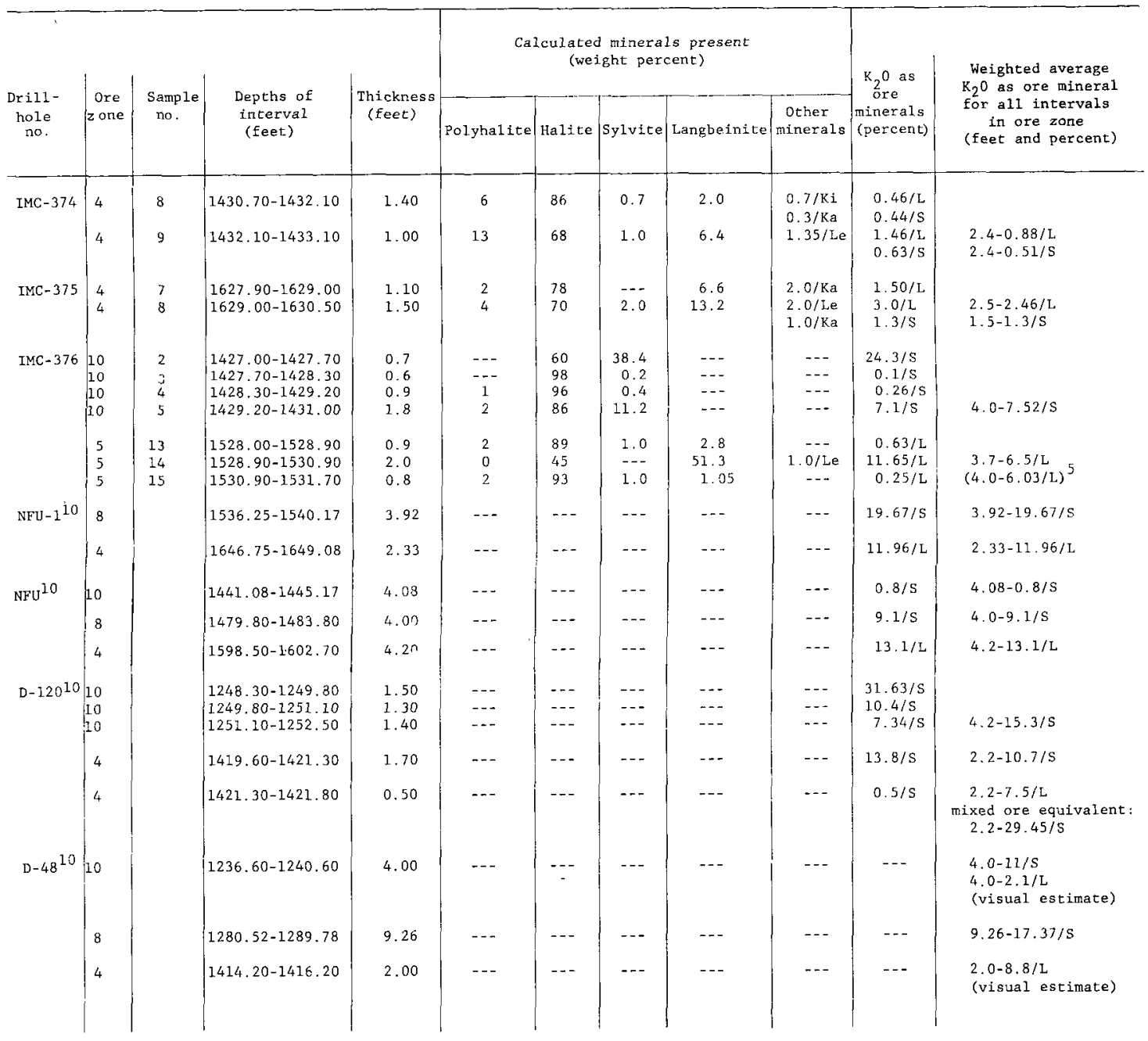




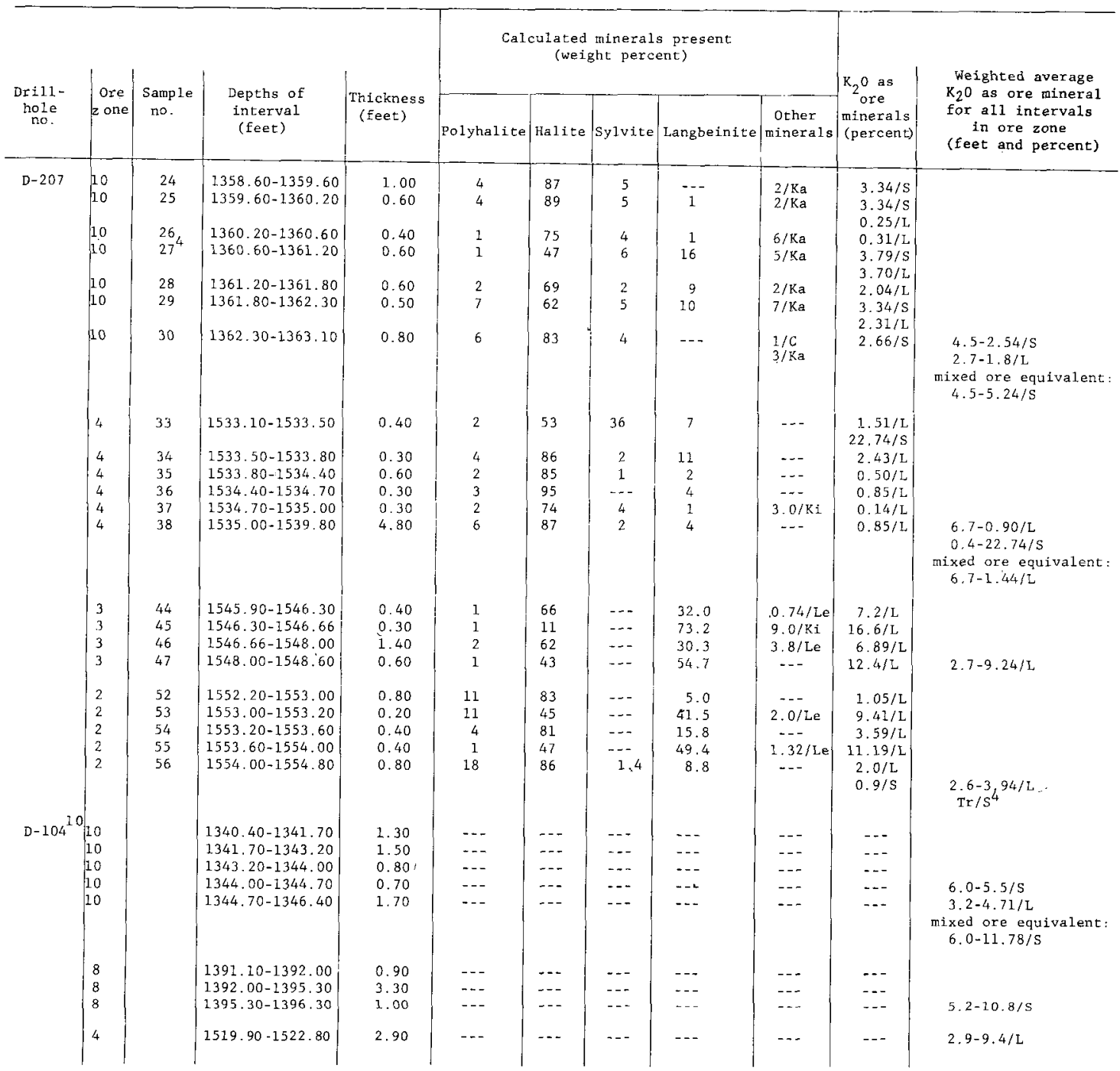




\begin{tabular}{|c|c|c|c|c|c|c|c|c|c|c|c|}
\hline \multirow[b]{2}{*}{$\begin{array}{l}\text { Drill- } \\
\text { nole } \\
\text { no. }\end{array}$} & \multirow[b]{2}{*}{$\begin{array}{l}\text { Ore } \\
\text { zone }\end{array}$} & \multirow[b]{2}{*}{$\begin{array}{l}\text { Sample } \\
\text { no. }\end{array}$} & \multirow[b]{2}{*}{$\begin{array}{l}\text { Depths of } \\
\text { interval } \\
\text { (feet) }\end{array}$} & \multirow[b]{2}{*}{$\begin{array}{l}\text { Thickness } \\
\text { (feet) }\end{array}$} & \multirow[b]{2}{*}{ Polyhalite } & \multicolumn{3}{|c|}{$\begin{array}{l}\text { Alculated minerals present } \\
\text { (weight percent) }\end{array}$} & \multirow[b]{2}{*}{\begin{tabular}{|l|} 
Other \\
minerals
\end{tabular}} & \multirow{2}{*}{$\begin{array}{l}\mathrm{K}_{2} \mathrm{O} \text { as } \\
\text { ore } \\
\text { minerals } \\
\text { (percent) }\end{array}$} & \multirow{2}{*}{$\begin{array}{l}\text { Weighted average } \\
\mathrm{K}_{2} \mathrm{O} \text { as ore mineral } \\
\text { for all intervals } \\
\text { In ore zone } \\
\text { (feet and percent) }\end{array}$} \\
\hline & & & & & & Halite & Sylvite & Langbeinite & & & \\
\hline \multirow[t]{3}{*}{$D-104^{10}$} & 3 & & $1527.50-1528.90$ & 1.40 & -- & -- & -- & -- & $\cdots$ & $-\cdots$ & $1.4-5.0 / \mathrm{L}$ \\
\hline & 3 & & $1528.90-1530.50$ & 1.60 & . & $\cdots$ & -- & $-\cdots$ & $-\cdots$ & $\cdots$ & $\begin{array}{l}2.9-11.4 / \mathrm{S} \\
\text { mixed ore equivalent: } \\
2.9-6.66 / \mathrm{L}\end{array}$ \\
\hline & 2 & & $1539.50-1540.20$ & 1.20 & -- & $\cdots$ & $\cdots$ & -- & -- & $\cdots$ & $1.2-15,0 / \mathrm{L}$ \\
\hline \multirow[t]{5}{*}{$\mathrm{U}-134^{10}$} & 20 & - & $1319.58-1321.25$ & 1.69 & 3 & -- & 6.0 & $-\infty$ & $2.0 / \mathrm{Ka}$ & $3.79 / 5$ & . \\
\hline & & & $1321.25-1322.83$ & 1.58 & 2 & $\cdots$ & -- & --- & $12.5 / \mathrm{Ka}$ & $17.22 / \mathrm{s}$ & $3.27-10.28 / \mathrm{S}$ \\
\hline & 8 & & $1361.10-1362.17$ & 1.08 & -- & -- & $-\cdots$ & -- & -- & -- & \\
\hline & 8 & & $1362.17-1364.50$ & 2.33 & -- & --- & $\cdots$ & $\cdots$ & --- & $\cdots$ & $6.33-7.89 / \mathrm{s}$ \\
\hline & $\begin{array}{l}8 \\
8\end{array}$ & & $\begin{array}{l}1364.50-1.366 .50 \\
1366.50-1367.42\end{array}$ & $\begin{array}{l}2.00 \\
0.92\end{array}$ & - & $\cdots$ & -- & - & $\begin{array}{l}--- \\
--\end{array}$ & $\cdots$ & $(4.0-12.5 / \mathrm{s})^{5}$ \\
\hline \multirow{7}{*}{ - } & 5 & & $1406.75-1409.42$ & 2.66 &.-- & -.. & $\ldots$ & -- &.-- & $14.44 / L$ & \\
\hline & 5 & & $1409.42-1410.00$ & 0.58 & --- & --- & -- & --- & -- & $8.03 / \mathrm{L}$ & \\
\hline & 5 & & $1410.00-1411.66$ & 1.66 & -- &.- & -- & ... & -- & $7.05 / \mathrm{L}$ & $4.9-11.2 / \mathrm{L}$ \\
\hline & 4 & & $1471.66-1474.00$ & 2.33 & -- & -- & -- & $\cdots$ & --- & $3.54 / 4$ & $2.33-8.54 / \mathrm{L}$ \\
\hline & 3 & & $1484.91-1487.33$ & 2.42 & -..- & --- & -- & -- & $\cdots$ & $3.6 / \mathrm{L}$ & \\
\hline & 3 & & $1487.33-1490.25$ & 2.92 & $\cdots$ & -.- & -- & $\cdots$ & $\cdots$ & $1.86 / 4$ & $642-3-7<3$ \\
\hline & 3 & & $1490.25-1491.33$ & 1.08 & $\cdots$ & $\cdots$ & $\cdots$ & $\cdots$ & $\cdots$ & $8.7 / \mathrm{L}$ & $0.42-3.6 / 2$ \\
\hline
\end{tabular}

*Values in table for percent mineral and $\mathrm{K}_{2} \mathrm{O}$ equivalent are not consistent owing to independent rounding of assays and conversion factors by numerous authors and investigators.

1 Trace amount; equals 0 to 2.0 percent

Incomplete dissolution of sample

5.9 percent insolubles, by weight

Incomplete or unreliable assay

Grade adjusted to 4-foot interval

High insoluble content

7. 1 percent potassium assay used

Dutside of the ERDA area by 300 feet, included due to influence

Rav data unavailable; these are company figures

Company interval data; raw data unavailable; no sample numbers assigned 